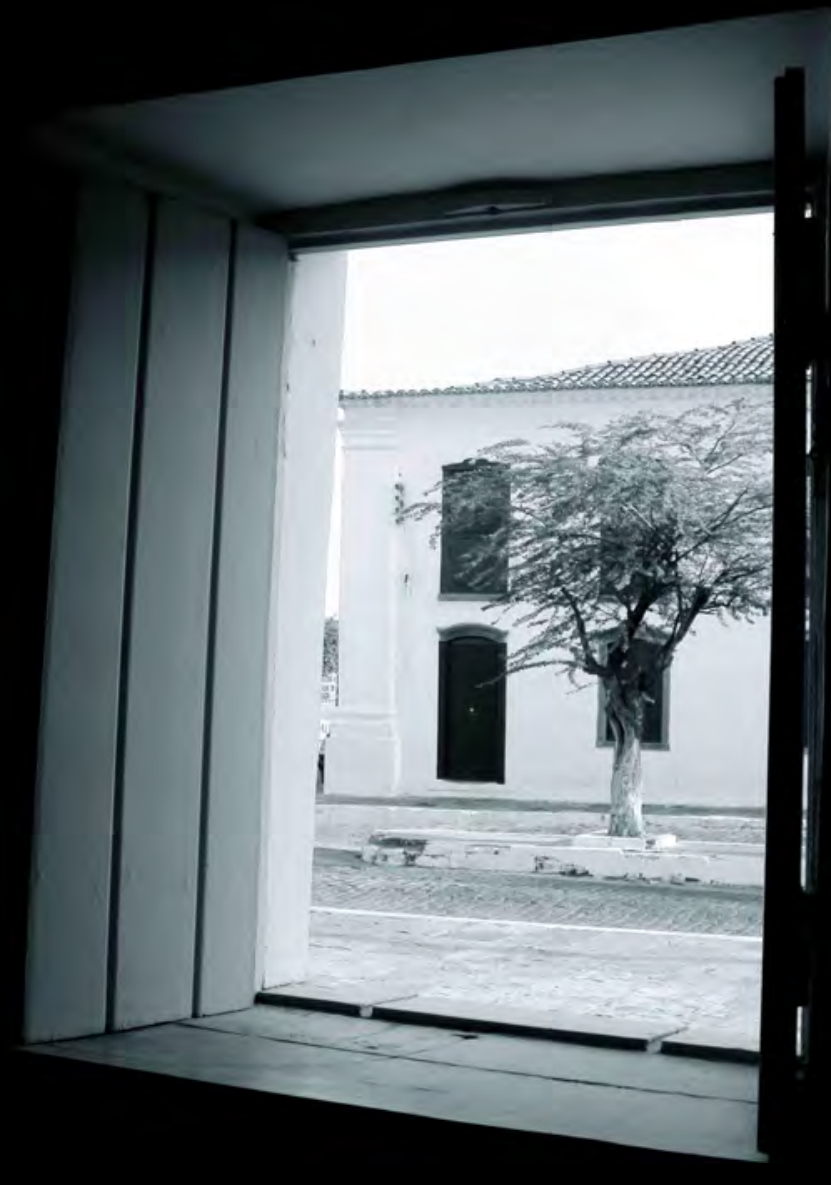

Curral de reses, Curral de almas: urbanização do sertão nordestino entre os séculos XVII e XIX 
UNIVERSIDADE DE SÃO PAULO - USP

FACULDADE DE ARQUITETURA E URBANISMO - FAU

\section{Curral de reses, Curral de almas: \\ urbanização do sertão nordestino entre os séculos XVII e XIX}

São Paulo, 
DAMIÃO ESDRAS ARAÚJO ARRAES

\title{
Curral de reses, Curral de almas: urbanização do sertão nordestino entre os séculos XVII e XIX
}

\author{
Dissertação de mestrado apresentada à \\ Faculdade de Arquitetura e Urbanismo da \\ Universidade de São Paulo (FAU - USP), área \\ de concentração História e Fundamentos da \\ Arquitetura e do Urbanismo, para a obtenção \\ do título de mestre, sob a orientação do Prof. \\ Dr. Luciano Migliaccio.
}

São Paulo, 
Autorizo a reprodução e divulgação total ou parcial deste trabalho, por qualquer meio convencional ou eletrônico, para fins de estudo e pesquisa, desde que citada a fonte.

e-mail: esdras_arraes@yahoo.com.br / esdrasarraes@gmail.com

Foto da capa: Vista do sobrado de João Nepomuceno desde a igreja de Nossa Senhora da Vitória, Oeiras - PI. Fotografia do autor, 2010.

Foto introdução: Fazenda Acauã - PB. Imagem doada pelo IPHAN/PB.

Foto capítulo 01: Caatinga do sertão nordestino. Imagem disponível em http://www.ibge.gov.br. Acesso em 06.12.2011.

Foto capítulo 02: Boiada da Bahia. Fotografia disponível em http://www.ibge.gov.br. Acesso em 25.08.2010

Foto capítulo 03: Povoado de Caboclo - PE. Imagem cedida pela FUNDARPE - PE.

Figura capítulo 04: Desenho do autor sobre manuscrito de Freire Alemão. Original FBN.

Foto capítulo 05: Igreja matriz de Oeiras e sobrado de João Nepomuceno. Foto do autor, 2010.

Foto capítulo 06: Panorama do Crato, início do século XX. Foto do acervo do AHDC.

Foto considerações finais: Casas da rua do Meio, Icó - CE. Fotografia do autor, 2010.

Arraes, Damião Esdras Araújo

A773c Curral de reses, curral de almas: urbanização do sertão nordestino entre os séculos XVII e XIX / Damião Esdras Araújo

Arraes. --São Paulo, 2012.

504 p. : il.

Dissertação (Mestrado - Área de Concentração: História e

Fundamentos da Arquitetura e do Urbanismo) - FAUUSP.

Orientador: Luciano Migliaccio

1.Urbanização 2.Sertão nordestino 3.Currais 4.Fazendas de gado

5.Jesuítas 6.Redes urbanas 7.Desenho urbano 8.Historia da arquitetura 9.Historia do urbanismo 10.Oeiras(PI) 11.Crato(CE) I.Título

CDU 301(1-21) 
Nome: ARRAES, Damião Esdras Araújo

Título: Curral de reses, curral de almas: urbanização do sertão nordestino entre os séculos XVII e XIX.

Dissertação apresentada à Faculdade de Arquitetura e Urbanismo da Universidade de São Paulo (FAUUSP) para obtenção do título de mestre em Arquitetura e Urbanismo, área de concentração História e fundamentos da Arquitetura e do Urbanismo.

Aprovado em:

BANCA EXAMINADORA

Prof.(a) Dr.(a): Instituição:

Julgamento: Assinatura:

Prof.(a) Dr.(a): Instituição:

Julgamento: Assinatura:

Prof.(a) Dr.(a): Instituição:

Julgamento: Assinatura: 
À mamãe e papai, com amor.

À Luiz Carlos Botelho Gomes e Juan Carlos Gonzáles, com carinho.

Ao meu eterno amigo e mestre Murillo Marx (in memoriam), pelo legado. 


\section{AGRADECIMENTOS}

Agradeço ao Prof. Dr. Luciano Migliaccio que num momento de perda aceitou generosa e pacientemente prosseguir os trabalhos desta pesquisa.

À Fundação de Amparo à Pesquisa do Estado de São Paulo - FAPESP -, pelos dois anos de bolsa e apoio a esta dissertação. Sem esse auxílio não teria sentido e espacializado o meu sertão.

Sou profundamente grato à Profa. Dra. Beatriz Siqueira Bueno, do Dep. de História da Arquitetura da FAU, pelo entusiasmo dispensado ao sertão nordestino, pelas competentes considerações ao longo do curso e durante o exame de qualificação.

À Profa. Dra. Renata Martins pelo sorriso e motivação dispensados. Por me mostrar a beleza da arte jesuítica. Obrigado pelas oportunas colocações pontuadas no exame de qualificação.

À Profa. Dra. Maria Ângela Faggin Pereira Leite, sem seus comentários não entenderia os textos do geógrafo Milton Santos.

Ao Prof. Dr. Jesús Úrrea da Universidade de Valladolid (UVa) ao me deixar a par das aglomerações espanholas na América, da arte missioneira e das praças e ruas espanholas. Pelas competentes indicações bibliográficas acerca da urbanização colonial espanhola nas Américas, tema que me fascina.

Ao Prof. Dr. Clovis Ramiro Jucá Neto que gentilmente forneceu sua tese e fotografias de núcleos urbanos e velhas fazendas de gado do estado do Ceará. Agradeço nossas conversas de domingo à noite.

Às minhas irmãs - Maria, Carla e Verônica, pela demonstração de carinho e apoio ao irmão caçula, que vive em movimentos cíclicos.

Ao Arquivo Histórico da Diocese do Crato (CE) por ceder as inspiradoras imagens da cidade do Crato tomadas no início do século XX.

Aos bibliotecários da Fundação do Patrimônio Histórico e Artístico Pernambuco FUNDARPE -, por me deixar digitalizar as fotos de capelas, igrejas, fazendas e aglomerados do sertão pernambucano. 
Muitíssimo obrigado aos componentes da cátedra Jaime Cortesão por conceder os cd's do Projeto Resgate Barão do Rio Branco. Sem esses valiosos manuscritos digitalizados, os resultados aqui apresentados seriam ralos e pouco fundados.

À Eliane, bibliotecária da Casa de Portugal, pelo interesse e atenção dispensados e às referencias bibliográficas pertinentes.

Aos profissionais do IPHAN da Paraíba - Gislene e Ana Luiza -, e do IPHAN - SE pelas fotografias enviadas, enquanto escrevia esta dissertação, da fazenda Acauã (PB) e da igreja de Nossa Senhora do Socorro de Tomar do Gerú (SE). E a querida Luciene do IPHAN - PI por enviar-me um cd contendo velhas fotos da cidade de Oeiras (PI) e úteis dados sobre sua urbanização.

Ao meu querido amigo Jader Alves da Silva que sempre me apoiou nesta jornada.

À Samyla Peixoto e Carla Martins, da Prefeitura do Crato (CE) e Prefeitura de Oeiras (PI), respectivamente, por fornecer, sem hesitação, as bases cartográficas de suas cidades.

À Profa. Dra. Maria Cecília França Lourenço e ao Prof. Dr. Luiz Munari por ter me auxiliado a ver os bons resultados de uma pesquisa com enfoque multidisciplinar.

Às secretárias da FAU Maranhão - Isa, Dinah, Ivani e Regina; À Flávia do Dep. de História da Arquitetura e as bibliotecárias da "duas" FAU's - Maria José, Paola, Estelita, Rejane e Regina -, pelas informações, paciência e alegria demonstrados enquanto eu vasculhava as prateleiras.

Obrigado à querida Sra. D. Regina del Monte pelas tardes a conversar tomando café. Agradeço a hospitalidade e alegria dispensados.

Aos meus amigos, Helton Andrade e Renato Cubas, pela demonstração de interesse ao meu objeto de estudo, às nossas conversas das noites de sábado e tardes de domingo, sobre história, arte, política e outros temas.

Ao arco - íris por colorir o céu da minha infância sertaneja. À chuva por dar vida à caatinga e transfigurá-la. 


\section{Resumo}

Esta dissertação estuda a urbanização do sertão nordestino entre os séculos XVII e XIX, vinculada ao diálogo que chamamos de curral de reses e curral de almas. Curral de reses tece as questões do fenômeno urbano no interior do Nordeste açucareiro, no que dizia respeito ao papel exercido pela pecuária extensiva no povoamento, na posse da terra e no desenvolvimento de aglomerados urbanos criados ao longo dos caminhos elaborados pelo gado. As reses tangidas do litoral devassaram o hinterland nordestino, criando aqui, ali $\mathrm{e}$ além caminhos, desmistificando o desconhecido. Posteriormente, essas trilhas foram usadas pelos autoridades coloniais e clericais para erguer aldeamentos missioneiros - currais de almas -, visando o bem material e espiritual da Igreja e da Ordem de Cristo e a conversão dos nativos. Curral de almas busca esclarecer a ação da Igreja Católica, unida ao Estado português, no que cerce a fixação e congregação tanto do índio tapuia como dos sertanejos nômades (que "vadiavam" pelo território), primeiramente em aldeamentos missioneiros, depois em núcleos urbanos estrategicamente locados no território. Focalizamos o trabalho missionário dos jesuítas, capuchinhos e oratorianos na elaboração de reduções religiosas principiadas a partir da segunda metade do século XVII.

Selecionamos a cidade pombalina de Oeiras (PI) e as vilas de índios Monte - Mor o Novo da América (CE) e Crato (CE) como estudos de caso, no intuito de analisar a influência da pecuária, dos caminhos do gado, das determinações provenientes de Lisboa e do papel eclesiástico da igreja em seus traçados intraurbanos.

Palavras - chave: Urbanização - sertão nordestino - pecuária - caminhos do gado - curral fazendas de gado - aldeamentos missioneiros - jesuítas - capuchinhos - oratorianos - rede urbana - desenho urbano - história da arquitetura - história do urbanismo - Oeiras - Monte Mor o Novo da América - Crato. 


\section{Abstract}

This dissertation analyzes the urbanization process in the Brazilian northeastern hinterland between the 17th and the 18th centuries as connected to the so called Curral de Reses (Cattle Corral) and Curral de Almas (Souls' Corral). Curral de Reses (Cattle Corral) investigates the several aspects of urbanization in the sugar-producing Northeast, relating it to the role of extensive cattle ranges in the process of population growth, to the land ownership and to the development of hamlets alongside the herding trails.

The herds pushed from the coast, broke through the Brazilian northeasterner hinterland, creating hither, thither and yonder new pathways, therefore demystifying the unknown.

Later in time, these trails were used by colonial and clerical authorities to start missionary settlements - "Currais de Almas" (Souls' Corrals)- that aimed at the material and spiritual welfare of the Church and the Order of Christ and the conversion of the native peoples.

"Curral de Almas" investigates the activity of the Catholic Church associated to the portuguese government as the "Tapuia " native people and the itinerant cowboys (who "bummed" around the land) settled and congregated at first in missions and later in strategically located urban centers.

Another focal point has been the investigation of the missionary work of Jesuit and Capuchin friars as well as "The Congragation of the Oratory" in the construction of religious settlements as early as the second half of the 17 th century.

The town of "Oeiras" (PI) -created by the Marquis of Pombal- and the Indian villages "Monte-Mor o Novo da América" (CE) and "Crato"(CE) were selected as case studies, attempting to analyze the influence of cattle industry, herding trails, determinations from Lisbon and the church in the planning of the urban center.

Key-words: urbanization - northeasterner hinterland- cattle management- herding trailscorral- cattle ranches- missionary settlements- Jesuits- Capuchins- Congregation of the Oratory- urban network- urban design - History of Architecture- History of Urbanism Monte-Mor o Novo da América - Crato 


\section{Siglas}

AHDC

AHEx

AHU

$\mathrm{BNF}$

BNP

CECI

CRL

FAU

FBN

FUNDARPE

IBGE

IEB

IHGB

IMS

IPAC

IPHAN

RIHGB

UFBA

UFC

UFPE

UFRN

UFRJ

USP

UVa
Arquivo Histórico da Diocese do Crato

Arquivo Histórico do Exército Brasileiro

Arquivo Histórico Ultramarino

Bibliotèque Nacionale de France

Biblioteca Nacional de Portugal

Centro de Estudos Avançados da Conservação Integrada

Center for Research Libraries

Faculdade de Arquitetura e Urbanismo

Fundação Biblioteca Nacional

Fundação do Patrimônio Histórico e Artístico de Pernambuco

Instituto Brasileiro de Geografia e Estatística

Instituto de Estudos Brasileiros

Instituto Histórico e Geográfico Brasileiro

Instituto Moreira Salles

Instituto do Patrimônio Artístico e Cultural

Instituto do Patrimônio Histórico e Artístico Nacional

Revista do Instituto Histórico e Geográfico Brasileiro

Universidade Federal da Bahia

Universidade Federal do Ceará

Universidade Federal de Pernambuco

Universidade Federal do Rio Grande do Norte

Universidade Federal do Rio de Janeiro

Universidade de São Paulo

Universidad de Valladolid 


\section{Lista de figuras}

$\begin{array}{lll}\text { Figura } 01 \quad \text { Casas em Triunfo - PE } & 20\end{array}$

Figura $02 \quad$ Cidade de Exú - PE 30

Figura $03 \quad$ Cidade de Ouricuri - PE 30

Figura $04 \quad$ Cidade de Oeiras - PI 31

$\begin{array}{lll}\text { Figura } 05 & \text { Cidade de Icó - CE } & 31\end{array}$

Figura $06 \quad$ Cidade do Crato - CE 31

Figura $07 \quad$ Cidade de Barbalha - CE 31

Figura 08 Cidade do Crato na década de trinta do século XX 31

Figura 09 Cidade de Amarante - PI em meados do século XX 31

Figura 10 Cidade de Rio de Contas em meados do século XX 32

Figura $11 \quad$ Cidade de Triunfo - PE 32

Figura 12 Cidade de Caxias - MA 32

Figura 13 Cidade de Regeneração - PI 32

Figura $14 \quad$ Vila de Simbres - PE 32

Figura 15 Cidade de Santa Maria da Boa Vista - PE 32

Figura $16 \quad$ Brasilia, mapa de Joan Bleau 45

$\begin{array}{lll}\text { Figura } 17 & \text { Rio de Contas - BA } & 48\end{array}$

Figura $18 \quad$ Brasil de Giacomo Gastaldi 51

Figura 19 Demonstração do rio das Preguiças athé o Seara 63

$\begin{array}{lll}\text { Figura } 20 & \text { Província do Brasil }\end{array}$

Figura $21 \quad$ Nova et Accurata Brasiliae totis Tabula 66 
Figura 22 Mappa Geographico da Capitania do Piauhy e parte das do Gram Pará e Maranhão

Figura 23 Carta Geográfica da Capitania do Piahuy 71

$\begin{array}{lll}\text { Figura } 24 & \text { Oeyras do Piahuy } & 72\end{array}$

Figura 25 Mappa Geographico da Capitania do Seará $\quad 74$

Figura 26 Pormenor do Mappa Geographico da Capitania do Seará 75

Figura 27 Mappa da região compreendida entre o rio Amazonas e São Paulo $\quad 76$

$\begin{array}{lll}\text { Figura } 28 \quad \text { Caatinga do sertão nordestino } & 81\end{array}$

$\begin{array}{llr}\text { Figura } 29 \quad \text { Mandacarú } & 81\end{array}$

Figura $30 \quad$ Caatinga em tempos de chuva 82

$\begin{array}{lll}\text { Figura } 31 \quad \text { Secca de } 1877-1878 & 85\end{array}$

$\begin{array}{llr}\text { Figura } 32 & \text { Fazenda Boa Esperança } & 88\end{array}$

$\begin{array}{lll}\text { Figura } 33 \quad \text { Vaqueiro em seu típico traje } & 89\end{array}$

$\begin{array}{lll}\text { Figura } 34 \quad \text { Grupo de vaqueiros do sertão piauiense } & 89\end{array}$

Figura $35 \quad$ Maniere de prendre Le Buffles por le vaqueiro $\quad 91$

$\begin{array}{lll}\text { Figura } 36 & \text { Chapéu de couro } & 92\end{array}$

Figura 37 Mappa Topographico da Capitania do Maranhão e Piahuy... 113

$\begin{array}{lll}\text { Figura } 38 \text { Carta da Capitania do Ceará levantada por ordem... } & 114\end{array}$

$\begin{array}{ll}\text { Figura } 39 & \text { Carro de bois em Jacobina - BA }\end{array}$

$\begin{array}{lll}\text { Figura } 40 \quad \text { Boiadas no sertão do Piauí } & 122\end{array}$

$\begin{array}{lll}\text { Figura } 41 & \text { Lista dos moradores das fazendas do Canindé de Cima } & 123\end{array}$

Figura 42 Mappa de todas as boiadas que tem sahido das fazendas de gado... $\quad 127$

$\begin{array}{lll}\text { Figura } 43 & \text { Produção da carne seca, carde de sol ou carne do sertão } & 128\end{array}$

$\begin{array}{lll}\text { Figura } 44 & \text { Planta da cidade de Oeiras do Piauí } & 129\end{array}$ 
Figura $45 \quad$ Feira de gado em Feira de Santana - BA

Figura $46 \quad$ Feira do Crato - CE

Figura $47 \quad$ Feira de Jacobina - BA

Figura 48 Mappa das sesmarias que a Casa da Torre e seus sócios...

Figura 49 Povoação do Jardim da fazenda Araripe em Exú - PE

Figura $50 \quad$ Planta da Villa de Jurumunha

Figura 51 Mappa Geographico da Capitania do Piahuy...

Figura $52 \quad$ Fazenda Canela

Figura 53 Fazenda de gado em Aracati - CE

Figura $54 \quad$ Fazenda Boa Vista

Figura $55 \quad$ Fazenda Cobra

Figura $56 \quad$ Fazenda Recreio

Figura 57 Fazenda Acauã

Figura 58 Demonstração do Morro de S. Paulo athe os Ilheos

Figura 59 Beneditinos; Capuchinhos

Figura 60 Igreja de Nossa Senhora da Penha de França, Recife - PE

Figura 61 Vila de Pambú pelo engenheiro Henrique Halfeld

Figura 62 Capela da missão de Ilha de S. Félix ou Cavalo

Figura 63 Fachada frontal da capela de São Félix

Figura 64 Planta baixa da capela de São Félix

Figura 65 Imagem setecentista da igreja de Nossa Sra. da Penha de França

Figura 66 Implantação da igreja de São Félix às margens do rio São Francisco

Figura 67 Panorama da cidade do Crato - CE em meados do século XX 
Figura 68 Igreja matriz do Crato - CE, dedicada à N. Sra. da Penha de França

Figura 69 Vista do casco viejo da atual cidade de Exú - PE

Figura $70 \quad$ Capela da missao jesuítica da Jacobina 196

Figura 71 Catecismo da doutrina cristã na língua brasílica da nação Kiriri...

Figura 72 Igreja Nossa Senhora do Socorro de Tomar do Gerú - SE

201

Figura 73 Igreja Nossa Senhora do Rosário, Oeiras - PI

Figura 74 Fazenda Brejo de Santo Inácio

208

Figura 75 Retábulo e forro da igreja de Nossa Sra. da Assunção

Figura 76 Igreja de Nossa Sra. da Assunção, Viçosa do Ceará - CE

Figura 77 Forro do altar mor da Igreja de Nossa Sra. da Assunção

Figura 78 Planta da missão de São Miguel

Figura 79 Planta típica de uma redução guarani

Figura $80 \quad \mathrm{R}^{\text {am. }}$ de todo o gado vacum, cavallar, meudo e dos mais que se acha...

Figura 81 Ermida de Santo Antônio

Figura 82 Missão de Arorobá do Oratório de São Felipe Nery

Figura 83 Igreja matriz da povoação de Simbres - PE

Figura 84 Legenda do mapa 09

Figura $85 \quad$ Igreja da Madre de Deus, Recife - PE

Figura 86 Ermida de Nossa Senhora dos Remédios

Figura 87 Planta da capela de Nossa Senhora dos Remédios

Figura 88 Igreja de Nossa Senhora das Mercês, Jaicós - PI

Figura 89 Igreja Nossa Senhora da Conceição do Monte, Icó - CE

Figura 90 Igreja Nossa Senhora da Expectação do Icó - CE 
Figura $91 \quad$ Cidade de Oeiras - PI

Figura $92 \quad$ Icó - CE

Figura 93 Sobrados da rua Idílio Sampaio em Icó - CE

Figura 94 Companhia Têxtil Caxiense

Figura $95 \quad$ Caxias - MA

306

Figura 96 Planta do aldeamento missioneiro de Pambú - BA

Figura $97 \quad$ Planta da vila de Pombal - PB

Figura 98 Planta da freguesia de Nossa Senhora da Guia de Patos - PB

Figura 99 Praça de Icó - CE

Figura 100 Praça de Oeiras - PI

Figura 101 Planta da vila de Monte - Mor o Novo da América

Figura 102 Praça do Crato - CE em foto tirada no início do séc. XX

Figura 103 Planta da aldeia de São Gonçalo dos Índios...

Figura 104 Capela de Nossa Senhora do Rosário

Figura 105 Núcleo primitivo do arraial da Fazenda Grande

Figura 106 Horizontalidade como marca da paisagem de Floresta - PE

Figura 107 Planta da freguesia de Nossa Sra. do Rosário, Floresta - PE

Figura 108 Panorama da cidade de Floresta - PE

Figura 109 Vista do largo da igreja de Nossa Senhora do Rosário

Figura 110 Planta do aglomerado de Estrema - BA

Figura 111 Perfil do núcleo baiano de Mucugê

Figura 112 Rua Direita ou do Comércio de Mucugê

Figura 113 Alinhamento dos lotes e moradias da cidade de Tauá - CE 
Figura 114 Vista aérea de Tauá - CE 336

$\begin{array}{lll}\text { Figura } 115 & \text { Planta de povoação não identificado } & 337\end{array}$

Figura 116 Planta da povoação de Alagoa do Sul - AL 338

$\begin{array}{lll}\text { Figura } 117 & \text { Planta da vila do Aracati - CE } & 338\end{array}$

Figura 118 Aglomerado urbano de São Sebastião nas Gerais 339

Figura $119 \quad$ Planta do aglomerado de Ipú - CE 341

Figura 120 As rugosidades de Ipú - CE 342

$\begin{array}{lll}\text { Figura } 121 & \text { Arraial de Caboclo - PE } & 343\end{array}$

Figura 122 Planta do núcleo urbano de Caboclo - PE 343

$\begin{array}{lll}\text { Figura } 123 & \text { Planta de Mirador - MA } & 344\end{array}$

Figura 124 Termo da vila de Simbres - PE 346

Figura 125 Aglomerado de Simbres na década de oitenta do século XX 346

Figura 126 Ocupação provável da freguesia de Nossa Sra. da Luz de Tacaratú 348

Figura 127 Provável ocupação da freguesia de Nossa Sra. da Vitória - PI 356

Figura 128 Planta da igreja de Nossa Senhora da Vitória 366

$\begin{array}{lll}\text { Figura } 129 & \text { Igreja matriz de Oeiras - PI } & 367\end{array}$

$\begin{array}{lll}\text { Figura } 130 & \text { Igreja de Nossa Senhora da Vitória, Oeiras - PI } & 367\end{array}$

Figura 131 Ocupação provável da vila do Mocha em $1733 \quad 368$

Figura 132 Igreja de Nossa Senhora do Rosário de Oeiras - PI 370

Figura 133 Provável ocupação da vila do Mocha após a construção

do hospício dos jesuítas $\quad 371$

Figura 134 Resumo de todas as pessoas, livres, e Captivas, e fogos... 380

Figura 135 Ocupação provável de Oeiras em 1761

Figura 136 Igreja Nossa Senhora da Conceição, Oeiras - PI 382 
Figura 137 Rua estreita no casco viejo da atual Oeiras - PI

$\begin{array}{lll}\text { Figura } 138 & \text { Rua estreita em Oeiras } & 384\end{array}$

$\begin{array}{lll}\text { Figura } 139 & \text { Rua com lotes alinhados } & 384\end{array}$

Figura $140 \quad$ Casas alinhadas nas proximidades do riacho do Mocha 384

Figura 141 Panorama da atual praça de Oeiras - PI 387

Figura 142 Planta da cidade de Oeiras em 1809

Figura 143 Casa de câmara e cadeia de Oeiras - PI 402

Figura 144 Ocupação provável de Oeiras em $1850 \quad 405$

Figura 145 Projeto para Lisboa após terremoto de 1755

$\begin{array}{lll}\text { Figura } 146 & \text { Planta de Baturité, } 1861 & 418\end{array}$

Figura 147 Esquema do plano idealizado para a vila Real do Crato em 1764

Figura $148 \quad$ Ritmo das aberturas das moradias da vila do Crato 429

Figura 149 Tipologias habitacionais da vila do Crato - CE 430

Figura 150 Zoneamento da vila do Crato proposto pelo ouvidor José da Costa

Dias de Barro em 1774

Figura 151 Vila do Crato em 1817

Figura 152 Engenho de rapadura localizado no termo da vila do Crato - CE 434

Figura 153 Casa com porão alto situado na praça da matriz do Crato - CE 436

Figura 154 Ocupação provável do Crato em 1850

Figura 155 Aquarela de José dos Reis Carvalho que retratou o Crato 438

Figura 156 Igreja matriz do Crato, dedicada à Nossa Sra. da Penha de França 439

Figura 157 Igreja, praça e casas alinhadas 439

$\begin{array}{lll}\text { Figura } 158 \text { Casa de câmara e cadeia do Crato } & 440\end{array}$

Figura 159 Rua das Laranjeiras $\quad 440$ 
$\begin{array}{lll}\text { Figura } 160 \quad \text { Rua Grande } & 440\end{array}$

$\begin{array}{lll}\text { Figura } 161 & \text { Rua do Fogo } & 441\end{array}$

Figura 162 Rua Formosa 441

$\begin{array}{lll}\text { Figura } 163 & \text { Rua da Liberdade } & 441\end{array}$

Figura 164 Planta da vila de Areia - PB 452

\section{Lista de mapas}

$\begin{array}{lll}\text { Mapa } 01 \quad \text { Estrada real do gado } & 104\end{array}$

Mapa 02 Roteiro de penetração de Recife às minas gerais, pelo rio Ipojuca 111

$\begin{array}{lll}\text { Mapa } 03 \quad \text { Caminhos do gado } & 118\end{array}$

$\begin{array}{lll}\text { Mapa } 04 & \text { Velhas estradas do Nordeste } & 119\end{array}$

$\begin{array}{lll}\text { Mapa } 05 & \text { Fluxos do gado no interior do Nordeste } & 121\end{array}$

Mapa 06 Dinâmica comercial do mercado da pecuária sertaneja 144

Mapa 07 Aldeamentos missioneiros do Nordeste, séculos XVII - XIX 163

Mapa 08 Itinerário das missões volantes dos capuchinhos italianos, século XVIII 191

Mapa 09 Patrimônio fundiário no sertão pernambucano dos padres oratorianos 226

Mapa $10 \quad$ Freguesias do Nordeste criadas entre 1640 - $1706 \quad 237$

$\begin{array}{lll}\text { Mapa } 11 & \text { Freguesias do Nordeste criadas entre } 1706-1750 & 241\end{array}$

Mapa $12 \quad$ Freguesias do Nordeste fundadas entre 1750 - $1777 \quad 249$

Mapa $13 \quad$ Freguesias do Nordeste fundadas entre $1777-1808 \quad 257$

Mapa $14 \quad$ Freguesias do Nordeste, $1808-1822$

Mapa $15 \quad$ Vilas e cidades do Nordeste entre $1640-1706 \quad 285$ 
Mapa 16 Vilas e cidades do Nordeste entre $1706-1750$

Mapa $17 \quad$ Vilas e cidades do Nordeste entre 1750 - 1777

296

Mapa 18 Vilas e cidades do Nordeste entre $1777-1808$

301

Mapa 19 Vilas e cidades do Nordeste entre $1808-1822$

304

Mapa 20 Termo da vila de Monte - Mor o Novo da América

416

Mapa 21 Termo da vila Real do Crato

426

\section{Lista de tabelas}

Tabela $01 \quad$ Lista das fazendas do Real Fisco

Tabela 02 Fazendas de gado do Piauí em 1772

Tabela 03 Fazendas de gado da capitania de Pernambuco e suas anexas

Tabela 04 Missões religiosas capuchinhas no rio São Francisco

Tabela 05 Missões capuchinhas pertencentes à Prefeitura de Pernambuco

Tabela 06 Freguesias do sertão nordestino entre 1640 - 1706

Tabela 07 Freguesias do sertão nordestino entre 1706 - 1750

Tabela 08 Moradias e população das freguesias do sertão baiano, 1706 - 1750

Tabela 09 Freguesias do sertão nordestino, 1750 - 1777

Tabela 10 Quantitativo de moradias e pessoas de desobriga das freguesias do Sertão nordestino, $1750-1777$

Tabela 11 Freguesias do sertão nordestino, $1777-1808$

Tabela 12 Freguesias do sertão nordestino, 1808 - 1822

Tabela 13 Vilas do sertão nordestino, $1706-1750$

Tabela 14 Vilas do sertão nordestino, $1750-1777$ 
Tabela 15 Titulação das novas vilas sertanejas, antes aldeamentos missioneiros

Tabela 16 Vilas do sertão nordestino, $1777-1808$

Tabela 17 Vilas do sertão nordestino, $1808-1822$

Tabela 18 Casas de aluguel das confrarias de Oeiras - PI

370

Tabela 19 Oficiais mecânicos e profissionais liberais de Oeiras - PI

Tabela $20 \quad$ Sociedade dos bairros Dezertto e Caquende de Oeiras em 1762

Tabela 21 Proprietários de imóveis alugados em Oeiras, 1762 


\section{Sumário}

$\begin{array}{ll}\text { INTRODUÇÃO } & 18\end{array}$

PRIMEIRA PARTE

CAPÍTULO 01: O SERTÃO 41

1.1 Miragens e delírios do ouro e da prata 43

1.2 Índios do sertão: prisão, escravização, conflitos e o conhecimento do território 51

1.3 O conhecimento do sertão através das representações cartográficas 61

1.4 “Ao primeiro olhar": o discurso acerca do sertão nordestino

$\begin{array}{ll}\text { pelos viajantes estrangeiros } & 77\end{array}$

CAPÍTULO 02: CURRAL DE RESES

2.1 Caminhos do gado do sertão nordestino 100

$\begin{array}{lll}2.2 & \text { Pecuária sertaneja e suas interfaces na economia colonial brasileira } & 120\end{array}$

2.2.1 As feiras sertanejas e sua posição na urbanização do sertão nordestino 137

2.3 A posse da terra: sesmarias, currais de gado e as fazendas de criar 145

CAPÍTULO 03: CURRAL DE ALMAS 161

3.1 Curral de almas: propagação da fé através de aldeamentos missioneiros 163

3.1.1 Missões religiosas capuchinhas 168

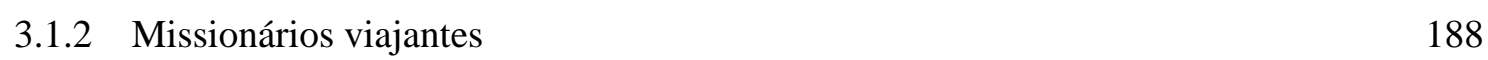

3.1.3 Missões religiosas jesuíticas do sertão nordestino 193

3.1.4 Missão jesuítica da Ibiapaba 208

3.1.5 Missões do Oratório de São Felipe Nery 220

3.1.6 Outras ordens religiosas 229

3.2 Freguesias e a urbanização do território 233

3.2.1 As "chaves do sertão": freguesias e o fenômeno urbano do sertão nordestino 236

3.3 As leis do Reino e a formação urbano - territorial do sertão nordestino 263

3.3.1 Ordenações no sertão nordestino 263

3.3.2 As leis do Reino e os nativos do sertão 270

3.3.3 O "Directório dos Índios" e a emancipação dos Tapuias 276

3.4 Fixar, povoar: evolução da rede urbana do sertão nordestino 282 


\section{SEGUNDA PARTE}

4.1 A praça: ordens pias, racionalidade, harmonia e a gênese dos núcleos urbanos sertanejos

4.2 Os caminhos do gado e a formação intraurbana de aglomerados do sertão nordestino

5.1 Freguesia de Nossa Senhora da Vitória

5.2 Hoc est domus Domini: vila do Mocha, autonomia municipal, crise fundiária e seus espaços

5.2.1 A vila do Mocha e seus símbolos de autonomia municipal: permanência e carência

5.2.2 Barro, vara e palha: uma ermida, uma matriz

5.2.3 A vila e os jesuítas 368

5.2.4 Mocha no contexto econômico e geopolítico da colônia

5.2.5 1758: a fundação da capitania de São José do Piauí

5.3 Oeiras, cidade pombalina

5.3.1 Oeiras e seus espaços no censo de 1762

5.3.2 Obras pias e temporais na Oeiras do ouvidor Antônio José Morais Durão 394

5.4 Oeiras no século XIX

6.1 Monte - Mor o Novo da América: desenho e seus espaços 412

6.2 De missão do Miranda à vila Real do Crato 422

6.2.1 Urbanização da vila do Crato nos Oitocentos 432

CONSIDERAÇÕES FINAIS $\quad 442$

REFERÊNCIAS BIBLIOGRÁFICAS

$\begin{array}{ll}\text { ANEXOS } & 490\end{array}$ 


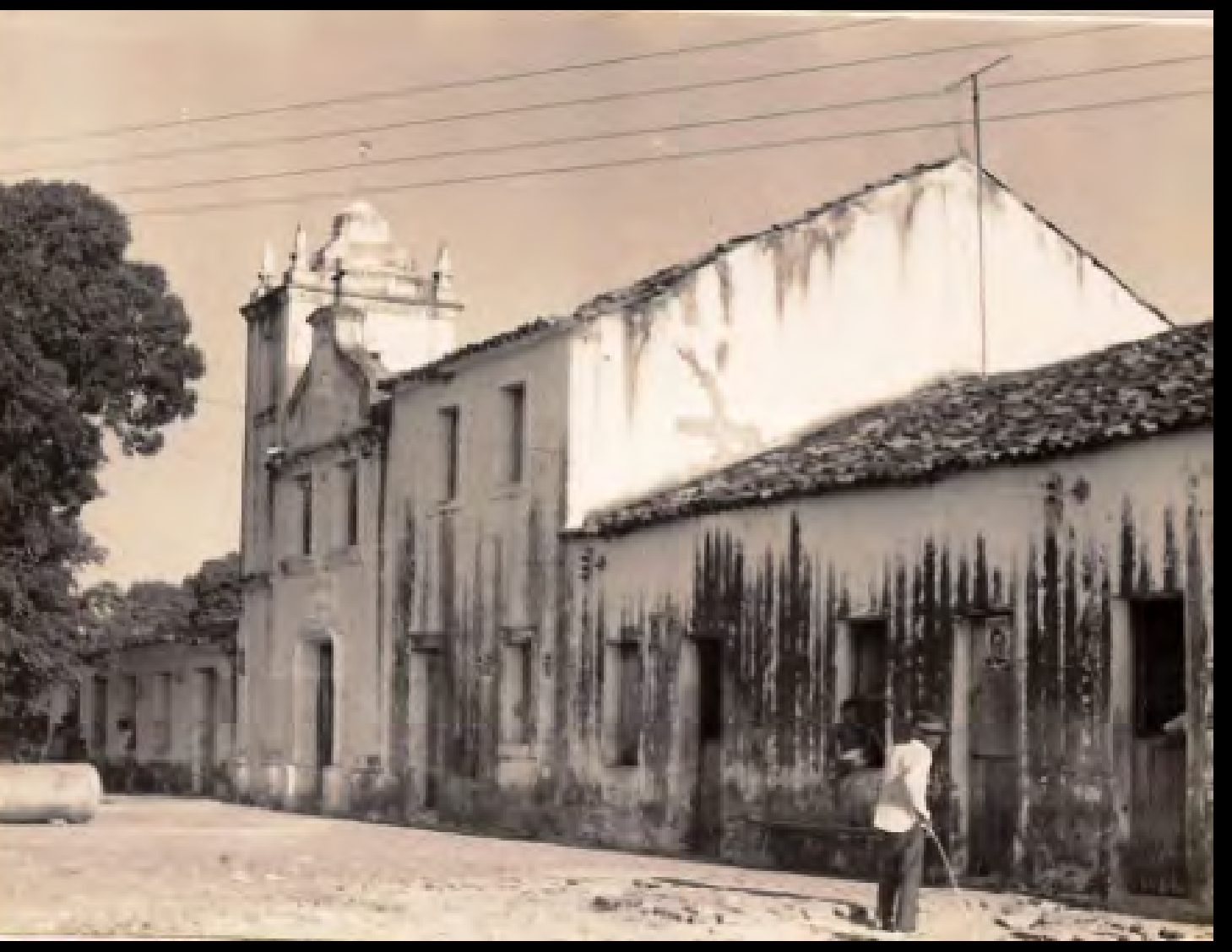

INTRODUÇÃO 


\section{INTRODUÇÃO}

"O meu boi morreu, O que será de mim? Manda buscar outro lá no Piauí.

O meu boi morreu, o que será da vaca? Manda buscar outro sem urucubaca.

Vamos criar boi, vamos criar vaca, vamos comer bife batido à faca."

Cantiga do folclore maranhense. 


\section{À seca, as cores...}

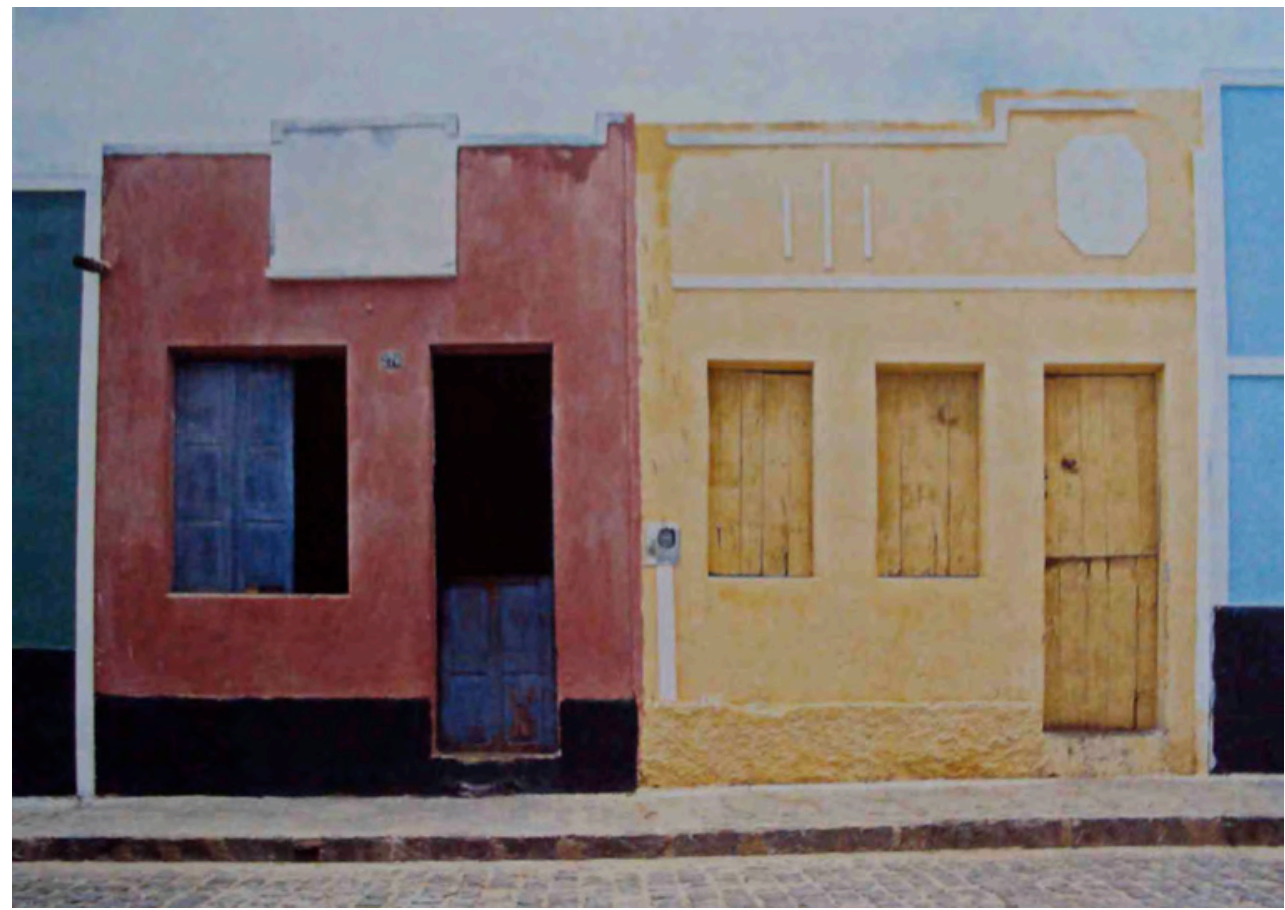

Figura 01 - Casas em Triunfo - PE. Foto de Anna Mariani, 1982. Extraída de MARIANI, Anna. Pinturas e platibandas. 2 ed. São Paulo, IMS, 2010. p. 90.

O sertanejo anima a monotonia da seca e do semi-árido pintando e elaborando geometricamente as formas das fachadas de suas casas [figura 01]: negação ao meio, ao estio, à realidade. A exposição fotográfica de Anna Mariani, para a $19^{\mathrm{a}}$ Bienal Internacional de São Paulo, sensivelmente exibiu a expressão artística do homem do sertão nordestino. A fachada das moradias retratadas, considerada "objeto puro" no olhar de Jean Baudrillard:

(...) trata-se de um objeto puro, nascido na confluência da expressão gráfica, luminosa e espontânea dos habitantes do Nordeste com sua pobreza e despojamento. (...) Cada fachada é como uma máscara ou um rosto, as aberturas são como os orifícios de uma mascara e o grafismo como os traços de um rosto. (...) Elas deram às suas fachadas a beleza de uma sobrevivência. ${ }^{1}$

Sobrevivência amalgamou a história do sertão nordestino, desde as primeiras tentativas de conhecimento territorial (a partir do final dos Quinhentos) até os dias atuais.

\footnotetext{
${ }^{1}$ Ver MARIANI, Anna. Pinturas e platibandas. 2 ed. São Paulo, IMS, 2010. p. 226.
} 
Sobreviver ao calor, à seca, à fome; sobreviver às guerras entre Tapuia e colono, às rixas criadas por clãs rivais, desejosos de uma fatia de terra; sobrevivência ao poderio despótico dos fazendeiros, senhores de grandes sesmarias. Sobreviver ao prejuízo, ao preconceito...

Quando eu era adolescente, viajando, caminhando pela caatinga pernambucana, inquietava-me saber que alguns eram donos de grandes latifundiários. Fixava curioso aos currais de gado do meu pai, tios e parentes. Tentava, sem sucesso, imitar o aboio que conduzia as reses para o pasto. Ao mesmo tempo, percebia que no sertão as fronteiras são poucas: o "oxente" de Pernambuco é o mesmo do Ceará, Bahia e Rio Grande do Norte. Algumas dessas indagações seriam parcamente elucidadas quando entrei no curso de Arquitetura e Urbanismo da Universidade Federal de Pernambuco - UFPE, em 2001. Contudo, os hiatos sobre a formação do sertão persistiam. Por isso, em 2008, decidi participar da seleção ao curso de pós-graduação, nível mestrado, na Faculdade de Arquitetura e Urbanismo da Universidade de São Paulo - FAU USP. Após a aprovação "vivenciei o passado" do meu sertão.

Como veremos, o conhecimento e colonização do sertão nordestino ocorreram a partir de meados dos Seiscentos. Antes, as investidas de devassamento visaram a busca de jazidas mineiras, o mítico El-dorado, e índios para trabalhos escravos na zona açucareira. Sem esquecer dos descimentos, os nativos depois de subjugados, eram remetidos para o litoral, sendo agrupados em aldeamentos missioneiros. $\mathrm{O}$ povoamento, a posse da terra e o surgimento de uma embrionária rede urbana sertaneja aconteceram em detrimento da pecuária extensiva e disseminação dos dogmas da cristandade em reduções religiosas (espalhadas em pontos estratégicos do hinterland nordestino). Entram, portanto, no rol do planejamento geopolítico da Metrópole portuguesa, ligada umbilicalmente à Igreja Católica² .

A pecuária foi responsável por estabelecer os primeiros currais e fazendas de gado "salpicados" em todo o território da caatinga nordestina, pontos distantes léguas e léguas uns dos outros. Em 1697, o padre Miguel de Carvalho viu, em seu trajeto do bispado de Pernambuco, situado em Olinda, ao sertão do Piauí, que o interior da capitania estava povoado com fazendas de gado com muitos moradores ${ }^{3}$. Para aqueles tempos, o gado era um meio de poder lucrar grandes conveniençias a fazenda de V. Mag ${ }^{t e}$ nos dízimos que se podem

\footnotetext{
${ }^{2}$ MARX, Murillo. Cidades no Brasil, terra de quem? São Paulo, Edusp/Nobel, 1991. 143 p.

${ }^{3}$ ENNES, Ernesto. As guerras nos Palmares. Rio de Janeiro, Editora Companhia Nacional, 1938. p. 371.
} 
tirar da cultura delles ${ }^{4}$. O jesuíta Antonil, em 1711, apontou 500 currais existentes no interior da capitania da Bahia ${ }^{5}$. Para Pernambuco os currais desta parte hão de passar de oitocentos, e de todos estes vão boiadas para Recife e Olinda e suas vilas e para o fornecimento das fábricas de engenho $(. . .)^{6}$.

Ao longo da arremetida, os rebanhos desenvolveram caminhos, irrigado aqui e além, unindo o litoral e o sertão dilatado. Às margens dessas vias e na ribeira dos principais cursos fluviais (rio São Francisco, Jaguaribe, Piranhas, Real, por exemplo), missionários ${ }^{7}$ ergueram núcleos de neófitos sob ordens oficiais, reunindo os Tapuias para sua catequização, domesticação e tentativa de integração (desculpem-me os inevitáveis "ãos") à empresa colonial portuguesa:

A principal cousa, que obrigou aos senhores Reys, meus predecessores, mandarem povoar essa Capitania, e as mais do Estado do Brazil foi a reducção do gentio à nossa Sancta fé catholica: e assim vos encomendo façaes guardar aos novamente convertidos, os prinvilegios, que lhes são concedidos, repartindo-lhes terras conforme as leys, que tenho feito sobre a sua liberdade $(\ldots)^{8}$.

É neste jogo dialético - pecuária x missões religiosas - que estruturamos o nosso quebra-cabeças da urbanização do sertão nordestino entre os século XVII e XIX. A partir desse diálogo, definimos o título de nosso trabalho: curral de reses, curral de almas. Curral de reses envolve a posse da terra por fazendeiros e arrendatários, negociantes de carne e couro. Abarca a fundação de currais e a fixação do homem. Nas terras das herdades, surgem os assentamentos humanos, modorrentos no início. Escolhem o curso de vias terrestres para facilitar a comunicação com outros centros urbanos, procuram um lugar ao sol. Ao longo dos caminhos edificam as suas casas e, em alguns casos, estrutura-se uma povoação longilínea.

Curral de almas equivale aos aldeamentos missioneiros nos Seiscentos e Setecentos. Agrupamentos de índios com fins civilizatório e colonizador. Muitas vezes reuniões pacíficas, em outro casos meio conflituoso de estabelecer o homem à terra: brigas e

\footnotetext{
${ }^{4}$ ENNES, Ernesto. As guerras nos Palmares...Opus cit., p. 350.

5 ANTONIL, André João. Cultura e opulência do Brasil. 3 ed. Belo Horizonte, Itatiaia/Edusp, 1982. (Coleção Reconquista do Brasil). p. 95.

${ }^{6}$ ANTONIL, André João. Cultura e opulência do Brasil...Opus cit., p. 96.

${ }^{7}$ Jesuítas, capuchinhos, franciscanos, oratorianos, carmelitas descalços, mercedários e clérigos do Hábito de São Pedro compuseram o casting dos religiosos incumbidos de aculturar e civilizar o gentio sertanejo.

${ }^{8}$ ANNAES da Bibliotheca Nacional do Rio de Janeiro. Vol XXVIII. Ano 1906. Rio de Janeiro, Officinas Graphicas da Bibliotheca Nacional, 1908. p. 16.
} 
até guerras foram travadas entre posseiros e nativos em nome do chão. Durante o período pombalino os currais de almas foram intensificados, fazem parte de uma política colonial de rígido controle administrativo e territorial. Algumas reduções religiosas receberam os foros de vila ou lugar de índios almejando congregar todos os homens vadios e vagabundos que afastando-se da sociedade civil à maneira de feras, vivem embrenhados pelo centro dos mattos virgens destes sertões (... $)^{9}$. Aos vadios e indígenas pretendiam sujeitá-los ao sistema de viver, isto é, avillados subordinados as Leis com seus legítimos Principais, e Superiores havendo em cada villa hum Director, hum Parocho Branco e Câmara composta de juízes ordinários, e Vereadores, em parte índios, em parte Brancos, são sempre pobres, sem alinhamento algum, Rústicos, e destituídos de toda a civilidade ${ }^{10}$.

\section{O sertão nordestino: uma questão de escala}

Ao observar a dialética entre curral de reses e curral de almas nos deparamos com a difícil tarefa de eleger o recorte espacial da pesquisa. Entretanto, verificando a evolução dos trabalhos e as apaixonantes descobertas, decidimos optar em estudar a urbanização da região delimitada por carta régia de 1701. Esse documento real fixou a criação de gado em no mínimo dez léguas afastadas zona açucareira. Geograficamente significa abarcar uma área de aproximadamente $670.000 \mathrm{~km}^{2}$, incluindo os sertões dos atuais estados do Maranhão, Piaú, Ceará, Rio Grande do Norte, Paraíba, Pernambuco, Alagoas, Sergipe e Bahia.

Como bem colocou a prof ${ }^{\mathrm{a}}$ Dra. Beatriz Bueno, durante o exame de qualificação, a tarefa exigia "fôlego" e dedicação. Além do mais, não bastava fracionar o território para esclarecer o fenômeno urbano sertanejo, porque as relações entre sertão e litoral eram muito mais amplas, envolveram a colônia e o Reino, eram totalizantes. Por exemplo, o gado criado no Piauí era destinado, por terra, ao Maranhão, Salvador, Pernambuco e Minas Gerais. No porto da Parnaíba, a carne e o couro eram remetidos, em sumacas (espécie de embarcação), para o Recife, Salvador e Rio de Janeiro. De Recife e Salvador, a courama embarcava para a Metrópole.

\footnotetext{
${ }^{9}$ OLIVEIRA, Perdigão. “A villa de Quixeramombim”. In Revista do Instituto do Ceará. Anno IV. Fortaleza, 1890. p. 278.

${ }^{10}$ PROJETO RESGATE. AHU_ACL_CU_014, Cx. 41, D. 2853.
} 
Para compreender o sistema urbano sertanejo e o marcado da pecuária, evitando juízos infundados, estabelecemos duas escalas de enfoque: regional e local. A primeira, a nível de Nordeste e colônia, esclarece fatos sobre a administração da Coroa em terras distantes (consideradas "periféricas" à colonização), a ação da Igreja Católica na formação territorial e como certos fenômenos se repetiram em variados pontos do interior do Nordeste.

No que tange a escala local ou intraurbana, como veremos, seguimos o conselho da banca do exame de qualificação ${ }^{11}$, concentramo-nos em analisar a forma, o desenho e a urbanização de três núcleos: Oeiras (por ser a primeira cidade e por estar no topo da rede de freguesias e vilas), e as vilas pombalinas de Monte - Mor o Novo da América e Crato, municípios que receberam a denominação de lugar de índios por emergirem de um aldeamentos missioneiros. Contudo, não podemos esquecer do papel da união entre Coroa e Mitra na estruturação desses núcleos urbanos.

A adoção de distintas escalas, como método de pesquisa, tem como base as assertivas do historiador francês Bernard Lepetit. Para ele, a investigação em diferentes escalas:

(...) muda-se também a 'óptica' e o nível de informação (...) escolher uma escala consiste então em selecionar um nível de informação que seja adequado ao nível de organização a ser estudado. A geografia que desejasse interrogar-se sobre a configuração de uma rede viária regional, um mapa na escala 1:25000 não acrescentaria nada, enquanto seria precioso para quem desejasse compreender a relação entre a distribuição do hábitat e o traçado das estradas rurais. (...) "Deve-se entender por proporções as relações entre o todo e as partes". ${ }^{12}$

No transcorrer dos capítulos, relacionaremos a urbanização com mapas e plantas por nós confeccionados. No segundo e terceiro capítulos inserimos cartografias na escala regional por enfocar temas relacionados com a pecuária e suas relações com o mercado interno, a formação da rede urbana de aldeamentos, freguesias e vilas no sertão nordestino. Do quarto ao sexto capítulo ilustramos a dissertação com plantas de aglomerados na escala intraurbana. Enfatizamos, desse modo, o desenho e suas relações com a urbanização do território. A

\footnotetext{
${ }^{11} \mathrm{O}$ exame de qualificação ocorreu em 04.07.2011 sob a presidência do prof. Dr. Luciano Migliaccio. Teve como componentes da banca as professoras Dra. Beatriz Siqueira Bueno, do departamento de História da Faculdade de Arquitetura da Universidade de São Paulo, e Dra. Renata Martins docente da Escola da Cidade.

${ }_{12}$ LEPETIT, Bernard. Por uma nova história urbana. Seleção de textos e apresentação por Heliana Angotti Salgueiro. São Paulo, Edusp, 2001. p. 210 - 211.
} 
produção cartográfica baseou-se em uma criteriosa pesquisa em fontes primárias cartográficas e manuscritas, encontradas em diferentes instituições nacionais: FUNDARPE -PE (Fundação do Patrimônio Histórico e Artístico de Pernambuco), Fundação da Biblioteca Nacional - RJ e AHEx - RJ (Arquivo Histórico do Exército). O cd-rom "Imagens de vilas e cidades do Brasil colonial”, belo trabalho do prof. Dr. Nestor Goulart Reis Filho, foi outro auxílio à produção dos mapas.

\section{As fontes primárias e secundárias na historiografia do sertão nordestino}

Ao longo da investigação acadêmica nos deparamos com sérios estudiosos: Capistrano de Abreu ${ }^{13}$, Basílio de Magalhães ${ }^{14}$, José Alípio Goulart ${ }^{15}$, Afonso Arinos ${ }^{16}$, José Antônio Gonsalves de Mello ${ }^{17}$, Manuel Correia de Andrade $^{18}$, Raimundo Girão ${ }^{19}$, Renato Braga $^{20}$, Carlos Studart Filho ${ }^{21}$, Barbosa Lima Sobrinho ${ }^{22}$ foram alguns dos que escreveram sobre a economia do gado, formação territorial e social do interior do Nordeste. Imaturidade a minha, ao afirmar no projeto de pesquisa de acesso ao mestrado, que havia poucos trabalhos historiográficos sobre o tema.

Com respeito ao tema das missões religiosas, sem dúvida as publicações do padre jesuíta Serafim Leite ${ }^{23}$ foram basilares para compreender a dinâmica eclesiástica dos jesuítas

\footnotetext{
${ }^{13}$ ABREU, Capistrano de. Capítulos de história colonial, 1500 - 1800. 7 ed. São Paulo, Publifolha, 2000. 280 p. ABREU, Capistrano. Caminhos antigos e o povoamento do Brasil. 2 ed. Rio de Janeiro, Livraria Briguiet, 1960. $311 \mathrm{p}$.

${ }^{14}$ MAGALHÃES, Basílio de. Expansão geográfica do Brasil colonial. 3 ed. Rio de Janeiro, Epasa, 1944.

${ }^{15}$ GOULART, José Alípio. "A formação da zona pecuária nordestina". In Revista do Instituto Histórico e Geográfico Brasileiro. vol. XXIX. Abr/jun. Rio de Janeiro, IHGB, 1963. p. 16 - 23.

GOULART, José Alípio. O ciclo do couro no Nordeste. Rio de Janeiro, Ministério da Agricultura, 1966.

GOULART, José Alípio. O Brasil do boi e do couro. vol. 2 (o couro). Rio de Janeiro, Edições GRD, 1966. $120 \mathrm{p}$.

${ }^{16}$ ARINOS, Afonso. Síntese da história econômica do Brasil. Salvador, UFBA, 1958. P. 47 - 56.

${ }^{17}$ MELLO, José Antônio Gonsalves de. Três roteiros de penetração do território pernambucano (1738 e 1802). Recife, Universitária, 1966. (Monografia 03).

${ }^{18}$ ANDRADE, Manuel Correia de. A terra e o homem do Nordeste. 3 ed. São Paulo, Brasiliense, 1973. 251 p. ANDRADE, Manuel Correia de. O processo de ocupação do espaço regional do Nordeste. 2 ed. Recife, SUDENE, 1979.

${ }^{19}$ GIRÃO, Raimundo. Bandeirismo Baiano e povoamento do Ceará. Fortaleza, Ed. Instituto do Ceará. 1949. 20p.

20 BRAGA, Renato. "Um capítulo esquecido da economia pastoril do Nordeste". In Revista do Instituto do Ceará. Tomo 61. Fortaleza, 1947. p. $149-162$.

${ }^{21}$ STUDART FILHO, Carlos. "Vias de comunicação do Ceará colonial”. In Revista do Instituto do Ceará. Tomo LI. Fortaleza, 1937. p. 15 - 47.

${ }^{22}$ SOBRINHO, Barbosa Lima. "Capistrano de Abreu e o povoamento do sertão pernambucano". In Revista do Instituto Arqueológico, Histórico e Geográfico de Pernambuco. Vol. L. Recife, IAHGP, 1978. p. 09 - 48.

${ }^{23}$ LEITE, Serafim. História da Companhia de Jesus no Brasil. Tomos II, III e V. Lisboa, Portugalia, 1950.
} 
na caatinga. Dentro dessa dinâmica, vale apontarmos o exercício temporal, isto é, administração dos bens fundiários adquiridos ao longo da catequese. Os capuchinhos também deixaram seu legado religioso na formação católica dos neófitos sertanejos. Entretanto, os estudos sobre a missão capuchinha no interior do Nordeste são poucos, se comparados com aqueles voltados à Companhia de Jesus. Frei Fidelis Primerio ${ }^{24}$ em seu livro - Capuchinhos em terra de Santa Cruz nos séculos XVII, XVIII e XIX - traçou um panorama geral da catequese exercida pelos barbadinhos no Brasil. Eduardo Horneart ${ }^{25}$ descreve, em poucas laudas, o ensino desses missionários em suas reduções instaladas no médio rio São Francisco. A tese de doutorado de Maria Cristina Pompa ${ }^{26}$ foi outra ajuda, pois conseguimos situar dentro da historiografia brasileira as práticas doutrinárias desses religiosos.

Aos padres congregados do Oratório de São Felipe Nery dedicaram investigação Ebion Lima ${ }^{27}$, Bartira Barbosa ${ }^{28}$, Maria do Céu Medeiros ${ }^{29}$ e Eugénio dos Santos ${ }^{30}$. E, por intermédio desses parcos informativos, tentamos interpretar espacialmente a catequese dos oratorianos no sertão nordestino. Aliás, resumida apenas à capitania de Pernambuco em poucos aldeamentos missioneiros: o mais evidente foi o de Ararobá, futura vila pombalina de Simbres. Para as outras ordens - franciscanos, mercedários e carmelitas descalços - devido à carência de fontes secundárias, pontuamos suas missões, não nos aprofundando no assunto.

Não bastava nos debruçar somente nas fontes secundárias, precisávamos "vivenciar o passado". Para conseguirmos isso, recorremos a velhos documentos coloniais e imperiais. Todavia, para termos acesso à tais informações realizamos um sério trabalho, diante da escassez do material arquivado nas prateleiras das bibliotecas. Ademais, a falta de interesse de alguns órgãos públicos em catalogar as fontes primárias, considerando-as "papéis" sem valor, somada à sua perda ao longo dos séculos, consistiram um impasse a solucionar. Assim, nós

LEITE, Serafim. Luiz Figueira: sua vida heróica e sua obra literária. Lisboa, Agência Geral das Colônias, 1940.

LEITE, Serafim. "João de Barros, lisboeta, apostolo dos Quiriris e Acarases". In Congresso do Mundo Português. Vol IX. Lisboa, Comissão Executiva do Centenário, 1940. p. 473 - 481.

${ }^{24}$ PRIMERIO, P.Fr. Fidelis M. de. Capuchinhos em Terras de Santa Cruz nos séculos XVII, XVIII e XIX. São Paulo, Livraria Martins, 1942.

${ }^{25}$ HORNEART, Eduardo. História da Igreja no Brasil: ensaio de interpretação a partir do povo: primeira época, Período Colonial. 5 ed. Petrópolis, Editora Vozes, 2008.

${ }^{26}$ POMPA, Maria Cristina. Religião como tradução: missionários, Tupi e "Tapuias" no Brasil colonial. Tese de doutorado. UNICAMP, 2001. $461 \mathrm{p}$.

${ }^{27}$ LIMA, Ebion, "As missões oratorianas no Brasil: informação sobre as missões oratorianas do Nordeste". In Revista do Instituto Histórico e Geográfico Brasileiro. no 323. Abr/jun. Rio de Janeiro, IHGB, 1979. p. 69 - 118.

${ }^{28}$ BARBOSA, Bartira Ferraz. Índios e missões: a colonização do médio rio São Francisco pernambucano nos séculos XVII e XVIII. Dissertação de mestrado. Recife, UFPE, 1991.

${ }_{29}^{29}$ MEDEIROS, Maria do Céu. Os oratorianos de Pernambuco: uma congregação "a serviço"do estado português. Dissertação de mestrado. Recife, UFPE, 1981.

${ }^{30}$ SANTOS, Eugénio dos. "Pombal e os oratorianos". In Revista Camões. no 15/16. Lisboa, 2003. p. 75 - 86. 
praticamos uma verdadeira "garimpagem" em arquivos públicos de distintos estados e cartórios municipais.

O primeiro órgão eleito, pela facilidade de locomoção e localização, foi o Instituto de Estudos Brasileiros (IEB), na sua coleção Alberto Lamego. Lendo o catálogo da coleção, encontramos cerca de vinte documentos da época colonial que abordam temas diversos sobre o sertão nordestino: condução das boiadas em caminhos feitos pelos vaqueiros e tangedores, missões jesuíticas no rio São Francisco, carência de carne para consumo nas capitanias da Bahia e Pernambuco, corrupção das câmaras sertanejas, entre outros assuntos que "enriqueceram" nosso inventário pessoal de manuscritos.

Outra instituição que auxiliou nossas buscas foi a Cátedra Jaime Cortesão. Obtivemos gentilmente os cd's do programa Resgate Barão de Rio Branco, referentes às capitanias do Maranhão, Piauí, Ceará, Rio Grande do Norte, Paraíba, Pernambuco, Alagoas, Sergipe e Bahia. Em 2010, visitamos o Arquivo Público do Estado de Pernambuco, a Biblioteca Nacional do Rio de Janeiro e o Arquivo Histórico do Exercito Brasileiro onde pudemos localizar importantes dados sobre a historiografia do interior do Nordeste entre os séculos XVII e XIX.

Hoje temos a facilidade de visitar virtualmente bibliotecas nacionais e internacionais. Os sites da Fundação da Biblioteca Nacional, Biblioteca Nacional de Portugal e Biblioteca Nacional da França contêm manuscritos que responderam a muitas das lacunas encontradas ao longo da investigação. Sem esquecer dos Anais da Biblioteca Nacional do Rio de Janeiro, onde muitos documentos oficiais estão transcritos e digitalizados.

Ler as observações oculares dos viajantes estrangeiros, distanciadas da realidade brasileira, elucidou algumas constatações sobre o fenômeno urbano sertanejo. No século XVIII os capuchinhos italianos, frei Aníbal de Gênova e frei Carlos de Spezia, através de suas missões ambulantes, descreveram as condições sociais, econômicas, religiosas e urbanas dos aglomerados por eles visitados. Porém, a partir do século XIX, com a abertura dos portos às nações amigas, a caatinga foi percorrida, principalmente, por viajantes alemães e ingleses, ávidos de conhecimento científico, no que dizia respeito à natureza e sociedade exóticas. Durante suas jornadas narraram sobre a fisionomia dos núcleos visitados, economia, política e aspectos do cotidiano da sociedade local, elementos da urbanização. 


\section{Velhas fotografias, cascos viejos: "pensar con los ojos" a urbanização do sertão nordestino}

Outra proposta metodológica deste trabalho abarcou a análise de velhas fotografias de povoações sertanejas. Esse artefato artístico, produto da cultura material, propicia a inusitada possibilidade de autoconhecimento, criação artística, memória e historicização do tempo ${ }^{31}$. A relação tempo x espaço cristaliza-se, temos um mundo portátil e fragmentado, revelador de aspectos peculiares de um povo, de uma cultura, sociedades, cidades, de um ser, de tempos...A foto faz com o meu sertão se torne familiar aos leitores.

Novamente, localizar fotografias tomadas no início do século passado apresentou uma tarefa difícil. Quando encontrávamos algumas, os donos das mesmas relutavam em doar. Em outros casos, protelavam o envio da imagem digitalizada. Murillo Marx, primeiro orientador desta dissertação, em 2009 me disse: meu velho, o melhor a fazer é viajar, sentir os espaços, vasculhar onde for necessário, e não esqueça: pense sempre com os olhos”. Essa última sentença marcou o rumo metodológico aplicado ao trabalho. Reunir velhas imagens e velhas cartografias, sentir os espaços públicos dos aglomerados sertanejos, conceituar sobre o contemplado. Nasce, portanto, a partir dessas premissas nossa Viagem científica pelo sertão nordestino, título batizado "carinhosamente" por Murillo.

A eleição das cidades a serem visitadas seguiu os seguintes critérios: núcleos que foram elevados à categoria de freguesias, vilas e cidades ao longo do período colonial; aglomerados que, nos primórdios de sua urbanização, serviram de aldeamento missioneiro; por fim, municípios que se estruturam fisicamente às margens dos velhos caminhos do gado e estradas coloniais. A análise das experiências sentidas, visualmente e in situ, serviram para fundamentar nossas considerações sobre a urbanização da hinterlândia nordestina.

Damián Bayón ${ }^{32}$, autor do livro Pensar con los ojos, esclareceu que para ser um bom viajante ou um bom historiador é necessário entrar en contacto con el mundo exterior, asumirlo. Uno se pierde, pregunta, descubre, se integra ${ }^{33}$. Consequentemente, distingue os pesquisadores de arte em fotógrafos e os que não o são:

\footnotetext{
${ }^{31}$ KOSSOY, Boris. Fotografia e história. 2 ed. São Paulo, Ateliê Editorial, 2001.

${ }^{32}$ BAYÓN, Damián. Pensar con los ojos. 2 ed. Cidade do México, Fondo de Cultura Económica, S.A., 1993. $400 \mathrm{p}$.

${ }^{33}$ BAYÓN, Damián. Pensar con los ojos...Opus cit., p. 18.
} 
(...) en el momento de disparar cada instantânea un vínculo se establece entre las cosas y nosotros. El registro mecânico demuestra a la larga ser más espiritual y duradero que gritos y exclamaciones. A las palabras se las lleva al viento; la imagen, buena o mala, queda. Y es precisamente porque queda, como yo recuerdo y considero haber vivido cien veces, mil, más que el historiador-crítico antiautomovilístico y antifotográfico por definición. (... $)^{34}$

Munido de uma simples câmera fotográfica, viajei pelo semi-árido, testemunhando, comprovando e sentido os relatos dos viajantes estrangeiros, admirados com as várias faces da caatinga. Percorri seis cidades sertanejas: Exú (PE) [figura 02], Ouricuri (PE) [figura 03], Oeiras (PI) [figura 04], Icó (CE) [figura 05], Crato (CE) [figura 06] e Barbalha (CE) [figura 07], faltam muitas...Ali registrei remanescentes do traçado colonial, cristalizei momentos do cotidiano, buscando vestígios de uma memória social passada; desenhei a forma dos aglomerados e dos principais edifícios (igrejas, casas de câmara e cadeia, casas de escravos), percebi o espaço e "pensei com os olhos" como o boi e os missionários criaram elementos que persistem no casco viejo dos municípios visitados.

Ao mesmo tempo, procurei os órgãos municipais para ver se forneciam fotos e cartografias da cidade. Devemos destacar a gentileza do Arquivo Histórico da Diocese do Crato (AHDC) que nos doou um cd com mais de 400 imagens digitalizadas do Crato, onde estão "congeladas" a paisagem urbana oitocentista, resquícios de um projeto setecentista, entre outras questões que abordaremos no sexto capítulo desta monografia. Em Recife, a FUNDARPE nos deixou digitalizar fotografias, tiradas na década de oitenta do século XX, de aglomerados pernambucanos situados às margens do rio São Francisco e alto sertão do estado.

Somando todas as fotografias (de nossa autoria e adquiridas nas repartições de pesquisa) temos um total de 1.400 fotos que abordam temas múltiplos: apropriação do espaço público, usos da cidade, hierarquia e funções urbanas, arquitetura colonial, qualidade dos espaços livres, praças, fazendas de gado, engenhos de rapadura e aguardente, igrejas, casas de câmara e cadeia, entre outros temas. Contudo, não exporemos exaustivamente muitas imagens; pelo contrário, selecionamos àquelas que são basilares ao entendimento da formação do sistema urbano sertanejo e do desenho intraurbano dos núcleos.

\footnotetext{
${ }^{34}$ BAYÓN, Damián. Pensar con los ojos...Opus cit., p. 18.
} 
Pierre Francastel informou, mesmo que indiretamente, a intenção encontrada nos eventos materializados na fotografia, quando nos diz: (...) o conhecimento das imagens, de sua origem, suas leis é uma das chaves de nosso tempo. (...) É o meio também de se julgar o passado com olhos novos e pedir-lhe esclarecimentos condizentes com nossas preocupações presentes, refazendo uma vez mais a história à nossa medida, como é direito e dever de cada geração ${ }^{35}$. E as fotos contribuem para uma outra visibilidade, sensível e abdutiva: de se pensar con los ojos:

A decir verdad, acercarse a los monumentos, estudiarlos, discutirlos me produce tanto placer - aunque de otra índole - como el de contemplar la obra de arte aislada y en todo su esplendor. Para mí, no obstante, esa obra que me deleita siempre quiere además decir algo, algo que transmite, señala hacia algo que no se agota en el simple placer de la contemplación, por apasionada que ella sea.

(...)

Si el título expresa bien lo que deseo, Pensar con los ojos será la reivindicación de dos de nuestras más admirables prerrogativas humanas: la de ver y la de meditar sobre lo contemplado ${ }^{36}$.

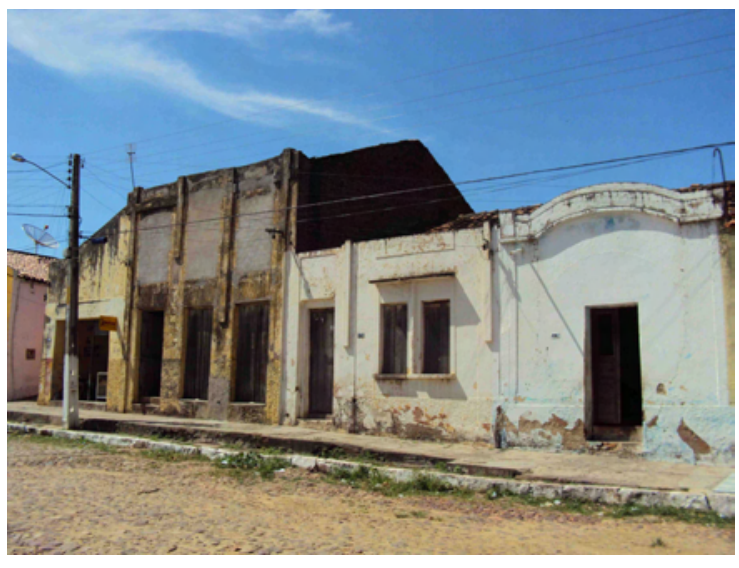

Figura 02 - Exú - PE. Foto do autor, 2010.

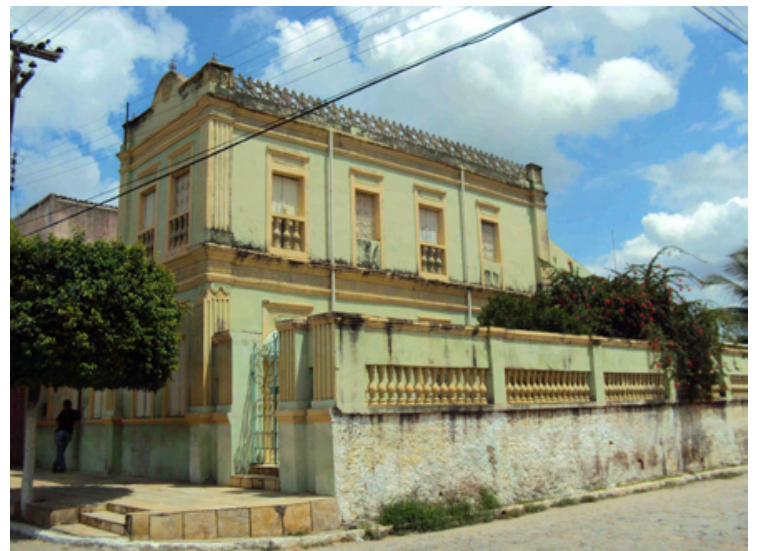

Figura 03 - Ouricuri- PE. Foto do autor, 2010.

\footnotetext{
${ }^{35}$ FRANCASTEL, Pierre. A realidade figurativa. São Paulo, Perspectiva, 1972.

${ }^{36}$ BAYÓN, Damián. Pensar con los ojos...Opus cit., p. 22.
} 


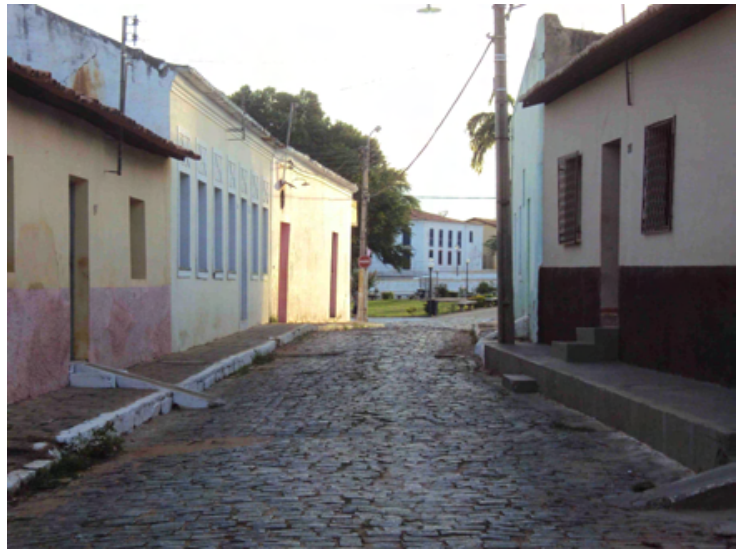

Figura 04 - Oeiras - PI. Foto do autor, 2010.

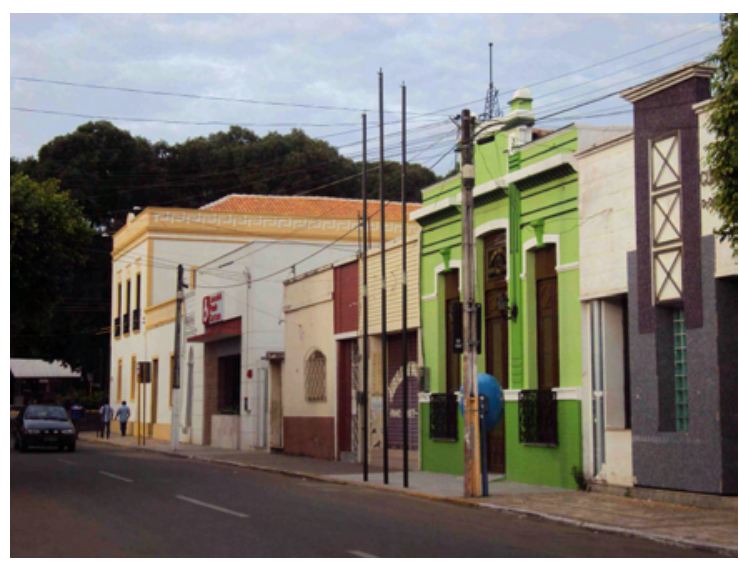

Figura 06 - Crato - CE. Foto do autor, 2010.

- Velhas fotografias

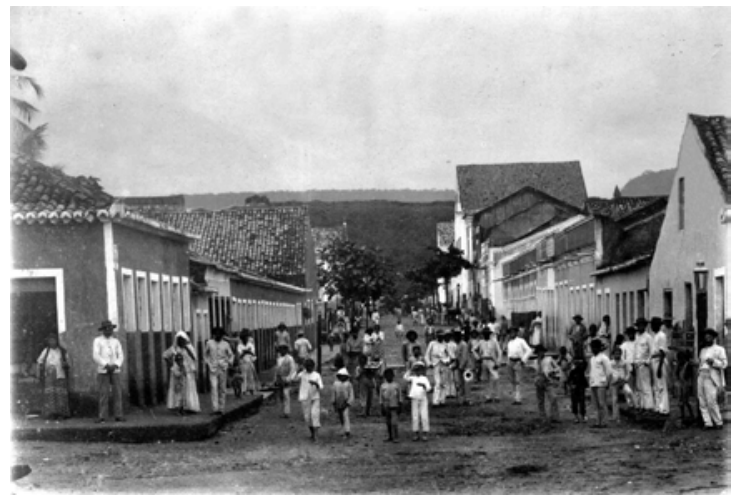

Figura 08 - Crato - CE. Foto cedida pelo AHDC.

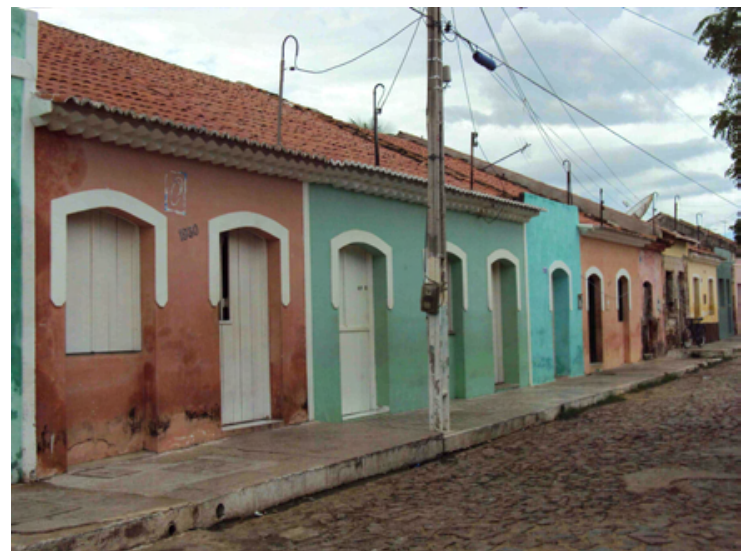

Figura 05 - Icó - CE. Foto do autor, 2010.

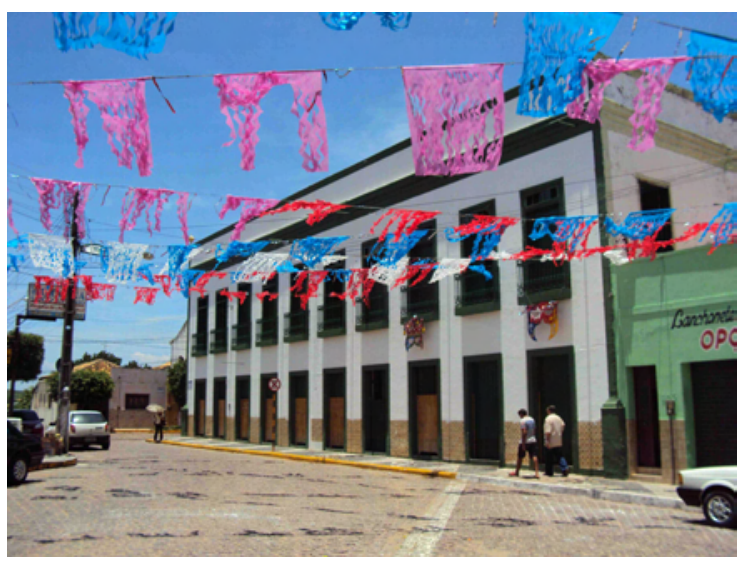

Figura 07 - Barbalha - CE. Foto do autor, 2010.

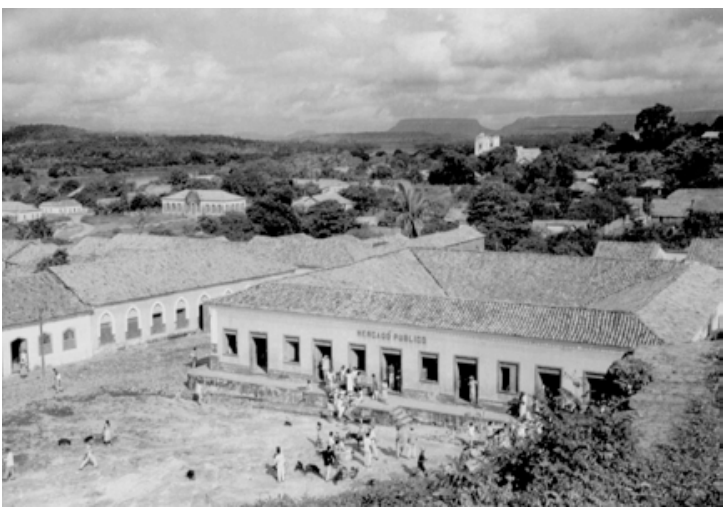

Figura 09 - Amarante - PI. Imagem disponível em http://www.ibge.gov.br. Acesso em 26.12.2009. 


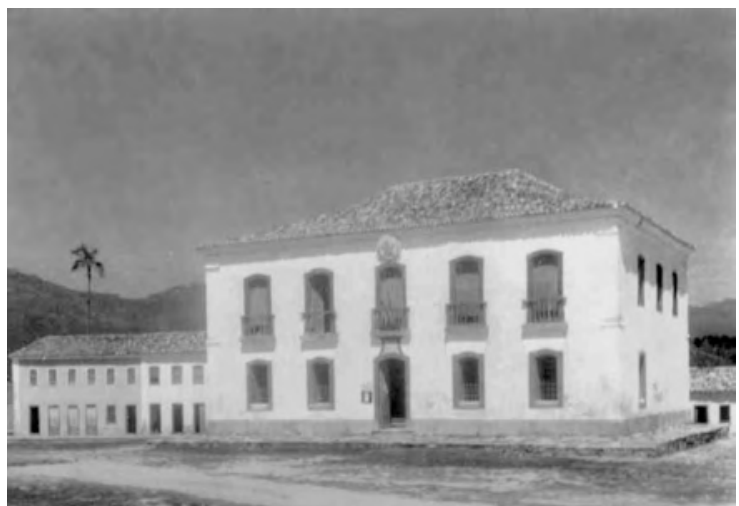

Figura 10 - Rio de Contas - BA. Imagem disponível em http://www.ibge.gov.br. Acesso em 18.09.2010.

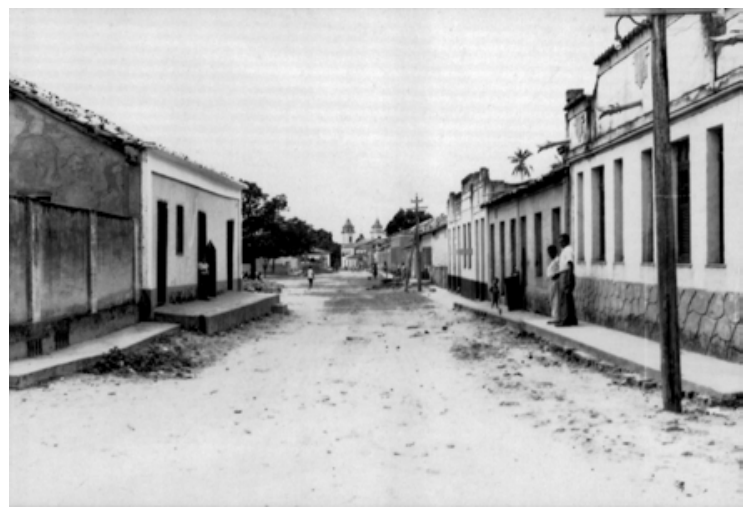

Figura 12 - Caxias - MA. Foto disponível em http://www.ibge.gov.br. Acesso em 11.03.2010.

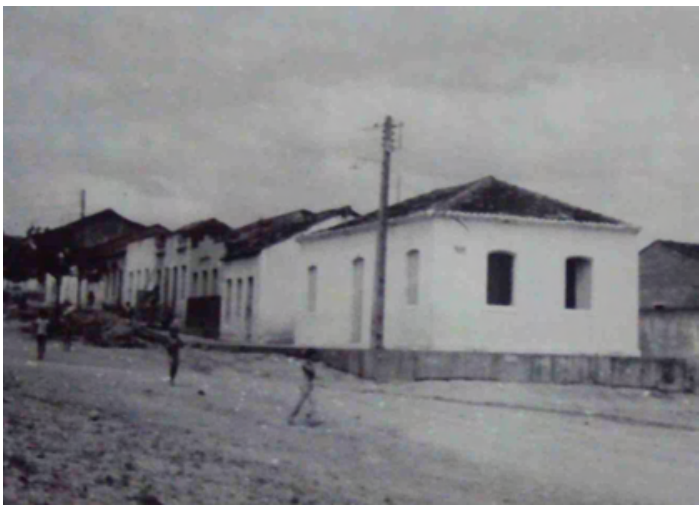

Figura 14 - Vila de Simbres - PE. Em primeiro plano a casa de Câmara e cadeia. Foto cedida pela FUNDARPE -PE.

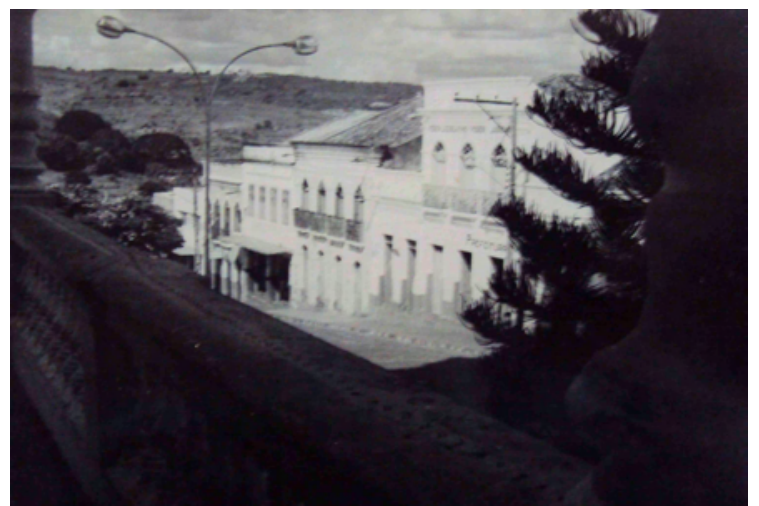

Figura 11 - Triunfo - PE. Foto cedida pela FUNDARPE - PE.

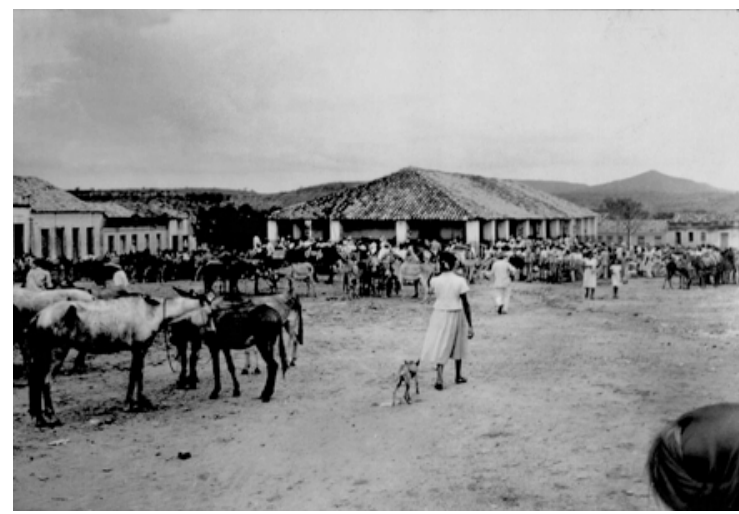

Figura 13 - Regeneração - PI. Foto disponível em http://www.ibge.gov.br. Acesso em 18.09.2010.

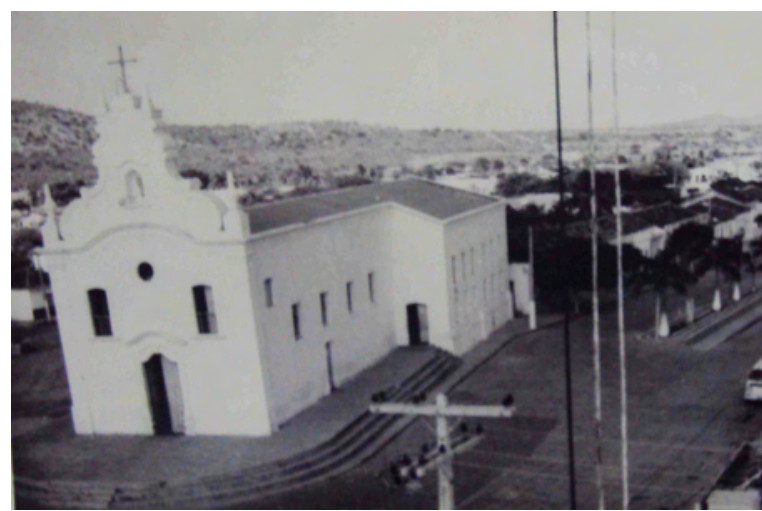

Figura 15 - Santa Maria da Boa Vista - PE. Foto original da FUNDARPE - PE 


\section{O estudo da urbanização do sertão nordestino: um enfoque multidisciplinar}

Segundo Nestor Goulart Reis Filho, o primeiro estudo sistemático do Brasil urbano colonial surgiu em 1936 com a publicação de Sobrados e Mocambos de Gilberto Freyre ${ }^{37} \mathrm{e}$ do ensaio de Sérgio Buarque de Holanda ${ }^{38}$ - Raízes do Brasil -, muito debatido pelos estudiosos do assunto ${ }^{39}$. Até então, a história da vida colonial, como reconhecimento da importância dos padrões urbanísticos estabelecidos naquele período foi se perdendo, no século XIX e no início do século XX. ${ }^{40}$

Um dos pioneiros, estrangeiro até, que deu a sua contribuição ao estudo da urbanização brasileira, fazendo alusão à gênese de suas estruturas intraurbanas, foi Pierre Deffontaines. Em seu boletim geográfico - Como se constituiu no Brasil a rede de cidades ${ }^{41}$ - demarcou a rede urbana brasileira e as implicações envolvidas neste sistema. Na opinião de Fania Fridman, Pierre Deffontaines afirmava que, no Brasil, a unidade de povoamento teria sido a grande propriedade privada, e em face da dispersão rural ser a característica preponderante da organização territorial, os núcleos e o sistema urbano "cerrado" supriram a falta de circulação ${ }^{42}$. Ademais, o pesquisador francês citado elencou as matrizes geradoras dos aglomerados nacionais: reduções religiosas, aglomerações de origem militar, as cidades mineiras, as cidades na estrada, as cidades da navegação, cidades-estação ferroviárias e as bocas de sertão ${ }^{43}$.

Rede urbana colonial foi tratada pelo geógrafo Aroldo de Azevedo ${ }^{44}$ em seu opúsculo Vilas e cidades do Brasil Colonial. Através de mapas correlatos com informações expostas em tabelas, temos um panorama geral do fenômeno urbano desde a instituição do regime das capitanias hereditárias até o alvorecer da independência do Brasil.

\footnotetext{
${ }^{37}$ FREYRE, Gilberto. Sobrados e Mocambos. 8 ed. Rio de Janeiro, Record, 1990. 758 p.

${ }^{38}$ HOLANDA, Sérgio Buarque de. Raízes do Brasil. 26 ed. São Paulo, Cia. das Letras, 1995. 220 p.

${ }^{39}$ REIS FILHO, Nestor Goulart. "Notas sobre a evolução dos estudos de história da urbanização e do urbanismo no Brasil". in Cadernos de pesquisa do LAP. n 29. Jan/Jun. São Paulo, FAU USP, 1999. p. 19.

${ }^{40}$ REIS FILHO, Nestor Goulart. "As principais cidades e vilas do Brasil - importância da vida urbana colonial”. In Oceanos. n41 (Jan/Mar, 2000). Lisboa, Comissão Nacional para as comemorações dos Descobrimentos Portugueses, 2000. p. 61.

${ }^{41}$ DEFFONTAINES, Pierre. Como se constituiu no Brasil a rede de cidades. Boletim geográfico. ${ }^{\circ} 14$. Rio de Janeiro, Conselho Nacional de Geografia - Instituto Brasileiro de Geografia e estatística, 1944. 34 p.

${ }^{42}$ FRIDMAN, Fania. "Breve história do debate sobre a cidade brasileira". in Cidades latino-americanas: um debate sobre a formação de núcleos urbanos. Fania Fridman e Mauricio de Abreu (organizadores). Rio de Janeiro, Casa da Palavra, 2010. p. 13.

${ }^{43}$ DEFFONTAINES, Pierre. Como se constituiu no Brasil a rede de cidades...Opus cit., p. 02 - 16.

${ }^{44}$ AZEVEDO, Aroldo de. Vilas e cidades do Brasil colonial. Ensaio de geografia urbana retrospectiva. Boletim $\mathrm{n}^{\circ}$ 208. Geografia nº11. São Paulo, FFLCH/ USP, 1956. 96 p.
} 
Nossas bases conceituais para o estudo da urbanização do sertão nordestino sedimentam-se em Nestor Goulart Reis Filho e Murillo Marx. O primeiro pelo seu contributo à definição de urbanização como processo social, elaborada em escalas variadas: local, continental e intercontinental ${ }^{45}$. Em Contribuição ao estudo da evolução urbana do Brail (1500 - 1720) o autor atribui a fundação da rede de vilas e cidades brasileiras como encargo dos administradores coloniais, representantes direto do monarca luso. A urbanização do Brasil colonial foi controlada pela Metrópole e seus agentes:

(...) nossa preocupação foi demonstrar que a prática de implantação e desenvolvimento do sistema urbano e do urbanismo coloniais destacou-se sempre e necessariamente das diretrizes da prática urbanizadora da Metrópole e de sua política colonizadora. Ou seja, as diretrizes oficiais sempre serviram para controlar o processo de urbanização e mantê-lo dentro das linhas e critérios prioritários da metrópole mas a realidade sempre foi muito mais complexa, dando margem a iniciativas autônomas dos colonos e ao aparecimento de soluções originais ${ }^{46}$.

Murillo Marx nos legou um outro olhar, respaldado na união entre Igreja e Estado. Como ele mesmo esclareceu na introdução de seu Cidades no Brasil, terra de quem ${ }^{47}$ :

No caso brasileiro e no que tange à constituição de sua paisagem, um aspecto institucional basilar tem sido negligenciado de maneira surpreendente: a relação Estado/Igreja. Enquanto nunca houve uma codificação colonial portuguesa, as normas e procedimentos eclesiásticos eram claramente estabelecidos. As implicações urbanísticas desse fato podem ser decisivas, pois às vagas determinações civis contrapunham-se recomendações expressas do clero que interferiam no desenho urbano. ${ }^{48}$

A respeito das investigações voltadas ao sertão nordestino, podemos dizer que um marco referencial se trata do ensaio de Paulo T. Barreto - O Piauí e a sua arquitetura ${ }^{49}$. Nessa obra, o arquiteto expôs as tipologias arquitetônicas das moradias piauienses. Ateve-se,

\footnotetext{
${ }^{45}$ REIS FILHO, Nestor Goulart. Contribuição ao estudo da evolução urbana do Brasil (1500 - 1720). 2 ed. São Paulo, Pini, 2000. p. 200.

${ }^{46}$ REIS FILHO, Nestor Goulart. Contribuição ao estudo da evolução urbana do Brasil...Opus cit., p. 200.

${ }^{47}$ MARX, Murillo. Cidades no Brasil, terra de quem? São Paulo, Edusp, 1991. 143 p.

${ }^{48}$ MARX, Murillo. Cidades no Brasil, terra de quem? ... Opus cit., p. 11.

49 BARRETO, Paulo T. "O Piauí e a sua arquitetura". In Arquitetura civil I. Revista do Serviço do Patrimônio Histórico e Artístico Nacional. vol 2. Rio de Janeiro, MEC, 1938. p. 191 - 219.
} 
também, aos planos reguladores do século XVIII destinados às novas vilas da capitania de São José do Piauí, influenciados pelo iluminismo pombalino:

Essas vilas e cidades não foram crescendo ao bel-prazer; logo de início, obedeceram a um plano. (...) Assim é que as cidades do Piauí, surpreendem pelo número de praças, pela unidade arquitetônica, pela largura das ruas e pelo seu bom traçado. Essas cidades que, desde então, vêm realmente crescendo, se nos apresentam como se fossem delineadas hoje, e em observância aos bons princípios. Essas cidades já nasceram urbanizadas. (...) De fato, aquelas instruções foram sempre seguidas: assim foi que, para a criação da vila de Parnaíba, aos 20 de dezembro de 1762, o governador remetia à câmara do senado "uma planta para regular o arruamento da vila, e baixou depois as mais terminantes e ameaçadoras ordens no sentido de reativar-se a edificação de casas e tornar-se efetivo o estabelecimento da nova vila no lugar determinado. ${ }^{50}$

Menção às fundações sertanejas de Icó, Monte - Mor o Novo da América e Icó fez a americana Roberta Marx Delson ${ }^{51}$. Segundo a especialista, a criação de aglomerados teve a participação direta da Coroa portuguesa, dentro da política de controle territorial dos seus domínios americanos. Tentou rebater a teoria de Sérgio Buarque de Holanda, acerca do desleixo vinculado à fisionomia das vilas brasileiras, enfatizando os ideais estéticos iluministas, isto é, regularidade foi traduzida como progresso e ordenamento social ${ }^{52}$.

Na década de oitenta do século XX, o sociólogo Luiz Mott ${ }^{53}$ dedicou uma séria pesquisa à capitania do Piauí. Através da transcrição de documentos setecentistas (como a descrição da capitania segundo o ouvidor Antônio José Moraes Durão) a paisagem das vilas piauienses foram narradas e expostas as suas deficiências urbanas e institucionais. Além desse foco, o autor enumera, através de tabelas, o quantitativo de fazendas de gado, população e moradias existentes ali durante a colônia. Outras questões foram abordadas: absenteísmo dos fazendeiros, tribos indígenas do Piauí e a economia do gado. Na mesma

\footnotetext{
${ }^{50}$ BARRETO, Paulo T. “O Piauí e a sua arquitetura”...Opus cit., p. 194, 197.

${ }^{51}$ DELSON, Roberta Marx. Novas vilas para o Brasil - colônia. Planejamento espacial e social no século XVIII. Brasília, Editora Alva-ciord., 1997.

${ }^{52}$ DELSON, Roberta Marx. Novas vilas para o Brasil - colônia...Apud FRIDMAN, Fania. "Breve história do debate sobre a cidade brasileira”...Opus cit., p. 20.

${ }^{53}$ MOTT, Luiz R. B. O Piauí colonial: população, economia e sociedade. Teresina, Projeto Petrônio Portela, 1985. 144 p.
} 
linha que Mott, a historiadora Miridan Knox ${ }^{54}$ levantou dados sobre a população, economia e sociedade das vilas do Piauí no século XIX.

Todavia, os estudos centrados na urbanização do sertão nordestino, pormenorizados em algumas capitanias, se deram em finais da década de noventa do século passado e início deste. Olavo Pereira da Silva Filho em seu belo trabalho de três volumes intitulado Carnaúba, pedra e barro na Capitania de São José do Piahuy $y^{55}$ - estudou a urbanização do Piauí e as fazendas de gado desse território. Clovis Ramiro Jucá Neto investigou a urbanização da capitania do Ceará setecentista em sua tese de doutorado - A urbanização do Ceará setecentista - as vilas de Nossa Senhora da Expectação do Icó e de Santa Cruz do Aracati $^{56}$. Com respeito à arquitetura rural da capitania do Rio Grande do Norte, Nathália Diniz $^{57}$ pesquisou e inventariou, para sua dissertação de mestrado, as fazendas de gado situadas na região do Seridó.

Mesmo antes desses autores e investigadores, o sertão pastoril e do couro foi divulgado pela literatura brasileira. Euclides da Cunha, observador ocular da guerra de Canudos e da sociedade sertaneja, expôs em Os sertões ${ }^{58}$ dados concernentes à cultura, religiosidade, economia, geografia, natureza, política e formação social do oeste nordestino. Parte deste escritor as hipóteses de "insulamento" e "religião mestiça" como peculiares à sociedade sertaneja.

Há um bom número de romances, novelas e poemas que narram a dura vida do homem do sertão, a criação de gado, a seca, o cotidiano, a relação de poder entre coronel e subjugados, a fome...Entre esses podemos citar Guimarães Rosa ${ }^{59}$ em Grande sertão: veredas; Raquel de Queiroz ${ }^{60}: O$ quinze; José de Alencar ${ }^{61}: O$ sertanejo; João Cabral de Melo Neto: Morte e vida Severina ${ }^{62}$; Ariano Suassuna ${ }^{63}$ : Romance da pedra do reino e o

\footnotetext{
${ }^{54}$ KNOX, Miridan Britto Falci. O Piauí na primeira metade do século XIX. Teresina, Projeto Petrônio Portela, 1992. $129 \mathrm{p}$

${ }^{55}$ SILVA FILHO, Olavo Pereira da. Carnaúba, pedra e barro na Capitania de São José do Piahuy. Vol 1 (estabelecimentos rurais), vol 2 (arquitetura urbana), vol. 3 (Urbanismo). Belo Horizonte, Rona, 2007.

${ }^{56}$ NETO, Clovis Ramiro Jucá. A urbanização do Ceará setecentista - as vilas de Nossa Senhora da Expectação do Icó e Santa Cruz do Aracati. Tese de doutorado. Salvador, UFBA, 2007. 531 p.

${ }^{57}$ DINIZ, Nathália Maria Montenegro. Velhas fazendas da Ribeira do Seridó. Dissertação de mestrado. São Paulo, FAU USP, 2008. 205 p.

${ }^{58}$ CUNHA, Euclides da. Os sertões. 3 ed. São Paulo, Martin Claret, 2009. 637 p.

${ }^{59}$ ROSA, Guimarães. Grande sertão: veredas. Rio de Janeiro, Nova Fronteira, 2006. 553 p.

${ }^{60}$ QUEIROZ, Raquel de. O quinze. São Paulo, Cia. Editora Nacional, 1942. 217 p.

${ }^{61}$ ALENCAR, José de. O sertanejo. São Paulo, Ática, 2004. 247 p.

${ }^{62}$ MELO NETO, João Cabral de. 4 ed. Rio de Janeiro, Editora Fronteira, 2002. 163 p.

${ }^{63}$ SUASSUNA, Ariano. Romance da pedra do reino e o príncipe do Sangue do Vai - e - volta. 7 ed. Rio de Janeiro, Livraria José Olympio, 2005. 754 p.
} 
príncipe do Sangue do Vai - e - volta e Patativa do Assaré em seus ritmados cordéis. Mesmo com alusões historicamente comprovadas, o poeta e o escritor são soberanos no reino da fantasia, cabendo-nos julgar o real do fantástico.

Josué de Castro, em 1946, lançou o seu Geografia da fome ${ }^{64}$, demarcando os espaços da fome no cenário nacional. O terceiro capítulo é dedicado a área do sertão nordestino. Fora das épocas de estiagem, viva esta gente em perfeito equilíbrio alimentar, num estado de nutrição bastante satisfatório ${ }^{65}$. Satisfatório porque elabora uma dieta à base de proteínas da carne e do leite bovino, mesclado com os carboidratos do milho e arroz ${ }^{66}$. Apesar de ser um trabalho voltado às questões nutricionais, averiguamos a influência da pecuária colonial em outras instâncias da cultura sertaneja.

Vale mencionar ainda que o trabalho tomou outros autores como referenciais, entre esses destacamos os trabalhos do geógrafo Milton Santos ${ }^{67}$, dos historiadores franceses Bernard Lepetit ${ }^{68}$ e Jacques Le Goff ${ }^{69}$. Por último, Giulio Carlo $\operatorname{Argan}^{70}$ que viu a cidade como um elemento material da cultura, dotado de senso artístico e de significações próprias.

Com a leitura dos trabalhos sobreditos, queremos evitar juízos sem base ou preconceitos que, sobremaneira, estão ultrapassados. Melhor, apoiamos a idéia de Ramón Gutierréz onde propõe um enfoque multidisciplinar e com perspectivas metodológicas variadas, sem restringir-se a visões parciais que poderiam empobrecer os resultados ${ }^{71}$. Ou como sublinhou Bernard Lepetit sobre o intercâmbio entre diferentes disciplinas: elas participam do mesmo tipo de conhecimento e que entre elas as inter-relações são múltiplas, $e$ os limites, jamais estanques. ${ }^{72}$ Junta-se isso ao que os franceses chamam de leitura em diagonal, aderimos às idéias que nos interessam e/ou refutamos àquelas que não se adaptam ao contexto de nosso trabalho.

\footnotetext{
${ }^{64}$ CASTRO, Josué de. Geografia da Fome: o dilema brasileiro - pão ou aço. 6 ed. Rio de Janeiro, Civilização Brasileira, 2006. 318 p.

${ }^{65}$ CASTRO, Josué de. Geografia da Fome...Opus cit., p. 158.

${ }^{66}$ CASTRO, Josué de. Geografia da Fome...Opus cit., p. 178.

${ }^{67}$ SANTOS, Milton. A natureza do espaço: técnia e tempo, razão e emoção. 4 ed. 5 reimpr. São Paulo, Edusp, $2009.384 \mathrm{p}$.

${ }^{68}$ LEPETIT, Bernard. "Proposições para uma prática restrita da interdisciplinaridade". In Por uma nova história urbana. Seleção de textos, revisão critica e apresentação Heliana Salgueiro. São Paulo, Edusp, 2001. 323 p.

${ }^{69}$ LE GOFF, Jacques. O apogeu da cidade medieval. São Paulo, Martins Fontes, 1992. 235 p.

${ }^{70}$ ARGAN, Giulio Carlo. História da arte como história da cidade. 5 ed. São Paulo, Martins Fontes, 2005. $280 \mathrm{p}$.

${ }^{71}$ GUTIÉRREZ, Ramón. "Reflexiones para una Metodologia de Análisis del Barroco Americano. In Simposio Internacionale Sul Barroco Latino Americano. Roma, 1980.

${ }^{72}$ LEPETIT, Bernard. "Proposições para uma prática restrita da interdisciplinaridade". In Por uma nova história urbana...Opus cit., p. 31- 44.
} 
Para responder às premissas expostas e a metodologia aplicada nesta pesquisa de mestrado, desejamos contribuir ao estudo da urbanização de áreas consideradas "periféricas" à colonização lusitana e, portanto, preencher certos hiatos que persistem na compreensão do fenômeno urbano colonial brasileiro.

Sendo assim, estruturamos esta dissertação em duas partes compostas de seis capítulos. A primeira parte envolve do primeiro ao terceiro capítulos. Serão tratadas as questões historiográficas de conhecimento do território, devassamento, povoamento, fixação do homem à terra e economia responsável por esses pressupostos. No primeiro capítulo - $\boldsymbol{O}$ Sertão - pontuamos os motivos da conquista do interior nordestino. Ao nosso ver, o conhecimento da região, nos anos primeiros da colonização do território semi-árido, abarcou dois motes: a procura de minérios e a necessidade de mão-de-obra escrava indígena. Inspecionando o lugar, vendo a possibilidade de encontrar ouro e prata, os sertanistas vão desmistificando o sertão. Além disso, com o avanço da economia açucareira e para cumprir os desígnios do padroado real, nativos eram trazidos para o litoral com o intuito de serem catequizados e usados nos engenhos. Estreitou-se a relação entre interior x litoral. Ainda neste capítulo, demonstramos como o sertão foi representado e entendido pelas cartografias da época, sem esquecer do viajante estrangeiro que, "ao primeiro olhar", narraram uma sociedade e meio natural desconhecidos.

O segundo capítulo - Curral de reses - dedicamos aos caminhos do gado e à pecuária extensiva, leit motiv da urbanização do sertão nordestino. A dinâmica da economia do gado e sua particularidade do mercado interno colonial são demonstrados por mapas elaborados a partir de fontes secundárias e primárias, obtidas nos órgãos elencados anteriormente.

Missões religiosas, o padroado real, a rede eclesiástica de freguesias e a rede urbana de vilas e cidade mostraremos no terceiro capítulo - Curral de almas. Listamos as principais ordens religiosas que atuaram no sertão nordestino: capuchinhos, jesuítas e oratorianos, sempre olhando sua interferência na urbanização do território. O controle geopolítico da Metrópole portuguesa, principiado em fins dos Seiscentos, e a união entre Coroa e Mitra são indicados na participação desses através da criação de aglomerados urbanos estrategicamente locados. Aqui exporemos o pouco caso dado pelas autoridades sertanejas às leis estabelecidas no Reino e transplantadas para a colônia. 
$\mathrm{Na}$ segunda parte entramos nos assuntos diretamente relacionados com o desenho e o desenvolvimento intraurbano. Como estudos de caso elegemos a cidade de Oeiras (PI), por ser o município situado no topo da hierarquia da rede urbana, e as vilas de índios cearenses Monte - Mor o Novo da América e Crato. À essas duas últimas, veremos a atuação do Diretório dos Índios, ou melhor, da política pombalina no que dizia respeito à formação de sua traça urbana.

Assim, no quarto capítulo - O Desenho - questionaremos a materialização da dialética defendida: curral de reses x curral de almas. Em miúdos: apontaremos que muitos dos aglomerados sertanejos crescem e se expandem ao longo dos caminhos coloniais, desenvolvendo uma fisionomia retilínea, linear ou alongada. Listamos alguns exemplos desse caso, as atuais cidades de Floresta (PE), Tauá (CE) e Mucugê (BA). Outros assentamentos humanos são formatados a partir da praça - zona central, de atração e demarcação das ruas. A praça surge, principalmente, por influência de normas pias, por exemplo, as "Constituçoens Primeyras do Arcebispado da Bahia", como também por cartas régias em forma de lei homologadas no curso dos Setecentos.

No quinto capítulo - Três caminhos, uma cidade - apresentaremos um panorama da evolução urbana da cidade de Oeiras. Essa passou pelos estágios defendidos por Murillo Marx: freguesia »vila » cidade. Ao longo de sua urbanização, notamos que praça, célula mater, foi a geratriz de sua expansão e zoneamento urbanos. Recebendo o foro de vila, em 1711, agora vila do Mocha, apresentou carências de cunho institucional, travando, de certo modo, o seu devido progresso físico. No reinado de D. José I, quando se confirmou o predicamento de cidade, Oeiras passa pelo que chamamos hoje de "operação urbana", adaptando o seu traçado dos estágios anteriores às diretrizes estéticas de regularidade, formosura e harmonia. Conseqüentemente, temos um desenho híbrido, agregando estruturas pré-definidas com as que seriam edificadas. Chegamos ao século XIX, obras públicas foram postas em pauta na câmara para o melhoramento de sua paisagem, urbanidade e saúde pública.

Por fim, o sexto capítulo - O Lugar do índio - disserta a urbanização de duas vilas cearenses, antes missões religiosas: Monte - Mor o Novo da América (missão da Palma) e vila Real do Crato (missão do Miranda). Na era pombalina, estes dois núcleos de índios são elevados à categoria de freguesia e, logo em seguida, ao status de vila. Monte - Mor o Novo da América, aglomerado conhecido pelos especialistas pelo seu Auto de Ereçcão, teve um 
plano urbano estabelecido a priori, porém, como veremos, os executores do projeto não seguiram o traço normatizado, conformando o desenho à estruturas existentes no lugar, por exemplo, estradas criadas antes da fundação do município. Entretanto, o resultado final é uma malha que valoriza a praça, a regularidade e linearidade das datas de terra concedidas. Em Crato, elevada à vila em 1764, sua carta régia foi clara quanto ao desenho pretendido. Ao que parece, as autoridades envolvidas nos trabalhos de demarcação não seguiram as normatizações do documento oficial. Contudo, somente em 1778, a vila sofreu intervenção e remodelação de sua paisagem, obras dirigidas pelo ouvidor José da Costa Dias Barros, adquirindo forma urbana à "moda" pombalina.

Curral de reses, curral de almas é um jogo dialético de dependência recíproca entre os caminhos trilhados pelo gado no sertão nordestino e a congregação de nativos e sertanejos em lugares determinados para sua fixação e civilização, visando revesti-los de uma personalidade delegada pelo sistema de viver colonial: eclesiástico e civil. 


\section{PRIMEIRA PARTE}

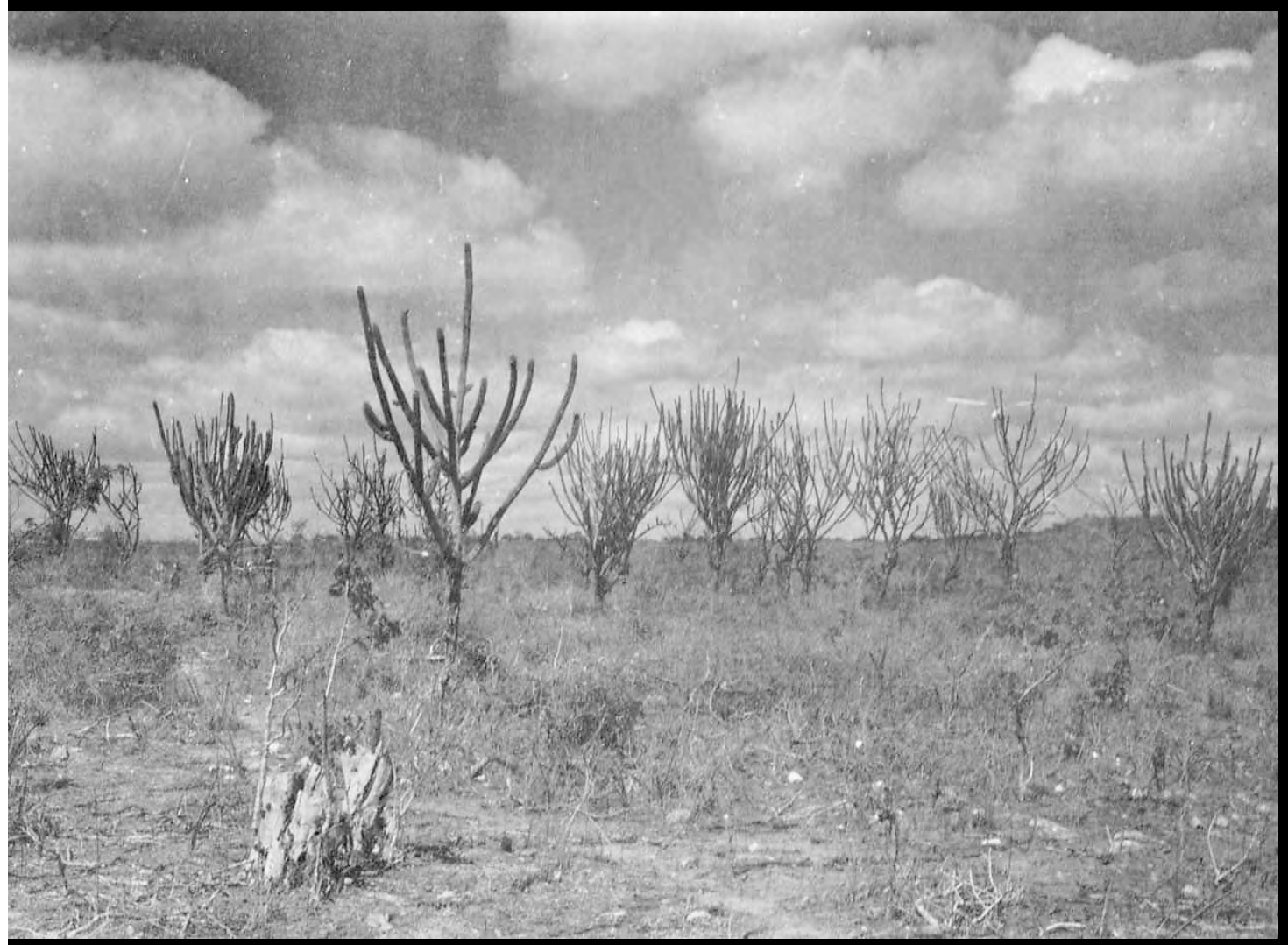

O SERTÃO 


\section{CAPÍTULO 01 - O SERTÃO}

O meu nome é Severino, como não tenho outro de pia.

Como há muitos Severinos, que é santo de Romaria, deram então de me chamar

Severino de Maria

Como há muitos Severinos com mães chamadas Marias, fiquei sendo o da Maria do finado Zacarias.

Mas isso ainda diz pouco: há muitos na freguesia, por causa de um coronel que se chamou Zacarias e que foi o mais antigo senhor desta sesmaria.

Somos muitos Severinos iguais em tudo e na sina: a de abrandar estas terras suando-se muito em cima, a de tentar despertar, terra sempre mais extinta,

a de querer arrancar alguns roçados da cinza. Mas, para que me conheçam melhor Vossas Senhorias e melhor possam seguir a história da minha vida, passo a ser o Severino que em vossa presença emigra.

João Cabral de Melo Neto, Morte e vida Severina 


\subsection{Miragens e delírios do ouro e da prata}

Quando no século XVII, as descobertas de minas determinaram a atração do interior sobre o litoral, os aventureiros que ao norte investiam com o sertão, demandando as serras da Jacobina, arrebatados pela miragem das minas de prata [grifo nosso] $e$ rastreando o itinerário enigmático de Belchior Dias, ali estacionavam longo tempo. A serra solitária - a Piquiaraçã dos roteiros caprichosos -, dominando os horizontes, norteava-lhes a marcha vacilante. $^{1}$

Assentada a cruz - como símbolo representativo do poder eclesiástico da Igreja Católica e do reino de Portugal - no lugar chamado Terra de Santa Cruz, veio com este ato não somente a introdução da cristandade aos pagão da nova terra, agregou, para aqueles anos iniciais e posteriores de colonização, a inclusão da terra brasilis na política mercantilista européia.

Coube, nos tempos primeiros do domínio português na América, aos cobiçadores de produtos naturais e especiarias o dever de explorar a terra. A Coroa lusa pouco se interessou em efetivar a posse dos seus domínios, basicamente por dois motivos: o primeiro dizia respeito à pouca utilidade dos produtos brasileiros nos mercados europeus e, segundo, pela presença de uma população autóctone rude em sua essência² ${ }^{2}$.

O escrivão enviado junto com as naus de Pedro Álvares de Cabral, Pero Vaz de Caminha, descrevendo às autoridades portuguesas sobre os fatos e feitos envoltos na conquista, assegurou sem rodeios, o verdadeiro objetivo da empreitada: (...)N'ella até agora não podemos saber que haja ouro, nem prata, nem cousa de metal, nem ferro lhe vimos. ${ }^{3}$ Esta citação ensejou os sabores desejados pelos portugueses no lado oriental da linha virtual do Tratado de Tordesilhas: ouro e prata, metais que os enobrecessem perante os outros reinos do Velho Mundo. É certo o comentário de Raymundo Faoro quando disse que o descobridor

\footnotetext{
${ }^{1}$ CUNHA, Euclides da. Os sertões. São Paulo, Editora Martins Claret, 2002. p. 178.

${ }^{2}$ FAORO, Raymundo. Os donos do poder: formação do patronato político brasileiro. 10 ed. São Paulo, Globo, 1996. p. 02.

${ }^{3}$ ABREU, Capistrano. Capítulos de história colonial, 1500-1800. 7.ed.rev. São Paulo, Publifolha, 2000. pp. 5354.
} 
antes de ver a terra, antes de ver as gentes, antes de sentir a presença da religião, queria saber do ouro e da prata. ${ }^{4}$

A decepção inicial não fatigou os conquistadores em suas investidas e arremetidas. Estavam contaminados pela busca de preciosidades minerais. Viam somente os efeitos de uma miragem que ulteriormente possibilitou entradas e penetrações aos sertões do Brasil, desde os Quinhentos chegando até os Setecentos. ${ }^{5}$

\section{(...) na fantasia, sonhando, imaginando ou estudando, se vão vendo, tratando e pelejando. ${ }^{6}$}

Uma análise mais acurada dos fenômenos que envolveram os primeiros contatos dos portugueses com a terra desprovida de prata, trigo, gado e especiarias, com uma população nativa pobre, ignorante e simples ${ }^{7}$, revela o descaso junto à política colonizadora. Após o descobrimento e, a partir de 1504, torna-se freqüente a presença de traficantes de variadas nacionalidades ${ }^{8}$ : franceses, holandeses, espanhóis e ingleses estão no rol dos mais conhecidos. Os trâmites envolvidos entre estrangeiros e índios estimularam os detentores legais do Brasil a povoá-lo, receosos de perdê-lo para outras potências ultramarinas da época.

Em 1549, quando é criado o governo geral, a obsessão do colonizador, fecundada pelas expedições de busca ao ouro, muitas delas apoiadas pela nova administração, fez aumentar a penetração ao interior do Brasil, alargando as fronteiras e as terras lusitanas ${ }^{9}$. Aqueles que se fixaram e desbravaram o litoral são repelidos de conhecer o interior, pelo temor das lendas divulgadas pelos catecúmenos, baseadas em monstros mitológicos, e habitados por índios guerreiros e antropofágicos. Em virtude disso, os conquistadores estancam-se junto ao mar, estreitando suas relações, ou melhor, familiarizando-se com os silvícolas integrado com o território desde muito tempo.

\footnotetext{
${ }^{4}$ FAORO, Raymundo. Os donos do poder..., Opus cit., p. 102.

${ }^{5}$ Nesta dissertação de mestrado enfatizaremos o conhecimento do sertão nordestino pelos agentes colonizadores. Entretanto, se for necessário pontuar outras regiões do Brasil colonial, faremos como método acessório para o entendimento do processo urbanizador do interior nordestino.

6 "Os Lusíadas", X, 150. In HOLANDA, Sérgio Buarque de. Visões do Paraíso. São Paulo, Companhia das Letras, 2010. p. 48.

${ }^{7}$ FAORO, Raymundo. Os donos do poder...,1996, Opus cit., p.102.

${ }^{8}$ FAORO, Raymundo. Os donos do poder..., 1996, Opus cit., p.106.

${ }^{9}$ LEITE, Serafim. História da Companhia de Jesus no Brasil. Tomo II. Lisboa, Livraria Portucália, 1938. p. 172.
} 
Outros, encorajados pela descoberta do Novo Mundo, se motivaram em procurar um fantasioso lugar, distante do litoral, paradisíaco, carregado de tesouros e metais preciosos. Crer-se na existência de um lago fechado, sem acesso, que surge no interior da colônia e que assumiu as nomeações: Dorado de Vupubaçu ou Paraupava. Acreditou-se que desse lugar nasciam os principais rios da colônia e seus afluentes, entre esses, o rio de São Francisco, Parnaíba, Tocantins e Paraná. ${ }^{10}$ Um mapa criado pelo cartógrafo holandês Joan Blaeu, datado provavelmente da primeira metade do século XVII, indica no centro da colônia a existência deste lago mítico [figura 16].

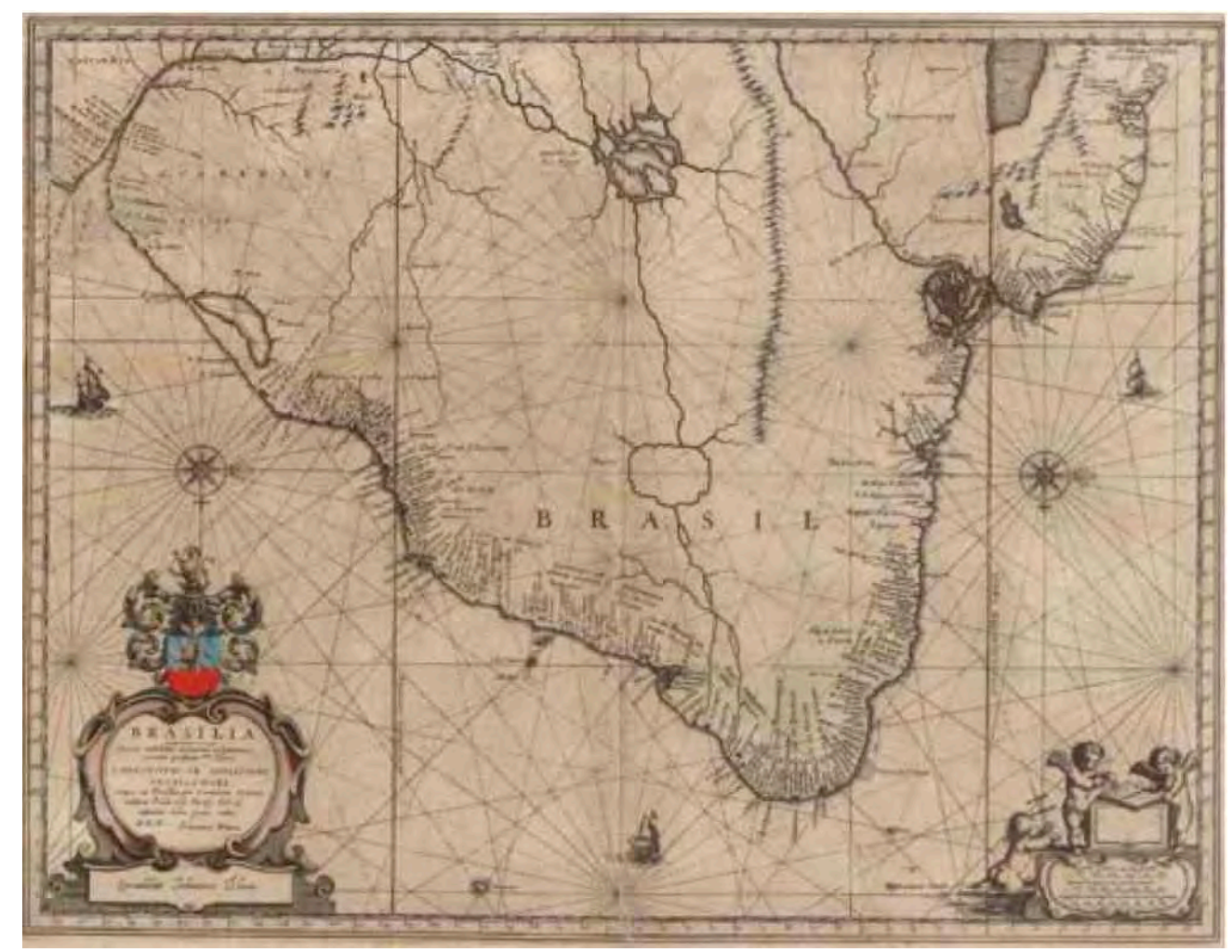

Figura 16 - BLEAU, Joan. Brasilia. Disponivel em http://www.fbn.br. Acesso em 18.12.2010.

\footnotetext{
${ }^{10}$ BOAVENTURA, Deusa Maria Rodrigues. Urbanização em Goiás no séculos XVIII. Tese de doutorado. Faculdade de Arquitetura e Urbanismo da Universidade de São Paulo (FAU - USP), 2007. p. 39.

Ainda sobre esta questão, Pero Magalhães de Gandavo, apontou que he publica fama entre elles que ha huma lagoa mui grande no interior da terra donde procede o Rio de Sam Francisco, de que já tratei, dentro da qual dizem haver algumas ilhas e nellas edificadas muitas povoações, e outras orredor della miu grandes onde tambem ha muito ouro, e mais quantidade, segundo se afirma, que em nenhuma outra parte desta Provincia. Ver GANDAVO, Pero Magalhães de. Tratado da terra do Brasil; História da província de Santa Cruz. São Paulo, Edusp, 1980. p. 145.
} 
Para Raymundo Faoro a corrida fabulosa e imaginária às minas de ouro, ao Paraupava, esteve extasiada com o desejo de fazer, de criar a realidade, estando na base da conquista do sertão, refletindo o escopo de rasgar o Tratado de Tordesilhas, sob o qual não seria possível manter o Brasil. ${ }^{11}$

O rio São Francisco, meio fluvial de penetração utilizado desde o século XVI, foi alvo de notícias fantásticas da existência, em seu leito e regiões limítrofes, do El Dorado. Urbino Viana, citando carta de Felippe de Guilhen ao El-rei Dom João III, opinou que no rio havia uma serra que resprandece muito e que he muito amarella da qual serra vão ter ao dito Rio pedras da mesma cor a que nós chamamos pedaço de ouro. ${ }^{12}$ Já Luiz Alberto Moniz Bandeira nos informa que, a propósito de descobrir essas regiões mineiras da bacia sanfranciscana, foram animados, em 1551, o governador geral do Brasil, Tomé de Sousa, em atenção e cumprimento às ordens de D. João III. ${ }^{13}$

Particular personagem dessas aventuras aos sertões da capitania da Bahia de Todos os Santos, através do rio São Francisco, fora Belchior Dias Moréia, alcunhado de Muribeca. Por volta de 1593, iniciou sua jornada para as serras e caatingas, partindo das margens do rio Real, onde possuía fazendas de criação de gado. Seu roteiro focalizou as serras da Jacobina e Pedra Furada. ${ }^{14}$ Pelo rio São Francisco alcançou a vertente da chapada da Diamantina, ausentando-se por oito anos dos centros urbanos litorâneos. Somente em 1601, o Muribeca, julgado morto pelos seus familiares e conhecidos, retornou à Bahia com amostras minerais. ${ }^{15}$ Entretanto, sua rota de conhecimento do sertão baiano nunca foi revelada, levando consigo, em sua memória, ao leito de morte. Essa atitude de não representar, mesmo em toscos mapas, o roteiro utilizado para chegar às minas, garantia aos sertanistas a autoridade sobre as jazidas supostamente achadas.

Com o intuito de obter honras e mercês do monarca Felipe II, Belchior Dias Moréia embarcou para Espanha, sendo congratulado em Madri pelas notícias acerca do território sertanejo e dos eventuais minérios. Recebeu da Coroa um morgadio de trinta léguas, semelhante a uma capitania hereditária, detendo autoridade absoluta e poder soberano em

\footnotetext{
${ }^{11}$ FAORO, Raymundo. Os donos do poder: formação do patronato..., Opus cit., p.157.

${ }^{12}$ Carta de Felippe de Guilhen a El-rei D. João III, datada da Bahia aos 20 de julho de 1550. Ver VIANA, Urbino. Bandeiras e sertanistas baianos. São Paulo, Companhia Editora Nacional, 1935.p. 127-128.

${ }^{13}$ BANDEIRA, Luiz Alberto Moniz. O feudo: a Casa da Torre de Garcia d'Ávilla - da conquista dos sertões à independência do Brasil. Rio de Janeiro, Civilização Brasileira, 2000. p. 123.

${ }^{14}$ BANDEIRA, Luiz Alberto Moniz. O feudo: a Casa da Torre de Garcia d'Ávilla...Opus cit., p. 125.

${ }^{15}$ BANDEIRA, Luiz Alberto Moniz. O feudo: a Casa da Torre de Garcia d'Ávilla...Opus cit., p. 125.
} 
seus novos domínios. Além desses, foram ofertados uma renda de 3.000\$000 cruzados das referidas minas e o hábito da Ordem de Cristo. ${ }^{16}$

Outras autoridades coloniais viam a saga do ouro e prata nos sertões do Nordeste e, até de outras capitanias da colônia, como uma utopia, um ideal intangível. O governador geral do Brasil na era dos felipes, D. Diogo de Menezes, escrevendo ao rei, reconheceu que as verdadeiras minas do Brasil são açúcar e pau-brasil ${ }^{17}$. Economias de valor perante o mercado europeu. Requeriam poucos investimentos da fazenda real, se comparadas com os gastos e honras ambicionados pelos sertanistas, através de suas incursões aos sertões da colônia. Os delírios causados pelas miragens do El dorado sertanejo eram explorados habitualmente por pandilhas que plantavam as amostras de minério, com o fim de obter graças reais prometidas aos que as encontrassem. ${ }^{18}$

Vale ressaltar que, outras partes do interior baiano, já em fins do século XVII, passaram pelo rush da procura do ouro e da prata. Os rios de Contas e Brumado são alguns dos cursos fluviais onde mineradores estabeleceram residência. Consequentemente, povoações e vilas foram criadas ao longo destes caminhos do ouro sertanejo. Para citar como exemplos temos a vila de Nossa Senhora do Rio de Contas, elevada a esta categoria em 1724, e a vila de Rio de Contas (1745) [figura 17].

\footnotetext{
${ }^{16}$ BANDEIRA, Luiz Alberto Moniz. O feudo: a Casa da Torre de Garcia d'Ávilla...Opus cit., p. 127.

${ }^{17}$ BANDEIRA, Luiz Alberto Moniz. O feudo: a Casa da Torre de Garcia d'Ávilla...Opus cit., p. 126.

${ }^{18}$ PUNTONI, Pedro. A guerra dos Bárbaros: povos indígenas e a colonização do sertão do Nordeste do Brasil, 1650 - 1720. São Paulo, Hucitec, 2002. p. 31.
} 


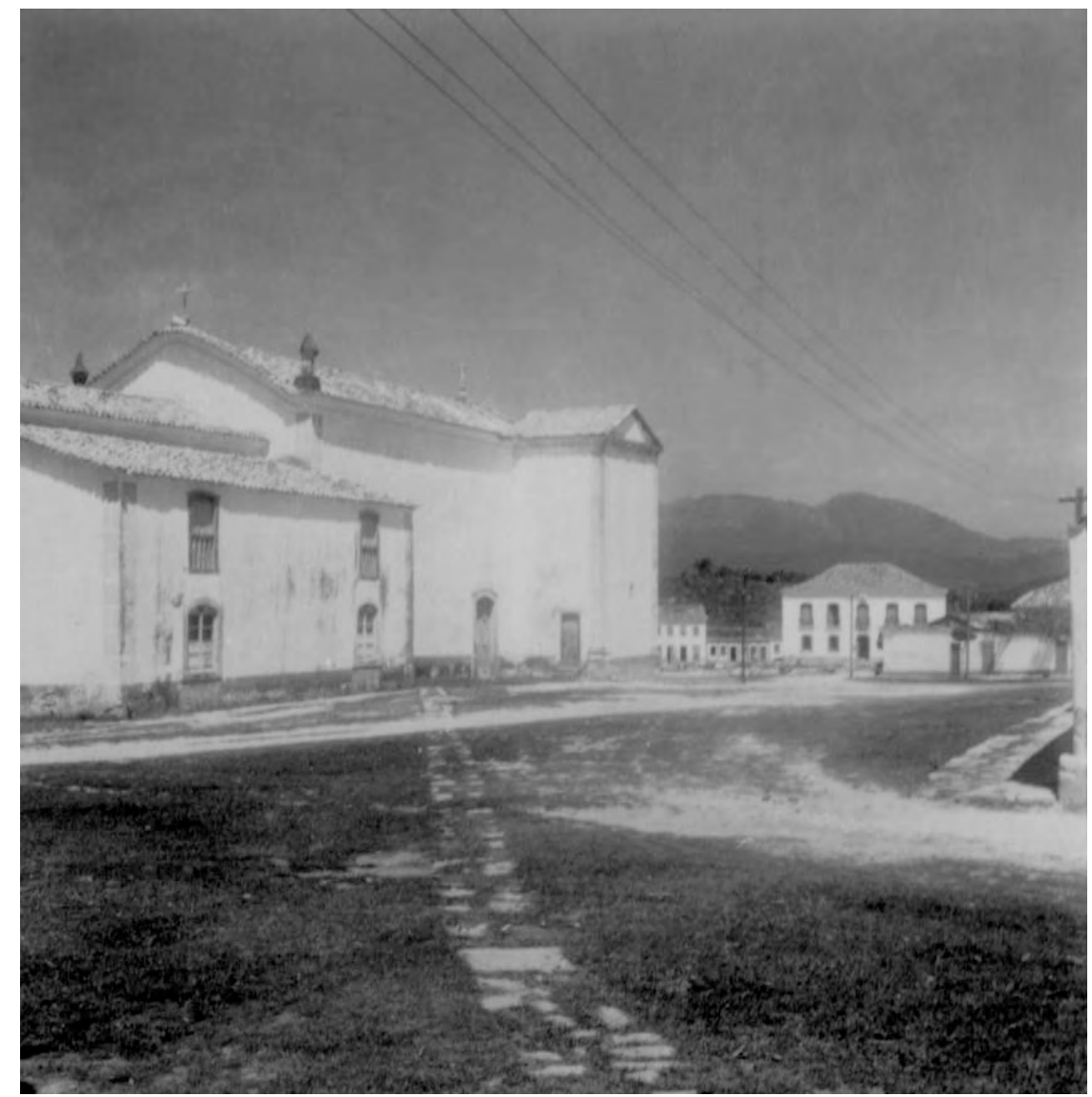

Figura 17 - Rio de Contas, vila elevada em 1745 por ordens do rei D. João V. Ao fundo Casa de Câmara e Cadeia e, de costas para o leitor, a igreja matriz do Santíssimo Sacramento. Foto disponível em http://www.ibge.gov.br. Acesso em 25.08.2010.

As atividades de extração nas jazidas baianas das jacobinas e em Rio de Contas fizeram com que a metrópole julgasse tais localidades de fácil acesso ao litoral, expondo, portanto, os produtos encontrados ao assalto de traficantes que viviam soltos pelo sertão, causando tumultos e desordens ${ }^{19}$. Com isso, foi vetada a exploração mineral no interior baiano, deslocando o monopólio, já em fins do século XVII e início dos Setecentos, à capitania das Minas Gerais. A ordem real possibilitou o fortalecimento da economia pastoril como especificidade do mercado sertanejo. ${ }^{20}$

Muitas dessas minas, aparecidas à vista dos conquistadores, eram compostas de outro tipo de mineral - o salitre ${ }^{21}$ - explorado durante o período colonial na caatinga baiana, por ser

\footnotetext{
${ }^{19}$ ABREU, Capistrano. Capítulos de história colonial..., Opus cit., pp. 168 - 169.

${ }^{20}$ ABREU, Capistrano. Capítulos de história colonial..., Opus cit., pp. 168 - 169.

${ }^{21}$ As jazidas de salitre mais conhecidas do sertão nordestino foram as de Pilão Arcado e Salinas de Cima, ambas localizadas cerca do rio São Francisco. Para as Minas Gerais, anualmente, eram transportados, pelo rio São Francisco mais de seis mil alquires de sal, segundo as informações capitão e intendente das minas dos cariris novos, Jerônimo Mendes da Paz. Ver PROJETO RESGATE. AHU_ACL_N_CEARÁ, Cx. 6, D. 380.
} 
útil à produção de pólvora e sal. Pedro Puntoni, citando Pedro Barbosa Leal, disse que as expedições do Muribeca aos sertões da Jacobina acharam, invés de algum nobre metal, o salitre. ${ }^{22}$ Por não indicar a precisa localização das supostas jazidas descobertas, Belchior Dias Moréia disseminou sonhos de riqueza provenientes da mineração. Assim, o hinterland pode ser conhecido.

Passados duzentos e cinqüenta e quatro anos de descobrimento, durante o reinado de Dom José I, precisamente no ano de 1754, rumores de minas de ouro no sertão da capitania do Ceará (na região dos Cariri Novos), motivaram averiguações por parte dos representantes do governador da capitania de Pernambuco, Luis José Correia de Sá. Descrevendo estas minas, Manuel Dias da Silva, garimpeiro das lavras, disse convincentemente que elas...

(...) não só farão conveniencias, como darão lucros aos que aqui abitão, para que se aumente na conveniencia e as ponhão com aumento, e valor, digo que estas (minas) pelo tempo não virão a ter menos valor que as gerais, e a razão he porque aparesse ouro em toda esta terra, mais ou menos; E o que as faz não estarem reputadas he a falta de agoas, por quanto, o ouro se tem descoberto he fora das vertentes, que só em tempo de emverno se pode trabalhar e nestes termos avendo agoas e Mineyros que o entendão, que he o que cá não tem, serão as melhores minas do mundo (...). [grifo nosso]. ${ }^{23}$

Contudo, outro minerador, Francisco Jorge Monteiro, levou consigo cinqüenta e seis bateias, extraindo um oitavo e dois grãos de ouro ${ }^{24}$, valor insignificante para o que seriam as melhores minas do mundo. Ou como o próprio interlocutor afirmou sobre tais jazidas: (...) não se tem achado grandeza(....). ${ }^{25}$

Em sua Descripção Geográfica Abreviada da Capitania do Ceará, datada de 1810, publicada através da Revista do Instituto do Ceará por Guilherme Sturdart, o engenheiro Antônio Jozé da Silva Paulet descreveu que, em épocas de chuva na região do Cariri cearense, moradores mizeráveis faíscam algum ouro, mas em tão pouca quantidade que de todo custa a

\footnotetext{
${ }^{22}$ PUNTONI, Pedro. A guerra dos Bárbaros: povos indígenas..., Opus cit., p. 30.

${ }^{23}$ PROJETO RESGATE. AHU_ACL_N_CEARÁ, Cx. 6, D. 376.

${ }^{24}$ PROJETO RESGATE. AHU_ACL_N_CEARÁ, Cx. 6, D. 381.

${ }^{25}$ PROJETO RESGATE. AHU_ACL_N_CEARÁ, Cx. 6, D. 381.
} 
ajuntar-se alguma oitava. ${ }^{26} \mathrm{O}$ profissional foi contumaz sobre os boatos envolvidos nas minas dos cariris novos, apontando que os resultados de tais lavras eram nulos. ${ }^{27}$

Seguindo mesmo raciocínio de Antônio Jozé Paulet, o médico naturalista inglês, George Gardner, viajando pelo sertão cearense entre 1836-1838, indicou o pouco ouro encontrado nas cercanias das minas dos cariris novos. Segundo o médico de tempos em tempos se tem aí estabelecido lavagem de ouro, sem nenhum resultado satisfatório(...) com quantidade demasiada pequena para compensar os gastos da extração. ${ }^{28}$ Viajando de Oeiras (PI), então capital da província piauiense, para a cidade de São Luiz, passando pela vila de Caxias (MA), Spix e Martius descreveram que no cume da montanha chamada Olho d'Água, ocorreu uma irrupção de sertanejos na tentativa de encontrar qualquer jazida de ouro lá existente. ${ }^{29}$ Porém, também todas as outras minas de ouro da província, que foram descobertas pelos aventureiros paulistas na época da conquista dessas terras, nunca mais, desde aí, foram exploradas. ${ }^{30}$

À tais roteiros destacam-se as notícias sobre o sertão nordestino, então pouco habitado. Mesmo com a efetivação da política colonizadora, através da centralização do poder exercida pela figura do governador geral, esta região continuou sendo espaço de isolamento, desconhecimento e dúvidas. A miragem do ouro e da prata não firmou o povoamento do lugar, consequentemente, não fixou o homem ao chão. A mineração do sertão foi uma economia frustrada, se embaraçou com os avanços da pecuária extensiva em meados dos Seiscentos.

\footnotetext{
${ }^{26}$ PAULET, Antônio Jozé da Silva. "Descripção Geográfica Abreviada da Capitania do Ceará, 1810”. In Revista do Instituto do Ceará. Ano XII. Fortaleza, 1898. pp. 10 - 11.

${ }^{27}$ PAULET, Antônio Jozé da Silva. "Descripção Geográfica Abreviada da Capitania...Opus cit., . p. 12.

${ }^{28}$ GARDNER, George. Viagem ao interior do Brasil. Belo Horizonte, Ed. Itatiaia, 1975. p. 89.

${ }^{29}$ SPIX, J.B Von; MARTIUS, C.P.F. Viagem pelo Brasil: 1817 - 1820. São Paulo, Edusp, 1981. Vol.II . p. 247.

${ }^{30}$ SPIX, J.B Von; MARTIUS, C.P.F. Viagem pelo Brasil...Opus cit., p. 247.
} 


\title{
1.2 Índios do sertão: prisão, escravização, conflitos e o conhecimento do território
}

\author{
(...) Querem impedir-nos de multiplicar-nos, perturbam a paz em que \\ vivíamos em nossas terras: nelas nascemos livres e somos obrigados \\ a tolerar que quatro pobres estrangeiros pretendam nos tornar \\ escravos? $?^{31}$
}

Para aqueles anos iniciais de dominação, braço indígena foi usado na extração de pau-brasil, na coleta de drogas do sertão e de condução destes produtos para as feitorias. Em cartografia atribuída a Giacomo Gastaldi, de 1565, observamos este tipo de trabalho e sua remuneração através da prática de escambo [figura 18].

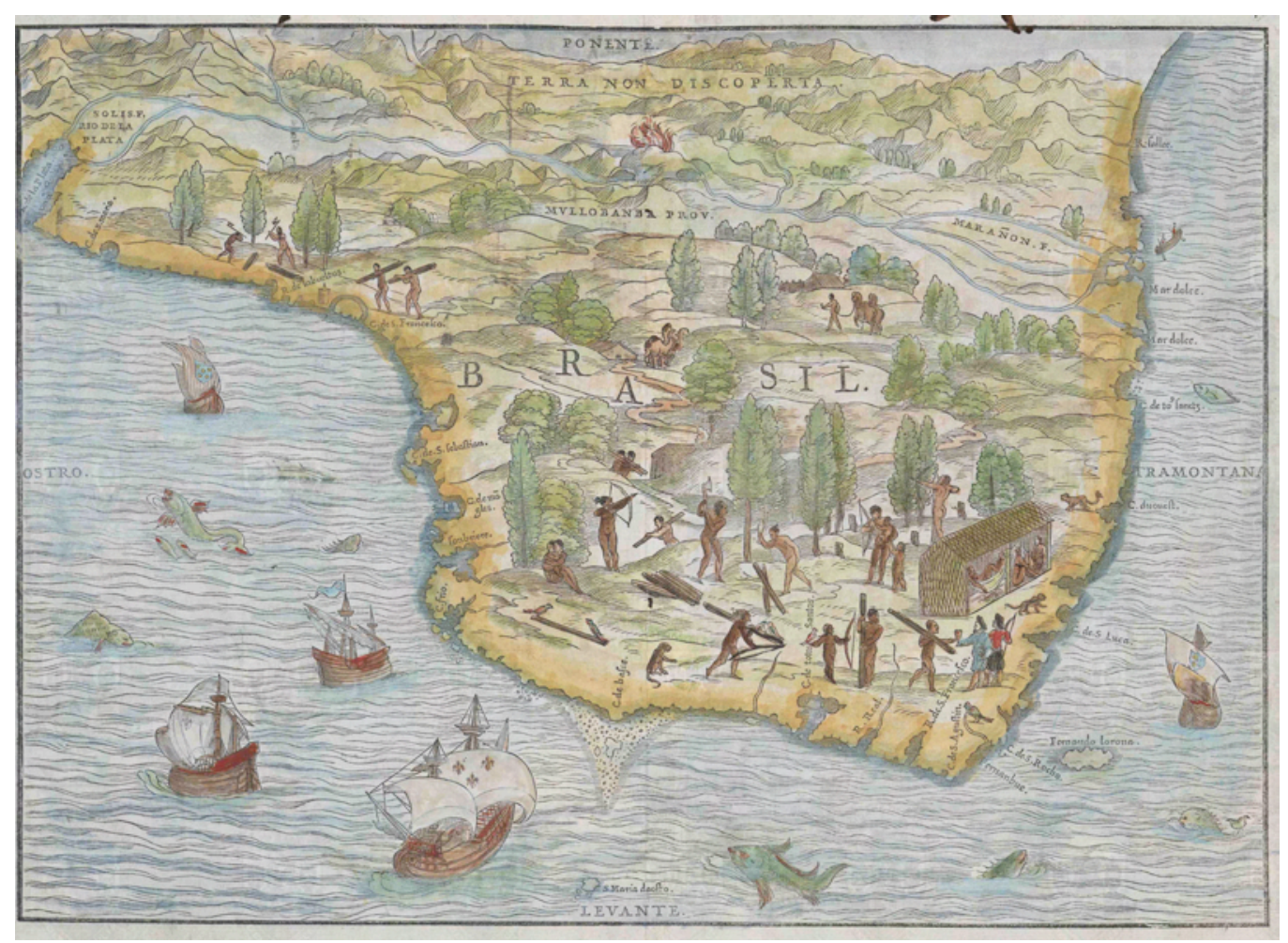

Figura 18 - Brasil de Giacomo Gastaldi, 1565. Disponível em http://www.cartografiahistorica.usp.br. Acesso em 07/09/2011.

\footnotetext{
${ }^{31}$ Palavras de um cacique de Loreto (missões jesuíticas dos índios guaranis do Paraguai) que tentou afugentar os jesuítas de suas terras. Ver HAUBERT, Máxime. Índios e Jesuítas no tempo das missões. São Paulo, Companhia das Letras, 1990. p. 144.
} 
Além de trabalhos que exigiam força física, os nativos serviram de guias para os caçadores de pedras e metais preciosos, supostamente localizados nos sertões. As veredas desenvolvidas pelos autóctones foram fundamentais para o conhecimento, povoamento e posse do território.

Depois de familiarizados com os catecúmenos, os portugueses viam, portanto, uma ótima oportunidade para usar o seu poder como mecanismo de subjugação.

Frei Martinho de Nantes, quando estava em seu aldeamento missioneiro, localizado no médio rio São Francisco, escreveu a sua Primeira Relação. Informou que em 1670, certo fazendeiro português, Antônio de Oliveira, procurando pastagens para o seu gado, encontrou uma tribo de índios. Com intuito de não perder as suas manadas, nem a terra para a implantação dos currais, após ter oferecido medíocres presentes aos nativos, foi incontinente a Pernambuco, à procura de algum missionário, que quisesse estabelecer-se entre esses índios, para melhor proteção do gado que lhe pertencia. ${ }^{32}$

Para conquistar os fins almejados pela colonização, seria necessária a total aculturação dos catecúmenos através da catequese. As missões religiosas, iniciadas com a instituição do governo geral em 1549, cumpriram o jogo dialético de interesses: uso do braço indígena para o beneficio colonial e domesticação para o proveito da Santa Sé. Ou como bem disse Eduardo Hornaert que por trás do discurso doutrinário esconde-se um discurso guerreiro $^{33}$, isto é, o sistema ao qual as missões religiosas estavam inseridas era estruturalmente agressivo diante de indígenas e africanos, o discurso evangelizador não conseguiu escapar à agressividade(...). A terminologia evangelização passou a ser justificativa de opressão e escravização dos indígenas(... $)^{34}$. Gentios convertidos justificavam presença e controle da união entre Coroa e Mitra, formariam um bem público sem os quais o Brasil se não poderia sustentar ${ }^{35}$. Significavam o aumento do patrimônio material das ordens religiosas, transformados em mão-de-obra gratuita e terras para o cultivo dos padres e frades. ${ }^{36}$ Em que termos a conversão visou o benefício dos neófitos?

\footnotetext{
${ }^{32}$ NANTES, O.F.M. Cap. Martinho de. Relação de uma missão no Rio São Francisco: relação sucinta e sincera da missão do padre Martinho de Nantes, pregador capuchinho, missionário apostólico no Brasil entre os índios chamados cariris. São Paulo, Editora Nacional, 1979. p. 1.

${ }^{33}$ HORNAERT, Eduardo. História da Igreja no Brasil: ensaio e interpretação a partir do povo: primeira época, período colonial. 5 ed. Petrópolis, Editora Vozes, 2008. p. 26.

${ }^{34}$ HORNAERT, Eduardo. História da Igreja no Brasil: ensaio e interpretação...Opus cit., . p. 26.

${ }^{35}$ LEITE, Serafim. História da Companhia de Jesus..., Opus Cit., p. 181.

${ }^{36}$ PERRONE-MOISÉS, Beatriz. "Índios livres e índios escravos: os princípios da legislação..., Opus cit., p. 116.
} 
Parai de armazenar para vós tesouros na terra, onde a traça e a ferrugem consomem, e onde ladrões arrombam e furtam. Antes, armazenai para vós tesouros no céu, onde nem a traça e a ferrugem consomem, e onde ladrões não roubam nem furtam. Pois, onde estiver o teu tesouro, ali também está o teu coração. ${ }^{37}$ [grifo nosso].

Verificando que seus hábitos e costumes culturais cambiavam, os índios reagiam aos abusos coloniais através de guerras, saques às vilas, fazendas ${ }^{38}$ e engenhos. Outra saída seria a fuga para o interior da colônia, queriam proteger-se. Inicia uma caça intolerante. Os resultados são escravização, aprisionamentos e um território devassado, conhecido.

Com a instituição das capitanias hereditárias, a partir de 1532, e sob as ordens do rei D. João III, reforça-se a necessidade de mão-de-obra (ao exigir a efetiva posse dos seus domínios ultramarinos) e a produtividade das terras. A liberdade indígena estava ameaçada ${ }^{39}$. Até porque, segundo as ordens do Reino, os donatários tinham o poder de cativar os silvícolas para o seu serviço e dos navios, e de mandá-los vender a Lisboa até certo número cada ano livres de sisa ${ }^{40}$.

Um aspecto pouco abordado pelos pesquisadores do assunto diz respeito ao uso dos índios como contribuintes do sistema colonial. Interessante a abordagem de frei Vicente de Salvador sobre a prisão de índios por tribos rivais. Após a captura, levam o prisioneiro para vender aos brancos, os quais lhe compram por um machado ou foice cada um, tendo-os por verdadeiros cativos(... $)^{41}$. Isto faz do índio vencedor, de um determinado clã, colaborador da escravização de grupos rivais. Colaboração basilar ao sistema colonial. ${ }^{42}$

\footnotetext{
37 Versículos tirados da Bíblia, no conhecido sermão do monte proferido por Jesus Cristo no Monte das Oliveiras, localizado no evangelho de Mateus, capítulo 06, versículos 19 - 21.

${ }^{38}$ O ouvidor do Piaui, Antônio Marques Cardoso, ao descrever o sertão piauiense, em 1727, para o rei D. João $\mathrm{V}$, disse que o motivo de muitas fazendas de gado estarem despovoadas se vinculou ao ataque dos índios aos gados criados nessas herdades. E muitos moradores, temerosos dos saques, mudam-se de lugar. Segundo as fontes primárias pesquisadas, a região das freguesias do Parnaguá e Jerumenha foram as mais afetadas pelas investidas dos silvicolas no interior da capitania do Piaui. Ver PROJETO RESGATE. AHU_ACL_CU_016, Cx. 1, D. 35.

${ }^{39}$ LOPES, Fátima Martins. Em nome da liberdade: as vilas de índios do Rio Grande do Norte sob o diretório pombalino do século XVIII. Tese de doutorado. Recife, UFPE, 2005. p. 56.

${ }^{40}$ MALHEIROS, Agostinho Perdigão. A escravidão no Brasil: ensaio histórico e jurídico. Petrópolis, Editora Vozes, 1973. v.2. p. 158.

${ }^{41}$ SALVADOR, frei Vicente do. História do Brasil: 1500-1627. 7 ed. São Paulo, Edusp, 1982. p. 86.

${ }^{42}$ Caio Prado Jr. já nos sinalizou sobre esta especificidade dos índios no processo colonizador. Os portugueses aproveitaram-se dos indígenas não apenas para obtenção dele, pelo tráfico mercantil, de produtos nativos, ou simplesmente como aliados, mas sim como elemento participante da colonização. Caio Prado Jr. apud Pedro Puntoni. In A guerra dos Bárbaros: povos indígenas e a colonização do sertão Nordeste do Brasil, 1650 - 1720. São Paulo, Edusp, 2002. p. 49.
} 
Serafim Leite, em sua conhecida obra - História da Companhia de Jesus no Brasil nos conta que, em 1592, o padre Amador Rebelo, escrevendo ao rei de Portugal, afirmou que as expedições de conhecimento e tomada do interior da Bahia seriam verdadeiras alegações para capturar os índios do sertão, ou como ele mesmo relatou: os práticos afirmam que não há minas, e que aquilo não é senão pretexto para tomar e saltear índios. ${ }^{43} \mathrm{O}$ conhecimento do sertão, dentro dos suas especificidades geográficas, naqueles tempos primeiros da colonização e, de reboque, nos séculos seguintes de domínio português, estava relacionado com a procura aos nativos. ${ }^{44}$

A prática de trazer índios desde o sertão até a costa, tanto para fins educacionaisreligiosos, nos aldeamentos missioneiros, como para uso escravo, foi conhecida como descimentos $^{45}$. Ato concebido como deslocamento de povos localizados no interior para novos aglomerados indígenas instalados no litoral, criados por particulares ou por alguma ordem religiosa. Os índios eram induzidos a uma suposta convivência pacífica com os moradores litorâneos. ${ }^{46}$ Este movimento de mão - dupla, sertão x litoral, realizado por padres, frades e sertanistas, visando o descimento dos catecúmenos, realçou o conhecimento do território, da cultura dos autóctones, fauna e flora, isto é, informações imprescindíveis para a conquista e posses futuras de terras sertanejas. ${ }^{47}$

Só no sertão de Orobó, área que pertencia à capitania da Bahia de Todos os Santos, foram transladados do hinterland, em dois anos, vinte mil almas. ${ }^{48}$ Fernão Cardim, a propósito dos descimentos, divulgou a seu superior, que muitos dos recém batizados foram trazidos do sertão pelos padres. Aprendendo a língua dos colonizadores, os nativos serviram como intérpretes de novas entradas. Comunicando-se através do idioma português, índios e mamelucos batizados serviam de interlocutores para missionários e agentes coloniais. Situação muito corriqueira que auxiliou o cativeiro indígena.

Através de frei Vicente de Salvador sabemos que por ordem do governador do estado do Brasil ${ }^{49}$, deram as devidas licenças aos conquistadores do sertão para descer índios, usando a persuasão dos línguas (índios domesticados ou mamelucos conhecedores dos idiomas falados pelos indígenas). Em certas ocasiões, os catecúmenos eram migrados por vontade

\footnotetext{
${ }^{43}$ LEITE, Serafim. História da Companhia de Jesus..., Opus cit., p. 179.

${ }^{44}$ PUNTONI, Pedro. A guerra dos Bárbaros: povos indígenas..., Opus cit., p. 29 - 30.

${ }^{45}$ BELLOTO, Heloísa Liberalli. "Política indigenista no Brasil colonial..., Opus cit., p. 49.

${ }^{46}$ PERRONE-MOISÉS, Beatriz. "Índios livres e índios escravos: os princípios..., Opus cit., p. 118.

${ }^{47}$ LEITE, Serafim. História da Companhia de Jesus..., Opus cit., p. 173.

${ }^{48}$ LEITE, Serafim. História da Companhia de Jesus..., Opus cit., p. 182.

${ }^{49} \mathrm{O}$ autor não nos especifica qual o governador relacionado com os fatos.
} 
própria, em outros casos, os conquistadores usavam a força da espada, isto é, de guerras para concretizar os seus intentos ${ }^{50}$. O religioso franciscano sobredito citou a entrada de Antônio Dias Adorno. Trouxeram sete mil nativos do interior. Nessa façanha, utilizaram a ajuda de um gentio amansado, vulgarmente chamado de Porquinho. ${ }^{51}$ De Pernambuco...

(...) foram Francisco de Caldas, que servia de provedor da fazenda, e Gaspar Dias de Ataíde com muitos soldados ao rio de São Francisco e, ajudando-se do Braço de Peixe (outro índio domesticado), que era um grande principal dos tabajares, e da sua gente, que era muito esforçada e guerreira, entraram muitas léguas pelo sertão, matando os que resistiam e cativando os mais. Tornado-se depois pera o mar com sete mil cativos (... $)^{52}$

Uma questão central acerca da escravização dos nativos, conflitos e descimentos de índios para aldeamentos localizados no litoral, se refere à posse de terras sertanejas para usufruto dos fazendeiros de gado. $\mathrm{O}$ uso da terra pelos curraleiros gerou a rivalidade dos índios, como também, de alguns missionários que detinham os poderes espirituais e temporais dos catecúmenos. O capuchinho Martinho de Nantes, escrevendo a sua Segunda relação, deixou a seguinte informação sobre o interesse dos fazendeiros:

O interesse de alguns particulares, que haviam colocado seu gado nas terras dos índios, sendo combatido por alguns missionários, que eles próprios haviam chamados para segurança de seu gado que pelo zelo da conversão dos índios, como os acontecimentos nos fizeram compreender, atiraram-se contra nós e empregaram todos os meios possíveis para nos afastar. ${ }^{53}$

Mesmas circunstâncias passaram os moradores da capitania do Rio Grande. Em carta ao rei, Dom Pedro II, no ano de 1697, o capitão mor daquela região julgava conseguir o intento de povoar os Sertõens, e precisamente o do Assú, metendo se gados em todas as partes porque desta sorte se aumentará logo em tudo esta Capitania, e subirião despois os Dízimos Reaes (...). ${ }^{54}$ Assegurou a dita autoridade a necessidade de guerra contra o índios (...) para deffensa e segurança dos gados (....). ${ }^{55}$

\footnotetext{
${ }^{50}$ SALVADOR, frei Vicente do. História do Brasil..., Opus cit., p. 180.

${ }^{51}$ SALVADOR, frei Vicente do. História do Brasil..., Opus cit., p. 181.

${ }^{52}$ SALVADOR, frei Vicente do. História do Brasil..., Opus cit., p. 182.

${ }^{53}$ NANTES, O.F.M. Cap. Martinho de. Relação de uma missão no Rio São Francisco: relação..., Opus Cit., p. 40.

${ }_{55}^{54}$ PROJETO RESGATE. AHU_ACL_CU_018,Cx.1, D. 42.

${ }^{55}$ PROJETO RESGATE. Ibidem.
} 
Ao verificar as querelas provocadas pela tomada das terras dos indígenas, os monarcas lusos, com relativo apoio das autoridades coloniais, emitiram leis ${ }^{56}$, ordens e alvarás numa tentativa de apaziguar as relações entre fazendeiros, índios e missionários. Compreender estas questões nos esclarece determinados fatos envolvendo, fundamentalmente, a liberdade dos índios, os seus direitos perante as leis coloniais e o povoamento da região.

Ação costumeira adotada pelos colonos consistiu nos chamados resgates, isto é, libertar os prisioneiros de uma tribo através de pagamentos irrisórios: ferramentas, contas de vidro e outras mediocridades. ${ }^{57}$ Gandavo, testemunha ocular deste fenômeno, disse que a troco destes produtos de pouquíssimo valor, vendião huns aos outros, e os portuguezes resgatavão muitos delles. ${ }^{58}$ Aqueles que resgatavam os índios podiam se servir deles, desde que houvesse conversão e bons tratos. Porém, uma restrição deve ser analisada. No Regimento de 25.05.1624 só poderiam ser resgatados os indivíduos que estiverem presos à corda - índios que aguardavam sua morte, decretada pelos grupos indígenas dos quais eram prisioneiros. ${ }^{59}$

O debate sobre a liberdade dos índios se notabilizou através da criação da Junta das Missões, em 1681, sob carta régia de seis de março do ano indicado. O objetivo da sua ereção abrigou o zelo pela prosperidade da fé católica, através da conversão dos silvícolas, nos domínios ultramarino de Portugal. ${ }^{60}$ Tal Junta seria formada por autoridades oficiais e eclesiásticas, numa franca demonstração da união entre Trono e Mitra. Assistiram o Bispo, $e$ em sua falta o Vigário Geral do Bispado, o Ouvidor Geral, o Provedor da Fazenda, o Governador da Capitania, encommendo-vos muito e mando que n'esta conformidade disponhaes este negócio $(. . .)^{61}$.

A Junta das Missões, organização subordinada à Mesa de Consciência e Ordens, designava territórios para os missionários reduzirem os silvícolas, bem como as atribuições

\footnotetext{
${ }^{56}$ (...) que deveis uzar na repartição da legoa de terra, que se ha de dar a casa Aldeã de índios de vossa Jurisdição, e principalmente os que se acham aldeados no districto da Capitania do Rio Grande (...) Me pareceo mandar-vos declarar por esta, que à ley de vinte e três de Novembro de mil sete centos se deve dar a execução, dando-se aos índios a terra, que n'ella se ordena para sua vivenda. VER ANNAES da Bibliotheca Nacional do Rio de Janeiro. Volume XXVIII. Rio de Janeiro, 1906. p. 380.

${ }^{57}$ BELLOTO, Heloísa Liberalli. "Política indigenista no Brasil colonial (1750 - 1757)..., Opus cit., p. 51.

${ }^{58}$ GANDAVO, Pero Magalhães de. Tratado da terra do Brasil; História da província de Santa Cruz. São Paulo, Edusp, 1980. p. 58.

${ }^{59}$ PERRONE-MOISÉS, Beatriz. "Índios livres e índios escravos: os princípios da legislação..., Opus cit., p. 128.

${ }^{60}$ ANNAES da Bibliotheca Nacional do Rio de Janeiro..., Opus Cit., p. 379.

${ }^{61}$ ANNAES da Bibliotheca Nacional do Rio de Janeiro..., Opus Cit., p. 379.
} 
que julgavam básicas para uma boa administração temporal e espiritual. Nos sertões nordestinos, devido à falta de comunicação e à precariedade das estradas, as normas e estatutos estabelecidos por essa instituição foram pouco praticadas, como mostrou a provisão do rei D. João V, em 1746, ao ouvidor geral da capitania do Ceará. Nesse documento são nomeados Juízes das Cauzas da Liberdade dos Índios (...) pella difficuldade em Juncta das Missões na execução das leis pellas grandes distancias, e longes daquelle governo(...). ${ }^{62}$

A fragilidade na execução e cumprimento das normas estabelecidas pela Junta das Missões podem ser vistos pela dimensão territorial dos bispados onde estavam localizados os aldeamentos missioneiro. O de Pernambuco, por exemplo, criado em $1676^{63}$, atendia espiritualmente desde o rio São Francisco, muito abaixo da vila da Barra do Rio Grande, até o Ceará. Agrupou as capitanias subalternas de Alagoas, Itamaracá, Paraíba e Rio Grande do Norte. $^{64}$

Somente no reinado de D. José I apoiado, principalmente, pelo Conde de Oeiras, o futuro Marquês de Pombal, percebe-se a fragilidade operacional da Junta das Missões. Tendo a sua destituição oficial ocorrida em $1759^{65}$. Entretanto, com a política pombalina ocorreu um lento processo de separação entre a Igreja e o Estado português ${ }^{66}$. A necessidade de evitar as confusões das jurisdições espirituais e temporais, com seus conseqüentes danos, foram reforçados, primariamente, com o Alvará de 07/01/1755, que buscou a honra, emprego e dignidade dos índios ${ }^{67}$.

O período pombalino (1750 - 1777) é visto como uma tentativa à emancipação do índio brasileiro diante da dominação eclesiástica exercida pelos religiosos. O sertão nordestino não ficou à parte das tramitações impostas por D. José I. Muitos são os documentos da época colonial que corroboram este pressuposto. Por exemplo, após a expulsão dos padres da Companhia de Jesus em 1759, o governador da capitania de

\footnotetext{
${ }^{62}$ PROJETO RESGATE. AHU_ACL_N_CEARÁ, Cx. 6, D. 271.

${ }^{63}$ Segundo Furtado de Almeida em seu título, "História da Igreja em Portugal",o bispado de Pernambuco foi criado pela bula Ad sacrum Beati Petri, de 16 de Novembro de 1676, e a pedido de D.Pedro II, desmembrou o papa Inocêncio XI do bispado da Bahia. Seu primeiro bispo foi D. Estevão Brioso de Figueiredo. Ver ALMEIDA, Furtado de. História da Igreja em Portugal. Vol II. Lisboa, Livraria Civilização - Editora, 1968. p. 41.

${ }^{64}$ MELlO, Márcia Eliane apud FRANCESCONI, Agatha. O Trâmite da fé: a atuação da Junta das Missões de Pernambuco, 1681 - 1759. Dissertação de Mestrado. São Paulo, FFLCH, 2009. p. 33.

${ }^{65}$ ASSUNÇÃO, Paulo de. Negócios Jesuíticos: o cotidiano da administração dos bens divinos. São Paulo, Edusp, 2009. p. 42.

${ }^{66}$ MARX, Murillo. Cidades no Brasil, terra de quem? São Paulo, Edusp, 1991. 143 p.

${ }^{67}$ SILVA, Jacionira Coelho. Arqueologia no médio São Francisco: indígenas, vaqueiros e missionários. Tese de doutorado. Recife, UFPE, 2003. p. 133.
} 
Pernambuco, Luís Diogo Lobo da Silva, em carta a Sebastião José de Carvalho e Melo, indicou algumas características essenciais à liberdade dos índios:

(...) relativas aos péssimos estabelecimentos das novas Villas, e lugares, q' a heróica constacia de Vossa Magestade Fidelíssima manda erigir das antigas Aldeyas, restituindo aos seus habitadores à liberdade e izençao de q' tanto careciao e facilitando-lhes o passo a sahirem das trevas da ignorância em q' erão conservados por políticos particulares dos mesmos destinados a destruilas. $(\ldots)^{68}$

Para saírem das trevas e alcançarem a luz fornecida pela política racional pombalina, seria útil introduzir aos silvícolas o comércio, a agricultura e diminuir as distâncias entre as povoações do sertão. ${ }^{69}$ Facilitar a civilização dos íncolas por meio do intercâmbio cultural e econômico, introduzindo vizinhos portugueses naquilo que viria a se tornar uma vila ou lugar de índios. Seria fundamental a presença de um diretor, cujas obrigações buscaram colocar o indígena na sociedade civil. ${ }^{70}$

Os ideais supracitados não modificaram as atitudes dos colonizadores ou dos agentes coloniais no modo de tratar os índios. A caça, os descimento e o indiscriminado uso dos catecúmenos persistiram no panorama social do interior do nordeste em todo o período pombalino, ultrapassando para os reinados ulteriores. A criação da redução de índios Guegué denominada pelo governador da capitania de São José do Piauí, João Pereira Caldas, de São João de Sende (hoje cidade de Regeneração - PI), foi desenvolvida devido um grande descimento envolvendo quinhentos e cinqüenta e oito índios. Sendo eles, para a dita autoridade colonial, pella qualidade do inimigo, sem duvida o mais feroz, e que mais hostilidades fazia a todos estes moradores. ${ }^{71}$

Acontecimento similar encontramos na formação do aldeamento missioneiro de Nossa Senhora das Mercês sob a administração espiritual dos mercedários, formada

\footnotetext{
${ }^{68}$ PROJETO RESGATE. AHU_ACL_N_CEARÁ, Cx. 6, D. 464.

${ }^{69}$ O rei D. José I escreve em carta datada de 17 de junho de 1761 ao governador da recém criada capitania de São José do Piauí, João Pereira Caldas: (...) Hatendose a que me faria a observância das Leis se nao pode athé agora conseguir para della instar aquelle indispensável fruto pella vastidão da mesma Capitania vivendo os seus habitantes em grandes distancias huns dos outros sem a communicação como inimigos da sociedade civil e do commercio humano padecendo assim os descômodos e os lugares muito remotos e longínquos de sorte que quando lhes chegam os despachos vem tão tarde que nao servindo para o remedeo das queixas lhes trazem sempre a ruína (...) - PROJETO RESGATE. AHU_ACL_CU_018, Cx.8, D.450.

${ }^{70}$ FLEXOR, Maria Helena Ochi. "Cidades e vilas pombalinas no Brasil do século XVIII". In Universo urbanístico português, 1415-1822. Lisboa, Comissão Nacional para as comemorações dos Descobrimentos portugueses, 1998. pp. $257-258$.

${ }^{71}$ PROJETO RESGATE. AHU_ACL_CU_016, Cx.9, D. 563.
} 
basicamente por índios da nação Jaicó. Informando o secretário de estado da Marinha e Ultramar, Francisco Xavier de Mendonça Furtado, novamente o governador da capitania de São José do Piauí relatou:

Na ribeira do Itahim pertencente a Freguezia desta Cidade (Oeiras - PI), e na distancia de couza trinta legoas existe uma Povoação de índios da Nação chamada Jaicó (...). Para esta mesma povoação nomeei eu no fim do anno passado por Director a hum soldado chamado Manuel de Araújo; e alem das ordens com que o intrui; Me determinei, que promptamente fizesse recolher e reconduzir a ditta Povoação todos os índios que dali se achassem auzentes, e separados (...); Com effeito assim o executou o Director recoduzindo vários índios, que se achavao fora da Povoação e ajustando com os outros seus descendentes espalhados por aquella Ribeira do Itahim, o hiremse estabelecer na mesma povoação athé o principio do presente mês de Setembro do prezente anno(... $)^{72}$

As autoridades do Reino e Ultramar, durante a época que compreende o reinado de D. José I, estiveram atentas às demarcações de fronteiras, segundo as determinações do Tratado de Madri. Reforçam o quadro de soldados e de engenheiros militares na colônia, para atender as demandas que esta ação necessitava.

O sertão nordestino se tornou uma espécie de centro de treinamento ou recrutamento de índios, usados em conflitos entre as coroas ibéricas, caso estes surgissem. A guerra contra os gentios bárbaros continuou no século XVIII, acarretando um paulatino despovoamento do território. A diminuição demográfica aconteceu nos sertões das freguesias de Parnaguá e Gurguéia, subordinadas ao bispado do Maranhão. Os moradores da região solicitaram auxílio ao rei D. José I, em 1760, diante das hostilidades e crueldades praticadas pelas nações Acaroá, Timbira e Guegué.

(...) Inexplicáveis são os insultos que as referidas Naçõens de gentio cometem incessantemente nas Villas, fazendas dos sobreditos moradores, matando muitos destes, escallando lhes as casas, roubando lhas, levando em sua companhia as mulheres, e filhas dos mesmos moradores, que conservão suas terras com indelével sentimento dos seus parentes. Muitas são as fazendas despovoadas [grifo nosso] por haverem incrementado semelhantes tiranias, e muitas mais se despovoarão brevemente, se a Paternal previdência

\footnotetext{
${ }^{72}$ PROJETO RESGATE. AHU_ACL_CU_016, Cx.10, D. 589.
} 
de Vossa Magestade não ocorrer, sem demora, a estas calamidades que igualmente redundarão em prejuízos da Real Fazenda de Vossa Magestade. ${ }^{73}$

Vendo os rendimentos reais afetados pelo arremetida dos colonos portugueses para outras regiões do sertão, as autoridades oficiais puseram em pauta a necessidade de uma guerra àquelas tribos hostis. A tática envolveria patrocínio da Corte, feitos por donativos em dinheiro, já que os moradores daquelas paragens eram miseráveis e não poderiam abarcar sozinhos tal empreitada. E, acima de tudo, nos termos que me pareceo indispensável que Vossa Magestade ordene ao governador de Pernambuco, que da Serra da Iviapaba mande marchar para esta capitania hum corpo de quinhentos, ou seis centos índios, para que unindosse a estes moradores, e hum Corpo de Tropas pagas (...) se possa conseguir por uma vez o êxito de tão importante negócio. ${ }^{74} \mathrm{O}$ documento analisado indica que foram solicitados soldados da capitania de Goiás para fortalecer este objetivo bélico.

Objetivos bélicos, escravocratas, de cunho religioso foram os mentores da redução do quadro das etnias indígenas brasileiras ${ }^{75}$. Infelizmente, quando estudamos estes eventos, verificamos que a consideração pelo outro foi desconsiderada e ignorada em muitos casos. Deixo as palavras dos moradores do sertão de Parnaguá como registro das metas físicas, espirituais e culturais exercidas pelos "estrangeiros" nas terras onde os nativos encontraram a sua liberdade oscilante e contraditória: (...) para que combatidos na mesma ocasião por huma, e outra parte se possão inteiramente extinguir. [grifo nosso]. ${ }^{76}$

\footnotetext{
${ }^{73}$ PROJETO RESGATE. AHU_ACL_N_MARANHÃO, D. 3848.

${ }^{74}$ PROJETO RESGATE. AHU_ACL_N_MARANHÃO, D. 3848.

${ }^{75}$ Segundo dados de A. J. R. Russel-Wood, calcula-se que a população índia do Brasil, em 1500, chegaria a 2.431.000. Entretanto, em 2000, o indice de indios rondava a 100.000. Muitos povos nativos desapareceram após a independência, mas, no final do período colonial, muitos tinham sucumbido vítimas de genocídios em massa e etnocídios. Ver RUSSEL - WOOD, A. J. R. "Fronteiras no Brasil colonial". In Oceanos. $\mathrm{n}^{\circ} 40$. Outubro-Dezembro/2000. Lisboa, Comissão Nacional para as Comemorações dos Descobrimentos Portugueses, 1999. p. 10.

${ }^{76}$ PROJETO RESGATE. AHU_ACL_N_MARANHÃO, D. 3848.
} 


\title{
1.3 O conhecimento do sertão através das representações cartográficas
}

\author{
(...) Parti daquella Capitania para o Piahuy já na idea de \\ entreprender (sic.) desde logo a construção do Mapa Geográfico \\ desta Capitania (...) observando miudamente os rumos das estradas, \\ medindo suas distancias, e tomando freqüentemente as alturas para \\ latitude, e fazendo todas as observações de longitude que me foy \\ possiviel $(\ldots)^{77}$
}

Em nossa Viagem científica pelo sertão nordestino (realizada entre os meses de fevereiro, março e abril de 2010, além do mês de fevereiro de 2011), averiguamos a persistência do isolamento que muitos sertanejos vivenciam nestes tempos da informação globalizada. Como ilhas localizadas no árido solo da caatinga, muitas cidades não possuem, em suas prefeituras ou outros órgãos municipais competentes, dados cartográficos que contam o percurso evolutivo das estruturas urbanas: ruas, quadras, lotes, entre outras. Tal precariedade, fruto muitas vezes do desinteresse das gestões públicas, é um mote antigo, o que fez desta pesquisa uma verdadeira garimpagem em instituições espalhadas pelo Nordeste e Sudeste brasileiro. $^{78}$

Compreender o isolamento, a dispersão e a tentativa de diminuir estes dois percalços equivale fazer uma análise empírica dos dados representados em velhas cartografias e iconografias adquiridos em dois anos de pesquisa acadêmica. Ter em mente a relação interior x litoral - nos elucida fatos como povoamento do território sertanejo, o interesse da metrópole lusa em terras afastadas do litoral, a atuação da igreja como uma das pioneiras em adensar a população dispersa e como o estrangeiro via esta região de formação sui generis. A cartografia $^{79}$, elemento material da cultura, "corporiza" tais relações sociais, dando-nos um

\footnotetext{
${ }^{77}$ Descrição dos métodos adotados pelo engenheiro militar, João Antonio Galucio, no que diz respeito à nova capitania criada, São José do Piauí, em 1758. Ver manuscrito em PROJETO RESGATE. AHU_ACL_CU_016, Cx.7, D. 437.

${ }^{78}$ Agradecemos ao Instituto de Estudos Brasileiro (IEB), a Casa de Portugal e a Cátedra Jaime Cortesão, localizados no estado de São Paulo. Na Biblioteca Nacional do Rio de Janeiro e o Arquivo Histórico do Exército Brasileiro, ambos instalados no Rio de Janeiro, conseguimos mapas e iconografias que ajudaram nossa compreensão acerca da urbanização do sertão nordestino. No Nordeste agradecemos as informações obtidas na Prefeitura das cidade de Oeiras - PI, Icó-CE e Triunfo - PE. Foram mais que úteis as velhas fotografias adquiridas na Fundação do Patrimônio Histórico e Artístico de Pernambuco (FUNDARPE) e no Arquivo Histórico da Diocese do Crato - CE.

${ }^{79}$ No dicionário de Raphael Bluteau (1712), selecionamos o verbete carta para deduzirmos o que há por trás do significado deste termo, colaborando com nossas explanações apresentadas neste subtópico. Para o autor, carta geographica, em geral. He uma descripção, ou representação de toda a terra, ou de alguã parte della em huma, ou em muitas grandes folhas de papel. (...) Carta, em que se vê só a descripção de algum paìs, ou lugar.
} 
panorama da urbanização encerrada no sertão nordestino e sua respectiva evolução territorial. Por trás das impressões cartográficas há realismo, ${ }^{80}$ por isso o estudo dos elementos iconográficos é fundamental para o conhecimentos das estratégias políticas, exercidas pelas potências européias, buscando aperfeiçoar as táticas de colonização e controle do território subjugado. ${ }^{81}$

Os primeiros mapas descritivos da Terra de Santa Cruz são específicos em identificar uma terra não descoberta, a terra non descoperta de Giacomo Gastaldi [figura 18, p. 51] referindo-se ao interior dos novos domínio. Escambo, extração do pau-brasil, mão-de-obra indígena e armazenamento dos produtos nas feitorias são índices visualmente comprovados pela carta do italiano. Um olhar mais apurado para os desenhos inscritos na figura 18 revela a localização, quase que precisa, dos principais cursos fluviais ${ }^{82}$ que serpenteiam o sertão.

Murillo Marx, em um poético artigo intitulado - Olhando por cima e de frente opinou que o território colonial brasileiro começou a ser visto pelos cartógrafos, por cima, através dos mapas em escalas reduzidas em que abarcavam com acuidade crescente o contorno continental, e onde os primeiros estabelecimentos seriam acusados por legendas ou pontos específicos. ${ }^{83}$ A mira dos desenhistas do Reino ou estrangeiros figura, segundo as condições técnicas da época, os elementos naturais e artificiais da nova terra.

É o caso dos desenhos legados pelo cosmógrafo ${ }^{84}$ João Teixeira Albernaz, o segundo. Em seu Atlas do Brasil, elaborado em 1666, a costa é delineada a vôo de pássaro. Os principais acidentes geográficos são mostrados com a precisão técnica da época. O sertão

BLUTEAU, Raphael apud BUENO, Beatriz P. Siqueira. Desenho e desígnio: O Brasil dos engenheiros militares (1500 - 1822). Tese de doutorado. São Paulo, Faculdade de Arquitetura da Universidade de São Paulo (FAU USP), 2001. p. 654.

${ }^{80}$ LEPETIT, Bernard. Por uma nova história urbana. Seleção de textos, revisão critica e apresentação Heliana Angotti Salgueiro; trad. Cely Arena. São Paulo, Edusp, 2001. 209.

${ }^{81}$ BUENO, Beatriz P. Siqueira. "A iconografia dos engenheiros militares no século XVIII: instrumento de conhecimento e controlo de território". In Universo Urbanístico português (1415 - 1822). Lisboa, Comissão Nacional para as comemorações dos Descobrimentos portugueses, 1998. p. 91.

Para aprofundar as questões sobre a atuação da cartografia na regulação do território colonial brasileiro, mostrou-se leitura corrente a tese de doutorado da Profa. Dra. Beatriz Piccolotto Siqueira Bueno, defendida na Faculdade de Arquitetura da Universidade de São Paulo - FAU USP - e, intitulada de "Desenho e desígnio: o Brasil dos engenheiros militares (1500 - 1822)".

${ }^{82}$ Estão nomeados e sinalizados os rios Real, São Francisco, Mearim, Itapicurú e Pinaré - eixos fundamentais para o processo de povoamento e urbanização dos sertões da Bahia, Pernambuco, Piauí e Maranhão.

${ }^{83}$ MARX, Murillo. "Olhando por cima e de frente". In Revista da USP. n³0. Junho / Agosto. São Paulo, 1996. p. $170-181$.

${ }^{84}$ A função do cosmógrafo-mor, para Beatriz Bueno, não se restringia à orientação e supervisão da preparação das extensas cartas náuticas e geográficas, como da instrução dos jovens fidalgos no exercício da matemática e suas aplicações à geometria, astronomia, náutica, cosmografia e arquitetura. Ver BUENOS, Beatriz P. Siqueira. “A Iconografia dos engenheiros militares no século XVIII...”, Opus cit., p. 94. 
nordestino, para Albernaz, não passava de um território desértico, com poucos caminhos terrestres, quase nulos, destacando-se visualmente os rios que uniam o desconhecido interior ao litoral. Ilustrando nossa assertiva, temos a carta Demostração do Rio das Preguiças athé o Seará, cujos originais encontram-se na Fundação da Biblioteca Nacional do Rio de Janeiro

[figura 19].

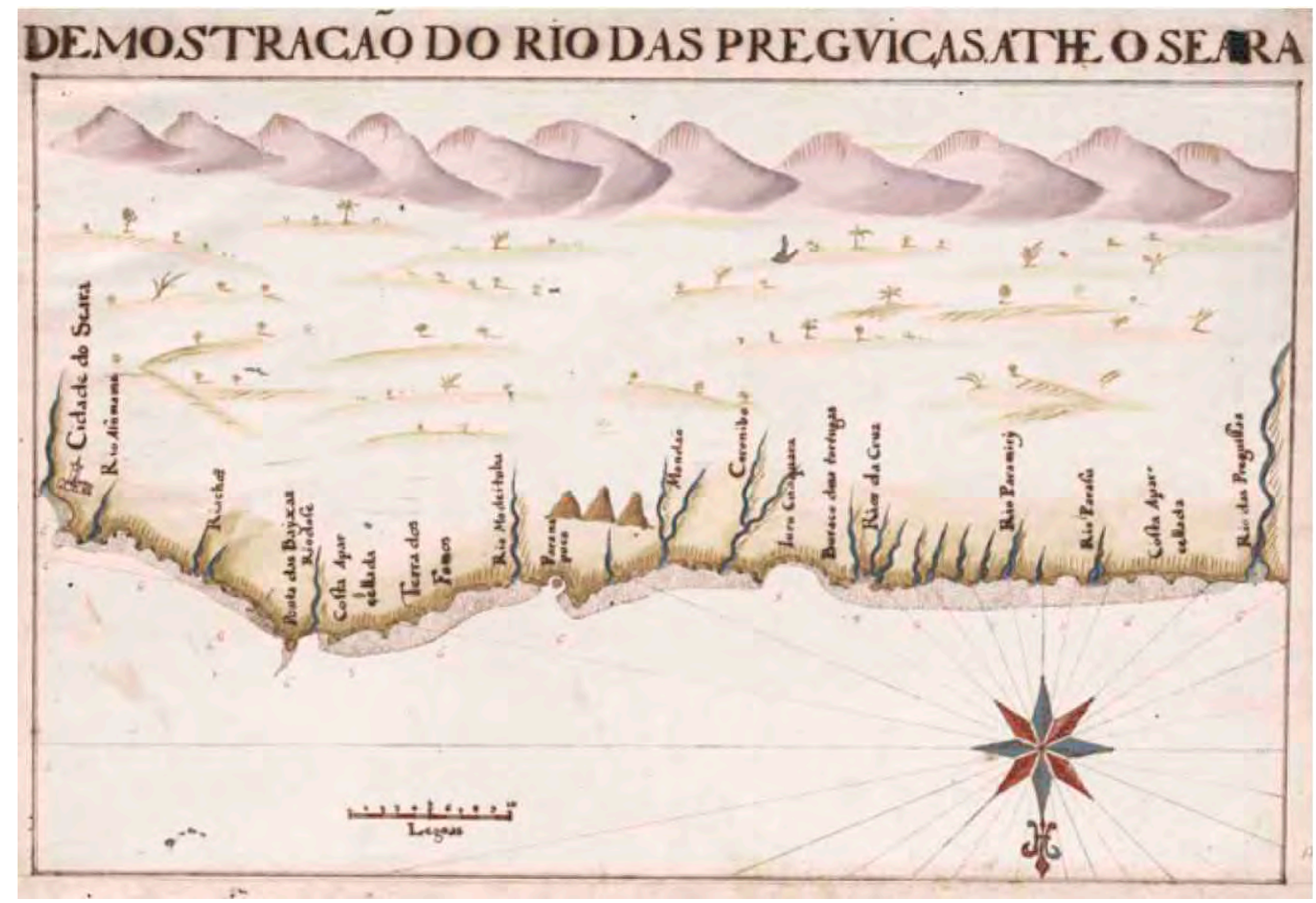

Figura 19 - Demonstração do rio das Preguiças athe o Seara. Mapa atribuído a João Teixeira Albernaz II. Disponível em http://www.bn.br. Acesso em 02.06.2010.

Como dissemos, as primeiras investidas para conquistar o sertão nordestino estavam voltadas, já no século XVI, às minas de ouro e prata escondidos no El Dorado, ou numa utópica lagoa situada no centro da colônia. Além do holandês, Joan Bleau, citado anteriormente na figura 16, João Teixeira Albernaz II se ocupou em indicar a presença do segundo local mítico em alguns de seus mapas, auxiliando a proliferação dessa flexível estória fantástica [figura 20]. Esboça-se, mesmo que de forma incipiente, o curso do rio São Francisco, como via condutora ao interior. A hierarquia da frágil rede urbana brasileira, limitada à costa, pode ser atestada pelas indicações das vilas de São Paulo, Santos, Rio de Janeiro, Porto Seguro e da cidade de Salvador da Bahia de Todos os Santos. Ainda na figura 
20, vê-se o desconhecido, o dilatado e o imprevisível como características reais do hinterland nordestino e brasileiro.

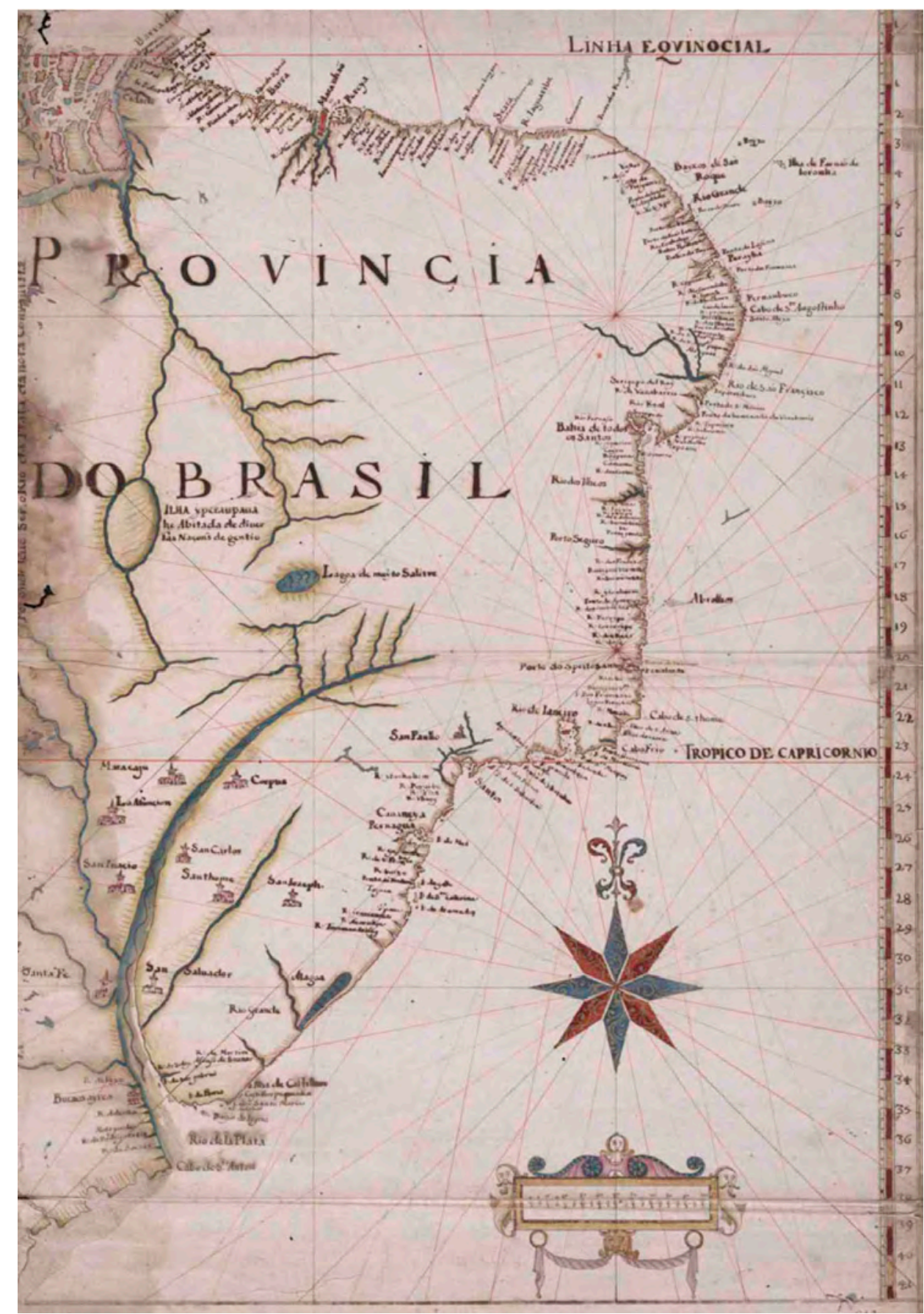

Figura 20 - Província do Brasil. Cartografia elaborada por João Teixeira Albernaz II. Disponível em http://www.bn.br. Acesso em 02.06.2010.

Com a instituição do governo geral, Dom João III estabeleceu uma organização mais vigorosa, sólida o bastante para concretizar os seus ideais de ordem interna ${ }^{85}$, devido à

\footnotetext{
${ }^{85}$ ABREU, Capistrano de. Capítulos de história colonial, 1500-1800. 7ed. rev. São Paulo, Publifolha, 2000. p. 74.
} 
acirrada procura por piratas e mercadores estrangeiros dos produtos naturais brasileiros e da terra que pertencia à Ordem de Cristo. Olhando mais de perto os seus domínios americanos, os monarcas portugueses, através dos seus funcionários especializados, viam a produção cartográfica como material apropriado às especificidades bélicas. Francisco de Holanda apontou esta particular qualidade dos mapas:

Digo pois que arte da Pintura e o Desenho se bem servem a república cristã em o tempo da paz, que muito melhor a servem (onde se dela melhor sabem aproveitar que em Portugal) no tempo da guerra, e Re Militar, de que escreve Vegécio e outros. Bem sabe se é isto verdade Itália e França e outras províncias, assim de fiéis como de infiéis. Porque o desenho da guerra vai bem desenhado, é vencida. Mas se o desenho vai descomposto, dê-se por perdida. Sirva-se pois Vossa Alteza do Desenho da pintura nas coisas da geurra: e verá quanto revela, e como nenhuma cisa sem ele será perfeita. ${ }^{86}$ [grifo nosso].

Locar as tribos indígenas residentes do sertão foi um partido adotado pelos cartógrafos, talvez para assegurar e proteger a colônia da subversão indígena se porventura emergisse uma faina entre colonos e nativos. Na visão do estrangeiro, a identificação das etnias ameríndias favorecia o contato entre forasteiros e autóctones, objetivando a tomada, conquista e posse das terras. Durante a era dos batavos no Nordeste, sérios historiadores ${ }^{87}$ narraram o uso que fizeram os holandeses da força indígena, com intuito de derrotar os seus oponentes lusos. Supomos que o mapa de Joan Bleau [figura 21], datado de 1640, envolva essa estratégia, por elencar diferentes grupos indígenas em seu desenho.

\footnotetext{
${ }^{86}$ HOLANDA, Francisco de. Apud BUENO, Beatriz P. Siqueira. In "A iconografia dos engenheiros militares no século XVIII...”, Opus Cit., p. 93.

${ }^{87}$ Capistrano de Abreu, José Gonsalves de Mello, Barbosa Lima Sobrinho, Raymundo Faoro, entre outros, lideram os estudos historiográficos acerca do Brasil colonial.
} 


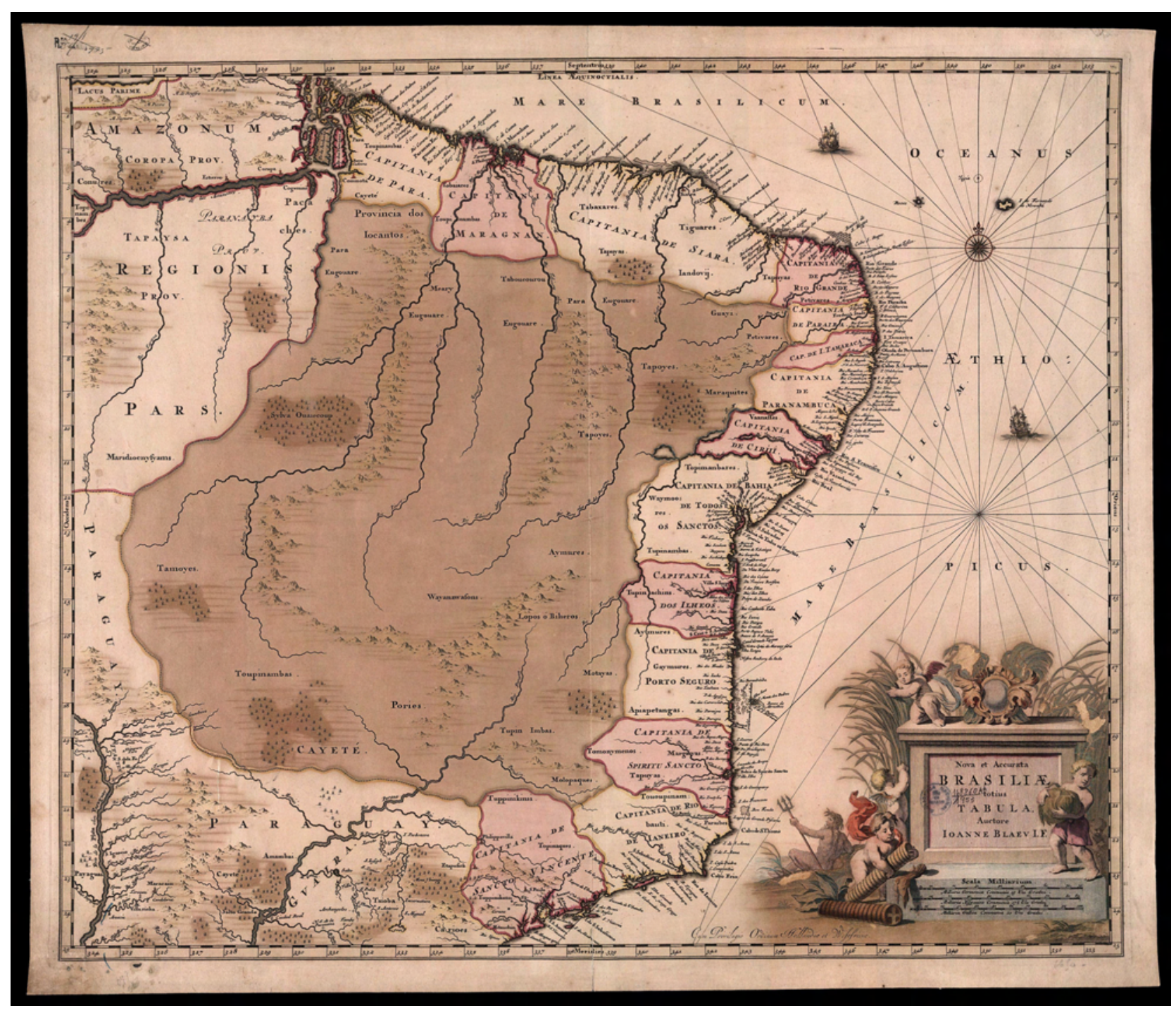

Figura 21 - BLEAU, Joan. Nova et Accurata Brasiliae totis Tabula. 1640.

Disponivel em http://www.bn.br. Acesso em 18. 11. 2010.

Realizando um paralelo entre as figuras 16 [ver primeiro subtópico deste capítulo] e 21, criadas pelo mesmo autor, distinguimos o grau de conhecimento e evolução territorial que o interior do Nordeste tomou nestas representações cartográficas. No primeiro, o interior do continente é figurado como uma região incógnita, onde residem os mitos divulgados pelos índios e é irrigado por alguns dos principais cursos de água. A segunda carta é delimitada por uma mancha, na cor marrom (centro do país), unindo boa parte da área que encerra o sertão 
do Nordeste. São listadas tribos dos nativos, principalmente os Tapuias ${ }^{88}$ e Caetés; e as rotas fluviais apresentam um contorno aproximado do real.

Dois foram os fatores que, ao nosso ver, minimizaram as dúvidas sobre o desconhecido, no que dizia respeito ao espaço geográfico sertanejo: busca de ligação entre as capitais de São Luiz do Maranhão e Salvador, através de caminhos terrestres, e a criação de gado - economia voltada basicamente para o mercado interno colonial brasileiro.

As dificuldades de navegação na costa maranhense interferiram nas transações econômicas e culturais entre a capital da colônia, Salvador, e a capital do Estado do Maranhão. Até o litoral cearense, a presença de baixios perigosos, arrecifes e correntes contrárias à navegação fizeram do trajeto pelo mar um dos mais difíceis de realização ${ }^{89}$. O pe. jesuíta Antônio Vieira provou dessa peculiaridade marítima quando disse: uma das mais difficultosas e trabalhosas navegações de todo o mar Oceano he a que se faz do Maranhão até o Ceará por costa, não só pelos muitos e cegos baixios, de que toda está cortada, mas muito pelas pertinácias dos ventos, e perpetua correnteza das águas. ${ }^{90}$

O fator supracitado fortaleceu as considerações das autoridades coloniais no que tange à construção de estradas que unissem as duas cidades. Vale destacar que o rei, Dom Pedro II, em 1696, agradeceu ao então governador geral do Brasil, D. João de Lencastre, sobre a criação de um caminho terrestre, passando pelos muitos sertões nordestinos ${ }^{91}$. Lencastre deu informações que hoje de pode ir e vir, daquelle Estado com muita facilidade. Como meio de facilitar o traslado por este novo caminho, foi incumbido o ouvidor geral do Estado do Maranhão, Dor. Mel. Nunes Colares, acompanhado de um jesuíta, Jacob Cloceo, que fizerão o seu Roteiro, e Mappa (...) para mayor clareza e conhecimento do Sertam. ${ }^{92} \mathrm{~A}$ carta elaborada pelo inaciano foi usada para repartir as terras para que dadas em Sismarias

\footnotetext{
${ }^{88}$ Serafim Leite esclarece que os índios classificados como Tapuias são, genericamente, aqueles que não falavam a língua tupi-guarani. Porém, não eram de uma mesma etnia, porque tinham diversas línguas que os separavam por subgrupos. LEITE, Serafim. "João de Barros, lisboeta, apóstolo dos Quiriris e Acarases." In Congresso do mundo português. Vol. IX. Tomo I - Do descobrimento a ocupação da costa. Lisboa, Comissão Executiva do Centenário, 1940. p. 474.

Entre essas tribos que se inserem no sistema étnico dos Tapuias podemos citar os Cariris, Janduís, Jaicós, Acaroas, Paiaiases, Icós, Icozinhos, Rodeleiros, Beiçudos, Precatis, Carapotangas, Pimenteiras, Guegués, Aruás, Acumes, Urius, Abetiras, Cupinharós, Macamasus, Anicuás, Alongas, entre outras. A listagem completa pode ser vista em MOTT, Luiz Roberto B. Piauí colonial: população, economia e sociedade. Teresina, Projeto Petrônio Portela, 1985. p. 112 - 113.

${ }^{89}$ STUDART FILHO, Carlos. "Vias de comunicação do Ceará colonial”. In Revista do Instituto do Ceará. Tomo LI. Fortaleza, 1937. p. 19.

${ }^{90}$ VIEIRA, pe. Antônio. Apud STUDART FILHO, Carlos. Vias de comunicação do Ceará colonial”. In Revista do Instituto do Ceará..., Opus cit., p. 19.

${ }_{91}$ PROJETO RESGATE. AHU_ACL_N_MARANHÃO, D. 957.

${ }^{92}$ PROJETO RESGATE. AHU_ACL_N_MARANHÃO, D. 957.
} 
se possão mais facilmente reduzir a cultura (...). ${ }^{93} \mathrm{O}$ território com a cartografia torna-se legível, como explicou o ouvidor Nunes Colares a D. João de Lencastre:

(...) Meu amigo e Snr. Como tenho conhecido que foi vm. sempre mais empenhado no descobrimento do Caminho do Maranhão para a Bahya, tantas vezes intentado nos muitos annos, que há, que Sua Magestade, que Deus guarde, o encarregou aos governadores daquelle Estado: do q' eu nesta empresa tam difícil a se intentar como venturosa se conseguir: me pareceo dedicar a vm., com esta carta o livro, que ordenou ao Capitão Manuel Ferreyra (principal explorador dos que mandey, e agora passa nesta Frota a essa Corte) fisesse de tudo o que conviesse obrar, a fiz para incurtar a distancia de ida, e vinda por novo rumo, como para facilitar, com a estrada, que abrisse, e montes, e Rios, que servissem de balizas às jornadas, aos passageiros que fossem, ou viessem de hum para outro estado como já vam freqüentando.

Também acompanho o mesmo livro hum Mappa, que a minha curiosidade fez exprimir por hum Religiozo da Companhia de Jesus, o que chamao Jacob Cloceo, a que o dito capittam assistio para as noticias mais necessárias aqualles Certoens, e para a certeza infalível dos rumos, que foi seguindo, quando os abrio o dito caminho. O qual elle explicará a vm., pessoalmente, para mais fácil inteligência do mesmo Mappa $(. . .)^{94}$ [grifo nosso].

Encurtando o mar e a caatinga, penetrando as terras por imensos currais, a pecuária extensiva foi figurada nas velhas cartografias através dos trajetos e caminhos desenvolvidos pelo gado. Os caminhos eram transitados por moradores, missionários e funcionários do governo. A localização das fazendas de gado, com uma simbologia específica, denota as especificidades que envolveram esta atividade econômica acerca do conhecimento do território. No Arquivo Histórico do Exército Brasileiro localizamos uma carta da capitania do Piauí [figura 22] onde estão representados os caminhos do gado e as respectivas fazendas de criar daquela região.

\footnotetext{
${ }^{93}$ PROJETO RESGATE. AHU_ACL_N_MARANHÃO, D. 957.

${ }^{94}$ PROJETO RESGATE. AHU__ACL_N_MARANHÃO, D. 957. Infelizmente, não conseguimos encontrar o referido mapa em nossas pesquisas pelas instituições sobreditas. Cremos que a transcrição de parte deste manuscrito revele o valor da cartografia na conquista dos sertões nordestinos.c
} 


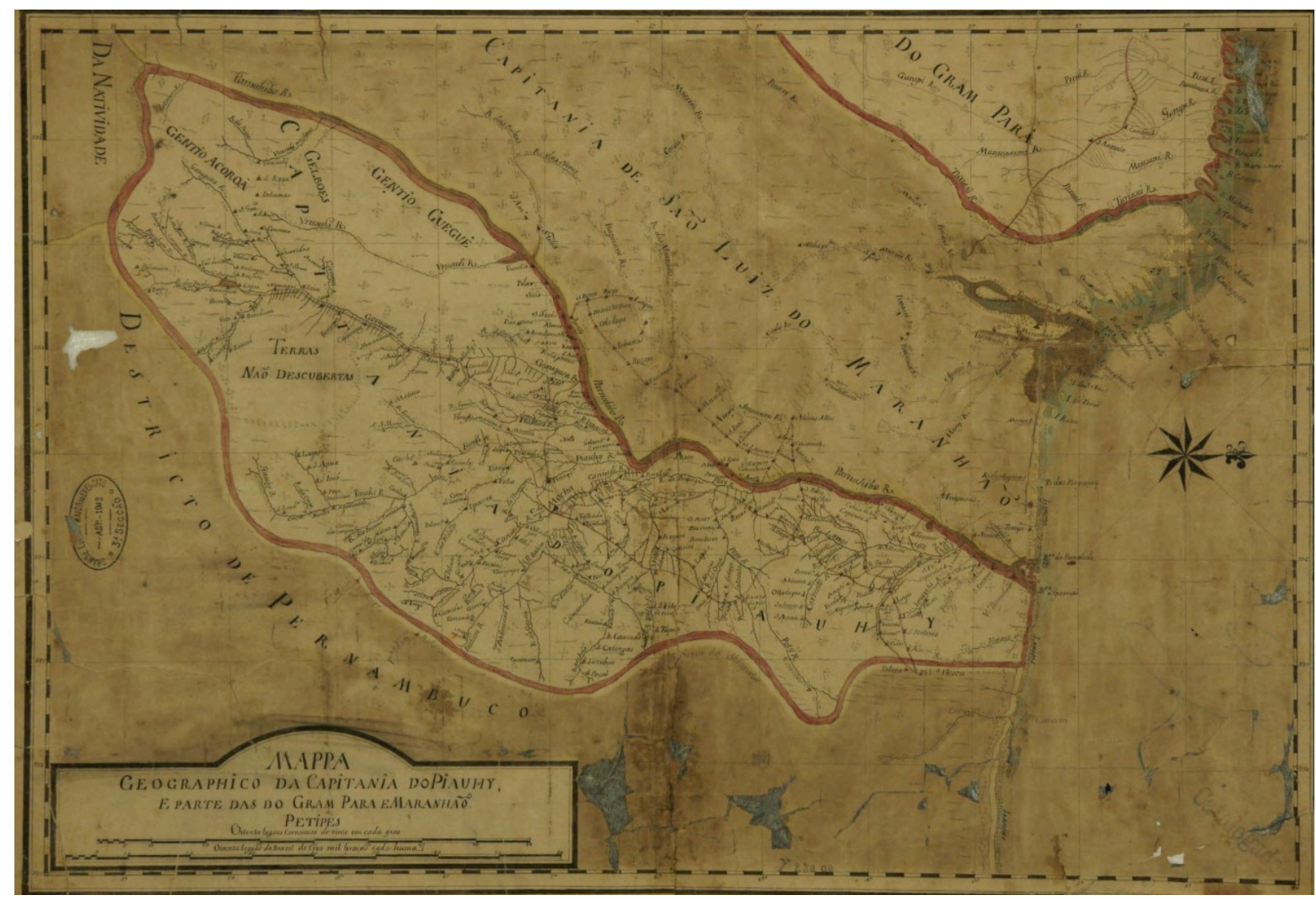

Figura 22 - Mappa Geographico da Capitania do Piauhy e parte das do gram Pará e Maranhão. Cartografia original do Arquivo Histórico do Exército Brasileiro - AHEx - RJ.

A existência de gentios bravios e guerreiros, os Tapuias, a sudeste da capitania do Piauí, fez desta parte do interior piauiense uma área pouco habitada. A indicação de Terras não Descobertas nos leva a esta hipótese. Alusão que pode ser confirmada na carta do engenheiro militar, João Antonio Galucio, enviado para aquela capitania após a sua criação, em 1758.

O desenho legado por Galucio [figura 23] identifica a nação dos Pimenteiras como habitantes da região sudeste do Piauí colonial. Esta nação de índios hostilizou os moradores portugueses e seus escravos, por intermédio de seqüestros, roubos e assassinatos, afugentadoos de suas fazendas de gado. 
Relatando os métodos usados para a produção da carta (da Capitania de São José do Piauí - figura 23) ao secretário de estado da Marinha e Ultramar, Francisco Xavier de Mendonça Furtado, o engenheiro Galucio escreveu:

(...) Parti daquella Capitania para o Piauhy já na idea de entreprender (sic) desde logo a construção do Mapa Geográfico deste Capitania, por cujo respeyto foy arrumado o Rio Itapicuru, e todo o caminho de terra que me conduzio athé esta Villa, observando miudamente os rumos das estradas, medindo suas distancias, e tomando frequentemente as alturas para latitude, e fazendo todas as observações de longitude que me foy possível (...)

No fim do anno passado (1759) foy para o Norte da Capitania; e logo no principio deste ao Sul athé Parnaguá, nao obstante o tempo das chuvas e a infestação do Gentio. Despoes da Páscoa foy para a parte Nascente, de donde atravessando as cabeceiras de muitos rios por caminhos nao practicados, e subindo o Rio Canindé, e descendo o Rio Piauhy acabei de adquirir todos os elementos precizos para a construção do Mapa Geográfico de toda a Capitania, o qual logo entrei a por em medida, e arrumar, e a reduzir três vezes, nao obstante huã grave doença adquirida na derradeira viagem, e finalmente delinei (sic) em limpo dois exemplares, que entregeuei ao Ilmo. Sr. Gov. Desta Capitania, para serem remetidas como entendo, nesta frota para V. Exa.

Nao ha duvida, que eu fuy sempre neste exerciço de minha obrigação, e principalmente quando me via cercado das mayores difficuldades, e mettido nos mais evidentes perigos, que fuy sempre allentado pella esperança, e fé certa de ver premiada a boa vontade, com que me empregava no serviço de Sua Magestade (...) ${ }^{95}$ [grifo nosso].

\footnotetext{
${ }^{95}$ PROJETO RESGATE. AHU_ACL_CU_016, Cx.7, D. 437.
} 


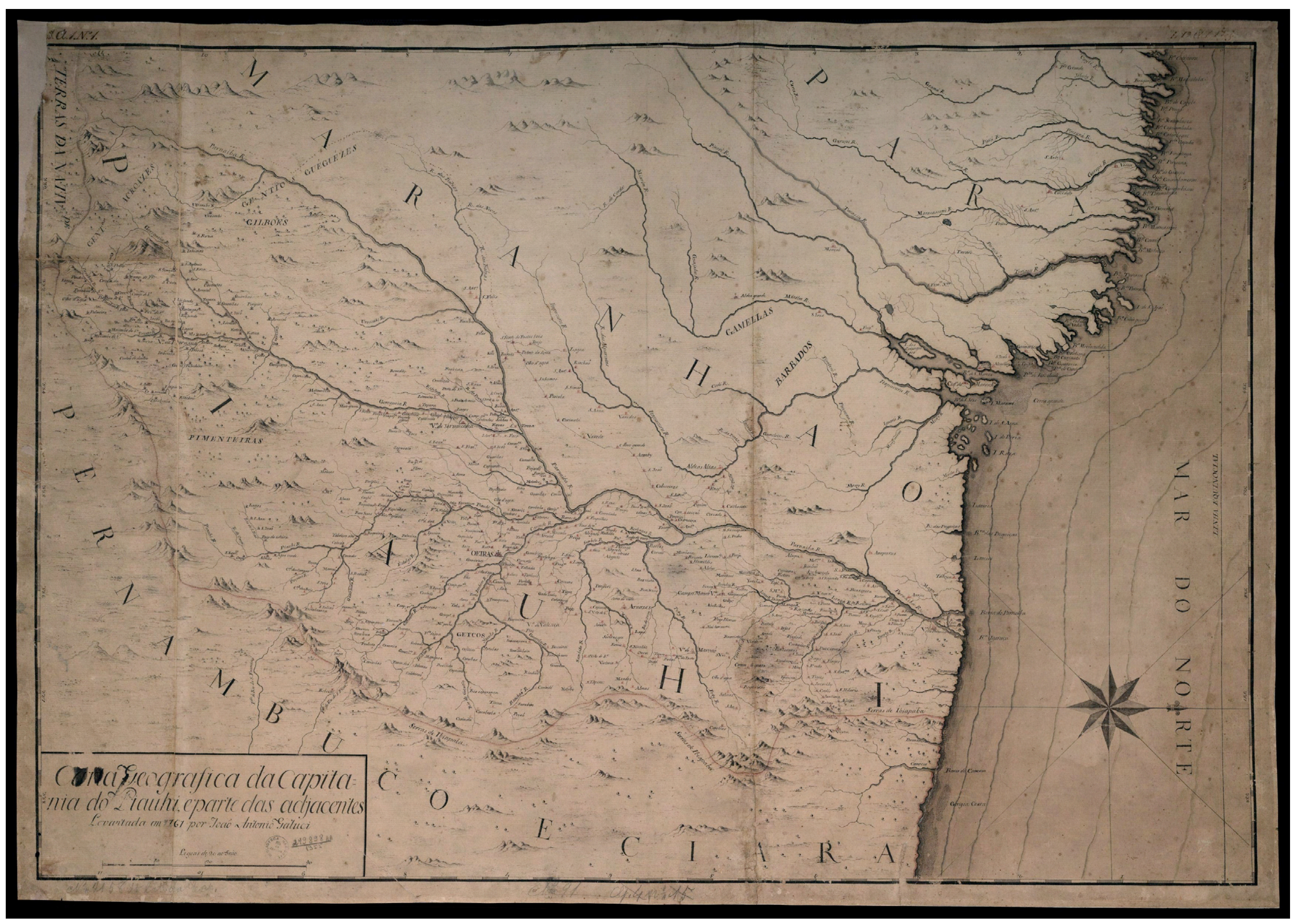


Galucio, assim como outros engenheiros militares ${ }^{96}$ estabelecidos no sertão nordestino, fizeram parte de um amplo projeto político, cuja figura chave é o conde de Oeiras. Coube ao seu comando medidas eficientes para centralizar as funções administrativas da colônia na mão de seus funcionários ${ }^{97}$. Além do mais, os planos de organização urbana, através das normas estabelecidas em cartas régias para a fundação das novas vilas e cidade do interior do Nordeste, trouxeram uma nova amostragem daquele território. Ainda prevaleciam as cartas geográficas delimitando as fronteiras entre as capitanias. Todavia, com o olhar do engenheiro militar, os núcleos sertanejos são vistos, dessa fez, de frente. ${ }^{98}$ Assim é apresentada a planta da cidade de Oeiras (PI) [figura 24], elevada a esta condição pelo rei Dom José I, por carta régia de 1761.

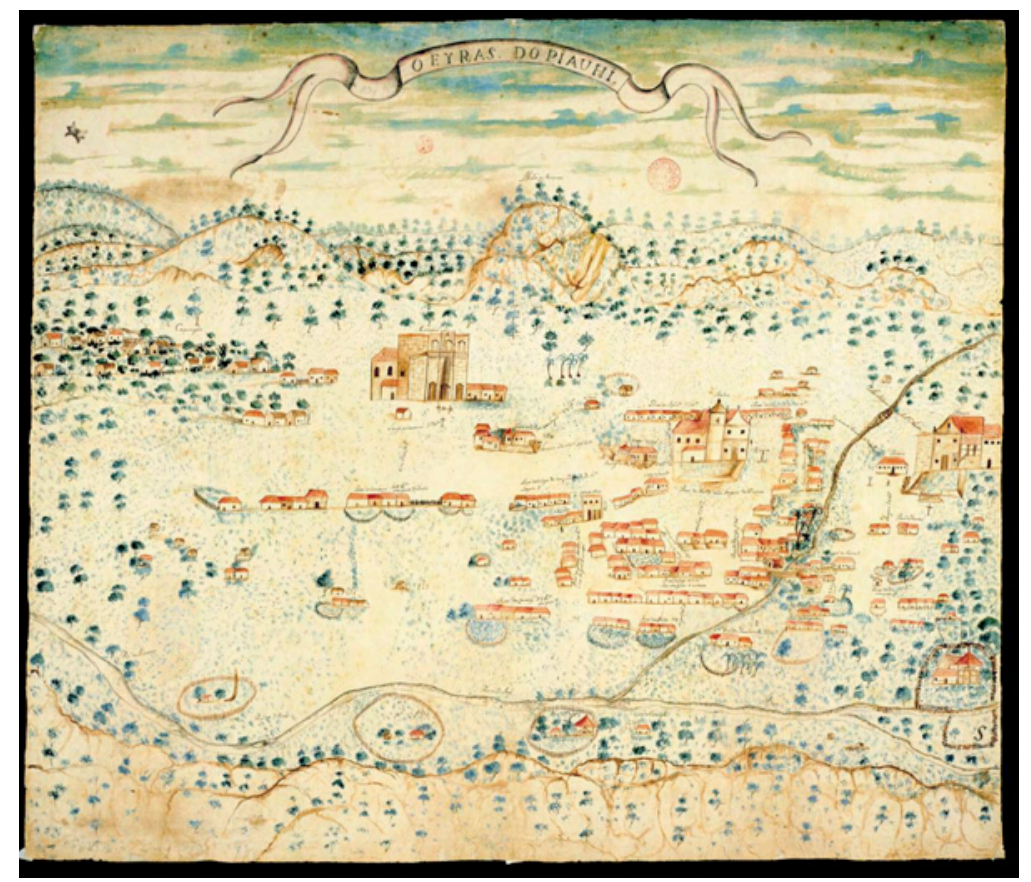

Figura 24 - Oyeras do Piauhi. De autor desconhecido. Imagem encontrada no CD - ROM Vilas e imagens do Brasil colonial.

\footnotetext{
${ }^{96}$ No Registro dos Autos da erecção da real villa de Monte-mór o Novo da America, atual Baturité (CE), é citado a presença de Custódio Francisco de Azevedo, engenheiro de profissão e morador na Serra dos Coquos d'esta capitania, que para a dita demarcação mandou convocar, e como tivesse vindo para a mesma demarcação, lhe ordenou trouxesse o instrumento chamado prancheta ou circulo dimensório. Ver "REGISTRO dos autos de erecção da real villa de Monte-Mór o Novo da América, na capitania do Ceará Grande. In Revista do Instituto do Ceará. Tomo V. Fortaleza, 1891.

Há transcrição destes mesmos autos em SANTOS, Paulo F. Formação de cidades no Brasil colonial. Rio de Janeiro, Editora da UFRJ, 2001. p. 54 - 57.

${ }^{97}$ DELSON, Roberta Marx. Novas vilas para o Brasil-Colônia: planejamento espacial e social no século XVIII. Brasília, Alva-Ciord, 1997. p. 49.

${ }^{98}$ MARX, Murillo. "Olhando por cima e de frente"..., Opus cit., p. 174.
} 
O olhar do desenhista que esboçou a paisagem da cidade de Oeiras do Piauí mirou de frente, para as fachadas das principais edificações, para o casario humilde, tendo relevo as construções de cunho religioso. ${ }^{99}$ A igreja matriz do município, dedicada à Nossa Senhora da Vitória, está locada quase que no epicentro da povoação. À direita do observador, notamos a atual igreja de Nossa Senhora do Rosário, que nos idos da construção de seus alicerces, por volta de $1732^{100}$, fora projetada para abrigar o hospício da Companhia de Jesus daquela capitania. Após a expulsão dos jesuítas do Brasil, o hospício passou a ser administrado pela Irmandade do Rosário dos Homens Pretos ${ }^{101}$. Já à nossa esquerda, situamos a igreja de Nossa Senhora da Conceição. Junto desse templo, há o seu adro e o açougue da cidade.

Destacam-se na imagem da figura 24 as construções religiosas, porque segundo Murillo Marx...

(...) As principais referências dos núcleos lusitanos na América são os templos e os claustros, constituindo os elementos dominantes retratados ao longo dos séculos. É que por razões econômico-socioculturais, por determinações institucionais e, de maneira menos declarada, também considerações militares, essas construções empatam no geral a maior soma de investimentos. E merecem, por isso, os pontos privilegiados $(. . .)^{102}$

Determinações institucionais referidas por Marx incluem a atuação da Igreja Católica na formação da paisagem urbana de nossos aglomerados. As Constituições Primeyras do Arcebispado da Bahia ${ }^{103}$ são um conjunto de leis eclesiásticas que interferiu na sociabilidade

\footnotetext{
${ }^{99}$ MARX, Murillo. "Olhando por cima e de frente"..., Opus cit., p. 174.

${ }^{100}$ PROJETO RESGATE. AHU_ACL_CU_016, Cx.2, D. 75.

${ }^{101}$ CARVALHO Jr., Dagoberto Ferreira de. Passeio a Oeiras. 6 ed. Teresina, Fundação Cultural do Piauí, 2010. p. $115-116$.

${ }^{102}$ MARX, Murillo. "Olhando por cima e de frente”..., Opus cit., p. 174.

${ }^{103}$ O quarto livro destas constituições, sob o titulo 17 (687) indica-nos: "Conforme o direito Canônico, as igrejas se devem fundar, e edificar em lugares decentes, e acommodados, pelo que mandamos, que havendo-se de edificar de novo alguma igreja parochial em nosso Arcebispado, se edifique em sitio alto, e lugar decente, livre da humanidade, e desviado, quanto for possível, de lugares immundos, e sórdidos, e de casas particulares, e de outras paredes, em distancia que possão andar as Procissões ao redor dellas, e que se faça em tal proporção, que não somente seja capaz dos freguezes todos, mas ainda de mais gente de fora, quando concorrer as festas, e se edifique em lugar povoado, onde estiver o maior numero de freguezes. E quando se houver de fazer, será com licença nossa: e feita vestoria, iremos primeiro, ou outra pessoa de nosso mando, levantar Cruz no lugar, aonde houver de estar a Capella maior, e demarcará o âmbito da Igreja, e adro della. Ver CONSTITUIÇÕES Primeyras do Acerbispado da Bahia feitas, e ordenadas pelo ilustríssimo, e reverendíssimo sernhor D. Sebastião Monteiro da Vide, 5 arcebispo do dito Acerbisopado,e do conselho de sua Majestade: propostas, e aceitas em o Synodo
} 
dos cidadãos brasileiros, tendo reflexos no desenho dos núcleos coloniais, inclusive àqueles instalados muito além do litoral.

Agindo sobre o território, a Igreja por intermédio das missões religiosas e, a posteriori, através das freguesias, equacionou a urbanização do sertão nordestino. As cartografias pesquisadas mostram a influência das paróquias no povoamento do território. Esse fenômeno é representado no Mapa Geographico da Capitania do Seará [figura 25], delineado em 1800 pelo visitador Marianno Gregório do Amaral, cujo original está na Biblioteca Nacional do Rio de Janeiro, setor das cartografias.

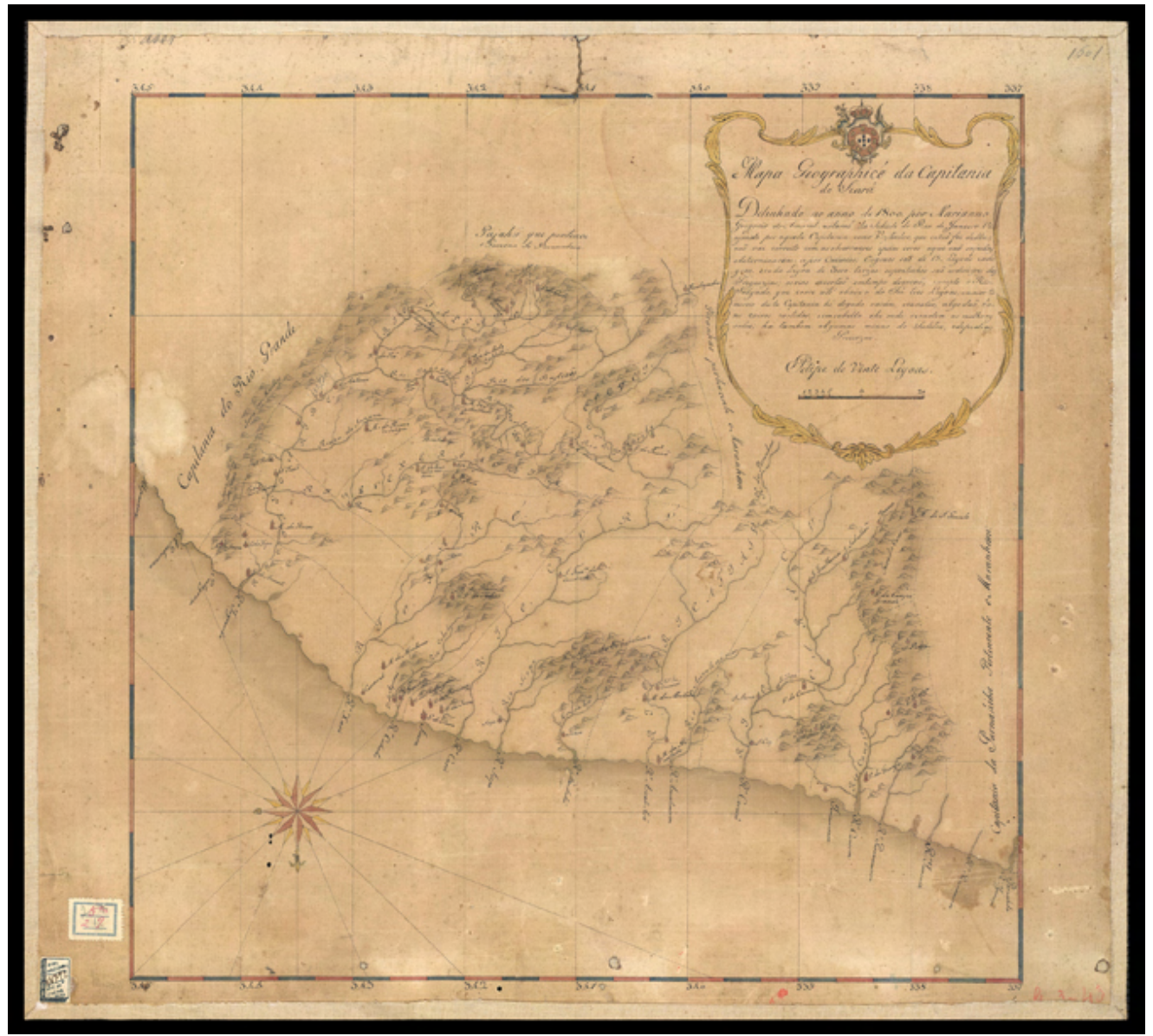

Figura 25 - Mapa Geographico da Capitania do Seará. Disponivel em http://www.bn.br. Acesso em 03.02.2010.

Diocesano, que o dito senhor celebrou em 12 de junho do anno de 1707. Introdução e revisão do cônego prebendano Idelfonso Xavier Ferreira. São Paulo, Typ. 2 de dezembro, 1853. 510p. 
Em virtude da dimensão do desenho da figura 25, para certificar as assertivas sobreditas, é necessário aumentar o zoom em algum ponto do mapa [figura 26]. Analisando a ampliação da área eleita, verificamos a demarcação, em linha pontilhada, dos respectivos termos das paróquias. Percebemos a hierarquia estabelecida pela rede urbana da capitania do Ceará: indicações de vilas (Icó e Crato), freguesias (São Matheus, Riacho do Sangue e Missão Velha), capelas curadas ou visitadas (por exemplo no termo da vila Real do Crato encontramos a capela de Santa Ana; já no da vila de Icó são apontadas as capelas do Bom Fim e Lavras da Mangabeira). Atenção deve ser dada à localização desses aglomerados. Em sua grande maioria situados à margem de um curso d'água, seja rio ou riacho. Fator decisivo para a sobrevivência dos moradores sertanejos, diante dos longos períodos de seca que assolam a região. ${ }^{104}$

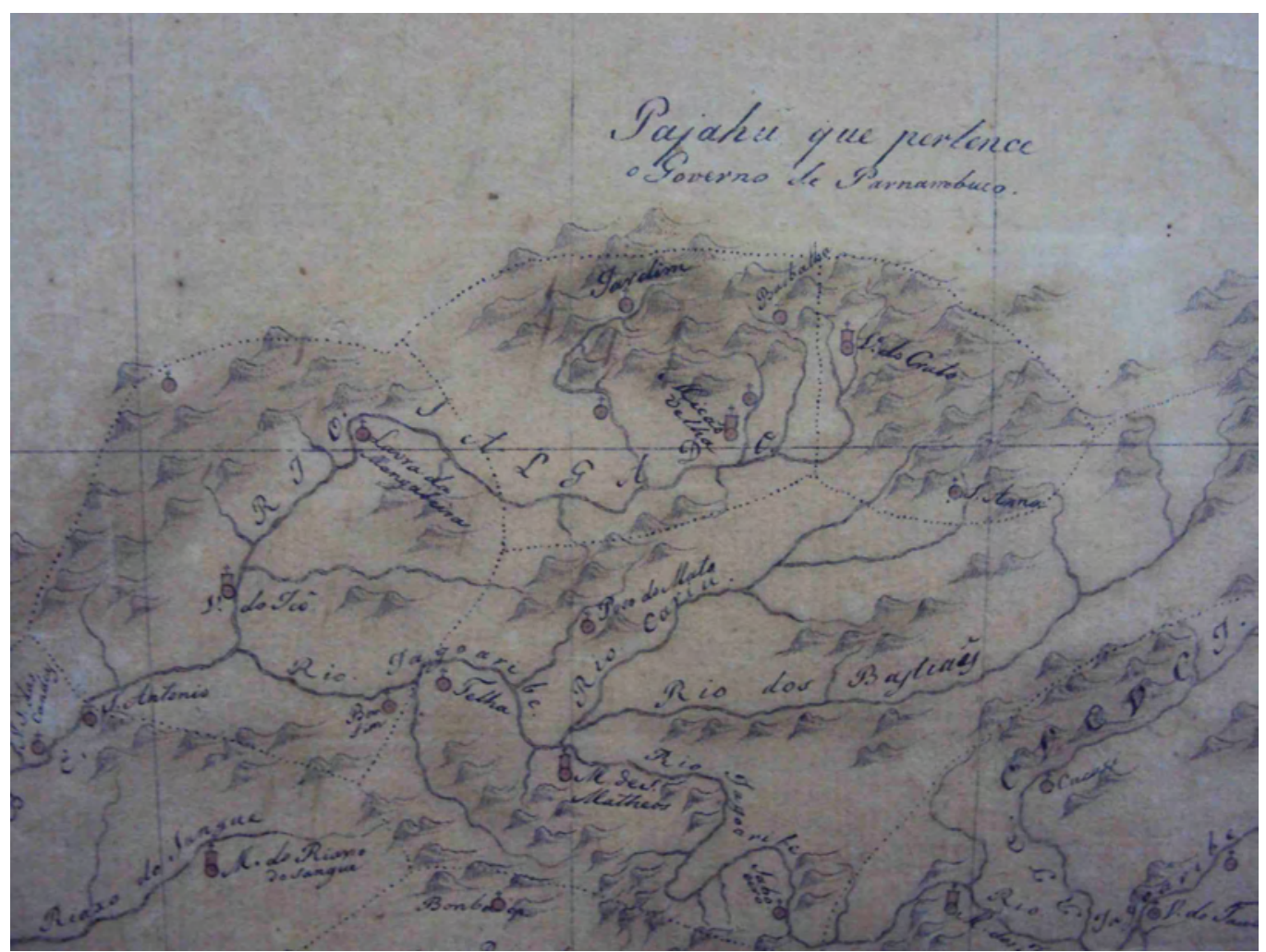

Figura 26 - Pormenor do Mapa Geographico da Capitania do Seará. Criada pelo visitador, Marianno Gregório do Amaral, em 1800. Fotografia do autor sobre original encontrado na Biblioteca Nacional do Rio de Janeiro, setor Cartografia. Data da foto: 26.10.2010.

\footnotetext{
${ }^{104}$ A seca, como um fator climatológico preponderante no sertão nordestino, deve ser analisada com maior cuidado, pois, este fenômeno deve ser atribuído como um índice de urbanização desta extensa área. Devido à seca vilas e povoados foram abandonados, provocando um déficit populacional. Entretanto, outros núcleos urbanos, devido à maior incidência de chuvas em sua região, passam a concentrar um maior número de habitantes migrados para o seu termo.
} 
Tocos desenhos, quem sabe um rascunho de um cartógrafo [figura 27], de bandeirantes ou sertanistas do terço deram as primeiras impressões dos sertões nordestinos. Observar a evolução da técnica de produção das velhas cartografias equivale em notar como ocorreu o paulatino povoamento e urbanização do sertão. Sertão descrito e relatado por viajantes estrangeiros. Spix e Martius, Gardner e Henry Koster foram alguns que nos legaram, em seus diários de bordo, vasta informação sobre o meio ambiente, geologia e sociedade sertaneja. Este será o tema dissertado no próximo tópico.

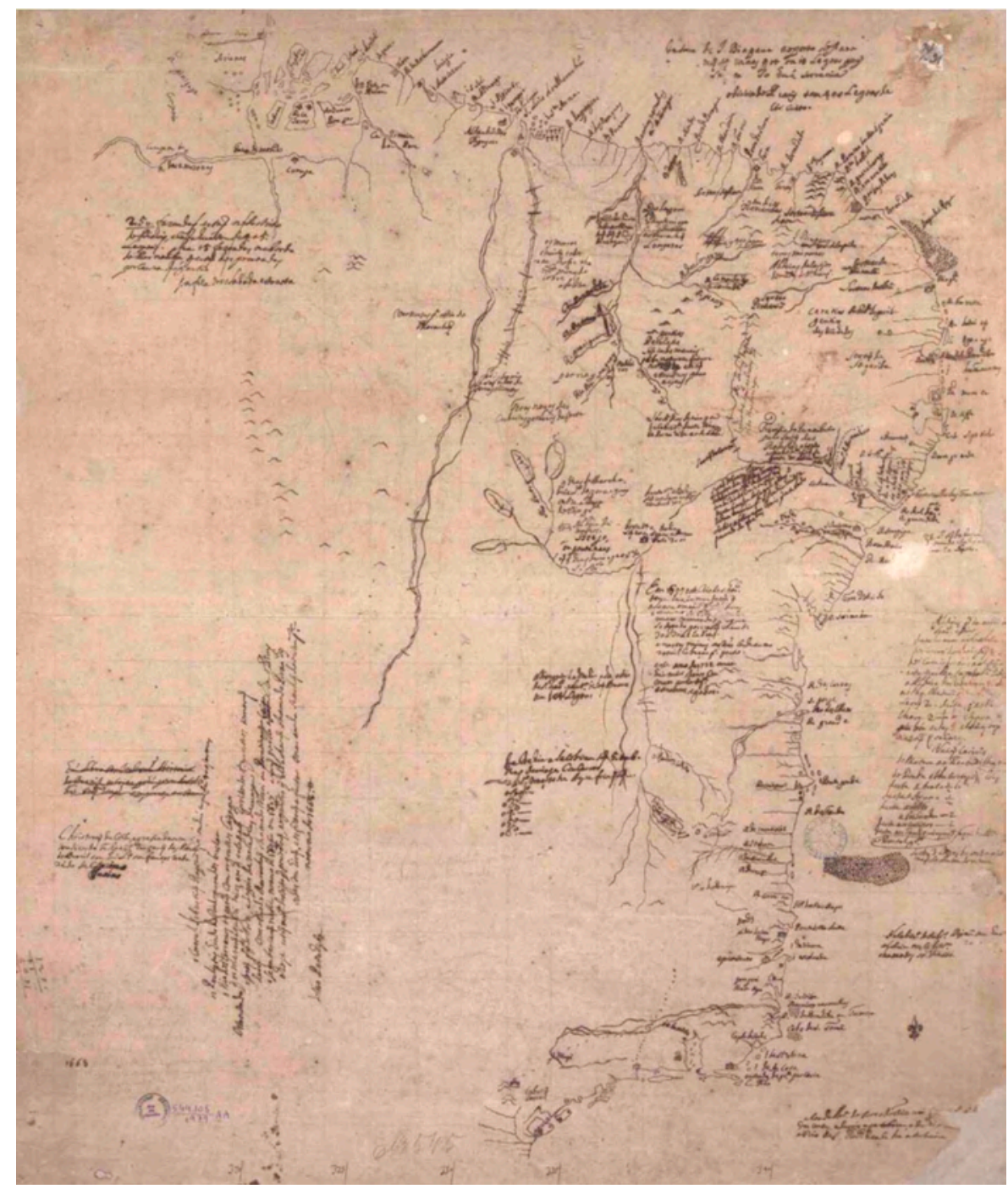

Figura 27 - Mapa da região compreendida entre o rio Amazonas e São Paulo, 1722. Cartografia com escala indeterminada. Disponível em http://www.bn.br. Acesso em 14.07.2010. 


\section{4 “Ao primeiro olhar": discurso acerca do sertão nordestino pelos viajantes estrangeiros}

Deixara o Sertão e, embora tivesse sofrido, sempre desejei regressar. Tenho um certo prazer em descrever e viajar em novas regiões e esta parte do território que atravessara era desconhecida para qualquer inglês. Pelas sensações pessoalmente sentidas, imagino quanto agradará ao viajante nessas zonas inexploradas o encontro de novidades ao primeiro olhar. Ha ainda neste continente da América do Sul grandes partes a serem percorridas e sempre desejei ardentemente ser o primeiro homem civilizado que fizesse jornada de Pernambuco a Lima. [grifo nosso]. ${ }^{105}$

(...) q' a distancia passava de centro e trinta legoas, sendo certões indômitos com difficultosos caminhos, habitados, a maior parte, por gentios(... $)^{106}$. Assim descreveram as autoridades do Conselho Ultramarino ao rei Dom João V, segundo análise feita a partir das informações contidas na correição de 1733 do ouvidor da capitania da Paraíba, Jorge Salter de Mendonça. O rei Dom José I, em carta régia para o governador da capitania de São José do Piauí, João Pereira Caldas, se surpreendeu com a realidade dos habitantes do Piauí, porque viviam...

(...) em grandes distancias huns dos outros sem a communicação como inimigos da sociedade civil e do commercio humano padecendo assim os descômodos e os lugares muito remotos e longínquos de sorte que quando lhes chegam os despachos vem tão tarde que não servindo para o remedeo das queixas lhes trazem sempre a ruína. (...) seguindo se daquella dispersão e separação de famílias enternadas em lugares ermos e dezertos faltaram lhes os estímulos e meyos para se fazerem concluídos na corte (...). ${ }^{107}$

As narrativas que avaliaram o sertão nordestino, ao longo do antigo regime colonial, descreveram-no numa aura norteada pelo esquecimento, isolamento e desgraça. Nesta última categoria estão inclusas a faina entre as variadas etnias que compuseram o território, violência

\footnotetext{
${ }^{105}$ KOSTER, Henry. Viagem ao Nordeste do Brasil. Tradução e notas de Luis Câmara Cascudo. Rio de Janeiro, Editora Nacional, 1942. p. 202-203.

${ }^{106}$ PROJETO RESGATE. AHU_ACL_CU_014, Cx.9, D. 727.

${ }^{107}$ PROJETO RESGATE. AHU_ACL_CU_018, Cx.8, D. 450.
} 
pela posse da terra e a miséria consequente da falta de rendimentos econômicos e, como veremos, pela seca que põe em consternação o sertanejo.

Entre os séculos XVII e XVIII, segundo os manuscritos por nós transcritos e analisados, o olhar do colonizador será muitas vezes pessimista para a paisagem urbana de núcleos sertanejos. Salvo alguns aspectos de cunho econômico e natural: a criação de gado, considerada o elemento motor do desenvolvimento urbano do interior do nordeste, e as espécies vegetais, como o juazeiro e o imbuzeiro, resistentes às intempéries climáticas, ganharam boas críticas dos relatores.

A partir do início do século XIX, quando a caatinga é percorrida por estrangeiros ávidos de conhecimento cientifico, no que tange à sua natureza e sociedade exóticas, aumentam as descrições sobre o hinterland do Nordeste. Através de penosas viagens pelo árido território, o viajante se confrontou com a falta de estradas, insegurança e, principalmente, com o rigor do ambiente. Impressionou-os a força do sertanejo e sua facilidade de adaptação ao meio:

(...) Resignado e tenaz, com a placabilidade superior dos fortes, encara de fito a fatalidade incoercível; e reage. O heroísmo tem nos sertões, para todo o sempre perdidas, tragédias espantosas. Não há de revivê-las ou episodiálas. Surgem uma luta que ninguém descreve - a insurreição da terra contra o homem. $(\ldots)^{108}$

O imaginário setecentista persiste com o seu prelúdio e o alvorecer dos Oitocentos? Qual a marca do sertão nordestino que o distingue das outras regiões brasileiras? Em um lugar onde a fronteira ${ }^{109}$ sócio-cultural quase inexiste, o visitante nos diz muito para efeito de minimizar preconceitos arraigados, infelizmente, com o passar dos séculos.

Focalizaremos as narrativas dos viajantes dos Oitocentos. Porém, apoiamos a análise de Ângela Domingues:

O conhecimento científico Brasil é anterior ao período da abertura dos portos brasileiros ao comércio e navegação das nações européias. Embora seja inegável a importância e a novidade trazidas pela obra de John Mawe,

\footnotetext{
${ }^{108}$ CUNHA, Euclides da. Os sertões..., Opus cit., p. 168.

${ }^{109}$ Bons comentários sobre a metáfora da fronteira nos sertões do Brasil colonial podem ser encontrados no artigo de RUSSEL-WOOD, A.J.R. "Fronteiras no Brasil colonial". In Oceanos. n ${ }^{\circ}$ 40, Outubro/Dezembro. Lisboa, Comissão Nacional para as Comemorações dos Descobrimentos de Portugueses, 1999. p. 10 - 20.
} 
Thomas Lindley, Henry Koster, Maximiliano de Wied-Neuwied ou Barão de Eschwege, há que considerar que o Brasil tornou-se mais conhecido dos europeus dos Setecentos graças aos roteiros, diários de viagens, mapas e vistas de marinheiros, traficantes, corsários e piratas que percorreram o litoral brasileiro durante o século XVIII. ${ }^{110}$

Entre os principais estrangeiros que escreveram sobre as paisagens natural e cultural do sertão nordestino estão Henry $\operatorname{Koster}^{111}$, natural de Lisboa e filho de pai inglês. Aportou em Recife no ano de 1809, donde viajou para os atuais estados do Rio Grande do Norte, Pernambuco, Paraíba e Ceará. O príncipe Maximiliano de Wied-Neuwied ${ }^{112}$ viajou pelo Brasil entre 1817 e 1819. Dele há interessantes anotações e ilustrações sobre o interior baiano. Os alemães Spix e von Martius ${ }^{113}$ que, além de dados estritamente relacionados ao meio ambiente do lugar investigado, escreveram sobre a economia e sociedade sertanejas. Também cruzou os áridos sertões outro germânico, Robert Ave- Lallemant ${ }^{114}$, as referências deste estrangeiro são válidas para as narrativas acerca do rio São Francisco. Por fim, temos o médico e naturalista inglês George Gardner ${ }^{115}$, indo pelos interiores do Ceará, Piauí, Alagoas e Sergipe entre os anos de 1838 - 1841. Suas notas sobre as atuais cidades de Oeiras (PI), Parnaguá (PI), Jaicós (PI), Crato (CE), Icó (CE), Jardim (CE), Russas (CE), entre outras, nos dão um quadro da urbanização no tempo de suas visitas.

Os discursos caracterizam o cotidiano e a cultura da população; a economia (ou as economias) dominante na época; ${ }^{116}$ a paisagem urbana com seus múltiplos aspectos: casario, templos religiosos, edificações oficiais e morfologia urbana; a fauna, flora e o relevo característicos da caatinga nordestina; as relações de poder exercidas pelos fazendeiros de

\footnotetext{
${ }^{110}$ DOMINGUES, Ângela. "O Brasil no relato dos viajantes ingleses do século XVIII: produção de discursos sobre o Novo Mundo.” In Revista Brasileira de História. V. 28. № 55. São Paulo, 2008. p. 133.

${ }^{111}$ KOSTER, Henry. Viagens ao Nordeste do Brasil. Tradução e notas de Câmara Cascudo. Rio de Janeiro, Editora Nacional, 1942.

${ }^{112}$ WIED-NEUWIED, Maximiliano. Viagem ao Brasil. São Paulo, Edusp 1989. 536 p.

${ }^{113}$ SPIX, J.B Von; MARTIUS, C.P.F. Viagem pelo Brasil: 1817 - 1820. 3 v. São Paulo, Edusp, 1981.

114 AVE-LALLEMANT, Robert. Viagens pelas províncias da Bahia, Pernambuco e Sergipe. São Paulo, Edusp, 1980. 347 p.

${ }^{115}$ GARDNER, George. Viagem ao interior do Brasil. São Paulo, Edusp, 1975.

116 Para fins de adaptação ao tema geratriz desta dissertação, enfatizaremos as especificidades da pecuária sertaneja no desenvolvimento territorial e urbano do sertão nordestino; assunto muito debatido pelos viajantes estrangeiros. Marginalmente e, pela carência de informações obtidas, indicaremos outras economias. É o caso da cultura algodoeira que sobrepôs a pecuária já no fim dos Setecentos e a extração da cana - de - açúcar, para a produção da rapadura e aguardente, em engenhos especializados no vale do Cariri cearense.
} 
gado, os quais, a posteriori, tornar-se-ão os coronéis do sertão, cuja literatura é rica em citálos. $^{117}$

Múltiplas especificidades compõem a paisagem sertaneja, o que ensejariam muitas páginas desta dissertação, cujo foco remete à outra particularidade. Por isso, atemo-nos em (des)escrever sucintamente as características acima detalhadas, apoiados no pensamento dos viajantes, com intuito de apresentar um panorama geral desse olhar estrangeiro.

Sentido, experimentando, tomando notas e descrevendo a caatinga do Nordeste brasileiro [figura 28], os viajantes em companhia de suas tropas, formadas geralmente por escravos carregadores e guias que orientavam o deslocamento, admiraram o mix existente na paisagem daquele território. Chocam-se com terras semi-desérticas, sobressaindo o verde das cactáceas como o mandacarú [figura 29] e a palma, alimentos certos para o pobre sertanejo em tempos de estiagem. ${ }^{118}$ Ora se alegram por adentrar em áreas arborizadas, de clima ameno, resquícios de uma mata perdida e não agredida pelos homens de outrora. O vale do Cariri cearense, localizado ao sul do atual estado do Ceará e ao sopé da chapada do Araripe [figura 30], é um bom exemplo no que compete à existência deste meio dual. Chegando por volta do ano de 1838 a este vale, o botânico inglês, Geoge Gardner, sentiu que era...

Impossível descrever o deleite que senti ao entrar neste distrito (Crato - CE), comparativamente rico e risonho, depois de marchar mais de trezentas milhas através de uma região que naquela estação era pouco melhor que um deserto. A tarde era das mais belas que me lembra ter visto, com o sol a sumir-se em grande esplendor por trás da Serra do Araripe, longa cadeia de montanhas a cerca de uma légua para o oeste da vila; e o frescor da região parece tirar aos seus raios o ardor que pouco antes do poente é tão opressivo ao viajante nas terras baixas. ${ }^{119}$

\footnotetext{
${ }^{117}$ Euclides da Cunha (Os sertões); Guimarães Rosa (Grandes sertões veredas); José de Alencar (O sertanejo); Raquel de Queiroz ( $O$ Quinze).

${ }^{118}$ CASTRO, Josué. Geografia da fome. 6 ed. Rio de Janeiro, Civilização Brasileira, 2006. p. 155 - 246.

Sobre estes alimentos elaborados com a vegetação local, Spiz e Martius, argumentam que durante as estiagens, o sertanejo se vê desesperado pela circunstancial falta de alimentos. Dizem: (...) os moradores, pela absoluta falta de mantimentos, conseqüiencia da esterilidade do tempo seco, eram obrigados a preparar, com a medula do caule da palmeia aricuri, uma espécie de broa, que não é mais rica em substancia nutritiva do que o pão dos normandos, feito com a casca de pinheiros. (...) Pode-se facilmente imaginar como devem ser indigestas e pobre em matéria alimentícia essas miseráveis broas, de gosto amargo. Ver SPIX, J.B Von; MARTIUS, C.P.F. Viagem pelo Brasil..., Opus cit., p. 376.

${ }^{119}$ GARDNER, George. Viagem ao interior do Brasil..., Opus cit., p. 92.
} 


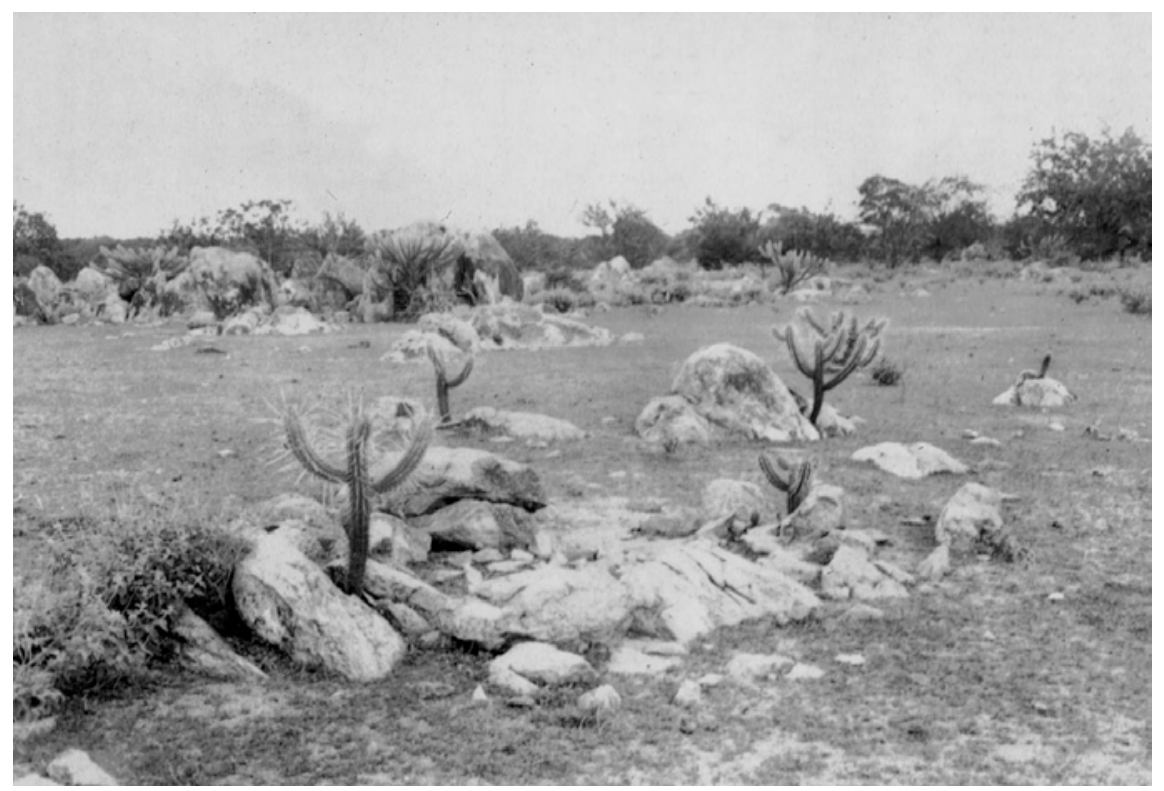

Figura 28 - Caatinga do sertão nordestino em tempos de estiagem. Imagem disponível em http://www.ibge.gov.br. Acesso em 11.03.2009.

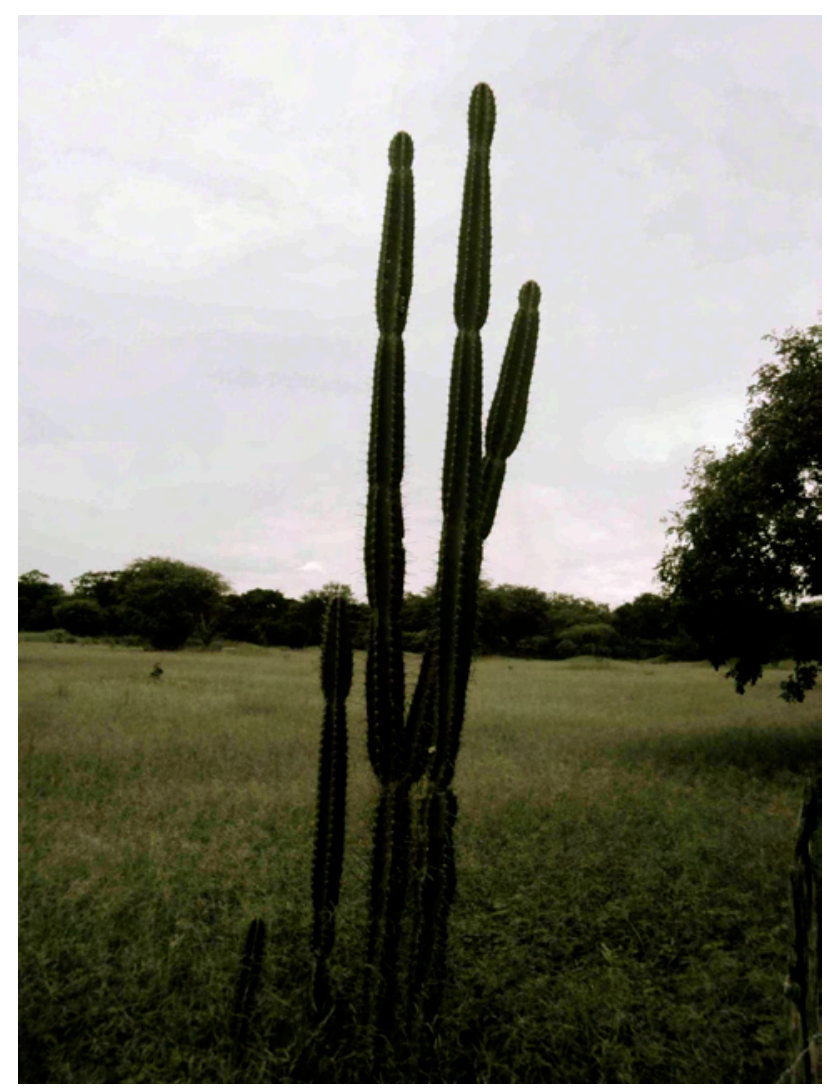

Figura 29 - Mandacarú. Foto do autor, 2010. 


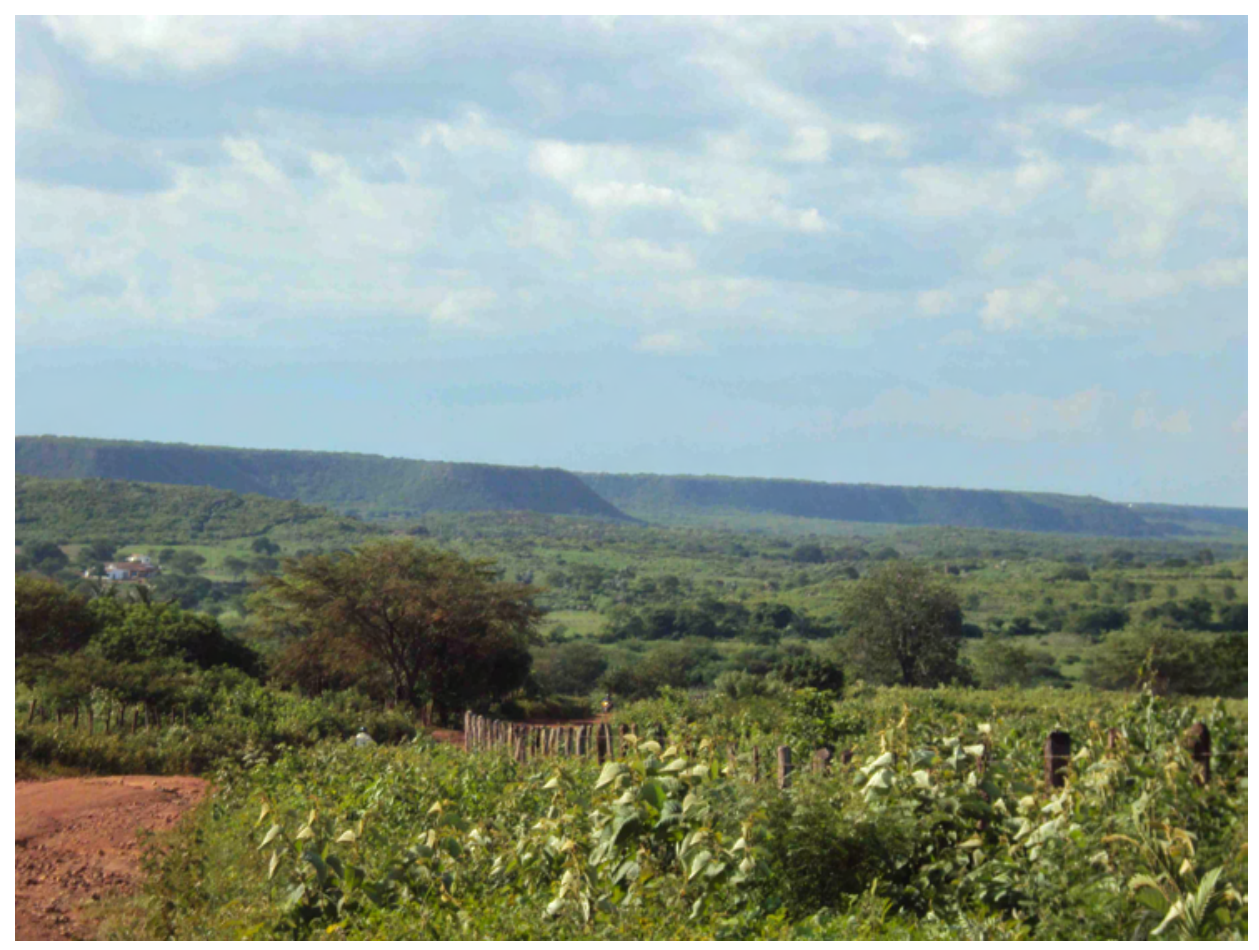

Figura 30 - Caatinga nordestina em tempos de chuva. Ao fundo a "muralha" da chapada do Araripe que impressionou o inglês George Gardner. Imagem autor, 2011.

Spix e Martius partiram da vila da Cachoeira, instalada no Recôncavo Baiano, com destino à cidade de Oerias do Piauí. Depararam-se com a metamorfose da paisagem natural sertaneja após o cair das chuvas:

(...) pois na seca perdem as folhas, e só se revestem de novo à entrada da estação das chuvas. (...) O brotar das folhas é, por isso, maravilhoso, pois, logo que chove, ele, no mais curto espaço de tempo, se faz como por encanto. Dessa singularidade da vegetação das catingas pudemos freqüentemente convencer-nos, porquanto no meio do sertão árido, onde todas as plantas estavam sem folhas, avistávamos trechos de mata e campina, que ostentavam o mais lindo verde primaveril. ${ }^{120}$

Maquiando cerca de seis meses no ano e quando há fartura de chuvas, o verde da caatinga esmiúça-se, dando lugar ao monótono tom de cinza, capaz de afugentar o viajante. Robert Ave-Lallemant, após sua decisão de visitar a cachoeira de Paulo Afonso, localizada no médio rio São Francisco, foi realista ao citar:

${ }^{120}$ SPIX, J.B Von; MARTIUS, C.P.F. Viagem pelo Brasil..., Opus cit., p. 365. 
(...) Quem com sonhos europeus da vegetação nas margens dum rio tropical sul-americano sobe o rio São Francisco, e da vila de Pão de Açúcar penetra um pouco na caatinga, nao poderá confiar nos seus olhos, quando em lugar de esplendor sonhado, contempla uma terra, cuja inospitalidade (sic.) e desolação realmente amedrontam. ${ }^{121}$

As causas para tal mudança na paisagem sertaneja, segundo o sobredito autor alemão, deve-se à seca. Para ele, sendo o sertão nordestino um lugar de perigos inesperados, todos eles se tornam pequenos,

(...) comparados a outro mais comum, para homens e animais. Acontece freqüentemente que por muitos meses, por toda a metade dum ano, não chove. A caatinga seca, desaparece o verde, cresta-se o ultimo pé de camará; o gado esfomeado e sedento, erra emagrecido dum lado para outro nas campinas, onde a relva esturricou, e onde toda a fonte de vida parece estancada. $^{122}$

Os efeitos da seca são rigorosos para o cotidiano sertanejo. Levando-os de sua vida pobre, vivida por muitos e vivenciada hoje por milhares, para uma vida de miséria. A água para consumo torna-se rara. Tesouro reservado e acumulados em cacimbas. ${ }^{123}$

Sentindo a estiagem, Spix e Martius viram episódios dignos de nota. Penetrando o sertão baiano em direção ao rio São Francisco, os alemães toparam com alguns moradores, ansiosamente ocupado em colher água das cavidades formadas, na base das folhas de ananás silvestres. Essa água, embora contaminada por insetos e ovas de rãs, era uma delícia para estes desgraçados sertanejos. ${ }^{124}$ Muitas das vezes, a reação do homem do sertão não é amistosa nem, tampouco, hospitaleira para os sedentos germânicos. Ao chegar no pequeno arraial de Coité, encontraram uma fonte de água onde estavam reunidas mais de trinta pessoas para abastecerem suas cuias com o líquido. Ato controlado pelo juiz local e por homens que traziam fuzis para, em caso de necessidade, fazerem valer os direitos dos seus (...) a água aqui é só para nós, e não para inglês vagabundo. ${ }^{125}$

\footnotetext{
${ }^{121}$ AVE-LALLEMANT, Robert. Viagens pelas províncias da Bahia, Pernambuco e Sergipe..., Opus cit., p. 310. ${ }^{122}$ AVE-LALLEMANT, Robert. Viagens pelas províncias da Bahia, Pernambuco e Sergipe..., Opus cit., p. 314. ${ }^{123}$ SPIX, J.B Von; MARTIUS, C.P.F. Viagem pelo Brasil..., Opus cit., p. 367.

${ }^{124}$ SPIX, J.B Von; MARTIUS, C.P.F. Viagem pelo Brasil..., Opus cit., p. 367.

${ }^{125}$ SPIX, J.B Von; MARTIUS, C.P.F. Viagem pelo Brasil..., Opus cit., p. 368.
} 
As consequências da seca não se limitam à falta e procura de água. Ocorre um sensível despovoamento de certas áreas e aumento, como se espera, de outros lugares menos atingidos. Uma migração regular, espécie de diáspora, cujos resultados são povoações desabitadas, com aspectos fantasmagóricos, ${ }^{126} \mathrm{e}$ aumento do preço dos alimentos para consumo. Henry Koster, em sua viagem de Pernambuco ao Ceará, analisou:

Na minha viagem de Goiana ao Ceará, tinha visto Pernambuco, e províncias vizinhas ao norte, em situação péssima por uma estação sem chuvas, mas a extrema penúria é produzida por dois anos, sucessivos, de estio. Durante o segundo ano os moradores morriam ao longo das estradas. Famílias inteiras se extinguiram. Vários distritos se despovoaram. A região esteve neste estado terrível em 1791, 1792, 1793, pois esses anos passaram sem que as chuvas fossem suficientes. Em 1810 podia-se procurar viveres, embora por preços exorbitantes $(\ldots)^{127}$

\author{
Xiquexique, mucunã \\ Raiz de imbu e cole \\ Feijão brabo, catolé \\ Macambira, imbiratã \\ Do pau-pedra e caimã \\ A perreira e o murão \\ Maniçoba e gordião \\ Comendo isso todo o dia \\ Incha a causa da hidropisia
}

Foge, povo do sertão! ${ }^{128}$ [grifo nosso].

Santo Antônio das Queimadas, atual Queimadas (BA), núcleo do sertão baiano, contava com seiscentos habitantes no termo de sua paróquia. Durante três anos de secura, sofria os resultados da aridez, levando os habitantes a uma forçada emigração ${ }^{129}$. O milho, que nós até então havíamos encontrado nas fazendas, não se obtinha aqui senão a preços exorbitantes, de modo que, havendo com felicidade escapado da seca, tínhamos agora que temer a fome, assinalaram Spix e Martius. ${ }^{130}$

\footnotetext{
${ }^{126}$ No sertão dos Inhamuns, atual estado do Ceará, o aglomerado de Cococi está despovoado pelas secas persistentes. Hoje, abriga o vazio como elemento característico de sua paisagem urbana.

${ }^{127}$ KOSTER, Henry. Viagens ao Nordeste do Brasil..., Opus cit., p. 179.

${ }^{128}$ NOGUEIRA, Bernardino apud CASTRO, Josué. Geografia da fome..., Opus cit., p. 203.

${ }^{129}$ SPIX, J.B Von; MARTIUS, C.P.F. Viagem pelo Brasil..., Opus cit., p. 371.

${ }^{130}$ SPIX, J.B Von; MARTIUS, C.P.F. Viagem pelo Brasil..., Opus cit., p. 371.
} 
No Ceará as condições climáticas foram semelhantes. Para o médico George Gardner:

Toda a província é sujeita por vezes a prolongadas secas, a última ocorrida no ano de 1825, durante a qual absolutamente não choveu. Grande foi o sofrimento resultante desta calamidade, de que o povo fala com supremo horror. Extinguiram-se gado e cavalos e a perda de vidas humanas na província avalia-se em trinta mil habitantes. Gente sem conta pereceu quando procurava chegar à costa; animais selvagens e domésticos sucumbiram por falta de água e alimento. ${ }^{131}$

Em virtude desse agravante climático, Robert Ave-Lallemant percebeu que o seu projeto de visitar o sertão seria algo impossível, pois uma seca de sete meses destruíra realmente tudo o que era mortal no sertão. Quase todo o gado morrera por falta de pasto e água para beber ${ }^{132}$. Visualmente, podemos exemplificar o flagelo da estiagem com a triste imagem da figura 31 (tomada entre 1877 - 1878 pelo fotografo, J.A. Corrêa) retirada do site da Fundação da Biblioteca Nacional.

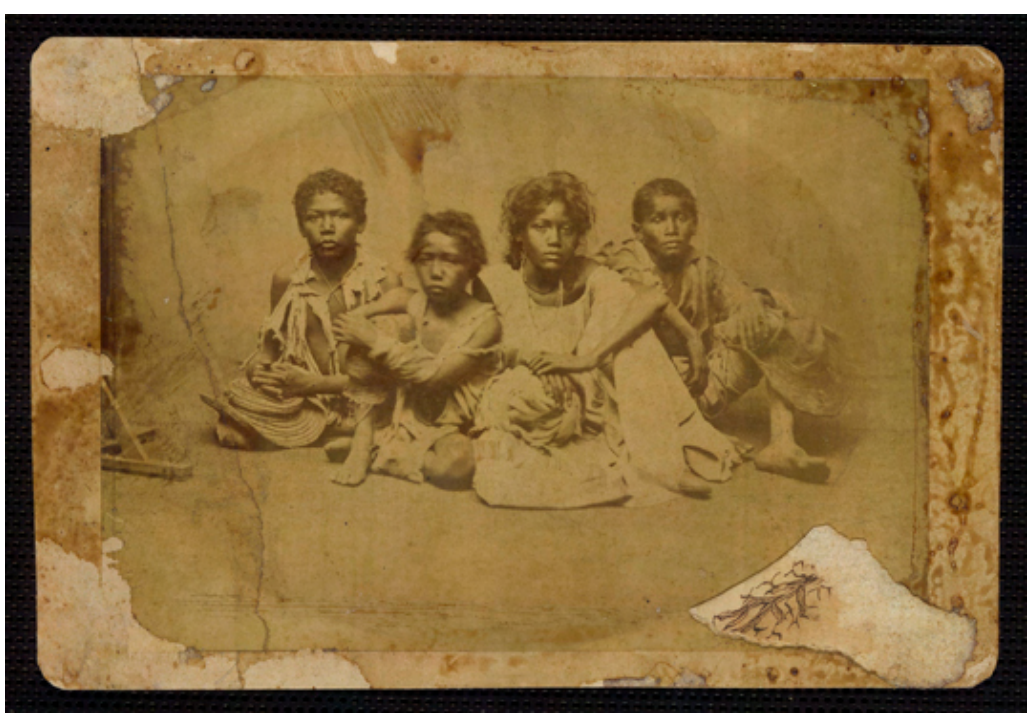

Figura 31 - Secca de 1877-1878 (Ceará). Foto de J. A. Corrêa. Disponível em http://www.bn.br. Acesso em 12.03.2010.

${ }^{131}$ GARDNER, George. Viagem ao interior do Brasil..., Opus cit., p. 82.

132 AVE-LALLEMANT, Robert. Viagens pelas províncias da Bahia, Pernambuco e Sergipe..., Opus cit., p. 308. 
A inexistência da seca traria para a população interiorana uma vida distinta. Como comprovou a pesquisa de Josué de Castro sobre o assunto. Segundo este médico pernambucano, fora das quadras das dolorosas secas, vive esta gente em perfeito equilíbrio alimentar, num estado de nutrição bastante satisfatório (...) se o sertão do Nordeste não tivesse exposto à fatalidade climática das secas, talvez não figurasse entre as áreas de fome do continente americano. ${ }^{133}$

Entretanto, os viajantes não fixaram os seus olhos somente nas desventuras e infelicidades do sertanejo. Antes, o seu cotidiano e a sociedade, foram sensivelmente descritos, auxiliando-nos em nossas constatações sobre a urbanização do sertão nordestino, ocorrida entre os séculos XVII e XIX.

A sociedade pastoril, instalada nas fazendas de criar, era formada, basicamente, pela figura do fazendeiro de gado e seus familiares, quando estes não estavam ausentes ${ }^{134}$. Situação percebida por Gardner em sua viagem do Crato (CE) à capital da província do Piauí, Oeiras. Após pousar na fazenda Curumatá, o médico inglês notou que o dono da fazenda não reside nela, mas deixa-a a cargo de um vaqueiro ${ }^{135}$. Von Martius e von Spix disseram que há muitos pequenos criadores de gado no sertão nordestino, ricos são poucos grandes fazendeiros, em cujas propriedades se estabeleceram agregados, e dominam a indústria de todo o distrito. ${ }^{136} \mathrm{O}$ fazendeiro era homem de negócio e, desse modo, conjugou o lucro obtido com a pecuária, exercida no interior, com a plantação da cana-de-açúcar litorânea. Esse mercado o tornava morador dos núcleos litorâneos, porém, nas épocas de chuva, residia em sua estância sertaneja. Henry Koster testemunhou que alguns donos vivem em suas terras mas

\footnotetext{
${ }^{133}$ CASTRO, Josué. CASTRO, Josué. Geografia da fome..., Opus cit., p. 158.

Como veremos a dieta alimentar do sertanejo é regrada por boas doses de proteínas, derivadas da carne bovina, caprina e leite. Junta-se a isso à quantidade de carboidrato adquirido no feijão, milho e mandioca colhidos por eles em suas roças. Como afirma Josué de Castro: É a alimentação bem servida de proteínas que dá ao sertanejo essa resistência um tanto impressionante para os habitantes de outras zonas do país. Na carne do bode, no leite e no queijo do sertão estão em boa parte as justificativas biológicas que respaldam a hoje famosa frase de Euclides da Cunha, que 'o sertanejo é, antes de tudo, um forte'. Realmente, só um povo forte pode "exibir esta tenacidade, esta resistência surpreendente às fadigas e às vicissitudes mais exacerbadoras, esta disposição incansável ao trabalho, esta constituição férrea que o torna sobranceiro às intempéries, aos reveses, às endemias, e o leva freqüentemente a cometimentos titânicos." Ver CASTRO, Josué. CASTRO, Josué. Geografia da fome..., Opus cit., p. 190.

${ }^{134}$ No que se refere a esta temática e na opinião de Luiz Roberto Mott, sérios estudiosos (Euclides da Cunha, Caio Prado Jr., Mauricio Vinhas, José Roberto Macedo, entre outros) afirmaram que, as fazendas de gado do Nordeste colonial brasileiro, apresentavam um auto grau de absenteísmo por parte dos seus donos, donde cujos viviam, preferencialmente, no litoral. Todavia, Mott em seu estudo sobre a capitania do Piauí colonial percebeu que o absenteísmo foi decaindo com o passar dos anos, chegando a ser mínimo em 1818. Estes resultados e sua respectiva tabela podem ser vistos em MOTT, Luiz Roberto B. Piauí colonial: população, economia e sociedade. Teresina, Projeto Petrônio Portella, 1985. p. 95 - 101.

${ }^{135}$ GARDNER, George. Viagem ao interior do Brasil..., Opus cit., p. 115.

${ }^{136}$ SPIX, J.B Von; MARTIUS, C.P.F. Viagem pelo Brasil..., Opus cit., p. 400.
} 
a maioria das fazendas que visitei, é propriedade de homens de ampla prosperidade e que residem nas cidades litorâneas onde são igualmente plantadores de cana de açúcar. ${ }^{137}$

Alguns grandes criadores de gado chegaram ao ponto de não obedecer as ordens reais, tampouco dos oficiais regulamentados pela Coroa. Koster argumentou essa atitude citando a família Feitoza, residente do interior cearense. Quando o clã esteve chefiado por João Carlos Feitoza chegou a tal poder que supunha estar inteiramente fora do alcance de qualquer castigo, recusando obediência às leis, tanto civis como criminais, fossem que fossem. $^{138}$

Felizmente, nem todos os fazendeiros adotaram a injustiça como modo de vida. É o caso do criador de gado e padre, Marcos de Araújo Costa, proprietário da fazenda Boa Esperança [figura 32], localizada no sertão do Piauí. Por intermédio de George Gardner temos a descrição do reverendo:

O padre Marcos de Araújo Costa é bem conhecido em todo o norte do Brasil, não só pela sua inteligência e saber, como por seu excelente caráter moral e benévola disposição, qualidades que vi amplamente confirmadas durante os oito dias que passei em sua casa. (...) Ele próprio é um excelente erudito e possui bem vasta biblioteca de clássicos e filósofos; de Botânica e História Natural possui conhecimento suficiente para ter nestes assuntos agradável distração. Entre os seus livros encontrei quase todas as obras de Lineu, as de Brotero, e uma de Vandelli, muito rara sobre as plantas de Portugal e do Brasil, obra que ele depois me presenteou bondosamente. ${ }^{139}$

\footnotetext{
${ }^{137}$ KOSTER, Henry. Viagens ao Nordeste do Brasil..., Opus cit., p. 208.

Romanceando esta situação vivida pelos fazendeiros e identificada pelos viajantes, José de Alencar escreve em, $O$ vaqueiro, o traslado de uma opulenta família, residente na capital pernambucana, para as suas terras de criação bovina, localizada nos sertões de Quixeramombim, capitania do Ceará.

${ }^{138}$ KOSTER, Henry. Viagens ao Nordeste do Brasil..., Opus cit., p. 176.

${ }^{139}$ GARDNER, George. Viagem ao interior do Brasil..., Opus cit., p. 116-117,
} 


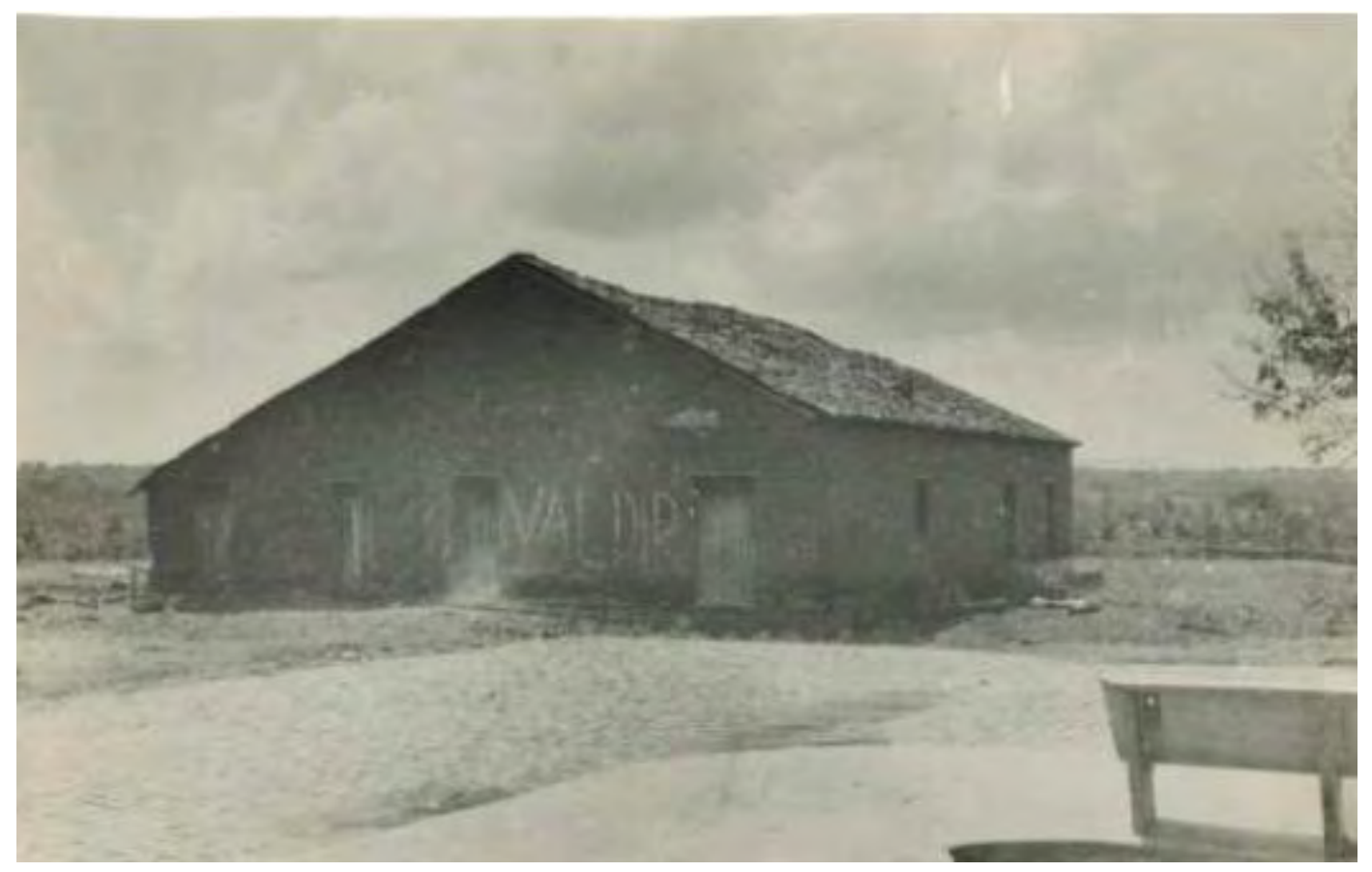

Figura 32 - Fazenda Boa Esperança, cujo proprietário, o pe. Marcos de Araújo Costa, foi visitado pelo naturalista inglês, George Gardner. Foto do acervo da Fundação Cultural do Piaui - IPAC.

Outros atores devem ser mencionados: vaqueiros, escravos e demais agregados, por exemplo, o tangedor das manadas. Este último conduzia as boiadas a serem vendidas nas cidades litorâneas ou nas feiras especializadas. Encontramos raras citações no que dizia respeito aos agregados dos fazendeiros. Das poucas, mencionaremos a dos viajantes alemães:

Só raramente os chamados agregados, em geral pretos forros ou mulatos, constroem, aqui ou acolá, na vastidão desse domínio, pequenas moradas ou quintais, pois os fazendeiros das grandes fazendas nao querem ceder porção alguma de suas terras, por considerarem indispensáveis as grandes extensões para atender à criação do seu gado ${ }^{140}$.

Nas fazendas do sertão piauiense que eram de Domingos Afonso Mafrense, doadas após sua morte aos padres da Companhia de Jesus do Colégio da Bahia, utilizaram mão de obra escrava. Ao chegarem na província do Piauí, Spix e Martius elaboraram um estudo sobre tais herdades, apontando o uso de vinte escravos, a metade dos quais basta para vigiar uma boiada de 1.000 cabeças $(. . .)^{141}$.

\footnotetext{
${ }^{140}$ SPIX, J.B Von; MARTIUS, C.P.F. Viagem pelo Brasil..., Opus cit., p. 420.

${ }^{141}$ SPIX, J.B Von; MARTIUS, C.P.F. Viagem pelo Brasil..., Opus cit., p. 419.
} 
O vaqueiro [figuras 33 e 34] é particularmente um personagem que requer destaque, pois o seu trabalho, o seu modus vivendi e o traje são elementos peculiares, por serem adaptações ao meio natural agressivo da caatinga e à economia do gado vigente.

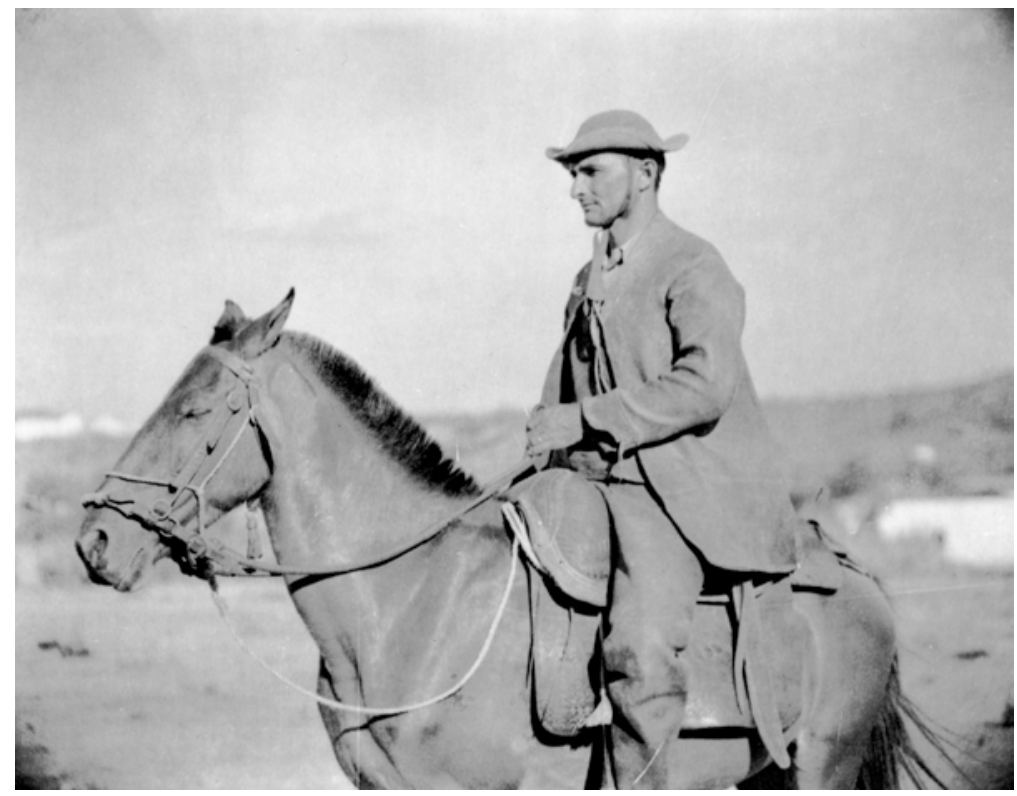

Figura 33 - Vaqueiro vestido em seus típicos trajes. Foto disponível em http://www.ibge.gov.br. Acesso em 18.09.2010.

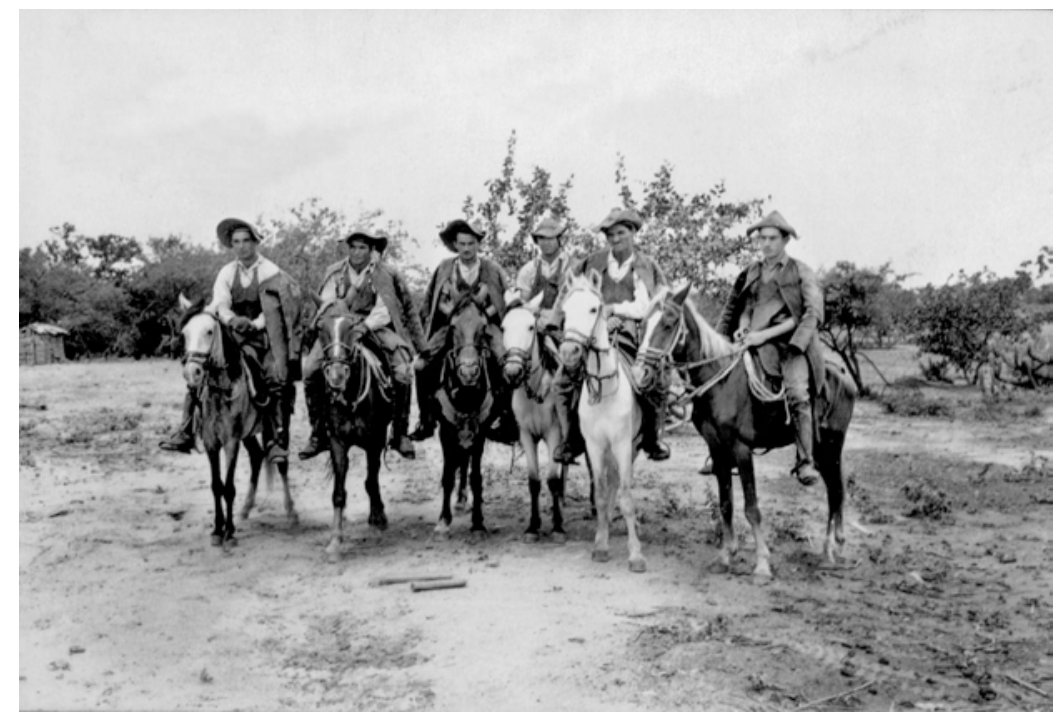

Figura 34 - Grupo de vaqueiros do sertão piauiense. Foto disponível em http://www.ibge.gov.br. Acesso em 18.09.2010.

Euclides da Cunha resumiu a essência do vaqueiro vinculada a um jogo dialético de situações: este sertanejo surge de uma intermitência, raro perturbada, de horas felizes $e$ horas cruéis, de abastança e miséria, tendo a cabeça, como ameaça perene, o sol, arrastando 
de envolta de volver das estações períodos sucessivos de devastação ${ }^{142}$. À luz da citação euclidiada e, com postura menos poética, os viajantes dão o tom realista ao desconstruir a figura do vaqueiro.

As pessoas que tomam conta do gado e vivem nesses domínios são chamadas 'vaqueiros'. Tem uma parte dos bezerros e galinhas que criam nos campos, ${ }^{143}$ relatou Koster sobre as atribuições dos boiadeiros. Sua lida os obriga a ter bom preparo físico, porque $o s$ deveres são pesados, exigindo coragem considerável, grande força física e atividade ${ }^{144}$ continua o viajante inglês. Destemor seria necessário para desbravar os sertões infestado de ladrões e perigos naturais, como cobras venenosas, onças e rios caudalosos.

A falta de água, durante a época de seca, requeria coragem para as jornadas de condução das boiadas pelo semi-árido. Avistando uma manada de trezentas reses, Spix e Martius ouviram as queixas dos vaqueiros que traziam os rebanhos do sertão do Piauí para serem vendidos em Salvador. Depois de ouvirem a situação lastimável do território sertanejo, o grupo de boiadeiros ficam duvidosos sobre que caminho percorrer. Resolveram desviar a rota para o rio Itapicurú, assim teriam condições de abastecerem o gado e a eles próprios. ${ }^{145}$

Força física seria útil para pelejar com bois bravos, animais perdidos nas matas e durante a travessia das reses pelos rios e riachos. O labor do vaqueiro foi bem dissertado por Henry Koster:

Duas vezes por ano os vaqueiros de várias fazendas se reúnem com o fim de apanhar o gado. As vacas são levadas, de toda a parte, para uma área em frente da casa e aí, cercadas por numerosos cavaleiros, são impelidas para espaçosos currais. Isto feito, desmontam os homens e se alguma vaca se torna furiosa, como sucede, um laço pelos cornos é bastante para prendê-la bem ou, ainda outro meio é adotado, que é passar o laço pela pata trazeira (sic.), e trazer a corda enrolando completamente o animal, sendo fácil derrubá-lo. ${ }^{146}$

\footnotetext{
${ }^{142}$ CUNHA, Euclides da. Os sertões..., Opus cit., p. 151.

${ }^{143}$ KOSTER, Henry. Viagens ao Nordeste do Brasil..., Opus cit., p. 208.

${ }^{144}$ KOSTER, Henry. Viagens ao Nordeste do Brasil..., Opus cit., p. 208.

${ }^{145}$ SPIX, J.B Von; MARTIUS, C.P.F. Viagem pelo Brasil..., Opus cit., p. 373.

${ }^{146}$ KOSTER, Henry. Viagens ao Nordeste do Brasil..., Opus cit., p. 209.
} 
O príncipe Maximiliano Wied-Neuwied esboçou a imagem da figura 35 sobre o trabalho executado pelos vaqueiros [figura 35]. Henry Koster descreveu a operação envolvida nas suas ocupações.

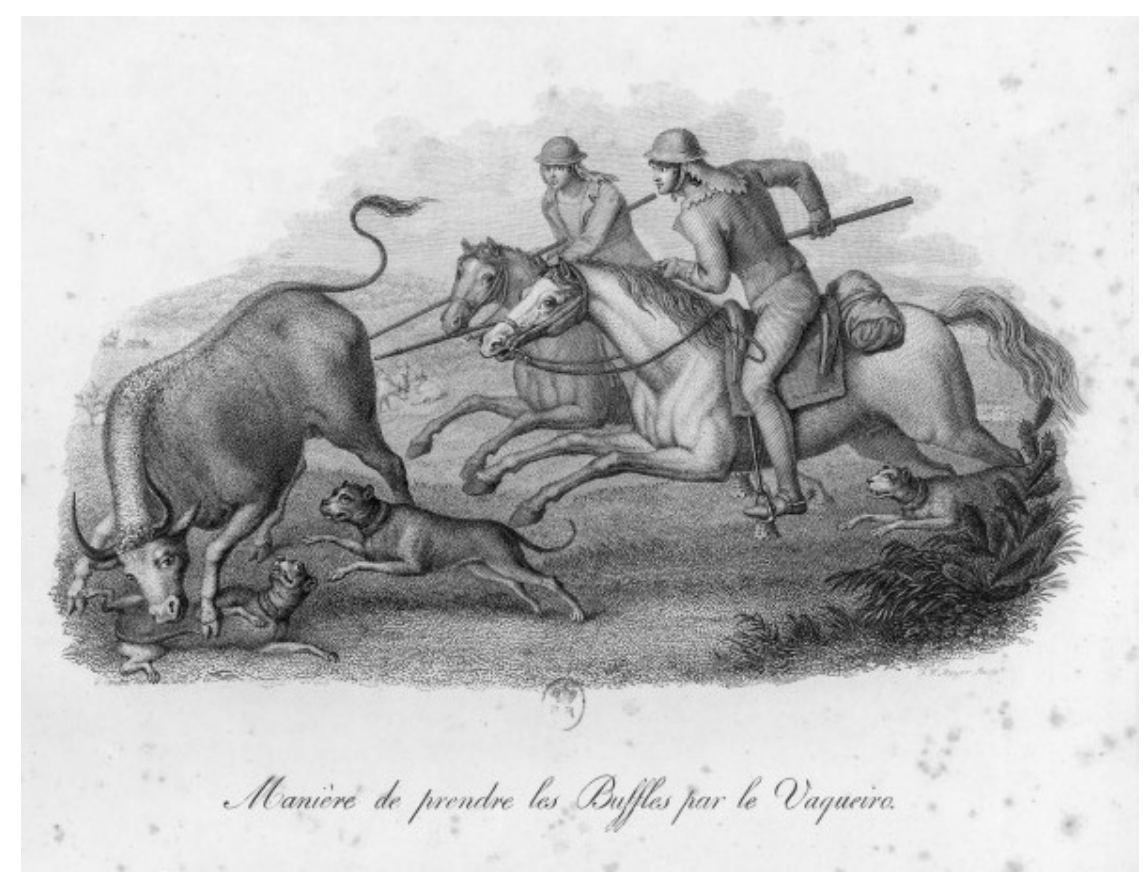

Figura 35 - Maniere de prendre les Buffles por le Vaqueiro. Imagem atribuída ao príncipe Maximiliano Wier-Neuwied. Disponívem em http://www.bnf.fr. Acesso em 25/08/2010.

(...) Quando o homem se aproxima, o boi foge para o mato vizinho, e é perseguido o mais próximo possível afim de aproveitar a vantagem dos ramos se entreabrirem na passagem do animal, fechando-se logo após, retomando sua primeira posição. N'um certo tempo o boi passa por baixo de um galho pouco elevado duma grande árvore, e o vaqueiro, às vezes, passa também, e para conseguir, pende para o lado direito, tão completamente que pode segurar na cilha da sela com a mão esquerda ao mesmo tempo que o calcanhar esquerdo se prende na orla da sela. E com a vara na mão direita, quase arrastado pelo solo, galopa sem diminuir o passo, voltando a sua posição logo que o obstáculo foi transposto. Quando atinge o boi, fere-o com a vara e, se o golpe foi certo, atira-o ao chão. Desmonta, prende as pernas do animal ou passa uma delas pelos chifres e, o tem rendido completamente. 
Muitas pancadas são recebidas pelo vaqueiro mas é raro ocasionar-lhe a morte. $^{147}$

Em decorrência do meio natural agressivo e da cultura do couro, o homem do sertão criou o seu vestuário, os acessórios e alguns mobiliários domésticos utilizando o curtume como matéria-prima [figura 36]. Capistrano de Abreu nomeou a sociedade pastoril nordestina como parte do ciclo do couro. Para Abreu há uma simbiótica adaptação entre homem, meio e criação de gado:

(...) De couro era a porta das cabanas, o rude leito aplicado ao chão duro, e mais tarde a cama para os partos; de couro todas as cordas, a borracha para carregar água, o mocó ou alforje para levar comida, a maca para guardar roupa, a mochila para milhar cavalo, a peia para prendê-lo em viagem, as bainhas de faca, as brocas e surrões, a roupa de entrar no mato, os bangüês para curtume ou para apurar sal; para os açudes, o material de aterro era levado em couros puxados por juntas de bois que calcavam a terra com seu peso, em couro pisava-se o tabaco para o nariz. ${ }^{148}$

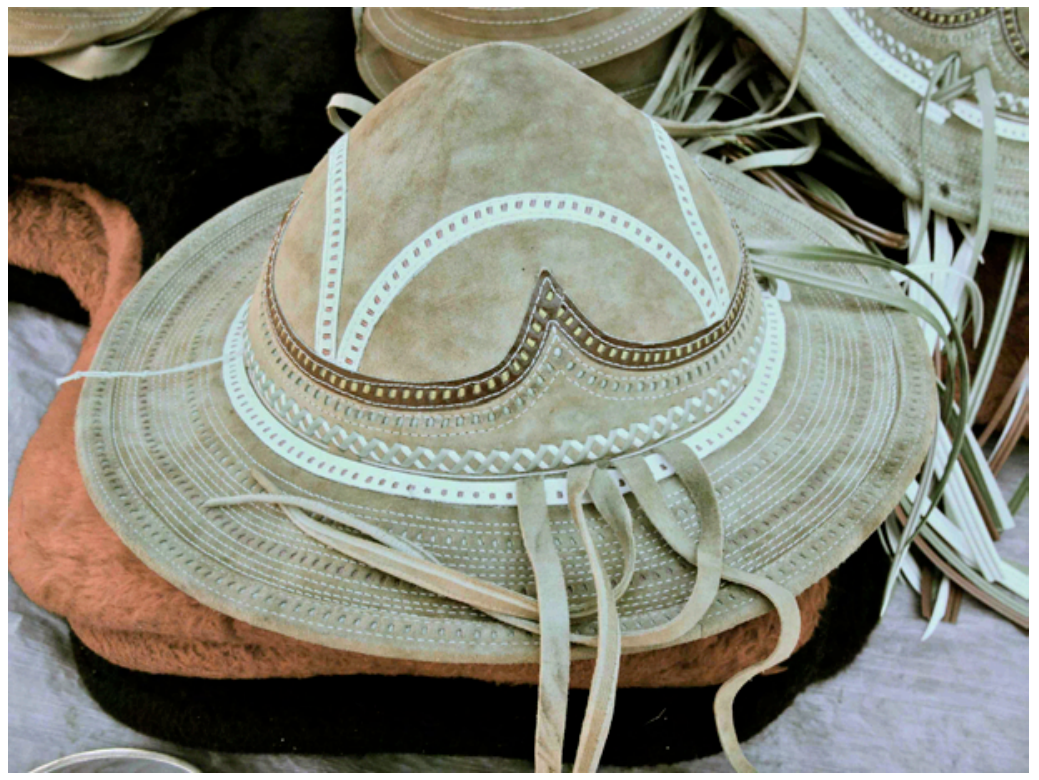

Figura 36 - Chapéu de couro. Usado por vaqueiros e homens do sertão nordestino. Foto do autor, 2010.

\footnotetext{
${ }^{147}$ KOSTER, Henry. Viagens ao Nordeste do Brasil..., Opus cit., p. 209.

${ }^{148}$ ABREU, Capistrano de. Capítulos de história colonial, 1500 - 1800. São Paulo, Publifolha, 2000. p. 153.
} 
Vivendo pelos sertões, antes mesmo da chegada do conquistador português, o Tapuia após sua domesticação e catequização torna-se, para a Igreja Católica e Coroa lusitana, indivíduos e vassalos da sociedade colonial. Por serem fundamentais ao processo de urbanização, os índios foram mirados pelo forasteiro, recebendo descrições próprias no que tange os agravantes sofridos em seu gradual processo de acomodação a um modo de vida alheio ao seu.

Rumando para São Luiz do Maranhão, saindo da capital piauiense, Spix e Martius associaram a tristeza dos íncolas, habitantes da missão de São Gonçalo do Amarante (PI), à experiência colonizadora: essa convicção é tanto mais dolorosa ao filantropo, porque essas experiências de colonização quase sempre custaram o sacrifício de muitas vidas humanas ${ }^{149}$. Reforçam o caráter desumano do colono e, de reboque, da Igreja, ao perceberem a falta de empatia, de consideração para com o outro, porque exige-se do índio imediata renúncia a todos os seus hábitos, tendências e costumes nativos, e ainda respeito às leis e uma religião que ele desconhece. ${ }^{150}$

Circunstâncias similares testemunhou George Gardner ao ir pelo rio São Francisco, da vila de Penedo à ilha de São Pedro - anteriormente missão de frades capuchinhos. Vendo a pobreza do pequeno povoado habitado por aproximadamente quarenta famílias, o viajante se sentou ao lado do capitão, trajando calças de algodão grosso, camisa do mesmo pano, chapéu e sandálias de couro $^{151}$. Através da autoridade indígena local, Gardner soube que os índios da ilha estão diminuindo gradativamente de número (...) não estava longe o dia em que sua raça estaria extinta ou, pelo menos, mesclada com outros habitantes. ${ }^{152}$

Deslocando-se também pelo sertão cearense (praticamente na mesma época que o naturalista inglês supracitado), Daniel Kidder endossou a exclusão social dos nativos ao dizer:

A grande massa do povo vive ao "Deus dará". Suas necessidades são poucas e simples. Conformam-se, em geral, à produção espontânea da natureza. (...) Apesar de todos os relatórios presidenciais fazerem referência ao lastimável

\footnotetext{
${ }^{149}$ SPIX, J.B Von; MARTIUS, C.P.F. Viagem pelo Brasil..., Opus cit., p. 248.

${ }^{150}$ SPIX, J.B Von; MARTIUS, C.P.F. Viagem pelo Brasil..., Opus cit., p. 248.

${ }^{151}$ GARDNER, George. Viagem ao interior do Brasil..., Opus cit., p. 70.

${ }^{152}$ GARDNER, George. Viagem ao interior do Brasil..., Opus cit., p. 70.
} 
estado de degradação do íncola, os anos vão passando sem que nada de positivo se faça para melhorar sua condição de instruí-lo. ${ }^{153}$

Datam por volta de 1818 a viagem de Spix e Martius ao Piauí; Gardner percorreu o rio São Francisco por embarcação entre 1838 - 1840. Kidder visitou o Ceará no mesmo ano que o inglês. A primeiras, das três grandes leis, acerca da liberdade dos índios e direito de uso à terra, segundo Beatriz Perrone-Moisés, ${ }^{154}$ é do inicio do século XVII, precisamente de 1609. Isto é, duzentos e nove anos depois os viajantes germânicos verificaram a permanência do cenário social indígena: desconsideração, exclusão e inadequação das leis governamentais. Para Gardner e Daniel Kidder são duzentos e vinte e nove anos de resultados mínimos e insuficientes dos códigos relativos aos silvícola convertidos à fé católica. Desta sorte, ficam esses recém-chegados entregues a si mesmos, perderam o seu primitivo modo de vida, sem receber ensino ou força para a vida melhor, e perdem finalmente, na ociosidade e na bebedeira, a pouca força de alma que possuíam, enquanto viviam independentemente nas $\operatorname{matas}^{155}$.

A empresa colonial tentou diminuir o insulamento dos sertanejos através da promoção e criação de estradas. Elas "irrigariam" todo o Nordeste, além de outras partes da colônia, visando a estruturação de uma nova unidade nacional. A partir do relato dos viajantes percebemos como as rotas de circulação sertaneja eram usadas no fortalecimento do mercado interno nacional.

Felippe Alberto Patroni Martins Maciel Parente, advogado nascido na província do Pará, nomeado posteriormente ao cargo de juiz, viajou em 1828, do Ceará à província do Rio de Janeiro ${ }^{156}$. Ao adentrar pelo sertão serpenteado pelo rio Jaguaribe, Patroni observou que $a$ estrada é cada vez mais aprazível, porque daqui em diante segue sempre a margem do famoso rio Jaguariba (sic.), cujas águas cristalinas regam e fertilisam a maior parte dos campos e prados da Província, que a banha quase toda. ${ }^{157}$

\footnotetext{
${ }^{153}$ KIDDER, Daniel P. Reminiscências de viagens e permanências nas províncias do Norte do Brasil. São Paulo, Edusp, 1980. p. 157.

${ }^{154}$ PERRONE-MOISÉS, Beatriz. "Índios livres e índios escravos: os princípios da legislação indigenista do período colonial (séculos XVI a XVIII). In História dos índios no Brasil. São Paulo, Companhia das Letras, 1992. p. 117.

${ }^{155}$ SPIX, J.B Von; MARTIUS, C.P.F. Viagem pelo Brasil..., Opus cit., p. 248.

${ }^{156}$ AS VIAGENS de Patroni pelas províncias brasileiras: de Ceará, Rio São Francisco, e Rio de Janeiro, nos anos de 1829, e 1830. 2 ed. Lisboa, 1850. p. 1.

${ }^{157}$ AS VIAGENS de Patroni pelas províncias brasileiras: de Ceará, Rio São Francisco..., Opus cit., p. 21.
} 
Arquitetando sua viagem para o interior do Ceará, Gardner se certificou com os moradores de Aracati (CE) qual seria a melhor estrada para concluir os seus intentos. Aconselharam que partisse desse porto (Aracati) para o interior, pois as estradas eram algo melhores que as que partiam de outros lugares da costa ${ }^{158}$. É quase certo, ao nosso ver, que a mesma via utilizada por Patroni tenha sido aquela que o viajante inglês usou para se deslocar do litoral cearense às vilas e povoações sertanejas. Conhecida como estrada geral do Jaguaribe $^{159}$, as boiadas que eram tangidas por esse caminho, vindas do interior para o litoral, costumavam ser comercializadas e abatidas nas charqueadas do Aracati. Carne e couro seriam comercializados em distintos centros urbanos da colônia e/ou do império. A estrada geral do Jaguaribe não ficou restrita ao Ceará. Através do médico inglês somos informados:

Sendo a estrada em que viajávamos a que levava ao interior do Ceará, bem como à região central do Piauí, muitos viajantes passavam pelo nosso acampamento. Carros cheios de algodão e couros desciam, enquanto outros, bem como tropas de cavalos subiam carregados de mercadorias européias e sal, que é raro e caro no interior. ${ }^{160}$

O trajeto realizado da vila da Cachoeira (BA) à cidade de Oeiras (PI) pelos viajantes alemães, Spix e Martius, é deveras carregado de boas informações sobre as vias terrestres. Em Cachoeira existiram três estradas que ligavam o Recôncavo Baiano ao seu interior. Optaram os viajantes germânicos pela via que conduzia as reses criadas nas fazendas Reais do Fisco, as herdades do rei, situadas no sertão do Piauí:

Da Vila da Cachoeira partem três estradas: a de Muritiba, que segue pelo Porto de São Félix, a sudoeste, até ao distrito do Rio de Contas e daí para as Minas Gerais, Goiaz, etc. a de Belém, que liga Cachoeira com a parte sul da província; e a de Capoeiraçú, que segue a O. e N.O., na comarca da Jacobina, e para a estrada Real do Gado, por onde são tocadas as boiadas do Piauí. Tomamos por este último caminho, quando saímos a 27 de fevereiro da Vila da Cachoeira (...). ${ }^{161}$

\footnotetext{
${ }^{158}$ GARDNER, George. Viagem ao interior do Brasil..., Opus cit., p. 79.

159 STUDART FILHO, Carlos. "Vias de comunicação do Ceará colonial". In Revista do Instituto do Ceará. Tomo LI. Fortaleza, 1937. p. 27 - 30.

${ }^{160}$ GARDNER, George. Viagem ao interior do Brasil..., Opus cit., p. 84.

${ }^{161}$ SPIX, J.B Von; MARTIUS, C.P.F. Viagem pelo Brasil..., Opus cit., p. 363.

Outras vias de penetração ao sertão nordestino estão indicadas em STUDART FILHO, Carlos. "Vias de comunicação do Ceará colonial”. In Revista do Instituto do Ceará. Tomo LI. Fortaleza, 1937.
} 
Encontraram dificuldades durante a viagem, principalmente os de cunho climático. Contudo, foram relatadas o nome de algumas fazendas: Boa Vista, Cumiciatá, Formigas, Santa Bárbara e Gravatá. Chegando na vila Nova da Rainha, atual Senhor do Bonfim - BA, perceberam que o pequeno núcleo, depende exclusivamente do tráfego comercial acometido internamente: Vila Nova da Rainha, ou Jacobina-Nova, como é chamada vulgarmente a aldeia pobre, cuja prosperidade depende em grande parte do tráfego comercial entre a Bahia e a província do Piauí (....). ${ }^{162}$

Nota-se que alguns núcleos urbanos sertanejos devem o seu desenvolvimento econômico e urbano, mesmo que em pequenos montantes, à sua localização nesta rede de caminhos. Sobre o tema, temos o arraial do Juazeiro, antes missão religiosa franciscana. Reunindo cerca de cinqüenta casas e duzentos habitantes ${ }^{163}$, a sua importância, porém, deve-a a freqüência de trânsito pela estrada do Piauí, a qual atravessa o rio aqui (São Francisco) ${ }^{164}$. Spix e Martius avaliaram o crédito desse mercado ao notar o seu intercâmbio com outras regiões brasileiras. Utilizando na maior parte os caminhos terrestres o comércio...

(...) se faz do interior para o Piauí e Maranhão, assim como também, por essas vilas acima mencionadas (Vila Nova da Rainha, Juazeiro, Sento Sé e Pilão Arcado), para Goiaz e Mato Grosso. O mais importante artigo de trânsito é gado para corte, dirigido à Bahia; de fato também mercadorias européias e ultimamente muitos escravos. ${ }^{165}$

Atravessando o rio São Francisco e pagando as taxas obrigatórias pela passagem de sua frota, os naturalistas alemães novamente apontam quatro $\operatorname{rotas}^{166}$ :

$\mathrm{Na}$ Passagem do Juazeiro encontram-se duas estradas do Piauí, que costumam chamar de Travessia- Nova, e dirigem-se para as nascentes do rio Canindé e, por ele abaixo, a Oeiras, ora se aproximando, ora se afastando do rio São Francisco. A leste das duas primeiras, entre a foz do arroio do Pontal e o arraial do Cabrobó, sai terceira estrada. A oeste da Travessia - Nova. A província do Piauí comunica-se com o sertão do rio São Francisco pela Travessia - Velha. Esta estrada começa na povoação do Sobrado, à margem

\footnotetext{
${ }^{162}$ SPIX, J.B Von; MARTIUS, C.P.F. Viagem pelo Brasil..., Opus cit., p. 375.

${ }^{163}$ SPIX, J.B Von; MARTIUS, C.P.F. Viagem pelo Brasil..., Opus cit., p. 399.

${ }^{164}$ SPIX, J.B Von; MARTIUS, C.P.F. Viagem pelo Brasil..., Opus cit., p. 399.

${ }^{165}$ SPIX, J.B Von; MARTIUS, C.P.F. Viagem pelo Brasil..., Opus cit., p. 407.

${ }^{166}$ A configuração espacial destas vias e seus efeitos na urbanização serão vistos no próximo capítulo dedicado aos caminhos de penetração bovina.
} 
do rio, e acompanha o curso do rio Piauí, que ela ora alcança na sua nascente, ora mais abaixo, conforme as suas diversas direções. ${ }^{167}$ [grifo nosso]

Descrevendo, anotando, esboçando e sentindo o espaço urbano-territorial sertanejo, o forasteiro, ao primeiro olhar, visualiza uma realidade estranha à sua. Contenta-se com a hospitalidade dos moradores e revela importantes dados sobre a urbanização do interior do Nordeste. Dessas informações, prevalecem àquelas vinculadas à criação de gado, à pecuária extensiva, considerada pelo jesuíta Antonil como uma das opulências do Brasil colonial ${ }^{168}$. No próximo capítulo dissertaremos sobre a economia do gado em tempos coloniais, o leitmotiv do desenvolvimento regional do interior nordestino. Os relatos dos viajantes serão fontes de constante análise para entendermos esse quebra-cabeças do curral de reses.

\footnotetext{
${ }^{167}$ SPIX, J.B Von; MARTIUS, C.P.F. Viagem pelo Brasil..., Opus cit., p. 408.

168 ANTONIL, André João. Cultura e opulência do Brasil. 3 ed. Belo Horizonte: Itatiaia; São Paulo, Edusp, 1982. (Coleção Reconquista do Brasil). 99 p.
} 


\section{CAPÍTULO 02 - CURRAL DE RESES}

“(...) Também da mesma povoação partia uma estrada para o Ceará, Rio Grande, Paraíba e Pernambuco, por onde poderiam ir socorros sempre que fosse preciso, em carros e cavalos, porque por todas aquelas paragens havia muitos currais de gados e farinhas para o sustento desses comboios, salvo nas 70 léguas já indicadas (...)

Carta de Domingos Afonso Mafrense ao governador geral, D. João de Lencastre, 1702.

"E nestas terras, parte os donos dela tem currais próprios, e parte dos que arrendam os sítios delas, pagando por cada sítio, que ordinariamente é de uma légua, cada ano, dez mil réis o foro. $\mathrm{E}$, assim como há currais no território da Bahia e Pernambuco, e de outras capitanias, de duzentas, trezentas, quatrocentas, quinhentas, oitocentas e mil cabeças, assim as fazendas a quem pertencem tantos currais que chegam até seis mil, oito mil, dez mil, quinze mil e vinte mil cabeças de gado, donde se tiram cada ano muitas boiadas, conforme os tempos são favoráveis à parição e multiplicação do mesmo gado, e aos pastos assim nos sítios como também nos caminhos."

André João Antonil, Cultura e opulência do Brasil. 


\subsection{Caminhos do gado do sertão nordestino}

O sertão nordestino esteve isolado e pouco comunicável por mais de cem anos de colonização. Isso decorre dos mitos criados pelos primeiros catequizadores, baseados em feras míticas, dos índios bravios e antropofágicos e a falta de interesse do colonizador português e, de reboque, da Coroa lusa em povoar o território do semi-árido do Nordeste.

Ao contrário do sertão, o Nordeste açucareiro concentrou todos os investimentos iniciais dos reis de Portugal, atraindo para a zona da mata os primeiros povoadores que chegavam em terras brasileiras. As lavouras, os engenhos e as fábricas de açúcar se localizaram, principalmente, junto à faixa litorânea. Por isso, os primeiros aglomerados criados no Brasil colonial estavam na costa, arranhando-a como caranguejo ${ }^{1}$, e boa parte sustentados economicamente pela cultura do açúcar: Olinda, Igarassú, Porto Calvo e Filipéia são alguns dos exemplos que podemos enumerar. Logicamente, os meios de comunicação terrestre se atrelaram a esta economia.

Somente a partir de meados dos Seiscentos, a Metrópole se envolve na empresa urbanizadora do sertão nordestino, por patrocinar o desenvolvimento de estradas. As vias ensejavam o conhecimento da região, diminuição do isolamento em que se achavam os moradores, aumento do comércio, das rendas da fazenda real e busca do exercício da justiça porque a maior difficuldade (...) que nas grandes distancias em que se achão se facilitão a prevaricar as ordens do governo. ${ }^{2}$

Carlos Studart Filho, em artigo publicado no ano de 1937 para a revista do Instituto do Ceará, mencionou a estrada velha ${ }^{3}$ conhecida desde 1611; sendo esta mal definida, perceptível só aos olhos dos tupis ${ }^{4}$, eram caminhos desenvolvidos por técnica rudimentar, feitos tanto de enchada, como foice e machado 5 . Segundo o historiador cearense, a rota serviu de trilha para os povoadores, bandeirantes, missionários e silvícolas ${ }^{6}$, além de unir os centros

\footnotetext{
${ }^{1}$ SALVADOR, Frei Vicente. História do Brasil: 1500 - 1627...Apud MARX, Murillo. Cidade brasileira. São Paulo, Edusp, 1980. p. 12.

${ }^{2}$ PROJETO RESGATE. AHU_ACL_CU_016, Cx. 3, D.187.

${ }^{3}$ STUDART FILHO, Carlos. "Vias de comunicação do Ceará colonial”. In Revista do Instituto do Ceará. Tomo LI. Fortaleza, 1937. p. $15-25$.

${ }^{4}$ STUDART FILHO, Carlos. "Vias de comunicação do Ceará colonial”...Opus cit., p. 15.

${ }^{5}$ SOBRINHO, Barbosa Lima. "Capistrano de Abreu e o povoamento do sertão pernambucano". In Revista do Instituto Arqueológico, Histórico e Geográfico de Pernambuco. Vol 50. Recife, 1978.

${ }^{6}$ STUDART FILHO, Carlos. "Vias de comunicação do Ceará colonial”. In Revista do Instituto do Ceará. Tomo LI. Fortaleza, 1937.
} 
urbanos litorâneos: Salvador, São Cristovão, Penedo, Marechal Deodoro, Porto Calvo, Serinhém, Olinda, Igarassú, Goiana, Filipéia, Natal, Aquirás e Vila Nossa Senhora da Assunção de Fortaleza. Em 1764, o ouvidor da capitania de Porto Seguro, Thomé Cauceiro de Abreu, chamou a estrada velha de estrada da praia $^{7}$ que he real e commum desde a Bahia athé o Rio de Janeiro $(. . .)^{8}$.

Entretanto, o curso do caminho sobredito terminava onde hoje estão os Lençóis Maranhenses, isolando a cidade de São Luiz de comunicação com os demais núcleos coloniais. Até 1674, a estrada velha não atingia a urbe maranhense por dificuldades de navegação em detrimento do regimento dos ventos, das correntes marítimas, da existência baixios perigosos de arrecifes e precariedade técnica das naus. ${ }^{9}$ A metrópole portuguesa pouco fez para resolver este impasse, demandando em comunicações difíceis e morosas que imprimem às relações da colônia um ritmo lento e retardado, responsável certamente em grande parte por esse tom geral de vida frouxa que caracteriza o país. ${ }^{10} \mathrm{As}$ barreiras que impediram o aumento da comunicação terrestre, entre os pontos da leste-oeste da costa, perduraram pelos Seiscentos, mostraram-se uma oposição ao efetivo povoamento dos domínios americanos de Portugal.

Os padres jesuítas, em busca de índios para suas reduções, usaram o caminho litorâneo para concretizar os seus intentos. Em 1607, o pe. Luiz Figueira apontou as dificuldades na jornada de Pernambuco ao Maranhão. Após ancoragem no litoral cearense, lentamente e, por terra, através do sertão próximo à costa, a perseverança do padre com todos estes perigos e difficuldades não empediram (sic.) a viagem ${ }^{11}$, obrigaram-no a penetrar o território e seguir por veredas criadas pelos Tapuias:

(...) Nós chegamos a serra do Ibigapaba, que está antes do Maranhão cem legoas; ate a qual fomos parte por mar (de Pernambuco ate Jaguaribe) e parte por terra em que somente não andam tapuyas junto do mar, mas dali por

\footnotetext{
${ }^{7}$ ANNAES da Bibliotheca Nacional do Rio de Janeiro. "Inventário dos documentos relativos ao Brasil existentes no Archivo de Marinha e Ultramar, organisado por Eduardo de Castro Almeida”. Vol XXXII. Ano 1910. Rio de Janeiro, Officinas Graphicas da Bibliotheca Nacional, 1914. p. 41.

${ }^{8}$ ANNAES da Bibliotheca Nacional do Rio de Janeiro. Inventário dos documentos relativos ao Brasil existentes no Archivo de Marinha e Ultramar..., Opus Cit., p. 41.

${ }^{9}$ STUDART FILHO, Carlos. "Vias de comunicação do Ceará colonial”...Opus cit., p.16 - 19.

${ }^{10}$ PRADO JR., Caio. História econômica do Brasil. São Paulo, Brasiliense, 2008. p. 109.

${ }^{11}$ LEITE, Serafim. Luiz. Figueira: sua vida heróica e a sua obra literária. Lisboa, Agencia Geral das Colônias, 1940. p. 157.
} 
diante desda praya começão os tapuyas, e toda a terra esta cheya delles. Isto he o que passa na verdade acerca das cousas e viagem do Maranhão $(. . .)^{12}$

Dificuldades naturais de navegação, entre o Estado do Maranhão e o Estado do Brasil, punham em risco a posse efetiva dos domínios lusos. O rei Dom Pedro II, juntamente com as autoridades coloniais, atentaram em descobrir ou desenvolver uma via terrestre que ligasse São Luiz à cidade de Salvador. Por volta de 1688, com o objetivo de chegar à Bahia, João Velho do Vale partia do Maranhão e atingia a Serra da Ibiapaba, deixando três estradas. Da segunda alcançou a capitania da Bahia de Todos os Santos, percorrendo as ribeiras do rio Poti e contravertentes do rio São Francisco, chegando às atuais áreas de Cabrobó, Ibó e Jeremoabo. ${ }^{13}$ Iniciava uma empreitada que culminaria numa rede de caminhos, estreitando a relação entre interior x litoral.

Ainda sob a regência de Dom Pedro II, o Conselho Ultramarino agradeceu a diligência do governador geral do Estado do Brasil, D. João de Lencastre, pela iniciativa de construir uma rota entre Salvador e São Luiz:

(...) Meu amigo e Snr. como tenho conhecido que foi vossa mercê sempre mais empenhado no descobrimento do Caminho do Maranhão para a Bahya, tantas vezes intentado nos muitos annos, que há, que Sua Magestade, que Deus guarde, o encarregou aos governadores daquelle estado $(. . .)^{14}$

Sabe-se, diga-se de passagem, que os objetivos envolvidos nessa empresa seriam offerecer negócios de farta importância ${ }^{15}$ ao Reino, isto é, conhecer a região para verificar a possível existência de riquezas minerais e vegetais a serem comercializadas nos mercados europeus. Ademais, esse foi um dos motivos basilares na fundação das primeiras freguesias sertanejas: poder lucrar grandez conveniençias a fazenda de V. Mag ${ }^{16}$. O padre Miguel de Carvalho, encaminhado para criar a paróquia de Nossa Senhora da Vitória, relatou ao bispo de Pernambuco sobre os rincões daquele território. Percebeu que havia um caminho sabido ${ }^{17} \mathrm{de}$ 80 legoas confina pella $p^{\text {te }}$ do nascente com os certoins dezertos que correm $p^{a}$ Pern $^{\text {co.18 }}$

\footnotetext{
${ }^{12}$ LEITE, Serafim. Luiz Figueira: sua vida heróica e a sua obra literária...Opus cit., p. 157.

${ }^{13}$ ABREU, Capistrano de. Capítulos de história colonial. 7 ed. São Paulo, Publifolha, 2000. p. 148

${ }^{14}$ PROJETO RESGATE. AHU_ACL_N_MARANHÃO, D.957.

${ }^{15}$ PROJETO RESGATE. AHU_ACL_N_MARANHÃO, D.957.

${ }^{16}$ ENNES, Ernesto. A guerra nos Palmares. Rio de Janeiro, Editora Nacional, 1938. p. 349.

${ }^{17}$ ENNES, Ernesto. A guerra nos Palmares...Opus cit., p. 371.

${ }^{18}$ ENNES, Ernesto. A guerra nos Palmares...Opus cit., p. 371.
} 
Apesar dos esforços dos representantes do rei na colônia em devassar o interior do Nordeste, é somente devido à criação de gado que muitos outros caminhos seriam construídos. Inicialmente, fazendeiros, vaqueiros e tangedores (aqui poderiam ser homens livres, índios ou escravos) utilizavam as velhas trilhas para levar as manadas às invernadas, feiras ou portos. A via patrocinada por D. João de Lencastre, unindo Maranhão à Bahia, ficou conhecida, a posteriori, como estrada real do gado, porque as boiadas pertencentes ao rei, criadas em terrenos da capitania de São José do Piauí, transitavam por esse caminho.

O roteiro da estrada real do gado, realizado em mais de três meses de viagem, tinha início, como era de se esperar, na capital da colônia - a cidade de Salvador. Deste centro urbano, os bois eram levados à feira de Capuame (hoje cidade de Camaçari - BA); partindo desta localidade, as reses eram tangidas sentido noroeste alcançando o povoado de Água Fria e, logo em seguida, o pouso de Jeremoabo. Após o descanso, o gado rumava para o rio São Francisco ou para a vila da Jacobina. Se optassem pelo "velho Chico" cruzava-o na passagem do Juazeiro (área que envolve as atuais Juazeiro - BA e Petrolina - PE). Chegavam ao território do atual estado do Piauí caminhando pelas margens do rio Canindé. Aportavam na freguesia de Nossa Senhora da Vitória, atual Oeiras (PI), onde novamente eram comercializadas. Logo em seguida, cruzavam o rio Parnaíba, cujo pouso para alimentação era acometido na freguesia de São Bento dos Pastos Bons. A rota, de Pastos Bons, seguia às margens do rio Itapicurú, eixo fluvial navegável do Maranhão, de onde avistavam as Aldeias Altas (hoje Caxias - MA), alcançando através do rio Itapicurú, o porto de São Luis.

Luiz Vilhena, analisando a paisagem de Salvador em 1802, indicou a estrada real do gado como sendo freqüentada de Boyadas innumeraveis, desde o principio da Cidade fundada há duzentos e cincoenta annos ${ }^{19}$. Já os viajantes germânicos, Spix e Martius, decidiram seguir sua jornada até o maranhão rumando por uma das três estradas que cruzavam a vila da Cachoeira (BA). Optaram pela estrada real do gado, por onde são tocadas as boiadas do Piaui $^{20}$. O mapa 01 mostra o trajeto feito pelo gado no caminho real arrolado. Apesar da distância percorrida, São Luiz e Salvador se aproximaram pelo sertão.

\footnotetext{
${ }^{19}$ VILHENA, Luiz dos Santos. Rcopilação de noticias soteropolitanas e brasílicas. Vol 1. Salvador, 1802. p. 84 - 85. Manuscrito disponível em http://www.bndigital.bn.br. Acesso em 01.11.2011.

${ }^{20}$ SPIX, J.B Von; MARTIUS, C.P.F. Viagem pelo Brasil. Rio de Janeiro, Imprensa Nacional, 1938. p. 363.
} 


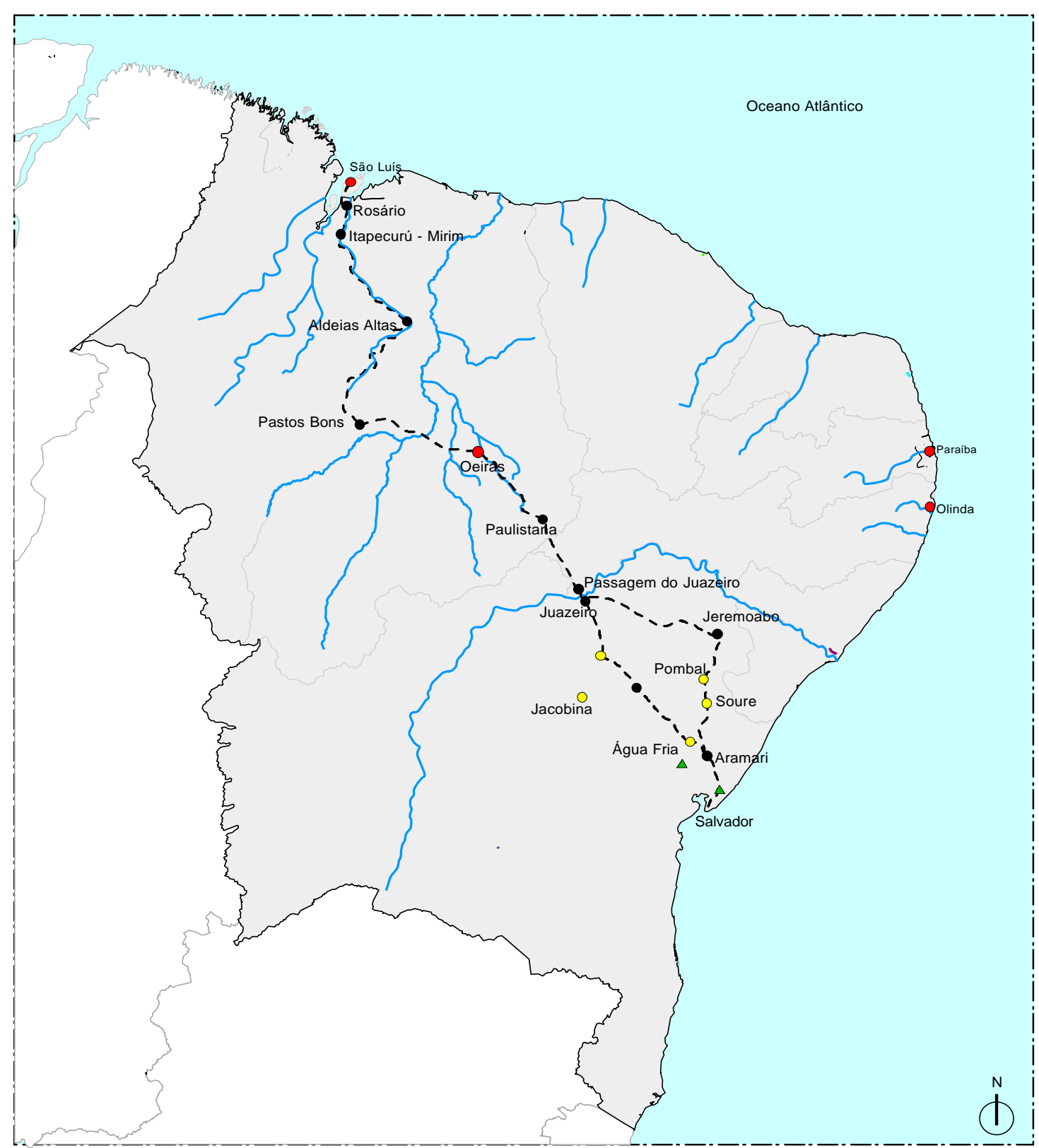

LEGENDA:

Cidades;

Vilas;

Povoações ou pousos das boiadas;

$\triangle$ Feiras de gado

Estrada real do gado

Principais rios
Mapa 01 - Estrada real do gado. Desenho do autor apartir de informações encontradas em Capistrano de Abreu, Raimundo Girão e Carlos Studart Filho.

A pecuária extensiva, economia base sertão nordestino, a partir de meados dos Seiscentos, foi o integrador de uma nova unidade territorial, àquela que extrapola os limites impostos às Coroas ibéricas pelo Tratado de Tordesilhas ${ }^{21}$. Melhor: os caminhos do gado, consequentes desta cultura econômica, como um sistema vascular, contribuíram para este

${ }^{21}$ ARINOS, Afonso. Síntese da história econômica do Brasil. Salvador, UFBA, 1958. p. 47 - 56. 
fenômeno geopolítico - espacial. Uma justificativa plausível para o povoamento do interior, realizado pelo gado, seria a necessidade intrínseca da pecuária de encontrar novos pastos para engorda dos animais, como foi observado por Spix e Martius:

(...) na ocasião da seca se torna necessário movimentar as boiadas em grandes espaços, alternando pastos para que elas consigam achar capim seco e frutas, daí os grandes proprietários das grandes fazendas não quererem ceder porção alguma de suas terras (para moradia dos agregados), por considerarem indispensável as grandes extensões para atender à criação do seu gado $(\ldots)^{22}$

Além de terras para as pastagens, os animais precisavam de água e sal, elementos essenciais para sua sobrevivência em áreas de caatinga, mantenedoras de secas prolongadas. Portanto, o transporte das manadas e a formação de caminhos se davam margeando os principais rios e seus afluentes. A estrada geral do Jaguaribe ${ }^{23}$, via que amarrou o litoral cearense ao rio São Francisco, foi uma rota criada às margens do rio de mesmo nome. Partindo de Aracati, as reses eram conduzidas para o termo da freguesia das Russas, passavam a povoação de Santa Rosa, chegando à vila de Icó pelas margens do rio Salgado. De Icó, as reses aportavam os sertões do Cariri, região guarnecida de boas pastagens. Atravessavam o platô da chapada do Araripe ${ }^{24}$, cruzavam a povoação do Exú (antiga missão jesuítica), em seguida a aldeia dos índios Aricuri, chegando ao rio São Francisco na paróquia de Cabrobó. George Gardner notou a dinâmica comercial acometida neste trajeto:

Sendo a estrada em que viajávamos a que levava ao interior do Ceará, bem como à região central do Piauí, muitos viajantes passavam pelo nosso acampamento. Carros cheios de algodão e couros desciam, enquanto outros, bem como tropas de cavalos, subiam carregados de mercadorias européias e de sal, que é raro e caro no interior. ${ }^{25}$

Conhecido como o rio dos currais $^{26}$, o rio São Francisco tornou caminho obrigatório de condução do gado de Pernambuco às minas gerais; de Salvador à São Luiz; de Penedo à vila da Barra do Rio Grande. Caminhos criados paralelamente ao seu curso, esse rio foi indispensável à posse e descobrimentos das terras sertanejas, alastrando currais e fazendas de

\footnotetext{
${ }^{22}$ SPIX, J.B Von; MARTIUS, C.P.F. Viagem pelo Brasil...Opus cit., p 419 - 420.

${ }^{23}$ STUDART FILHO, Carlos. "Vias de comunicação do Ceará colonial”...Opus cit., p. 27.

${ }^{24}$ STUDART FILHO, Carlos. "Vias de comunicação do Ceará colonial”...Opus cit., p. 27 - 30.

${ }^{25}$ GARDNER, George. Viagem ao interior do Brasil. São Paulo, Edusp, 1975. p. 84.

${ }^{26}$ MAGALHÃES, Basílio de. Expansão geográfica do Brasil colonial. 3 ed. Rio de Janeiro, Epasa, 1944. p. 238.
} 
criar, desde sua nascente até sua foz. Na Passagem do Juazeiro, aglomerado urbano situado às margens do rio São Francisco, lado pernambucano, existiram dois caminhos terrestres usados por gado e pela população local: a travessia nova com destino ao Piauí, e a estrada que interligou a Passagem do Juazeiro à freguesia de Cabrobó ${ }^{27}$.

Em 1702, o sertanista português, Domingos Afonso Mafrense, apelidado posteriormente de Sertão, escreveu ao governador geral do Brasil, D. João de Lencastre, um relato minucioso sobre suas descobertas no hinterland nordestino, dando conta dos caminhos, povoações e distâncias do último aglomerado à parte norte, até chegar em terras maranhenses. O rio São Francisco aparece como eixo condutor, baliza nos intentos de devassar, conhecer e povoar o sertão nordestino. Alípio Goular transcreveu o relatório em 1963, publicando-o na Revista do Instituto Histórico e Geográfico Brasileiro. Diz parte da carta:

Da cidade da Bahia ia uma estrada coimbrã pela Jacobina até o rio São Francisco, numa extensão de aproximadamente 130 léguas, pela qual vinham a maior parte dos gados que se criavam naqueles sertões, para o sustento da cidade e seus arrabaldes. Dalí seguia para o Norte, sempre beirario, umas 20 léguas, ao cabo das quais começava uma estrada, também coimbrã por onde vinham os gados das povoações novas do Callindê, Piagohy e Parnaíba. Da estrada do rio São Francisco aos currais de gado do primeiro povoado distavam umas 40 léguas e deste último, para o lado do Maranhão, 30 léguas; daqui até a cidade do Maranhão iam umas 70, havendo também um caminho mandado descobrir por D. João de Lencastro (citado anteriormente), mas todo ele despovoado, devido a gentio bravo que por ali havia. Também da mesma povoação partia uma estrada para o Ceará, Rio Grande, Paraíba e Pernambuco, por onde poderiam ir socorros sempre que fosse preciso, em carros e cavalos, porque por todas aquelas paragens havia muitos currais de gados e farinhas para o sustento desses comboios, salvo nas 70 léguas já indicadas. (...) Havia um outro caminho da Bahia para as minas de ouro, que se abria por onde chamavam Perogoassu, que era mais perto e ia sair ao rio de São Francisco perto da Barra do Rio das Velhas, mas também era despovoado. (...) Os caminhos por terra eram bons, conduzindo-

${ }^{27}$ SPIX, J.B Von; MARTIUS, C.P.F. Viagem pelo Brasil...Opus cit., p. 408. 
se por eles os gados do rio Grande de S. Francisco, para o sustento dos fabricadores das minas de ouro $(\ldots)^{28}$

Podemos indicar o grau de urbanização apontado pelo sertanista e futuro fazendeiro de gado, Domingos Afonso Mafrense, auferido em seu testemunho. Uma das evidências é atestada pelo número de estradas criadas para a condução do gado. Apesar do insignificante povoamento, os caminhos citados por Mafrense indicam um processo, mesmo embrionário, do surgimento de uma rede de vias e, consequentemente, de povoações fixadas às margens dessas veredas. Estão indicadas as povoações de Jacobina, Canindé (Callindê), Piauí (Piagohy) e Parnaíba. No final dos Seiscentos, próximo ao rio Canindé, ergueram a paróquia de Nossa Senhora da Vitória, futura vila da Mocha e cidade de Oeiras; talvez a indicação da povoação Canindé se refira a este arraial. Dessa maneira, uma rede urbana de povoações e vilas estava em franca ascensão, graças ao gado conduzido de um ponto a outro do Nordeste.

Não só entre lugares nordestinos, a carta de Domingos Afonso Sertão informou o intercâmbio existente entre a Bahia, através do rio São Francisco, às minas gerais. Essa ligação entre capitanias, devido ao comércio gado, foi movida pelo abastecimento dos gêneros da pecuária: carne e couro eram elementos necessários ao funcionamento dos núcleos mineiros, no que cerne à alimentação e uso dos atanados em distintas aplicações. Relatando sobre os tratos comerciais entre Bahia, Pernambuco e Minas Gerais, o governador da capitania mineira, Luís Diogo da Silveira descreveu que pelos caminhos do Certão, Bahya e Pernambuco o negocio da fazenda seca e molhados, gado vaccum e cavallar, escravos e o mais que se julgava ter sahida em huma nova povoação ${ }^{29}$.

Outros caminhos de penetração bovina podemos elencar. A estrada das boiadas ${ }^{30}$ remonta sua origem ao inicio do século XVIII, interligando o litoral pernambucano, passando pela Paraíba, ao sertão piauiense. Para Carlos Studart Filho o seu traçado primitivo:

(...) passava pelos lugares chamados S. João do Rio do Peixe, Sousa, Pombal e Patos, ia depois margeando o rio Espinharás; galgava as encostas orientaes da Borborema, encontrando, seis léguas além, a lagoa do Batalhão, seguia do

\footnotetext{
${ }^{28}$ GOULART, José Alípio. “A formação da zona pecuária nordestina”. In Revista do Instituto Histórico e Geográfico Brasileiro. Vol. 259. Abril - Junho. Rio de Janeiro, Imprensa Nacional, 1963. pp. 16 - 26.

29 "EXTRACTO do descobrimento das Minnas Geraes, tempo em que nellas principiou a arrecadação da Real fazenda, origem dos contractos, creação das villas, of. De Justiça..., dirigido e ordenado pelo Governador e Capitão General de Minas Geraes Luís Diogo da Silveira. Livro 81, D.F. do Arquivo Público Mineiro. Apud ZEMELlA, Mafalda P. O abastecimento da capitania das Minas Gerais no século XVIII. 2 ed. São Paulo, Edusp, 1990. p. 70.

${ }^{30}$ STUDART FILHO, Carlos. "Vias de comunicação do Ceará colonial”...Opus cit., p. 31 - 35.
} 
Taperoá até a povoação de Milagres; alcançava a pequena ribeira de Santa Rosa, para chegar a Campina Grande. De Campina Grande para o littoral, a estrada principiava atravessando densa floresta de quatro léguas até os lugares Caboclo e Torres, onde descia a Borborema; dava no pequeno Valle do Rio Ingá; passava nos lugares onde existem as povoações do Riachão, Várzea Nova, Villa Ingá, Mogeiro, e, uma légua além, attingia o rio Paraíba, na povoação de Salgado, seguia pelas margens desse rio (...) até a Capital. $\mathrm{Na}$ altura de Itabaiana, porém, bifurcava-se, dirigindo também para Itambé ou Desterro, Goiana e Recife, onde findava.(... $)^{31}$

Após cruzarem o território da capitania do Ceará Grande, as boiadas eram conduzidas para a vila do Icó, onde eram comercializadas; depois, partiam para o Piauí, pela fazenda de José Alves Feitosa, embrião da vila de Tauá; rumavam, finalmente, à vila da Mocha que, em feira local, eram negociadas e abatidas nos açougues locais.

No início do século XVIII, o jesuíta Antonil ${ }^{32}$ descreveu um roteiro detalhado do caminho que uniu Salvador - Minas Gerais, pelo sertão da capitania da Bahia. Sintetizando a sequência dos nós dessa rota, temos: Salvador à vila da Cachoeira (12 léguas), daí à aldeia de Santo Antônio de João Amaro (25 léguas), em seguida chegavam à fazenda Tranqueira (mais 43 léguas), aqui o caminho bifurcava-se. Trilhando pela mão direita aportavam o arraial de Matias Cardoso (52 léguas). Do arraial até o rio das Velhas (54 léguas) e, deste rio até a povoação do Borba, onde havia jazidas de ouro (51 léguas). Esse trajeto totalizou duzentas e trinta e sete léguas, isto é, aproximadamente $1.564,20 \mathrm{~km}^{33}$.

Nos manuscritos da coleção Alberto Lamego, pertencentes ao Instituto de Estudos Brasileiros (IEB), há um velho documento encaminhado ao ouvidor geral de Pernambuco, datado provavelmente do inicio dos Setecentos, que nos informa sobre a existência de uma rota de penetração bovina, do litoral pernambucano às minas gerais, seguindo o rio Ipojuca. À maneira da carta de Mafrense, este percurso indicou as povoações, pousos, fazendas de gado e a distância total, desde a partida até sua parada final. Os historiadores pernambucanos, Barbosa Lima Sobrinho e José Gonsalves de Mello, transcreveram os dados contidos na carta e mapearam as suas informações. Diz-nos o documento:

\footnotetext{
${ }^{31}$ STUDART FILHO, Carlos. "Vias de comunicação do Ceará colonial"...Opus cit., p. 31

${ }^{32}$ ANTONIL, André João. Cultura e opulência do Brasil. 3 ed. Belo Horizonte, Itatiaia/Edusp, 1982. p. 88 - 89. Disponível em http://www.dominiopublico.gov.br. Acesso em 12.05.2010.

${ }^{33}$ Levando em consideração que 1 légua é aproximadamente $43,56 \mathrm{~km}^{2}$. Ver FEITOSA, Carlos. As gentes dos Inhamuns na criação da Real Vila do Crato.Crato. p. 16.
} 
Para o Senhor Doutor Ouvidor Geral ver os caminhos que são necessários abertos para seguir pela estrada de Santo Antão para o rio S. Francisco.

$\mathrm{Na}$ freguesia de Santo Amaro de Jaboatão é necessário abrir caminho tanto de enchada como de foice e machado, até o sitio chamado Queimadas. Nas ditas Queimadas começa a freguesia de Santo Antão da Mata, a qual lhes toca abrir até à passagem do rio das Pedras de Ipojuca, donde acaba a dita freguesia. Da dita passagem do rio das Pedras para a outra banda, no sitio chamado Carará, pega a freguesia de Ararobá e acaba no sitio chamado Tacaito. Esta freguesia é a mais fechada estrada que se acha em todo o sertão, por nunca ser aberta senão no tempo em que se começou a cultivar, e hoje já a deixam muitos passageiros pela não poderem seguir com os seus comboios. Nesta freguesia é necessário abrir para a estrada do rio de S. Francisco, a estrada que entra na fazenda Tacaeté para a Missão de Ararobá. E de Ararobá para o Pajeú. Como também todas as aguadas que há, é necessário pô-las publicas, com caminhos e cruz na estrada, por estas ficarem afastadas nas ditas estradas pouco espaço. Principalmente se deve abrir o caminho da Lagoa da Pedra do Tacaitó, a todas as aguadas do riacho Liberal e Pedra do Cachorro e Lagoinha, fazendo-lhes caminho para sair para a porteira do Macaco. E os caldeiros do riacho Mororó, por-lhe cruz. Esta freguesia é dilatada, que tem de comprimento 70 léguas, mas está toda cultivada de moradores e fazendas e aldeias do gentio, como seja a nação dos Xucurús, dos Paraquiós e Parariconha, circunvizinhas da nação Carnijó. E como tem todo este presídio é muito mais fácil por as estradas prontas em poucos dias. Do dito sitio, chamado Tacaicó, donde acaba a freguesia, começa a freguesia de Cabrobó, a qual tem só para (sic.). Para abrir do sitio Tacaratú a sair para o de São Francisco que distam 5 léguas. E entrando nesta estrada da beira do rio até as minas é caminho deveras aberto e aprazível.

Dista o rio de São Francisco desta praça 100 léguas, pela estrada dita. E seguindo para as minas se caminha à vista do dito rio 350 léguas, e largando o tal rio se passa o tal rio das Velhas na barra onde se encontra com o de São Francisco e a chegar às minas se fazem 100 léguas $(. . .)^{34}$

\footnotetext{
${ }^{34}$ SOBRINHO, Barbosa Lima. "Capistrano de Abreu e o povoamento do sertão pernambucano". Opus cit., pp.
} $34-35$. 
O teor das notícias narradas no roteiro merece nossa atenção sobre o papel da ação criar caminhos - como influentes na urbanização dos sertões pernambucano e baiano. A primeira razão e, sem dúvida, a mais esclarecedora, refere-se ao surgimento de povoações no curso dessas estradas. Foram citadas as freguesias de Santo Antão (hoje Vitória de Santo Antão - PE), de Ararobá (atual vila de Cimbres - PE) e Cabrobó. A rede eclesiástica de paróquias, como pontas de lança no povoamento do sertão, transcreve a existência de considerável quantidade de fregueses e a garantia destes de acesso ao batismo, ao casamento, ao amparo dos enfermos, aos sacramentos e matrimônio com todas as implicações jurídicas e sociais. Para além do rito religioso, a elevação de uma ermida à freguesia denotava benefícios das formalidades civis. ${ }^{35}$ A "rede sacra de paróquias" aspirava à autonomia municipal. Para compreender a dimensão do trajeto entre Recife e as minhas gerais, pelo rio Ipojuca, elaboramos o mapa 02.

\footnotetext{
${ }^{35}$ MARX, Murillo. Cidade no Brasil: terra de quem? São Paulo, Edusp, 1991. pp. 18 - 19.
} 


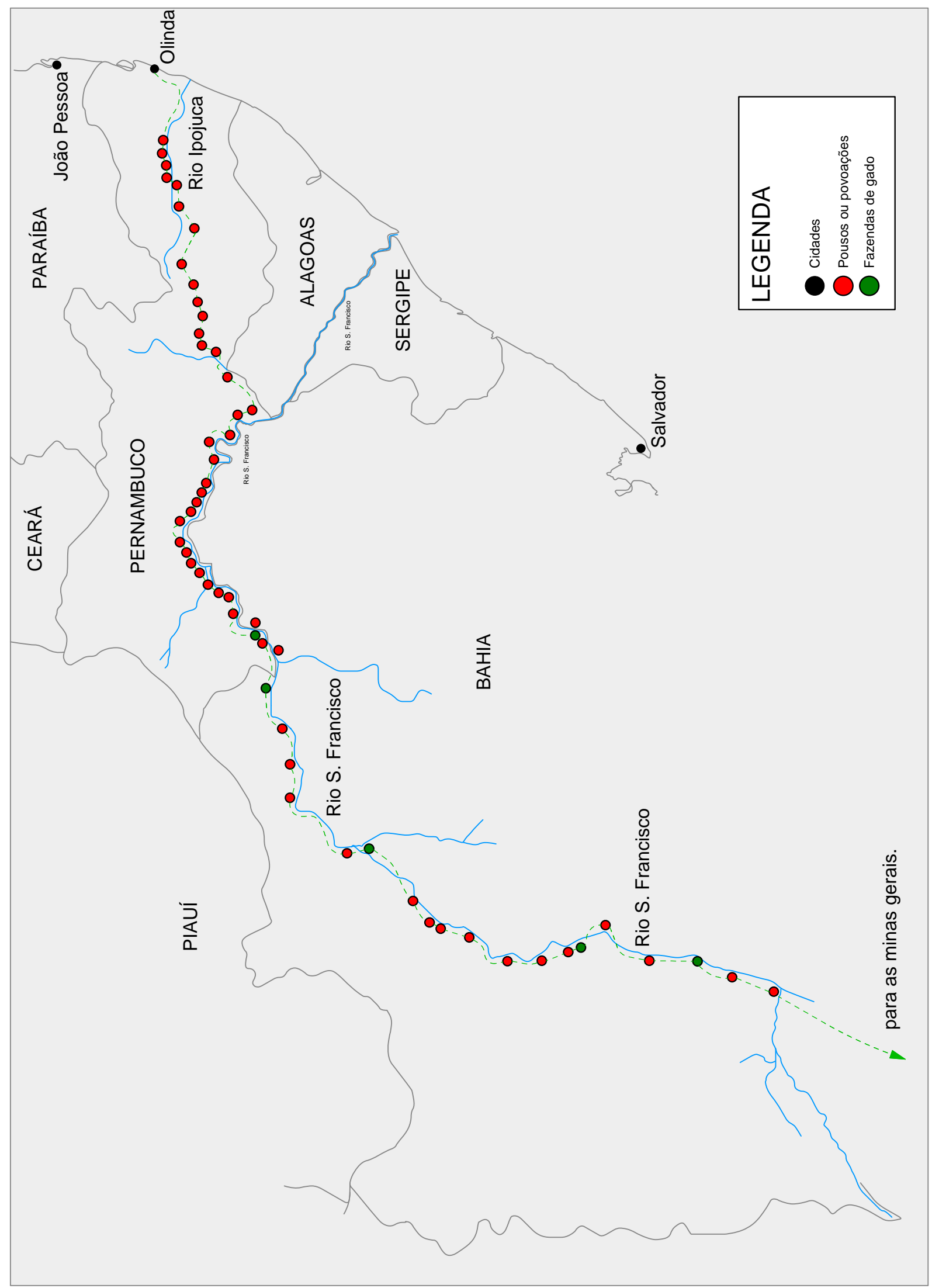

Mapa 02 - Roteiro de penetração de Recife às minas gerais, pelo rio Ipojuca. Desenho do autor sobre informaçoes de Barbosa Lima Sobrinho e José Antônio Gonsalves de Mello. 
Sob o reinado de D. José I, com apoio do Conde de Oeiras, futuro marquês de Pombal, novas decisões administrativas foram tomadas visando o controle do território sertanejo e melhoria da comunicação terrestre, porque os caminhos eram maus, despovoados $(\ldots)^{36}$ áridos e escabrosos $(\ldots)^{37}$ e a falta do devido intercâmbio com as outras partes do Nordeste e colônia é sem duvida hum embaraço bem consideravel, e quaze o principio de quantos difficultão a sua boa economia $(. . .)^{38}$. Mesmo assim, após duzentos e cinqüenta anos de colonização, nos confins do sertão nordestino:

(...) os seus habitantes vivem em grandes distancias huns dos outros sem a communicação, como inimigos da sociedade civil e do commercio humano padecendo assim os descomodos e os lugares muito remotos e longinquos de sorte que quando lhes chegam os despachos vem tão tarde que não servindo para o remedeo das queixas lhes trazem sempre a ruína $(. . .)^{39}$

A criação de mapas, elaborados por engenheiros militares ou outros funcionário da administração colonial (governadores, capitães mores e ouvidores), cumpria os anseios da Coroa portuguesa e de seus agentes. A “carta geográfica da Capitania do Piauhi e parte das adjacentes"'[ver figura 23, capítulo 01] levantada pelo engenheiro João Antônio Galucio, em ordem do governador João Pereira Caldas, é um bom exemplo de iconografia, apesar da retaliação de um viajante anônimo ao dizer que na cartografia de Galucio há muitas posições erradas, e ommissões tão substanciais ${ }^{40}$. Contudo, estão delineadas as estradas por onde a população e o gado transitaram, indicadas as fazendas de gado e as seis vilas e uma cidade quem formaram o Piauí "pombalino".

Caminhos mapeados aparecem em outras cartografias setecentistas e oitocentistas, as quais reforçam nossas considerações sobre o surgimento de povoações e rede urbana ao longo de tais rotas. Para exemplificarmos, temos o Mappa Topographico das Capitanias do Maranhão e Piahuy e parte das adjascentes, offerecido pelo Ilmo. Snr. João Ferreira da Costa Sampayo, levantado pelo Capitão Mathias Jozé Pereira [figura 37] e a Carta da Capitania do Ceará levantada por ordem do Governador Manoel Ignácio de Sampaio, por seu ajudante de ordens Antônio Jozé da Silva Paulete (1818) [figura 38].

\footnotetext{
${ }^{36}$ PROJETO RESGATE. AHU_ACL_CU_016, Cx.8, D. 462.

${ }^{37}$ PROJETO RESGATE. AHU_ACL_CU_016, Cx.11, D. 633.

${ }^{38}$ PROJETO RESGATE. AHU_ACL_CU_016, Cx.11, D. 649.

${ }^{39}$ PROJETO RESGATE. AHU_ACL_CU_018, Cx.8, D. 450.

40 "ROTEIRO do Maranhão a Goiaz pela Capitania do Piahui". In Revista do Instituto Histórico e Geográfico Brasileiro. Tomo LXII. Vol. 99. Rio de Janeiro, Imprensa Nacional, 1900. p. 61.
} 


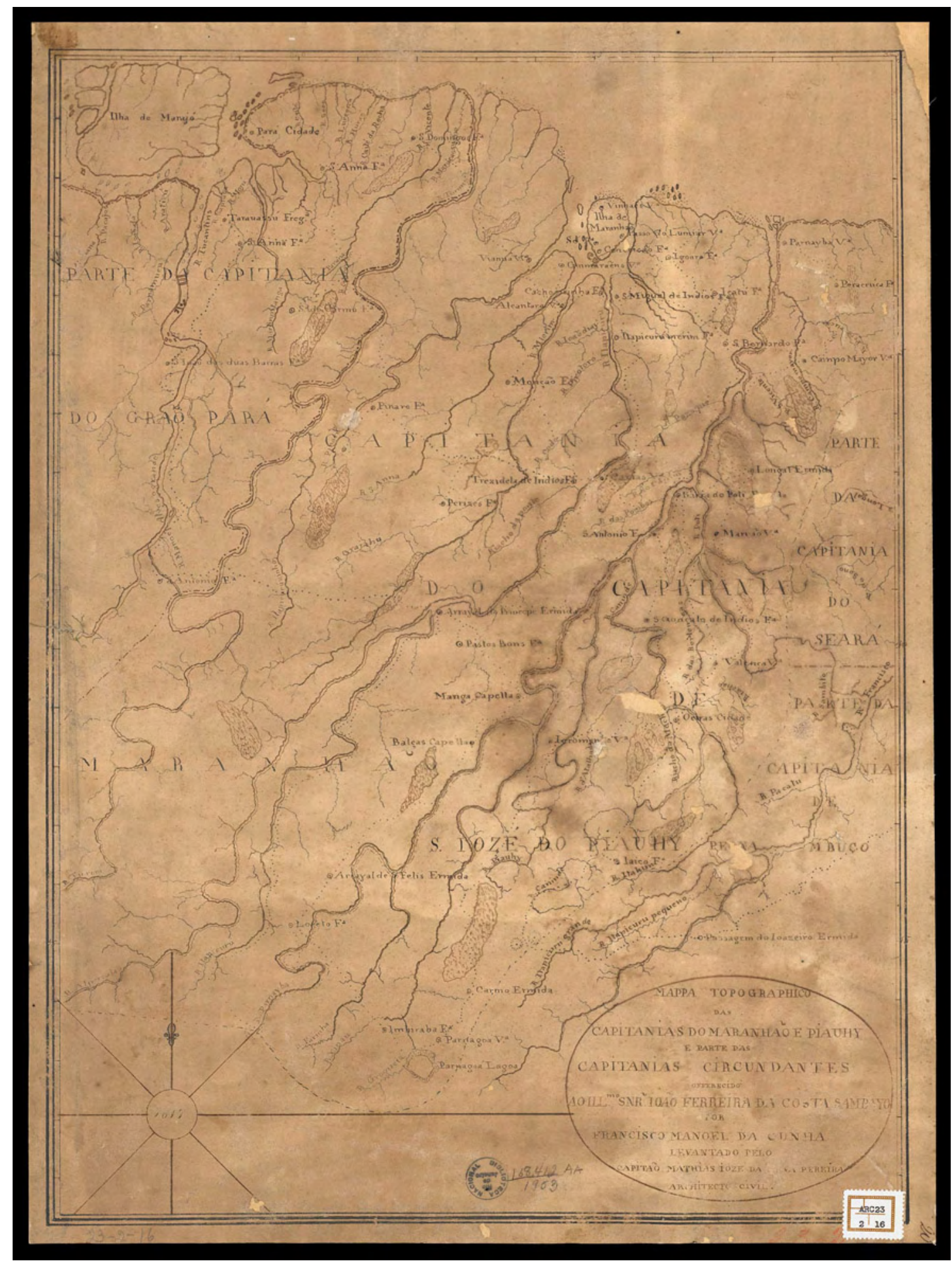

Figura 37 - Mappa Topographico das Capitanias do Maranhão e Piahuy e parte das adjascentes, offerecido pelo Ilmo. Snr. João Ferreira da Costa Sampayo, levantado pelo Capitão Mathias Jozé Pereira. Disponível em http://www.bn.br. Acesso em 23.03.2010. 


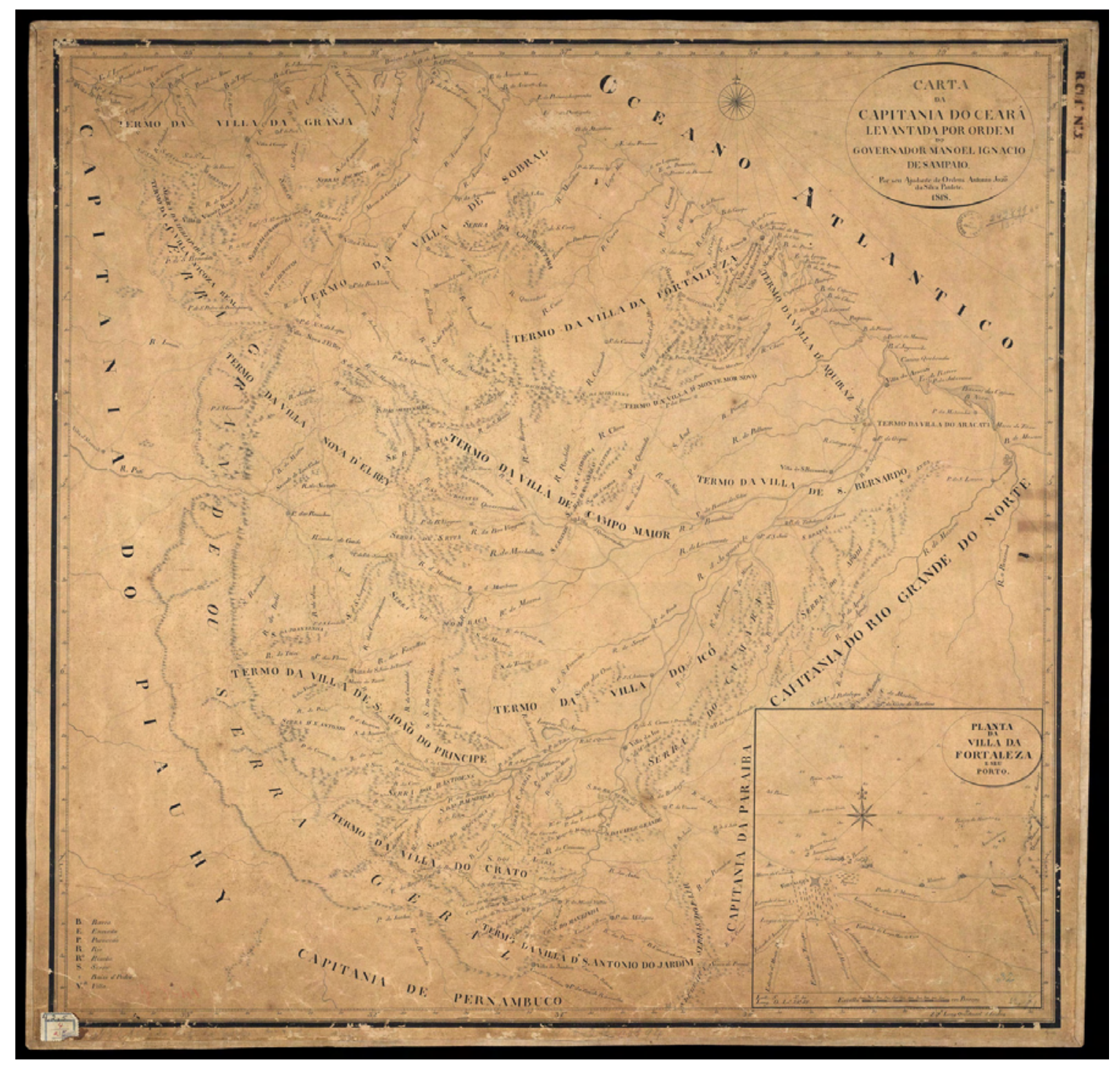

Figura 38 - Carta da Capitania do Ceará levantada por ordem do Governador Manoel Ignacio de Sampaio. Por seu Ajudante de Ordens Antônio Jozé da Silva Paulete, 1818. Disponível em http://www.bn.br. Acesso em 03.02.2010.

Os mesmos objetivos de facilidade de comunicação, locomoção e desenvolvimento econômico, obtidos através das vias terrestres, encontramos nos relatos oitocentistas dos administradores das capitanias nordestinas. Escrevendo em 1802, ao visconde de Anadia, o governador da recém instalada capitania do Ceará Grande, Bernardo Manuel de Vasconcelos, ressalvou a necessidade da construção de duas estradas que ligariam os eixos: vila de Fortaleza - vila de Sobral - rio Parnaíba:

Assim tendo eu sempre em vista tão importantíssimo objecto e sendo entre estes sem duvida a communicação das Estradas de humas para as outras Povoaçõens hum dos que pedia sem duvida muito particular attenção pois que por meio dellas se facilita indivizivelmente a condução dos gêneros do 
País. Passei em conseqüência disto a fazer abrir huma Estrada de sessenta legoas desde esta Villa até Sobral, e outra dalli até as Magens do Rio Parnahiba, que devide as duas Capitanias Seará e Piauhi, fazendo deste modo a total distancia das ditas duas Estradas a conta de 111 legoas $(. . .)^{41}$

Se continuarmos a leitura da sobredita carta, veremos como patrocinadores na execução das estradas dois fazendeiros de gado, um com título de capitão mor de ordenanças da vila da Granja, Joaquim José Borges de Pinho, e o outro um negociante da vila de Sobral, Jozé da Silva Castro. A ação - abrir caminhos - só que desta vez por iniciativa privada, consistiu uma atividade comum nos tempos coloniais, cujos proveitos desse negócio poderiam ser convertidos em honras honoríficas ou o monopólio da via, isto é, a passagem de gados de outras fazendas por tais rotas deveriam ter prévia aprovação do executor da mesma (na maioria dos casos fazendeiros de gados).

Caminhos oficiais criados por ordens da Metrópole ou por seus representantes oficiais e estradas patrocinadas por civis, semi - públicas, são as atribuições que podemos dar, segundo os acontecimentos relatados nos documentos coloniais, aos caminhos elaborados no sertão nordestino, desde seu efetivo povoamento (meados do século XVII) até os Oitocentos. No início do século XIX, novamente o governador do Ceará, Bernardo Manuel de Vasconcelos, em ofício ao visconde de Anadia, descreveu os progressos relativos ao desenvolvimento de uma estrada pública de Baturité (antes vila de Monte-Mor o Novo da América) às minas de salitre da Tatajuba ${ }^{42}$. A rota criada beneficiou os cofres da fazenda real e a urbanização do Ceará: (...) espero que por todo este anno fique a referida Estrada acabada e capaz de por ella se carregarem os gêneros do commercio recíproco e interior das terras desta Capitania sem risco algum em carros carregados dos mesmos gêneros (... $)^{43}$.

Em 1850, segundo Francisco Ignácio Homem de Mello, a província do Ceará contou com muitas estradas, que se cortam em todas as direções. As linhas mais importantes são as que irradiam da capital para S. João do Príncipe (Tauá), Sobral, Ipú, Viçosa, Aracaty, Icó, Crato e Jardim. E as que desses centros se dirigem aos respectivos portos do litoral ${ }^{44}$. Para Homem de Mello, a estrada do Crato a Aracati, provavelmente a estrada geral do Jaguaribe,

\footnotetext{
${ }^{41}$ PROJETO RESGATE. AHU_ACL_CU. Cx.16, D. 905.

${ }^{42}$ PROJETO RESGATE. AHU_ACL_CU. CEARÁ, Cx. 17, D. 994.

${ }^{43}$ PROJETO RESGATE. AHU_ACL_CU. CEARÁ, Cx. 17, D. 994.

${ }^{44}$ MELLO, Francisco Ignácio Marcondes Homem de Mello. "Excursões pelo Ceará, S. Pedro do Sul, e São Paulo". In Revista do Instituto Histórico e Geográfico Brasileiro. Tomo XXXV. Segunda parte. Rio de Janeiro, B.L. Garnier, 1872. p. 100.
} 
citada por Carlos Studart Filho, é a mais importante de todas, além de sua grande extensão, cerca de $480 \mathrm{~km}$, transitaram por ela o gado, o algodão e demais produtos comerciais para abastecer os núcleos litorâneos ${ }^{45}$.

Visando o desenvolvimento do Nordeste, o príncipe regente, Dom João VI, em ofício datado de 1800 para o governador da Bahia, Francisco da Cunha Menezes, percebeu as grandes vantagens que devem resultar a este Reino e a estes meus Domínios de se abrir huma estrada (... $)^{46}$. O percurso e os produtos comerciais focalizados na criação do caminho foram listados em seguida:

(...) a qual dirigindo-se desde os Montes Altos até o porto da Villa do Camamú (...) Sou Servido ordenar-vos que na conformidade que determinei ao vosso antecessor em carta régia tambem de 12 de julho do anno proximo passado, procedaes logo a fazer trabalhar na continuação de uma tão interessante e gloriosa empreza, executando fielmente as minhas reaes determinações e por isso mandando prosseguir naquella obra pella direcçao que for mais breve e tal que possa dar a melhor sahida á exportação do salitre, á conducção dos gados, e de todos os grandes productos das culturas, que se introduzirem com esta maior facilidade, que se lhes procura; e seguindo acerca d'este tão attendivel objecto da estrada nova de Montes Altos $(\ldots)^{47}$

Logo após a homologação real, o governador principiou a execução da estrada. Primeiro, foi elaborado um diagnóstico do lugar acerca da possibilidade ou impossibilidade de se abrir hum caminho até os Montes Altos pelo interior do Certão, interessando particularmente aos que vão estabelecer fazendas de gado e roças ao longo da mesma estrada $(\ldots)^{48}$. Destaca-se, portanto, a importância dessa via, como eixo condutor do povoamento do sertão baiano, na fixação de fazendas e algumas moradias daqueles que se ofereceram em colonizar a região.

\footnotetext{
${ }^{45}$ MELLO, Francisco Ignácio Marcondes Homem de Mello. Excursões pelo Ceará...Opus cit., p. 101.

46 "CARTA régia em que se dirigem diversas instrucções ao Capitão General da Capitania da Bahia, Francisco da Cunha Menezes". in Annaes da Bibliotheca Nacional do Rio de Janeiro. Vol XXXVI. Ano 1914. Rio de Janeiro, Officinas Graphicas da Biblioteca Nacional, 1916. p. 239.

47 "CARTA régia em que se dirigem diversas instrucções ao Capitão General da...Opus cit., p. 239.

48 "OFFICIO do governador D. Fernando José de Portugal para D. Rodrigo de Sousa Coutinho, em que se refere a abertura de uma estrada até Montes Altos pelo interior do Sertão". In Annaes da Bibliotheca Nacional do Rio de Janeiro. Vol XXXVI. Ano 1914. Rio de Janeiro, Officinas Graphicas da Biblioteca Nacional, 1916. p. 250.
} 
O presidente da província do Piauí, José Idelfonso de Sousa Ramos, ao longo do sua gestão, se preocupou em projetar e melhorar o aparato viário de sua jurisdição. Em sua Falla de 1844, admitiu que na classe dos melhoramentos materiais figurou em primeiro lugar as estradas, pontes e navegação dos rios do interior da Província, isto he, os meios se sua communicção, que formão a principal necessidade (... $)^{49}$. Já em 1845, teceu a necessidade de reparar as estradas e suas infra-estruturas:

O melhoramento das estradas, sempre útil em qualquer parte, porque equivale a huma diminuição no custo da produção dos gêneros, que se transportão, em beneficio do consumidor, e sem prejuiso, antes com proveito do productor, merece mais a solicitude do legislador Piahuiense do que o de muitas outras Províncias, porque, Senhores daqui tudo sae, e para aqui tudo entra, às costas de animais. Entretanto o péssimo estado das estradas da Província prova-se com o clamor geral. Eu não tenho experiência de todas, mas avaliando as que sai da de Caxias para esta Capital (Oeiras), que he a mais frequientada, e importante da província (...) Cumpre, pois, melhorar as estradas, e esse dezejado melhoramento deve consistir em extinguir atoleiros que nellas haja, arredar pedras que a emburacão em catar os matos que de hum e outro lado incommoda o viajante $(. . .)^{50}$.

O que antes eram apenas rudes passagens de gado ou precárias vias de comunicação terrestre, localizadas espaçadamente no território, unindo pontos nodais que detiveram o interesse da coroa Portuguesa, dos oficiais do governo e de fazendeiros colonizadores, deu lugar a um complexo sistema viário. Os caminhos irrigaram o sertão nordestino numa tentativa de tirá-lo do isolamento e desconhecimento. Esse gradual desenvolvimento pode ser observado nos mapas 03 e 04, o primeiro com indicações dos caminhos das boiadas e o segundo com as velhas estradas, muitas delas verdadeiras adaptações das rotas do gado, cujo maior beneficiário dessa evolução "vascular" foi o mercado interno da pecuária extensiva, como veremos na segunda parte deste capítulo.

\footnotetext{
${ }^{49}$ FALLA, que derigio a assembléia legislativa do Piahuy no ato da sua instalaçam, o Presidente da Província no dia 07 de julho de 1844. Oeiras do Piahuy, Typ. de Silveira e Companhia, 1844. p. 37. Disponível em http://www.crl.edu. Acesso em 26. 07. 2010.

${ }^{50}$ RELATORIO do Presidente da Província do Piahuy no dia 01 de Agosto de 1845. Oeiras do Piahuy, Typ. de Silveira e Companhia, 1845. p. 25. Disponível em http://www.crl.edu. Acesso em 26. 07. 2010.
} 


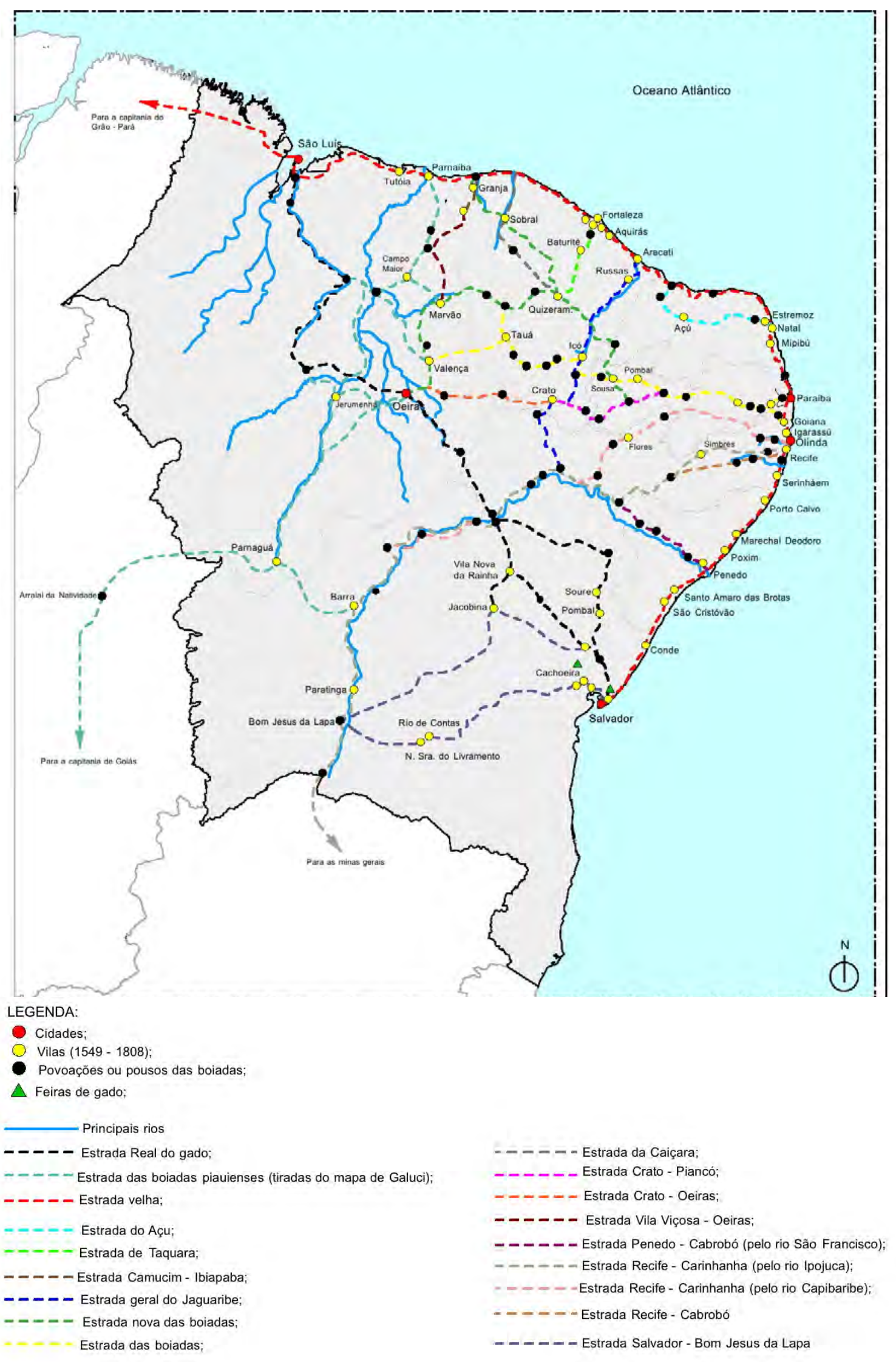

Mapa 03 - Caminhos do gado. Desenho do autor a partir de informações de Carlos Studart Filho, Capistrano de Abreu e Barbosa Lima Sobrinho. Como também dos manuscritos das coleções Alberto Lamego e Projeto Resgate Barão de Castelo Branco. 


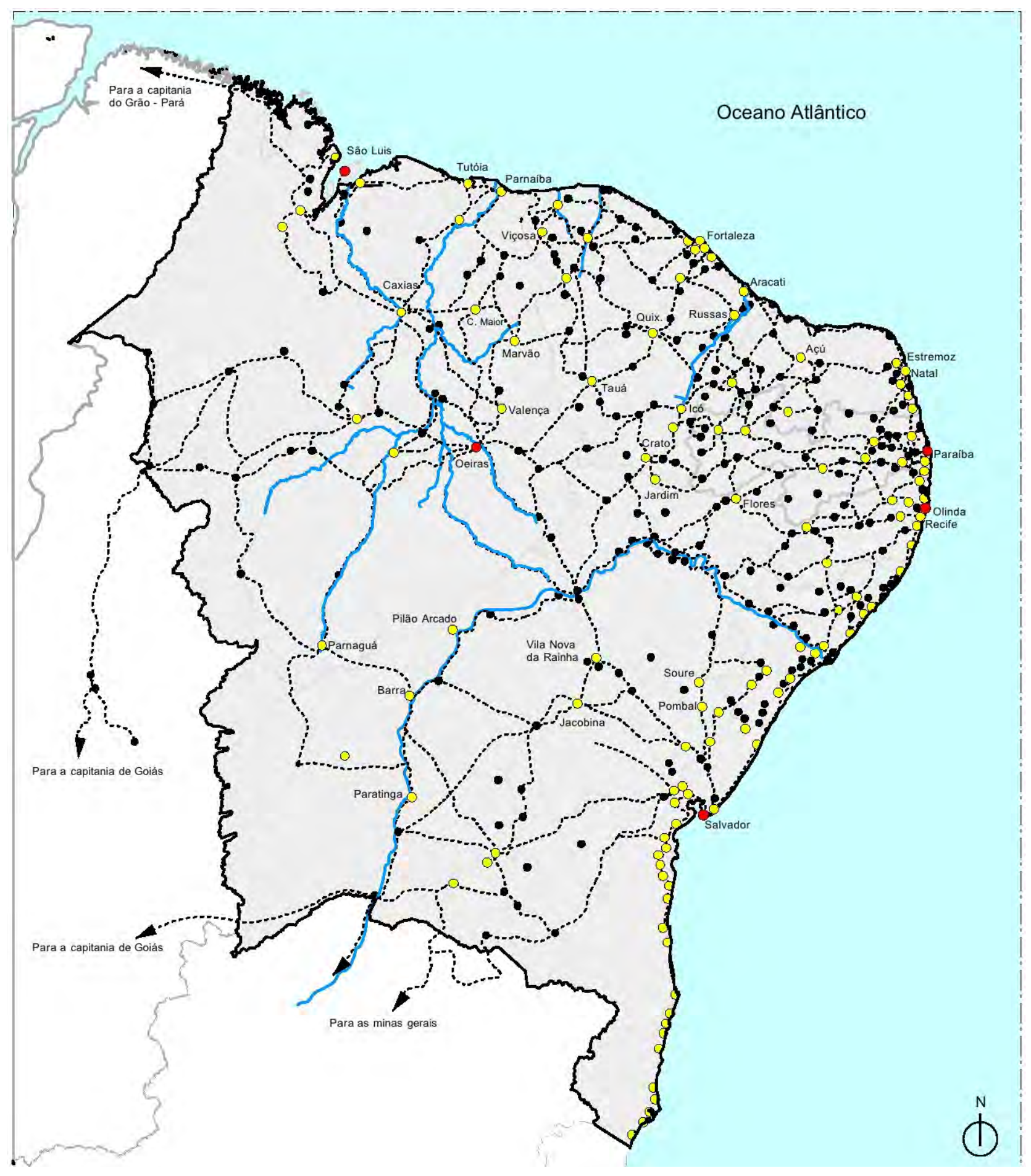

\section{LEGENDA:}

Cidades;

Vilas;

Povoações;

Estradas coloniais;

Principais rios;
Mapa 04 - Velhas estradas do nordeste. Séculos XVII - XIX. Desenho do autor a partir de informações encontradas em Capistrano de Abreu, Barbosa Lima Sobrinho, Carlos Studart Filho, Manuel Correia de Andrade e nos manuscritos da coleção Alberto Lamego e Projeto Resgate Barão de Rio Branco. 


\subsection{Pecuária sertaneja e suas interfaces na economia colonial brasileira}

A ocupação do interior do Nordeste foi determinada pela necessidade de prover a área açucareira de animais (gado vacum) para trabalho e alimento ${ }^{51}$. Originou dois pólos de expansão gadeira - Salvador e Olinda/Recife. Capistrano de Abreu, em seu conhecido Capítulos de História Colonial, informou que da Bahia o gado seguia às margens e vertentes dos rios das Velhas, Itapecurú, Real, Vasa - Barris, das Rãs, Verde, Paranamirim, Sergipe e São Francisco. Chamou essa arremetida de sertão de dentro por penetrar o sertão, desde a capital da colônia, até as terras interioranas do Maranhão, Piauí, Ceará, Pernambuco e Paraíba, devassando sempre o hinterland sertanejo. De Olinda/Recife, o mesmo historiador opinou que os animais, em comboio, eram tangidos paralelamente à linha litorânea. Os pernambucanos, desse modo, protegiam a capitania e seus domínios de ataques piratas e de estrangeiros que os cobiçavam. Por isso, a denominação de sertão de fora é atribuída aos condutores de gado de Pernambuco. A eles couberam a conquista dos sertões de Alagoas, Pernambuco, Paraíba, Rio Grande do Norte e Ceará ${ }^{52}$. Desses fluxos do gado [mapa 05], originaram caminhos, depois estradas, e a pecuária extensiva - economia base do sertão nordestino e acessória, no dizer de Caio Prado Jr. ${ }^{53}$, aos mercados voltados à exportação.

Nos anos iniciais de dominação portuguesa, o gado era criado junto às lavouras de cana - de - açúcar. Serviam de alimento, força motriz para as fábricas dos engenhos e como meio de transporte; carros - de - bois [figura 39] de duas, três ou mais juntas, transportavam a população para os núcleos urbanos em dias de festas e carregavam lenhas, canas, o próprio açúcar e outros produtos para os portos e feiras. Com o tempo, a simbiose gado/açúcar se embaraçou. Os gados criados na zona da mata e no recôncavo baiano começaram a destruir as grandes lavouras, levando o rei D. Pedro II, em 30 de janeiro de 1698, emitir uma provisão, ordenando os pecuaristas que despejassem suas boiadas soltas [figura 40] no interior, no reduzido prazo de um mês por ser conveniente ao meu serviço e ao bem público (... $)^{54}$. $\mathrm{O}$ curto prazo causou transtornos aos criadores, sendo provável que muitos não conseguiram evacuar suas reses no tempo estabelecido.

\footnotetext{
51 ANDRADE, Manuel Correia de. O processo de ocupação do espaço regional do Nordeste. 2ed. Recife, SUDENE, 1979.

${ }^{52}$ ABREU, Capistrano. Capítulos de história colonial, 1500 - 1800. 7 ed. São Paulo, Publifolha, 2000. p. 150 160.

${ }^{53}$ Caio Prado Jr. afirma que, durante a primeira fase da colonização brasileira, é preciso distinguir dois setores de produção. O primeiro é dos grandes produtos para a exportação: açúcar, tabaco, ouro. O outro é das atividades acessórias cujo fim é manter em funcionamento aquela economia de exportação, nessa última categoria se enquadra a pecuária.

${ }^{54}$ GOULART, José Alípio. O ciclo do couro no Nordeste. Rio de Janeiro, Ministério da Agricultura, 1966.
} 


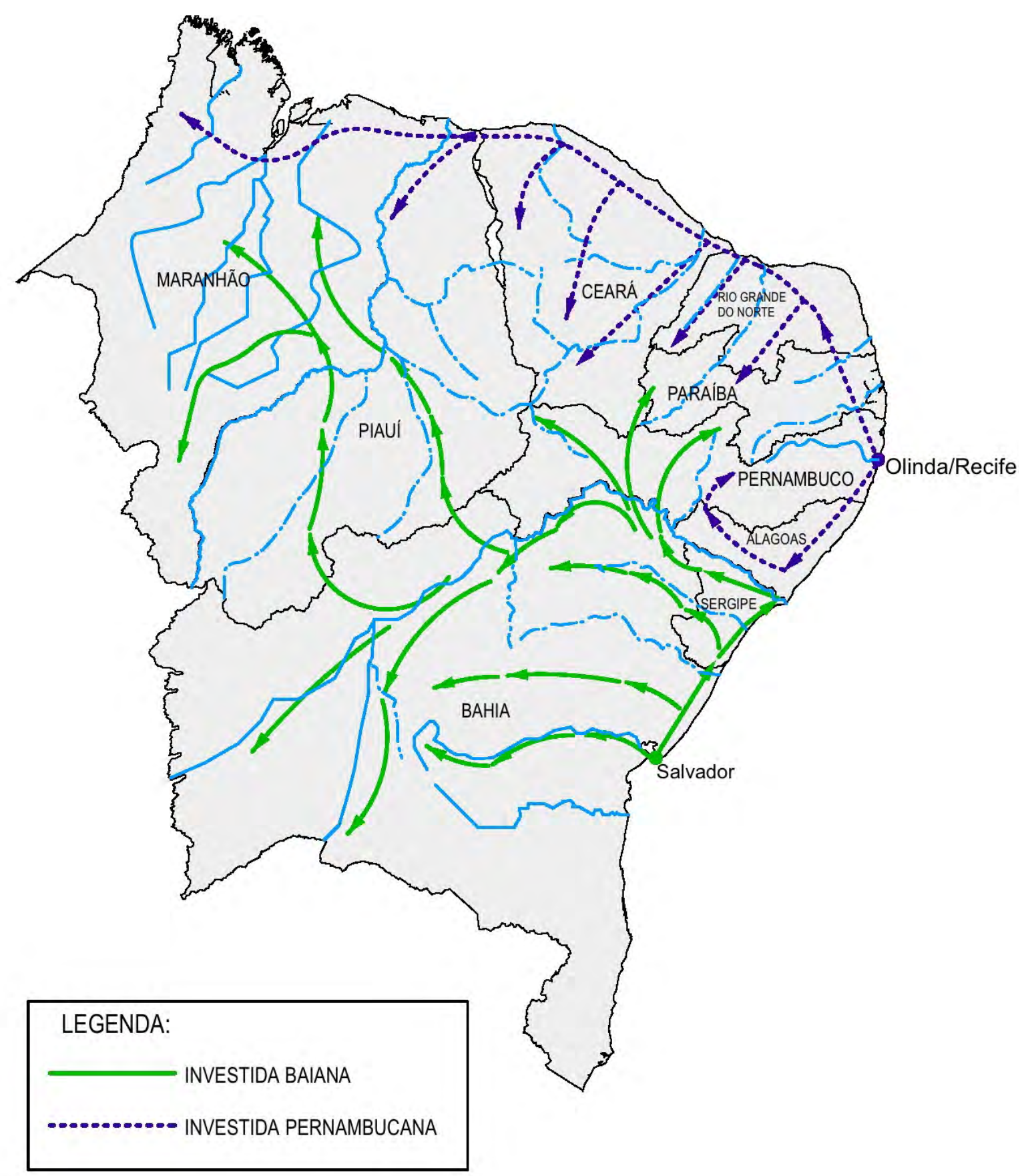

Mapa 05 - Fluxos da do gado no interior do Nordeste. Desenho do autor sobre informações encontradas em Capistrano de Abreu (2000) e Manuel Correia de Andrade (1973).

Vendo os problemas provocados pela provisão de 30 de janeiro de 1698, o monarca dessa vez emite, em 1701, uma carta régia renovando a resolução anterior. O documento real estabeleceu a criação de gado em no mínimo dez léguas afastadas das áreas lavoureiras ${ }^{55}$. Esta

\footnotetext{
${ }^{55}$ HOLLANDA, Sérgio Buarque de. História da civilização brasileira. vol II. Tomo I. São Paulo, Difusão Européia do Livro, 1960. P. 221.
} 
ordem foi mais que significativa nos processos de ocupação e urbanização dos sertões nordestinos.

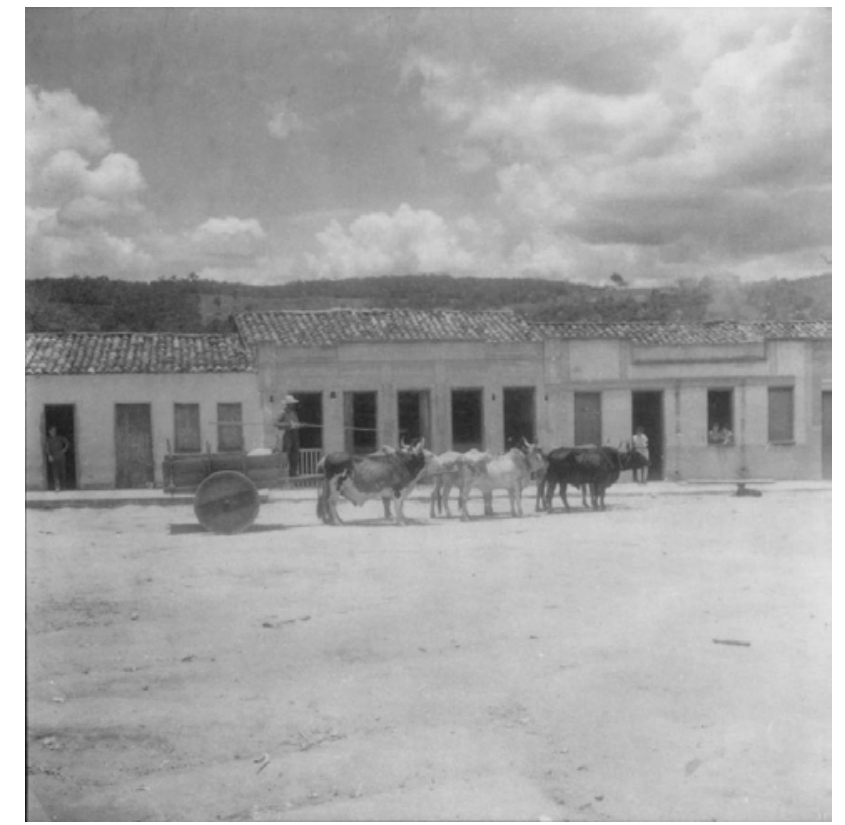

Figura 39 - Carro de bois em Jacobina (BA). Disponível em http://www.ibge.gov.br. Acesso em $14 / 08 / 2010$.

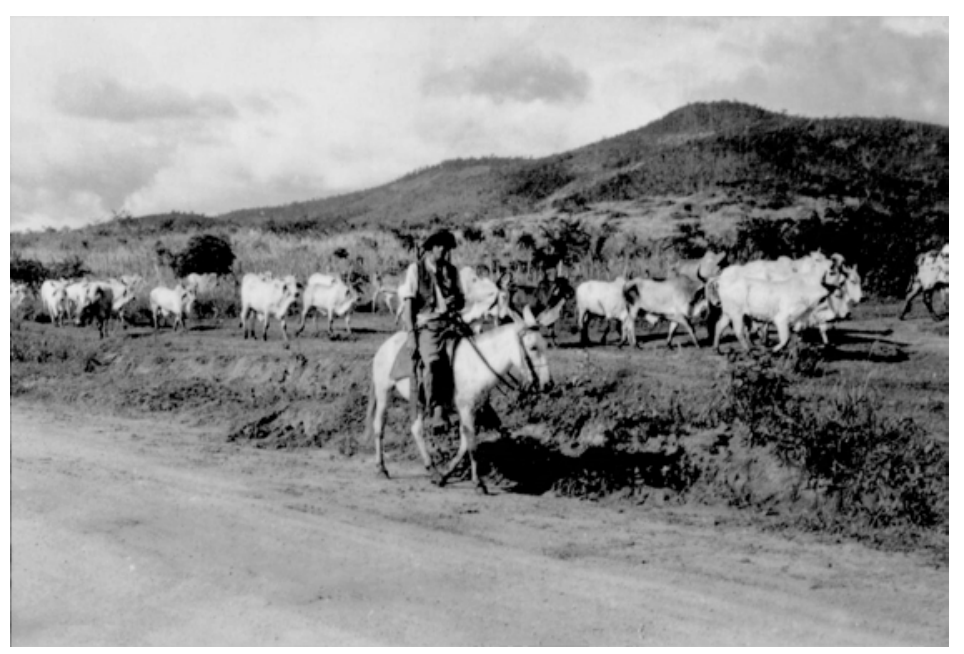

Figura 40 - Boiadas no sertão do Piauí. Disponível em http://www.ibge.gov.br. Acesso em $14 / 08 / 2010$.

Muito contribuiu a pecuária para a posse da terra sertaneja, principalmente quanto ao uso de grande faixa territorial com uma população reduzida. O clima semi-árido e vegetação resistente às intempéries das secas e às altas temperaturas fizeram das áreas de caatinga, nos Seiscentos e Setecentos, apropriadas à criação de gado. Sérgio Buarque de Holanda listou dois fatores positivos ao povoamento e ao desenvolvimento dos rebanhos: o relevo formado por peneplanícies, e os barreiros salinos, encontrados, as mais das vezes, ao longo do médio São Francisco. ${ }^{56}$

\footnotetext{
${ }^{56}$ HOLANDA, Sérgio Buarque de. História da civilização brasileira...Opus cit., p. 221.
} 
A ocupação e o conhecimento da região foram, sem dúvida, os elementos que mais se beneficiaram da criação de gado. Mas a população ficou escassa, distribuída em espaçados pontos distantes léguas e léguas uns dos outros. Às margens dos rios perenes, a população apresentou suas maiores densidades, como informado pelo jesuíta Antonil: as fazendas, e os currais se situão aonde há largueza de campo, e agoa sempre manente de rios, ou lagoas $(\ldots)^{57}$.

Em 1765, o governador da capitania de São José do Piauí remeteu um ofício ao Secretário de Estado da Marinha e Ultramar, Francisco Xavier de Mendonça Furtado, informando sobre o total da população piauiense - 120.744 habitantes - distribuída em uma cidade (Oeiras), seis vilas (São João da Parnaíba, Campo Maior, Marvão, Viçosa do Piaú, Jerumenha e Parnaguá) e dois aldeamentos indígenas (São João de Sende e Nossa Senhora das Mercês de Jaicós $)^{58}$. O critério estabelecido para criar o censo se deu a partir das fazendas de gado, situadas nas ribeiras dos rios que serpenteiam o território daquela capitania: Canindé, Piauí e Itaim. É interessante notar que, em algumas herdades, seus habitantes eram compostos exclusivamente de escravos [figura 41], denotando uma relativa liberdade em como se tratavam os cativos no interior piauiense.

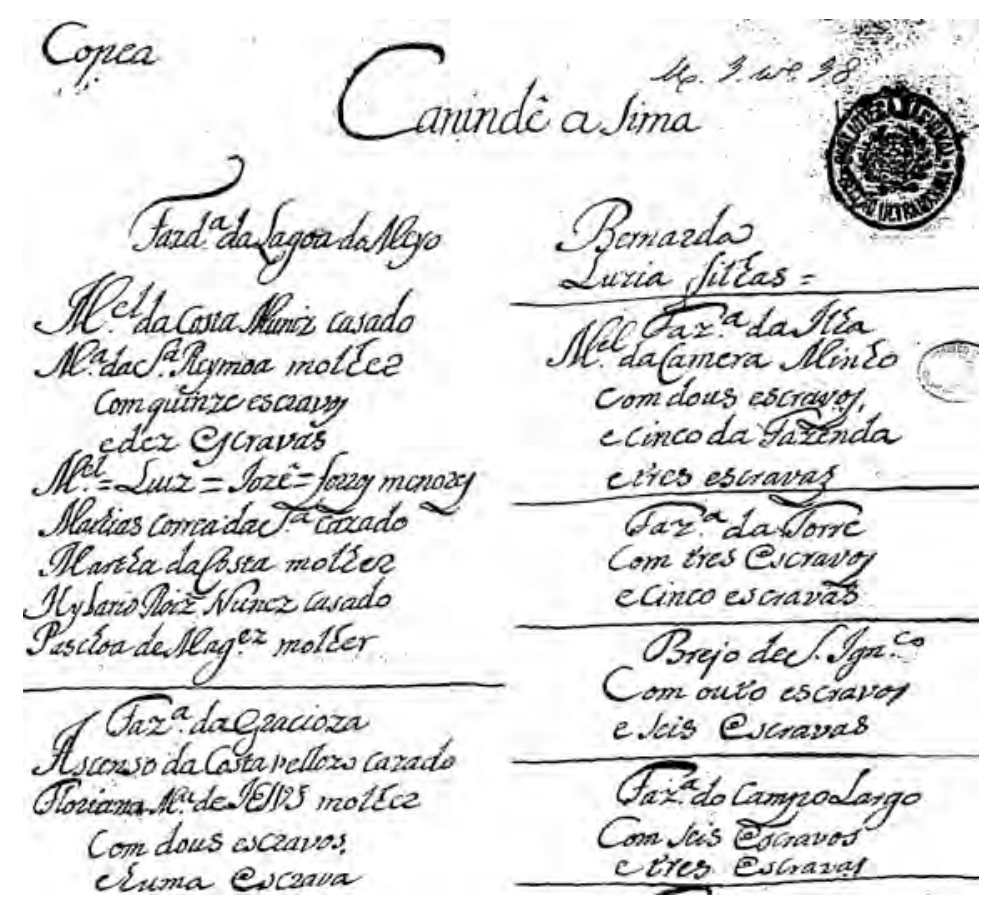

Figura 41 - Parte da lista dos moradores das fazendas localizadas na ribeira do Canindé de Cima, capitania de São José do Piauí. Projeto Resgate: AHU_ACL_CU_016, Cx.9, D. 457.

\footnotetext{
${ }^{57}$ ANTONIL, André João. Cultura e opulência do Brasil. 3 ed. Belo Horizonte, Itatiaia/Edusp, 1982.

${ }^{58}$ PROJETO RESGATE. AHU_ACL_CU_016, Cx. 9, D. 547.
} 
Criava-se o gado à solta, nas terras sem fronteiras, em pastos comuns. Os fazendeiros soltavam os animais nas pastagens, permanecendo muito tempo até atingir o peso ideal para venda $^{59}$. Em terras indivisas, virtualmente delimitadas pelas cartas de doação de sesmarias, manadas de dois, três ou mais criadores se misturavam. Diferenciavam-nas pela marca da fazenda chamada de ferra ${ }^{60}$. Segundo Lycurgo Santos, a ferra era praticada anualmente em crias de mais de seis meses, sendo a garantia de identificação e posse do animal, não havendo perigo de passar a outro dono ${ }^{61}$. Houve outra maneira de separar boiadas de distintos curraleiros, um método mais poético e sonoro: o aboio, isto é, canto melódico, sem palavras definidas. O boi era domesticado pelo peculiar conjunto de sons do vaqueiro, ao ouvi-lo põese em retirada ao curral ${ }^{62}$.

\author{
Meu povo, tome coragem \\ Se aventure, se levante \\ $\mathrm{Na}$ arribação deste boi \\ Se aproxime dos apelos \\ E chamamento \\ Do canto do boiadeiro, oi. \\ (...) \\ No desespero do mundo \\ Acorda, meu Coração \\ Levanta, boi Valoroso \\ Levanta, meu boi Desordem \\ Pra viver o teu destino \\ De martírio ou salvação \\ Ecô $^{63}$
}

O predomínio da pecuária pode ser visto em todas as capitanias que estruturaram o Nordeste colonial, se assim podemos o classificar. No Piauí o principal rendimento da Fazenda Real (...) consiste nos dízimos dos gados vacuns e cavallares, genero cujo consumo sendo dependente da indigência em que delles estavão as Capitanias circunvezinhas (... $)^{64}$. A situação do Ceará foi semelhante, como expôs o Conselho Ultramarino: neste país tão vasto, estando hoje povoado porque só na Robeira do Jogoaribi estão mais de tresentas rossas e currais (...) e tanta gente q' cada ves se vay augmentando mais em razão do grande lucro que tirão dos muitos bois e cavallos que crião e mandão para as Minnas (... $)^{65}$. Na Paraíba, o

\footnotetext{
${ }^{59}$ SANTOS FILHO, Lycurgo. Uma comunidade rural do Brasil antigo (aspectos da vida patriarcal no sertão da Bahia nos séculos XVIII e XIX). São Paulo, Companhia Editora Nacional, 1956. p. 208.

${ }^{60}$ SANTOS FILHO, Lycurgo. Uma comunidade rural do Brasil antigo...Opus cit., p. 218.

${ }^{61}$ SANTOS FILHO, Lycurgo. Uma comunidade rural do Brasil antigo...Opus cit., p. 218.

${ }^{62}$ NICÉAS, Alcides. Aboio: um ritual agreste. Recife, Fundaj - Centro de Estudos Folclóricos, 1979. (Folclore, $\left.n^{\circ} 93\right)$.

${ }^{63}$ Estrofes da canção Aboio de Gilberto Gil.

${ }^{64}$ PROJETO RESGATE. AHU_ACL_CU_016, Cx. 11, D. 633.

${ }^{65}$ PROJETO RESGATE. AHU_ACL_CU_CEARÁ, Cx. 01, D. 67.
} 
capitão - mor, João da Maia da Gama, em carta a Dom João V, observou que hacha-se os Certoens desta Capitania muy povoadas de gente, fazendas e gado (... $)^{66}$. Os bens dos sertanejos potiguares foram identificados pelos edis da câmara de Natal como sendo gado vacuns $q$ ' se crião nestes Sertoens $(. . .)^{67}$. Referindo-se à freguesia de Bezerros, sertão pernambucano, o relatório do governador Jozé Cezar de Menezes, datado de 1774, descreveu que a população da paróquia vive de crear gados, outros de alguma lavoura que plantão nos brejos, e de curtir couros e sollas; a conduta (sic.) destes gados he para a cidade da Bahia, onde fica mais proximo ${ }^{68}$.

No termo da vila de Penedo - AL, Luís Vilhena informou, em 1802, ao príncipe regente Dom João VI: o trafico principal do Penedo são gados, de que no seo districto ha de duzentas e cincoenta, a trezentas fazendas, entre grande e pequenas (... $)^{69}$. Para Salvador, vinham manadas da vila da Jacobina, capitania da Bahia, pois abundão os dittos sertões de gado, cujas estradas livres de gentio e beneficiados podem fazer hum extenso commercio com a comarca e com a capital, sendo aquella tão desprovida de gado (... $)^{70}$.

Toponímia apropriada para as áreas criatórias encontramos no interior do Maranhão, em Pastos Bons. Distintamente das outras partes do hinterland nordestino, Pastos Bons, território localizado ao sul da capitania, possuía boas pastagens e água dos rios perenes ${ }^{71}$. Acerca deste lugar, o major Francisco de Paula Ribeiro comentou:

A natureza de uns e de outros terrenos, excessivamente prodiga na sua vegetação, é que talvez adquiriu para todo este districto o nome de Pastos Bons! Os seus campos nutridores, o seu ar commodo, preciosas águas, grande fertilidade seguida ao mais pequeno cultivo e a sua nunca interrompida verdura, são circumstancias que fazem com que este paiz seja o mais abundante e delicioso: por isso mesmo é que elle chama dos sertões das outras capitanias confinantes os negociantes de gados, que d'alli transportam

\footnotetext{
${ }^{66}$ PROJETO RESGATE. AHU_ACL_CU_014, Cx. 4, D. 310.

${ }^{67}$ PROJETO RESGATE. AHU_ACL_CU_018, Cx. 2, D. 140.

68 "Idéia da População da Capitania de Pernambuco, e das annexas, extenção de suas Costas, Rios, e Povoações notáveis, Agricultura, numero dos Engenhos, Contractos, e Rendimentos Reaes, augmento que estes tem tido $\& . \&$ desde o anno de 1774 em que tomou posse do Governo das mesmas Capitanias o Governador e Capitam Jozé Cezar de Menezes". in Annaes da Bibliotheca Nacional do Rio de Janeiro. Volume XL. Ano 1918. Rio de Janeiro, 1923. p. 38.

${ }^{69}$ VILHENA, Luís dos Santos. Recopilação de noticias referentes às Capitanias de Pernambuco e Goiás, e do pensamento político aplicados nas colônias portuguesas. Salvador, 1802. p. 10. Manuscrito disponível em http://bn.br. Acesso em 01. 11. 2011.

${ }_{70}$ ANNAES da Bibliotheca Nacional do Rio de Janeiro. Vol XXXVI. Ano 1914. Rio de Janeiro, Officinas Graphicas da Biblioteca Nacional, 1916. p. 112.

${ }^{71}$ CABRAL, Maria do Socorro Coelho. Os caminhos do gado. São Luís, Siorge, 1992. p. 110.
} 
para manutenção e povoação dos seus infecundos campos a criação das vaccas e novilhas $(\ldots)^{72}$

O gado se revelou essencial ao mercado interno colonial, sem esquecermos de sua participação econômica com o Reino. Observando os velhos documentos da época, notaremos o interesse da fazenda real em receber os dízimos relativos à pecuária sertaneja. Nas capitanias de Pernambuco e Paraíba, o segundo produto que mais pesou na balança das exportações eram os derivados do boi. Em carta aos representantes do Estado e Negócios Ultramarinos, os edis da câmara de Olinda atestaram que os donativos com que aqueles povos servem de presente a Vossa Magestade que seja servido ordenar que se satisfaçam nos gêneros como seja açúcar e sola que são os que servem ao comércio (... $)^{73}$.

Do porto do Recife saíam para Portugal sete ou oito embarcações por ano, carregados de couro e produtos derivados da pecuária ${ }^{74}$. Além do comércio das fábricas de carne, haviam outros muitos com que se faziam grandiosos negócios, como sejam, couro de boi, vaquetas (...) cujos gêneros orçavam em cada ano de 25 a 30.000 couros salgados, 50 a 60.000 meios de sola e vaquetas (...), ${ }^{75}$ realidade do Ceará setecentista. Em Salvador, era muito considerável o commercio que esta Praça tinha com a Capitania do Ceará, e Parnahiba, em carnes salgads, seccas, courama $(. . .)^{76}$.

Domingos Afonso Mafrense, após sua morte, ocorrida em 1711, doou suas 35 fazendas de gado, localizadas na capitania do Piauí, para os padres da Companhia de Jesus, sendo administradas pelos inacianos do colégio de Salvador. Com a expulsão dos jesuítas, em 1759, as fazendas foram seqüestradas e passaram a ser comandadas por representantes da Coroa, sendo chamadas, desde então, como as fazendas do Real Fisco. As herdades reais, em 1757, abrigavam em seus currais um total de 32.000 cabeças de gado vacum. ${ }^{77}$ No Mappa de Todas as Boiadas que tem sahido das Fazendas de Gado do Real Fisco desta Capitania desde

\footnotetext{
${ }^{72}$ RIBEIRO, Francisco de Paulo, major. "Descripção do Território de Pastos Bons, nos sertões do Maranhão: propriedades dos seus terrenos, suas producções, caracter dos seus habitantes colonos, e estado actual dos seus estabelecimentos". In Revista do Instituto Histórico e Geográfico Brasileiro. Tomo XII. Rio de Janeiro, IHGB, 1849. p. 44.

${ }^{73}$ GOULART, Alípio José. Brasil do boi e do couro. Vol 2 (O couro). Rio de Janeiro, Edições GRD, 1966. p. 25

${ }^{74}$ VILHENA, Luís dos Santos. Recopilação de noticias referentes às Capitanias...Opus cit., p. 26.

Para Lisboa e Porto, saíam do Recife assucares, melaço, solla vermelha e branca, atanados, couro em cabellos (...) os Gêneros especiaes do Pays para negocio são: Assucar, Gado Vaccum, e Cavallar, Tabaco e madeiras. Ver "informação geral da capitania de Pernambuco, 1749". In Annaes da Bibliotheca Nacional do Rio de Janeiro. Vol XXVIII. Ano 1906. Rio de Janeiro, Officinas Graphicas da Baibliotheca Nacional, 1908. p. 483.

${ }^{75}$ GOULART, Alípio José. Brasil do boi e do couro...Opus cit., p. 24.

${ }^{76}$ VILHENA, Luiz dos Santos. Recopilação de noticias soteropolitanas e brasílicas...Opus cit., p. 342.

${ }^{77}$ LEITE, Serafim. História da Companhia de Jesus no Brasil. Tomo V. Livro III. Rio de Janeiro, Instituto Nacional do Livro, 1945. p.552.
} 
o anno de 1770 té (sic.) 1788 [figura 42] foram arrolados os lucros obtidos com a venda dos bois na capital da capitania da Bahia de Todos os Santos. Pelos índices analisados, a criação de gado mostrou ser uma produtiva transação econômica, durante os dezenove anos venderam 33.532 animais, angariando para os cofres reais um lucro médio de 76:945\$920 réis.

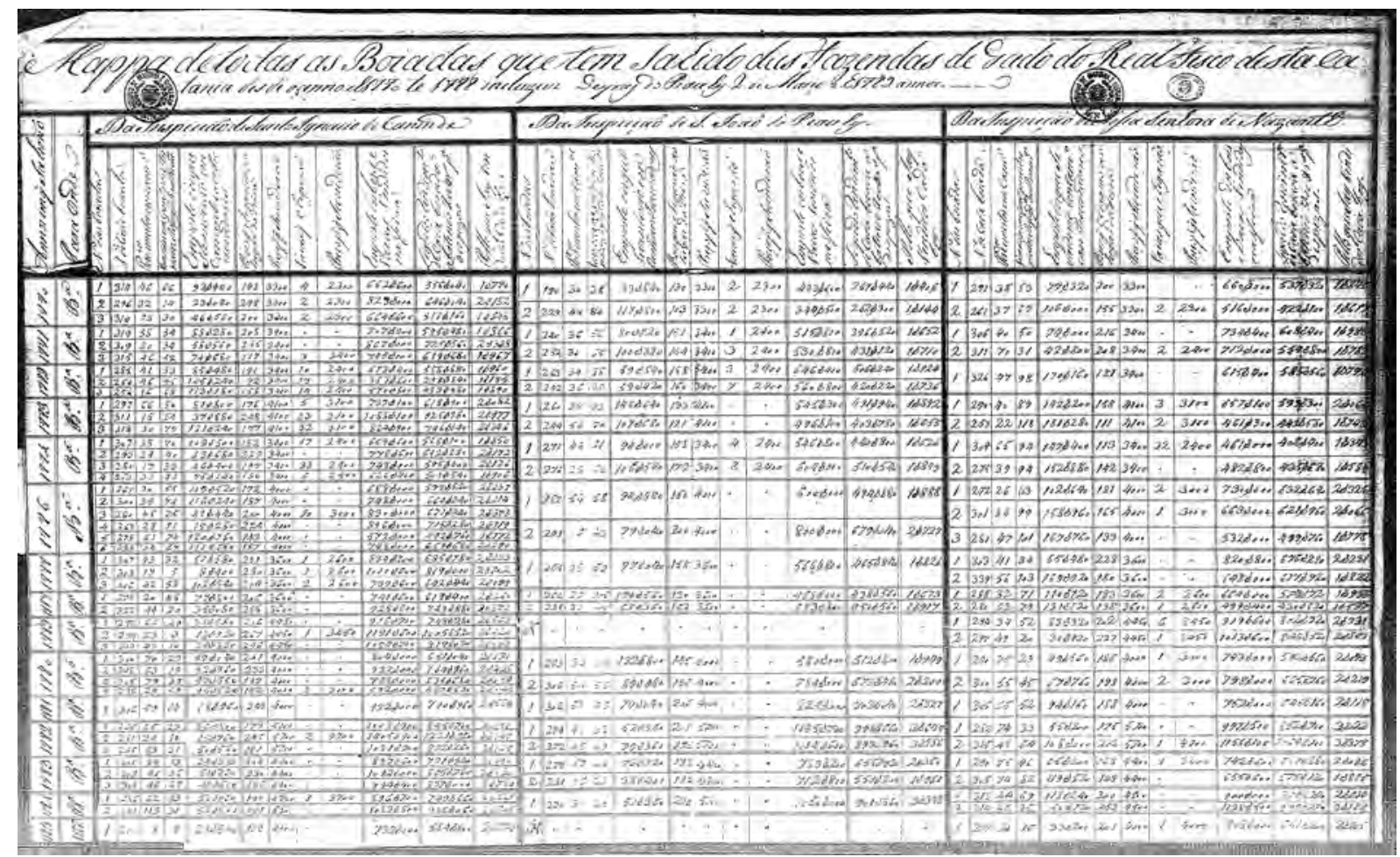

Figura 42 - Mappa de Todas as Boiadas que tem Sahido das Fazendas de Gado do Real Fisco desta Capitania desde o anno de 1770 té 1788. Projeto Resgate: AHU_ACL_CU_016, Cx. 18, D. 904.

Spix e Martius informaram os montantes anuais envolvidos na criação do gado pertencente ao rei em suas trinta e cinco fazendas. Disseram que o preço de um boi custava $5 \$ 400$ réis em 1818; em 1819 a cabeça de gado foi vendida por $8 \$ 400$ réis. Um terço das fazendas do Real Fisco, naqueles anos, venderam 1.100 bois, lucrando para o cofre da Coroa 8:000\$000 réis. Já as trinta e cinco herdades, em um ano, venderam 3.000 animais, obtendo a quantia de 18:000\$000 réis. ${ }^{78}$ É importante observar que, tais lucros, poderiam ser maiores se o gado vacum fosse estritamente utilizado para venda, já que boa parte das reses eram abatidas para o consumo dos moradores, trabalhadores e escravos das estâncias.

\footnotetext{
${ }^{78}$ SPIX, J.B Von; MARTIUS, C.P.F. Viagem pelo Brasil. Rio de Janeiro, Imprensa Nacional, 1938. p. 419.
} 
O couro, como produto comercial, não constituiu o único elemento material da cultura sertaneja a gerar lucros para os cofres dos fazendeiros, das câmaras e da Ordem de Cristo. A pecuária desenvolveu o comércio da carne bovina. Chamada de carne - seca, carne de sol ou carne do sertão os músculos dos animais abatidos passavam por um processo de salga, em seguida eram postos em varais de madeira [figura 43] localizados nos terreiros das fazendas. Ali recebiam ventilação adequada e luz solar para a sua desidratação, este processo servia (como serve até hoje em alguns lugares) para a conservação da carne. Na fazenda Brejo do Campo Seco, situada no sertão do rio de Contas, capitania da Bahia, a carne do sertão foi vendida, entre 1795 e 1816, por 40, 50, 60 e 80 réis $^{79}$. Em Salvador, segundo Vilhena, a classe mais pobres dos moradores compravam a carne de sol para sua família, e os ricos para os escravos, visto que hé mais barata que a fresca $(. . .)^{80}$.

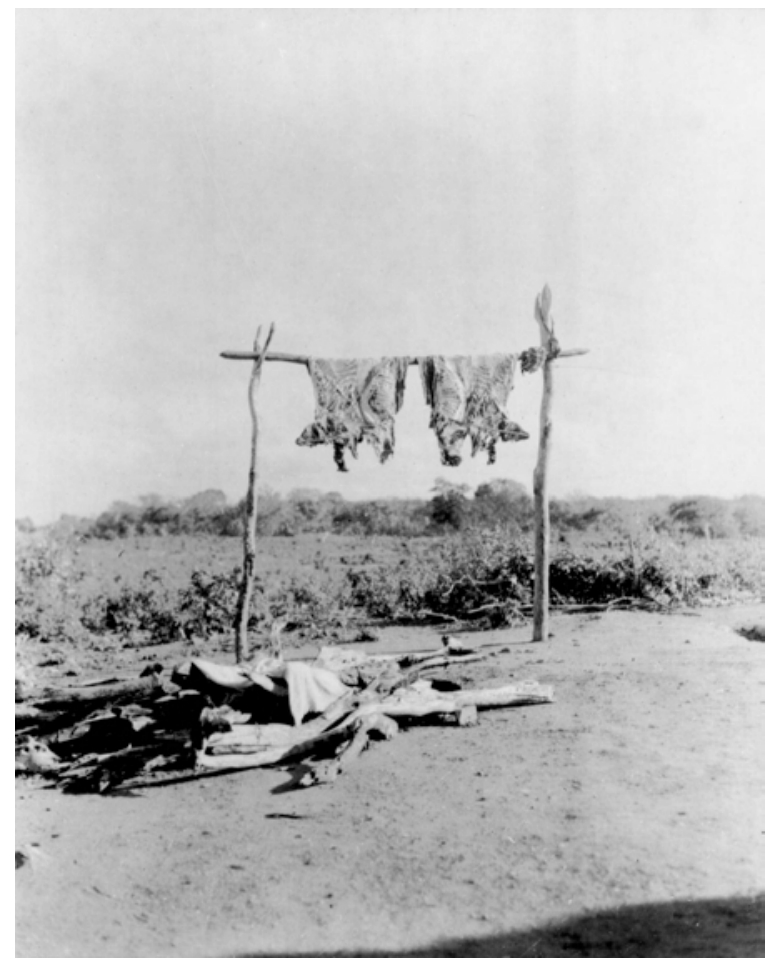

Figura 43 - Produção da carne seca, carne de sol ou carne do sertão. Disponível em http://www.ibge.gov.br. Acesso em 18/09/2010.

Há indicação, em alguns núcleos do sertão nordestino, da existência de açougues que serviram para o abate das reses e extração da carne vendida localmente. Oeiras (PI), Parnaguá (PI), Jacobina (BA) e Icó (CE) são alguns dos aglomerados que detiveram esse tipo de estabelecimento em seu perímetro urbano. Na capital da capitania de São José do Piaú, Oeiras, existiram dois: um localizado próximo ao riacho do Mocha, o outro, de menor porte, se instalou nos arrabaldes da igreja Nossa Senhora da Conceição [figura 44]. O senado de Mocha solicitou à Metrópole que os rendimentos do açougue da vila, isto é, 240 réis por

\footnotetext{
${ }^{79}$ SANTOS FILHO, Lycurgo. Uma comunidade rural do Brasil antigo...Opus cit., p. 236.

${ }^{80}$ VILHENA, Luiz dos Santos. Recopilação de noticias soteropolitanas e brasílicas...Opus cit., p. 83.
} 
cabeça de gado abatida, fosse incorporado ao cofre da câmara, visto que estavam anexados à fazenda real ${ }^{81}$.

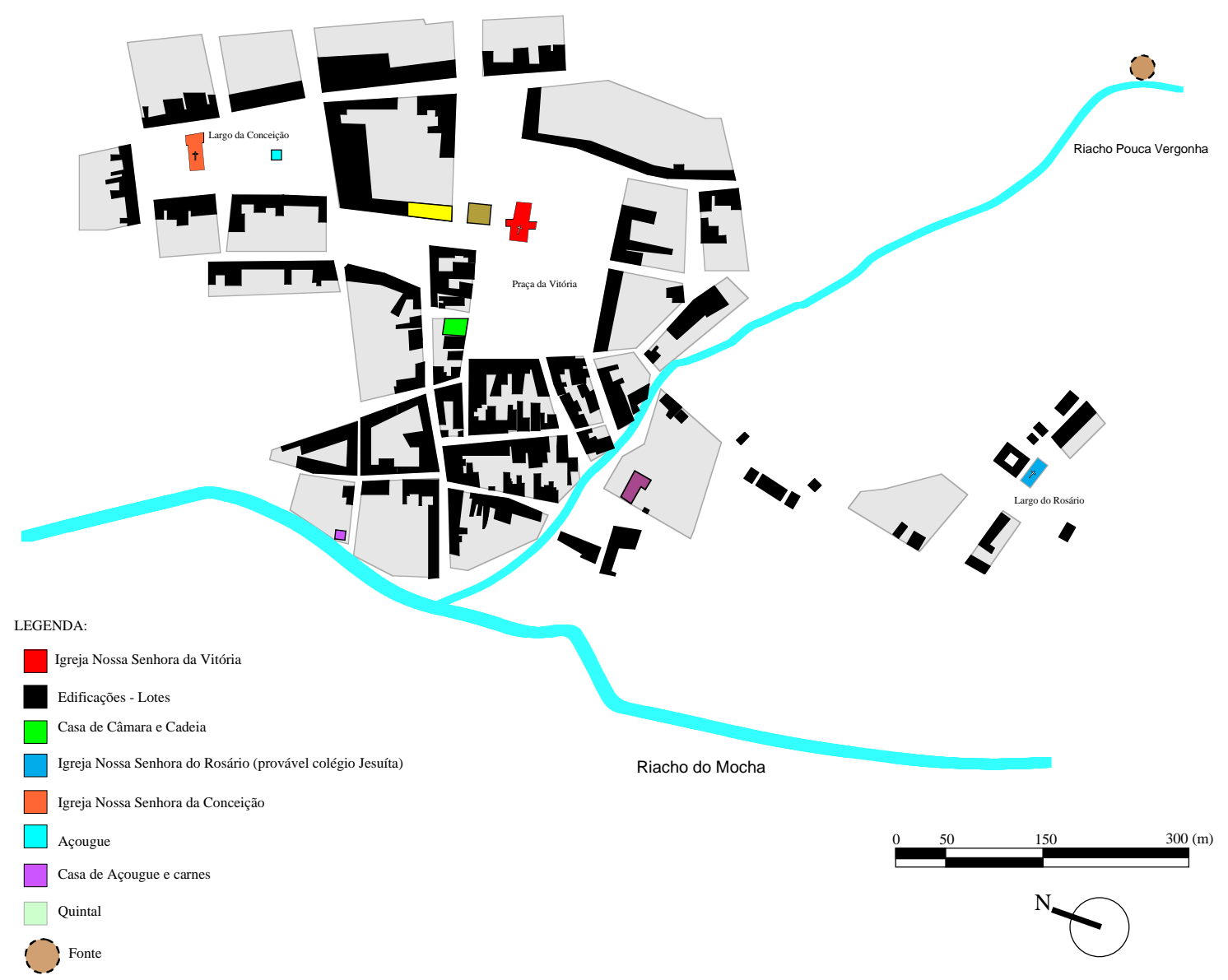

Figura 44 - Planta da cidade de Oeiras. Desenho do autor sobre mapa elaborado por José Pedro Cezar de Menezes, sob ordens do governador Carlos Cezar Burlamaque, 1809. Original do AHEx_RJ.

O capital de giro de algumas câmaras sertanejas se concentrou nos açougues, contudo, de poucos montantes para auxiliar a expansão urbana ou melhoria de seus espaços públicos. Em comunicação com o secretário de estado da Marinha e Ultramar, D. Rodrigo de Sousa Coutinho, o governador da capitania do Piauí, D. João de Amorim Pereira, em 1798, descreveu a situação econômica das casas de câmera dos núcleos urbanos, (...) as Câmeras nam tem quaze nenhuma outra renda do que o pequeno tributo [grifo nosso] das poucas carnes que se matão nos açougues, que he insignificante, porque além de terem pouca gente as Villas, o que tem gado se o mata para a sua família, por cujo motivo quaze nada se rende $(\ldots)^{82}$. Na vila do Icó (CE), os oficiais do senado, em vereação de 07 de abril de 1747, resolveram estabelecer um tributo à população do município e seu termo, em razão do estado de indigência da câmara. $\mathrm{O}$ imposto foi estipulado para cada fazenda uma cabeça de gado por

\footnotetext{
${ }^{81}$ PROJETO RESGATE. AHU_ACL_CU_016, Cx.1, D. 35.

${ }^{82}$ PROJETO RESGATE. AHU_ACL_CU_016, Cx.1, D. 35.
} 
cem que possuise ou duas por quinhentos ${ }^{83}$. O povo reagiu diante do novo ônus, allegando o estado de pobreza do paiz, onde os fazendeiros estão sempre a principiar a vida por causa das seccas freqüentes, da pouca fertilidade do solo e da baixa consideraval que tem soffrido os gêneros do paiz, gados e cavallos (...). ${ }^{84}$

O comércio da carne movimentou fazendeiros a abastecer as cidades de Olinda, Recife, Salvador, São Luiz, Rio de Janeiro e os arraiais mineiros. As já citadas fazendas do Real Fisco munia de carne, principalmente, a cidade de Salvador, por isso, o governador do Maranhão remeteu um pedido, em 1785, ao ministro da Marinha e Ultramar, solicitando que as boiadas se deslocassem para São Luiz, por dois motivos: o primeiro dizia respeito à subordinação da capitania do Piauí, naqueles tempos, à do Maranhão e, segundo, por padecer a urbe maranhense...

(...) de huã falta continuada de gados para subsistencia de seus moradores e desejando eu procurar lhes os meyos de gozarem da abundacia sobretudo hum genero de primeira necessidade de vida, como são as carnes frescas (...). Para fornecerem a esta Capital, me pareceo justo por não chegarem os senhores das fazendas e mais criadores de gado a mudarem o commercio, que neste genero tem com a Capitania da Bahia, Pernambuco para onde mandão os seus gados (...). Ordeno Vossa Mercê passar ordens competentes para que todas as Boyadas q' são do Fisco, sejão remetidas para esta do Maranhão $(. . .)^{85}$

Outros pontos comerciais, localizados especialmente na costa atlântica ou próximo desta, forneceram carne para venda e consumo nos principais centros coloniais. Referimo-nos às oficinas de carne - seca ou charqueadas. Atuaram como feitorias em prol da economia da carne e do couro. As oficinas de carne, toscos edifícios em sua essência, tornaram-se pontos quentes no processo de urbanização, por estreitarem a relação interior x litoral. $\mathrm{O}$ gado que antes rumava para o litoral baiano ou pernambucano, foi deslocado para outros portos de menor porte, como os de Parnaíba e Aracati. As charqueadas chegaram a ser referência para a localização e instalação de uma nova vila piauiense, São João da Parnaíba. Fomentaram o desenvolvimento urbano da vila do Aracati (CE). No Maranhão, o seu negócio se concentrou

\footnotetext{
83 "EXTRACTOS dos assentos do antigo senado de Icó, desde 1738 até 1835. Colligido nos archivos de Icó, Aracaty, Fortaleza, etc. pelo Dr. Theberge". In Revista do Instituto Histórico e Geográfico Brasileiro. Tomo XXV. Rio de Janeiro, IHGB, 1862. p. 66.

${ }^{84}$ EXTRACTOS dos assentos do antigo senado de Icó, desde 1738 até 1835...Opus cit., p. 66.

${ }^{85}$ PROJETO RESGATE. AHU_ACL_CU_016, Cx. 14, D. 816.
} 
na mão quatro homens. Em terras potiguares, causaram uma baixa econômica de duas povoações: Mossoró e Açú.

Sendo um negócio tipicamente sertanejo, a pecuária lá desenvolvida impossibilitou a concorrência dos rebanhos oriundos das áreas litorâneas. Os charqueadores, já na primeira metade do século XVIII, exportavam o gado abatido em embarcações denominadas sumacas. A fixação das oficinas de carne - seca nos arredores dos portos e, às vezes, ao longo dos rios, permitiu a comercialização direta, por mar, com os centros de consumo, sem precisar esperar meses pelos bois oriundos do sertão. Cambia-se o rumo das boiadas, ao invés de se deslocarem para as feiras pernambucanas e baianas, elas também eram destinadas às fozes dos rios Jaguaribe, Acaraú, Parnaíba, Mossoró e Açứ ${ }^{86}$. O litoral e o sertão interpenetravam-se comercialmente e os laços administrativos entre as duas zonas tornavam-se mais significativos. $^{87}$

Renato Braga opinou que a feição hidrográfica do rio Paranaíba, cuja navegabilidade se condiciona à maré montante, permitiu a penetração de oficinas de carne-seca rio acima ${ }^{88}$. Assim fez, em 1770, o fazendeiro e negociante da vila de São João da Parnaíba, João Paulo Diniz, que ergueu uma charqueada a oitenta léguas da foz do rio Parnaíba, no epicentro da área criatória ${ }^{89}$. Segundo um viajante anônimo, o seu gado era transformado em carne e conduzido em barcas, pelo rio Parnaíba, até o Porto das Barcas; do porto da vila, as embarcações carregadas de carne eram remetidas às principais províncias do Brasil. ${ }^{90}$

A produção da carne nas oficinas piauienses era de grande utilidade para a Capitania $^{91}$, porque era habitual abater 12.000 reses por ano, segundo as informações do primeiro governador João Pereira Caldas. A mesma autoridade, em carta dirigida a D. Fernando da Costa Ataíde, mencionou as vantagens da existência das oficinas no litoral. Entre essas, estão incluídas a carência e precariedade das estradas, por onde as reses eram conduzidas aos portos; as longas distâncias a serem vencidas e as condições climáticas que, em tempos de seca, reduzia a um oitavo as boiadas tangidas. No litoral, os animais

\footnotetext{
${ }^{86}$ GIRÃO, Valdelice Carneiro . “As charqueadas”. In Revista do Instituto do Ceará. Tomo CX. Fortaleza, 1996. p. $71-92$

${ }^{87}$ GIRÃO, Valdelice Carneiro . "As charqueadas”...Opus cit., 74.

${ }^{88}$ BRAGA, Renato. "Um capítulo esquecido da economia pastoril do Nordeste". In Revista do Instituto do Ceará. Tomo LXI. Fortaleza, Ed. do Instituto do Ceará, 1947. p. 149 - 162.

89 “ROTEIRO do Maranhão a Goiaz pela Capitania do Piahui”...Opus cit., p. 64.

90 “ROTEIRO do Maranhão a Goiaz pela Capitania do Piahui”....Opus cit., p. 64.

${ }^{91}$ PROJETO RESGATE. AHU_ACL_CU_016_Cx. 11, D. 642.
} 
encaminhados ao porto da Parnaíba não tinham perda e com grandíssima facilidade reputando se alli cada boi de dois mil réis até dois mil e duzentos de modo ordinário. ${ }^{92}$

No Rio Grande do Norte, região rica em ribeiros salinos, abundância dos ventos e presença dos maiores currais da capitania, foi um dos centos produtores de carne-seca para exportação. Anualmente, atracavam em seus litoral de três a quatro embarcações que enchiam os seus porões de material derivado do boi ${ }^{93}$. Nessas circunstâncias, a vila do Açú e a povoação de Mossoró cresceram economicamente, provocando séria crise de abastecimento de carne à população do Recife e faixa canavieira, supridas pelos gados do sertão potiguar. ${ }^{94}$

Ao ver a alimentação dos pernambucanos prejudicada, o governo da capitania tomou rígidas resoluções contra as oficinas de carne - seca das ribeiras do Mossoró e Açú. Uma delas acarretou no fechamento ou extinção dos estabelecimentos, transferindo o monopólio da carne do sertão para os portos de Aracati e Paraníba, contudo, esses lugares receberam maior fiscalização e controle dos negócios ${ }^{95}$.

Aracati, chamada por Renato Braga, de "empório da carne-seca", manteve por mais de meio século a privilegiada situação de maior exportador de produtos pecuários, tanto vindos do interior, como daqueles originados no litoral ${ }^{96}$. Quando ainda era uma freguesia, abatia, anualmente, entre 18 e 20.000 bois, e mais de vinte e cinco sumacas freqüentavam o seu ancoradouro, na faina de transportarem a carne e courama para Pernambuco, Bahia e Rio de Janeiro, a troco de fazendas, ferragens e quinquilarias. ${ }^{97}$ Quando alcançou o status de vila, a produção aumentou, chegando a sacrificar 25.000 bois. Importava mais de seiscentos mil cruzados e as exportações caminhavam perto do dobro, vindas sempre da carne e do couro. Cerca de dois mil carros de bois asseguravam as comunicações desse empório com o interior cearense. $^{98}$

Em 1761, o missionário capuchinho, frei Aníbal de Gênova, em sua missão volante, visitou o porto do Aracati. Testemunhou o intenso mercado de carne do sertão nas oficinas daquela vila: (...) lugar de muito comércio. Consistia a sua principal riqueza na criação,

\footnotetext{
${ }^{92}$ SANTANA, Mario Pires. "De Nossa Senhora do Monserrath”. In Paranaíba de A a Z: guia afetivo. José de Nicodemos Alves Ramos. (org.). Brasília, Multicultural Arte e Comunicação, 2008. p. 96.

${ }^{93}$ GOULART, Alípio José. Brasil do boi e do couro...Opus cit., p. 25.

${ }^{94}$ GIRÃO, Valdelice Carneiro . "As charqueadas”...Opus cit., p. 86.

${ }^{95}$ GIRÃO, Valdelice Carneiro . "As charqueadas”...Opus cit., p. 87.

${ }^{96}$ BRAGA, Renato. “Um capítulo esquecido da economia pastoril do Nordeste”...Opus cit., p. 152.

${ }^{97}$ BRAGA, Renato. "Um capítulo esquecido da economia pastoril do Nordeste”...Opus cit., p. 152.

${ }^{98}$ BRAGA, Renato. "Um capítulo esquecido da economia pastoril do Nordeste”...Opus cit., p. 153 - 154.
} 
embarcando anualmente grandes boiadas para Pernambuco. Via-se também freqüentado por numerosos marchantes baianos (... $)^{99}$. Analisando o relato do religioso, percebemos que o "empório da carne seca" do Ceará mobilizou e supriu outros mercados da colônia e da América. Como ele mesmo indicou, eram fornecidas carnes para a cidade argentina de Buenos Aires ${ }^{100}$. Com a queda da pecuária em fins dos Setecentos, Aracati sofreu baixas em sua produtividade: grandes quantidades de carne seca se preparava aqui, em tempos idos, para a exportação a outras partes do Brasil, mas este comércio tem declinado grandemente $(\ldots)^{101}$.

Os fatos acima indicam certas facilidades comerciais promovidas pela pecuária ao sertão nordestino, no entanto, alguns entraves continuaram a lesar a região, dificultando o seu desenvolvimento territorial, urbano e econômico. As longas distâncias dos portos e feiras, carência de água e perigo de roubo dos animais foram os fatores que diminuíram o preço das manadas, levando, em alguns casos, ao prejuízo. Quando abordado sobre as dificuldades encontradas na gestão da capitania do Piauí, principalmente àquelas que afetaram diretamente os cofres reais, o governador João Gonçalo Lourenço informou sobre a venda do gado criado naquelas paragens:

(...) vendose pela falta de compradores postos os habitantes desta Capitania na precizão de os hirem vender fora della com mais de a metade de diminuição no preço, com que antigamente os reputavão e sujeitando se não só aos prejuízos que experimentavão conduzindo-os por longos caminhos áridos, escabrosos e faltos em certas estaçõens, e lugares de pastos, e agoa necessária para a conservação dos mesmos gêneros; mas tambem os virem muitas vezes obrigados a fazer delles venda a pessoas extranhas pouco seguras, e que totalmente os faltão com os pagamentos ou os retardão com irreparavel perda de tempo, que he necessário aos vendedores para voltarem a cuidar no augmento das creaçõens dos referidos gados $(. . .)^{102}$

Danos comerciais ocorriam nos costumeiros roubos realizados por índios "não civilizados", vadios ou escravos enviados por fazendeiros concorrentes. Para conter os furtos, o remédio seria:

\footnotetext{
${ }^{99}$ PRIMERIO, P.Fr. Fidelis M. de. Capuchinhos em Terras de Santa Cruz nos séculos XVII, XVIII e XIX. São Paulo, Livraria Martins, 1942. p. 191.

${ }^{100}$ PRIMERIO, P.Fr. Fidelis M. de. Capuchinhos em Terras de Santa...Opus cit., p. 191.

${ }^{101}$ GARDNER, George. Viagem ao interior do Brasil. São Paulo, Edusp, 1975. p. 81.

102 PROJETO RESGATE. AHU_ACL_CU_016, Cx.11, D. 663.
} 
(...) para se evitar os furtos dos gados he perguntarsse pelos ouvidores daquella Capitania (Piauí) na devaça geral se nas boyadas são levados gados alheyos sem o devido consentimento de seos domnos e dos espantos que se lhes fas no caminho, porque atravessão Pernambuco, Bahia e Minas em q' os affugentão para depois appanharem encarregando-se adquirir delles espantos não so aos Ouvidores Gerais, mas muito especialmente aos Juízes Ordinários de Rodellas e Jacobina, e lhe passe a elle Procurador se lhes passe esta Ordem Geral, tãobem para os Ouvidores das Minas para pronunciarem os culpados, castigando-os com as pennas impostas por direito aos q' affugentão os gados, e depois os appanhão para vender $(. . .)^{103}$

Situação constrangedora vivenciou o fazendeiro dos sertões de Parnaguá (capitania do Piauí), Manuel Ferreira Leite, ao conduzir suas 450 cabeças de gado para venda na cidade de Salvador. Durante a travessia no rio São Francisco, em um lugar chamado Passagem do Juazeiro $^{104}$, foi obrigado a pagar ao coronel Lourenço de Barros Lima e ao escrivão, João Moreyra da Costa, dois tostões por animal, embolsando do criador um total de 90 mil réis. No mesmo rio São Francisco, só que desta vez na freguesia da Barra do Rio Grande, os animais do fazendeiro e coronel, Antônio Álvares da Silva, vindos dos sertões dos Pastos Bons (MA) eram conduzidos a Salvador, atravessando o rio na passagem daquele lugar. Um oficial, denominado "executor das fintas", obrigou os tangedores do fazendeiro pagar 120 réis pela boiada mais cinco bois ao governo de Pernambuco. Sentido-se lesado pelos impostos infundados, pois inexistiam tributações ao longo dos caminhos e nas fronteiras das capitanias limítrofes às suas terras, o criador de gado solicitou ao governo geral reembolso dos seus gastos e que tais fintas fossem consideradas vexatórias ao bem público. ${ }^{105}$

Estes exemplos mostram a corrupção, usurpação de poder e falta no cumprimento das leis em lugares periféricos. Realidade, infelizmente, comum no Brasil colonial. Buscando fiscalizar o comércio e evitar o contrabando, a Metrópole adotou, principalmente na era pombalina, um sistema de monopólio comercial mais amplo. O projeto tratou de favorecer companhias mercantis, reservando a certos grupos o direito de realizar o comércio externo da colônia $^{106}$. É por esses fins que surgiu a Companhia Geral de Comércio de Pernambuco e Paraíba em 1759. Para Caio Prado Jr., a política de restrição econômica procurou impedir a

\footnotetext{
${ }^{103}$ PROJETO RESGATE. AHU_ACL_CU_016, Cx. 1, D. 68.

${ }^{104}$ A atual localização desta passagem situa-se entre as cidades de Juazeiro, na Bahia, e Petrolina, lado esquerdo do rio São Francisco, município do estado de Pernambuco.

${ }^{105}$ COLEÇÃO ALBERTO LAMEGO. IEB/USP - COL.ML, 50.5.

${ }^{106}$ PRADO JR., Caio. História econômica do Brasil...Opus cit., p. 53.
} 
produção de qualquer gênero que não interessasse diretamente à Metrópole e seu comércio, ou que fizesse concorrência à sua produção nacional ${ }^{107}$.

Segundo José Ribeiro Júnior, a Companhia foi instituída através do encaminhamento à Coroa de um anteprojeto elaborado por "homens de negócios" de Lisboa, Porto e Pernambuco $^{108}$. No que tange o sertão da capitania de Pernambuco, o governador Luís Diogo Lobo da Silva, em conjunto com os negociantes, pretendeu incrementar a produção do couro e carne distribuindo-os em toda a colônia, desejavam dilatar o mercado interno da pecuária ${ }^{109}$.

$\mathrm{Na}$ opinião dos fazendeiros, oficiais das câmaras pernambucanas e paraibanas em associação com os demais moradores, a Companhia Geral explorou os preços, prejudicando os curraleiros e produtores da carne seca e courama. Por exemplo, sobre a sola, os edis em carta à rainha D. Maria I expuseram:

Queixam-se os representantes dos prejuízos que lhes causa a Companhia no gênero da sola, dizendo que antes da Companhia se contavam naquela praça 20 cortumes, que fabricavam mais de 70.000 meios de sola; que antes da Companhia se vendia cada meio da vermelha pelo preço de $1 \$ 400$ réis e $1 \$ 600$ réis; e da branca do sertão de $\$ 640$ a $\$ 800$ réis, uns e outros a dinheiro liquido; e que a Companhia como árbitra de tudo, lhes põem os preços que lhes parece; e lhes paga a sola vermelha de cabeça de $1 \$ 100$ a $1 \$ 300$ o meio; e de sola branca de $\$ 320$ até $\$ 640$ réis; no que experimentam uma grande perda. ${ }^{110}$

A pecuária nordestina mudou de contexto ao findar o século XVIII e início dos Oitocentos. O primeiro motivo dizia respeito às secas apelidadas de três setes (1777-1778 e 1790-1793) responsável pela redução de 12,5\% do gado criado na região sertaneja. O segundo justifica-se pela ascensão, ante o mercado nacional e, depois, internacional, das charqueadas do sul, cuja fórmula de produção da carne, segundo Valdelice Girão, foi emigrada do Ceará com seus especialistas ${ }^{111}$. Luís Vilhena presenciou esse cambio de pólo:

\footnotetext{
${ }^{107}$ PRADO JR., Caio. História econômica do Brasil...Opus cit., p. 54.

${ }^{108}$ RIBEIRO Jr., José. Colonização e monopólio no Nordeste brasileiro: a Companhia Geral de Pernambuco e Paraíba, 1759 - 1780. São Paulo, Hucitec/Edusp, 2004. p. 81.

${ }^{109}$ RIBEIRO Jr., José. Colonização e monopólio no Nordeste brasileiro: a Companhia Geral...Opus cit., p. 80.

${ }^{110}$ GOULART, Alípio José. Brasil do boi e do couro...Opus cit., p. 30.

${ }^{111}$ GIRÃO, Valdelice Carneiro. Opus cit., p. 160.
} 
Era muito considerável o commercio que esta Praça tinha com a Capitania do Ceará, e Parnahiba, em carnes salgadas, seccas, courama e algum algodão, este porém se transferio para o Rio Grande de S. Pedro do Sul, depois que as secas extremosas consumirão todos os gados naquellas paragens; de forma que por acaso apparece hoje na Bahia alguma pequena embarcação do Ceará, ou Parnahiba, com carne e couros; visto que em Pernambuco achão prompta sahida a todos os seus gêneros e effeitos. ${ }^{112}$

O decréscimo econômico pode ser visto na ocupação dos habitantes da capitania da Paraíba do Norte em 1798, quando são elencados apenas 174 criadores de gado. ${ }^{113}$ Diminuição da exportação ocorreu nos sertões dos Pastos Bons (MA). Segundo o relatório do major Francisco de Paula Ribeiro, de 1815, a freguesia de São Bento dos Pastos Bons atrofiou sua negociação com a Bahia e São Luiz pela alta dos preços e pouca compra dos animais. ${ }^{114}$

Apesar da crise sofrida pela pecuária sertaneja, a economia mobilizou os funcionário da coroa, fazendeiros, roceiros, vaqueiros, tangedores e escravos. Fez conhecido o sertão nordestino que, dantes, era classificado apenas como incomunicável, cheio de índios bravios, dotado de caminhos áridos e escabrosos; lugar de vadios e facinorosos de todas as espécies. Preconceitos e julgamentos à parte, a criação de gado vacum deu uma nova dimensão ao Nordeste brasileiro e, porque não dizer, do Brasil colonial, pois, por intermédio dela, foram ligados o sul e o norte, o litoral e o interior.

\footnotetext{
${ }^{112}$ VILHENA, Luiz dos Santos. Recopilação de noticias soteropolitanas e brasílicas...Opus cit., p. 342. 113 PROJETO RESGATE. AHU_ACL_CU_014, Cx. 14, D. 2510.

114 RIBEIRO, Francisco de Paulo, major. "Descripção do Território de Pastos Bons, nos sertões do Maranhão...Opus cit., p. 52.
} 


\subsection{1 - As feiras sertanejas e sua posição na urbanização do sertão nordestino}

Quando a comunicação era difícil e perigosa, quando os lugares nos quais se podiam encontrar artigos europeus ou de primeira necessidade estavam distantes e eram escassos, as feiras rompiam tais barreiras, levando para o isolado e incomunicável a agilidade das trocas, a aproximação do sertão com o litoral, em nosso caso.

Etimologicamente a palavra feira agregou qualidades como a solenidade e festa, sacralidade e mercado. Rapheal Bluteau definiu o verbete atribuindo sua origem aos romanos: feiras se fazião nos dias feriados, ou de festas, poderamos derivar feira do latim Feria ${ }^{115}$. O caráter solene e pio paulatinamente da lugar à práticas profanas, comerciais, mais he provável, que feira derive do latim Fórum, que hera o lugar ou praça destinada para a venda dos mantimentos; humas que erão próprias, \& particularmente de certas cousas, como o fórum Boarium, a feira do boi (... $)^{116}$. A simbiose entre festa e mercado foi uma característica medieval que ultrapassou o atlântico, chegando até nós com a cultura lusitana.

Para Virgínia Rau, quase todas as feiras medievais portuguesas se realizavam em épocas relacionadas com a Igreja, ou seja, as romarias, as peregrinações atraem peregrinos vindos de longe, e como o peregrino, muitas vezes, um mercador, essas reuniões estavam destinadas a transforma-se em centros de troca ${ }^{117}$. Henri Pirenne já dizia que as feiras foram instituídas para servirem de congregação periódica de mercadores profissionais, a fim de os porem em contato com os outros e fazê-los confluir para elas em épocas fixas. Eram pontos de reunião e lugares de troca, unindo a população de distintas direções ${ }^{118}$.

Em vista disso, a feira define uma função econômica às vilas e freguesias. Os núcleos urbanos que a detém se situam no ponto alto da hierárquica rede urbana, delimitam zonas de influência e explicam o porquê da localização dos aglomerados no sistema ${ }^{119}$. E, segundo Jacques Le Goff, as feiras são antes de tudo fenômenos urbanos. Os produtos que ali se trocam são fabricados ou financeiramente controlados. Os atores, os mercadores, são a

\footnotetext{
${ }^{115}$ BLUTEAU, Raphael, S. J. Vocabulário português, e latino...Coimbra, Real Collegio das Artes da Companhia de Jesus, 1712 - 1719. Disponível em http://www.brasiliana.usp.br. Acesso em 24. 11. 2011

${ }^{116}$ BLUTEAU, Raphael, S. J. Vocabulário português, e latino...Opus cit. Disponível em http://www.brasiliana.usp.br. Acesso em 24. 11. 2011

${ }^{117}$ RAU, Virgínia. Estudos da história medieval. Lisboa, Editorial Proença, 1986. p. 21.

${ }^{118}$ PIRENNE, Henri. As cidades da idade média. 4 ed. S.l., Europa-América, 1973. p. 108.

${ }^{119}$ RONCAYOLO, Marcel. "Cidade”. In Enciclopédia Einaudi. Vol VIII (Região). Lisboa, Imprensa Nacional Casa da Moeda, 1984. p. 411.
} 
quintessência da sociedade urbana ${ }^{120}$. Algumas feiras do sertão nordestino, feiras de gado em certos casos, favoreceram o desenvolvimento de arraiais, todavia, não podemos admitir que elas tenham provocado sua gênese. Roberto Simonsen relacionou as principais feiras de gado do Nordeste colonial:

Graças a intensificação do comércio do gado e ao aumento das populações, a partir do século XVIII, foram surgindo várias feiras: de Santana, Curralinho e Condeúba na Bahia, Brejo d’Areia na Paraíba; Itapecurú-mirim no Maranhão (.... $)^{121}$

Em Capuame, distante oito léguas de Salvador, o fazendeiro Francisco Dias d'Ávila, em 1618, organizou a primeira feira de gado no sistema da pecuária que ascendia naqueles tempos para o interior do Nordeste ${ }^{122}$. Como dissemos anteriormente, no início dos Seiscentos o boi era criado junto dos canaviais, ademais, os sertões estavam em fase de conquista e conhecimento territorial. As áreas de criação, ao expandir-se para o hinterland, propiciaram o surgimento de caminhos. A feira de Capuame funcionou como balizador na criação dessas rotas. Dela partiram duas estradas essenciais à pecuária: a conhecida estrada real do gado e a estrada das boiadas.

Expôs Antonil um dos primeiros relatos sobre o mercado do gado empreendido em Capuame. Segundo o jesuíta, chegavam à feira cem, cento e cinqüenta, duzentas cabeças de gado $^{123}$, eram compradas por marchantes para o abate e venda da carne verde e couro. A condução das boiadas para o lugar de comércio realizavam brancos, mulatos e pretos, $e$ também índios, que com este trabalho procuram ter algum lucro. Guiam-se indo uns adiante cantando, para serem desta sorte seguidos do gado, e outros vêm atrás das reses, tangendoas, e tendo o cuidado que não saiam do caminho, nem se amontoem. ${ }^{124} \mathrm{Na}$ feira, os animais eram vendidos por quatro até cinco mil réis. $O$ boi manso por sete para oito mil réis ${ }^{125}$.

As reses criadas nas fazendas do Real Fisco, erguidas na capitania do Piaú, anualmente encaminhavam boiadas das distintas inspeções à Capuame. Por exemplo, em 1772 saíram da Capela Grande 288 animais; Capela Pequena 242 bois; de Nazaré 283 cabeças

\footnotetext{
${ }^{120}$ LE GOFF, Jacques. O apogeu da cidade medieval. São Paulo, Martins Fontes, 1992. p. 72.

${ }^{121}$ SIMONSEN, Roberto C. História econômica do Brasil. 7 ed. São Paulo, Editora Nacional, 1977. p. 178.

${ }^{122}$ MOREIRA, Vicente Deocleciano. "Caminhos históricos da feira de Feira de Santana: origens e secularidade". In Sitientibus. n 10. Jul/dez. Feira de Santana, 1992. p. 186.

${ }^{123}$ ANTONIL, André João. Cultura e opulência do Brasil...Opus cit., p. 97.

${ }^{124}$ ANTONIL, André João. Cultura e opulência do Brasil...Opus cit., p. 97.

${ }^{125}$ ANTONIL, André João. Cultura e opulência do Brasil...Opus cit., p. 97.
} 
de gado; da inspeção do Canindé foram 250 cabeças e em São João 263 animais ${ }^{126}$. Durante as estiagens nenhuã Boyada se pode extrahir daquellas fazendas, para se dispor na Feira de Capuame da Bahia, como era costume, e conforme as ordens de Sua Magestade, porque a extraordinária secca deste inverno, fes impocivel o tranzitarem aquelles pellas travecias $(\ldots)^{127}$.

Quando as manadas aportavam em Capuame, agitadas por vaqueiros e tangedores, em que só área, estrumes, destes são conduzidos para a Cidade sem comerem mais o que andando podem apanhar com a lingoa, por huma so e única estrada freqüentada de Boyadas innumeraveis (... $)^{128}$. A etapa seguinte, compra e venda dos animais em Salvador, foi rigidamente controlada pelos oficiais do senado, conforme a narração de Luis Vilhena:

Chegão finalmente, e ahi são recolhidos no Curral do Concelho, donde só sahem em quartos para os asougues, desde a sexta-feira de huma semana athe a quinta-feira da outra, e neste meyo tempo sahem, he so para beber, e nunca para pastarem, por não haver nesta Cidade hum palmo de baldio $(\ldots)^{129}$

A feira de gado de Capuame declinou no século XVIII quando usaram imensas áreas limítrofes para o cultivo da cana - de - açúcar ${ }^{130}$. Surgiram outros pólos de compra e venda de rebanhos e seus produtos derivados, emergiram as feiras de Santana e Condeúba, na capitania da Bahia, e Itapicurú-Mirim no Maranhão. Vale apontar que, o aglomerado de Santana não nasce por influência direta da feira, mas o seu destaque no sistema urbano da pecuária deveu a tal. Até porque a feira cresce "à sombra" da Igreja. Em 1732, o casal Domingos Barbosa de Araújo e Ana Barbosa doou cem braças em quadra de terra à santa de devoção, Sant'Ana. Construíram a capela e, ao redor dela viajantes, mascates, compradores e vendedores de gado se reuniam para comercializar os produtos em dia pré-estabelecido ${ }^{131}$. A partir dessa congregação de mercadores surgiu a feira de Santana [figura 45]. Esse fenômeno mostra a freqüência de feiras realizadas nos adros das ermidas solitárias e pouco povoadas, o que não significa necessariamente que tivessem origem numa romaria ou outro tipo de ritual

\footnotetext{
${ }^{126}$ PROJETO RESGATE. AHU_ACL_CU_016,Cx. 11, D. 656.

${ }^{127}$ PROJETO RESGATE. AHU_ACL_CU_016, Cx. 12, D. 730.

${ }^{128}$ VILHENA, Luiz dos Santos. Recopilação de noticias soteropolitanas e brasílicas...Opus cit., p. 81.

${ }^{129}$ VILHENA, Luiz dos Santos. Recopilação de noticias soteropolitanas e brasílicas...Opus cit., p. 82.

${ }^{130}$ MOREIRA, Vicente Deocleciano. "Caminhos históricos da feira...Opus cit., p. 187.

131 POPPINO, Rollie E. Feira de Santana. Trad. Arquimedes Pereira Guimarães. Salvador, Ed. Itapuã, 1968. p. 20.
} 
religioso, principalmente, católico. Antes de tudo, ofereceram o intercâmbio mercantil em locais pios, secularizando-os.

No Maranhão, como citou Simonsen, encontramos outro aglomerado beneficiado pelas feiras de gado: Itapicurú - Mirim. Na opinião do major Francisco de Paula Ribeiro, Itapicurú - Mirim foi um lugar de negócio aonde se faz a grande feira dos gado do sertão, e que hoje é villa ${ }^{132}$. Recebia dos sertões de Pastos Bons e de outras partes do Piauí o gado necessário para comercializar ${ }^{133}$. Spix e Martius descreveram o comércio desse núcleo maranhense em seu trajeto de Oeiras (PI) à São Luiz (MA):

Este lugar, antigamente denominado Feira, deve a sua origem ao comércio de gado bovino, pois aqui os sertanejos negociam a venda das boiadas, vindas do Piauí e do interior do Maranhão, em troca de tudo o que precisam. Na maioria das casas, acham-se lojas, onde são expostas à venda grandes quantidades de chitas, artigos de ferro, porcelanas e louças de barro, vinhos, licores e gêneros de Portugal. ${ }^{134}$ [grifo nosso]

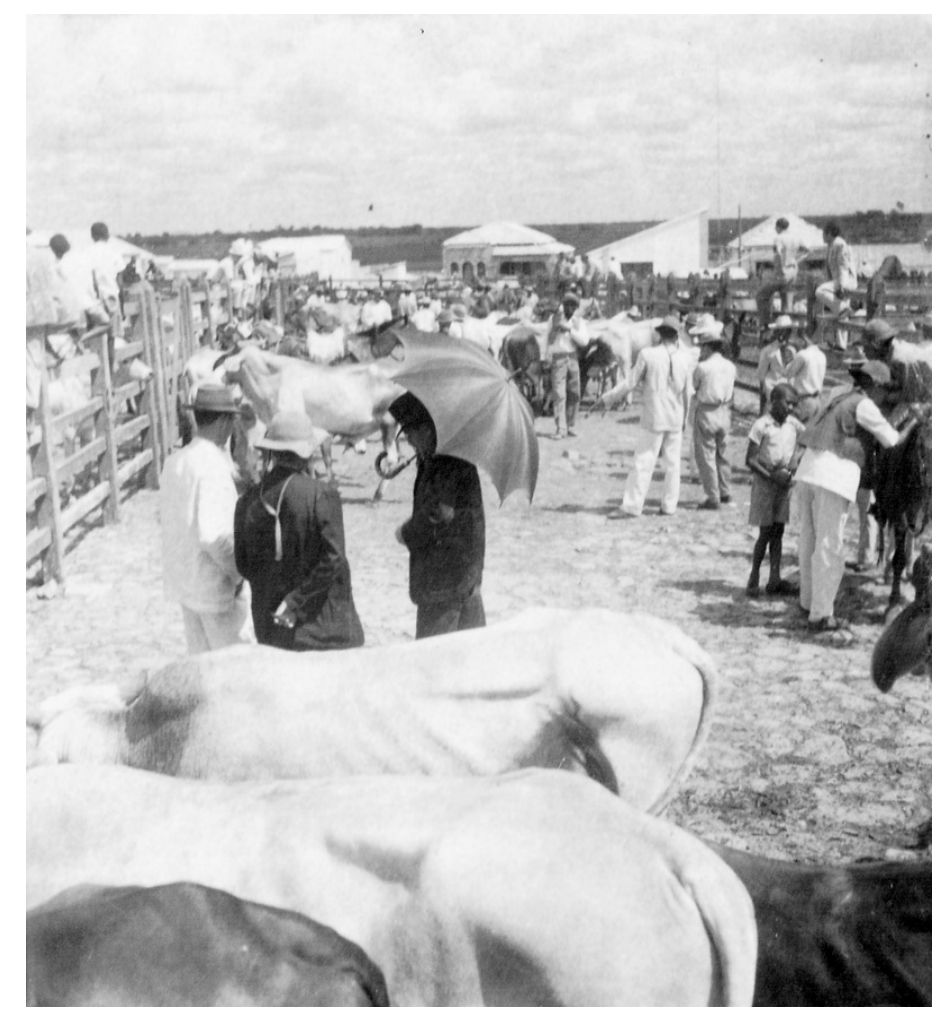

Figura 45 - Feira de gado em Feira de Santana, Bahia. Imagem disponível em http://www.ibge.gov.br. Acesso em 30.09.2011.

\footnotetext{
${ }^{132}$ RIBEIRO, Francisco de Paula, major. Descripção do Território de Pastos Bons...Opus cit., p. 55.

${ }_{133}^{13}$ RIBEIRO, Francisco de Paula, major. Descripção do Território de Pastos Bons...Opus cit., p. 56.

${ }^{134}$ SPIX, J.B Von; MARTIUS, C.P.F. Viagem pelo Brasil...Opus cit., p. 263.
} 
Outras feiras nasceram da vontade do povo ou dos oficiais da câmara, no intuito de enobrecer o aglomerado na rede urbana, atraindo comércio e fama. Entretanto, quando o clima e o lugar onde a feira fora implantada não eram favoráveis, essa teve uma pequena vida útil, efêmera. Fato ocorrido na vila cearense do Icó. O vereador José Raymundo, em vereação de 18 de fevereiro de 1818, inculcou nos outros edis a necessidade de uma feira local, por ser rico, commerciante e optimamente situado para o negócio ${ }^{135}$. Parece que a feira icoense não prevaleceu, apesar disso, a qualidade de "negociante" não lhe foi quitada, como notou George Gardner: grande parte dos habitantes são comerciantes que suprem o interior com mercadorias européias, recebendo em troca os produtos da terra que enviam para a Costa ${ }^{136}$.

Em contrapartida, a feira da vila do Crato atraiu mercadores de variadas partes do sertão nordestino para o seu perímetro urbano. No princípio, é provável que tenham usado o adro da matriz para realizar as transações econômicas, porém, com o tempo, as barracas espalharam-se pelas ruas, zoneando os espaços, hierarquizando-os segundo o produto à venda. Gustavo Horácio vivenciou a feira do Crato [figura 46]:

Reúne-se nas segundas-feiras de toda a semana. Até 2.500 cargas de gêneros de todas as qualidades. Geralmente a feira regula de 3 a 4.000 pessoas, mas nas de agosto a dezembro reúnem-se até 8 mil pessoas. Enchem-se de povo commerciando na praça de S. Vicente, do Rosário, a rua da Califórnia, donde o encontro das da Laranjeiras até o encontro da rua da Valla, a rua Grande até quase a praça do Rosário, a Formosa, dessa praça até o encontro da Califórnia. E alem disso um dia de agitação em toda a cidade e nas entradas. Não de deve causar admiração o numero de cargas entradas em uma feira; por quanto na segunda-feira, 02 de janeiro do corrente anno, retiraram-se a feira do Crato mais de 500 cargas de comboeiros de outros estados $(\ldots)^{137}$

\footnotetext{
${ }^{135}$ EXTRACTOS dos assentos do antigo senado de Icó, desde 1738 até 1835 ...Opus cit., p. 80.

${ }^{136}$ GARDNER, George. Viagem ao interior do Brasil...Opus cit., p. 87.

137 "DESCRIPÇÃO da cidade do Crato em 1882 pelo Dr. Gustavo Horácio". In Revista do Instituto do Ceará. Ano XX. Fortaleza, 1906. p. 318.
} 


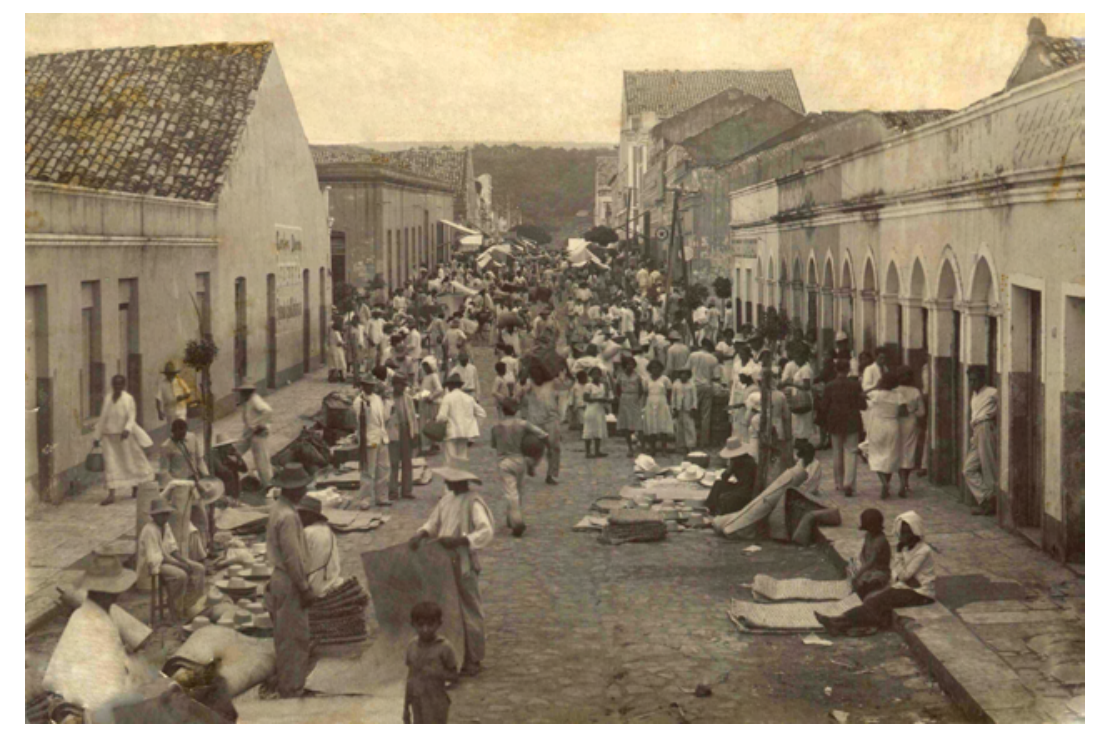

Figura 46 - Feira do Crato. Imagem dos anos vinte do século passado. Foto cedida pelo AHDC.

O cruzamento de caminhos foi um ponto propício para a fundação de uma feira. A vila do Juazeiro (BA), situada estrategicamente no entroncamento de estradas com destino à Oeiras (PI), Ceará, Recife, Minas Gerais e Salvador (BA), tornar-se nos Oitocentos, um aglomerado conhecido pelo seu vivo comércio, no dizer do engenheiro Henrique Halfeld ${ }^{138}$. Theodoro Sampaio assinalou que os sertanejos a chamavam de praça por manter transações com variados centros urbanos do Brasil, principalmente com a capital piauiense. Em suas feiras, chegavam as mercadorias européias por preços bem razoáveis ${ }^{139}$.

Perguntamo-nos: além do gado, que outros artigos eram comercializados? Quem os comprava? Spix e Martius perceberam que na vila do Juazeiro vendiam-se couros, talcos, carne salgada, fumo e sal ${ }^{140}$. Seus compradores foram magistrados e párocos, que só raro aparecem nessas paragens solitárias, também se encontram nessas feiras (...) $)^{141}$. Sendo assim, ocorreu a delimitação de um espaço democrático, onde autoridades eclesiásticas e públicas se misturavam com o povo em busca da mercadoria desejada. Gardner, sentindo os espaços proporcionados pela feira de Propriá (SE), discorreu sobre o material vendido em seu mercado ao ar livre:

\footnotetext{
${ }^{138}$ HALFELD, Henrique Guilherme Fernando. Atlas e relatório concernente a exploração do Rio São Francisco desde a cachoeira da Pirapora até o oceano Atlântico. Levantado por ordem do governo de S.M.I D. Pedro II em 1852, 1853 e 1854. Rio de Janeiro, 1860. Légua 247.

${ }^{139}$ SAMPAIO, Theodoro. O Rio São Francisco: trechos de um diário de viagem e a Chapada da Diamantina. São Paulo, Escolas Profissionaes Salesianas, 1905. p. 37.

${ }^{140}$ SPIX, J.B Von; MARTIUS, C.P.F. Viagem pelo Brasil...Opus cit., p. 400.

${ }^{141}$ SPIX, J.B Von; MARTIUS, C.P.F. Viagem pelo Brasil...Opus cit., p. 404.
} 
Os preparativos da feira criaram certo movimento, pois durante o dia anterior, especialmente ao entardecer, não cessavam de chegar mercadorias para venda, trazidas pelo rio em canoas ou por terra em cavalos da região interior. (...) Como estivesse tomado pela enchente o lugar onde habitualmente se realiza a feira, a multidão se reunira num ponto elevado da beira rio, a oeste da Vila, em frente do sitio onde as canoas tinham sido amarradas umas ao lado das outras. Logo que me vesti, dei uma volta pelo meio da turba para observar a espécie de artigos expostos à venda, achandoos extremamente variados como seria de esperar, mas consistindo principalmente de produtos alimentícios e de vestuário. Entre outros de importância inferior, particularizaremos por serem mais abundantes os seguintes: farinha de mandioca, carne seca, grandes peixes, rapaduras em pedaços grandes com forma de queijo ou em pedaços menores em forma de tijolo, melado em odre, carne verde, banana, sabão, sapatos, panos e chitas, cordas de fibra nativas, fumo, pranchas e esteios, utensílios de cozinha feitos de barro, jarros cozidos pelos índios, couros, peles, aguardentes e outros. ${ }^{142}$

Jacobina (BA) [figura 47], Mocha (PI), Paratinga (BA), Barra (BA), Regeneração (PI) e Rio de Contas (BA) foram outras vilas e arraiais onde a necessidade primordial das transações comerciais e a facilidade de comunicação foram proporcionadas pela reunião de pessoas em feiras.

A dinâmica comercial do sertão nordestino, apresentada neste subcapítulo, foi por nós espacializada no mapa 06.

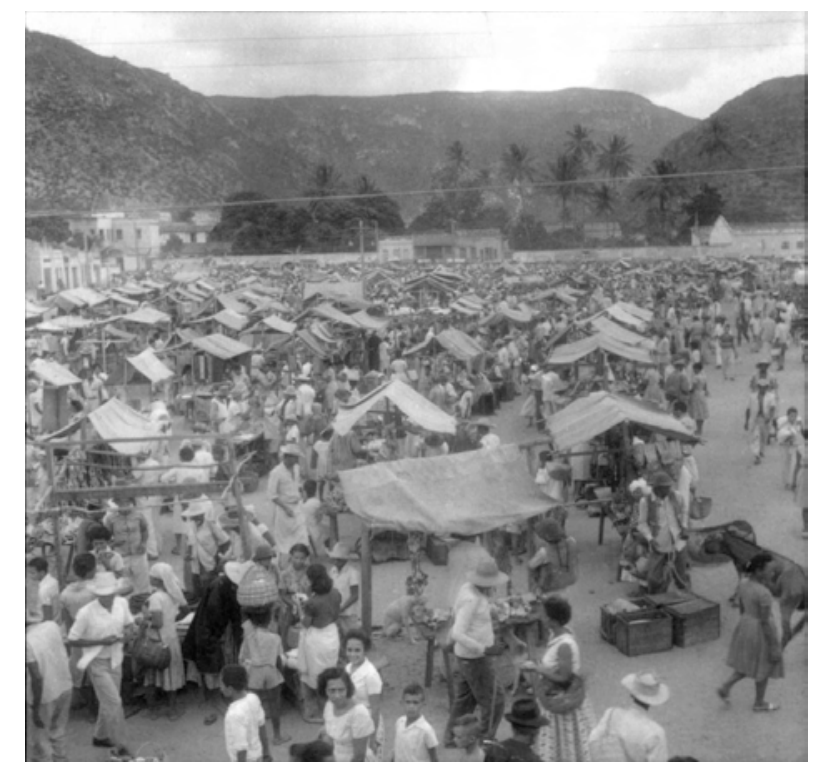

Figura 47 - Feira de Jacobina (BA). Imagem disponível em http://www.ibge.gov.br. Acesso em 30.09.2010.

\footnotetext{
${ }^{142}$ GARDNER, George. Viagem ao interior do Brasil...Opus cit., p. 67.
} 


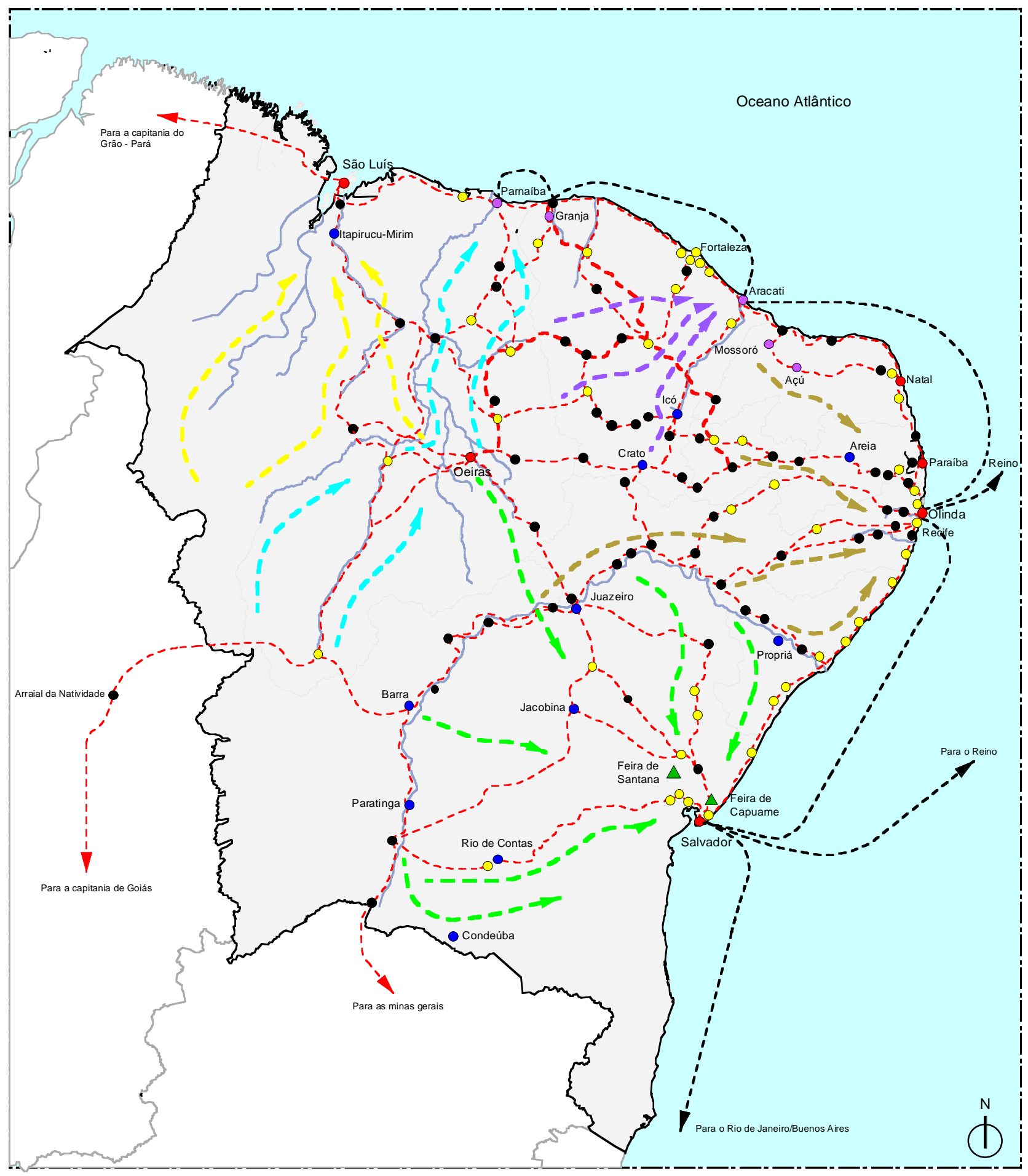

LEGENDA:

Cidades;

Vilas (1549 - 1808);

Vilas ou arraiais com feiras

Vilas com charqueadas ou oficinas de carne do sertão;

Freguesias ou povoações;

$\triangle$ Feiras de gado;

- - - - - - - - Caminhos do gado;

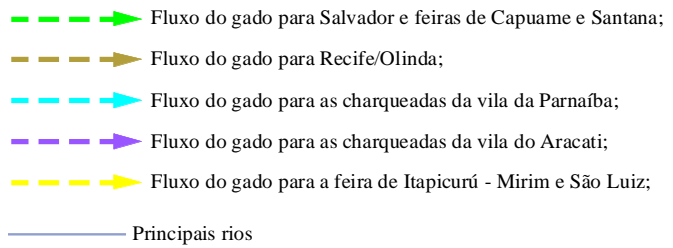

Mapa 06 - Dinâmica comercial do mercado da pecuária sertaneja. Elaboração do autor segundo fontes do Projeto Resgate Barão do Rio Branco, relato dos viajantes estrangeiros e outros autores citados neste capítulo. 


\subsection{A posse da terra : sesmarias, currais de gado e as fazendas de criar}

Os fluxos do gado, os sertões de dentro e de fora, os caminhos das boiadas e a pecuária sertaneja facilitaram o conhecimento e o povoamento do interior do Nordeste em tempos coloniais. Surge, como auxílio à criação, uma camada social "nômade" composta de vaqueiros e tangedores, os quais, durante as jornadas de trabalho, pouco se fixam nas terras do sertão. Para alguns estudiosos do assunto, ${ }^{143}$ os fazendeiros adotaram uma postura absenteísta, ${ }^{144}$ intercalando sua estadia ora onde viviam, nos aglomerados litorâneos, ora nas suas fazendas sertanejas. Percebemos que no sertão nordestino, entre os séculos XVII e XIX, existiram os dois tipos de criadores de gado: aqueles que se ausentavam por um tempo e os que viveram integralmente em suas estâncias.

Muitas dessas herdades adquiriram o seu pedaço de chão segundo os critérios legais pré-estabelecidos pelas Ordenações do Reino. Suas terras foram doadas em sesmarias com extensão que não poderiam exceder o limite de três léguas em quadra. Os sesmeiros eram ordenados a povoar e florescer a terra no período pré-determinado, caso contrário, o chão seria considerado devoluto. Além destes requisitos, deveriam pagar o foro, ou dízimo real, ao verdadeiro dono da terra, a Ordem de Cristo, sendo o rei de Portugal o seu Grão-mestre. ${ }^{145}$ Alguns fazendeiros esqueceram desse pormenor, agiram como os "verdadeiros" donos da terra. Formaram potentados, dilatando progressivamente os seus domínios fundiários, extrapolando os limites legais de posse. À Casa da Torre, da família Dias d'Ávila, e à Casa da Ponte, dos Guedes de Brito, lhes concederam grandes latifúndios, equivalentes territorialmente, sem exagero, a certos países da Europa ou da Ásia.

Mesmo com essa injustiça fundiária (detenção de grandes domínios na mão de poucos), a atuação dessas famílias favoreceu o povoamento e a urbanização do sertão. Tangendo os animais catorze léguas acima da cidade de Salvador, os vaqueiros da Casa da Torre adentraram o interior da capitania da Bahia de Todos os Santos, no início dos Seiscentos, criando imensos currais às margens dos principais rios. Os currais dos d'Ávila foram implantados seguindo direção oeste até o território do atual estado de Tocantins. Ao norte chegaram aos Pastos Bons (MA) e sertão do Parnaguá (PI). Inicialmente, esta empresa

\footnotetext{
${ }^{143}$ Luiz Mott, em seu ensaio sobre o Piauí colonial, enquadra nesta categoria de pesquisadores, os historiadores Caio Prado Jr. e Roberto Simonsen.

${ }^{144}$ MOTT, Luiz. Piauí colonial: população, economia e sociedade. Teresina, Projeto Petrônio Portella, 1985. $144 \mathrm{p}$.

${ }^{145}$ LIMA, Ruy Cirne. Pequena história territorial do Brasil: sesmarias e terras devolutas. São Paulo, Secretária de Estado da Cultura, 1990. p. 35.
} 
teve como sócio o sertanista português, Domingos Afonso Sertão, ator citado anteriormente. O mapa das sesmarias que a Casa da Torre e os seus sócios pretendem nos sertõens do Piauhy [figura 48] mostra que grande parcela de terra, excedendo o mínimo de três léguas em quadra, foi repartida em quatro sesmarias para quatro sócios da Casa da Torre. A primeyra he de quarenta legoas em quadra para quatro sosios a dez em quadra para cada hum (...) A segunda he de vinte e cindo legoas em quadra (...) A terceira doze legoas em quadra (...) a quarta (pasmem) he de secenta legoas em quadra (...). ${ }^{146}$

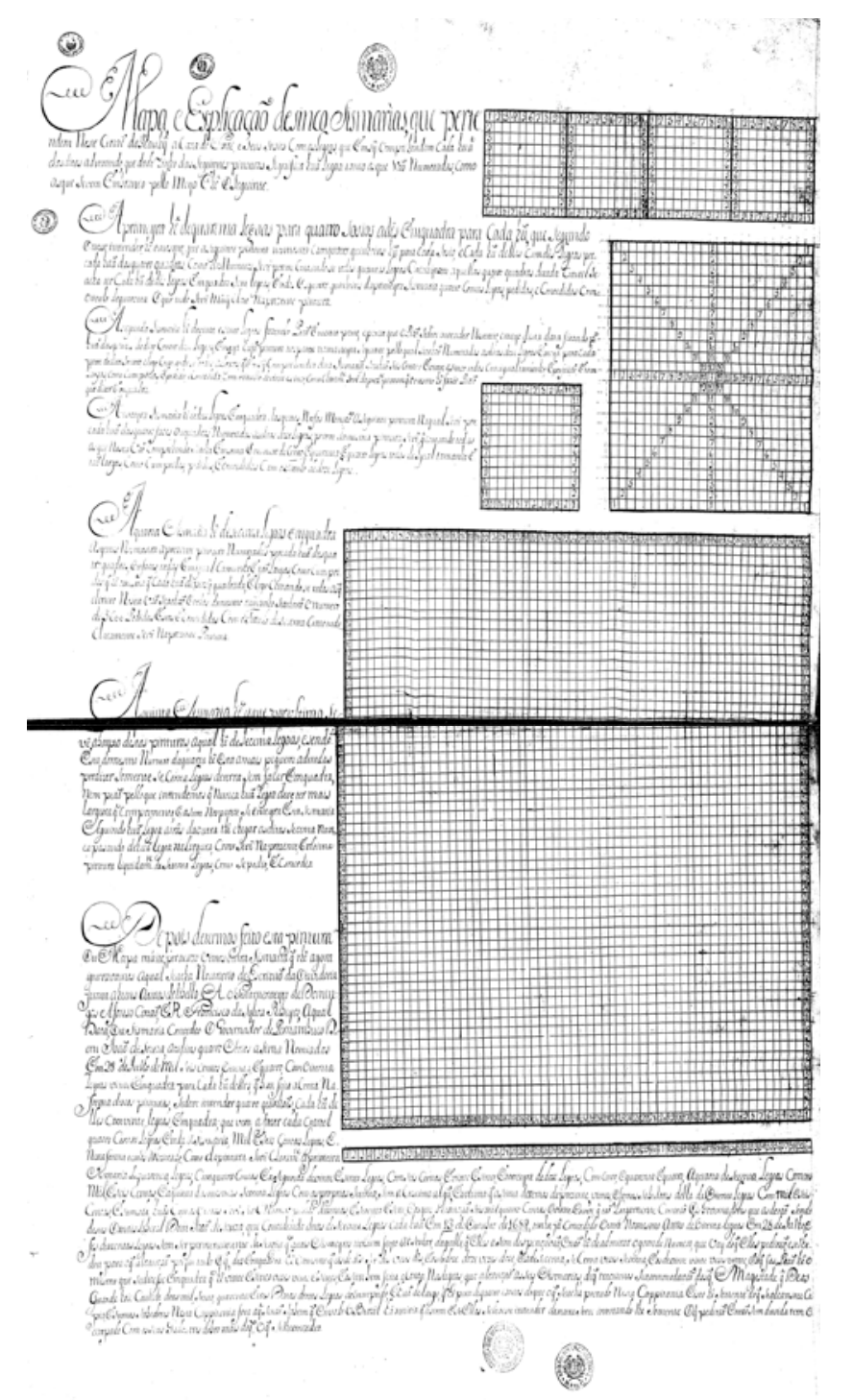

Figura 48 - Mapa das sesmarias que a Casa da Torre e seus sócios pretendem no sertão do Piaui. Projeto Resgate. AHU_ACL_CU_016, Cx.1, D.1.

\footnotetext{
${ }^{146}$ PROJETO RESGATE. AHU_ACL_CU_016,Cx.1, D.1.
} 
Boa parte dos currais erguidos no sertão do rio São Francisco, também chamado de Sertão dos Rodelas, pertenceram aos senhores do morgadio da Casa da Torrte:

Por que a casa da Torre tem duzentas e sessenta léguas pelo rio de São Francisco, acima à mão direita indo para o sul, e indo do dito rio para o norte tem oitenta léguas (...) E, nestas terras, parte dos donos tem currais próprios, e parte são dos que arrendam sítios delas, pagando por cada sítio, que ordinariamente é de uma légua, cada ano, dez mil réis de foro $(\ldots)^{147}$

A truculência desses em adquirir mais terras, chegando a sacrificar centenas de índios Tapuias, destruir uma igreja nas missões dos padres Jesuítas e destituir pequenos criadores de seus chãos, fez o potentado obter seus domínios através de irregularidades, tornando, a posteriori, alguns como terras devolutas. Esqueciam os d'Ávila que o projeto colonizador de novas áreas exigia dos povoadores a fundação de arraiais, freguesias e vilas, dotar a colônia de atrativos que agregassem os membros da sociedade em ascensão. O corpo da Casa da Torre não se interessou em criar núcleos urbanos, cada povoação criada equivalia a uma fatia de terra a menos do seu patrimônio fundiário. ${ }^{148}$ Dos poucos arraiais fundados, podemos citar a povoação da ribeira do rio do Peixe, futura freguesia de Nossa Senhora dos Remédios, elevada à condição de vila, em 1800, com o novo título de vila de Sousa (PB). O documento de doação do patrimônio religioso para a fundação da capela determina: que para a creação della lhe fes Patrimônio e doação os senhorios da Casa da Torre da Bahia do ditto sitio do Jardim com todas as suas terras (...) $)^{149}$

Apesar da ilegalidade, os fazendeiros da Torre obtiveram o aval positivo do rei Felipe IV. Em alvará de 21.04.1624, o monarca autorizou a Francisco Dias d'Ávila procurar as minas de prata e ouro, indicadas em um suposto mapa elaborado pelo seu tio Belchior Dias Moréia, sem que os governadores do mesmo Estado nem outro ministro algum entenda com ele antes nem depois de feita a dita diligencia ${ }^{150}$. Deveria obedecer a uma cláusula: prestar contas ao rei, dentro de um ano, com as amostras colhidas. ${ }^{151}$ As mercês recebidas por Dias d'Ávila materializaram-se em mais terras, seus parentes mais próximos receberam cargos oficiais nas câmaras de vilas interioranas.

\footnotetext{
${ }^{147}$ ANTONIL, André João. Cultura e opulência do Brasil. 3 ed. Belo Horizonte, Itatiaia/Edusp, 1982. p. 96.

${ }^{148}$ SILVA, Jacionira Coelho. Arqueologia no médio São Francisco: indígenas, vaqueiros e missionários. Tese de Doutorado. Recife, UFPE, 2003. p. 117.

149 PROJETO RESGATE. AHU_ACL_CU_014, Cx. 30, D. 2200.

${ }^{150}$ BANDEIRA, Luiz Alberto Moniz. O feudo: a Casa da Torre de Garcia d'Ávila - da conquista dos sertões à independência do Brasil. Rio de Janeiro, Civilização Brasileira, 2000. 602 p.

${ }^{151}$ SILVA, Jacionira Coelho. Arqueologia no médio São Francisco: indígenas...Opus cit., p. 111.
} 
Analisando uma sequência de documentos de concessão de terras a criadores de gado, percebemos que os solicitantes e familiares não se limitaram em pedir o tradicional lote sesmarial. Após o primeiro pedido, requerem as terras adjacentes à primeira. Alargam-se seus chãos. Prática comum por dois motivos: busca de novas pastagens para o gado criado solto nas caatingas e ganância fundiária. Spix e Martius observaram:

(...) na ocasião da seca se torna necessário movimentar as boiadas em grandes espaços, alternando pastos para que elas consigam achar capim seco e frutas, daí os grandes proprietários das grandes fazendas não quererem ceder porção alguma de suas terras (para moradia dos agregados), por considerarem indispensável as grandes extensões para atender à criação do seu gado $(\ldots)^{152}$

A pecuária sertaneja foi considerada pelo jesuíta Antonil como uma das opulências do Brasil colonial. Certificou que, em 1711, existiram mais de 800 currais pertencentes aos pernambucanos. Nos sertões baianos a ocorrência chegou a 500 currais. Segundo o padre:

(...) assim como há currais nos territórios da Bahia e de Pernambuco, e de outras capitanias, de duzentas, trezentas, quatrocentas, quinhentas, oitocentas mil cabeças, assim a fazenda a quem pertencem tantos currais que chegam a ter seis mil, oito mil, dez mil, quinze mil e mais de vinte mil cabeças de gado, donde se tiram cada ano muitas boiadas, conforme os tempos são mais ou menos favoráveis à parição e multiplicação do mesmo gado, e aos pastos assim nos sítios como também nos caminhos. ${ }^{153}$

Não satisfeitos em fundar povoações e vilas, segundo os ditames impostos ao colonizador português, os fazendeiros para não perderem suas enormes faixas de terra povoaram-nas com gado e edificaram currais. A presença dos animais nos pastos, subentendia a existência de "donos da terra". Em conseqüência do tipo de criação bovina - extensiva -, temos grandes áreas despovoadas, com focos de aglomerações humanas distantes léguas e léguas uma dos outras. A paisagem desses assentamentos humanos, seiscentistas e setecentistas [figura 49], elaborou modorrentos arraiais fundados ao longo dos caminhos do gado, com poucas habitações ${ }^{154}$, geralmente em taipa de mão, raros exemplares construídos à

\footnotetext{
${ }^{152}$ SPIX, J.B Von; MARTIUS, C.P.F. Viagem pelo Brasil...Opus cit., p. 419 - 420.

${ }^{153}$ ANTONIL, André João. Cultura e opulência do Brasil...Opus cit., p. 96.

${ }^{154}$ Segundo um levantamento elaborado em 1774 pelo governador da capitania de Pernambuco, José Cezar de Menezes, encontramos povoações e freguesias, por exemplo Exú, onde se viviam, em seu Termo, 82 pessoas de desobriga. Na capitania de São José do Piauí, o ouvidor, Antônio José Morais Durão, remete para o Conselho
} 
base de taipa de pilão ou adobe. Vaqueiros, tangedores, artesãos do couro, escravos e, nalguns casos, vadios, formaram a sociedade desses lugarejos.

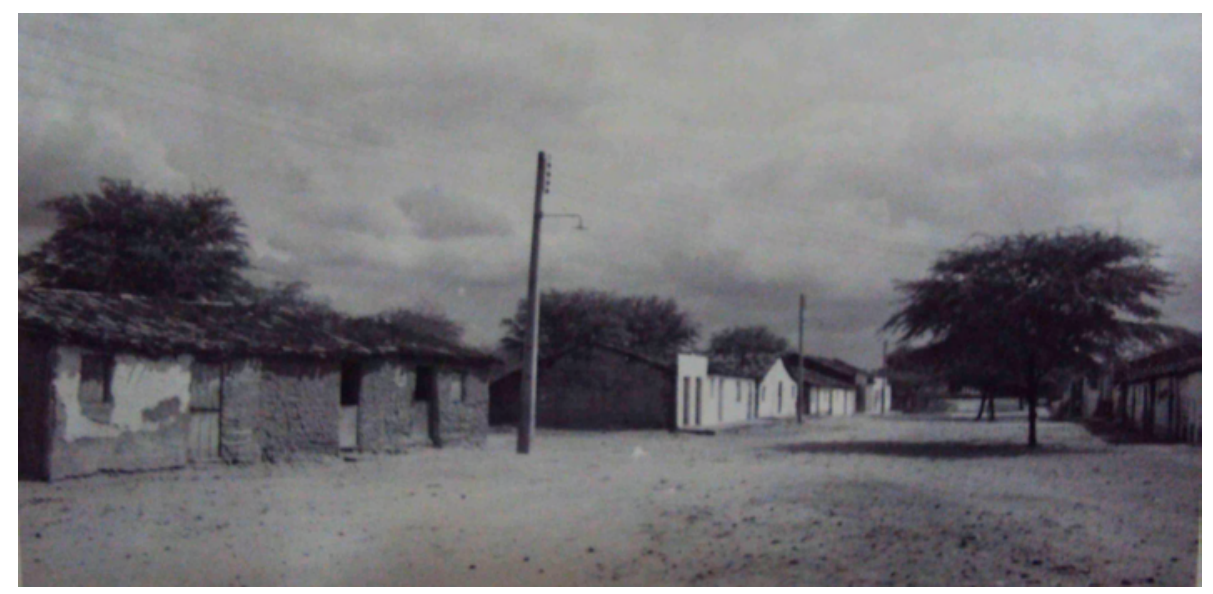

Figura 49 - Povoação do Jardim da fazenda Araripe. Exú - PE. Foto cedida pela FUNDARPE - PE.

Currais e fazendas de gado entram no quebra-cabeças da posse de terras sertanejas. A fixação do homem na rede urbana em crescimento se baseou na política colonizadora, visando assegurar os domínios da Ordem de Cristo. A fundação de herdades no sertão nordestino cumpria os objetivos:

(...) ainda poderá ser maiz util com o intento q' tem de povoarem aquellas terraz, reduzindoas a Collonias, e Povoações, sendo este o meyo não só de se segurarem aquelles Certoens com estas defenças, mas tambem o de poder lucrar grandez conviniençias a fasenda de V.Mag. ${ }^{\text {de }}$ nos dízimos que se podem tirar da Cultura dellaz que pella sua excellençia, é fertilidade prometem a mayor abundançia de fruitos [grifo nosso] $(. . .)^{155}$

\footnotetext{
Ultramarino, em 1772, seu relatório de vistoria, referente às novas vilas e cidade criadas naqueles sertões. Exceto a cidade de Oeiras, as outras vilas (excluímos a vila da Parnaíba pela sua localização litorânea) possuem fogos que não ultrapassam uma centena: Parnaguá: 29 fogos; Marvão: 03 fogos; Valença: 67 fogos; Jerumenha: 05 fogos; Campo Maior: 79 fogos. A vila de Marvão, para o ouvidor, "é a pior de toda a Capitania, porque se acha no sitio mais seco e fúnebre da mesma. Tem únicas três casas ou moradores, para melhor dizer, pois ainda que aquelas são mais, não tem inquilino algum (...)”. MOTT, Luiz Roberto. Piauí colonial: população, economia e sociedade. Teresina, Projeto Petrônio Portela, 1985. pp. 22 - 30. Especulando a lista dos moradores das fazendas do Piauí, inserida no segundo subtópico deste capítulo, notaremos a diminuta quantidade de habitantes existente das herdades situadas nas ribeiras dos rios piauienses.

${ }^{155}$ ENNES, Ernesto. As guerras nos Palmares. Rio de Janeiro, Cia. Editora Nacional, 1938. pp. 349 - 350.
} 
Em todo o interior do Nordeste colonial hachase povoado de gentes, fazendas, $e$ gados $^{156}$. Podemos constatar este fato pela cartografia. A planta da Villa de Jurumunha (atual Jerumenha - PI) [figura 50] figura, além do pequeno núcleo, o Termo da vila constituído de fazendas e sítios de gado, localizados às margens dos rios Parnaíba, Gurguéia e Canindé. No Mappa Geographico da Capitania do Piauhy, e parte das do Maranhão e Grão - Pará [figura 51] estão desenhados os caminhos da referida capitania, as estâncias e suas principais povoações.

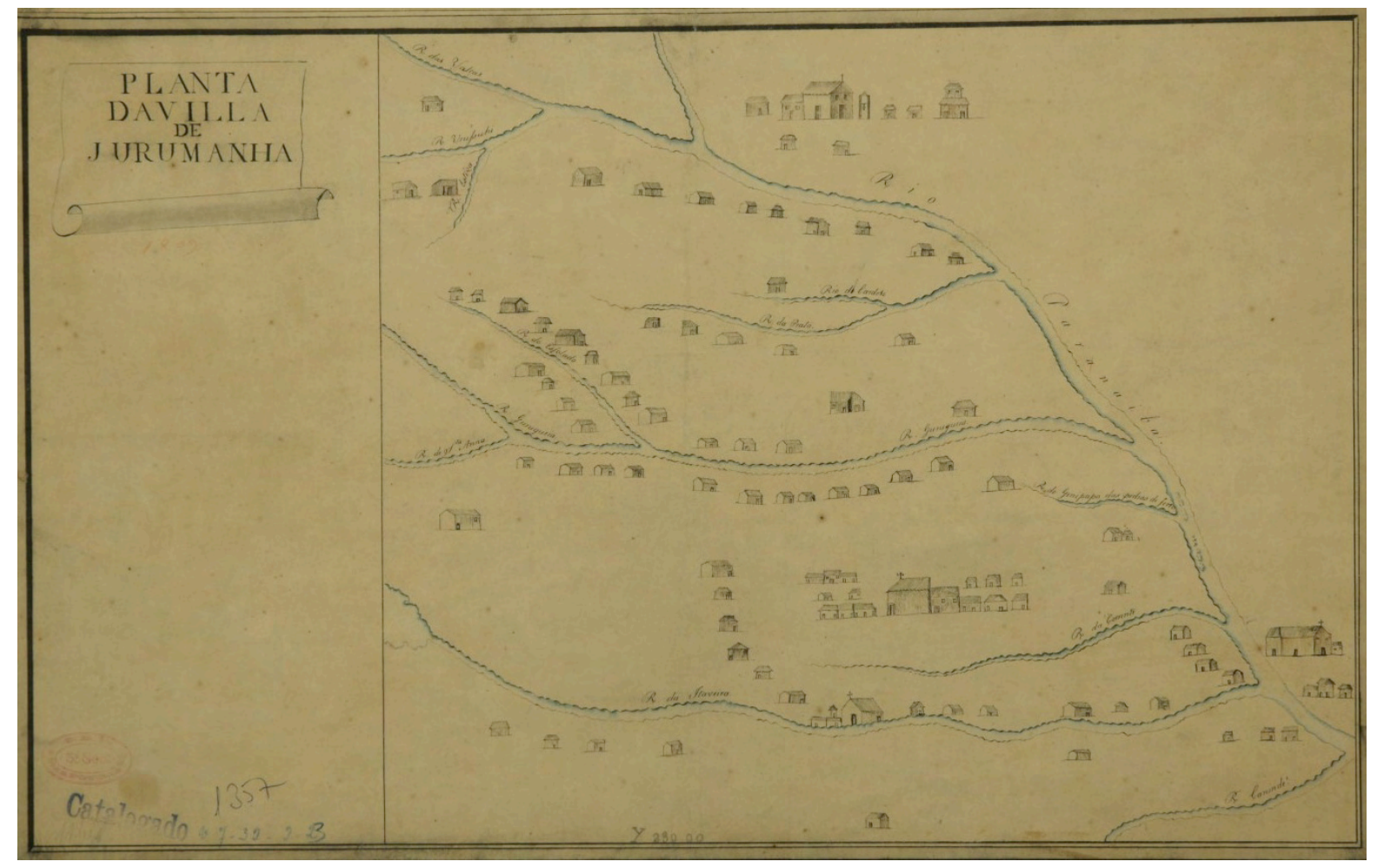

Figura 50 - Planta da Villa de Jurumanha. Original do AHEx- RJ.

${ }^{156}$ PROJETO RESGATE. AHU_ACL_CU_014, Cx. 4, D. 310. 


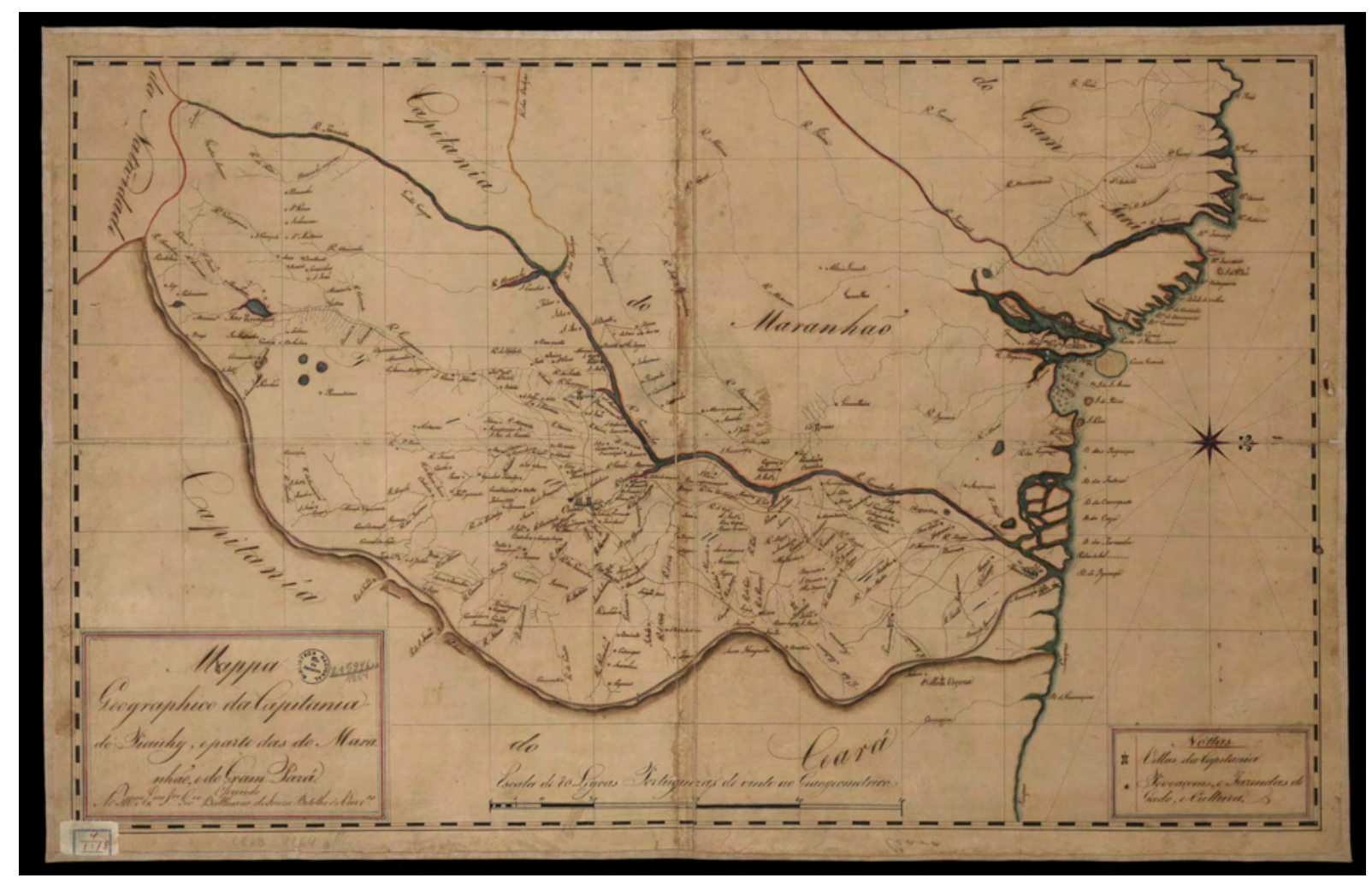

Figura 51 - Mappa Geographico da Capitania do Piauhy e parte das do Maranhão e Grão - Pará. Disponível em http://www.bn.br. Acesso em 22.10.2010.

Após a definitiva expulsão da Companhia de Jesus dos domínios portugueses ultramarinos, todas as fazendas e mais bens jesuíticos do Piauí foram seqüestrados e incorporados ao patrimônio régio. Separaram as trinta e cinco fazendas em três inspeções: Piauí, Nazaré e Canindé. Nomearam para cada uma das inspeções um administrados com preciso número de vaqueiros, tangedores e escravos. O patrimônio jesuítico está listados na tabela 01:

\begin{tabular}{|c|c|}
\hline \multicolumn{2}{|c|}{ INSPEÇÃO DE NAZARÉ } \\
\hline FAZENDA & DIMENSÃO \\
\hline Gameleira & 03 léguas de N-S (norte-sul) e 03 L-O (leste-oeste) \\
\hline Guaribas & 03 léguas de N-S e $04 \mathrm{~L}-\mathrm{O}$ \\
\hline Matos & 04 léguas N-S e 02 L-O \\
\hline Lagoa de São João & 04 léguas N-S e 02 L-O \\
\hline Olho D’água & $2 \frac{1}{2}$ léguas $\mathrm{N}-\mathrm{S}$ e $1 \frac{1}{2} \mathrm{~L}-\mathrm{O}$ \\
\hline Mocambo & 03 léguas N-S e 03 léguas L-O \\
\hline Serrinha & 02 léguas N-S e 03 L-O \\
\hline Jenipapo & 03 léguas N-S e $02 \mathrm{~L}-\mathrm{O}$ \\
\hline
\end{tabular}




\begin{tabular}{|c|c|}
\hline $\begin{array}{l}\text { Algodões } \\
\text { Cataréns } \\
\text { Tranqueira }\end{array}$ & $\begin{array}{l}04 \text { léguas N-S e } 04 \text { L-O } \\
03 \text { léguas N-S e } 03 \text { L-O } \\
03 \text { léguas N-S e } 02 \text { L-O }\end{array}$ \\
\hline \multicolumn{2}{|c|}{ INSPEÇÃO DO PIAUÍ } \\
\hline Salinas & 06 léguas N-S e 01 légua L-O \\
\hline Brejinho & $41 / 2$ léguas $\mathrm{N}-\mathrm{S}$ e $1 \frac{1}{2}$ légua $\mathrm{L}-\mathrm{O}$ \\
\hline Grande & 03 léguas N-S e 1 légua L-O \\
\hline Gameleira & 03 léguas $\mathrm{N}-\mathrm{S}$ e 02 léguas L-O \\
\hline Caché & 1 légua $\mathrm{N}-\mathrm{S}$ e $1 / 2$ légua $\mathrm{L}-\mathrm{O}$ \\
\hline Serra Cajazeiras & 03 léguas N-S e 02 léguas L-O \\
\hline Boqueirão & 07 léguas N-S e 1 légua L-O \\
\hline Mocambo & 03 léguas N-S e 1 légua L-O \\
\hline Cachoeira & 04 léguas N-S e $1 \frac{1}{2}$ légua L-O \\
\hline Espinhos & 4 1⁄2 léguas N-S e 1 légua L-O \\
\hline Julião & 05 léguas N-S e 14 léguas L-O \\
\hline \multicolumn{2}{|c|}{ INSPEÇÃO DO CANINDÉ } \\
\hline Ilha & 02 léguas $\mathrm{N}-\mathrm{S}$ e $21 / 2$ léguas $\mathrm{L}-\mathrm{O}$ \\
\hline Pobre & 03 léguas N-S e 02 léguas L-O \\
\hline Baixa dos veados & sem informação \\
\hline Sítio & 02 léguas N-S e 02 léguas L-O \\
\hline Tranqueira & $31 / 2$ léguas N-S e 03 léguas L-O \\
\hline Poções & 04 léguas N-S e 02 léguas L-O \\
\hline Saco & 04 léguas N-S e 04 léguas L-O \\
\hline Saquinho & sem informação \\
\hline Castelo & 02 léguas N-S e 02 léguas L-O \\
\hline Buriti & 02 léguas $\mathrm{N}-\mathrm{S}$ e $1 \frac{1}{2} 2$ léguas L-O \\
\hline Campo Grande & 04 léguas de extensão \\
\hline Campo Largo & 05 léguas de extensão \\
\hline
\end{tabular}

Tabela 01 - Lista das Fazendas do Real Fisco, antes patrimônio fundiário da Cia. de Jesus no Piaui. NUNES, Odilon. Pesquisa para a história do Piauí. vol 1. 2 ed. São Cristóvão, Artenova, 1975. p. 137

Algumas "curiosidades" da tabela 01 devem ser pronunciadas. A primeira diz respeito à dimensão de dezesseis fazendas: grande parte ultrapassou os limites de concessão de terras estabelecidos pelas Ordenações do Reino: a fazenda Julião, da Inspeção do Piaú, media 05 léguas no sentido Norte - Sul por 14 léguas Leste - Oeste. Só essa herdade abrigou uma área de aproximadamente $3.049,20 \mathrm{~km}^{2}$, maior que os países de Luxemburgo, Martinica 
e Singapura (exemplificando alguns) ${ }^{157}$. Excluindo as fazendas da Baixa dos Veados, Campo Largo, Campo Grande e Saquinho pela incompletude de dados, as outras estâncias somam 110 léguas eixo Norte - Sul por 75 léguas sentido Leste - Oeste, num total de aproximadamente $359.370,00 \mathrm{~km}^{2}$. Eis o patrimônio da Companhia de Jesus no Piauí "seqüestrado" pela Coroa lusa!

Os inspetores das fazendas do real fisco recebiam um ornado anual de 300\$000 réis $^{158}$. Sujeito a estes estava o vaqueiro, o qual dirigia uma das fazendas, permanecendo no posto entre três a cinco anos sob as ordens dos administradores e do governador da capitania. Cabia-lhe os principais misteres, as principais obrigações: ferrar os bezerros, conduzir as boiadas para os pastos, invernadas, currais, portos e feiras, entre outros ${ }^{159}$. Os emolumentos dos vaqueiros, no início de seus serviços, foram convertidos em moradia e alimentação gratuitos. Após quatro anos de trabalho recebiam a quarta, ou seja, a quarta parte anual dos bois criados na fazenda. Esse sistema de pagamento favorecia o boiadeiro, permitindo-lhe adquirir um bom pecúlio e, com o tempo, conseguir uma sesmaria e tornar-se criador. $\mathrm{Na}$ fazenda Brejo do Campo Seco, sertão baiano, por exemplo, o primeiro vaqueiro, José Pinheiro, em 1796, deixou seu cargo para empenhar-se na lavoura do algodão e na pecuária $^{160}$.

Existiu o tangedor, posição logo abaixo ao vaqueiro. Auxiliava no traslado das manadas, evitando a sua dispersão e perda de animais pela caatinga. Eram pagos por jornada de trabalho, podendo ser brancos pobres, mestiços, índios, negros forros e escravos. No relatório de 1771 do governador da capitania de São José do Piauí, Gonçalo Lourenço Botelho de Castro, acerca da condução do gado da inspeção Canindé à feira de Capuame, contrataram seis tangedores: Joaquim (mestiço), José Bernardo (índios), Francisco Nunes (mulato), Luiz (mulato), Romão e Antônio (brancos) e mais escravos (número não indicado) ${ }^{161}$. Receberam um ornado total de 67\$000, vão alugados a salário o mestisso Joaquim por doze mil réis, e os cinco cada hum a onze mil réis (... $)^{162}$.

Grifamos anteriormente na presença de escravos que, nas fazendas do Real Fisco, recebiam roupa em algodão, alimentação e moradia. Tiveram roças e animais domésticos,

\footnotetext{
${ }^{157}$ Informações tiradas do site http://www.wikipedia.org. Acesso em 11/03/2011.

${ }^{158}$ SPIX, J.B Von; MARTIUS, C.P.F. Viagem pelo Brasil...Opus cit., p. 418.

${ }^{159}$ SANTOS FILHO, Lycurgo. Uma comunidade rural do Brasil antigo...Opus cit., p. 211.

${ }^{160}$ SANTOS FILHO, Lycurgo. Uma comunidade rural do Brasil antigo...Opus cit., p. 213.

${ }^{161}$ PROJETO RESGATE. AHU_ACL_CU_016, Cx. 11, D. 656.

${ }^{162}$ PROJETO RESGATE. AHU_ACL_CU_016, Cx. 11, D. 656.
} 
como galinhas, porcos e cabras. ${ }^{163}$ Em Brejo do Campo Seco, segundo Lycurgo Santos, o fazendeiro Pinheiro Pinto, em 1803, cessou o regime de quarta, desenvolvendo a criação com os seus agregados e escravos especializados na lida pastoril, nada pagando pelos seus serviços ${ }^{164}$. Não só o rei e Pinheiro Pinto utilizaram escravos no pastoreio. Também o fizeram outros criadores na caatinga nordestina, conforme verificou George Gardner na fazenda Curumatá:

A fazenda, ao que me informou (o vaqueiro), produz anualmente cerca de duzentos bezerros; o gado interna-se grandes distâncias nas matas e campos; mas nesta época do ano, que é a da produção de bezerros, o vaqueiro e seus ajudantes, geralmente escravos, estão sempre campeando as vacas paridas. Trazem então para casa os bezerros e os encerram em grandes cercados, a que chamam de currais $(. . .)^{165}$ [grifo nosso]

Em 1697, foi enviado do bispado de Pernambuco, por ordens do então bispo, D. Francisco de Lima, o reverendo Miguel Carvalho, para edificar a matriz e fundar a nova freguesia de Nossa Senhora da Vitória, atual Oeiras (PI). Lá, o pe. Miguel Carvalho redigiu a Dezcripção do certão do Peauhy Remetida ao Ilmo. e Rm. Sr. Frei Francisco de Lima Bispo de Pernambuco ${ }^{166}$. Conta-nos o relatório que, em tais sertões, havia 129 fazendas de gado, residindo 441 pessoas entre brancos, negros, índios, mulatos e mestiços. É interessante indicar que, todas as terras são senhores Domingos Afonso Mafrense e da Casa da Torre. Em tais fazendas o cotidiano, a formação social e o sítio eleito para a fundação das sedes foram relatados:

(...) estão cituadas em vários Riachos, distantes huas das outraz ordinariamente mais de duas legoas: em cada hua vive hu homem com hum negro e em alguas se achão mais negros, e tambem maiz brancos mas no comum se acha hu homem branco só; vivem estes moradores de arrendamento dessas fazendas de gados de 4 cabeças que crião lhe toca hua ao depois de pagos os dízimos, são obrigados quando fazem partilhas a entregarem ao sr. da fazenda tantas cabeças como acharão nella quando entrarão e o mais se parte ao quarto comem estes homenz só carne de vaca com latecinios e algum mel que tirão pellos paus, a carne ordinariamente se

\footnotetext{
${ }^{163}$ SPIX, J.B Von; MARTIUS, C.P.F. Viagem pelo Brasil...Opus cit., p. 418.

${ }^{164}$ SANTOS FILHO, Lycurgo. Uma comunidade rural do Brasil antigo...Opus cit., p. 215.

165 GARDNER, George. Viagem ao interior do Brasil... Opus cit., p. 115.

166 As informações destas descrições estão transcritas em ENNES, Ernesto. As guerras nos Palmares. Rio de Janeiro, Cia. Ed. Nacional, 1938. Documentos 59 - 65.
} 
come asada, porque não ha panellas em que se coza, bebem agoa dos poços, e lagoas, sempre turba (sic.), e muito asalitrada os ares são muito groços e pouco sadios, desta sorte vivem estes mizeraveis homenz vestindo couros e parecendo tapuyas. $(\ldots)^{167}$

Chegando ao século XVIII, segundo informe do ouvidor Antônio José de Morais Durão, a capitania de São José do Piauí possuía 579 fazendas de gado (incluindo as do Real Fisco), distribuídas nos Termos da cidade de Oeiras e vilas de Parnaíba, Campo Maior, Marvão, Valença do Piauí, Jerumenha e Parnaguá [tabela 02].

\begin{tabular}{|c|c|}
\hline \multicolumn{2}{|c|}{ FAZENDAS DA CAPITANIA DO PIAUÍ, 1772 } \\
\hline TERMO & QUANTIDADE \\
\hline Oeiras & 182 \\
Parnaguá & 60 \\
Jerumenha & 69 \\
Valença do Piauí & 58 \\
Marvão & 39 \\
Campo Maior & 91 \\
Parnaíba & 79 \\
\hline TOTAL & $\mathbf{5 7 9}$ \\
\hline
\end{tabular}

Tabela 02 - Fazendas do Piaui. MOTT, Luiz Roberto. O Piauí colonial: população, economia e sociedade. Teresina, Projeto Petrônio Portela, 1985. p. 34.

Os jesuítas não foram os únicos religiosos a dedicar parte do seu tempo nos exercícios temporais, no negócio do gado. Os carmelitas da Bahia adquiriram 14 curraes de gado vaccum e cavallar no sertão do Palmar, freguesia do Lagarto e 14 curraes de gado vaccum no Rio São Francisco ${ }^{168}$, em um ano lucraram $270 \$ 000$ réis. Na capitania de Pernambuco, a ordem do Carmo possuiu cinco fazendas de gado, quatro na Ribeyra do Jagoaribe, e uma no Cariri, somaram um montante anual de $700 \$ 000^{169}$. Segundo a

\footnotetext{
${ }^{167}$ ENNES, Ernesto. As guerras nos Palmares...Opus cit., p. 373.

168 ANNAES da Bibliotheca Nacional do Rio de Janeiro. Vol XXXII. Ano 1910. Rio de Janeiro, Officinas Graphicas da Bibliotheca Nacional, 1914. p. 77.

169 "INFORMAÇÃO geral da Capitania de Pernambuco, 1749". In Annaes da Bibliotheca Nacional do Rio de Janeiro. Vol XXVIII. Ano 1906. Rio de Janeiro, Officinas Graphicas da Bibliotheca Nacional, 1908. p. 414.
} 
"Informação Geral da Capitania de Pernambuco, de 1749", os congregados do Oratório de São Felipe Nery tiveram vários sítios no Certão, rendendo para seus cofres $100 \$ 000$ réis ${ }^{170}$.

Para ilustrar esta parte, arrolamos a sede de algumas fazendas de gado do sertão nordestino situadas em distintos pontos da região: Piauí: fazenda Canela [figura 52]; Ceará: fazenda de gado em Aracati [figura 53]; Pernambuco: fazenda Boa Vista [figura 54]; Alagoas: fazenda Cobra [figura 55]; Bahia: fazenda Recreio [figura 56]; Paraíba: fazenda Acauã [figura 57].

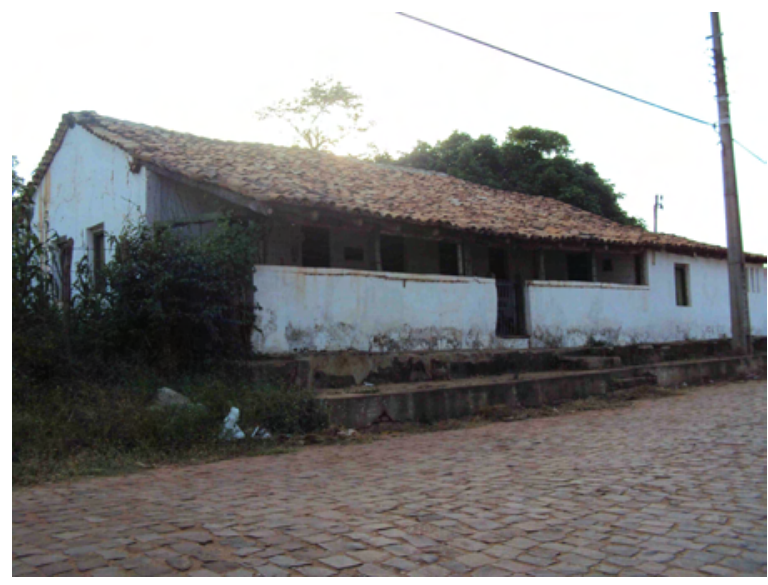

Figura 52 - Fazenda Canela. Foto do autor, 2010.

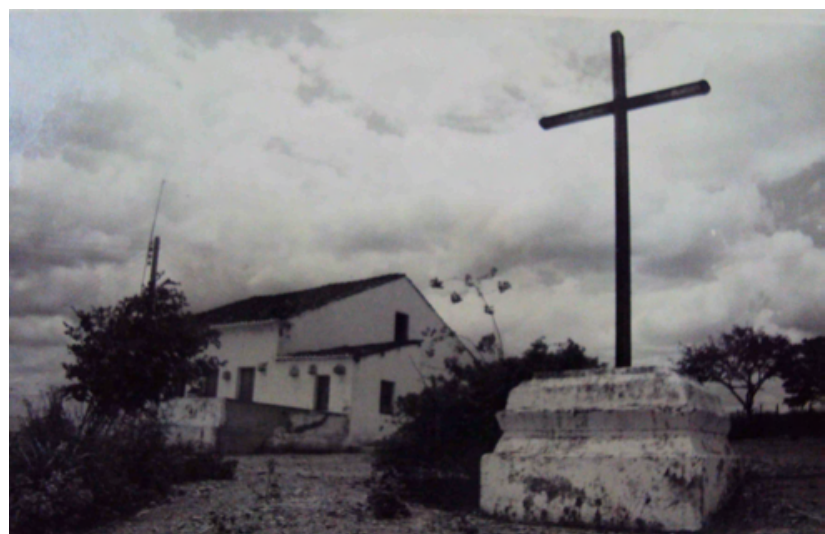

Figura 54 - Fazenda Boa Vista em Exú - PE. Foto cedida pela FUNDARPE - PE.

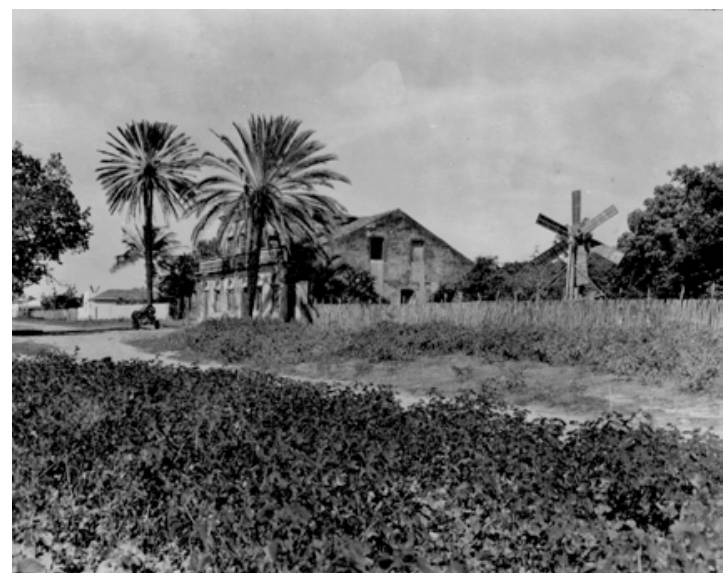

Figura 53 - Fazenda de gado em Aracati - CE. Foto disponível em http://www.ibge.gov.br. Acesso em 18 . 09. 2010.

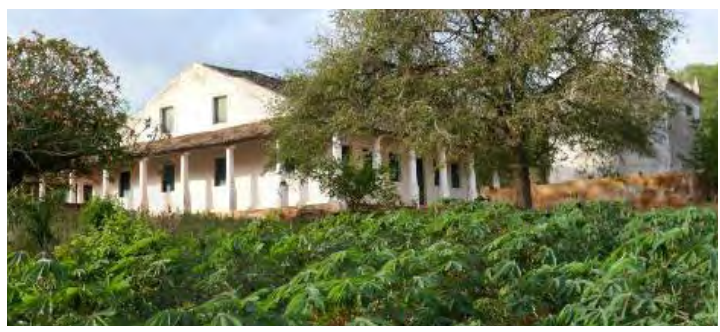

Figura 55 - Fazenda Cobra - AL. Foto do CECI - PE.

170 “INFORMAÇÃO geral da Capitania de Pernambuco, 1749”... Opus cit., p. 418. 


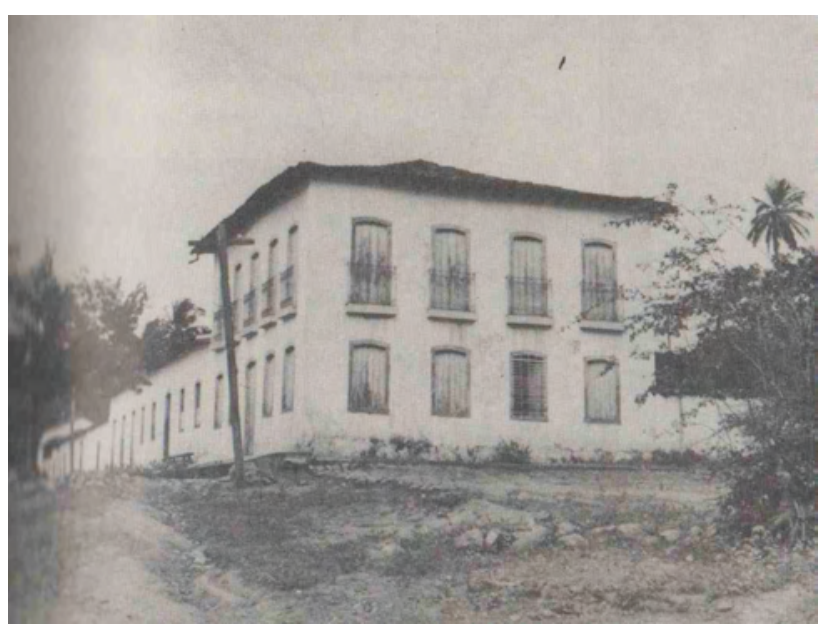

Figura 56 - Fazenda Recreio - BA.

Foto do IPAC - BA.

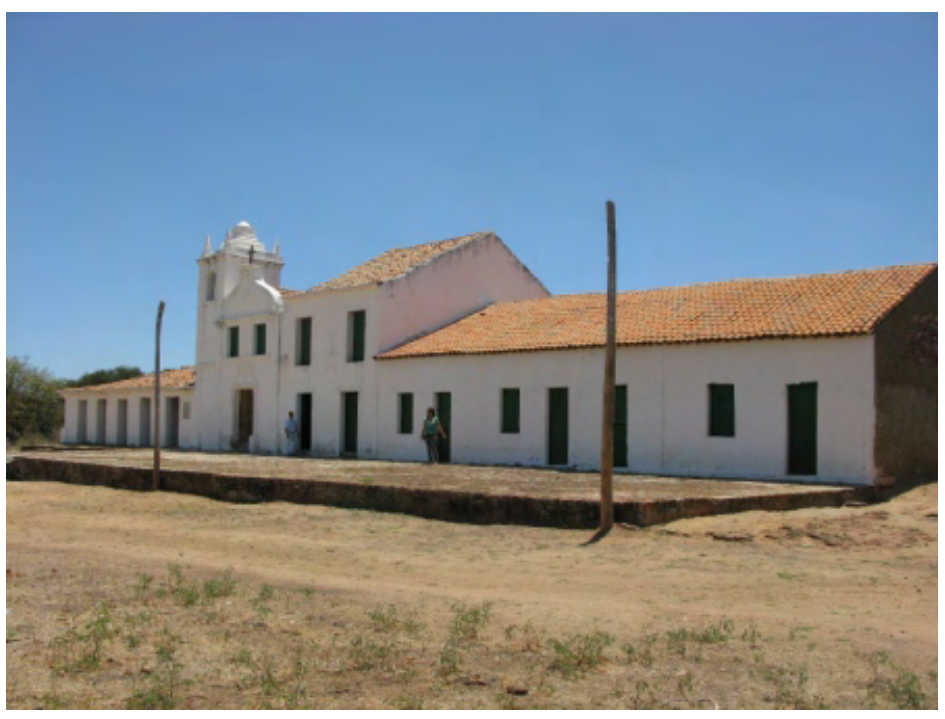

Figura 57 - Fazenda Acauã - PB. Foto cedida pelo IPHAN - PB.

O capitão-mor do Cariri (capitania da Paraíba) enviou um requerimento ao rei D. João V, em 1743, apontando dados relativos à capitania, entre esses, o da existência de 190 fazendas de gado que "povoam os ditos Certoens". ${ }^{171}$ Já em outro censo ${ }^{172}$, realizado em 1774, durante a administração do governador da capitania de Pernambuco, Jozé Cezar de Menezes, o rei D. José I e o marquês de Pombal foram postos a par dos índices populacionais

\footnotetext{
${ }^{171}$ PROJETO RESGATE. AHU_ACL_CU_014, Cx. 12, D. 1011.

172 IDÉIA da População da Capitania de Pernambuco, e das suas annexas, extenção das suas Costas, Rios, e Povoações notáveis, Agricultura, numero de Engenhos, Contractos, e Rendimentos Reaes, augmento que este tem sido \&.\& desde o anno de 1774, em que tomou posse do Governo das mesmas Capitanias o Governador e Capitam General Jozé Cezar de Menezes. in Annaes da Bibliotheca Nacional do Rio de Janeiro. Volume XL. Rio de Janeiro, 1918.
} 
e quantidade de fazendas de gado e engenhos localizados naquela região. ${ }^{173}$ Resumiremos as informações do comunicado por intermédio da terceira tabela:

\begin{tabular}{|c|c|}
\hline \multicolumn{2}{|c|}{ FAZENDAS DA CAPITANIA DE PERNAMBUCO E SUAS ANEXAS, 1774} \\
\hline \multicolumn{2}{|c|}{ CAPITANIA DO CEARÁ GRANDE } \\
\hline Ribeira & Fazendas \\
\hline Ribeira do Ceará & 93 \\
\hline Ribeira do Acaracú & 325 \\
\hline Ribeira do Jaguaribe & 240 \\
\hline Ribeira do Icó & 314 \\
\hline TOTAL & 962 \\
\hline \multicolumn{2}{|c|}{ CAPITANIA DO RIO GRANDE DO NORTE } \\
\hline Ribeira & Fazendas \\
\hline Ribeira do Norte & 28 \\
\hline Ribeira do Assú & 96 \\
\hline Ribeira do Apodi & 54 \\
\hline Ribeira do Seridó & 70 \\
\hline Ribeira do Sul & 35 \\
\hline TOTAL & 283 \\
\hline \multicolumn{2}{|c|}{ CAPITANIA DA PARAÍBA } \\
\hline Freguesias & Fazendas \\
\hline Taipú & 99 \\
\hline Pilar & 01 \\
\hline Iacocá & - \\
\hline Alandra & - \\
\hline Barra da Traição & - \\
\hline Cariris & 87 \\
\hline Mamanguape & 75 \\
\hline Pombal & 560 \\
\hline Campina & 47 \\
\hline TOTAL & 869 \\
\hline \multicolumn{2}{|c|}{ CAPITANIA DE PERNAMBUCO } \\
\hline Freguesias & Fazendas \\
\hline Taquara & - \\
\hline Alhandra & - \\
\hline Goyana & - \\
\hline
\end{tabular}

${ }^{173}$ A capitania de Pernambuco tinha como capitanias subalternas as do Ceará Grande, Rio Grande do Norte, Paraíba, Pernambuco e Alagoas. Detinha as margens esquerdas do rio São Francisco limitando, ao sul, com o rio Carinhanha. 


\begin{tabular}{|c|c|}
\hline També & - \\
\hline Tejucopapo & - \\
\hline Itamaracá & - \\
\hline Iguaraçú & - \\
\hline Limoeiro & - \\
\hline Tracunhaem & - \\
\hline Bom Jardim & - \\
\hline Maranguape & - \\
\hline São Pedro Martir & - \\
\hline Sé de Olinda & - \\
\hline Vargem & - \\
\hline Jaboatão & - \\
\hline São Lourenço & - \\
\hline Luz & - \\
\hline Santo Antão & - \\
\hline Ararobá & 25 \\
\hline Simbres & - \\
\hline Águas Belas & - \\
\hline Cabrobó & 60 \\
\hline Bezerros & 88 \\
\hline Tacaratú & 60 \\
\hline Pilão Arcado & 35 \\
\hline São Frei Pedro Gonçalvez & - \\
\hline Moribeca & - \\
\hline Cabo & 01 \\
\hline Ipojuca & 01 \\
\hline Escada & - \\
\hline Porto Calvo & - \\
\hline Camaragibe & - \\
\hline São Bento & - \\
\hline Unna & - \\
\hline Meirim & - \\
\hline Alagoas & - \\
\hline São Miguel & 32 \\
\hline Alagoa do Norte & - \\
\hline Atalaia & 08 \\
\hline Poxim & 14 \\
\hline Penedo & 80 \\
\hline Porto Real & - \\
\hline Nossa Senhora do Ó & 114 \\
\hline São Francisco da Barra do Rio Grande & Sem informação \\
\hline
\end{tabular}




$$
\text { Campo Largo }
$$

São Romão

Aldeia de indios da Assumpção

Vila de Santa Maria
Sem informação

Sem informação

Sem informação

Sem Informação

Tabela 03 - Fazendas encontradas na capitania de Pernambuco, 1774. Elaborada pelo autor segundo informações da "Idéia da População da Capitania de Pernambuco, e das suas annexas, extensão de suas Costas, Rios, e Povoações notáveis, Agricultura, numero de Engenhos, Contractos, e Rendimentos Reaes, augmento que estes tem tido \&.\& desde o anno de 1774 em que tomou posse do Governo das mesmas Capitanias o Governador e Capitam General Jozé Cezar de Menezes”. in Annaes da Bibliotheca Nacional do Rio de Janeiro. Volume XL. Ano 1918. p. 05-116.

A partir do Mapa do Interior da Capitania do Maranham, elaborada por Domingos Monteiro, detectamos cerca de 195 fazendas que povoaram o sertão maranhense. Sem adicionarmos as capitanias Bahia e Sergipe, pela falta de dados, a soma das fazendas de gado dos sertões do Maranhão, Piauí, Ceará, Rio Grande do Norte, Paraíba, Pernambuco e Alagoas, entre 1772 -1774, é de aproximadamente 3.406 herdades. Tinha razão o capitão-mor da Paraíba, João da Maia da Gama, ao enviar uma carta ao rei D. João V, em 1710, quando lhe disse: Hacha-se hoje os certõens desta Capitania muy povoada de gente, fazendas [grifo nosso], e gados (... $)^{174}$. Ao analisar os índices da capitania de Pernambuco, contidos na tabela 03, veremos que parte de suas freguesias, mesmo no auge da pecuária sertaneja, não possuíram em seus Termos um sequer exemplar de fazenda de criar. Situação válida, pois a zona da mata da capitania se especializou na produção do açúcar.

Mesmo sendo pontos afastados uns dos outros, as fazendas de gado transformaram a paisagem do sertão nordestino. No entorno das herdades, a maioria dos aglomerados urbanos tiveram sua gênese, chamados pelos contemporâneos de vila de brancos. Oeiras (PI), Marvão (PI), Icó (CE) e Tauá (CE) são alguns exemplares. Apesar da criação de freguesias e vilas, como veremos no terceiro capítulo, o caráter geral da urbanização do sertão nordestino, entre os séculos XVII e XIX, persistiu com o isolamento e a dispersão.

${ }^{174}$ PROJETO RESGATE. AHU_ACL_CU_014, Cx.4, D. 310. 


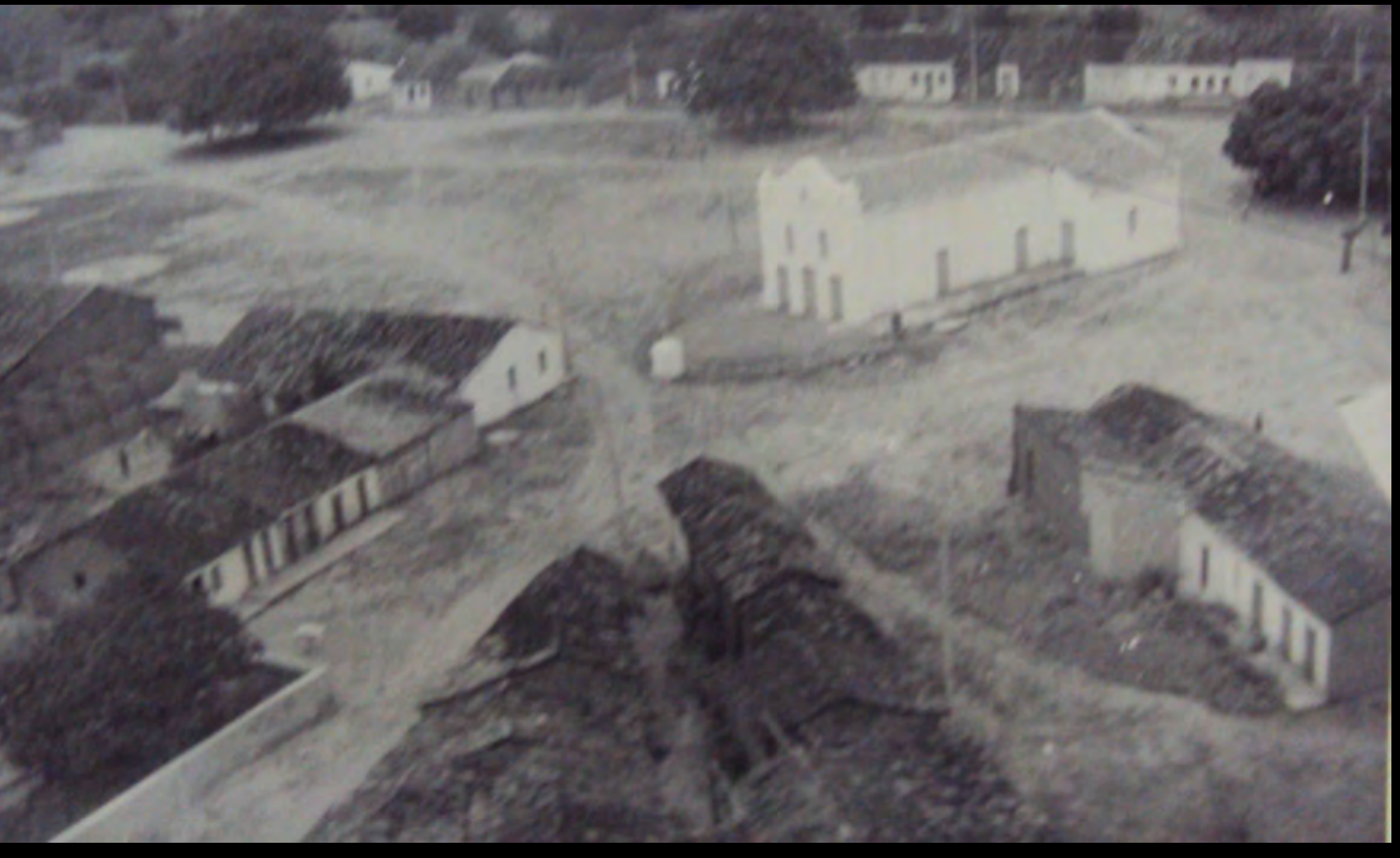

CURRAL DE ALMAS 


\section{CAPÍTULO 03 - CURRAL DE ALMAS}

"A uma distância dupla, ou seja, cento e vinte léguas, encontra-se outra aldeia de bárbaros de língua difícil: Acaraz. Aqui trabalha o incansável ministro do Evangelho João de Barros, grande conhecedor da língua, levando-os para o curral de Cristo com trabalho contínuo, suportando incômodos e dureza."

Pe. Antônio Vieira, 1689

“(...) e se acha o Parocho Missionário com curral de gado, e de bestas, tudo seu. E os seus freguezes em manadas por essas prayas, nus, brutos, e pobres, como os vemos."

Missionário jesuíta do Maranhão em carta ao rei de Portugal, D. João V.

“(...) E ainda fica continuando e com determinação de hir para os sertões do seu Bispado, onde inda não foi algum dos seus antecessores. Sendo certo que lá carece muito e com mais efficacia do pasto espiritual e sem duvida fará nisso hum grande servisso. Pello bem que alcançará as almas que dispersas vivem por aquelles remontados sertões como pello árduo e defectuoso caminho que tem de passar em tão prolongada viagem. (...)"

D. Fr. Luís de Santa Teresa, bispo de Pernambuco 


\subsection{Curral de almas: propagação da fé através de aldeamentos missioneiros}

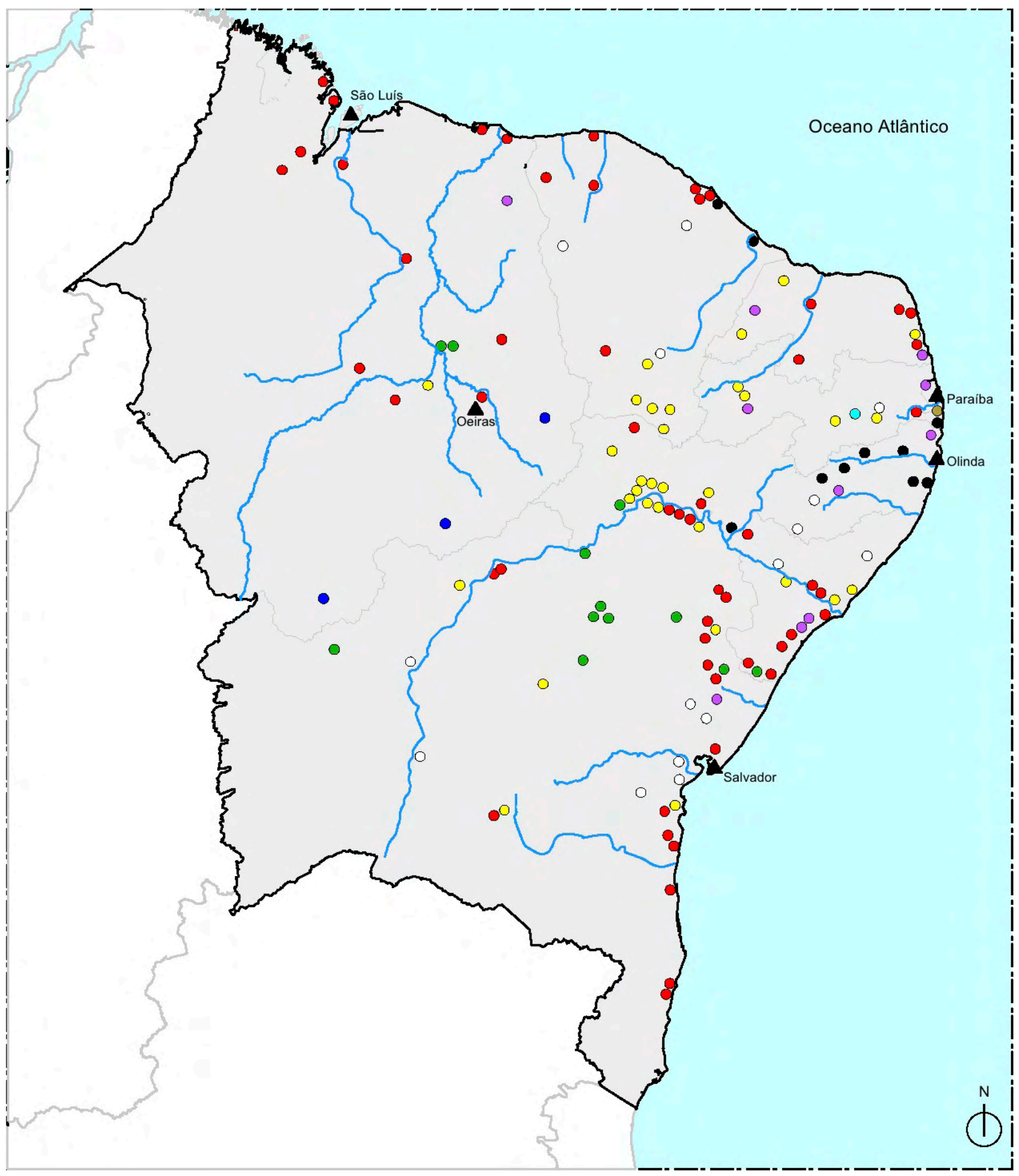

\section{LEGENDA:}

- Missåo Jesuitica; Missão Capuchinha: Missăo Carmelita; $\bigcirc$ Missăo Hábito de Săo Pedro; Missăo Franciscana:
- Missão Oratoriana (São Felipe Nery): Missão Terésios; Missăo Beneditina;
Mapa 07 - Aldeamentos missioneiros do Nordeste desenvolvidos entre os séculos XVII e XIX. Desenho do autor.

Cidades coloniais: 
O governo geral do Brasil, criado em 1549, com Tomé de Sousa à frente de sua gestão, trouxe ao Brasil a necessidade de converter os nativos à fé católica. No parágrafo vinte e quatro, do regimento dado por D. João III ao primeiro governador, lê-se que $a$ principal cousa que me moveu a mandar às ditas terras do Brasil, foi para que a gente delas se convertesse à nossa santa fé católica (... $)^{l}$. A cristianização dos silvícolas era um dever do Estado português. E, para concretizar os seus objetivos envoltos na empresa colonial, foram enviados com a frota de Tomé de Sousa os primeiros missionários jesuítas incumbidos de catequizar e converter os índios brasileiros.

Antes de abordarmos a gradual evolução das missões religiosa no Nordeste colonial, e evidentemente, a ocorrida no seu sertão, precisamos entender, em linhas gerais, que além do "espírito cristão" do rei lusitano, a conquista de novas almas ao seio da cristandade se enquadrou numa estratégia geopolítica, cujos principais envolvidos foram a Metrópole lusa e a Santa Sé, numa clara evidência da união entre Coroa e Mitra, muito bem estudada por Murillo Marx².

Esta união pode ser vista através do direito de padroado ${ }^{3}$. Dentro das normas eclesiásticas, o padroado conferia ao rei, melhor, à Ordem de Cristo, controle da religião católica em seus domínios ultramarinos. Foi a forma através da qual o governo lusitano exerceu sua função de proteção sobre a Igreja Católica, como religião oficial dos seus territórios conquistados e que viriam a ser dominados ${ }^{4}$. Em miúdos: cabia ao Estado português a administração temporal e espiritual de suas colônias. Caio Boschi opina que

\footnotetext{
${ }^{1}$ HORNEART, Eduardo. História da Igreja no Brasil: ensaio de interpretação a partir do povo: primeira época, Período Colonial. 5 ed. Petrópolis, Editora Vozes, 2008. p. 165.

${ }^{2}$ MARX, Murillo. Nosso Chão: do sagrado ao profano. São Paulo, Edusp, 1988. 219 p.

MARX, Murillo. Cidades no Brasil, terra de quem? São Paulo, Edusp, 1991. 143 p.

${ }^{3} \mathrm{O}$ sistema de padroado implantado nas regiões ultramarinas portuguesas foi instituído através de uma série de bulas papais editadas entre os anos de 1452 e 1534. A primeira, chamada de Dum Diversas, foi atestada em 18 de junho de 1452 pelo papa Nicolau V, concedia à Coroa a faculdade de adquirir os domínios dos mulçumanos e infiéis e de possuir os bens públicos e particulares. Em 1455, criou-se a bula Romanus Pontifex. Um dos encargos desse edito cabia de construir, nos domínios africanos, capelas, igrejas e oratórios. Com o papa Calisto III foi determinada a bula Inter caetera. Concedeu à Ordem de Cristo a jurisdição espiritual sobre todas as possessões ultramarinas. A quarta bula foi Dum fidei, concedida por Leão X, em 1514, reforça os direitos territoriais da Ordem de Cristo. Dom Manuel conseguiu a bula Praecelsae Devotionis, envolvendo o direito de prover bispados, paróquias e capelas. Ver ALMEIDA, Fortunato de. História da Igreja em Portugal. Lisboa, Livraria Civilização - Editora, 1968.

${ }^{4}$ AZZI, Riolando. "A instituição eclesiástica durante a primeira época colonial". In História da Igreja no Brasil: ensaio de interpretação a partir do povo: primeira época, Período Colonial. 5 ed. Petrópolis, Editora Vozes, 2008. p. 162.
} 
desde cedo se estabeleceu íntima colaboração entre as duas instituições, pois que, para o Estado Moderno, a unidade política exigia unidade religiosa.

Alguns privilégios foram obtidos pela Ordem de Cristo consequentes do padroado. Entre esses estão a arrecadação e administração dos dízimos eclesiásticos ${ }^{6}$; seleção dos nomes de bispos e padres para ocupar o governo das dioceses e freguesias ${ }^{7}$; nenhum clérigo europeu poderia sair de Portugal sem a autorização real, fato que exigiu audiência particular com declaração de um juramento de fidelidade ${ }^{8}$. Aliás, a Corte podia e decidia os limites para a jurisdição dos bispados e paróquias ${ }^{9}$. Em contrapartida, aos papas cabiam a confirmação das posturas adotadas pela Coroa.

O padroado apresentou benefícios mútuos para os seus coligados. Os reis deveriam patrocinar a construção de capelas, igrejas, monastérios e bispados. Pagar as devidas côngruas dos clérigos, como funcionário eclesiásticos ${ }^{10}$. Riolando Azzi atesta que a proteção do Estado português trouxe sempre privilégios e honras materiais à Santa Sé, principalmente, convertidos em patrimônio fundiário. Entretanto, essa relação significou sempre compromisso, e não poucas vezes, a opressão da Igreja ${ }^{11}$. Cumprir ou não tais acordos facultou no grau de urbanização encerrado no Brasil durante o largo período vigorado pela aliança entre Igreja e Estado.

Evidentemente, a fundação e organização dos aldeamentos missioneiros entraram no rol das obrigações da Igreja impostas à Coroa. Tais núcleos cumpriram o programa traçado

\footnotetext{
${ }^{5}$ BOSCHI, Caio César. Os leigos e o poder: irmandades leigas e política colonizadora em Minas Gerais. São Paulo, Ática, 1986. p. 42.

6 A Idéia da População da Capitania de Pernambuco, e das annexas, extenção de suas Costas, Rios, e Povoações notáveis, Agricultura, numero dos Engenhos, Contractos, e Rendimentos Reaes, augmento que estes tem tido \&.\& desde o anno de 1774 em que tomou posse do Governo das mesmas Capitanias o Governador e Capitam Jozé Cezar de Menezes, confere só para a capitania de Pernambuco um depósito para os cofres reais no valor de 102:006\$938. Ver "Idéia da População da Capitania de Pernambuco, e das annexas, extenção de suas Costas, Rios, e Povoações notáveis, Agricultura, numero dos Engenhos, Contractos, e Rendimentos Reaes, augmento que estes tem tido \&.\& desde o anno de 1774 em que tomou posse do Governo das mesmas Capitanias o Governador e Capitam Jozé Cezar de Menezes". in Annaes da Bibliotheca Nacional do Rio de Janeiro. Volume XL. Ano 1918. Rio de Janeiro, 1923. p. 64 - 65.

${ }^{7}$ RIZZI, Riolando. “A instituição eclesiástica durante a primeira época colonial”. In História da Igreja no Brasil: ensaio de interpretação a partir do povo: primeira época...,Opus cit., p. 164.

${ }^{8}$ PRIMERIO, P.Fr. Fidelis M. de. Capuchinhos em Terras de Santa Cruz nos séculos XVII, XVIII e XIX. São Paulo, Livraria Martins, 1942. p. 80.

${ }^{9}$ BOXER, C. R. Igreja e expansão ibérica. Lisboa, Edições 80, 1981. p. 100.

${ }^{10}$ Segundo a Informação Geral da Capitania de Pernambuco de 1749, o missionário do aldeamento do Miranda (futura vila Real do Crato) recebeu em cada ano 30\$000. Os padres da Companhia de Jesus, localizados na redução da Ibiapaba, admitem da Ordem de Cristo um salário anual de 60\$000. Ver Annaes da Bibliotheca Nacional do Rio de Janeiro. Volume XXVIII. Ano 1906. Rio de Janeiro, 1908. p. 326.

${ }^{11}$ AZZI, Riolando. "A instituição eclesiástica durante a primeira época colonial". In História da Igreja no Brasil: ensaio de interpretação a partir do povo: primeira época...,Opus cit., p. 161.
} 
pela Metrópole lusitana, fortalecido com a centralização administrativa do governo geral ${ }^{12}$. O padre Manuel da Nóbrega compreendeu, desde logo, que para cristianizar e trazer os índios para a civilidade, seria necessário agrupá-los, isto é, criar aldeamentos missioneiros visando sua conversão e total aculturação ${ }^{13}$. Tais aglomerados de índios funcionaram como verdadeiros currais de almas - redil de aculturação - para o controle do Trono e do Altar. Como veremos, seriam o alicerce de freguesias e vilas no interior nordestino, como em outras regiões da colônia ${ }^{14}$.

As primeiras tentativas de reduzir índios ocorreram, já em meados dos Quinhentos, na costa atlântica, próximo dos principais núcleos urbanos da época. Serafim Leite informou acerca dos ensaios iniciais de aldeamentos ocorridos na Bahia, através de simples catequese nas cercanias da cidade de Salvador, elaborados pelo padre João Navarro e o irmão Vicente Rodrigues, auxiliados por intérpretes nativos - os línguas ${ }^{15}$. Os índios que viviam no sertão eram trazidos, através dos descimentos, por padres ou frades e autoridades coloniais para as reduções ubicadas no litoral. Através do Atlas do Brasil, confeccionado por João Teixeira Albernaz II, verificamos esta característica dos primeiros núcleos de índios [figura 58].

Reforçando a determinação de segregar os silvícolas em missões religiosas, as autoridades vêem a necessidade de situá-los cerca de cursos d'água, como rios e riachos. Destarte, os índios teriam onde pescar e plantar, facilitando sua adaptação à nova realidade. Assim fez o capitão-mor da capitania da Paraíba, Francisco Pedro de Mendonça Gorjão, em carta para o rei D. João V, em 1733, sobre a necessidade de mudar os índios da nação Coremas para o lugar chamado Riacho Aguiar, situado no sertão do Piancó:

(...) Faço saber a vos Capitão Mor da Capitania da Parahiba que por parte dos moradores do Peancó se me reprezentou haverem alcansado a sentença que com esta se vos ha de aprezentar pela qual ordenou Ouvidor Geral que foi dessa mesma Capitania João Nunes (...) que os Tapuyas da Nasçao

\footnotetext{
${ }^{12}$ LEITE, Serafim. História da Companhia de Jesus no Brasil. Volume II. Lisboa, Livraria Portucália, 1938. p. 43.

${ }^{13}$ AZEVEDO, Aroldo de. Aldeias e aldeamentos de índios. Separata do Boletim Paulista de Geografia. № 33. São Paulo, 1959. p. 27.

${ }^{14}$ Acerca deste tema recomenda-se a leitura dos trabalhos da pesquisadora Maria Helena Ochi Flexor no que tange a política pombalina para as novas vilas das capitanias de Porto Seguro e São Paulo. Ver FLEXOR, Maria Helena Ochi. Os núcleos urbanos planejados do século XVIII: Porto Seguro e São Paulo. Salvador, CEB UFBA, 1989. 40p.

Para os núcleos do Grão-Pará contamos com a tese de doutorado, defendida na FAU USP, da especialista Renata Martins, em MARTINS, Renata Maria de Almeida. Tintas da terra, tintas do Reino: arquitetura e arte nas missões jesuíticas do Grão-Pará (1653-1759). São Paulo, Universidade de São Paulo, 2009.

${ }^{15}$ LEITE, Serafim. História da Companhia de Jesus no Brasil. Volume II..., Opus cit., p. 46.
} 
Corema se mudasse para o lugar do Riacho do Aguiar por serem terras de matas q' produzem mendioca, milho e outras plantas aonde mais commodamente podiao viver no qual sitio os ditos Tapuyas tomando posse o largarão, e tornarão a habitar o primeiro de donde tinhao sahido, continuando nos distúrbios e damnos q' cuzavão aos supplicantes matando lhes os seus gados, e destruindo the as suas rossas $(\ldots)^{16}$

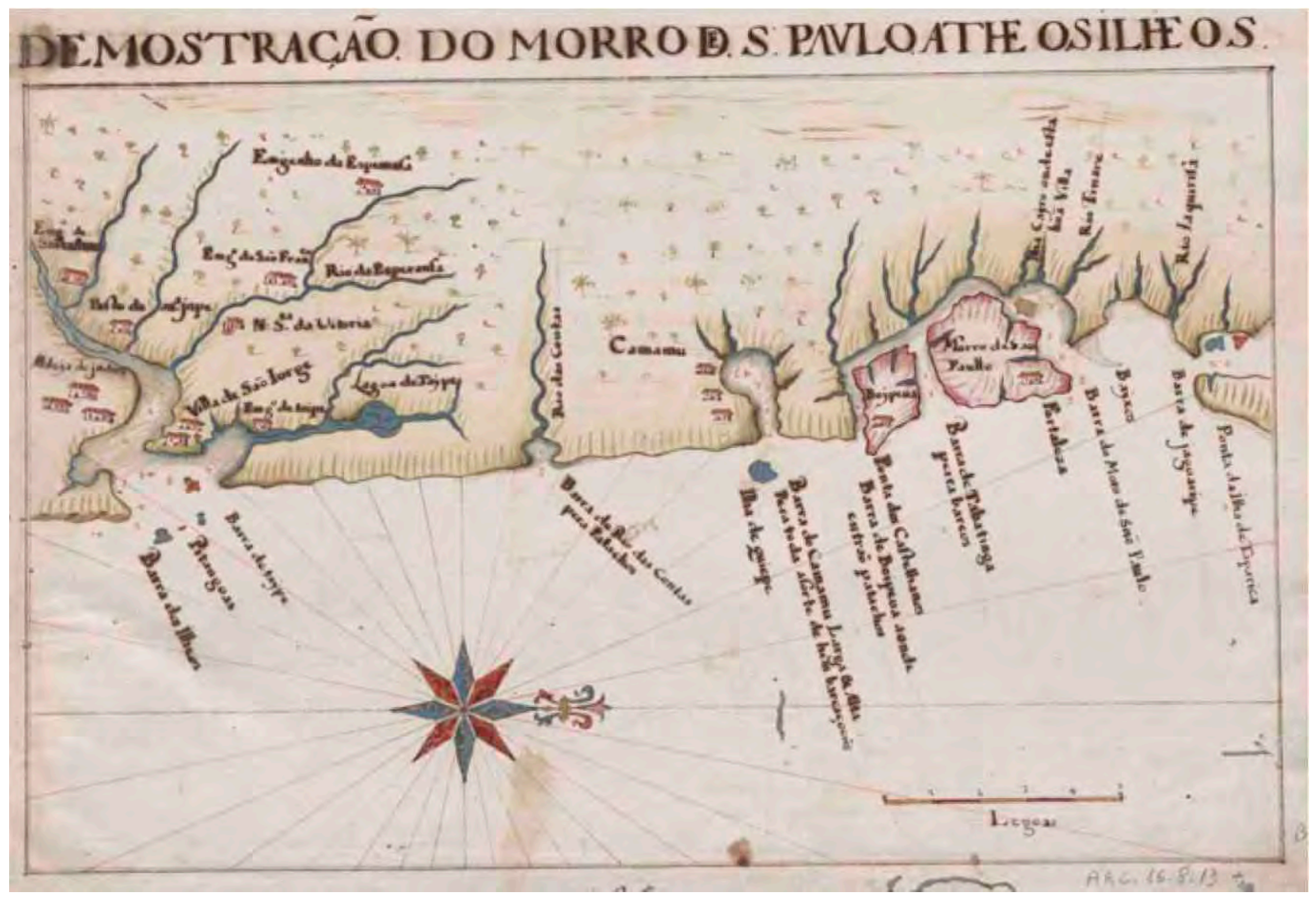

Figura 58 - Demonstração do Morro de S. Paulo athe os Ilheos. Mapa atribuído a João Teixeira Albernaz II. Disponível em http://www.bn.br. Acesso em 02/06/2010.

${ }^{16}$ PROJETO RESGATE. AHU_ACL_CU_014,Cx. 8, D.707. 
A data precisa para o estabelecimento de reduções religiosas no sertão nordestino, segundo os especialistas do tema ${ }^{17}$, é imprecisa. Porém, através de nossas constatações, consideramos a segunda metade do século XVII como o marco temporal para a fixação dos Tapuias em aldeamentos missioneiros. Tal temporalidade está atrelada à conquista, povoamento e posse do interior nordestino exercidos pelos currais de gado, segundo a economia da pecuária extensiva. Reses e almas estão vinculadas ao um conjunto de relações sociais, culturais e religiosas cujo denominador comum é revelado através da urbanização do hinterland do Nordeste.

As ordens religiosas que atuaram no cenário sertanejo foram os capuchinhos, Companhia de Jesus, Oratório de São Felipe Nery, franciscanos, carmelitas e mercedários [mapa 07]. Devido à incompletude de dados encontrados em fontes primárias e estudos acerca das ordens carmelitas, mercedários e franciscanos, dedicaremos os tópicos que seguem à catequese dos capuchinhos, jesuítas e oratorianos.

\subsection{1 - Missões religiosas capuchinhas}

Os estudos sobre a missão capuchinha ${ }^{18}$ em terras sertanejas são poucos, se comparados com aqueles voltados à Companhia de Jesus. Frei Fidelis Primerio ${ }^{19}$ em seu livro intitulado - Capuchinhos em terra de Santa Cruz nos séculos XVII, XVIII e XIX - traçou um panorama geral da catequese praticada pelos barbadinhos no Brasil. Eduardo Horneart ${ }^{20}$ descreve, em poucas laudas, o ensino destes missionários em suas reduções localizadas no médio rio São Francisco. A tese de doutorado de Maria Cristina Pompa ${ }^{21}$ foi outro auxilio

\footnotetext{
${ }^{17}$ LEITE, Serafim. História da Companhia de Jesus no Brasil. Volume II e III. Lisboa, Livraria Portucália, 1938.

PRIMERIO, P.Fr. Fidelis M. de. Capuchinhos em Terras de Santa Cruz nos séculos XVII, XVIII e XIX. São Paulo, Livraria Martins, 1942.

HORNEART, Eduardo. História da Igreja no Brasil: ensaio de interpretação a partir do povo: primeira época, Período Colonial. 5 ed. Petrópolis, Editora Vozes, 2008.

LIMA, Ebion de. "As missões oratorianas no Brasil: informações sobre as missões oratorianas do Nordeste". In Revista do Instituto Histórico e Geográfico Brasileiro. no 323. Abr./jun. Rio de Janeiro, 1979. p. 69 - 118.

${ }^{18}$ A reforma dos capuchinhos foi inaugurada em 1525 por Mateus de Basci. Esta ordem é uma vertente dos franciscanos. Para frei Fidelis Primeiro os franciscanos podem ser agrupados em três famílias com a mesma regra, mas com constituições distintas: os conventuais, os menores (observantes) e os capuchinhos. Estes últimos adotaram o hábito aproximado daquele usado por são Francisco, máxime na forma de capuz. Ver PRIMEIRO, P.Fr. Fidelis M. de. Capuchinhos em Terras de Santa Cruz..., Opus cit., p. 21.

${ }^{19}$ PRIMERIO, P.Fr. Fidelis M. de. Capuchinhos em Terras de Santa Cruz..., Opus cit.

${ }^{20}$ HORNEART, Eduardo. História da Igreja no Brasil..., Opus cit.

${ }^{21}$ POMPA, Maria Cristina. Religião como tradução: missionários, Tupi e "Tapuias" no Brasil colonial. Tese de doutorado. UNICAMP, 2001. 461 p.
} 
para situar, dentro da historiografia brasileira, as práticas religiosas dos capuchinhos [figura 59]. Sobretudo, há fontes primárias impressas que relatam as dificuldades em criar núcleos de índios nas região árida do Nordeste. As duas relações de frei Martinho de Nantes ${ }^{22}$ nos contam o cotidiano dos índios e as querelas ocorridas entre eles e Francisco Dias d'ávila, fazendeiro do morgadio da Casa da Torre. Por fim, na História da missão dos padres capuchinhos na ilha do Maranhão e terras circunvizinhas o frei francês Claude D'abbeville ${ }^{23}$ narrou o curto período de atuação desses frades no Maranhão dominado pelos franceses. Essas obras são de caráter historiográfico, cabendo-nos a tarefa de interpretá-las para esclarecer o papel das missões religiosas na urbanização do território de caatinga.

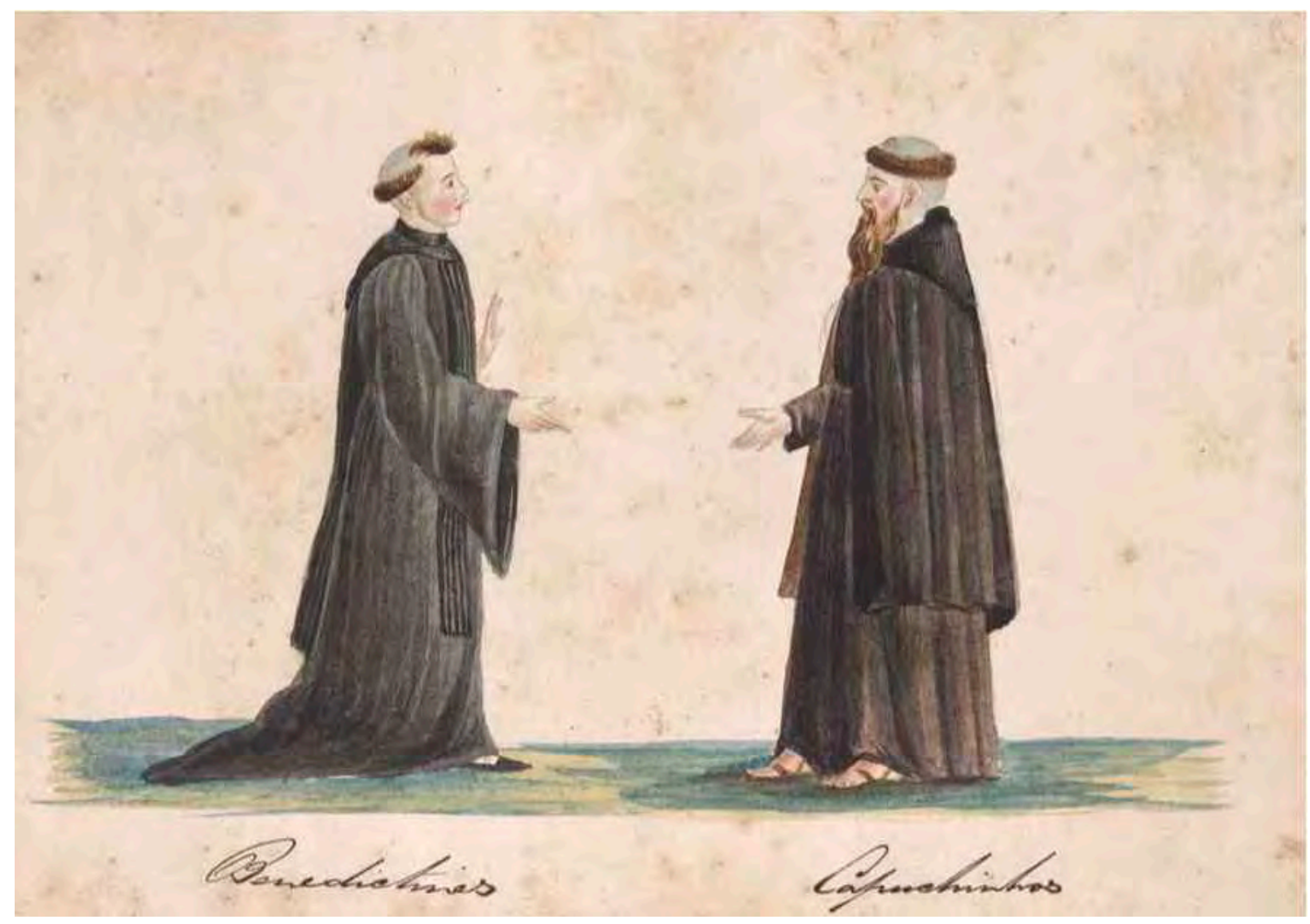

Figura 59 - CALLCOTT, Lady Maria. Beneditinos; Capuchinhos. Desenho do século XVIII. Disponível em http://www.fbn.br. Acesso em 28/09/2010.

\footnotetext{
${ }^{22}$ MARTINHO DE NANTES, padre O.F.M. Cap. Relação de uma missão no Rio São Francisco: relação sucinta e sincera da missão do padre Martinho de Nantes, pregador capuchinho, missionário apostólico no Brasil entre os índios chamados cariris. Tradução e comentário de Barbosa Lima Sobrinho. São Paulo, Ed. Nacional, 1979. 123 p.

${ }^{23}$ D'ABBEVILLE, Claude. História da missão dos padres capuchinhos na ilha do Maranhão e terras circunvizinhas. Belo Horizonte, Itatiaia, 1975. 297 p.
} 
Vale ressaltar que, antes de partirem para as suas missões, os capuchinhos eram preparados em cursos especiais de formação, cuja proposta visava a adequação do trabalho catequético em comunidades indígenas ${ }^{24}$. Faziam votos de pobreza, incentivo ao estudo das Sagradas Escrituras, dedicação exclusiva à pregação e ojeriza ao pecado. Reflexos de seu hábito são vistos no seu modo de vida: casas e igrejas eram construídas com materiais simples, através de donativos provenientes exclusivamente das esmola. Buscavam afastar-se dos centros urbanos para conseguir o equilíbrio espiritual desejado ${ }^{25}$.

Entre 1612 e 1614 os capuchinhos franceses pe. frei Ivo de Evreux, pe. frei Claude D’abbeville, pe. frei Arsensino de Paris e o pe. frei Ambrósio de Amiens doutrinaram os índios maranhenses situados na ilha de São Luiz ${ }^{26}$. Mostraram uma atitude audaz por querer converter todos os nativos do Brasil. Logo que chegaram, trataram de construir uma ermida com materiais de construção pouco arrojados e abundantes na região: madeira para as vedações e cobertura elaborada com folhas de palmeiras. ${ }^{27}$ Santificando o chão da primeira capela erguida, cantaram o Te deum e rezaram missa para um português, escravos, cinco índios batizados e outros não convertidos. Adeptos dos dogmas do Concilio de Trento (1545 1563) os frades franceses sobrepujaram a teoria eclesiástica pela prática doutrinária. Não se limitavam às palavras e aos desejos, partiram à ação:

Ide, portanto, e fazei discípulos de pessoas de todas as nações, batizando-as em nome do pai, e do filho e do espírito santo, ensinando-as a observar as coisas que vos ordenei. ${ }^{28}$

Na opinião de Primeiro, o trabalho de catequese dos capuchinhos não se restringiu à ilha de São Luiz, estendendo-se para Tapuitapera (atual Alcântara) e Coman ${ }^{29}$. Muitos eram os neófitos curiosos da nova religião, materializada na figura do missionário e nos signos da Igreja (cruz, rosários, velas e imagens). O progresso da obra, fora da cidade maranhense, acarretou na migração de frei Arsensino de Paris para Tapuitapera. Ali congregou os indígenas em um aldeamento missioneiro, um curral de almas, aculturando aqueles dispostos aos rigores eclesiásticos da Igreja dos Seiscentos. Batismo e casamento foram os ritos praticados pelo barbadinho. Contudo, um índio convertido ergueu capela e construiu casa para

\footnotetext{
${ }^{24}$ PARAÍSO, Maria Hilda Baqueiro. Os capuchinhos e os índios do sul da Bahia: uma análise preliminar de sua atuação. São Paulo, Museu Paulista, 1986. p. 151.

${ }^{25}$ PARAÍSO, Maria Hilda Baqueiro. Os capuchinhos e os índios do sul da Bahia..., Opus cit., p. 152.

${ }^{26}$ PRIMERIO, P.Fr. Fidelis M. de. Capuchinhos em Terras de Santa Cruz..., Opus cit., p. 25.

${ }^{27}$ PRIMERIO, P.Fr. Fidelis M. de. Capuchinhos em Terras de Santa Cruz..., Opus cit., p. 26.

${ }^{28}$ Trecho da Bíblia: Mateus 28:19,20.

${ }^{29}$ PRIMERIO, P.Fr. Fidelis M. de. Capuchinhos em Terras de Santa Cruz..., Opus cit., p. 30.
} 
o missionário, facilitando a gênese de um novo núcleo. Não se sabe a forma que tomou este aldeamento missioneiro. As fontes pesquisadas não nos dão indícios para construir um adequado panorama urbano.

A estadia dos barbadinhos no Maranhão vigorou enquanto existiu a França Equinocial, destituída pelos portugueses, vindos do Ceará, sob o comando de Jerônimo de Albuquerque $^{30}$. Foram deixados mais de 20.000 almas de nativos catequizados pelos capuchinhos que, a partir de então, ficariam sob a tutela dos padres jesuítas Manuel Gomes e Diogo Nunes e dos carmelitas frei Cosme da Anunciação e frei André da Natividade ${ }^{31}$.

Cerca de cinqüenta e sete anos voltariam os capuchinhos a reunir indígenas em suas missões religiosas, dessa vez às margens do médio rio São Francisco, sertão do Cariri cearense e regiões do Piancó paraibano. Viriam tais missionários imbuídos de converter silvícolas e combater a falta de compromisso do padroado português na América ${ }^{32}$. A Santa Sé, notando a inflexibilidade da Ordem de Cristo, no que dizia respeito ao exercício do poder espiritual desempenhado em suas colônias ultramarinas, fundou, como reação ao padroado, em 1622, a Propaganda Fide ${ }^{33}$.

Os capuchinhos foram eleitos pela Propaganda como 'missionários apostólicos' que, no dizer de Eduardo Horneart, dependem do papado para executar os seus serviços pios, tomando um certo distanciamento do rei e do sistema colonial vigente por serem, na maioria dos casos, estrangeiros ${ }^{34}$. Portanto, as correspondências relatando o cotidiano e os problemas das missões eram encaminhadas aos superiores da Propaganda. Este fato é confirmado pela Relação do frei Martinho de Nantes: apresentei esta relação a Monsenhor o núncio de Portugal, na forma em que aqui aparece. Esse digno prelado desejava saber o fruto que se obtinha em nossas missões, para informar a Sagrada Congregação da Propaganda Fide, como o fez, remetendo-lhe esta relação ${ }^{35}$.

O hiato deixado na obra capuchinha em terras brasileiras foi paulatinamente preenchido após a construção, na vila do Recife, capitania de Pernambuco, da capela do Espírito Santo dos Pescadores, onde mais tarde seria o convento e igreja de Nossa Senhora da

\footnotetext{
${ }^{30}$ ABREU, Capistrano de. Capítulos de história colonial, 1550 - 1800. São Paulo, Publifolha, 2000. p. 93.

${ }^{31}$ PRIMERIO, P.Fr. Fidelis M. de. Capuchinhos em Terras de Santa Cruz..., Opus cit., p. 36.

${ }^{32}$ HORNEART, Eduardo. História da Igreja no Brasil..., Opus cit., p. 63.

${ }^{33}$ PRIMEIRO, P.Fr. Fidelis M. de. Capuchinhos em Terras de Santa Cruz..., Opus cit., p. 43.

${ }^{34}$ HORNEART, Eduardo. História da Igreja no Brasil..., Opus cit., p. 64.

${ }^{35}$ MARTINHO DE NANTES, padre O.F.M. Cap. Relação de uma missão no Rio São Francisco: relação sucinta e sincera da missão do padre Martinho de Nantes..., Opus cit., p. 27.
} 
Penha de França [figura 60]. O terreno para edificação da sede foi doado por Belchior Alves e Joana Bezerra, tendo 40 braças de terra, de norte a sul, e 24 de largo. Situado nas proximidades do forte das Cinco Pontas, correndo para a estrada que vai para Afogados ${ }^{36}$.

Renovados os empenhos dos frades em cristianizar e domesticar os índios, os trabalhos de catequese aconteceram nas proximidades da cidade de Olinda e vila do Recife. Pregavam em engenhos de açúcar e fazendas para senhores e escravos; realizavam descimentos de indígenas do interior para missões fixadas no entorno imediato das povoações atlânticas ${ }^{37}$. O itinerário dos missionários, em busca de silvícolas sertanejos, duravam entre seis meses a um ano, caminhando a pé, rompendo matos, padecendo de fome, sede, perigos $e$ trabalho $^{38}$.

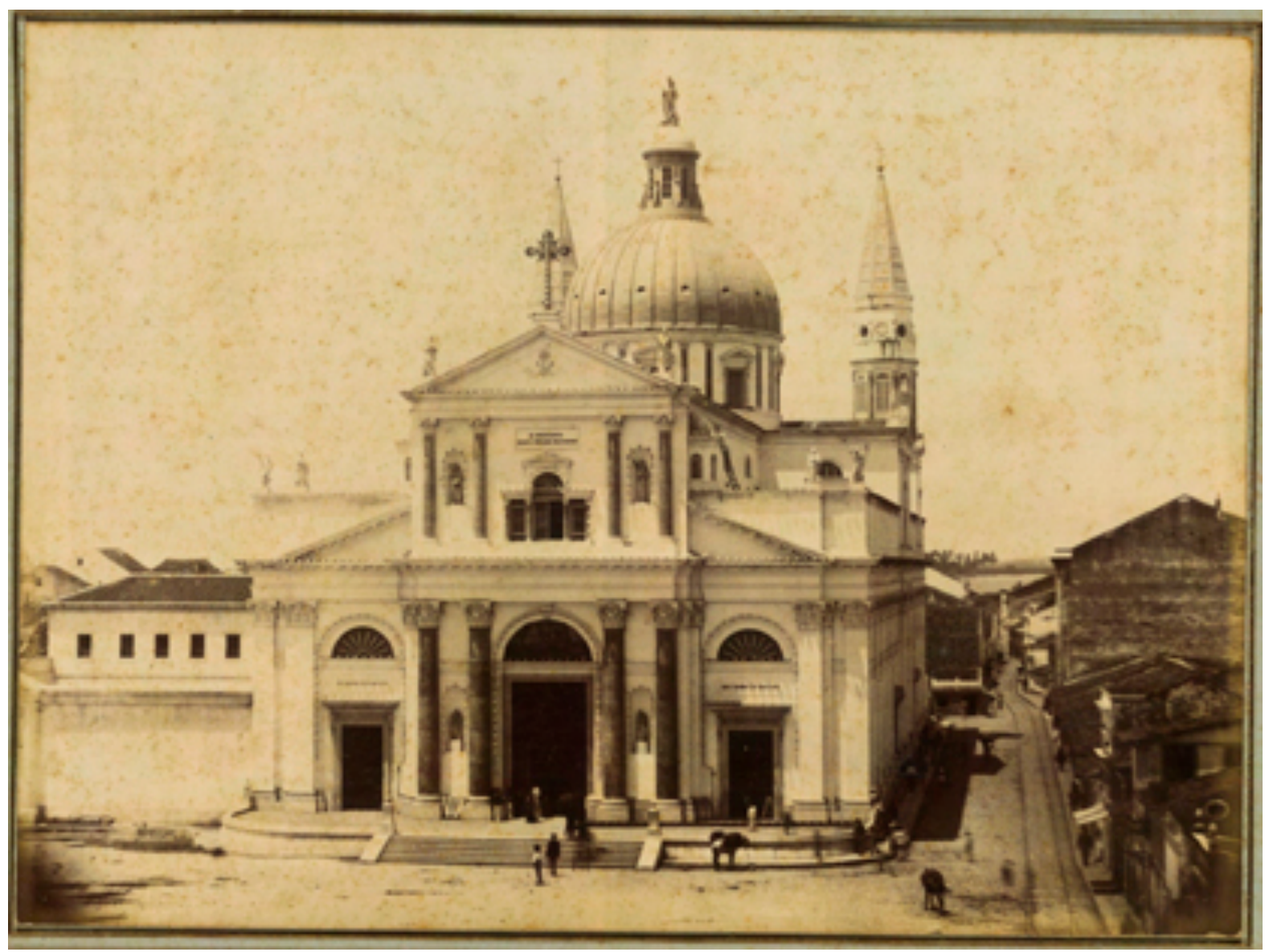

Figura 60 - Igreja Nossa Senhora da Penha de França, em 1880. Foto disponível em http://www.fbn.br. Acesso em 12/03/2010.

\footnotetext{
${ }^{36}$ TINOCO, Jorge Eduardo Lucena. Conservação da Basílica da Penha: proposta de tombamento. Recife, CECI, 2006. p. 09. Disponível em www.ceci-br.org. Acesso em 14.05.2010.

${ }^{37}$ PRIMERIO, P.Fr. Fidelis M. de. Capuchinhos em Terras de Santa Cruz..., Opus cit., p. 56.

${ }^{38}$ PRIMERIO, P.Fr. Fidelis M. de. Capuchinhos em Terras de Santa Cruz..., Opus cit., p. 57.
} 
A pouca praticidade dos descimentos fez com que o superior capuchinho, frei Cirilo de Mans, designasse para os sertões das capitanias de Pernambuco e Paraíba os evangelizadores frei Martinho de Nantes, frei Teodoro de Lucé ${ }^{39}$, frei Anastácio de Audierne e frei Francisco Domfront. O primeiro e os últimos citados erigiram aldeamentos missioneiros às margens do rio São Francisco (cerca de cem léguas da capital pernambucana). Tais missões, conhecidas como Rodelas, influenciaram dentro dos moldes coloniais, a nação de índios Cariris.

Os frades franceses, durante sua atuação nas reduções sanfranciscanas (1670 -1686), segundo dados do Arquivo Histórico Ultramarino de Portugal, fundaram sete aldeamentos missioneiros: Porcá, Araxá, Vargem, Pambú, Uracapá e Cavalo e Pacatuba ${ }^{40}$. Reunir índios para difundir a fé católica constituiu a principal meta dos assentamentos, entretanto, muitos portugueses habitantes dos arredores se beneficiaram dessas comunidades: o fruto da missão não se limitou aos próprios índios, os portugueses também se beneficiaram consideravelmente, tanto no temporal como no espiritual ${ }^{41}$.

Partindo para sua missão de Uracapá, Martinho de Nantes relatou sua chegada à missão de Pambú. Encontrou uma capela, dedicada a Santo Antônio, construída em taipa por portugueses $^{42}$. O engenheiro Henrique Halfeld, em seu Atlas e Relatório Concernente a Exploração do Rio São Francisco, desde a Cachoeira da Pirapora até o Oceano Atlântico ${ }^{43}$, elaborado em 1860, por ordens do imperador D. Pedro II, representou em um mapa a forma adquirida pelo aglomerado de Pambú [figura 61].

\footnotetext{
${ }^{39}$ Segundo frei Fidelis de Primerio, Teodoro de Lucé entrou na Ordem dos Capuchinhos em 1656, foi superior da Penha, em Pernambuco, sucedendo o padre Cirilo. Catequizou os cariris e faleceu, de volta para Europa, em 1686. Foi missionário da aldeia da Paraíba, na qual deve ter principiado seu trabalho. Em seguida, substituiu o frei Anastácio d'Audierne na aldeia dos aramus, proximo ao rio São Francisco, provavelmente onde hoje seria Traipu - AL ou São Pedro do Porto da Folha - AL.

${ }^{40}$ AHU, Bahia, Doc. 344 apud POMPA, Maria Cristina. Religião como tradução..., Opus cit., p. 306.

${ }^{41}$ MARTINHO DE NANTES, padre O.F.M. Cap. Relação de uma missão no Rio São Francisco: relação sucinta e sincera da missão do padre Martinho de Nantes..., Opus cit., p. 22.

${ }^{42}$ MARTINHO DE NANTES, padre O.F.M. Cap. Relação de uma missão no Rio São Francisco: relação sucinta e sincera da missão do padre Martinho de Nantes..., Opus cit., p. 35.

43 HALFELD, Henrique Guilherme Fernando. Atlas e relatório concernente a exploração do rio São Francisco desde a cachoeira da Pirapora até o oceano Atlântico. Levantado por ordem do governo de S.M.I. o Senhor D. Pedro II. Em 1852, 1853 e 1854. Rio de Janeiro, 1860.
} 


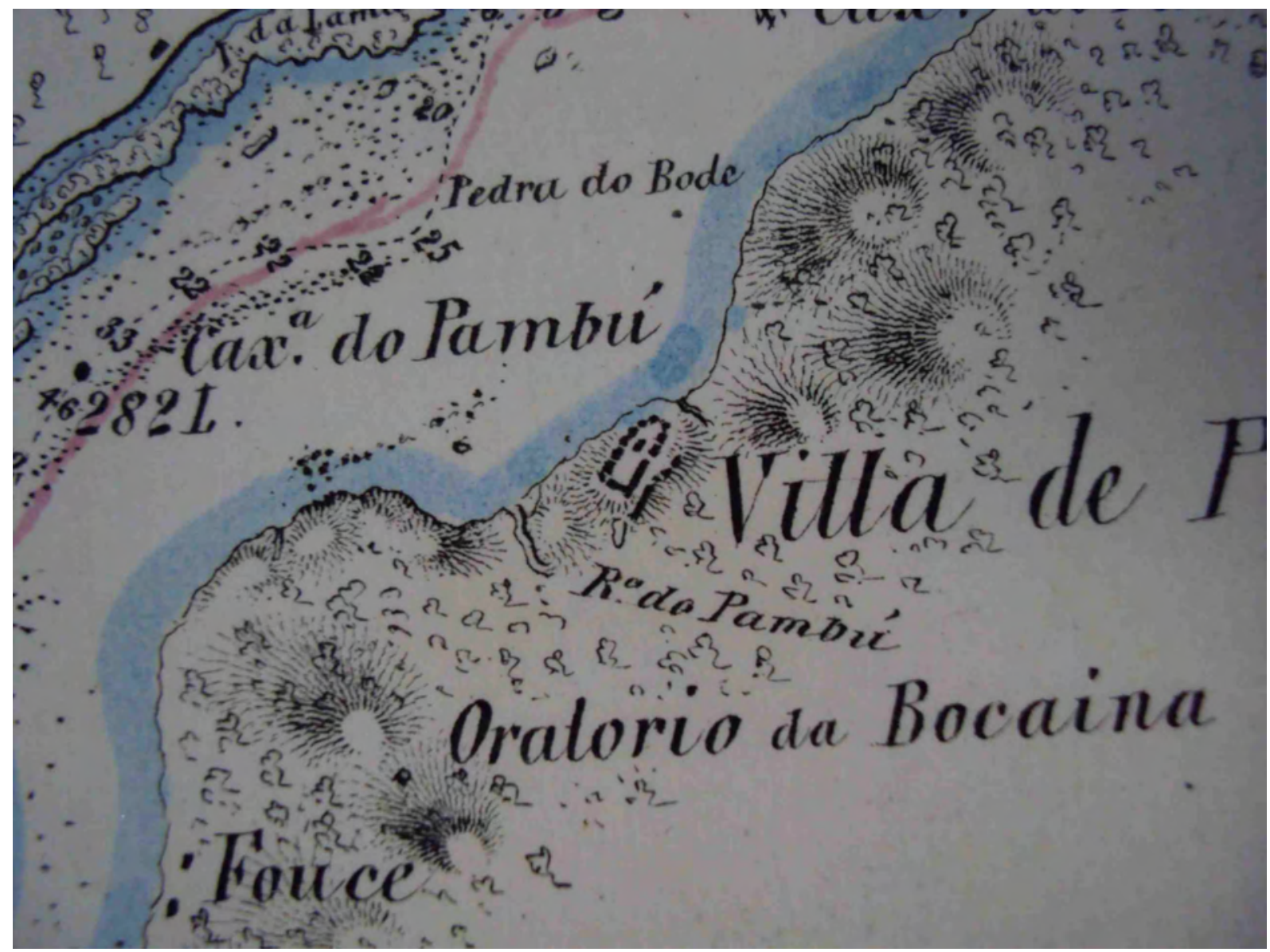

Figura 61 - Villa de Pambú. In HALFELD, Henrique Guilherme Fernando. Atlas e relatório concernente a exploração do rio São Francisco desde a cachoeira da Pirapora até o oceano Atlântico. Levantado por ordem do governo de S.M.I. o Senhor D. Pedro II. Em 1852, 1853 e 1854. Rio de Janeiro, 1860. Mapa 23.

Analisando a imagem da figura 61, avaliamos a predominância de um traçado regular - figura trapezoidal - com o casario dos índios circundando a igreja, notadamente instalada em seu centro. Centro de autoridade eclesiástica e temporal sobre os subjugados. Mesmo sem encontrar relatos precisos acerca da evolução urbana do aldeamento de Pambú, aludimos que a ordem geométrica do núcleo resultou das exigências da catequese. A descrição de frei Martinho de Nantes é deveras esclarecedora sobre esta especificidade: uma república não de pode governar sem leis penais; razão pela qual eu as estabeleci, sempre muito humanas, algumas suficientemente eficazes para sustentar os fracos nos seus deveres para punir os culpados ${ }^{44}$. Acrescentou o religioso:

\footnotetext{
${ }^{44}$ MARTINHO DE NANTES, padre O.F.M. Cap. Relação de uma missão no Rio São Francisco: relação sucinta e sincera da missão do padre Martinho de Nantes..., Opus cit., p. 39.
} 
Como os encontrei mais animais do que homens na sua maneira de viver, apliquei-me, primeiramente, a formar pouco a pouco, uma vida racional e civil, falando-lhes muitas vezes, em discursos de todos os dias, do que se praticava entre pessoas policiadas, revelando pelos pormenores, segundo o alcance de seu espírito e de seu estado, a utilidade da vida civil, o que eles aprovaram muito na sua percepção, e, ao contrario, a desordem e a infelicidade dos que viviam sem lei e sem governo, tornando tudo acessível ao seu entendimento, em face da sua própria experiência ${ }^{45}$. [grifo nosso].

Chegando na missão de Uracapá ou Aracapá, Martinho de Nantes foi recebido por portugueses e índios nativos. Alí, após um mês de estadia, todos labutaram na edificação da igreja, em madeira e barro, coberta por uma espécie de palha, mas tudo muito agradável ${ }^{46}$. A missão se instalou a uma légua do atual município de Orocó-PE e quatro léguas do arraial de Nossa Senhora da Assunção. Os resultados da doutrinação pareciam lentos, mas garantiram que todos os habitantes do rio teriam muita alegria com a minha presença (...) comecei então, em nome de Nosso Senhor, no fim do mês, a chamar os índios para a igreja, ao som de um pequeno sino. Vieram sem demora. É de supor que a curiosidade os atraísse mais que a devoção $o^{47}$. Progressivamente o aldeamento almejou novos edifícios, em função do aumento da catequese. Foram construídas uma nova igreja e uma casa para o religioso, dessa vez, supomos, que em alvenaria e telha cerâmica, uma e outra mais bonitas e mais cômodas do que as anteriores ${ }^{48}$, conclui o capuchinho relator.

Efêmero regozijo obtiveram índios e frades franceses. A população de neófitos e, igualmente suas terras, estavam ameaçadas por fazendeiros de gado da região, principalmente, os da Casa da Torre.

Conhecido como inimigo das Missões ${ }^{49}$, Francisco Dias d'Ávila para fortalecer o seu poderio, formado por currais de reses e imensos domínios territoriais, afrontou a Igreja e as

\footnotetext{
${ }^{45}$ MARTINHO DE NANTES, padre O.F.M. Cap. Relação de uma missão no Rio São Francisco: relação sucinta e sincera da missão do padre Martinho de Nantes..., Opus cit., p. 08.

${ }^{46}$ MARTINHO DE NANTES, padre O.F.M. Cap. Relação de uma missão no Rio São Francisco: relação sucinta e sincera da missão do padre Martinho de Nantes..., Opus cit., p. 38.

${ }^{47}$ MARTINHO DE NANTES, padre O.F.M. Cap. Relação de uma missão no Rio São Francisco: relação sucinta e sincera da missão do padre Martinho de Nantes..., Opus cit., p. 37 e 38.

${ }^{48}$ Idem. Ibidem., p. 49.

${ }^{49}$ Idem. Ibidem., p. 93.
} 
autoridades eclesiásticas das missões e, de reboque, enfrentou a Coroa portuguesa por pensar que a terra era sua propriedade. Olvidou o criador de gado que todo o chão da colônia pertencia à Ordem de Cristo. A contenda entre a Casa da Torre e religiosos iniciou devido ao...

(...) interesse de alguns particulares, que haviam colocado seu gado nas terras dos índios, sendo combatido por alguns missionários, que eles próprios haviam chamado mais para a segurança do seu gado que pelo zelo da conversão dos índios, como os acontecimentos nos fizeram compreender, atiraram-se contra nós e empregaram todos os meios possíveis para nos $\operatorname{afastar}^{50}$.

Esqueceram os fazendeiros do alvará régio relativo à doação de uma légua em quadra para os índios reduzidos. Hey por bem e mando que a cada Missão se dê uma legoa em terra, em quadra para a sustentação dos Índios e Missionários ${ }^{51}$. Restringia a lei às reduções compostas de, no mínimo, cem casais de nativos. A ordem real ainda dizia que as terras não deveriam ser arbitradas por sesmeiros ou donatários, advertindo-se que para cada Aldea e não para os Missionários mando dar esta terra, porque pertence aos Índios, e nam a elles ${ }^{52}$.

Usurpando os mandatos de Portugal, Francisco Dias D’Ávila penetrou os rincões dos sertões do rio São Francisco, havia senhoriado todas as fazendas, que chamavam de curralo, dos dois lados do rio, numa extensão de trinta léguas, depois de haver matado os donos e seus negros, como já informei, em um número de oitenta e cinco, fazendo todos os dias uma grande matança de gado ${ }^{53}$. Atravessou os domínios de seu aliado de conquista, Domingos Afonso Mafrense, no Piauí, chegando ao território dos Pastos Bons, no Maranhão.

Fatigado pelas desavenças, os catequizadores dos índios cariris do rio São Francisco solicitaram ajuda à Coroa e as autoridades coloniais localizadas na cidade de Salvador. Disposto a caminhar até a capital da colônia, frei Martinho de Nantes viajou para lá no intuito de solucionar os entraves envolvendo a posse da terra, as lutas e a religiosidade dos nativos.

\footnotetext{
${ }^{50}$ MARTINHO DE NANTES, padre O.F.M. Cap. Relação de uma missão no Rio São Francisco: relação sucinta e sincera da missão do padre Martinho de Nantes..., Opus cit., p. 40.

51 “Informação geral da Capitania de Pernambuco, 1749". In Annaes da Bibliotheca Nacional. Volume XXVIII. Ano 1906. Rio de Janeiro, Officina de Artes Graphicas da Bibliotheca Nacional, 1908. p. 393.

52 “Informação geral da Capitania de Pernambuco, 1749”. In Annaes da Bibliotheca Nacional...Opus cit., p. 393

${ }^{53}$ MARTINHO DE NANTES, padre O.F.M. Cap. Relação de uma missão no Rio São Francisco: relação sucinta e sincera da missão do padre Martinho de Nantes..., Opus cit., p. 52.
} 
Em certas ocasiões conseguiu o aval positivo do governo, em outras recebeu a oposição dos representantes do rei, desejosos de dilatar os domínios de Portugal através do devassamento do território sertanejo, cumprir, de fato, os desígnios colonizadores.

Fui visto como um inimigo e não como um missionário, visto que me opunha aos bens do Estado e às ordens, que o rei havia dado, para povoar as terra do rio para a subsistência das cidades da Bahia e Pernambuco. Foi assim que Dias me apontou. Dizia, também, que eu tinha grande crédito junto aos índios e que se podia temer que me valesse deles, em alguma ocasião, contra o próprio Estado ${ }^{54}$.

Os capuchinhos franceses permaneceram em suas missões até o surgimento de crises diplomáticas entre Roma e Lisboa. Frei Fidelis Primerio endossou que os distúrbios começaram quando o trono lusitano negou o acesso às suas conquistas à religiosos apostólicos não portugueses e dependentes da Congregação da Propaganda Fide ${ }^{55}$. Exigia a Coroa dos missionários, antes de partirem para suas designações, reconhecimento dos direitos da soberania lusitana em seus domínios do ultramar, através de um voto de fidelidade ${ }^{56}$. Portugal pretendia o verdadeiro monopólio das missões das Índias.

Soma-se a estas circunstâncias o falecimento da regente, em 1683, D. Maria Izabel de Sabóia, cuja origem francesa amparou os missionários conterrâneos ${ }^{57}$. A partir de então, não se tolerou religiosos franceses na colônia, cujo motivo basilar se atrelou em questões geopolíticas. Para a Metrópole os estrangeiros, sem o prévio voto de fidelidade, seriam uma ameaça às suas estratégias colonizadoras. A solução foi deportar os capuchinhos franceses opostos ao juramento. Relatou frei Martinho de Nantes:

A Corte de Portugal, cheia de desconfiança, acrescentou circunstâncias de tal forma onerosas, que a Sagrada Congregação proibiu o juramento. Assim, todos os nossos missionários, que haviam vindo da França, em número de oito, foram obrigados, como eu mesmo, a deixar nossas missões. A obediência me convocou em primeiro lugar; os outros vieram depois ${ }^{58}$.

\footnotetext{
${ }^{54}$ MARTINHO DE NANTES, padre O.F.M. Cap. Relação de uma missão no Rio São Francisco: relação sucinta e sincera da missão do padre Martinho de Nantes..., Opus cit., p. 61.

${ }_{55}^{5}$ PRIMERIO, P.Fr. Fidelis M. de. Capuchinhos em Terras de Santa Cruz..., Opus cit., p. 77.

${ }^{56}$ PRIMERIO, P.Fr. Fidelis M. de. Capuchinhos em Terras de Santa Cruz..., Opus cit., p. 77.

${ }^{57}$ PRIMERIO, P.Fr. Fidelis M. de. Capuchinhos em Terras de Santa Cruz..., Opus cit., p. 80.

${ }^{58}$ MARTINHO DE NANTES, padre O.F.M. Cap. Relação de uma missão no Rio São Francisco: relação sucinta e sincera da missão do padre Martinho de Nantes..., Opus cit., p. 97.
} 
Os aldeamentos missioneiros situados às margens do rio São Francisco ficaram, com a deportação dos frades franceses, sob a tutela dos carmelitas descalços ${ }^{59}$. A partir do início dos Setecentos foram encarregados os capuchinhos italianos de cristianizar e domesticar os cariris sanfranciscanos. A obra dos frades italianos expandiu-se. Não se limitou às áreas ribeirinhas do "Velho Chico", estendendo-se para os confins das capitanias do Ceará, Paraíba e Rio Grande do Norte. A experiência brasileira para os missionários franceses esteve carregada de realismo, permaneceu na memória a definição do Brasil como um exílio e um retiro para diversos criminosos, condenados seja pelo Tribunal da Inquisição, seja pela justiça comum. Esse país se encheu assim de mais habitantes viciosos do que de outros, pois que ali se vive com uma independência e libertinagem e os crimes raramente são punidos ${ }^{60}$.

Em 1705, os capuchinhos italianos iniciaram sua obra evangelizadora nos sertões nordestinos. Diferentemente da postura adquirida pelos seus companheiros de ordem franceses, o rei de Portugal aprovou tais missionários pelas suas virtudes e labor demonstrados ${ }^{61}$.

O trabalho de catequese a partir de então foi dividido em suas prefeituras: Bahia ${ }^{62}$ e Pernambuco. Agrupadas na jurisdição baiana estavam as missões: Irapoá, Ilha de São Felix ou Cavalo, Pambú, Vargem, Araxá, Rodelas, São Pedro, Vacapará, Pacatuba e Rio de Contas ${ }^{63}$. Os designados para converter os catecúmenos aos dogmas da Igreja Católica vieram ou de Angola ou enviados diretamente pela Propaganda Fide. A tabela 04 é uma relação sucinta dos aldeamentos capuchinhos no sertão da capitania da Bahia de Todos os Santos.

\footnotetext{
${ }^{59}$ HORNEART, Eduardo. História da Igreja no Brasil..., Opus cit., p. 66.

${ }^{60}$ HORNEART, Eduardo. História da Igreja no Brasil..., Opus cit., p. 55.

${ }^{61}$ PRIMERIO, P.Fr. Fidelis M. de. Capuchinhos em Terras de Santa Cruz..., Opus cit., p. 143.

${ }^{62}$ Frei Fidelis Primerio indica a origem da prefeitura da Bahia, criada pela Propaganda Fide, sob decreto de 29 de fevereiro de 1712. Como gestor foi encaminhado frei Miguel Anjo de Nápoles. Ver PRIMERIO, P.Fr. Fidelis M. de. Capuchinhos em Terras de Santa Cruz..., Opus cit., p. 147.

${ }^{63}$ PRIMERIO, P.Fr. Fidelis M. de. Capuchinhos em Terras de Santa Cruz..., Opus cit., p. 149.
} 


\begin{tabular}{|c|c|c|c|}
\hline MISSÃO & ORAGO & $\begin{array}{l}\text { POPULAÇÃO } \\
\text { DE ÍNDIOS }\end{array}$ & $\begin{array}{l}\text { CAPUCHINHO } \\
\text { RESPONSÁVEL }\end{array}$ \\
\hline Irapoá & Santo Antônio & 200 & $\begin{array}{c}\text { Fr. Domingos de } \\
\text { Brescia }\end{array}$ \\
\hline São Félix ou Cavalo & São Félix & 200 & $\begin{array}{c}\text { Fr. Domingos de } \\
\text { Brescia }\end{array}$ \\
\hline Pambú & $\begin{array}{l}\text { Nossa Senhora da } \\
\text { Conceição }\end{array}$ & 360 & $\begin{array}{c}\text { Fr. Ângelo Maria de } \\
\text { Chiavari }\end{array}$ \\
\hline Vargem & Beato Serafim & 320 & Fr. Vitalino de Milão \\
\hline Araxá & Nossa Senhora de Belém & 260 & $\begin{array}{l}\text { Fr. Domingos de } \\
\text { Cesena }\end{array}$ \\
\hline Rodelas & São João Batista & 600 & $\begin{array}{c}\text { Fr. Bernardino de } \\
\text { Scurcola }\end{array}$ \\
\hline São Pedro & São Pedro & 320 & $\begin{array}{c}\text { Fr. Francisco Maria } \\
\text { de Todi }\end{array}$ \\
\hline Vacapará & São Francisco & 260 & $\begin{array}{l}\text { Fr. Simplício de } \\
\text { Bórgia }\end{array}$ \\
\hline Pacatuba & São Félix & 466 & Sem informação \\
\hline Rio de Contas & $\begin{array}{l}\text { Nossa Senhora dos } \\
\text { Remédios }\end{array}$ & 360 & $\begin{array}{c}\text { Fr. Bernardino de } \\
\text { Milão }\end{array}$ \\
\hline
\end{tabular}

Tabela 04 - Missões dos capuchinhos italianos na jurisdição da prefeitura da Bahia. Elaborada pelo autor segundo Arquivo da Propaganda Fide, Ata $\mathrm{n}^{\circ}$ 1742, fol. 77 Apud PRIMERIO, P.Fr. Fidelis M. de. Capuchinhos em Terras de Santa Cruz..., Opus cit., p. 152; MAPPA Geral de todas as Misoens ou Aldeias de Gentio mando que estão situadas nesta Capitania da Bahia, e nas mais q' comprehende o seo governo com os nomes delas, Vilas de que são termo, Freguezias a q' pertencem, qualidade dos Missionários q' as administrão, Orago das Igrejas q' nelas existem e Novas Villas e Paroquias a q' são elevadas.

Não raro se viram os frades italianos empenhados em reformar e construir novas igrejas, agrupar índios em casas dispostas regularmente para facilitar a domesticação dos mesmos, além da tentativa de organizá-los nos moldes da vida civil-portuguesa. Acresce à essas atividades a necessidade de comunicação com outros aldeamentos e núcleos urbanos para abastecimento de alimento, velas e incensos para os ritos sacros e panos para confecção de roupas. Por isso, se interessavam os missionários em percorrer o território sertanejo, abrindo estradas, para tirá-los da exclusão em que viviam, buscavam um lugar ao sol na rede urbana sertaneja.

O aldeamento da missão da Ilha de São Félix ou Cavalo é particularmente curioso. Não temos notícia do atual estado da igreja desta redução [figuras 62] dedicada a São Félix e cujo religioso administrador foi frei Domingos de Brescia. Analisando velhas fotografias, 
tomadas na década de oitenta do século passado, localizadas no arquivo da Fundação do Patrimônio Histórico e Artístico de Pernambuco, FUNDARPE, avaliamos que para aquele sítio (devido o porte da capela, se comparada com outras da mesma época e região) migraram portugueses moradores daquelas paragens para ouvir os sermões católicos. Com as poucas informações coletadas em fontes secundárias, o desenho da fachada principal [figura 63] abriga características clássicas como simetria, ordem e harmonia. Ela é formada por um só plano, ladeado por duas pilastras e dois muros, idênticos, semelhantes a contrafortes. Na parte superior do alçado há três imagens assentadas em pedestais que desenvolvem uma balaustrada.

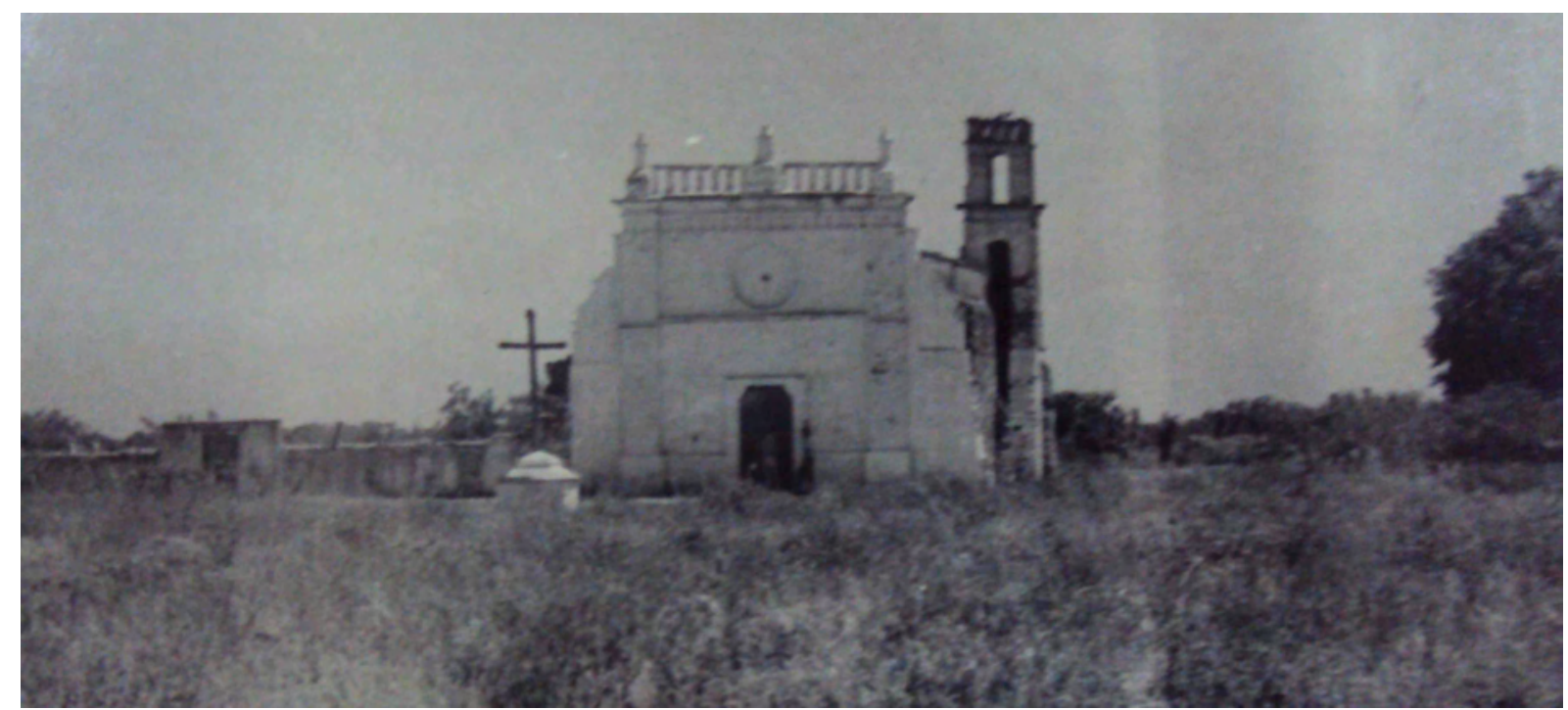

Figura 62 - Capela da missão da Ilha de São Félix ou Cavalo, cuja responsabilidade estava aos cuidados de frei Domingos de Brescia. Foto fornecida pela FUNDARPE - PE.

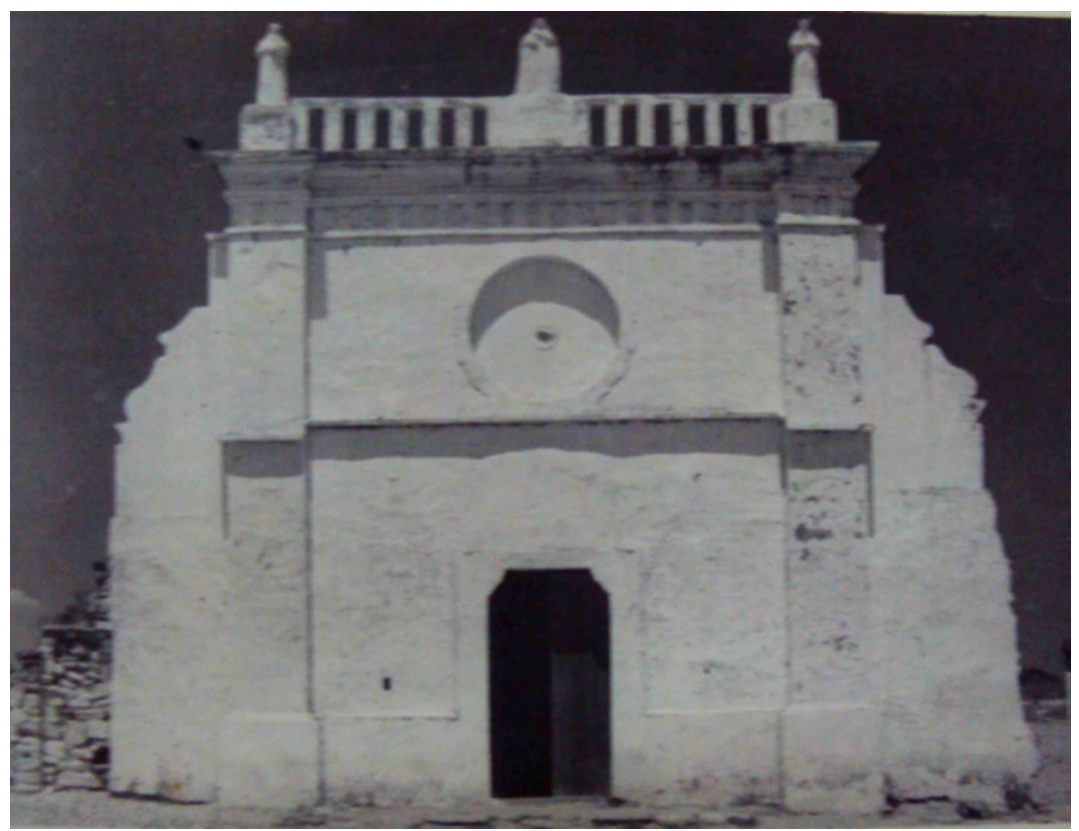

Figura 63 - Vista da fachada principal da capela dedicada a São Félix. Foto fornecida pela FUNDARPE - PE. 
A planta do edifício [figura 64] apresenta uma nave central, altar mor, sacristia e um ambiente fechado, não se sabe qual função este espaço encerrou. Interligando o lado direito da igreja há um cemitério, elemento comum em aldeamentos doutras ordens religiosas. A localização da torre sineira - lado esquerdo, parte posterior - revela adoção formal de outros edifícios religiosos europeus, demonstrando que o autor da obra possuía apuro técnico e conhecimento artístico, quiçá dos tratados de arquitetura. Hipótese que pode ser fundamentada pelo tipo de formação religiosa que os capuchinhos obtinham antes de sua ordenação e designação missionária. Se não estudavam nas universidades ou centros especializados da época, eram enviados para o Seminário de Santo Antônio dos Olivais ${ }^{64}$, em Portugal. Vale notar que, adotando a mesmo partido arquitetônico, no que diz respeito à localização da torre sineira, temos a primeira igreja da Ordem Capuchinha, localizada na vila do Recife e dedicada à Nossa Senhora da Penha de França [figura 65].

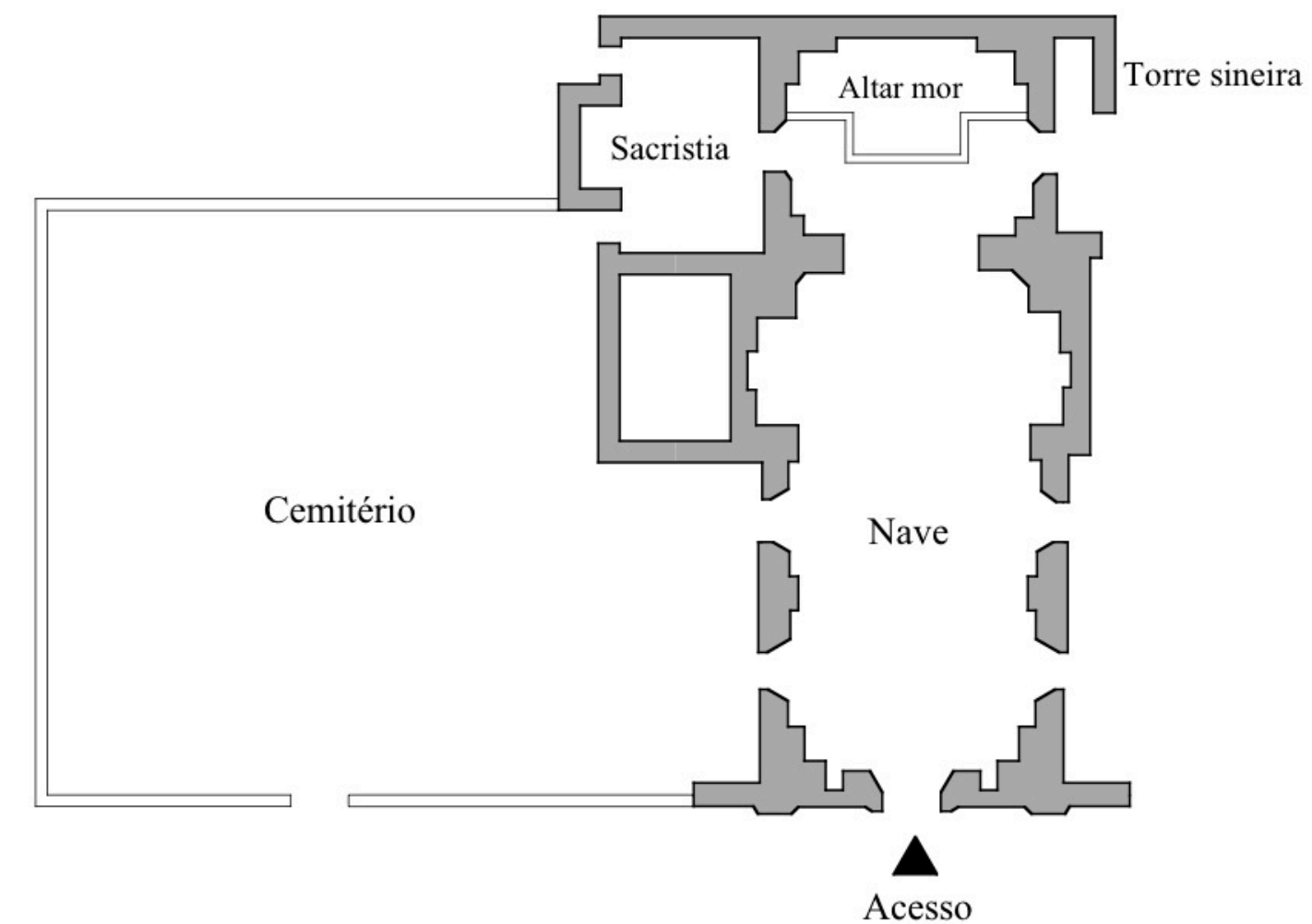

Figura 64 - Planta da igreja da missão capuchinha da ilha de São Félix. Desenho do autor sobre planta elaborada pela FUNDARPE-PE. Desenho sem escala.

\footnotetext{
${ }^{64}$ SILVA, Jacionira Coelho. Arqueologia no médio São Francisco: indígenas, vaqueiros e missionários. Tese de doutorado. Recife, UFPE, 2003. P. 129.
} 


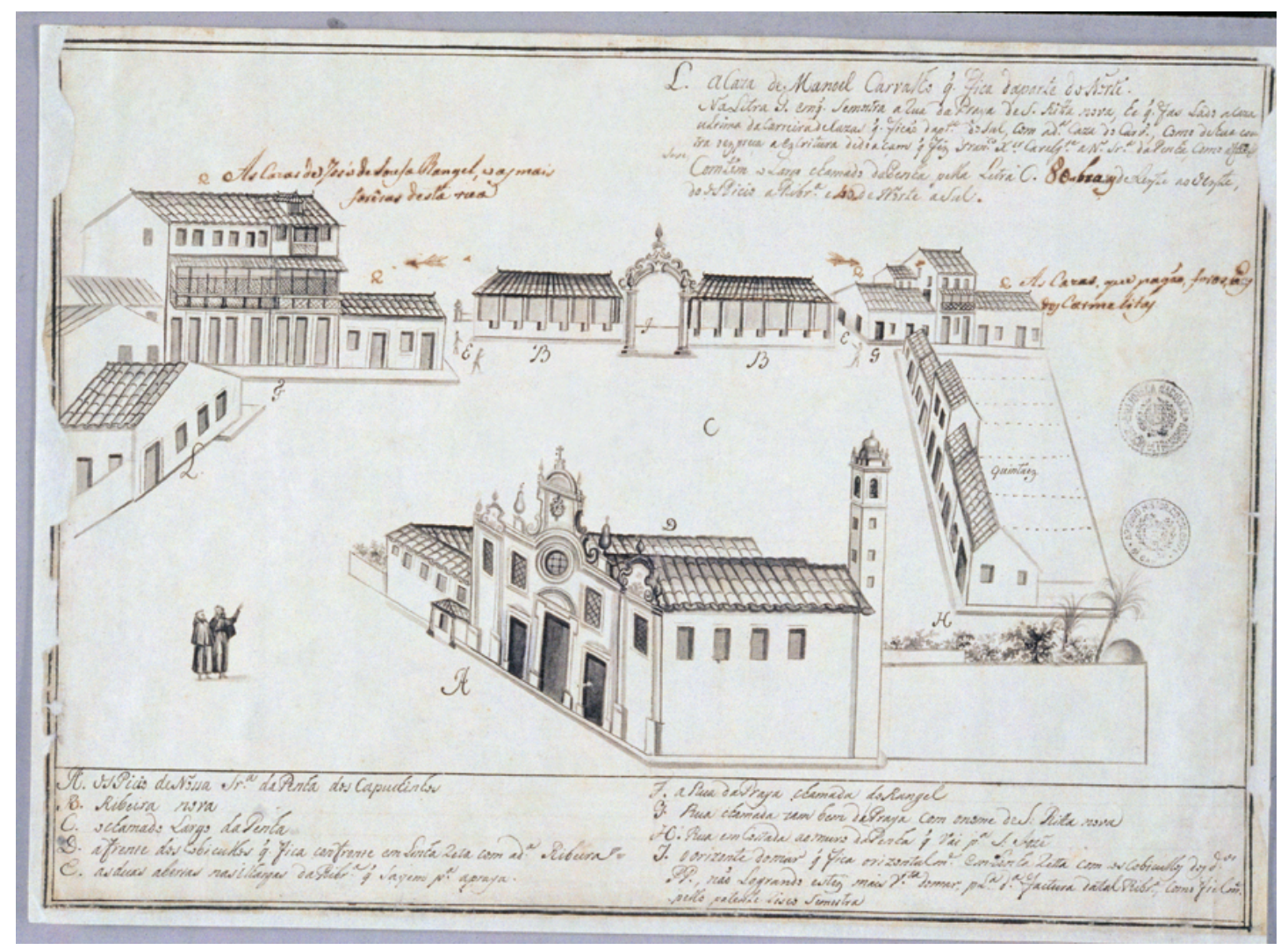

Figura 65 - A igreja dedicada a Nossa Senhora da Penha de França aparece indicada pela letra A. Imagem retirada do CD - ROM Vilas e imagens do Brasil colonial.

É provável que a igreja da missão da ilha de São Félix tenha sido construída após 1707, as obras pesquisadas não nos dão a indicação certa. Deduzimos isso porque sua implantação [figura 66] cumpre os rigores estabelecidos pelas Constituiçõens Primeyras do Arcebispado da Bahia, redigidas em 1707 e publicadas em 1719. Murillo Marx demonstrou que este código eclesiástico estava atento à uniformidade e clareza dos ritos necessários à Contra-Reforma definidos pelo Concilio de Trento (...) e que - unida a Igreja aos estados nacionais que se formavam na Europa, como no reino português - passavam a representar normas aceitas pelo poder temporal e também oficiais ${ }^{65}$. Em seu livro quarto, no título sétimo, constituição 687, a normativa canônica reza:

Conforme o direito Canônico, as igrejas se devem fundar, e edificar em lugares decentes, e acommodados, pelo que mandamos, que havendo-se de edificar de novo alguma igreja parochial em nosso Arcebispado, se edifique em sitio alto, e lugar decente, livre da humanidade, e desviado, quanto dor possível, de lugares immundos, e sórdidos, e de casas particulares, e de

\footnotetext{
${ }^{65}$ MARX, Murillo. Cidades no Brasil, terra de quem? São Paulo, Edusp, 1991. p. 20.
} 
outras paredes, em distancia que possão andas as Procissões ao redor dellas, e que se faça em tal proporção, que não somente seja capaz dos fregueses todos, mas ainda de mais gente de fora, quando concorrer ás festas, e se edifique em lugar povoado, onde estiver o maior numero de freguezes. E quando se houver de fazer, será com licença nossa: e feita vestoria, iremos primeiro, ou outra pessoa de nosso mando, levantar Cruz no lugar, aonde houver de estar a Capella maior, e demarcará o âmbito da Igreja, e adro della ${ }^{66}$.

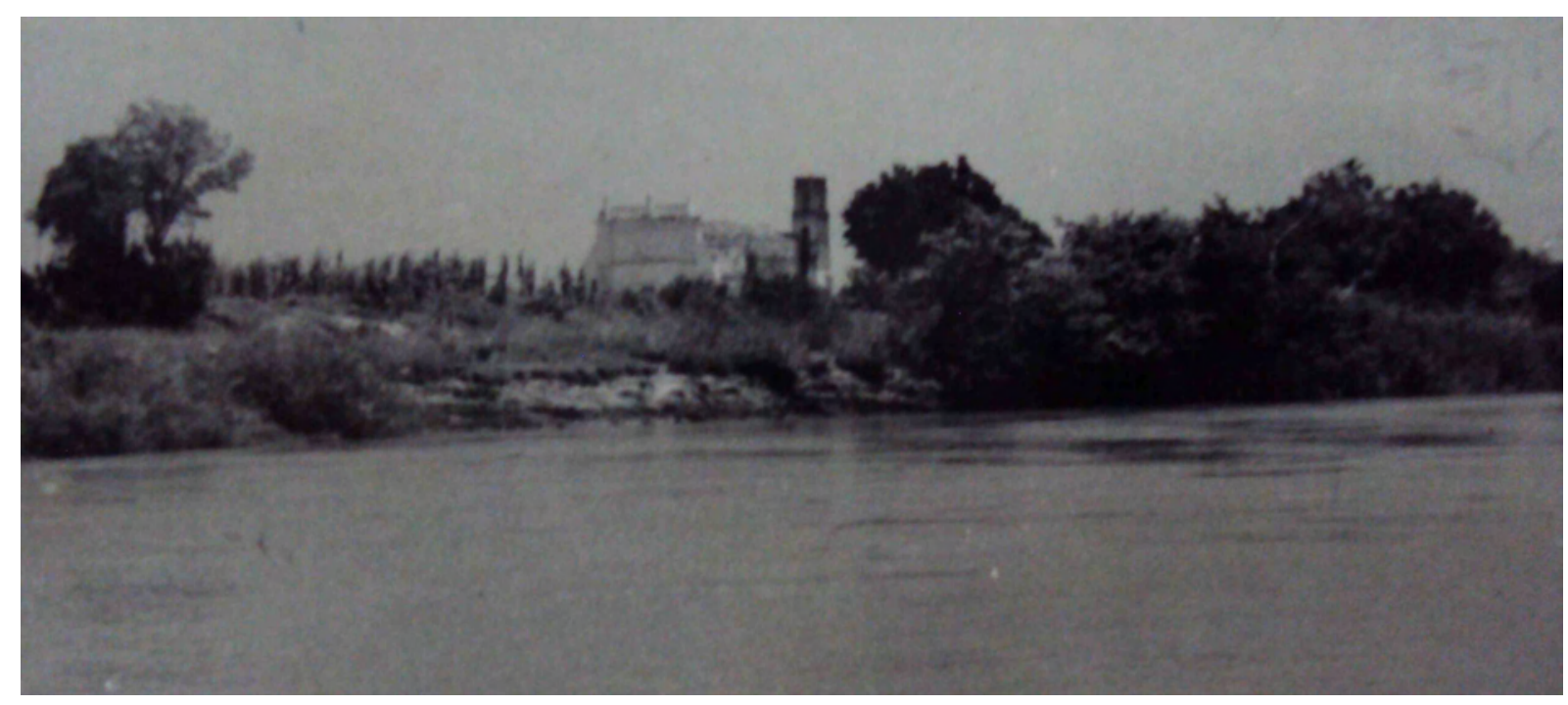

Figura 66 - Implantação da igreja de São Félix da missão da ilha do Cavalo. Vista desde o rio São Francisco. Foto cedida pela FUNDARPE-PE.

Ator que merece atenção nessas missões, coordenadas pela prefeitura da Bahia, é frei Apolônio de Todi. Conhecido como um pregador inabalável por catequizar índios e distribuir sacramentos, desde 1785, aos sertanejos de Jeremoabo, Curral de Bois, Colégio, São Pedro, Natuba, Canabrava, Paratinga, Barcelos, Massacará, entre outras localidades do interior das capitanias de Bahia e Sergipe ${ }^{67}$. O seu feito mais singular foi Monte Santo, chamado por Euclides da Cunha de lugar lendário ${ }^{68}$.

Em Monte Santo, o capuchinho de Todi moldou a religiosidade do homem do sertão através da ereção, no alto de um monte, de uma capela percorrida pelos passos da via sacra.

\footnotetext{
${ }^{66}$ CONSTITUIÇÕES Primeyras do Acerbispado da Bahia feitas, e ordenadas pelo ilustríssimo, e reverendíssimo sernhor D. Sebastião Monteiro da Vide, 5 arcebispo do dito Acerbisopado,e do conselho de sua Majestade: propostas, e aceitas em o Synodo Diocesano, que o dito senhor celebrou em 12 de junho do anno de 1707. Introdução e revisão do cônego prebendano Idelfonso Xavier Ferreira. São Paulo, Typ. 2 de dezembro, 1853. $510 \mathrm{p}$.

${ }^{67}$ PRIMERIO, P.Fr. Fidelis M. de. Capuchinhos em Terras de Santa Cruz..., Opus cit., p. 156.

${ }^{68}$ CUNHA, Euclides da. Os sertões. São Paulo, Martin Claret, 2009. p. 178.
} 
Ao longo do trajeto os fiéis são induzidos a pausar diante de pequenas ermidas onde relembram as dores de Cristo em sua subida ao Calvário. Na via sacra sertaneja mesclam a teatralidade barroca - exercida pelas procissões, ladainhas e preces enquanto sobem - com a fé difundida pela Igreja. Poeticamente Euclides da Cunha descreveu Monte Santo:

Amparada por muros capeados; calçada em certos trechos, tendo, noutros como leito, a rocha viva talhada em degraus ou rampeada, aquela estrada branca, de quartzito, onde ressoam, há cem anos, as litanias das procissões da quaresma, e têm passado legiões de penitentes, é um prodígio de engenharia rude e audaciosa. Começa investindo com a montanha, segundo a normal de máximo declive, em rampa de cerca de vinte graus. Na quarta ou quinta capelinha inflecte à esquerda e progride menos íngreme. Adiante, a partir da capela maior - ermida interessantíssima ereta num ressalto da pedra a cavaleiro do abismo, volta à direita, diminuindo de declive até a linha de cumeadas. Segue por esta segundo uma selada breve. Depois se alteia, de improviso, retilínea, em ladeira forte, arremetendo com o vértice pontiagudo do monte, até o Calvário, no alto ${ }^{69}$

A prefeitura de Pernambuco ${ }^{70}$ ficou encarregada dos aldeamentos missioneiros do Piancó, Serra Branca e Brejo na Paraíba; Miranda, Missão Velha, Missão Nova e Araripe no Ceará. Em 1780, segundo Primerio, foram conduzidos religiosos para Monte - Mor o Novo da América (atual Baturité - CE). No Rio Grande do Norte administraram as reduções de Apodi e Mipibú. Observando a Relação das Aldeas, que ha no Districto d'este Governo de Pernambuco e Capitania da Paraíba subgeitos á Junta das Missões d'este Bispado ${ }^{71}$, é incluída a missão do Corima localizada no sertão paraibano. A tabela 05 apresenta um breve resumo das missões capuchinhas realizadas no interior da antiga capitania de Pernambuco. Não encontramos dados referentes à população de nativos catequizados nesses assentamentos de índios.

\footnotetext{
${ }^{69}$ CUNHA, Euclides da. Os sertões. São Paulo, Martin Claret, 2009. p. 179.

${ }^{70}$ Instituída pela Congregação da Propaganda Fide em 1725 desmembrada da Bahia. Ocupou o cargo de primeiro prefeito o frei André de Mornico, vindo de São Tomé, após seis meses de viagem. Ver PRIMERIO, P.Fr. Fidelis M. de. Capuchinhos em Terras de Santa Cruz..., Opus cit., p. 169.

${ }^{71}$ ANNAES da Bibliotheca Nacional. Volume XXVIII. Ano 1906. Rio de Janeiro, Officina de Artes Graphicas da Bibliotheca Nacional, 1908. p. 419 - 422.
} 


\begin{tabular}{|c|c|c|}
\hline MISSÃo & ORAGO & CAPUCHINHO RESPONSÁ VEL \\
\hline Piancó & $\begin{array}{c}\text { Nossa Senhora da Conceição } \\
\text { Nossa Senhora da Penha de } \\
\text { França } \\
\text { Miranda }\end{array}$ & Fr. José de Calvatone \\
Missão Velha & Fr. Carlos de Ferrara \\
Missão Nova & Sem informação & Fr. Joaquim de Veneza \\
Araripe & São João Batista & Sem informação \\
Apodi & São João Batista & Fr. Carlos Maria de Ferrara \\
Mipibú & São José & Fr. Juvenal de Albano \\
Corima & Santa Rita de Cássia (?) & Fr. Félix Maria de Casalmaggiore \\
\hline
\end{tabular}

Tabela 05 - Algumas missões capuchinhas pertencentes à prefeitura de Pernambuco. Elaboração do autor segundo informações encontradas em PRIMERIO, P.Fr. Fidelis M. de. Capuchinhos em Terras de Santa Cruz nos séculos XVII, XVIII e XIX. São Paulo, Livraria Martins, 1942. p. 170 - 171; "Relação das Aldeas, que ha no Districto d'este Governo de Pernambuco e Capitania da Paraíba subgeitos á Junta das Missões d'este Bispado". In ANNAES da Bibliotheca Nacional. Volume XXVIII. Ano 1906. Rio de Janeiro, Officina de Artes Graphicas da Bibliotheca Nacional, 1908. p. 419 - 422.

Catequizando e "amansando" os índios cariris, no vale que leva o nome desta nação, frei Carlos de Ferrara fixou o seu aldeamento, adotando a denominação de Miranda, no lugar que seria o primitivo núcleo da vila Real do Crato, atual Crato - CE [figura 67]. Antes da chegada do capuchinho, provavelmente na década de trinta dos Setecentos, o padre Miguel Couto qualificou o sertão cearense como rodeado de varias Naçoenz de Tapuyas bravos ${ }^{72}$.

Dando um panorama histórico da missão do Miranda, o pe. Antônio Gomes de Araújo mencionou que a colonização efetuada no interior cearense ocorreu através do arrendamento de sesmarias da Casa da Torre. Participaram desta ação Gil de Miranda, capitão Antônio Mendes Lobato e Manuel Rodrigues Airosa do Vale ${ }^{73}$. Estabelecidos tais agentes em suas terras sertanejas, seria necessário povoá-las. Inicialmente com suas fazendas de criação, ou por intermédio dos currais de gado, e , a posteriori, com povoações de índios cristianizados.

72 "DEZCRIPÇÃO do certão do Peauhy Remetida ao Ilmo. e Rmo. Snr. Frei Francisco de Lima Bispo de Pernambuco". In ENNES, Ernesto. As guerras nos Palmares. Rio de Janeiro, Cia. Editora Nacional, 1938. p. 371.

${ }^{73}$ ARAÚJO, pe. Antônio Gomes de. A cidade de frei Carlos. Crato, FFCrato, 1971. Vol 5. p. 65. 


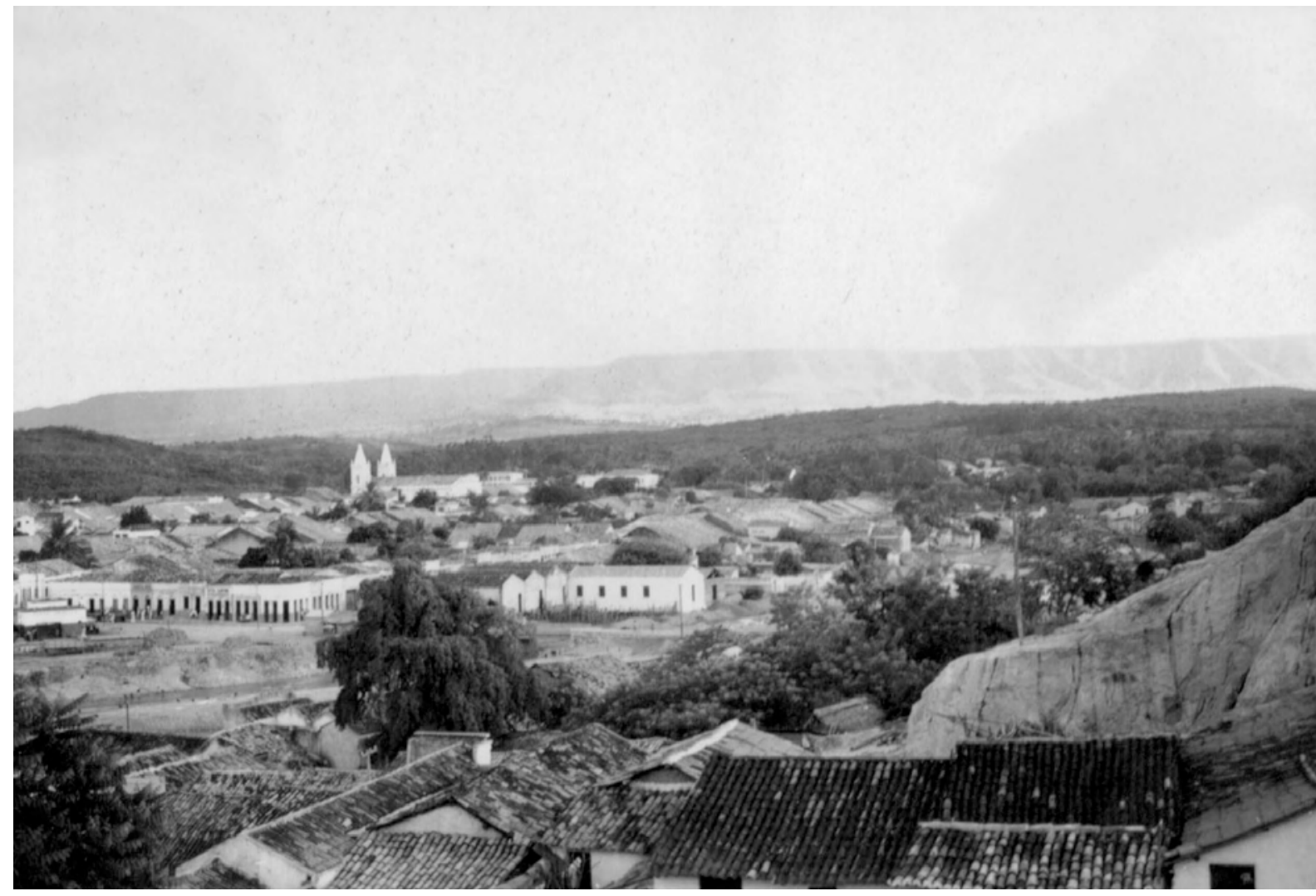

Figura 67 - Panorama da cidade do Crato - CE na década de cinquenta do século passado. Ao fundo vista da Chapada do Araripe. Foto disponível em http://www.ibge.gov.br. Acesso em 01/10/2009.

A fama adquirida de índios guerreiros, os cariris enfrentaram os seus colonos no hinterland cearense através de sucessivas batalhas e saques às herdades. Com intuito de evitar mais assaltos em suas terras, os criadores solicitaram ao bispado de Pernambuco missionários para doutrinar os nativos. Tática já mencionada por frei Martinho de Nantes na sétima década do século XVII: (...) que eles próprios (fazendeiros) haviam chamado (os religiosos) mais para a segurança do seu gado que pelo zelo da conversão dos índios (... $)^{74}$. Reforçando este fato, em 24 de fevereiro de 1716, o Conselho Ultramarino emitiu uma ordem para se conservar os missionários dos Certoins do Ciará, facilitando o progresso das primeiras povoações lá existentes ${ }^{75}$.

Segundo o alvará de 25 de setembro de 1700, os índios detinham as prerrogativas para escolher o sítio do seu futuro aldeamento, desde que sofresse aprovação da Junta das Missões $^{76}$. Os neófitos de frei Carlos de Ferrara se instalaram à beira do rio Salgado, no vale do Miranda. Este sítio respeitava as experiências e os costumes primitivos de caça e pesca dos

\footnotetext{
${ }^{74}$ MARTINHO DE NANTES, padre O.F.M. Cap. Relação de uma missão no Rio São Francisco: relação sucinta e sincera da missão do padre Martinho de Nantes..., Opus cit., p. 40.

${ }^{75}$ PROJETO RESGATE. AHU_ACL_CU_CEARÁ, Cx. 1, D.63.

${ }^{76}$ ANNAES da Bibliotheca Nacional do Rio de Janeiro. Volume XXVIII. Ano 1906. Rio de Janeiro, 1908. p. 380.
} 
índios, por ser arejado e saudável ${ }^{77}$. A suposta empatia, demonstrada pelas autoridades coloniais, visou a prevenção de fugas e revoltas dos catecúmenos da redução.

À semelhança das capelas erguidas nas missões capuchinhas francesas do rio São Francisco, o pequeno templo do aldeamento do Miranda, dedicado à Nossa Senhora da Penha de França, foi elaborado em taipa e coberto com folhas de babaçu, palmeira abundante na região ${ }^{78}$. Em 1737, foi constatado que frei Carlos de Ferrara reformou a ermida da missão, dessa vez em pedra e cal, materiais mais resistentes às intempéries naturais ${ }^{79}$. George Gardner, descrevendo a igreja da vila do Crato, por volta de 1838, disse que está inacabada, já tem toda aparência de ruína ${ }^{80}$. O edifício atual [figura 68] é resultado de reforma realizada em 1862.

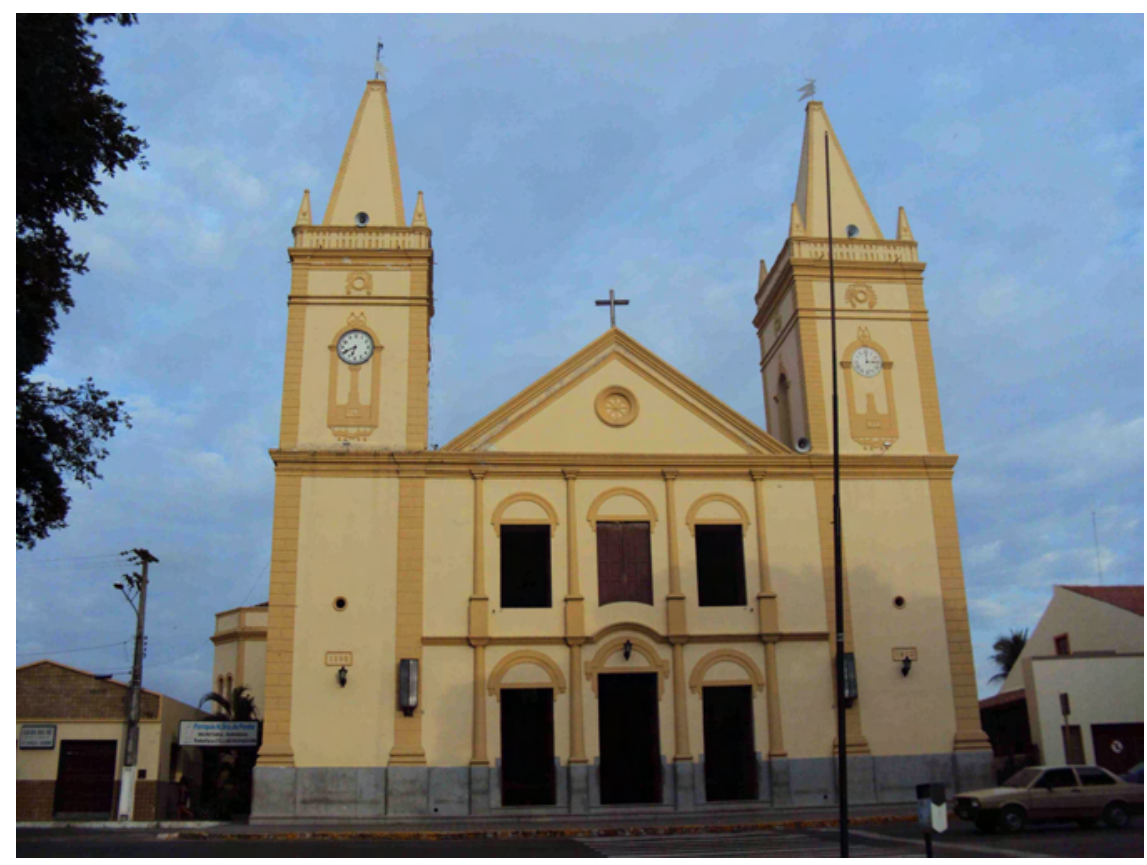

Figura 68 - Igreja matriz do Crato - CE. Orago: Nossa Senhora da Penha de França. Acervo do autor, 2010.

\footnotetext{
${ }^{77}$ SILVA, Jacionira Coelho. Arqueologia no médio São Francisco: indígenas, vaqueiros e missionários. Tese de doutorado. Recife, UFPE, 2003. p. 157.

${ }^{78}$ ARAÚJO, pe. Antônio Gomes de. A cidade de frei Carlos..., Opus cit., p. 73 - 74.

${ }^{79}$ ARAÚJO, pe. Antônio Gomes de. A cidade de frei Carlos..., Opus cit., p. 82.

${ }^{80}$ GARDNER, George. Viagem ao interior do Brasil, principalmente nas províncias do norte e nos distritos do ouro e do diamante durante os anos de 1836-1841. São Paulo, Edusp, 1975. p. 93.
} 


\subsection{2 - Missionários viajantes}

Trilhando o sertão nordestino em suas missões volantes ${ }^{81}$, os capuchinhos italianos, através de seus relatos setecentistas, nos dão um balanço da urbanização do interior do Nordeste. Os religiosos viajantes trilharam pelos velhos caminhos de gado - abertos pelos vaqueiros para tanger as manadas em busca de pasto -, e as vias elaboradas por bandeirantes e sertanistas ávidos de metais preciosos e índios. Com o avanço do tempo, essas rotas evoluíram para estradas coloniais de uso civil. As narrativas dos freis Aníbal de Gênova e Carlos de Sperzia, transcritas por frei Fidelis Primerio ${ }^{82}$, são ricas em pormenores de cunho social, econômico, cultural e religioso.

Frei Aníbal de Gênova iniciou sua peregrinação em 05 de outubro de 1762 finalizando-a um ano depois na vila do Recife. A princípio, percorreu os núcleos litorâneos: Igarassú, Goiana e Natal. Percebeu o capuchinho a carência espiritual dos católicos em todo o seu trajeto. Vale informar que, o missionário não limitou sua catequese aos indígenas, pois os aldeamentos missioneiros cumpriam esse papel. Devotou seu trabalho em administrar os sacramentos, realizar os ofícios pios e ouvir as confissões dos fiéis, independente da raça.

Seu itinerário principiou ao visitar o aglomerado urbano do Açú, situado no interior da capitania do Rio Grande do Norte. A investida teve apoio da fazendeira de gado, dona Joana Gomes, a qual ofereceu seu filho e dois escravos para compor a caravana ${ }^{83}$. Entre as oitenta léguas que separaram Natal do Açú, o religioso genovês não avista uma única igreja ou ermida. Certificamos, nessas circunstâncias que, poucos foram os investimentos do bispado de Pernambuco e da Coroa portuguesa para construção de templos religiosos, verdadeiras fontes de atração e adensamento populacional dos habitantes dispersos pelo sertão durante a colônia ${ }^{84}$.

Dispersão pode ser vista quando o religioso chega à fazenda Cacimbas, do coronel Antônio da Rocha Bezerra. Na estância foram reunidas, por ordens do fazendeiro, 1.453 dos seus agregados e arrendatários ${ }^{85}$. A ação do criador de gado reforçou o seu papel como

\footnotetext{
${ }^{81}$ Missões voltantes consistiam na assistência intermitente dada às povoações, onde não havia residência pernamente dos missionários e em que se beneficiavam tanto os índios como portugueses. Ver LIMA, Ebion. “As missões oratorianas no Brasil". In RIHGB. No 323. Abr/Jun. Rio de Janeiro, IHBG, 1979. p. 88.

${ }^{82}$ PRIMERIO, P.Fr. Fidelis M. de. Capuchinhos em Terras de Santa Cruz..., Opus cit., p. 174 - 193.

${ }^{83}$ PRIMERIO, P.Fr. Fidelis M. de. Capuchinhos em Terras de Santa Cruz..., Opus cit., p. 187.

${ }^{84}$ MARX, Murillo. Cidades no Brasil, terra de quem? São Paulo, Edusp, 1991. p. 14.

${ }^{85}$ PRIMERIO, P.Fr. Fidelis M. de. Capuchinhos em Terras de Santa Cruz..., Opus cit., p. 188.
} 
contribuinte da política colonizadora, sem esquecer do poder exercido sobre os moradores humildes de suas terras.

Chegando à redução do Miranda, frei Aníbal de Gênova notou um território próspero, consequente da pecuária extensiva voltada para exportação. Além dos índios catequizados, 5.103 vizinhos migraram para aquele lugar. É possível que os sertanejos viessem dos arredores da missão, talvez de Missão Velha, Barbalha e Barra do Jardim, como é previsível que fossem da freguesia do Exú [figura 69] ou povoação de Flores do Pajéú, ambas da capitania de Pernambuco. Depois de catequizar no Miranda, parte para vila da Fortaleza.

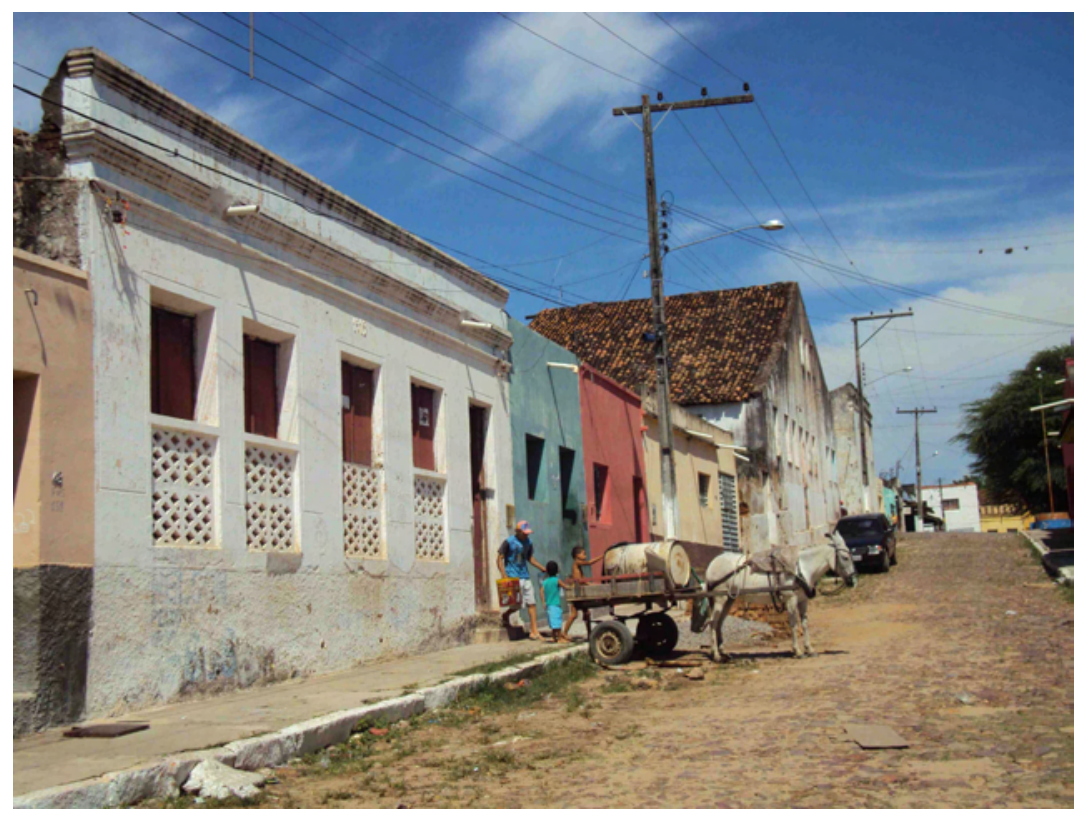

Figura 69 - Vista do casco viejo da atual cidade de Exú. Acervo do Autor, 2010.

O capuchinho seguiu caminho de Fortaleza para a missão da Ibiapaba, dos padres jesuítas. Nos deixou a par da existência de 7.000 residências e um comércio ativo, tanto em escala colonial, exercido entre as capitanias do Maranhão, Grão-Pará e Rio de Janeiro, como internacional, para Buenos Aires ${ }^{86}$. Nesse núcleo urbano o capuchinho avaliou os efeitos da catequese jesuítica: incluso o colégio, de avantajadas dimensões ${ }^{87}$, a redução dos padres da Companhia de Jesus comportou mais de dez mil índios e uma milícia com doze companhia prontas para a batalha ${ }^{88}$ !

\footnotetext{
${ }^{86}$ PRIMERIO, P.Fr. Fidelis M. de. Capuchinhos em Terras de Santa Cruz..., Opus cit., p. 191.

${ }^{87}$ PRIMERIO, P.Fr. Fidelis M. de. Capuchinhos em Terras de Santa Cruz..., Opus cit., p. 191.

${ }^{88}$ PRIMERIO, P.Fr. Fidelis M. de. Capuchinhos em Terras de Santa Cruz..., Opus cit., p. 191.
} 
O próximo ponto de parada seria o porto do Aracati, mui freqüentado por embarcações baianas e cariocas. Iam os barcos se abastecer de carne seca para suprir o mercado interno brasileiro. Frei Aníbal de Gênova finalizou sua viagem rumando de Aracati, por mar, à cidade da Paraíba (atual João Pessoa - PB). Em seguida, volta à Recife. Durante todo o seu percurso, trilhando a seca caatinga, passando necessidades físicas, correndo perigo de saúde e estando à mercê de animais ferozes, o missionário viajante pregou para 128.523 penitentes ${ }^{89}$.

Apelidado de Apóstolo de Pernambuco ${ }^{90}$, frei Carlos de Spezia $^{91}$ visitou algumas das povoações do sertão nordestino também catequizadas por frei Aníbal de Gênova. O caráter de sua missão seguiu os mesmos moldes adotados pelo seu companheiro de ordem: ensino nas igrejas ou capelas, distribuição dos sacramentos, necessariamente, a eucaristia e realizar confissões. Frei Fidelis Primerio transcreveu sua carta ${ }^{92}$, enviada a um irmão capuchinho, contando-nos sua missão volante.

Basicamente, concentrou a maior parte do seu tempo em aglomerados humanos situados na costa ou próximos desta. Chegou em Camocim (CE), porto freqüentado por embarcações de diversas partes da colônia, em 06 de outubro de 1744. Deste porto segue caminho por terra até a missão jesuítica da Ibiapaba. Em seguida, ruma para a serra dos Cocos [Ipú - CE (?)] onde uma multidão de regiões limítrofes estavam reunidas para ouvir seu ofício. Outras localidades interioranas percorridas foram Russas (CE), São João (CE), Açú (RN) e missão dos Cariris na Paraíba. Este frade não especificou o quantitativo populacional migrado para esses arraiais. Diferentemente do capuchinho de Gênova, os relatos de frei Carlos de Spezia são menos dotados de "informações profanas", expondo-nos somente a sua arte de catequizar. Para facilitar a visualização dos itinerários das missões volantes dos capuchinhos italianos - os religiosos viajantes - desenvolvemos o mapa 08.

\footnotetext{
${ }^{89}$ PRIMERIO, P.Fr. Fidelis M. de. Capuchinhos em Terras de Santa Cruz..., Opus cit., p. 193.

${ }^{90}$ Idem. Ibidem, p. 174.

${ }^{91}$ Frei Carlos de Spezia ingressou na ordem dos capuchinhos em 1702. Antes de vir para o Brasil, fora enviado para catequizar os africanos de Luanda, Angola. Ali sofreu grave doença, sendo designado pela Propaganda Fide, em 1729, para a prefeitura de Pernambuco. Sabe-se que voltou para Itália em 1740. Em 1742 embarca para o Brasil. Ver PRIMERIO, P.Fr. Fidelis M. de. Capuchinhos em Terras de Santa Cruz..., Opus cit., p. 175.

${ }^{92}$ A transcrição desta carta está em PRIMERIO, P.Fr. Fidelis M. de. Capuchinhos em Terras de Santa Cruz..., Opus cit., p. $175-182$.
} 

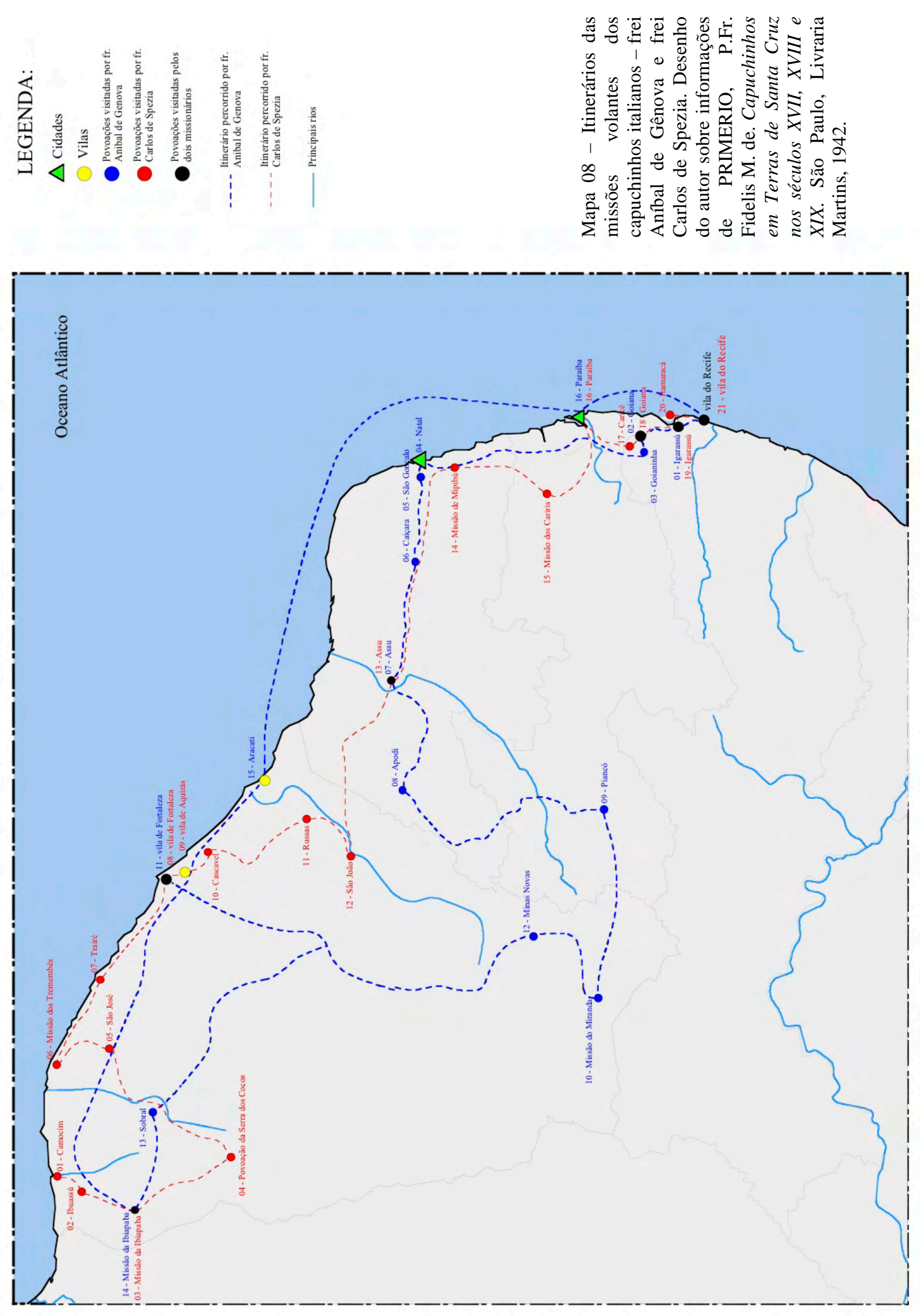
O panorama do Brasil colonial mudou com a posse de Dom José I ao trono português (1750 - 1777), sendo auxiliado por Sebastião José de Carvalho e Melo, futuro marquês de Pombal. Spix e Martius se referiram ao seu projeto colonizador como tentativa de introduzir a cidadania aos índios ${ }^{93}$. Para conseguir seus objetivos, seria necessário quitar a má influência da sociedade residida, segundo Pombal, na administração dos padres da Companhia de Jesus.

Um dos maiores reveses sofridos pelos inacianos foi sua total expulsão dos domínios portugueses em 1759. Porém, não foram os únicos. As ordens religiosas que se opuseram às normas pombalinas foram acusadas de inimigos do Estado, entre esses os capuchinhos italianos instalados nas missões do rio São Francisco ${ }^{94}$, do lado pernambucano: Irapoá, Ilha de São Félix e Cavalo, Vargem, Rodelas e São Pedro ${ }^{95}$. A causa para esse incidente, na opinião de frei Aníbal de Gênova, resultou do conluio entre os governador de Pernambuco, capitão general Luiz Diogo Lobo da Silva, com o bispo da mesma capitania, D. Francisco Xavier Aranha:

(...) soube-se no mesmo tempo que o sobredito Governador, junto com o Bispo, não muito amigo nosso, D. Francisco Xavier Aranha (1754 - 1771) por meio do Sargento Mor Jerônimo Mendes da Paz, haviam despoticamente sequestrado e expulsado das suas aldeias aos nossos missionários que estavam no Rio Grande de São Francisco, da parte de Pernambuco, jurisdição, em quanto ao temporal, do Governador Luiz Diogo Lobo da Silva, e em quanto ao espiritual, do Arcebispo e do Prefeito da Baía de Todos os Santos ${ }^{96}$.

Ao libertar os índios das reduções missioneiras, através das leis de 06 e 07 de junho de 1755 e alvará de 08 de maio de 1758, a Metrópole ordenou a elevação das antigas aldeias de índios às categorias de vila ou lugar de índios (freguesias), desejando integrá-los à

\footnotetext{
${ }^{93}$ VON SPIX, J. B.; VON MARTIUS, C.F.P. Viagem ao Brasil. Rio de Janeiro, Imprensa Nacional, 1938. Vol 01. p. 182 .

${ }^{94}$ Segundo o padre jesuíta, José Caieiro, na mesma frota que foram levados os jesuítas para Portugal, haviam quarenta capuchinhos. Ver CAIEIRO, pe. José. Jesuítas do Brasil e da Índia. Apud PRIMERIO, P.Fr. Fidelis M. de. Capuchinhos em Terras de Santa Cruz..., Opus cit., p. 198 (nota de rodapé).

${ }_{95}$ PRIMERIO, P.Fr. Fidelis M. de. Capuchinhos em Terras de Santa Cruz..., Opus cit., p. 197.

${ }^{96}$ PRIMERIO, P.Fr. Fidelis M. de. Capuchinhos em Terras de Santa Cruz..., Opus cit., p. 198.
} 
sociedade civil ${ }^{97}$. O aldeamento do Miranda (CE) e São José do Mipibú (RN), sob a tutela dos capuchinhos, foram transformados, respectivamente, na vila Real do Crato $(1764)^{98} \mathrm{e}$ Mipibú (1762). O poder espiritual das novas freguesias e vilas foi transferido, sob carta régia escrita em Belém ao Arcebispado da Bahia, aos clérigos do Hábito de São Pedro ${ }^{99}$, por apoiarem a política pombalina.

\subsection{3 - Missões religiosas jesuíticas do sertão nordestino}

A pesquisa historiográfica sobre a atuação dos padres da Companhia de Jesus no Novo Mundo é vasta, podendo ser classificada como rica. Sem dúvida, o padre jesuíta Serafim Leite ${ }^{100}$ legou, em sua História da Companhia de Jesus no Brasil, uma obra que alavancou outras investigações acadêmicas não restritas à historiografia, mas, apontando rumos multidisciplinares. A Arquitetura e o Urbanismo receberam esta positiva influência, os "arquitetos - historiadores" puderam visualizar o desenvolvimento arquitetônico - urbanístico do Brasil colonial abarcado em outro prisma, desvinculado da forma e função.

Labor consistiu esquematizar este tópico, diante da amplitude dos dados encontrados. Sintetizamos ao máximo. Explanaremos em linhas gerais as missões jesuíticas ${ }^{101}$ do sertão nordestino ocorridas no interior da capitania da Bahia, médio rio São Francisco, capitania do Rio Grande do Norte e Piauí. Destacaremos a redução da Ibiapaba pelo grau de urbanização adquirida e, sobretudo, como centro hierárquico de núcleos limítrofes.

No Mapa geral de todas as Misoens ou Aldeias de gentio mando que estão situadas nesta Capitania da Bahia... ${ }^{102}$ cuja data de produção é 20 de dezembro de 1758 , são apontados como aldeamentos missioneiros organizados pelos inacianos no sertão baiano: Juru (atual Gerú - SE), Saco dos Morcegos (Mirandela - BA), Canabrava (Ribeira do Pombal -

\footnotetext{
${ }^{97}$ FLEXOR, Maria Helena Ochi. "Núcleos urbanos criados por Pombal no Brasil do século XVIII". In Anais do IV Seminário de História da Cidade e do Urbanismo. Denese B. Pinheiro (Org.). Rio de Janeiro, UFRJ/PROURB, 1996. Vol 01. p. 603.

${ }_{98}^{98}$ Ano de elevação ao predicamento de vila.

${ }^{99}$ PRIMERIO, P.Fr. Fidelis M. de. Capuchinhos em Terras de Santa Cruz..., Opus cit., p. 198.

${ }^{100}$ LEITE, Serafim. História da Companhia de Jesus no Brasil. 10 volumes. Rio de Janeiro, Instituto Nacional do Livro, 1945.

${ }^{101}$ Agradecemos à profa. Dra. Renata Maria Martins de Almeida pelas inteligentes observações e indicações de leitura apontadas no exame de qualificação de mestrado, ocorrido em 04/07/2011.

${ }^{102}$ CALDAS, Jozé Antônio. Notícia Geral de toda esta capitania da Bahia desde o seu descobrimento até o prezente anno de 1759. Ed. fac similar. Salvador, Tip. Beneditina, 1951.
} 
BA) e Natuba (Nova Soure - BA). Serafim Leite inclui nessa lista a missão da Jacobina de São Francisco Xavier, de $1667^{103}$.

A catequese dos jesuítas no interior da capitania da Bahia acompanhou o progresso territorial motivado pela pecuária extensiva. Devido o uso ilegítimo de terras e índios, os fazendeiros de gado travaram constantes brigas com os religiosos, fato já conhecido por nós quando abordamos as missões capuchinhas dos franceses no rio São Francisco. Leite dedicou boa parte do capítulo destinado aos aldeamentos do sertão baiano aos conflitos de cunho necessariamente fundiário:

Mas ia defrontar-se com o grave obstáculo assinalado em toda a história dos sertões baianos: o consederem-se grandes sesmarias a particulares, dentro das quais ficavam homens não civilizados, que não compreendiam, nem podiam compreender ainda, a razão porque outros homens invadiam as suas terras, e colocavam nelas currais, dificultando-lhes a própria subsistência. ${ }^{104}$

Pior: os curraleiros, principalmente aqueles da Casa da Torre, exigiram do governo índios domesticados pelos padres para remeterem como se fossem seus escravos. O rei, em 1680, ordenou que duzentos e trinta índios fossem conduzidos para suas aldeias localizadas no interior ${ }^{105}$. As questões vinculadas à escravização e liberdade dos índios tornaram-se o âmago das rixas entre missionários e criadores de gado. Novamente, Serafim Leite opinou sobre o assunto:

A mais grave dificuldade era que, ao contrario do que ainda então se não praticava no rio Amazonas e no rio Uruguai, as terras do sertão da Bahia e do rio São Francisco, por serem mais próximas, já tinham sido dadas em sesmarias ou se tratava disso, por as cobiçarem muitos, e os senhores delas dissimulavam o equivoco de suporem que com elas se tornavam também senhores da liberdade dos homens que as habitavam.

A ebulição destes conflitos, da prepotência dos fazendeiros da Casa da Torre, exercida sobre chão e índios, ocorreu em detrimento de Francisco Dias d'Ávila destruir duas residências e uma igrejas missioneira, ao que parece, após o pedido de três léguas em terra feito para os índios pelo pe. Jocob Rolando. Os edifícios destruídos, ainda que humildes

\footnotetext{
${ }^{103}$ LEITE, Serafim. História da Companhia de Jesus no Brasil. Tomo V...Opus cit., p. 282.

${ }^{104}$ LEITE, Serafim. História da Companhia de Jesus no Brasil. Tomo V...Opus cit., p. 278.

${ }^{105}$ LEITE, Serafim. História da Companhia de Jesus no Brasil. Tomo V...Opus cit., p. 280.
} 
edificações, eram sacros. E este ato merecia arbítrio do Tribunal Eclesiástico da Bahia ${ }^{106}$. Prontamente, o cura e fazendeiro, pe. Antônio Pereira, tio de Francisco Dias d'Ávila, solicitou pedido de misericórdia ao reitor do Colégio da Bahia, pe. Antônio Forti ${ }^{107}$. Podemos aludir que a ação - destruir igrejas - no ver do morgadio dos d'Ávila, além tentar afugentar os jesuítas ou qualquer religioso metido em suas terras, impediu a eclosão de um arraial, quiçá futura freguesia ou vila, reduzindo o seu "generoso" patrimônio fundiário sertanejo. A solicitação foi aprovada com a obrigação de reconstruir as igrejas devassadas. Na opinião de Luiz Alberto Moniz Bandeira,

Com toda a força que dispunha, a Companhia de Jesus não pode contraporse frontalmente aos interesses da Torre de Garcia d'Ávila, a qual, não obstante constituir uma propriedade privada, dispunha de imenso poder, não apenas político, mas também militar, tanto que continuava como um baluarte tão importante quanto as outras fortalezas pertencentes ao Estado Português, fornecendo as tropas necessárias para reprimir não apenas índios rebelados como também mocambos $(\ldots)^{108}$

Na missão da Jacobina, sob a administração dos padres João de Barros e Jacob Roland, foram catequizados os índios das nações Cariri e Acarases ${ }^{109}$. Durante os anos de ensino, João de Barros compôs, como demonstração de interesse ao outro, o Catecismo da Doutrina Cristã na Língua Brasileira da Nação Kiriri (Lisboa, 1698) e a Arte Gramática da Língua Brasileira da Naçam Kiriri (Lisboa, 1698) ${ }^{110}$. Ainda na Jacobina, construíram os padres a capela dedicada a São Francisco Xavier [figura 70], hoje elemento material da cultura tombado pelo Instituto do Patrimônio Histórico e Artístico Nacional (IPHAN). O edifício segue o partido adotado pelas construções jesuíticas em outras áreas da colônia, como por exemplo, a capela de São Miguel localizada no estado de São Paulo. Lúcio Costa afirmou que o programa dessas simples construções pode ser dividido em três partes, sendo a primeira destinada ao culto, com igreja, coro e sacristia ${ }^{111}$. Sendo o objetivo da Companhia de Jesus a

\footnotetext{
${ }^{106}$ LEITE, Serafim. "João de Barros, lisboeta, apóstolo dos Quiriris e Acarases". In Congresso do Mundo Português. Vol IX. Lisboa, Comissão Executiva do Centenário, 1940. Tomo I: Do descobrimento a ocupação da costa. p. 475.

${ }^{107}$ BANDEIRA, Luiz Alberto Moniz. O feudo: a Casa da Torre de Garcia d'Ávila: da conquista dos sertões à independência do Brasil. Rio de Janeiro, Civilização Brasileira, 2000. p. 170.

${ }^{108}$ Idem. Ibidem.

${ }^{109}$ LEITE, Serafim. “João de Barros, lisboeta, apóstolo dos Quiriris e Acarases”. In Congresso do Mundo Português..., Opus cit., p. 474.

${ }^{110}$ LEITE, Serafim. “João de Barros, lisboeta, apóstolo dos Quiriris e Acarases”. In Congresso do Mundo Português..., Opus cit., p. 479.

${ }^{111}$ COSTA, Lúcio. "A arquitetura jesuítica no Brasil”. Revista do Serviço do Patrimônio Histórico e Artístico Nacional. vol 5. Rio de Janeiro, 1941. p. 17.
} 
doutrina e catequese, a igreja devia ser ampla a fim de abrigar número sempre crescente de convertidos e curiosos e localizada, de preferência, em frente a um espaço aberto - um terreiro - onde o povo pudesse se reunir e andar livremente (...). Outras características seriam o acréscimo de alpendre e a introdução de indispensáveis beirais, evitando que as águas pluviais agredissem a frágil estrutura de taipa, comprometendo sua estabilidade ${ }^{112}$.

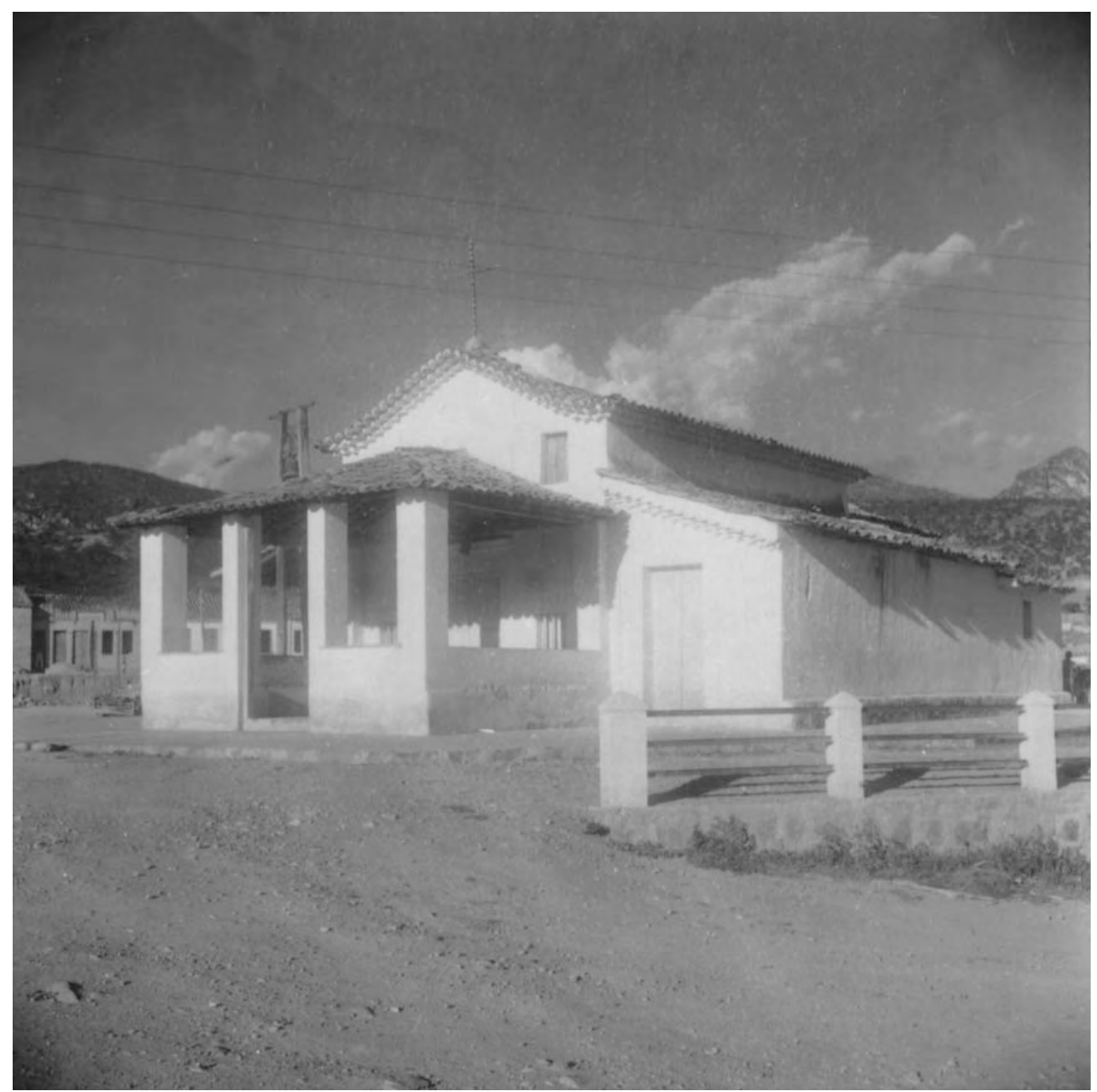

Figura 70 - Capela da missão jesuítica da Jacobina, dedicada a São Francisco Xavier. Disponível em http://www.ibge.gov.br. Acesso em $18 / 09 / 2010$.

Em 1691, o Colégio de Olinda, por intermédio da ânua, informou o estado físico e demográfico das missões encerradas no sertão da Bahia:

A este Colégio pertencem as missões de assistência dentro do sertão da Baía, nas Aldeias dos índios Tapuias, que hoje são as mais numerosas de nação Quirtrises de língua mui dificultosa: a saber, a de Canabrava, distante 60 léguas da Baía, que hoje consta quasi de oitocentas almas e mais de

\footnotetext{
${ }^{112}$ COSTA, Lúcio. “A arquitetura jesuítica no Brasil”..., Opus cit., p. 21.
} 
setecentas estão batizadas. A de Natuba, quasi quinhentas. Além destas missões, outros padres tratam do bem espiritual de outras casta de Tapuias, no sertão alto do Rio São Francisco, e ao presente são três mil e novecentas almas, divididas em suas aldeias maiores e três menores. ${ }^{113}$ [grifo nosso]

O aldeamento de Canabrava, dedicado a santa Tereza, fundado em 1667 pelos padres João de Barro e Jacobo Rolando, administrado temporal e espiritualmente por Jacobo Cloceo $^{114}$, abrigou novecentos índios cariris de natureza instável e propensos ao nomandismo $^{115}$. A localização estratégica de Canabrava, a caminho do rio São Francisco, provavelmente naquilo onde seria a estrada real do gado, fez dela hospedaria e repouso para viajantes. Talvez sua posição dentro da rede urbana sertaneja em formação, fosse um dos motivos que levaram o marquês de Pombal elevá-la à categoria de vila em 1758. A missão cultivou roças de milho, mandioca e outros cereais para o sustento da comunidade indígena $^{116}$. Leite mencionou algumas fazendas de gado anexas à esta redução, cujo detentor seria o Colégio da Bahia ${ }^{117}$.

Natuba, com quinhentos índios recolhidos, foi administrado pelo pe. Mateus Falleto, se tornou centro de confluência de vizinhos portugueses para ouvir a missa e receber os sacramentos. Um deles, Matias Perdigão, ofereceu madeira e tijolo para edificação da igreja e prata para o santíssimo ${ }^{118}$. A situação fundiária de Natuba agravou pela recusa das autoridades em cumprir a lei de 23 de novembro de 1700. A postura, em suma, garantia aos índios moradores de alguma redução com mais de cem casais o direito à terra, à uma légua em quadra donde tirariam a sua subsistência. Ademais, o aldeamento estava rodeado de currais de gado, retraindo o seu desenvolvimento, haja vista as exigências territoriais da pecuária ${ }^{119}$.

O pe. Antônio de Andrade, sucessor de Mateus Falleto, em carta ao rei, ressalvou a carência fundiária dos seus neófitos como a principal precariedade da missão: foi servido deixar a dita missão sem mais terra que o lodo de uns brejos ${ }^{120}$. Nessas circunstâncias, os índios eram obrigados a plantar a cinco ou mais léguas, o que nos leva a crer que muitos não retornavam aos núcleos missioneiros, retornando ao seu anterior modo de vida.

\footnotetext{
113 LEITE, Serafim. "João de Barros, lisboeta, apóstolo dos Quiriris e Acarases". In Congresso do Mundo Português..., Opus cit., p. 478.

${ }^{114}$ POMPA, Maria Cristina. Religião como tradução: missionários, Tupi e “Tapuias”..., Opus cit., p. 329.

${ }^{115}$ LEITE, Serafim. História da Companhia de Jesus no Brasil. Tomo V...Opus cit., p. 290.

${ }^{116}$ LEITE, Serafim. História da Companhia de Jesus no Brasil. Tomo V...Opus cit., p. 290.

${ }^{117}$ LEITE, Serafim. História da Companhia de Jesus no Brasil. Tomo V...Opus cit., p. 290.

${ }^{118}$ LEITE, Serafim. História da Companhia de Jesus no Brasil. Tomo V...Opus cit., p. 287.

${ }^{119}$ LEITE, Serafim. História da Companhia de Jesus no Brasil. Tomo V...Opus cit., p. 287

${ }^{120}$ LEITE, Serafim. História da Companhia de Jesus no Brasil. Tomo V...Opus cit., p. 287.
} 
A última missão do sertão baiano foi Saco dos Morcegos. Congregou este curral de almas, em 1758, 960 catecúmenos. No que tange este agrupamento indígena, Serafim Leite atrelou os seus acontecimentos à necessidade de um novo sítio, ou melhor, de um lugar adequado para sua fixação ${ }^{121}$. O primeiro local eleito era precário, árido e falto d'água. Situação geográfica que facilitou a falta de compromisso dos índios ao aldeamento. Acarretou, sobretudo, em fuga e dispersão. Os padres administradores solicitaram nova terra para abrigar os índios, tendo o pedido negado pela Junta das Missões ${ }^{122}$. Para não perder mais almas, o pe. Francisco Matos, construiu igreja de dimensões consideráveis, atraindo vizinhos portugueses e estabelecendo o índio na sua redução. Devido ao Diretório dos Índios de 1758, a missão do Saco dos Morcegos foi instituída como vila, adotando a toponímia portuguesa de Mirandela.

Anexo às missões da Jacobina, o aldeamento do Juru, hoje Tomar do Gerú - SE, implantada entre os rios Real e Itamirim e braço do Piauí. Aparece no Catálogo de 1692 com o nome de Juru, cujo significado é boca, entrada ${ }^{123}$. No mesmo catálogo foram arrolados os padres Luís Mimiani e João Batista como tutores da missão ${ }^{124}$. Após doze anos de catequese entre várias aldeias de índios cariris, o pe. Luís Vicêncio Mimiani redigiu o Catecismo da doutrina cristã na língua brasílica da nação quiriri, composto pelo padre Luís Vicêncio Mimiani da Companhia de Jesus, missionário da província do Brasil (Lisboa, 1698) [figura 71].

Comparada com outras reduções jesuíticas do sertão baiano, Gerú apresentou uma catequese pacífica e simples. Poucos foram os conflitos entre curraleiros e os missionários ou entre fazendeiros e comunidade indígena. A paz fez do aldeamento um centro de viva religiosidade $^{125}$. Os moradores do rio Real, por exemplo, compadecidos pela difícil condição dos jesuítas, solicitaram a Dom João V melhoras físicas do aglomerado:

Dizem os moradores do Certão do Rio Real termo da Villa do Largado adiante assignados, q' reconhecem o muito serviço que fazem a Deos os Missionários da Companhia de Jesus da Missão do Jurú, que dista da mesma Villa quatorze legoas, accodindo de dia, e de noite aos enfermos, dizendo lhes Missa em distancia de quatro, sinco, e seis legoas; por ficarem as

\footnotetext{
${ }^{121}$ LEITE, Serafim. História da Companhia de Jesus no Brasil. Tomo V...Opus cit., p. 291.

${ }^{122}$ LEITE, Serafim. História da Companhia de Jesus no Brasil. Tomo V...Opus cit., p. 291.

${ }^{123}$ LEITE, Serafim. História da Companhia de Jesus no Brasil. Tomo V...Opus cit., p. 325.

${ }^{124}$ HORNEART, Eduardo. História da Igreja no Brasil..., Opus cit., p. 73.

${ }^{125}$ LEITE, Serafim. História da Companhia de Jesus no Brasil. Tomo V...Opus cit., p. 325.
} 
Parochias distantes nove, e dez legoas, e por serem muytos os moradores, são continuas as hidas, no qual exercícios excede esta Missão a todas do Certao da Bahia, alem dos mais Sacramentos, que administrão na sua Igreja, sendo como Parochos, de três, ou quatro Parochias, sem levarem estipêndio e vivendo de esmolas, que já são muy poucas por se muyta a pobreza dos moradores que existem, e vendo se de todo destituídos da mayor esmola, que se lhes dava de seis bois, o que tudo consta das certidõens juntas; por tanto. ${ }^{126}$

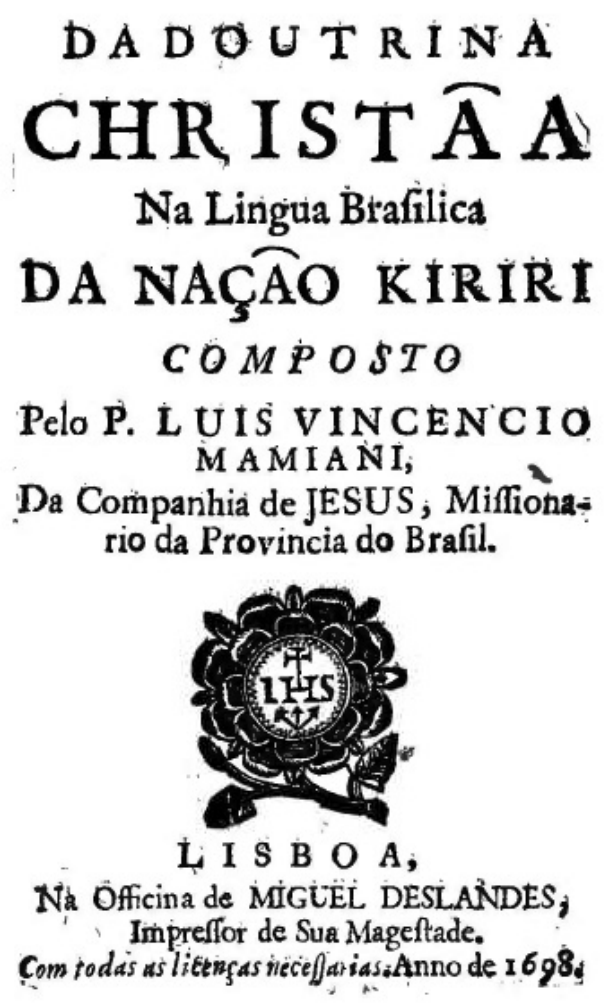

Figura 71 - Catecismo da doutrina cristã na língua brasílica da nação Kiriri, composto pelo padre Luís Vicêncio Mimiani da Companhia de Jesus, missionário da província do Brasil. Disponível em http://www.brasiliana.usp.br. Acesso em 04/10/2011.

O bom relacionamento dos jesuítas da missão do Gerú com os párocos de freguesias vizinhas pode ser visto na carta do cura da matriz de Itapicurú de Cima e suas anexas de Jeremoabo e Rio Real, escrita em 31 de agosto de 1737:

Certifico eu Miguel Vra. Montr. Vigário collado da Parochia de Nossa Senhora de Nazareth do Itapicurú de Sima do Certao da Bahia, e vigário da vara da dita Freguesia, e suas anexas Inhambupe, Rio Real e Jeromoabo, que

${ }^{126}$ PROJETO RESGATE. AHU_ACL_CU_SERGIPE, Cx. 3, D. 199. 
os Reverendos Padres Missionários da Companhia de Jesus da Missão sita no Rio Real acodem com grande zelo, cuidado e diligencia a todos os enfermos, que os mandão chamar; e tão bem desobrigão na quaresma a muytos dos fregueses desta Freguesia, que morao distantes della allem do Sacramento do bautismo, que exercitao na sua Missão aos mesmos; e como me consta desta verdade passo esta certidão jurada in verbo sacerdotis. ${ }^{127}$

No centro da comunidade estava a igreja dedicada à Nossa Senhora do Socorro [figura 72] construída através de dízimos obtidos pela Confraria do santo padroeiro, cujos associados eram os afortunados da região, talvez fazendeiros de gado ou senhores de engenho. Lúcio Costa, qualificando o edifício como belíssimo, assegurou que a arte jesuítica do seu retábulo é mestiça e vigorosa que se enquadra no importante surto de arte ocorrido, de fins do século XVII a meados de Setecentos, naquela região, constituindo uma escola à parte $^{128}$.

Eduardo Horneart chamou atenção para o movimento cíclico das missões religiosas: o litoral brasileiro estava irremediavelmente ligado aos percursos coloniais e por isso entrou em declínio com o estabelecimento da cultura baseada na cana - de - açúcar, razão pela qual a qualificamos de ciclo $^{129}$. A pecuária firmou o ciclo da catequese no sertão nordestino. No rio São Francisco, incluindo capuchinhos franceses e italianos, os jesuítas situaram alguns aldeamentos missioneiros nas Missões dos Rodelas, um conjunto de cinco aldeias às margens do rio citado ${ }^{130}$. A ânua de 1690-1691 indicou a fundação no Sertão alto do rio S. Francisco a presença de 3.900 almas, divididas em duas Aldeias maiores e três menores. Os padres assistiram em uma principal e visitaram as outras ${ }^{131}$. Dentre essas estão as de Sorobabel e Curral dos Bois ${ }^{132}$.

\footnotetext{
${ }^{127}$ PROJETO RESGATE. AHU_ACL_CU_SERGIPE, Cx. 3, D. 199.

${ }^{128}$ COSTA, Lúcio. "A arquitetura jesuítica no Brasil". Revista do Serviço do Patrimônio Histórico e Artístico Nacional..., Opus cit., p. 67.

${ }^{129}$ HORNEART, Eduardo. História da Igreja no Brasil..., Opus cit., p. 63.

${ }^{130}$ LEITE, Serafim. “João de Barros, lisboeta, apóstolo dos Quiriris e Acarases”. In Congresso do Mundo Português..., Opus cit., p. 477.

${ }^{131}$ LEITE, Serafim. História da Companhia de Jesus no Brasil. Tomo V...Opus cit., p. 295.

${ }^{132}$ Concentramos nossas explanações nestas missões pelo favorecimento de maiores informações primárias e secundárias. Contudo, Serafim Leite lista as aldeias de Curumambá, Acará e Procá administradas, respectivamente, pelos inacianos Agostinho Correia e Francisco Inácio. Ver LEITE, Serafim. História da Companhia de Jesus no Brasil. Tomo V...Opus cit., p. 303.
} 


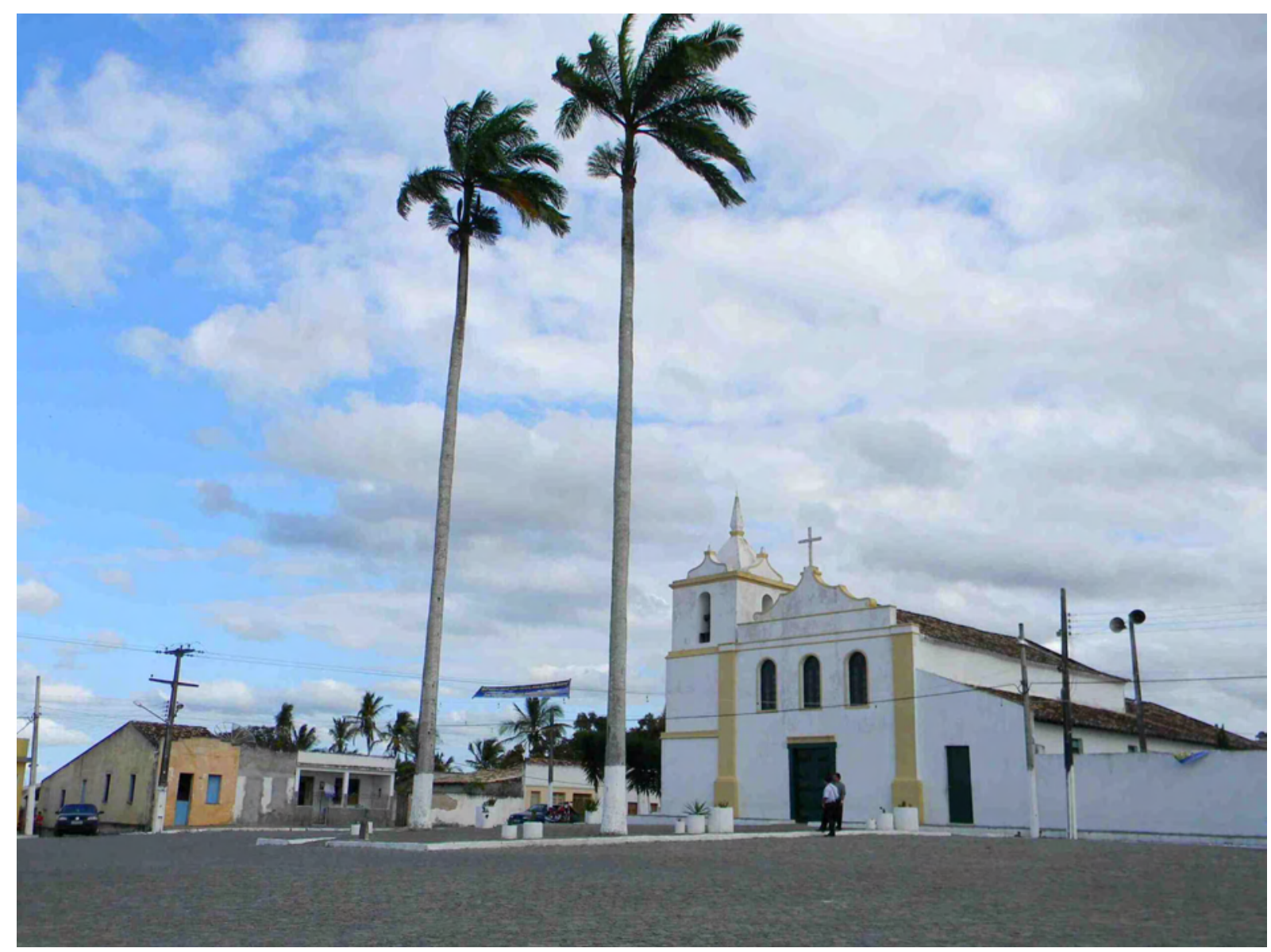

Figura 72 - Igreja jesuítica de Nossa Senhora do Socorro e seu adro. Local Tomar do Gerú - SE. Foto fornecida pelo IPHAN/SE.

Sorobeba, Zorobabé ou Sorobabel foi uma missão criada na ilha do mesmo nome, território da atual cidade de Itacuruba - PE. Em 1696, existia na ilha um aldeamento com capela edificada pelos missionários auxiliados por índios encurralados ${ }^{133}$. O orago da redução foi Nossa Senhora do Ó, e os padres gestores foram João Guincel e Antônio Ferreira ${ }^{134}$. No mesmo ano, devido à peleja estimulada pela Casa da Torre, os jesuítas foram expulsos de suas missões no rio São Francisco. A autoridade de suas aldeias trasladou para os capuchos de Santo Antônio, os franciscanos ${ }^{135}$. Dessa vez, os mentores da expulsão foram as Senhoras da Torre, Catarina Fogaça e Leonor Pereira Marinho ${ }^{136}$. Mais uma vez, a légua em quadra obrigatória para as missões constituiu o estopim das brigas. Numa estranha reação, o arcebispo da Bahia, João Franco d'Oliveira, em carta para Dom Pedro II, não acusou os vaqueiros nem os fazendeiros do morgadio da Torre. Alertou ao monarca que, em terras de

\footnotetext{
${ }^{133}$ LEITE, Serafim. História da Companhia de Jesus no Brasil. Tomo V...Opus cit., p. 299.

${ }^{134}$ LEITE, Serafim. História da Companhia de Jesus no Brasil. Tomo V...Opus cit., p. 303.

135 BARBOSA, Bartira Ferraz. Índios e missões: a colonização do médio São Francisco pernambucano nos séculos XVII e XVIII. Dissertação de mestrado. Recife, UFPE, 1991.

${ }^{136}$ BANDEIRA, Luiz Alberto Moniz. O feudo: a Casa da Torre de Garcia d'Ávila: da conquista dos sertões à independência do Brasil. Rio de Janeiro, Civilização Brasileira, 2000. p. 205.
} 
Leonor Pereira Marinho, sucedeu levantar os índios contra os religiosos da Companhia que lhes assistiam como missionários, e à força das armas os fizeram ausentar ${ }^{137}$.

Alexandre de Gusmão, vendo a situação de seus companheiros de ordem, destacou que o início dos conflitos esteve vinculado à recusa de dar os sacramentos aos vizinhos portugueses, afiliados à família Dias d'Ávila ${ }^{138}$. A resolução do monarca português foi dada através de um alvará de 27 de novembro de 1700, isto é, os Tapuias teriam a posse da terra e o direito de decidir, ouvida a Junta das Missões, sobre a localização dos aldeamentos, não ficando ao arbítrio dos sesmeiros ou donatários, mas a Igreja e os missionários teriam o seu usufruto no que fosse necessário $^{139}$. Em 1703, a lei de 04 de junho, reforçou a de 1700 criando adros e passais para as igrejas e certificando privilégios aos religiosos: a cada aldeia de índios se dará uma légua de terra em quadra, para mantimentos; espaços para Igreja e adro; terras para casa e passal do Pároco; côngrua aos párocos, esta pela fazenda real ${ }^{140}$.

Ruínas compõem a paisagem atual da missão de Sorobabel. Gabriela Martín escavou em 1986 o velho sítio de Sorobabel. As cheias e inundações do rio São Francisco foram os motivos do estado físico de hoje. Disserta-nos a arqueóloga sobre a igreja do aglomerado:

(...) $\mathrm{O}$ recinto da missão que conseguimos escavar (...), consistia na igreja, na sacristia e um pátio de dependências com o total de $1.200 \mathrm{~m}^{2}$. A igreja media 18 x 6,5 m e foi construída no começo do século XVIII (...) obedecendo aos padrões estabelecidos para as missões, como se comprovou também na igreja da missão da ilha do Pontal e na Matriz de Santa Maria da Boa Vista. $^{141}$

Curral de Bois foi outra missão jesuítica às margens do rio São Francisco. Localizava-se a cem léguas acima da cachoeira de Paulo Afonso. As atividades religiosas estavam submissas às fazendas de gado do Piauí, doadas por Domingos Afonso Mafrense, após sua morte em 1711, ao Colégio da Bahia ${ }^{142}$. Os missionários jesuítas residentes das

\footnotetext{
${ }^{137}$ BANDEIRA, Luiz Alberto Moniz. O feudo: a Casa da Torre de Garcia...Opus cit., p. 207..

138 "Carta do padre Alexandre de Gusmão ao padre Geral Tirso Gonzáles, Bahia, 15/05/1696”. ARSI, Bras. 4, fl. 9v. Apud POMPA, Maria Cristina. Religião como tradução: missionários, Tupi e "Tapuias”..., Opus cit., p. 333. 139 “Alvará de D. Pedro II sobre a concessão de terras para as aldeias das missões". Annaes do APEB. Vol. XXIX, 1943. p. 75 e 77. Apud BANDEIRA, Luiz Alberto Moniz. O feudo: a Casa da Torre de Garcia d'Ávila: da conquista dos sertões à independência do Brasil. Rio de Janeiro, Civilização Brasileira, 2000. p. 209.

${ }^{140}$ LEITE, Serafim. História da Companhia de Jesus no Brasil. Tomo V...Opus cit., p. 307.

141 MARTIN, Gabriela Apud BARBOSA, Bartira Ferraz. Índios e missões: a colonização do médio São Francisco pernambucano nos séculos XVII e XVIII. Dissertação de mestrado. Recife, UFPE, 1991.

${ }^{142}$ LEITE, Serafim. História da Companhia de Jesus no Brasil. Tomo V...Opus cit., p. 309.
} 
herdades, através de missões volantes, ensinavam e catequizavam os moradores das áreas vizinhas.

Antônio Guedes de Brito, fazendeiro de gado, possuidor de imensas sesmarias no sertão baiano, doou terras ao Colégio da Bahia para fundar residências no sertão. Uma dessas, edificada na aldeia de Carurus, evoluiu para o atual aglomerado de Santo Inácio, sertão da Bahia $^{143}$. O verdadeiro objetivo dos "poderosos" do sertão, ao conceder pedaços de suas terras para os padres, foi obter mercês eclesiásticas, isto é, eles e seus familiares queriam ser sepultados na igreja do Colégio baiano ${ }^{144}$. Território controverso é o sertão nordestino, porque ora os curraleiros ameaçam e expulsam os religiosos, ora estão em conluio, chegando a doar chãos para edificação de suas residências. Leite destacou esta atitude oscilante como basilar para a formação da região, do imaginário, cultura e sociedade sertanejos ${ }^{145}$.

Nas fronteiras dos atuais estado do Rio Grande do Norte e Ceará, nas proximidades do rio Jaguaribe, a Companhia de Jesus instituiu a criação de aglomerados indígenas. Dois foram eles, o primeiro sob a invocação de Nossa Senhora da Anunciação; o segundo dedicado a São João Batista, nas cercanias do lago Podi. Foram designados os padres João Guincel e Felipe Bourel para a cristianização dos índios das nações Janduí, Icó e Paiacú. Contou Bourel, em 10 de janeiro de 1700, o princípio das atividades, isto é, um verdadeiro exílio, à proporção que se afastava das vilas e colônias habitadas por brancos ${ }^{146}$. Nesse tempo, o aldeamento congregou seiscentas almas.

Conflitos de terra, guerras ao gentio bravo, troca de sítio para a instalação da redução e violência foram as características do cotidiano de alguns aldeamentos missioneiros. Comuns até, se observarmos a condição das missões jesuíticas no sertão baiano e às margens do rio São Francisco. Os silvícolas dessa zona sofreram consideráveis hostilidades, em face de sua fragilidade perante os colonizadores, apoiados por bandeirantes do terço. O padre do Hábito de São Pedro, Domingos Ferreira Chaves, testemunha ocular desses incidentes, escreveu ao Reino sobre os maus tratos sofridos pelos indígenas sertanejos:

(...) as grandes violências e injustas guerras com que são perseguidos e tiranizados os Índios do Piogui, Ceará e Rio Grande, Cappitanias contiguas (...), e refere muitos cazos de guerra nao so injustas mas aleivozias em todas

\footnotetext{
${ }^{143}$ LEITE, Serafim. História da Companhia de Jesus no Brasil. Tomo V...Opus cit., p. 308 (nota de rodapé).

${ }^{144}$ LEITE, Serafim. História da Companhia de Jesus no Brasil. Tomo V...Opus cit., p. 309.

${ }^{145}$ LEITE, Serafim. História da Companhia de Jesus no Brasil. Tomo V...Opus cit., p. 310.

${ }^{146}$ LEITE, Serafim. História da Companhia de Jesus no Brasil. Tomo V...Opus cit., p. 539.
} 
as mortes e cativeiros feitos debaixo da pax e amizade, sendo chamados os Índios de propozito e convidados com enganos para esta aleivozia e mortos a sangue frio aquelles que são capazes de tomar armas para o seu (sic.) salva lhe cativarem as molheres e filhos. Que estas guerras as mandão fazer os Capitães mores todas as vezes q' se lhe enseja e lho persuada a sua ambição e a dos moradores por que todos são interessados nos cativeiros dos pobres Índios $(\ldots)^{147}$

Uma carta da Junta das Missões, de 1702, reforçou a paisagem adversa encontrada na capitania do Rio Grande:

(...) no território do Jaguaribe de Pernambuco muito padeceram os padres João Guincel e Vicente Vieyra, não só nas assaltadas que derão aos seus índios Payakises; mas muito mais dos vaqueiros, que em aldeandose em algum lugar os tapuyas, logo querem meter currais junto a elles, com notável estorvo e insolência, semos (sic.) poder reprimir, instigando a outras nações paraque os dezenquietem, quando deverião como cristão ajudar os padres para os atrahirem e affeiçoarem a fé ${ }^{148}$.

Ainda na mesma carta citada foi apresentado o rol demográfico dos aldeamentos assistidos pelos padres na capitania de Pernambuco e suas anexas: na lagoa do Podi do Assú passão de 1000; na cabeceira do Jaguaribe passão de 1000. ${ }^{149}$

Os eventos sobre a atuação dos jesuítas no sertão piauiense estão entrelaçados com a história do sertanista e fazendeiros Domingos Afonso Mafrense. Este, após falecer em 1711, como irmão da Companhia de Jesus, doou legalmente um morgadio ou capela ao Colégio da Bahia $^{150}$, em troca foi sepultado com o hábito de Santo Inácio de Loiola. A herança jesuítica foi decisiva para as posturas eclesiásticas e temporais adotadas e exercidas no sertão do Piauí, pois, a partir dessa doação os padres entram no sistema econômico - fundiário da pecuária sertaneja.

\footnotetext{
${ }^{147}$ PROJETO RESGATE. AHU_ACL_CU_CEARÁ, Cx. 1, D. 67.

${ }^{148}$ Carta para a Junta das Missões. ARSI. Bras. 10 (2) 23 - 25 Apud POMPA, Maria Cristina. Religião como tradução: missionários, Tupi e “Tapuias”..., Opus cit., p. 336.

${ }^{149}$ Carta para a Junta das Missões. ARSI. Bras. 10 (2) 23 - 25 Apud POMPA, Maria Cristina. Religião como tradução: missionários, Tupi e “Tapuias”..., Opus cit., p. 336.

${ }^{150}$ LEITE, Serafim. História da Companhia de Jesus no Brasil. Tomo V...Opus cit., p. 551.
} 
As trinta e cinco fazendas recebidas foram separadas em quatro grupos para melhor administrá-las: capela grande, capela pequena, fazendas do Colégio e bens do noviciado ${ }^{151}$. Pertenciam à capela grande: Algodões, Baixa dos Veados, Boqueirão, Brejinho, Brejo de Santo Inácio, Brejo de São João, Buriti, Caché, Cachoeira, Cajazeiras, Campo Grande, Campo Largo, Castelo, Caratães, Espinhos, Fazenda Grande, Gameleira do Canindé, Gameleira do Piauí, Genipapo, Ilha, Inxú, Julião, Lagoa de São João, Mocambo, Olha d'Água, Pobres, Poções, saco, Salinas, Salinas de Itaueira, Saquinho, Serra Grande, Serrinha, Tranqueira de Baixo e Tranqueira do Meio. As estâncias da capela pequena foram: Guaribas e Matos. Fazendas do Colégio da Bahia: Água Verde, Riacho dos Bois e São Romão Tatu. Os bens do noviciado foram destinados a garantir a sustentação de futuros padres. Tiraram esse patrocínio de algumas das fazendas sobreditas: Água Verde, Castelo e Campo Grande ${ }^{152}$.

Serafim Leite indicou os rendimentos angariados por estes patrimônios aos cofres da Companhia de Jesus: capela grande avaliada em 120.110\$000 réis; capela pequena, terras e animais criados, poderiam lucrar $9.410 \$ 640$ réis; fazendas do Colégio, $21.576 \$ 400$ réis, já os bens do noviciado foram avaliados em $878 \$ 000$ réis $^{153}$. Em 1732, as fazendas possuíam 30.000 cabeças de gado. A quantidade dilatou em 1757, quando o total de animais foram calculados em 32.000. A política colonial e mercantilista facilitou a gestão dos bens temporais jesuíticos, porque esta gozava de alguns benefícios reais que permitiam uma autonomia em relação às obrigações impostas pelo sistema colonial. (...) Tais privilégios favoreceriam suas propriedades, cuja produção, praticamente, era comercializada com isenção de taxas e impostos reais, assegura-nos Paulo de Assunção ${ }^{154}$.

Ainda esclarecendo algumas especificidades das estâncias jesuíticas no sertão do Piauí, Domingos Gomes, em suas Notícias do Piahuy, realizou um inventário de todo o patrimônio fundiário detido pelos padres inacianos da Bahia que, segundo ele, foram apreciados cousa de duzentos e trinta mil cruzados ${ }^{155}$. Na fazenda Espinhos, da capela grande, o relator encontrou casa grandiosa e construída com pedra. Em Castelo do Canindé criaram mais de 1.000 cabeças de gado milhor do sertam $^{156}$. Os padres para não perder de

\footnotetext{
${ }^{151}$ LEITE, Serafim. História da Companhia de Jesus no Brasil. Tomo V...Opus cit., p. 552.

${ }^{152}$ LEITE, Serafim. História da Companhia de Jesus no Brasil. Tomo V...Opus cit., p. 553 - 554.

${ }^{153}$ LEITE, Serafim. História da Companhia de Jesus no Brasil. Tomo V...Opus cit., p. 553.

${ }^{154}$ ASSUNÇÃO, Paulo de. Negócios Jesuíticos: o cotidiano da administração dos bens divinos. 1 ed. São Paulo, Edusp, 2009. p. 25.

155 PROJETO RESGATE. AHU_ACL_CU_016, Cx. 1, D. 15.

${ }^{156}$ PROJETO RESGATE. AHU_ACL_CU_016, Cx. 1, D. 15.
} 
vista os seus animais os marcavam sempre com ferro do colégio ${ }^{157}$. Domingos Gomes mencionou que o dinheiro da venda de trinta reses foi revertido na compra de negros de Angola. A escravidão foi adotada pelos padres jesuítas, igualando-os aos colonizadores que aceitaram os ditames da política mercantilista portuguesa. Endossa Paulo de Assunção sobre o tema:

(...) Os negócios temporais realizados pelos jesuítas, durante o período colonial na América Portuguesa, foram norteados por atitudes, práticas, regras de caráter econômico, em consonância com o modelo de exploração colonial, que permitiram consolidar a imagem de um poder temporal. ${ }^{158}$

O desvio de foco, isto é, a atenção dada à gestão dos bens temporais do Piauí fez daquele sertão espaço de poucos aldeamentos missioneiros. De fato, exercitaram os inacianos outro tipo de atividade, transformaram em catequese cada visita às fazendas e ao pessoal que nela viviam ${ }^{159}$ : camaradas $^{160}$, vaqueiros e seus familiares, tangedores ${ }^{161}$ e escravos. A este tipo de atividade religiosas temos o exemplo do padre Felipe Bourel, o qual percorreu duzentas léguas (por volta de $1332 \mathrm{~km}$ ) para confessar e pregar aos boiadeiros do rio São Francisco e Piauí ${ }^{162}$.

A solidificação dos jesuítas em terras piauienses ocorreu com a construção do hospício do Piauí, nos arredores da vila do Mocha, atual cidade de Oeiras - PI. O vigário da matriz de Nossa Senhora da Viória, Tomé Carvalho da Silva, detentor do passal da igreja, além de ofertar o chão para a fundação da residência, doou doze mil cruzados e huã fazenda de gado para a fábrica deste colégio-internato ${ }^{163}$, com seis padres e um irmão hospedados. $\mathrm{O}$ objetivo da moradia se concentrou na catequese e ensino dos moradores da vila e termo do Mocha. O viajante inglês George Gardner foi observador ocular, em 1838, da presença desta edificação na paisagem urbana do núcleo de Oeiras. Descreveu o naturalista que na parte norte da cidade há um grande e belo edifício, ora em ruínas, que foi o colégio dos jesuítas

\footnotetext{
${ }^{157}$ PROJETO RESGATE. AHU_ACL_CU_016, Cx. 1, D. 15.

${ }_{158}$ ASSUNÇÃO, Paulo de. Negócios Jesuíticos: o cotidiano da..., Opus cit., p. 25.

${ }^{159}$ LEITE, Serafim. História da Companhia de Jesus no Brasil. Tomo V...Opus cit., p. 560.

${ }^{160}$ Camaradas era o encarregado de vigiar as atividades dos vaqueiros e se estes cumpriam o seu trabalho. Seu salário consistiu em um oitavo do todos os bezerros nascidos, em um ano, na fazenda. Ver "Memória Relativa às Capitanias do Piahuy e Maranhão por Francisco Xavier Machado, 1810.” In Revista do Instituto Histórico e Geographico do Brazil. Tomo XVII. Rio de Janeiro, Typographia Universal de Laemmert, 1854. p. 57.

${ }^{161}$ A função dos tangedores consistiu em conduzir as boiadas em seu trajeto, para que estas não se perdessem ao longos dos caminhos e matos.

162 LEITE, Serafim. História da Companhia de Jesus no Brasil. Tomo V...Opus cit., p. 560.

${ }^{163}$ PROJETO RESGATE. AHU_ACL_CU_016, Cx. 2, D. 75.
} 
antes de sua expulsão do Brasil ${ }^{164}$. Hoje nos resta admirar a igreja deste edifício religioso dedicado à Nossa Senhora do Rosário [figura 73].

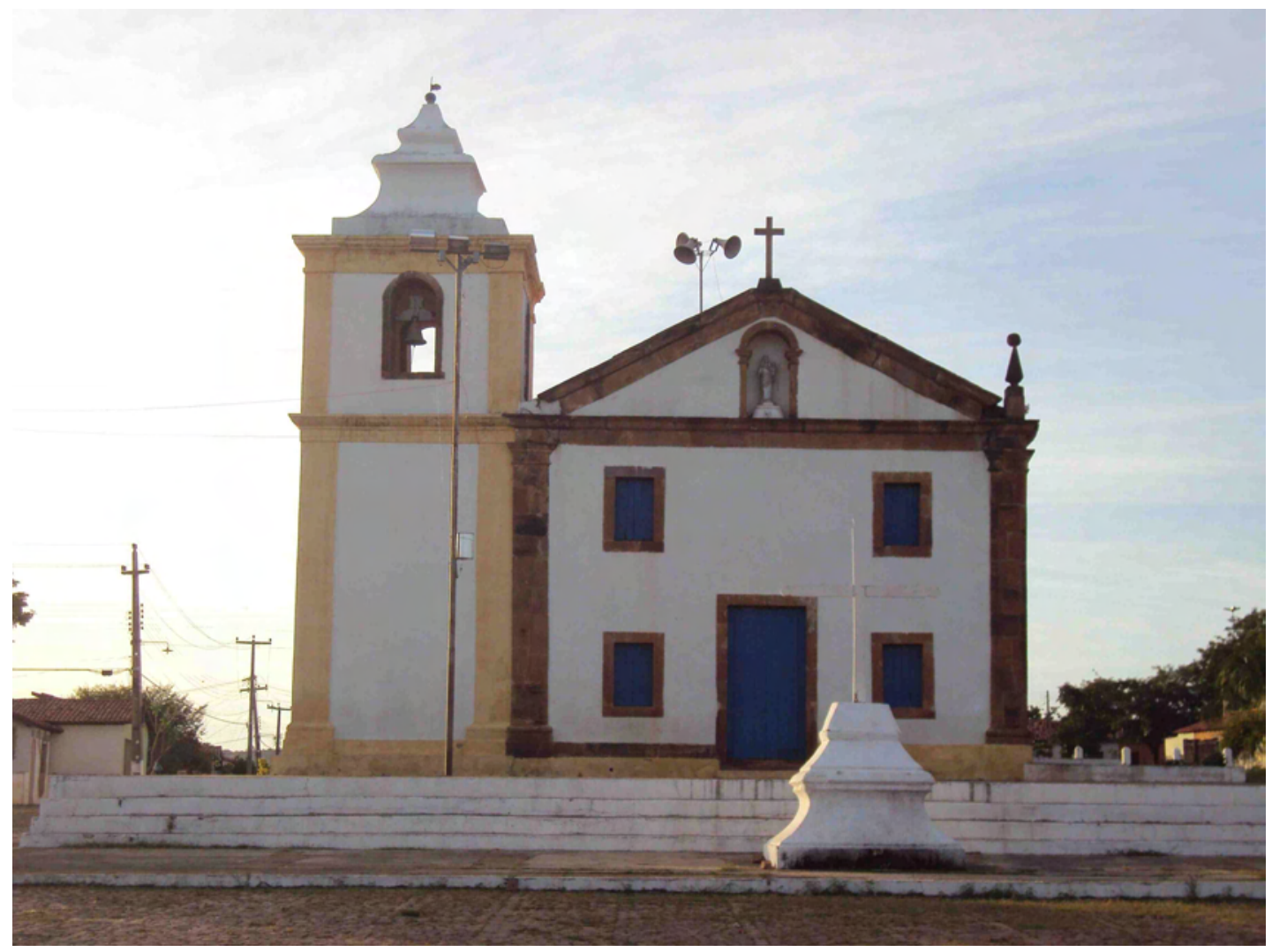

Figura 73 - Atual igreja de Nossa Senhora do Rosário dos Homens Pretos, Oeiras - PI. Neste sítio, em 1732, foi fundado o hospício da Companhia de Jesus no Piauí. Foto do Autor, 2010.

A lei de 23 de Novembro de 1700 ordenou a concessão de uma légua em quadra para cada aldeamento missioneiro com cem casais de índios, pudemos constatar em nossa pesquisa que, dos bens fundiários dos jesuítas no Piauí ou fazendas, alguns chegaram a desenvolver aglomerados urbanos. Por exemplo, a fazenda Brejo de Santo Inácio [figura 74] evoluiu para a atual cidade de Santo Inácio do Piauí165.

\footnotetext{
${ }^{164}$ GARDNER, George. Viagem ao interior do Brasil, principalmente nas províncias do norte e nos distritos do ouro e do diamante durante os anos de 1836-1841. São Paulo, Edusp, 1975. p. 125.

${ }^{165}$ CARVALHO Jr. Dagoberto Ferreira. Passeio a Oeiras. 6 ed. Teresina, Fundação Cultural do Piauí, 2010. p. 193.
} 


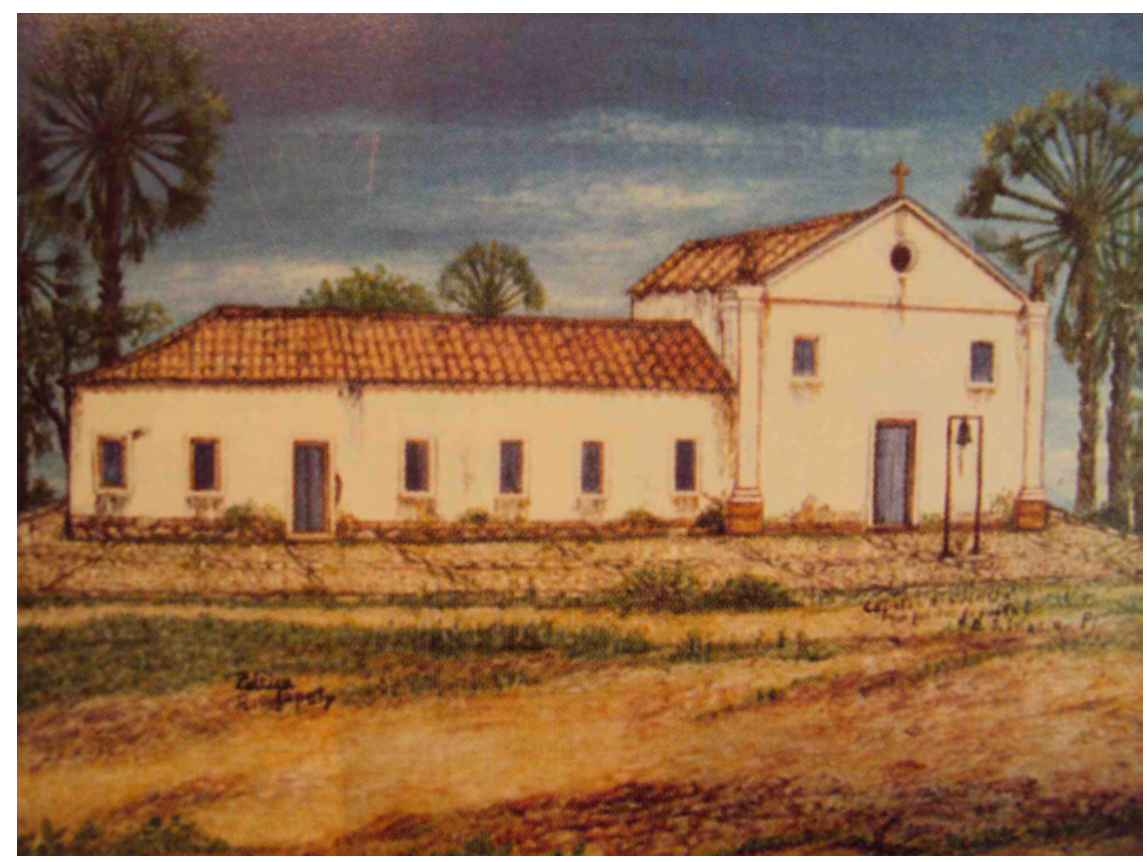

Figura 74 - Fazenda Brejo de Santo Inácio, da capela grande. Óleo inspirado em desenho de 1925. Elemento estruturador do atual município piauiense de Santo Inácio do Piauí. Imagem encontrada em CARVALHO Jr. Dagoberto Ferreira. Passeio a Oeiras. 6 ed. Teresina, Fundação Cultural do Piauí, 2010. p. 192.

\subsection{4 - Missão jesuítica da Ibiapaba}

A fundação da missão da Serra da Ibiapaba se cercou de trabalhos frustrados, podemos caracterizá-los como sangrento: o padre Francisco Pinto foi martirizado até a morte ao tentar doutrinar os nativos. Movimentos efêmeros chegaram ao fim em 1691, quando o pe. Ascenso Gago instalou definitivamente a redução ${ }^{166}$. Esse aldeamento missioneiro é curioso, em virtude da quantidade de índios reduzidos, do seu desenho regular elaborado pelos missionários, pelos seus bens fundiários, lucros obtidos na criação de gado e outros fatores que o qualificaram como a maior missão do Nordeste ${ }^{167}$.

Buscando unir, por via terrestre, o Estado do Maranhão com o Estado do Brasil, foram enviados os padres Francisco Pinto e Luiz Figueira ao Ceará para inspecionar o território e seus nativos. Viam nesta experiência a possibilidade de reduzir os índios e

\footnotetext{
${ }^{166}$ LEITE, Serafim. História da Companhia de Jesus no Brasil. Tomo III...Opus cit., p.03.

${ }^{167}$ POMPA, Maria Cristina. Religião como tradução: missionários, Tupi e “Tapuias”..., Opus cit., p. 335.
} 
encontrar um sítio adequado para este fim $^{168}$. Os caminhos abertos e percorridos auxiliaram as autoridades coloniais no que tange o conhecimento do interior daquela parte do Nordeste.

Os planos dos padres Francisco Pinto e Luiz Figueira malograram com o assassinato de Pinto pelos Tabajaras. Todavia, em 1654, Antônio Vieira recebeu autorização do governador do Maranhão, André Vidal de Negreiros, para erguer a missão da Ibiapaba ${ }^{169}$. O local é geograficamente privilegiado por apresentar água excelente para consumo e vegetação que varia entre o bosque e grandes campinas. Segundo Serafim Leite, somente por volta da expulsão dos holandeses do Nordeste que os jesuítas construíram a primeira igreja da redução, marco simbólico da catequese e domesticação do indígena ${ }^{170}$.

Fatores geopolíticos favoreceram a seleção da serra da Ibiapaba. Antes, a capitania do Ceará pertencia ao Estado do Maranhão, porém, devido às dificuldade de comunicação entre os dois estados da colônia, permaneceu como espaço norteado pela indecisão, se pertencia ao Maranhão ou Estado do Brasil ${ }^{171}$. Diante disso, elegeram um local que fosse ao mesmo tempo de fácil acesso aos padres e autoridades coloniais localizados em São Luiz, como àqueles instalados em Olinda/Recife e Salvador.

As etnias agrupadas no aldeamento foram compostas por Tabajaras vindos de Pernambuco, Tapuias do sertão trazidos desde a chapada do Araripe e fronteiras do Rio Grande com Ceará, além de índios da nação Tremembé descidos do litoral cearense. Sobre este tema, uma carta João Pereira ao padre geral, datada de 26 de junho de 1702, narrou que subjugadas as nações bárbaras...

(...) Foram reunidos num só (missão) os habitantes de três aldeias, para que os padres pudessem ensiná-los mais facilmente, e esta agora é a maior da região; foi construída uma grande igreja e uma casa para os padres, e também as cabanas dos índios foram distribuídas de tal forma que possam ficar o tempo todo sob o olhar dos padres, ótima decisão para o bom governo dos índios e para que vivam vizinhos sujeitos, mais quietos e bem controlados. (...) $)^{172}$

\footnotetext{
${ }^{168}$ LEITE, Serafim. História da Companhia de Jesus no Brasil. Tomo III...Opus cit., p. 04.

${ }^{169}$ LEITE, Serafim. História da Companhia de Jesus no Brasil. Tomo III...Opus cit., p. 16.

${ }^{170}$ LEITE, Serafim. História da Companhia de Jesus no Brasil. Tomo III...Opus cit., p. 22.

${ }^{171}$ LEITE, Serafim. História da Companhia de Jesus no Brasil. Tomo III...Opus cit., p. 30.

172 João Pereira, carta ao padre geral, 26/06/1702. ARSI. Bras. 10, f. 27 Apud POMPA, Maria Cristina. Religião como tradução: missionários, Tupi e “Tapuias”..., Opus cit., p. 335.
} 
João Pereira sublinhou em sua carta o período de estabilização da missão da Ibiapaba, sendo este, segundo Serafim Leite ocorrido entre os anos de $1691-1759^{173}$. Nessa época o aldeamento esteve guiado temporal e espiritualmente pelos padres Afonso Gago e Manuel Pedroso. A sobredita carta menciona, mesmo que indiretamente, dados da cultura urbanística difundidos em boa parte das reduções da Companhia de Jesus das Américas portuguesa e espanhola. Quando discrimina a disposição das cabanas distribuídas de tal forma que possam ficar o tempo todo sob o olhar dos padres, deduzimos princípios de ordem e regularidade, necessários para o bom governo dos índios, conduzindo-os à adaptação aos novos dogmas religiosos e culturais.

Sob o cajado tutelar de Ascenso Gago a organização temporal, eclesiástica e espacial ganharam a sua conformação definitiva. $O$ aldeamento se torna o lugar por excelência da concretização dos ideais jesuíticos no Brasil. A Carta Ânua do que se tem obrado na missão da Serra de Ibiapaba desde o ano de 93 até o presente de noventa e 5 para o Padre Alexandre de Gusmão da Companhia de JESUS Provincial da província do Brasil, transcrita por Serafim Leite ${ }^{174}$, é um interessante documento para o estudo da urbanização articulado naquela parte do sertão nordestino. Consequentemente, concentraremos nosso olhar sob o prisma social e arquitetônico-urbanístico moldados em suas informações.

Apontou Gago, no início da carta, as dificuldades de penetrar o sertão, em função da carência de caminhos terrestres adequados e por ser a serra dotada de um relevo íngreme. Vencidas as barreiras naturais e viárias, chegaram ao local ideal para a ereção da redução. Sacralizaram o chão e edificaram pequena ermida dedicada à Nossa Senhora da Assunção, não grande, por não haver ainda modo para isso, porém quando fosse suficiente para doutrinar e ensinar aos de língua geral $^{175}$. A segregação acometida pelos padres pode ser vista na atitude de separar os neófitos batizados dos pagãos, os primeiros dentro da igreja ouviam os ofícios, os catecúmenos da parte de fora em o terreiro dela ${ }^{176}$. Terreiro dela indica a existência de um adro, espaço pio reservado às festas religiosas e outros cultos sacros ${ }^{177}$.

O padroado impunha à Coroa, entre algumas prerrogativas, impulsionar a catequese e investir seu tesouro na decoração das igrejas. Sabe-se que o monarca luso da época, D. Pedro II, enviou cem mil réis para a ornamentação do espaço interior do templo, porém, cá

\footnotetext{
${ }^{173}$ LEITE, Serafim. História da Companhia de Jesus no Brasil. Tomo III...Opus cit., p. 03.

${ }^{174}$ LEITE, Serafim. História da Companhia de Jesus no Brasil. Tomo III...Opus cit., p. 38 - 56.

${ }^{175}$ LEITE, Serafim. História da Companhia de Jesus no Brasil. Tomo III...Opus cit., p. 49.

${ }^{176}$ LEITE, Serafim. História da Companhia de Jesus no Brasil. Tomo III...Opus cit., p. 49.

${ }^{177}$ MARX, Murillo. Nosso chão: do sagrado ao profano. São Paulo, Edusp, 1988. p. 121.
} 
não aparecem mais que dois frontais de felipexim de lã e suas casulas do mesmo, sem roupa branca alguma, para os altares, nem missais, nem cálices ${ }^{178}$. O primitivo altar mor, retábulo [figura 75] e decoração do forro da matriz de Viçosa do Ceará [figura 76] (cidade cujo primeiro núcleo deve-se à missão da Ibiapaba) são produtos dos esforços dos padres da redução. Investiram os seus rendimentos, obtidos em suas fazendas de gado, no embelezamento da igreja. O forro é particularmente interessante por apresentar motivos estéticos, em molduras alegóricas, que figuram os cinco sentidos humanos [figura 77].

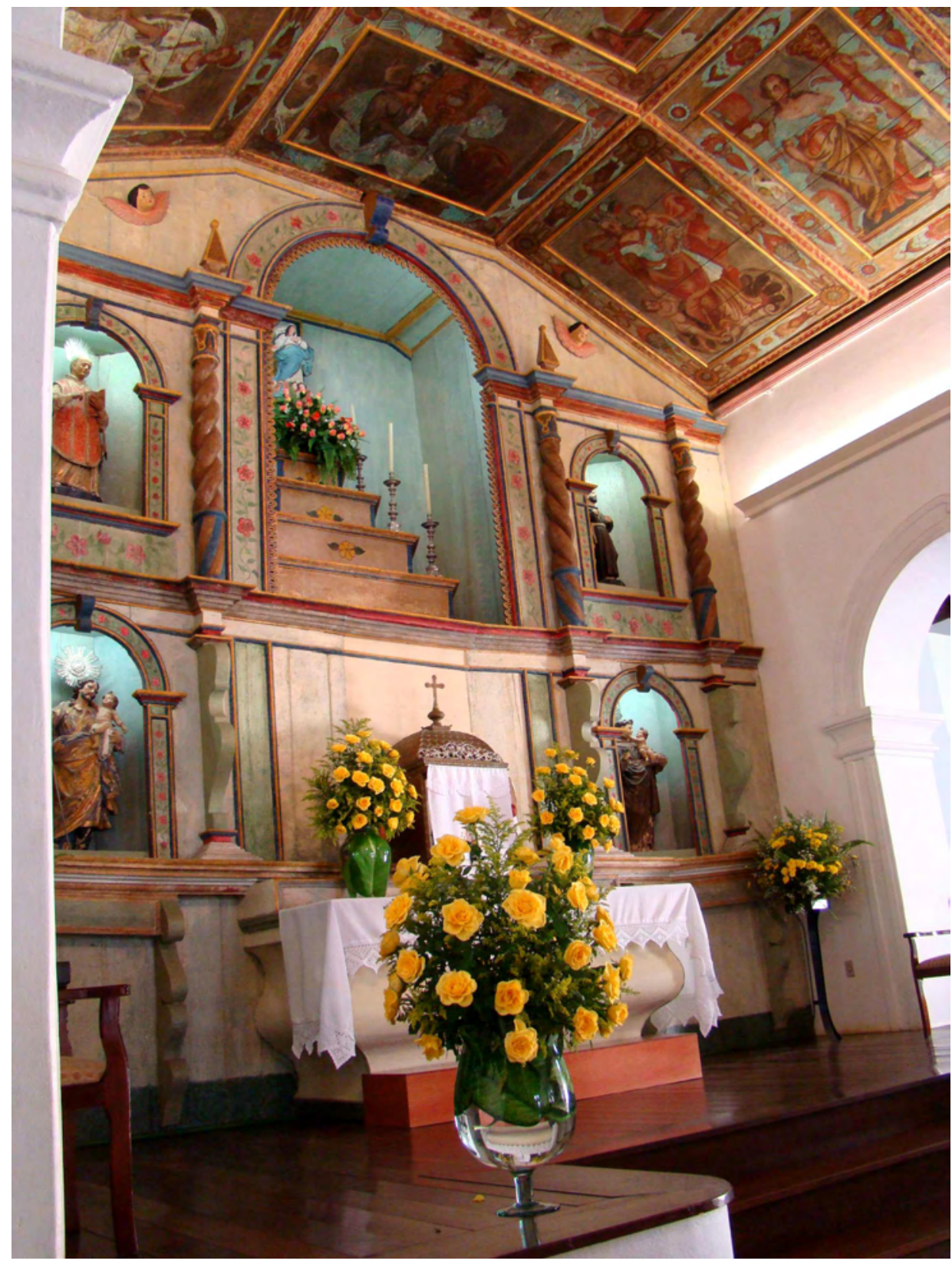

Figura 75 - Retábulo da atual igreja de Nossa Senhora da Assunção, do atual município de Viçosa do Ceará - CE.

Foto cedida por Clovis Jucá.

\footnotetext{
${ }^{178}$ LEITE, Serafim. História da Companhia de Jesus no Brasil. Tomo III...Opus cit., p. 52.
} 


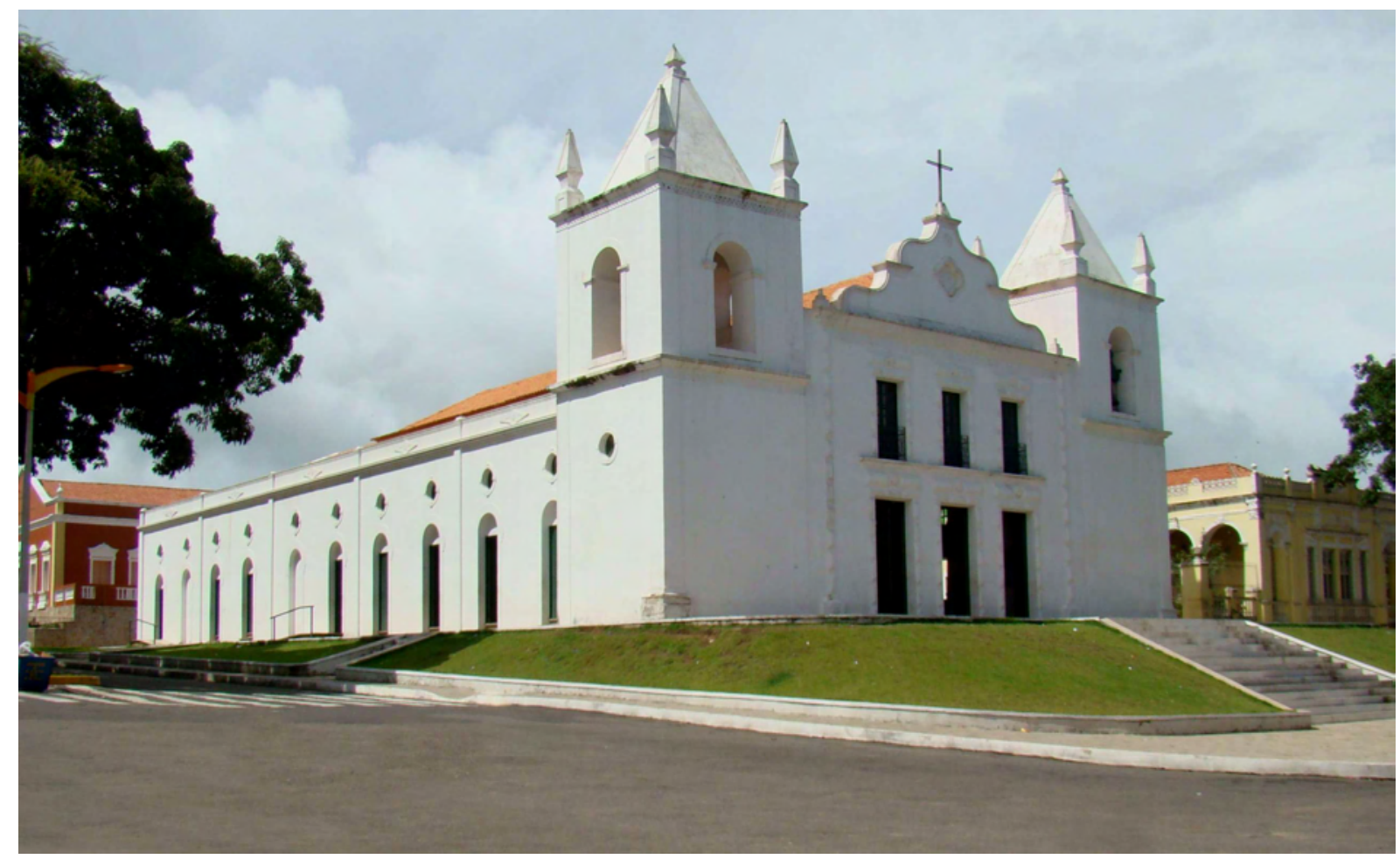

Figura 76 - Igreja Nossa Senhora da Assunção, edificação jesuítica. Foto de Clovis Jucá.

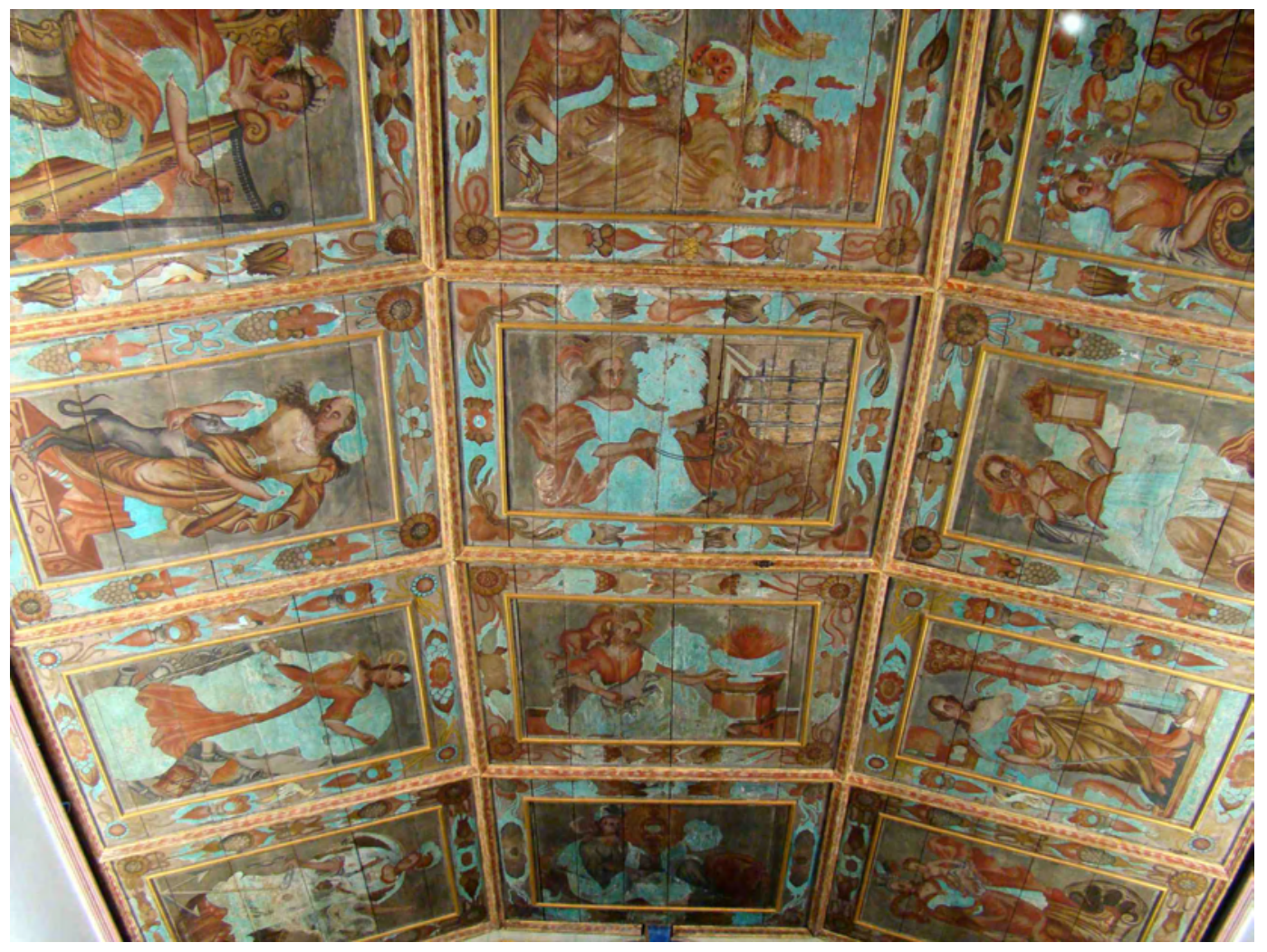

Figura 77 - Forro do altar mor da igreja dedicada à Nossa Senhora da Assunção. Arte jesuítica, com molduras alegóricas representativas dos sentidos humanos. Foto de Clovis Jucá. 
A cultura urbanística é visivelmente identificada na carta do padre Ascenso Gago. O primeiro passo para alicerçar a planificação do aldeamento seria eleger um sitio propício, ou como ele disse aonde lhes sinalássemos (... $)^{179}$. Sem fundos para a obra (...) não foi possível fazer igreja grande, e Aldeia em forma, lhes mandamos fazer uma igreja pequena e de pouca dura junto à qual fizeram suas casas para pouco tempo e se aldearam todos (...) $)^{180}$. A precariedade monetária impossibilitou, a priori, os avanços iniciais do assentamento. A expressão "aldeia em forma" presume desenho ordenado, regular. Nessa fase todos os elementos edificados - pequena igreja, cabanas e o aldeamento em sua totalidade - eram de curta duração, efêmeros.

Posteriormente, provavelmente por volta do ano 1700, unidas as três nações a serem catequizadas, cada uma ocupou o seu respectivo bairro. A redução em forma quadrangular teve três lados destinados ao zoneamento das etnias indígenas: o Principal D. Jacobo de Sousa para a parte do nascente, com todos os seus vassalos; o principal Salvador Saraiva, com os seus, para a parte do poente; e para a parte do sul, fechando a quadra da Aldeia, o Principal D. Simão Taminhombá, com seus vassalos. ${ }^{181}$

A população estimada superou as quatro mil almas. Várias filas de casas foram dispostas linearmente em ruas paralelas. Estruturação que veio a calhar com a vigilância dos missionários. Acima de tudo, o novo núcleos de índios da Ibiapaba é seccionado pela praça em duas partes claramente definidas, nasceram dois mundos: de um lado o domínio do divino, pio, dos jesuítas. Aqui estavam o colégio, a igreja e o cemitério. Do outro lado, o domínio humano, pecador, carnal: os bairros dos índios com suas moradias. A dialética imperou entre a autoridade e os súditos.

Outros exemplos de missões jesuíticas seguiram esta mesma fábrica, o mesmo modelo urbanístico. Na missão de São Miguel [figura 78], a praça, as moradias indígenas, o colégio e a igreja seguem, ao nosso ver, o mesmo partido exposto por Ascenso Gago em sua carta. Similitudes formais observadas em algumas missões guaraníticas do Paraguai. ${ }^{182}$ [figura 79]

\footnotetext{
${ }^{179}$ LEITE, Serafim. História da Companhia de Jesus no Brasil. Tomo III...Opus cit., p. 57.

${ }^{180}$ LEITE, Serafim. História da Companhia de Jesus no Brasil. Tomo III...Opus cit., p. 57 - 58.

${ }^{181}$ LEITE, Serafim. História da Companhia de Jesus no Brasil. Tomo III...Opus cit., p. 63 - 64.

${ }^{182}$ HAUBERT, Maxime. Índios e jesuítas no tempo das missões. São Paulo, Companhia das Letras, 1990. p. 197
} 


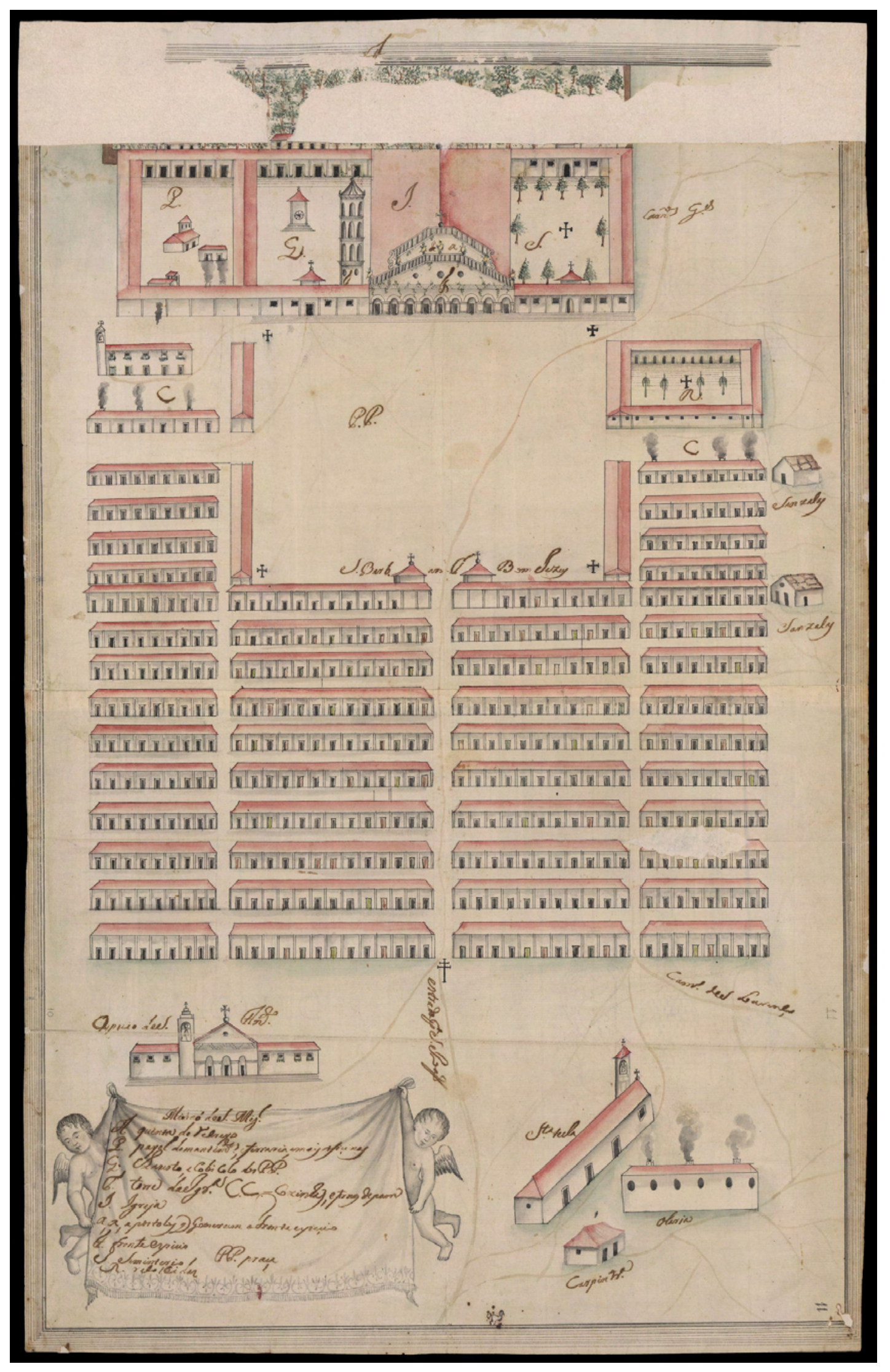

Figura 78 - Planta da missão de São Miguel, 1756. Imagem disponível em http://www.bn.br. Acesso em 24/04/2011. 


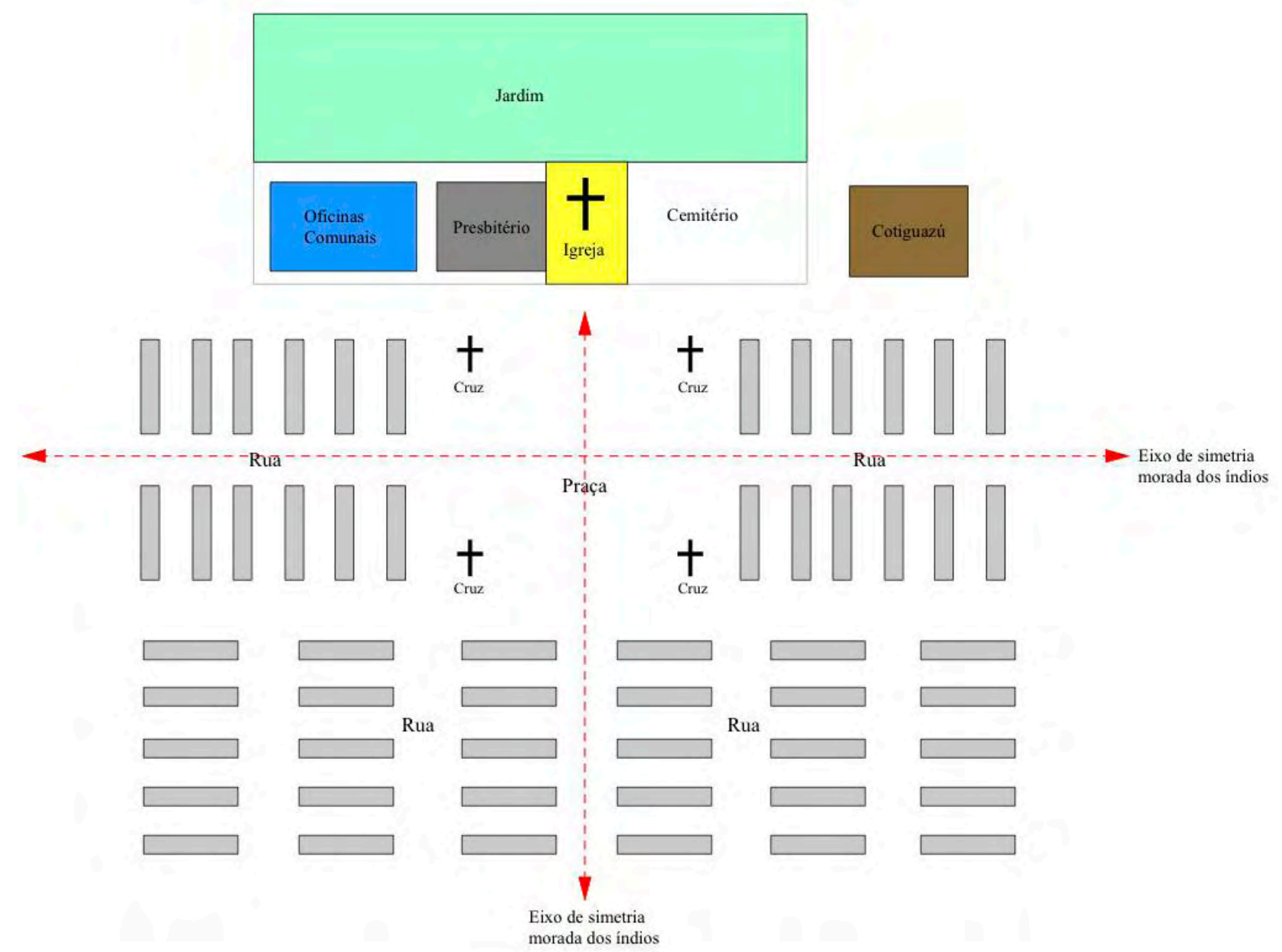

Figura 79 - Planta típica de uma redução guarani. Desenho do autor sobre planta desenvolvida por Maxime Haubert. Ver HAUBERT, Maxime. Índios e jesuítas no tempo das missões. São Paulo, Companhia das Letras, 1991. p. 197.

A tradição urbanística dos jesuítas é fruto da sua rígida formação religiosa no Colégio de Jesus de Coimbra ou no Colégio de Santo Antão de Lisboa. Na capital portuguesa os padres estudaram perspectiva e matemática com o pe. Inácio Vieira através do Tractado de Prospectiva de Inácio Vieira, S. J. ${ }^{183}$ Também, a localização do colégio, igreja e residência dos padres talvez sigam normas do Regulamento do padre Antônio Vieira, resultado de sua experiência missionária no Amazonas. No parágrafo 10 a determinação de Vieira incluiu os seguintes aspectos:

Nas Aldeias de visita tenham os padres casa própria, separada das dos Índios junto à Igreja quando for possível, e na mesma casa tenham cerca fechada, de modo que, para nenhuma coisa lhes seja necessário sair fora da casa; e

\footnotetext{
${ }^{183}$ MELLO, Magno; LEITÃO, Henrique. "A pintura barroca e a cultura matemática dos jesuítas: o Tractado de Prospectiva de Inácio Vieira, S. J. (1715). In Revista de História da Arte. $\mathrm{N}^{\circ} 01$. Lisboa, Instituto de História da Arte - Faculdade de Ciências Sociais e Humanas (UNL), 2005. p. 95 - 141.
} 
quando o fizerem, ainda que seja à Igreja, se estiver apartada a casa, o não farão, se não ambos juntos; ${ }^{184}$

A missão ganhou vultos quando foi proposto a Dom Pedro II a construção de um hospício para os padres residentes e para aqueles que estavam de passagem no núcleo. Ascenso Gago solicitou côngruas da fazenda real para subsidiar o projeto. O monarca em resposta: fuy servido resolver que no Ceará se faça um hospício ou casa de rezidencia para assistirem os Padres da Companhia q' tiverem a sua conta esta missão, para que desta tal casa possão entrar nas terras e assistir Aldeas servindo como cabeça principal da dita missão ${ }^{185}$.

Por motivos diversos, um deles remete às questões fundiárias e posse do chão, impediram o estabelecimento do hospício. Gago, em 1706, fez novo requerimento à Corte de Lisboa, perdurando o caso até a administração do pe. João de Guedes. Este último religioso solicitou a Dom João V a concretização dos intentos de edificar a residência. Como executor dos direitos de padroado, o rei percebeu que...

(...) o bem espiritual que pode resultar aos moradores da Serra da Ibiapaba, em se fundar, naquella aldea, hum hospício de religiosos da mesma companhia para sahirem em missoes ás capitanias do Ceará e Piahuy (...) cujo effeito recorria á minha real grandeza e piedade mandar dar algumas côngruas moderadas (...) Hei por bem se dê 6.000 cruzados por tempo de três anos a 2.000 cruzados por anno, que estavao determinados para a fábrica do primeiro hospício e que se dê côngrua a cada um dos missionários 40:000 $(\ldots)^{186}$

Paulatinamente, os jesuítas da Ibiapaba dilataram seus domínios fundiários e gados, quer por arrematação, quer por doações de particulares. Em 1706, recebeu o padre Ascenso Gago duas datas de sesmarias com duas léguas de terra cada uma, desde o rio Camocim até o lugar do Itacolomi ${ }^{187}$. Surge a fazenda Tiaia nessas datas de sesmarias. Já em 1710, Francisco

\footnotetext{
${ }^{184}$ VIEIRA, Antônio, S. I. "Relação da missão da Serra de Ibiapaba [1660]”. In GIORDANO, Cláudio (coord.). Escritos instrumentais sobre os índios. São Paulo, EDUC/Loyola/Giordano, 1992. p. 122-190 Apud MAIA, Ligio José de Oliveira. Serras de Ibiapaba, de aldeia à vila de índios: vassalagem e identidade no Ceará colonial - século XVIII. Tese de doutorado. Niterói, UFF, 2010. p. 119.

${ }^{185}$ MARTINS, Vicente. "O hospício dos jesuítas de Ibiapaba". In Revista do Instituto do Ceará. vol XLIII. Fortaleza, 1930. p. 158.

${ }^{186}$ MARTINS, Vicente. "O hospício dos jesuítas de Ibiapaba"....Opus cit., p. 97 - 98.

${ }^{187}$ Cf. Datas de Sesmarias do Ceará, vol.3, n 140. 03/09/1706. Datas de sesmarias do Ceará, vol. 3, no 180. 09/12/1706 Apud MAIA, Ligio José de Oliveira. Serras de Ibiapaba, de aldeia à vila de índios: vassalagem e identidade no Ceará colonial - século XVIII. Tese de doutorado. Niterói, UFF, 2010. p. 181 - 182.
} 
da Cunha, doou 450 cabeças de gado vacum à Nossa Senhora da Assunção. Os rendimentos da fazenda Tiaia foram responsáveis pela compra dos sítios: Pacoti, Ipueira e Tiaia de Baixo, mais duas léguas de terra no lugar Panacuy e três léguas adquiridas em haste pública ${ }^{188}$. Adicionando este patrimônio e outros não mencionados, a fazenda Tiaia abrigou doze léguas de terra com 1.010 cabeças de gado vacum.

Serafim Leite destacou que, em 1759, possuíram os jesuítas quatro fazendas: Imboeira, Missão, Tiaia e Poetinga. O gado vacum excedia as 4.700 cabeças; cavalar: 470 cabeças, e o gado miúdo, 200 animais $^{189}$. Extraditados os padres da Companhia de Jesus dos domínios portugueses, o governo da capitania de Pernambuco realizou o seqüestro de todos os bens de sua jurisdição. Na $R^{a m}$. de todo o gado vacum, cavallar, meudo e do mais que se achou na antiga Aldea, que por ordem de S. Mag. Fidelíssima se erigirão em Villas, repartição que delles se fez às pessoas abayxo desveladas [figura 80] está demonstrado o quantitativo do gado da fazenda Tiaia na época da expulsão dos jesuítas.

A subsistência dos padres e dos índios era provida pela pecuária, roças onde se plantavam verduras e legumes, e algum pomar cultivado nas terras doadas à Companhia ${ }^{190}$. Entretanto, a condição do gentio reduzido era precária. Em um aldeamento com uma população de índios de 5.474 almas $^{191}$, a légua em quadra legal para a manutenção física dos silvícolas cessou sua produtividade:

(...) por constarem as terras, q' lhes foram demarcadas de mtos. dias, e quebradas inuteis e as poucas q' foram capazes de prontas já estarem cançada; nam acham já aonde possam prantar seus mantimentos, de q' naçe haver na aldeã huã continua fome, e se nao fora a charidade de seus Padres missionários, q' com algum gado, q' criao para seus sustento acodem os mais necessitados, mais de cem viúvas dexamparadas, e mtos. meninos orfaons, cujos pais morreram nas guerras, ou nas doenças em climas estranhos $(\ldots)^{192}$

\footnotetext{
${ }^{188}$ MAIA, Ligio José de Oliveira. Serras de Ibiapaba, de aldeia à vila de índios: vassalagem e identidade no Ceará colonial - século XVIII. Tese de doutorado. Niterói, UFF, 2010. p. 182 - 184.

${ }^{189}$ LEITE, Serafim. História da Companhia de Jesus no Brasil. Tomo III...Opus cit., p. 66.

${ }^{190}$ PROJETO RESGATE. AHU_ACL_CU_CEARÁ, Cx. 3, D. 182.

${ }^{191}$ PROJETO RESGATE. AHU_ACL_CU_CEARÁ, Cx. 6, D. 416

${ }^{192}$ PROJETO RESGATE. AHU_ACL_CU_CEARÁ, Cx. 1, D. 65.
} 
A solução parecia simples:

(...) Pedimos humildemente a Vossa Real Magestade, q' seja servido de alargar lhes o districto de suas terras concedendo lhes toda a terra q' fica em sima da Serra visto ser incapax de criar gado. Começando desde a ladeira da Uruoca athé o lugar chamdo Itapéuna, q' sam as terras em q' prantaram sempre os seus pais, e avós, e estam oje descançadas, e capazes de darem mantimentos (...). ${ }^{193}$

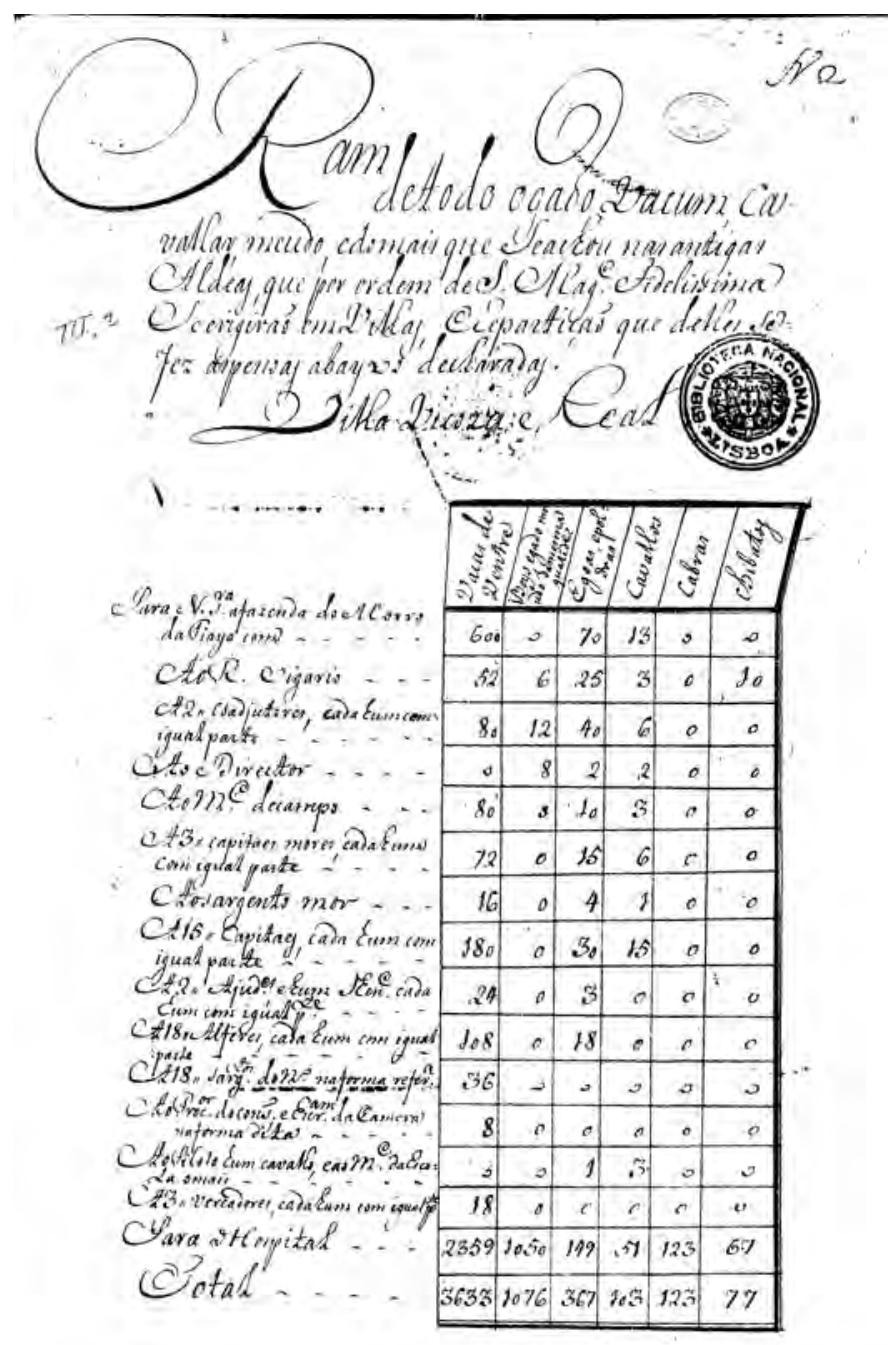

Figura $80-R^{a m}$. de todo o gado vacum, cavallar, meudo e do mais que se achou na antiga Aldea, que por ordem de S. Mag. Fidelíssima se erigirão em Villas, repartição que delles se fez às pessoas abayxo desveladas - Villa Viçosa. Ver PROJETO RESGATE. AHU_ACL_CU_PERNAMBUCO, Cx. 95, D. 7493.

Após a deportação dos padres, foi determinado continuaram com o confisco dos bens e o desenvolvimento de inventário detalhado deles, identificando fazendas, gados vacuns e cavalares e terras, contando inclusive indicações sobre os rendimentos de cada bem

${ }^{193}$ PROJETO RESGATE. AHU_ACL_CU_CEARÁ, Cx. 1, D. 65. 
sequiestrado ${ }^{194}$. Foi incumbido o governador da capitania de Pernambuco, Luís Lobo da Silva, de catalogar os bens jesuíticos da Serra da Ibiapaba ${ }^{195}$.

Escrevendo a Sebastião José de Carvalho e Melo sobre as condições físicas do aldeamento, cuja pretensão consistia em erigir freguesia de índios ou vila, de acordo com o Diretório dos Índios, elaborado em 1758 e expandido para o Estado do Brasil no mesmo ano, a autoridade colonial assinalou a pouca civilidade dos nativos convertidos pelos inacianos:

Todo o referido ficaria inútil à vista da notória barbaridade, em q’ tem sido conservados estes mizeraveis, se nao lhes dessem pessoas, de bons costumes q' lhes servissem de Directores pelo tempo necessário a entrarem na intelligencia perciza a se regularem sem carencia de quem os dirija elles evite os enganos a q' a sua rusticidade os habilita $(. . .)^{196}$

O bispo da capitania de Pernambuco, D. Francisco Xavier Aranha, governou a diocese na época da deportação dos jesuítas. Justificando os abusos e infrações cometidos pelos padres da Companhia em suas missões, transferiu a administração eclesiástica aos clérigos do Hábito de São Pedro. Em seguida, eleva ao status de freguesia e vigaria de índios para que daqui em diante fiquem do padroado a proteção Real (...) A missão de Nossa Senhora d'Assumpção da serra da Ibapaba se chamará Igreja Parochial e Vigaria da notável Villa Viçosa Real ${ }^{197}$. O aldeamento jesuítico da serra da Ibiapaba obteve os foros de vila em 1772, durante o reinado de Dom José I, sendo chamado a partir de então de vila Viçosa Real.

\footnotetext{
${ }^{194}$ ASSUNÇÃO, Paulo de. Negócios Jesuíticos: o cotidiano da administração dos bens divinos. 1 ed. São Paulo, Edusp, 2009. p. 349.

195 PROJETO RESGATE. AHU_ACL_CU_CEARÁ, Cx. 7, D. 464.

${ }^{196}$ PROJETO RESGATE. AHU_ACL_CU_CEARÁ, Cx. 7, D. 464.

197 "ORDEM para a criaçao das Villas e Vigaria dos índios". Arquivo da matriz da cidade de Viçosa, livro de registro n02. In Revista do Instituto do Ceará. Fortaleza, 1929 - 1930. p. 01- 07.
} 


\subsection{5 - Missões do Oratório de São Felipe Nery}

Poucas são as pesquisas e informativos acerca da atuação missionária dos oratorianos no Nordeste colonial, quiçá em seu sertão. Detemo-nos em expor algumas considerações encontradas nos estudos de Ebion Lima ${ }^{198}$, Bartira Barbosa ${ }^{199}$, Maria do Céu Medeiros ${ }^{200}$ e Eugénio dos Santos ${ }^{201}$. Das fontes primárias acessíveis, selecionamos as do Projeto Resgate Barão de Rio Branco, cujos cd's foram fornecidos pela cátedra Jaime Cortesão (FFLCH USP).

Chamados de congregados ou recoletas, a ordem do Oratório de São Felipe Nery nasceu dentro de contradições internas, organizacionais, entre os seus fundadores: o padre Bartolomeu de Quental, em Lisboa, e o padre João Duarte do Sacramento, em Pernambuco. Divergências que os puseram negativamente diante das autoridades eclesiásticas de Olinda e Salvador. Basicamente, por valorizar os bens temporais aos sacrifícios que envolviam seu hábito religioso. Sua ação missionária se restringiu à capitania de Pernambuco, pois ali estabeleceram sua primeira residência ou hospício na ermida de Santo Amaro, por ser a mais retirada e conforme ao recolhimento de seus espíritos e própria para os padres dela saírem para as missões $(\ldots)^{202}$.

Eduardo Honaert expõe o caráter envolvido na formação religiosa dos seus adeptos, incluindo a formação clerical dos seus principais componentes:

O movimento missionário dos padres oratorianos no Brasil é na realidade um movimento do clero secular, um belo fruto do novo espírito religioso que surgiu em Portugal na segunda metade do século XVII. (...) O movimento da "reforma da vida cristã" nasce no mundo dos ermitões, dos leigos e dos terciários e se estende ao mundo clerical $(. . .)^{203}$

\footnotetext{
${ }^{198}$ LIMA, Ebion, "As missões oratorianas no Brasil: informação sobre as missões oratorianas do Nordeste". In Revista do Instituto Histórico e Geográfico Brasileiro. $\mathrm{n}^{\circ}$ 323. Abr/jun. Rio de Janeiro, IHGB, 1979. p. 69 - 118. ${ }^{199}$ BARBOSA, Bartira Ferraz. Índios e missões: a colonização do médio rio São Francisco pernambucano nos séculos XVII e XVIII. Dissertação de mestrado. Recife, UFPE, 1991.

${ }^{200}$ MEDEIROS, Maria do Céu. Os oratorianos de Pernambuco: uma congregação "a serviço" do estado português. Dissertação de mestrado. Recife, UFPE, 1981.

${ }^{201}$ SANTOS, Eugénio dos. "Pombal e os oratorianos". In Revista Camões. n ${ }^{\circ}$ 15/16. Lisboa, 2003. p. 75 - 86.

${ }^{202}$ LIMA, Ebion, "As missões oratorianas no Brasil: informação sobre as missões oratorianas do Nordeste"..., Opus cit., p. 70.

${ }^{203}$ HORNAERT, Eduardo. História da Igreja no Brasil: ensaio de interpretação a partir do povo: primeira época, Período colonial. 5 ed. Petrópolis, Editora Vozes, 2008. p. 68.
} 
Quatro missões de assistência externa em aldeias de gentios caboclos e tapuias em as quais se acham sujeitos de pousada (...) Dista a primeira desta praça (Recife), quinze léguas e é a que chamam Ipojuca; a outra intitulada Uratagui, dista dezoito léguas; a terceira a quem o sitio dá o nome de Limoeiro dista vinte léguas e a última é de Arorobá, dista sessenta léguas grandes que outros com mais consciência contam oitenta (...)[grifo nosso $^{204}$. Nesse pequeno relato estão identificadas as primeiras reduções oratorianas em Pernambuco. Vale ressaltar que, uma delas estava no litoral - Ipojuca -, duas na zona da mata - Limoeiro e Uratagui -, Ararobá seria a primeira, a priori, a se fixar no sertão.

Chegaram, em 1659, João Duarte do Sacramento e João Rodrigues Vitória (cofundador da ordem em Pernambuco) após a expulsão dos holandeses do Nordeste. Jesuítas e franciscanos, pelo apoio dado à Coroa portuguesa, foram expulsos de algumas de suas reduções pelos batavos. Reunidas as autoridades católicas de Pernambuco, decidiram transferir os poderes espirituais e temporais desses aldeamentos aos padres do Oratório de São Felipe Nery. Entre estas, uma aldeia localizada no rio São Francisco - Brejo dos Padres -, e a missão do Podi (fronteira do Rio Grande do Norte com Ceará), ambas sob a coordenação da Companhia de Jesus ${ }^{205}$. Destas, somente a missão potiguar retornou aos seus anteriores detentores.

No núcleo indígena do Brejo dos Padres, situado nas proximidades da atual cidade de Tacaraú - PE, edificaram os padres da recoleta ermida sob a invocação de Santo Antônio [figura 81], datada do século XVII. O "Inventário do Patrimônio Cultural do Estado de Pernambuco - Sertão do São Francisco", elaborado pela FUNDARPE, descreve as características arquitetônicas deste templo: uma nave central, capela mor e sacristia lateral compõem o programa da edificação ${ }^{206}$.

\footnotetext{
${ }^{204}$ Notícias que dão os padres da Congregação de Pernambuco. AHU, manuscritos do Brasil, $\mathrm{n}^{\circ}$ 23. Apud LIMA, Ebion, “As missões oratorianas no Brasil: informação sobre as missões oratorianas do Nordeste”..., Opus cit., p. 70.

${ }^{205}$ BARBOSA, Bartira Ferraz. Índios e missões: a colonização do médio rio São Francisco..., Opus cit. LIMA, Ebion, “As missões oratorianas no Brasil: informação sobre as missões oratorianas do Nordeste”..., Opus cit., p. 75.

${ }^{206}$ INVENTÁRIO do Patrimônio Cultural do Estado de Pernambuco: Sertão do São Francisco. Recife,

FUNDARPE. p. 75.
} 


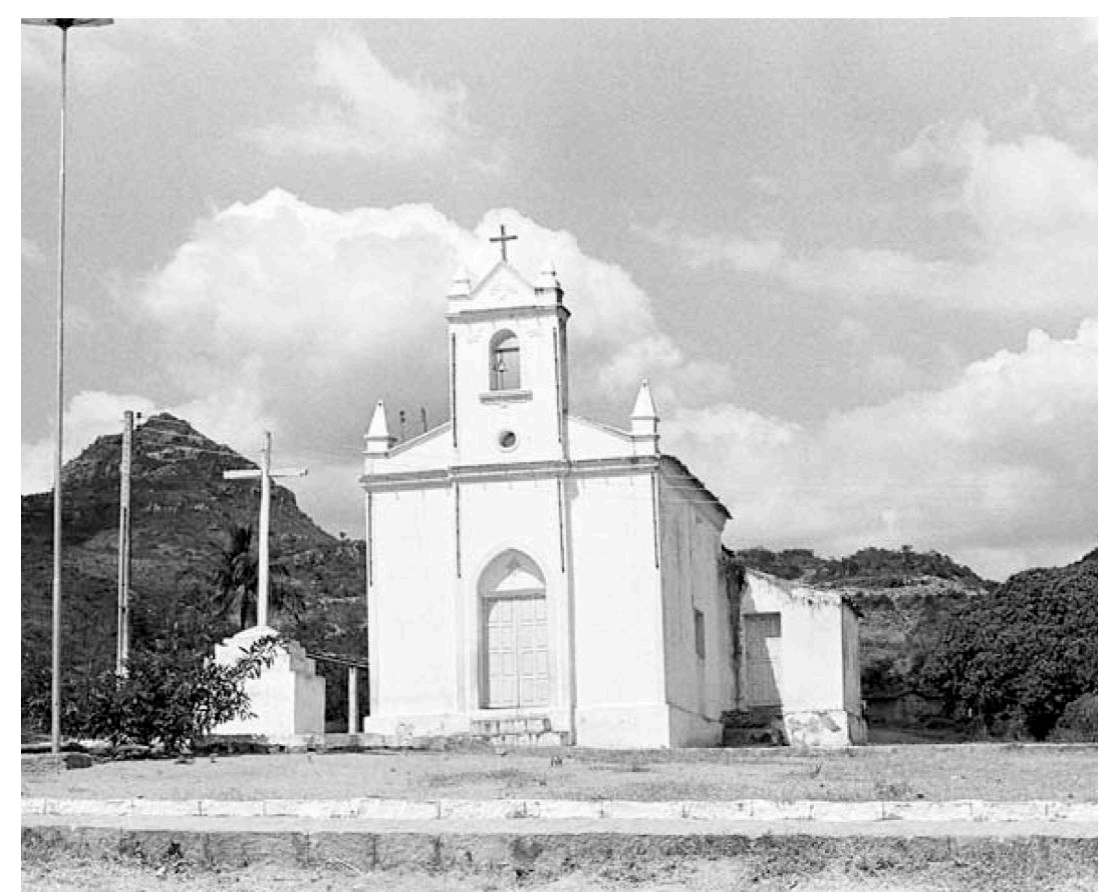

Figura 81 - Ermida de Santo Antônio, autoria dos padres do oratório de São Felipe Nery. Foto cedida pela FUNDARPE - PE.

$\mathrm{Na}$ "Relação das Aldeas, que ha no Destricto deste Governo de Pernambuco e Capitania da Paraíba subgeitos á Junta das Missões d'este Bispado", encontrado na Informação Geral da Capitania de Pernambuco - $1749^{207}$, estão elencadas as reduções e suas respectivas ordens religiosas. Situamos na freguesia do Ararobá o aldeamento que carrega a mesma nomeação da paróquia, dirigida pelos congregados - Domingos Gonçalves e Filipe da $\mathrm{Cruz}^{208}$. Nesta época, o censo calculou 642 pessoas reduzidas na missão de Ararobá, compostas basicamente por índios xucurús ${ }^{209}$.

Dedicada à Nossa Senhora da Montanha, a missão de Ararobá - a chave do sertão $o^{210}$ - foi estabelecida em 1679, dentro da sesmaria de João Fernandes Vieira ${ }^{211}$. Seu progresso deveu à pecuária extensiva exercida em fazendas e sítios sob o comando dos oratorianos do hospício de Recife. Posicionado estrategicamente, no caminho das boiadas Recife - Minas

\footnotetext{
207 "Informação Geral da Capitania de Pernambuco - 1749". In Annaes da Bibliotheca Nacional do Rio de Janeiro. Vol XXVIII. Ano 1906. Rio de Janeiro, Officinas de Artes Graphicas da Bibliotheca Nacional, 1908. p. 421.

${ }^{208}$ LIMA, Ebion, “As missões oratorianas no Brasil: informação sobre as missões oratorianas do Nordeste”..., Opus cit., p. 96.

209 “Informação Geral da Capitania de Pernambuco - 1749”. In Annaes da Bibliotheca Nacional do Rio de Janeiro. Vol XXVIII ..., Opus cit., p. 421.

${ }^{210}$ PROJETO RESGATE. AHU_ACL_CU_PERNAMBUCO, Cx. 10, D. 242.

${ }^{211}$ BARBALHO, Nelson. Cronologia pernambucana: subsídios para a história do agreste e do sertão. Recife: CEHM/FIAM, 1983. 17 v.
} 
Gerais $^{212}$, o aldeamento de Ararobá evolui à guisa desta estrada sertaneja. Sua composição espacial, com desenho retangular, foi ordenada pelos padres ao situar os nativos em moradias feitas em taipa e cobertas com palha. A grande praça ou largo da igreja apresenta um desenho regular, quadrangular [figura 82]. O templo religioso tem sua posição centralizada, hierarquizando o sistema urbano do núcleo. Deve-se a uma reforma, ocorrida em meados do século XIX, a atual "fisionomia" da matriz [figura 83].
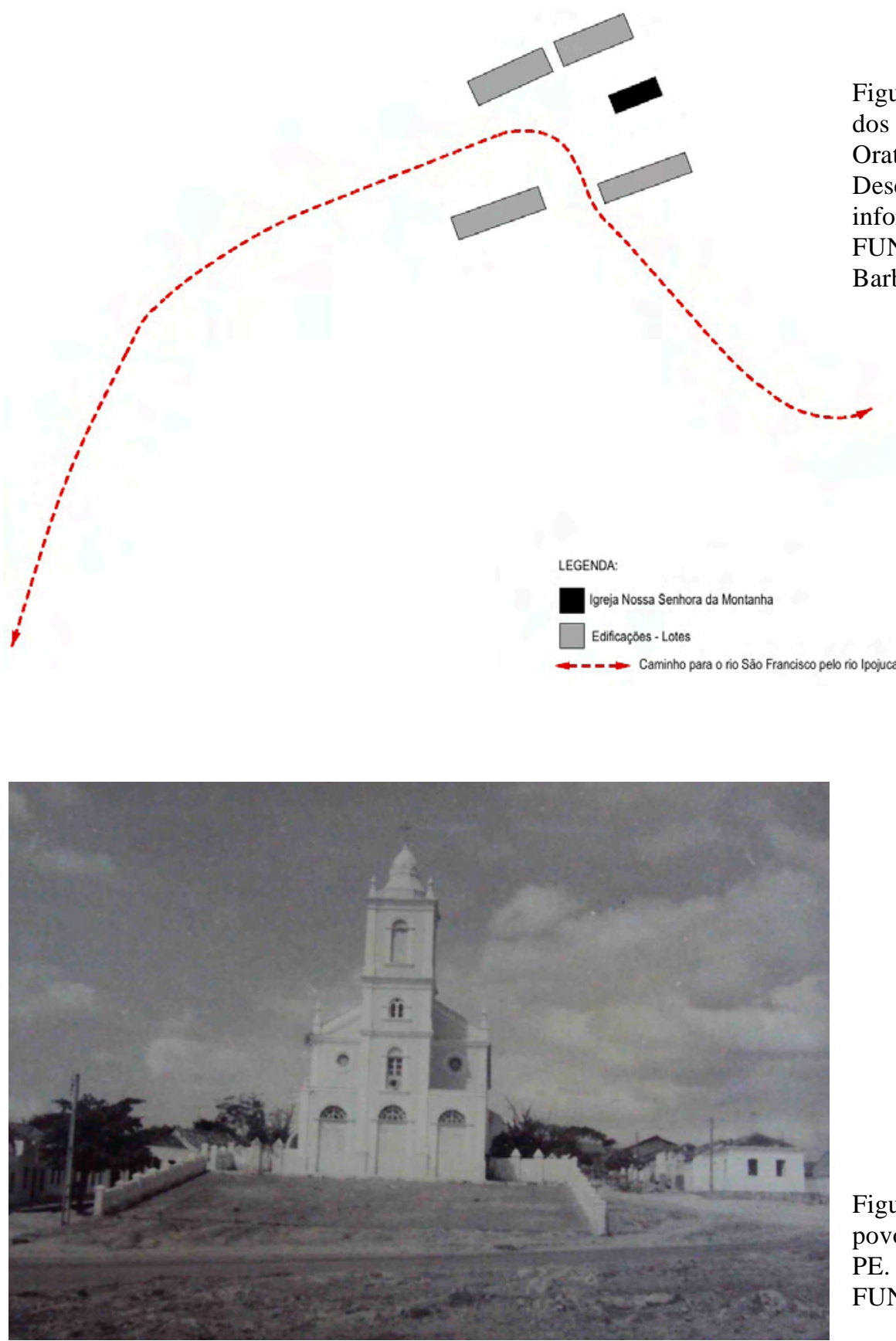

Figura 83 - Igreja matriz da povoação atual de Simbres PE. Foto cedida pela FUNDARPE - PE.

\footnotetext{
${ }^{212}$ SOBRINHO, Barbosa Lima. Capistrano de Abreu e o povoamento do sertão pernambucano. In Revista do Instituto Arqueológico, Histórico e Geográfico Pernambucano. Separata do volume 50. Recife, 1978. 32 - 40.
} 
Outros aldeamentos oratorianos subsidiaram a urbanização de distintas partes do sertão nordestino. A capitania do Ceará, após sua indexação ao bispado de Pernambuco, em 1680, recebeu estes religiosos em suas povoações de índios e colonos portugueses. Dirigiu-se o padre João do Sacramento à autoridade diocesana solicitando novos missionários para cinco aldeias de índios que tinham sido e já não eram aldeados ${ }^{213}$. Numa carta régia de 1694 , ordenou o rei a fundação de seis aldeias para povoar a ribeira do Açu, Pinharanhas e Jaguaribe. Mote vinculado à proteção dos gados e fazendas, em face da intensa atividade bélica indígena da região. Tais missões eram fortalezas contra o avanço gentio no sertão nordestino, porque muito da fazenda real foi gasto em combatê-lo:

(...) a guerra contra os índios era em (...) deffensa e segurança dos gados (...) em que todos concordão em meter nas Ribeyras do Assú, a fim de que se povoasse e as mais partes destes Sertõens (...) em quanto o Governo Geral deste estado mande socorrer com effeito aquelles lugares, para que se perpetuem nellas as povoaçõens, que naquella parte podem haver as quaes convem estejão com toda a segurança, pela pouca fé que costuma goardar os Tapuyas $(\ldots)^{214}$

Em 1698, Dom Pedro II congratulou a Congregação do Oratório de São Felipe Nery com proteção real, pelo fervor em penetrar os sertões e trazer os índios ao grêmio da igreja e obediência às leis civis ${ }^{215}$. A soberba dos padres, diante da graça real, resultou em abusos de autoridade, convertendo sua religiosidade em acúmulo de bens temporais, traduzidos em grandes glebas de terra e gados. Ebion Lima afirmou que, a esses interesses econômicos territoriais, estava agregada uma vida frouxa, com os regimentos burlados pelos superiores e aqueles localizados no interior, nas povoações de índios ${ }^{216}$. As missões religiosas se instalaram onde havia dinâmica econômica, onde as facilidades comerciais pudessem enriquecer a Ordem.

O domínio territorial dos oratorianos pode ser visto no mapa 09, elaborado segundo velha cartografia encontrada na Fundação da Biblioteca Nacional: Mapa Topográfico em que e mostrão as terras que forão dos Reverendos Congregados, desde a Barra do Buriti pelo Rio

\footnotetext{
${ }^{213}$ LIMA, Ebion, “As missões oratorianas no Brasil: informação sobre as missões oratorianas do Nordeste”..., Opus cit., p. 78.

${ }^{214}$ PROJETO RESGATE. AHU_ACL_CU_018, Cx. 1, D. 42.

${ }^{215}$ LIMA, Ebion, “As missões oratorianas no Brasil: informação sobre as missões oratorianas do Nordeste”..., Opus cit., p. 86.

${ }^{216}$ LIMA, Ebion, “As missões oratorianas no Brasil: informação sobre as missões oratorianas do Nordeste”..., Opus cit., p. 95.
} 
Ipojuca asima até as nassenças, e do passo fundo pelo rio Capibaribe asim té Alagoa do Angu, em as quais se achão comprehendidos os sítios Madre de Deus, São João, Inhumas e os três como abaixo se demonstra. Levantado a vista das ditas, títulos, enformaçõens e exames pelo Piloto Jozé da Silva Pinto, no anno de 1811, e reofrmado pelo mesmo, a vista de outros documentos. Esta carta, além de indicar as terras dos congregados no sertão pernambucano, aponta o grau de urbanização daquela área interiorana à sombra das fazendas de gado, freguesias (antes missão religiosa) e vila encontrados em seu território.

O mapa 09 lista cinco parcelas de terras: Curral de Bois, fazenda Madre de Deus, sítio São João, sítio dos Inhumas e Sapato e fazenda Jacarará. Curral de Bois foi a primeira sesmaria da ordem, doada por Antônio Vieira de Melo para pacificar os índios Xucurús e Panatiós no aldeamento de Ararobáa ${ }^{117}$. Não era gratuita a política de boa vizinhança. Da instalação da aldeia, Vieira de Melo recebeu uma sesmaria na região, por ter ofertado terras e ferramentas à redução ${ }^{218}$. Essa simbiose entre curral e missão punha a congregação diante de uma oportunidade de alargar o seu domínio fundiário através da compra de terras contiguas às suas. Compra feita, muitas vezes, com o dinheiro das esmolas. Pelo desenho averiguamos a dimensão "generosa” do latifúndio dos padres de São Felipe Nery.

No ano de 1757, o patrimônio da Ordem esteve avaliado em vinte e uma léguas, agrupando alguns sítios. A fazenda Madre de Deus surge de uma parcela, meia légua em quadra, concedida pelo governador da capitania, Luis Correia de Sá ${ }^{219}$. Sendo devoto de São José, a autoridade doou o lote de terra para edificação de ermida dedicada ao seu santo. $\mathrm{O}$ local escolhido, para sacralização do patrimônio religioso ${ }^{220}$, consistiu na célula-máter da freguesia Madre de Deus.

\footnotetext{
${ }^{217}$ LIMA, Ebion, "As missões oratorianas no Brasil: informação sobre as missões oratorianas do Nordeste"..., Opus cit., p. 76.

${ }^{218}$ MEDEIROS, Maria do Céu. Os oratorianos de Pernambuco: uma congregação "a serviço"do estado português. Dissertação de mestrado. Recife, UFPE, 1981.

${ }^{219}$ LIMA, Ebion, "As missões oratorianas no Brasil: informação sobre as missões oratorianas do Nordeste"..., Opus cit., p. 75.

${ }_{220}^{20}$ DEFFONTAINES, Pierre. Como se constituiu no Brasil a rede das cidades. Boletim geográfico, $\mathrm{n}^{\circ}$ 14. Rio de Janeiro, IBGE, 1944. p. 18.
} 


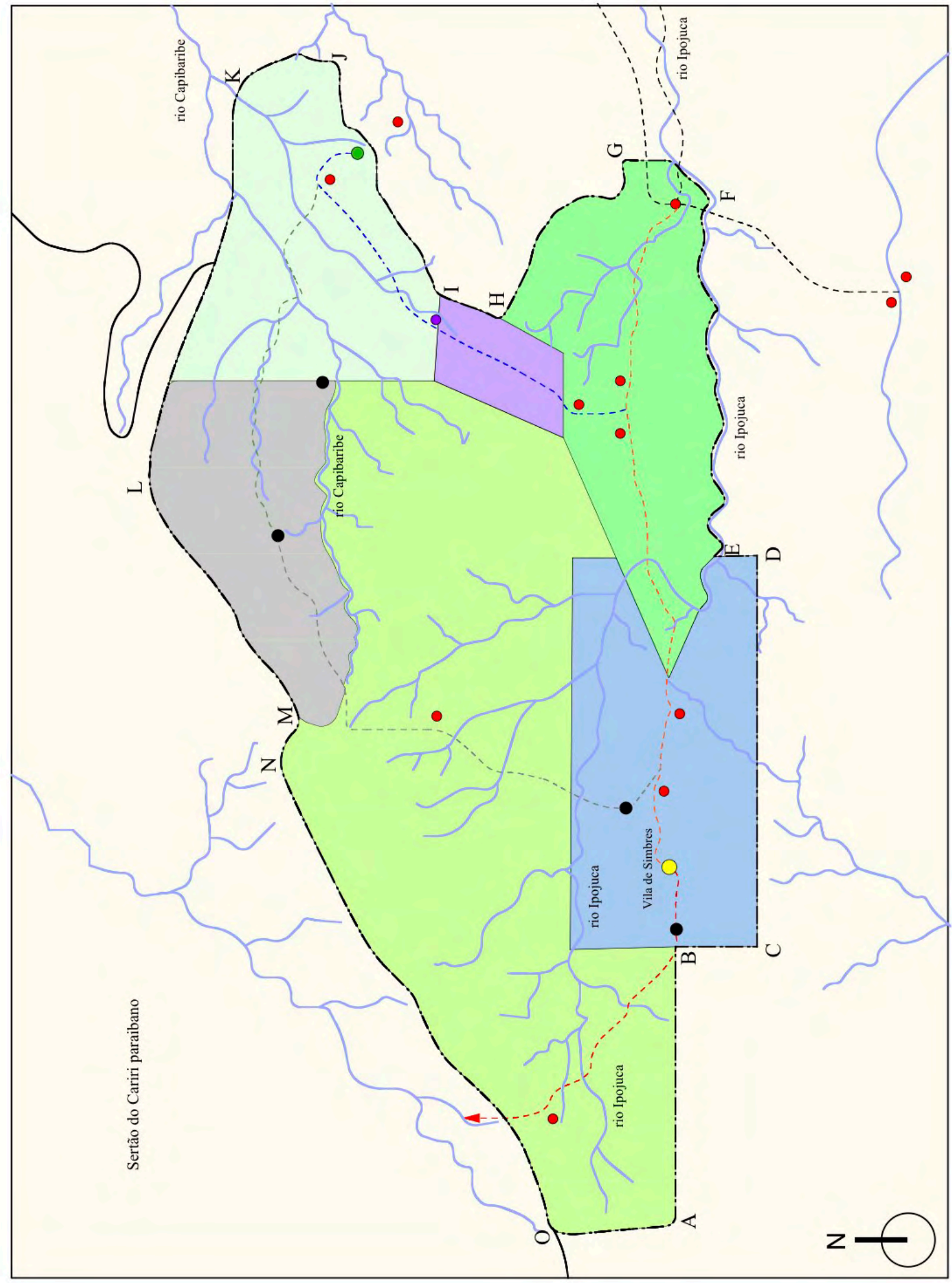

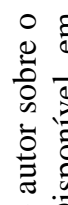

$\because 0$

官

ดิ

串。

:

踏

ะ

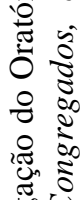

.

范

त

o 2

ฮิ

造

8

‡ ฐ

है है

है

电 \&

ए जे

$\stackrel{2}{2}$

密

焉

. ำ

ชิ

焉喜

204

요

产

$\geqslant$ 


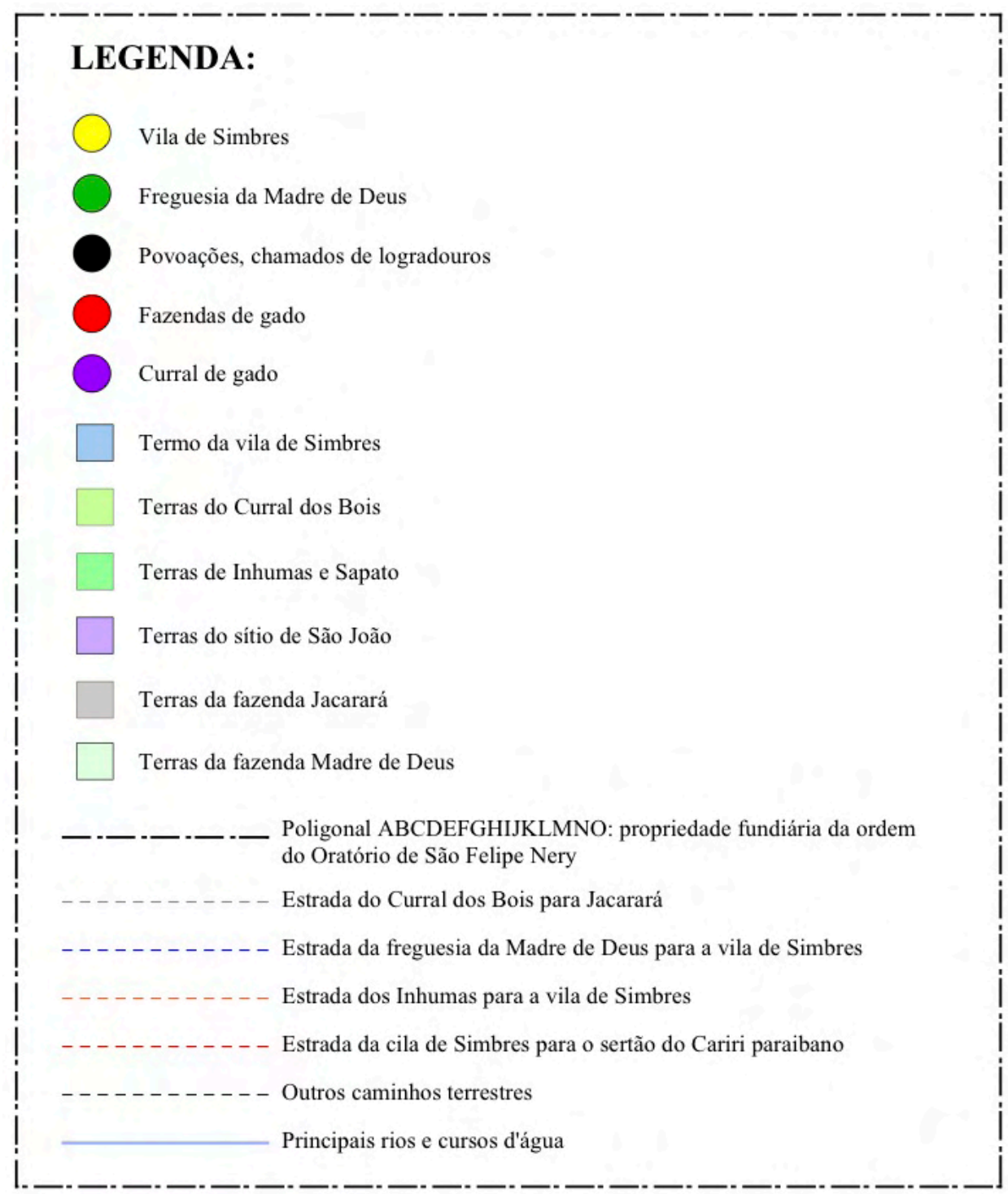

Figura 84 - Legenda do mapa 09: Patrimônio fundiário no sertão pernambucano dos reverendos da Congregação de São Felipe Nery. Elaboração do autor.

Caíram os oratorianos na sede de poder, usaram os seus neófitos em trabalhos pessoais, contrariando normas sancionadas pela Junta das Missões: não consentireis que os missionários usem dos índios para alguma outra coisa que não seja dos que se requerem para a missão e sustento dela (... $)^{221}$. Pior: nos seus relatórios é algo impressionante a soma dos seus cabedais. Relataram os padres que os seus sítios do sertão rendiam por ano 100\$00 réis, enquanto que as esmolas geravam um montante anual de 1:000\$000 réis ${ }^{222}$. Comparando os negócios oratorianos com os negócios jesuíticos, observaremos que os padres congregados rentabilizaram uma pequena parte daquilo conseguido pelos inacianos no sertão nordestino: trinta e cinco fazendas de gado em um patrimônio fundiário com mais de $3.000 \mathrm{~km}^{2}$. Sede de

\footnotetext{
221 “Informação Geral da Capitania de Pernambuco - 1749”. In Annaes da Bibliotheca Nacional do Rio de Janeiro. Vol XXVIII ..., Opus cit., p. 386.

222 “Informação Geral da Capitania de Pernambuco - 1749". In Annaes da Bibliotheca Nacional do Rio de Janeiro. Vol XXVIII ..., Opus cit., p. 418.
} 
poder, acúmulo de bens temporais e usurpação de leis foram uma constante na ação missionária do Brasil colônia.

Armazenados terras e dinheiros, os padres da recoleta continuaram com boa relação entre as autoridades locais e no Reino. Desde o tempo da fundação da Congregação de São Felipe Nery em Lisboa, pelo reverendo Bartolomeu Quental, até o reinado de Dom José I, foram dispensados favores e proteção pela $\mathrm{Coroa}^{223}$. Destaca-se que na colônia, o seu poderio territorial não sofreu seqüestro, como ocorreu aos religiosos da Companhia de Jesus. Os congregados foram os promotores, com o conde de Oeiras, da expulsão dos jesuítas do Brasil e reformulação do ensino pedagógico dos novos núcleos de índios ${ }^{224}$.

No início do século XIX, diminuíram as missões oratorianas no sertão da capitania de Pernambuco. Restringem seus ofícios canônicos aos moradores da vila do Recife, realizados na igreja da Madre de Deus [figura 85]. Por ordens de Dona Maria I, ofereceram cursos de Filosofia e Teologia aos interessados em seguir carreira sacerdotal. Em vista da falta de zelo e suas fazendas sertanejas serem cobiçadas pelos governadores, a Congregação do Oratório de São Felipe Nery extinguiu em $1830^{225}$.

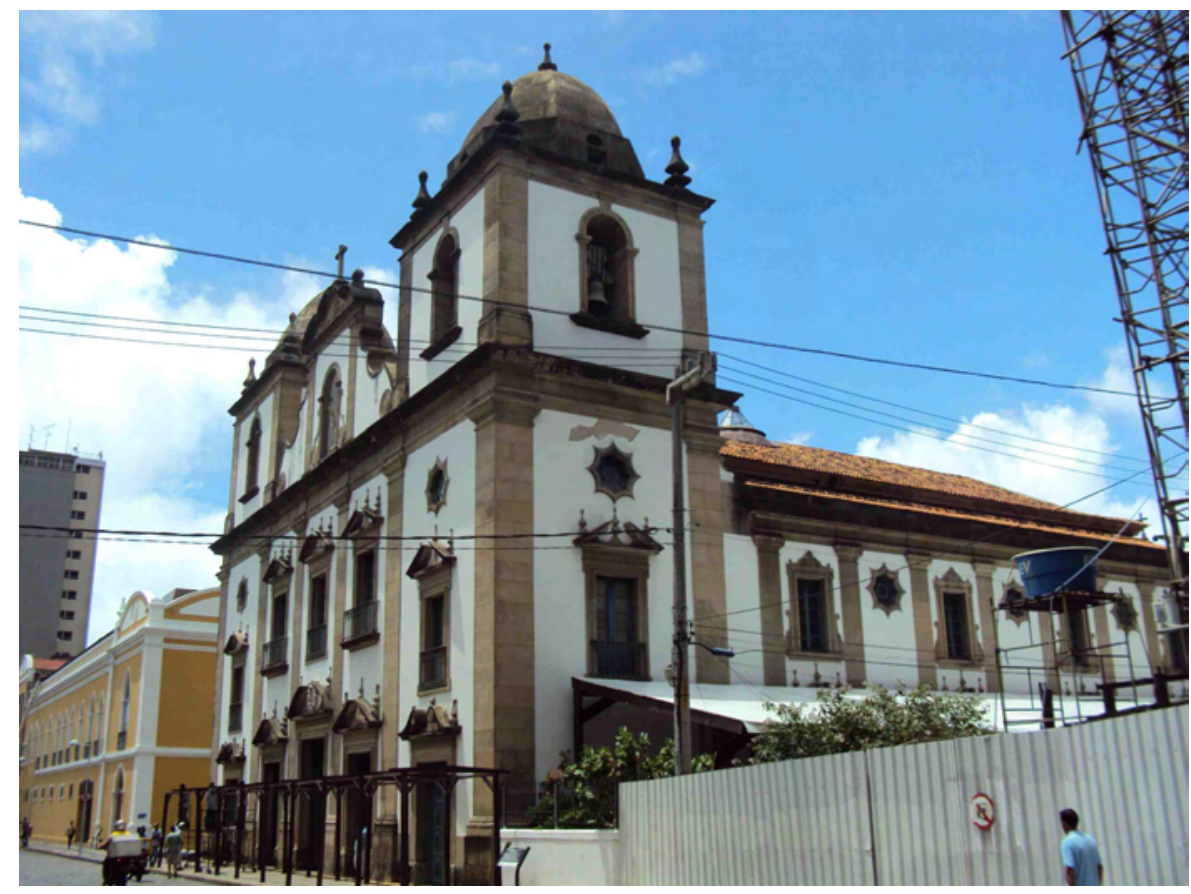

Figura 85 - Igreja da Madre de Deus. Foto do autor, 2010.

\footnotetext{
${ }^{223}$ SANTOS, Eugénio dos. "Pombal e os oratorianos". In Revista Camões..., Opus cit., p. 78.

${ }^{224}$ SANTOS, Eugénio dos. "Pombal e os oratorianos". In Revista Camões..., Opus cit., p. 78.

${ }^{225}$ LIMA, Ebion, “As missões oratorianas no Brasil: informação sobre as missões oratorianas do Nordeste"..., Opus cit., p. 88.
} 


\subsection{6 - Outras ordens religiosas}

Franciscanos, carmelitas descalços e mercedários também compuseram o casting dos missionários atuantes no cenário do sertão nordestino. Pelas ralas informações obtidas, pontuaremos a catequese e contribuição destas na urbanização do interior do Nordeste.

Os capuchos de Santo Antônio, ou franciscanos, converteram os Tapuias moradores das margens do rio São Francisco, desde sua foz, nos arredores do seu convento instalado na vila de Penedo, até a barra do rio Grande, nas proximidades da fronteira com as Minas Gerais. Pelas informações contidas no Annaes da Bibliotheca Nacional do Rio de Janeiro, volume XXVIII, estiveram sob o comando franciscano as reduções: missão Nova de São Francisco do Brejo, Nossa Senhora da Piedade da ilha do Inhamum, Nossa Senhora do Pilar da ilha do Caripóz, aldeia da ilha do Pontal, Aricobé na fronteira com a capitania de São José do Piauí, hoje Santa Rita de Cássia - BA.

$\mathrm{Na}$ ilha do Pontal, os capuchos edificaram, provavelmente no princípio dos Setecentos, uma ermida sob a invocação de Nossa Senhora dos Remédios [figura 86], marco espacial arquitetônico daquele aldeamento. A planta encerra o programa mínimo de uma capela: nave central, capela mor, sacristia e coro [figura 87]. A sacristia, anexa ao altar mor, funde simplicidade e carência econômica do habitante indígena da ilha. A transição entre nave central e capela mor é feita por um arco cruzeiro. O retábulo é singelo, elaborado por mão-deobra nativa. Sustentado sob vigas de madeira, o coro é acessível por uma escada de inclinação mui acentuada, locada no lado da epístola. Alvenaria mista de pedra e tijolo compuseram os materiais que estruturam o templo, coberto com telha canal, apoiada em tesoura tipo cangade-porco ${ }^{226}$.

Frei Nicolau de São José, carmelita descalço, foi designado pelo arcebispo da Bahia, D. João Franco de Oliveira, em 1699, para analisar a situação espiritual das ovelhas perdidas no sertão de sua jurisdição. O empenho da autoridade eclesiástica visou $q$ ' não faltassem missionários em o seu Arcebispado para que aonde elle não pudesse hir fossem elles a destruir vícios e por as suas ovelhas no caminho da salvação para que asim lhe desse parte do que havia para lhe por remédio, e pedindosseme esta certidão do q’ no Rio de Sam

\footnotetext{
226 “INVENTÁRIO do Patrimônio Cultural do Estado de Pernambuco: sertão pernambucano do São Francisco". Recife, Fundação do Patrimônio Histórico e Artístico de Pernambuco - FUNDARPE, 1985. p. 215 - 216.
} 
Francisco $^{227}$. Buscou D. João Franco de Oliveira reforçar as missões volantes ou centralizar a catequese em aldeamentos missioneiros.

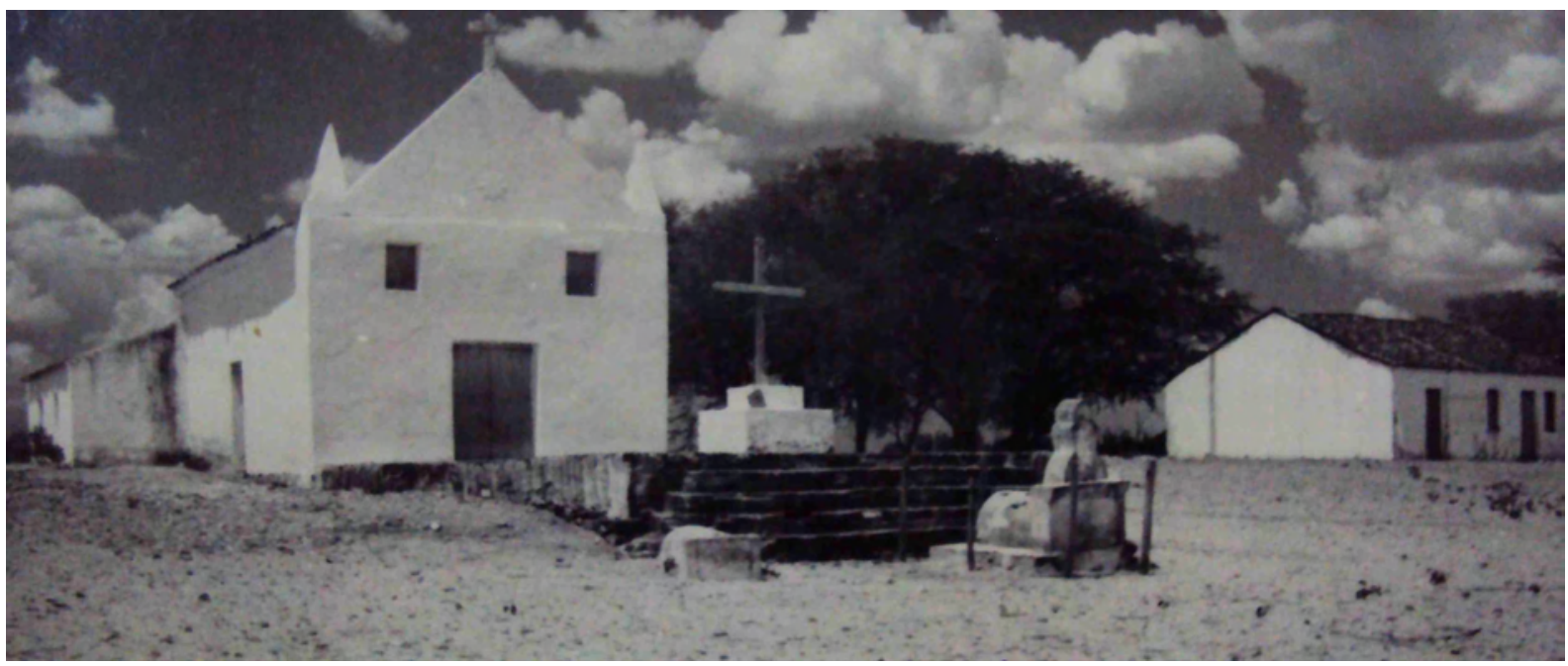

Figura 86 - Ermida de Nossa Senhora dos Remédios, missão franciscana da ilha do Pontal. Foto cedidade pela FUNDARPE - PE.

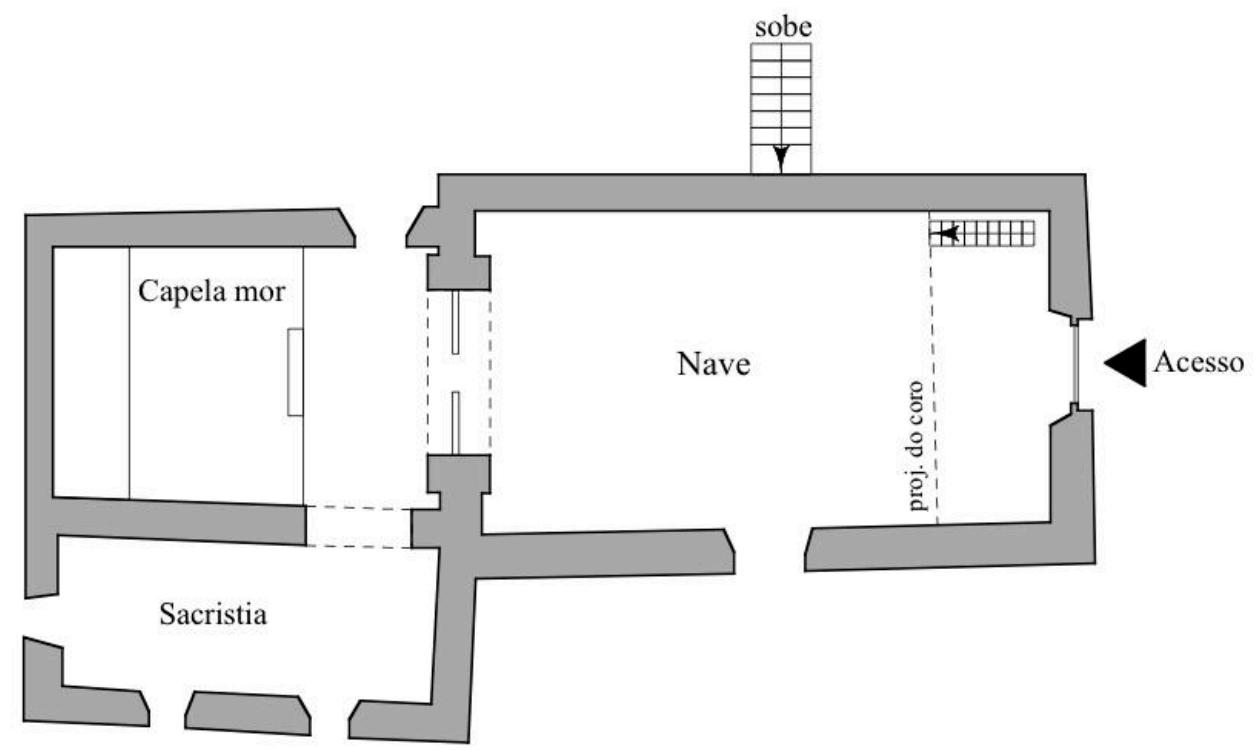

Figura 87 - Planta da capela de Nossa Senhora dos Remédios, missão franciscana da ilha do Pontal. Desenho do autor sobre informações elaboradas pela FUNDARPE - PE.

Percorrendo o sertão, frei Nicolau notou a fragilidade religiosa dos seus moradores expressa pelo diminuto número de igrejas ou capelas, párocos e/ou missionários: (...) quando passava por aquellas partes alguõ Religioso a pedir esmollas davão graças a Deos delle de parar tão grande bem para as suas almas, e asim lhe pedião q' tivesse ali mais tempo e que tinha aquella freguesia mais de trezentas legoas, e quando ali chegava o vigário he huo

${ }^{227}$ PROJETO RESGATE. AHU_ACL_CU_016, Cx. 1, D. 4. 
jubillo para elles ${ }^{228}$. A razão dessa atrofia que, consequentemente, impediu o progresso urbano da região, através da fundação de freguesias ou vilas, deveu, como dito, à ganância fundiária dos fazendeiros da Casa da Torre e família Guedes de Brito:

(...) E preguntandolhe eu porq' não fazião Igreja e substentavão Padres q' lhes desse missão responderão me q' Leonor Pereira Marinho hera senhora da mayor parte do sertão e q' não queria q' se fizesse Igrejas, e o mesmo dizia Antonio Guedes de Brito q' he senhor de mais de trezentas legoas entre o sertão e o Rio de São Francisco e q' nao sabião q' rezão ouvesse para q' so achey como tambem Domingos Affonso Sertão se lhes desse todas as terras q' Sua Magestade tem nos seus governos de Pernambuco e Bahia, as quais forão perdidas $(\ldots)^{229}$

A criação de freguesias e vilas impunha perda de parcela de terra para o termo da nova povoação. Foi este particular pormenor que impulsionou os fazendeiros a guerrear contra os índios, a desenvolver rixas contra os missionários estabelecidos em seus domínios e expulsar àqueles contrários aos seus desígnio.

Os mercedários centralizaram sua catequese no sertão do Piauí. Vindos do bispado do Maranhão, desenvolveram três aldeamentos missioneiros: Nossa Senhora das Mercês dos índios Jaicós, São Raimundo Nonato e Nossa Senhora do Livramento.

Nossa Senhora das Mercês, redução fundada em 1767 pelo governador da capitania de São José do Piauí, João Pereira Caldas, cumpriu os desígnio do Diretório dos Índios: civilizar os silvícolas e inserí-los na sociedade como cidadãos emancipados. Ademais, a seleção do lugar para a fixação dos índios Jaicós - ribeira do Itahim - distante cerca de $121 \mathrm{~km}$ da cidade de Oeiras, serviu para povoar aquela parte do sertão piauiense. João Pereira Caldas informou ao secretário de estado da Marinha e Ultramar, Francisco Xavier de Mendonça Furtado:

(...) Para esta mesma povoação nomeei eu no fim do anno passado por Director a hum soldado chamado Manoel de Araújo; e allem das Ordens com que o instrui; Me determinei, que proptamente fizesse recolher e reconduzir a dita Povoação todos os Índios que dalli se achassem auzentes, e separados; e que o mesmo praticasse o respeito da mais gente da referida

\footnotetext{
${ }^{228}$ PROJETO RESGATE. AHU_ACL_CU_016, Cx. 1, D. 4.

${ }^{229}$ PROJETO RESGATE. AHU_ACL_CU_016, Cx. 1, D. 4.
} 
Nação, aonde quer que aparecesse, e se achasse algumas pessoas cazadas, que tal Povoação pertencem $(. . .)^{230}$.

O lugar de índios de Nossa Senhora das Mercês foi administrado espiritualmente, no ato da sua instalação, pelo mercedário fr. Francisco Tavares ${ }^{231}$. A espacialização das moradias da redução apresentou um desenho regular, segundo o costume racional da política pombalina. George Gardner visualizou o traçado urbano do arraial de Jaicós. Após sua estada na fazenda Boa Esperança, chegou ao núcleo notando que contém de setenta a oitenta casas edificadas em uma grande praça quadrada, da qual apenas três lados estavam então completos, com uma bela igrejinha ao centro ${ }^{232}$ [figura 88].

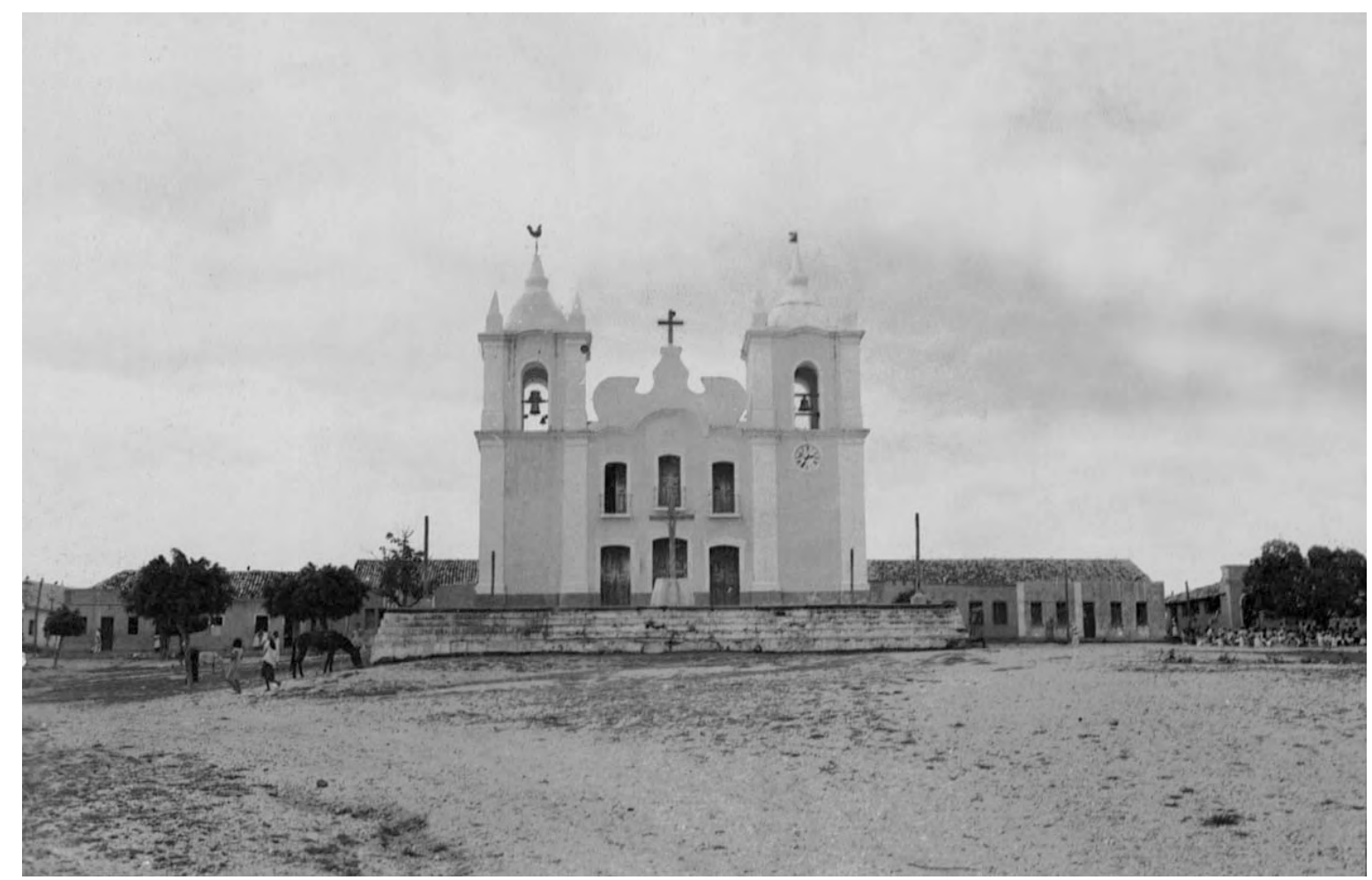

Figura 88 - Igreja de Nossa Senhora das Mercês, Jaicós - PI. Pela imagem constatamos as descrições de George Gardner: grande praça, templo religioso ao centro e casario ocupando três laterais do largo. Foto disponível em http://www.ibge.gov.br. Acesso em 22/03/2010.

\footnotetext{
${ }^{230}$ PROJETO RESGATE. AHU_ACL_CU_016, Cx. 10, D. 589.

${ }^{231}$ OLIVEIRA, José do Carmo. Bicentenário da paróquia de Nossa Senhora das Mercês de Jaicós - Piauí (1805 - 2005). Jaicós, 2005. Artigo disponível em http://www.jaicos.com. Acesso em 14/07/2009.

${ }^{232}$ GARDNER, George. Viagem ao interior do Brasil, principalmente nas províncias do norte e nos distritos do ouro e do diamante durante os anos de 1836-1841. São Paulo, Edusp, 1975. p. 118.
} 


\subsection{Freguesias sertanejas e a urbanização do território}

Currais, fazendas de gado e missões religiosas numa simbiose pacífica, às vezes turbulenta, foram os pioneiros na urbanização do território do sertão nordestino em tempos coloniais. As herdades, em decorrência do interesse comercial desenvolvido pelo mercado interno da carne e do couro, proliferaram consideravelmente sobre o espaço geográfico sertanejo. Os aldeamentos missioneiros pontuaram alguns nós da crescente rede urbana, instalados de acordo com os critérios normativos da Junta das Missões, órgão subordinado à Mesa de Consciência e Ordem, que estava sujeita ao rei.

O chão sacralizado para edificação da igreja das reduções atraiu índios e colonos portugueses que viviam nos arredores. Aqueles habitantes mais isolados, permaneciam meses, anos sem ouvir os ofícios religiosos, sem receber os sacramentos:

(...) q'emtrando em o Rio de São Francisco aonde andei mais de duzentas legoas fazendo a ditta missão achei muitas pessoas que havia dous annos q' se nao conffessavão e a cauza q' apontavão para isso hera q' quando o seu vigário ou coadjutor hia a dezobrigallos os nao achava nas fazendas, por hir já tão fora de tempo q' julgando q' os deixava aquelle anno sem o pasto espiritual e como hera ja fora de tempo hião tratar de suas vidas $(. . .)^{233}$

O Estado português, ligados à Igreja, difundiu em suas colônias projetos e anseios para adensar a população dispersa pela caatinga. A criação de freguesias ou paróquias ensejou esta meta urbanizadora, atraindo para o seio da Igreja e do Reino os filii ecclesiae e $^{234}$.

Raphael Bluteau definiu freguezia como a igreja parrochial. O lugar da cidade, ou do campo, em que vivem os freguezes ${ }^{235}$. O Código do Direito Canônico atribui à freguesia uma comunidade de fiéis, constituída estavelmente na igreja particular, e seu cuidado pastoral é confiado ao pároco como seu pastor próprio, sob a autoridade do bispo ${ }^{236}$. $\mathrm{O}$ termo estabilidade denota fixação. Esta seria outro contributo das paróquias no fenômeno urbano, o de povoar pequenos núcleos que almejavam a autonomia municipal de vilas ${ }^{237}$.

\footnotetext{
${ }^{233}$ PROJETO RESGATE. AHU_ACL_CU_016,CX. 1, D. 4.

${ }^{234}$ MARX, Murillo. Cidades no Brasil, terra de quem? São Paulo, Edusp, 1991. p. 27.

${ }^{235}$ BLUTEAU, Raphael, S.J. Vocabulário português, e latino...Coimbra, Real Collegio das Artes da Companhia de Jesu, 1712-1719. Disponível em http://www.ieb.usp.br. Acesso em 10/10/2011.

${ }^{236}$ CÓDIGO do Direito Canônico. Cân. 515 §1 ${ }^{\circ}$. São Paulo, Loyola, 1983.

${ }^{237}$ MARX, Murillo. Cidades no Brasil, terra..., Opus cit., p. 18.
} 
Ainda no Código do Direito Canônico, título 374, parágrafo primeiro, as dioceses seriam divididas, em partes distintas, compostas pelas freguesias ${ }^{238}$.

Hierarquizando o território eclesiástico colonial brasileiro, no topo esteve o arcebispado da Bahia, atuante a partir de 1676 através do edito papal Inter Pastoralis officii $\operatorname{curas}^{239}$. Em seguida encontra-se a diocese ou bispado, sede de poder erguido em uma cidade. Os bispos eram nobres vinculados à coroa real, e portanto sua atuação religiosa estava limitada com freqüência aos interesses políticos. Alguns bispos que agiram com certa independência foram afastados de seu cargo pela autoridade do rei ${ }^{240}$. O surgimento de um bispado devia ao rei em cumprimento do direito de padroado. Consequentemente, e na opinião de Riolando Azzi, o processo de criação de dioceses foi ocasional e lento ${ }^{241}$, haja vista os interesses prioritários de Portugal, concentrados na exploração da terra com intuito de aumentar os rendimentos da fazenda real.

O sertão nordestino foi administrado por dois bispados, Pernambuco e Maranhão. Com sede em Olinda, a diocese pernambucana, ereta em $1676^{242}$, sufragânea do arcebispado da Bahia. O bispado do Maranhão, criado pelo papa Inocêncio XI, em 30 de agosto de 1677, através da bula Super universas ${ }^{243}$. Cada sede bispal abrigou uma área de influência. O território da diocese de Olinda abrangia desde a fortaleza do Ceará, pela costa e para o interior, até o rio São Francisco, lado esquerdo. Incluía as capitanias subalternas de Alagoas, Paraíba, Rio Grande e Ceará (a partir de 1680) ${ }^{244}$. Localizado em São Luiz, o bispado do Maranhão contou com a capitania que leva o seu nome e São José do Piauí. Vastas extensões deu poucas condições aos prelados de exercerem suas atividades pastorais, por isso foram corriqueiras as rixas entre autoridades religiosas, no que dizia respeito à demarcação das fronteiras dos dois bispados sobreditos.

(...) Intentando me daqui para o Riacho chamado Paranauguá, que dista desta Villa (Mocha) 120, ou 130 legoas, tivemos noticia que aquelles moradores

\footnotetext{
${ }^{238}$ CÓDIGO do Direito Canônico..., Opus cit., Cân. $374 \S 1^{\circ}$.

${ }^{239}$ ALMEIDA, Fortunato de. História da Igreja em Portugal. Vol II. Lisboa, Livraria Civilização - Editora, 1968. p. 23.

${ }^{240}$ AZZI, Riolando. "A instituição eclesiástica durante a primeira época colonial." In História da Igreja no Brasil: ensaio de interpretação a partir do povo: primeira época, período colonial. Eduardo Hornaert... [et. al]. 5 ed. Petrópolis, Editora Vozes, 2008. p. 172.

${ }^{241}$ AZZI, Riolando. "A instituição eclesiástica durante a primeira época colonial." In História da Igreja no Brasil..., Opus cit., p. 173.

${ }^{242}$ ALMEIDA, Fortunato de. História da Igreja em Portugal. Vol II. Lisboa, Livraria Civilização - Editora, 1968. p. 41.

${ }^{243}$ ALMEIDA, Fortunato de. História da Igreja em Portugal...Opus cit., p.39.

${ }^{244}$ ALMEIDA, Fortunato de. História da Igreja em Portugal...Opus cit., p. 41 (nota de rodapé).
} 
intentavão não dar obediência a esta jurisdição espiritual do Maranhão com o affectado pretexto de q' o Bispado de Pernambuco lhes mandara por cura para me não darem obediência com o fundamento de dizer pertencerem a sua jurisdição (...). ${ }^{245}$

Logo abaixo das dioceses temos o patamar ocupado pelas freguesias, território submetido à jurisdição espiritual de um padre que também exerce a administração civil ${ }^{246}$. Cabia ao bispo, na maioria dos casos, elevar uma ermida em freguesia. Entretanto, outras foram criadas pelo poder régio, como aconteceu no sertão piauiense e cearense, durante o governo de Dom José I. Subordinadas à igreja matriz, ou paróquia, estavam as capelas colativas e as curadas. Fania Fridman define as primeiras como, mais raras, os párocos exerciam seu labor mantidos pela Coroa. As curadas, ao contrário, dependiam das esmolas dos fiéis para sua edificação e subsistência ${ }^{247}$.

Elevada uma ermida ao status de freguesia significava a ascensão de uma região isolada ao acesso garantido e necessário da assistência religiosa. Firmação de direitos do arraial diante da Igreja e do Estado. Na opinião de Murillo Marx, não se tratava apenas do acesso ao batismo, matrimônio, comunhão, aos sacramentos de fato. Tornavam acessíveis os registros de batismo, matrimônio e óbito, documentos oficiais, com todas as implicações jurídicas e sociais da época ${ }^{248}$. A recém inaugurada igreja matriz recebia seus limites, seu território de ações eclesiástica e temporal. Fronteiras frágeis, às vezes com pouca definição, em detrimento dos verdadeiros focos do governo colonial brasileiro.

Surge uma rede eclesiástica de aglomerados urbanos, que sofreria uma lenta e considerável mutação. Esta rede precede à civil, de vilas e cidades ${ }^{249}$. Trata-se de um fenômeno urbano ${ }^{250}$. Como veremos, o salto numérico da quantidade de paróquias instaladas no sertão nordestino, e em outras partes do Nordeste, assegura essa hipótese. Acompanhar a evolução territorial do interior do Nordeste colonial equivale em analisar o progresso urbano e fundiário exercido pelas freguesias.

\footnotetext{
${ }^{245}$ PROJETO RESGATE. AHU_ACL_CU_016, Cx. 2, D. 85.

${ }^{246}$ FRIDMAN, Fania. "Freguesias do Rio de Janeiro ao final do século XVIII". In Anais do II Encontro Internacional de História Colonial. Mneme - Revista de Humanidades. Vol. 9. № 24, Set/Out. Caicó, UFRN, 2008. Disponível em http://cerescaico.ufrn.br/mneme/anais. Acesso em 25/05/2010.

${ }^{247}$ FRIDMAN, Fania. "Freguesias do Rio de Janeiro ao final do século XVIII". In Anais do II Encontro Internacional de História Colonial..., Opus cit., p. 03.

${ }^{248}$ MARX, Murillo. Cidades no Brasil, terra..., Opus cit., p. 19.

${ }^{249}$ MARX, Murillo. Cidades no Brasil, terra..., Opus cit., p. 17 - 30.

${ }^{250}$ LE GOFF, Jacques. O apogeu da cidade medieval. São Paulo, Martins Fontes, 1992. p. 43.
} 


\subsection{1 - As “chaves do sertão": freguesias e o fenômeno urbano do sertão nordestino}

A metáfora da chave, autoria do padre oratoriano João Duarte do Sacramento, esclarece o papel balizador das freguesias do fenômeno urbano da área em estudo. Ao abrir a porta do território, as primeiras paróquias desembaraçaram alguns mitos, atraíram moradores litorâneos interessados na pecuária, fixaram o homem sertanejo, mesmo que, a priori, em modorrentos povoados.

As primeiras freguesias do Nordeste, como é fácil de se supor, foram estabelecidas no litoral, como justificativa à política colonizadora: proteção dos domínios do Novo Mundo e facilidade de escoamento do açúcar ao continente europeu. Até 1640 nenhuma paróquia foi criada no hinterland nordestino. Surgem em fins do século XVII, sob o reinado de Dom Pedro II, cinco igrejas matrizes na área da caatinga. Atestamos este fato no mapa 10. Na tabela 06 especificamos quais foram essas freguesias instituídas, as primeiras chaves do sertão.

Nossa Senhora da Conceição de Cabrobó, situada às margens do rio São Francisco, foi a primeira paróquia do interior da capitania de Pernambuco. Erigida por volta de 1675 (não encontramos nas fontes primárias e secundárias precisão da data), abrangia um termo com mais de quatrocentas léguas de Norte, Oeste e Sul. Os párocos desobrigavam seus fregueses esporadicamente. A distribuição dos sacramentos e coleta dos dízimos eclesiásticos ocorriam a cada ano ou a cada dois anos. O bispo de Pernambuco, o carmelita D. Francisco de Lima, consultou o rei, em 1697, a fim de fracionar a imensa freguesia de Cabrobó em duas: Nossa Senhora da Vitória (Piauí) e São Francisco da Barra do Rio Grande (Bahia) ${ }^{251}$. A subdivisão poderá ser maiz util o intento q. tem de povoarem aquellas terraz, reduzindoas a Collonias, e Povoaçõens, sendo este o meyo, não só de segurarem aquelles Certoens ${ }^{252}$.

\footnotetext{
${ }^{251}$ ENNES, Ernesto. As guerras nos Palmares. Rio de Janeiro, Companhia Editora Nacional, 1938. p. 349.

${ }^{252}$ ENNES, Ernesto. As guerras nos Palmares. Rio de Janeiro, Companhia Editora Nacional, 1938. p. 349.
} 


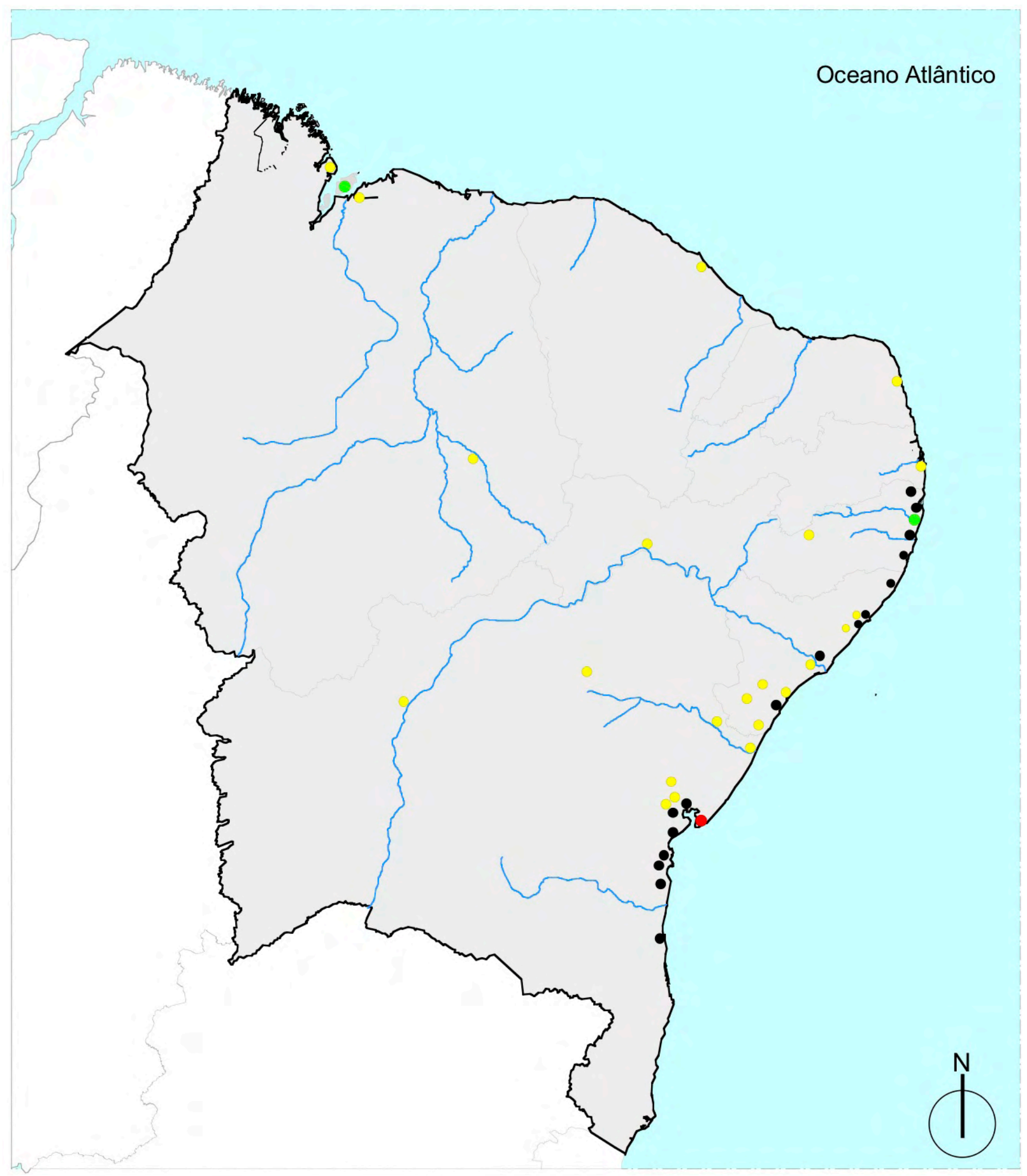

\section{LEGENDA:}

Sede de Arcebispado (Salvador,1671);

Sede de Bispado (Pernambuco [1676], Maranhão [1677]);

Freguesias instaladas no período;

Freguesias instaladas em períodos anteriores;

Principais rios;
Mapa 10 - Freguesias do Nordeste colonial, criadas entre os anos de 1640 - 1706. Desenho do autor. 


\begin{tabular}{|c|c|}
\hline \multicolumn{2}{|c|}{ FREGUESIAS DO SERTÃO NORDESTINO, 1640 - 170 } \\
\hline ANO DE FUNDAÇÃo & FREGUESIA \\
\hline $1675(?)$ & Nossa Senhora da Conceição de Cabrobó \\
1682 & Santo Antônio da Jacobina Velha \\
1693 & Santo Antônio da Jacobina \\
1697 & Nossa Senhora da Vitória \\
1698 & São Francisco da Barra do Rio Grande \\
\hline
\end{tabular}

Tabela 06 - Freguesias do sertão nordestino instaladas entre os anos de 1640 - 1706. Elaboração do autor segundo informações encontradas em ENCICLOPÉDIA municípios brasileiros. Rio de Janeiro, 1947.

Dom Francisco de Lima apontou outras finalidades das novas paróquias, além de povoar, tambem o de poder lucrar grandez conviniençias a fazenda de Vossa Magestade nos dízimos $^{253}$ (...) assim para o bem spiritual das almas, como tambem para o augmento temporal deste Estado ${ }^{254}$. Lucros para a Ordem de Cristo estavam envolvidos na urbanização por intermédio das freguesias.

No documento Termo de eleição q' fizerão os moradores do certão do Piauhi; do lugar, para se fazer Igreja de Nossa Senhora da Victoria, os envolvidos estabeleceram um lugar adequado para a construção do templo,

(...) que se fundaçe, e fizeçe a Igreja no Breyo, chamado a Mocha por ser a parte mais conveniente aos Moradores de toda a Povoação, ficando no meio della com iguais distançias, e Caminhos para todos os riachos e partes povoadas, e detriminada a Sobre dita parte, se elegeu para lugar de Igreja e cazas do Reverendo cura, o taboleiro que se acha pegado a passayem do Jatubá para a parte do Canindé e para roças e possais do Reverendo Cura e Igreja; ${ }^{255}$

Abençoado o chão, a nova matriz de Nossa Senhora da Vitória edificada em taypa, $e$ Cuberta de Pindoba por ser parte adonde não há telha; a coal Capella consta de vinte e

\footnotetext{
${ }^{253}$ ENNES, Ernesto. As guerras nos Palmares. Rio de Janeiro, Companhia Editora Nacional, 1938. p. 349.

${ }^{254}$ ENNES, Ernesto. As guerras nos Palmares...Opus cit., p. 362.

${ }^{255}$ ENNES, Ernesto. As guerras nos Palmares...Opus cit., p. 364.
} 
coatro palmos de comprido, e doze de largo feita com a decência poçivel. ${ }^{256} \mathrm{O}$ pároco designado pelo bispo foi Thomé de Carvalho e Silva. Aos 441 moradores da região ficaram os encargos de conservar, e paramentar, de ornamentos, e todo o mais necessário, a igreja que o Ilustríssimo e Reverendíssimo o Senhor Bispo de Pernambuco manda fazer neste Sertão. À parte da decoração, os fregueses eram obrigados a pagar aos Reverendos curas as proçoins ordinárias q' ate agora pagavao aos da Matris da Conceição do Rodella, a saber cada morador, dois mil rs. ${ }^{257}$

Outro documento sobre a fundação da freguesia de Nossa Senhora da Vitória do Piauí é a Dezcripção do certao do Paeuhy Remetida ao Ilmo. e Rmo. Snr. Frei Francisco de Lima, Bispo de Pernambuco. Quantitativo demográfico da recém inaugurada matriz, economia base dos seus habitantes e território de abrangência foram especificados:

Dentro em sy he esta povoação redonda, em tal forma q' fazendo peão na nova Igreja com igoal distancia para as mais remotas fazendas que ficão para todas as partes dentro de 60 legoas formando a freguezia hua cruz de Nascente a ponte e de norte ao sul com 120 legoas de coprido e outras e cento e vinte de Largo; compoemce de fazendas de gados sem mais moradores; estão cituadas em vários Riachos, distantes huas das outras ordinariamente de duas legoas; ${ }^{258}$

Antes da criação das matrizes de Nossa Senhora da Vitória e São Francisco da Barra do Rio Grande, foram eretas as freguesias de Santo Antônio da Jacobina Velha e Santo Antônio de Ararobá. Infelizmente, não dispusemos de informações para dissertar sobre a paróquia baiana. Santo Antônio de Ararobá, antes aldeamento missioneiro dirigido pelos padres do Oratório de São Felipe Nery, foi instituída por D. Francisco de Lima em 1692. À semelhança da paróquia piauiense, a matriz de Ararobá estava às margens de uma estrada colonial, que partia do Recife às minas gerais. Este condicionante geográfico, quiçá político, ensejou a sua elevação de missão religiosa ao status de paróquia ${ }^{259}$. Barbosa Lima Sobrinho assinalou as dimensões geográficas da freguesia, concluídas a partir da transcrição de um itinerário das boiadas que partiam do litoral pernambucano:

\footnotetext{
${ }^{256}$ ENNES, Ernesto. As guerras nos Palmares...Opus cit., p. 368.

${ }^{257}$ ENNES, Ernesto. As guerras nos Palmares. Rio de Janeiro, Companhia Editora Nacional, 1938. p. 367.

${ }^{258}$ ENNES, Ernesto. As guerras nos Palmares...Opus cit., p. 312 - 373.

${ }^{259}$ SOBRINHO, Barbosa Lima. "Capistrano de Abreu e o povoamento do sertão pernambucano". In Revista do Instituto Arqueológico, Histórico e Geográfico Pernambucano. Separata do vol. 50. Recife, 1978. p. 32 - 33.
} 
Esta freguesia é dilatada, que tem de comprimento 70 léguas, mas está toda cultivada de moradores e fazendas e aldeias do gentio, como seja a nação dos Xucurús, dos Panatiós e Parariconha, circunvizinhas da nação Carnijó. E como tem todo este presídio é muito fácil por as estradas prontas em poucos dias. Do dito sitio, donde acaba a freguesia, começa a freguesia do Cabrobó. ${ }^{260}$

Para Hilton Sette a expansão geográfica e o povoamento do sertão pernambucano principia com a instalação da freguesia de Arorobá ${ }^{261}$. Em 1749, essa paróquia contava com três capelas filiais, entre elas Madre de Deus, dois clérigos, cento e sessenta e nove fogos e novecentas e quatro pessoas de desobriga.

A difusão da rede eclesiástica de paróquias sertanejas alargou no reinado de Dom João V (1706 - 1750). A política expansionista joanina acelerou o povoamento do sertão através da fundação de vinte e cinco freguesias dispersas nas variadas capitanias nordestinas: duas no Maranhão, cinco no Piauí, quatro na capitania do Ceará, seguindo o curso do rio Jaguaribe, duas no Rio Grande do Norte, uma na Paraíba, uma em Pernambuco, uma nas Alagoas, uma em Sergipe del Rey e oito na Bahia de Todos os Santos. Cremos que outro motivo basilar para este salto deva-se à redação das Constituições Primeiras do Arcebispado da Bahia, em 1707. Normas rigorosas, atentas à uniformidade e clareza dos ritos, à dilatação da fé católica condicionada pelo Concilio de Trento reunido entre 1545 e 1563. Leis pias aceitas pelos poderes temporais e espirituais. ${ }^{262}$ Esta frente urbanizadora do período joanino pode ser analisada pelo mapa 11 e tabela 07.

\footnotetext{
${ }^{260}$ SOBRINHO, Barbosa Lima. "Capistrano de Abreu e o povoamento do sertão pernambucano”..., Opus cit., p. 35.

${ }^{261}$ SETTE, Hilton. Pesqueira: aspectos de sua geografia urbana e de suas interrelações regionais. Recife, 1956.

p. $40-41$.
${ }^{262}$ MARX, Murillo. Cidades no Brasil, terra..., Opus cit., p. 20.
} 


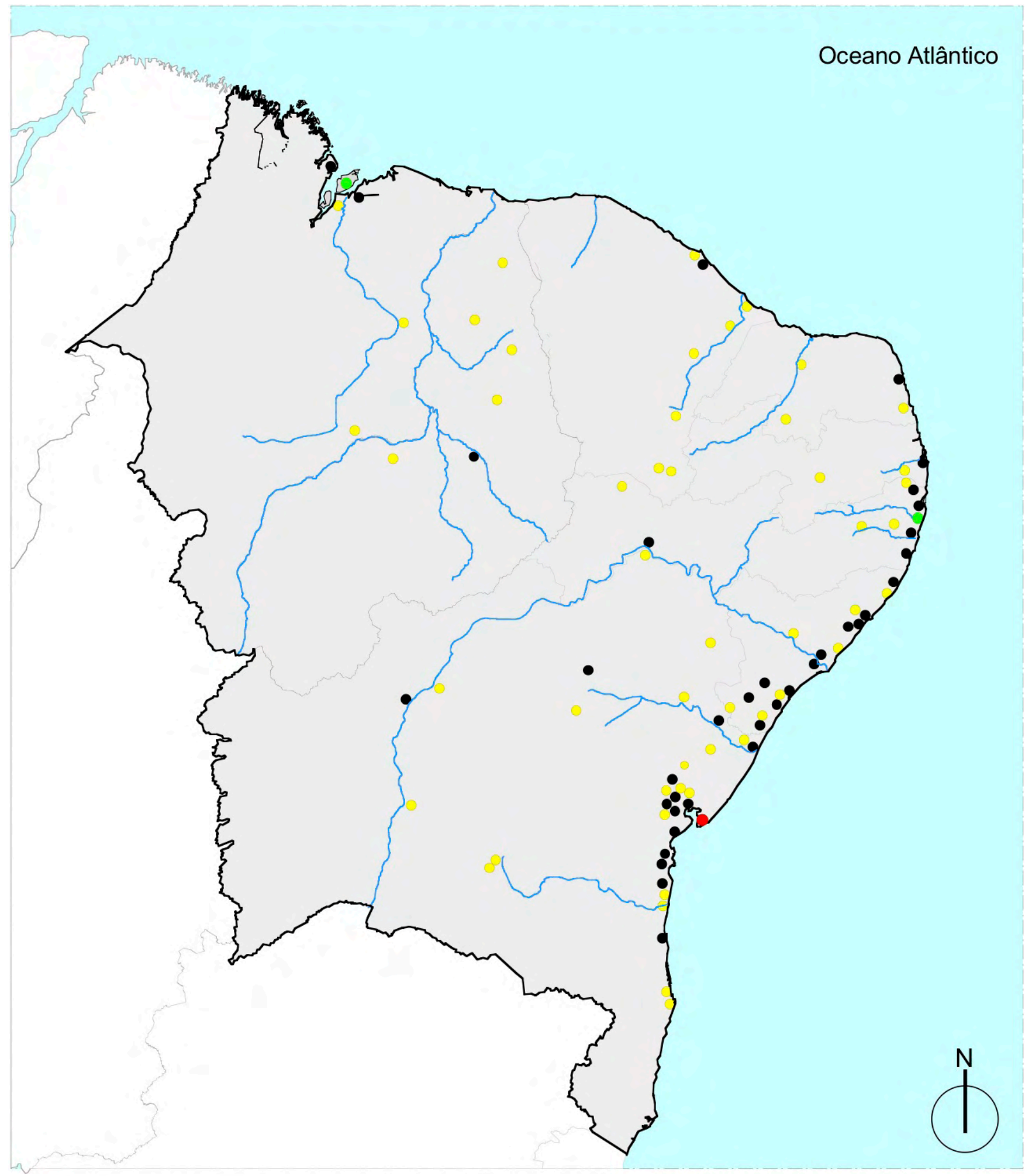

\section{LEGENDA:}

Sede de Arcebispado (Salvador,1671)

Sede de Bispado (Pernambuco [1676], Maranhão [1677]);

Freguesias instaladas no período;

Freguesias instaladas em períodos anteriores;

Principais rios;
Mapa 11 - Freguesias do Nordeste colonial, criadas entre os anos de 1706 - 1750. Desenho do autor. 


\begin{tabular}{|c|c|}
\hline \multicolumn{2}{|c|}{ FREGUESIAS DO SERTÃO NORDESTINO, 1706 - 1750} \\
\hline \multicolumn{2}{|c|}{ CAPITANIA DO MARANHÃO } \\
\hline ANO DE FUNDAÇÃO & FREGUESIA \\
\hline 1741 & Nossa Senhora de Nazaré das Aldeias Altas \\
\hline 1741 & São Bento das Balças dos Pastos Bons \\
\hline \multicolumn{2}{|c|}{ CAPITANIA DE SÃO JOSÉ DO PIAUÍ } \\
\hline 1723 & Santo Antônio do Surubim \\
\hline 1723 & Nossa Senhora do Carmo de Piracuruca \\
\hline 1723 & Santo Antônio do Gurguéia \\
\hline 1740 & Nossa Senhora da Conceição dos Oroazes \\
\hline 1742 & Nossa Senhora do Desterro \\
\hline \multicolumn{2}{|c|}{ CAPITANIA DO CEARÁ } \\
\hline 1713 & Nossa Senhora do Rosário das Russas \\
\hline 1715 & Nossa Senhora da Expectação \\
\hline 1748 & São José dos Cariris Novos \\
\hline 1748 & Nossa Senhora da Conceição do Riacho do Sangue \\
\hline 1748 & Nossa Senhora da Luz de Milagres \\
\hline \multicolumn{2}{|c|}{ CAPITANIA DO RIO GRANDE DO NORTE } \\
\hline 1726 & São João Batista do Açu \\
\hline 1748 & Gloriosa Sant'Ana do Seridó \\
\hline \multicolumn{2}{|c|}{ CAPITANIA DA PARAÍBA } \\
\hline 1750 & Nossa Senhora dos Milagres da Ribeira do Cariri \\
\hline \multicolumn{2}{|c|}{ CAPITANIA DE PERNAMBUCO } \\
\hline
\end{tabular}




\section{CAPITANIA DE ALAGOAS}

\begin{tabular}{|c|c|}
\hline ANO DE FUNDAÇÃO & FREGUESIA \\
\hline 1714 & Nossa Senhora do Ó do Rio São Francisco \\
\hline \multicolumn{2}{|c|}{ CAPITANIA DE SERGIPE DEL REY } \\
\hline 1718 & Nossa Senhora do Campo do Rio Real \\
\hline \multicolumn{2}{|c|}{ CAPITANIA DA BAHIA DE TODOS OS SANTOS } \\
\hline 1714 & Santo Antônio do Pambú \\
\hline 1718 & Nossa Senhora do Nazaré de Itapicurú de Cima \\
\hline 1718 & São João Batista do Jeremoabo \\
\hline 1718 & Santíssimo Sacramento do Rio de Contas \\
\hline 1719 & São José da Barra do Sento Sé \\
\hline 1720 & Santo Antônio da Jacobina \\
\hline 1724 & Livramento de Nossa Senhora do Rio de Contas \\
\hline 1748 & Santo Antônio do Urubú de Cima \\
\hline
\end{tabular}

Tabela 07 - Freguesias do sertão nordestino criadas entre os anos de 1706 - 1750. Elaboração do autor segundo informações encontradas em: ENCICLOPÉDIA municípios brasileiros. Rio de Janeiro, 1947; e nos manuscritos do Projeto Resgate Barão do Rio Branco.

Aldeias Altas, Pastos Bons e as quatro freguesias da capitania de São José do Piauí estavam debaixo das ordens do bispo do Maranhão, D. fr. Manuel da Cruz $(1738-1745)^{263}$. Nessa época, as condições físicas das matrizes sertanejas, situadas no bispado do Maranhão, punham em jogo o cumprimento do pacto feito entre a Coroa e a Mitra: (...) representando a Vossa Magestade o Bispo do Maranhão (...) veyo no pleno conhecimento de que em todas

\footnotetext{
${ }^{263}$ Período em que governou o bispado do Maranhão.
} 
(paróquias) havia tão grande falta de paramentos (...). ${ }^{264} \mathrm{O}$ sucessor de Manuel da Cruz, D. João Rodrigues Covette, emitiu, em 1756, uma relação dos lugares, povoações e freguesias do seu governo. Foram incumbidos os vigários das respectivas paróquias de realizar a descrição do território eclesiástico que lhe competia.

Santo Antônio do Surubim (hoje Campo Maior - PI) apresentou três capellas (...) Nossa Senhora dos Humildes, sita nove legoas desta Matriz, a qual assitião mui moradores; A segunda capella tem a invocação de Nossa Senhora do Livramento (...) A terceira he invocada com Nossa Senhora da Conceição das Barras (Teresina - PI), que foi a melhor e bem fundada (... $)^{265}$. O padre da matriz de Nossa Senhora de Nazaré das Aldeias Altas (Caxias - MA) reforçou a posição do ex-bispo, Manuel da Cruz, ao indicar a precariedade de sua paróquia, antes aldeamento missioneiro jesuítico, sita às margens do rio Itapicurú: tem a dita Freguezia 608 pessoas de comunhão, expalhadas por 30 fazendas de gado vacum, e cavallar, a maior parte he gente miserável, por falta de beinz da fortuna, e pelo estado da escravidão (...). ${ }^{266}$

Pastos Bons, criada em 1741, foi desmembrada da freguesia de Nossa Senhora da Vitória do Piauí (Oeiras - PI), logo fora para ella o dito pe. Joseph Ayres entrara na diligencia de persuadir os seus freguezes a q' edificassem huã Igreja q' lhes servisse de Parochia; e com effeyto principiara a dita obra ${ }^{267}$. Conta-nos o manuscrito do pároco de Pastos Bons que, em 1743, o projeto do templo religioso permanecia no alicerce. Declarou Joseph Ayres:

(...) a obrigaçam q' tem a Fazenda Real de dar a dita Igreja paramentos para o culto Divino, digo q' não se de obrigação; só tenho noticia, q' as muitas Parochias do Brasil tem Vossa Magestade com mão liberal,e pia mandado dar, e inviar desse Reyno os paramentos necessários; por supplicas, e representaçoens, q' os Parochos dellas fazem a Vossa Magestade como Governador, e perpetuo Administrador do Mestrado, Cavallaria, e Ordem de Nosso Senhor Jesus Christo, a quem como tal pertencem os Dízimos destas terras: Razam porq' parecia, q' fazendose, e acabandose a dita Igreja na

\footnotetext{
${ }^{264}$ PROJETO RESGATE. AHU_ACL_N_ MARANHÃO, D. 2980

${ }^{265}$ PROJETO RESGATE. AHU_ACL_CU_009, Cx. 37, D. 3692.

${ }^{266}$ PROJETO RESGATE. AHU_ACL_CU_009, Cx. 37, D. 3692.

${ }^{267}$ PROJETO RESGATE. AHU_ACL_CU_009, Cx. 27, D. 2794.
} 
forma q' o dito Parocho insinua fica sendo accredora da mesma mercê, q' Vossa Magestade tem feito as mais Parochias do Brasil (... $)^{268}$.

Em 1756, quando o relatório das freguesias maranhenses foi enviado à diocese, São Bento das Balças dos Pastos Bons congregou 148 pessoas de comunhão, permanecia à mercê das honras bispais e reais. Sua realidade persistiu após quinze anos de fundação: (...) o que desta Matriz existe he somente o nome; pois o Snr. S. Bentto seu padroeyro, desde q' deste lugar tomou posse, está metido em huma casa de madeira, tapada de barro, coberta de palha, e quasi de todo arruinada; e contão pouca capacidade, q' não tem mais que treze passos de cumprido, e outro de largo (....). ${ }^{269}$

A condição econômica dos fregueses sertanejos, em sua maioria pobres e com rendimentos destinados à sua subsistência, impedia a fábrica de igrejas, altares e imagens religiosas com a beleza desejada. Por isso, as fachadas e o interior das capelas e igrejas sertanejas, dos séculos XVII e XVIII, foram elaborados com o mínimo de elementos decorativos, templos simples em sua essência [figura 89].

Outras paróquias eram formadas por moradores ricos, porém, avessos às necessidades arquitetônicas das igrejas matrizes as quais eram fregueses. A freguesia de Nossa Senhora da Expectação do Icó é um exemplo. Desassociada da paróquia de São José do Ribamar de Aquirás em 1742, o novo padre de Icó achou a igreja matriz [figura 90] tão falta de ornamentos e paramentos necessários para cinco Altares com o Mayor, e outras tantas partes com a principal, e hu púlpito, que já não é capaz com que se cultuem os Sacrifícios nas festas Solemnes (...) sendo o motivo, e causa a grande pobreza desta terra, na qual supposto hajão alguns effeytos de gado vacum, e cavallar ${ }^{270}$. Dom João V, numa atitude burocrática, enviou carta régia ao provedor da fazenda real da capitania do Ceará Grande, informado que o padre da matriz do Icó enviasse solicitação à Mesa de Consciência e Ordens, instituição responsável pelos deveres espirituais das colônias portuguesas ${ }^{271}$.

\footnotetext{
${ }^{268}$ PROJETO RESGATE. AHU_ACL_CU_009, Cx. 27, D. 2794.

${ }^{269}$ PROJETO RESGATE. AHU_ACL_CU_009, Cx. 37, D. 3692.

270 PROJETO RESGATE. AHU_ACL_CU_CEARÁ, Cx. 4, D. 237.

${ }^{271}$ PROJETO RESGATE. AHU_ACL_CU_CEARÁ, Cx. 4, D. 237 (documentos anexos).
} 
No documento, Relação de todas as Freguezias, Capellas e Clérigos que tem o Bispado de Pernambuco ${ }^{272}$, os números são incompletos acerca da quantidade de paroquianos e fogos das freguesias do Ceará. Os dados citados se restringem à freguesia de Russas com oito capelas filiais e quinze clérigos; e à paróquia de Nossa Senhora da Expectação do Icó: quatro capelas filiais e vinte e um clérigos.
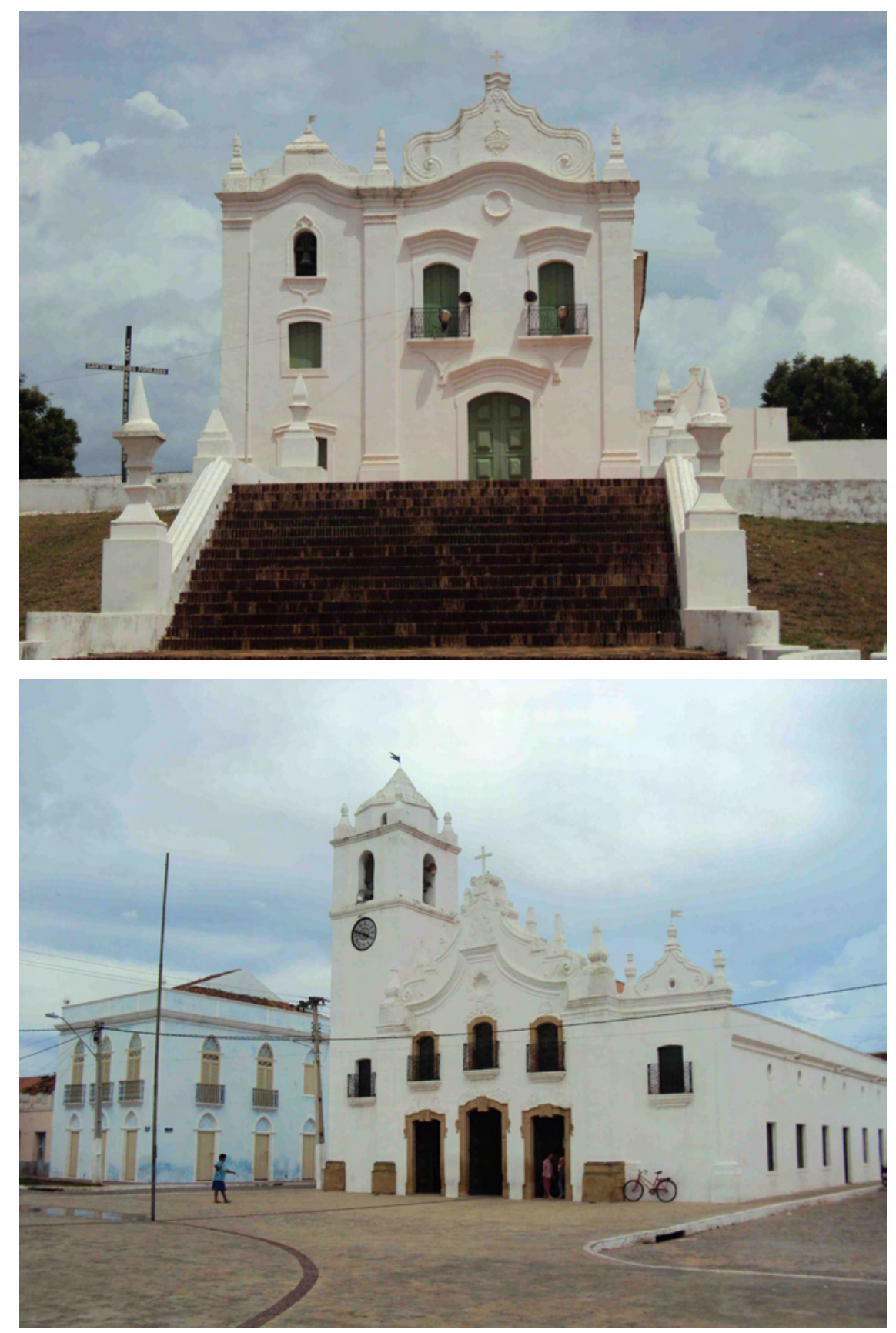

Figura 89 - Igreja Nossa Senhora do Monte. Icó - CE. Foto do autor, 2010.

Figura 90 - Igreja matriz de Nossa Senhora da Expectação do Icó - CE. Acervo do autor, 2010 .

Segundo a Informação Geral da Capitania de Pernambuco - 1749, obtemos um balanço quantitativo das freguesias existentes no bispado de Olinda. Indica o relatório que,

272 “Informação Geral da Capitania de Pernambuco - 1749”. In Annaes da Bibliotheca Nacional do Rio de Janeiro. Vol XXVIII ..., Opus cit., p. 407. 
no sertão paraibano, a freguesia de Nossa Senhora dos Milagres do Cariri abrigou uma capela filial e sete clérigos. Os dados são mais nítidos a respeito do núcleo urbano do Porto da Folha do Rio São Francisco (Traipú - AL): sete capelas em seu território, seis clérigos, duzentos e noventa e cinco fogos e mil setecentos e seis pessoas de desobriga ${ }^{273}$.

$\mathrm{Na}$ Bahia, o percentual de paróquias interioranas eleva-se. Ao nosso ver, deve-se à política eclesiástica do arcebispo D. Sebastião Monteyro da Vide, criador das Constituiçoens Primeyras do Arcebispado da Bahia. Tais normas sacras incidiram sobre a paisagem urbana dos aglomerados coloniais ${ }^{274}$ e, também, sobre a fundação de novas freguesias. Eram leis estabelecidas para fixar o homem nas vizinhanças do templo.

Podemos analisar a evolução das freguesias baianas através do censofeito em 1759 pelo governador Jozé Antônio Caldas. Nessas notícias são arrolados o número de fogos e fregueses de todas as paróquias da capitania da Bahia de Todos os Santos [tabela 08].

\section{FREGUESIA}

Santo Antônio do Pambú

Nossa Senhora do Nazaré de Itapicurú de Cima

São João Batista do Jeremoabo

Santíssimo Sacramento do Rio de Contas

São José da Barra do Sento Sé

Santo Antônio da Jacobina

Livramento de Nossa Senhora do Rio de Contas

Santo Antônio do Urubú de Cima

\section{FOGOS}

93

182

250

663

243

287

362
ALMAS

1.019

1.728

1.822

3.223

2.023

2.212

3.425

Tabela 08 - Infomações quantitativas acerca das freguesias baianas criadas entre 1706 - 1750. Elaboração do autor segundo CALDAS, Jozé Antônio. Notícia Geral de toda esta Capitania da Bahia desde o seu descobrimento até o prezente anno de 1759. Edição fac. Similar. Salvador, Tip. Beneditinas, 1951. p. 68 - 70.

\footnotetext{
273 “Informação Geral da Capitania de Pernambuco - 1749”. In Annaes da Bibliotheca Nacional do Rio de Janeiro. Vol XXVIII ..., Opus cit., p. $411-412$.

${ }^{274}$ MARX, Murillo. Cidades no Brasil, terra..., Opus cit., p. 20 - 21.
} 
O marco temporal de 1750 - 1777 compreendeu o governo de Dom José I e, do seu ministro, Sebastião José de Carvalho e Melo. Foi neste período que assinaram os Tratados de Madrid (1750) e Santo Idelfonso (1777), desencadeando importantes ações de cunho geopolítico no Brasil ${ }^{275}$. Além de desenhar o contorno fronteiriço dos reinos de Portugal e Espanha, a emancipação dos índios e sua eventual civilização foram postos como ideais do governo. Surgem novas leis garantindo a liberdade dos índios - 06 e 07 de junho de 1755 , alvará de 08 de maio de 1758 e o Diretório dos Índios - que se materializam, naquilo que antes eram aldeamentos missioneiros, em lugares de índios, freguesias cuja parcela majoritária dos moradores era composta de indígenas domesticados.

A elaboração do mapa 12 seguiu os fundamentos da política do marquês de Pombal. Constatação que pode ser averiguada conjuntamente com a tabela 09. As novas paróquias povoaram o sertão nordestino, espalhando-se desde a capitania do Piauí até a Bahia. Os índices apresentados no mapa 12 relacionam a criação de duas novas paróquias no Piauí, sete no Ceará, três no Rio Grande do Norte, duas no interior paraibano, quatro na capitania de Pernambuco, uma no sertão de Alagoas, uma em Sergipe e sete na Bahia. Uma consideração para esta "semeadura" vincula-se aos propósitos de Dom José I, cuja estratégia política atingiu áreas afastadas dos centros litorâneos, consideradas periféricas, porque...

(...) vivendo os seus habitantes em grandes distancias huns dos outros sem a communicação como inimigos da sociedade civil e do commercio humano padecendo assim os descômodos e os lugares muito remotos e longínquos de sorte que quando lhes chegam os despachos vem tão tarde que não servindo para o remedeo das queixas lhes trazem sempre a ruína $(. . .)^{276}$

275 FLEXOR, Maria Helena Ochi. "Cidades e vilas pombalinas no Brasil do século XVIII". In Universo Urbanístico português, 1415 - 1822. Lisboa, Comissão Nacional para as Comemorações dos Descobrimentos portugueses, 1998. p. 257.

${ }^{276}$ PROJETO RESGATE. AHU_ACL_CU_018, Cx. 8, D. 450. 


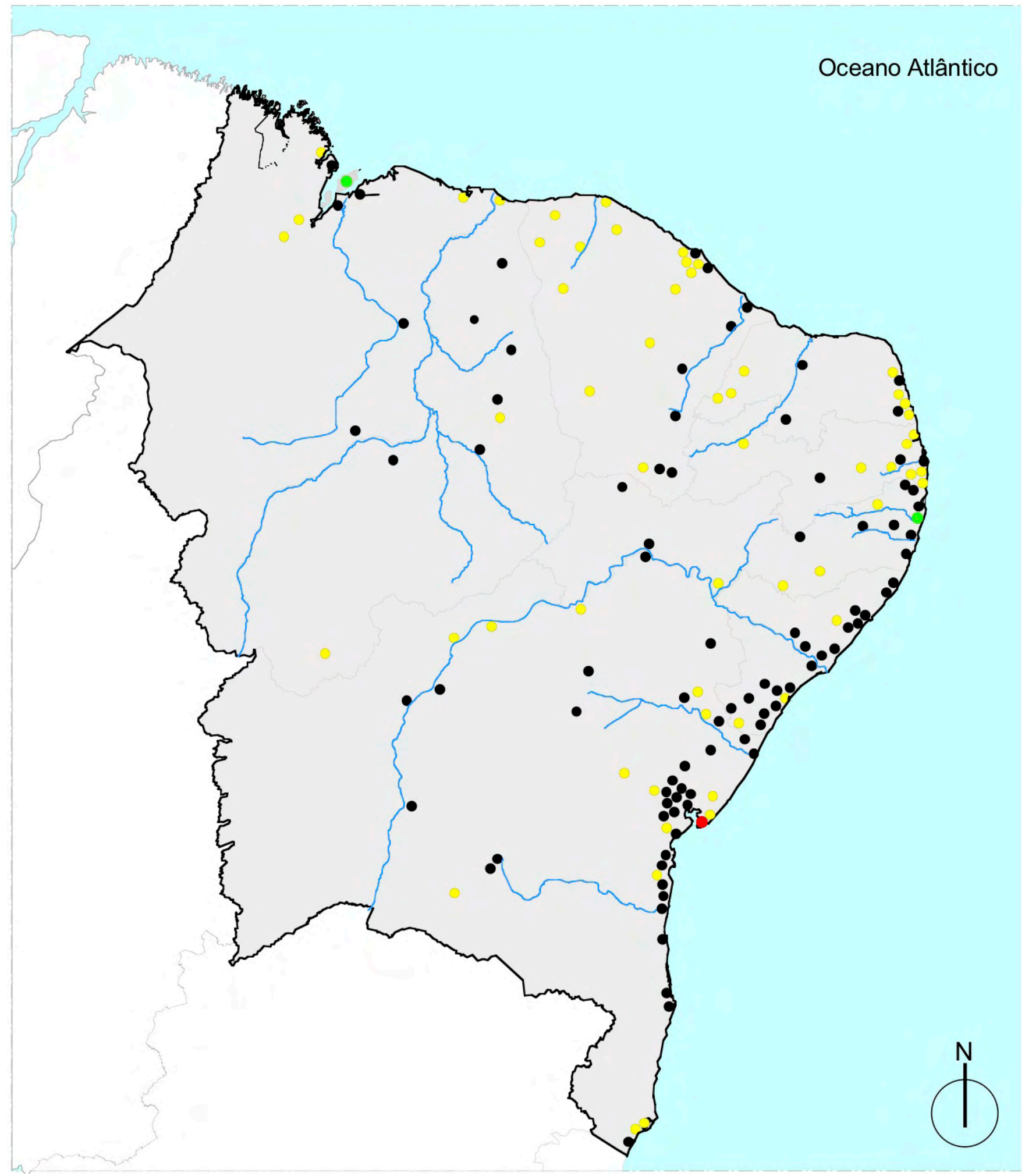

\section{LEGENDA:}

Sede de Arcebispado (Salvador,1671);

Sede de Bispado (Pernambuco [1676], Maranhão [1677]);

Freguesias instaladas no período;

Freguesias instaladas em períodos anteriores;
Mapa 12 - Freguesias do Nordeste colonial, fundadas entre os anos de 1750 - 1777. Sob o governo de D. José I e do seu braço direito, marquês de Pombal. Desenho do autor.

\section{Principais rios;}




\begin{tabular}{|c|c|}
\hline \multicolumn{2}{|c|}{ FREGUESIAS DO SERTÃO NORDESTINO, 1750 - 1777} \\
\hline \multicolumn{2}{|c|}{ CAPITANIA DE SÃO JOSÉ DO PIAUÍ } \\
\hline ANO DE FUNDAÇÃO & FREGUESIA \\
\hline 1755 & Nossa Senhora do Livramento de Parnaguá \\
\hline 1761 & Nossa Senhora do Ó \\
\hline \multicolumn{2}{|c|}{ CAPITANIA DO CEARÁ } \\
\hline 1754 & Nossa Senhora da Palma \\
\hline 1755 & Santo Antônio de Quixeramombim \\
\hline 1755 & Nossa Senhora do Carmo dos Inhamuns \\
\hline 1757 & São Gonçalo da Serra dos Cocos \\
\hline 1757 & Nossa Senhora da Conceição de Sobral \\
\hline 1757 & Nossa Senhora da Assunção \\
\hline 1758 & Nossa Senhora da Penha de França \\
\hline \multicolumn{2}{|c|}{ CAPITANIA DO RIO GRANDE DO NORTE } \\
\hline 1756 & Nossa Senhora da Conceição dos Pau dos Ferros \\
\hline 1761 & Nossa Senhora da Conceição de Portalegre \\
\hline 1766 & São João Batista das Várzeas do Apodi \\
\hline \multicolumn{2}{|c|}{ CAPITANIA DA PARAÍBA } \\
\hline 1769 & Nossa Senhora da Conceição de Campina Grande \\
\hline 1772 & Nossa Senhora do Bom Sucesso \\
\hline \multicolumn{2}{|c|}{ CAPITANIA DE PERNAMBUCO } \\
\hline 1761 & Nossa Senhora da Saúde de Tacaratú \\
\hline 1762 & Santo Antônio de Garanhuns \\
\hline 1762 & Santa Maria da Boa Vista \\
\hline
\end{tabular}




\begin{tabular}{|c|c|}
\hline 1766 & Nossa Senhora da Conceição das Águas Belas \\
\hline \multicolumn{2}{|r|}{ CAPITANIA DE ALAGOAS } \\
\hline 1763 & Nossa Senhora da Conceição do Porto Real do Colégio \\
\hline \multicolumn{2}{|c|}{ CAPITANIA DE SERGIPE DEL REY } \\
\hline 1758 & Nossa Senhora do Socorro de Gerú \\
\hline \multicolumn{2}{|c|}{ CAPITANIA DA BAHIA DE TODOS OS SANTOS } \\
\hline 1754 & Santa Tereza de Pombal \\
\hline 1754 & Nossa Senhora da Conceição de Soure \\
\hline 1754 & Santa Ana do Caitité \\
\hline 1755 & Senhor do Bom Jesus do Xique-xique \\
\hline 1755 & Freguesia de Sant'Ana \\
\hline 1766 & Nossa Senhora das Brotas do Juazeiro \\
\hline 1771 & Santo Antônio do Pilão Arcado \\
\hline
\end{tabular}

Tabela 09 - Freguesias do sertão nordestino criadas entre os anos de 1750 - 1777. Elaboração do autor segundo informações encontradas em: ENCICLOPÉDIA municípios brasileiros. Rio de Janeiro, 1947; manuscritos do Projeto Resgate Barão do Rio Branco; Mappa Geral de Todas as Misoens ou Aldeas....

Governadores, ouvidores e autoridades clericais, durante o período pombalino, submetem um rigoroso controle do território, elaborando recenseamentos populacionais nas capitanias, bispados e freguesias onde exerceram seus cargos. As obrigações dos clérigos incluíam a apresentação de dados acerca da distribuição e gestão das freguesias, com descrição detalhada do número de ermidas filiais, coladas ou colativas, capelães, côngruas e almas de comunhão ${ }^{277}$. Estatística populacional constitui um mecanismo analítico que mede o grau de urbanização de um território ${ }^{278}$. Antes de ser um espaço despovoado, as amostragens expressas na tabela 10 mostram um sertão em franca expansão demográfica. A imigração de portugueses do Minho, Douro e Açores, nos anos em questão, para o interior da Paraíba, Rio

${ }^{277}$ FRIDMAN, Fania. "Freguesias do Rio de Janeiro ao final do século XVIII". In Anais do II Encontro Internacional de História Colonial..., Opus cit., p. 09.

${ }^{278}$ RONCAYOLO, Marcel. "Cicade". In Enciclopédia Einaudi. vol. 8 (Região). Lisboa, Imprensa Nacional Casa da Moeda, 1984. p. 400. 
Grande do Norte e Piauí talvez seja um dos motivos para este "aquecimento" populacional. Na paróquia de Nossa Senhora da Conceição da vila de Portalegre, por exemplo, contaram, em 1774, trezentas e sessenta pessoas de desobrigas de origem portuguesa.

\begin{tabular}{|c|c|c|}
\hline FREGUESIA DO MARANHÃO & FOGOS & ALMAS \\
\hline Nossa Senhora do Nazaré das Aldeias Altas & - & 3.735 \\
\hline São Bento das Balças dos Pastos Bons & - & 3.235 \\
\hline FREGUESIAS DO PIAUÍ & FOGOS & ALMAS \\
\hline Nossa Senhora da Vitória & 821 & 4.366 \\
\hline Nossa Senhora do Ó & 305 & 1.435 \\
\hline Nossa Senhora do Desterro & 195 & 1.055 \\
\hline Santo Antônio do Surubim & 307 & 1.867 \\
\hline Santo Antônio do Gurguéia & 93 & 697 \\
\hline Nossa Senhora do Livramento de Parnaguá & 164 & 902 \\
\hline Nossa Senhora do Carmo de Piracuruca & 334 & 2.368 \\
\hline FREGUESIAS DO CEARÁ & FOGOS & ALMAS \\
\hline Nossa Senhora da Palma & 129 & 355 \\
\hline Nossa Senhora da Conceição do Sobral & 678 & 2.708 \\
\hline São Gonçalo da Serra dos Cocos & 544 & 1.875 \\
\hline Nossa Senhora da Assunção & 1.559 & 3.908 \\
\hline Nossa Senhora da Expectação do Icó & 725 & 3.312 \\
\hline Nossa Senhora do Rosário das Russas & 1.027 & 4.525 \\
\hline Santo Antônio de Quixeramombim & 226 & 924 \\
\hline Nossa Senhora do Carmo dos Inhamuns & 613 & 2.519 \\
\hline Nossa Senhora da Penha de França & 172 & 412 \\
\hline
\end{tabular}


São José dos Cariris Novos

\begin{tabular}{|c|c|c|}
\hline FREGUESIAS DO RIO GRANDE DO NORTE & FOGOS & ALMAS \\
\hline São João Batista do Açu & 571 & 2.864 \\
Nossa Senhora da Conceição de Portalegre & 141 & 636 \\
São João Batista da Várzea do Apodi & 421 & 4.094 \\
Nossa Senhora da Conceição dos Paus de Ferros & 210 & 2.058 \\
Gloriosa Sant'Ana do Seridó & 200 & 3.174 \\
\hline FREGUESIAS DA PARAÍBA & FOGOS & ALMAS \\
\hline
\end{tabular}

Nossa Senhora da Conceição de Campina Grande

Nossa Senhora dos Milagres da Ribeira do Cariri

410

1.799

Nossa Senhora do Bom Sucesso

2.451

5.422

\begin{tabular}{|l|l}
\hline FREGUESIAS DE PERNAMBUCO & \\
\hline
\end{tabular}

\section{FOGOS}

411

166

633

261

Nossa Senhora da Saúde de Tacaratú

FREGUESIAS DE ALAGOAS

Nossa Senhora do Ó do Rio São Francisco

Nossa Senhora da Conceição do Porto Real do Colégio

Santa Maria da Boa Vista

Bom Jesus dos Aflitos de Exú

\section{FOGOS}

689

112

93

$-$

$498(?)$

\begin{tabular}{|l|l|}
\hline FREGUESIAS DE SERGIPE \\
\hline
\end{tabular}

Nossa Senhora do Campo do Rio Real

FOGOS

228
ALMAS

1.546

213

1.121

Nossa Senhora do Socorro de Gerú 


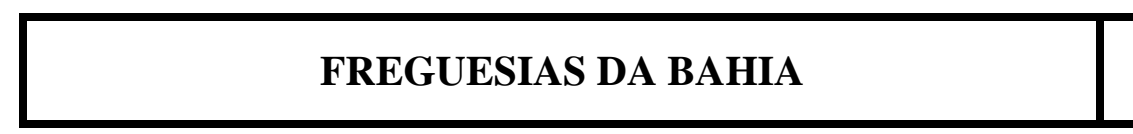

FOGOS

Santo Antônio do Pambú

Nossa Senhora do Nazaré de Itapicurú de Cima

São João Batista do Jeremoabo

Santíssimo Sacramento do Rio de Contas

São José da Barra do Sento Sé

Santo Antônio da Jacobina

Livramento de Nossa Senhora do Rio de Contas

Santo Antônio do Urubú de Cima

Santa Tereza de Pombal

Nossa Senhora da Conceição de Soure

Santa Ana do Caitité

Senhor do Bom Jesus do Xique-xique

Freguesia de Sant'Ana

Nossa Senhora das Brotas do Juazeiro

Santo Antônio do Pilão Arcado

São Francisco da Barra do Rio Grande
93

1.019

182

1.728

250

1.822

663

3.223

243

2.023

287

2.212

362

3.425

100

143

1.018

286

1.982

91

540

$-$

100

419

1.805

692

Tabela 10 - Quantitativo de moradias e pessoas de desobriga das freguesias do sertão nordestino, 1750 - 1777. Elaboração do autor segundo informações encontradas em: ENCICLOPÉDIA municípios brasileiros. Rio de Janeiro, 1947; manuscritos do Projeto Resgate Barão do Rio Branco; Mappa Geral de Todas as Misoens ou Aldeas....; CALDAS, Jozé Antônio. Notícia Geral de toda esta capitnia da Bahia desde o seu descobrimento até o prezente. Edição Fac. similar. Salvador, Tip. Beneditina, 1951.

Outras observações devem ser comentadas acerca do período pombalino. Em primeiro lugar, a atitude anti-clerical e racional do ministro português transformou anteriores reduções religiosas em paróquias. No Ceará foram elevadas as missões da Ibiapaba, São Gonçalo da Serra dos Cocos, Miranda e Nossa Senhora da Palma. Em terras potiguares, a missão jesuítica do Apodi e a capuchinha de Nossa Senhora da Conceição. No sertão pernambucano, são novas igrejas matrizes as reduções de Tacaratú e Águas Belas. Na Bahia de Todos os Santos, os núcleos de índios de Canabrava, Natuba e Juazeiro tornam-se, 
respectivamente, as paróquias de Santa Tereza de Pombal, Nossa Senhora da Conceição de Soure e Nossa Senhora das Brotas do Juazeiro. Em segundo lugar, a administração espiritual das novas freguesias foi passada ao clero secular, diante do apoio destes à política pombalina. Em decorrência disso, o regalismo passa a ser mentalidade dominante, e a vinculação das dioceses e freguesias ao poder civil se torna mais patente ${ }^{279}$.

O fracionamento territorial ocasionado pela criação de freguesias, contribuiu para a gradual urbanização do sertão nordestino. Os índices populacionais, acima inventariados, dão uma margem do fenômeno urbano sertanejo. A divisão de uma paróquia beneficiou os mais pobres, encurtando as distâncias a percorrer:

(...) persuadio a que criou uma Igreja no Rio Meary pello grande desamparo em que se achava aquella povoação, que já hoje constava de quinhentas almas capazes de recebe os Santos Sacramentos, como lhe constava pello rol das confissõens, e que cada vez hiao augmentando os moradores vendo que tem Parochia naquelle Citio (...) $)^{280}$

A facilidade de obtenção dos registros de batismo, matrimônio e óbito alargaram com a implantação dos territórios eclesiásticos. O acesso à justiça, pouco executada na colônia e, segundo os representantes da Coroa, aumentou um pouco mais para os habitantes interioranos, com cuja mercê se evitaram tantos incômodos, e se administrará (...) Justissas sem confuzão, nem detrimento dos povos pellos longes e remontados Sertoins ${ }^{281}$.

É interessante marcar como foi absorvida a criação de gado na gerência e progresso das freguesias. Sendo a economia base do sertão nordestino, os dízimos a Deus eram convertidas em gado. Diz o Estatutos da freguesia de Nossa Senhora do Risário das Russas assentados e concordados em 29 de Setembro de 1761 pello Rdo. Dr. o Pe. Veríssimo Roiz Rangel no seu primeiro capítulo: pagarão os fregueses desta freguesia que tiverem e recolherem cincoenta bezerros, hum boy na forma do costume e antigo, sendo boy que valha dois mil réis e na falta o seu valor, indo o Rdo. Pároco desobrigalos a suas cazas por sy ou por sacerdote de licença sua ${ }^{282}$ (...). Uma igreja edificada às margens do rio Mearim,

\footnotetext{
${ }^{279}$ AZZI, Riolando. “A instituição eclesiástica durante a primeira época colonial.” In História da Igreja no Brasil..., Opus cit., p. 181.

${ }^{280}$ PROJETO RESGATE. AHU_ACL_CU_009, Cx. 13, D. 1352.

${ }^{281}$ PROJETO RESGATE. AHU_ACL_CU_CEARÁ, Cx. 6, D. 418.

282 "ESTATUTOS da freguezia de Nossa Senhora do Rosário das Russas concordados em 29 de Setembro de 1761”. In Revista do Instituto do Ceará. Ano XV. Fortaleza, 1901. p. 89.
} 
capitania do Maranhão, com quinhentas pessoas de desobriga, foi sustentada por um curral de bois, doado por um fazendeiro morador daquele sertão ${ }^{283}$.

A queda de Pombal e a subida de Dona Maria I (1777 - 1808) ao trono lusitano provocaram uma retração na fundação de paróquias. Treze novas freguesias no total se estabeleceram em terras da caatinga nordestina. Duas no Piauí, São Gonçalo do Amarante e Nossa Senhora das Marcês, antes aldeamentos missioneiro. No Ceará observamos o surgimento de apenas uma nova igreja matriz locada no sertão dos Inhamuns, Nossa Senhora da Paz de Arneiroz. Três na Paraíba. Em Pernambuco são criadas quatro, dados que sobrepõem às criadas na capitania da Bahia de Todos os Santos: três freguesias. [mapa 13] [tabela 11]

Justifica-se a redução do número de novas paróquias à primária laicização do espaço urbano do Brasil colonial, iniciada com D. João V e fortalecidas por Pombal. Ademais, a submissão do clero à Coroa, durante o recorte temporal em análise, recuou a ação da Igreja nas resoluções que competiam à autoridade real. Afrouxa-se o cordão tríplice do padroado: Coroa+Igreja Católica+Divino. Os negócios eclesiásticos, principalmente os que envolveram a arrematação dos dízimos, foram integralmente enviados ao soberano de Portugal. ${ }^{284}$

Expressiva foi a carta régia enviada, em 1800, ao capitão general da Bahia, Francisco da Cunha Menezes. A absoluta dignidade dos reis e a submissão da Igreja aos direitos reais foram os motes para sua redação:

(...) e assim, por este motivo, como razão da qualidade que me é inerente de defensor e protetor da Igreja (...) vos proporeis zelar a minha soberana autoridade, não consentindo que debaixo de aparentes pretextos do bom serviço de Deus e da Igreja, se violem os meus reais direitos, de que por uma parte vêm a resultar graves inconvenientes ao meu real serviço $(. . .)^{285}$

\footnotetext{
283 PROJETO RESGATE. AHU_ACL_CU_009, Cx. 13, D. 1352.

${ }^{284}$ PRADO Jr. Caio. Formação do Brasil contemporâneo: Colônia. São Paulo, Brasiliense, 1961. p. 330.

${ }^{285}$ ANNAES da Bibliotheca Nacional do Rio de Janeiro. Vol XXXVI. Ano 1914. Rio de Janeiro, Officinas Graphicas da Bibliotheca Nacional, 1916. p. 235.
} 


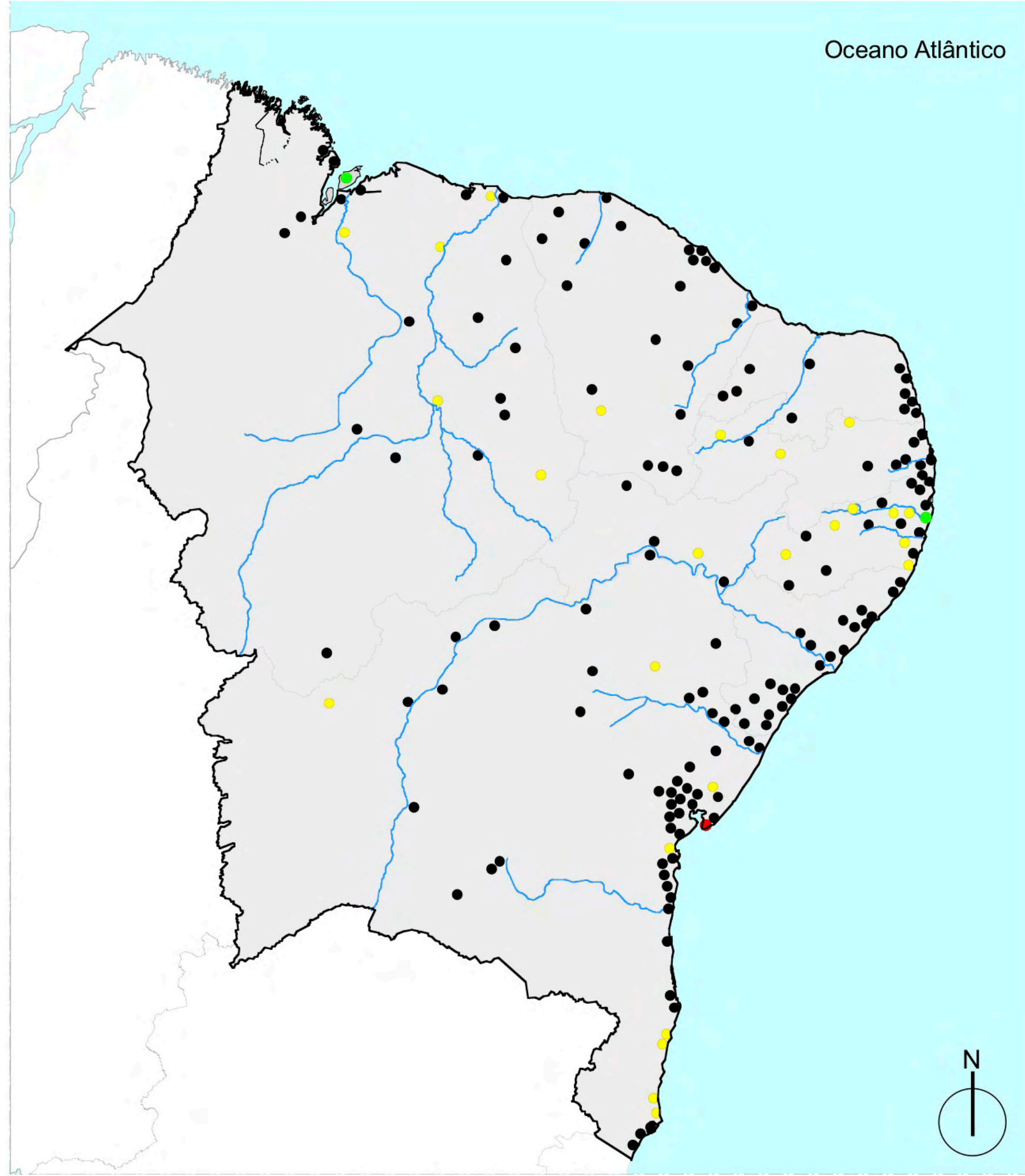

\section{LEGENDA:}

Sede de Arcebispado (Salvador,1671);

Sede de Bispado (Pernambuco [1676], Maranhão [1677]);

Freguesias instaladas no período;

Freguesias instaladas em períodos anteriores;

Principais rios;
Mapa 13 - Freguesias do Nordeste colonial, fundadas entre os anos de 1777-1808. Desenho do autor. 


\begin{tabular}{|c|c|}
\hline \multicolumn{2}{|c|}{ FREGUESIAS DO SERTÃO NORDESTINO, 1777 - 1808} \\
\hline \multicolumn{2}{|r|}{ CAPITANIA DE SÃO JOSÉ DO PIAUIí } \\
\hline ANO DE FUNDAÇÃO & FREGUESIA \\
\hline 1801 & São Gonçalo de Amarante \\
\hline 1805 & Nossa Senhora das Mercês \\
\hline \multicolumn{2}{|r|}{ CAPITANIA DO CEARÁ } \\
\hline 1783 & Nossa Senhora da Paz de Arneiroz \\
\hline \multicolumn{2}{|r|}{ CAPITANIA DA PARAÍBA } \\
\hline 1784 & Nossa Senhora dos Remédios do Jardim do Rio do Peixe \\
\hline 1788 & Nossa Senhora da Guia de Patos \\
\hline 1801 & Nossa Senhora das Mercês de Cuité \\
\hline \multicolumn{2}{|r|}{ CAPITANIA DE PERNAMBUCO } \\
\hline 1793 & São Félix de Cantolice \\
\hline 1797 & Brejo da Madre de Deus \\
\hline 1801 & Santo Amaro de Taquaritinga \\
\hline 1801 & Nossa Senhora do Rosário da Fazenda Grande \\
\hline \multicolumn{2}{|r|}{ CAPITANIA DA BAHIA } \\
\hline 1790 & Nossa Senhora do Carmo do Monte Santo \\
\hline 1795 & Senhor do Bonfim de Taperá \\
\hline 1804 & Santa Rita de Cássia \\
\hline
\end{tabular}

Tabela 11 - Freguesias do sertão nordestino, 1777 - 1808. Elaboração do autor segundo informações encontradas em: ENCICLOPÉDIA municípios brasileiros. Rio de Janeiro, 1947; manuscritos do Projeto Resgate Barão do Rio Branco;

Os motivos e práticas, concernentes à criação de freguesias, persistem ao longo do período mariano. Vivendo isolados e padecendo de inconvenientes, os moradores solicitaram ao bispo a elevação de uma capela, curada talvez, à condição de paróquia. Sendo obrigados a 
pagar as côngruas do pároco, arcar com os materiais para a edificação ou reforma do templo religioso e ornar o interior da igreja. Presenciaram esses eventos alguns fregueses da paróquia de Nossa Senhora do Carmos dos Inhamuns, sertão cearense. Distantes mais de cinqüenta léguas da sua igreja matriz, o padre não acudia, como se devia, seus fiéis com o pasto espiritual. Os habitantes pediram ao bispo da diocese pernambucana o desmembramento do território eclesiástico da freguesia dos Inhamuns, criando uma nova paróquia: Nossa Senhora da Paz de Arneiroz, instituída em 1783. Francisco Alves Feitosa, fazendeiro e criador de gado daquela região, doou cem braças em quadra de terra como passal ao pároco da igreja matriz do núcleo de Arneiroz ${ }^{286}$.

Grandes concessionários de terra, como as famílias Garcia d'Ávila e Guedes de Brito, em busca de honras honoríficas, tais como o título de "homens - bons", se desfaziam eventualmente de pequena parcela do que detinham para atender à comunidade menos favorecida ${ }^{287}$. Podemos averiguar isso na doação do patrimônio religioso, pelos fazendeiros da Casa da Torre, à paróquia de Nossa Senhora dos Remédios do Rio do Peixe, futura vila de Sousa - PB, cujos intentos revigoram a perspectiva de crescimento urbano:

(...) que para a creação della lhe fes Patrimônio e doação os senhorios da Casa da Torre da Bahia do ditto Sitio do Jardim com todas as suas terras, e logradouros na forma que sempre forão possuídas as dittas terras, as quaes partem pela parte do Poente com o sitio do Bom Sucesso, e pella parte do Norte com o sitio de Santa Rosa, e pella parte do Sul com a da Conceipção e São Gonçalo, e porque a ditta capella não tem outro titulo, mas que a doação dos ditos senhorios da casa da Torre, queria o supplicante para milhor direito, e conservação do domínio, e posse em que está a mesma capella ha mais de desaseis anos, tirar datas de Sixmaria da ditta terra com três legoas de comprido e huma de largo, ou três de largo e huma de comprido, ou legoa e meia em quadra, na forma que milhor for, ficando sempre dentro das três legoas, ou na largura, ou no comprido, o logradouro chamado de Jardim $(\ldots)^{288}$

Doar terra a um santo envolvia perda, mesmo que pequena, do patrimônio fundiário dos fazendeiros de gado. O rico poderio latifundiário da Casa da Torre, englobando terras

\footnotetext{
286، “APONTAMENTOS sobre as freguezias de Arneiroz e de Saboeiro”. In Revista do Instituto do Ceará. Ano XVI. Fortaleza, 1902. p. $72-80$.

${ }^{287}$ MARX, Murillo. Cidades no Brasil, terra..., Opus cit., p. 38.

${ }^{288}$ PROJETO RESGATE. AHU_ACL_CU_014, Cx. 30, D. 2200.
} 
desde a Bahia até o Maranhão paulatinamente diminuiu com a eclosão de novas freguesias em seus domínios. Por isso, tão comum a reação destes contra o povoamento de suas terras. O caso de Inhambupe (BA) deve ser analisado. Ao ser elevada à condição de paróquia, Francisco Dias d'Ávila III, suscitou duras controvérsias com o padre empossado da nova matriz. Quando viu que a terra fora doada para construir igreja à favor dos índios e pobres moradores da localidade, tratou logo de vender o lote ao capitão João Barbosa Rabelo, a quem arrendara por um dote de $6 \$ 000$ rs. anuais, a fim de retirar de lá o rendimento possível, pois sabia que mais cedo ou mais tarde perderia tais terras para a Igreja e aos interessados em povoar a nova freguesia ${ }^{289}$.

Em 1808, o Reino de Portugal decidiu trasladar sua sede para a colônia americana. As fortes tensões internacionais, instigadas pela supremacia de Napoleão Bonaparte na Europa, concentraram os planos do príncipe regente, instalado no Rio de Janeiro, na política internacional e reordenamento urbano da capital do Reino. Os interesses de Dom João VI voltaram-se para o algodão produzido no Maranhão, Ceará, Rio Grande do Norte e Paraíba. A pecuária extensiva sofria considerável declínio, em detrimento de fatores climáticos e concorrência com o gado criado no sul do Brasil.

Destarte, observa-se a queda do número de novas freguesias fundadas no interior nordestino. A quantidade de paróquias instaladas entre 1808 - 1822 somaram três no Ceará; uma no Rio Grande do Norte; uma na Paraíba; uma em Pernambuco; uma em Sergipe; quatro na Bahia, resultando um total de onze freguesias. [mapa 14] [tabela 12]

D. João VI, ao longo do seu governo, notou as potencialidades territoriais, demográficas e econômicas do seu novo Reino ${ }^{290}$. As estratégias administrativas se concentraram no Rio de Janeiro e regiões limítrofes, como Minas Gerais e nos núcleos litorâneos do Nordeste:

Eis aqui, pois, como El-rei nosso Senhor é mal visto nas províncias mais distantes de suas vistas, e como é também que o miserável público padece

\footnotetext{
${ }^{289}$ BANDEIRA, Luiz Alberto Moniz. O feudo: a Casa da Torre de Garcia d'Ávila: da conquista dos sertões à independência do Brasil. Rio de Janeiro, Civilização Brasileira, 2000. p. 356.

${ }^{290}$ BANDEIRA, Luiz Alberto Moniz. O feudo: a Casa da Torre...Opus cit., p. 365.
} 
sacrificado aos caprichos e à rivalidade de certos homens, que por infelicidade representam o estado das cousas. ${ }^{291}$

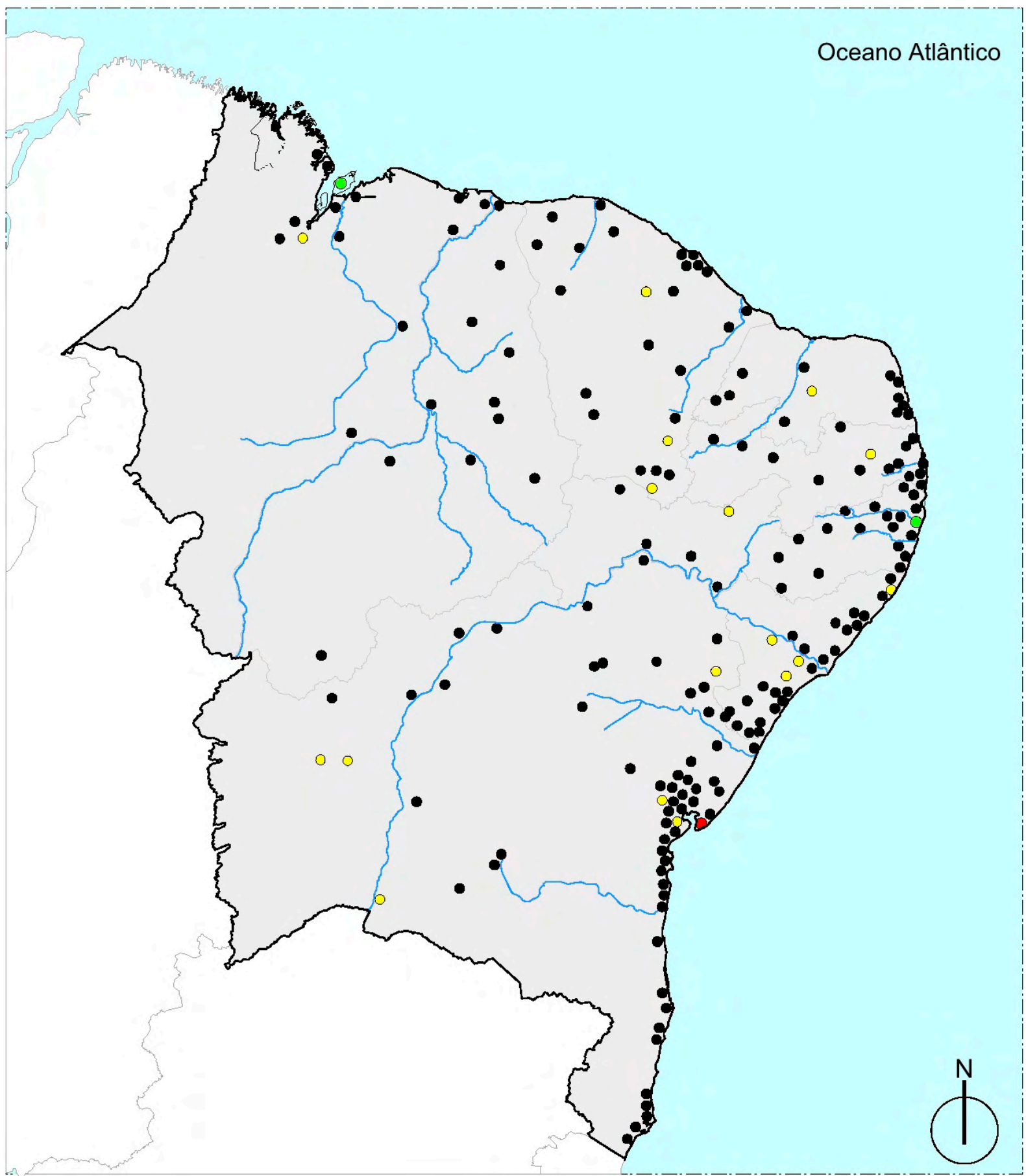

\section{LEGENDA:}

Sede de Arcebispado (Salvador, 1671);

Sede de Bispado (Pernambuco [1676], Maranhão [1677]);

Freguesias instaladas no período;

Freguesias instaladas em períodos anteriores;

Principais rios:
Mapa 14 - Freguesias do Nordeste colonial, fundadas entre os anos de 1808 - 1822. Desenho do autor.

${ }^{291}$ RIBEIRO, major Francisco de Paula. "Descripção do território de Pastos Bons, nos sertões do Maranhão: propriedades dos seus terrenos, suas producções, caráter dos seus habitantes colonos, e estado actual dos seus estabelecimentos". In Revista do Instituto Histórico e Geográfico Brasileiro. Tomo XII. Rio de Janeiro, IHGB, 1849. p. 60. 


\begin{tabular}{|c|c|}
\hline \multicolumn{2}{|c|}{ FREGUESIAS DO SERTÃO NORDESTINO, 1808 - 1822} \\
\hline \multicolumn{2}{|c|}{ CAPITANIA DO CEARÁ } \\
\hline ANO DE FUNDAÇÃO & FREGUESIA \\
\hline 1813 & São Vicente Ferrer das Lavras da Mangabiera \\
\hline 1814 & Santo Antônio do Jardim \\
\hline 1817 & São Francisco das Chagas do Canindé \\
\hline \multicolumn{2}{|c|}{ CAPITANIA DO RIO GRANDE DO NORTE } \\
\hline 1821 & Santana dos Matos \\
\hline \multicolumn{2}{|c|}{ CAPITANIA DA PARAÍBA } \\
\hline 1813 & Nossa Senhora da Conceição do Brejo da Areia \\
\hline 1814 & Santo Antônio do Piancó \\
\hline \multicolumn{2}{|c|}{ CAPITANIA DE PERNAMBUCO } \\
\hline 1810 & Nossa Senhora da Conceição de Flores do Pajeú \\
\hline \multicolumn{2}{|c|}{ CAPITANIA DE SERGIPE } \\
\hline 1821 & São Pedro do Porto da Folha \\
\hline \multicolumn{2}{|c|}{ CAPITANIA DA BAHIA } \\
\hline 1813 & São José do Carinhanha \\
\hline 1817 & Nossa Senhora do Bom Conselho \\
\hline 1820 & Nossa Senhora de Santana \\
\hline 1822 & Sant'Ana do Sacramento \\
\hline
\end{tabular}

Tabela 12 - Freguesias do sertão nordestino, 1808 - 1822. Elaboração do autor segundo informações encontradas em: ENCICLOPÉDIA municípios brasileiros. Rio de Janeiro, 1947; manuscritos do Projeto Resgate Barão do Rio Branco; 


\subsection{As leis do Reino e a formação urbano-territorial do sertão nordestino}

(...) nas grandes distancias em que se achão, Se facilitão a prevaricar as Ordens do governo, especialmente alguns Ministros, que ordinariamente afectão huã total independência ${ }^{292}$. O isolamento que afetou os primeiros núcleos urbanos do sertão nordestino, a corrupção foi exercida em algumas câmaras sertanejas. As leis emitidas por cartas régias ou alvarás também eram burladas por fazendeiros de gado, os quais viam as normas do Reino como entrave para o seu progresso fundiário e econômico. Que códigos legais foram implantados e supostamente obedecidos pelas autoridades locais?

A dualidade defendida nesta dissertação - curral de reses x curral de almas diferencia as leis homologadas para território do interior do Nordeste. De um lado, estão àquelas que favoreciam o povoamento, a posse, uso e alargamento de domínios fundiários do sertão. Por outro, a aculturação dos nativos em aldeamentos missioneiros potencializou a formação urbana com códigos legais específicos. Na primeira variante enquadra-se as Ordenações do Reino (Manuelinas, século XVI; Filipinas, século XVIII); adéquam-se à segunda vertente os alvarás, cartas régias e ordens em forma de lei, centralizados na liberdade indígena e sua adaptação à cultura católica-portuguesa.

\subsection{1 - Ordenações no sertão nordestino}

A organização municipal portuguesa e suas funções político - administrativa e judiciária foram transmitidas para o Brasil por meio das Ordenações do Reino ${ }^{293}$. Ordenações ligeiras, genéricas e dispersivas onde o fato urbano foi abordado numa perspectiva casuística e pontual, se abrangermos a legislação portuguesa dentro do período colonial ${ }^{294}$. Isto é, os códigos do Reino foram baixados para a Metrópole e transplantados, persistentemente, para suas colônias do ultramar. ${ }^{295}$ Postura contrária à colonização espanhola nas Américas, cuja variante legal se deu dentro de estatutos pré-determinados - Recopilación de las Leyes de los Reynos de las Indias, publicada em 1584, com um capítulo destinado ao ordenamento físico dos aglomerados coloniais ${ }^{296}$.

\footnotetext{
${ }^{292}$ PROJETO RESGATE. AHU_ACL_CU_016, Cx. 3, D. 210.

${ }^{293}$ REIS FILHO, Nestor Goulart. Contribuição ao estudo da evolução urbana do Brasil (1500/1720). 2 ed. rev. e ampl. São Paulo, Pini, 2000. p. 24.

${ }^{294}$ MARX, Murillo. Cidades no Brasil, em que termos? São Paulo, Studio Nobel, 1999. p. 35.

${ }^{295}$ BARRETO, Paulo Thedin. "Casas de Câmara e Cadeia". in Revista do IPHAN. Rio de Janeiro, 1947. p. 115.

${ }^{296}$ Não pretendemos retornar ao debate cansativo e exaustivo da forma urbana adotada pelos portugueses - fruto do desleixo - daqueles efetuados nas colônias espanholas: núcleos regulares, em dameiro. Nos valemos em
} 
As Ordenações do Reino versaram sobre todos os aspectos da vida colonial brasileira, estabelecendo normas de conduta, punição aos delitos e, principalmente, o meio de adquirir terras, ou sesmarias, para o povoamento do território. No período em estudo, as Ordenações sofreram adaptações de acordo com a necessidade do seu tempo, em detrimento disso, foram acrescidos uma série de ordens, alvarás, cartas régias e provisões para ancorar as lacunas deste código reinol ${ }^{297}$. Por isso, para Nestor Goulart Reis Filho as condições do processo de colonização no Brasil se fizeram com que na prática o esquema administrativo proposto pelas Ordenações sofressem consideráveis adaptações, características próprias, diversas das portuguesas ${ }^{298}$.

Essa flexibilidade das Ordenações do Reino foi apontada por Murillo Marx:

Não houve na vasta porção oriental das Américas o constrangimento de normais gerais especificamente coloniais, que apontassem um quadro obrigatório, detalhado e uniformizador para o ordenamento físico das suas fundações de qualquer categoria e para embasar a atuação dos concelhos ou câmaras municipais. (...) $)^{299}$

Os primeiros títulos das Ordenações observados no sertão nordestino referiram-se à posse do chão, através das sesmarias. Faixas de terras foram doadas àqueles colonos desejosos de cultivá-las. Trata-se de um sistema restritivo e seletista, concedendo domínios fundiários aos candidatos que cumprissem os requisitos estabelecidos pelas Ordenações ${ }^{300}$. Não as povoando dentro do prazo estipulado, o sesmeiro era obrigado a devolver, às autoridades competentes, a parcela de terra agora considerada devoluta. Diz o livro quarto, título 43: das Sesmarias:

(...) E se as não allegarem ou as não provarem, ou não vierem à dita citação assinem-lhes hum anno (que he termo conveniente) para que as lavrem, ou aproveitem, e repairem os ditos bens, ou as vendão, emprazem, ou arrendem,

apontar, através de fontes primárias, como ocorreu o comprimento das leis do Reino em terras do sertão nordestino, cujo resultado pode ser avaliado na conformação de nossas povoações, vilas e cidades.

${ }^{297}$ BARRETO, Paulo Thedin. "Casas de Câmara e Cadeia"..., Opus cit., p. 115.

${ }^{298}$ REIS FILHO, Nestor Goulart. Contribuição ao estudo da evolução urbana do Brasil..., Opus cit., p. 25.

${ }^{299}$ MARX, Murillo. Cidades no Brasil, em que termos? São Paulo, Studio Nobel, 1999. p. 49 - 50.

${ }^{300}$ LIMA, Ruy Cirne. Pequena história territorial do Brasil: sesmarias e terras devolutas. Fac-símile da 4 ed. São Paulo, Secretaria do Estado e da Cultura, 1990. p. 41. 
a quem possa aproveitar ou lavrar. E se não fizerem, passado o dito anno, dêm os Sesmeiros as ditas sesmarias a quem as lavre ou aproveite. ${ }^{301}$

Concentrado vastos territórios nas mãos de poucos, muitas foram as sesmarias devolvidas pelo não cultivo. Desse modo, a Coroa lusa restringiu a dimensão territorial das glebas, não havia de exceder, no máximo, de três léguas por uma légua, ou três léguas em quadra. Área que devería ser demarcada e medida, conforme os preceitos antigos. Estava sujeita a desfalques, dado que, nas concessões mais distantes, o arbítrio pertencia aos grandes sesmeiros $^{302}$. Assim sucedeu nos sertões do Piauí, Bahia, Pernambuco e outras capitanias nordestinas. As famílias Dias d'Ávila e Guedes de Brito, em associação com os fazendeiro Domingos Afonso Mafrense, eram detentores de latifúndios que iam muito além do lote sesmarial de três léguas em quadra.

De fato, no Mapa e Explicação de Sinco Sismarias que pertendem neste Certão do Piahuy a Caza da Torre, e seus Sosios (... $)^{303}$, os lotes obtidos, em 1687, eram gigantescos, incapazes de serem povoados dentro do período estipulado pelas Ordenações do Reino: (1) quarenta léguas, (2) vinte e cinco léguas, (3) doze léguas; (4) sessenta léguas em quadra. Pior: concedia essas glebas o governador da capitania de Pernambuco, Dom João de Sousa, suposto conhecedor dos códigos legais ${ }^{304}$. A única explicação plausível para a doação desses imensos domínios se deve à pecuária extensiva, prática econômica que requeria "generosas" quantidades de terra para implantação dos currais de gados e pastagem para os animais.

Em decorrência disso, o povoamento no sertão nordestino, nos tempos primeiros de sua colonização, apresentou como característica preponderante $\mathrm{o}$ isolamento, as concentrações humanas eram pontos distantes umas das outras. Sendo tais pontos, na maioria dos casos, fazendas de gado com reduzido número de moradores. Vale ressaltar que, a Casa da Torre e seus associados deixaram à margem, sem cultivo e povoamento, boas porções de suas semarias. Chegaram a impedir a posse de rendeiros em algumas áreas de seus domínios. Bloqueio que favoreceu o isolamento dos assentamentos humanos.

\footnotetext{
301 “ORDENAÇÕES Filipinas - Livro IV, Título XLIII: Das sesmarias”. Disponível em http://www.uc.pt/ihti/proj/filipinas/ordenacoes.htm. Acesso em 14/10/2011.

${ }^{302}$ LIMA, Ruy Cirne. Pequena história territorial do Brasil: sesmarias..., Opus cit., p. 41 e 45.

303 PROJETO RESGATE. AHU_ACL_CU_016, Cx. 1, D. 1. O título do mapa aponta cinco sesmarias, porém no escopo descritivo descreve somente quatro lotes de terra.

${ }^{304}$ PROJETO RESGATE. AHU_ACL_CU_016, Cx. 1, D. 1
} 
A Igreja tomou algumas decisões administrativas e judiciárias, como expressão da fragilidade e flexibilidade das Ordenações do Reino. O bispo da diocese de Pernambuco, D. Francisco de Lima, em 1697, escreveu ao rei, D. Pedro II, acerca da situação temporal encontrada no sertão de Rodelas, margem média do rio São Francisco. Disse o clérigo que comum foram os crimes sem ação imediata da justiça colonial, pella distançia em que são cometidoz $^{305}$. A autoridade eclesiástica solicitou intervenção do monarca para que, a cada cinco léguas, haia hum juiz ordinário com a jurisdição de tirar devaças, tomar as denunciações, e querellas nos delictos que aly se fizerem e remetellas por treslado ao Ouvidor geral de Pernambuco, ou ao Ouvidor da comarca da Bahia, segundo a quem pertencer a jurisdição para se proceder nesta matéria como for justiça ${ }^{306}$.

A respostas ao pedido de Dom Francisco de Lima veio em janeiro de 1699, através de uma carta régia dirigida ao governador da capitania de Pernambuco. Dom Pedro II pôs-se a par da situação geográfica e social vivenciada pelos sertanejos, sendo servido resolver que em cada freguezia das que tenho mandado formar pelos ditos Certões, haja um juiz á similhança dos juízes de vintenna, que há neste Reyno 307 . "À similhança do Reyno" é uma sentença que abarca, mesmo sem indicação direta, as normas legais de Portugal, as Ordenações do Reino. O próprio rei, ao invés de citar diretamente o livro, o título e o código específico das Ordenações, adapta suas normas às circunstâncias da colônia.

Como patrono da Igreja o monarca foi solicitado pelos bispos do Brasil, a fim de solucionar questões de fronteiras, demarcação do território dos bispados. Fundamental essa delimitação, porque muitos distúrbios acometidos nas dioceses, de ordem espiritual e temporal, seriam desembaraçados diante dos limites de cada instituição clerical. O bispo do Maranhão, em 1747, ao notar a desobediência dos fregueses do sertão piauiense, numa área de intersecção dos bispados de Pernambuco, Maranhão e São Paulo, informou ao rei D. João $\mathrm{V}$ a causa de todos estes distúrbios: não se houverem demarcado os limites dos Bispados confinantes, na forma das divisoens e desmembrações, uniões (...) pedia a Vossa Magestade fosse servido mandar que a vista das ditas bulas q' fizesse divisão e demarcação formal dos limites de cada hum dos Bispados (... $)^{308}$.

\footnotetext{
${ }^{305}$ ENNES, Ernesto. A guerra nos Palmares. Rio de Janeiro, Companhia Editora Nacional, 1938. p. 350.

${ }^{306}$ ENNES, Ernesto. A guerra nos Palmares...Opus cit., p. 350.

307 "Informação Geral da Capitania de Pernambuco, 1749". In Annaes da Bibliotheca Nacional do Rio de Janeiro. Vol. XXVIII. Ano 1906. Rio de Janeiro, Officinas de Artes Graphicas da Biblioteca Nacional, 1908. p. 343.

${ }^{308}$ PROJETO RESGATE. AHU_ACL_CU_009, Cx. 35, D. 3494.
} 
Como se vê as bulas e acordos papais influenciaram às decisões reais no que dizia respeito às questões geopolíticas. Problemas de cunho administrativo foram sanados à base dos editos papais. Nos sertões do Maranhão e Piauí, território dominado por gentios guerreiros e contrários à colonização, Dom José I nomeou para as paróquias ali instaladas o cargo de tesoureiros segundo os ditames da bulla das cruzadas $^{309}$ :

Fuy servido resolver em consulta da Junta da mesma Bulla, que nas Capellas do dito Certão, aonde com authoridade Ordinária se administrao os Sacramentos, haja daqui em diante Thesoureiros menores da Bulla das Cruzadas, para que com maior commodidade possao repetir as Bullas pelos Fregueses, que morao em grandes distancias de suas Igrejas Paroquiaes; e que estes Thesoureiros gozem dos privilégios, que tem os das cabeças das ditas Freguesias, na conformidade das minhas reaes Resoluçoens, em que mandei praticar do governo da Bahia, e Minas Geraes (...) $)^{310}$

Aplicação da bula das cruzadas pode ser vista na vila de Icó (CE). Nas atas da câmara do núcleo cearense foi registrada a provisão real de 15 de setembro de 1748, nomeando o tenente João Ferreira Quintaes mam-posteiro das bullas da santa cruzada, para a fundação de uma nova freguezia, com a invocação de Nossa Senhora da Luz dos Cariris Novos (...) sendo a dita freguezia desmembrada da de N. S. da Expectação do Icóo ${ }^{311}$.

Nas vilas, o cumprimento normativo das Ordenações do Reino, dentro das suas especificidades jurídicas e administrativas, ficou centralizado na casa de câmara ou concelhos. Eram tomadas decisões que interferiam na sociabilidade e no espaço urbano dos aglomerados: abertura de caminhos, instalação de chafarizes, trabalho dos oficiais mecânicos, monopólio dos açougues, reforma da cadeia, entre outros assuntos. Para Nestor Goulart a hierarquia administrativa da colônia esteve bem alicerçada. Havia o governo geral, centro gestor dos assuntos em escala de colônia, e os concelhos, poder municipal, que recebeu do governo geral autonomia administrativa ${ }^{312}$.

\footnotetext{
${ }^{309}$ A bula das cruzadas, segundo Fortunato de Almeida, foi um dos meios de que os papas se serviram para auxiliar os reis de Portugal na obra dos descobrimentos e conquistas. Após batalhas e conflitos contra os oponentes, os monarcas eram obrigados, segundo o edito das cruzadas, de reparar e edificar as igrejas. Ver ALMEIDA, Fortunato de. História da Igreja em Portugal. Tomo II. Lisboa, Livraria Civilização - Editora, 1968. p. 242.

${ }^{310}$ PROJETO RESGATE. AHU_ACL_CU_MARANHÃO, Cx. 38, D. 3767.

311 "EXTRACTOS dos assentos do antigo senado do Icó, desde 1738 até 1935". In Revista do Instituto Histórico Geográfico Brasileiro. Rio de Janeiro, IHGB, 1862. p. 67.

${ }^{312}$ REIS FILHO, Nestor Goulart. Contribuição ao estudo da evolução urbana do Brasil..., Opus cit., p. 26.
} 
Quando elevadas as paróquias do sertão da capitania do Piauí em vilas, sob a gestão do governador João Pereira Caldas, as ordens de Dom José I foram claras, dando as porem com as clauzulas e Ordenaçõens que tenho ordenado. Endossou o rei que, para o desenvolvimento urbano dos núcleos criados, os "homens-bons" eleitos para os $\operatorname{cargos}^{313}$ da câmara deveriam observar as Ordenações do Reyno. Ou, como menciona o mesmo documento, como se achão determinadas pelas Ordenaçõens ${ }^{314}$. Cumprir ou não as Ordenações, adaptá-las às situações locais, obedecer bulas e normas pias e independência municipal eram decisões a ser tomadas pelos oficiais locais.

Vereadores, juízes e procuradores conviveram com a fiscalização de outras autoridades. Prestavam auxílio os juízes de fora, pessoa estranha ao concelho, e, se por um lado fazia cessar a magistratura dos juízes ordinários, por outro lado contribuía para eliminar certas manifestações de origarquia e injustiças concelhiais. ${ }^{315}$ Ouvidor foi outro agente "forasteiro", era o representante do Reino. À ele cabia apurar como era ministrada a justiça e como corriam os serviços de administração e rendimentos monetários da câmara. Sua presença na vila significava a aprovação, a emenda ou a reprovação dos encaminhamentos legislativos e judiciários propostos pela municipalidade ${ }^{316}$.

As correições dos ouvidores são deveras elucidativas para o tipo de urbanização substanciada na colônia. Antônio Marques Cardosos, ouvidor geral do Piauí, relatou a carência daquele sertão pela inexistência de edifício próprio para casa de câmara e cadeia, por não poderem os moradores concorrer para esta obra ${ }^{317}$. Os edis solicitaram fundos à fazenda real para concretizar a construção da sede do concelho. Porém, receberam a reprovação do ouvidor designado:

(...) Nestes termos não se (...) mandar Vossa Magestade fazer da sua real fazenda dispensio algum, nem applicar rendimento para a ditta obra, porq' a custa dos moradores se ha de fazer ainda que muito importe, porquanto o official aceyta em pagamento gados, de que a mayor parte das dittas

\footnotetext{
${ }^{313}$ Eram eleitos dois juízes ordinários ou da terra, três ou quatro vereadores e o procurador, que nos conselhos menores, acumulavam as funções de tesoureiro. Os juízes ordinários exerciam alternadamente a presidência da câmara. $O$ juiz, os vereadores e o procurador formavam o corpo da câmara e diziam oficiais da câmara. In BARRETO, Paulo T. “Casas de Câmara e Cadeia”..., Opus cit., p. 115.

${ }^{314}$ PROJETO RESGATE. AHU_ACL_CU_018,Cx. 8, D. 450.

${ }^{315}$ BARRETO, Paulo T. "Casas de Câmara e Cadeia”..., Opus cit., p. 113.

${ }^{316}$ MARX, Murillo. Cidades no Brasil, em que termos"... Opus cit., p. 15.

${ }^{317}$ PROJETO RESGATE. AHU_ACL_CU_016, Cx. 1, D. 35.
} 
promessas consta, e como todos os possuem hão de concorrer com elles para esta obra q' he preciso $(\ldots)^{318}$

Antônio Marques Cardoso concluiu ser os interior do Piauí lugar onde (...) não se podem logo sobjeytar com o rigor da justiça porq' os que habitão se pode vir no conhecimento q' os não povoarão, se não ou por grande inópia (sic.), ou por fugirem da mesma justiça (...) $)^{319}$. Falta de justiça e observância às leis coloniais testemunhou o ouvidor da capitania da Paraíba, Pedro Monteiro de Macedo:

São tantas as desordens, violências e demandas e ainda mortes, que se tem experimentado nesta Capitania, respeito das terras que se tem dado aos descobridores, por que huns por conservar o que se lhe deu, outros por allargar o que possuem, todos por ignorarem os limites das suas terras, por nenhum estar demarcado, e continua a darem inquietação de queichas, de que pisão as sercas, com gente armada, e de que outros se armão para esse fim, e que muitos conservão vadios para que com a farsa tomem o que não lhes pertence $(\ldots)^{320}$

Outros velhos documentos são rigorosos em caracterizar o sertão como falto de justiça, sítio de facinorozos e desordeiros. Revelam a incostância de compromisso às normas estabelecidades pela Metrópole. Portanto, o interior do Nordeste foi um lugar ambíguo onde a obediência e a ilegalidade conviveram juntas, algumas vezes imparcialmente.

Peculiar foi a atitude demostrada por fazendeiros e religiosos diante do uso da terra e dos nativos como mão-de-obra escrava. Muito se fez para garantir a emancipação do indígena. Instalaram a Junta das Missões para vigiar os cumprimentos reais e eclesiásticos nos aldeamentos missioneiros. Homologaram cartas régias e alvarás em forma de lei, o tema eram específico: liberdade indígena. $\mathrm{O}$ foco de certas posturas reais centralizou na civilização do gentio, contudo, com ações incidentes no chão, no espaço urbano dos aglomerados sertanejos - tema que particularmente interessa esta dissertação.

\footnotetext{
318 PROJETO RESGATE. AHU_ACL_CU_016, Cx. 1, D. 35

${ }^{319}$ PROJETO RESGATE. AHU_ACL_CU_016, Cx. 1, D. 35

${ }^{320}$ PROJETO RESGATE. AHU_ACL_CU_014, Cx. 10, D. 800.
} 


\subsection{2 - As leis do Reino e os nativos do sertão.}

O debate sobre as leis acerca da liberdade dos índios e seus direitos como vassalos do rei ocuparam os especialistas desde os Oitocentos. João Francisco Lisboa, no século XIX, caracterizou esses discursos como "questões abrasadoras", preocupou-se em afirmar que $a$ dominação portuguesa, em relação aos índios, foi uma série nunca interrompia de hesitações e contradições até o ministério do marques de Pombal (...). Promulgava-se, revogava-se, transigia-se, ao sabor das paixões e interesses em voga, e quando enfim, se supunham as idéias assentadas por uma vez, recomeçava-se com novo ardor a teia interminável ${ }^{321}$. Spix e Martius atestaram a pouco eficiência dos códigos aplicados aos neófitos catequizados: exigese dos índios imediata renúncia a todos os seus hábitos, tendências e costumes nativos, e ainda mais respeito às leis e a uma religião que ele desconhece ${ }^{322}$.

No regimento levado pelo primeiro governador geral do Brasil (1548), Tomé de Souza, o parágrafo vinte e quatro determinou que a principal cousa que me moveo a mandar povoar o Brazil foy pera que a jente delas se convertese a nosa santa fee catholica (...) e não consentão que lhes seja feita opreção nem agravo allgu e fazendo-se-lhe lho fação corregir e emandar de maneira que fique satisfeitos $(. . .)^{323}$. Quase dois séculos depois, o Regimento dos Governadores da Capitania de Pernambuco persistiu na conversão dos nativos, só que dessa vez, além do simbólico tratamento de "filhos espirituais", a Coroa de Portugal os encarou, em tese, como vassalos, concedendo-lhes privilégios materiais: (...) repartindo-lhes terras conforme a ley, que tenho feito sobre a sua liberdade ${ }^{324}$. Concessões de pequenas faixas de terra consistiram nas mercês reais aos silvícolas, após longo período de aculturação, guerra e escravização.

A pequena gleba fundiária, convertida em uma légua quadrada, ficou restrita aos índios residentes em algum aldeamento missioneiro, catequizados enfim. Usavam-na para o sustento comunitário através da criação de gados e pequenas roças. Em 23 de novembro de 1700, as autoridades reforçaram a lei de doação da légua em quadra aplicada somente aos

\footnotetext{
321 JORNAL de Timon: apontamentos, notícias e observações para servirem à história do Maranhão. Lisboa, 1858. v. 3. Cap. 9. p. 85. Apud BELLOTO, Heloísa Liberalli. "Política indigenista no Brasil colonial (1570 1757). In Revista do IEB. São Paulo, IEB, 1988. p. 50.

322 SPIX, J.B Von; MARTIUS, C.P.F. Viagem pelo Brasil: 1817 - 1820. 3 v. São Paulo, Edusp, 1981. p. 248.

323 "1 Regimento que levou Thomé de Souza, Governador do Brazil”. In Revista do Instituto Histórico Geográfico Brasileiro. Tomo LXI. Rio de Janeiro, Imprensa Nacional, 1898. p. 48 - 49.

324 "Regimento dos Governadores da Capitania de Pernambuco". In Annaes da Bibliotheca Nacional. Vol. XXVIII. Ano 1906. Rio de Janeiro, Officina de Artes Graphicas da Bibliotheca Nacional, 1908. p. 121.
} 
Tapuyas, que vivem no Certam, e nam aos Cabocollos que vivem na Marinha ${ }^{325}$. O chão "presenteado" pretendia civilizar o gentio sertanejo, para viverem como homens sociáveis, $e$ meus vassalos ${ }^{326}$. Ademais, a terra seria doada às missões religiosas com mais de cem casais. Previa o alvará o desenvolvimento da redução, aumentando o número de vizinhos dividia-se o aldeamento em dois, outra légua em quadra seria doada à nova comunidade. Se este código reinol fosse seguido, paulatinamente o sertão nordestino apresentaria concentrações humanas mais adensadas no território, não existiriam tantos vácuos territoriais.

Ainda no que cerne o alvará sobredito (23.11.1700), a Metrópole advertiu que a posse efetiva da terra pertencia aos nativos, não aos religiosos catequistas, que possam ser logradouros das cazas, que tiverem $^{327}$. Entende-se por logradouro, segundo Raphael Blauteau, como campo público de uma villa, ou lugar, onde todos podem pastar o gado (...) he o chão, que cada qual tem diante das suas casas para sua esterqueira (sic.), neste sentido se diz, humas casas com suas pertenças ${ }^{328}$. Os espaços públicos, como o largo ou praça da missão e as ruas que viessem existir, formariam os logradouros do aldeamento. Incluiu a área comum para pastagem dos animais e plantio das roças. É interessante notar que, estas especificidades se assemelham ao rossio obrigatório às vilas coloniais, isto é, um patrimônio público para o usufruto comum dos habitantes e a serviço das necessidades de expansão física da vila ${ }^{329}$.

A légua em quadra era exclusividade dos autóctones, porém, os religiosos poderiam ver nesta concessão o progresso fundiário de sua ordem. Quando uma área doada estava supostamente esgotada pelo uso, os missionários requeriam outra parcela justificando carência alimentar dos seus neófitos. Na capitania do Rio Grande do Norte o padre jesuíta, Hieronimo de Souza, em 1726, solicitou outra légua de terra ao rei, Dom João V, porque seus índios...

(...) estão ordinariamente muy faltos de mantimentos por não terem terras em que plantar porq' as poucas reboladas de Mattos q' há nos tabuleyros (...) estão tão cansadas, e tão cheyas de formigueyros, que perdem todo o

\footnotetext{
325“Informação Geral da Capitania de Pernambuco". In Annaes da Bibliotheca Nacional do Rio de Janeiro...Opus cit., p. 384.

326 "Informação Geral da Capitania de Pernambuco". In Annaes da Bibliotheca Nacional do Rio de Janeiro...Opus cit., p. 384

327 "Informação Geral da Capitania de Pernambuco". In Annaes da Bibliotheca Nacional do Rio de Janeiro...Opus cit., p. 394.

${ }^{328}$ BLUTEAU, Raphael, S. J. Vocaculario português, e latino...Coimbra, Real Collegio das Artes da Companhia de Jesus, 1712 - 9. Disponível em http://www.ieb.usp.br. Acesso em 16.10.2011.

${ }^{329}$ MARX, Murillo. Cidades no Brasil, terra..., Opus cit., p. 68.
} 
trabalho (...) lhe mande demarcar huã legoa no lugar chamado Cidade dos Veados, visto ser terra despovoada $(\ldots)^{330}$

Terras cansadas e improdutivas foram a base para pedir outra légua em quadra para os aldeados na missão jesuítica da Ibiapaba.

Dizem os índios da aldea da Serra da Ibyapaba da Capitania do Ceará Grande q' por elles serem mtos., e cada vês se lhes agregarem mais tapuyas, já oje passam de quatrocentos, e por constarem as terras, q' lhes foram demarcadas de mtos. dias, e quebradas inuteism e as poucas q' foram capazes de prontas já estarem cançada; nam acham já aonde possam prantar seus mantimentos, de q' naçe haver na aldeã huã continua fome, e se nao fora a charidade de seus Padres missionários, q' com algum gado, q' criao para seus sustento acodem os mais necessitados $(\ldots)^{331}$

Entretanto, para chegarem ao merecimento do chão, o gentio sertanejo sofreu descimentos, resgates, abusos dos fazendeiros de gado e sua escravização. Foram alvos de leis indefinidas, oscilantes e ambíguas. Para Heloísa Bellotto, a Coroa ocupou o pólo da apropriação dos nativos, já que interferia por meio de suas prerrogativas de empregador de mão-de-obra para edificações públicas ${ }^{332}$. Acima de tudo, a relativa liberdade indígena, fundamentada por leis, pode ser entendida como ação para melhor servir às estratégias colonizadoras, índios domesticados prontos para a proteção dos domínios ultramarinos em serviços militares e sociais ${ }^{333}$.

José Oscar Beozzo opina que o maior documento de liberdade dos catecúmenos, referência para futuras posturas, é a lei de 30 de julho de 1609, pois consagra o princípio de que em nenhum caso se podia escravizar os silvícolas, os quais todos serão tratados $e$ havidos por pessoas livres, como são ${ }^{334}$. A lei caducou rapidamente, sendo renovada pela de 10 de setembro de 1611, declarando todos os Gentios das ditas partes do Brazil por livres, conforme o direyto, e seu nascimento natural, assy os que já forem batizados, e reduzidos a

\footnotetext{
${ }^{330}$ PROJETO RESGATE. AHU_ACL_CU_018, Cx. 2, D. 116.

331 PROJETO RESGATE. AHU_ACL_CU_CEARÁ, Cx. 1, D. 65.

${ }^{332}$ BELLOTO, Heloísa Liberalli. "Política indigenista no Brasil colonial (1570 - 1757)..., Opus cit., p. 52.

${ }^{333}$ BEOZZO, José Oscar. Leis e regimentos das missoes: política indigenista no Brasil. São Paulo, Ed. Loyola, 1983. p. 28.

${ }^{334}$ Idem. Ibidem.
} 
nossa santa feé catholica, como os que inda viverem como Gentios conforme os seus ritos $(\ldots)^{335}$.

Para serem livres, segundo as normas de 1611, os nativos seriam inspecionados por um capitão da Aldeia, pessoa secular cazado e de boa vida, e costumes que lhes parecessem mais convinientes (...) de boa geração e abastardo de bens (...). ${ }^{336}$ Seriam catequizados pela Companhia de Jesus, ou outra ordem, em reduções repartidas pelo governador com até trezentos cazaes, pouco mais ou menos, limitandolhe sitio conviniente donde possãoa seo modo (...) distantes dos Engenhos, e matas de pao Brazil, que nao possão prejudicar a huã couza (...) e assy se repartirá Lugares para nelles lavrarem, e Cultivarem (...) ${ }^{337}$. O elemento arquitetônico destacado nessas missões seria a sua igreja e nella hum cura ou Vigário (...) os quaes serão apresentados por my ou pello Governador do dito Estado do Brazil em meu nome $(\ldots)^{338}$. É interessante destacar que, no final dessa lei, foram impostas as penas, segundo as Ordenações do Reino (livro segundo, titulo quarenta e quatro), àqueles que continuassem a cativar os índios: (...) vinte cruzados, e mais cem réis de custos se forem impedidos os despachos $(\ldots)^{339}$.

Infelizmente as leis sobreditas não foram cumpridas pelas autoridades coloniais, nem pelos religosos detentores dos poderes espirituais e temporais dos silvícolas. Para Heloísa Bellotto a verdade é que independentemente das variações das leis os religiosos utilizavam realmente a mão-de-obra agrícola de seus catecúmenos ${ }^{340}$. Além do mais, os ânimos dos fazendeiros de gado esquentaram, poucos foram aqueles que obedeceram os códigos reais no que tange a liberdade dos índios. Na opinião de Capistrano de Abreu a negligência às leis se fez pela falta de gente honesta e bastante enérgica para fazê-la respeitada ${ }^{341}$.

Em resposta à contradição legislativa e falta de compromisso dos colonos, a Metrópole emitiu o alvará de 01.04.1680 onde proibía a escravidão por guerra justa. Ocorrendo o conflito, o indígena rebelde tornaria cativo. Desnecessários seriam os

\footnotetext{
335 "LEI de 10 de setembro de 1611". In Revista do Instituto do Ceará. Tomo 77. Fortaleza, Editora do Instituto do Ceará, 1963. p. 325.

336 "LEI de 10 de setembro de 1611". In Revista do Instituto do Ceará...Opus cit., p. 326.

${ }^{337}$ LEI de 10 de setembro de 1611”. In Revista do Instituto do Ceará...Opus cit., p. 326.

338 "LEI de 10 de setembro de 1611". In Revista do Instituto do Ceará. Tomo 77. Fortaleza, Editora do Instituto do Ceará, 1963. p. 327.

339 “ORDENAÇÕES Filipinas - Livro II, Título XLIV: Que não se entenda derrogada pelo Rei Ordenação, se da substância dela não fizer expressa menção". Disponível em http://www.uc.pt/ihti/proj/filipinas/ordenacoes.htm. Acesso em 16/10/2011.

${ }^{340}$ BELLOTO, Heloísa Liberalli. "Política indigenista no Brasil colonial (1570 - 1757)..., Opus cit., p. 54.

${ }^{341}$ ABREU, Capistrano de. Capítulos de história colonial, 1500 - 1800. 7 ed. rev. São Paulo, Publifolha, 2000. p. 147.
} 
descimentos dos silvícolas, pois a lei garantia a conservação dos Tapuias em aldeamentos no interior. Novamente, a liberdade é assinalda como conversão dos bárbaros costumes aos hábitos da cristandade. ${ }^{342}$

As tensões surgidas entre missionários e colonizadores, fizeram a Coroa criar o Regimento das Missões de 1686, formulado com base nas doutrinas do padre Antônio Vieira e nas experiências missionárias do século $\mathrm{XVII}^{343}$. Tratava de questões basilares sobre a liberdade dos índios e uso dos nativos nas reduções. Os índios seriam livres no temporal, porém obrigados a servir e trabalhar aos administradores da aldeia. Receberiam um salário por sua jornada de trabalho, depositados na mão do pároco ${ }^{344}$ impedindo o desvirtuamento dos neófitos, principalmente, pelo uso do pecúlio na compra de aguardente. O Regimento das Missões, como regulamento indigenista, perdurará até 1758 quando a política pombalina legisla o Diretório dos Índios, dispositivo legal que logo será dissertado.

Em meados do século XVIII um novo prisma incidiu na questão da liberdade indígena. A bula de Benedicto XIV de 1741, dirigida a todos os bispos do Brasil, vetou a prisão dos silvícolas. Entronizado Dom José I, emerge no panorama ultramarino as propostas iluministas do marquês de Pombal, donde se advogam o sair da humanidade da escuridão intelectual para a luz do $\operatorname{saber}^{345}$. A catequese religiosa foi transferida para a civilização através do comércio, agricultura e convívio com os portugueses. Civilizar os índios siginificou, naquele momento histórico, ter uma vida espiritual e temporal idêntica aos brancos, vestir-se como tais e impor valores portugueses: vida sedentária, ambição, acúmulos de bens e vida unifamiliar ${ }^{346}$.

As demarcações das fronteiras entre as duas Coroas ibéricas, seguindo os acordos dos Tratados de Limites, estiveram no bojo da locação de Francisco Xavier de Mendonça Furtado ao cargo de governador geral do Brasil. Chegando em 24 de setembro de 1751, Mendonça Furtado testemunhou a inaptidão dos autóctones aos conceitos de economia e

\footnotetext{
342 “CÂMARA de Aquirás: ordens régias, alvarás, provisões, regimentos, etc. (1700 - 1801). In Revista do Instituto do Ceará. Tomo LXXXII. Fortaleza, 1964. p. 187.

343 ALMEIDA, Rita Heloísa. O Diretório dos Índios: um projeto de civilização no Brasil do século XVIII. Brasília, Editora da UnB, 1997. p. 162.

${ }^{344}$ BELLOTO, Heloísa Liberalli. "Política indigenista no Brasil colonial (1570 - 1757)..., Opus cit., p. 57.

345 ARAÚJO, Renata. "A razão na selva: Pombal e a reforma urbana da Amazônia”. In Revista Camões. $\mathrm{n}^{\circ}$ 15/16. Lisboa, Instituto Camões, 2003. p. 157.

${ }^{346}$ FLEXOR, Maria Helena Ochi. "Cidades e vilas pombalinas no Brasil do século XVIII”. In Universo urbanístico português (1415 - 1822). Lisboa, Comissão Nacional para as comemorações dos Descobrimentos Portugueses, 1998. p. 264.
} 
mercado $^{347}$. Viu a conversão pela religião como bloqueio ao desenvolvimento social dos nativos. Para ele, civilizar seria adotar uma sociedade laica, civil em sua essência. De suas recomendações ao rei e, em especial ao seu irmão - Sebastião de Carvalho e Melo -, resultaram em duas cartas régias em forma de lei, 06 e 07 de junho de 1755, abolindo a administração temporal dos missionários nos aldeamentos, proclamando a emancipação total dos gentios ${ }^{348}$.

Nos quaes ficarão incorporados os referidos Índios sem distincção, ou exepção alguma, para gozarem de todas as honras, privilégios, e liberdades, de que os meus Vassallos gozão actualmente conforme as suas respectivas graduaçoens, e cabedaes ${ }^{349}$. Assim sublinhou o primeiro parágrafo da lei de 06 de junho de 1755 sobre a nova condição dos índios da Amazônia. Tirava-se o poder temporal dos missionários, tranferindo-o para um governador ou principal de justiça. Os índios receberiam um jornal por seus trabalhos, convertidos em salários pagos em pano. A sujeição do indígena se daria somente às leis coloniais e ao monarca, à semelhança dos portugueses.

Primeiramente, estas cosiderações legais foram aplicadas no Estado do Grão-Pará e Maranhão. Em 08 de maio de 1758 o Conselho Ultramarino alargou essa lei ao Estado do Brasil, estendia-se aos Tapuias do Nordeste: (...) ordeno que as suas disposições estenda aos índios que habitam os meus domínios em todo aquele continente sem restrição alguma, e a todos os seus bens assim de raiz como semoventes e moveis e na sua lavoura e comércio 350 (...). O ápice das reformas pombalinas, cessando a ação missionária no governo temporal dos aldeamentos, aconteceu com a aprovação e aplicação do Diretório dos Índios.

\subsection{3 - O "Directório dos Índios" e a emancipação dos Tapuias}

Composto de noventa e cinco parágrafos, o Directório dos Índios buscou emancipar os autóctones brasileiros inciadas pelas leis de 06 e 07 de junho de 1755. Para conseguir isso, o governo tirou definitivamente a interferência eclesiástica na condução dos indígenas. Como

\footnotetext{
${ }^{347}$ RODRIGUES, Isabel Vieira. “A política de Francisco Xavier de Mendonça Furtado no Norte do Brasil (1751 - 1759)”. In Revista Oceanos. no 40 (out/dez). Lisboa, Comissão Nacional para as comemorações dos descobrimentos Portugueses, 1999. p. 107.

${ }^{348}$ ABREU, Capistrano de. Capítulos de história colonial, 1500 - 1800..., Opus cit., p. 188.

${ }^{349}$ LEY, porque V. Mag. ha por bem restituir aos Índios do Grão-Pará, e Maranhão a liberdade das suas pessoas, e bens, e commercio - na forma que nella se declara. Lisboa, 1755. Disponível em http://www.bnportugal.pt. Acesso em 18.11.2010.

350 "CÂMARA de Aquirás: ordens régias, alvarás, provisões, regimentos, etc. $(1700$ - 1801)..., Opus cit., p. 183.
} 
bem disse Heloísa Bellotto o Diretório pesou mais o problema da aversão ao jesuíta do que os interesses propriamente indigena ${ }^{351}$.

A civilização foi tratada como abandono à rusticidade e ignorância em que viviam. Para conseguir esse ideal, seriam necessárias algumas mudanças nos hábitos culturais dos índios, como por exemplo, a fabricação de residências unifamiliares em oposição às malocas com muitas famílias habitanto o mesmo espaço.

Incapacitados de auto-gestão, o primeiro parágrafo do Diretório nomeia um Director (...) dotado de bons costumes, zelo, prudência, verdade, sciencia da língua, e de todo mos mais requisitos necessários para poder dirigir com acerto os referidos Índios debaixo das ordens, e determinações $(\ldots)^{352}$. O diretor administraria os núcleos de índios de forma diretiva, nunca coativa. Eram representações únicas do poder nas povoações criadas, muitos deles desvirtuaram sua autoridade agindo tiranicamente sob os seus subjugados ${ }^{353}$.

Em cada lugar seria encaminhado um pároco. À este competia somente o exercício espiritual sem interferir na civilização dos nativos (§ 4). Verificou-se nos aldeamentos missioneiros do sertão nordestino a mudança de missionários para curas do clero secular, do Hábito de São Pedro. Entre alguns destes estão as novas vilas do interior cearense de Monte Mor o Novo da América, Vila Real do Crato e Vila Viçosa.

O parágrafo doze ordenou a edificação de casas unifamiliares, segundo os moldes portugueses e civis. As habitações indígenas tem concorrido muito a indecência, com que se trataõ em suas casas, assistindo diversas Famílias em huma só, na qual vivem como brutos $^{354}$. Era da responsabilidade dos diretores desterrar das Povoaçoens este prejudicialissimo abuso, persuadindo aos Indios que fabriquem as suas casas á imitação dos Brancos; fazendo nellas diversos repartimentos, onde vivendo em Família com separação, possaõ guardar, como Racionaes, as Leys da honestidade, e policia. ${ }^{355}$

\footnotetext{
${ }^{351}$ BELLOTO, Heloísa Liberalli. "Política indigenista no Brasil colonial (1570 - 1757)..., Opus cit., p. 59.

352 "DIRECTORIO, que se deve observar nas Povoaçoens dos Indios do Para, e Maranhaõ, em quanto Sua Magestade naõ mandar o contrario”. In ALMEIDA, Rita Heloisa. O Diretório dos Indios: um projeto de civilização no Brasil do século XVIII. Brasília, Editora da UnB, 1997.

${ }^{353}$ ALMEIDA, Rita Heloísa. O Diretório dos Índios: um projeto de civilização no Brasil do século XVIII. Brasília, Editora da UnB, 1997. p. 168.

354 "DIRECTORIO, que se deve observar nas Povoaçoens dos Indios do Para, e Maranhaõ, em quanto Sua Magestade naõ mandar o contrario”. In ALMEIDA, Rita Heloisa. O Diretório dos Indios..., Opus cit., §12.

${ }^{355}$ Idem. Ibidem.
} 
A agricultura e o comércio foram valorados no Diretório como práticas de civilidade (§ 17). Cuidariam os diretores de examinar a produtividade da terra que possuem os índios para nellas fazerem plantaçoens, $e$ as lavouras ${ }^{356}$. Não possuindo chão para o sustento da comunidade, o tutor remeteria carta ao governador solicitanto a parcela de terra necessária, situadas no continente das mesmas Povoaçoens ${ }^{357}$, em terras adjascentes ao assentamento.

O Diretório dos Índios não dispunha de modo específico sobre a forma urbana a ser adotada nas novas vilas e lugares de índios. Entretanto, possuía algumas implicações quanto à sua configuração. O título 74 ordenou ao diretor que ao chegarem às suas respectivas Povoaçoens, appliquem logo todas as providencias para que nellas se estabeleçã̃ casas de Câmera, e Cadêa, cuidando muito em que estas sejã̃ erigidas com toda a segurança, e aquellas com a possível grandeza. Casa de câmara e cadeia realçou a diferenciação dos novos núcleos criados com os antigos aldeamentos missioneiros. A igreja nos aldeamentos compunha o espaço dos diversos aspectos da vivência social dos índios: lugar de ensino, doutrinação e adesão à conduta colonial. Nos aglomerados criados à sombra do Diretório, a igreja dividiu o espaço com a municipalidade. Hierarquicamente estavam no mesmo patamar.

Em questões de densidade populacional, discriminou a constituição que o número ideal de habitantes seriam de 150 ou mais ( $\$ 77$ ), acompanha, portanto, as posturas dos Regimento das Missões. Segundo Rita de Almeida, o aumento das populações urbanas é considerado um fator introdutório do conceito de civilidade (...) Há neste dispositivo a preocupação com um aspecto: a condição dos índios como indivíduos, civis, ponderando-se, por exemplo, não ser conveniente que eles vivam em povoações pequenas ${ }^{358}$. Na Real Vila do Crato, elevada em 1764, já estão agregados nesta dita Villa a amostra geral q' a todos passou na qual apparecerão 208 homens $^{359}$. Idem para a vila Monte - Mor o Novo da América com 154 moradas de casas ${ }^{360}$.

Renata Araújo estabelece outro papel Diretório dos Índios. Seu discurso era destinado aos brancos. Eram eles que precisavam ser convencidos da igualdade, eram eles

\footnotetext{
356 "DIRECTORIO, que se deve observar nas Povoaçoens dos Indios do Para, e Maranhaõ, em quanto Sua Magestade naõ mandar o contrario”. In ALMEIDA, Rita Heloisa. O Diretório dos Indios..., Opus cit., §19.

357 Idem. Ibidem.

${ }^{358}$ ALMEIDA, Rita Heloísa. O Diretório dos Índios: um projeto de civilização no Brasil do século XVIII. Brasília, Editora da UnB, 1997. p. 217.

359 "CREAÇÃO da Villa do Crato, em 1764, 14 de Junho". In FEITOSA, Carlos. As gentes dos Inhamuns na criação da Real Vila do Crato. p. 21.

360 "REGISTRO dos Autos de erecção da real villa de Monte - mor o Novo da América, na capitania do Ceará Grande”. In Revista do Instituto do Ceará. Fortaleza, 1891. p. 267.
} 
que deveriam mudar os hábitos. Para tal instaurou-se uma política de incentivo aos casamentos mistos, insistindo na eliminação dos preconceitos e discriminações sofridos pelos indígenas $^{361}$. Seguindo o pressuposto da especialista, o parágrafo 88 mencionou:

(88) Pelo qye recommendo aos Directores, que appliquem hum incessante cuidado em facilitar, e promover pela sua parte os matrimônios entre os Brancos, e os Indios, para que por meio deste sagrado vinculo se acabe de extinguir totalmente aquella odiosissima distinçaõ (poligamia), que as Naçoens mais polidas do Mundo abominaraõ sempre, como inimigo commum do seu verdadeiro, e fundamental estabelecimento ${ }^{362}$.

A partir de 1758, ano de homologação do Diretório, observa-se a ascensão no número de vilas, freguesias e lugares de índios fundados no sertão nordestino. Na capitania de São José do Piauí, desmembrada do Maranhão, foram criadas três novas povoações de silvícolas seguindo os critérios do Diretório: São Gonçalo do Amarante, São João de Sende e Nossa Senhora das Mercês de Jaicós. Na povoação das Mercês o diretor reconduziu vários (...) Índios, que se achavão fora da Povoação e ajustando com os outros seus descedentes espalhados por aquella Ribeira do Itahim, o hiremse estabelecer na mesma povoação athé o principio do prezente mez de Setembro do prezente anno, ficando todos dispostos sem a menor contradição ${ }^{363}$. O governador do Piauí, João Pereira Caldas, em carta destinada a Francisco Xavier de Mendonça Furtado, destacou a observância das Ordens de Sua Magestade que há no Directorio (... $)^{364}$ [grifo nosso].

No sertão da capitania de Pernambuco, o governador Luís Diogo Lopes da Silva encaminhou Manuel de Gouveia Álvares, ouvidor geral da comarca das Alagoas para inspecionar as reduções religiosas do interior da capitania, erigindo-as em vilas àquelas que cumprissem os parágrafos do Diretório dos Índios. Daquelas situadas à margem esquerda do rio São Francisco foram elevadas à freguesia, ou lugar de índios, Tacaratú (1761) e Águas Belas (1762). A missão de Ararobá, dos congregados de são Felipe Nery, apresentou os requisitos mínimos para sua elevação à vila, fato ocorrido em 1762:

\footnotetext{
${ }^{361}$ ARAÚJO, Renata. “A razão na selva: Pombal e a reforma urbana da Amazônia”. In Revista Camões. $\mathrm{n}^{\circ}$ 15/16. Lisboa, Instituto Camões, 2003. p. 161.

362 "DIRECTORIO, que se deve observar nas Povoaçoens dos Indios do Para, e Maranhaõ, em quanto Sua Magestade naõ mandar o contrario". In ALMEIDA, Rita Heloisa. O Diretório dos Indios..., Opus cit., $§ 88$.

363 PROJETO RESGATE. AHU_ACL_CU_016, Cx. 10, D. 589.

${ }^{364}$ PROJETO RESGATE. AHU_ACL_CU_016, Cx. 10, D. 589.
} 
(...) e como pela relação dos moradores que atualmente se acham habitando esta povoação antigamente chamada Ararobá, e depois Monte Alegre, a qual agora fica sendo denominada povoação de Cimbres, para evitar a equivocação de outras povoações do mesmo antecedente nome, e constar ter o número de casais e moradores que prescrevem as ordens régias para que da dita povoação se possa criar uma vila $(. . .)^{365}$ [grifo nosso].

O Diretório, como plano político e social para a colônia, buscou uniformizar as povoações e vilas criadas. Em alguns casos a tarefa parecia mais difícil. Na missão da Ibiapaba, localizada na fronteira entre as capitanias do Ceará e Piauí, após a extradição dos jesuítas daquele aldeamento, notou o governador da capitania de Pernambuco, Luís Diogo Lobo da Silva:

(...) para conferir o meyo, com q' mais prompta e cabalmente se havião executar os q' nos era recíprocas, e relativas aos péssimos estabelecimentos das novas Villas, e lugares, q' a heróica constancia de Vossa Magestade Fidelíssima manda erigir das antigas Aldeyas, restituindo aos seus habitadores à liberdade e izenção de q' tanto carecião e facilitando-lhes o passo a sahirem das trevas da ignorância em q' erão conservados por políticos particulares dos mesmos destinados a destrui-las ${ }^{366}$.

A ojeriza aos padres da Companhia de Jesus, desmerecendo sua catequese e ação política da redução da Serra da Ibiapaba, pode ser comprovada no mesmo documento do governador de Pernambuco, enviado a Sebastião de Carvalho e Melo. Obedecer o Diretório e nomear um diretor parecia a saída para a desejada civilização dos moradores indígenas:

Todo o referido ficaria inútil à vista da notória barbaridade, em q' tem sido conservados estes mizeraveis, se nao lhes dessem pessoas, de bons costumes q' lhes servissem de Directores pelo tempo necessário a entrarem na intelligencia perciza a se regularem sem carencia de quem os dirija elles evite os enganos a q' a sua rusticidade os habilita: a escolha destes foy para mim o ponto de mayor trabalho, poes em hum para, em q' se florece a lascidão, e dezordem, e predomina o vicio he muito difícil achar sujeitos com as predictas qualidades para com ellas nao so seguirem o q' se lhes

\footnotetext{
${ }^{365}$ NEVES, André Lemoine. Estudo morfológico de cidades do agreste pernambucano - séculos XVIII e XIX. Dissertação de mestrado. Recife, UFPE/CAC, 2003. p. 67.

${ }^{366}$ PROJETO RESGATE. AHU_ACL_CU_CEARÁ, Cx. 7, D. 464.
} 
ordena, mas com o seo exemplo persuadirem a mudança de costumes, e introdução da civilidade de q' nos Índios se procura ${ }^{367}$.

Demarcando o rossio da nova vila, os neófitos construiríam suas moradias dentro dos padrões de uniformidade e harmonia, pregados pela ilustração pombalina. Além do mais, em vila Viçosa novamente são cumpridos os parágrafos 82 - 86 do Diretório dos Índios:

No referido Dirctorio, como V. Exa. verá reger-lhes a repartição das terras q' se devia fazer aos moradores, attendendo os gradualmente, segundo as suas distincoens, numero de filho, e famílias, para o q' me vali das lembranças do q' se havia practicado na Ilha de Sta. Catarina, quando se povoou $(. . .)^{368}$.

Os conceitos de libertação e humanismo da política do marquês de Pombal, baseados na filosofia iluminista francesa, foram postos em prática no sertão nordestino pelos governadores, ouvidores e demais autoridades coloniais. Entretanto, com o correr das décadas, uma outra realidade na sociedade sertaneja pode ser testemunhada. Práticas legais foram usurpadas e igonoradas. Fato observado no lugar dos índios de São Gonçalo do Amarante (PI) pelos viajantes germânicos, von Spix e von Martius. Eles foram contudentes ao relembrar que, a imposição de costumes e leis avessos ao indígena, resultou uma vida ambígua, tristissima. Só por meio de grande força moral se poderia esperar qualquer mudança favorável nesses desfavorecidos filhos das selvas (... $)^{369}$.

Entronizada Dona Maria I, o Diretório dos Índios foi abolido em 1798 por intermédio de carta régia de doze de maio do mesmo ano. Tal documento oficial apresentou uma proposta de civilização indígena com pretensão inovadora, contudo, poucas alterações foram formuladas, a base continuou sendo a legislação pombalina anterior ${ }^{370}$.

As leis emitidas durante o reinado de Dom José I provocaram uma incipiente laicização do espaço urbano brasileiro. Reforçaram a rede de vilas no sertão nordestino, buscando o controle do território e fixação do sertanejo em núcleos urbanos. Visualizar a evolução das vilas no interior do Nordeste dentro do âmbito econômico : pecuária extensiva; político: reinado dos monarcas lusitados; e eclesiástico: ação da Igreja Católica

\footnotetext{
${ }^{367}$ PROJETO RESGATE. AHU_ACL_CU_CEARÁ, Cx. 7, D. $464 .$.

368 PROJETO RESGATE. AHU_ACL_CU_CEARÁ, Cx. 7, D. 464.

${ }^{369}$ SPIX, J.B Von; MARTIUS, C.P.F. Viagem pelo Brasil..., Opus cit., p. 248.

${ }^{370}$ ALMEIDA, Rita Heloísa de. "A carta régia de 12 de maio de 1798 e outros documentos sobre índios no códice 807". In Revista do Instituto Histórico e Geográfico Brasileiro. no 416 (jul/set). Rio de Janeiro, IHGB, 2002. p. 171.
} 
umbilicalmente ligada ao Estado português será a proposta do próximo tópico. Para auxiliar nossas constatações, foram elaborados mapas seguindo uma criteriosa análise em fontes primárias manuscritas e impressas. 


\subsection{Fixar, povoar: evolução da rede urbana do sertão nordestino}

Quando em 1956 Aroldo de Azevedo lança o seu estudo pioneiro - Vilas e cidades do Brasil colonial ${ }^{371}$ - foram indicados, através de tabelas e mapas, o panorama geral da urbanização brasileira. $\mathrm{O}$ autor comprovou a hierarquização da rede urbana de vilas e cidades coloniais por balancear índices populacionais, econômicos e de localização dos aglomerados humanos. Analisando as informações publicadas por Azevedo, concernentes ao século XVIII, percebemos a não inclusão de vilas do sertão nordestino nas tabelas e cartografias do opúsculo, talvez isso tenha ocorrido devido à carência em obter fontes primárias para complementar os dados.

Na década de sessenta do século passado, Nestor Goulart Reis Filho incrementou a pesquisa da rede urbana colonial brasileira com outro olhar, aquele voltado à materialização das relações sociais no espaço urbano e arquitetônico, apoiado na legislação portuguesa. Em Contribução ao estudo da evolução urbana do Brail: $1500-1720^{372}$, o olhar do especialista é no "saber fazer cidades" como fenômeno empírico, mais que teórico. O uso de um acervo de imagens coloniais ressalta o conceito de urbanização: que permite trabalhar com todas as escalas de tempo e de espaço, explicar as relações entre essas escalas de organização social no território, explicar as relações entre a dinâmica do sistema urbano com a dinâmica do espaço intraurbanos ${ }^{373}$.

Murillo Marx interpretou nossos núcleos urbanos a partir da união entre Estado x Igreja, aspecto fundamental e institucional para compreender a evolução de nossa rede povoações. Para ele, o clero e constituições pias (Constituições Primeyras do Arcebispado da Bahia) impuseram recomemdações eclesiásticas com reflexos na paisagem urbana: a Coroa na prática delegava à Mitra o desenvolvimento físico de nossos arraiais, vilas e cidades, a confecção de sua paisagem familiar ${ }^{374}$. Outro aspecto basilar tratado por Marx se refere à progressiva laicização sofrida pelos espaços públicos dos núcleos de origem colonial, dos

\footnotetext{
${ }^{371}$ AZEVEDO, Aroldo de. Vilas e cidades do Brasil colonial. Ensaio de geografia urbana. Boletim no 208. Geografia no 11. São Paulo, FFLCH, 1956. 96 p.

372 REIS FILHO, Nestor Goulart. Contribuição ao estudo da evolução urbana do Brasil (1500/1720). 2 ed. rev. e ampl. São Paulo, Pini, 2000. 239 p.

${ }^{373}$ REIS FILHO, Nestor Goulart. Contribuição ao estudo da evolução urbana...Opus cit., p. 201.

${ }^{374}$ MARX, Murillo. Cidades no Brasil, terra de quem? São Paulo, Edusp, 1991. p. 12.
} 
sagrados adros e percursos de procissões à completa profanização dos logradouros citadinos $^{375}$.

Para entender a estruturação da rede urbana do sertão nordestino, entre os séculos XVII e XIX, a leitura dos estudiosos supracitados solidificou nossas conceituações. Ademais, o apoio em estudos econômicos, políticos, religiosos, antropológicos, multidisciplinaridade de fato, conferiu o mote substancial desse tópico, e da dissertação em sua totalidade. Seríamos incapazes de fundamentar esta pesquisa sem agregar evidências historiográficas e da geografia histórica brasileira. Como bem assinalou Bernard Lepetit, todas as ciências sociais participam do mesmo tipo de conhecimento e que entre elas as inter-relações são múltiplas, $e$ os limites, jamais estanques ${ }^{376}$.

A definição de Milton Santos para rede foi outro ponto de partida para entendermos os nós e o quebra-cabeças da urbanização do sertão. Segundo o geógrafo, as redes são formadas por troços, instalados em diversos momentos, diferentemente datados, muitos dos quais já não estão presentes na configuração atual e cuja substituição no território também se deu em momentos diversos ${ }^{377}$. A hierarquia da rede, na opinião de Santos, está entrelaçada à questão de poder, a divisão territorial do trabalho resultante atribui a alguns atores um papel privilegiado na organização do espaço ${ }^{378}$.

$\mathrm{Na}$ trama urbana do interior do Nordeste, alguns aglomerados foram cabeças do território, os quais dominaram o cenário político-econômico e religioso do sertão. As vilas da Mocha (PI), Jacobina (BA), Barra (BA), Rio de Contas (BA), Icó (CE) e Crato (CE) são alguns exemplos que se sobressaíram pelo seu "poder" diante da rede urbana em formação.

Não nos restringimos ao espaço sertanejo, porque sabemos que na formação de um território estão niveladas variadas escalas. Estabelecemos como primordiais as escalas local, regional e ultramarina, assim podemos explicar sobre diversos ângulos a realidade sertaneja. O elemento que alavanca essa análise múltipla é o mercado interno do sertão, essencialmente criado pelo gado através da pecuária extensiva. Sobretudo, as posturas legais da Metrópole,

\footnotetext{
${ }^{375}$ MARX, Murillo. Nosso chão: do sagrado ao profano. São Paulo, Edusp, 1988. 219 p.

${ }^{376}$ LEPETIT, Bernard. Por uma nova história urbana. Seleção de textos, revisão critica e apresentação Heliana Angotti Salgueiro. São Paulo, Edusp, 2001. p. 35.

${ }^{377}$ SANTOS, Milton. A natureza do espaço: técnica e tempo, razão e emoção. 4. ed. 5. reimp. São Paulo, Edusp, 2009. p. 263.

${ }^{378}$ SANTOS, Milton. A natureza do espaço...Opus cit., p. 270.
} 
unida com a Igreja tridentina, condicionaram a evolução urbana do sertão nordestino, como de outras áreas dos domínios portugueses.

A preocupação da Metrópole, após a instituição do governo geral, ensejou proteger suas posses. O parcelamento da colônia em capitanias hereditárias aponta as precauções da Coroa em preservar suas terras. Ademais, a localização dos primeiros aglomerados humanos, ao longo da costa, concretiza a consideração de Portugal em defender seus domínios. Surgem as vilas litorâneas, as sentinelas do território luso-brasileiro.

Até 1706, as vilas eram essencialmente litorâneas, meio de facilitar as transações mercantis entre Lisboa e a sua colônia americana. A necessidade de defesa de piratas e de outras potências ultramarinas recorria precisamente esta situação ${ }^{379}$. São Luiz (MA), Aquirás (CE), Natal (RN), Filipéia (PB), Igarassú (PE), Olinda (PE), Porto Calvo (AL), Salvador (BA), Ilhéus (BA) e Porto Seguro (BA) foram alguns centros urbanos que materializaram esse partido voltado à defesa e comunicação marítima com o Reino [mapa 15]. Nítido é o desequilíbrio geográfico, poucas povoações costeiras, concentradas das capitanias da Bahia de Todos os santos e Pernambuco ${ }^{380}$, em relação ao gigantesco território do hinterland do Nordeste, composto de aldeamentos missioneiros e pequenas freguesias dispersas.

Nos Quinhentos e Seiscentos há uma continuidade em criar vilas no litoral ou em suas cercanias. O açúcar produzido no Recôncavo Baiano e zona da mata pernambucana uniu o litoral ao seu entorno imediato. A cana - de - açúcar foi semeada onde houvesse solo proprício para sua cultura. Esse paradigma mudou com as investidas de povoamento atreladas à criação de gado e à corrida alucinada em busca de ouro e prata.

Somente nos Setecentos são criadas as primeiras vilas interioranas subsidiadas, necessariamente, pela criação de gado. Carne e couro surpriram as necessiadades alimentares e de vestuário de outras capitanias da colônia. A importância da pecuária sertaneja, como comércio destinado ao abastecimento mercantil do Brasil e de couro para Metrópole, foi assinalada pelo governador da capitania de Pernambuco, em 1749:

Levão deste Porto (Recife) assucar, solla vermelha, algudão, madeiras, e dinheiro em moeda.

\footnotetext{
${ }^{379}$ MARX, Murillo. Cidade brasileira. São Paulo, Edusp - Melhoramentos, 1980. p. 19.

${ }^{380}$ MARX, Murillo. Cidade brasileira...Opus cit., p. 12.
} 
Do Certão do Pays passão aos Governos da Bahia e Minas por negocio Grandes comboyos de Gado de gado vaccum, e cavallar que reduzem a dinheiro. Para Liboa, e Cidade do Porto, adonde o negócio é mayor dão sahydas aos assucares, melaço, solla vermelha e branca, atanados, couros em cabello (...) Os Gêneros Especiais do Pays para o negócio são: assucar, Gado vaccum, e cavallar, Tabacos e madeiras. ${ }^{381}$

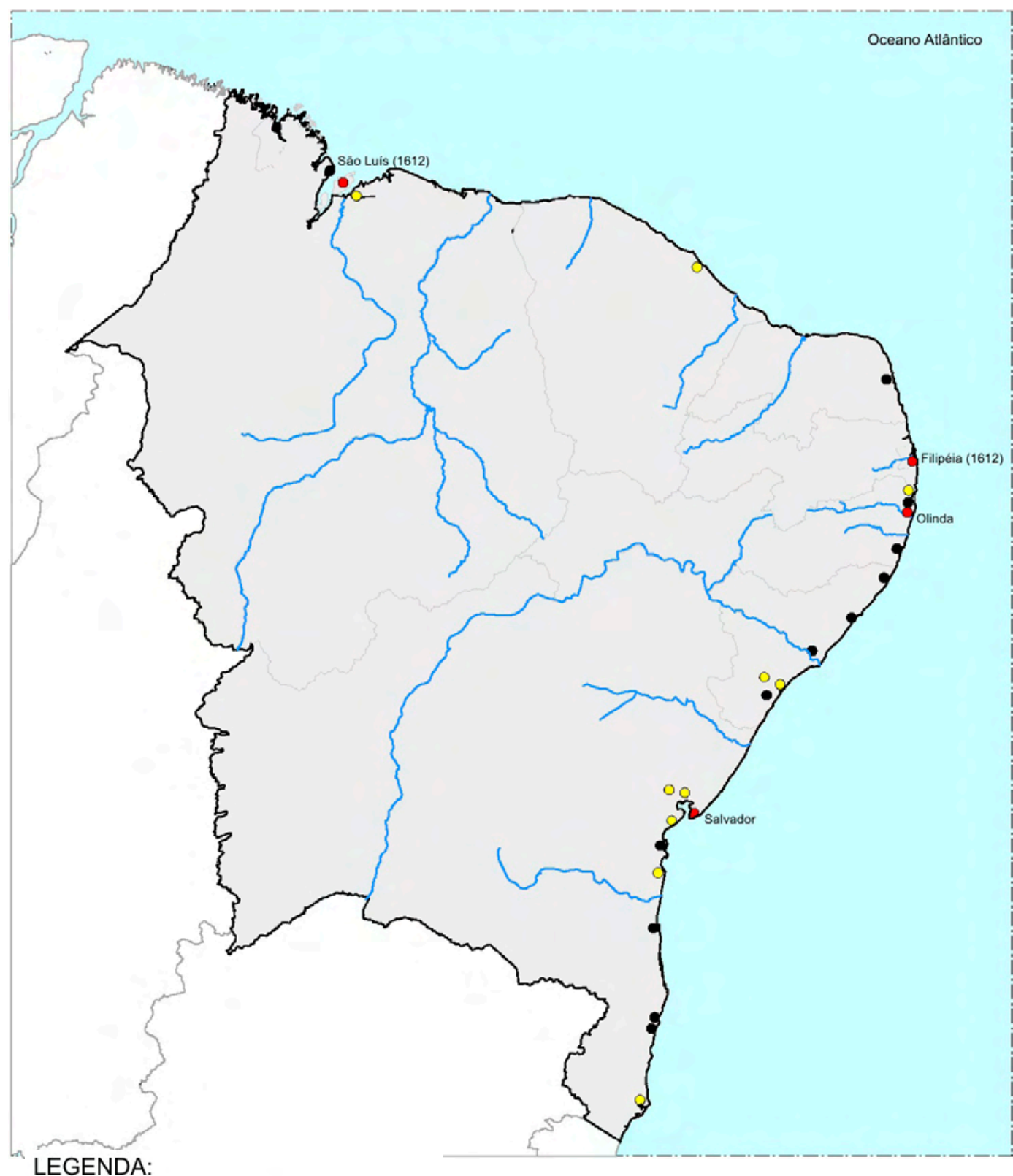

Cidades;

Vilas Instaladas no período;

Vilas instaladas em períodos anteriores; Principais rios;
Mapa 15 - Vilas e cidades do Nordeste entre 1640 - 1706. Desenho do autor sobre variadas fontes primárias e secundárias.

381 “Informação Geral da Capitania de Pernambuco, 1749”. In Annaes da Bibliotheca Nacional do Rio de Janeiro. Vol. XXVIII. Ano 1906. Rio de Janeiro, Officina de Artes Graphicas da Bibliotheca Nacional, 1908. p. 483. 
Piauí, Ceará, Rio Grande do Norte e Paraíba tiveram o seu povoamento desde o interior seguindo o fluxo sertão » litoral. Os sertões de dentro e de fora de Capistrano de Abreu, deslocando sobre o sertão imensas quantidades de cabeças de gado, fundaram pousos e currais como apoio ao desenvolvimento comercial da pecuária.

Os caminhos do gado criaram às suas margens os primeiros indícios de adensamento populacional. Os primeiros povoadores escolheram as estradas como eixo motor ao desenvolvimento urbano da região, a comunicação com outros aglomerados e com o litoral ficou menos dificultosa. Por isso mesmo, as vias terrestres compuseram a "espinha dorsal" 382 so sistema urbano e da forma adquirida por muitos dos seus núcleos. Pierre Deffontaines ${ }^{383}$ chamou atenção para esta particularidade, classificando esses arraiais instalado ao longo de caminhos como as cidades nas estradas. No princípio eram pousos, lugares onde os vaqueiros, sertanistas e caçadores de índios se estabeleceram para continuar sua jornada, seguir os seus objetivos de conquista.

Fixar os Tapuias em aldeamentos missioneiros e auxiliar a comunicação com os bispados e com outras povoações foram os princípios básicos, averiguados pelos religiosos, para edificar suas missões. Ao longo da estrada que partia do Recife à Minas Gerais fundaram os aldeamentos de Ararobá, Juazeiro e Nossa Senhora de Belém ${ }^{384}$. No conhecido caminho que ia do porto de Aracati (CE) ao rio São Francisco - a estrada do Jaguaribe - a Junta das Missões e o bispado de Pernambuco criaram as reduções de Telha, Miranda, Missão Velha e Araripe $^{385}$. Canabrava, Natuba e Mirandela - reduções jesuíticas do sertão baiano localizaram-se na conhecida estrada real do gado ${ }^{386}$.

Caminhos do gado, pousos, currais, fazendas, missões religiosas, freguesias e vilas estruturaram o fenomeno urbano do sertão nordestino. Estruturaram uma definida hierarquia funcional entre os aglomerados, uns serviram apenas como passagens para as boiadas, outros eram cabeças de capitania ou de um território limitado por sua influência social e religiosa. Novamente, veremos através de mapas, auxiliados por tabelas, como se codificou a urbanização da área de caatinga nordestina.

\footnotetext{
${ }^{382}$ AZEVEDO, Aroldo de. Vilas e cidades do Brasil colonial..., Opus cit., p. 71.

${ }^{383}$ DEFFONTAINES, Pierre. "Como se constituiu no Brasil a rede de cidades". Boletim Geográfico (14), maio de 1944, e (15), junho de 1944.

${ }^{384}$ MELLO NETO, José Antônio Gonsalves de. Três roteiros de penetração do território pernambucano (1733 e 1802). Recife, UFPE, 1966. 41 p.

385 STUDART FILHO, Carlos. "Vias de comunicação do Ceará colonial”. In Revista do Instituto do Ceará. Tomo LI. Fortaleza, 1937. p. 27 - 30.

${ }^{386}$ SPIX, J.B Von; MARTIUS, C.P.F. Viagem pelo Brasil..., Opus cit., p. 404.
} 
Anteriormente frisamos que a rede eclesiástica de freguesias antecede à civil ${ }^{387}$. Criar uma vila siginificou acesso a outra categoria institucional, apresentaria autonomia administrativa e política, surgiria no lugar os símbolos oficiais de municipalidade: pelourinho e casa de câmara e cadeia. Tería suficiente número de moradores para merecer este status: (...) me pareceo ordernarvos informeis com o vosso parecer sobre as ditas freguezias há um número de moradores que bastem para se formarem em villas (... $)^{388}$. A nova aglomeração abrigaria um patrimônio público, ou rossio, uma tradição medieval regulamentada pelas ordenações lusitanas (...) Em linhas gerais, constituiu uma área para o usufruto comum dos moradores e servir às necessidades de expansão da nova vila ${ }^{389}$. Além do rossio, as vilas receberam um termo ou o território municipal ${ }^{390}$. Segundo Murillo Marx, o crescimento econômico, populacional e arquitetônico de uma paróquia movimentaria os moradores da localidade a aspirar autonomia municipal:

A sua aspiração seguinte seria constituir não mais um embrião oficial, a célula menor eclesiástica e administrativa, porém algo mais, que não se referia apenas ao tamanho ou à ascensão hierárquica: seria alcançar autonomia política e administrativa, seria passar a constituir a sede de um município, passar a zelar por si mesma, aglomeração, e por um território próprio correspondente que lhe seria designado, seu termo. (...) O povoado se tornaria a sede de uma área territorial bem definida, entre outras as mais antigas ou a serem criadas, temos municipais na ocasião definidos ou redefinidos. Ganhava, então, para todos os efeitos, um lugar ao sol. ${ }^{391}$

As primeiras vilas sertanejas surgiram no reinado de Dom João V [mapa 16] [tabela 13], seis ao todo: Mocha - PI; Jacobina - BA; Paratinga - BA; Rio de Contas - BA; Nossa Senhora do Livramento do Rio de Contas - BA e Icó - CE. As aglomerações Mocha, Icó, Jacobina e Paratinga tiveram seu desenvolvimento dentro da intricada rede viária dos caminhos do gado. As demais eclodem nas estradas que levavam às jazidas de extração aurífera no rio de Contas, além de serem balizas de controle do ouro das minas gerais. Interessante ressaltar que, todas passaram pelo estágio anterior de freguesia ou paróquia. Nesse mesmo período existiram no litoral, ou junto dele, trinta e oito vilas, ou seja, somente $16 \%$ das vilas estavam no semi-árido brasileiro.

\footnotetext{
${ }^{387}$ MARX, Murillo. Cidades no Brasil, terra..., Opus cit., p. 17 - 30.

${ }^{388}$ PROJETO RESGATE. AHU_ACL_CU_018, Cx. 8, D. 450.

${ }^{389}$ MARX, Murillo. Cidades no Brasil, terra..., Opus cit., p. 68.

${ }^{390}$ REIS FILHO, Nestor Goulart. Contribuição ao estudo da evolução urbana do Brasil..., Opus cit., p. 118.

${ }^{391}$ REIS FILHO, Nestor Goulart. Contribuição ao estudo da evolução urbana do Brasil..., Opus cit., p. 52.
} 


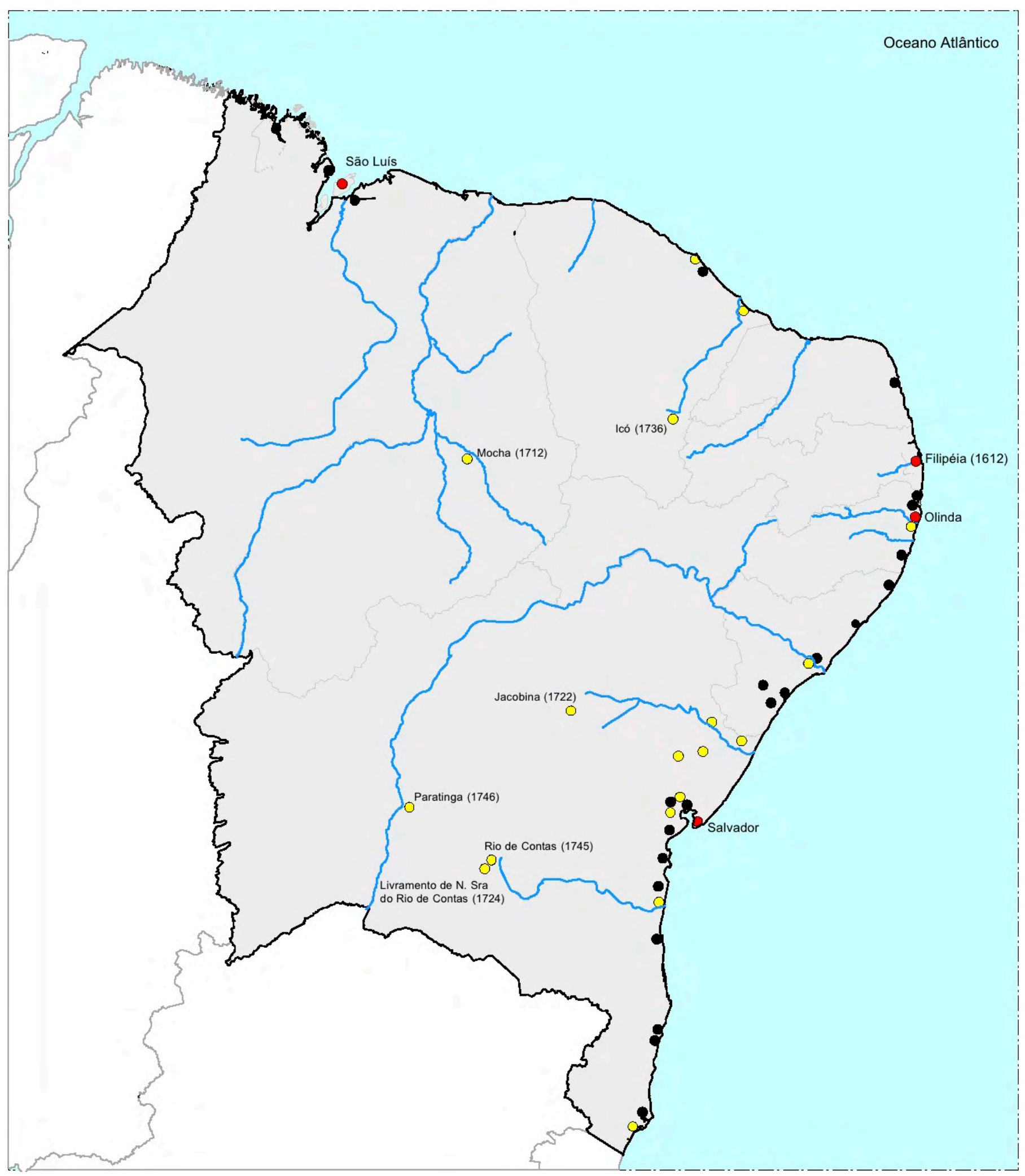

\section{LEGENDA:}

Mapa 16 - Vilas e cidades do Nordeste entre 1706 - 1750.

Cidades;

Desenho do autor sobre variadas fontes primárias e secundárias.

Vilas Instaladas no período;

Vilas instaladas em períodos anteriores;

Principais rios; 


\begin{tabular}{|c|c|}
\hline \multicolumn{2}{|c|}{ VILAS DO SERTÃO NORDESTINO, 1706 - 1750 } \\
\hline ANO DE FUNDAÇÃO & VILA \\
\hline 1711 & Mocha (instalada em 1717) \\
1722 & Jacobina \\
1724 & Livramento de Nossa Senhora do Rio de Contas \\
1736 & Icó \\
1745 & Rio de Contas \\
& Paratinga \\
\hline
\end{tabular}

Tabela 13 - Vilas do sertão nordestino criadas no reinado de D. João V, 1706 -1750. Elaboração do autor segundo AZEVEDO, Aroldo de. Vilas e cidades do Brasil colonial..., Opus cit., p. 38 - 40.

Viviam os moradores e fazendeiros do Piauí em constante coflito com gentio não catequizado. Sucessivos saques às fazendas, seqüestros e conflito bélico encrementaram o cotidiano dos colonos portugueses fixados ali. Como se sabe, a proposta do bispo de Pernambuco, D. Francisco de Lima, ao criar a freguesia de Nossa Senhora da Vitória, idealizou a concentração de moradias ao redor da matriz, buscou a evolução da paróquia e dos bens da fazenda Real.

O ouvidor da capitania do Piauí, Antônio Marques Cardoso, atestou esses motivos a D. João $\mathrm{V}$, que a elevação da freguesia à vila do Mocha [figura 91] diminuiría as discórdias entre Tapuias e moradores, a justiça seria exercida e a comunicação entre outras localidades sertanejas dilataria:

(...) Mas antes para sugeytar esta gentilidade ao grêmio da Igreja, e ao domestico tracto parece conveniente se ordene ao supplicante, que possa crear algumas Villas nas partes que achar com pessoas capazes de servirem aos cargos de Officiaes das Câmeras, e nas ditas Villas as justiças, que forem necessárias, porque nesta forma começa a crescer povoação, que unida em partes, que fiquem para a ex ${ }^{\mathrm{a}}$ à habitaçam dos gentios, os intimida, e se facilita a comunicação com o curso das passagens, de que poderá resultar 
concórdia, sem haver contenda para os expulsar, e parece conveniente a sua conservaçam, por se augmentar a povoação com os mesmos naturaes $(. . .)^{392}$

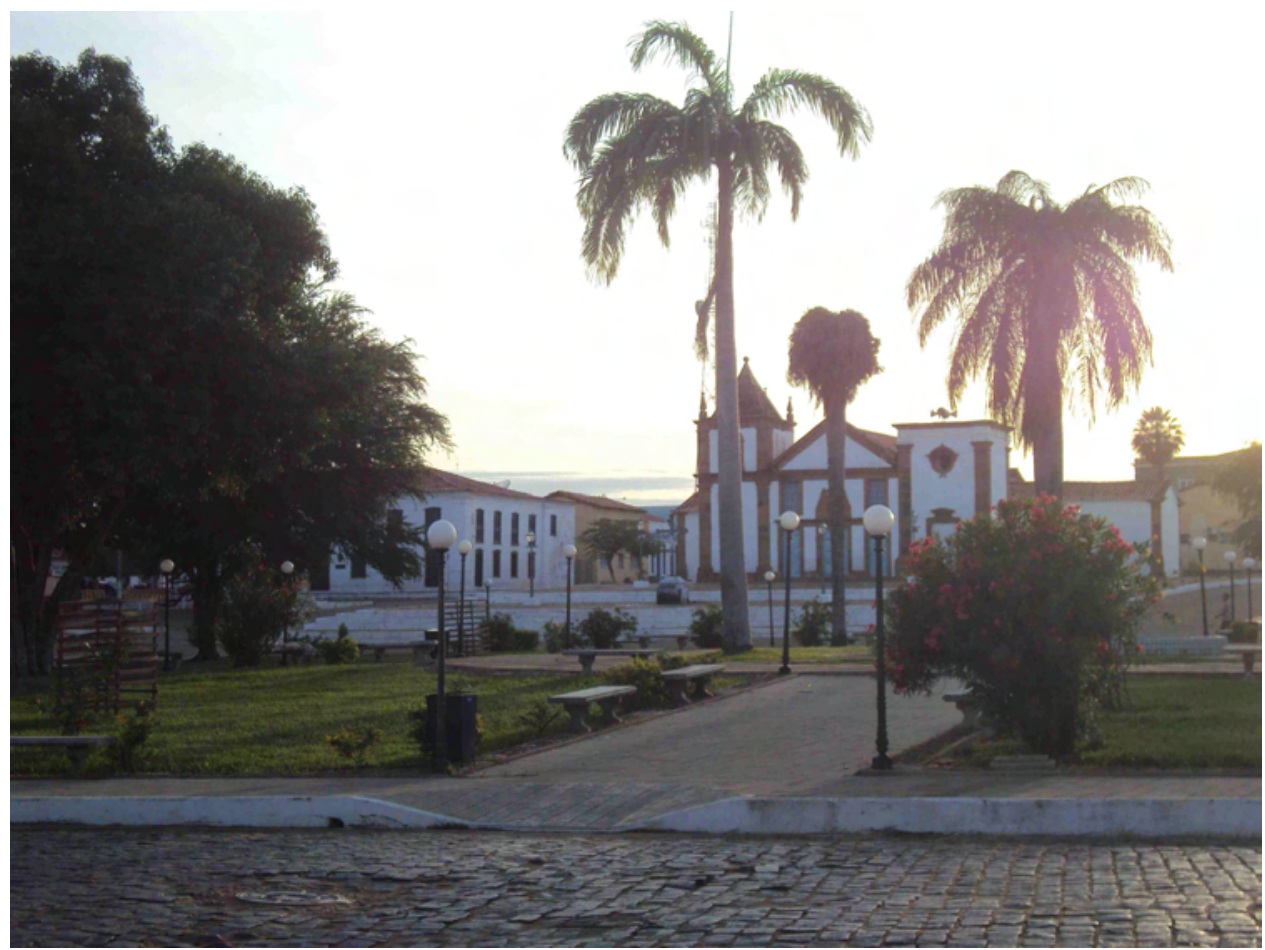

Figura 91 - Cidade de Oeiras - PI, antes vila do Mocha, elevada à categoria de vila em 1712, instalada em 1717. Foto do autor, 2010.

Segundo a correição de Marques Cardoso inexistiram na vila do Mocha os símbolos de autonomia municipal: pelourinho e casa de câmara e cadeia. O rossio da vila estava sob a posse do pároco da matriz. Veremos mais adiante que rixas entre os oficiais da câmara e os curas da vila surgiram em detrimento da falta do patrimônio público do concelho.

Em 1729, o novo ouvidor do Piaú, José Barros Coelho, inspecionou o núcleo do Mocha relatando à Metrópole as condições físicas do lugar. A paisagem urbana praticamente não mudou, faltava-lhe a casa de câmara. As audiências e assembléias eram realizadas em casa de particulares:

(...) Compoemsse este lugar de húa Villa q' terá 25 the 30 vezinhos, e 450 the 500 curraes de gados, devedidos por toda a Capitania de 4 em 4 legoas, e em muitos desses de vinte a 30 legoas se não acha morador algú, e donde são mais os curraes, e rossas he no citio do Rio chamado Pernagua, e outros no Rio Parnahiba, nao q' sejao Villas ou aldeyas, mas pella ditta rezão deferem

${ }^{392}$ PROJETO RESGATE. AHU_ACL_CU_016, Cx. 1, D. 19. 
nos taes citios mais freqüentes as rossas e os curraes; Não tem esta Villa Casa de Câmera e quando se ajuntão os vereadores fazem os accordios em casas de amigos ou na do Juiz ordinário (... $)^{393}$

Nestor Goulart acertadamente disse que a situação de uma aglomeração determina as possibilidades que encontram os seus habitantes de estabelecer relações e portanto determina, em parte, os papéis que a cidade ou vila poderá desempenhar no conjunto da rede ou sistema urbano e do processo de urbanização ${ }^{394}$. Realidade vista em Icó [figura 92]. Instalada em sítio privilegiado, no cruzamento de duas importantes artérias viárias que ligavam a povoação ao litoral e à outras regiões do semi-árido nordestino. A primeira é a conhecida estrada do Jaguaribe, unindo o porto do Aracati (litoral), ao rio São Francisco e, consequentemente, à cidade de Salvador. A segunda foi a estrada das boiadas ligando a vila aos sertões piauiense e paraibano ${ }^{395}$. Seleciona a Coroa lusa a freguesia de Nossa Senhora da Expectação para erigir o município, principalmente pelo seu ponto estratégico diante do comércio do gado sertanejo, isto é, ponto de parada das boiadas a serem comercializadas na localidade e que rumavam para o mar.

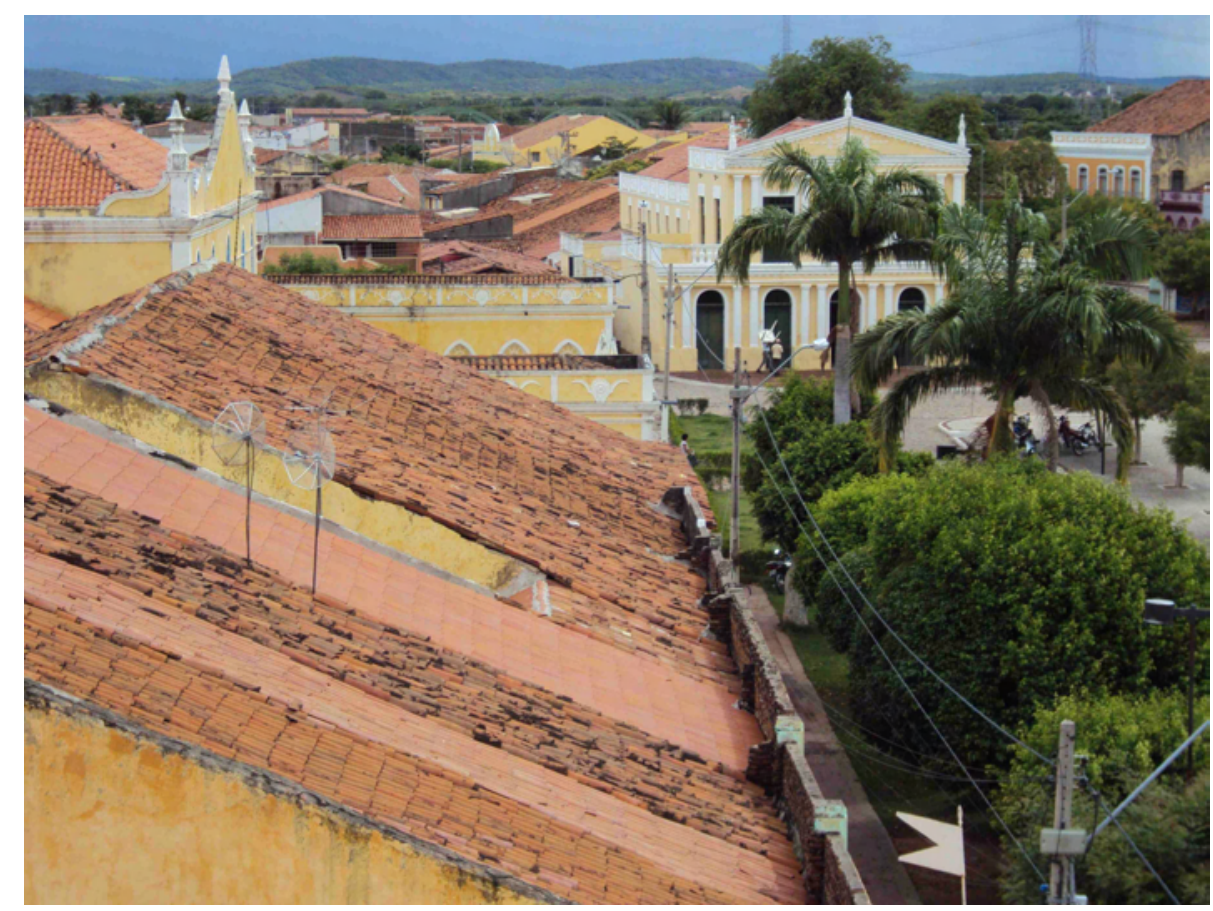

Figura 92 - Icó - CE. Vista parcial do largo da matriz, da casa de câmara e cadeia (esquerda) e do teatro da Ribeira em estilo neoclássico. Foto do autor, 2010.

\footnotetext{
${ }^{393}$ PROJETO RESGATE. AHU_ACL_CU_016, Cx. 1, D. 57.

${ }^{394}$ REIS FILHO, Nestor Goulart. Contribuição ao estudo da evolução urbana do Brasil..., Opus cit., p. 124.

${ }^{395}$ STUDART FILHO, Carlos. "Vias de comunicação do Ceará colonial”..., Opus cit., p. 31 - 35.
} 
Tais circunstâncias territoriais e econômicas deram a Icó um aval positivo. Em 1782, o capitão-mor, João Batista de Azevedo Coutinho de Montaury, a qualificou como uma vila considerável e comerciante $^{396}$. O progresso mercantil da vila cearense está corporizado nos elementos materiais da cultura existentes em seu casco viejo: os sobrados da rua Idílio Sampaio [figura 93]. A escala, os materiais utilizados na construção e a sua precisa localização na trama urbana - logadouro estruturado no século XIX para abrigar as residências dos "principais" do município - apontam a importância comercial do núcleo se compararmos com outros instalados em suas cercanias.

O índice populacional do seu termo, identificado em 1810 pelo engenheiro Antônio Jozé da Silva Paulet, com 15.887 habitantes, reforça as considerações progressitas de Icó. População esta superior a da vila de Fortaleza, povoação litorânea implantada quase que a ponto médio dos portos de Aracati e Acaraú. Icó foi descrita por Antônio Paulet, no início dos Oitocentos: seu termo é o mais povoado e civilizado da comarca é a villa de muito comércio, e em proporção das mais villas (...) pela produção dos gados nas duas margens do Jaguaribe ${ }^{397}$.

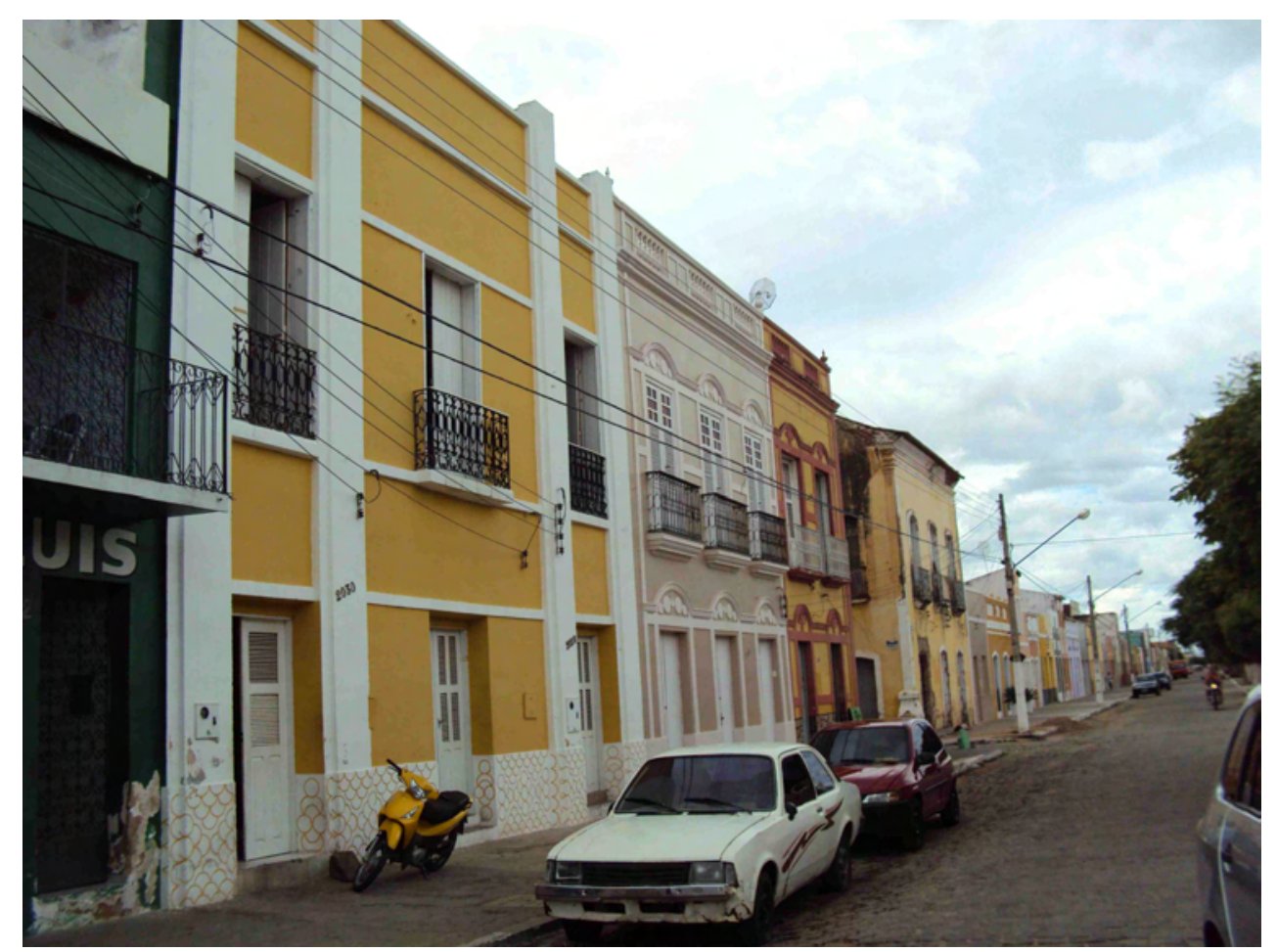

Figura 93 - Sobrados da rua Idílio Sampaio, Icó - CE. Foto do autor, 2010.

\footnotetext{
${ }^{396}$ PROJETO RESGATE. AHU_ACL_CU_CEARÁ, Cx. 9, D. 591.

397 “DESCRIPÇÃO Geographica Abreviada da Capitania do Ceará, pelo Coronel dos Engenheiros Antônio Jozé da Silva Paulet”. In Revista do Instituto do Ceará. Anno XII. Fortaleza, 1898. p. 27 - 28.
} 
A política pombalina aplicada primeiramente na Amazônia e nas capitanias do Grão - Pará e Maranhão, teve sua repercussão no sertão nordestino através do aumento de vilas em seu território: cinco na nova capitania de São José do Piauí, desmembrada do Maranhão; quatro no Ceará; duas no Rio grande do Norte; uma no sertão paraibano; uma em Pernambuco e três na Bahia de Todos os santos, perfazendo um total de dezesseis vilas. Acima de tudo, vale mencionar a criação de uma cidade no interior do Nordeste, Oeiras, antes vila do Mocha. A cidade de Oeiras cumpriu o papel central na urbanização sertaneja. [tabela 14] [mapa 17].

O sertão foi lugar inóspito que facilitou a dispersão dos seus moradores e a fuga dos silvícolas das reduções religiosas. Sítio adequado para facinorozos e ladrões de gado habitarem e cometerem delitos sem punição dos oficiais de justiças. Apesar do aumento do número de estradas nessa época, os meios de transitá-las permaneciam precários, por isso, a comunicação continuou frágil, (...) e difficuldade que se considerara em Juncta das Missões na execução dellas (ordens do rei) pelas grandes distancias, e longes daquelle governo $(\ldots)^{398}$. Agrega-se a esses fatores o preconceito das autoridades eclesiásticas e coloniais. Viam o território como espaço do conflito, da injustiça e dúvida, (...) são tantas as desordens, violências e demandas e ainda mortes, que se tem experimentado nesta capitania (...) $)^{399}$.

Para sanar a realidade, o governo português criou núcleos urbanos em anteriores freguesias ou em lugares cujo embrião fora um aldeamento missioneiro. Concentrou seus objetivos em fixar o homem disperso pelo campo, vivendo como fugitivos, e vagabundos ${ }^{400}$ em aglomerados regulamentados por lei.

(...) que nos certões d'essa capitania (Ceará Grande) tem commetido vadios e facinorosos que vivem nelles separados da sociedade civil e commercio humano, sou servido ordenar que todos os homens que nos ditos certões se acharem vagabundos ou em sítios volantes, sejao logo obrigados a escolherem lugares acomodados para viverem juntos ou em povoações civis, com juiz ordinário, Vereadores, e Procuradores do concelho, repartindo-se entre elles com justa proporção as terras adjascentes $(\ldots)^{401}$.

\footnotetext{
${ }^{398}$ PROJETO RESGATE. AHU_ACL_CU_CEARÁ, Cx. 4, D. 271.

${ }^{399}$ PROJETO RESGATE. AHU_ACL_CU_014, Cx. 10, D. 798.

${ }^{400}$ PROJETO RESGATE. AHU_ACL_CU_014,CX. 41, D. 2853.

401 “CREAÇÃO da Villa de Sobral”. In Revista do Instituto do Ceará. Anno V. Fortaleza, 1891. p. 114.
} 
Dom José I, em suas cartas régias de criação de vilas, foi contumaz ao apontar o aumento do commercio como gregário ao surgimento de novos municípios, solução à dispersão latente do sertanejo, (...) vivendo os seus habitantes em grandes distancias huns dos outros sem a communicação como inimigos da sociedade vicil e do commercio humano padecendo assim os descômodos (... $)^{402}$.

As leis de 06 e 07 de junhos de 1755 e, a posteriori, o Diretório dos Índios libertaram teoricamente os nativos catequizados do julgo missionário. Os índios convertidos ficam subgeitos ao estabelecido sistema de viver, avillados, subordinados, as Leis com seus legítimos principais, e superiores havendo em cada villa hum director, hum pároco Branco e Câmara composta de juízes ordinários, e Vereadores, em parte Índios, em parte Brancos $\left(\right.$.... ${ }^{403}$ [grifo nosso]. Tal sistema de viver foi construído a partir dos noventa e cinco parágrafos do Diretório que, na opinião de Maria Helena Flexor, tiveram como base as teorias de JeanJacques Rousseau, sobre a origem e fundamento da desigualdade entre os homens, em especial a teoria da inocência dos primitivos ${ }^{404}$.

Dá-se o status de vila ou lugar de índios às reduções missioneiras jesuíticas ou àquelas que abrigassem qualificações para adquirir a autonomia administrativa. Muda-se o nome bárbaro das aldeias empondolhes os nomes das Villas mais notáveis deste reyno ou conservando o das Freguezias no caso que nao sejão bárbaros (...) como se achão determinado pelas Ordenações (... $)^{405}$ [tabela 15]. Civilizar ao invés de catequizar, cambiar nomes nativos para titulações portuguesas e emancipar os índios conferiram o papel laicizante, incipiente neste estágio, que Pombal implantou nas aglomerações humanas criadas em sua gestão.

\footnotetext{
${ }^{402}$ PROJETO RESGATE. AHU_ACL_CU_018, Cx. 10, D. 450.

403 PROJETO RESGATE. AHU_ACL_CU_014, Cx. 41, D. 2853.

${ }^{404}$ FLEXOR, Maria helena Ochi. "Cidades e vilas pombalinas no Brasil do século XVIII". In Universo Urbanístico português, 1415 - 1822. Lisboa, Comissão Nacional para as comemorações dos Descobrimentos Portugueses, 1998. p. 258.

${ }^{405}$ PROJETO RESGATE. AHU_ACL_CU_018, Cx. 10, D. 450.
} 


\begin{tabular}{|c|c|c|}
\hline \multicolumn{2}{|c|}{ VILAS DO SERTÃO NORDESTINO, 1750 - 1777 } \\
\hline ANO DE & VILA & CAPITANIA \\
\hline 1752 & Barra & Pernambuco \\
1754 & Pombal & Bahia \\
1755 & Soure & Bahia \\
1758 & Viçosa Real & Ceará \\
1761 & Campo Maior & São José do Piauí \\
1761 & Marvão & São José do Piauí \\
1761 & Valença do Piauí & São José do Piauí \\
1761 & Jerumenha & São José do Piauí \\
1761 & Parnaguá & São José do Piauí \\
1762 & Cimbres & Pernambuco \\
1762 & Portalegre & Rio Grande do Norte \\
1764 & Real do Crato & Ceará \\
1764 & Monte Mor - o- Novo da & Ceará \\
1766 & América & Rio Grande do Norte \\
1772 & Açu & Paraiba \\
1773 & Pombal & Ceará \\
\hline
\end{tabular}

Tabela 14 - Vilas do sertão nordestino, 1750 - 1777. Elaboração do autor.

\begin{tabular}{|c|c|}
\hline \multicolumn{2}{|c|}{ TITULAÇÃO DAS NOVAS VILAS SERTANEJAS, $\mathbf{1 7 5 0}$ - 1777 } \\
\hline ALDEAMENTO OU FREGUESIA & VILA \\
\hline São Francisco da Barra do Rio Grande & Barra \\
Missão de Canabrava & Pombal \\
Missão de Natuba & Soure \\
Missão da Ibiapaba & Viçosa Real \\
Santo Antônio do Surubim & Campo Maior \\
Nossa Senhora do Desterro & Marvão \\
Nossa Senhora dos Oroazes & Valença do Piauí \\
Santo Antônio do Gurguéia & Jerumenha \\
Nossa Senhora do Livramento de Parnaguá & Parnaguá \\
Missão de Ararobá & Cimbres \\
Missão do Apodi & Portalegre \\
Missão do Miranda & Real do Crato \\
Missão da Palma & Açu \\
São João Batista do Açu & Pombal \\
Nossa Senhora do Bom Sucesso & Sobral \\
Nossa Senhora da Conceição de Sobral & Monte - Movo da América \\
\hline
\end{tabular}

Tabela 15 - Titulação das novas vilas do sertão nordestino, 1750 - 1777. Elaboração do autor segundo informações encontradas na Enciclopédia dos Municípios Brasileiros e nos manuscritos do Projeto Resgate Barão do Rio Branco. 


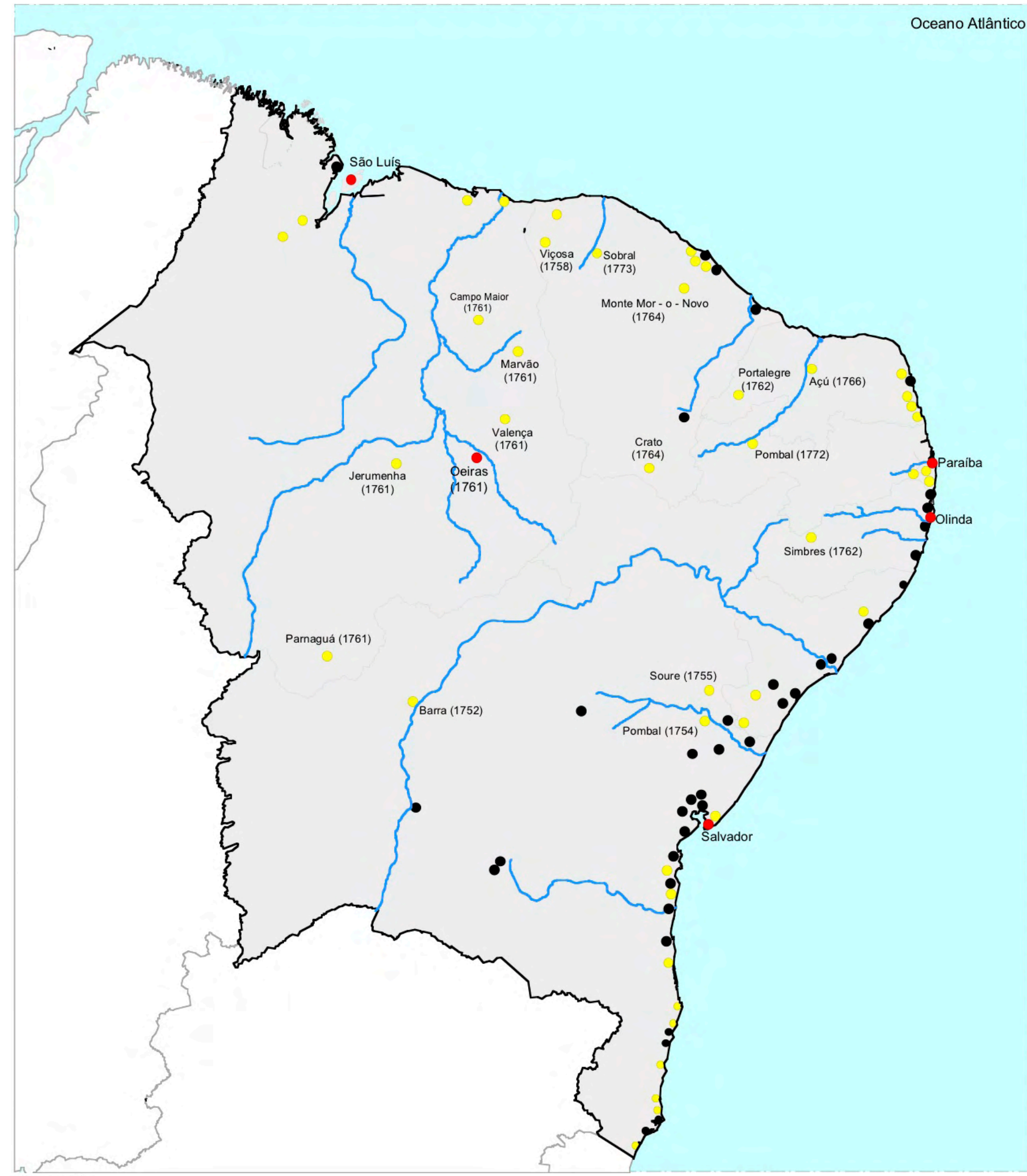

\section{LEGENDA}

Cidades;

Vilas Instaladas no período;

Vilas instaladas em períodos anteriores;
Mapa 17 - Vilas e cidades do Nordeste entre 1750 - 1777. Desenho do autor sobre variadas fontes primárias e secundárias.

-Principais rios; 
João Pereira Caldas, primeiro governador da capitania de São José do Piauí, empossado em 1758, ficou incumbido de demarcar o termo e local apropriado para a fundação das novas vilas piauienses. As cartas de ereção apresentam algumas semelhanças que devem ser analisadas. Paranguá, Jerumenha, Valença, Marvão e Campo Maior foram estabelecidas no mesmo lugar em que se acha a paróquia ${ }^{406}$. Apesar da embrionária laicização conferida pela política pombalina, o Estado português elegeu como termo das vilas o território eclesiástico das suas respectivas freguesias, fusão entre os poderes temporais com os domínios pios. Isto é, não se tratou delimitar, a priori, um novo território para os aglomerados, mas respaldou como oficial o existente ${ }^{407}$.

A paisagem urbana dos núcleos piauienses eram, de fato, paisagens rurais. Sob o ponto de vista físico-material e demográfico as poucas moradias e o número de habitantes denunciam essa fisionomia aos estabelecimentos pombalinos. Em Paranguá, por exemplo, assistiram vinte e oito moradores, doze cazas sem elles, e em toda a Freguezia mil coatrocentos e sete, o que tudo mostrão os documentos (.... $)^{408}$. Marvão, segundo o ouvidor Antônio José de Morais Durão, é a pior de toda a Capitania, porque se acha no sítio mais seco e fúnebre. Tem únicas três casas ou moradores, para melhor dizer, pois ainda que aqueles são mais, não tem inquilino algum ${ }^{409}$. Somente Campo Maior foi considerada pelo ouvidor Durão vila com espaço urbano que merecesse tal designação: com 79 fogos a semelhança de povoações do Reino, desafrontada dos matos; é mais capaz de ser cidade que esta de Oeiras, que fica numa cafurna ${ }^{410}$.

Na capitania do Ceará, o governador Luís Diogo Lobo da Silva, encarregado de averiguar os bens dos padres da Companhia de Jesus, caracterizou o lugar, onde seria implantada a futura vila Viçosa, como péssimo para restituir aos seus habitantes à liberdade e izenção de q' tanto carecião aos seus passos para sahirem ds trevas da ignorância que erão conservado $(\ldots)^{411}$. Apesar disso, usaram como alicerce para o núcleo o anterior aldeamento missioneiro, uma nítida demonstração de abertura e falta de preconceito para com o traçado

\footnotetext{
${ }^{406}$ PROJETO RESGATE. AHU_ACL_CU_018, Cx. 8, D. 507.

${ }^{407}$ GUTIÉRREZ, Ramón. "Povoados e reduções indígenas na região de Cuzco: persitencias e inovações". In Cidades latino-americanas: um debate sobre a formação de núcleos urbanos. Fania Fridman e Mauricio Abreu (org.). Rio de Janeiro, Casa da Palavra, 2010. p. 50.

408 PROJETO RESGATE. AHU_ACL_CU_018, Cx. 8, D. 507.

409 MOTT, Luiz Roberto B. Piauí colonial: população, economia e sociedade. Teresina, Projeto Petrônio Portela, 1985. p. 29.

${ }^{410}$ Idem. Ibidem., p. 30. Raphael Bluteau define o verbete cafurna como uma cova, lugar escuro e subterrâneo. Ver BLUTEAU, Raphael, S. J. Vocaculario português, e latino...Coimbra, Real Collegio das Artes da Companhia de Jesus, 1712 - 9. Disponível em http://www.ieb.usp.br. Acesso em 19.10.2011.

${ }^{411}$ PROJETO RESGATE. AHU_ACL_CU_CEARÁ, Cx. 7, D. 464.
} 
da redução religiosa. A igreja matriz, sob a invocação de Nossa Senhora da Assunção, e o colégio dos jesuítas, estruturaram a trama urbana da vila.

Monte - Mor o Novo da América representa um caso particular das chamadas vilas de índios, por apresentar um plano previamente defindo por carta régia com preocupações urbanísticas apreciáveis $^{412}$. Nos Registro dos Autos de erecção da real villa de Monte-mór o Novo da América, na capitania do Ceará Grande, primeiramente transcrito na revista do Instituto do Ceará em 1891, depois publicada por Paulo F. Santos ${ }^{413}$, há indicação como responsável da demarcação do aglomerado o engenheiro Custódio Francisco de Azevedo. Fincaram o pelourinho e delimitaram o termo e o rossio:

(...) estando ahi todos os moradores da terra e de fora, logo no meio da dita praça e centro della, depois de repetidas todas as ordens de Sua Magestade Fidelíssima, que acima estão copiadas, immediatamente mandou o dito ministro levantar o pelourinho que no dito lugar estava feito e posto no em que havia de ficar (...) assignar o districto do termo da dita villa e patrimônio competente para a camara d'ella e o rocio em que se haviam de edificar as novas casas e continuar as mais que pelo tempo adiante fossem necessáras fazerem se para os moradores d' ella $(. . .)^{414}$

As fontes primárias que possuímos acerca das vilas pombalinas das capitanias de Pernambuco, Paraíba, Rio Grande do Norte e Bahia são específicas em indicar as datas de elevação e o estabelecimento do pelourinho, nada nos informando sobre o seu termo, rossio ou forma urbana adquirida.

Roberta Delson se perguntou sobre as aglomerações setecentistas do Piauí: qual a razão do empenho tão grande da Coroa de conferir a essas novas comunidades uma aparência harmoniosa, quando o Piauí em si estava tão afastado dos núcleos de “civilização” mais próximos? $?^{415}$ Continuou a especialista: não é fácil responder à segunda pergunta, mas é evidente que, pelo menos no caso de Mocha, os portugueses estavam

\footnotetext{
${ }^{412}$ SANTOS, Paulo F. Formação de cidades no Brasil colonial. Rio de Janeiro, Editora UFRJ, 2001. p. 50.

${ }^{413}$ SANTOS, Paulo F. Formação de cidades no Brasil colonial..., Opus cit., p. 54 - 57.

414 "REGISTRO dos Autos da erecção da real villa de Monte - mor o Novo da América, na capitania do Ceará Grande". In Revista do Instituto do Ceará. Anno V. Fortaleza, 1891. p. 265 - 269.

${ }^{415}$ DELSON, Roberta Marx. Novas vilas para o Brasil colônia: planejamento espacial e social no século XVIII. Brasília, Ed. Alva-ciord, 1997. p. 19.
} 
decididos a supervisionar inteiramente o desenvolvimento da comunidade, inclusive o seu traçado físico ${ }^{416}$.

Esqueceu a pesquisadora de analisar os fatores econômicos envolvidos no desmembramento da capitania de São José do Piauí da província maranhense, economia esta, como sabemos, voltada para pecuária e fundamental ao abastecimento alimentar da colônia, (...) a importância de que he a Capitania do Piahuy para a subsistência da Bahia e Pernambuco e ao muito que emporta nas presentes circunstancias fortificarnos nos centros dos Certoes do Brazil depois que se manifestou que por elles pertendiam arruinar e dominar aquelle estado os Religiozos Jezuítas (... $)^{417}$. Ademais, o projeto político de D. José I, com o marquês de Pombal em sua liderança, abarcou a colônia em sua totalidade. Os ideias de liberdade indígena, a fixação do homem em aglomerações para o progresso comercial e social das mesmas, emancipação dos nativos, projeto de núcleos fabricados com harmonia e alinhamento também foram encontrados no sertão nordestino, mesmo estando suas povoações afastadas dos núcleos de "civilização".

O ápice do interesse da economia do gado, da centralização administrativa e promoção do desenvolvimento territorial do sertão nordestino ocorreu coma elevação da vila do Mocha ao foro cidade - Oeiras - localizada quase que no epicentro do Nordeste, ponto médio entre Salvador, São Luiz e Pernambuco. Centro de controle das boiadas levadas à comercialização nas charqueadas da vila da Parnaíba, empório piauiense de extração da carne boina e venda do couro. Do porto piauiense, chamado Barcas, saíam sumacas com subsídios derivados do boi, destinados aos portos do Aracati (CE), Recife, Salvador e Rio de Janeiro.

São José do Piauí (titulação em homenagem ao rei D. José I) como capitania seguiu a regra. Toda capitania exigia uma cidade como "cabeça", centro detentor das autoridades máximas de um governo. Melhor, seguindo o raciocínio de Nestor Goulart as cidades eram criadas em pontos especiais. Funcionavam como centros regionais e por meio delas revelavam-se as tendências centralizadoras da política portuguesa, que se opunham, ainda que discretamente, à dispersão dominante ${ }^{418}$. Seria uma cidade, para Murillo Marx, núcleos não dependentes ou tributários de um poder regional delegado ou de senhores de terra; foi a de se subordinarem diretamente à Coroa, ao poder central, em tese, à autoridade maior ${ }^{419}$. A

\footnotetext{
${ }^{416}$ DELSON, Roberta Marx. Novas vilas para o Brasil colônia...Opus cit., p. 19.

${ }^{417}$ PROJETO RESGATE. AHU_ACL_CU_016, Cx. 5, D. 359.

${ }^{418}$ REIS FILHO, Nestor Goulart. Contribuição ao estudo da evolução urbana do Brasil..., Opus cit., p. 63.

${ }^{419}$ MARX, Murillo. Cidades no Brasil, terra de quem?..., Opus cit., p. 100.
} 
seleção da vila do Mocha, com posições estratégicas em relação à rede urbana sertaneja e como núcleo de controle da economia gadeira, foi merecida para sua elevação à condição de cidade.

As considerações sobre a urbanização da cidade de Oeiras, agregando as particularidades do seu desenho e outros aspectos relacionados ao intraurbano serão dissertados no quinto capítulo desta investigação.

Assim como ocorreu com o fenômeno urbano-eclesiástico das freguesias, o número de vilas criadas no sertão nordestino decaiu entre o final da era pombalina (1777) e à chegada da família real ao Brasil (1808). Ao todo foram criados oito núcleos urbanos: quatro no Ceará, agora capitania independente desmembrada da de Pernambuco em 1799; uma vila no Rio Grande do Norte; duas na Paraíba e uma na Bahia [mapa 18] [tabela 16]. A toponímia das vilas eretas valorizou a figura do monarca regente, como centro da política e vida colonial. Temos a vila Nova da Rainha, vila Nova del Rey e vila Nova do Príncipe. Princípio oposto ao pombalino cujos nomes das aglomerações sertanejas estiveram dentro de uma postura laica: à semelhança dos que haviam no Reino.

\begin{tabular}{|c|c|c|}
\hline \multicolumn{2}{|c|}{ VILAS DO SERTÃO NORDESTINO, 1777 - 1808 } \\
\hline $\begin{array}{c}\text { ANO DE } \\
\text { FUNDAÇÃo }\end{array}$ & VILA & CAPITANIA \\
\hline 1789 & Campo Maior de & Ceará \\
1789 & Quixeramombim & Rio Grande do Norte \\
1791 & Vila Nova do Príncipe & Ceará \\
1797 & Vila Nova del Rey & Bahia \\
1800 & Vila Nova da Rainha & Paraíba \\
1800 & Vila de Sousa & Paraiba \\
1801 & São João do Cariri & Ceará \\
1802 & São Bernardo das Russas & Ceará \\
\hline
\end{tabular}

Tabela 16 - Vilas do sertão nordestino, 1777 - 1808. Elaboração do autor segundo informações encontradas na Enciclopédia dos Municipios Brasileiros. 


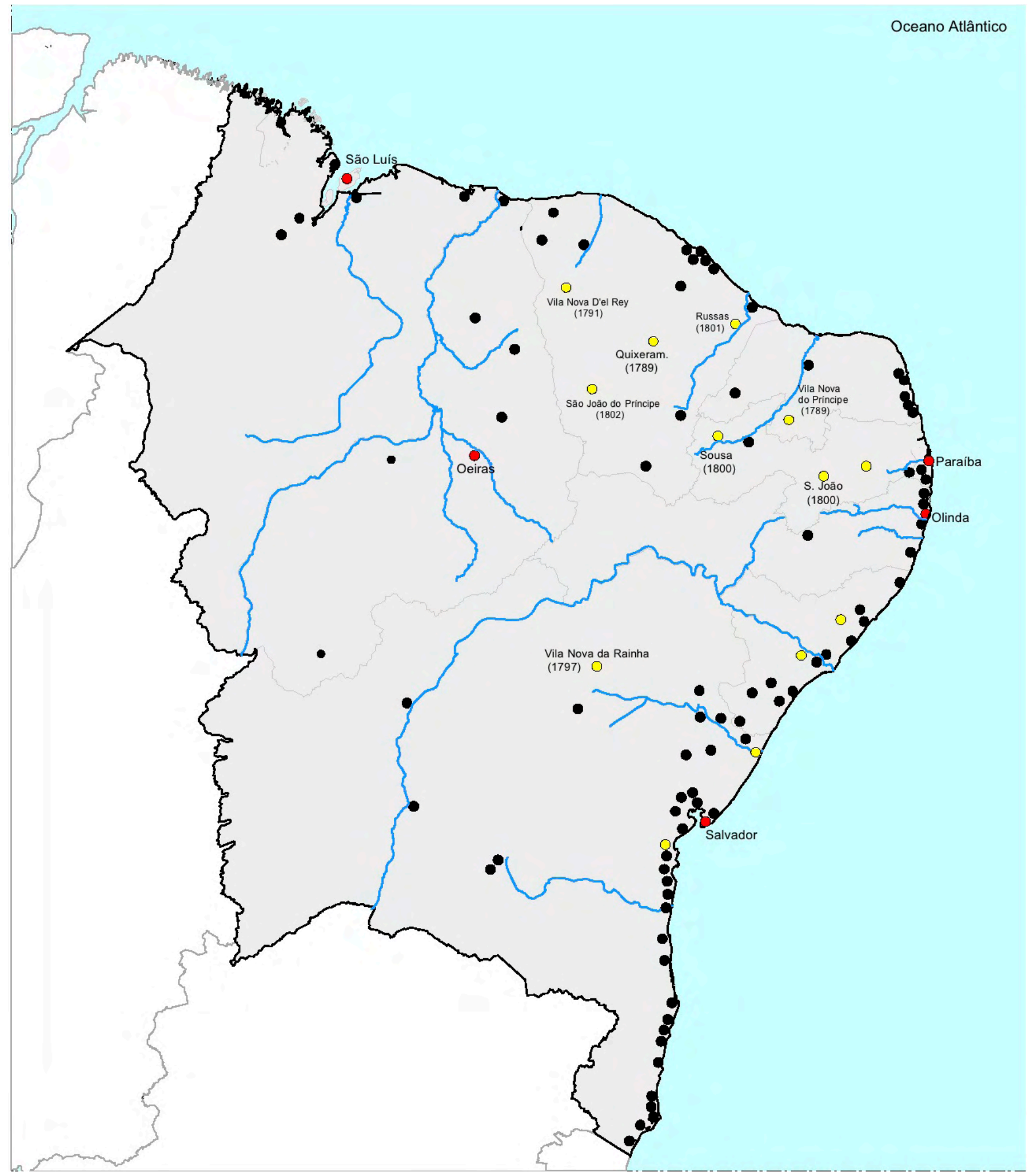

\section{LEGENDA:}

Cidades;

$\bigcirc$ Vilas Instaladas no período;

Vilas instaladas em períodos anteriores; -Principais rios;
Mapa 18 - Vilas e cidades do Nordeste entre 1777 - 1808. Desenho do autor sobre variadas fontes primárias e secundárias. 
As posturas de Dona Maria I pouco mudaram sobre a necessidade de se criar assentamentos humanos no sertão. O controle do território e a fixação do homem continuaram como objetivos. As vilas eram locais de congregação dos vadios e facinorosos, auxílio físico à adaptação às normais coloniais. Quando criadas as vilas de Campo Maior de Quixeramombim e São Bernardo das Russas, ambas da capitania do Ceará, a carta régia afirmou a função dos municípios:

(...) que se erigisse em villa esta povoação de Santo Antônio de Quixeramombim, para nella se recolherem e congregarem todos os homens vadios e vagabundos que afastando-se da sociedade civil á maneira de feras, vivem embrenhados pelo centro dos mattos virgens destes sertões $(. . .)^{420}$

(...) Eu o Soberano sou servido ordenar que todos os homens nos ditos certoens se acharem Vagabundos ou em sítios volantes sejão logo obrigados a escolherem lugares acomodados para viverem juntos em Povoações Civis que pello menos tenhão cincoenta Fogos para sima $(. . .)^{421}$

A civilização dos vadios seria obtida através da agricultura. Estabelecidos nas vilas e determinado o rossio, os moradores teriam acesso ao chão pagando uma pequena parcela, o foro, ao concelho:

(...) as terras que ainda não forão cultivadas e se achão devolutas (...) reservadas para se repartirem pellas pessoas que sendo compreendidas nos Editais e Ordem Régia viessem agregar-se a esta Villa das quais se lhe arbitraria a casa hum aquelle numero de brasas ou de terreno que a Camara julgasse bastante para as suas Lavouras e plantaçoens pagando cada hum a módica porção de foro que a Mesma Camara lhe impuzer para as dispezas do Conselho $(\ldots)^{422}$

Caio Prado Jr. considerou o período que vai de 1777 até 1808 como o apogeu da colônia $^{423}$, no que cerne o liberalismo econômico sucedido pela abertura dos portos às nações amigas. Ascende no mercado mundial o progresso técnico da Revolução Industrial. Os

\footnotetext{
${ }^{420}$ OLIVEIRA, Perdigão. “A villa de Quixeramombim”. In Revista do Instituto do Ceará. Anno IV. Fortaleza, 1890. p. 278.

421 “AUTO da creação da Villa de S. Bernardo do Governador”. In Revista do Instituto do Ceará. Anno XX. Fortaleza, 1906. p. 234.

422 “AUTO da creação da Villa de S. Bernardo do Governador"..., Opus cit., p. 245.

${ }^{423}$ PRADO Jr. Caio. História econômica do Brasil. $45^{\circ}$ reimpressão. São Paulo, Brasiliense, 2008. p. 78 - 119.
} 
mercados da colônia alargaram. ${ }^{424}$ Entretanto, assistimos a baixa da produção gadeira nordestina. Sucessivas secas e o posicionamento da pecuária do Rio Grande do Sul no cenário colonial foram alguns dos motivos da queda econômica sofrida pelos currais nordestinos. Em contrapartida, os teares ingleses consumiram boas arrobas de algodão ${ }^{425}$. A economia algodoeira cresceu no sertão, contribuindo para a fundação de novas vilas no Maranhão e Ceará.

Nesse novo contexto econômico, e entre os anos de 1808 - 1822, as autoridades instituíram onze vilas: três no Maranhão; duas no Ceará; uma na Paraíba; duas em Pernambuco e três na Bahia [tabela 17] [mapa 19]. Os reflexos da queda da pecuária são notados na capitania do Piauí, principal região criatória do Nordeste, nenhuma vila foi erguida ao longo do recorte temporal citado. Em contrapartida, no sertão maranhense aparecem os primeiros núcleos instituídos de casa de câmara e pelourinho: Pastos Bons, Caxias e Itapicurú - Mirim. A segunda deteve um dos melhores percentuais da produção algodoeira. Edificam em seu perímetro urbano a Companhia Têxtil Caxiense [figura 94], como resposta à expansão do algodão na economia global.

\begin{tabular}{|c|c|c|}
\hline \multicolumn{2}{|c|}{ VILAS DO SERTÃO NORDESTINO, 1808 - 1822 } \\
\hline ANO DE & VILA & CAPITANIA \\
\hline FUNDAÇ̃̃O & Flores do Pajeú & Pernambuco \\
1810 & Pilão Arcado & Pernambuco \\
1810 & Vila Nova do Prícipe & Bahia \\
1810 & Caxias & Maranhão \\
1811 & Jardim & Ceará \\
1811 & Garanhuns & Pernambuco \\
1815 & Brejo da Areia & Paraiba \\
1816 & Lavras da Mangabeira & Ceará \\
1817 & Itapicurú - Mirim & Maranhão \\
1820 & Pastos Bons & Maranhão \\
1820 & Campo Largo & Bahia \\
\hline
\end{tabular}

Tabela 17 - Vilas do sertão nordestino, 1808 - 1822. Elaboração do autor segundo informações encontradas na Enciclopédia dos Municipios Brasileiros.

\footnotetext{
${ }^{424}$ PRADO Jr. Caio. História econômica do Brasil..., Opus cit., p. 80.

${ }^{425} \mathrm{Na}$ segunda metade do século XVIII, com o incio da Revolução Industrial, as exportações do algodão brasileiras apresentaram um forte avanço, contribuindo para o fortalecimento econômico da colônia e do progresso demográfico. Ver DOURADO, José Ribamar; BOCLIN, Roberto Guimarães. A indústria do Maranhão: um novo ciclo. Brasília, IEL, 2008. p. 36.
} 


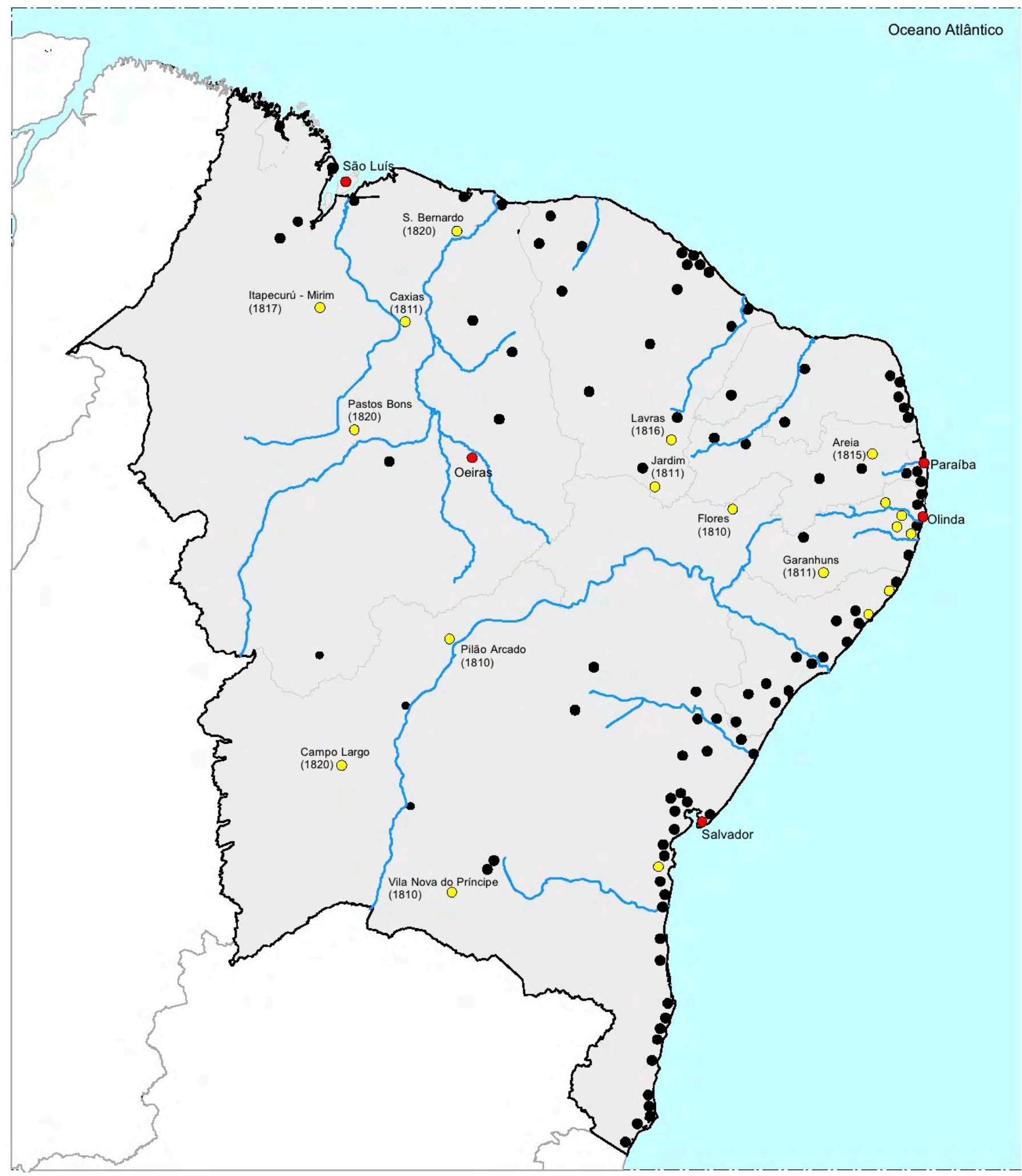

\section{LEGENDA:}

Cidades

Vilas Instaladas no período;

Vilas instaladas em períodos anteriores;

Principais rios;
Mapa 19 - Vilas e cidades do Nordeste entre 1808 - 1822. Desenho do autor sobre variadas fontes primárias e secundárias. 


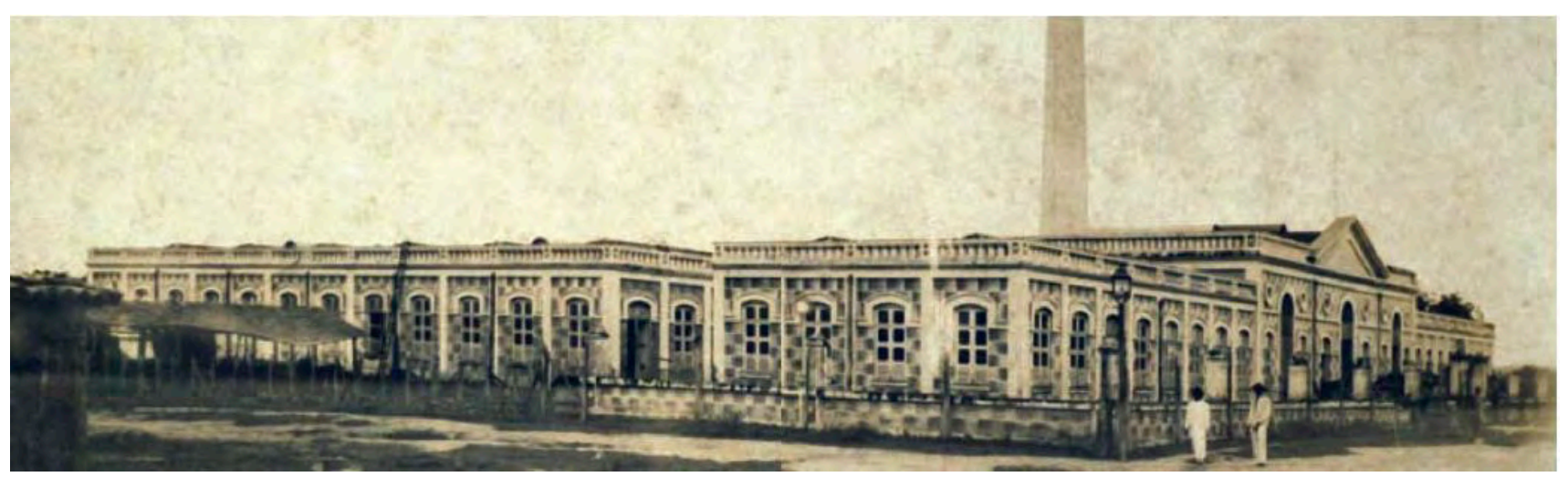

Figura 94 - Companhia Têxtil Caxiense. Imagem encontrada em DOURADO, José Ribamar; BOCLIN, Roberto Guimarães. A industria do Maranhão: um noco ciclo. Brasília, IEL, 2008. p. 38 - 39.

Caxias (MA) ${ }^{426}$ [figura 95] fora um aldeamento missioneiro jesuítico, as Aldeias Altas. No auge da implantação do Diretório dos Índios, por algum motivo, não o privilegiaram com o foro de vila. Somente em 1811, como centro produtor de algodão, recebeu sua emancipação. Temos parcas descrições de sua paisagem urbana e o grau de sua urbanização. Bem ilustra a narrativa de Spix e Martius, o teor do fenômeno urbano caxiense:

(...) antigamente Arraial das Aldeias Altas, é uma das mais florescentes vilas do interior do Brasil. Monta a 30.000 o número de habitantes do seu termo. Deve a sua prosperidade à cultura do algodão, explorada desde uns vinte e tantos anos, com afinco, em seu interior, e fomentada em toda a província pela Companhia de Comércio do Maranhão e Grão - Pará, assim como à atividade comercial dos seus habitantes, entre os quais se encontram muitos europeus. Mais da metade de todo o algodão produzido na província é depachado daqui para a capital, e, nos últimos anos, o número de fardos embarcados em Caxias, cada um do peso de 5 e 6 arrobas, subiu a 25.000 e até 30.000, que, avaliado baixo, mesmo no interior, vale uns 1.650 .000 ou 1.980 .000 florins. ${ }^{427}$

Adentrando a província do Maranhão chegamos ao sertão dos Pastos Bons. Aqui a pecuária continuou sendo a economia motora dos moradores, apesar de alguns fazendeiros de

\footnotetext{
${ }^{426}$ O major Francisco de Paula Ribeiro relatou em 1813 sobre Caxias: (...) tem sua população que não chega a trinta mil almas livres, vantajosas lavouras de algodão e arroz, em que occupa mais de duzentos mil escravos que possue, cujos resultados, fazendo até hoje por um nunca interrompido trafico commercial o principal motivo da sua opulência (...) a mais commerciavel de toda a capitania, e também a mais carecida dos gêneros de lavouras próprios para a sua subsistencia, porque é aqui preterida esta pela do algodão (...). Ver RIBEIRO, Francisco de Paula. "Descripção do território de Pastos Bons, nos Sertões do Maranhão: propriedades dos seus terrenos, suas produções, caracter dos seus habitantes colonos, e estado actual dos seus estabelecimentos". In Revista do Instituto Histórico e Geográfico Brasileiro. Tomo XII. Rio de Janeiro, IHGB, 1849. p. 07, 55.

${ }^{427}$ SPIX, J.B Von; MARTIUS, C.P.F. Viagem pelo Brasil..., Opus cit., p. 255.
} 
gado seguir o rush algodoeiro. Da freguesia de São Bento das Balças de Pastos Bons surge a vila de Pastos Bons. Enviado para aquele território em 1813, o major Francisco de Paula Ribeiro descreveu as condições físicas da vila:

(...) Não chega a ter trinta fogos, e todos os seus edifícios são ridículas palhoças, à exepção da igreja sua matriz e do quartel militar do destacamento que o guarnece, por estes são construídos de pedra e cal e cobertos de telha. Terá de circunferência para mais de seiscentas braças, o que parece imcompativel com tal numero de habitantes $(. . .)^{428}$

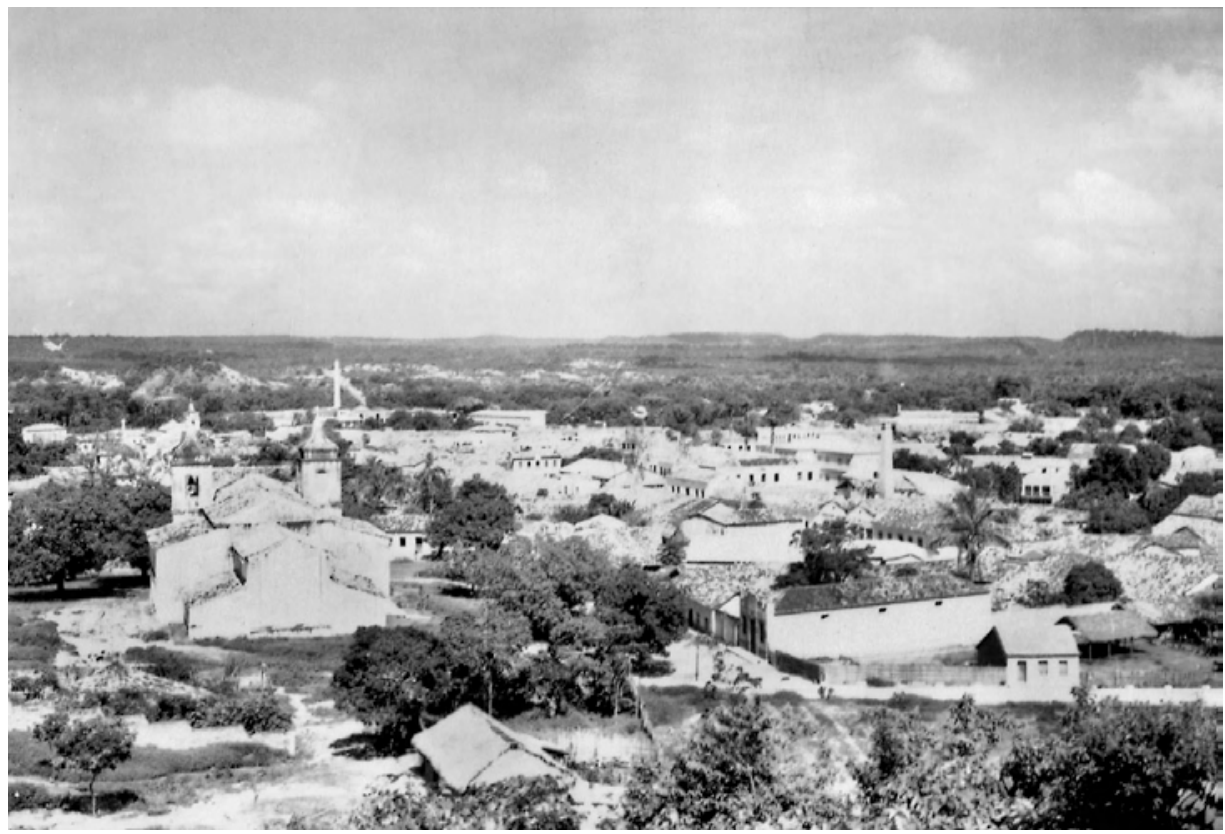

Figura 95 - Caxias do Maranhão. Foto da década de cinquenta do século passado. Imagem disponível em http://www.ibge.gov.br. Acesso em 21.03.2010.

Lavras da Mangabeira (CE), elevada à categoria de vila em 1818, eclode dos interesses de alguns mineradores, que migram de variadas partes do sertão cearense e de regiões contíguas. A pequena quantidade de ouro encontrada frustrou os planos da maioria de seus exploradores. George Gardner circulou sobre os seus espaços públicos. Narrou sobre esta vila vinte anos após a sua criação: está situada nas margens do rio Salgado, contendo de oitenta a cem casas, todas pequenas e muitas caindo em ruínas ${ }^{429}$.

\footnotetext{
${ }^{428}$ RIBEIRO, Francisco de Paula. "Descripção do território de Pastos Bons, nos Sertões do Maranhão: propriedades dos seus terrenos, suas produções, caracter dos seus habitantes colonos, e estado actual dos seus estabelecimentos". In Revista do Instituto Histórico e Geográfico Brasileiro. Tomo XII. Rio de Janeiro, IHGB, 1849. p. 47.

${ }^{429}$ GARDNER, George. Viagem ao interior do Brasil, principalmente nas províncias do norte e nos distritos de ouro e diamante durante os anos de 1836 - 1841. Belo Horizonte, Itatiaia, 1975. p. 89.
} 
Ao observar o Auto de Creação e Levantamento da Povoação de S. Vicente Ferrer das Lavras da Mangabeira em villa... a municipalidade surgiu pela necessidade do exercício da justiça, escassa naquelas paragens:

(...) a difficuldade em que na província do Ceará-grande se acha a prompta administração da justiça em razão das distancias e incommodos porque são obrigados a passar aquelles povos para conseguirem os despachos dos seus negócios, sendo como impossível que um só ouvidor possa a fazer as devidas correcções em tão grande extenção, e ouvir mais de cento e cinqüenta mil habitantes, com que a dita província se acha povoada $(. . .)^{430}$

Algumas citações do Auto de ereção de Lavras da Mangabeira estão presentes em outras cartas régias como elementos de persistência. Continua o patrimômio da camara uma sesmaria de uma légua de terra em quadra, conjuncta ou separadamente, onde houver desembaraçada ${ }^{431}$. Para termo da vila é evidente a união entre Coroa e Mitra. O Estado não se preocupou em delimitar uma nova área para o aglomerado, apenas confirmou o já existente de domínio eclesiástico: terá por termo todo o território da sua freguezia (... $)^{432}$.

Depois deste ligeiro panorama religioso, político e econômico do sertão nordestino algumas perguntas merecem respostas. Qual o desenho obtido por aglomerações que se destacam no sistema de aldeamentos missioneiros, freguesias, vilas e cidade? Seriam díspares daqueles conferidos aos centros urbanos do litoral? Há reflexos da divisão social do trabalho incidentes no traçado urbano dos núcleos sertanejos? Como se materializou a união entre Igreja e Estado na paisagem urbana? A segunda parte deste trabalho priorizará alguns conceitos de desenho, válidos para os núcleos afastados da costa do Nordeste. Seremos alicerçados pelos estudos de Paulo F. Santos, Mário Chicó, Nestor Goulart Reis Filho, Murillo Marx, Giulio Carlo Argan e outros pesquisadores do tema.

\footnotetext{
430 “AUTO de Creação e Levantamento da povoação de S. Vicente Ferrer das Lavras da Mangabeira em villa,...". in Revista do Instituto do Ceará. Anno IV. Fortaleza, 1890. p. 300.

431 "AUTO de Creação e Levantamento da povoação de S. Vicente Ferrer das Lavras da Mangabeira em villa...", Opus cit., p. 302.

432 “AUTO de Creação e Levantamento da povoação de S. Vicente Ferrer das Lavras da Mangabeira em villa...", Opus cit., p. 301.
} 
SEGUNDA PARTE

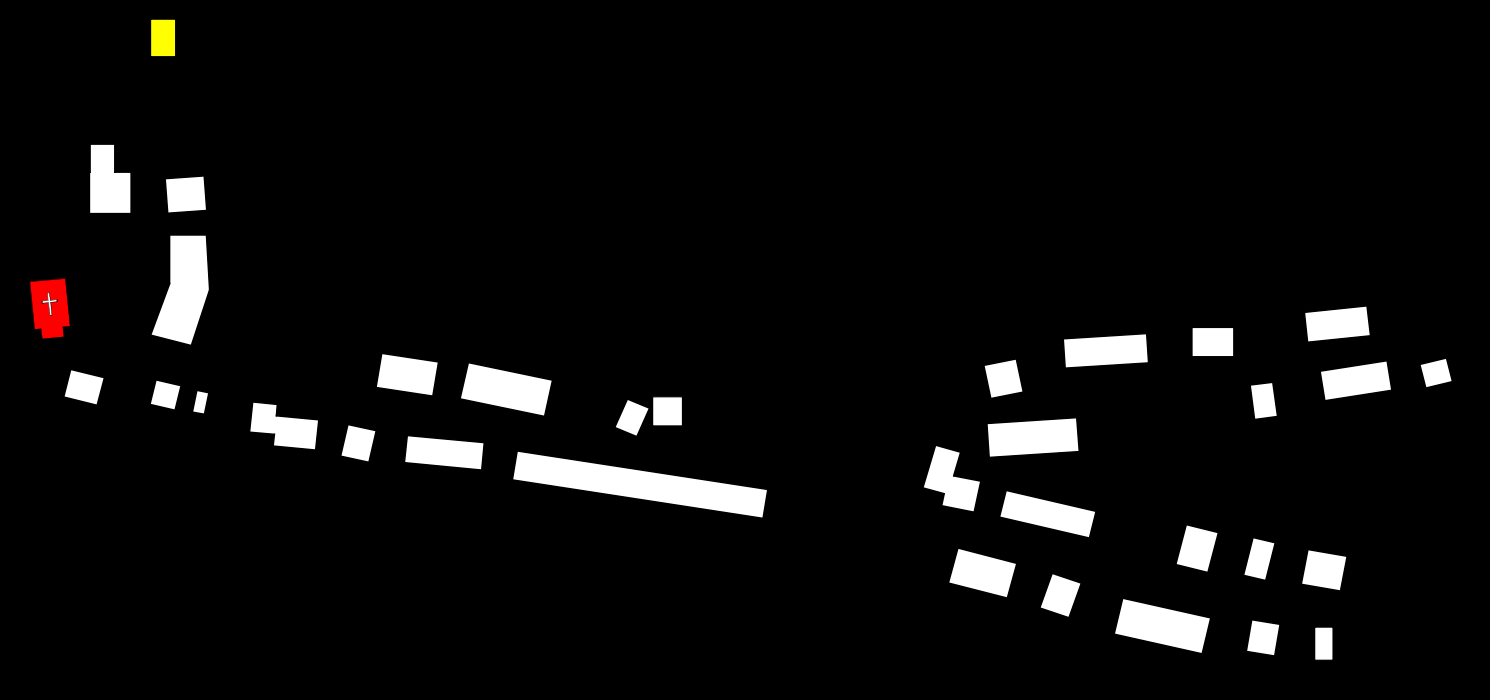

O DESENHO 


\section{CAPÍTULO 04 - O DESENHO}

“(...) Havendo por isso acontecido que nas respostas em que eu me preparava para pessoalmente hir fazer lhes a divizão do terreno para Igreja, e cazas de suas habitaçoens (tudo regulado por huma planta o fiz para ficar com armonia e em boa ordem este estabelecimento) que mayor parte dessa gentilidade levada da sua mesma inconsistência e das brutaes máximas em que se crearão e sempre viverão (...)"

Gonçalo Lourenço Botelho de Castro, governador da capitania de São José do Piauí, 1774.

"Jacobina compõe-se de um extenso arruado, que se estende longitudinalmente por uma apertada garganta de serras. Nas extremidades ficam duas praças bonitas: uma em que fica a Matriz com o orago Santo Antônio e outro o cemitério. No centro do arruado, no lugar mais espaçoso, fica o edifício público, parecido a um reduto, onde funciona, no pavimento superior - a casa da câmara e no térreo a enxovia."

Durval de Aguiar, meados do século XIX. 


\subsection{A praça: ordens pias, racionalidade, harmonia e a gênese dos núcleos urbanos sertanejos}

Walter Gropius, em um dos congressos do CIAM, ocorrido na Inglaterra, em 1951, assinalou suas impressões ao viajar à Cidade do México. Chamou à atenção para o coração da cidade - praça maior da urbe mexicana. Lugar de intensa vida, uma espécie de sala de estar pública, onde se compra e exprime os sentimentos humanos ${ }^{1}$. A opinião do vanguadista moderno é carregada de sensibilidade ao olhar a praça como um macrocosmo da moradia familiar. O vazio urbano em questão é de origem hispano - americano, cujas Leyes de Índias dotaram como núcleo dos assentamentos coloniais uma praça, local de encontro das ruas e geração das mesmas. Símbolo de vitalidade e troca social.

Na colônia lusa das Américas a praça foi definida, nos anos iniciais da conquista, pela existência de um adro ou terreiro. A igreja situava-se ali, identificando as principais atribuições daquele espaço, essencialmente de cunho religioso. Ou como afirmou Murillo Marx, seria espaço público de reunião e para o exercício de um sem número de atividades distintas, surgiu entre nós de maneira marcante e típica, diante de capelas ou igrejas, de conventos ou irmandades religiosas ${ }^{2}$.

Bluteau traçou o verbete "praça" como lugar público, plano, e espaçoso, nas Cidades, Villas. Para feiras, e jogos públicos (...) praça onde se compra, e vende. Praça onde se vende hortaliças (...) erão no tempo dos Romanos as praças, em que se vendião boys, porcos, vinho $(\ldots)^{3}$. Atribuições recreativas e comerciais são dadas à praça segundo a definição do jesuíta. Características físicas, lugar plano, confere especificidade topográfica para a existência do vazio público. Algumas dessas características encontramos na praça sertaneja, lugar de reunião e convivência dos moradores.

A praça do sertão nordestino deve-se à Igreja, subsidiada por ordens eclesiásticas. Mais tarde, a partir do governo de Dom João V, a praça sofrerá intervenções físicas e estéticas, propostas por cartas régias em forma de lei. À sombra da Igreja e do seu terreiro foram acolhidos os fregueses, ali edificaram suas moradias, expandindo a urbanização da localidade. Distinguia-se um espaço sacro do humano. Baseadas em leis setecentistas, a praça

\footnotetext{
${ }^{1}$ GROPIUS, Walter. "El corazón de la ciudad por una vida más humana de la comunidad". In Congreso Internacional de Arquitectura Moderna. 2 ed. Bacelona, 1961. p. 75.

${ }^{2}$ MARX, Murillo. Cidade brasileira. São Paulo, Melhoramentos - Edusp, 1980. p. 50.

${ }^{3}$ BLUTEAU, Raphael, S. J. Vocabulário português, e latino...Coimbra, Real Collegio das Artes da Companhia de Jesus, 1712 - 1719. Disponível em http://www.ieb.usp.br. Acesso em 25. 10. 2011.
} 
dos núcleos sertanejos seguem princípios da tratadística do Renascimento, adaptados à realidade local. Harmonia, simetria e métrica bem definida vigoraram em alguns largos promovidos, principalmente, pela política pombalina.

Pontuadas algumas de suas atribuições, a delimitação do átrio da igreja ou da praça setecentista estruturou os núcleos urbanos em áreas afastadas do litoral. Jacques Le Goff opina que a vitalidade de um aglomerado se deve aos chamados pontos quentes, isto é, aceleradores da vida urbana porque exercem sobre os moradores poder de atração ou repulsão, pontos de ordenamento das casas ou ruas e, sobretudo, da circulação ${ }^{4}$. Nessa categoria, para o historiador francês, encontram-se as praças. Nestor Goulart confere esse atributo ao dizer que nas povoações mais humildes, como as aldeias de índios ou paróquia, reunidas em torno de modestas igrejas isoladas, desenvolviam grande parte das suas funções nas praças, as quais, por isso mesmo, eram sempre os locais de maior importância e muitas vezes a origem da povoação ${ }^{5}$. Definidas por ordens canônicas ou por códigos reinóis, a lógica evolutiva da paisagem urbana sertaneja esteve agregada à presença desse vazio de uso sacro, profano e um mix de ambos.

Os terreiros dos aldeamentos missioneiros eram espaços de ensino, doutrinação, domesticação e difusão dos ideais colonizadores. Ao som do sino da capela, os missionários controlaram militarmente a conduta cotidiana dos neófitos. No centro do adro, todos rezavam e cantavam as ladainhas católicas antes do início das atividades diárias. Ali também presenciavam a punição dos índios avessos à conversão católica. O governo do aldeamento missioneiro administrado pelo capuchinho Martinho de Nantes requereu normas bem fundadas, regras pregadas no altar da capela e na praça missioneira ${ }^{6}$. A missão de Pambú [figura 96], situada às margens do rio São Francisco, teve o desenho do assentamento em figura regular, contribuindo para a difusão do bom governo aos aldeiados.

\footnotetext{
${ }^{4}$ LE GOFF, Jacques. O apogeu da cidade medieval. São Paulo, Martins Fontes, 1992. p. 34.

${ }^{5}$ REIS FILHO, Nestor Goulart. Contribuição ao estudo da evolução urbana do Brasil (1500/1720). 2 ed. rev. e ampl. São Paulo, Pini, 2000. p. 135 - 136.

${ }^{6}$ NANTES, padre, O.F.M. Cap. Martinho de. Relação de uma missão do padre Martinho de Nantes, pregador capuchinho, missionário apostólico no Brasil entre os índios chamados cariris. Tradução e comentário de Barbosa Lima Sobrinho. São Paulo, Editora Nacional, 1979. p. 39.
} 


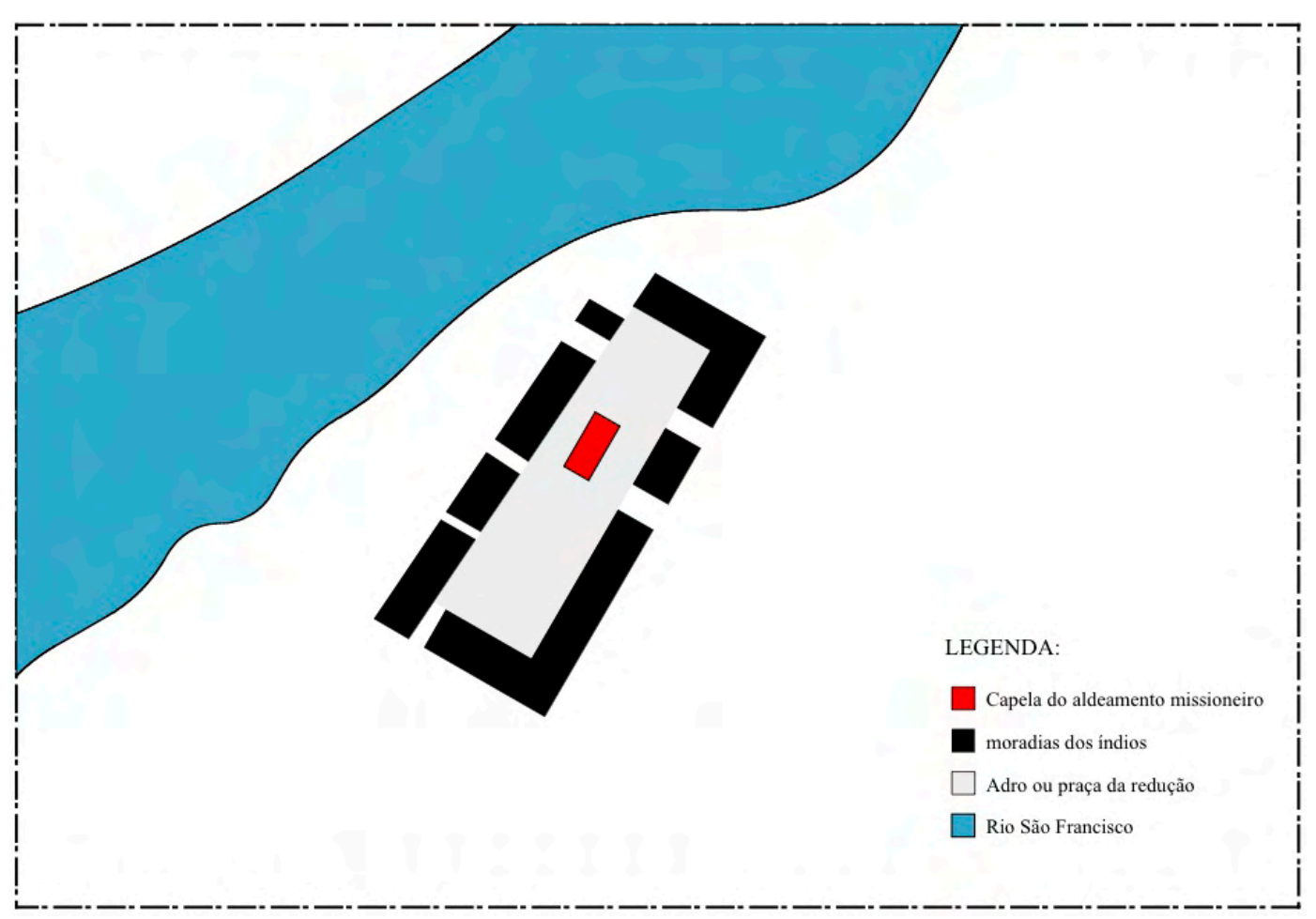

Figura 96 - Aldeamento missioneiro capuchinho de Pambú. Desenho do autor sobre original de HALFELD, Henrique Gulherme Fernando. Atlas e relatório concernente a exploração do rio São Francisco desde a cachoeira da Pirapora até o oceano Atlântico. Rio de Janeiro, 1860. Mapa 23.

Na serra da Ibiapaba, o largo da capela fabricado pelo jesuíta Ascenso Gago originou um espaço ordenado e geométrico. O primeiro assentamento, diante da precariedade material dos gentios e religiosos, não era possível fazer uma igreja grande, e Aldeia em forma, lhes mandamos fazer uma igreja pequena e de pouca dura ${ }^{7}$. Em 1700, quando a redução esteve definitivamente fincada ao chão sob a proteção real, Gago ergueu uma aldeia e Igreja em forma, para a qual se vai tirando a madeira necessária ${ }^{8}$.A forma regular, quadrangular, com preciso zoneamento, garantiu à administração dos inacianos a ordem necessária. Disse Lúcio Costa que, sendo o objetivo da Companhia de Jesus a doutrina e catequese, a igreja devia ser ampla e a fim de abrigar número sempre crescente de convertidos e curiosos e localizada, de preferência, em frente de um espaço aberto - um terreiro - onde o povo pudesse se reunir e andar livremente $(. . .)^{9}$.

\footnotetext{
${ }^{7}$ LEITE, Serafim. História da Companhia de Jesus no Brasil. Tomo III. Livro I. Rio de Janeiro, Instituto Nacional do Livro, 1945. p.57.

${ }^{8}$ LEITE, Serafim. História da Companhia de Jesus no Brasil... Opus cit., p. 61..

${ }^{9}$ COSTA, Lúcio. "A arquitetura jesuítica no Brasil". In Revista do Serviço do Patrimônio Histórico e Artístico Nacional. Vol 5. Rio de Janeiro, MEC, 1941. p. 17.
} 
No Termo de eleição q' fizerão os moradores do certão do Piahui; do lugar, para se fazer Igreja de Nossa Senhora da Victoria, escrito no final do século XVII, os paroquianos da futura vila do Mocha foram orientados pelo bispo de Pernambuco que se fundaçe, e fizeçe a Igreja no Breyo, chamado a Mocha por ser a parte mais conveniente aos Moradores de toda a Povoação, e fincando no meio dela com Iguais distançias, e Caminhos para todos os riachos e partes povoadas, e detriminada a Sobre dita parte, se elegeu para lugar da Igreja e Cazas do Rdo. cura (.... $)^{10}$. Mais adiante, os habitantes presenciaram a sacralização do adro, definindo o espaço pio da povoação: (...) E assim mais Benzeu o Rdo. Vigário hu Adro que de Redor da Cappella conçinou com marcos de Pedra para sepultura dos Deffuntos e lugar donde se ha de fazer a nova Igreja a coal tem sem passos de comprido e sessenta de largo $(\ldots)^{11}$.

O teor das indicações clericais atribui ao largo da primeira paróquia o ponto alto de todo o assentamento piauiense, ou o mais importante dos locais sagrados no que dizia respeito à compreensão e consideração do espaço urbano ${ }^{12}$. A igreja seria fabricada com vinte e coatro palmos de comprido, e doze de largo feita com a decência Poçivel ${ }^{13}$. Destacando-se na paisagem rural da freguesia, o templo religioso se fez poderosamente presente em sua dupla função: religiosa - transmissão dos dogmas da cristandade, revistos pelo Concilio de Trento -, e temporal - centro de arrecadação dos dízimos e exercício da justiça. Ao pároco, portanto, concentraram os papéis de reverendo e administrador local. A provável posição de sua residência - no largo e diante da matriz - inscreve simbolicamente o imparcial diálogo entre Igreja e seus representantes. Ao redor da igreja um vazio, assim, procissões e festa do santo padroeiro eram realizadas sem o bloqueios de elementos arquitetônicos.

A partir do início dos Setecentos leis eclesiásticas foram homologadas com reflexos claros na formação de nossos aglomerados. As Constituiçoens Primeyras do arcebispado da Bahia, como direito canônico, são reconhecidas pelas leis civis e até a tinham como subsidiária $^{14}$. Lembrou Murillo Marx que a configuração da paisagem urbana dos núcleos coloniais e imperiais obedeceu ao cumprimento dessa normativa eclesiástica, com implicações pertinentes e restritivas sobre os vazios urbanos e locais pios ${ }^{15}$. No Quarto livro,

\footnotetext{
${ }^{10}$ ENNES, Ernesto. As guerras nos Palmares. Rio de Janeiro, Companhia Editora Nacional, 1938. p. 364.

${ }^{11}$ ENNES, Ernesto. As guerras nos Palmares...Opus cit., p. 367.

${ }^{12}$ MARX, Murillo. Nosso chão: do sagrado ao profano. São Paulo, Edusp, 1988. p. 121.

${ }^{13}$ ENNES, Ernesto. As guerras nos Palmares..., Opus cit., p. 368.

${ }^{14}$ OLIVEIRA, Miguel de, padre. História eclesiástica de Portugal. Lisboa, União, 1940. p. 172. Apud MARX, Murillo. Nosso chão: do sagrado ao profano..., Opus cit., p. 22.

${ }^{15}$ MARX, Murillo. Cidades no Brasil, terra de quem? São Paulo, Edusp: Nobel, 1991. p. 25.
} 
título 17, constituição 683 , em toda capela e igreja recaem a necessidade simbiótica de um adro:

Conforme o direito Canônico, as igrejas se devem fundar, e edificar em lugares decentes, e acommodados, pelo que mandamos, que havendo-se de edificar de novo alguma igreja parochial em nosso Arcebispado, se edifique em sitio alto, e lugar decente, livre da humanidade, e desviado, quanto dor possível, de lugares immundos, e sórdidos, e de casas particulares, e de outras paredes, em distancia que possão andas as Procissões ao redor dellas, e que se faça em tal proporção, que não somente seja capaz dos fregueses todos, mas ainda de mais gente de fora, quando concorrer ás festas, e se edifique em lugar povoado, onde estiver o maior numero de freguezes. $\mathrm{E}$ quando se houver de fazer, será com licença nossa: e feita vestoria, iremos primeiro, ou outra pessoa de nosso mando, levantar Cruz no lugar, aonde houver de estar a Capella maior, e demarcará o âmbito da Igreja, e adro della ${ }^{16}$.

As ermidas erguidas e as freguesias instituídas na rede urbana do sertão nordestino apresentaram largos definidos e dimensionados segundo a escala apropriada ao lugar, à posição da povoação dentro do sistema, ao número de habitantes e às medidas do chão doado para a planificação do templo. Em decorrência desses fatores, observamos praças maiores nos núcleos que se destacaram na trama regional da pecuária e, para os aglomerados que serviam apenas como passagem ou pouso das boiadas, de menor hierarquia na economia gadeira, um largo com menores dimensões.

Fixada na velha estrada das boiadas, cujo roteiro partia do litoral da Paraíba, até a vila do Mocha, a paróquia de Nossa Senhora do Bom Sucesso, criada em 1721, foi constituída essencialmente de moradores portugueses. Destarte, em 1774, quando é elevada à categoria de vila, recebeu a denominação dos ouvidores da capitania de Pombal, uma "vila de brancos". Na escritura de doação do patrimônio da matriz estiveram presentes, em 1740, os doadores da fatia de terra, Francisco Dias d'Ávila III e sua esposa Catharina Francisca Correia de Aragão, membros do morgadio da Casa da Torre. Encontramos nesse documento as dimensões do chão concedido à freguesia, cem braças de terra principiando das

\footnotetext{
${ }^{16}$ CONSTITUIÇÕES Primeyras do Acerbispado da Bahia feitas, e ordenadas pelo ilustríssimo, e reverendíssimo sernhor D. Sebastião Monteiro da Vide, 5 arcebispo do dito Acerbisopado,e do conselho de sua Majestade: propostas, e aceitas em o Synodo Diocesano, que o dito senhor celebrou em 12 de junho do anno de 1707. Introdução e revisão do cônego prebendano Idelfonso Xavier Ferreira. São Paulo, Typ. 2 de dezembro, 1853. Livro quarto, titulo 17 (683).
} 
ribanceiras do rio Pinhancó para o Nascente (...) das quaes cem braças uniformemente pozerão hua pedra por marco e baliza dahi correndo para a parte Norte (... $)^{17}$. Cem braças em quadra, ou melhor, um terreno quadrado com lados medindo $220 \mathrm{~m}$ foi conferido como terreiro da paróquia [figura 97]. A vizinha povoação de Nossa Senhora da Guia dos Patos, mesmo estando dentro da estrada que conduzia à paróquia de Nossa Senhora do Bom Sucesso, apresentou uma praça com tamanho bem inferior daquela delimitada em Pombal (PB). [figura 98]
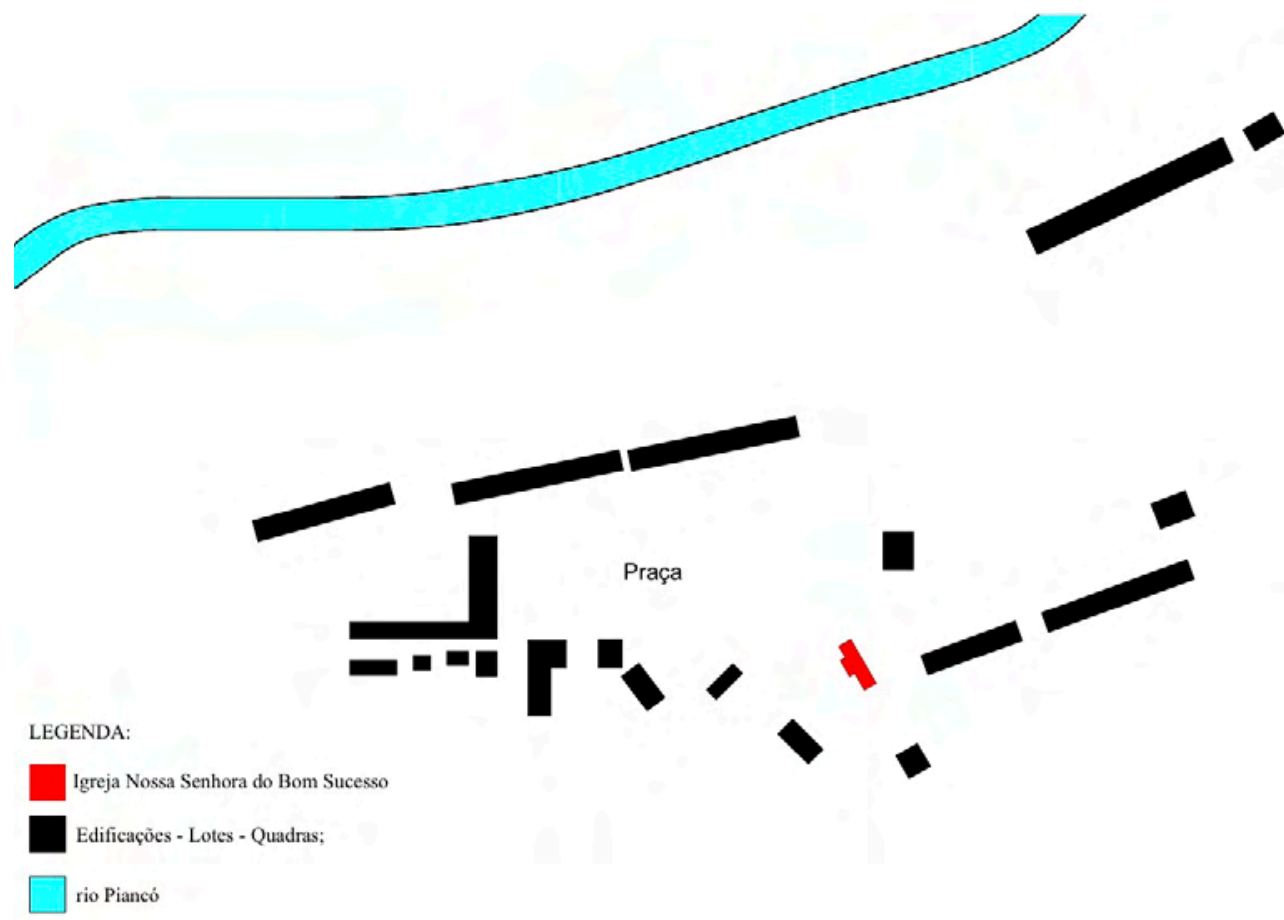

Figura 97 - Pombal - PB. Desenho do autor sobre original do engenheiro Francisco Pereira da Silva. Cartografia cedida pelo AHEx- RJ

17 "ESCRITURA de doação de terras que faz o coronel Francisco Dias d’Ávila e sua mãe, Ignacia de Araújo Pereira, à Igreja Matriz de Nossa Senhora do Bom Sucesso, 03.03.1740". Arquivo do Cartório do $1^{\circ}$ Oficio do Município de Pombal. Livros de Notas. Livro n07. Fl.98 - 99. In SEIXAS, Wilson. O velho arraial de Piranhas (Pombal): no centenário de sua elevação a cidade. 1 ed. João Pessoa, A Imprensa, 1962. p. 44 - 45. 

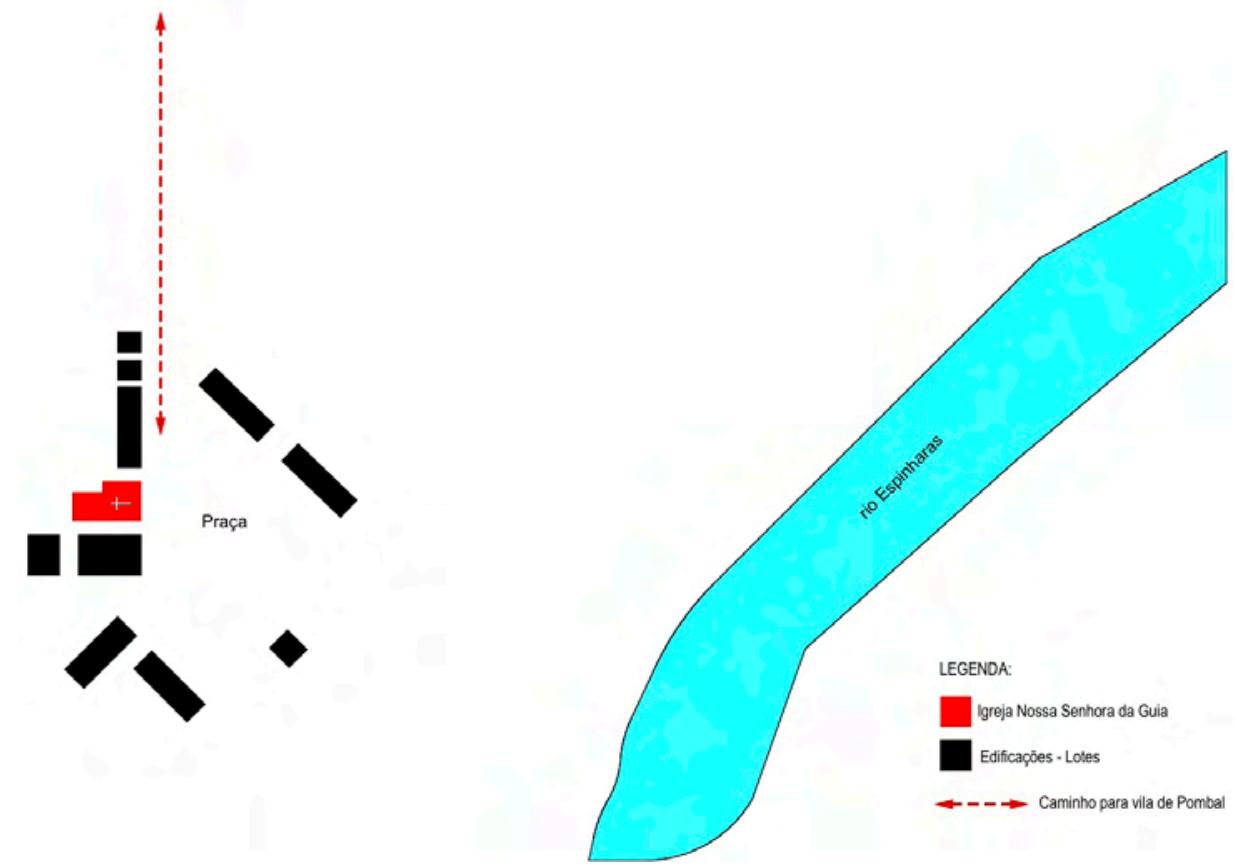

Figura 98 - Freguesia de Nossa Senhora da Guia de Patos. Desenho do autor sobre cartografia cedida pelo AHEx - RJ.

Para demarcação da área doada à igreja, encarregaram as Constituições Primeiras no Livro Quarto, título 17, constituição 688, um provisor, em sua falta tornaria incumbência do vigário geral: (...) quaes adros serão demarcados por nosso Provisor, ou Vigário Geral, como acima fica dito, e os autos desta demarcação se guardarão no nosso Cartório, e o traslado no Cartório de cada uma das Igrejas (... $)^{18}$. Os clérigos controlavam e gerenciavam os dotes fundiários da Igreja, sabiam meticulosamente qual a medida da terra concedido ao santo. Hoje muitos arquivos eclesiásticos contêm documentos esclarecedores de fatos sobre a urbanização de qualquer parte do Brasil colonial.

Paulo F. Santos acentou a cultura urbanística dos Setecentos, expressa nas cartas régias de fundação de vilas, como tendo preocupações consideráveis ${ }^{19}$. O mesmo autor opinou a freqüência dos preceitos, que tratavam da fundação de vilas e cidades, iam passando de umas para outras e constituindo-se em corpo de doutrina ${ }^{20}$. No documento que ordena a criação da vila do Icó (1736) a praça se mostra como elementos basilar à sua fundação: (...) que se erija uma nova vila no Icó junto onde se acha a igreja matriz elegendo-se para ela o sitio que parecer mais saudável e com provimento de água, demarcando-se-lhe logo lugar da

\footnotetext{
${ }^{18}$ CONSTITUIÇÕES Primeyras do Acerbispado da Bahia feitas, e ordenadas pelo ilustríssimo, e reverendíssimo sernhor D. Sebastião Monteiro da Vide..., Opus cit., Livro quarto, título 17 (688).

${ }^{19}$ SANTOS, Paulo F. Formação de cidades no Brasil colonial. Rio de Janeiro, Editora UFRJ, 2001. p. 50.

${ }^{20}$ SANTOS, Paulo F. Formação de cidades no Brasil colonial...Opus cit., p. 50.
} 
praça no meio da qual se levante o pelourinho $(. . .)^{21}$. No casco viejo da atual cidade de Icó (CE) observamos um largo com dimensões avantajadas [figura 99], fluido e capaz de agrupar, já no século XVIII, boa quantidade de fregueses ao grêmio da Igreja.

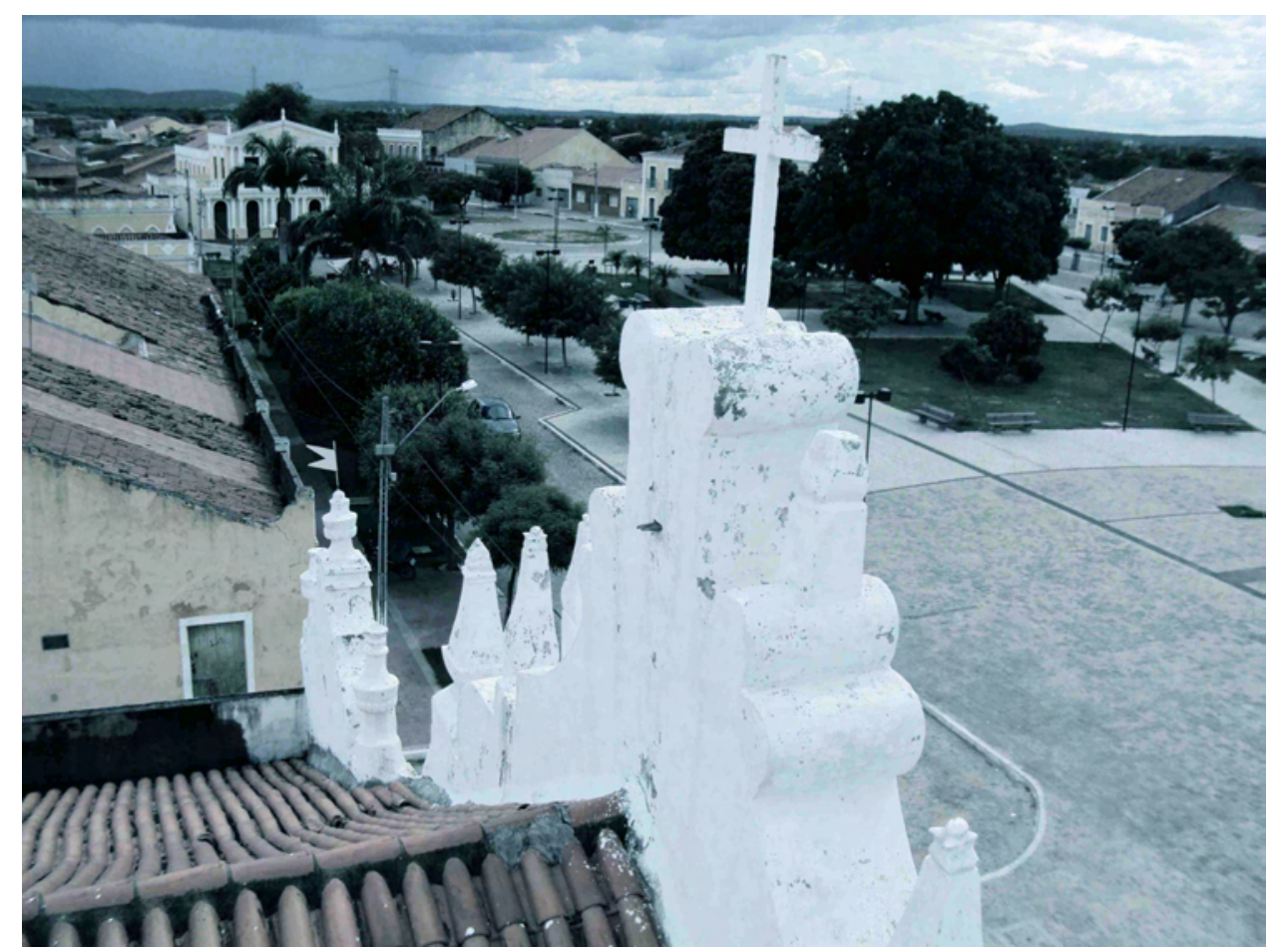

Figura 99 - Praça de Icó - CE, vista desde a matriz de Nossa Senhora da Expectação. Foto do autor, 2010.

A centralidade da praça, em relação aos núcleos nos período joanino, e posteriores a este, surge das idéias do Renascimento. Fundamentos que punham o homem no centro do mundo, fortalecendo sua condição antropocêntrica. Ao largo, como espaço para o exercício de atividades humanas, adiciona-se o simbólico caráter de centro do mundo. Segundo Beatriz Bueno as cartas régias norteadoras da fundação de novos municípios na colônia, ao longo dos Setecentos, o conceito de simetria aparecia não no sentido vitruviano, como relação da proporção entre as partes e o todo, mas como foi definido por Perrault - uma relação especular, eqüidistante dos elementos formais de composição arquitetônica, semelhantes entre si, em relação a um eixo. ${ }^{22}$

É verdade que a administração de Pombal quebrou certos paradigmas impostos à muitas aglomerações coloniais brasileiras. O seu método de fundar vilas seguiu os conceitos da tratadística do Renascimento e filosofia do Iluminismo. Harmonia, simetria, civilização e

\footnotetext{
${ }^{21}$ SANTOS, Paulo F. Formação de cidades no Brasil colonial..., Opus cit., p. 51.

${ }^{22}$ BUENO, Beatriz P. Siqueira. Desenho e desígnio: o Brasil dos engenheiros militares $(1500-1822)$. Tese de doutorado. FAU - USP, 2001. p. 628.
} 
liberdade são dados intrínsecos à fabricação das praças pombalinas e dos elementos que formaram a paisagem urbana das novas vilas.

As vilas piauienses de Parnaguá e Jerumenha, por exemplo, elevadas a este status em 1761, foram alicerçadas no lugar da mesma Freguezia ${ }^{23}$ por ordem de Sua Majestade. Levantaram seus pelourinhos no largo e Prassa mais publica deste mesmo lugar, que de novo passava a ser Villa ${ }^{24}$. Exigiu a doutrina da carta régia que, em um ano, os novos moradores, auxiliados pelos oficiais da câmara, edificassem suas moradias ao menos que pella parte exterior que componha a formosura da terra (... $)^{25}$. A praça e o conjunto arquitetônico idealizados pela Metrópole, fabricariam um corpo, uma unidade, figurariam a formosura da terra.

Raphael Bluteau definiu "formosura" como huma excellencia, que resulta da Symmetria, ou bem ordenada porporção das partes (...) Não porque as partes não tenhã̃ sua formosura particular, mas porque fallamos da fermosura de hum todo perfeyto (...). ${ }^{26}$ À esta definição aliam-se intenções estéticas e sociais. Estéticas porque recuperam a essência da urbe ideal renascentista. As praças agora seguirão formas geométricas definidas a priori, seguindo modelos arquitetônicos e matemáticos uniformes ${ }^{27}$. Adaptando às características físicas e culturais do lugar, os assentamentos humanos do século XVIII, na opinião de Fernando Goitia, no pasaron de doctrinas, utopias o ejercicio ideal del intelecto en los países de Europa donde se originaron, tuvieron su campo de realización real en América $(. . .)^{28}$.

Os espaços públicos eram vistos pela política pombalina como lugares de uniformidade civil, sociedade organizada, em que se tomam as decisões políticas com efeitos duradouros e longínquos ${ }^{29}$. O apuro pretendido para a sociedade colonial representaria o nível de civilidade dos seus habitantes, os princípios de simetria, harmonia e formosura também estão associados à comodidade pública, política e cultural $^{30}$.

\footnotetext{
${ }^{23}$ PROJETO RESGATE. AHU_ACL_CU_018,CX. 8, D. 507.

${ }^{24}$ PROJETO RESGATE. AHU_ACL_CU_018, Cx. 8, D. 507.

${ }^{25}$ PROJETO RESGATE. AHU_ACL_CU_018, Cx. 8, D. 507

${ }^{26}$ BLUTEAU, Raphael, S. J. Vocabulário português, e latino...Coimbra, Real Collegio das Artes da Companhia de Jesus, 1712 - 1719. Disponível em http://www.ieb.usp.br. Acesso em 26. 10. 2011

${ }^{27}$ TEIXEIRA, Manuel C. "As praças urbanas portuguesas quinhentistas". In A praça na cidade portuguesa. Manuel C. Teixeira (org.). Lisboa, Livros Horizonte, 2001. p. 82.

${ }^{28}$ GOITIA, Fernando Chueca. Breve historia del urbanismo. Madrid, Alianza Editorial S.A, 1968. p. 126 - 127.

${ }^{29}$ ARGAN, Giulio Carlo. História da arte como história da cidade. 5 ed. São Paulo, Martins Fontes, 2005. p. 113.

${ }^{30}$ BUENO, Beatriz P. Siqueira. Desenho e desígnio: o Brasil dos engenheiros...Opus cit., p. 629.
} 
Dom José I aspirou para Oeiras (PI), agora como cidade, reformular sua paisagem urbana. Na carta régia que elevou a vila do Mocha à condição de cidade, os conceitos de formosura e uniformidade persistem e são indicados como diretrizes para a fundação da aglomeração piauiense: convocareis todos para determinados dias, nos quaes sendo presente o povo, determineis o lugar mais apropriado para servir de praça $(. . .)^{31}$. Estrutura-se o corpo da cidade ao redor do largo [figura 100], embrião do núcleo urbano. Circundando o vazio da praça, os moradores são ordenados de que as ditas cazas sejão sempre fabricadas na mesma figura uniforme pella parte exterior $(\ldots)^{32}$. Fábrica, no sentido aqui aplicado, segue a definição do seu verbete segundo Bluteau, ou seja, uma composição ${ }^{33}$.

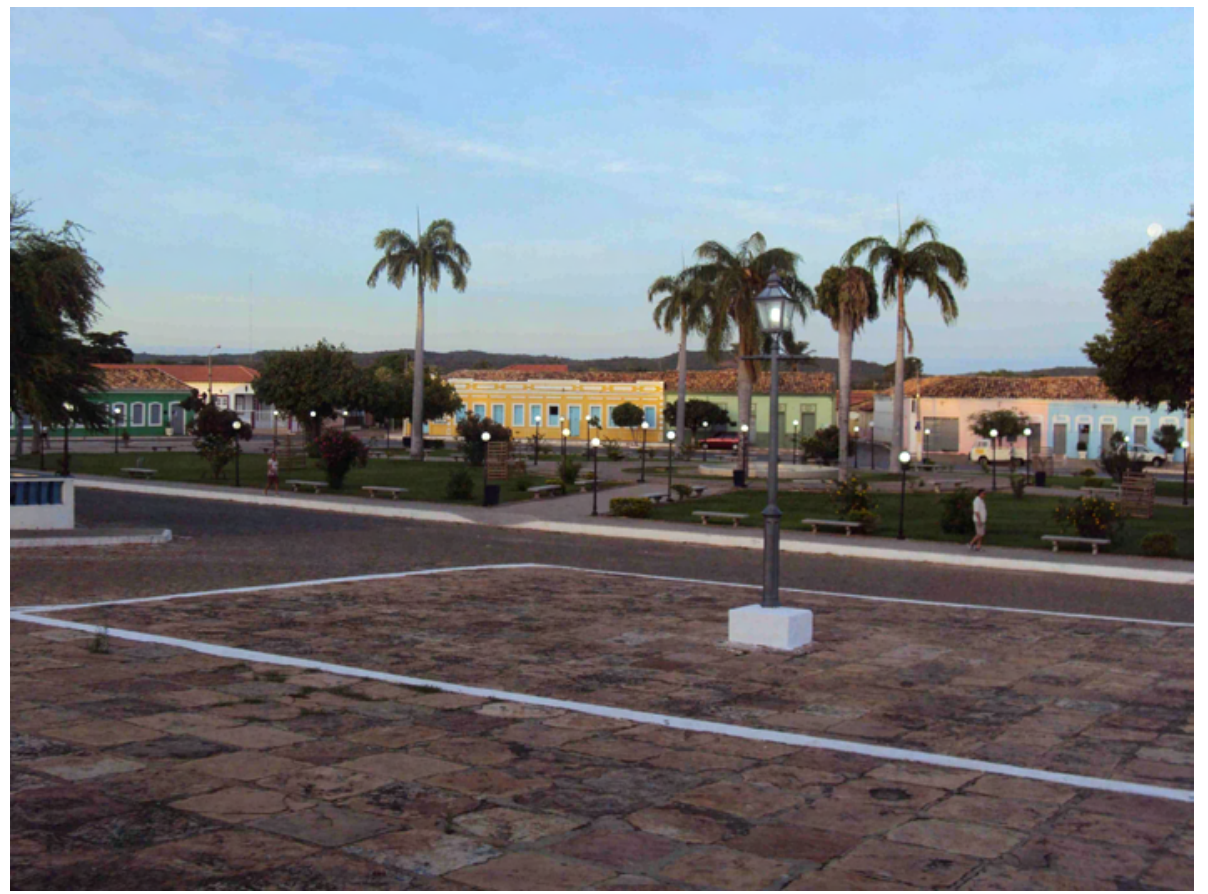

Figura 100 - Praça atual de Oeiras - PI. Ao fundo as moradias que circundam este vazio urbano. Foto do autor, 2010.

A legislação pombalina preconizou a incorporação do indígena, supostamente livre, à sociedade. O Diretório dos Índios, documento que associou a cristianização pregadas pelos missionários como barbaridade, viu como saída para os silvícolas a civilização através do comércio, agricultura, contato social com outros portugueses e ensino do português como língua oficial. A praça foi considerada o lugar de expressão do ideal de civilidade dentro dos

\footnotetext{
${ }^{31}$ PROJETO RESGATE. AHU_ACL_CU_018, Cx. 8, D. 450.

32 PROJETO RESGATE. AHU_ACL_CU_018, Cx. 8, D. 450.

${ }^{33}$ BLUTEAU, Raphael, S. J. Vocabulário português, e latino...Opus cit. Disponível em http://www.ieb.usp.br. Acesso em 26. 10. 2011.
} 
moldes iluministas, isto é, como definiu Renata Araújo espaço submetido a racionalização do homem, ao seu uso e fomento em proveito da 'felicidade pública',34.

Uma das vilas mais conhecidas entre os especialistas do tema se trata da cearense Monte - Mor o Novo da América, antes missão da Palma. O Termo da Demarcação e Assignação do Terreno $^{35}$ sublinhou a presença do engenheiro Custódio Francisco de Azevedo. Para os trabalhos foi auxiliado com os instrumentos de desenho prancheta ou círculo dimensório (...) com corda já encerada e capaz de medir qualquer terra com dez braças de comprido (... $)^{36}$. Dentro de um paralelogramo de 165 braças de comprimento por 135 braças de largura planificaram a praça para a dita nova Villa (...) dando-lhe pelo mesmo rumo do comprimento 80 braças e pello rumo da largura 45 fazendo a sobredita figura $(. . .)^{37}$.

Tangenciando o largo e nas ruas a serem demarcadas fundariam 154 moradas de casas com 30 palmos de frente e de fundo. Do centro da povoação, sairíam quatro ruas com 40 palmos de largura. Funcionando como eixo de simetria, a rua principal partiria da praça com 85 palmos de largura. Casa de câmara e cadeia e outros edifícios públicos seriam edificados em lotes institucionais com 60 palmos de largo e comprido, duas vezes maiores que os terrenos destinados às residências unifamiliares. Interpretamos os Autos de ereção da vila Monte-Mor o Novo da América e desenvolvemos a figura 101. Ordem, hierarquia, harmonia e composição formal foram algumas recomendações de desenho à criação da vila. Cumprí-los ou não couberam aos responsáveis do governo e daqueles que executariam as indicações do documento oficial.

\footnotetext{
${ }^{34}$ ARAÚJO, Renata Malcher de. "Engenharia miltar e urbanismo". In MOREIRA, Rafael (dir.). História das fortificações portuguesas no mundo. Lisboa, Alfa, 1989. Vol II. p. 269.

35 “TERMO da Demarcação e Assignação do Terreno”. In Revista do Instituto do Ceará. Fortaleza, 1891. p. 265.

36 “TERMO da Demarcação e Assignação do Terreno"...Opus cit., p. 265.

37 “TERMO da Demarcação e Assignação do Terreno"...Opus cit., p. 266.
} 


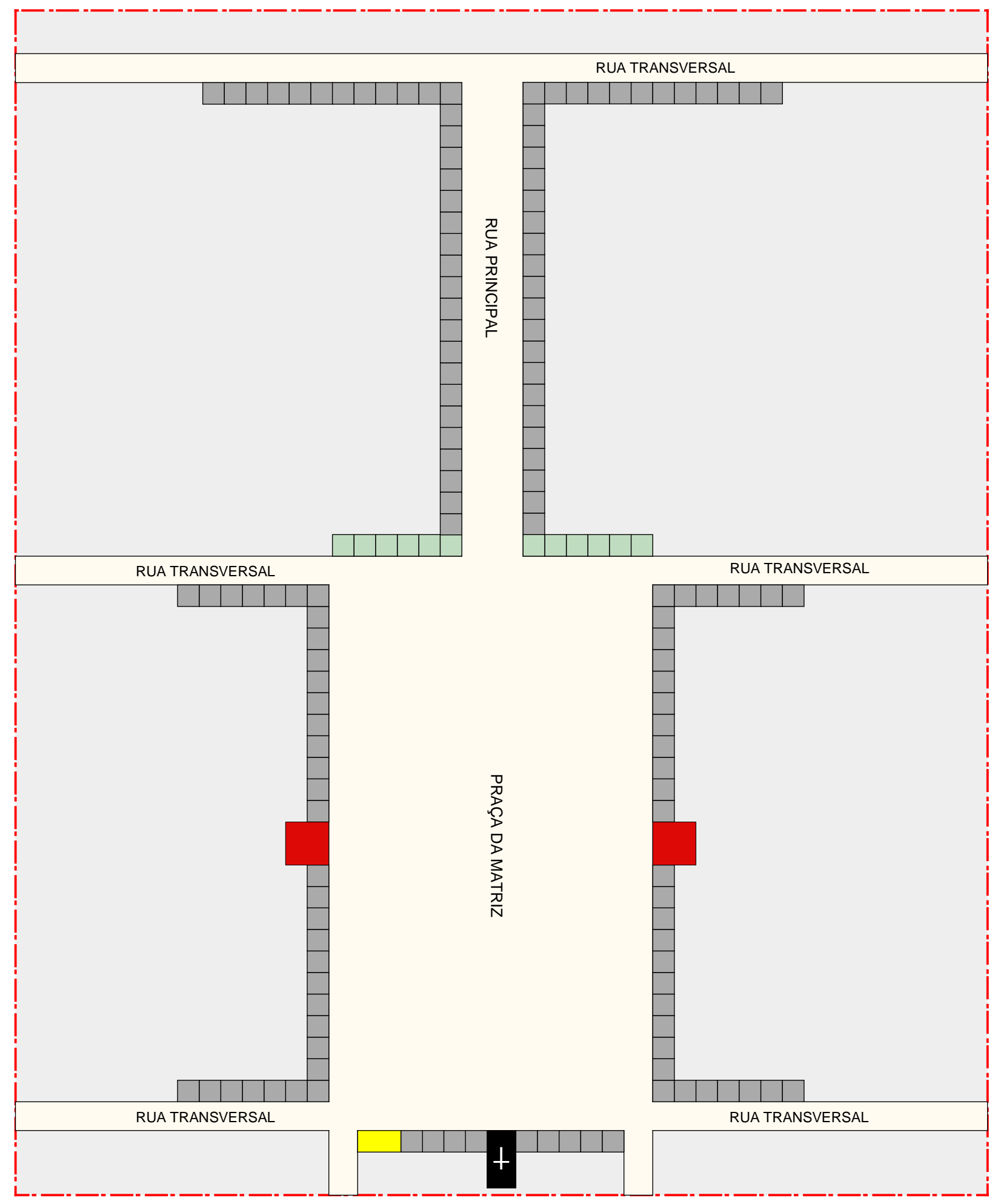

\section{LEGENDA:}

Matriz $(80 \times 40$ palmos $)$

Lotes Institucionais $(60 \times 60$ palmos)

$\square$ Armazém (60 × 30 palmos)

$\square$ Lotes residenciais ( $30 \times 30$ palmos)

$\square$ Lotes para comboeiros (30 30 palmos)

[.] Área para nova vila ( $165 \times 135$ braças)

TOTAL: 154 moradias, porém para esta

vila foram contruídas 156 habitações.

NOTA: 1 braça $=2,20$ metros;
Figura 101 - Planta da vila de Monte - Mor o Novo da América. Interpretação gráfica do autor segundo o "REGISTRO dos Autos da erecção da real villa de Montemor o Novo da América, na capitania do Ceara Grande. Termo da Demarcação e Assignação do Terreno". In Revista do Instituto do Ceará. Fortaleza, 1891. p. 265 - 267. 
Vila Real do Crato, ereta em 1764, antes missão capuchinha chamada Miranda, edificada segundo as prerrogativas do Diretório dos Índios, teve o desenho de sua praça como base para eventual expansão do núcleo. Na fonte primária - Creação da Villa do Crato $^{38}$ - foi apontada a praça regulada pela igreja $q$ ' nella existe arruinada $(. . .)^{39}$. Destinaram como rossio do aglomerado uma área de 300 braças de cada lado, no centro um quadrilaptero ou praça de 30 braças de cada lado (... $)^{40} .40$ palmos de largura para as ruas, ordenando as casas, sem exceção sejam por um padrão que lhes forneceará o ministro Ouvidor (... $)^{41}$. A dimensão das ruas acompanhou o mesmo padrão das de Monte - Mor o Novo da América. As velhas fotografias cristalizaram este panorama urbano proposto pelas recomendações setecentistas. Nelas visualizamos o quadrado da matriz de Nossa Senhora da Penha de França da vila do Crato [figura 102].

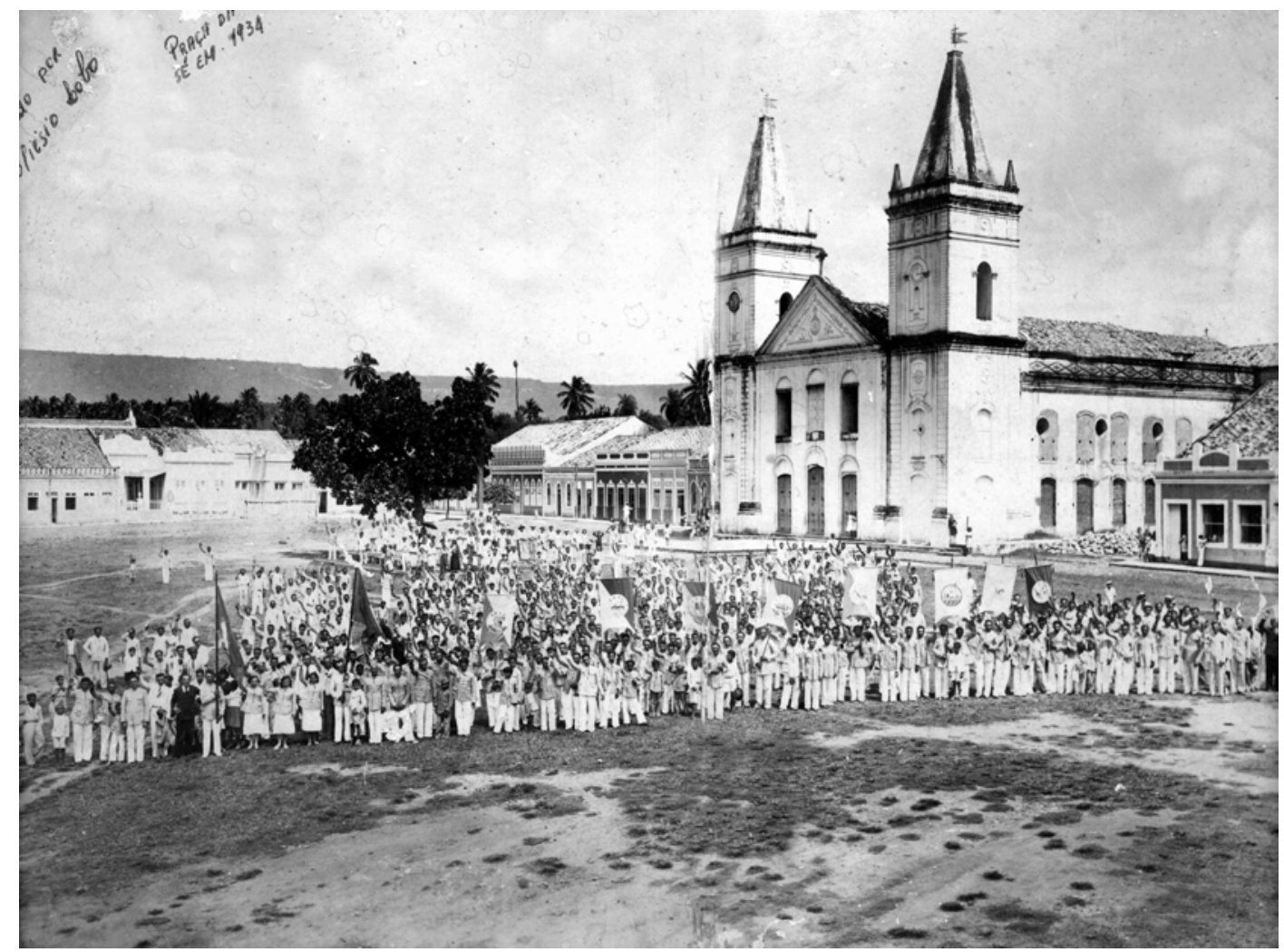

Figura 102 - Cidade do Crato - CE, provavelmente por volta da década de trinta do século passado. Vê-se o quadrado da matriz ou praça do aglomerado. Ao centro como balizador hierárquico a igreja. Foto cedida pelo Arquivo Hisórico da Diocese do Crato.

\footnotetext{
38 “CREAÇÃO da Villa do Crato, 14 de junho de 1764”. In FEITOSA, Carlos. As gentes dos Inhamuns na criação da Real Vila do Crato. Crato. p. 14 - 26.

39 “CREAÇÃO da Villa do Crato, 14 de junho de 1764”...Opus cit., p. 18.

40 “CREAÇÃO da Villa do Crato, 14 de junho de 1764”...Opus cit., p. 18.

41 “CREAÇÃO da Villa do Crato, 14 de junho de 1764”...Opus cit., p. 24.
} 
A raíz do racionalismo das traças urbanas de algumas povoações do sertão nordestino, estabelecidas no período pombalino, deve aos trabalhos teóricos dos engenheiros militares portugueses. Luís Serrão Pimentel se destacou com as suas lições do Methodo Lusitanico de desenhar as fortificaçoens das praças regulares e irregulares... $(1680)^{42}$, pregadas tanto no Reino como no território das conquistas ${ }^{43}$. Nosso interesse volta-se para o capítulo XI, Das partes interiores da Fortaleza, Cidade, ou Villas fortificadas. Dizia o método: primeiramente no centro da fortaleza, ou povoação se deve deixar hu terreiro, ou praça grande que deve ser a principal das armas $^{44}$. Os largos de Monte-Mor o Novo da América e vila Real do Crato, e de outros núcleos criados no século XVIII, eram como o "coração da povoação", ponto de condução e orientação para as ruas a serem delimitadas. É o núcleo gerador, elemento estruturador da forma intraurbana. Com forma geométrica regular, a praça foi o embrião em seu caráter intimo e individual ${ }^{45}$.

Maria Helena Ochi Flexor analisou o papel dos governadores, ouvidores, juízes de fora, ajudantes de ordens, bispos e outros atores coloniais na criação de vilas ao longo do reinado de D. José $\mathrm{I}^{46}$. Seguiram critérios regularizadores e claramente explicitados para o reordenamento dos núcleos ou para a fundação de novos ${ }^{47}$. Na capitania de São José do Piauí, o governador João Pereira Caldas desenvolveu uma povoação de índios jaicós na observância das Ordens de Sua Magestade que no Directorio athé permite estabeleceremse em semelhante Povoação(...). ${ }^{48}$

O sucessor de João Pereira Caldas, Gonçalo Lourenço Botelho de Castro, fundou em 1773, a missão dos índios Acaroás, nomeando-a de São Gonçalo do Amarante, onde pessoalmente foi fazer-lhes a divizão do terreno para Igreja, e cazas de suas habitaçoens (tudo regulado por huma planta o fiz para ficar com armonia e em boa ordem este estabelecimento $)^{49}$. São João de Sende foi outro assentamento de índios criado por Gonçalo de Castro. Em novembro de 1773, quando rumava para São Gonçalo do Amarante, fuy

\footnotetext{
42 "METHODO Lusitanico de desenhar as fortificaçoens das praças regulares e irregulares ...". in BUENO, Beatriz P. Siqueira. Desenho e desígnio: o Brasil dos engenheiros...Anexo III.

${ }^{43}$ BUENO, Beatriz P. Siqueira. Desenho e desígnio: o Brasil dos engenheiros...Opus cit., p. 637.

44 "METHODO Lusitanico de desenhar as fortificaçoens das praças regulares e irregulares ...". in BUENO, Beatriz P. Siqueira. Desenho e desígnio: o Brasil dos engenheiros...Opus cit., p. 319.

${ }^{45}$ CORREA, Antonio Bonet. El urbanismo en España e hispanoamerica. Madrid, Ediciones Cátedra, 1991. p. 178.

${ }^{46}$ FLEXOR, Maria Helena Ochi. "Cidades e vilas pombalinas no Brasil do século XVIII". In Universos Urbanístico português, 1415 - 1822. Lisboa, Comissão Nacional para as comemorações dos Descobrimentos Portugueses, 1998. p. 261.

${ }^{47}$ MARX, Murillo. Cidade no Brasil, em que termos? São Paulo, Studio Nobel, 1999. p. 84.

${ }^{48}$ PROJETO RESGATE. AHU_ACL_CU_016, Cx. 10, D. 589.

${ }^{49}$ PROJETO RESGATE. AHU_ACL_CU_016, Cx. 12, D. 710.
} 
servido vizitar esta Aldeya passando pela de São João de Sende, e levei plano para a boa regularidade da Povoação $(. . .)^{50}$.

Em 1809, o governador do Piauí, Carlos Cezar Burlamaqui, encomendou a Joze Pedro Cezar de Menezes a elaboração da planta do assentamento de índios de São Gonçalo do Amarante [figura 103]. A grande praça, ou o terreno da igreja, teve forma regular, em figura quadrangular. O templo católico evidencia-se no aglomerado, fixa-se no centro de um dos lados do átrio. Ao seu redor, as casas dos nativos. Outras foram alicerçadas ao longo de caminhos que levam para variadas partes da capitania e de outras regiões do Nordeste. Apesar dos ideais de comodidade pública para os aldeados em São Gonçalo do Amarante, sua realidade foi outra. Spix e Martius comentaram sobre seu estado físico no início dos Oitocentos. Chegando na Serra de São Gonçalo, do outro lado dessa serra, fomos dar com o pequeno arraial do mesmo nome, um quadrado de palhoças baixas em volta de uma capela em ruína, e sede de uma colônia de índios (...) segundo nota o vigário, constava apenas de umas 120 pessoas $(. . .)^{51}$.

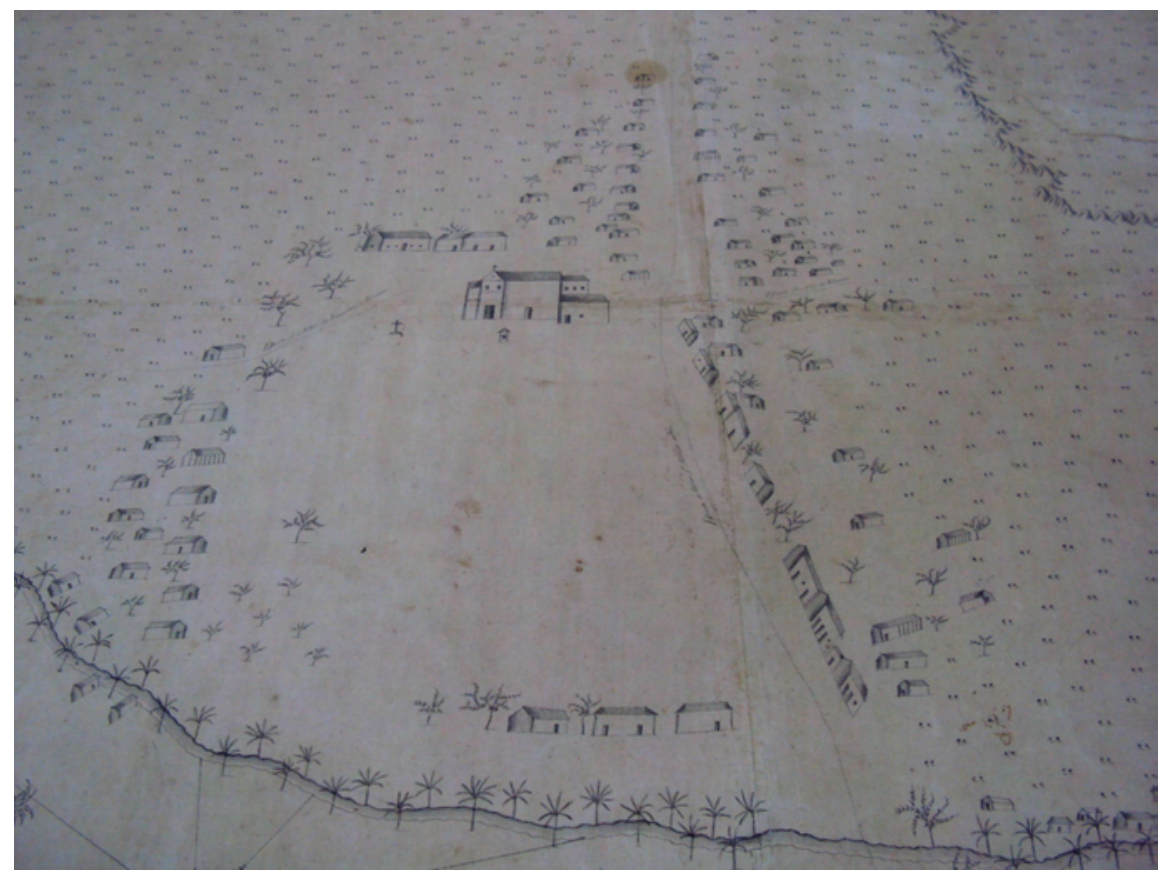

Figura 103 - Planta da Aldeia de S. Gonçalo dos Indios, mandada levantar pelo Ilmo. Snr. Gov. Carlos Cezar Burlamaqui, na Cap. De S. Joze do Piauhi, por Joze Pedro Cezar de Menezes. Vista da parte do Sul. 1809. Original no AHEx - RJ.

\footnotetext{
${ }^{50}$ PROJETO RESGATE. AHU_ACL_CU_016, Cx. 12, D. 711.

${ }^{51}$ SPIX, J.B Von; MARTIUS, C.P.F. Viagem pelo Brasil: 1817 - 1820. 3 v. São Paulo, Edusp, 1981. p. 247 248.
} 
As vilas e povoações sertanejas, ao longo dos mandatos reais de D. José I, Dona Maria I e Dom João VI, foram lugares para recolhimento dos vadios, malfeitores $e$ vagabundos que infestam o paiz com roubos, assassínios e toda a qualidade de crimes atrozes $(\ldots)^{52}$. Almejou a Coroa fixar o homem em núcleos povoados para adaptá-lo ao meio social. A praça, como espaço de congregação, favoreceu as trocas culturais e aceitação do sistema de viver $^{53}$, isto é, submissão aos oficiais da câmara ou diretores (em caso de aglomerados de índios), aos governadores, ao rei como autoridade máxima, à Igreja e às leis coloniais, muitas vezes desconhecidas e impraticadas.

Nas cartas régias que elevam freguesias à condição de vila, entre os anos de 1777 _ 1808, observamos a redução da especulação estética. Ausentam-se os termos formosura e uniformidade, persiste a linha reta, empregam o termo alinhamento: (...) foi dito aos Officiais que elle consinava para Territorio desta Villa o mesmo espaço do terreno que the agora servia de Povoação de Nossa Senhora do Rozario das Rusias dentro do qual poderião os novos agregados a ella edificarem suas cazas no alinhamento ${ }^{54}$ [grifo nosso].

Alinhar denotaria tirar a cordel, dispor em linha recta (...) lançamento recto ${ }^{55}$. Onde alinhar? Ao redor das praças - área urbana destinada às residências dos "homens - bons" e dos principais do termo da vila -, e ao longo das ruas. Murillo Marx argumentou que desde muito cedo o ato de dispor em linha recta foi objeto de atenção dos vereadores das câmaras, atenção com a forma urbana de suas sedes e aqueles aglomerados localizados em seu termo ${ }^{56}$. Apontou Murillo Marx o trabalho da edilidade na evolução urbana dos municípios:

O cuidado com o alinhamento e com o nivelamento persiste no pequeno rol das atenção das câmaras municipais, no que diz respeito à configuração do espaço urbano em geral, ao traçado viário e à disciplina devida pelos concessionários de data. Lentamente, esse cuidado cresce com a expansão de determinadas vilas e cidades e com uma vida mais intensa. Timidamente, os edis fazem observar ou corrigir desvios ou abusos, referidos com alguma constância ao longo dos tempos, votam novas posturas a respeito e, muito

\footnotetext{
52 PERDIGÃO, J. Batista de Oliveira. "A Villa de Quixeramombim”. In Revista do Instituto do Ceará. Anno IV. Fortaleza, 1890. p. 273.

${ }^{53}$ PROJETO RESGATE. AHU_ACL_CU_014,Cx. 41, D. 2853.

54 “AUTO da creação da Villa de S. Bernardo do Governador”. In Revista do Instituto do Ceará. Anno XX. Fortaleza, 1906. p. 245.

${ }^{55}$ MARX, Murillo. Cidade no Brasil, em que termos?..., Opus cit., p. 75.

${ }^{56}$ MARX, Murillo. Cidade no Brasil, em que termos?..., Opus cit., p. 76.
} 
esporadicamente, antevêm a necessidade dessa linha, ou de por logo "na linha" uma nova rua. ${ }^{57}$

Alinhadas ao longo da praça, as residências da vila de São Bernardo do Governador impressionaram o inglês George Gardner. Ao avistar o assentamento, provavelmente por volta de 1838 , viu...

(...) a pequena vila chamada S. Bernardo, a dez léguas de Aracati. É construída em forma de quadrado, sendo o lado ocidental ocupado principalmente por uma bela igreja, a qual, erguida em uma vargem ornada de um ou outro Zizyphus (juazeiro) frondoso e palmeiras de carnaúba no meio das casinhas brancas, apresenta de longe imponente aspecto. ${ }^{58}$

As praças quer originária de ordens pias, quer elaboradas por ordens oficiais, com desenho regular, foram as células estruturadoras de muitas povoações sertanejas. Entretanto, outro aspecto central na urbanização do sertão nordestino remete ao surgimento de caminhos do gado que "irrigaram" todo o Nordeste, unindo-o à outras regiões da colônia. Aqueles arraiais situados na intricada rede viária desenvolveram um desenho tradicional - "povoação - rua" - aglomerado de forma linear, longilíneo, resultado da simbiose entre caminhos $\mathrm{x}$ curral de reses. Já outros mesclam a dualidade praça x via terrestre, conferindo um desenho híbrido, um mix de ambos.

\footnotetext{
${ }^{57}$ MARX, Murillo. Cidade no Brasil, em que termos?..., Opus cit., p. 77.

${ }^{58}$ GARDNER, George. Viagem ao interior do Brasil: principalmente nas províncias do Norte e nos distritos do ouro e diamante durante os anos de 1836 - 1841. Belo Horizonte, Itatiaia, 1975. p. 83.
} 


\subsection{Os caminhos do gado e a formação intraurbana de aglomerados do sertão nordestino}

Pierre Deffontaines mencionou que no Nordeste brasileiro, onde as trocas de gado foram mais importantes entre o sertão seco e o estreito litoral úmido, a maioria das aglomerações tiveram origem nos pousos. Classificou-as de cidades nas estradas, por nascerem às margens dos cursos terrestres, numa rede de rodovias que interligou o interior à $\operatorname{costa}^{59}$.

Os portos receberam da caatinga sertaneja carne, couro e gado. As reses eram conduzidas meses a fio, em grandes rebanhos, por estradas cuja toponímia se adéqua à criação de gado. Surgem a estrada real do gado, a estrada das boiadas, o roteiro das boiadas do Recife às minas gerais, entre outras. Criam-se pousos e currais: pastos bons, curral de bois, malhada, curralinho, bezerros, capim grosso, mimoso, numa evidente alusão à pecuária.

Percursos matrizes ou linhas de crescimento ${ }^{60}$, os caminhos do gado no início e as estradas coloniais a posteriori suportaram o crescimento de certos aglomerados e, ao longo deles as moradias se estruturaram. A paisagem foi estabelecida, em alguns casos, num desenho linear, o casario elaborou horizontalidade marcante. Não se trata de um modelo concebido a priori, mas de um processo de adaptação à peculiar urbanização que se encerrou no território sertanejo. Disse Aroldo de Azevedo: (...) os caminhos coloniais constituíram a espinha dorsal da rede urbana, quer se dirigissem do litoral para o sertão do Nordeste ou para a Chapada da Diamantina, quer procurassem atingir as áreas mineradoras de Minas Gerais, Goiás ou Mato Grosso (.... $)^{61}$.

Murillo Marx seguiu o mesmo raciocínio de Azevedo ao atribuir a linearidade como característica tradicional que chegou aos nossos dias ${ }^{62}$. Ainda indicou que, a localização de arraiais nas vias, explorando suas potencialidades comerciais, é uma característica medieval presente na formação de nossos aglomerados humanos ${ }^{63}$.

\footnotetext{
${ }^{59}$ DEFFONTAINES, Pierre. Como se constituiu no Brasil a rede das cidades. Botetim geográfico. № 14 . Rio de Janeiro, Instituto Brasileiro de Geografia e Estatística, 1944. p. 7 - 10.

${ }^{60}$ PANERAI, Phillippe. Elementos de analisis urbano. Madrid: Instituto de Estudios de Administración local, 1983. 280p.

${ }^{61}$ AZEVEDO, Aroldo de. Vilas e cidades do Brasil colonial. Ensaio de geografia urbana retrospectiva. Boletim $\mathrm{n}^{\circ}$ 208. Geografia $\mathrm{n}^{\circ}$ 11. São Paulo, FFLCH, 1956. p. 71.

${ }^{62}$ MARX, Murillo. Cidade brasileira..., Opus cit., p. 27.

${ }^{63}$ MARX, Murillo. Cidade brasileira...,Opus cit., p. 27.
} 
Um parêntese deve ser estabelecido. Segundo Jorge Hardoy, na América espanhola muitas povoações de menor hierarquia cresceram de uma fundação formal, sem ajustar-se à normas de desenho predeterminadas. $\mathrm{O}$ autor acrescentou que o paradigma divulgado por muitos especialistas, acerca das aglomerações hispanoamericanas serem exclusivamente ordenadas, em damero, ou como ele chamou de modelo clássico, tem se tornado um mito no estudo da urbanismo. Assim como no Brasil, surgiram povoações lineares ao longo de caminhos ou em agrupamentos de índios ${ }^{64}$. Uma interessante análise foi proposta por Ramón Gutiérrez quando escreveu que o urbanismo é, portanto, muito mais que uma forma de traçado, e os modos de uso são o caminho essencial para entender a cidade e seus habitantes ${ }^{65}$.

A rede urbana sertaneja, com definições hierárquicas determinadas a partir da economia gadeira - curral de reses - e da evangelização missioneira - curral de almas -, os assentamentos humanos com forma longilínea eram subsidiários àqueles que se destacaram no sistema. Muitos desses "rua-núcleo" obtiveram sua autonomia municiapal somente no Império ou na República. Eram passagens das boiadas, descanso necessário para fazendeiros, vaqueiros e tangedores. Feiras de gado e derivados, realizadas na praça, movimentavam essas pesquenas localidades. Os largos da igreja detiveram as maiores dimensões físicas, em virtude do exercício de atividades sacras e profanas ali acometidas.

Antes de serem vias estáticas, os caminhos do gado ou as estradas coloniais eram espaços dinâmicos, de passagem. Transitavam por elas mascates, vendedores ambulantes de produtos europeus em troca de gados ou cavalos ${ }^{66}$. Sendo a estrada em que viajávamos a que levava ao interior do Ceará, bem como à região central do Piauí, muitos viajantes passavam pelo nosso acampamento. Carros cheios de algodão e couros desciam, enquanto outros, bem como tropas de cavalos, subiam carregados de mercadorias européias e de sal (...) ${ }^{67}$, descreveu o naturalista inglês Gardner sobre a dinâmica comercial das rotas sertanejas.

Alguns nós da teia de arraiais, freguesias e vilas do sertão nordestino estiveram balizados por ermidas ou paróquias. Para chegar à sua edificação, latifundiaristas ou

\footnotetext{
${ }^{64}$ HARDOY, Jorge E. "La forma de las ciudades coloniales en la America española". SOLANO, Francisco (coord.). Estudios sobre la ciudad iberoamericana. Madrid, Consejo Superior de Investigaciones Científicas Instituto Gonzalo Fernandez de Oviedo, 1983. p. 315 - 344.

${ }^{65}$ GUTIÉRREZ, Ramón. "Povoados e reduções indígenas na região de Cuzco: persistências e inovações". In FRIDMAN, Fania; ABREU, Mauricio. Cidades latino-americanas: um debate sobre a formação de núcleos urbanos. Rio de Janeiro, Casa da Palavra, 2010. p. 49.

${ }^{66}$ GARDNER, George. Viagem ao interior do Brasil..., Opus cit., p. 93.

${ }^{67}$ GARDNER, George. Viagem ao interior do Brasil..., Opus cit., p. 84.
} 
arrendatários doaram pequenas parcelas de seus domínios a seu santo de devoção, fenômeno este definido por Pierre Deffontaines como patrimônio religioso ${ }^{68}$, pregado por Murillo Marx em seu Cidades no Brasil, terra de quem? por suas peculiaridades transmitidas ao desenho urbano das povoações coloniais brasileiras.

Em geral um fazendeiro ou grupo destes se desfaziam de "brechas" ou sobras de suas sesmarias para atender à população não possuidora de terra e para valer de sua instalação gregária e consumidora ${ }^{69}$. Ofereciam as terras com intuito de obedecer as Ordenações do Reino, no que tange ao povoamento de áreas isoladas. Cumpriam seu papel de colonizadores e agentes da política portuguesa. O patrimônio religioso, na definição de Murillo Marx, eram porções de terras doadas nominalmente a uma devoção, a um santo padroeiro ${ }^{70}$. Concedia este chão à Igreja para edificação de ermida, administrada por uma entidade autorizada pelo clérigo superior.

As Constituiçoens Primeyras do Arcebispado da Bahia em seu livro Quarto, título 19 (693) ordenaram a ereção de capelas ou igrejas em lugares povoados. ${ }^{71}$ Tal postura garantia a construção e manutenção do templo por parte daqueles interessados em habitar o seu entorno imediato ou cercanias. Através de aforamentos e pagando as devidas tributações $^{72}$, os habitantes conseguiam um lote ou data de terra para edificar suas casas. Gravitando nos limites do adro, estão as moradias dos fazendeiros ou dos principais da região. Seus vizinhos se contentaram com datas situadas ao longo das estradas. Trata-se de um processo acumulativo e de concentração de gente. Marcou a formação da paisagem, preponderantemente rural $^{73}$ dos núcleos do interior do Nordeste como de sua costa atlântica.

\footnotetext{
${ }^{68}$ DEFFONTAINES, Pierre. Como se constituiu no Brasil a rede das cidades...,Opus cit., p. 18 - 22.

${ }^{69}$ MARX, Murillo. Cidades no Brasil, terra de quem? São Paulo, Edusp, 1991. p. 39.

${ }^{70}$ MARX, Murillo. Cidades no Brasil, terra de quem? São Paulo, Edusp, 1991. p. 38.

${ }^{71}$ CONSTITUIÇÕES Primeyras do Acerbispado da Bahia feitas, e ordenadas pelo ilustríssimo, e reverendíssimo sernhor D. Sebastião Monteiro da Vide..., Opus cit., Livro quarto, titulo 19 (693).

${ }^{72}$ Segundo Pierre Deffontaines os proprietários da terra, desejosos de aproveitar das vantagens deste novo agrupamento de casas, obtêm lotes por locação, por arrendamento muito longo por perpetuidade mediante o pagamento de um foro. Os benefícios realizados são destinados à construção da capela, à organização das festas e ao embelezamento do assentamento humano. Ver DEFFONTAINES, Pierre. Como se constituiu no Brasil a rede das cidades...,Opus cit., p. 19. Em consonância, Murillo Marx definiu o foro como um contrato, pelo qual, a exemplo das concessões sesmariais com a obrigação de pagar o dizimo à Ordem de Cristo, obrigava-se o beneficiário a um módico pagamento anual para custeio das despesas do templo. Seria um sistema de pagamento sutil e complexo. Em MARX, Murillo. Cidades no Brasil, terra de quem? São Paulo, Edusp, 1991. p. 44.

${ }^{73}$ MARX, Murillo. Cidades no Brasil, terra de quem?..., Opus cit., p. 41.
} 
A atual cidade de Floresta - PE, instalada no roteiro das boiadas que partiam da cidade de Recife às minas gerais (criado em 1738), se estruturou à sombra da capela dedicada, inicialmente, ao Senhor Bom Jesus dos Aflitos [figura 104]. Chão doado, às margens do rio Pajeú em 02 de Marco de 1778, pelo fazendeiro e capitão José Pereira Maciel, no lugar chamado Fazenda Grande ${ }^{74}$ [figura 105]. Em fins do século XVIII, em virtude de sua estratégica posição diante da via colonial e ao espírito religioso do homem do sertão, migraram para o arraial da Fazenda Grande moradores de outras paragens e dos arredores. Solicitaram datas de terra ao capitão José Maciel, alicençando suas moradias, paralelamente à linha virtual do caminho dos rebanhos. O progresso da pequena povoação, e a pedidos da população residente, mereceu o status de freguesia em 1801, sendo desmembrada da paróquia de Nossa Senhora da Luz de Tacaratú ${ }^{75}$. De arraial da Fazenda Grande para freguesia de Nossa Senhora do Rosário.

A paisagem da nova freguesia criou uma forma longilínea, percebida tanto na apropriação do solo como na horizontalidade das residências [figura 106] expandida segundo sua "espinha dorsal". A linearidade do aglomerado se materializou, de fato, nos Oitocentos [figuras 107 e 108]. Delimita-se no espaço urbano dois vazios de distintos usos. O primeiro, o largo da matriz de caráter sacro [figura 109]. O segundo, cuja toponímia denuncia sua atividade, trata-se da praça do Boiadeiro, lugar para feiras de couro e do gado, sítio para as trocas mercantis. Vale ressaltar a escala obtida pela rua principal do núcleo primitivo de Floresta. Ultilizaram o espaço público homens e manadas (algumas chegaram a transportar mais de 900 reses), por isso, a dimensão física desse eixo se adaptou às necessidades do gado, dos seus criadores e dos habitantes da localidade.

\footnotetext{
${ }^{74}$ FERRAZ, Álvaro. Floresta memórias duma cidade sertaneja no seu cinquentenário. Recife, Secretária de Educação e Cultura, 1957. p. 55.

${ }^{75}$ FERRAZ, Álvaro. Floresta memórias duma cidade sertaneja...Opus cit., p. 57.
} 


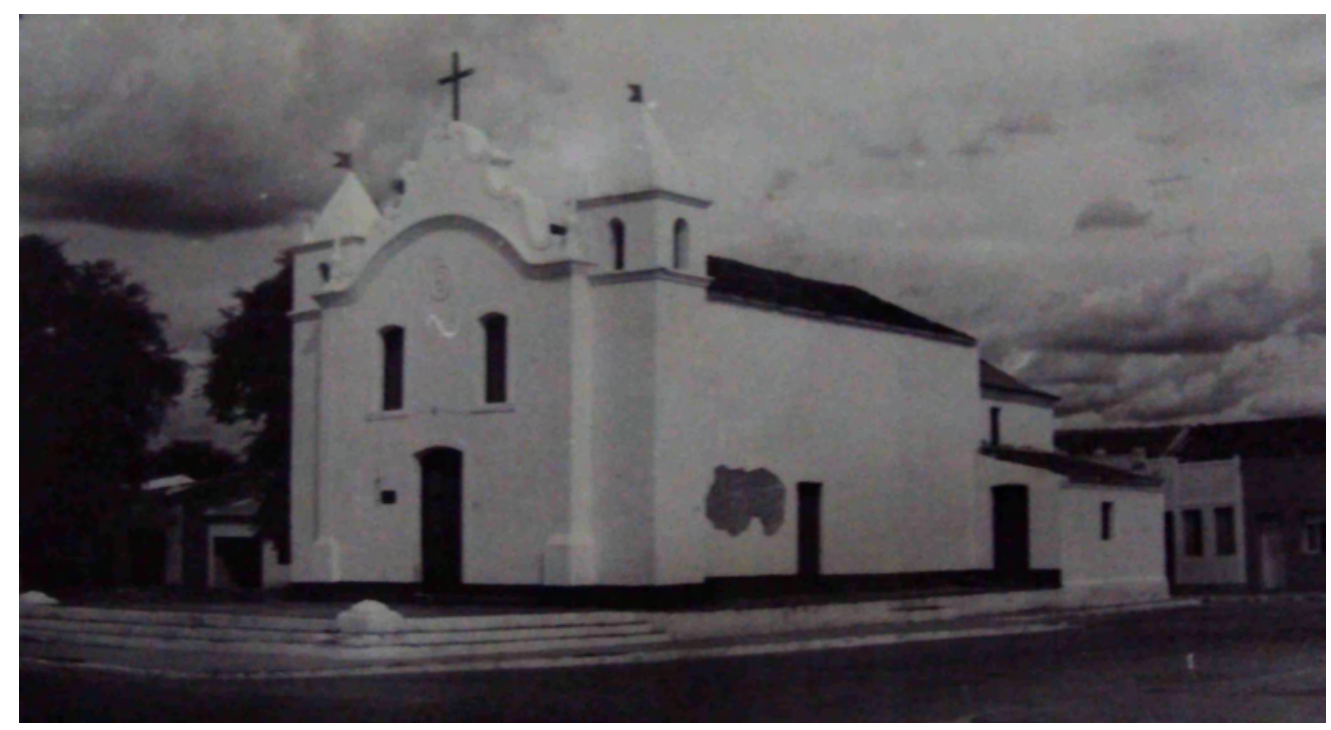

Figura 104 - Capela Nossa Senhora do Rosário, Floresta -PE. Foto cedida pela FUNDARPE - PE.

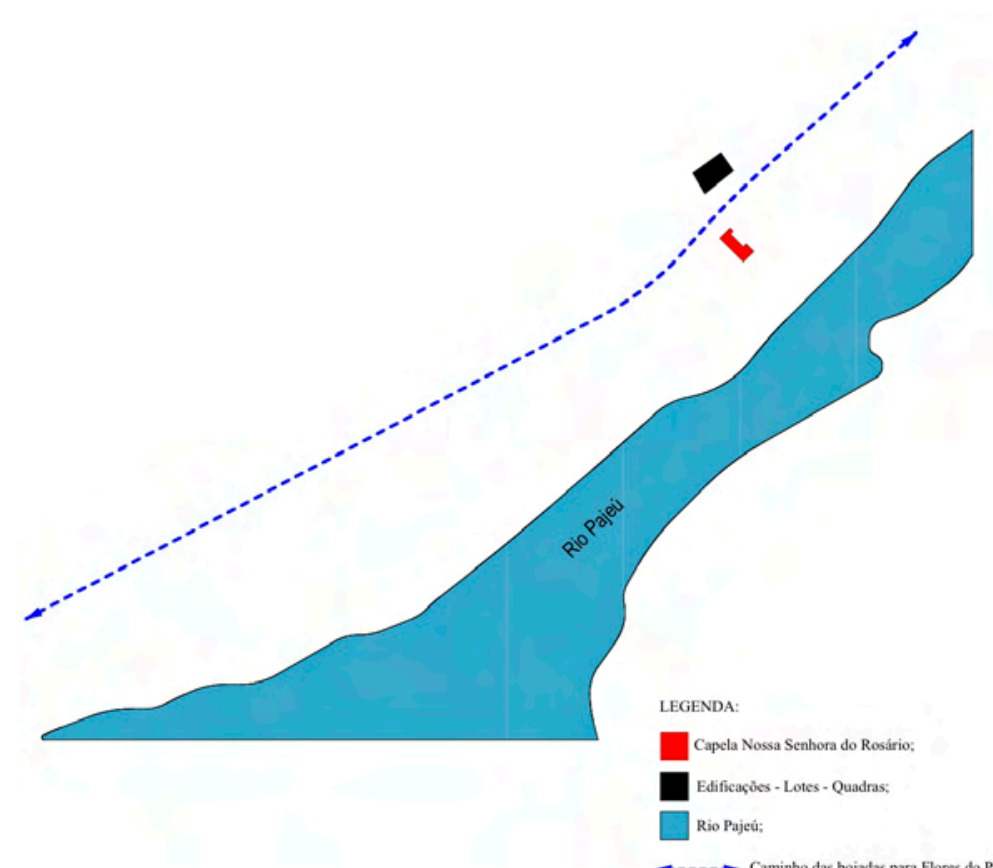

Figura 105 - Núcleo primitivo do arraial da Fazenda Grande. Desenho do autor segundo cartografias e dados obtidos na FUNDARPE - PE.

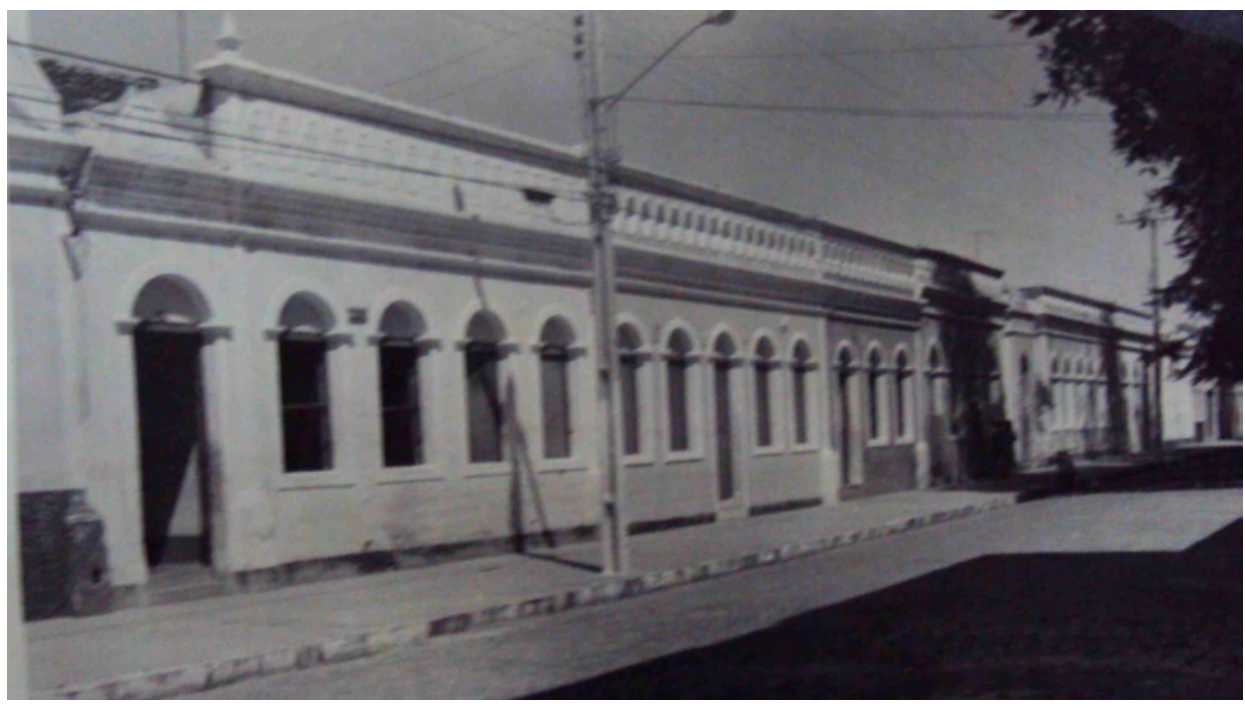

Figura 106 - Horizontalidade das residências da atual cidade de Floresta - PE. Foto cedida pela FUNDARPE - PE. 


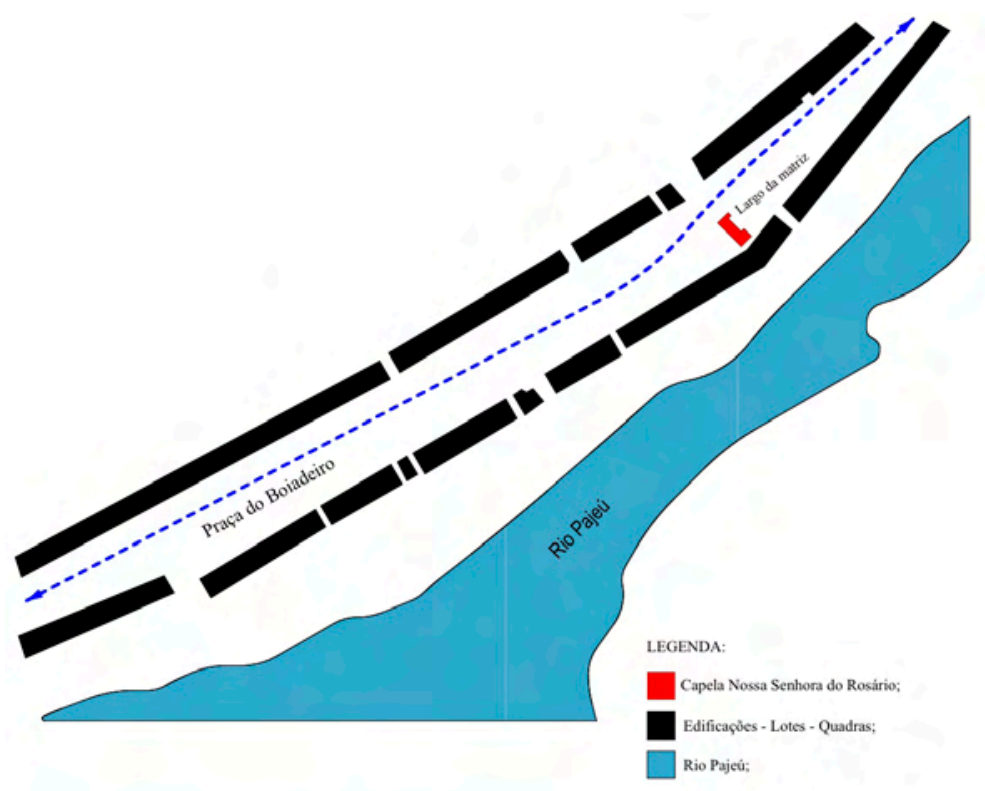

Figura 107 - Freguesia de Nossa Senhora do Rosário de Floresta nos Oitocentos. Desenho do autor segundo cartografias e dados obtidos na FUNDARPE - PE.
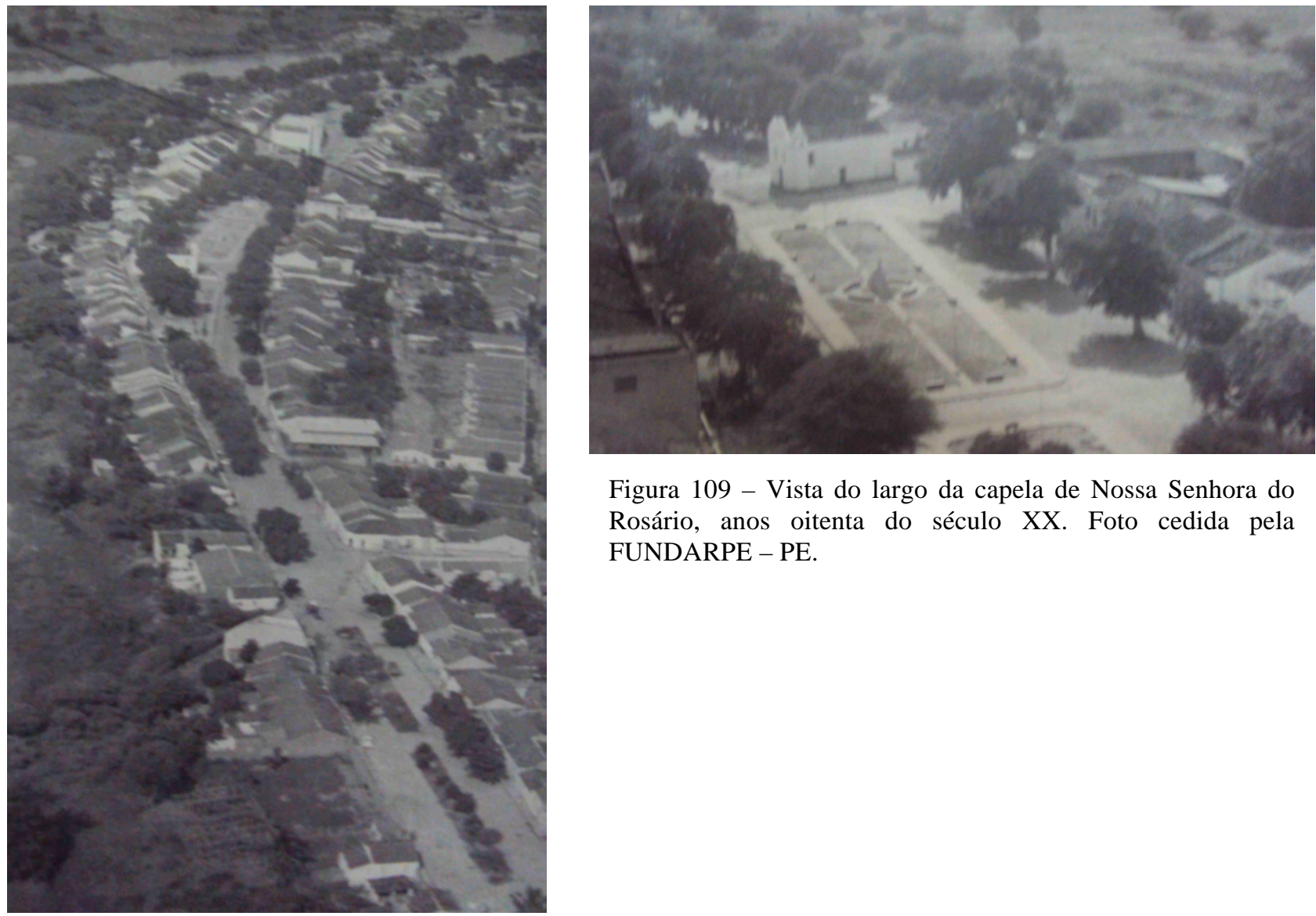

Figura 109 - Vista do largo da capela de Nossa Senhora do Rosário, anos oitenta do século XX. Foto cedida pela FUNDARPE - PE.

Figura 108 - Panorama da cidade de Floresta - PE nos anos oitenta do século XX. Nota-se a linearidade como característica formal deste município. Foto cedida pela FUNDARPE - PE. 
Na mesma estrada onde se fundou o arraial da Fazenda Grande, só que dessa vez mais ao sul, na margem direita do rio São Francisco, encontramos a povoação de Estrema. Mapeada, em 1853, pelo engenheiro Henrique Halfeld em uma viagem de inspeção ao "Velho Chico", patrocinada pelo imperador D. Pedro II. Estrema cresceu linearmente, expandindo-se sobre o território seguindo paralelamente o curso do rio e o caminho que ligou o sertão baiano às minas gerais [figura 110].

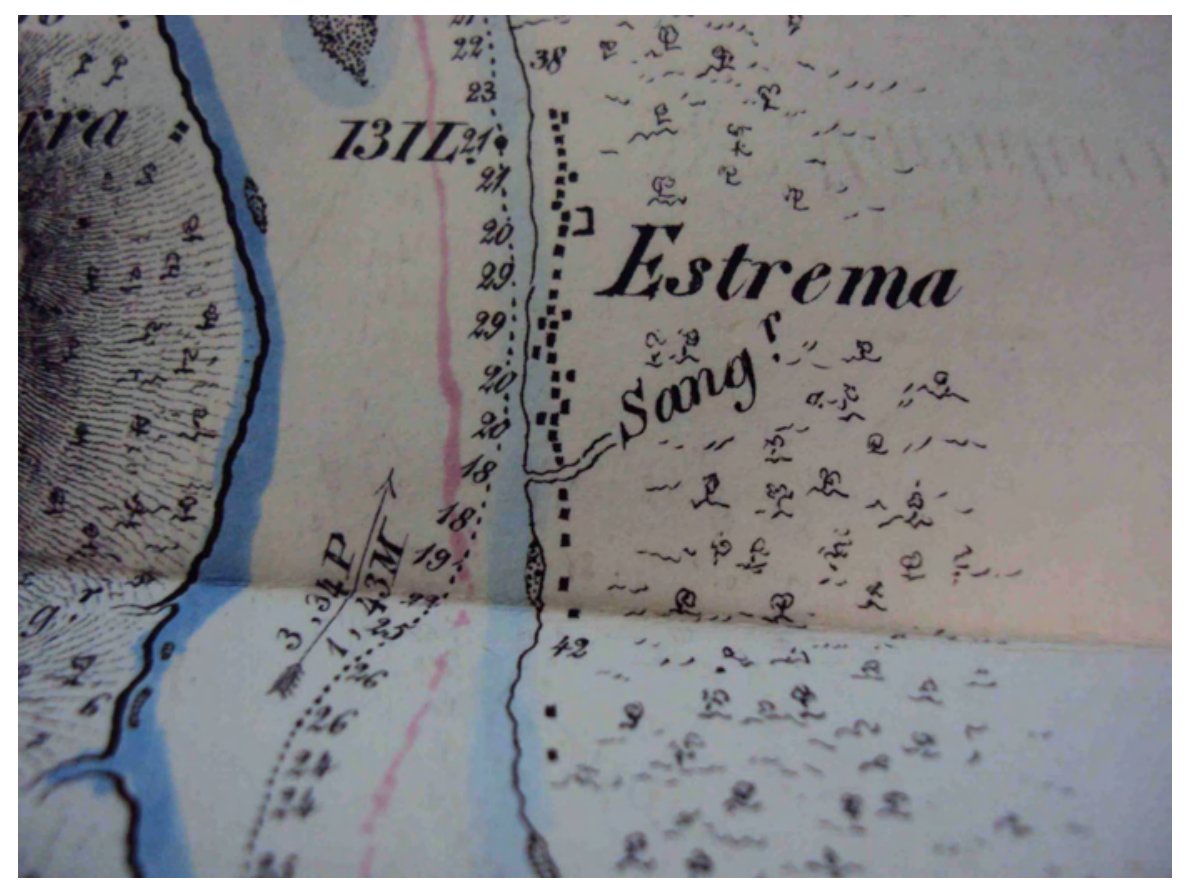

Figura 110 - Aglomerado sertanejo de Estrema. Localizado no sertão baiano, às margens do rio São Francisco. Imagem fac símile encontrada em HALFELD, Henrique Gulherme Fernando. Atlas e relatório concernente a exploração do rio São Francisco desde a cachoeira da Pirapora até o oceano Atlântico. Rio de Janeiro, 1860. Mapa 11.

O mito do ouro, pregado por Belchior Dias Moréia, acelerou a migração de sertanistas para o interior baiano ilusionados em extrair o metal. Os minerais encontrados, em poucas quantidades, eram extraídos ainda no século XIX. Uma das rotas que serviu de trânsito para os garimpeiros seguiu até a vila da Jacobina. Outra foi criada nas beiras do rio de Contas. Nasceram, no sopé da chapada da Diamantina, alguns núcleos urbanos de mineradores. As vias que serviram de passagem para os sertanistas muitos boiadeiros adotaram como canalização das reses ao litoral da Bahia ${ }^{76}$. Entre os assentamentos está a atual cidade de Mucugê - BA [figura 111], cuja paisagem urbana entrou no rol das urbes preservadas pelo IPHAN.

\footnotetext{
${ }^{76}$ VIANA, Urbino. Bandeiras e sertanistas baianos. São Paulo, Companhia Editora Nacional, 1935.p. 125.
} 


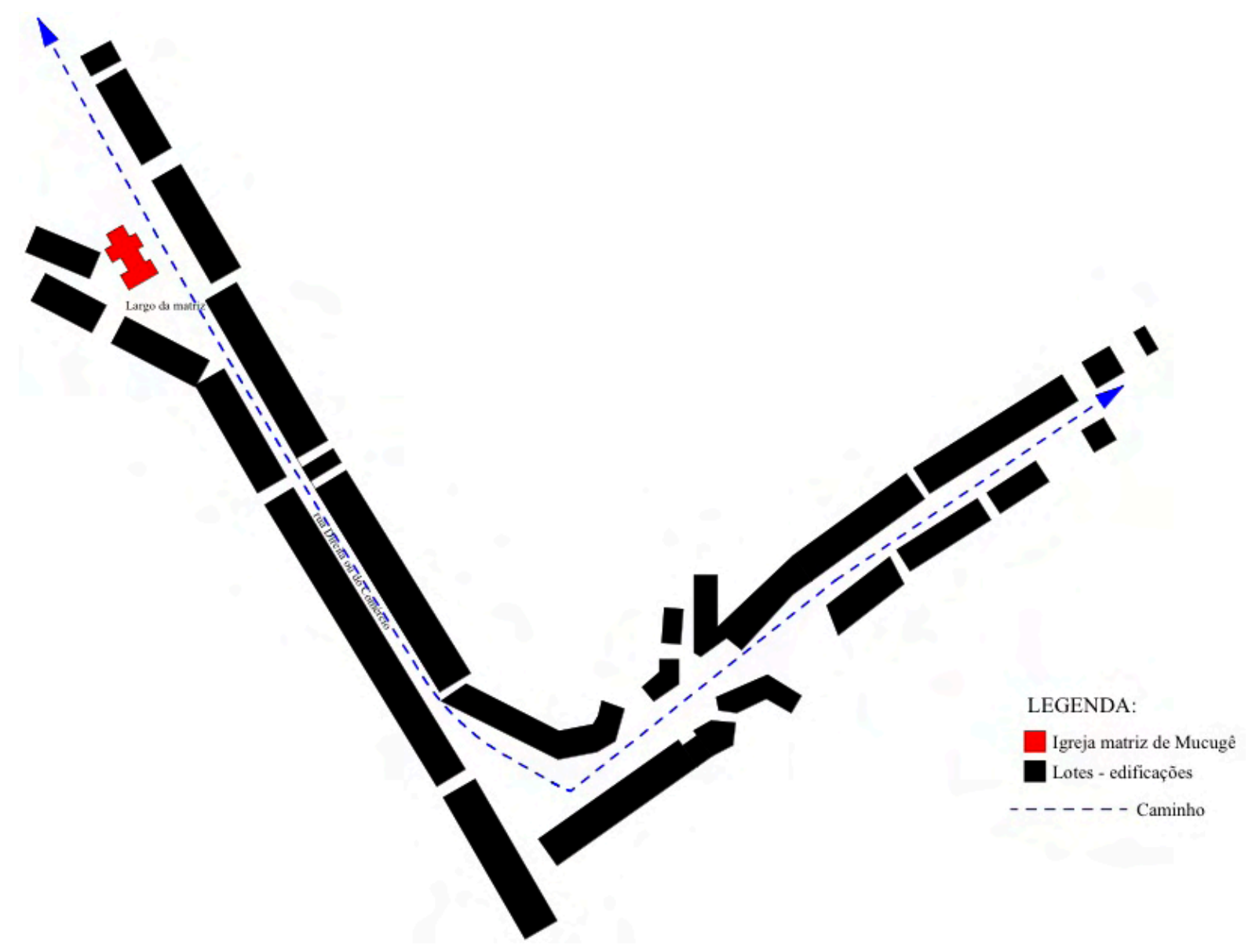

Figura 111 - Perfil da cidade de Mucugê - BA. Núcleo longilíneo cuja conexão central visa a igreja Matriz da localidade. Desenho do autor sobre planta desenvolvida pelo IPAC - BA. Ver "INVENTÁRIO de proteção do acervo cultura (Bahia)". IPAC. Salvador, 1975.

A forma linear do percurso das moradias conferiu a necessidade do contato da população com aqueles que transitaram entre proto - urbano e o rural. O largo da matriz é permeado pela dinâmica do uso: os moradores através das festas e outras trocas sociais; os viajantes pelo trânsito; os comerciantes realizaram suas feiras com produtos de longe, muitos do além mar. [figura 112]

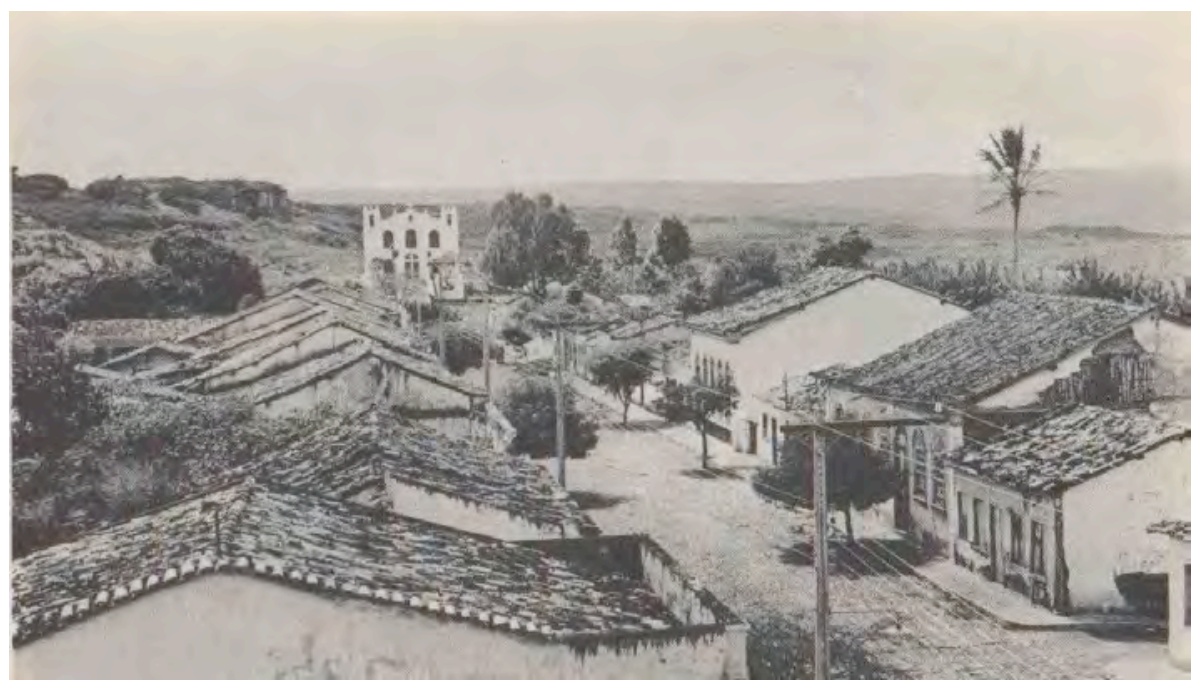

Figura 112 - Rua direita ou do Comércio, conferem a linearidade do aglomerado baiano de Mucugê. Ao fundo a igreja matriz. Foto do IPAC BA em Ver "INVENTÁRIO de proteção do acervo cultura (Bahia)". IPAC. Salvador, 1975. 
Inspecionando a região do rio São Francisco e chapada da Diamantina, por volta de 1875, Theodoro Sampaio passou por Mucugê, antes chamado de povoação de Santa Isabel, descreveu o aglomerado como um arraial de garimpeiros que prosperou com a lavra de diamantes; surgio com ella e com ella decahio (...) O logar, mesmo, é um pouso para garimpeiros à beira do garimpo. Contavam-se então 245 prédios dentro da villa e quasi o dobro fora; duas ruas longitudinais e dez outras transversais pequenas (...). ${ }^{77}$

(...) que se erigice em Villa esta Povoação do Tauá para nella se recolherem e congregarem todos os homens vadios e vagabundos que afastandoce da sociedade civil a maneyras de Feras indômitas vivessem inbrenhados pello centro das matas vigens e destes Certoins $(\ldots)^{78}$, recomendações oficiais para a criação, em 1802, da vila de São João do Príncipe, atual Tauá - CE. Cumpriram os edis do município a ordem régia: (...) os novos agregados a ella devem edificar suas casas no alinhamento que para isso the madarião consignar os sobreditos officais da Câmera (... $)^{79}$ [grifo nosso], cujo resultado são moradias bem alinhadas [figuras 113 e 114].

Segundo Carlos Studart Filho, na rede viária do Ceará colonial, há nos textos dos documentos de doação de sesmarias menção do caminho dos Inhamuns, cujo roteiro entrelaçou os nós: Iço » missão da Telha » freguesia de São Matheus » Saboeiro » paróquia de Arneiroz » Tauá. De Tauá, na fazenda da família Feitosa, a estrada atravessou a fronteira com a capitania de São José do Piauí rumando para a freguesia de Valença do Piauí e, logo em seguida, vila do Mocha ${ }^{80}$.

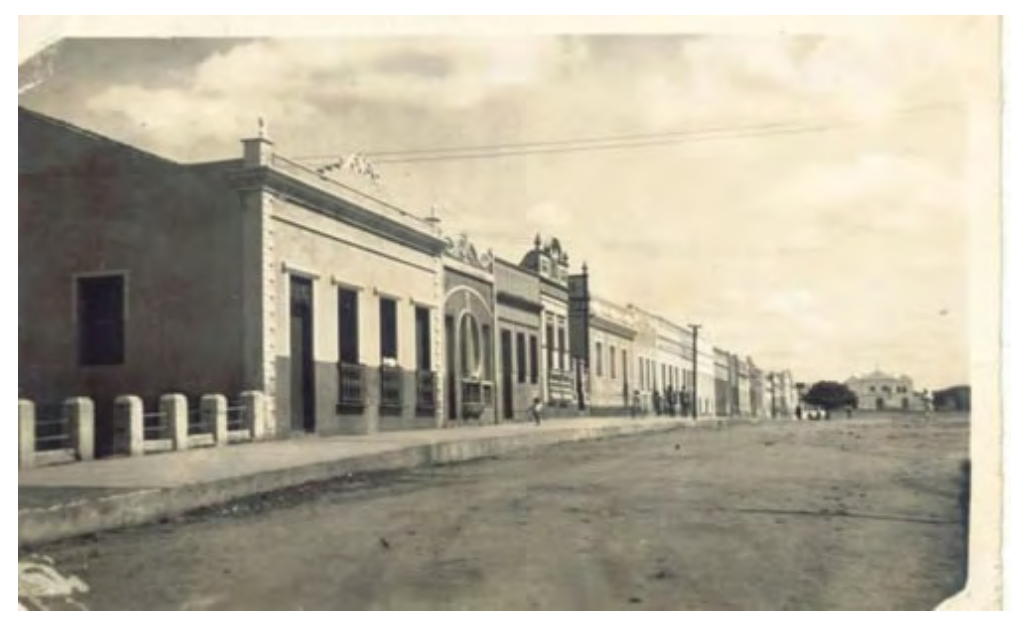

Figura 113 - Alinhamento dos lotes e moradias da cidade de Tauá - CE, anterior vila de São João do Príncipe (1802). No horizonte a igreja matriz dedicada à Nossa Senhora do Rosário. Foto disponível em http://www.taua.ce.gov.br. Acesso em 23.11.2010.

\footnotetext{
${ }^{77}$ SAMPAIO, Theodoro. O rio São Francisco: trechos de um diário de viagem e a chapada da Diamantina. São Paulo, Escolas Profissionais Salesianas, 1905. p. 128.

${ }^{78}$ MOTA, Aroldo. "Município de Tauá: origem”. In Revista do Instituto do Ceará. Ano CXV. Fortaleza, 2001. p. 112.

${ }^{79}$ MOTA, Aroldo. "Município de Tauá: origem”...Opus cit., p. 121.

${ }^{80}$ STUDART FILHO, Carlos. "Vias de communicação do Ceará colonial”. In Revista do Instituto do Ceará. Ano LI. Fortaleza, 1937. p. 31, 32, 45.
} 


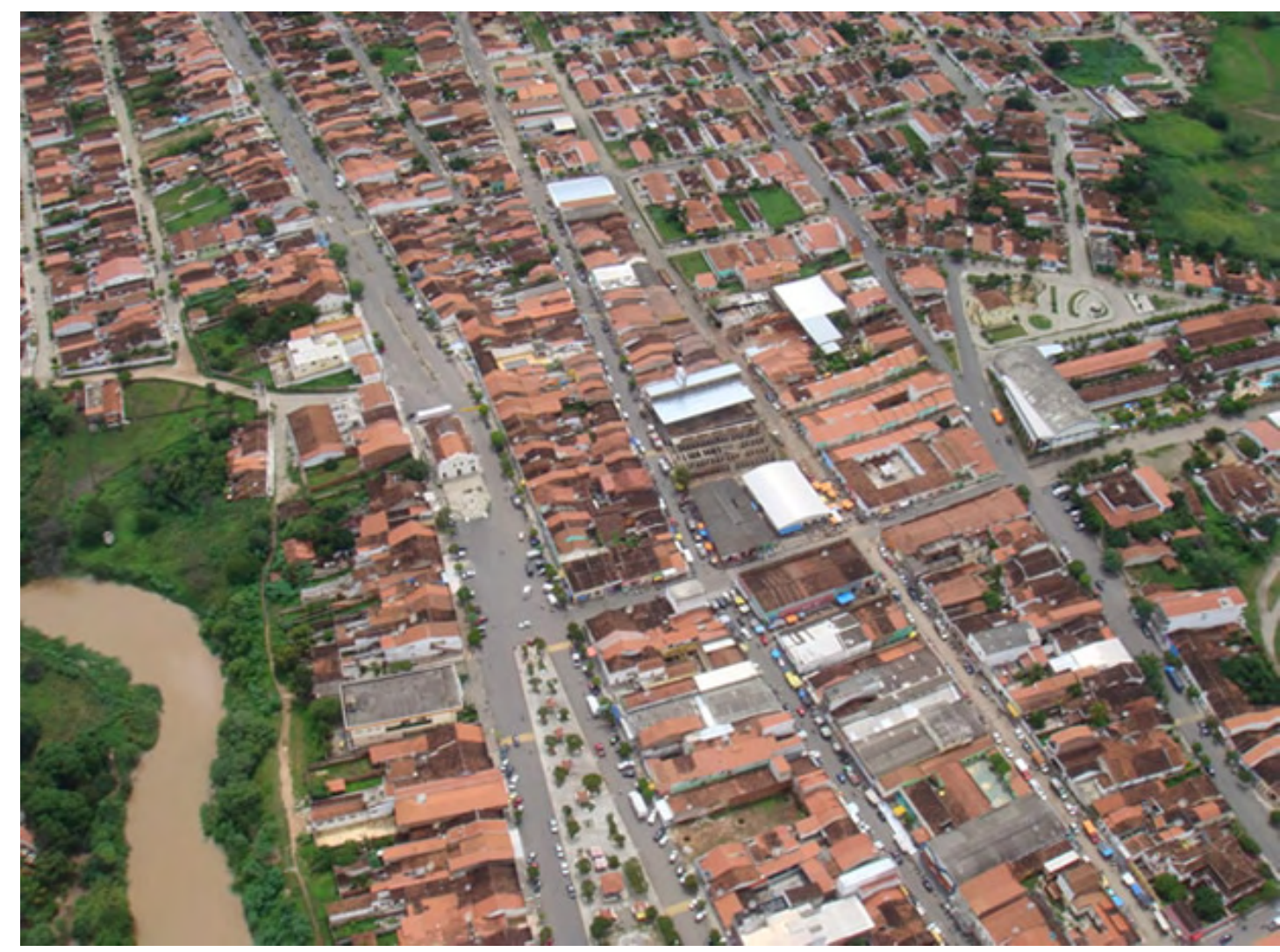

Figura 114 - Tauá - CE. Linearidade marcante na avenida principal da cidade. Foto disponível em http://www.taua.ce.gov.br. Acesso em 23.11.2010.

Atraindo a atenção da sociedade científica internacional, principalmente no século XIX, as terras exóticas do Brasil constituíram objeto de análise por parte de expedições estrangeiras. Em 1859, Dom Pedro II patrocinou uma pioneira comissão exploradora. Buscou informações pertinentes às ciências naturais. Selecionaram a província do Ceará por apresentar motivos de demoradas e velhas discussões: gado, cana-de-açúcar, metais preciosos, vale do Cariri, entre outros aspectos. A suposição prepoderante ocorreu em virtude da suposta existência de reservas metalíferas, a que a imaginação popular, a lenda e a observação fortuita deu proporções nacionais ${ }^{81}$.

Na liderança dessa inspeção esteve Freire Alemão que nos legou alguns desenhos de povoações cearenses ${ }^{82}$, entre esses um assentamento de casas não identificado [figura 115], cujo percurso evolutivo dos lotes seguiu duas vias: um caminho principal, encaminhando o visitante ao adro da matriz, e outro de menor hierarquia que desemboca na primeira estrada. Este povoado está localizado, provavelmente, no vale do Cariri por possuir em seu perímetro

\footnotetext{
${ }^{81}$ DAMASCENO, Darcy; CUNHA, Waldir da. "Os manuscritos do botânico Freire Alemão". In Anais da Biblioteca Nacional do Rio de Janeiro. Vol 81. Ano 1961. Rio de Janeiro, Fundação da Biblioteca Nacional, 1964. p. $25-26$.

${ }^{82}$ Todos estão localizados na Fundação da Biblioteca Nacional - RJ. Setor de Manuscritos.
} 
urbano uma engenhoca de aguardade e rapadura. Sabe-se que essa região ficou conhecida, em fins dos Setecentos e, principalmente, no século XIX pela produção de rapadura e outros derivados do melaço do açúcar.

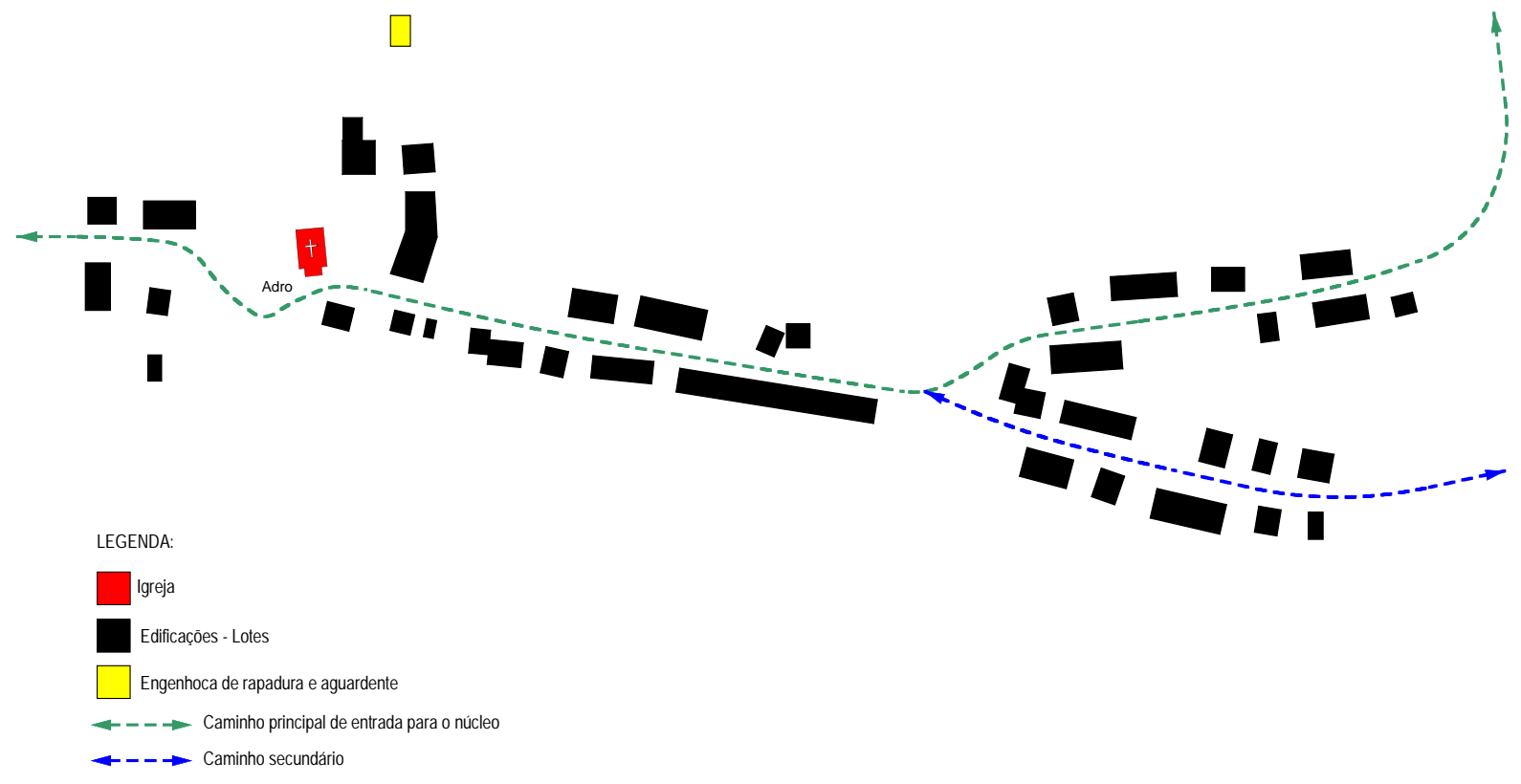

Figura 115 - Plano de povoamento não identificado, com referências a pessoas, prédios e lugares. Desenho do autor segundo manuscrito de Freire Alemão localizado na Fundação da Biblioteca Nacional - RJ. Chamada: I - 28,11,48.

Caminhos e estradas coloniais foram eixos estruturadores de núcleos urbanos de outras capitanias e de concentrações humanas litorâneas. A estada velha ${ }^{83}$ alongava-se pela costa atlântica interligando os centros urbanos. Por ela transitaram índios, mercadores, bandeirantes e missionários. As vilas de Alagoa do Sul (atual Marechal Deodoro - AL) [figura 116] e Aracati - CE [figura 117] surgiram beirando rotas terrestres desenvolvidas nas proximidades do oceano. Aracati foi descrita pelo viajante Henry Koster como formada principalmente n'uma longa rua, com varias outras de menor importância, partindo desta, em rumo ao sul ${ }^{84}$. O naturalista inglês George Gardner argumentou sobre o traçado retilíneo de Aracati: consistia quase só de uma rua longa e larga ${ }^{85}$. Luiz Barba Alardo de Menezes,

\footnotetext{
${ }^{83}$ STUDART FILHO, Carlos. "Vias de communicação do Ceará colonial”..., Opus cit., p. 15.

${ }^{84}$ KOSTER, Henry. Viagens ao Nordeste do Brasil. Tradução e notas: Luís Câmara Cascudo. Rio de Janeiro, Editora Nacional, 1942. p. 10.

${ }^{85}$ GARDNER, George. Viagem ao interior do Brasil..., Opus cit., p. 81.
} 
enviado à capitania do Ceará Grande em 1811, descreveu a rua principal da vila cearense de grande extensão e largura, fazem uma perspectiva muito agradável ${ }^{86}$.

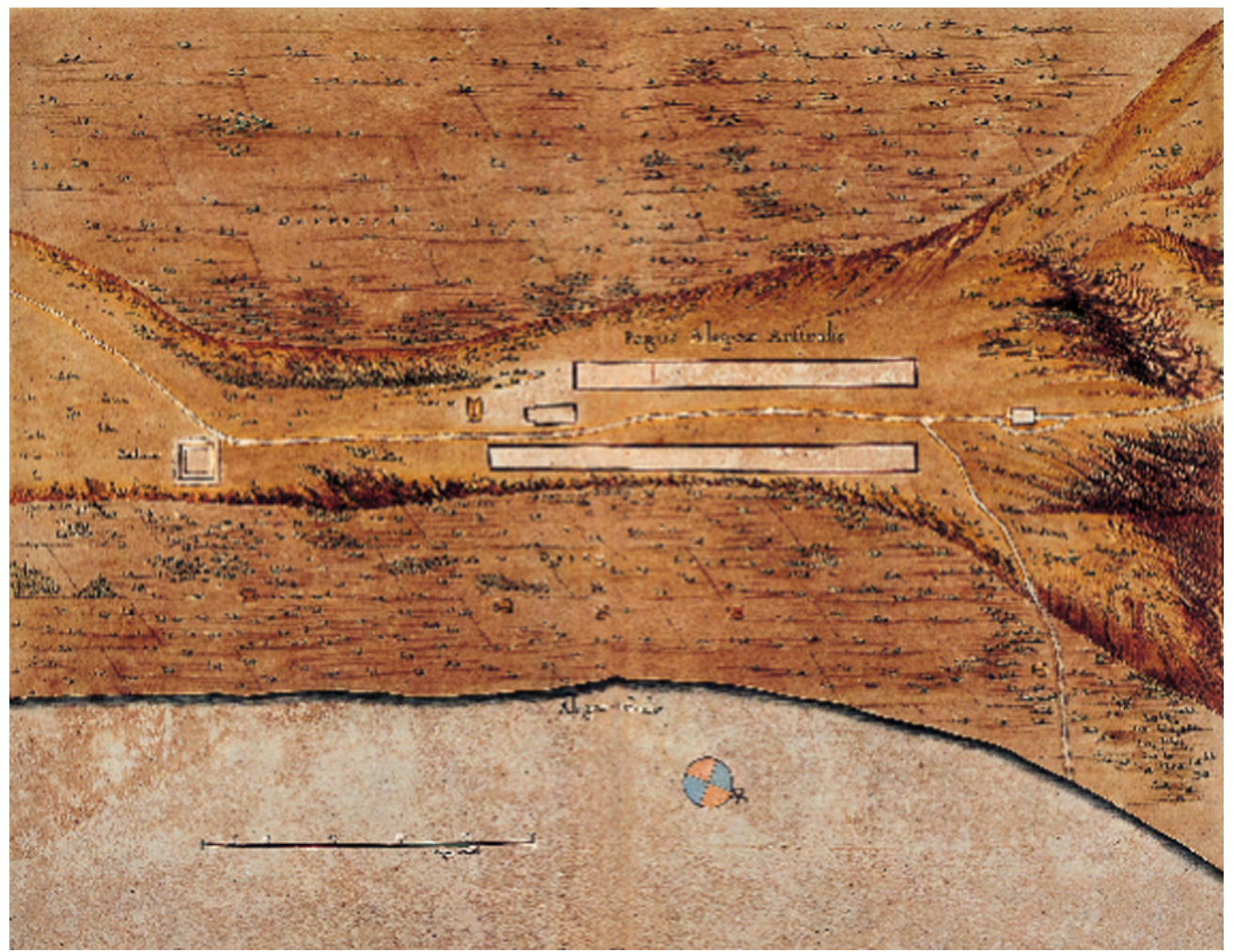

Figura 116 - Povoação de Santa Maria Madalena da Alagoa do Sul, atual Marechal Deodoro - AL. Composta de uma rua simples com casas dos dois lados margeando o caminho do Conde. Imagem retirada do CD - ROM Vilas e imagens do Brasil colonial.

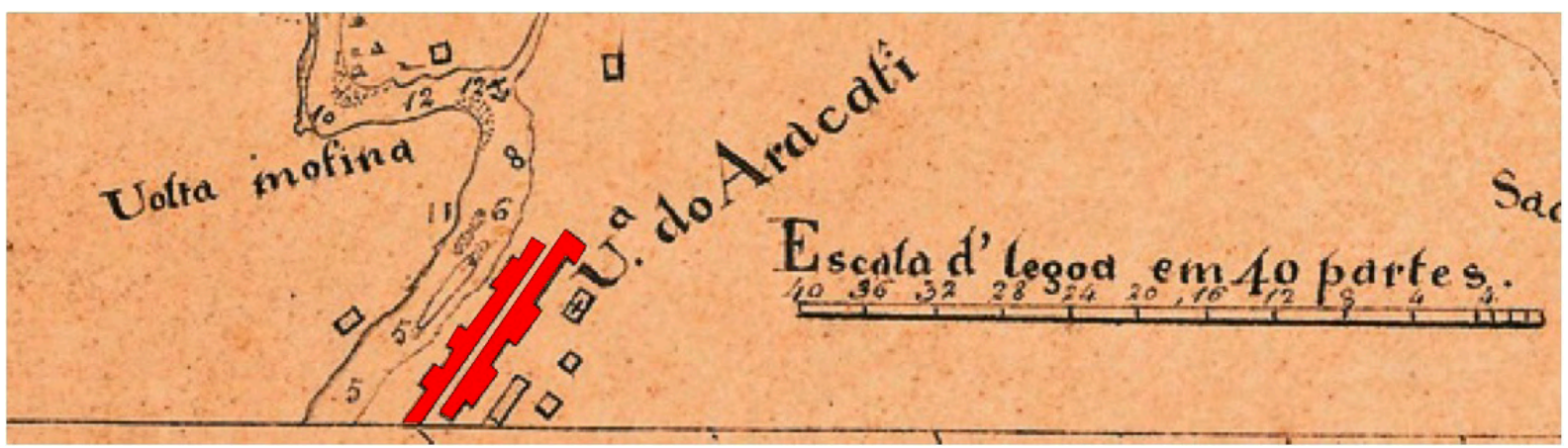

Figura 117 - Vila do Aracati - CE. Traçado retilíneo (em destaque, cor vermelha) com casas edificadas dos dois lados da grande rua. Planta atribuida ao engenheiro Antônio Jozé da Silva Paulet, 1813. Imagem retirada do CD - ROM Vilas e imagens do Brasil colonial.

\footnotetext{
${ }^{86}$ MENEZES, Luiz Barba Alardo de. "Memória sobre a Capitania do Ceará". in Revista do Instituto Histórico e Geographico e Etnographico do Brasil. Tomo XXXIV. Rio de Janeiro, IHGB, 1871. p. 266.
} 
As datas de terra de alguns arraiais mineiros foram estruturados ao longo de caminhos terrestres [figura 118]. Para Sylvio de Vasconcellos, os núcleos urbanos nascidos na expansão mineradora se alicerçaram linearmente, ao longo de estradas cuja continuidade se solucionava em determinados pontos em virtude de acidentes geográficos ou do estabelecimento do comércio necessário ao reabastecimento das correntes de trânsito ou ao adiantamento da população circunvizinha ${ }^{87}$. Segundo a opinião de Hélcio Campos, a atual cidade de Tiradentes foi fundada no caminho obrigatório - travessia da serra da Mantiqueira em direção a Taubaté e ao litoral fluminense-, numa rota chamada caminho velho ${ }^{88}$. Chamado no século XVIII de Arraial Velho do Rio das Mortes, Tiradentes cresceu alongando-se sob a via terrestre, com edificações térreas marcando sua paisagem construída.

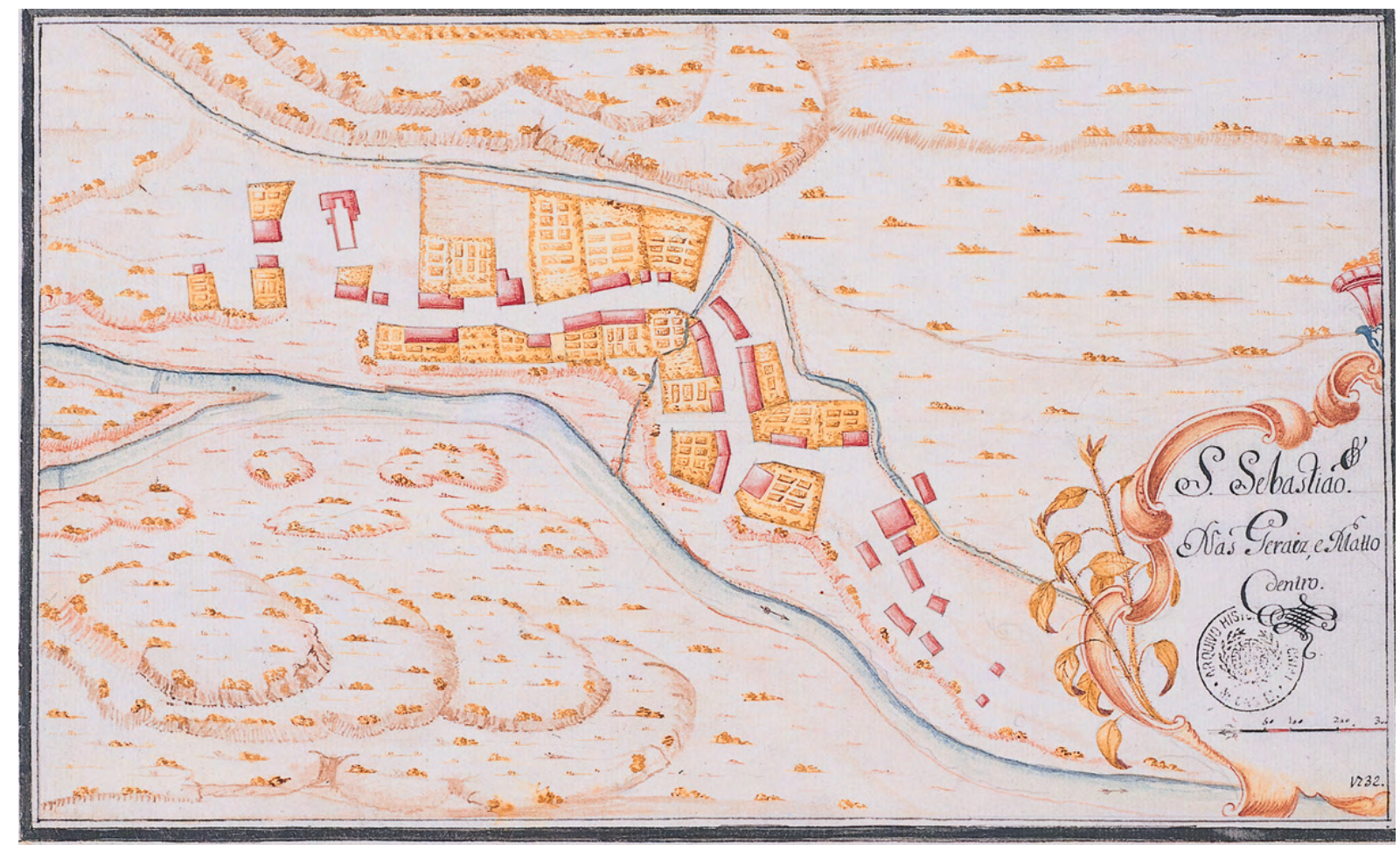

Figura 118 - Aglomerado urbano de São Sebastião nas Gerais, 1732. Desenho com casario disposto irregularmente, ao longo do caminho. Imagem retirada do CD - ROM Vilas e imagens do Brasil colonial.

Voltemos ao sertão nordestino. Outros arraiais apresentaram um mix em sua morfologia urbana. Seria a simbiose entre caminhos $\mathrm{x}$ adro ou entre praça missioneira $\mathrm{x}$ caminhos. A coexistência destes fatores no tempo e no espaço, agregados à expansão do aglomerado, realçam a forma híbrida, heterogênea, por corporizar as relações sociais dos habitantes e posturas do poder oficial no espaço intraurbano.

\footnotetext{
${ }^{87}$ VASCONCELLOS, Sylvio de. "Formação urbana do arraial do Tejuco". In Revista do Patrimônio Histórico e Artístico Nacional. $\mathrm{n}^{\circ}$ 14. Rio de Janeiro, MEC, 1959. p. 121.

${ }^{88}$ CAMPOS, Hélcio Ribeiro. Transformações urbanas recentes em Tiradentes - MG: anos 80 e 90 do século $X X$. Dissertação de mestrado. São Paulo, FFLCH, 2006. p. 25.
} 
Em 1694, na capitania do Ceará, nas proximidades da serra dos Cocos, fronteira com a capitania de São José do Piauí, a fazendeira Joanna Paula Vieira Mimosa, contribuiu para a catequese dos índios residentes de suas terras ${ }^{89}$. Preocupada com os ataques e saques em currais vizinhos, Joanna Mimosa solicitou missionário ao bispado de Pernambuco para domesticação dos Tapuias. Intentos frustrados devido à efemeridade do aldeamento. Entretanto, em 1740, Manuel Alves Fonte doou meia légua em quadra ao orago São Gonçalo, construiu capela no lugar determinado pela carta de doação. Para Eusébio de Souza, o patrimônio religioso fez ascender para as proximidades da ermida sertanejos necessitados de terras para lavoura de subsistência ${ }^{90}$.

A freguesia de São Gonçalo da Serra dos Cocos foi criada em 1757. Seu termo eclesiástico tinha perto de duzentas léguas de circunferência he a ultima da Ribeira, e que fez extrema com os Caratius da capitania do Piahui ${ }^{91}$. Possuía, em 1774, duas capelas filiais, noventa e sete fazendas de gado, quinhentos e quareta e quatro fogos com mil oitocentas e setenta e cinco pessoas de dezobriga ${ }^{92}$. Carlos Studart Filho atribuiu à esta paróquia uma comunicação terrestre com a vila Viçosa ${ }^{93}$. E desta via originou a rua direita da povoação, ou melhor, a rua Guela ${ }^{94}$, nomeação encontrada no manuscrito do naturalista Freire Alemão ${ }^{95}$ [figura 119]. Hoje é possível ver a rota que atravessou o aglomerado de São Gonçalo com destino à cidade de Viçosa do Ceará que, para Milton Santos, seria a rugosidade do lugar ${ }^{96}$. Sua matriz está posicionada no epicentro da praça [figura 120], donde a rua Guela conectava o rural, em uma tênue transição, ao embrionário mundo urbano.

\footnotetext{
${ }^{89}$ SOUZA, Eusébio de. "Um pouco de história (Chronica de Ipu)". In Revista do Instituto do Ceará. Anno XXIX. Fortaleza, 1915. p. 153.

${ }^{90}$ SOUZA, Eusébio de. “Um pouco de história (Chronica de Ipu)”...Opus cit., p. 156.

91 "IDEA da População da Capitania de Pernambuco, e das suas annexas, extensão de suas Costas, Rios, e Povoações notáveis, Agricultura, numero dos Engenhos, Contractos, e Rendimentos Reaes, augmento que estes tem tido \&.\& desde o anno de 1774 em que tomou posse do Governo das mesmas capitanias o Governador e Capitam General Jozé Cezar de Menezes”. in Annaes da Bibliotheca Nacional do Rio de Janeiro. Volume XL. Ano 1918. Rio de Janeiro, Officinas Graphicas da Bibliotheca Nacional, 1923. p. 05.

92 Idem.

${ }^{93}$ FILHO, Carlos Studart. "Vias de communicação do Ceará colonial”. In Revista do Instituto do Ceará. Ano LI. Fortaleza, 1937. p. 43.

${ }^{94}$ Termo sertanejo para garganta.

95 ALEMÃO, Freire. Plano aproximado da Villa do Ipu, 30 de outubro de 1860. No verso notícias sobre as casas e desenhos azulejos. Rio de Janeiro, Fundação da Biblioteca Nacional. Sessão de manuscritos: I 28,11,28.

${ }^{96}$ Milton Santos apresenta rugosidade como o tempo atual se defrontando com o tempo passado, cristalizado em formas. Ver SANTOS, Milton. A natureza do espaço: técnicas e tempo, razão e emoção. 4 ed. São Paulo, Edusp, 2009. p. 140.
} 
São Gonçalo da Serra dos Cocos obteve autonomia municipal em 1791. Homenageando a Coroa portuguesa, a vila passou a ser chamada de Nova del Rei. Em 1810 foi descrita pelo engenheiro Antônio Jozé da Silva Paulet:

É pobríssima, ainda que o termo é extenso e despovoado (...) Contém 48 cazas de taipa e arruinadas; a maior parte sem se ter acabado. (...) A villa está quase sempre deshabitada, principalmente no inverno, que os moradores descem para o sertão, onde tem suas cazas e famílias, e vem á serra no verão para plantar e colher. ${ }^{97}$

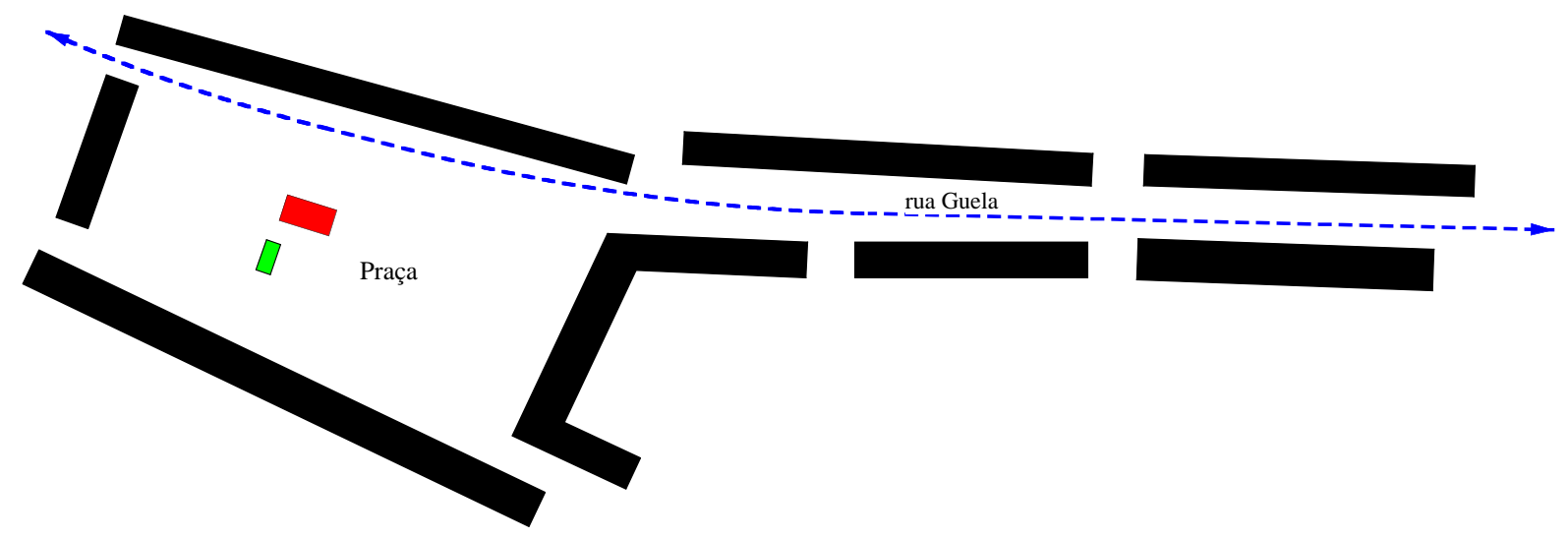

LEGENDA:

Igreja de São Gonçalo

Edificações - Lotes

Velha casa de câmara e cadeia

Nova casa de câmara e cadeia

Caminho para vila Viçosa
Figura 119 - Freguesia de São Gonçalo da Serra dos Cocos (1757) e vila Nova del Rei (1791). Desenho do autor sobre manuscrito de Freire Alemão - original Fundação da Biblioteca Nacional: I - 28, 11, 28.

${ }^{97}$ PAULET, Antônio Jozé da Silva. "Descripção Geográfica abreviada da Capitania do Ceará". in Revista do Instituto do Ceará. Anno XII. Fortaleza, 1898. p. 21 - 22. 


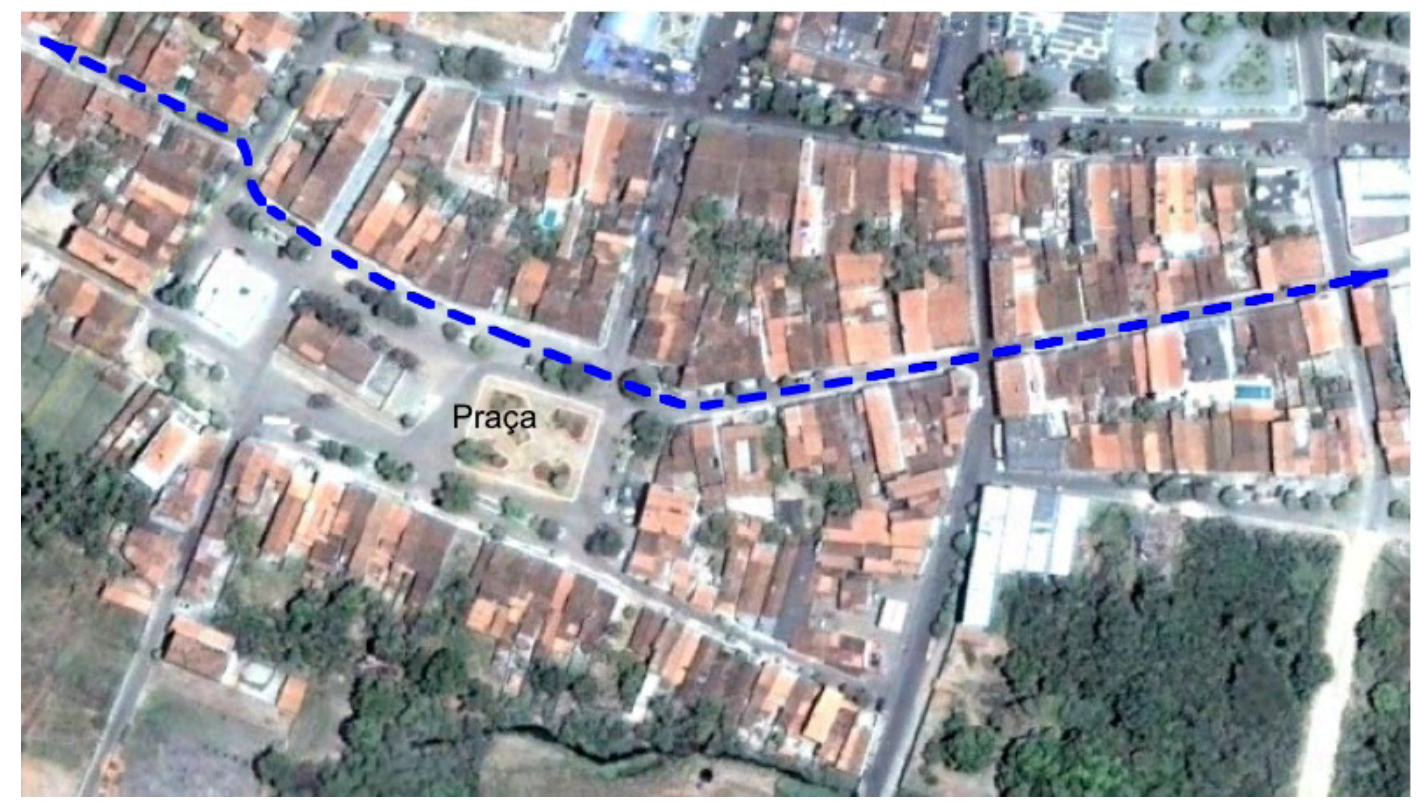

Figura 120 - As rugosidades de Ipú - CE. Em destaque, linha tracejada azul, caminho que uniu a freguesia de São Gonçalo dos Cocos à vila Viçosa. Imagem de satélite do Google Earth.

Nas cercanias da atual cidade de Afrânio (PE), existe o povoado de Caboclo. A documentação historiográfica a respeito de sua formação quase inexiste ou está perdida nos arquivos estaduais ou paroquiais. Entretanto, Caboclo foi um dos nós da velha estrada real do gado. As manadas vinda dos sertão piauiense obrigatoriamente passavam pela Passagem do Juazeiro (hoje Petrolina - PE), ponto de tributação fiscal entre as capitanias de Pernambuco e Bahia. No final do século XVIII, Roberto Ramos da Silva doou uma parte de suas terras ao Senhor Bom Jesus do Bonfim ${ }^{98}$. A ermida do assentamento teve sua construção finalizada em 1817.

Congelado no tempo, Caboclo denuncia a presença da Igreja em sua evolução urbana: a capela, atalaia dos moradores e viajantes forasteiros, "olha" a entrada do aglomerado, reforço dado pelo grande largo, envolto pelo casario térreo e horizontal [figura 121] talvez de caboclos, como atesta a sua titulação. Seu minguado crescimento [figura 122], ocorrido nos Oitocentos, em direção ao rio São Francisco deve à estrada das boiadas, à fazenda Inveja e ao mercado interno do gado realizado na freguesia do Juazeiro - BA.

\footnotetext{
98 “INVENTÁRIO do Patrimônio Cultural do Estado de Pernambuco: sertão pernambucano do São Francisco". Recife, Fundação do Patrimônio Histórico e Artístico de Pernambuco - FUNDARPE, 1985. p. 221.
} 


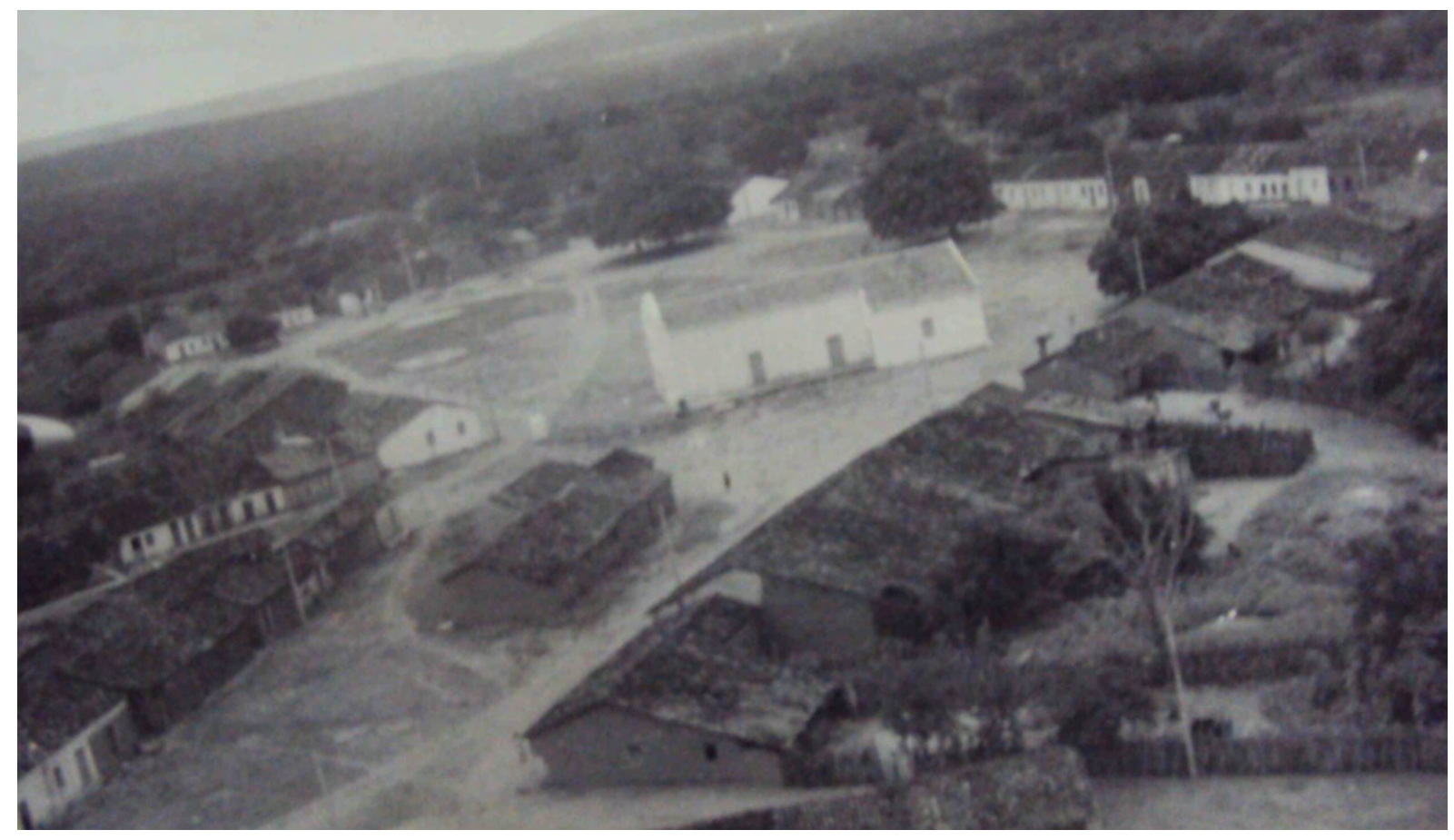

Figura 121 - Ermida e largo do arraial de Caboclo -PE. Casario em volta da grande praça. Foto cedida pela FUNDARPE - PE.

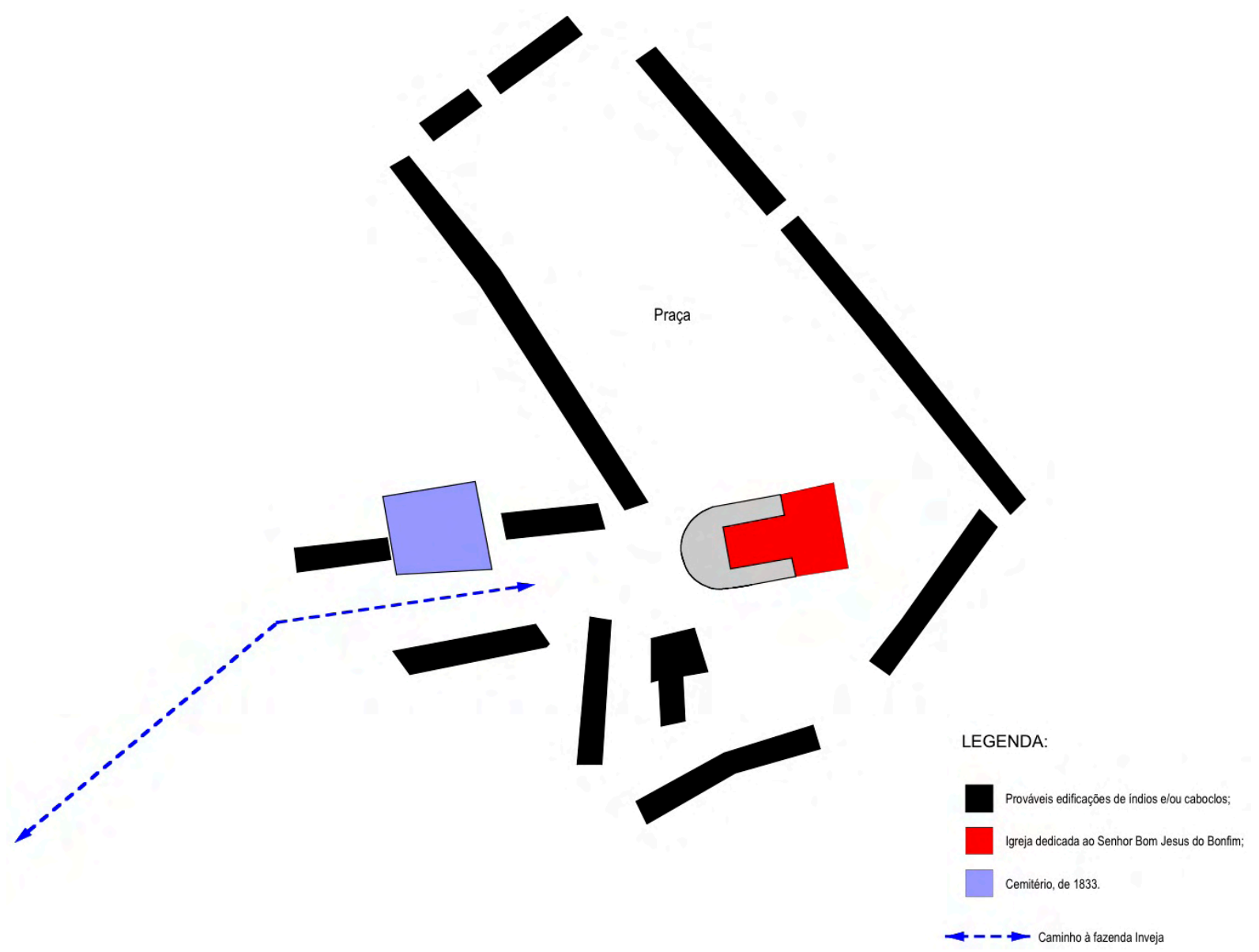

Figura 122 - Desenho híbrido de Caboclo. Mix entre caminhos do gado e patrimônio religoso. Desenho do autor elaborado segundo cartografia desenvolvida pela FUNDARPE - PE. 
No sertão dos Pastos Bons, capitania do Maranhão, devido à revolta da balaiada as autoridades criaram um arraial de soldados. $\mathrm{O}$ assentamento evoluiu, passando a ser denominado, em 1807, como arraial do Príncipe Regente. Segundo o coronel Sebastião Gomes da Silva Berford, que deixou um interessante relato sobre aquelas paragens, o assentamento maranhense contou com 215 almas, tudo arruado com cazas, quartel, e Capella $(\ldots)^{99}$. O relator informou sobre as importações e exportações de produtos primários, um fluxo de mão-dupla entre o interior e as Aldeias Altas (Caxias - MA), sempre seguindo o curso fluvial do rio Itapicurú como por hum caminho de dezoito legoas $(\ldots)^{100}$. Lentamente o aglomerado se expande, partindo da praça em direção aos rios Parnaíba e Itapicurú, à freguesia de Pastos Bons e à fazenda Inhuma. [figura 123]

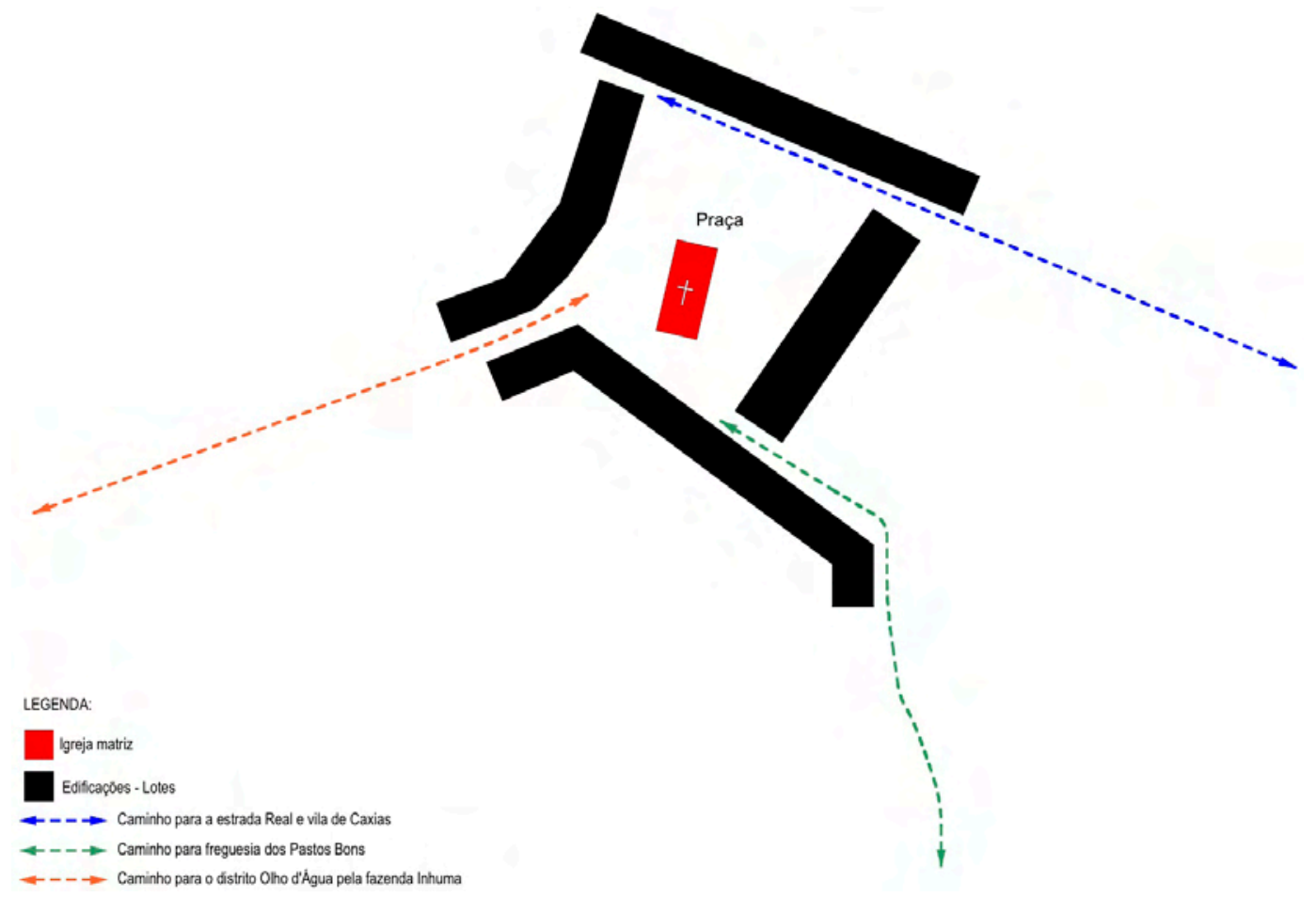

Figura 123 - Mirador - MA. Antes arraial do Príncipe Regente. Desenho do autor sobre imagem satélite do Google Earth.

Os aldeamentos missioneiros se beneficiaram dos caminhos sertanejos. Os missionários escolheram fixar os seus neófitos ao longo da rede viária que progressivamente emergia no interior do Nordeste. Facilidade de comunicação, intercâmbio com outros núcleos

\footnotetext{
${ }^{99}$ BERFORD, Sebastião Gomes da Silva. Roteiro e Mappa da viagem da cidade de S. Luiz do Maranhao até a corte do Rio de Janeiro, feita por ordem do Governador, e Capitao General daquella Capitania, pelo Coronel Sebastião Gomes da Silva Berford, Fidalgo da Casa real, com os officios relativos a mesma viagem. Rio de Janeiro, Impressão Régia, 1810. p. 10.

${ }^{100}$ BERFORD, Sebastião Gomes da Silva. Roteiro e Mappa da viagem da cidade...Opus cit., p. 14.
} 
interioranos e acesso aos centros urbanos do litoral foram fatores considerados pelos religiosos para implantar suas reduções.

A missão franciscana do Juazeiro, situada na margem direita do rio São Francisco, lado baiano, foi instalada na estrada real do gado. Spix e Martius argumentaram sobre os privilégios de sua posição territorial: o arraial do Joazeiro, pequena aldeia de umas cinqüenta casas e uns duzentos habitantes, deve sua origem à missão que existiu antigamente na vizinhança, a sua atual importância, porém, deve-a à freqüência de trânsito pela estrada do Piauí, a qual atravessa o rio aqui (... $)^{101}$.

Henrique Halfeld, engenheiro enviado ao rio São Franciso, entre 1852 - 1854, por ordens do imperador D. Pedro II, descreve Juazeiro: (...) tem uma igreja de invocação a Nossa Senhora das Grotas, uma casa de Câmara e cadêa anexa, 334 casas, sendo destas 287 cobertas de telha, e sujeitas ao pagamento da décima urbana ${ }^{102}$, com 1328 habitantes, sendo destes 1052 livres e 276 escravos (... $)^{103}$. Os velhos caminhos do gado deram ao aglomerado do Juazeiro o progresso necessário à sua evolução urbana. Theodoro Sampaio comparou a urbanidade da sua população com o grau de urbanização de seu contorno territorial. $\mathrm{O}$ motivo?

Situada na encrusilhada de duas grandes artérias de communicação interior, isto é, a velha estrada histórica que da Bahia se encaminha para o Maranhão através do Piahuy, e a amplíssima estrada fluvial que desce de Minas e vae ao Oceano através da Bahia, Pernambuco, Alagoas e Sergipe, o Joazeiro, fundado pelos fins do século XVII, se tornou logo um centro preferido de transações comerciais destas regiões, e cresceu e se constituiu o foco mais poderoso da civilisação e da riqueza desta parte do Brasil que se pode designar como a região média dentre os rios São Francisco e Tocantins ${ }^{104}$.

\footnotetext{
${ }^{101}$ SPIX, J.B Von; MARTIUS, C.P.F. Viagem pelo Brasil: 1817 - 1820..., Opus cit., p. 399.

102 Beatriz Bueno informa-nos que a décima urbana foi o primeiro imposto predial estabelecido para as cidades brasileiras. Implantada no Brasil em 1808 com implicações na definição do perímetro urbano das vilas e cidades, na numeração dos imóveis e na listagem, rua a rua, lote a lote, de todos eles, bem como de seus proprietários, inquilinos, tipologias edilícias e valor. Ver BUENO, Beatriz P. Siqueira. "A cidade como negócio: mercado imobiliário em São Paulo no século XIX”. In FRIDMAN, Fania; ABREU, Mauricio. Cidades latinoamericanas: um debate sobre a formação de núcleos urbanos. Rio de Janeiro, Casa da Palavra, 2010. p. 160.

${ }^{103}$ HALFELD, Henrique Gulherme Fernando. Atlas e relatório concernente a exploração do rio São Francisco desde a cachoeira da Pirapora até o oceano Atlântico. Levantado por ordem do governo de S.M.I. o Senhor D. Pedro II. Em 1852, 1853 e 1854. Rio de Janeiro, 1860. Légua 247.

${ }^{104}$ SAMPAIO, Theodoro. O rio São Francisco: trechos de um diário de viagem..., Opus cit., p. 36 - 37.
} 
Nos domínios fundiários dos padres congregados de São Felipe Nery, sertão do Ararobá, a vila de Cimbres foi estabelecida em 1762. Como freguesia de Nossa Senhora da Montanha de Ararobá, Cimbres esteve cortada por dois conhecidos caminhos de gado, cujo marco zero sediou a vila do Recife. Um deles, que faceou o rio Ipojuca, cruzou Cimbres [figura 124]. O adro da vila [figura 125] é uma sobreposição da praça missioneira, conjugando forma retilínea com o conceito de uniformidade implícita na estética pombalina: (...) e para se delinear a forma em que hão de ficar as ruas e se regular a construção das casas e quintaes dos moradores (.... $)^{105}$.

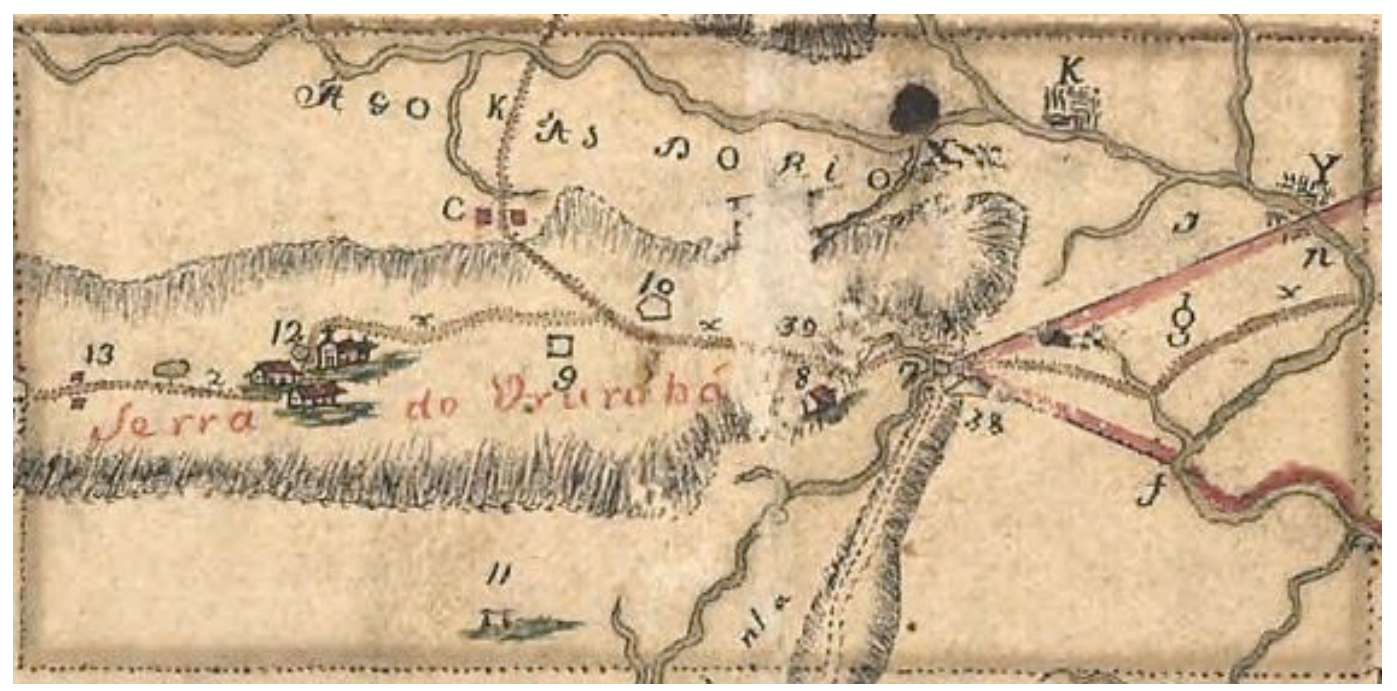

Figura 124 - Termo da vila de Cimbres - PE ( $\left.\mathrm{n}^{\circ} 12\right)$. Caminho que corta o interior da vila marcado na figura pela letra x. Imagem tirada de Mapa topographico em que se mostrão as terras que forão dos Reverendos Congregados...Disponível em http://www.bn.br. Acesso em 08.10.2011.

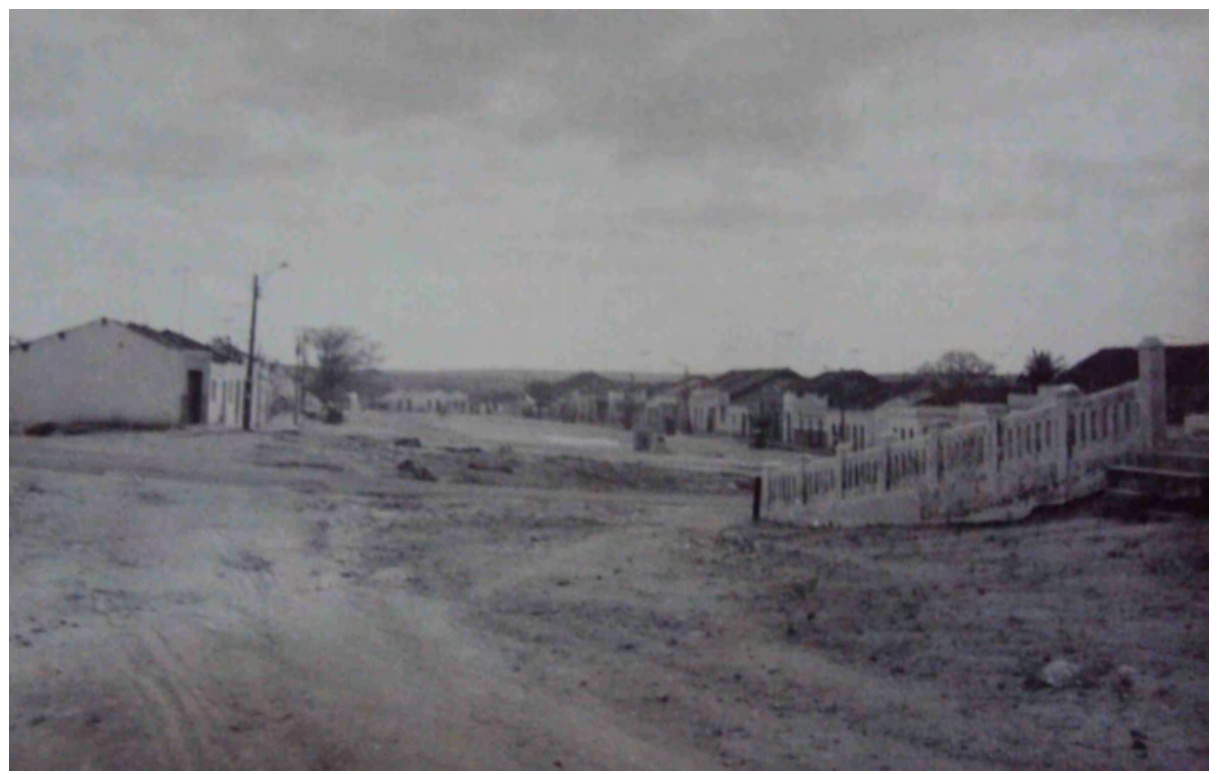

Figura 125 - Povoação de Cimbres por volta da década de oitenta do século passado. Destaca-se o terreiro da matriz que é, ao mesmo tempo, a praça do aglomerado urbano. Foto cedida pela FUNDARPE - PE.

105 "CARTA do governador da Capitania de Pernambuco, Luís Diogo Lopes da Silva em 26.03.1762”. in LEMOINE, André. Estudo morfológico de cidades do agreste pernambucano - séculos XVIII e XIX. Dissertação de mestrado. Recife, UFPE/MDU, 2003. p. 67. 
Atentou a lei de 23 de novembro de 1700 em determinar, a favor dos índios reduzidos em alguma missão religiosa, acesso à terra para cultivo de gêneros primários. Alguns traslados de aldeias para sítios com melhores condições geográficas ocorreram no sertão nordestino. A localização dos currais de almas, para o grêmio da Igreja e domesticação dos Tapuias, fundamentou-se em estratégias políticas, econômicas e religiosas. Por exemplo, na capitania da Paraíba, as autoridades coloniais e eclesiásticas decidiram migrar os nativos da nação Corema para o lugar do Riacho do Aguiar por serem terras de matas q' produzem mandioca, milho e outras plantas aonde mais commodamente podião viver $(. . .)^{106}$.

A influência do indígena foi percebida na elaboração do aldeamento missioneiro onde antes era a tribo dos nativos. Nesse caso, a adaptação e a criação simultânea de um núcleo missioneiro foram as contribuições da cultura dominada para resolver os problemas impostos pela circunstância colonial ${ }^{107}$. Na verdade essa atitude seria um método de persuasão para atrair neófitos à nova condição social: (...) reprehendendo os vícios e reformando os costumes tanto com a efficacia das palavras, como com a pureza das obras $(\ldots)^{108}$. Assim fez frei Martinho de Nantes: concordei em ficar com eles no lugar em que já se achavam estabelecidos, como sendo também mais conveniente para mim $(\ldots)^{109}$. Na estrada que uniu o litoral pernambucano ao rio São Francisco, o capuchinho francês criou o aldeamento de Aracapá, hoje cidade de Tacaratú - PE. A primeira aglomeração evoluiu ao redor da praça missioneira. Com o passar das décadas, se expandiu em dois fluxos: o primeiro “às costas" da ermida, numa simbólica submissão ao despótico poderio católico. O segundo buscou o rio São Francisco, edificando as residências no trajeto definido por reses e moradores [figura 126]. A partir do relatório do governador da capitania de Pernambuco, Jozé Cezar de Menezes, em 1774, somos informados que em Tacaratú, já como freguesia, existiram 261 fogos $^{110}$.

\footnotetext{
${ }^{106}$ PROJETO RESGATE. AHU_ACL_CU_014,Cx. 8, D. 707.

107 GUTIÉRREZ, Ramón. "Povoados e reduções indígenas na região de Cuzco: persistências e inovações". In FRIDMAN, Fania; ABREU, Mauricio. Cidades latino-americanas: um debate sobre a formação de núcleos urbanos. Rio de Janeiro, Casa da Palavra, 2010. p. 39.

108 "INFORMAÇÃO Geral da capitania de Pernambuco, 1749". In Annaes da Bibliotheca Nacional do Rio de Janeiro. Vol XXVIII. Ano 1906. Rio de Janeiro, Officinas Graphicas da Bibliotheca Nacional, 1908. p. 381.

${ }^{109}$ MARTINHO DE NANTES, padre, O.F.M. Cap. Relação de uma missão no Rio São

110 "Idéia da População da Capitania de Pernambuco, e das annexas, extenção de suas Costas, Rios, e Povoações notáveis, Agricultura, numero dos Engenhos, Contractos, e Rendimentos Reaes, augmento que estes tem tido $\& . \&$ desde o anno de 1774 em que tomou posse do Governo das mesmas Capitanias o Governador e Capitam Jozé Cezar de Menezes". in Annaes da Bibliotheca Nacional do Rio de Janeiro. Volume XL. Ano 1918. Rio de Janeiro, 1923. p. 36.
} 


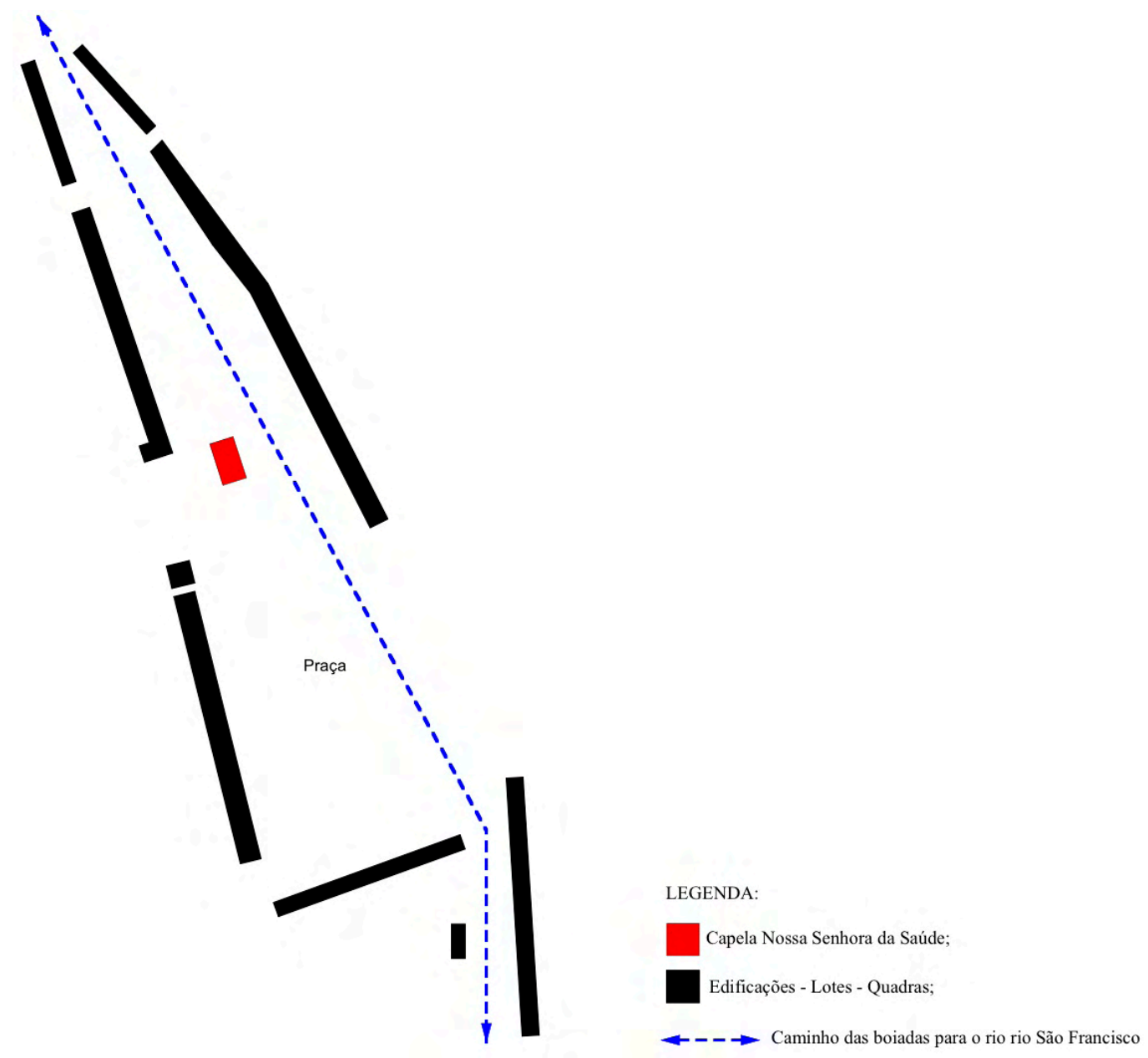

Figura 126 - Provável ocupação da freguesia Nossa Senhora da Luz de Tacaratú, 1774. Desenho do autor sobre informações contidas em Idéia da População da Capitania de Pernambuco... in Annaes da Bibliotheca Nacional do Rio de Janeiro. Volume XL. Ano 1918. Rio de Janeiro, 1923. p. 36. E através de planta elaborada pela FUNDARPE - PE.

No rol dos núcleos com maior hierarquia da rede urbana do sertão nordestino, destacaram-se aqueles onde a pecuária se estabeleceu como economia urbana e, por isso, a Coroa criou estreitos vínculos. Por isso, o desenho intraurbano de tais aglomerados sofreu interferência da Metrópole. Uniformidade e formosura, princípios da estética setecentista, pontuaram as cartas régias e, em alguns casos, modelaram a paisagem urbana de vilas, como por exemplo, Icó, Crato e Monte - Mor o Novo da América na capitania do Ceará; Pombal na Paraíba e os municípios da recém inaugurada capitania de São José do Piauí. Entretanto, os caminhos do gado continuaram a intervir na malha urbana dos núcleos. Sublinharemos no próximo capítulo, como estudo de caso, a cidade de Oeiras, nó basilar do fenômeno urbano sertanejo. 


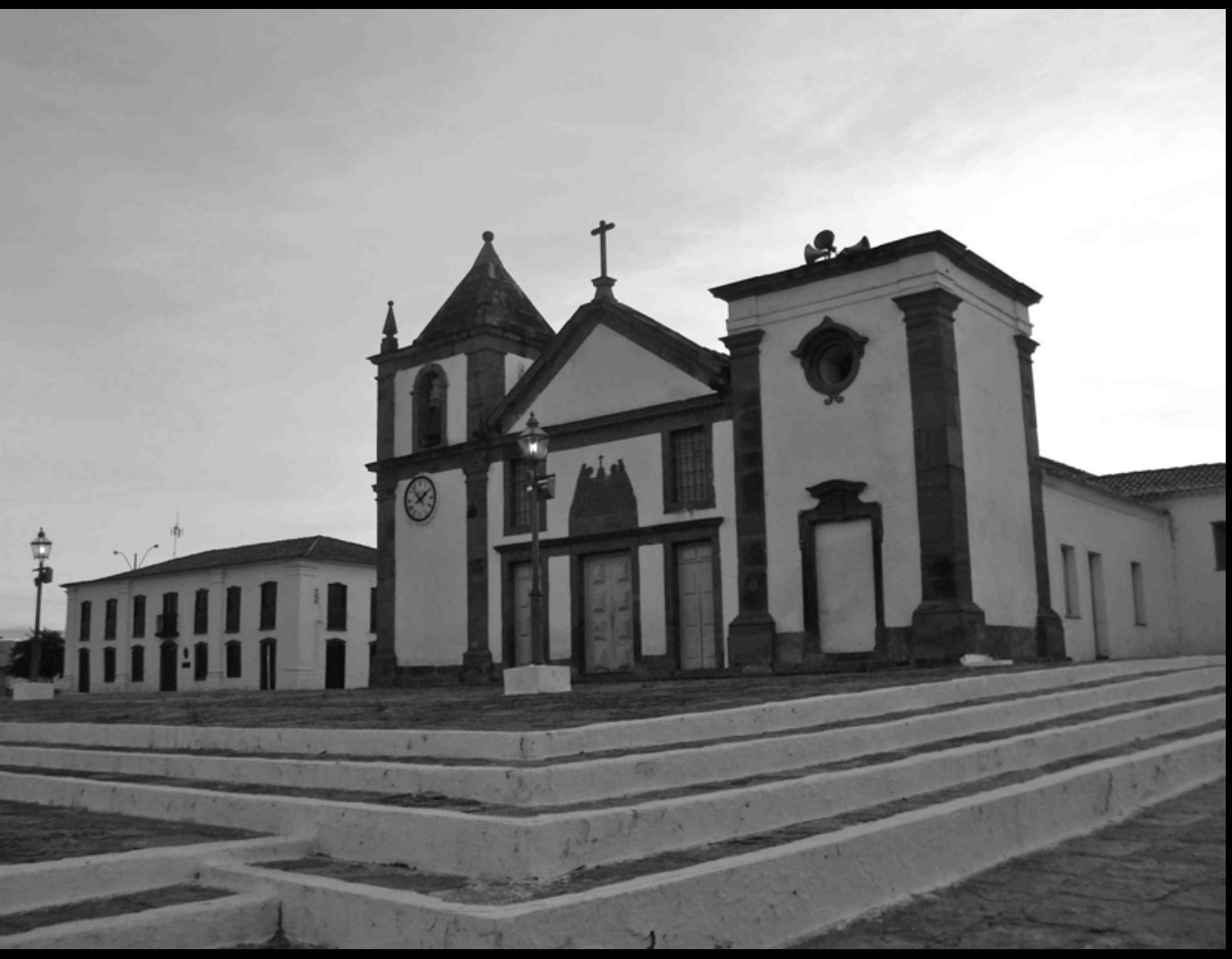

TRÊS CAMINHOS, UMA CIDADE 


\section{CAPÍTULO 05 - TRÊS CAMINHOS, UMA CIDADE}

“(...) fazendo delinear as cazas dos moradores por linha recta de sorte que fiquem largas e direitas as ruas. Aos Officiaes eleitos ficara pertecendo darem gratuitamente os terrenos que se lhes pedirem para cazas e quintaes nos lugares que para isso se houverem determinado. Só com a obrigação de que as ditas cazas sejao sempre fabricadas na mesma figura uniforme pella parte exterior ainda que na outra parte interior as faça cada hum comforme lhe parecer para que desta sorte se conserve sempre a mesma formozura nas Villas, nas ruas dellas a mesma largura que se lhes assignar nas fundaçoens (...)"

Carta régia de 19.06.1761

“Tem uma rua inteira, outra de uma só face, e metade de outra. Tudo o mais são nomes supostos; o de cidade verdadeiramente só goza o nome."

Oeiras pelo ouvidor Antônio José de Moraes Durão, 1772.

"É de construção muito irregular e formada principalmente de uma grande praça, e umas poucas ruas que lhe partem dos lados de oeste e sul."

George Gardner ao visitar a cidade de Oeiras, 1838 . 
Fica esta cidade no meio da capitania; é situada numa baicha, cercada de montes, com sua inclinação para o poente, donde banha o Ribeiro do Mouxa q' deu nome á Povoação enquanto Villa (...) $)^{l}$. Localização precisa para a povoação que esteve no topo da hierárquica rede urbana do território da economida gadeira. A citação do ouvidor Antônio José Moraes Durão nos faz entender o porquê da criação de Oeiras como cidade. Ponto médio entre Salvador e São Luiz, urbes de consumo da carne e couro, separadas muito tempo pelas barreiras naturais marítimas. Comunicação alargada com a elaboração de caminhos terrestres.

Como dissemos, Dom Pedro II autorizou a execução de uma via terrestre para facilitar as mais difficuldades, que se podião offerecer em negócio de farta importância (... $)^{2}$, além de conhecer a calidade, e préstimo das terras, e como podem ser de utilidade para a fazenda de Sua Magestade e dos mais de hum, e outro Estado (... $)^{3}$. Aqui nada de novo, no que tange a empresa colonial portuguesa. Entretanto, a abertura desta rota alicerçou a urbanização da grande faixa regional do semi-árido nordestino.

O sertanista e criador de gado, Domingos Afonso Mafrense, relatou ao governador geral do Brasil, D. João de Lencastro, em 1702, sobre a estrada que uniu Bahia e Maranhão: (...) Da cidade da Bahia ia uma estrada coimbrã pela Jacobina até o rio São Francisco, numa extensão de aproximadamente 130 léguas, pela qual vinham a maior parte dos gados que se criavam naqueles sertões, para o sustento da cidade e seus arrabaldes (...) $)^{5}$. O padre Miguel de Carvalho descreveu este caminho como sabido ${ }^{6}$, ou conhecido, e ali fundou a primeira freguesia piauiense.

Em 1607, o padre da Companhia de Jesus, Luiz Figueira, em viagem para o Maranhão, decidiu seguir o roteiro por via terrestre, pois o percurso por mar apresentou perigos e dificuldades. Tentou sem êxito erigir uma redução na serra da Ibiapaba, culminando em sua morte. O caminho trilhado pelo jesuíta foi a base para urnir o centro do Piauí ao litoral norte da capitania. Alargou, também, o intercâmbio entre Oeiras e vila Viçosa (CE):

\footnotetext{
${ }^{1}$ PROJETO RESGATE. AHU_ACL_CU_016, Cx. 12, D. 684.

${ }^{2}$ PROJETO RESGATE. AHU_ACL_CU_MARANHÃO, D. 957.

${ }^{3}$ Idem.

${ }^{4}$ Encontramos no dicionário de Rapheal Bluteau o significado para o verbete "coimbraan": (...) no sentido metaphorico caminho Real, direyto, \& trilhado sem atalhos, nem rodeos (...). Ver BLUTEAU, Raphael, S. J. Vocabulário português, e latino...Coimbra, Real Collegio das Artes da Companhia de Jesus, 1712 - 1719. Disponível em http://www.ieb.usp.br. Acesso em 03.11.2011.

${ }^{5}$ GOULART, José Alípio. "A formação da zona pecuária nordestina”. In Revista do Instituto Histórico e Geográfico Brasileiro. Vol. 259. Abril - Junho. Rio de Janeiro, Imprensa Nacional, 1963. pp. 16 - 26.

${ }^{6}$ ENNES, Ernesto. As guerras nos Palmares. Rio de Janeiro, Editora Nacional, 1938. p. 371.
} 
Eu El Rey Faço saber aos que este Alvará virem, que sendo-me prezente a grande distância de trezentas legoas, que medea entre a Capital de Pernambuco, e a nova Villa Viçosa Real, ultimamente fundada sobre a Serra da Ibiapaba, e a outra distancia, que vai da Freguezia de São Bento dos Pastos Bons, ou das Balças, onde ha duas Povoaçoens de Índios Amarajós, e de São Félix, pertencente à Capital do Maranhão, e a grande facilidade com que os moradore da ditta Villa podem recorrer à Cidade de Oeyras, Capital do Pyahuy; e da mesma sorte à dita Freguezia: Hey por bem anexar a ditta Villa Viçoza Real, e seu termo, e a referida Freguezia de São Bento de Pastos Bons, creada em Villa, com o a denominação de Villa de São Bento, á sobredita Capital do Pyahuy, em beneficio daqueles meus Vassallos, vexados com as violências, que necessariamente grassam, onde falta quem Administre a Justiça $(. . .)^{7}$

Carlos Studart Filho apontou que, em 1731, há menção nos velhos documentos coloniais da estrada que passa para o Piaui ${ }^{8}$. O itinerário, a começar pelo litoral pernambucano, foi: Goiana (PE) » Itaipú $(\mathrm{PE}) »$ Pilar $(\mathrm{PB})$ » Ingá (PB) » Campina Grande $(\mathrm{PB}) »$ Milagres $(\mathrm{PB}) »$ Patos $(\mathrm{PB}) »$ Pombal $(\mathrm{PB}) »$ Souza $(\mathrm{PB}) »$ Milagres $(\mathrm{CE}) »$ Missão Velha $(\mathrm{CE}) »$ vila Real do Crato $(\mathrm{CE}) »$ Várzea da Vaca $(\mathrm{CE}) »$ fazenda Boa Esperança $(\mathrm{PI}) »$ Oeiras (PI).

Oeiras, uma cidade irrigada por três artérias. Fator prepoderante para a seleção do local onde se implantaria a freguesia de Nossa Senhora da Vitória, posicionando-a, nos Setecentos, no topo da intrincada rede urbana do sertão nordestino. Proporemos um percurso evolutivo da cidade ao longo do antigo regime colonial, atravessando o império. A reconstrução de seus estágios iniciais - paróquia e vila do Mocha - fornece úteis dados sobre a posse e uso do solo, evidenciando velhos dogmas medievais de criar povoações, imigrados com os portugueses aos domínios ultramarinos: logradouro público, rossio, passal, foros, pelourinho, patrimônio da câmara, entre outros. O que lerão será um esforço de síntese, porém, algumas lacunas persistirão e ficaremos curiosos por respostas. Fundamentais foram as fontes primárias do Projeto Resgate Barão do Rio Branco, elas elucidaram alguns eventos deste quebra-cabeças primariamente estruturado nesta dissertação de mestrado. Oeiras foi reses e almas, três caminhos, uma cidade.

\footnotetext{
${ }^{7}$ PROJETO RESGATE. AHU_ACL_CU_016, Cx. 11, D. 647.

${ }^{8}$ STUDART FILHO, Carlos. "Vias de communicação do Ceará colonial". In Revista do Instituto do Ceará. Ano LI. Fortaleza, 1937. p. 31.
} 


\subsection{Freguesia de Nossa Senhora da Vitória}

Para alguns especialistas, a cidade de Oeiras evoluiu de um aldeamento missioneiro criado, em 1676, por Julião Afonso Serra, com intuito de proteger seu gado e terras. Outros indicam sua gênese no território da fazenda Cabrobó, domínio fundiário de Domingos Afonso Mafrense $^{9}$. Seja como for, a gradual expansão urbana de Oeiras passou pelo predicamento de freguesia, parcialmente explanado no terceiro capítulo deste trabalho.

Não bastava povoar o sertão nordestino com fazendas de gado dotadas de uma minguada população - comuns foram as herdades habitadas por duas pessoas. Para efetivar a posse da terra seria indispensável dotá-la de povoações, reunindo os desejosos de um pedaço de terra para sua conservação.

Em comunicação com o rei Dom Pedro II, o bispo de Pernambuco, Dom Francisco de Lima, assegurou a carência de igrejas nos rincões da capitania. Ora, como se sabe, era dever do monarca favorecer a conquista das almas por intermédio da construção de ermidas e igrejas. Esse ato favorecia, sobretudo, os cofres da Ordem de Cristo. Por isso, o clérigo esclareceu que poderá ser maiz util com o intento q' tem de povoarem aquellas Terraz, reduzindoas a Collonias, e Povoaçoens, sendo este meyo, não só de se segurarem aquelles Certoens com estas defenças, mas tambem o de poder lucar grandes conviniençias a fazenda de Vossa Magestade (... $)^{10}$. Povoar o sertão era preciso, poderia rentabilizar bons negócios à Metrópole.

Em 1696, o sertão da capitania de Pernambuco apresentou duas freguesias: Nossa Senhora da Conceição de Cabrobó - com uma extensão de aproximadamente 400 léguas (cerca de $2.666 \mathrm{~km}$ ) - , e Ararobá, cujo território eclesiástico compreendeu entre a serra do Opi e o rio São Francisco, limitando-se com a freguesia de Cabrobó ${ }^{11}$. As longas distâncias a serem percorridas pelo cura da matriz de Cabrobó, em época de desobriga, alertaram as autoridades eclesiásticas e a Junta das Missões em fundar novas paróquias. Dividiu-se Cabrobó em duas: São Francisco da Barra do Rio Grande do Sul (atual Barra - BA) e Nossa Senhora da Vitória.

\footnotetext{
${ }^{9}$ COSTA, F. A. Pereira da. Cronologia histórica do estado do Piauí. Rio de Janeiro, Artenova, 1974. p. 82.

${ }^{10}$ ENNES, Ernesto. As guerras nos Palmares. Rio de Janeiro, Companhia Editora Nacional, 1938. p. 349.

${ }^{11}$ GALVÃO, Sebastião. Dicionário Corográfico, Histórico e Estatístico de Pernambuco. Apud SOBRINHO, Barbosa Lima. "Capistrano de Abreu e o povoamento do sertão pernambucano". In Revista do Instituto Arqueológico, Histórico e Geográfico Pernambucano. Separata do vol. 50. Recife, 1978. p. 37.
} 
Segundo Murillo Marx a crição de uma freguesia visou a institucionalização da vida de homens dispersos. Tratava-se do acesso aos sacramentos e ofícios religiosos e usufruir da formalidade civil com todo o direito e a segurança que pudesse propiciar ${ }^{12}$. Indicava ascensão demográfica de um arraial capaz de arcar com as despesas da igreja matriz.

A primeira ação a ser tomada pelos paroquianos do sertão do Piaú envolveu a sacralização do chão doado ao orago. Aos onze dias do mês de fevereiro de 1697, na fazenda Tranqueira, residência de Antônio Soares Touguia, juntaram-se o padre Miguel de Carvalho (designado pelo bispo de Pernambuco), com mais treze pessoas a fim de elegerem o sítio adequado à ereção da igreja. Nestor Goulart Reis Filho opina que vários são os aspectos a serem levados em consideração na escolha do local de uma povoação, entre esses, natureza do solo, relevo, fontes de água para abastecimento, cursos d'água ${ }^{13}$, etc. A escolha do lugar pelos primitivos povoadores, para Reis Filho, tinha em vista a maior parte desses fatores, buscando em princípio a localização que oferecesse o máximo de comodidade para o agrupamento, em geral modesto ${ }^{14}$.

O grupo dos treze votaram...

(...) e detriminarão, que se fundaçe, e fizeçe a Igr. ${ }^{\text {ia }}$ no Breyo, chamado a Mocha por ser a parte mais conveniente aos moradores de toda a Povoação, fincando no meio della com iguais distançias, e Caminhos para todos os riachos e partes povoadas (...) se elegeu para lugar de Ig. ${ }^{\text {ia }}$ e Cazas do R. ${ }^{\text {do }}$, o taboleiro que se acha pegado a passayem do Jatubá $(. . .)^{15}$

Riachos, partes povoadas e caminhos foram as características naturais e físicas vigoradas pelos fregueses. Na Dezcripção do certão do Peahuy remetida ao Ilmo. e Rm. ${ }^{o}$ S. ${ }^{\text {or }}$ Frei Francisco de Lima Bispo de Pernam. ${ }^{c o}$ o encarregado de institucionalizar a paróquia de Nossa Senhora da Vitória, o pe. Miguel de Carvalho, descreveu sobre o sertão daquele território:

Tem o Certao do Peahuy pertencentes à nova Matriz de N. S. da Victória quatro rios correntes; vinte Riachos, sinco Riachinhos dous olhos de agoa, e duas alagoas, a beira das quaiz, estão 129 fazendas de gado, em que morão

\footnotetext{
${ }^{12}$ MARX, Murillo. Cidades no Brasil, terra de quem? São Paulo, Edusp: Nobel, 1991. p. 18 - 19.

${ }^{13}$ REIS FILHO, Nestor Goulart. Contribuição ao estudo da evolução urbana do Brasil (1500/1720). 2 ed. rev. São Paulo, Pini, 2000. p. 126.

${ }^{14}$ REIS FILHO, Nestor Goulart. Contribuição ao estudo da evolução...Opus cit., p. 126.

${ }^{15}$ ENNES, Ernesto. As guerras nos Palmares..., Opus cit., p. 364.
} 
441 pessoas, entre brancos, Negros, hindios Mullatos e Mestiços, Mais alagoas, e olhos de agoa tem, em que morão alguas pessoas que por todas as de sacram. ${ }^{\text {to }}$ fazem numero de 605 em que entra hu arayal de Paullistas com m. ${ }^{\text {tos }}$ tapuias christaoz o qual governa o Capp. ${ }^{\mathrm{m}}$ mor Francisco Dias de Siqueira $(\ldots)^{16}$

Depois de eleito o local da igreja - o brejo do Mocha - o padre Miguel de Carvalho consagrou o chão em 02 de março de 1697. Definiu-se, de fato, o patrimônio religioso da paróquia nas terras de Mafrense: (...) E asim benzeu o . $^{\text {do }}$ Vig. ${ }^{\text {rio }}$ hu Adro que de Redor da Capella conçinou com marcos de pedra para a sepultura dos Deffuntos e lugar donde se hade fazer a nova Ig. ${ }^{\text {ra }}$ a coal tem sem passos de comprido e sessenta de largo (... $)^{17}$ [sem grifo no original]. Para cargo de pároco nomeram Thomé de Carvalho e Silva, um dos principais atores das ulteriores etapas de urbanização de Oeiras.

Aos fregueses competiam q' elles se obrigavão a fazer, conservar, e paramentar, de ornam. ${ }^{\text {tos }}$, e todo o mais necessário, a Ig. ${ }^{i a}$ que o Ilustríssimo e Reverendíssimo o senhor Bispo de Parnãobuco manda fazer neste Sertão (... $)^{18}$. Também se obrigavão todos a pagarem aos $R^{d o s}$ curas as proçois ordinárias $q$ ' ate agora pagavão aos da Matris da Conceição do Rodella, a saber cada morador, dois mil rs. (... $)^{19}$. Acerca do amparo material do templo a ser erguido, o padre recomendou a fundação de uma irmandade ou confraria. De início, criaram a de Nossa Senhora da Vitória. Temos notícia de mais quatro existentes em 1762: São João Nepomuceno, Santíssimo Sacramento, Santa Anna e Irmandade das Almas ${ }^{20}$.

De caráter provisório, a ermida seria substituída por outra de material mais resistente, logo que os habitantes obtivessem fundos para obra. Entretanto, a pequena Cappella Consta de vinte e Coatro palmos de comprido, e doze de largo feita com a decência Poçivel de taypa, e cuberta de Pindoba por ser parte adonde não ha telha $(. . .)^{21}$.

Basicamente o assentamento da primeira freguesia piauiense, em seu patrimônio religioso, seguiu o esquema da figura 127 . Foi nessa fatia de terra, talvez uma sobra dos

\footnotetext{
16 "DEZCRIPÇÃO do certão do Peahuy remetida ao Ilmo. e Rm. ${ }^{\circ}$ S. ${ }^{\text {or }}$ Frei Francisco de Lima Bispo de

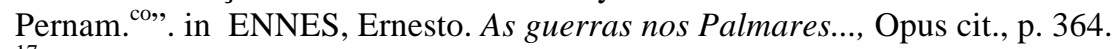

17 "TERMO da Benção da Nova Capella e Poçe q. Se deu ao R. ${ }^{\circ}$ Cura". In ENNES, Ernesto. As guerras nos Palmares..., Opus cit., p. 368.

18 “TERMO da obrigação dos Moradores". In ENNES, Ernesto. As guerras nos Palmares..., Opus cit., p. 366.

19 “TERMO da obrigação dos Moradores". In ENNES, Ernesto. As guerras nos Palmares..., Opus cit., p. 366.

${ }^{20}$ FALCI, Miridan Britto. "A cidade de Oeiras do Piauî". in Revista do Instituto Histórico de Oeiras. Oeiras, Secretaria de Cultura, 2000. p. 174 - 206.

21 "TERMO da Benção da Nova Capella e Poçe q. Se deu ao R. ${ }^{\circ}$ Cura". In ENNES, Ernesto. As guerras nos Palmares..., Opus cit., p. 368.
} 
domínios do fazendeiro doador, que se materializaram o terreiro da capela primitiva, de seu adro e da área necessária à sua volta, livre de impedimentos, espaço fluido para as futuras procissões e festas sacras. Progressivamente, vai se desenhando sobre as datas solicitadas, o traçado da aglomeração. Informou Murillo Marx sobre as datas de terra:

A gente eventualmente beneficiária das doações de terra que se fizeram a tantos santos por aí, de sua parte, obtém a possibilidade de conseguir um chão, ainda que restrito, de construir seu abrigo, de plantar alguma coisa para si e talvez de vender, a segurança de contar com o apoio de outros na mesma situação e o respaldo não só espiritual oferecido, ainda que intermitentemente, por uma capela. O chão, a substiência, a oportuniade de trabalho, ou mais, a complementaridade interessante para o trabalho. ${ }^{22}$

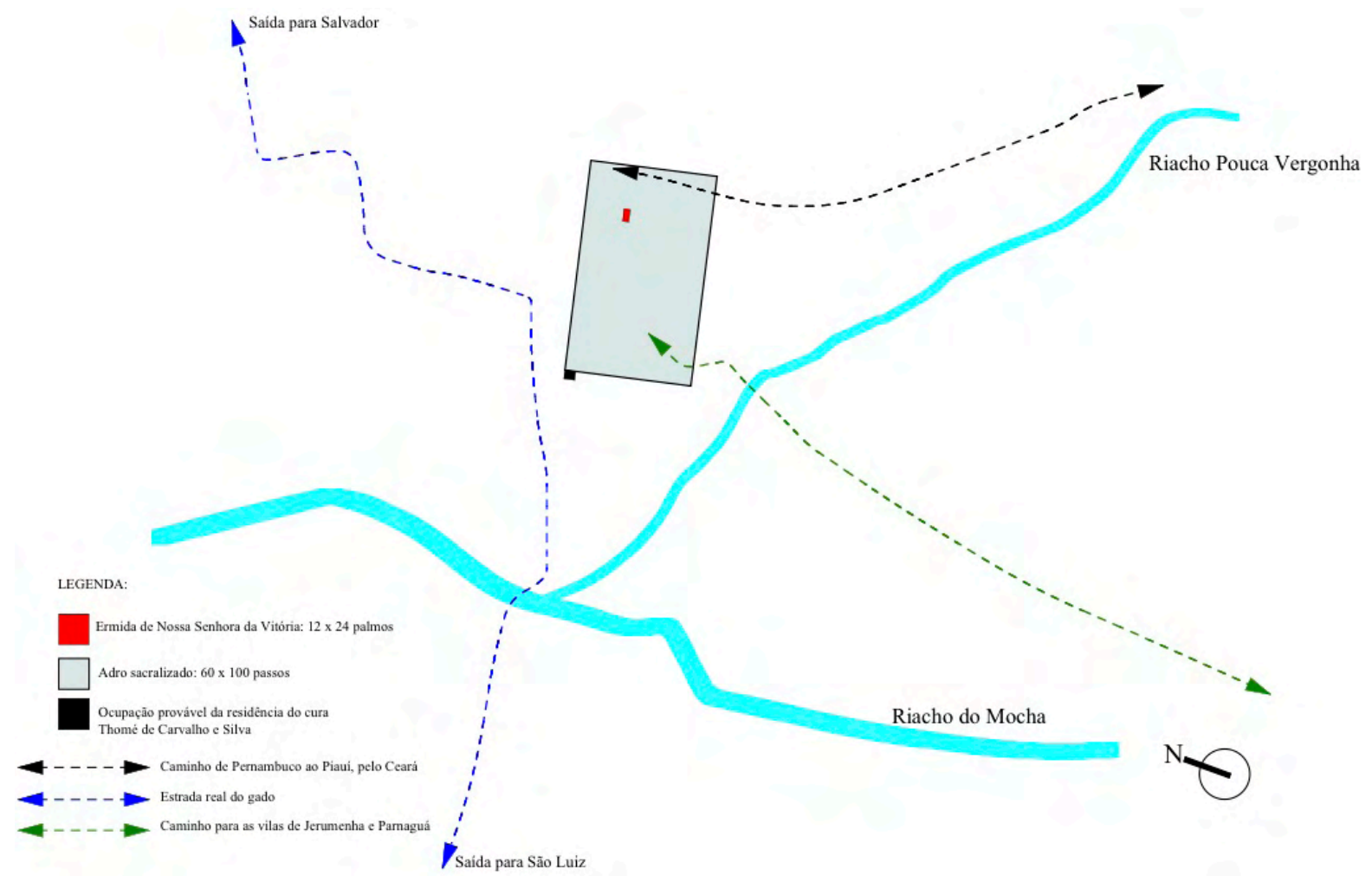

Figura 127 - Provável ocupação da freguesia de Nossa Senhora da Vitória, em 1697. Desenho do autor sobre cartografia fornecida pela Prefeitura da cidade de Oeiras - PI. Planta sem escala.

Oficializada uma paróquia, esta envolveria um território donde seriam acudidas as almas espiritual e temporalemente. Seria uma espécie de termo, só que eclesiástico. O de Nossa Senhora da Vitória abrangeu: dentro em sy esta povoação redonda em tal forma q' fazendo peão na nova Igr. ${ }^{\text {ia }}$ fica com igoal distancia para as mais remotas fazendas que ficão

\footnotetext{
${ }^{22}$ MARX, Murillo. Cidades no Brasil, terra de quem..., Opus cit., p. 45.
} 
dentro de 60 De sessenta legoas formando a freguezia uma cruz de Nascente a poente e de norte ao sul com 120 léguas de comprido e outras 120 de largo (... $)^{23}$. Ao sul confinou com a povoação de São Francisco da Barra dão Rio Grande do Sul. Para o norte trangenciou a serra da Ibiapaba, local onde os jesuítas buscavam implantar uma redução de índios. A leste fazia fronteira com a igreja matriz de Nossa Senhora da Conceição de Cabrobó, sita na margem média do rio São Francisco.

Três anos após a criação da paróquia a realidade dos sertanejos permaneceu a mesma: emtrando em o Rio de São Francisco aonde andei mais de duzentas legoas fazendo a ditta missão achei muitas pessoas que havia dous annos q' se não conffessavão (... $)^{24}$. Os intentos do bispo de Pernambuco - povoar e atrair para o átrio da nova igreja os dispersos seriam concretizados muito tempo depois. Sublinhamos anteriormente que, um dos motivos para o estancamento urbanizador no sertão nordestino, ocorreu em virtude do bloqueio dos grandes fazendeiros de gado, poucos até, em povoar seus domínios:

(...) E preguntandolhe eu porq' não fazião Igreja e substentavão Padres q' lhes desse missão responderão me q' Leonor Pereira Marinho hera senhora da mayor parte do sertão e q' não queria q' se fizesse Igrejas, e o mesmo dizia Antônio Guedes de Brito q' he senhor de mais de trezentas legoas emtre (sic.) o sertão e o Rio de São Francisco e q' não sabião q' rezão ouvesse para q' so achey como tambem Domingos Affonso Sertão se lhes desse todas as terras q' Sua Magestade tem nos seus governos de Pernambuco e Bahia, as quais forão perdidas $(\ldots)^{25}$

Diante dos sucessivos conflitos entre nativos e criadores de gado, a Coroa lusitana decidiu, em 1723, fundar novas freguesias no Piauí, agora sob a jurisdição do bispado do Maranhão (...) para sugeytar esta gentilidade ao grêmio da Igreja, e ao domestico tracto (...) porque nesta forma começa a crescer a povoação $(. . .)^{26}$. Foram elevadas à categoria de paróquia, no citado ano, três novas aglomerações: Nossa Senhora do Carmo de Piracuruca, Santo Antônio do Sorubim e Santo Antônio do Gurguéia. Nessa época o arraial de Nossa Senhora da Vitória havia adquirido sua autonomia municipal. Como vila chamou-se Mocha, em homenagem ao riacho que serpenteia sua cercania.

\footnotetext{
23 “DEZCRIPÇÃO do certão do Peahuy remetida ao Ilmo. e Rm. ${ }^{\circ}$ S. ${ }^{\text {or }}$ Frei Francisco de Lima Bispo de

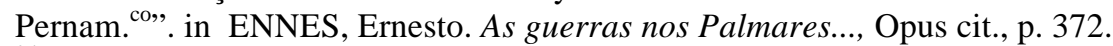

${ }^{24}$ PROJETO RESGATE. AHU_ACL_CU_016, Cx. 1, D. 4.

${ }^{25}$ PROJETO RESGATE. AHU_ACL_CU_016, Cx. 1, D. 4.

${ }^{26}$ PROJETO RESGATE. AHU_ACL_CU_016, Cx. 1, D. 19.
} 


\subsection{Hoc est domus Domini ${ }^{27}$ : vila do Mocha, autonomia municipal, crise}

\section{fundiária e seus espaços}

As vilas criadas nos Setecentos na área do semi-árido nordestino e, ao que pudemos constatar, em outras áreas da colônia, estavam revestidas de um ideal civilizatório. Os termos usuais das cartas régias foram: congregar os vadios e facinorosos; com a creação desta Villa se attrahirão; para o fim de se recolher a ellas os vadios [grifo nosso]. Metaforicamente são, assim como os aldeamentos missioneiros, os nossos currais de almas, interstícios de congregação, atração e recolhimento humano.

Com o predicamento de vila os congregados deveriam obedecer a Igreja e ao Estado, este corporizados nos símbolos da casa de câmara, cadeia e pelourinho. Para a Metrópole, o espaço urbano modelaria o caráter daqueles habituados à rusticidade: índios, degredados e ciganos são alguns que podemos listar.

Verifica-se que a atividade urbanizadora se intesifica a partir do reinado de Dom João V (1706 - 1750), ou como analisou Nestor Goulart Reis Filho, Portugal buscou vínculos mais estreitos com o território através de um programa de controle da vida colonial chamando para si a responsabilidade de urbanização ${ }^{28}$.

Os conflitos bélicos envolvendo a posse da terra entre fazendeiros e gentios marcaram a paisagem social do sertão. O Piauí não foi exceção. Por conseguinte, buscando solucionar esse problema, a Coroa lusa decidiu (...) crear algumas Villas nas partes que achar com pessoas capazes de servirem aos cargos de Officiaes das Câmaras (...) mas antes para sugeytar este gentilidade ao gremio da Igreja (...) E desta forma começa a crescer a povoação $(. . .)^{29}$. Nota-se, então, que o desenvolvimento de certos núcleos populacionais esteve atrelado aos interesses da Metrópole ${ }^{30}$.

\footnotetext{
${ }^{27}$ Parte da frase latina inscrita na portada da igreja de Nossa Senhora da Vitória, edificada no local da primitiva capela. A oração completa é Hoc est Domus Domini firmiter Adificata Anno Domini 1733, cuja tradução significa: esta é a casa do Senhor edificada solidamente no Ano do Senhor de 1733. Ver CARVALHO Jr. Dagoberto Ferreira de. Passeio a Oeiras. 6 ed. Teresina, Fundação Cultural do Piauí, 2010. p. 75 - 79.

${ }^{28}$ REIS FILHO, Nestor Goulart. Contribuição ao estudo da evolução urbana..., Opus cit., p. 71.

${ }^{29}$ PROJETO RESGATE. AHU_ACL_CU_016, Cx. 1, D. 19.

${ }^{30}$ BOSCHI, Caio. "Colonialismo, poder e urbanismo no Brasil Setecentista". In Anais do I Colóquio de Estudos Históricos Brasil-Portugal. Belo Horizonte, PUC, 1994. p. 102. Apud FONSECA, Cláudia Damasceno. "Do arraial à cidade: a trajectória de Mariana no contexto do urbanismo colonial português". In Universo urbanístico português (1415 - 1822). Lisboa, Comissão Nacional para as comemorações dos Descobrimentos Portugueses, 1998. p. 274.
} 
A expansão da pecuária atraiu novos colonos do Reino, principalmente das províncias do Minho e do Douro ${ }^{31}$. Segundo Pereira da Costa, foram enviados trezentos degredados portugueses vindos dos Açores, por ordem do govenador da capitania do Maranhão. Assim colaboraram com a expansão da vila do Mocha ${ }^{32}$. Juntaram-se a estes vinte soldados maranhenses conduzidos com suas familias para o dito Certão (...) $)^{33}$. Tais povoadores catalizaram a urbanização daquele território. Os nativos, aos poucos, eram minimizados ou repelidos para as "brenhas".

\subsection{1 - A vila do Mocha e seus símbolos de autonomia municipal: permanência e carência}

A freguesia de Nossa Senhora da Vitória recebeu o status de vila em 1711, instalada somente em 1717. Seria conhecida, a partir de então, como vila do Mocha. Por ordens de Dom João V, o ouvidor geral do Maranhão foi incumbido de no lugar aonde está a Igreja crieis huma Villa com Senado da Câmara (...) para se administrar a justiça, e se evitarem os delictos que nella se cometem por falta de castigos $(\ldots)^{34}$. Diferentemente da vila cearense de Icó, a carta régia que instituiu Mocha não se paltou por ideais estéticos. Antes, houve uma conversão da área sacralizada e conferida pela Igreja - freguesia - em município, ou melhor, uma sobreposição do poder estatal sobre o território pio.

O templo passou a dividir o seu átrio, como é o caso da maioria das vilas estudadas, com a casa de câmara e cadeia. Cabia a este órgão legislar, administrar, policiar e punir ${ }^{35}$. As decisões que implicavam na modelação do espaço e uso do chão eram tomadas em pregões, alguns realizados em praça pública. Foram eleitos para Mocha dois juízes, três vereadores, almotacés, escrivão e procurador ${ }^{36}$ em acordo às Ordenações do Reino. Entretanto, em 1723, ou seja, onze anos depois da ereção (...) não se acha ainda a dita Villa com casas de Câmara, e audiência sufficiente, ou cadeya em que se possão segurar os que merecem prisão (...) ${ }^{37}$.

\footnotetext{
${ }^{31}$ PROJETO RESGATE. AHU_ACL_CU_014, Cx. 5, D. 426.

${ }^{32}$ COSTA, F. A. Pereira da. Cronologia histórica do estado..., Opus cit., p. 82.

${ }^{33}$ PROJETO RESGATE. AHU_ACL_CU_016, Cx. 1, D. 19.

34 “O LIVRO grosso do Maranhão". In Anais da Biblioteca Nacional do Rio de Janeiro. Vol. LXVII. $2^{\mathrm{a}}$ parte. Rio de Janeiro, Divisão de Obras Raras e Publicações, 1948. p. 104.

${ }^{35}$ BARRETO, Paulo T. "Casas de câmara e cadeia”. in Arquitetura oficial I. São Paulo, MEC, 1978. p. 115.

36 “O LIVRO grosso do Maranhão”. In Anais da Biblioteca Nacional..., Opus cit., p. 105.

${ }^{37}$ PROJETO RESGATE. AHU_ACL_CU_016, Cx. 1, D. 35.
} 
Outros bloqueios surgiram, dificultando a administração da justiça no aglomerado piauiense. O ouvidor geral, Antônio Marques Cardoso, descreveu, em 1727, um aspecto da realidade urbana de Mocha ao Conselho Ultramarino:

(...) q' por ser a terra pobre carecião que se ajudassem para fazerem cadea, e casa de Câmara por não poderem os moradores concorrer para a obra (...) Depois de tomar posse deste lugar vendo q' na terra não havião cadea, nem modo de prisão alguã (...) tractey de introduzir cadea em huãs casas em que morava hum official de justiça com o pretexto de guardar os q' se prendessem mandando fazer para esse prisão hum tronco, a q' se seguião outro e nesta forma enchendosse as ditas casas com os presos e expulsar della o ditto official e ficarão servindo ate o presente de Cadea ainda q' com pouca segurança por falta de materiaes q' a podessem fortificar de q' por essa causa fugirão por vezes os presos. ${ }^{38}$

A inabilidade dos "homens - bons" de Mocha, no que cerne o exercício das obrigações civis e governamentais, levou o ouvidor a capacitá-los sobre que decisões tomar para a obra pública da casa de câmara e cadeia: (...) sem demora tractey da dilligencia, $e$ prometteo cada hum o que lhe pareceo conforme a possibilidade (...) ${ }^{39}$. Ademais, a falta de mestres de ofício na região, basicamente pedreiros e carpinteiros, fragilizou a execução do projeto do edifício. Porém, os edis foram auxiliados por um dos moradores da vila que possue Escravos a fazer a sua custa a cadea, e casa de câmara o q' não regeytou (...) este arrojo a mais deo abrir se o alicerse e chegar alguns materiais para a ditta obra, no q' se gastou tempo bastante e passado sem fundamento, ou cousa alguã se não continuou com a ditta obra $(\ldots)^{40}$.

Os oficiais de Mocha desejavam o amparo material da fazenda real para concretizar as operações públicas. A correição de Antônio Marques Cardoso foi rigorosa, recomendando o rei não fornecer de sua real fazenda dispêndio algum, nem applicar rendimento para a ditta obra, porq' a custa dos moradores se ha de fazer ainda que muito importe (...) porq' sem cadea segura e capaz não se pode administrar a justiça (...) e a casa de Câmara para se fazerem as vereações e audiências (.... $)^{41}$.

\footnotetext{
${ }^{38}$ PROJETO RESGATE. AHU_ACL_CU_016,Cx. 1, D. 35.

${ }^{39}$ PROJETO RESGATE. AHU_ACL_CU_016, Cx. 1, D. 35.

${ }^{40}$ PROJETO RESGATE. AHU_ACL_CU_016, Cx. 1, D. 35.

${ }^{41}$ PROJETO RESGATE. AHU_ACL_CU_016, Cx. 1, D. 35.
} 
Empossado em 1729 o novo ouvidor do Piauí, José Barros Coelho, a vila contou com, no máximo, 30 vezinhos ${ }^{42}$. Contudo, o local para as audiências e a cadeia permaneceram no centro das discussões entre os oficiais e os representantes da Metrópole. Relatou João Barros Coelho, em sua primeira correição:

(...) Não tem esta Villa Casa de Câmara e quando se ajuntão os vereadores fazem os accordos em casa de amigos ou na do juiz ordinário; não tem também Cadea, e querendo o meu antecessor obrigou o conselho a q' fizesse cadea se desculparão com mostrarem q' não tinhão hum só vintém de renda, o q' foi preciso o meu antecessor fazer hum tronco a sua custa, e por lhes guardas aos presos cujos guardas são pagos e substentados a custta dos ouvidores porq' nenhú da terra ama a justiça, antes solecitão extinguila, tanto assim q' se unirão alguns relagos para matarem meu antecessor $(. . .)^{43}$.

Em 1735, o ouvidor Francisco Xavier Morato Boroa, sucessor de José Barros Coelho, escreveu ao rei D. Joao V acerca da estrutura da cadeia e ausência de prédio adequado para as vereações:

(...) sendo esta Villa creada ha mais de 20 annos se acha athe o presente destituída de toda a forma necessariamente precisa para o bom regime de qualquer Republica. Por quanto esta Villa sem casas de Câmara, nem cadea capas (...) a cadea desta Villa consiste em hum horrível, e tormentozo tronco em que os presos estão metidos, cuja prisão serve mais para martirizar, e aleyjar, do que para os segurar (...) porquanto consta a ditta prisão de húas casas térreas formadas de paos a pique, e por entre eles vão formadas as paredes de barro amassado com agoa, sem levarem cal alguma pella não a ver nas vezinhanças desta Villa, e por cima cubertas de telha (...) e porque as casas de cadea não tem segurança alguma, e são de qualidade que qualquer crianssa as pode com qualquer pao arrombar $(\ldots)^{44}$

A única justificativa encontrada pelos edis da vila do Mocha, diante da precariedade dos edifícios públicos, do espaço intraurbano do núcleo e permanência dessa realidade por muito tempo se deveu: (...) a Câmara não tem rendimento algú, por estar de posse o vigário da Villa de todo o cítio em q' foi creada por mercê q' della fizesse Vossa Magestade do ditto

\footnotetext{
${ }^{42}$ PROJETO RESGATE. AHU_ACL_CU_016, Cx. 1, D. 57.

${ }^{43}$ PROJETO RESGATE. AHU_ACL_CU_016, Cx. 1, D. 67.

${ }^{44}$ PROJETO RESGATE. AHU_ACL_CU_016, Cx. 2, D. 115.
} 
cítio antes da Villa ser fundada (... $)^{45}$. Entramos em uma das questões mais delicadas na formação de nossos aglomerados urbanos: a definição do rossio e do termo que competia à municipalidade, uma tradição medieval lusitana regulamentada pelas Ordenações do Reino, transplantadas para suas colônias ultramarinas.

Definia-se o rossio da vila através das cartas régias, alvarás e autos de ereção em forma de lei. Servia esta área para distintos usos: local de pastagem para o gado, coleta de lenha e madeira, algumas roças, bem como uma área reservada para a expansão da vila, seja prevendo novas cessões de terra, seja a abertura dos correspondentes caminhos e estradas, ruas ou praças ${ }^{46}$. Cabia aos vereadores zelar esse patrimônio fundiário, isto é, eles deveriam cuidar para que as possessões, servidões, caminhos ou ressios do concelho não sofressem invasões ou abusos de qualquer espécie e da parte de quem quer que fosse $(. . .)^{47}$.

Em Mocha o chão destinado como rossio detinha o pároco da matriz, Thomé Carvalho e Silva. Desse modo, os vereadores solicitaram o terreno que competia à municipalidade. Os atritos entre cura e representantes da câmara chegaram ao Reino através das correições dos ouvidores. Consequentemente, os atritos reverberaram na paisagem da vila. Sem rossio, onde auferir os rendimentos necessários à evolução do espaço urbano, o município apresentou, em seus tempos primeiros de autonomia, um déficit de desenvolvimento, uma fisionomia essencialmente rural.

Quando fundada a freguesia de Nossa Senhora da Vitória, o patrimônio religioso ou da Igreja se restringiu em um adro de 60 x 100 passos. Porém, em 1704, Portugal homologou uma lei concedendo um passal, ou uma gleba de terra aos vigários colados, servindo-lhes de sustento. Cumprindo o mandato oficial, o desembargador do Maranhão, Carlos de Azeredo Leyte, doou ao padre Thomé Carvalho e Silva o seu respectivo passal, englobando o território da fazenda Passagem (...) que este sitio comprehende de norte a sul o espaço de três legoas, e de nascente ao poente duas legoas e meia, pouco mais ou menos $(. . .)^{48}$ e em hua ponta della se acha a ditta Villa fundada, e a Igreja; e ao redor da qual fizeram alguns moradores suas rossas com casas de vivenda (... $)^{49}$. Os habitantes pagavam o foro ao padre. Este cria que, sendo as terras do padroeiro ou da Igreja, seria justo receber o tributo. Entretanto, competia à câmara a coleta do ônus referente as datas de terra concedidas dentro do rossio.

\footnotetext{
${ }^{45}$ PROJETO RESGATE. AHU_ACL_CU_016,CX. 1, D. 66.

${ }^{46}$ MARX, Murillo. Cidades no Brasil, terra de quem..., Opus cit., p. 68.

${ }^{47}$ MARX, Murillo. Cidades no Brasil, terra de quem..., Opus cit., p. 68.

${ }^{48}$ PROJETO RESGATE. AHU_ACL_CU_016, Cx. 2, D. 143.

${ }^{49}$ PROJETO RESGATE. AHU_ACL_CU_016, Cx. 1, D. 35.
} 
A Coroa, em decreto especial de 12 de novembro de 1710, resolveu aos mais estados do Brasil revogar os passaes, q' se tinhão permitido aos dittos Parochos, declarando que so se lhes conservasse a terra, q' bastasse para o pasto de três, ou quatro cavallos (... $)^{50}$. Os vereadores piauienses notificaram a população para não pagar ao padre o foro das datas de terra. E asi para se evitarem duvidas, me parece conceder Vossa Magestade à Câmara desta Villa hua legoa em quadra para a sua fundação, e mais rossaria, q' forem precisas para os moradores della se sustentarem (...) e q' para o Parocho se reserve fora da ditta concessão da legoa de terra para a Câmara a terra bastante para o pasto de três ou quatro vacas (.... ${ }^{51}$, solicitou o ouvidor do Piauí ao Reino.

Em troca do passal, o novo clérigo da vila do Mocha aceitou, em 1736, uma côngrua anual de vinte mil réis: o vigário collado Thomé Carvalho e Sylva falaceo em o mês de setembro do anno passado, e por se achar servindo o vigário encomendado o pe. Antônio Henrique de Almeida Rego (...) deu por escripto (...) aseytar os dittos vinte mil réis em cada anno $(\ldots)^{52}$.

O termo de uma vila era a demarcação do território municipal. Ou como definiu Murillo Marx seria uma área bem definida, entre outras mais antigas ou a serem criadas, termos municipais na ocasião definidos ou redefinidos. Não conseguimos identificar nos velhos documentos analisados a respectiva área do termo da vila do Mocha. Supomos que este envolveu o terriório de sua freguesia - 120 léguas de comprido com 120 léguas de largo ${ }^{53}$ -, assim constatamos na carta régia passada ao governador do Maranhão: Me pareceo ordenar-vos passeis ao Piahuy, e no lugar aonde está a Igreja crieis huma Villa ${ }^{54}(. .$.$) . [sem$ grifo no origial]

O termo poderia abranger paróquias, ermidas curadas, simples capelas, sesmarias, fazendas povoadas, aldeamentos missioneiros e sertões desconhecidos. Até o ano de 1723 poucas foram as capelas erguidas no Piauí. Com a visita do bispo do Maranhão foram tomadas algumas providências eclesiásticas, uma delas (...) mandar erigir algumas capellas, nomeando para ellas capellães para os moradores q' ficão em notáveis distancias poderem receber mais promptamente os sacramentos (...) mandey destinar lugares, e benzellos (...).

\footnotetext{
${ }^{50}$ PROJETO RESGATE. AHU_ACL_CU_016,Cx. 1, D. 35.

${ }^{51}$ PROJETO RESGATE. AHU_ACL_CU_016, Cx. 2, D. 115.

${ }^{52}$ PROJETO RESGATE. AHU_ACL_CU_016, Cx. 2, D. 126.

53 "DEZCRIPÇÃO do certão do Peahuy remetida ao Ilmo. e Rm. ${ }^{\circ}$ S. ${ }^{\text {or }}$ Frei Francisco de Lima Bispo de

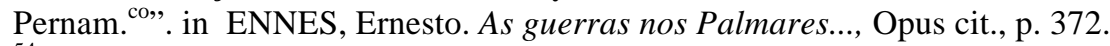

54 “O LIVRO grosso do Maranhão”. In Anais da Biblioteca Nacional..., Opus cit., p. 105.
} 
Nasceram, dentro do termo da vila do Mocha, as paróquias de Nossa Senhora do Carmos de Piracuruca (1723), Santo Antônio do Surubim (1723), Santo Antônio do Gurguéia (1723), Nossa Senhora da Conceição dos Aruazes (1740), Nossa Senhora do Desterro (1742) e Nossa Senhora do Livramento do Parnaguá (1755).

\subsection{2 - Barro, vara e palha: uma ermida, uma matriz}

De caráter provisório, a primeira capela dedicada à Nossa Senhora da Vitória foi construída com materiais da terra, em taipa coberta com palha de pindoba, uma espécie de palmeira abundante na região. Construído segundo as circunstâncias físicas, naturais e econômicas da época, o templo da paróquia piauiense e sua localização no átrio repercutiram alguns debates nos Setecentos, com nítidos reflexos na paisagem urbana da vila do Mocha, em sua urbanização de fato.

Os oficiais da câmara argumentaram para o ouvidor Antônio Marques Cardosos a existência de melhor sítio para a fixação da vila: No destricto da dita villa se diz haver milhor fundação para ela, do que aquella em que esta estabelecida (...) sendo mais solutifera, e capaz de comercio (...) porque nesta forma se continuará a aumentar a povoação neste limite $(\ldots)^{55}$. Apesar da indicação, não relocaram a vila para o local mencionado, mesmo sendo vantajoso. Antes, a reformulação da igreja matriz atraiu mais fregueses à vila, estruturando ao seu redor e ao longo dos caminhos as suas residências.

Aumentando a população do núcleo, um novo templo foi almejado (...) com mayor grandeza (...), pois em dias festivos a capela para os congregados (...) mostrou ser ainda pequena, porq' nas occaziões de festas de Natal, e Páscoa em q' comemora a esta vila muita gente (...) ficava a mayor parte da gente fora a da Igreja pella sua pequenhes o que precisou o ditto vigário mandalla acrescentar mais $(\ldots)^{56}$.

A reedificação da matriz cabia aos leigos. Contudo, as iniciativas de reforma principiariam em 1699, tendo em sua liderança o vigário Thomé Carvalho e Silva. Segundo os relatos do ouvidor José Barros Coelho, o reverendo teve grande trabalho com a fundação da Igreja q' fez nesta Villa com esmollas de todos os moradores da Capitania por não haver em

\footnotetext{
${ }^{55}$ PROJETO RESGATE. AHU_ACL_CU_016, Cx. 1, D. 19.

${ }^{56}$ PROJETO RESGATE. AHU_ACL_CU_016, Cx. 2, D. 96.
} 
toda ella outra alguã Igreja $(. . .)^{57}$. Ainda foram apontadas as necessidades de um novo espaço conveniente à implantação do templo. Adotaram, ao nosso ver, as obrigações estipuladas pelas "Constituiçoens Primeyras do Arcebispado da Bahia": edificar em lugares decentes, acommodados (...) e desviados, quando for possível, de lugares immundos, e sórdidos, e de casas particulares (...) em distancia que possão andar as Procissões ao redor dellas (... $)^{58}$.

Enquanto paróquia, o padre da igreja matriz fez neste vastíssimo deserto huã capella de Materiais da terra, Barro, Vara, e Palha (...). Com materiais simples, a fragilidade estrutural da ermida era latente. Em decorrência disso, Thomé Carvalho e Silva com seu trabalho e também com dispêndio do pouco q' possuía; agreguey para este lugar algún Povo, q' com nossas próprias mãos, à falta de offertas e cabedais fizemos a outra Igreja mayor, e com mais segurança que a antiga $(. . .)^{59}$. Mais segurança confere estabilidade estrutural, materiais mais resistentes às intempéries como pedra e cal. Acrescentaram à igreja uma torre com campanário com cuja obra se anda de presente engenho o ditto vigário tem feito despesas pellos moradores esta torre já atenuados, e não poderem concorrer para toda a despesa $(\ldots)^{60}$.

A sociedade pieuiense era composta, em sua maioria, de pequenos fazendeiros de gado e rosseiros, por isso, as contribuições foram mínimas para as despesas da nova matriz de Mocha. O socorro esperado viria do Trono, através do padroado: causa porq' recorrer a Vossa Magestade o ditto vigário com a ditta petiçam para q'o socorresse. Com as causas necessárias para a fabrica da ditta Igreja por ser do padroado $(. . .)^{61}$. Em resposta a todos os estados do Brasil, o monarca lusitano conferiu responsabilidade aos fregueses: (...) Me pareceo ordernar-vos informeis com o vosso parecer, o que poderá importar o reparo d'esta Igreja, especialmente a obra da Capella-mór, que é a que me pertence; porque o corpo da Igreja devem concorrer os fregueses (... $)^{62}$.

\footnotetext{
${ }^{57}$ PROJETO RESGATE. AHU_ACL_CU_016,CX. 2, D. 96.

${ }^{58}$ CONSTITUIÇÕES Primeyras do Acerbispado da Bahia feitas, e ordenadas pelo ilustríssimo, e reverendíssimo sernhor D. Sebastião Monteiro da Vide, 5 arcebispo do dito Acerbisopado,e do conselho de sua Majestade: propostas, e aceitas em o Synodo Diocesano, que o dito senhor celebrou em 12 de junho do anno de 1707. Introdução e revisão do cônego prebendano Idelfonso Xavier Ferreira. São Paulo, Typ. 2 de dezembro, 1853. Livro quarto, titulo 17 (683).

${ }^{59}$ PROJETO RESGATE. AHU_ACL_CU_016,CX. 2, D. 96.

${ }^{60}$ PROJETO RESGATE. AHU_ACL_CU_016, Cx. 2, D. 96.

${ }^{61}$ PROJETO RESGATE. AHU_ACL_CU_016, Cx. 2, D. 96.

${ }^{62}$ ANNAES da Bibliotheca Nacional. Volume XXVIII. Ano 1906. Rio de Janeiro, Officina de Artes Graphicas da Bibliotheca Nacional, 1908. p. 253.
} 
Em carta a Dom João V, datada de 1742, o pároco João Rodrigues Covete descreveu os aspectos físicos da matriz de Mocha e a ausência do rei diante de suas obrigações como patrono da Igreja em suas colônias. A partir dessas informações elaboramos a planta da figura 128:

He esta freguesia de Nossa Senhora da Victória da Villa do Moucha, cabeça da capitania do Piahui, Bisp. ${ }^{\text {do }}$ de São Luiz do Maranhão povoada a cincoenta annos, e a sua custa fizerão os Parochianos a sua $\operatorname{Igr}^{\text {ia }}$ Matriz, e a paramentarão conforme a sua possibilidade, sem athe o presente V. Mag. contribuhir com cousa alguã para o seu ornato (...) Tem a Igreja três altares a saber Mor com 12 palmos de comprido e os dous laterais cada hú com $\underline{8}$ os quais não tem mais q' somente huns ornamentos [grifo nosso] $(\ldots)^{63}$

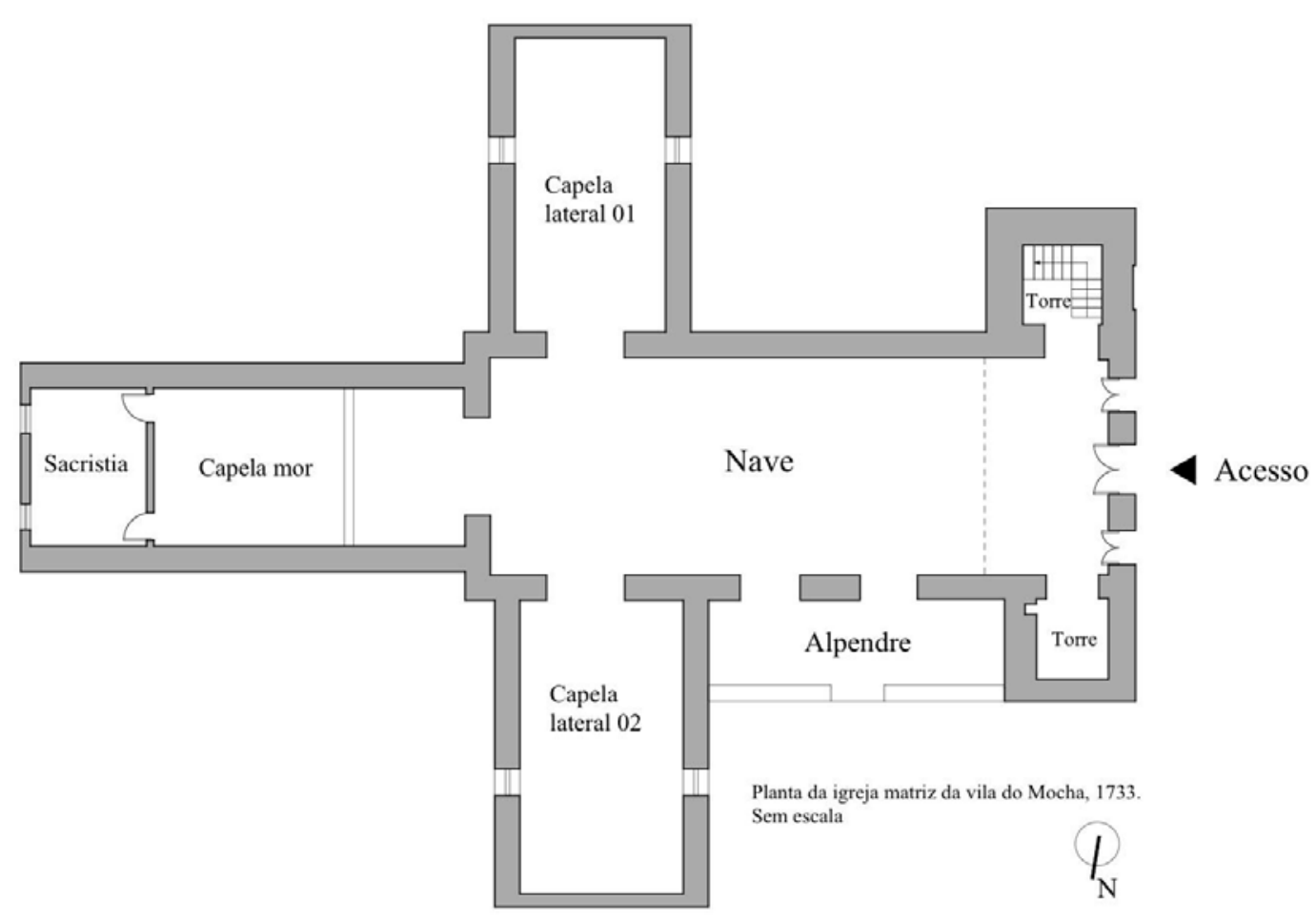

Figura 128 - Planta da igreja de Nossa Senhora da Vitória da vila do Mocha, 1733. Desenho do autor segundo informações elaboradas pela $19^{a}$ SR/IPHAN. Sem escala.

${ }^{63}$ PROJETO RESGATE. AHU_ACL_CU_016, Cx. 3, D. 187. 
Mesmo o cura indicando os benefícios obtidos pela fazenda real, (...) mas sim sendo os dízimos de Vossa Magestade so trezentos mil réis, hoje passão de settenta e dous cruzados $(\ldots)^{64}$, materializou na igreja de Nossa Senhora da Vitória a falta de recursos para finalizar a construção da outra torre campanária, como para se completar a fábrica desejada [figuras 129 e 130].

Presume-se, a partir da reforma da igreja da vila do Mocha, o poder de atração que esta exerceu sobre habitantes de outras paragens. O aumento dos dízimos eclesiásticos é um indício de expansão urbana encerrado no núcleo. Até a conclusão do templo, em 1733, Mocha apresentou cerca de trinta fogos com roças e quintais. Na praça residiaram os oficiais e os ricos fazendeiros de gado. Outros locais próximos ao largo tendiam a ser valorizados. Nas cercanias, às margens dos caminhos, viveram os moradores de vida mais modesta [figura 131]. A igreja é, portanto, presença econômica e religiosa, se faz marcante no espaço por seu peso adensador.

Enquanto os fregueses (re)modelavam a matriz, dando-lhe a fisionomia que hoje vemos, sugem debates, por volta de 1730, entre o vigário Thomé de Carvalho e Silva e a Metrópole no que dizia respeito à necessidade de um hospício de religiosos, os quais seriam incumbidos de catequizar nativos, escravos e portugueses das redondezas. Mocha alongava-se para o subúrbio, surgirá o futuro bairro do Rosário.
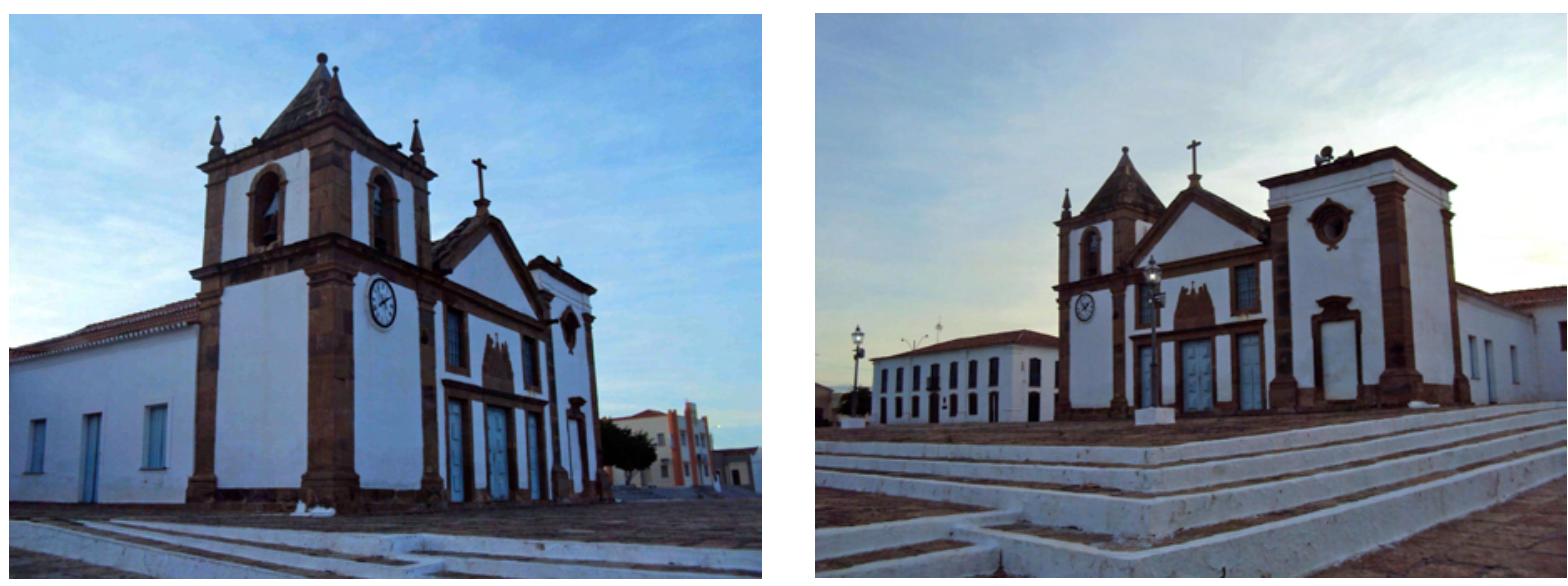

Figura 129 - Igreja matriz de Nossa Senhora da Vitória. Foto do autor, 2010.

Figura 130 - Igreja matriz de Nossa Senhora da Vitória, tirada desde sua praça. Foto do autor, 2010.

\footnotetext{
${ }^{64}$ PROJETO RESGATE. AHU_ACL_CU_016,Cx. 2, D. 96.
} 


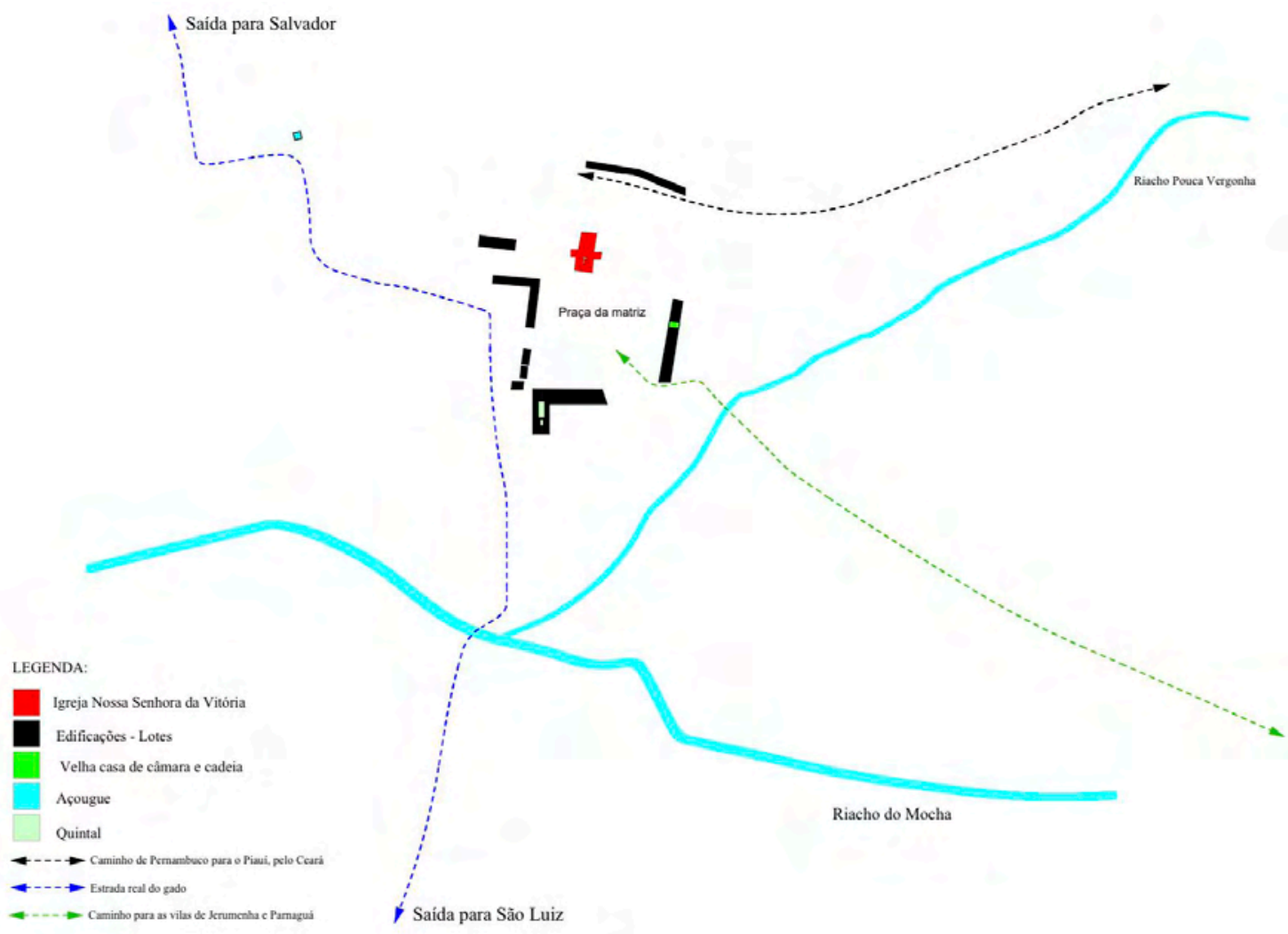

Figura 131 - Ocupação provável da vila do Mocha em 1733. Desenho do autor sobre cartografia fornecida pela prefeitura da cidade de Oeiras - PI. Planta sem escala.

\subsection{3 - A vila e os jesuítas}

Alguns especialistas analisam os fenômenos urbanos associados à implantação de conventos ou hospícios de ordens religiosas. Fania Fridman ${ }^{65}$ estudou a ação dos religiosos no Rio de Janeiro. Murillo Marx ${ }^{66}$, em sua tese de doutorado - Seis conventos, seis cidades -, ressaltou o domínio das ordens eclesiásticas na formação social e urbana. Os conventos superavam os demais edifícios pela sua escala, situação no tecido urbano e por seus domínios fundiários. Estes trabalhos conferem aos conventos ou outro edifício de religiosos o reordenamento espacial dos aglomerados brasileiros, organização que culminaria na segregação dos espaços por uso e classe social ${ }^{67}$.

Fenômeno semelhante ocorreu em Mocha. Vale ressaltar que, apesar das observações aqui apresentadas, não nos aprofundamos neste interessante assunto pela carência de fontes

\footnotetext{
${ }^{65}$ FRIDMAN, Fania. Donos do Rio em nome do rei: uma história fundiária da cidade do Rio de Janeiro. 2 ed. Rio de Janeiro, Editora Garamond, 1999. 302 p.

${ }^{66}$ MARX, Murillo. Seis conventos, seis cidades. Tese de doutorado. São Paulo, FAU/USP, 1984. 237 p.

${ }^{67}$ FRIDMAN, Fania. Donos do Rio em nome do rei: uma história fundiária..., Opus cit., p. 15.
} 
primárias. Mostraremos como a ereção do hospício dos padres da Companhia de Jesus conferiu ao rossio da vila um novo pólo de atração, estruturando o bairro do Rosário da futura cidade de Oeiras.

Ao que parece, o hospício dos jesuítas no Piaui objetivou domesticar os ferozes gentios daquela Capitania (... $)^{68}$ e evangelizar, sacramentar os moradores, brancos e negros, daqueles confins por viverem todos ignorantes da doutrina (... $)^{69}$. Além dos valores essencialmente religiosos, o hospício administraria as finanças das trinta e cinco fazendas de gado deixadas por Mafrense como herança à Companhia. Sede da gestão dos bens temporais existentes no Piauí. Por último, cumpriu a sua função basilar, servir de hospedagem àqueles religiosos a pregar em suas missões volantes pelo sertão. Um descanso para o viajante.

À frente do projeto esteve o vigário Thomé Carvalho e Silva. Este ofereceu doze mil cruzados e huã fazenda de gado (...) para a instalação do prédio. Assinalou Riolando Azzi ${ }^{70}$ a participação ativa dos fiéis na construção de templos religiosos e na promoção da devoção. $\mathrm{O}$ ouvidor Antônio Marques Cardoso conseguiu um montante de 46 mil réis para a obra, ofertados por três fazendeiros de gado: João Campello da Fonseca (10 mil réis), Hylário Ribeiro de Carvalho (20 mil réis) e Maria da Encarnassão (16 mil réis) ${ }^{71}$. Mobilizados estiveram os oficiais da câmara e, principalmente, a Coroa. Dom João V auxiliou a fundação do hospício com 3 mil cruzados ${ }^{72}$.

Em 20 de abril de 1733, Vossa Magestade tem concedido a este Parocho licença que pretendia para fundar o Hospício de Religiosos da Companhia de Jesus, e deve deixar se ao cuidado do mesmo Parocho a fábrica e dotação deste Hospício ${ }^{73}$. Thomé Carvalho e Silva contratou o mestre predeiro, Domingos Dias da Costa, residente da vila, para realizar a obra do projeto. Interessante é o relato do pedreiro sobre o partido, ou como se usou na colônia, a fábrica do edifício:

(...) que constanto a obra do tamanho da matriz desta Villa com sua Sacristia por detrás do Altar-mor como se costuma nos Colégios dos dittos Padres.

\footnotetext{
${ }^{68}$ PROJETO RESGATE. AHU_ACL_CU_016, Cx. 2, D. 75. (documentos anexos).

${ }^{69}$ LEITE, Serafim. História da Companhia de Jesus no Brasil. Tomo V. Livro III. Rio de Janeiro, Instituto Nacional do Livro, 1938 - 1950. p. 563.

${ }^{70}$ AZZI, Riolando. "A instituição eclesiástica durante a primeira época colonial”. In História da igreja no Brasil: ensaio de interpretação a partir do povo: primeira época, período colonial. Eduardo Hornaert [et al.]. 5 ed. Petrópolis, Vozes, 2008. p. 234.

${ }^{71}$ PROJETO RESGATE. AHU_ACL_CU_016, Cx. 2, D. 75. (documentos anexos).

${ }^{72}$ PROJETO RESGATE. AHU_ACL_CU_016, Cx. 2, D. 75.

${ }^{73}$ PROJETO RESGATE. AHU_ACL_CU_016, Cx. 2, D. 75. (documentos anexos).
} 
Tendo também o ditto Hospício de huma parte da ditta igreja huma coadra de Sobrados para cubícullos por sima com seu salam de Hospedes e por baicho a oficina deste $(\ldots)^{74}$

Ao dizer como se costuma no colégio dos dittos Padres, o mestre de ofício sem querer aludia a uma prática ou tradição arquitetônica jesuítica. Na opinião de Lúcio Costa, o programa dos colégios, conventos e hospícios contou em dispor vários corpos da construção em "quadra", formando um pátio para a convivência dos religiosos. A igreja alinhada ao quarto, ou cubícullo contíguo, resultaria numa fachada de único plano, uma linha horizontal contínua $^{75}$.

Fania Fridman, Apud Paulo F. Santos, afirma que, os jesuítas e outras ordens religiosas, além de serem sensíveis à forma e ao material da construção, tinham cuidado com sua localização, o que imprimia um caráter funcional ${ }^{76}$. Empenhados em estar presentes no aglomerado, os jesuítas associados com o pároco da igreja matriz de Mocha, estudaram as condições do lugar para o seu estabelecimento. Para não competir espacialmente com o templo local, elegeram uma área mais afastada, após o riacho Pouca Vergonha. Trata-se de um sítio mais elevado que o terreno da matriz, o cume de um pequeno promontório [figura 132]. Ali podiam literalmente ver o cotidiano do núcleo e a chegada dos viajantes vindos de São Luiz para Salvador, pela estrada real do gado.

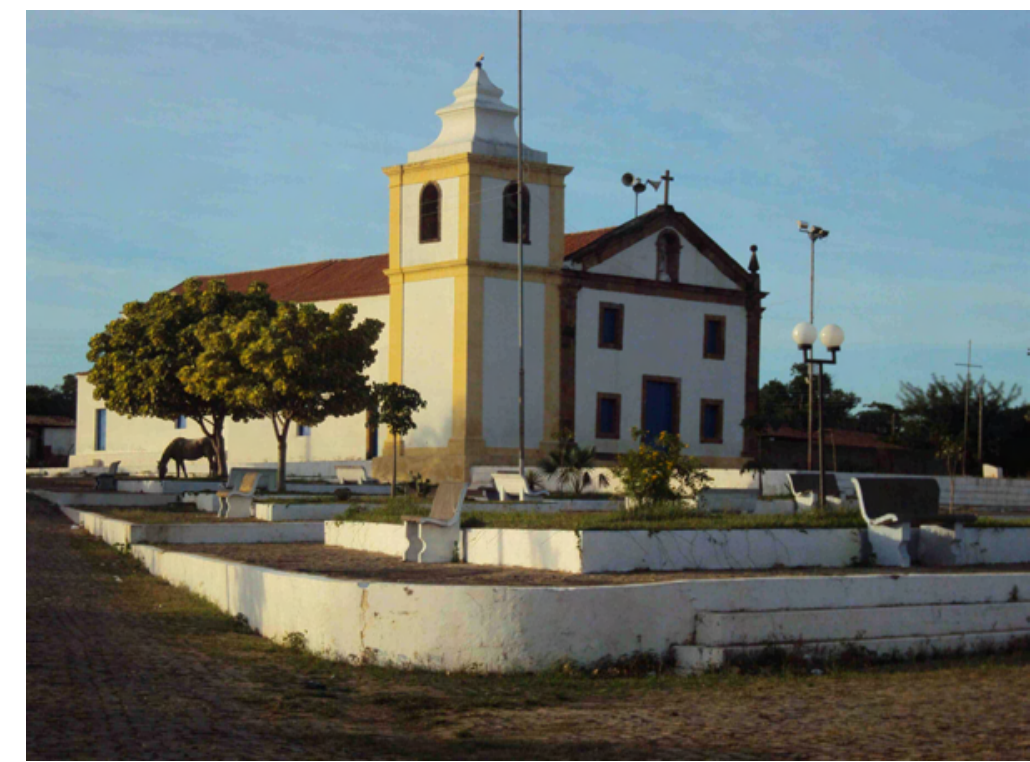

Figura 132 - Igreja Nossa Senhora do Rosário dos Homens Pretos. Capela do hospício que foi dos jesuítas na capitania do Piauí. Foto do autor, 2010.

\footnotetext{
${ }^{74}$ PROJETO RESGATE. AHU_ACL_CU_016, Cx. 2, D. 75. (documentos anexos).

${ }^{75}$ COSTA, Lúcio. "A arquitetura jesuítica no Brasil". In Revista do Serviço do Patrimônio Histórico e Artístico Nacional. vol 5. Rio de Janeiro, MEC, 1941. p. 27.

${ }^{76}$ FRIDMAN, Fania. Donos do Rio em nome do rei: uma história fundiária..., Opus cit., p. 16.
} 
O fluxo de crescimento da vila do Mocha apresentou dois pólos distintos: ao redor da praça ou próximo desta e o largo do hospício [figura 133]. Um documento ${ }^{77}$ da época pombalina cita que, nesta área da localidade, se concentrou a população pobre de brancos, alguns escravos e forros. Após a expulsão dos inacianos do Brasil, a ordem do Rosário dos Homens Pretos obteve a licença para usar o templo em seus ofícios religiosos. A segregação social é destacada pelo isolamento desta parte da vila com o centro do aglomerado. A ligação entre os dois pólos era feita por uma ponte de longarinas de madeira sobre colunas de cantaria, construída no século XVIII sobre o riacho Pouca Vergonha ${ }^{78}$. Quando visitamos o casco viejo da atual cidade de Oeiras, em abril de 2010, em nossa Viagem científica pelo sertão nordestino, notamos que a comunidade do bairro do rosário é composta, em sua maioria, por afrodescendentes.

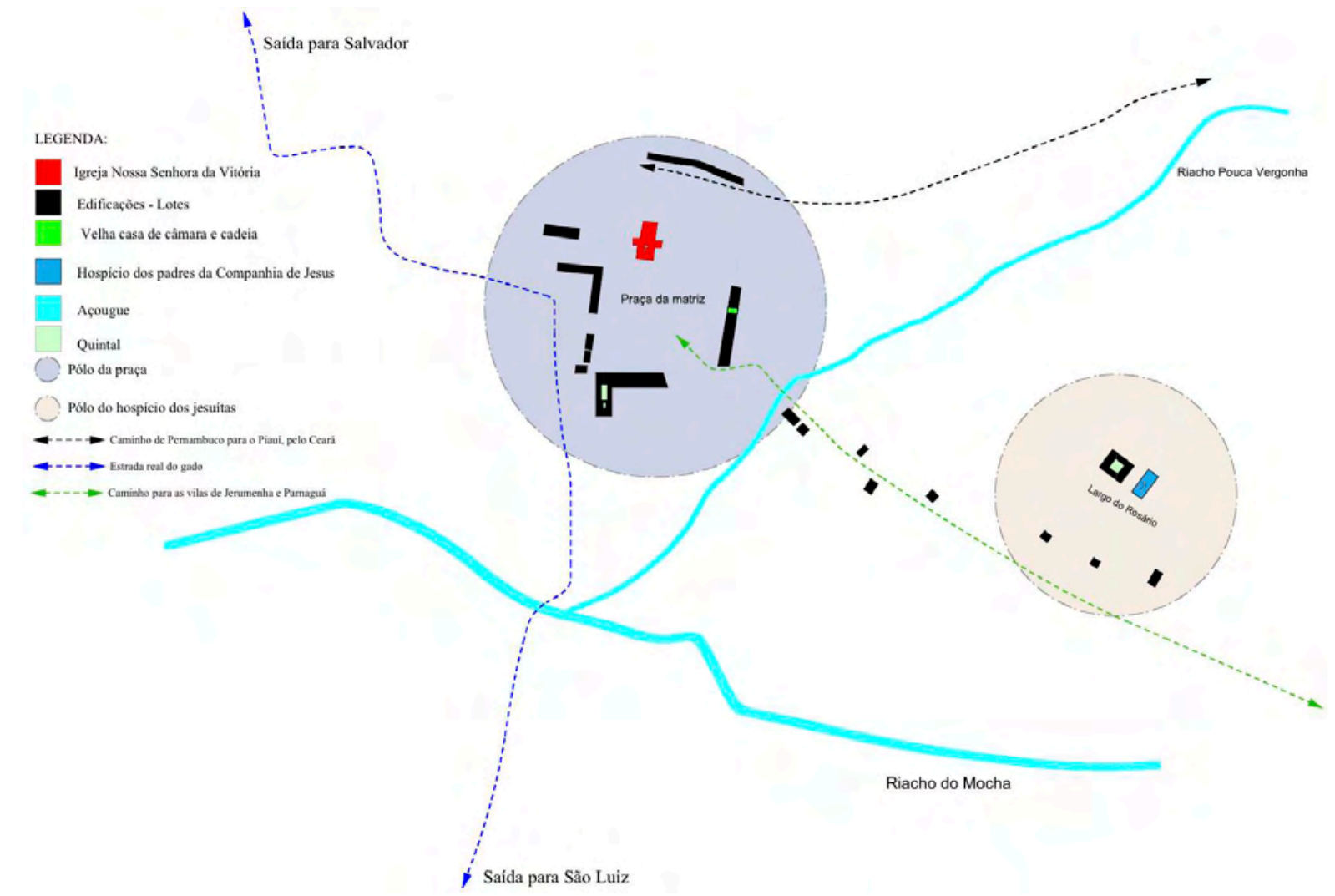

Figura 133 - Ocupação provável da vila do Mocha após a construção do hospício dos jesuítas. Distinção de dois pólos de atração e expansão do núcleo urbano. Desenho do autor segundo Planta da cidade de Oeyras, encontrada no AHEx - RJ.

\footnotetext{
${ }^{77}$ FALCI, Miridan Britto. “A cidade de Oeiras do Piauî”. in Revista do Instituto Histórico de Oeiras. Oeiras, Secretaria de Cultura, 2000. p. 189 - 190.

${ }^{78}$ FERREIRA, Murilo Cunha (coord.). Cidades do Piauí testemunhas da ocupação do interior do Brasil durante o século XVIII: conjunto histórico e paisagístico de Oeiras - dossiê de tombamento. Teresina, IPHAN/ Regional do Piauí, 2010. p. 62.
} 
Por volta de 1818, Spix e Martius percorreram aquele lugar descrevendo os usos da construção de fundação loyolista: (...) atualmente casa do vigário, o qual tem autorização do bispo do Maranhão para exercer certas funções (... $)^{79}$. Ao contrário dos alemães que consideraram a prédio insignificante, George Gardner chamou atentou para a localização e aspectos estéticos ao dizer: (...) na extremidade norte da cidade há um grande e belo edifício, ora em ruínas, que foi o colégio dos jesuítas antes da expulsão do Brasil ${ }^{80}$.

\subsection{4 - Mocha no contexto econômico e geopolítico da colônia}

Nestor Goulart Reis Filho chamou à atenção para a situação de um núcleo urbano diante das modalidades de relações que seus habitantes poderão estabelecer com outras áreas da rede urbana brasileira e com a Metrópole ${ }^{81}$. Refere-se, portanto, à divisão internacional do trabalho, com atores bem definidos no hierárquico sistema urbano brasileiro.

No contexto da pecuária extensiva, a freguesia de Nossa Senhora da Vitória foi elevada à categoria de vila devido à fatores econômicos e geopolíticos ${ }^{82}$. Segundo Roberta Delson, a Coroa resolveu estabelecer novas comunidades no interior nordestino para vigiar o tráfego das boiadas e seu conseqüente comércio. O desenvolvimento dessas prosperaria se fossem corretamente administradas pelos funcionários do governo ${ }^{83}$.

No final do século XVII, o território eclesiástico da paróquia de Mocha contou com 129 fazendas de gado distribuídas ao longo dos rios Parnaíba, Canindé, Piauí, Itaim e outras ribeiras. Relatório detalhado dessas herdades elaborou o padre Miguel de Carvalho a ser enviado ao bispo de Pernambuco, D. Francisco de Lima ${ }^{84}$. O mercado da pecuária atraiu para o sertão portugueses imigrados do Minho, Douro e Açores, como também, outros residentes no litoral. O número de fazendas do Piauí, em 1730, aumentou para $400^{85}$.

\footnotetext{
${ }^{79}$ SPIX, J.B Von; MARTIUS, C.P.F. Viagem pelo Brasil: 1817 - 1820. 3 v. São Paulo, Edusp, 1981. p. 422.

${ }^{80}$ GARDNER, George. Viagem ao interior do Brasil. São Paulo, Edusp, 1975. p. 125.

${ }^{81}$ REIS FILHO, Nestor Goulart. Contribuição ao estudo da evolução urbana..., Opus cit., p. 123.

${ }^{82}$ MARX, Murillo. Cidades no Brasil, terra de quem..., Opus cit., p. 92.

${ }^{83}$ DELSON, Roberta Marx. Novas vilas para o Brasil colônia: planejamento espacial e social no século XVIII. Brasília, Ed. Alva-Ciord., 1997. p. 20, 23.

84 “DEZCRIPÇÃO do certão do Peahuy remetida ao Ilmo. e Rm. ${ }^{\circ}$ S. ${ }^{\text {or }}$ Frei Francisco de Lima Bispo de

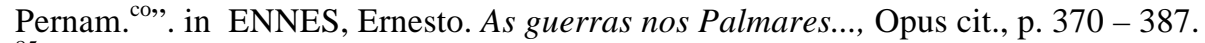

${ }^{85}$ MOTT, Luiz R.B. Piauí colonial: populacao, economia e sociedade. Teresina, Projeto Petrônio Portella, 1985. p. 57.
} 
Do Piauí setecentista foram abastecidos de carne e couro os centros urbanos litorâneos: Salvador, Recife e São Luiz. Não apenas, os arraiais mineiros receberam consideráveis quantidades de produtos da pecuária. As outras minas, da capitania de Goiás, através do sertão do Parnaguá, entraram no rol dos lugares receptores de gados. Tratava-se de um mercado interno, como frisou o primeiro governador da capitania: o principal rendimento da Fazenda Real nesta Capitania tudo consiste nos dízimos dos gados vacuns e cavallares, gêneros cujo consumo sendo dependente da indigência em que delles estavão as capitanias circunvizinhas $(\ldots)^{86}$.

As transações da vila do Mocha se deram, principalmente, com a capital da colônia, Salvador. As fazendas de gado dos jesuítas, cujas finanças eram gerenciadas por religiosos enviados do colégio da Bahia, renderam um montante de $151.098 \$ 018$ réis ${ }^{87}$. O controle das manadas piauienses apresentou um certo rigor: achey conveniente o methodo de estabelecerem Procuradores, que nas suas paragens se encarregassem de evitar a perda de gados, fugas e mais ruínas (...). Entre os pontos de paragem, situamos a Passagem do Juazeiro (capitania de Pernambuco), Passagem da Barra (capitania de Pernambuco), a Passagem da Manga (do Piauí aos Pastos Bons pelo rio Parnaíba), a vila da Jacobina (capitania da Bahia) e as feiras de Santana e Capuame (capitania da Bahia).

O monopólio exercido por Salvador foi invejado por São Luiz. O gado criado nos sertões dos Pastos Bons boa parte era trasladado e vendido na Bahia. O governador interino de São Luiz solicitou que todos os animais criados no interior do Piauí (até então capitania subalterna a do Maranhão) (...) sejão remetidos para esta do Maranhão (...) $)^{88}$. Pernambuco não entrou nesse embate político e econômico porque as reses criadas nos rincões de sua capitania, e demais anexas, eram remetidas ao seu porto.

Apesar dos lucros registrados na comercialização da carne e couro, o capital circulou fora do contexto urbano da vila do Mocha. Os maiores beneficiários foram os fazendeiros que, por motivos de gestão dos seus negócios, residiam em suas casas da vila somente em dias especiais. A câmara de Mocha nam tem quaze nenhuma outra renda do que o pequeno tributo das poucas carnes que se matão nos açougues, que he insignificante, porque alem de terem pouca gente as Villas, o que tem gado se o mata para a sua família, por cujo motivo quaze

\footnotetext{
${ }^{86}$ PROJETO RESGATE. AHU_ACL_CU_016,Cx. 11, D. 633.

${ }^{87}$ LEITE, Serafim. História da Companhia de Jesus no Brasil..., Opus cit., p. 553, 554.

${ }^{88}$ PROJETO RESGATE. AHU_ACL_CU_016, Cx. 15, D. 826.
} 
nada rende $(\ldots)^{89}$. Antes do assentamento ser elevado ao predicamento de cidade, o vigário colado do município apontou que a maior parte dos fregueses são criadores de gado vacum e cavalar e não podem morar junto da vila se acham dispersos por vários riachos, morando com suas famílias para a comodidade tratarem da criação dos seus gados $(. . .)^{90}$.

Entre os anos de 1752 - 1754 foram arrematados os dízimos reais referentes às freguesias do Piauí. Mocha favoreceu aos cofres reais 52.900\$000 réis, desses aproximadamente $7.127 \$ 000$ réis $^{91}$ são atribuídos ao gado criado em seu termo. Isso indica que, dentro do sistema agropecuário, o Reino se beneficiou das tramitações realizadas entre sertão e litoral.

O primeiro açougue e seus currais contíguos foram erguidos em uma área afastada do centro do aglomerado, talvez por uma questão de higiene [ver figura 131]. Esteve situado estrategicamente na trama viária de condução das boiadas: na porta de entrada e saída da vila, junto ao caminho que ligou o litoral baiano ao maranhense, a estrada real do gado. Antes de rumarem para São Luiz os animais eram comercializados na casa de carne e couro local. Os edis do concelho requereram à Corte o monopólio dos lucros do açougue, diante dos poucos rendimentos obtidos e à falta de patrimônio público: (...) de que paga o Marchante ${ }^{92}$ duzentos e quarenta réis de cada cabeça, que matta para o provimento do povo, cuja renda anda por hora incorporada na fazenda real (...) com tudo poderá pelo tempo em diante augmentarsse $(\ldots)^{93}$.

Trilhando por veredas, o gado antes criado no litoral, foi conduzido por vaqueiros e tangedores, elaborando caminhos, úteis passagens para moradores, autoridades civis e eclesiásticas. A arremetida buscou o melhor pasto, o pouso apropriado para engorda. Encontraram no interior piauiense o capim mimoso, o qual engorda o animal e sua carne é mais apreciada dos que se alimentam das rudes pastagens dos distritos agrestes ${ }^{94}$. Para lá deslocaram grandes rebanhos, devassando o sertão, abrindo roteiros aqui e ali, onde pousos eram fundados, currais delimitados e povoações erguidas.

\footnotetext{
${ }^{89}$ PROJETO RESGATE. AHU_ACL_CU_016, Cx. 21, D. 1092.

${ }^{90}$ MOTT, Luiz R.B. Piauí colonial: populacao, economia e sociedade..., Opus cit., p. 46.

${ }^{91}$ PROJETO RESGATE. AHU_ACL_CU_016, Cx. 6, D. 388.

${ }^{92}$ Bluteau define "marchante" como mercador de gado para o açougue. Ver BLUTEAU, Raphael, S. J. Vocabulário português, e latino...Coimbra, Real Collegio das Artes da Companhia de Jesus, 1712 - 1719. Disponível em http://www.ieb.usp.br. Acesso em 07.11.2011.

${ }^{93}$ PROJETO RESGATE. AHU_ACL_CU_016, Cx. 1, D. 35.

${ }^{94}$ GARDNER, George. Viagem ao interior do Brasil. São Paulo, Edusp, 1975. p. 117.
} 
Mocha foi cruzada, nos seus primeiros anos como vila, por três caminhos. O principal roteiro, como sabemos, é a velha estrada que ligou o Estado do Brasil ao Estado do Maranhão, conhecido, a posteriori, por estrada real do gado, por onde são tocadas as boiadas do Piauí (... $)^{95}$. Estrada freqüentada de Boyadas innumeraveis, desde o princípio da Cidade (Salvador) fundada há duzentos e cincoenta annos $(. . .)^{96}$.

Situado no centro do Nordeste, o aglomerado do Piauí foi atravessado por vias terrestres unindo distintos litorais: pernambucano, paraibano, cearense, para mencionar alguns. A estrada das boiadas, citada por Studart Filho ${ }^{97}$, interligou Recife e a cidade da Paraíba, pelo sertão paraibano e cearense, à vila do Mocha. Da vila Real do Crato partiu outra vertente, resultando num interessante intercâmbio entre couro e rapadura ${ }^{98}$.

Nesse cenário rodoviário e mercantil, Mocha se evidenciu como um importante ponto nodal da rede urbana do sertão nordestino. Dividiu seu patamar com outras vilas: Icó (CE), Jacobina (BA) e Paratinga (BA), por exemplo. Contudo, a povoação piauiense revelou seu crédito ao governo geral, sobretudo, ao Reino: a importância de que he a Capitania do Piahuy para a subsistência da Bahia e Pernambuco e ao muito que emporta nas presentes circunstâncias fortificarnos nos centros dos Certoens do Brazil ${ }^{99}$ [sem grifo no origianal](...). Fortaleza urbana nos confins do Nordeste colonial, centro de controle da pecuária, a vila do Mocha, devido às funções econômica e geopolítica, foi elevada ao predicamento de cidade por Dom José I, auxiliado pelo marquês de Pombal.

\footnotetext{
${ }^{95}$ SPIX, J.B Von; MARTIUS, C.P.F. Viagem pelo Brasil..., Opus cit., p. 363.

${ }^{96}$ RECOPILAÇÃO de Notícias Soteropolitanas e Brasílicas contidas em XX cartas, que da cidade do Salvador da Bahia de Todos os Santos escreve hum a outro amigo em Lisboa...Tomo I. Salvador, 1802. p. 84. Disponível em http://www.fbn.br. Acesso em 30.10.2011.

${ }^{97}$ STUDART FILHO, Carlos. "Vias de communicação do Ceará colonial”..., Opus cit., p. 31 - 35.

${ }^{98}$ STUDART FILHO, Carlos. "Vias de communicação do Ceará colonial”..., Opus cit., p. 38, 39.

${ }^{99}$ PROJETO RESGATE. AHU_ACL_CU_016, Cx. 5, D. 359.
} 


\subsection{5 - 1758: a fundação da capitania de São José do Piauí}

A 29 de julho de $1758^{100}$ foi criada a capitania de São José do Piauí, autônoma do Maranhão, para cumprir o objetivo de ocupação do sertão vigiada pelo aparato político administrativo da Metrópole. Nomearam para o cargo de governador, o minhoto João Pereira Caldas.

A independência do Piauí veio auxiliar sua organização administrativa, econômica e judicial. Os problemas enfrentados pelo território decorriam, na visão de Francisco Xavier de Mendonça Furtado, primeiro da ação corrupta de alguns ouvidores, (...) acresse tão bem para a mesma ruína, os grandíssimos roubos que alguns Ministros, que governarão esta Capitania fizerão aos seus moradores (... $)^{101}$. Segundo, dos grandes latifúndios detidos nas mãos da Companhia de Jesus ${ }^{102}$.

As primeiras medidas tomadas por Pereira Caldas dizia respeito à descrição das condições geográficas, econômicas, sociais e urbanas do Piauí. Não poupou a realidade comercial ao informar a Dom José I:

(...) participo a Vossa Magestade o miserável estado que se acha reduzida esta Capitania, e a total ruína que se experimenta no seu commercio, cujas causas exporei com mais vagar a Vossa Magestade, para que a vista della, possa Vossa Magestade dar a respeito de tão interessantíssimo negocio, as providencias úteis para se evitar a ruína, e se aumentar o commercio desta Capitania $(\ldots)^{103}$

Novamente entram as discussões sobre o poderio jesuítico. Na visão do governador, o monopólio dos inacianos foi o âmago dos desagravos piauienses: (...) para a miséria destes, concorre tambem as circunstancias de serem muitas destas fazendas dos Padres da Companhia da Bahia, para os quais vay os productos das ditas Fazendas, ficando apenas nesta capitania os limitados interesses dos vaqueiros ou feitores que as administrão ${ }^{104}$.

\footnotetext{
${ }^{100}$ COSTA, F. A. Pereira da. Cronologia histórica do estado..., Opus cit., p. 129.

${ }^{101}$ PROJETO RESGATE. AHU_ACL_CU_016, Cx. 6, D. 378.

102 D'ALENCASTRE, José Martins Pereira. "Memória Choronologica, Histórica e Corographica da Província do Piauí". in Revista do Instituto Histórico e Geographico Brazileiro. Tomo XX. Rio de Janeiro, 1857. p. 48 61.

${ }^{103}$ PROJETO RESGATE. AHU_ACL_CU_016, Cx. 6, D. 378.

${ }^{104}$ PROJETO RESGATE. AHU_ACL_CU_016, Cx. 6, D. 378.
} 
O território da capitania recém inaugurada esteve seccionado por sete freguesias e um aldeamento missioneiro de índios Jaicós, que na conformidade das ordens de Sua Magestade detrimino erigir em Villa, parecendome que o mesmo se deve praticar com as duas das primeiras, denominadas Pernaguá, e Sto. Antonio do Serubim (.... ${ }^{105}$. Em Mocha, João Pereira Caldas advertiu a Coroa não ter achado casa própria de Sua Magestade, destinada para a minha residência (... $)^{106}$.

Dados sobre os ataques indígenas foram temas de algumas correspondências do governo piauiense a Francisco Xavier de Mendonça Furtado: Huma das principais matérias que devo participar a V. Exa. para por na presença de Sua Magestade (...) pellas repetidas hostilidades que com elles (moradores) practicão as Naçoens de gentio (...) ${ }^{107}$. Reforçou o governador que o despovoamento de partes da região é provocado pela agressividade dos nativos, muitas são as fazendas despovoadas por haverem experimentado similhantes tiranias $(\ldots)^{108}$.

A guerra contra os Tapuias gerou a necessidade de um corpo de soldados. Segundo a carta régia de criação da capitania seria fundamental a formação de um Regimento de Cavalaria Auxiliar para a vila do Mocha, composto de 10 companhias com 60 praças, ou seja, 600 soldados. Passados três anos, em 1761, Pereira Caldas não havia criado o Regimento por insuficiência de homens no aglomerado e termo deste. Alertou como solução repartir a companhia pelas demais paróquias do Piauí ${ }^{109}$.

O desembargador Francisco Marcelino de Gouvêa remeteu um plano ao Secretário de estado da Marinha e Ultramar, onde sugeria a divisão da capitania em duas ouvidorias, para serem nellas mais fáceis as Correyçoens (... $)^{110}$. Tinham em mente os gestores do Piauí, com esta subdivisão territorial, analisar quais freguesias cumpririam os requisitos básicos ao foro de vila: (...) sobre os lugares que julgasse mais dignos de serem Villas erigidas. Sobre os termos que as mesmas se havia de dar e sobre as Paroquias e casas de spiritual instrução que de novo deviao estabelecer (.... $)^{111}$. Dos arraiais visitados - Santo Antônio do Gurguéia,

\footnotetext{
${ }^{105}$ PROJETO RESGATE. AHU_ACL_CU_016,Cx. 6, D. 381.

${ }^{106}$ PROJETO RESGATE. AHU_ACL_CU_016, Cx. 6, D. 381.

${ }^{107}$ PROJETO RESGATE. AHU_ACL_CU_016, Cx. 6, D. 378.

${ }^{108}$ PROJETO RESGATE. AHU_ACL_CU_016, Cx. 6, D. 378.

${ }^{109}$ SANTOS, Fabiano Vilaça dos. "Uma vida dedicada ao real serviço: João Pereira Caldas, dos sertões do Rio Negro à nomeação para o Conselho Ultramarino (1753 - 1790)". In Varia História. vol 26. nº 44. Jul/dez 2010. p. 505. Disponível em http://www.scielo.com. Acesso em 05. 07. 2011.

${ }^{110}$ PROJETO RESGATE. AHU_ACL_CU_016, Cx. 6, D. 395.

${ }^{111}$ PROJETO RESGATE. AHU_ACL_CU_016, Cx. 6, D. 395.
} 
Nossa Senhora do Desterro, Nossa Senhora da Conceição dos Aroazes, Nossa Senhora do Livramento do Parnaguá, Santo Antônio do Surubim e Nossa Senhora do Monte do Carmo de Piracuruca -, avaliou Francisco Marcelino de Gouvêa que estavam aptos à autonomia municipal somente Paranguá e Surubim ${ }^{112}$.

Henrique Antônio Galucio foi o engenheiro que acompanhou o desembargador em sua inspeção pela capitania. Sua meta de viagem constou em tirar o dito plano ou elaborar um mapa do território. Percorreu a capitania através de caminhos, rios e ribeiras, observando miudamente os rumos das estradas, medindo suas distancias, e tomando frequentemente as alturas para latitude, e fazendo todas as observações de longitude que me foy possível ${ }^{113}$. $\mathrm{O}$ resultado da análise in situ do profissional é o mapa geográfico da capitania, apresentado no primeiro capítulo desta investigação [figura 23, página 71].

O auge das reformas de Dom José I no Piauí ocorreu em 19 de junho de 1761, quando seis freguesias foram elevadas à condição de vila: Parnaíba, Campo Maior, Marvão, Valença, Jerumenha e Paranguá. Como em todas as fundações pombalinas, tais núcleos cumpriram o ideal de congregar os dispersos que viviam distantes uns dos outros sem comunicação $^{114}$. Logo no início da carta régia, ponto auto das resoluções oficiais, foi conferido o status de cidade à vila do Mocha.

\footnotetext{
112 PROJETO RESGATE. AHU_ACL_CU_016, Cx. 7, D. 407.

${ }^{113}$ PROJETO RESGATE. AHU_ACL_CU_016, Cx. 7, D. 437.

114 FLEXOR, Maria Helena Ochi. "Cidades e vilas pombalinas no Brasil do século XVIII". In Universo Urbanístico português, 1415 - 1822. Lisboa, Comissão Nacional para as Comemorações dos Descobrimentos Portugueses, 1998. p. $257-266$.
} 


\subsection{Oeiras, a cidade pombalina}

As cidades eram fundadas em pontos especiais do sistema urbano e do território. Centros regionais que revelaram a política de centralização, em oposição à domindante dispersão $^{115}$. Para Murillo Marx, uma cidade seria um núcleo subordinado diretamente à Coroa, em tese, à autoridade maior ${ }^{116}$. No reinado de D. José I, a vila do Mocha (agora Oeiras) e as seis novas vilas da capitania de São José do Piauí integraram-se num programa que procurou aproveitar as potencialidades do território. A centralização e o apoio do poder real nesta fase do Brasil é sensível. Como disse Caio Prado Jr.: quem administrava efetivamente a colônia eram os delegados do rei (...). Em meados do séc. XVIII todas as capitanias terão voltado ao domínio direto da coroa, e serão governadas por funcionários de nomeação real $^{117}$. Segundo Roberta Delson, Dom José I preferiu deixar o controle da política nas mãos de Sebastião José de Carvalho e Melo, o conde de Oeiras, futuro marquês de Pombal $^{118}$.

Oeiras se expandiu. Apresentou, em 1762, 270 fogos [figura 134] distribuídos em cinco zonas: Praça, Rosário, entorno da igreja de Nossa Senhora da Conceição, bairro do Caquende e um bairro chamado Dezertto [figura 135]. Zoneamento resultante da presença de novos equipamentos no núcleo - hospício jesuítico - e da existência de irmandades leigas, afirmando sobre o solo o seu poder através da segregação de classes ${ }^{119}$. Opinou Luís Lacombe sobre o papel aristocrático destas confrarias numa sociedade em formação: mas o grande $e$ inegável papel das irmandades foi (...) constituir-se, na medida do possível, em meio de acesso para a pacífica evolução social da colônia ${ }^{120}$. Anteriormente listamos as confrarias de Santa Ana, São João Nepomuceno, das Almas, Santíssimo Sacramento e Nossa Senhora da Vitória existentes em Oeiras.

A cidade se estruturou ao redor da praça e dos caminhos. As datas de terra, ao longo das vias, eram dadas aos menos afortunados. Subindo a colina, procuravam o adro do hospício dos padres da Companhia de Jesus, polarizando um dos subúrbios da localidade. A igreja dedicada à Nossa Senhora da Conceição [figura 136], em construção a partir de

\footnotetext{
${ }_{115}^{115}$ REIS FILHO, Nestor Goulart. Contribuição ao estudo da evolução urbana..., Opus cit., p. 63.

${ }^{116}$ MARX, Murillo. Cidades no Brasil, terra de quem..., Opus cit., p. 100.

${ }^{117}$ PRADO JR., Caio. História econômica do Brasil. 48a reimpressão. São Paulo, Brasiliense, 2008. p. 51.

${ }^{118}$ DELSON, Roberta Marx. Novas vilas para o Brasil colônia: planejamento espacial e social no século XVIII. Brasília, Ed. Alva-ciord., 1997. p. 49.

${ }^{119}$ FRIDMAN, Fania. Donos do Rio em nome do rei: uma história fundiária..., Opus cit., p. 20.

${ }^{120}$ LACOMBE, Luís Lourenço. "Ordens religiosas, irmandades e confrarias". In Revista do Instituto Histórico e Geográfico Brasileiro. vol. 288. Jul/set 1970. Rio de Janeiro, 1971. p. 79.
} 
meados dos Setecentos, por donativos dos irmãos de alguma confraria, por nós ainda não identificada, aglutinou moradias em seu entorno imediato.

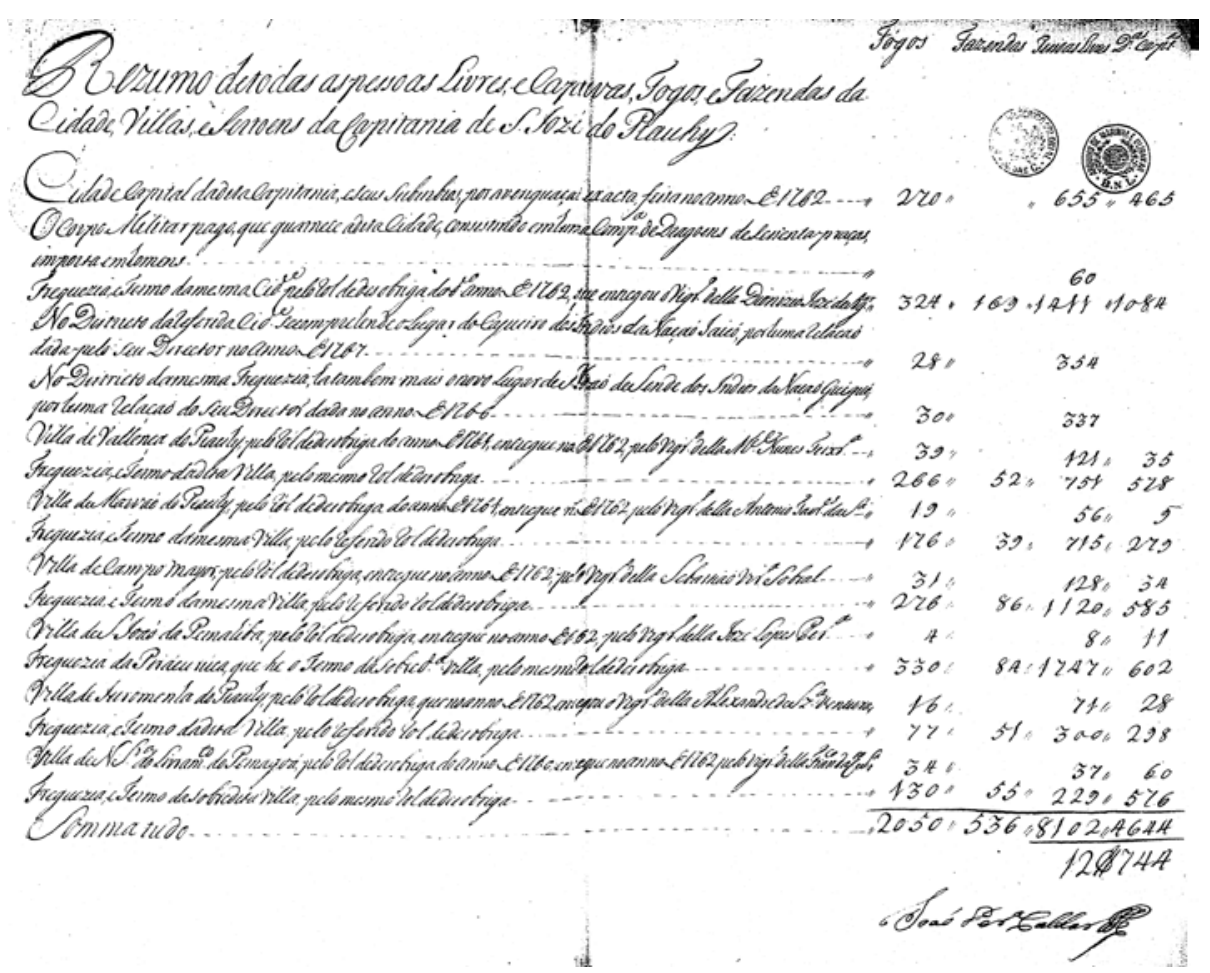

Figura 134 - Resumo de todas as pessoas livres, e captivas, Fogos, e Fazendas da Cidade, Villas e Sertoens da Capitania de S. Jozé do Piahuy. Projeto Resgate. AHU_ACL_CU_016, Cx. 9, D. 547.

O papel do governador João Pereira Caldas seria de complementar ou adaptar as ordens da carta régia às condições físicas pré-existentes em Mocha, ao contrário das novas vilas erguidas e lugares de índios planificados segundo as orientações do Diretório dos Índios. Sobre o papel dos representantes da Coroa, como planejadores do espaço intraurbano, Maria Helena Ochi Flexor sublinha:

(...) verificamos que os próprios Ouvidores e Capitães - Generais foram os urbanistas, arquitetos e mestres de obra, e o povo, na ausência de oficiais mecânicos especializados, o construtor. Coube a eles a organização espacial dos núcleos programados e a expansão da rede urbana. Sendo essas regiões extremamente pobres, só tardiamente puderam contar com a presença de engenheiros militares em suas obras públicas e particulares $(\ldots)^{121}$.

\footnotetext{
${ }^{121}$ FLEXOR, Maria Helena Ochi. "Núcleos urbanos criados por Pombal no Brasil do século XVIII". In Anais do IV Seminário de História da cidade e do Urbanismo. Rio de Janeiro, UFRJ/PROURB, 1996. p. 611.
} 

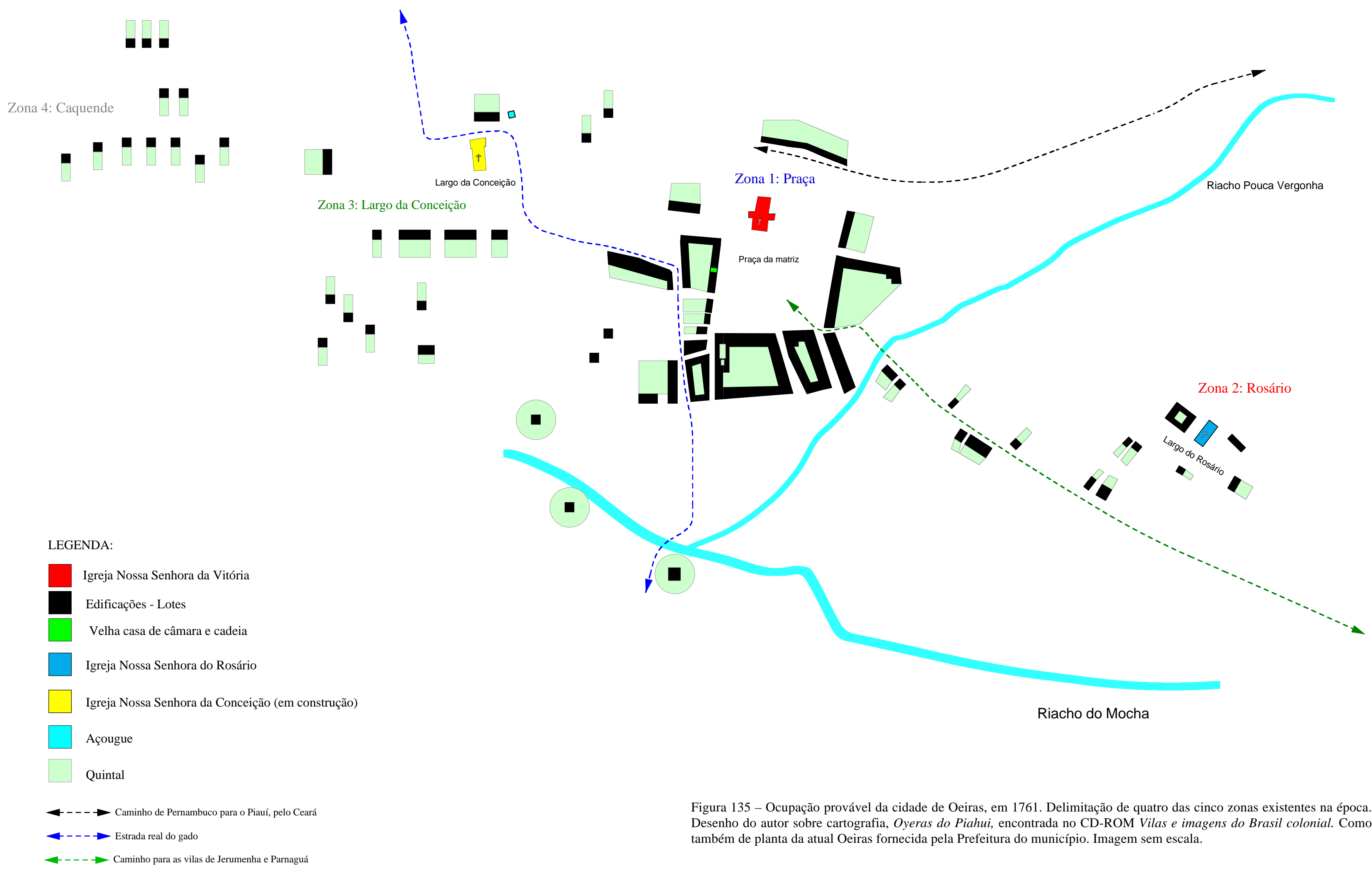

Figura 135 - Ocupação provável da cidade de Oeiras, em 1761. Delimitação de quatro das cinco zonas existentes na época. Desenho do autor sobre cartografia, Oyeras do Piahui, encontrada no CD-ROM Vilas e imagens do Brasil colonial. Como mbém de planta da atual Oeiras fornecida pela Prefeitura do município. Imagem sem escala. 


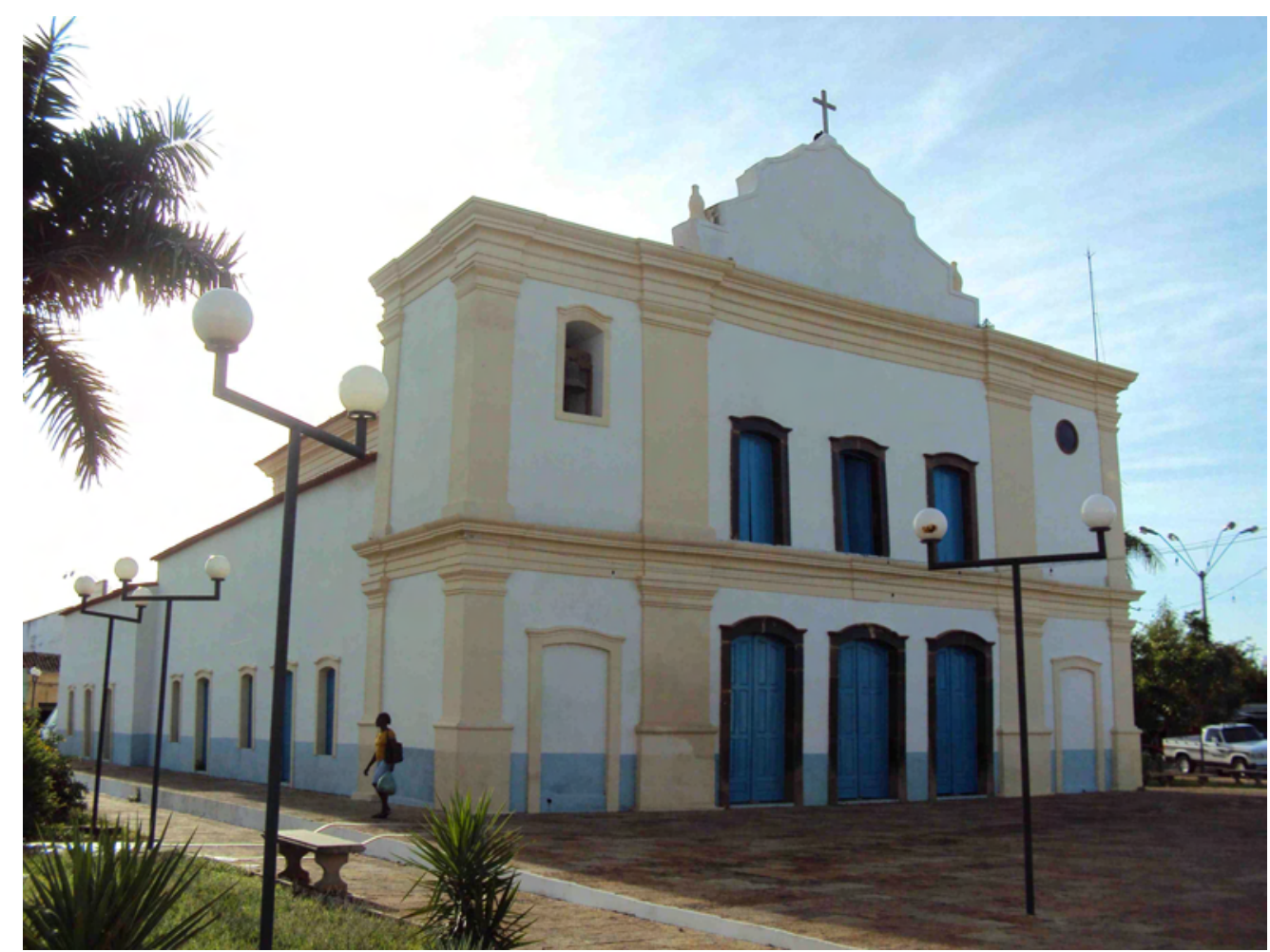

Figura 136 - Igreja Nossa Senhora da Conceição. Foto do autor, 2010.

Mudou o nome Mocha para Oeiras, em homenagem a Sebastião José de Carvalho e Melo, então conde de Oeiras, (...) porque dele inferirão não só os atuais moradores da mesma vila como ainda os vindores (sic.), que os senhores da verdadeira Oeiras foram o instrumento da felicidade deste país (... $)^{122}$. Devido à influência do conde de Oeiras, as novas áreas construídas na cidade piauiense foram galgadas em teorias renascentistas e iluministas, divulgadas na conhecida carta régia de 19 de junho de $1761^{123}$.

O trecho da informação real com considerável difusão entre os arquitetos historiadores é: (...) só com a obrigação de q’as ditas casas sejão sempre fabricadas na mesma figura uniforme pella parte exterior ainda que na outra parte interior os faça cada hum conforme lhe parecer para que desta sorte se conserve sempre a mesma formosura nas Villas, nas ruas dellas a mesma largura que se lhe assignar nas fundações (... $)^{124}$. Os administradores da colônia pretendiam construir um cenário, uma fachada harmônica voltada para as ruas e

\footnotetext{
${ }^{122}$ SANTOS, Fabiano Vilaça dos. "Uma vida dedicada ao real serviço: João Pereira Caldas..., Opus cit., p. 508.

${ }^{123}$ Encontramos a transcrição deste documento em SANTOS, Paulo F. Formação de cidades no Brasil colonial. Rio de Janeiro, Editora UFRJ, 2001. p. 57 - 58. Outros historiadores publicaram esta carta régia, com vocabulário do atual português, entre esses COSTA, F. A. Pereira da. Cronologia histórica do estado..., Opus cit., p. 143 - 149. Entretanto, por questões de método esta pesquisa usou as próprias transcrições elaboradas a partir dos manuscritos do Projeto Resgate Barão do Rio Branco.

${ }^{124}$ PROJETO RESGATE. AHU_ACL_CU_016, Cx. 8, D. 450.
} 
praças, palcos do espetáculo barroco. A preocupação com a formosura foi exclusividade do mundo exterior, do convívio humano, das trocas e sociabilidade. O interior dos novos edifícios seria de total comando dos moradores, ali impuseram suas tradições arquitetônicas importadas de outras partes da colônia, quiçá da Metrópole, donde muitos vieram imigrados. A organização social e política desejada por Portugal foram traduzidos no alinhamento das fachadas e largura das novas ruas.

Um aglomerado formoso geraria uma comunidade satisfeita e feliz, isto é, qualidades que nortearam o método de civilizar os índios, facinorosos e vadios dispersos pelos sertões. Acerca deste tema, apontou com muito saber Beatriz Bueno sobre as fundações setecentistas com os ideais propostos pelos iluministas:

(...) Voltaire e Adam Smith atribuíram a origem da cidade ao trabalho dos monarcas, funcionando como centros de liberdade e ordem em oposição à barbárie da época feudal. Esta noção esteve presente no discurso oficial do período joanino, pombalino e mariano - os cuidados com a organização espacial da cidade representariam o nível de civilidade que se pretendia dos seus habitantes. A vila setecentista, fruto de estrita ação metropolitana, funcionou como um importante instrumento de controle do território, revestido de uma missão civilizatória $(. . .)^{125}$

Oeiras, a cidade pombalina, se revestiu de tais dogmas adaptando-os às estruturas urbana e social existentes. Um híbrido formado pelas rugosidades dos estágios anteriores (freguesia e vila) com os princípios de estética iluminista. A partir de então, coube aos oficiais da câmara e outros agentes por "a régua" os novos lotes e as datas concedidas: (...) aos Officiaes eleitos ficará pertecendo darem gratuitamente os terrenos que se lhes pedirem para casas e quintaes nos lugares $q$ ' para isso se houverem determinado (... $)^{126}$. Ademais, o discurso foi claro: (...) fazendo delinear as casas dos moradores em linha recta de sorte que fiquem largas $e$ direitas as ruas (... $)^{127}$. O núcleo central de Oeiras, ou melhor, a praça delimitada já no final dos Seiscentos tendia à regularidade e alinhamento formal. As ruas a ela contíguas [figuras 137, 138] apresentam ainda hoje no casco viejo dimensões inferiores àquelas propostas pelos citados

\footnotetext{
125 BUENO, Beatriz P. Siqueira. Desenho e desígnio: o Brasil dos engenheiros militares (1500-1822), Tese de doutorado. São Paulo, FAU/USP, 2001. p. 630.

${ }^{126}$ PROJETO RESGATE. AHU_ACL_CU_016, Cx. 8, D. 450.

${ }^{127}$ PROJETO RESGATE. AHU_ACL_CU_016, Cx. 8, D. 450.
} 
tratados de engenharia portugueses ${ }^{128}$. Por exemplo, em Monte - Mor o Novo da América as ruas foram estipuladas em 40 palmos $(8,8 \mathrm{~m})$, a principal tería 85 palmos $(18,70 \mathrm{~m})$. Contudo, os lotes próximos ao riacho do Mocha estão alinhados, como requerido pela orientação oficial [figuras 139, 140]. Estes, talvez, foram concedidos e arruados após a homologação da carta régia.
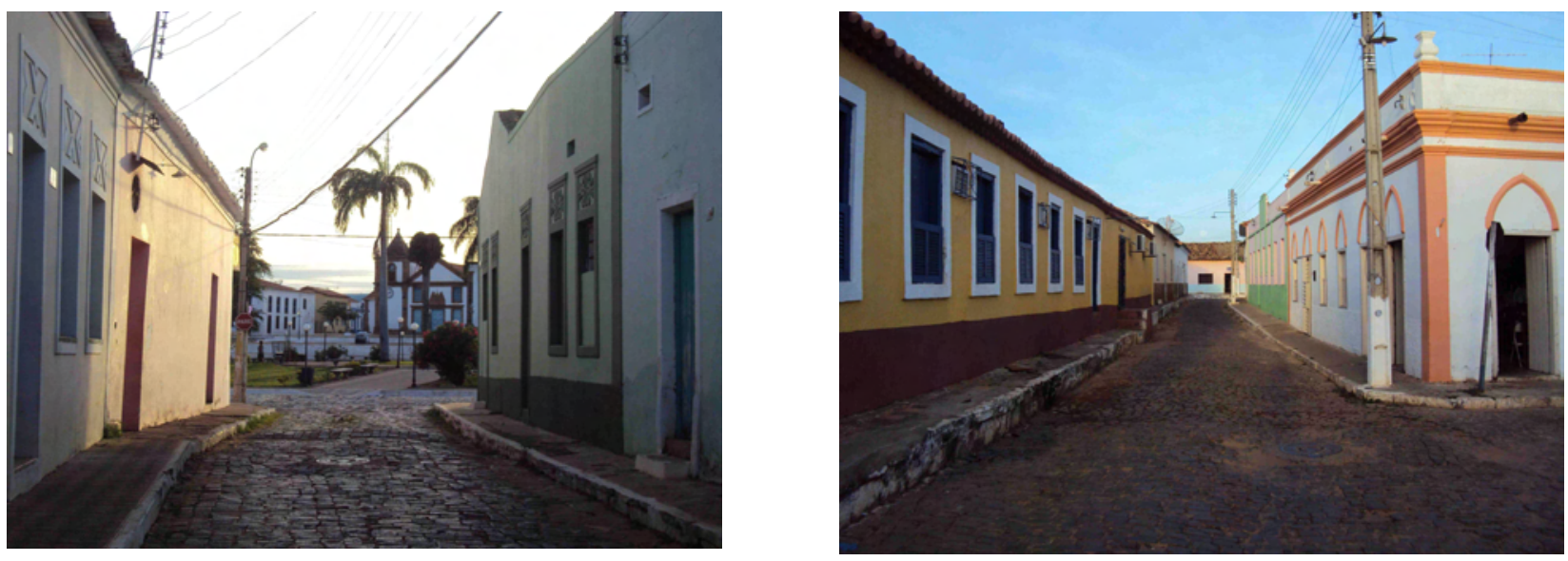

Figura 137 - Rua estreita que dá para praça, atual Manuel Rodrigues. Foto do autor, 2010.

Figura 138 - Rua estreita na Oeiras colonial. Foto do autor, 2010.
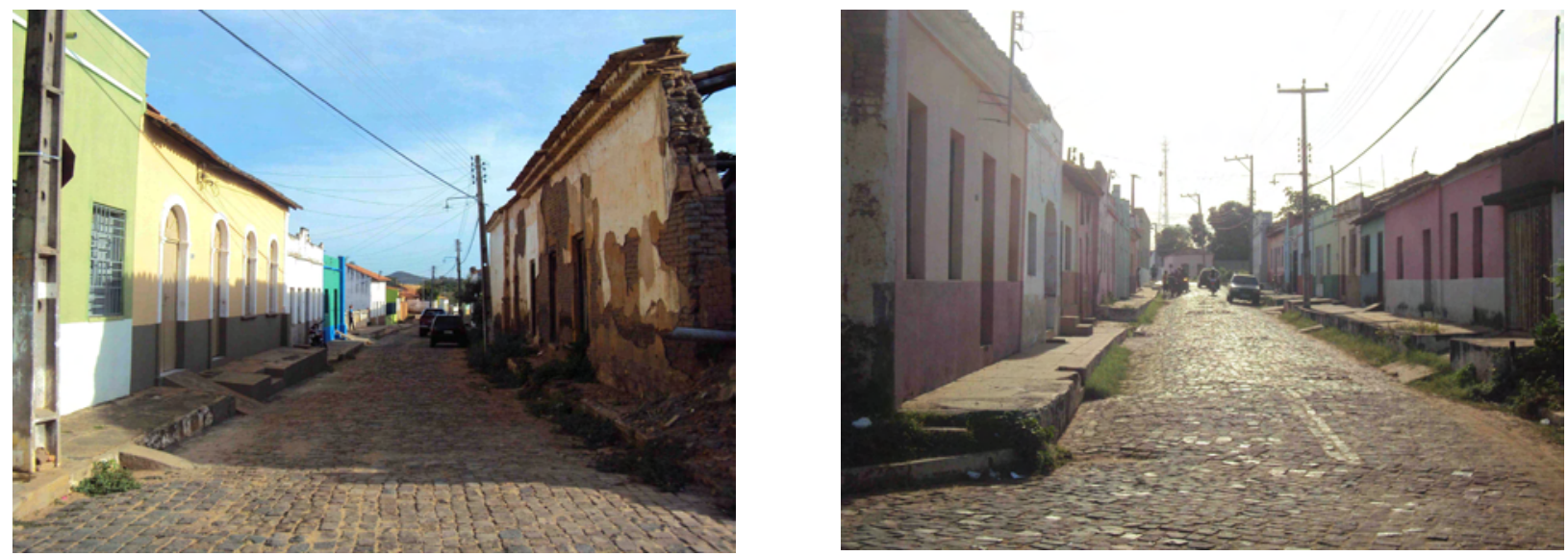

Figura 139 - Rua com edificações alinhadas. Foto do autor, 2010.

Figura 140 - Lotes próximos ao riacho do Mocha com o alinhamento desejado pelos órgãos oficiais da colônia. Foto do autor, 2010.

Os demais meios para uniformizar a cidade incluiríam o apoio do clero secular, numa franca demonstração do velho laço entre Igreja e Estado. Diz a carta régia: (...) assignando para edificar huma igreja capaz de receber hum competente numero de fregueses quando a povoação

\footnotetext{
${ }^{128}$ Ver quarto capítulo deste trabalho.
} 
augmentar $(\ldots)^{129}$. Interessou aos eclesiásticos a ascensão demográfica e urbana de uma localidade porque, inevitavelmente, cresceriam os dízimos a Deus. A matriz de Nossa Senhora da Vitória havia sido edificada vinte e oito anos antes, com proporções que atendiam os moradores do núcleo e seu termo.

Preocupação com o rossio, termo e desenvolvimento das vilas e cidade são outros pontos altos do documento de 1761: (...) para que augmentando se as mesmas Villas possão ter as suas datas de terra todos os moradores (... $)^{130}$. Às seis vilas criadas, João Pereira Caldas encaminhou uma planta que mandei previnir para milhor regular o estabelecimento ${ }^{131}$ ao desembargador Francisco Marcelino de Gouvêa, em sua larga correição ao território da capitania. Destacamos o documento - Acento das cazas propias, e de aluguer q' ocupa os moradores da Cidade de Oeyras capitannia de Sa'Iozé do Piahuy', Suas Famílias, Pessoas de hum, e outro sexo, mossos, Escravos, Seus Subúrbios, e Rebaldes, cazas, Rossas delles q’o Ilmo. Sr. Ioao Pereyra Caldas Goverdador da ditta Capitania mandou fazer, e averiguar por Domingos Barreyra de Macedo Capp. ${ }^{a m}$ mor da mesma Cid. ${ }^{e}$, e da Governaça della, que foy Escrivão o Luis Ant..$^{o}$ Ribr. ${ }^{o}$ da mesma Governaça ${ }^{132}$ - por ser o primeiro censo realizado com ricos pormenores sobre a uso do chão, segregação social, hierarquia espacial, zoneamento e mercado imobiliário urbano ocorridos na cidade.

No próximo tópico analisaremos algumas especificidades do censo supracitado. Detemo-nos, principalmente, nas informações que respondam algumas questões acerca da formação urbana de Oeiras e sua respectiva estratificação social. Outros condicionantes esclareceremos em trabalhos futuros por não estarmos devidamente alicerçados para publicá-los.

\footnotetext{
${ }^{129}$ PROJETO RESGATE. AHU_ACL_CU_016, Cx. 8, D. 450.

${ }^{130}$ PROJETO RESGATE. AHU_ACL_CU_016, Cx. 8, D. 450.

${ }^{131}$ PROJETO RESGATE. AHU_ACL_CU_016, Cx. 9, D. 547.

132 “ACENTO das cazas propias, e de aluguer q' ocupa os moradores da Cidade de Oeyras capitannia de Sa'Iozé do Piahuy', Suas Famílias, Pessoas de hum, e outro sexo, mossos, Escravos, Seus Subúrbios, e Rebaldes, cazas , Rossas delles q' o Ilmo. Sr. Ioao Pereyra Caldas Goverdador da ditta Capitania mandou fazer, e averiguar por Domingos Barreyra de Macedo Capp. ${ }^{\text {am }}$ mor da mesma Cid. ${ }^{\mathrm{e}}$, e da Governaça della, que foy Escrivão o Luis Ant. ${ }^{\circ}$ Ribr. ' da mesma Governaça". Ver FALCI, Miridan Britto. "A cidade de Oeiras do Piauí". in Revista do Instituto Histórico de Oeiras. Oeiras, Secretaria de Cultura, 2000. p. 174 - 206.
} 


\subsection{1 - Oeiras e seus espaços no censo de 1762}

O documento Acento das cazas propias, e de aluguer q' ocupa os moradores da Cidade de Oeyras capitannia de Sa' Iozé do Piahuy', Suas Famílias, Pessoas de hum, e outro sexo, mossos, Escravos, Seus Subúrbios... ${ }^{133}$ é um censo realizado pelo governador João Pereira Caldas em 1762. Subsídio de controle e conhecimento do território, esse tipo de averiguação foi comum na política pombalina. Os administradores das capitanias deveriam informar o número de habitantes, fogos, ocupação, idade, sexo, estado civil, etnia, população escrava e forra, caminhos, rios, riachos, bairros, edifícios religiosos e públicos, engenhos e engenhocas, fazendas, ruas e suas denominações, termo, rossio, roças, milícias, escolas, lugares de índios, entre outros fatores ${ }^{134}$. Apesar dos índices apresentados abarcarem o rossio da cidade de Oeiras, focalizaremos o perímetro urbano propriamente dito.

Em setembro de 1762, Oeiras foi seccionada em cinco áreas: Praça, bairro do Rosário, bairro do Dezertto, bairro do Caquende e subúrbio. Jacques Le Goff, identificando uma sociotopografia urbana, opina que o bairro se caracteriza quase sempre pela relativa homogeneidade de sua população ${ }^{135}$. Para o historiador francês há uma separação social por afinidades raciais, profissionais e econômicas nos bairros. Por exemplo, os imigrantes da França medieval tendiam a se agrupar em ruas que levavam o seu nome ${ }^{136}$. Em Oeiras houve distinções por classe, raça e profissão, como também de forros viverem nas proximidades da praça e possuírem casas próprias. Como bem mencionou Pedro de Almeida Vasconcelos, num interessante estudo sobre as freguesias de Salvador, as cidades não apresentavam, de forma alguma, divisões estanques, apesar da imensa desigualdade social ${ }^{137}$.

Primeiro são descritos os principais símbolos da comunidade: igrejas e pelourinho. A matriz tem seu acento no meyo da praça principal da mesma Cidade de ordinaria grandeza, com duas capellas; dous altares, além do mor, e duas sacristias (... $)^{138}$. No bairro do Rosário há

\footnotetext{
${ }^{133}$ Este censo, segundo Miridan Britto Falci, foi cedido para publicação pela historiadora americana Mary Karash, professora da Universidade de Michigan, pesquisadora "brasilianista". A transcrição do documento ficou sob a responsabilidade de Marcus Simões Amorim e pode ser encontrado em Ver FALCI, Miridan Britto. A cidade de Oeiras do Piauí..., Opus cit., p. 174 - 206.

${ }^{134}$ FLEXOR, Maria Helena Ochi. Cidades e vilas pombalinas no Brasil do século XVIII...Opus cit., p. 262.

${ }^{135}$ LE GOFF, Jacques. O apogeu da cidade medieval. São Paulo, Martins Fonte, 1992. p. 185 - 188.

${ }^{136}$ LE GOFF, Jacques. O apogeu da cidade medieval..., Opus cit., p. 186.

${ }^{137}$ VASCONCELOS, Pedro de Almeida. "Complexidade racial: mitos e realidade em duas freguesias de Salvador em 1775". In Cidades latino-americanas: um debate sobre a formação de núcleos urbanos. Fania Fridman e Mauricio de Abreu (org.). Rio de Janeiro, Casa da Palavra, 2010. p. 103.

${ }^{138}$ ACENTO das cazas propias, e de aluguer q' ocupa os moradores da Cidade de Oeyras capitannia de Sa'Iozé do Piahuy', Suas Famílias, Pessoas de hum, e outro sexo, mossos, Escravos, Seus Subúrbios..., Opus cit., p. 174.
} 
a igreja dedicada à santa que carrega o seu nome (...) com bastante grandeza, seus altares em cuja obra ainda se continua (... $)^{139}$. Elemento da autonomia municipal, o pelourinho de Oeiras foi relocado, por ser de antes sentado em lugar menos próprio $(. . .)^{140}$, estando a média distância da matriz e paço do concelho.

Circulando a praça da igreja matriz de Nossa Senhora da Vitória [figura 141] e, nas suas proximidades, adensa-se a vida urbana. Existiram trinta e três casas onde viveram 114 pessoas, entre estes, os abastardos da cidade e funcionários do governo. Fazendeiros tinham ali suas residências de domingos ou dias festivos. Entre os oficiais da capitania, residiram ao redor da praça o governador, dois tabeliães, um intendente, um sargento mor, o vigário colado, um capitão mor e um mercador ${ }^{141}$. A população que habitou o centro foi composta de setenta homens (23 escravos e 45 livres) com quarenta e quatro mulheres (26 escravas, 15 livres e três índias).

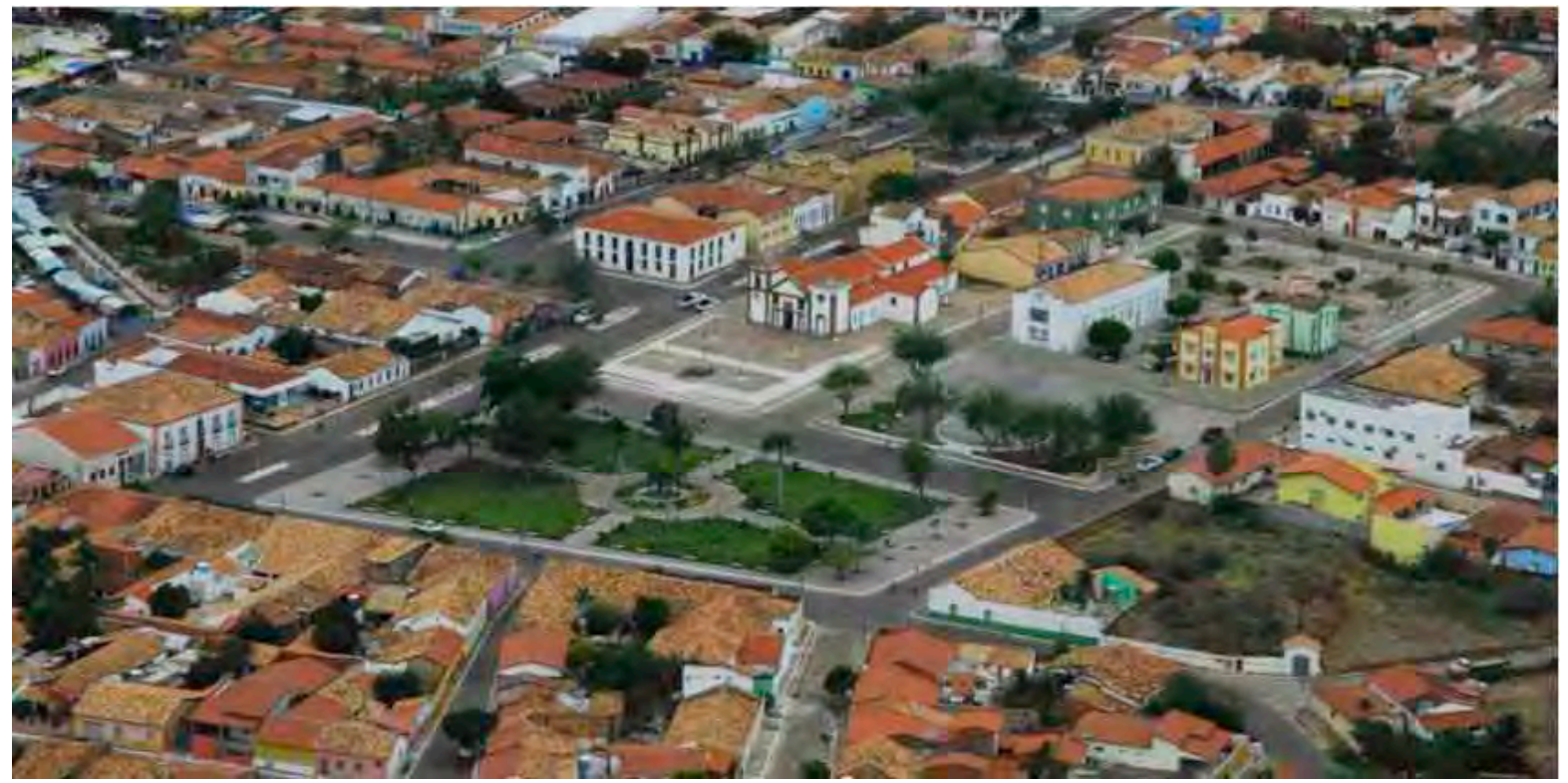

Figura 141 - Panorama atual da praça de Oeiras. Foto do acervo da 19áSR/IPHAN, 2007

As irmandades eram detentoras das principais moradias do largo, alugaram-nas para o governador, desembargador e vigário da matriz, Dionísio José de Aguiar. O palácio do governo,

\footnotetext{
${ }^{139}$ ACENTO das cazas propias, e de aluguer q' ocupa os moradores da Cidade de Oeyras capitannia de Sa'Iozé do Piahuy', Suas Famílias, Pessoas de hum, e outro sexo, mossos, Escravos, Seus Subúrbios..., Opus cit., p. 174.

${ }^{140}$ ACENTO das cazas propias, e de aluguer q' ocupa os moradores da Cidade de Oeyras capitannia de Sa'Iozé do Piahuy', Suas Famílias, Pessoas de hum, e outro sexo, mossos, Escravos, Seus Subúrbios..., Opus cit., p. 175.

${ }^{141}$ FALCI, Miridan Britto. A cidade de Oeiras do Piauí..., Opus cit., p. 171.
} 
por exemplo, pertenceu à irmandade de Santa Anna, sendo cobrado um aluguel de $84 \$ 000$ réis $^{142}$; o desembargador alugou a casa da confraria de São João Nepomuceno; o cura morou numa residência da irmandade de Nossa Senhora da Vitória. Vale ressaltar que todas estas edificações estavam localizadas na praça ou próximas desta. A tabela 18 indica as moradias de aluguel das confrarias de Oeiras.

\begin{tabular}{|c|c|c|}
\hline CONFRARIA & $\begin{array}{c}\text { CASAS DE } \\
\text { ALUGUEL } \\
\text { (QUANTIDADE) }\end{array}$ & LOCALIZAÇÃo \\
\hline Santa Anna & 01 & Praça \\
São João Nepomuceno & 01 & Praça \\
Nossa Senhora da Vitória & 01 & Praça \\
Santíssimo Sacramento & 01 & Rua Nova da Bica \\
Almas & 02 & Praça \\
\hline
\end{tabular}

Tabela 18 - Casas de alguel das confrarias de Oeiras - PI. Elaboraçao do autor segundo informações do ACENTO das cazas propias, e de aluguer q' ocupa os moradores da Cidade de Oeyras capitannia de Sa’Iozé do Piahuy', Suas Famílias, Pessoas de hum, e outro sexo, mossos, Escravos, Seus Subúrbios..., Opus cit., p. $174-206$.

Em seguida foram arroladas as ruas que cruzam o átrio da matriz ou àquelas que são a ele paralelas: rua das Direita, Pataratas, Paço, Poeyra, do Jorge, do Príncipe, Nova das Flores e Nova da Bica. Segue a lista de com as particularidades de cada uma:

- Rua Direita:

Casas: 07

Alugadas: -

Homens: 10 (04 livres, 05 escravos e 01 forro)

Mulheres: 12 (02 livres, 05 escravas e 05 forras)

- Rua das Pataratas (atual Isaac Sérvio)

Casas: 12

Alugadas: 10

Homens: 24 (12 livres e 12 escravos)

Mulheres: 05 (02 livres, 02 escravas e 01 forra)

Índio: 01

${ }^{142}$ PROJETO RESGATE. AHU_ACL_CU_018, Cx. 8, D. 504. 
- Rua do Paço

Casas: 05

Alugadas: 02

Homens: 08 (05 livres e 03 escravos)

Mulheres: 03 (02 livres 01 escrava)

- Rua das Poeyras

Casas: 26

Alugadas: 12

Homens: 42 (27 livres, 14 escravos e 01 forro)

Mulheres: 25 (11 livres, 11 escravas e 03 forras)

- Rua do Príncipe

Casas: 11

Alugadas: 02

Homens: 06 (04 livres e 02 forros)

Mulheres: 06 (01 livre, 03 escravas e 02 forras)

- Rua Nova das Flores (atual Clodoaldo Freitas)

Casas: 05

Alugadas: 02

Homens: 08 (05 livres, 01 escravo e 02 forros)

Mulheres: 13 (07 livres, 04 escravas e 02 forras)

- Rua Nova da Bica (atual Padre Damasceno)

Casas: 16

Alugadas: 05

Homens: 28 (09 livres, 15 escravos e 04 forros)

Mulheres: 25 (07 livres, 11 escravas e 07 forras)

Além dos cargos governamentais, no núcleo central e ruas adjacentes existiram oficiais mecânicos e o que hoje denominam de profissionais liberais [tabela 19]. A presença deles na cidade é indicio de uma população permanente e urbana, cujo capital girava em torno do 
aglomerado, favorecendo seu progresso. Como disse Nestor Goulart Reis Filho era uma incipiente sociedade civil em ascensão ${ }^{143}$.

\begin{tabular}{|c|c|}
\hline LOCALIZAÇÃo & OFICIAIS MECÂNICOS E PROFISSIONAIS \\
LIBERAIS
\end{tabular}

Tabela 19 - Oficiais mecânicos e profissionais liberais de Oeiras - PI. Elaboraçao do autor segundo informações do ACENTO das cazas propias, e de aluguer q' ocupa os moradores da Cidade de Oeyras capitannia de Sa’Iozé do Piahuy', Suas Famílias, Pessoas de hum, e outro sexo, mossos, Escravos, Seus Subúrbios..., Opus cit., p. $174-206 .(. . .)^{*}$ refere-se ao quantitativo correspondente.

A segunda zona - o bairro do Rosário - além das residências cercanas ao largo da igreja de Nossa Senhora do Rosário, existiram outras edificadas em duas ruas: Cadeya Velha e Cadeia Nova. Totalizando 36 casas, dessas 10 eram alugadas. Em uma delas viveu o carpinteiro Fellix Pereyra da Sylva, cuja moradia pertencia ao patrimônio da cadeia, isso nos leva a crer que o ato de alugar parecia um negócio valorizado por distintas esferas da sociedade oeirense.

No Rosário habitaram em 13 casas distintas uma comunidade de aproximadamente 53 pessoas. Dessas, 25 eram homens (13 livres, 08 escravos e 04 forros) e 28 mulheres (11 livres, 13 escravas e 04 forras). Dois, dos treze homens livres, eram carpinteiros. A mulher forra, Quitéria de Souza, vivia de aluguel na casa de Manuel de Souza Pacheco, com sua família e mais quatro escravos seus. Em uma sociedade escravista, como seria possível um ex-escravo dispor de cativos? Ainda não temos solidez para responder a esta pergunta, todavia, alguns paradigmas podem ser rompidos ao estudar a sociedade pastorial nordestina.

\footnotetext{
${ }^{143}$ REIS FILHO, Nestor Goulart. Contribuição ao estudo da evolução urbana..., Opus cit., p. 49.
} 
Seis casas próprias e quatro alugadas formaram a paisagem da rua da Cadeya Velha (hoje Nogueira Tapety). A população deste logradouro, em 1762, era de 41 moradores arrolados em 18 homens (13 livres, 03 escravos, 01 forro e um índio) com 23 mulheres (11 livres, 06 escravas, 03 forras, 02 índias e uma índia forra). Presume-se com a atribuição - índia forra - a continuidade da escravidão dos gentios, mesmo após a homologação das leis que garantiram, em tese, a liberdade indígena. É provável que ela tenha obtido sua liberdade com a sanção das leis de 06 e 07 de junho de 1755 ou devido ao Diretório dos Índios. Viveram neste espaço misto um sargento e um mercador.

Distribuídos ao longo da rua da Cadeia Nova identificamos, além da nova cadeia, 13 moradias (04 alugadas) totalizando 38 residentes: 23 homens (14 livres, 08 escravos e 01 forro); 15 mulheres (12 livres, 02 escravas e uma forra).

No que tange os bairros do Dezertto e Caquende criamos a tabela 20. No subúrbio da cidade, detectamos 88 moradias.

\begin{tabular}{|c|c|c|}
\hline \multicolumn{3}{|c|}{ BAIRRO DO DEZERTTO } \\
\hline CASAS & $\begin{array}{l}\text { Próprias: } 12 \\
\text { Alugadas: } 02\end{array}$ & $\begin{array}{c}\text { TOTAL: } 14 \text { (uma das casas alugadas serviu como } \\
\text { açougue da cidade) }\end{array}$ \\
\hline HOMENS & $\begin{array}{c}\text { Livres: } 19 \\
\text { Escravos: } 13 \\
\text { Forros: } 02\end{array}$ & $\begin{array}{c}\text { TOTAL: } 34 \\
01 \text { marchante } \\
01 \text { cirurgião } \\
01 \text { vendeiro } \\
01 \text { ferreiro }\end{array}$ \\
\hline MULHERES & $\begin{array}{c}\text { Livres: } 14 \\
\text { Escravas: } 17 \\
\text { Forras: } 03\end{array}$ & TOTAL: 34 \\
\hline \multicolumn{3}{|c|}{ BAIRRO DO CAQUENDE } \\
\hline CASAS & $\begin{array}{l}\text { Próprias: } 12 \\
\text { Alugadas : - }\end{array}$ & TOTAL: 12 \\
\hline HOMENS & $\begin{array}{l}\text { Livres: } 05 \\
\text { Escravos: } 08\end{array}$ & TOTAL: 16 \\
\hline
\end{tabular}




\begin{tabular}{|c|c|c|}
\hline & Forros: 02 & \\
& Índios: 01 & \\
\hline \multirow{3}{*}{ MULHERES } & Livres: 02 & TOTAL: 10 \\
& Escravas: 01 & \\
& Forras: 07 & \\
\hline
\end{tabular}

Tabela 20 - Bairros do Dezertto e Caquente. Tipologia habitacional e "qualidade"dos moradores. Elaboraçao do autor segundo informações do ACENTO das cazas propias, e de aluguer q' ocupa os moradores da Cidade de Oeyras capitannia de Sa'Iozé do Piahuy', Suas Famílias, Pessoas de hum, e outro sexo, mossos, Escravos, Seus Subúrbios..., Opus cit., p. $174-206$.

A análise dos índices parcialmente apresentados nos dá um prévio balanço sobre o comportamento social e urbano de Oeiras pombalina. Seguindo o raciocínio de Pedro Vasconcelos, não é possível conceber a existência de duas categorias bem definidas para o período em questão, ou melhor, uma sociedade de senhores e escravos, domintes e dominados ${ }^{144}$. A heterogeneidade marcante do centro urbano piauiense confere uma sociedade dinâmica e heterogênea: forros poderiam alugar casas e ter seus escravos, brancos pobres que viviam de aluguel sem possuir escravos, irmandades detentoras das grandes casas do aglomerado, casas térreas alugadas por brancos, escravos e forros.

Houve homens que lucraram com a prática de alugar. Beatriz Bueno opina que os imóveis urbanos eram passíveis de compra, venda e aluguel, implicando em lucro para os que neles investissem ${ }^{145}$. Estudando o censo de 1762, avaliamos que todos os vinte e sete atores envolvidos na prática do aluguel, excluindo as irmandades religiosas, não residiam em Oeiras, talvez em sua fazenda de gado, ou, quem sabe, em alguns casos, no litoral ${ }^{146}$. A ascensão da pecuária na colônia, junta-se à queda do açúcar no mercado internacional, atraiu para o sertão alguns senhores de engenho interessados no gado e no couro. Interessante sublinhar o fazendeiro Antônio Glz' Jorge. Uma rua próxima à praça recebeu o seu nome. Dos quatro edifícios localizados nesse logradouro, três lhe pertenciam e estiveram alugados. Como resultado de nossa

\footnotetext{
${ }^{144}$ VASCONCELOS, Pedro de Almeida. Complexidade racial: mitos e realidade em duas freguesias de Salvador em 1775”. In Cidades latino-americanas: um debate sobre a formação..., Opus cit., p. 112.

${ }^{145}$ BUENO, Beatriz. "A cidade como negócio: mercado imobiliário em São Paulo no século XIX". In Cidades latino-americanas: um debate sobre a formação de núcleos urbanos. Fania Fridman e Mauricio de Abreu (org.). Rio de Janeiro, Casa da Palavra, 2010. p. 146.

${ }^{146}$ Por exemplo, o criador de gado, Antônio José de Sousa Freire Tavares Castro Leal, morador de Salvador, possuiu duas fazendas de gado nos sertões do Piauí. Uma com o nome de Empoeira e a outra chamada de Ryacho. A dimensão da primeira estância era duas léguas de comprido por uma de lago. A segunda abarcou dez léguas de comprido por uma de largo. Ver PROJETO RESGATE. AHU_ACL_CU_018, Cx. 8, D. 513.
} 
análise ao Acento das cazas propias, e de aluguer q' ocupa os moradores da Cidade de Oeyras capitannia de Sa' Iozé do Piahuy', Suas Famílias, Pessoas de hum, e outro sexo, mossos, Escravos, Seus Subúrbios...desenvolvemos a tabela 21. Nela elencamos os "homens de negócios" e o número de casas alugadas no núcleo piauiense:

\begin{tabular}{|c|c|}
\hline PROPRIETÁRIOS DE IMÓVEIS & $\begin{array}{l}\text { CASAS DE ALUGUEL } \\
\text { (QUANTIDADE) }\end{array}$ \\
\hline Antônio de Seixas & 02 \\
\hline Manuel Soares da Silva & 02 \\
\hline Leonardo Tavares & 03 \\
\hline Lourenço Francisco & 05 \\
\hline José Esteves Falcao & 09 \\
\hline Bernardo de Souza Estrella & 02 \\
\hline Francisco Xavier de Saá & 03 \\
\hline Manuel Glz' Vieira & 01 \\
\hline Antônio Madeira Brandão & 01 \\
\hline Pe. José dos Reys Moreira & 01 \\
\hline Antônio de Souza Dias & 07 \\
\hline Manuel Alz' Cabessa & 03 \\
\hline Antônio Rabello de Sepúlveda & 01 \\
\hline Manuel Dias Correia & 02 \\
\hline Manuel dos Santos & 01 \\
\hline Antônio Glz’ Jorge & 02 \\
\hline Manuel Fellipe Azevedo & 01 \\
\hline João da Silva Medeiros & 01 \\
\hline Gonçallo da Silva Teixeira & 02 \\
\hline Francisco Barreira Macedo & 01 \\
\hline Manuel de Souza Pacheco & 01 \\
\hline Francisco Caetano de Mello & 04 \\
\hline Nicollau Soares & 01 \\
\hline José Antônio Monteiro & 01 \\
\hline Pedro Fernandes Barros & 01 \\
\hline Cosme de Souza Rego & 01 \\
\hline Não identificados & 04 \\
\hline
\end{tabular}

Tabela 21 - Proprietário de imóveis em Oeiras, 1762. Elaboraçao do autor segundo informações do ACENTO das cazas propias, e de aluguer q' ocupa os moradores da Cidade de Oeyras capitannia de Sa'Iozé do Piahuy', Suas Famílias, Pessoas de hum, e outro sexo, mossos, Escravos, Seus Subúrbios..., Opus cit., p. $174-206$. 
Um dado que sobressai às nossas vistas refere-se à diminuta presença de nativos no espaço urbano. Será que poucos se revestiram da civilidade almejada para o convívio urbano? Os parágrafos 87, 88 e 89 do Diretório dos Índios mencionaram o matrimônio e a sociabilização entre brancos e gentios: para facilitar os ditos matrimonios, empregarã̃ os Directores toda a efficacia do seu zelo em persuadir a todas as Pessoas Brancas, que assistirem nas suas Povoaçoens, que os Indios tanto nã̃ sã̃ de inferior qualidade (...). Neste caso, ao nosso ver, a cidade agiu como objeto de repulsão para aqueles que gravitaram entre a "barbárie" e a "civilidade", por isso a latente segregação dos Tapuias em três lugares de índios erguidos na capitania de São José do Piauí: Nossa Senhora das Mercês de Jaicós, São José de Sende e São Gonçalo do Amarante.

\subsection{2 - Obras pias e temporais na Oeiras do ouvidor Antônio José de Morais Durão}

A chegada à Oeiras, em 1772, do ouvidor Antônio José de Moraes Durão trouxe, ao bojo dos discursos oficiais, necessidades urbanas supostamente solucionadas na administração do governador João Pereira Caldas, dez anos antes.

Moraes Durão, em sua primeira correição à capitania, produziu um detalhado relatório $^{147}$ no que tange as condições físicas, naturais e urbanas das seis vilas e cidade piauiense. Conduzido por uma realidade aceita pelo governador de então, Gonçalo Lourenço Botelho de Castro, a descrição do território chegou ao Reino, ao marquês de Pombal. Surgiram atritos entre as duas autoridades locais. Para Luiz Mott, Durão devia ser homem culto, pois tanto a sua argumentação como seu vocabulário, refletem razoável erudição. Não se contenta em descrever a capitania da qual foi incumbido: diagnostica, faz prognósticos, sugere remédios para os problemas que afetam a região $(. . .)^{148}$.

Antes de enviar seu escrito para Metrópole, Durão relatou uma concisa história da capitania. Em seguida, listou o total da população dos aglomerados oficializados em 1761: Oeiras apresentou, em seu termo, 1.002 fogos, 5.700 almas (3.202 homens; 2.498 mulheres), 192

\footnotetext{
${ }^{147}$ Luiz Mott transcreveu os documentos oficiais, referentes à descrição da capitania de São José do Piauí, elaborada pelo ouvidor Antônio José de Moraes Durão, ver MOTT, Luiz R.B. Piauí colonial: populacao, economia e sociedade..., Opus cit., p. 22 - 33. Para fins de metodologia, quando indicarmos os textos de Moraes Durão, utilizaremos nossas transcrições feitas segundo os manuscritos localizados na caixa do Piauí do Projeto Resgate Barão do Rio Branco.

${ }^{148}$ MOTT, Luiz R.B. Piauí colonial: populacao, economia e sociedade..., Opus cit., p. 19.
} 
fazendas de gado e 103 sítios $^{149}$. Estando a par da localização da cidade no sertão nordestino, ele mencionou sobre a mesma: (...) Fica esta Cid. ${ }^{e}$ no meyo da Capit. ${ }^{i a}$, he situada numa baicha cercada de montes, com sua inclinação para o poente desde a ribeira do Riacho da Mouxa q' deo nome à Povoação emq. ${ }^{\text {to }}$ Villa $(. . .)^{150}$.

Logo, dissertou assuntos polêmicos: (...) Não tem Rellogio, Casas de Câmara, Cadea, Açougue, ferreiro ou outra Officina pública. Servem de Camr ${ }^{a}$ humas casas térreas de barro sobre que corre litígio. A Cadea he cousa indignissima, sendo necessário estarem os presos em troncos e ferros $p .^{a}$ segurança. A casa do Açougue hé alugada (... $)^{151}$. Desde a ereção da freguesia em vila do Mocha e, apesar de todas as discussões sobre a carência de edifícios públicos para a edilidade e segurança local, a paisagem do núcleo persiste, fruto da má gestão e usurpação de poder exercidos pelos representantes do rei.

Para o ouvidor, mesmo com o predicamento de cidade, a paisagem urbana de Oeiras era embrionária e pobre. Este juízo crítico se deveu aos poucos rendimentos da câmera e ao tipo de oficial que ocupou os cargos administrativos: tem a Cam. ${ }^{\text {ra }}$ pouco mais de $200 \$ 000$ de renda, aos Camaristas nada de propina; mas daqui nasce a repugnância com q' ficão gozando, e não obstante chamarem-se os próprios vaqueiros para juízes e vereadores (... $)^{152}$. Ainda sobre a fisionomia de Oeiras, disse Durão: as casas da Cid. ${ }^{\text {de }}$ todas são térreas ate o próprio palácio do governo. Tem huã rua inteira, a outra de huma face, e a metade de outra; tudo o mais são nomes supostos, e de Cid. ${ }^{\text {de }}$ verdadeiramente só goza o nome (... $)^{153}$.

A sinceridade de Antônio José Moraes Durão incomodou Botelho de Castro, sucessor de João Pereira Caldas. Em resposta à descrição, o governador aparenta acatar as críticas do ouvidor, por isso enviou um ofício para Pombal relatando quais os motivos da precariedadede local:

No temporal dous são os motivos que infelismente substentão a Capitania no estado, que à V. Exa. vou manifestando; E o primeiro he a falta de Officindas públicas, e principalmente cadeas. Nesta parte he tão evidente este ponto como experimentado: porque faltando as ditas Cadeas em todas as Villas, e ainda

\footnotetext{
${ }^{149}$ PROJETO RESGATE. AHU_ACL_CU_016, Cx. 12, D. 684.

${ }^{150}$ PROJETO RESGATE. AHU_ACL_CU_016, Cx. 12, D. 684.

${ }^{151}$ PROJETO RESGATE. AHU_ACL_CU_016, Cx. 12, D. 684.

${ }^{152}$ PROJETO RESGATE. AHU_ACL_CU_016, Cx. 12, D. 684.

${ }^{153}$ PROJETO RESGATE. AHU_ACL_CU_016, Cx. 12, D. 684.
} 
nesta Cidade, fica impossibilitada a justiça de castigar os delinqüentes, frustrando-se qualquer diligencia $(. . .)^{154}$

Outro problema apontado pelo ouvidor dizia respeito à falta de pasto espiritual para os moradores do aglomerado e de seu termo: (...) Ha nesta Cid. ${ }^{e}$ e todo o seu destricto huã só freguesia (...) mas he extença demais, e por esta causa impossibilitada a administração dos sacram. $^{\text {tos }}(\ldots)^{155}$. Soma-se a este fato, as condições dos padres locais, (...) não haver nella mais de quatro sacerdotes com dous ocupados nos Lugares de Indios, sendo destes hú de oitenta e dous annos e outro de oitenta e quatro annos de idade $(. . .)^{156}$.

Gonçalo Lourenço Botelho de Castro escreveu ao Conselho Ultramarino, mencionando como solução à pouca espiritualidade do núcleo a construção de um hospício de religiosos franciscanos, pois o anterior, que pertenceu à Companhia de Jesus, foi incorporado ao patrimônio da confraria de Nossa Senhora do Rosário dos Homens Pretos:

(...) o remédio pois que decepará pela raiz todo este mal não he outro que o que representou o meu Antecessor primeira e segunda vez nas datas de 22 de septembro do anno de 1761 e 13 de julho de 1768 (...) consiste este remedio em S. Mag. permitir a graça de se fundar nesta cidade hum Hospício de Religiosos Capuchos da Província da Conceyção bastando, que sejão em numero de seis os sacerdotes com dous leygos para serviço da casa, e communidade. Naquelle tempo, que o ditto meu Antecessor fez similhante representação se havião offerecido muytas esmollas, que davão os fieis para a execução desta obra $(\ldots)^{157}$

Os embates entre ouvidor e governador, além das tensões locais, chegaram ao Estado do Pará, a João Pereira Caldas. Amigo de Botelho de Castro, Pereira Caldas ameaçou Moraes Durão em função das negativas informações sobre Oeiras e demais vilas da capitania que, diretamente, atingiram sua gestão ${ }^{158}$. Todavia, o ouvidor tinha seus aliados na cidade: um reverendo e o escrivão. Para o clérigo, Antônio José Moraes Durão procurou os meios possíveis para desenvolver o aglomerado, fazendo nas Villas e Cidade se fizessem Casas de Câmara e Cadeya e Assougues, que nunca nella houve, e em outras partes, Pontes, calçadas, reparos de

\footnotetext{
${ }^{154}$ PROJETO RESGATE. AHU_ACL_CU_016,CX. 12, D. 690.

${ }^{155}$ PROJETO RESGATE. AHU_ACL_CU_016, Cx. 12, D. 684.

${ }^{156}$ PROJETO RESGATE. AHU_ACL_CU_016, Cx. 9, D. 524.

${ }^{157}$ PROJETO RESGATE. AHU_ACL_CU_016, Cx. 12, D. 690.

${ }^{158}$ PROJETO RESGATE. AHU_ACL_CU_016, Cx. 12, D. 714.
} 
caminhos, adiantando a agricultura, e protegendo o comercio com imnegavel utilidade para todos os moradores desta Capitania (....). ${ }^{159}$

Apesar dos esforços de Durão, Oeiras continuou praticamente com a mesma fisionomia ao longo do século XVIII. Com o declínio da pecuária sertaneja e ascensão do algodão no cenário nacional e internacional, a cidade piauiense progrediu a passos lentos. Nas épocas pombalina e mariana, as autoridades locais cogitaram em mudar a capital para São João da Parnaíba por questões de localização (atlântica) e facilidade de comunicação e intercâmbio comercial, por mar, com outras capitanias da colônia. Concretizaram este intento em 1852, quando é transferida, de fato, a capital, não para Parnaíba, mas para a quadriculada Teresina.

${ }^{159}$ PROJETO RESGATE. AHU_ACL_CU_016, Cx. 12, D. 690 (documentos anexos). 


\section{4 - Oeiras no século XIX}

Oeiras se destacou o século XVIII, principalmente quando recebeu o foro de cidade, por sua estratégica posição na trama viária sertaneja e por sediar o controle burocrático e financeiro das fazendas reais do fisco, antes da Companhia de Jesus ${ }^{160}$. Entretanto, a crise da pecuária, o governo mal administrado e as prolongadas secas deram ao espaço urbano do núcleo um desenvolvimento lento, moroso.

As autoridades oficiais cogitaram, já na década de setenta do século XVIII, em mudar a capital para a vila de São João da Parnaíba, cujas carnes seccas constituem o principal objecto do comercio dos seus habitantes. E considerando por huma parte, que esta Villa tem toda a disposição para fazer hum comercio florecente pella sua cituação (...) ${ }^{161}$. Em 1803, os vereadores da câmara da vila de Parnaguá informaram, em carta ao príncipe regente, os prejuízos comerciais sofridos por Oeiras. Viam como meio de escape a nomeação de Parnaíba em cidade capital da província:

(...) É a triste cituação, em q’ se axa a Cidade desta Comarca (...) Cituação no meio do coração do certão lugar tão exteril e q' jamais nunca poderá ter aumento algú, como com effeito não tem tido por viver desamparada dos portos do Mar q' lhe possa servir de canal, p. a sua população porq' tanto da Bahia, como do Maranhão e Pernambuco, se axa em grande longitude.

As pequenas negociações q' nella ha (...) Vossa Alteza houver por bem servir, de mandar passar a cidade para a vila de S. João da Parnahiba, porto de Mar franco q' pode fazer a Cid. ${ }^{\mathrm{a}} \mathrm{em}$ poucos annos, muito populosa $(. . .)^{162}$

Velhos problemas urbanos permeiam os discursos apresentados nos documentos oficiais. Os debates acerca da precariedade da casa de câmara e cadeia ultrapassam o século XVIII, somente em meados dos Oitocentos veremos o problema sanado: (...) nesta Cidade não ha cadeia publica, con suficiência e capacidade, para receber presos, por cuja razão estão em actual fuga, os facinorosos que se recolhem a huã casa particular destinada para esse fim, pagando o ditto senado o seu devido aluguel (.... ${ }^{163}$. Em 1822, a Junta Governativa do Piauí, em

\footnotetext{
${ }^{160}$ Essas herdades, desde a transferência de gestao dos jesuítas para os administradores do fisco (como eram chamados os funcionários que comandavam as fazendas), sofrem intensas crises no que dizia respeito ao controle monetário e fundiário.

${ }^{161}$ PROJETO RESGATE. AHU_ACL_CU_016, Cx. 15, D. 826.

${ }^{162}$ PROJETO RESGATE. AHU_ACL_CU_016, Cx. 26, D. 1363.

${ }^{163}$ PROJETO RESGATE. AHU_ACL_CU_016, Cx. 17, D. 849.
} 
ofício ao secretário de estado da Mararinha e Ultramar, Inácio da Costa Quintela, assegurou que a casa em que nesta Cidade se acha allocado o Tribunal de Justiça e fazenda Nacional (...) he hum prédio muito velho, e sem a menor segurança (...) sendo elle huma casa térrea, e muito baixa, são de mais a mais suas paredes de taipa $(. . .)^{164}$.

O governador Paulo Cezar Burlamaqui providenciou em 1809 a execução de uma planta da cidade [figura 142]. Nela se observa a diminuta expansão da povoação, se fizermos um paralelo com o desenho da figura 135. Vale destacar alguns novos elementos locados no mapa de Burlamaqui: um novo açougue (1) (chamado de casa de açougue e carnes), uma fonte em uma das saídas da cidade, beirando o riacho Pouca Vergonha (2), o cemitério (3) e o hospital do fisco (4). Nessa época a igreja de Nossa Senhora da Conceição estava concluída. Admitimos como hipótese que a produção desta carta esteve condicionada com a arredadação da décima urbana, primeiro imposto predial estabelecido em 1809 para a Corte e principais vilas, cidades e lugares notáveis da faixa litorânea, pago à Fazenda Real, correspondendo a $10 \%$ do rendimento liquido de todos os bens de raiz, incindindo sobre proprietários e inquilinos, com exceção daqueles pertencentes à Santa Casa da Misericórdia (.... $)^{165}$.

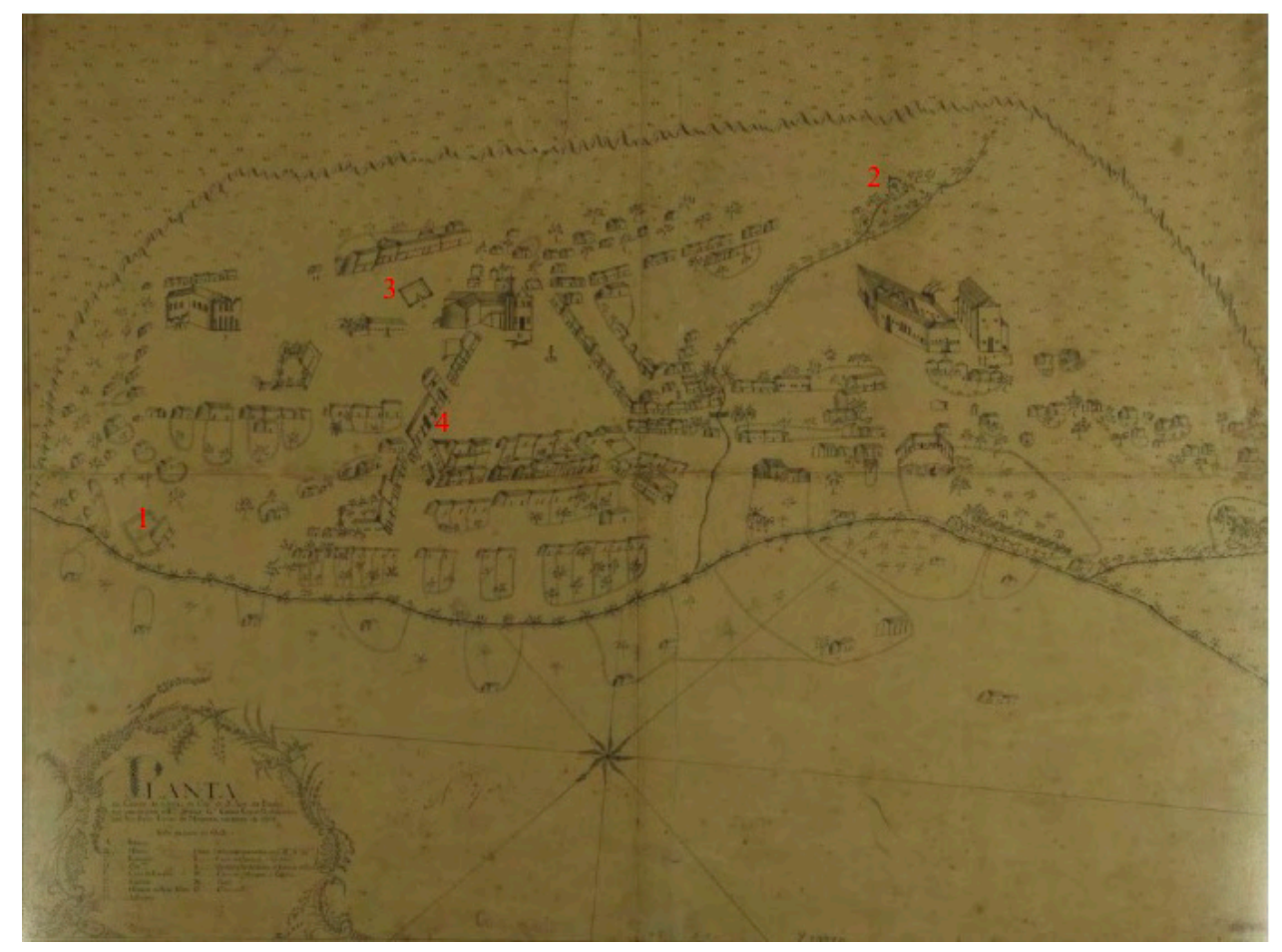

Figura 142 - Planta da

Cidade de Oeiras, 1809. Pelo governador Carlos Cezar Burlamaqui. Original do AHEx - RJ.

\footnotetext{
${ }^{164}$ PROJETO RESGATE. AHU_ACL_CU_016,Cx. 31, D. 1622.

${ }^{165}$ BUENO, Beatriz P. Siqueira. "Tecido urbano e mercado imobiliário em São Paulo: metodologia de estudo com base na Décima Urbana de 1809”. In Anais do Museu Paulista. v. 13. nº 01. Jan/jun 2005. São Paulo, 2005. Disponível em http://www.scielo.com. Acesso em 03. 11. 2011.
} 
Segundo Franciso Xavier Machado, examinador ocular do espaço intraurbano de Oeiras, a cidade foi considerada, em 1810, verdadeiramente uma pequena aldeã, sem forma, sem ordem (...), tem trezentos e cincoenta fogos, e pouco mais de dous mil habitantes (...) ${ }^{166}$. Discordamos, em partes, de Xavier Machado quanto à falta de ordem. A praça da matriz, delimitada como adro no ato da fundação da freguesia, ordenou o casario ali construído. A carta régia de 1761 preconizou normas de regularidade, linearidade e uniformidade vistos posteriormente nas casas edificadas "a régua" pelos oficiais da câmara. O índice de 350 fogos demonstra uma parca evolução: em 1762 existiram 270 fogos, isto é, uma diferença de 80 fogos erguidos em 48 anos. Por conseguinte, a migração forçada de moradores contribuiu para esta realidade : (...) esta se axa exaurida de gente por terem disertado famílias inteiras, para os destrictos da Bahia, e Pernambuco (.... $)^{167}$.

O olhar estrangeiro não poupou Oeiras de críticas. Spix e Martius, por volta de 1818, depois de uma longa jornada iniciada na vila da Cachoeira (BA) à São Luiz do Maranhão, disseram que o núcleo piauiense é uma povoação insignificante que consta de ruas irregulares, com casas de barro caiadas de branco (... $)^{168}$. Relataram algumas das principais edificações do município: encontramos as farmácias no mais deplorável estado, pois todos os medicamentos vêm da Bahia ou do Maranhão, onde às vezes já permaneceram anos. O hospital, instalado especialmente para soldados, contem 40 leitos. A principal igreja, dedicada à Nossa Senhora da Vitória, e as duas capelas, são edifícios insignificantes (... $)^{169}$. Espacializaram os viajantes germânicos, sem ser a intenção, a crise econômica de Oeiras comparando-a com Parnaíba:

Oeiras, em civilização e riqueza é inferior à vila de Parnaíba que, por sua situação na costa e pelo considerável comércio de algodão, fumo, couros, talco e carne salgada, florece sempre mais do que todas as outras vilas da província. Acontece que a própria Oeiras nem mesmo pode ser o empório para os produtos do interior da província; de fato as outras vilas, Pernaguá, Jerumenha, Valença, Campo Maior, Marvão, levam as suas mercadorias, quer diretamente ao mar, para Bahia, Parnaíba e Maranhão, quer para a vila de Aldeias Altas, que,

\footnotetext{
${ }^{166}$ MACHADO, Francisco Xavier. "Memória Relativa às Capitanias do Piahuy e Maranhão por Francisco Xavier Machado". In Revista do Instituto Histórico e Geographico do Brazil. Tomo XVII. Rio de Janeiro, Typographia Universal de Laemmert, 1854. p. 56.

${ }^{167}$ PROJETO RESGATE. AHU_ACL_CU_016, Cx. 17, D. 849.

${ }^{168}$ SPIX, J.B Von; MARTIUS, C.P.F. Viagem pelo Brasil..., Opus cit., p. 421.

${ }^{169}$ SPIX, J.B Von; MARTIUS, C.P.F. Viagem pelo Brasil..., Opus cit., p. 422.
} 
situada no navegável itapicurú, é o mais apropriado empório para o comércio do Maranhão ${ }^{170}$.

Voltando à tona dos assuntos que envolveram a construção da cadeia, a Junta Governativa propôs ao Conselho Ultramarino, em 12 de junho de 1822, a obra de uma cadeia pella insuficiência da existente (...) ${ }^{171}$. Apontaram algumas operações locais e para a província, mirando o desenvolvimento do território piauiense: (...) abrirem estradas públicas, em que possão andar carros nas quaes se effectuarem os transportes, e estabeleça a communicação desta cidade, e mais Villas com os Portos daquelle Rio (Parnaíba) ${ }^{172}$. Solicitaram profissionais qualificados para as obras, (...) também mandar destinar hum official do corpo de Engenheiros, que melhor, e com mais acerto possa dirigir aquelle trabalho, e igualmente a construção de pontes, e estivas em alguns riachos (... $)^{173}$. Consequentemente, esta província surgirá do profundo lethargo, em que jaz amortecida, florecerá nella a agricultura (...) a indústria ainda te hoje desconhecida $(. . .)^{174}$.

Em 1826, segundo Miridan Knox citando Monteiro de Santana, havia no núcleo piauiense 1.050 fogos ${ }^{175}$, um verdadeiro salto numérico de 700 fogos em 16 anos, se confrontarmos com a cifra mencionada por Francisco Xavier Machado para o ano de 1810. Manuel de Sousa Martins, o barão da Parnaíba, empossado na Junta Governativa em 1823, preocupou-se com o estado físico de Oeiras e realizou operações em seus espaços, com auxilio de engenheiros contratados. Entre algumas das operações, podemos listar: ponte sobre o riacho Pouca Vergonha, a definitiva casa de câmara e cadeia e um novo cemitério para a cidade.

Sobre a administração do barão da Parnaíba, George Gardner o considerou um déspota, possuidor de grande esperteza e astúcia, qualidades altamente proprícias à manutenção do despotismo com que tem regido a província, que por certo tem gozado de mais paz e sossego do que quase todas as outras províncias do Império ${ }^{176}$.

Influenciado pelo relato de Spix e Martius, por mencionar com certa freqüência as informações dos germânicos sobre o interior do Nordeste, Gardner descreveu Oeiras em 1838

\footnotetext{
${ }^{170}$ SPIX, J.B Von; MARTIUS, C.P.F. Viagem pelo Brasil..., Opus cit., p. 423.

${ }^{171}$ PROJETO RESGATE. AHU_ACL_CU_016, Cx. 31, D. 1654.

${ }^{172}$ PROJETO RESGATE. AHU_ACL_CU_016, Cx. 31, D. 1654.

${ }^{173}$ PROJETO RESGATE. AHU_ACL_CU_016, Cx. 31, D. 1654.

${ }_{175}^{174}$ PROJETO RESGATE. AHU_ACL_CU_016, Cx. 31, D. 1654.

${ }^{175}$ BRITTO, Miridan Knox. O Piauí na primeira metade do século XIX. Teresina, Projeto Petrônio Portela, 1992. p. 16.

${ }^{176}$ GARDNER, George. Viagem ao interior do Brasil..., Opus cit., p. 126 - 127.
} 
como de construção muito irregular e formada principalmente de uma grande praça, e umas poucas ruas que lhe partem dos lados de oeste e $\operatorname{sul}^{177}$. O naturalista inglês narrou sobre a paisagem edificada do aglomerado, a casa de câmara e cadeia [figura 143] enfím construída segundo as exigências do senado local:

A cidade tem três igrejas, duas das quais, embora já bem velhas, estao inacabadas. Há ainda vários outros edifícios públicos, como cadeia, quartel, a casa da assembléia da província, a câmara municipal e um hospital, mas nenhum deles merece menção, exceto a cadeia, que acabara de ser construída. Foi edificada sob a superitendência de um engenheiro alemão, que reside na província desde muitos anos, a serviço do governo; o prédio é de dois andares, havendo apenas dois outros edifícios na cidade que lhes são iguais neste particular; a parte inferior serve de cárcere e casa de correção; a parte de cima é usada como tribunal de justiça ${ }^{178}$.

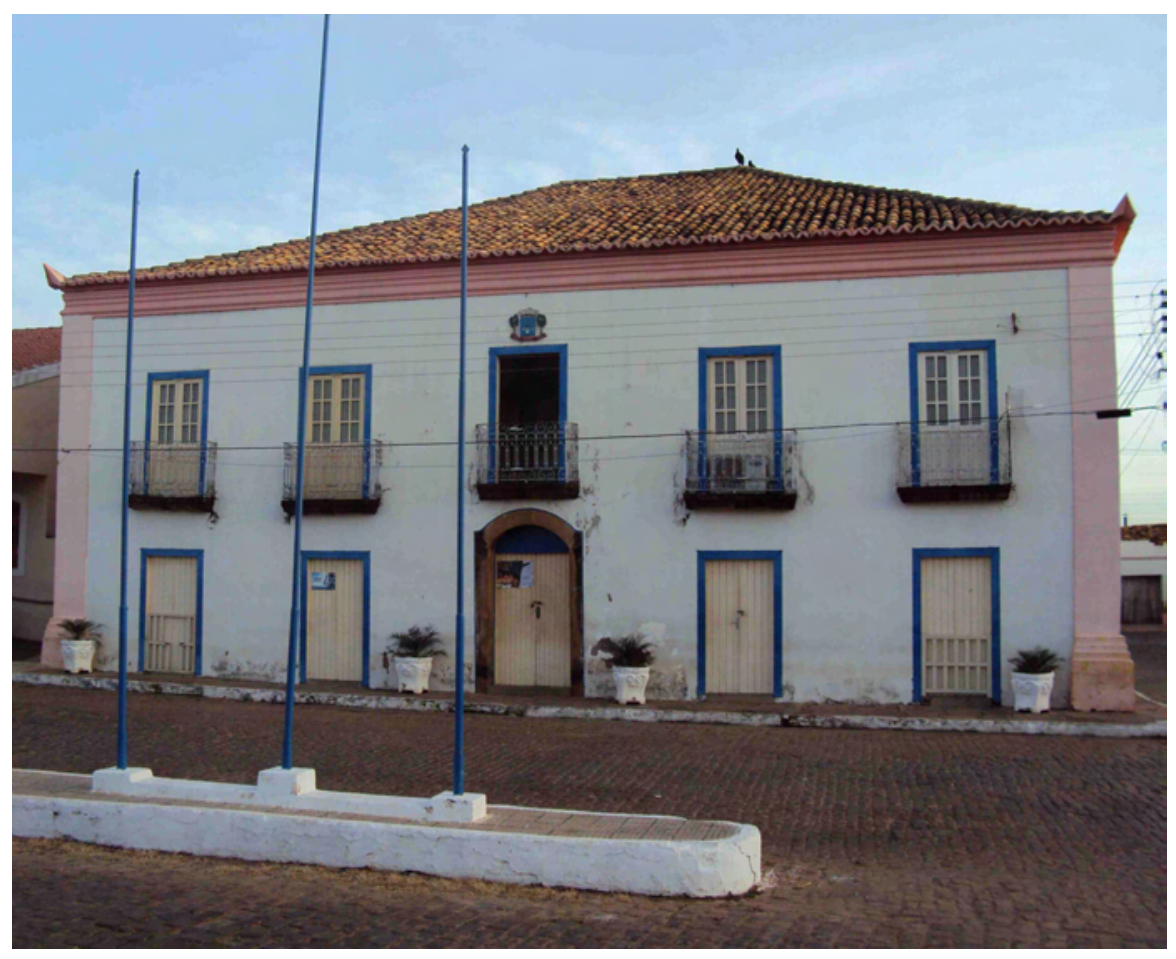

Figura 143 - Edificação que serviu de casa de câmara e cadeia em Oeiras. Hoje sede da prefeitura local. Foto do autor, 2010.

${ }_{177}^{177}$ GARDNER, George. Viagem ao interior do Brasil..., Opus cit., p. 124. 
Interessantes informativos são as "Fallas" dos presidentes da Província. Neles encontramos pistas sobre a dinâmica urbana das vilas e cidade piauienses, relatos que contam muito sobre sua urbanização. Por exemplo, o barão da Parnaíba, preocupado com a higiene da cidade, percebeu a precariedade do velho ato de enterrar mortos em adros e dentro dos templos religiosos. Por isso, planejou um cemitério ${ }^{179}$ afastado do centro: vós sabeis, senhores, quanto he contraria à salubridade geral a inhumaçam nas igrejas feitas por escravos, e ao seu modo; ella infecta o ar, que nos cerca, e causa enfemidades, que nos destroem (... $)^{180}$. O barão talvez estivesse inteirado sobre os debates oitocentistas acerca da higienização dos espaços públicos, ou como ele nomeou, saúde pública:

A Saúde Pública não tem podido ainda obter aqui os benefícios, que ella exige em seu favor; seja por falta de posturas estabelecidas a aniquilar, ou ao menos dminuir os funestos germens, que vão de encontro a nossa conservaçam existente, ou seja mesmo pelas atrasadas circunstâncias em que nos achamos tanto em finanças como em posiçam local ${ }^{181}$.

$\mathrm{Na}$ "Falla" de 1835, Manuel de Sousa Martins informou sobre algumas obras em execução na cidade:

A obra da Cadea, e Casa de Correiçam com trabalho desta capital entregue ao Empreiteiro Pedro Cronemberger tem sofrido hum atraso inesperado, não só para se emendarem erros, que huma comissam nomeada pella Camara Municipal descobrio na sua construçam, como para de novo se calcularem, e avaloarem as substituiçoens dos defeitos, que devem ser reparados (...) As outras mais obras, que se acham determinadas, como sejam Cemetério, Casa de Misericórdia, Ponte do Riacho Pouca-Vergonha (...) ${ }^{182}$

Os temas das "Fallas" gravitaram em finanças, segurança, obras públicas locais e provinciais, educação, catequese dos nativos, instrução religiosa e justiça. Em 1837, quanto as obras públicas ellas se achão com a mesma paralisação, que dantes; em conseqüência da falta

\footnotetext{
${ }^{179}$ Executaram o cemitério com apoio da irmandade do Santíssimo Sacramento da cidade. Ver FERREIRA, Murilo Cunha (coord.). Cidades do Piauí testemunhas da ocupação do interior do Brasil..., Opus cit., p. 94.

${ }^{180}$ FALLA, que derigio a assembléia legislativa do Piahuy no ato da sua instalaçam, o Presidente da Província no dia 04 de maio de 1835. Oeiras do Piahuy, Typ. de Silveira e Companhia, 1835. p. 06. Disponível em http://www.crl.edu. Acesso em 26. 07. 2010.

${ }^{181}$ FALLA, que derigio a assembléia legislativa do Piahuy no ato da sua instalaçam..., Opus cit., p. 06.

${ }^{182}$ FALLA, que derigio a assembléia legislativa do Piahuy no ato da sua instalaçam..., Opus cit., p. 08.
} 
de meios monetários, e só a Cadeia e Casa de Correcção desta Cidade vai progredindo, segundo as vossas vistas se apresentam (... $)^{183}$.

José Martins Pereira d'Alencastre cotou, em sua Memória Chronologica, Histórica e Corographica da Província do Piahuy, como existentes no perímetro urbano de Oeiras, no ano de 1843, 30 quarteirões com 3.855 edificações ${ }^{184}$ [figura 144]. Nessa década, outros projetos foram lançados pelo presidente Zacarias Vasconcellos à população. Pensou-se em um mercado público: huma caza de mercado público recolhe e abriga os objectos de consumo da Cidade e chama a hum só lugar os compradores e vendedores (...) ${ }^{185}$. A iluminação do aglomerado entrou no rol das intenções a realizar:

Depois de 10 annos de promessa, creio em fim chegado o tempo, em que, a illuminação desta Cidade vae passar de esperança à realidade. O negociante João Bernardo d'Azevedo Braga, que contractou com a Presidência, em datta de 21 de junho do anno precedente, collocar nesta Cidade 44 lampeoens pello preço de $68 \$$ rs. cada hum $(\ldots)^{186}$

Demorou por volta de 114 anos para que obras públicas fossem executadas. Os oficiais da vila do Mocha solicitaram a Dom João V melhorias em sua casa de câmara e cadeia. Requerimentos persistentes ao longo da história urbana de Oeiras. A contragosto do presidente da província, foi mudada a capital do Piauí, em 1852, para Teresina: é uma das mais novas cidades do Piauí, mas sua formação ainda obedeceu aos princípios da carta régia de 1761, opinou Paulo T. Barreto ${ }^{187}$. A localização da nova sede da província e revitalização do quadro econômico do território, amortecido pela queda do comércio do gado, foram os motivos basilares para essa ação. Oeiras cristalizou no tempo, no meio do coração do certão $^{188}$.

\footnotetext{
${ }^{183}$ FALLA, que derigio a assembléia legislativa do Piahuy no ato da sua instalaçam, o Presidente da Província no dia 04 de maio de 1837. Oeiras do Piahuy, Typ. de Silveira e Companhia, 1837. p. 02. Disponível em http://www.crl.edu. Acesso em 27. 07. 2010.

${ }^{184}$ D'ALENCASTRE, José Martins Pereira. "Memória Chronologica, Histórica e Corographica da Província do Piauí". in RIHGB. Tomo XX. Rio de Janeiro, 1857. p. 48 - 61.

${ }^{185}$ FALLA, que derigio a assembléia legislativa do Piahuy no ato da sua instalaçam, o Presidente da Província no dia 04 de maio de 1845. Oeiras do Piahuy, Typ. de Silveira e Companhia, 1845. p. 25. Disponível em http://www.crl.edu. Acesso em 10. 11. 2011.

${ }^{186}$ FALLA, que derigio a assembléia legislativa do Piahuy no ato da sua instalaçam, o Presidente da Província no dia 04 de maio de 1843. Oeiras do Piahuy, Typ. de Silveira e Companhia, 1843. p. 52. Disponível em http://www.crl.edu. Acesso em 10. 11. 2011.

${ }^{187}$ BARRETO, Paulo T. "O Piauí e sua arquitetura”. In Arquitetura Civil I. Vol 2. Rio de Janeiro, MEC, 1938. p. 200.

${ }^{188}$ PROJETO RESGATE. AHU_ACL_CU_016,CX. 26, D. 1363.
} 


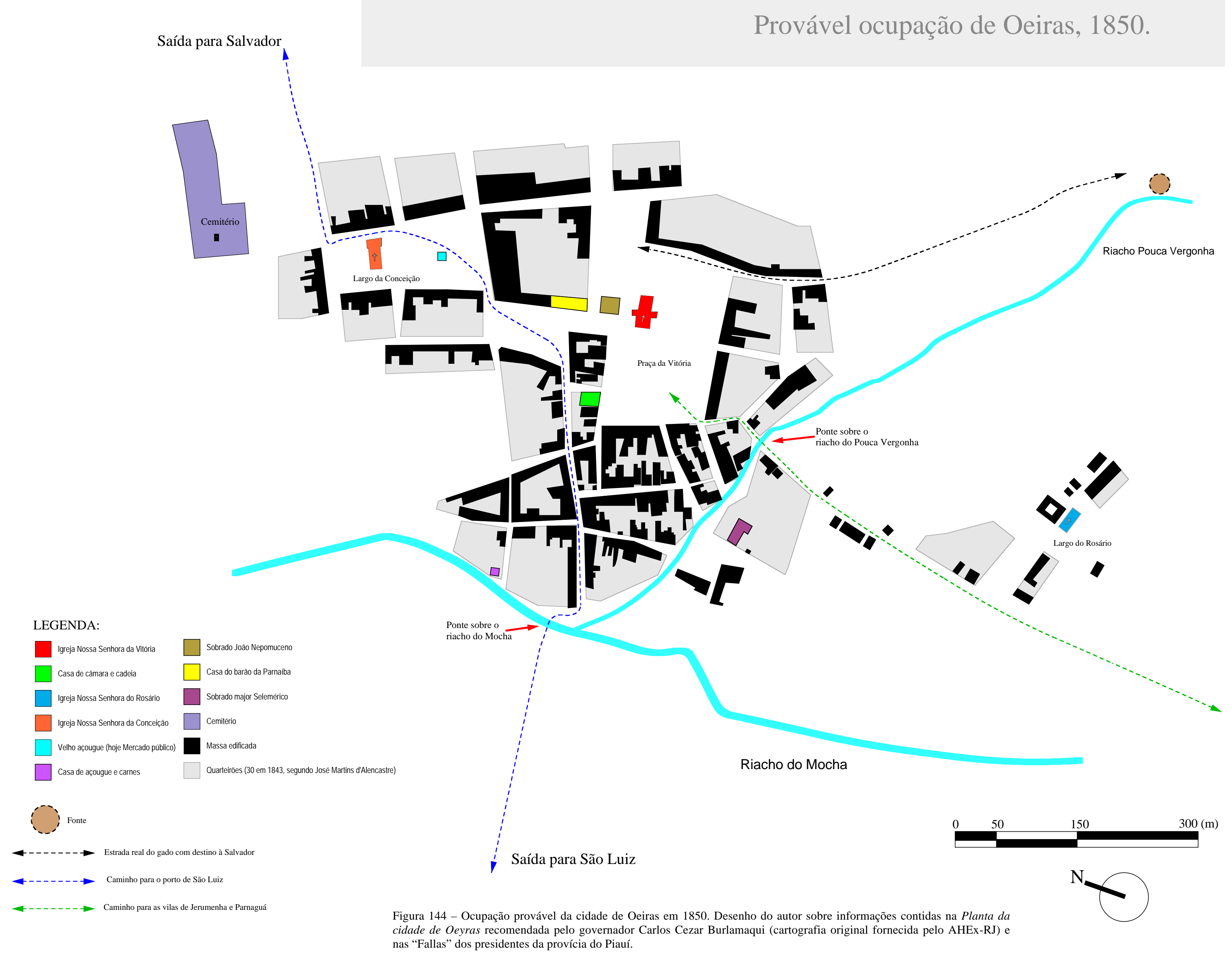




\section{CAPÍTULO 06 - O LUGAR DO ÍNDIO}

“(...) As outras Villas que não tem crescido em população com os moradores Brancos, da parte dos Índios vão sempre em decadência por que quando nos Certoens desta Capitania não ha os selvagens, que são apanhados e recolhidos nas Villas para o seu augmento, e depois disto os que estão avilados, ou são inclinados a bárbaros costumes, e por consequiência sempre atentos a viver fugitivos, e vagabundos nos Mattos, sustentando-se de furtos, caças, e frutos silvestres, ou os que são de melhor inclinação fogem mais antes para viver de officios mecânicos e jornaleiros nas povoaçoens, Villas e Cidades, e Agricultura dos Brancos, aquelles, porem, que se sugeitão ao estabelecido sistema de viver, avillados, subordinados, as Leis com seus legítimos Principaes, e Superiores havendo em cada Villa hum Director, huma Parocho Branco e Câmera composta de Juízes ordinários, e Vereadores, em parte Índios, e em parte Brancos, são sempre pobres, sem alinhamento algum, rústicos, e destituídos de toda a civilidade." [grifo nosso]

\section{Luiz da Mota Fêo, governador da capitania da Paraíba em carta ao príncipe regente D. João VI, 1803.}


Dentro do sistema urbano colonial do sertão nordestino, os aldeamentos missioneiros cumpriram o papel de adensador populacional. Aos missionários couberam o governo temporal e espiritual dos neófitos. Buscaram os velhos caminhos terrestres, a beira de rios e riachos e serras para implantar os assentamentos de índios.

Os nativos obtiveram sua primária secularização nos Setecentos, no governo de Dom José I, auxiliado pelo seu principal ministro Sebastião José de Carvalho e Melo. As leis de 06 e 07 de junho de 1755 e o Diretório dos Índios conferiram ao gentio a pretendida liberdade ${ }^{1}$. Também, pode ser visto a gradual laicização do espaço urbano. Os aldeamentos foram convertidos em lugares ou vilas de índios, empondolhes os nomes das Villas mais notáveis deste Reyno ou conservando o das referidas Freguezias no cazo que não sejão bárbaros (... $)^{2}$. Tão comum uma Oeiras, Marvão, Crato, Viçosa, Portalegre, Monte - Mor, Barcelos, Soure, Mirandela...espalhadas pelos confins do Nordeste e Amazônia.

Sobretudo, o apogeu dos jesuítas no contexto econômico, político, religioso, cultural e administrativo da colônia criou incômodos entre a Coroa, o papado e a Companhia de Jesus. Como informou Paulo de Assunção:

(...) os religiosos possuíam um "temerário, e façanhoso projeto de usurpação de todo o Estado do Brasil, com um tão artificioso, e tão violento progresso, que, não sendo pronta e eficazmente atalhado, se faria no espaço de menos de dez anos inacessível, e insuperável todas as forças da Europa unidas (...) as atividades temporais dos inacianos, no decorrer de três déculos de permanência nas terras portuguesas, forneciam uma série de exemplos sobre a interferência dos jesuítas ao poder e à população de modo a serem malquistos pelas suas práticas. ${ }^{3}$

Expulsos os jesuítas em 1759, seus aldeamentos foram transformados em vilas ou lugares de índios. As reduções de outras ordens religiosas também passaram por esta conversão. No sertão pernambucano, a missão do Ararobá dos padres oratorianos se tornou a vila de Cimbres; no Cariri cearense, os capuchinhos administraram a missão do Miranda que, em 1764, eleva-se à vila Real do Crato. Em algumas reduções sertanejas, a catequese foi

\footnotetext{
${ }^{1}$ FLEXOR, Maria Helena Ochi. "Cidades e vilas pombalinas no Brasil do século XVIII". In Universo Urbanístico Português, 1415 - 1822. Lisboa, Comissão Nacional para as Comemorações dos Descobrimentos Portugueses, 1998. p. 258.

${ }^{2}$ PROJETO RESGATE. AHU_ACL_CU_016, Cx. 8, D. 450.

${ }^{3}$ ASSUNÇÃO, Paulo de. Negócios jesuíticos: o cotidiano da administração dos bens divinos. São Paulo, Edusp, 2009. p. 41.
} 
incumbida aos padres seculares do Hábito de São Pedro, por exemplo, em Monte - Mor o Novo da América. Em outros lugares, franciscanos e mercedários foram requisitados como párocos: Nossa Senhora das Mercês de Jaicós (mercedários) e São João de Sende (franciscanos).

Criada a vila, esta seguiu as recomendações das Ordenações do Reino e do Diretório dos Índios, no que tange os cargos administrativos dos oficiais da câmara. Cumpriam as formalidades e elegiam os vereadores, almotacés, procuradores, juízes ordinários para o concelho. Segundo Flexor, os nativos poderiam ser eleitos mesmo sendo analfabetos, havendo gentio habilitado ou que soubesse ler e escrever ocuparia o cargo de escrivão ${ }^{4}$. Na vila, os silvícolas seriam civilizados por um diretor, como traçou o primeiro parágrafo do Diretório:

(...) haverá em cada huma das sobreditas Povoaçoens, em quanto os Indios naõ tiverem capacidade para se governarem, hum Director, que nomeará o Governador, e Capitão General do Estado, o que deve ser dotado de bons costumes, zelo, prudência, verdade, sciencia da língua, e de todo os mais requisitos necessários para poder dirigir com acerto os referidos Indios debaixo das ordens, e determinações seguintes, que inviolavelmente se observarão em quanto Sua Magestade o houver assim por bem, e naõ o contrario. ${ }^{5}$

A recém - criada freguesia de índios, agora gerida por um diretor supostamente zeloso, prudente, honesto, letrado, de bons costumes, entre outros. No campo espiritual, o parágrafo quarto do Diretório nomeou um pároco:

Para se conseguir o primeiro fim, qual he o christianizar os Indios, deixando esta matéria, por ser meramente espiritual, á exemplar vigilância do Prelado desta Diocese; recomendo unicamente aos Directores, que da sua parte dem todo o favor, e auxilio, para que as determinaçoens do dito Prelado respectivas á direcçaõ das Almas, tenhaõ a sua devida execuçaõ; e que os Indios tratem os seus Párocos com aquella veneraçaõ, e respeito, que se deve ao seu alto caracter, sendo os mesmos Directores os primeiros, que com as

\footnotetext{
${ }^{4}$ FLEXOR, Maria Helena Ochi. "Núcleos urbanos criados por Pombal no Brasil do século XVIII". In Anais do IV Seminário de História da cidade e do Urbanismo. Vol 1. Denese B. Pinheiro Machado (org.). Rio de Janeiro, UFRJ/PROURB, 1996. p. 605.

5 "DIRECTORIO que se deve observar nas Povoaçoens dos Indios do Pará, e Maranhão em quanto Sua Magestade naõ mandar o contrario". In ALMEIDA, Rita Heloísa. O Diretório dos Índios: um projeto de civilização no Brasil do século XVIII. Brasília, Editora da UnB, 1997. (anexos).
} 
exemplares acçoens da sua vida lhes persuadaõ a observância deste Parágrafo. ${ }^{6}$

O desenho dos núcleos, erguidos após o Diretório, seguiu os princípios formais da carta régia de 03 de março de 1755 para a criação da capitania do Rio Negro ${ }^{7}$. O conteúdo da carta é similar das outras emitidas no século XVIII:

(...) convoqueis todo para determinados dias nos quais sendo prezente o povo determineis o lugar mais próprio para servir de Praça (...) fazendo levantar no meyo della o Pelourinho; assignando para se edificar huma igreja capaz de receber hum competente número de fregueses quando a povoação se augmentar (...) Só com a dita obrigação de que as ditas casas sejão sempre fabricadas na mesma figura uniforme pella parte exterior (...) para que desta sorte se conserve sempre a mesma formosura da terra e a mesma largura das $\operatorname{ruas}(\ldots)^{8}$

Como explanado no quarto capítulo desta dissertação, a praça estruturou o desenvolvimento de certos aglomerado. As ruas retilíneas eram traçadas a partir do largo. A malha dos núcleos tendia à regularidade, ou como disse novamente Maria Helena Flexor:

(...) a regularidade que os núcleos urbanos passaram a ter, mesmo baseados num traçado empírico, foi adotada em toda a rede urbana que então se estabelecia. (...) Na realidade é classificado como um traçado moderno das cidades, necessidades ideológicas e prática do iluminismo, como utilizaram Manuel da Maia em Lisboa, na reconstrução após o terremoto, os engenheiros Francisco Xavier do Rego, Francisco Pinheiro da Cunha, no Porto, Luís Serrão Pimentel, Manuel de Azevedo Fortes, José de Figueiredo Seixas, este último em seu "Tratado de Ruaçaõ para emenda das ruas das cidades, villas e lugares deste Reino"... primeiro tratado do urbanismo pombalino conhecido $(. . .)^{9}$

\footnotetext{
6 "DIRECTORIO que se deve observar nas Povoaçoens dos Indios do Pará, e Maranhão em quanto Sua Magestade naõ mandar o contrario". In ALMEIDA, Rita Heloísa. O Diretório dos Índios: um projeto de civilização no Brasil..., Opus cit., anexos.

${ }^{7}$ ARAÚJO, Renata Klautau Malcher. As cidades da Amazônia no século XVIII: Belém, Macapá e Mazagão. Porto, FAUP, 1998. p. 58.

${ }^{8}$ PROJETO RESGATE. AHU_ACL_CU_016, Cx. 8, D. 450.

${ }^{9}$ FLEXOR, Maria Helena Ochi. "Núcleos urbanos criados por Pombal no Brasil do século XVIII". In Anais do IV Seminário de História da cidade e do Urbanismo..., Opus cit., p. 612.
} 
Ainda sobre o tema, Renata Araújo opina que o traçado das ruas é destacado nas suas virtudes racionais e geométricas e a arquitectura de programa e o ideal de padronização das fachadas (...) permitindo ver na clareza geométrica do desenho urbano a ordem social que se pretendia (.... $)^{10}$. Para Beatriz Bueno o desenho geométrico desses núcleos urbanos não se fazia em abstrato. Era fruto de minucioso exame do sítio, sendo notável a relação dialética entre a atividade de levantamento e o ato de projetar o edifício ou a forma urbana ${ }^{11}$. Os ideais de Pombal para as vilas e povoações de índios da colônia americana se concentraram em caracterizar os espaços concebidos como urbanos, isto é, em que vive uma sociedade organizada, donde as decisões políticas e administrativas teriam efeitos duradouros ${ }^{12}$.

Neste capítulo, analisaremos a formação urbana de duas vilas sertanejas erguidas no século XVIII, tendo o aldeamento missioneiro como embrião urbano: Monte - Mor o Novo da América, conhecida vila pelos estudiosos do assunto diante da larga difusão de seu Registro dos Autos de Erecção ${ }^{13}$, e vila do Crato - povoação do Cariri cearense cujo casco viejo denuncia uma proposta urbanística previamente concebida. Não descartaremos a realidade do lugar, porque apesar das pretenções iluministas de ordenamento e, no caso de Monte - Mor, o traçado resultante do núcleo obedeceu às normas dos seus autos adaptando-as à situação do lugar: lotes demarcados ao longo dos caminhos existentes antes de sua fundação. Em Crato, somente após quatorze anos de sua criação, os ideais de linearidade e harmonia do conjunto foram tratados pelas autoridades coloniais.

\footnotetext{
${ }^{10}$ ARAÚJO, Renata Klautau Malchel. “A razão na selva: Pombal e a reforma urbana da amazônia”. In Camões Revista de Letras e Cultura Lusófona. no 15 - 16, jan/jun 2003. Lisboa, Instituto Camões, 2003. p. 160.

${ }^{11}$ BUENO, Beatriz P. Siqueira. Desenho e Desígnio: o Brasil dos engenheiros militares (1500 - 1822). Tese de doutorado. São Paulo, FAU/USP, 2001. p. 631.

${ }^{12}$ ARGAN, Giulio Carlo. História da arte como história da cidade. 5 ed. São Paulo, Martins Fontes, 2005. p. 113.

${ }^{13}$ A Revista do Instituto do Ceará publicou estes Autos em 1891. Paulo F. Santo republica em seu conhecido Formação de cidades no Brasil colonial, em 1968. Usaremos os textos mencionados pela citada revista.
} 


\subsection{Monte-Mor o Novo da América: desenho e seus espaços}

Localizada nas proximidades do maciço de Baturité, a vila de Monte - Mor o Novo da América, instituída em 1764, foi antes a missão da Palma. Segundo Liberal de Castro, a povoação foi elevada em 19 de abril de 1762 ao status de freguesia antes de receber o foro de vila $^{14}$. O estudo de sua formação urbana, seu traçado e outros condicionantes à sua urbanização é o que nos interesse nesta parte.

O já citado Registro dos Autos da erecção da real villa de Monte-mor o Novo da América, na capitania do Ceara Grande ${ }^{15}$ trata-se de um documento oficial dotado de princípios reguladores e projetuais para a citada aglomeração de índios. Beatriz Bueno, arrolando o período de demarcação do rossio, termo, patrimônio da câmara e espaço intraurbano, nos informa que, os executores das normas, levaram um mês e quatorze dias para concretizar os trabalhos. Sendo vinte e cinco dias usados para a delimitação da légua em quadra correspondente ao patrimônio da câmara ${ }^{16}$.

Outro dado que merece indicação, se refere à participação do ouvidor geral e corregedor da comarca Victorino Soares Barbosa e do engenheiro Custódio Francisco de Azevedo, morador da serra dos $\operatorname{Cocos}{ }^{17}$. A autoridade e o profissional supostamente garantiriam a execução do risco. Todavia, não era um trabalho fácil. Em virtude da topografia local e existência de um caminho percorrido pela população, o desenho resultante conferiu harmonização entre os fatores geográficos e a teoria geométrica pombalina.

A tarefa inicial do engenheiro resultou na demarcação do terreno onde seria alicerçada a vila. Consequentemente, marcariam os lotes dos moradores e estipulariam lugar apropriado para a edificação da igreja e sua praça: (...) e n'elle fez medir toda a área d'ella e achou ter 165 praças de comprido, correndo o rumo de sueste para o noroeste, e de largo 135 braças, correndo o rumo de nordeste para o sudeste $(. . .)^{18}$. Dentro deste retângulo

\footnotetext{
${ }^{14}$ CASTRO, José Liberal de. "Urbanização pombalina no Ceará: a paisagem da vila de Montemor - o - Novo d'América”. In Revista do Instituto do Ceará. Ano CXIII. Fortaleza, 1999. p. 43.

15 "REGISTRO dos Autos da erecção da real villa de Monte-mór o Novo da América, na capitania do Ceara Grande.” In Revista do Instituto do Ceará. Ano V. Fortaleza, 1891.

${ }^{16}$ BUENO, Beatriz P. Siqueira. Desenho e desígnio: o Brasil dos engenheiros militares (1500 - 1822). Tese de doutorado. São Paulo, FAU/USP, 2001. p. 635.

17 "REGISTRO dos Autos da erecção da real villa de Monte-mór o Novo da América..., Opus cit., p. 265.

18 "REGISTRO dos Autos da erecção da real villa de Monte-mór o Novo da América..., Opus cit., p. 265.
} 
alinharam a área competente à praça, esta com 80 x 40 braças $^{19}$. O largo da matriz seria o elemento balizador às etapas subseqüentes da estruturação de Monte - Mor. No Tratado Da Ruação Para emenda das ruas das cidades, villas, e lugares deste Reyno...de José de Figueiredo Seixas, dedicado à Sebastião José de Carvalho e Melo, nos inteiramos que as povoações seriam implantadas em centros quadrangulares, postos em sítio fértil, saudável e defensivo. Segundo esse tratado, as praças são huas arias de terra plana e figura quadrilátera, e são como salas da cidade, em que as pessoas podem passiar, e negociar, porque em ellas se fazem os mercados e das couzas necessárias ao viver dos homens $(. . .)^{20}$.

O método para realizar as diretrizes dos Autos foi apontado na sentença: como manda o novo methodo de fazer as cartas geográficas $(. . .)^{21}$. As lições de Luís Serrão Pimentel foram disseminadas no Reino e no território das conquistas ${ }^{22}$. Em Lisboa após o terremoto, seguido de maremoto e incêndio, ocorridos em 1755, a Coroa reformulou o seu tecido urbano [figura 145]. Maria Fernanda Derntl, citando a Dissertação do engenheiro mor do Reino, Manuel da Maia, aponta que, a reconstrução da capital portuguesa, valorizou as noções de "formosura", "simetria" e "boa ordem",23, conceitos estéticos impostos às cartas régias de ereção de vilas no ultramar no século XVIII. Ainda sobre a técnica de projetar vilas de Luís Serrão Pimentel, Beatriz Bueno acrescenta:

Os lotes e as ruas seguiram em geral um padrão de pouca variação, situandose via de regra dentro dos limites propostos por Luís Serrão Pimentel. No entanto, as praças ultrapassaram as medidas sugeridas pelo engenheiro português. Comparativamente às normas fornecidas para a fundação dos núcleos urbanos hispnoamericanos, os nossos apresentaram dimensões mais modestas. Praça central $=120$ a 200 ou 250 palmos (cada lado); Praças menores $=80$ a 100 palmos (cada lado); Ruas principais $=30$ a 35 palmos; Ruas secundárias $=25$ a 30 palmos; Casas (frente do lote) $=24$ a 36 ou 40

\footnotetext{
${ }^{19}$ Braças, antiga medida portuguesa, anterior ao sistema métrico, corresponde a 2,20 m e se subdivide em 2 varas. Palmo, velha medida portuguesa, correspondente a 0,22 m do sistema métrico. Ver FEITOSA, Carlos. As gentes dos Inhamuns na criação da Real Vila do Crato. Crato. p. 16.

${ }^{20}$ GOMES, Luís Miguel Martins. "Geometria no traçado de praças, teorias versus prática, no tempo de Pombal”. In TEIXEIRA, Manuel C. (org.). A praça na cidade portuguesa. Lisboa, Livros Horizonte, 2001. p. 204 - 205.

21 "REGISTRO dos Autos da erecção da real villa de Monte-mór o Novo da América..., Opus cit., p. 265.

${ }^{22}$ BUENO, Beatriz P. Siqueira. Desenho e desígnio: o Brasil dos engenheiros militares..., Opus cit., p. 637.

23 DERNTL, Maria Fernanda. Método e arte: criação urbana e organização territorial na capitania de São Paulo (1765 - 1811). Tese de doutorado. São Paulo, FAU/USP, 2010. p. 16 - 17.
} 
palmos; Casas (fundo do lote) $=68$ a 70 ou 80 palmos; Casa do governador $=80 \times 40 \times 25$ palmos $^{24}$.

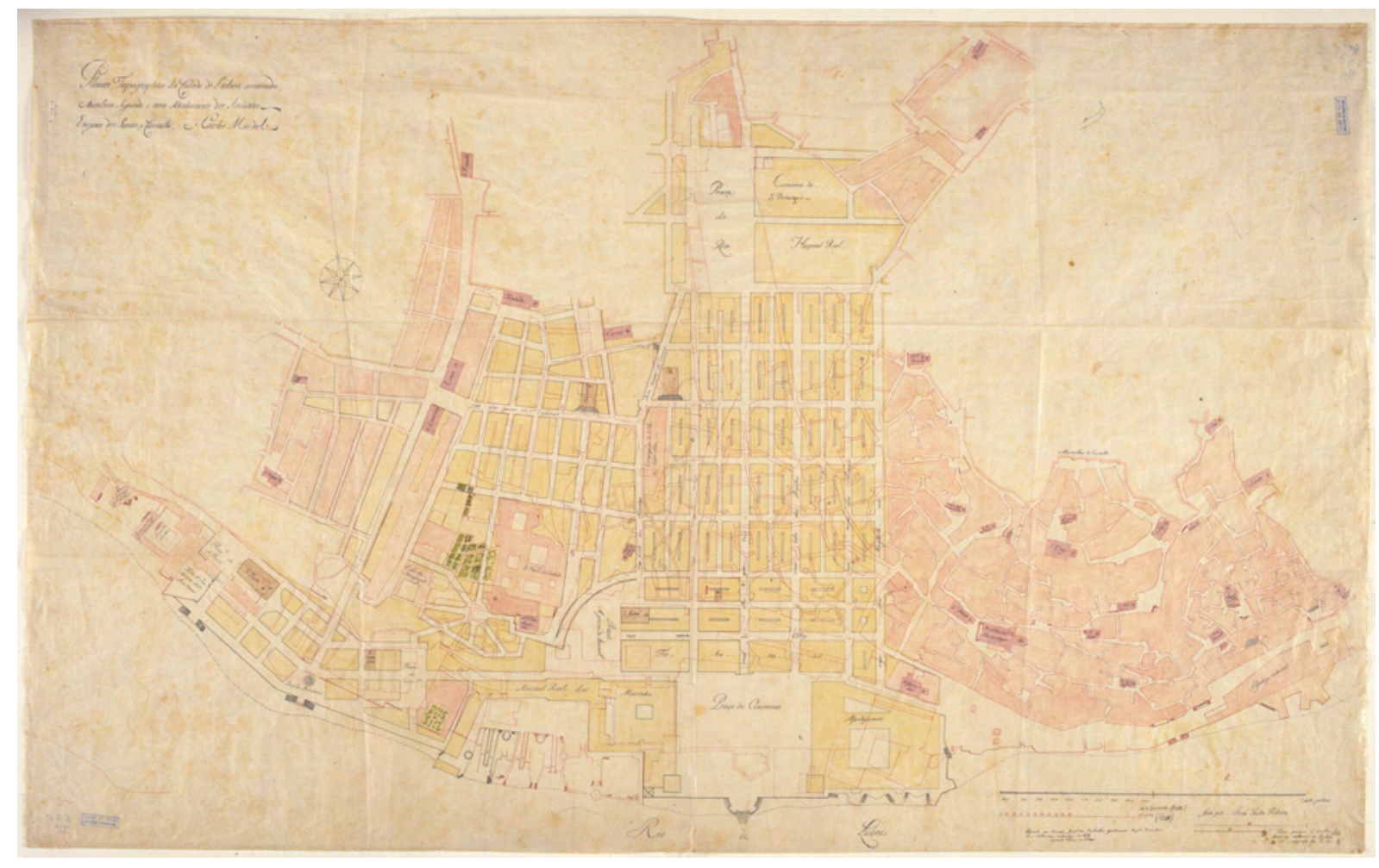

Figura 145 - Projeto para Lisboa após o terremoto de 1755. Cartografia disponível em http://www.nead.unama.br/site/bibdigital/cartografia_portuguesa. Acesso em 13. 11. 2011.

As próximas recomendações dos Autos de Erecção para Monte - Mor o Novo da América se destinaram às moradias e edifícios públicos. Os lotes das casas com 30 x 30 palmos, já a casa de câmara e demais prédios públicos teriam a forma quadrada em seu terreno com dimensão de 60 x 60 palmos. O templo católico, centralizado num dos lados da praça, edificaram-no em um lote de 80 palmos de fundo e 40 palmos de largo, deixando um vazio de 10 palmos em cada lado da igreja ${ }^{25}$, ampliações eram previstas. É interessante destacar a proporção dupla das medidas da praça e igreja. Os lotes institucionais e residenciais também foram hierarquizados no mesmo rigor matemático.

40 palmos estabeleceram como largura ideal às ruas transversais e paralelas ao núcleo da povoação. A rua principal, como assim foi chamada o logradouro de maior dimensão, teria 85 palmos. A boa perspectiva foi esperada, tendo como ponto de fuga a igreja matriz. Interpretamos as instruções deste documento, como resultado elaboramos a planta da figura 101, capítulo 04 .

\footnotetext{
${ }^{24}$ BUENO, Beatriz P. Siqueira. Desenho e desígnio: o Brasil dos engenheiros militares..., Opus cit., p. 639.

25 "REGISTRO dos Autos da erecção da real villa de Monte-mór o Novo da América..., Opus cit., p. 266.
} 
Planearam 154 moradias a serem construídas num espaço temporal de dois anos. Elas possuiríam quintais, exepto doze casas, por ficarem intermédias, que sevem servir para os comboieirosque vierem de fora ${ }^{26}$. Como não reuniram o número mínimo de povoadores para a nova vila, congregaram vadios, degredados e dispersos de outras regiões da capitania, além de seram migrados índios de distintos aldeamentos missioneiros da capitania: (...) á de Baturité q'igualmente me segurão se achar bem situada, por lograr as mesmas vantagens da do Miranda, unirá Va. Me a da Telha ${ }^{27}$ com todos os diperersos que achar, da mesma natureza q' deixo o dito na primeira $(. . .)^{28}$.

Finalizando o Termo de demarcação e asignação do terreno, o ouvidor aconselhou aos futuros habitantes da vila a fabricar as ditas casas pelas frentes seriam uniformes e pelo mesmo alinhamento demarcado ${ }^{29}$. Em seguida, a população presente foi lembrada a obedecer os parágrafos 82 e 86 do Diretório dos Índios ${ }^{30}$ :

$\S 82$ Primeira: Que de nenhum modo poderã̃ possuir as terras, que na forma das reaes Ordens de Sua Magestade se acharem distribuídas pelos Indios, pertubando-os da posse pacifica dellas, ou seja em satisfaçaõ de alguma divida, ou a titulo de contracto, doaçaõ, disposiçaõ, Testamentária, ou de outro qualquer pretexto, ainda sendo apparentemente licito, e honesto.

§86 Quinta: Que deixando de observar qualquer das referidas condiçoens, seraõ logo expulsos das mesmas terras, perdendo todo o direito, que tinhaõ adquirido, assim á propriedade della, como a todas as Lavouras, e plantaçoens, que tiverem feito.

Fixado o símbolo de autonomia municipal - o pelourinho - e o seu respectivo local, as autoridades presentes estabeleceram os limites do termo da vila. Sabe-se que o termo confere um território municipal, podendo existir nele freguesias, arraiais, fazendas de gado, caminhos públicos e sesmarias. Para termo de Monte - Mor designaram [mapa 20]:

(...) o termo da referida villa ficava comprehedendido para a parte norte até o lugar chamado o Hipu do Riacho do Acarape inclusive, para a parte do sul

\footnotetext{
${ }^{26}$ REGISTRO dos Autos da erecção da real villa de Monte-mór o Novo da América..., Opus cit., p. 267.

${ }^{27}$ A missão da Telha foi o embrião da cidade de Iguatú - CE.

${ }^{28}$ FEITOSA, Carlos. As gentes dos Inhamuns na criação da Real Vila do Crat..., Opus cit., p. 15.

${ }^{29}$ REGISTRO dos Autos da erecção da real villa de Monte-mór o Novo da América..., Opus cit., p. 267.

30 "DIRECTORIO que se deve observar nas Povoaçoens dos Indios do Pará, e Maranhão em quanto Sua Magestade naõ mandar o contrario". In ALMEIDA, Rita Heloísa. O Diretório dos Índios: um projeto de civilização no Brasil..., Opus cit., §§ 82 e 86 (anexos).
} 
até a fazenda chamada Cabifaz inclusive no riacho Xoró, e por este abaixo buscando a nascente até a fazenda chamada Humari, e para a parte do poente se incluiriam no dito termo todas as serras que deságuam as suas águas vertentes para o dito rio Xoró ${ }^{31}$.

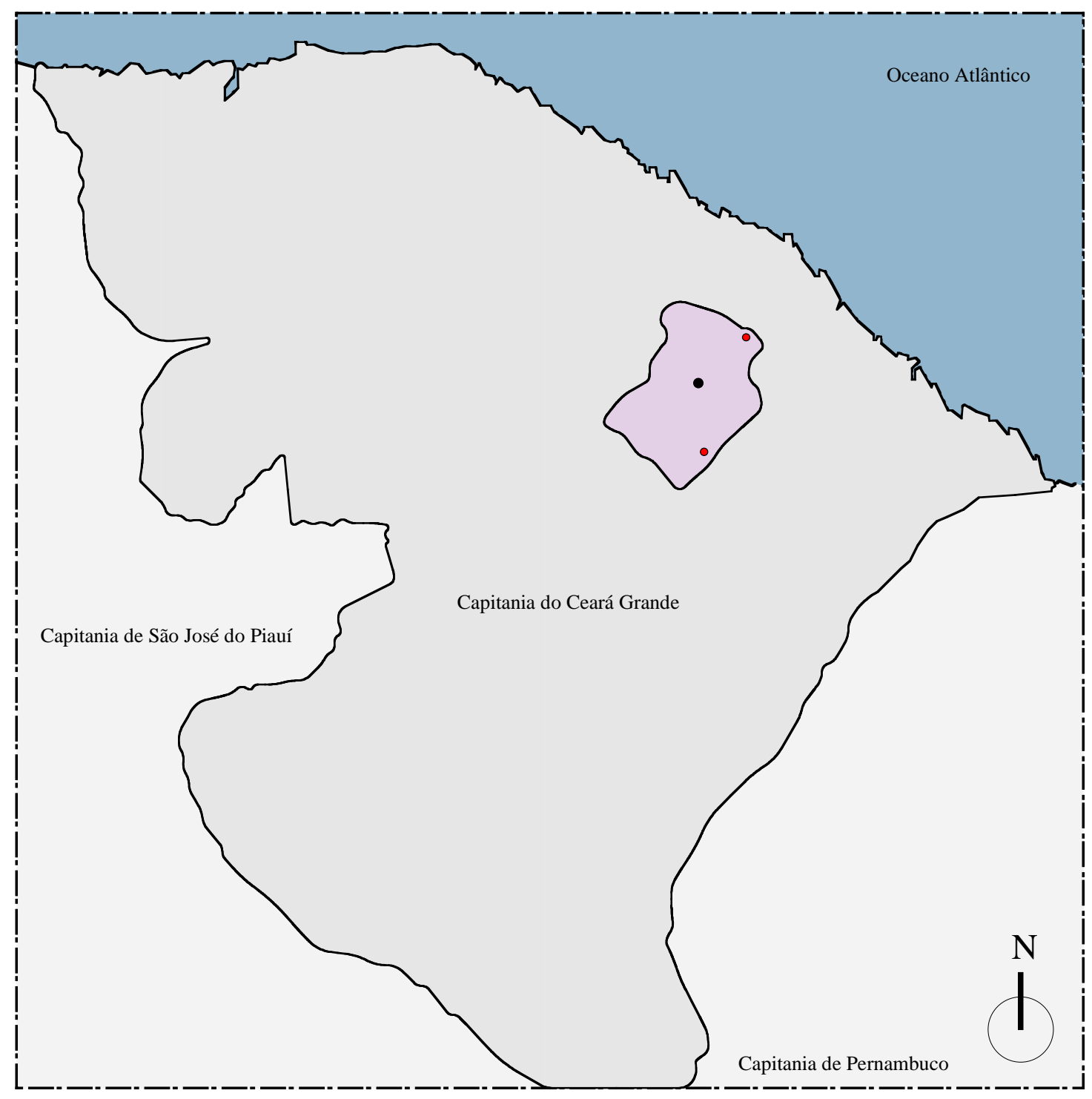

LEGENDA:

Termo da vila de Monte-Mor o Novo da América

Vila de Monte-Mor o Novo da América Povoações
Mapa 20 - Termo da vila de Monte - Mor o Novo da América. Desenho do autor sobre mapa elaborado por NETO, Clovis Ramiro Jucá. Urbanização do Ceará Setecentista - as vilas de Nossa Senhora da Expectação do Icó e Santa Cruz do Aracati. Tese de doutorado. Salvador, UFBA, 2007. p. 262.

Para garantir o sustendo da câmara e delimitação das datas de terras solicitadas pelos moradores, concederam ao senado um patrimônio fundiário:

\footnotetext{
${ }^{31}$ REGISTRO dos Autos da erecção da real villa de Monte-mór o Novo da América..., Opus cit., p. 269.
} 
E para patrimônio da mesma camara lhe assignou particularmente todos os sítios já feitos nas margens do rio Aracauaba, que são dos comprehendidos na medição das terras próprias d'esta villa e dois mais das margens do rio Putihy, comprehendidos na mesma medição, os quaes se aforariam, e alem dos referidos sítios lhe assignou tambem todas as sobras que ficarem da mesma medida, depois de demarcadas as datas particulares dos moradores n'ella; e outro sim, consignou mais em particular para o dito patrimonio a terra chamada a Missão Velha, onde primeiro foi situada, e o que n'ella se comprehender em uma légua de duas mil e oitocentas braças quadradas, e para pasto comum da mesma villa o sitio chamado o Geritana $(\ldots)^{32}$

Os anseios reguladores conferidos à vila de índios cearense encontraram um elemento balizador - caminho terrestre - sendo necessário conjugar as ordens dos autos com a realidade geográfica. Freire Alemão, em sua inspeção pelo Ceará, por volta de 1860, nos legou uma planta da vila, chamada nos tempos de sua visita de Barturité [figura 146]. Para o botânico, os executores do traçado do núcleo urbano não haviam seguido exatamente o plano dados para as construções, de sorte que o quadro não ficou bem regular(... $)^{33}$. Nesse desenho, verifica-se a linearidade das casas da praça e àquelas encontradas nas ruas paralelas. A rua principal, de consideráveis dimensões, demarcaram-na com uma pequena inclinação. Recomendaram uma praça em paralelogramo perfeito, entretanto, a presença do caminho (logo atrás da igreja matriz) comandou o ordenamento dos lotes solicitados por alguns residentes, quebrando a regularidade almejada. Além do mais, quatro lotes avançam para a praça, novamente, rompendo com a forma idealizada pelos Autos.

As regras dos Autos de Erecção referentes aos chãos vizinhos à igreja atestavam: (...) e nos lados da mesma frente da igreja alinhou dez moradas de casas, cinco para cada parte $(\ldots)^{34}$. O templo católicose destacou no largo, marcando a presença da religião na civilização dos sertanejos recolhidos. Deixaram mais de 10 palmos (medida aconselhada), em cada lado da igreja, como folga para futuras reformas ou ampliações. Expandindo-se sobre o rossio, a povoação cresce linearmente com lotes retos. O número ideal de habitações fora estipulado

\footnotetext{
${ }^{32}$ REGISTRO dos Autos da erecção da real villa de Monte-mór o Novo da América..., Opus cit., p. 269 - 270.

33 “OS MANUSCRITOS do botânico Freire Alemão: catálogo e transcrição". In Anais da Biblioteca Nacional. Vol 81. Rio de Janeiro, Divisão de Publicação e Divulgação, 1964. p. 339.

${ }^{34}$ REGISTRO dos Autos da erecção da real villa de Monte-mór o Novo da América..., Opus cit., p. 266.
} 
em 154. Porém, em 1774, segundo o relatório do governador da capitania de Pernambuco, Jozé Cezar de Menezes, estavam erguidos em Monte - Mor 99 fogos ${ }^{35}$.

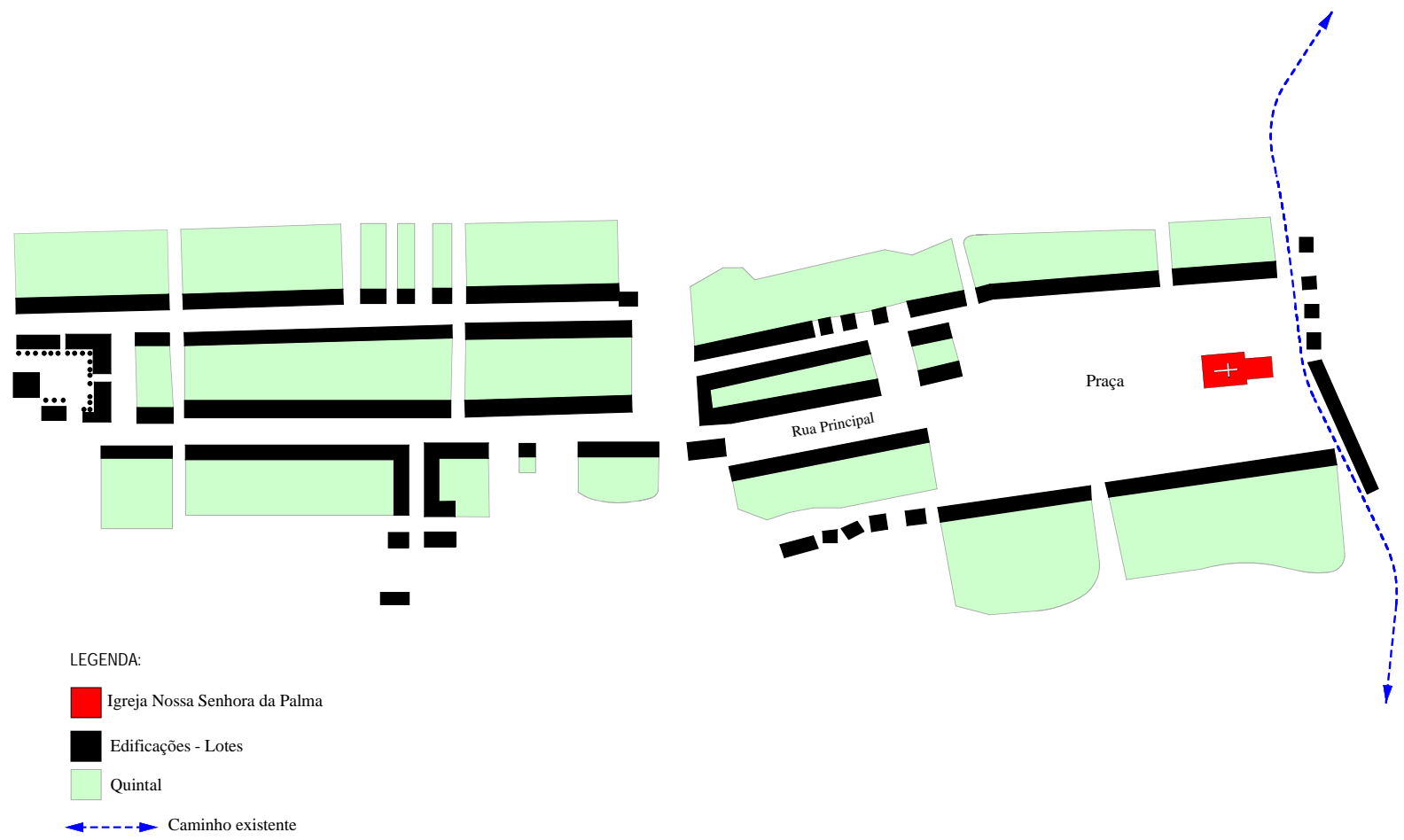

Figura 146 - Planta de Baturité, antes vila de Monte - Mor o Novo da América, 1861. Desenho elaborado pelo autor segundo manuscrito do naturalista Freire Alemão. Cujo original encontra-se no setor de Manuscritos da Fundação da Biblioteca Nacional. Número de chamada I - 28, 9, 33.

O diminuto crescimento econômico e urbano de Monte - Mor, a partir de seu predicamento de vila, deveu a idênticos fatores acometidos em outras vilas da capitania, como de outras partes do sertão nordestino. Um deles dizia respeito ao tipo de transação econômica, ou melhor, ao produto efetivado nas trocas, entre a população de nativos e moradores brancos:

(...) que hum dos motivos mais fortes da decadência das Villas, e Povoaçoens dos Indios he proveniente da ambição de alguns indivíduos desta mesma Capitania, e de outros, que a ella vam, que esquecendo-se do sancto temor a Religião (...) se valem da innocencia e rusticidade dos mesmos Indios, indo as suas rossas as Serras, e montes das suas Povoaçoens

\footnotetext{
35 "IDEA da População da Capitania de Pernambuco, e das aus annexas, extensão de suas Costas, Rios, e Povoaçoens notáveis, Agricultura, numero dos Engenhos, Contractos, e Rendimentos Reaes, augmento que estes tem tido \&.\& desde o anno de 1774, em que tomou posse o Governador das mesmas Capitanias o Governador e Capitam General Jozé Cezar de Menezes". in Annaes da Bibliotheca Nacional do Rio de Janeiro. Vol. XL. Ano 1918. Rio de Janeiro, Officinas Graphicas da Bibliotheca Nacional, 1923. p. 03.
} 
a comprar-lhes algodões, e outros gêneros, que elles agricultão, a troco de aguardente, cachassa, e vinhos trazidos nelles $(\ldots)^{36}$

Outras duas causas foram sublinhadas por Clovis Jucá Neto. A primeira diz respeito à inexistência de casa de câmara e cadeia nos municípios cearenses, servindo-se de huns casebres informes construídos de paos e barro que só servem de irrisão e de escândalo; mas de nenhuma segurança aos presos (... $)^{37}$. A segunda causa atrela-se ao estado de "indigência" encontrado nas câmaras do Ceará:

\begin{abstract}
Uma indigência resultante tanto da "omissão e incurialide com q' foram criadas" as vilas - quando na ocasião não foram estabelecidos patrimônios sólidos e suficientes - como da falta de "padroins, de ordenanças, dos cofres, dos livros e de todos os demais acessórios" que elas não podem deixar de ter para a "boa governança dos povos e para a conservação do decoro". 38
\end{abstract}

Soma-se a estes problemas a difícil realidade do sertão no final do século XVIII: queda da pecuária no mercado colonial, grande período de seca e migração da população para outros centros da região. Para Liberal de Castro, em Monte - Mor os índios congregados começaram a abandonar a vila ou por decorrência das secas ou pela pouca adaptabilidade ao cotidiano urbano ${ }^{39}$. O sistema de viver civilizatório imposto ao Tapuia, mostrou sua ineficiência, acarretando na expulsão de muitos pelos moradores brancos do aglomerado. Realidade contrária às nova lei de civilização do indígena - carta régia de 12 de maio de 1798 - que substituiu o Diretório dos Índios no reinado de Dona Maria I. Em partes, essa norma oficial afirmou: iguaes os Indios em direito e obrigações com os meus outros vassallos, ainda falta facillitar-lhes alianças com os brancos como um meio mais efficaz para a sua perfeita civilisação (.... $)^{40}$.

\footnotetext{
${ }^{36}$ PROJETO RESGATE. AHU_ACL_CU_CEARA, Cx. 9, D. 593.

${ }^{37}$ NETO, Clovis Ramiro Jucá. Urbanização do Ceará Setecentista - as vilas de Nossa Senhora da Expectação do Icó e Santa Cruz do Aracati. Tese de doutorado. Salvador, UFBA, 2007. p. 289.

${ }^{38}$ NETO, Clovis Ramiro Jucá. Urbanização do Ceará..., Opus cit., p. 289.

${ }^{39}$ CASTRO, José Liberal de. "Urbanização pombalina no Ceará: a paisagem da vila..., Opus cit., p. 63.

40 "CARTA régia de 12 de Maio de 1798 ao capitão-general do Pará acerca da emancipação e civilisação dos índios, e resposta do mesmo acerca da sua execução". In Revista do Instituto Histórico e Geographico Brazileiro. Tomo XX. Rio de Janeiro, 1857. p. 439.
} 
Os lotes doados aos nativos acabaram gradativamente, sendo transferidos a outros usuários $^{41}$ : com a destruição dos índios foi a vila, e lugares adjacentes se povoando de maior número de brancos, que hoje se constituem a maioria dos habitantes do lugar. ${ }^{42} \mathrm{Na}$ vereação de 29 de março de 1830, os edis leram um ofício do presidente da província, um dos motes do documento mencionou a retirada do velho título colonial de vila de índios ${ }^{43}$.

Freire Alemão descreveu a paisagem de Monte - Mor em 1810:

Parece que esta vila não teve uma existência muito próspera, do que pude obter por tradição da gente mais antiga com que pude conversar, até 1810 ela não apresentava grande proseridade; havia então pouca gente branca na vila, e os índios viviam vida miserável, sustentando-se principalmente da pesca (que faziam com arco e frecha). Não havia inda igreja decente, nem casa alguma cômoda (...) muitos casebres eram de telha mas de triste aspecto. ${ }^{44}$

No início dos Oitocentos, o coronel Antônio Jozé da Silva Paulet elaborou uma breve descrição da capitania do Ceará, destacando suas principais vilas. Apresentou Monte - Mor o Novo:

Na Serra do Batorité ao S. de Fortaleza está situada está villa, erecta para Indios congregados de outros lugares, e hoje quazi toda habitada de extranaturaes, nome que se dá a todo o que não é índio. Não tem casa de câmara, nem cadê, nem o conselho patrimonio. A villa tem 84 cazas muito arruinadas, muitas cobertas de palha, e muito insignificante. ${ }^{45}$

O relato de Freire Alemão apontou algumas distinções e permanências quando visitou a localidade por volta de 1860 :

A cidade vai crescendo em edificações, as ruas novas vão sendo bem alinhadas, as casas feitas de tijolos, cobertas de telhas ladrilhadas, caiadas, etc., e algumas com salas forradas com Iona. Têm salas amplas, comunicando de ordinários, por uma porta lateral com as lojas, quando são

\footnotetext{
${ }^{41}$ CASTRO, José Liberal de. "Urbanização pombalina no Ceará: a paisagem da vila..., Opus cit., p. 65.

${ }^{42}$ OS MANUSCRITOS do botânico Freire Alemão: catálogo e transcrição". In Anais da Biblioteca Nacional..., Opus cit., p. 339.

${ }^{43}$ CATÃO, Pedro. "Baturité". In Revista do Instituto do Ceará. Ano LIII. Fortaleza, 1939. p. 157.

${ }^{44}$ OS MANUSCRITOS do botânico Freire Alemão: catálogo e transcrição". In Anais da Biblioteca Nacional..., Opus cit., p. 339.

${ }^{45}$ PAULET, Antônio Jozé da Silva. "Descripção Geografica Abreviada da Capitania do Ceará". in Revista do Instituto do Ceará. Ano XII. Fortaleza, 1898. p. 29.
} 
casas de negócios antes; algumas têm casas bem mobilhadas (...) Ouvi calcular-se em 1.500, a 2.000 o número de habitantes da vila de Baturité; são em grande parte brancos ou mamelucos; geralmente pobres. ${ }^{46}$

Somente após a primeira metade do século XIX conseguimos diferenciar duas áreas por uso em Monte - Mor. A primeira diz respeito à sua fundação, ao núcleo pombalino, onde se detiveram funções essencialmente residenciais. Ao expandir-se, uma zona comercial é fomada, encontrando seu centro de agregação no largo da igreja de Santa Luzia. ${ }^{47}$ Esta evolução no tecido urbano buscou harmonizar-se ao casco viejo setecentista. Segundo Liberal de Castro, o trecho oitocentista se configurou seguindo o eixo diretor - a rua pincipal -, a partir dele as ruas foram desenvolvidas em linha reta e os lotes alinhados ${ }^{48}$ [ver figura 146].

Mesmo passando por pontuais alterações em seu plano pombalino, alguns lotes da praça e da rua principal apresentam hoje a medida de sua frente em aproximadamente 30 palmos (6,6 m), como o estipulado pelo Termo de Demarcação ${ }^{49}$. Em 1764, ano de fundação de Monte - Mor o Novo da América, outro aldeamento indígena localizado ao sul da capitania do Ceará recebeu o título de vila. A missão do frei capuchinho Carlo de Ferrara adquiriu a denominação portuguesa de vila Real do Crato. Situada na região do Cariri cearense, a malha da atual cidade denuncia a concretização de normas que viam o alinhamento e a forma do conjunto como partido de sua fábrica.

\footnotetext{
${ }^{46}$ OS MANUSCRITOS do botânico Freire Alemão: catálogo e transcrição”. In Anais da Biblioteca Nacional..., Opus cit., p. $340-341$.

${ }^{47}$ CASTRO, José Liberal de. "Urbanização pombalina no Ceará: a paisagem da vila..., Opus cit., p. 70.

${ }^{48}$ CASTRO, José Liberal de. "Urbanização pombalina no Ceará: a paisagem da vila..., Opus cit., p. 69.

${ }^{49}$ CASTRO, José Liberal de. "Urbanização pombalina no Ceará: a paisagem da vila..., Opus cit., p. 67.
} 


\subsection{De missão do Miranda à vila Real do Crato}

A missão do Miranda, administrada temporal e espiritualmente pelo capuchinho italiano frei Carlos de Ferrara, foi fundada em $1741^{50}$ na região do Cariri cearense, ao sopé da chapada do Araripe, divisor orográfico entre Ceará e Pernambuco. Congregou os índios da nação Cariri: quixelôs, inhamuns, jucás, icós, entre outros, situando-os definitivamente às margens do riacho granjeiro ${ }^{51}$. Instalaram a redução na mais abundante e deliciosa região do Ceará, ficando mais pelo país adentro, sobre uma das correntes menores que formam o rio Salgado, sendo notável por fazerem os habitantes de seu distrito uso da irrigação, podendo assim em ocasiões de seca fornecer víveres a outras partes da província ${ }^{52}$.

Inicialmente, a preocupação em erigir o aldeamento ocorreu em função dos conflitos entre nativos e colonizadores criadores de gado. Os constantes ataques às fazendas e furtos de reses, realizados pelos índios, estimularam os fazendeiros da região a proteger seu patrimônio. Solicitaram missionários ao bispado de Pernambuco e Junta das Missões no intuito de apaziguar os tratos, domesticar e catequizar o gentio. Preferiram os capuchinhos pelo seu voto de pobreza, zelo aos ofícios religiosos e pequeno anseio material ${ }^{53}$. O primeiro templo, contruído em taipa e coberto com palha, logo foi substituído por outro de pedra e cal em $1742^{54}$.

Situada no trajeto de importantes vias terrestres, a missão do Miranda foi irrigada por duas artérias que intercambiavam o sertão cearense ao porto de Aracati, aos litorais pernambucano e paraibano, ao rio São Francisco e à vila do Mocha. A estrada geral do Jaguaribe $^{55}$ além de atravessar os arrebaldes da vila do Icó, cruzou a redução do Miranda margeando o rio Salgado, ultrapassava o platô da chapada do Araripe, chegando à pequena povoação do Exú, donde rumava para a freguesia do Cabrobó, sita às margens do médio rio São Francisco. Outra rota que marcou a paisagem da futura vila do Crato foi a estrada das boiadas $^{56}$, esta ligou Pernambuco ao Piauí, cruzando o território cearense.

\footnotetext{
${ }^{50}$ PRIMERIO, P.Fr. Fidelis M. de. Capuchinhos em Terras de Santa Cruz nos séculos XVII, XVIII e XIX. São Paulo, Livraria Martins, 1942. p. 170.

${ }^{51}$ ARAÚJO, pe. Antônio Gomes. A cidade de frei Carlos. Vol. 5. Crato, FFCrato, 1971. p. 69.

52 SALEMA, Vasco da Costa. Pelourinhos do Brasil. Lisboa, Sociedade Acadêmica da Independência de Portugal, 1982. p. 81.

${ }^{53}$ PROJETO RESGATE. AHU_ACL_CU_CEARA, Cx. 12, D. 674.

${ }^{54}$ ARAÚJO, pe. Antônio Gomes. A cidade de frei Carlos..., Opus cit., p. 74.

${ }^{55}$ FILHO STUDART, Carlos. "Vias de comunicação do Ceará colonial”. In Revista do Instituto do Ceará. Tomo LI. Fortaleza, 1937. p. 27 - 30.

${ }^{56}$ FILHO STUDART, Carlos. “Vias de comunicação do Ceará colonial”..., Opus cit., p. 31 - 35.
} 
Seccionada por esses dois velhos caminhos, o aldeamento governado por frei Carlos de Ferrada foi elevado à freguesia em 1762 e ao predicamento de vila em 1764, chamada a partir de então de vila Real do Crato. Sua fundação seguiu as propostas de controle do sertão pela Metrópole, instalando em diversos pontos do interior do Nordeste vilas ou lugares de índios.

Estabelecida no mesmo ano que Monte - Mor o Novo da América, a carta régia que elevou Crato à vila consta de um apanhado feito, em 1860, pelo botânico Freire Alemão durante sua visita ao núcleo, sendo transcrita por Carlos Feitosa. No documento notamos algumas semelhanças de trato urbano com os Autos de Erecção de Monte - Mor. Seria o conhecido corpo de doutrinas ${ }^{57}$ iniciado no reinado de D. João V e transmitido aos períodos seguintes. Atemo-nos em examinar e interpretar as poucas e pontuais informações do carta régia focalizando o urbano, em seu desenho e uso do chão. No princípio da criação da vila, os códigos não foram cumpridos, cabendo ao ouvidor Jozé da Costa Dias e Barros, em 1778, reformar o traçado do núcleo assegurando a harmonia desejada.

Elegeram o sítio para a nova vila. Viram que o terreiro da igreja matriz apresentou os condicionantes necessários para a fixação dos índios e demais moradores. Reuniram-se ali, além dos neófitos catequizados por Carlos de Ferrara, indígenas da missão da Telha e aldeia do Jucá, como todos os índios que andarem dispersos, e não pertencendo a alguma das novas villas e povoaçoens $(. . .)^{58}$. Agruparam o número dos moradores q' por ora ficão, e estão já agregados nesta dita Villa a mostra geral q' a todos passou (o ouvidor) na qual apparecerão 208 homens $(\ldots)^{59}$.

As atividades de demarcação iniciaram em 21 de junho de 1764, utilizando para os trabalhos enxadas, foices e machados trazidos da vila potiguar de Portalegre pelo juiz de fora

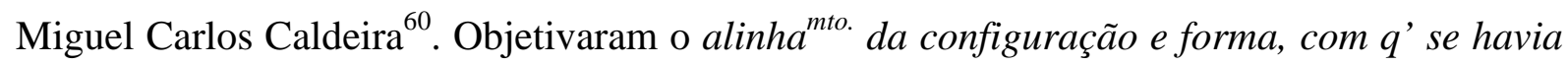
de fazer o arruamento (... $)^{61}$. Segundo Rafael Moreira, arruar não significa mais do que alinhar, traçar a direito, sem implicar ortogonalidade (...) uma rua arruada está direcionada em linha direita ou retilínea ${ }^{62}$. Murillo Marx (apud Viterbo) analisou o verbete "arruar” como separar, dividir em ruas, e bairros. Distribuir pelas ruas, as lojas para diversas profissões e

\footnotetext{
${ }^{57}$ SANTOS, Paulo F. Formação de cidades no Brasil colonial. Rio de Janeiro, Editora da UFRJ, 2001. p. 47.

${ }^{58}$ FEITOSA, Carlos. As gentes dos Inhamuns na criação da Real Vila do Crato. Crato. p. 14.

${ }^{59}$ FEITOSA, Carlos. As gentes dos Inhamuns na criação da Real..., Opus cit., p. 21.

${ }^{60}$ FEITOSA, Carlos. As gentes dos Inhamuns na criação da Real..., Opus cit., p. 15.

${ }^{61}$ FEITOSA, Carlos. As gentes dos Inhamuns na criação da Real..., Opus cit., p. 17.

${ }^{62}$ MOREIRA, Rafael. "A arte de ruaçao e a cidade luso-brasileira". in Cadernos de pesquisa LAP. No 37. Jan Jun 03. São Paulo, FAU/USP, 2003. p. 16, 24.
} 
ofícios $^{63}$. Para Marx, há muito mais envolvido nesta ação do que simplesmente por os lotes “a régua". Presume-se separação da sociedade por classe e ofícios: segregava-se não mais verticalmente, loja embaixo, morada em cima, porém, horizontalmente, no seu setor de negócios, no seu setor de morar ${ }^{64}$.

Antes de surgir uma nítida estratificação social na malha urbana, isto é, nos primeiros anos de fundação de algum assentamento, coube aos engenheiros a tarefa de arruar, na falta destes eram substituídos pelo ruador, cargo camarário ${ }^{65}$. Em Crato, não obtivemos notícia desses atores atuando na concretização do plano da vila, por isso, somos levados a considerar que os executores da obra ou foram os edis da câmara eleitos ou o capitão-mor do núcleo, porque, como novamente opinou Marx: o cuidado com o alinhamento e com o nivelamento persiste no pequeno rol de atenções das câmaras municipais, no que diz respeito à configuração do espaço urbano em geral, ao traçado viário e à disciplina devida pelos concessionários de data ${ }^{66}$.

A igreja seria o ponto de referência para a marcação do espaço correspondente à praça: (...) regulada a praça pela igreja q' nella ainda existe arruinada, a qual tem de frente 50 palmos, e 100 palmos de fundos, se deixarão 20 palmos de área na frente de seos dois lados em cada hum o que pudesse ser necessário pelo tempo adiante vindo-se a fazer de novo como carece $(\ldots)^{67}$. Quarenta palmos de largura reservaram para as ruas paralelas e transversais ao átrio, idem Monte - Mor o Novo da América.

O quadrado, figura geométrica proposta para o núcleo central do Crato, mediria $30 \mathrm{x}$ 30 braças. Como rossio, as autoridades estabeleceram um quadrilátero de 300 braças em quadra. Estimaram para a época a arruação de 11 logradouros com 228 moradias ${ }^{68}$. Fincaram o pelourinho no largo, o qual foi destruído em 1817, durante a Confederação do Equador, por uma multidão superexitada e aos clamores, para a cadea soltar os presos e armá-los com as armas tomadas aos moradores; os moradores foram obrigados a sair das casas para a rua e gritar viva a Pátria, viva a liberdade; o pelourinho foi derrubado e arvorada a bandeira

\footnotetext{
${ }^{63}$ MARX, Murillo. Cidades no Brasil, em que termos? São Paulo, Studio Nobel, 1999. p. 95.

${ }^{64}$ MARX, Murillo. Cidades no Brasil, em que termos?..., Opus cit., p. 99.

${ }^{65}$ MOREIRA, Rafael. "A arte de ruaçao e a cidade luso-brasileira”..., Opus cit., p. 24.

${ }^{66}$ MARX, Murillo. Cidades no Brasil, em que termos?..., Opus cit., p. 77.

${ }^{67}$ FEITOSA, Carlos. As gentes dos Inhamuns na criação da Real..., Opus cit., p. 18.

${ }^{68}$ FEITOSA, Carlos. As gentes dos Inhamuns na criação da Real..., Opus cit., p. 18.
} 
republicana ${ }^{69}$. Esquematizamos o plano idealizado pela Metrópole à vila Real do Crato conforme a figura 147.

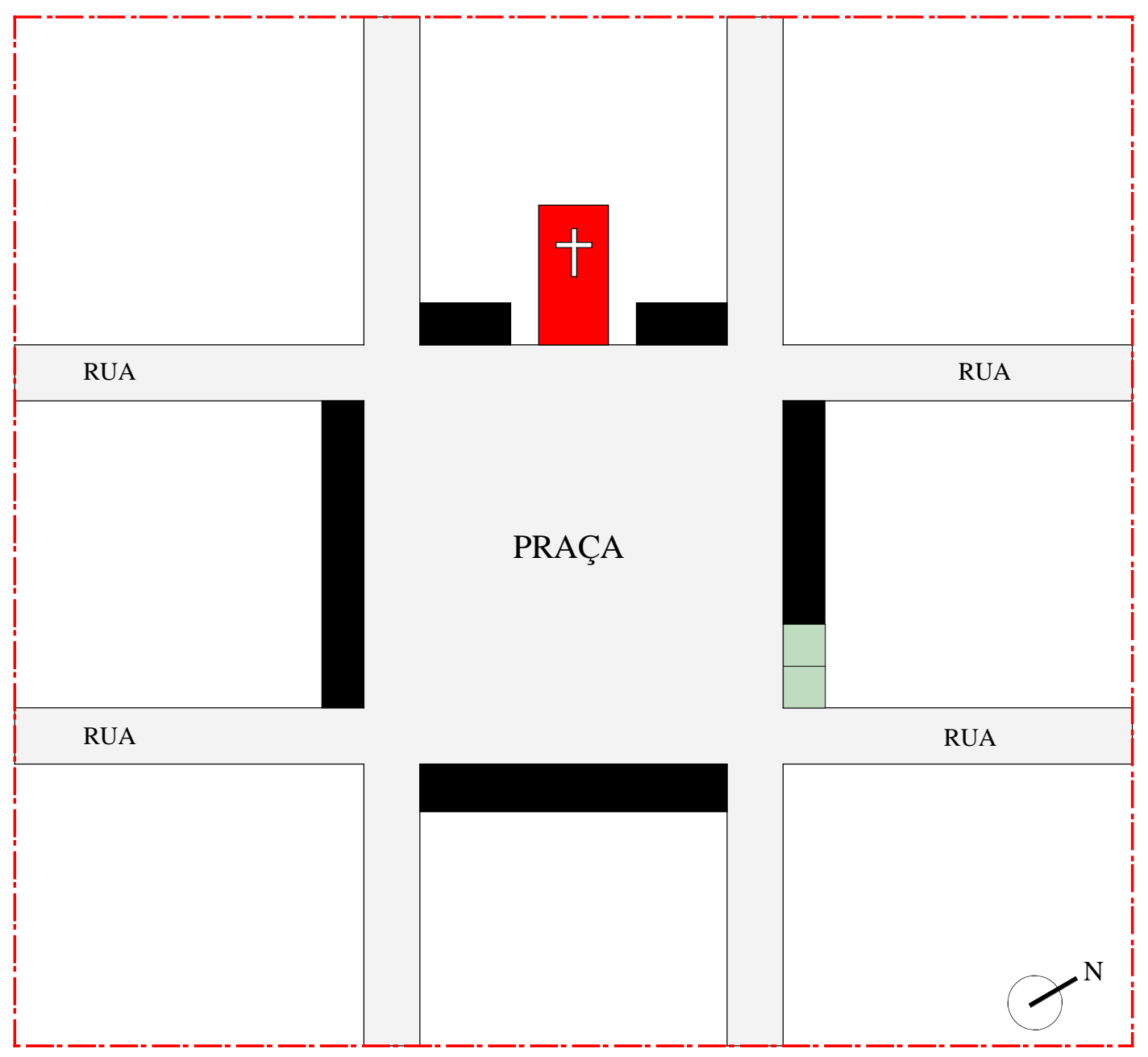

\section{LEGENDA:}

Igreja matriz de Nossa Senhora da Penha de França (50 x 100 palmos)

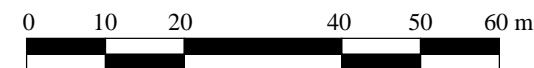

Lotes institucionais: casa de câmara e cadeia

Lotes residenciais

Praça: 30 x 30 braças

Ruas: 40 palmos de largo

Figura 147 - Esquema do plano idealizado para a vila Real do Crato em 1764. Desenho do autor segundo informações tiradas in loco e através da carta régia de criação da vila. Ver FEITOSA, Carlos. As gentes dos Inhamuns na criação da Real..., Opus cit., p. 17 - 18.

\footnotetext{
${ }^{69}$ SALEMA, Vasco da Costa. Pelourinhos do Brasil..., Opus cit., p. 81 - 82.
} 
Para termos da vila [Mapa 21] e patrimônio da câmara a carta foi específica em dizer:

(...) q' esta ficaria sendo tudo o que mais comprehende a divisão da Freg. ${ }^{a}$ de S. José dos Cariris dita na Missão Velha, e alem do q' esta comprehendendo lhe ficará mais pertencendo no sobredito terreno pelo Rio do Carihu abaixo a todas as suas vertentes até onde faz barra o Rio dos Bastiões, Freg. ${ }^{\text {a dos }}$ Inhamuns, e por este rio acima, e Fazenda da Conceição (...) inclusive entrando pelo Riacho da Cruz the indo confins esta Capitania com a do Piahui pela parte do sul, e pela parte do norte ficará pertencendo a Villa do Icó, como dantes era; e para patrimonio da d. ${ }^{a}$ Camara assinou as terras em q’ está o Eng. . das Almecegas, e todos os mais sítios q' se aforarem por ella, e assim mais todas as sobras das terras, q' por elle d. ${ }^{\circ}$ Ministro fica medidas, e demarcadas, e q' ficarem depois de repartidas aos seus moradores ${ }^{70}$;

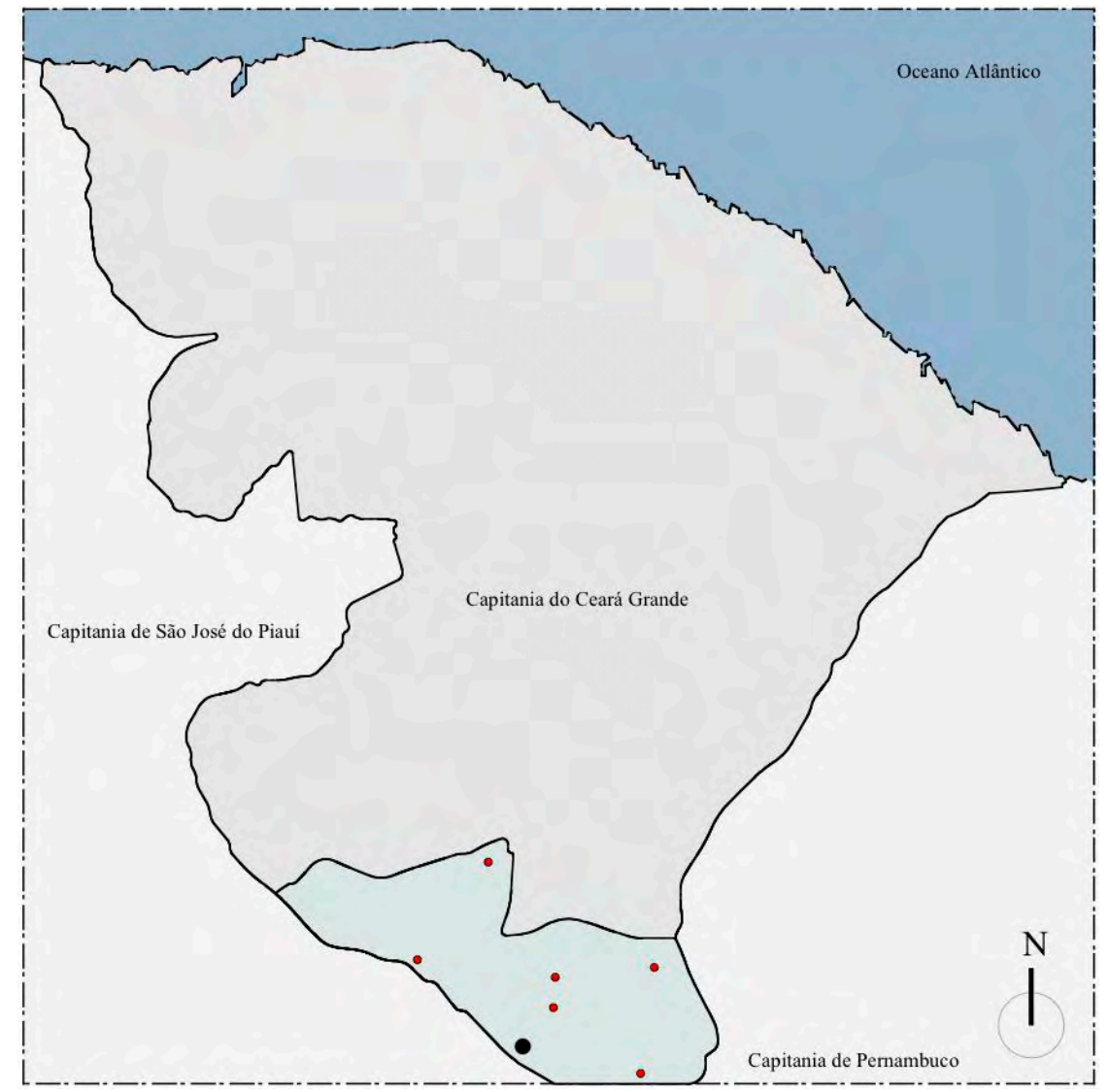

LEGENDA:

Termo da vila Real do Crato

Vila do Crato

Povoações (aldeamentos, arraiais ou freguesias)

Mapa 21 - Termo da vila Real do Crato. Desenho do autor sobre mapa elaborado por NETO,

Clovis Ramiro Jucá. Urbanização do Ceará Setecentista..., Opus cit., p. 262.

${ }^{70}$ FEITOSA, Carlos. As gentes dos Inhamuns na criação da Real..., Opus cit., p. 18 - 19. 
A vila do Crato por ter uma economia essencialmente rural, voltada à pecuária extensiva, à pequenas lavouras de cana - de - açúcar e produção da rapadura em engenhocas, apresentou uma formação urbana demorada. Por isso, em 1774, existiram no núcleo urbano 172 fogos com 412 pessoas de desobriga ${ }^{71}$. No final do período pombalino sua sociedade era uniforme, ou seja, composta basicamente de índios.

Realidade cambiada já em 1783. Segundo o Mappa das Villas e principaes Povoaçoens de Brancos, e Indios... ${ }^{72}$ foram arrolados os aglomerados de toda a capitania do Ceará. Situaram Crato no rol das vilas de brancos. Maria Helena Flexor explica o porquê da retirada dos indígenas do espaço urbano das vilas criadas por Pombal: a fixação nos limites da vila foi um dos problemas mais sério enfrentados pelos ministros encarregados das diligências de fundação da mesma. A deserção, como eram tidas as fugas dos núcleos urbanos, foi constante ${ }^{73}$.

A pouca adaptabilidade dos Cariris ao sistema de viver colonial e a falta de empatia dos diretores ao civilizá-los acelerou a emigração para o seu anterior modo de vida. $\mathrm{O}$ governador João Baptista de Azevedo Coutinho Montoury testemunou essa realidade: $a$ Villa do Crato e a Povoação de Arneiroz, forão erectas na sua primitiva creação para Indios, por inquanto (sic.) eu cheguei nesta Capitania, já achei aquelles fora, e dispersos, e a dita Villa, e Povoação habitados por Brancos ${ }^{74}$. Os brancos poderiam ser vadios e facinorosos, homens violentos reunidos, segundo as ordens reais, para conviver com o Tapuia nos mesmos espaços públicos. Supomos que, devido à diferença cultural, surgiram atritos entre índios e brancos encurralados, causando a deserção dos primeiros da vila.

O ouvidor José da Costa Dias Barros, em sua correição de 1778, notou a pouca regularidade e falta de alinhamento nas moradias e respectivas datas de terra da vila:

Sendo notória e sumam ${ }^{\text {te. }}$ estranhada a deformidade em que se axa esta Villa, e a indiscupavel negligencia dos seos moradores, q' pella mayor parte vivem em casas bárbaras cobertas de palha e outras de telhas; mas todas indignas

\footnotetext{
71 "IDEA da População da Capitania de Pernambuco, e das aus annexas, extensão de suas Costas, Rios, e Povoaçoens notáveis, Agricultura, numero dos Engenhos..., Opus cit., p. 08.

${ }^{72}$ PROJETO RESGATE. AHU_ACL_CU_CEARA, Cx. 9, D. 592.

${ }^{73}$ FLEXOR, Maria Helena Ochi. "Cidades e vilas pombalinas no Brasil do século XVIII". In Universo Urbanístico português, 1415 - 1822. Lisboa, Comissão Nacional para os Descobrimentos Portugueses, 1998. p. 265.

${ }^{74}$ PROJETO RESGATE. AHU_ACL_CU_CEARA, Cx. 9, D. 592.
} 
de abitação de homens, e desviados do devido alinhamento ao mesmo tempo da creação da mesma ${ }^{75}$.

Ao que parece, os executores do termo de demarcação e configuração da vila não seguiram o rigor necessário para estruturar os ideais planejados ao assentamento humano, como observamos em outros exemplares criados nos períodos pombalino e mariano. Buscando melhorar a paisagem edificada do Crato, o ouvidor propõe um Provimento sobre o estabelecimento dos foros das casas da $R^{a l .} V^{a}$ do Crato, e Regulam ${ }^{\text {to. }}$ Dellas dado na Aud ${ }^{a}$. Geral da Corr $^{\text {am. }}$ da mesma Villa ${ }^{76}$, documento discorrido em sete parágrafos. Em função dessas "operações urbanas" podemos visualizar a linearidade como predominante no casco viejo da atual cidade do Crato.

No primeiro parágrafo, os oficiais da câmara foram alertados a edificar suas habitações dentro do alinhamento $q$ ' deixo feito $p^{a}$ os homens brancos (...) para construírem ao menos hum plano de casas de quatro braças de frente, q' são quarenta palmos (...) no ano em q' servirem deixará feita a sua morada de casas perfeitas e acabadas ao menos pella parte da frente $(\ldots)^{77}$. A começar pelos "homens - bons" do município, os demais ficariam motivados a cumprir as exigências instituídas por José da Costa Dias Barros.

Em seguida, no segundo parágrafo, as obrigações são destinadas à população q' tem casas de palha, ou ainda de telhas desformes e indignas ${ }^{78}$. Deveriam reconstruir suas casas ou as largarão de suas mãos a $q^{m .}$ quiser reedificar com as condições abaixo estabelecidas ${ }^{79}$. Interessante a postura do ouvidor diante da requalificação proposta: mais isto se entenderá daquellas casas $q$ ' se achão citas no alinhamento $q$ ' deixo formado das ruas e da praça ${ }^{80}$. Antes de ser uma concepção abstrata, a traça em desenvolvimento era fruto de um minucioso exame do sítio, e das condições físicas da localidade. Aos detentores de habitações maiores e mais adiantadas serão obrigados a cordalas ou a hir enxer terreno, e formar prospecto das mesmas casas no alinhamento $q$ ' lhe for competente e confrontante ${ }^{81}$. Àqueles que desobedecessem as normas pagariam um ônus, uma pena.

\footnotetext{
${ }^{75}$ PROJETO RESGATE. AHU_ACL_CU_CEARA, Cx. 9, D. 564.

${ }^{76}$ PROJETO RESGATE. AHU_ACL_CU_CEARA, Cx. 9, D. 564.

${ }^{77}$ PROJETO RESGATE. AHU_ACL_CU_CEARA, Cx. 9, D. 564.

${ }^{78}$ PROJETO RESGATE. AHU_ACL_CU_CEARA, Cx. 9, D. 564.

${ }^{79}$ PROJETO RESGATE. AHU_ACL_CU_CEARA, Cx. 9, D. 564.

${ }^{80}$ PROJETO RESGATE. AHU_ACL_CU_CEARA, Cx. 9, D. 564.

${ }^{81}$ PROJETO RESGATE. AHU_ACL_CU_CEARA, Cx. 9, D. 564.
} 
Os materiais de construção seriam tijolo ou adobe cru ligados com barro formado principalmente as paredes com bons paus mestres a pique, rebocadas de cal e caíadas ${ }^{82}$. $\mathrm{O}$ provimento determinou para as fachadas uma altura de 12 palmos $(2,64 \mathrm{~m})$, o vão luz das portas teria 10 palmos de altura por cinco de largura $(2,20$ x 1,10 m). O vão das janelas tería sinco palmos ao alto e coatro e meyo ao largo, mas sempre a altura das janellas goardarão o mesmo nível das alturas das portas ${ }^{83}$. Visitanto a cidade do Crato, em março de 2010, visualizamos em poucos exemplares remanescentes, a distribuição do ritmo das portas e janelas [figura 148] : (01): porta - janela; (02): janela - porta - janela; (03): porta - janela janela; (04): porta - porta - porta; (05): porta - janela - janela - janela; (06): porta - janela janela - porta; (07): janela - janela - porta - janela - janela.
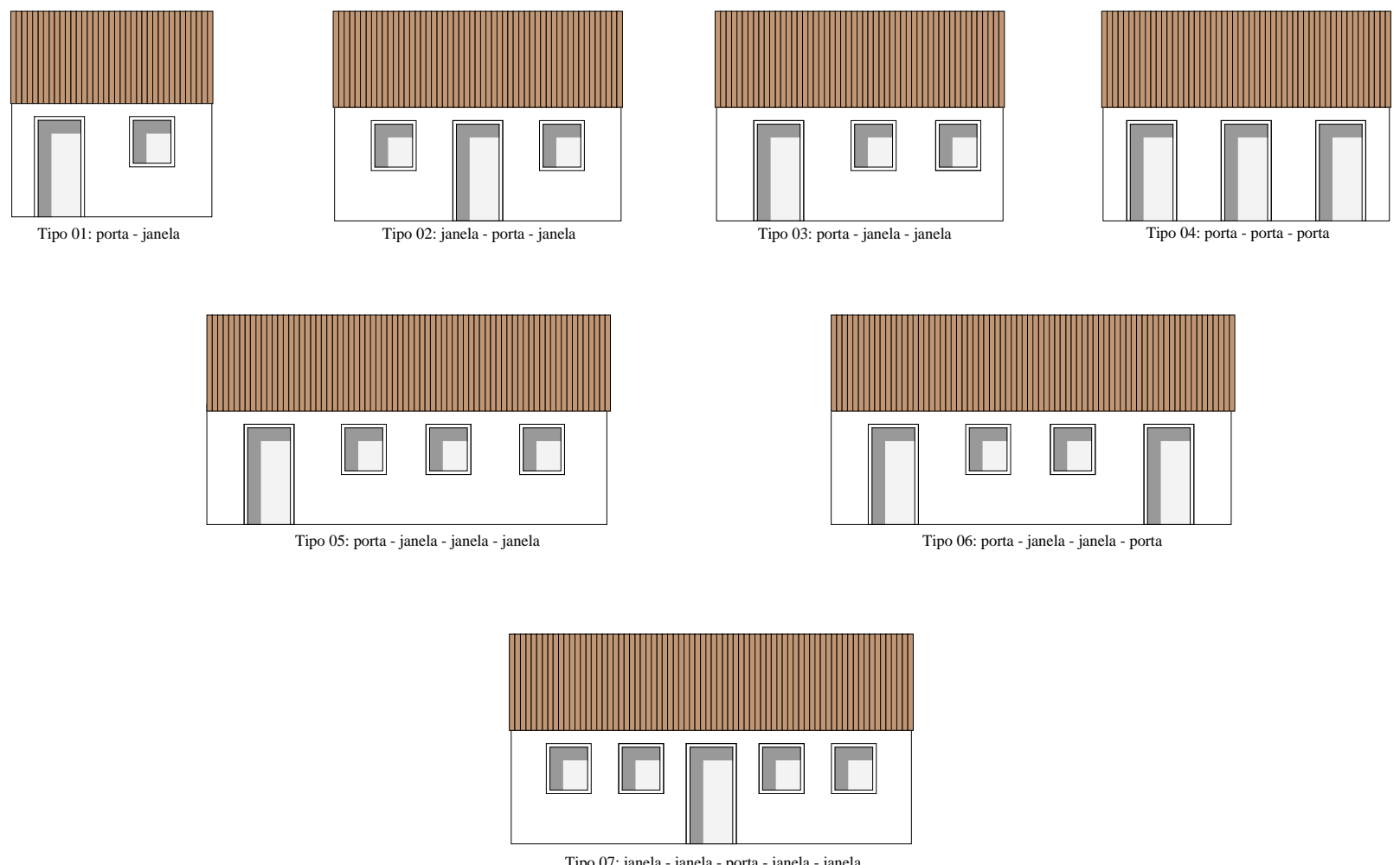

Figura 148 - Ritmo das aberturas das moradias da vila do Crato. Desenho do autor através de observações in situ.

\footnotetext{
${ }^{82}$ PROJETO RESGATE. AHU_ACL_CU_CEARA, Cx. 9, D. 564.

${ }^{83}$ PROJETO RESGATE. AHU_ACL_CU_CEARA, Cx. 9, D. 564.
} 
No tempo da correição do ouvidor José da Costa Dias Barros não havia sobrados no perímetro da aglomeração, exprimindo uma paisagem horizontal. As plantas das residências térreas do sertão nordestino foram sublinhadas por Paulo T. Barreto e outros pesquisadores. Barreto listou quatro tipos de programa para a arquitetura civil piauiense, três destas detectamos no Cariri cearense: porta - janela, meia morada e morada inteira [figura 149].
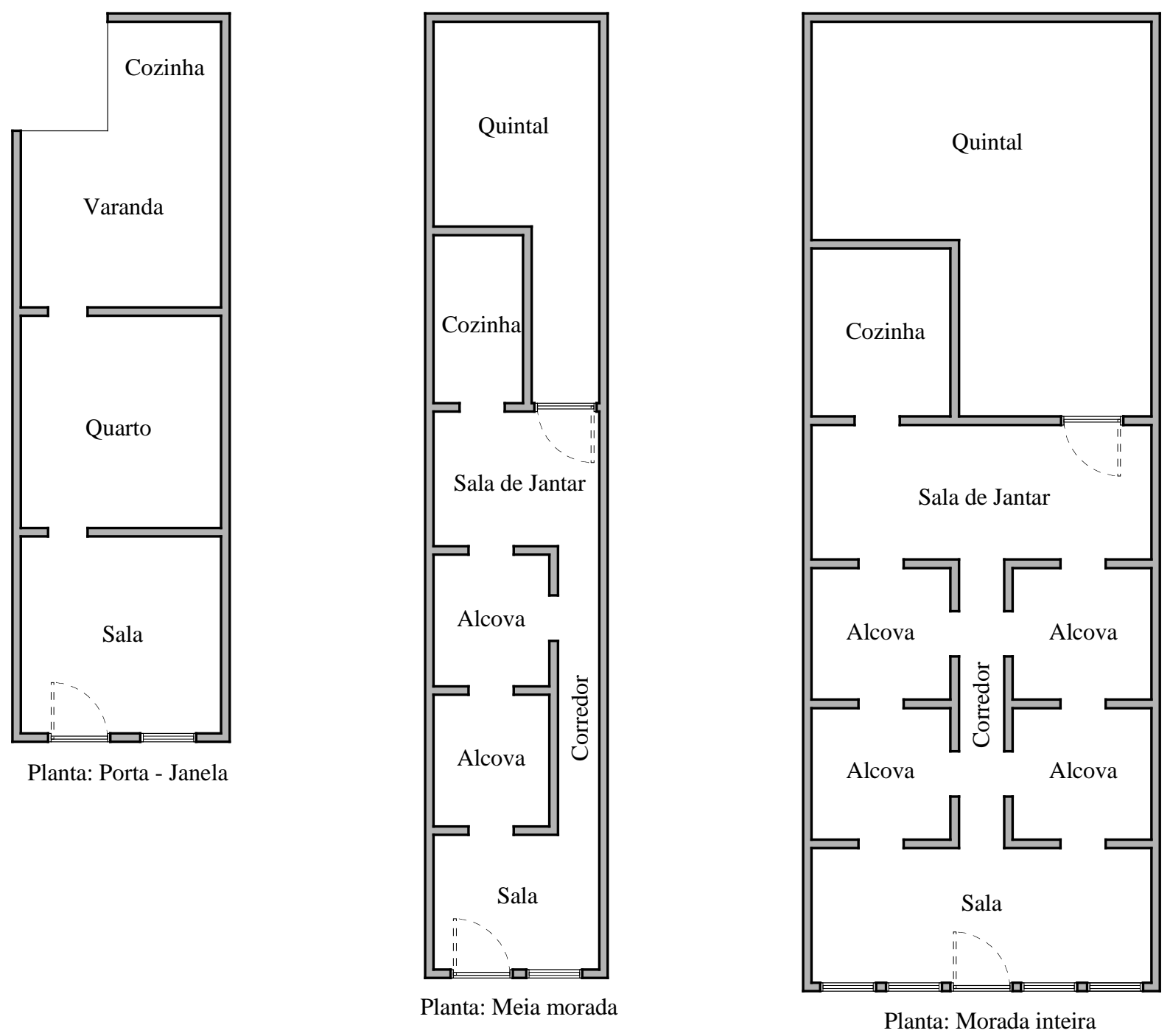

Figura 149 - Tipologias habitacionais da vila do Crato. Desenho do autor sobre informações encontradas em BARRETO, Paulo T. "O Piauí e sua arquitetura”. In Arquitetura Civil I. Vol 2. Rio de Janeiro, MEC, 1938. p. 196; FARIAS FILHO, Waldemar Arraes de. Crato: evolução urbana $e$ arquitetura 1740 - 1960. Fortaleza, Expressão Gráfica, 2007. p. 59 - 60.

O tipo "porta - janela" compreende uma sala, um quarto, uma varanda e uma cozinha. Na "meia morada" há uma pequena sala e alcovas distribuídas ao longo de um corredor localizado em um dos lados da casa, dando acesso à cozinha e ao quintal. Por último, 
a "morada inteira" apresenta uma sala maior, um corredor central donde eram distribuídas, simetricamente, as alcovas. Em seguida há uma sala de jantar, cozinha e quintal ${ }^{84}$.

As edificações erguidas na praça da matriz nos sentidos norte e sul, donde geralmente vem os xuveiros, poderiam construir em sua fachada um alpendre. Isoladas nesses sentidos, a intenção do ouvidor se centrou na harmonia do cenário formado pelo casario circundante ao átrio do templo católico. Analisando velhas fotografias do Crato, tomadas na década de trinta do século passado, cremos que não existiram este tipo de moradia tanto no centro do núcleo como em seus arredores.

No quarto parágrafo o ouvidor informou $q$ ' todas as casas $q$ ' se axão feitas nesta $V^{a}$ e seus arebaldes pagarão o foro estipulado em 80 rs. por braça de dez palmos da fachada projetada $^{85}$. Na parte oriental da praça, lado da igreja, os brancos não poderiam edificar suas casas, por ser o bairro destinado p a morada dos moradores Indios, os quaes não poderá edificar em outra parte ${ }^{86}$. Simbolicamente, os nativos continuariam à sombra da cruz. A separação do Tapuia no aglomerado principia um zoneamento por função, classe e etnia [figura 150]. Por fim, Dias Barros para fortalecer os editos da correição, ordenou que fossem expostos em público suas resoluções porq' os sobreditos officiaes da camara morão fora da mesma e costuma dilatar as vereaçoens $(. . .)^{87}$.

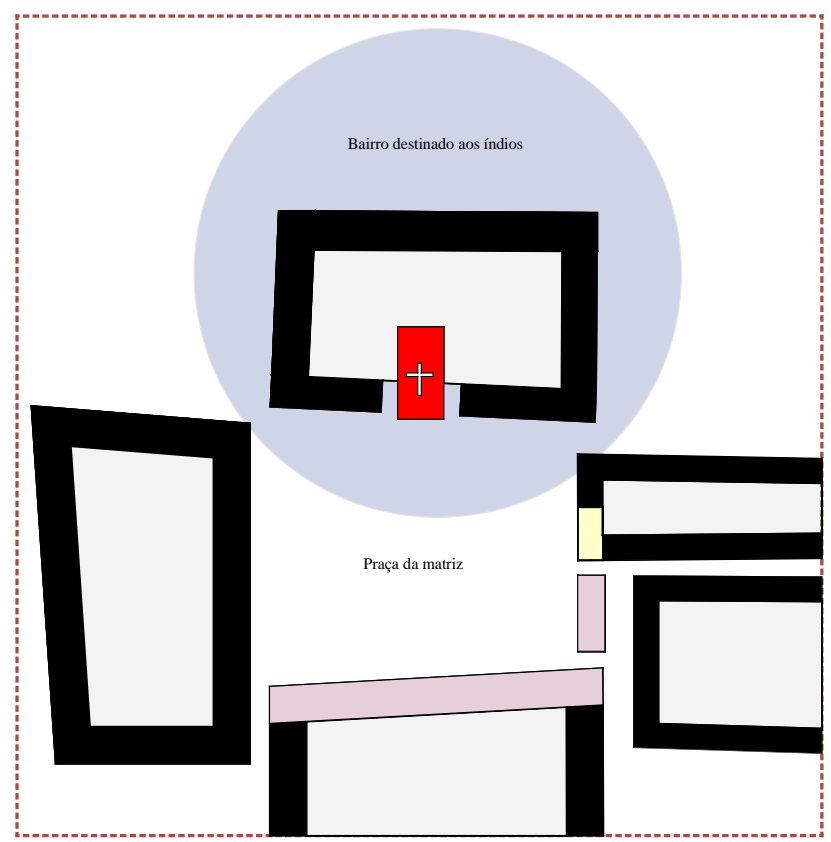

\section{LEGENDA:}

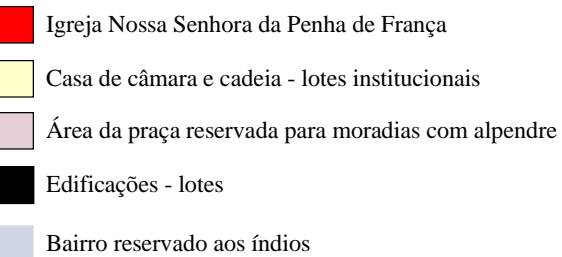

Figura 150 - Zoneamento da vila do Crato proposto pelo ouvidor José da Costa Dias Barros, em 1778. Planta elaborada pelo autor segundo cartografia fornecida pela prefeitura da cidade do Crato e resoluções da correição do ouvidor.

\footnotetext{
${ }^{84}$ BARRETO, Paulo T. “O Piauí e sua arquitetura”. In Arquitetura Civil I. Vol 2. Rio de Janeiro, MEC, 1938. p. $201-215$.

${ }^{85}$ PROJETO RESGATE. AHU_ACL_CU_CEARA, Cx. 9, D. 564.

${ }^{86}$ PROJETO RESGATE. AHU_ACL_CU_CEARA, Cx. 9, D. 564.

${ }^{87}$ PROJETO RESGATE. AHU_ACL_CU_CEARA, Cx. 9, D. 564.
} 


\subsection{1 - A urbanização da vila do Crato nos Oitocentos}

As reformas urbanas ocorridas na vila do Crato, na década de setenta do século XVIII, revestiu sua paisagem da linearidade idealizada pelas autoridades coloniais. $\mathrm{O}$ aglomerado cresceu em um sentido: alongando-se em ruas paralelas acampanhando o nordeste geográfico. Segundo nos conta José Figueiredo Filho ${ }^{88}$, Crato no início do século XIX era um pequeno povoado. Ao seu centro o quadrado da matriz, tendo a igreja como edifício principal. Tal local era chamado de Praça dos Índios que depois passou a se chamar Praça da Matriz ${ }^{89}$. A casa de câmara e cadeia estava na esquina da rua do Fogo. As edificações, nesta época, iam até a praça Siqueira Campos, cujos logradouros eram: Laranjeiras, Grande, do Fogo e Missao Velha [figura 151]. Thomaz Pompeu cifrou a população cratense para os anos iniciais dos Oitocentos em 11.735 habitantes ${ }^{90}$, terceira em número logo abaixo da vilas vilas Icó (17.698 hab.) e Sobral (14.629 hab.) ${ }^{91}$.

Em sua descrição da capitania do Ceará, Antônio Jozé da Silva Paulet mencionou a existência de muitas engenhocas de rapadura no termo da vila ${ }^{92}$ [figura 152]. O solo fértil e o intercâmbio comercial entre variados pontos do Nordeste propiciaram o desenvolvimento dessa economia no Cariri cearense. Uma perfeita simbiose surgiu entre a vila do Icó criadora de gado - e a vila do Crato - fornecedora de melaço, aguardente e rapadura. Como disse Carlos Feitosa, o consórcio entre estas duas regiões satisfez as suas necessidades mercantis e sociais ${ }^{93}$.

A estiagem que assolou o sertão nordestino, conhecida como seca dos três setes $(1777,1778,1779)$, provocou um intenso êxodo. Os sertanejos procuravam lugar adequado para sua sobrevivência. Muitos seguiram o norte, buscando a praia e seu conforto ambiental, outros rumaram para o sul, para o sopé da chapada do Araripe. A vila do Crato os acolheu dilatando sua população. Assim esclareceu Luiz Borba Alardo Menezes: as preciosas nascentes de água a fazem muito procurada dos povos nas occasiões da secca, motivo porque vai sendo muito povoada e commerciante ${ }^{94}$. Em 1813, os historiadores somaram 32.822

\footnotetext{
${ }^{88}$ FIGUEIREDO FILHO, José. História do Cariri. Vol. III/IV. Crato, FFCrato, 1968. p. 17.

${ }^{89}$ FIGUEIREDO FILHO, José. História do Cariri..., Opus cit., p. 17.

${ }^{90}$ Dado referente à população do termo da vila.

${ }^{91}$ POMPEU, Thomaz. "A população do Ceará”. in Revista do Instituto do Ceará. Ano III. Fortaleza, 1889. p. 81.

92 PAULET, Antônio Jozé da Silva. "Descripção Geografica Abreviada da Capitania do Ceará"..., Opus cit., p. 25.

${ }^{93}$ FEITOSA, Carlos. As gentes dos Inhamuns na criação da Real..., Opus cit., p. 12.

${ }^{94}$ MENEZES, Luiz Barba Alardo de. "Memória sobre a capitania do Ceará". in Revista do Instituto Histórico e Geographico e Etnographico do Brasil. Tomo XXXIV. Rio de Janeiro, B.L.Garnier, 1871. p. 268.
} 
habitantes para o território municipal da vila, superando Icó (18.216 hab.) e Sobral (15.218 hab.) $)^{95}$.

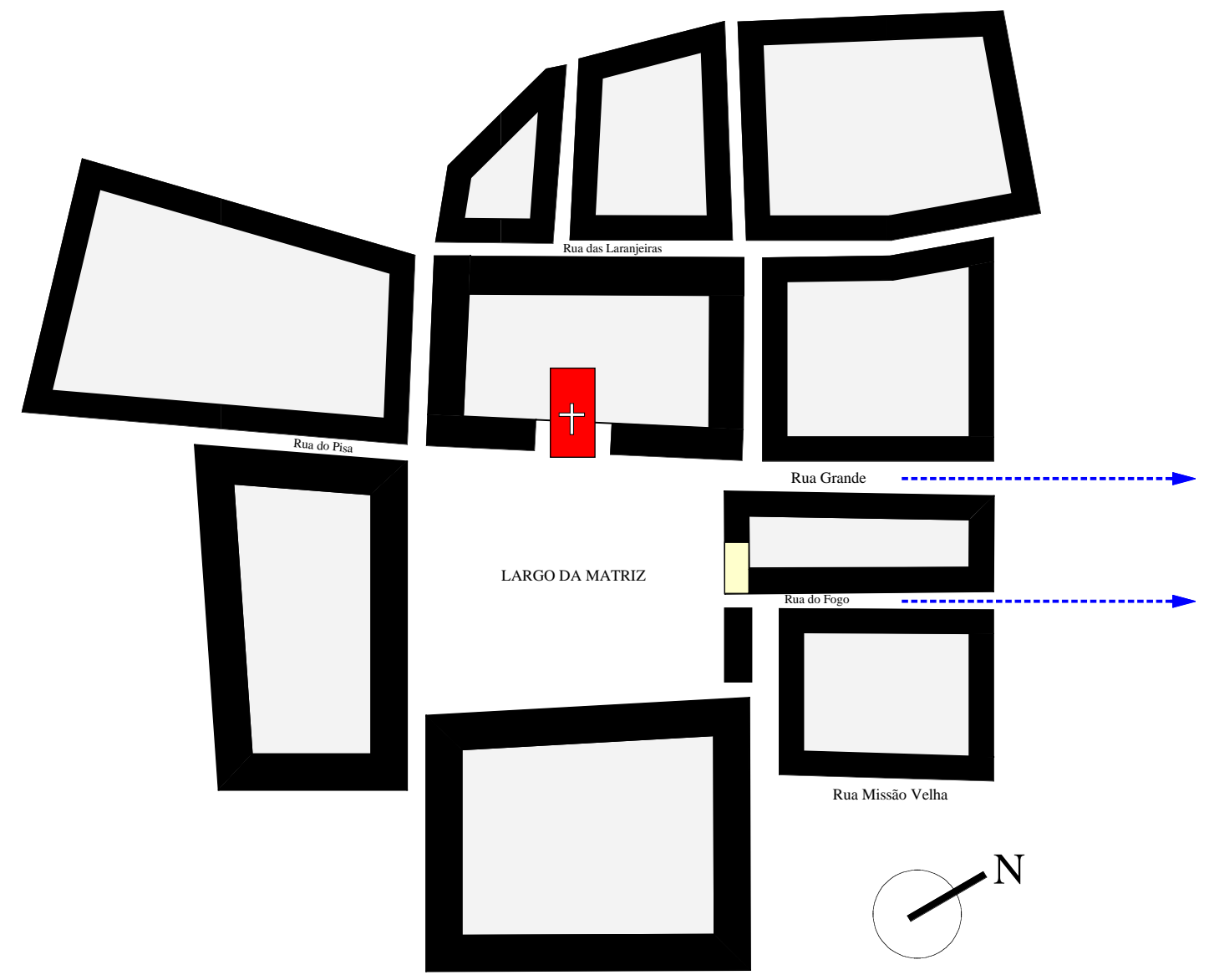

VILA DO CRATO, 1817

LEGENDA:

$\square$ Igreja Nossa Senhora da Penha de França

$\square$ Casa de câmara e cadeia

Edificaçōes - lotes

Riacho Granjeiro
Figura 151 - Vila do Crato, 1817. Desenho do autor sobre informações de FIGUEIREDO FILHO (1968). Base cartográfica fornecida pela prefeitura da cidade do Crato.

\footnotetext{
${ }^{95}$ POMPEU, Thomaz. “A população do Ceará”..., Opus cit., p. 82.
} 


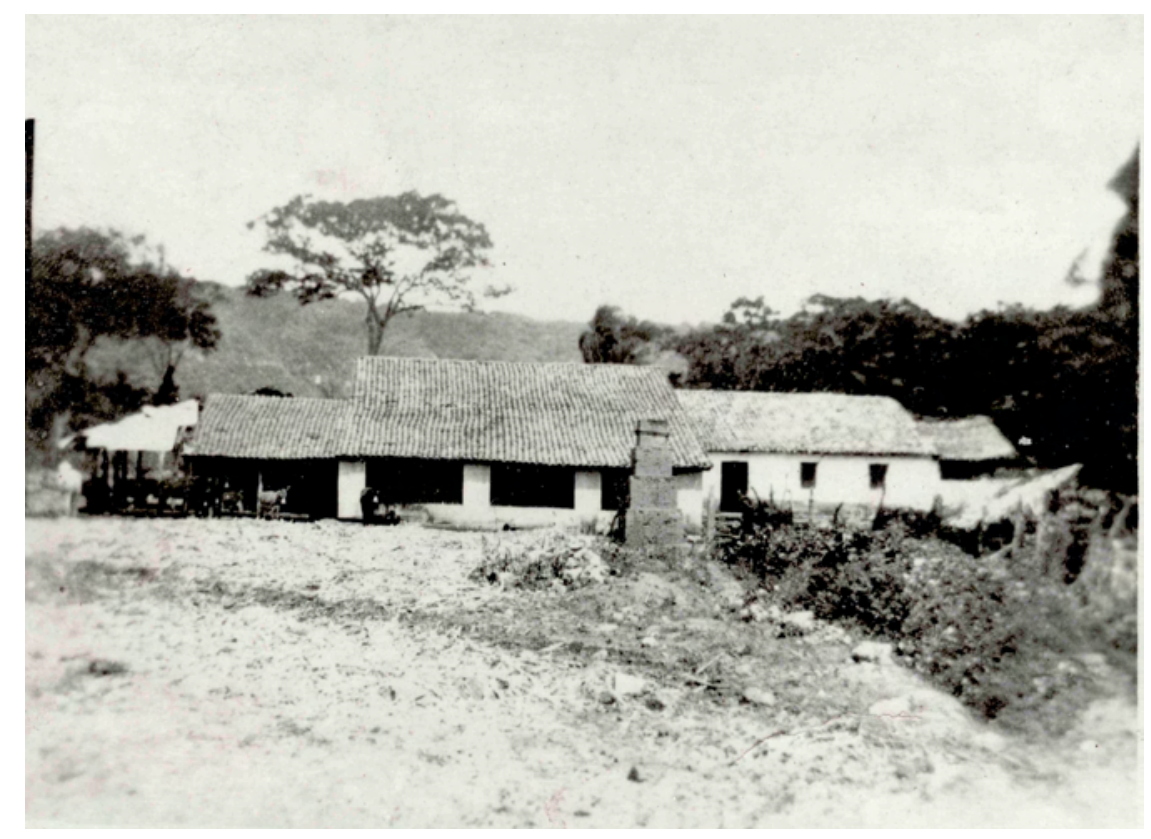

Figura 152 - Engenho de rapadura. Foto tomada por volta da década de trinta do século passado e cedida pelo Arquivo Histórico da Diocese do Crato.

O movimento revolucionário em prol da república, principiado em Recife, no ano de 1817, repercutiu no núcleo urbano do Crato. Alguns dos moradores revoltaram-se contra o Reino, como informou a ata da câmara do Crato datada de 19 de maio de 1817:

Sendo infelizmente sublevada esta vila no dia 3 de Maio pelos Tyrannos padre José Martiniano, Tristão Gonçalves, Fr. Francisco de Sant'Anna Pessoa, e Ignácio Tavares Gondim, recommendado pelo insultante governo provisório de Pernambuco, opprimindo os mesmos tyrannos as reaes intenções dos fieis vassallos d'esta villa e termo, querendo fossem aterradas as sagradas leis do nosso muito alto e poderoso rei o Sr. D. João VI (...) e que alem de toda a cautella e providencia este senado e mais chefes offereceram ao Exm. Sr. governador d'esta capitania para espontaneamente atacarem as villas que se achassem ainda em revolução, e fazerem observar as leis sagradas e tão recommendadas $(. . .)^{96}$ 96 "ACTAS da Camara do Crato de 11 de maio de 1817, até 27 de janeiro de 1823”. In Revista do Instituto
Histórico e Geográfico Brasileiro. Tomo XXV. Rio de Janeiro, IHGB, 1862. p. 44. 
Após os ataques dos insurretos, a paisagem urbana da vila era de completa desolação. Em carta ao Dr. Pedro Théberge, João Brígido relatou o aspecto físico do município:

Não ficou no Crato, sinão uma casa, cujas portas não foram derribadas. Tudo mais foi esbandalhado, a matriz ficou limpa de jóias e alfaias; as toalhas, as vestes sacerdotais, tudo foi roubado. As famílias fugião espavoridas e ninguém ousou voltar à villa. ${ }^{97}$

Na visita de George Gardner à, por volta de 1838, o fraco desenvolvimento, pós revolução, fora testemunhado, tendo os seus espaços descritos:

É uma cidade pequena e suficiente mísera com um terço de Icó em tamanho. Suas casas, muito irregularmente construídas, são todas térreas, como uma só exceção. Tem uma cadeia e duas igrejas, mas a primeira destas, inacabada, já tem aparência de ruína, pelo tempo em que a deixaram assim. A cadeia, também, está de mal modo arruinada, que mal lhe cae o nome de prisão, embora encerre sempre uns poucos criminosos. (...) Toda a população da Vila chega a dois mil habitantes, na maioria todos índios ou mestiços que deles descendem. Os habitantes mais notáveis são brasileiros, em maioria negociantes; ${ }^{98}$

Segundo o naturalista inglês, a horizontalidade da localidade é um forte traço, porque não há, em todo o núcleo, um único sobrado. No entanto, construíram na praça da igreja uma edificação que gravita entre o sobrado e a habitação térrea, a morada de porão alto [figura 153]. Nestor Goulart Reis Filho caracteriza este tipo de habitação:

Longe do comércio, nos bairros de caráter residencial, a nova fórmula de implantação permitiria aproximar as residências da rua, sem os defeitos das térreas, graças aos porões mais ou menos elevador, cuja presença era muitas vezes denunciada pela existência de óculos ou seteiras com gradia de ferro, sob as janelas dos salões. Nesse caso para solucionar o problema do desnível

\footnotetext{
${ }^{97}$ BRIGIDO, João. "Carta ao Dr. P. Theberge”. In Revista do Instituto do Ceará. Ano II. Fortaleza, 1888. p. 115.

${ }^{98}$ GARDNER, George. Viagem ao interior do Brasil. São Paulo, Edusp, 1975. p. 93.
} 
entre o piso a a habitação e o plano do passeio, surgia uma pequena escada, em seguida a porta de entrada. ${ }^{99}$

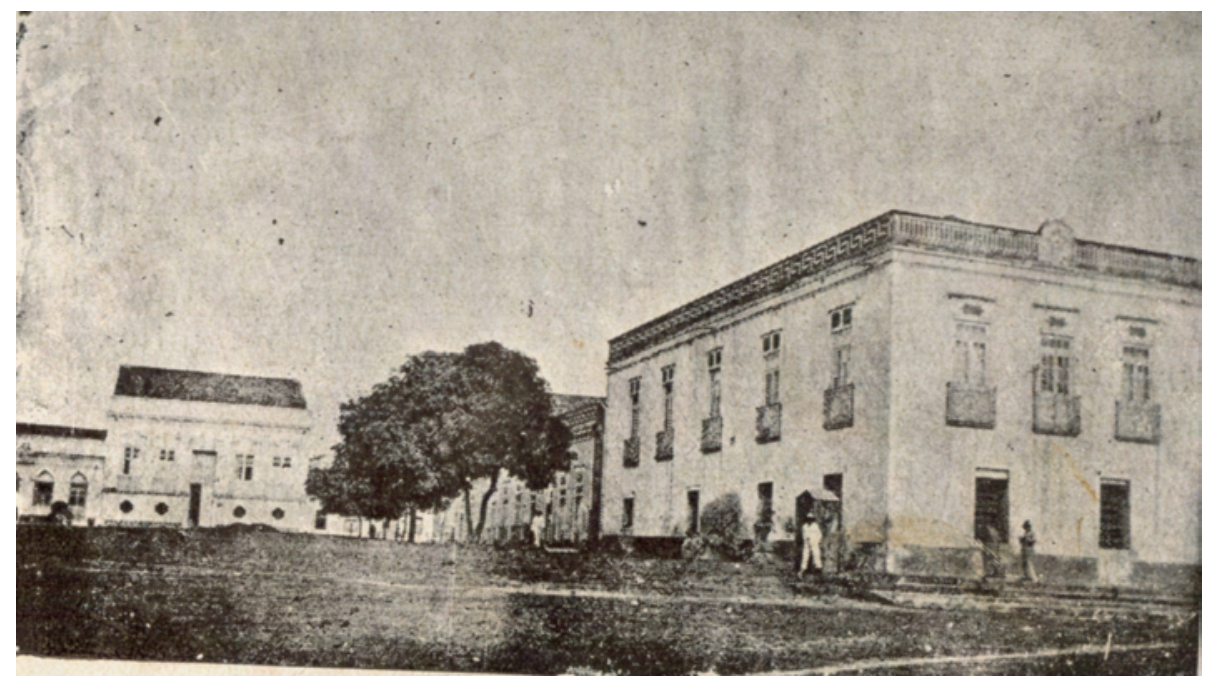

Figura 153 - Casa com porão alto situada na praça da matriz (lado esquerdo, ao fundo). No primeiro plano, lado direito da imagem, a casa de câmara e cadeia. Foto cedida pelo Arquivo Histórico da Diocese do Crato.

Crato cresceu e, em 1850, abrigou duas praças - matriz e Siqueira Campos -, com ruas distribuídas linearmente em alguns pontos e em outros com pequenas inclinações. Cercada com 550 casas de telha e 600 de palha, totalizando 1150 moradas [figura 154]. Na metade dos Oiticentos, passando pelo interior do Ceará, o viajante Filippe Alberto Patroni relatou sobre o progresso econômico e urbano da vila:

A Villa do Crato é populosa, não pequena; mas longe de prometter augmento, ao contrário annuncia decadência e ruína; e os culpados d'isto são os governantes da província que até agora não tem cuidado de mandar abrir uma boa estrada de Icó para o Crato e Jardim, para se facilitarem os transportes e conducções, e prosperar por esse meio o commercio daquellas villas, prosperando também a agricultura, a qual nunca poderá levantar-se do estado baixo, em que se acha, sem primeiro haver ahi um commercio considerável, cujos fundos de importação se empreguem no assucar, que se tenha de fabricar em ambas aquellas villas para ser exportado e bem vendido no Icó, Aracati e Fortaleza. ${ }^{100}$

\footnotetext{
${ }^{99}$ REIS FILHO, Nestor Goulart. Quadro da arquitetura no Brasil. 2 ed. São Paulo, Editora Perspectiva, 1973. P. 40.

${ }^{100}$ PARENTE, Fillipe Alberto Patroni Martins Maciel. As viagens de Patroni pelas províncias brasileiras: de Ceará, Rio de S. Francisco, e Rio de Janeiro: nos anos de 1829, e 1830. 2 ed. Lisboa, 1851. p. 57.
} 


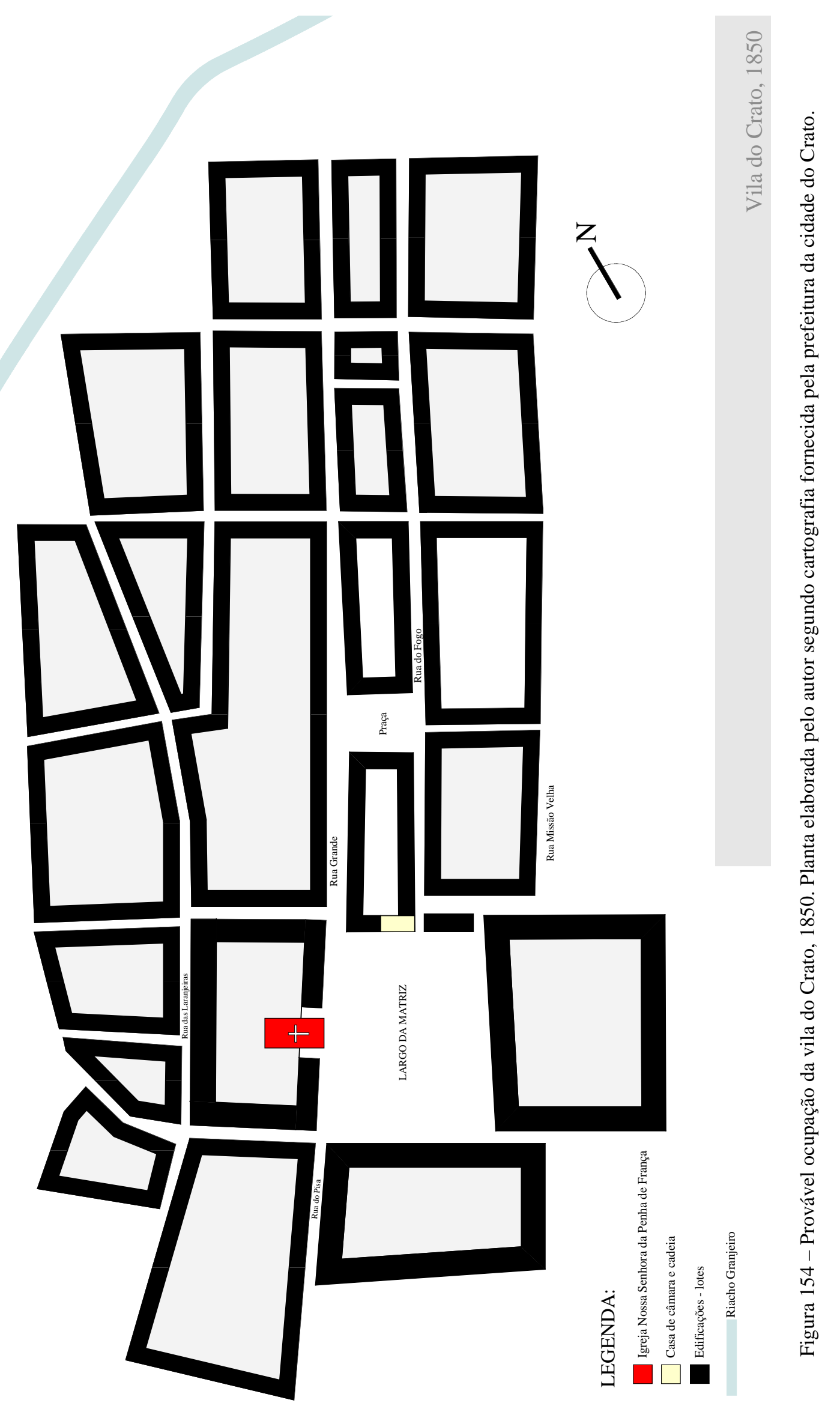


No ano de 1853 a vila recebeu o foro de cidade. Freire alemão, durante sua inspeção chamada Comissão das Borboletas, verificou os espaços intraurbanos:

Tem a cidade algumas ruas paralelas e direitas, e largas que são a Rua Grande, a Rua do Fogo, a Rua da Vala, a Rua da Boa Vista, a Rua das Laranjeiras, etc. etc., mas algumas travessas e becos. A praça da Matriz é um grande quadrilátero; algumas ruas são compridas e mal povoadas. Logo na Rua da Vala, e das Laranjeiras, assim como nos extremos das outras, as casas são ou todas ou em geral parte de palha. O geral das casas é de tijolo; são térreas, baixas, ladrilhadas e de telha - vã, vidraças (...) Há vários sobrados principiados (...) as palhoças se espalham pelos montes, em roda da cidade. ${ }^{101}$

A estática horizontalidade da paisagem colonial da vila se revestiu com os primeiros sobrados, mesmo que parcamente. Podemos enxergar o panorama descrito pelo botânico através da aquarela do pintor José dos Reis Carvalho [figura 155], integrante da Comissão das Borboletas. Longe do espectador, contorna-se a igreja matriz, ainda com uma torre companária, seguidas por casas térreas e uma com porão alto. Distribuída no chão horozontalmente, a cidade rompe sua pequena escala, dinamizando a paisagem no lado oposto ao templo, ali estão os sobrados do lugar. No primeiro plano, os casebres ou choças de taipa cobertas com palha, afastadas do núcleo corporizam a segregação por classe.

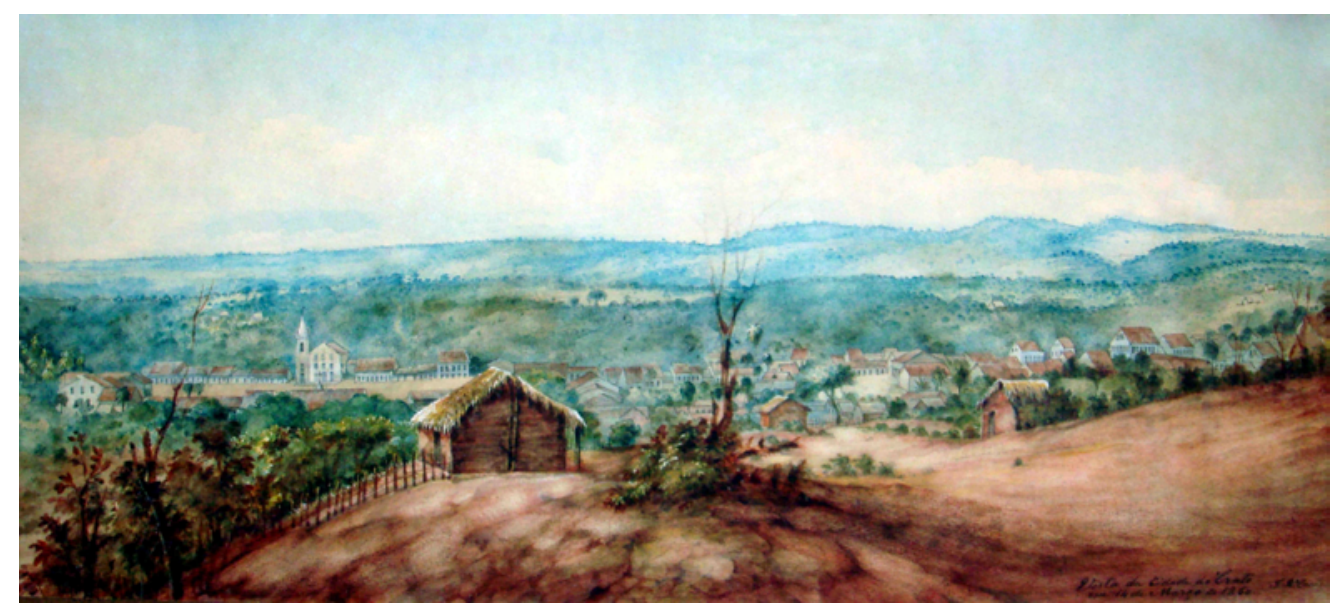

Figura 155 - Vista da cidade do Crato. Aquarela de José dos Reis Carvalho. Original: acervo do Museu de Arte Vicente Leite.

101 “OS MANUSCRITOS do botânico Freire Alemão: catálogo e transcrição”. in Anais da Biblioteca Nacional. Vol. 81. Ano 1961. Rio de Janeiro, Divisão de Publicações e Divulgação, 1964. p. 300 - 301. 
A qualidade dos espaços públicos do Crato, os resquícios das recomendações do ouvidor José da Costa Dias Barros, o alinhamento das ruas, o quadrilátero da praça pombalina, o uso, a hierarquia dos espaços e das contruções e o zoneamento por classe são vistos em velhas fotografias. Por isso, para atestar as considerações discorridas neste tópico, elencamos algumas fotos tiradas no início do século passado. Para Pierre Francastel o uso de imagem, aqui podemos cituar as fotografias, é o meio também de se julgar o passado com olhos novos e pedir-lhe esclarecimentos condizentes com nossas preocupações presentes, refazendo uma vez mais a história à nossa medida, como é direito e dever de cada geração 102. A foto contribuiu, portanto, para outra visibilidade, sensível e abdutiva, de se pensar con los ojos. ${ }^{103}$

\section{- $\quad$ Praça e igreja matriz}

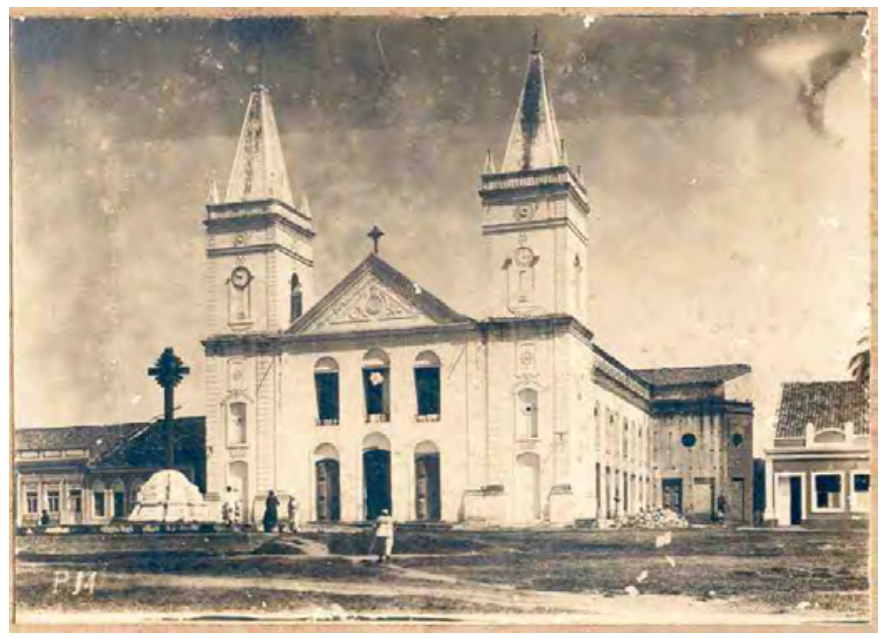

Figura 156 - Igreja matriz de Nossa Senhora da Penha de França. Foto cedida pelo AHDC - CE.

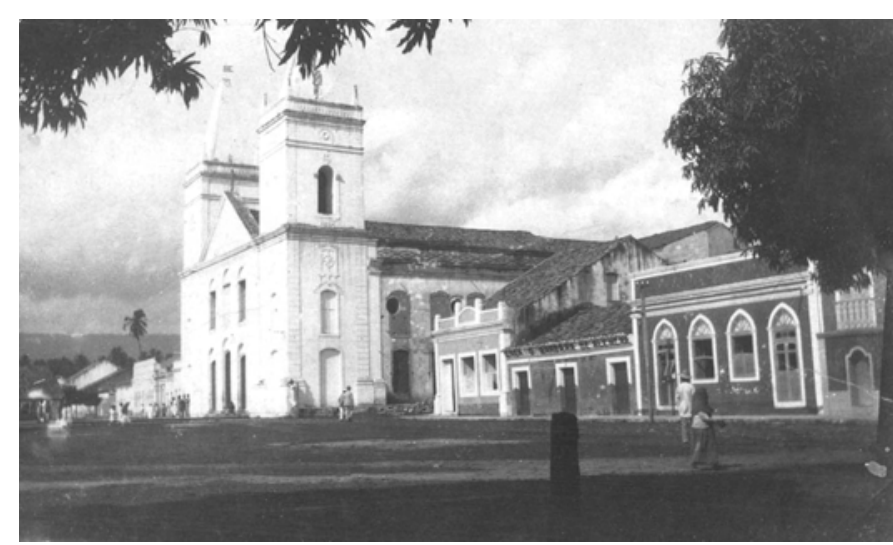

Figura 157 - Igreja, praça e casas alinhadas. Foto cedida pelo AHDC - CE.

\footnotetext{
${ }^{102}$ FRANCASTEL, Pierre. A realidade figurativa. 2 ed. São Paulo, Perspectiva, 1972. 444 p.

${ }^{103}$ BAYÓN, Damián. Pensar con los ojos: Ensaios de arte latinoamericano. 2 ed. México, Fondo de Cultura Econômica, 1993. 400 p.
} 
- Casa de câmara e cadeia

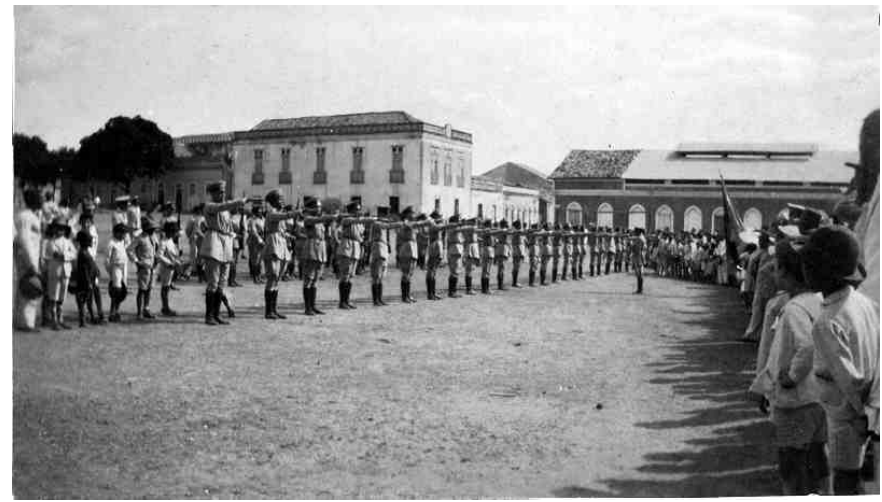

- Rua das Laranjeiras

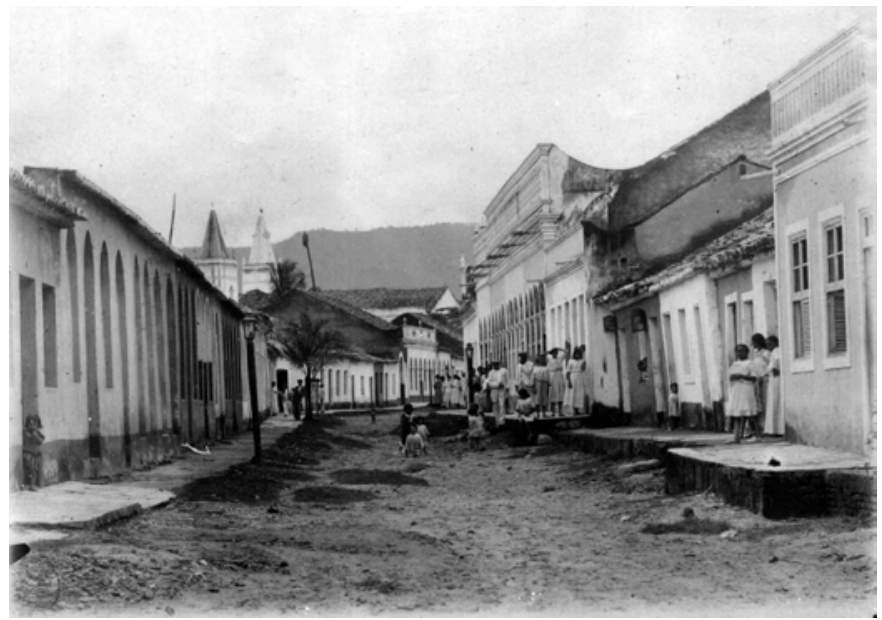

Figura 158 - Casa de câmara e cadeia do Crato, ao fundo lado esquerdo. Foto cedida pelo AHDC - CE.
Figura 159 - Rua das Laranjeiras. Foto cedida pelo AHDC - CE.
- Rua Grande

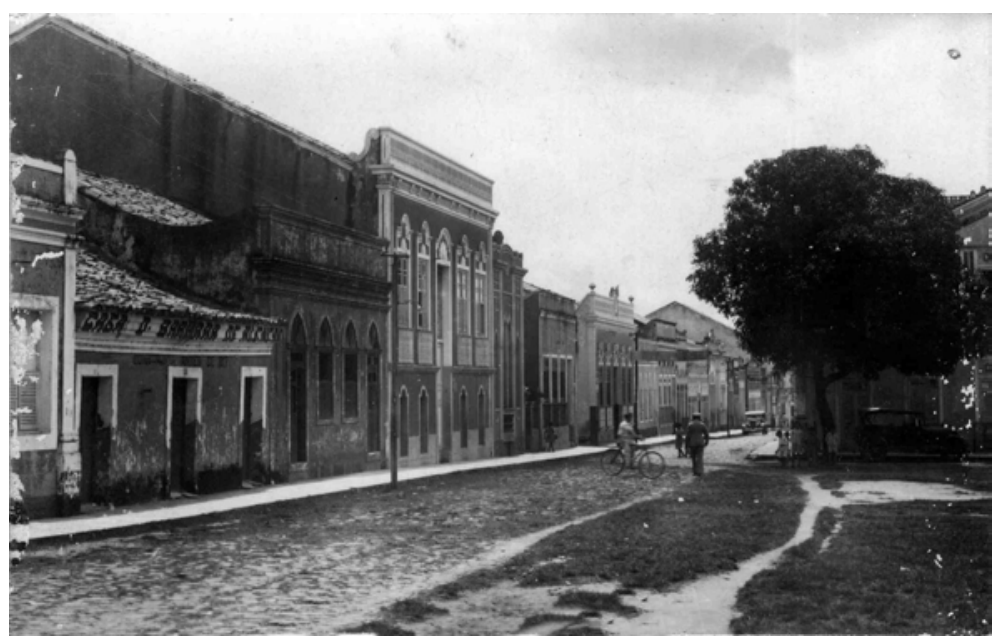

Figura 160 - Rua Grande, partindo da praça da matriz. Foto cedida pelo AHDC - CE. 


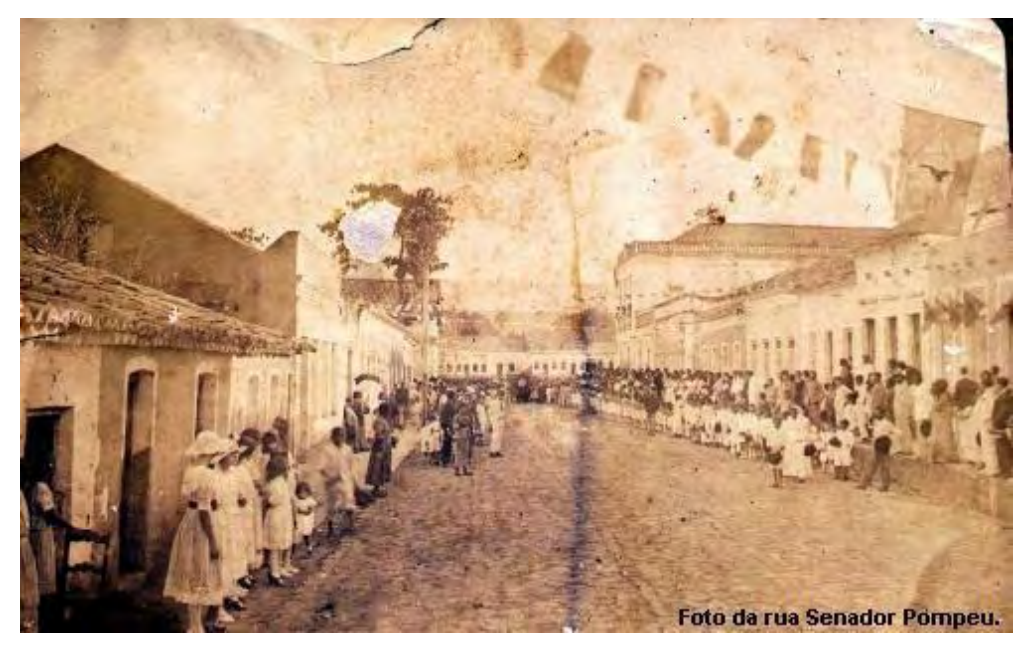

- Rua Formosa

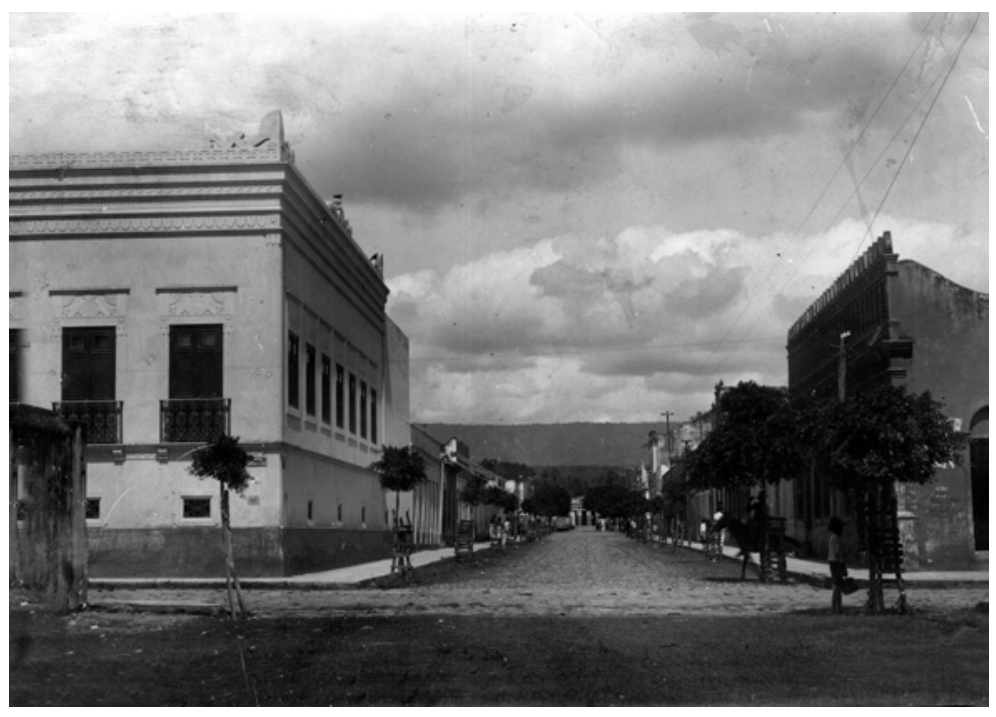

- O lugar dos pobres

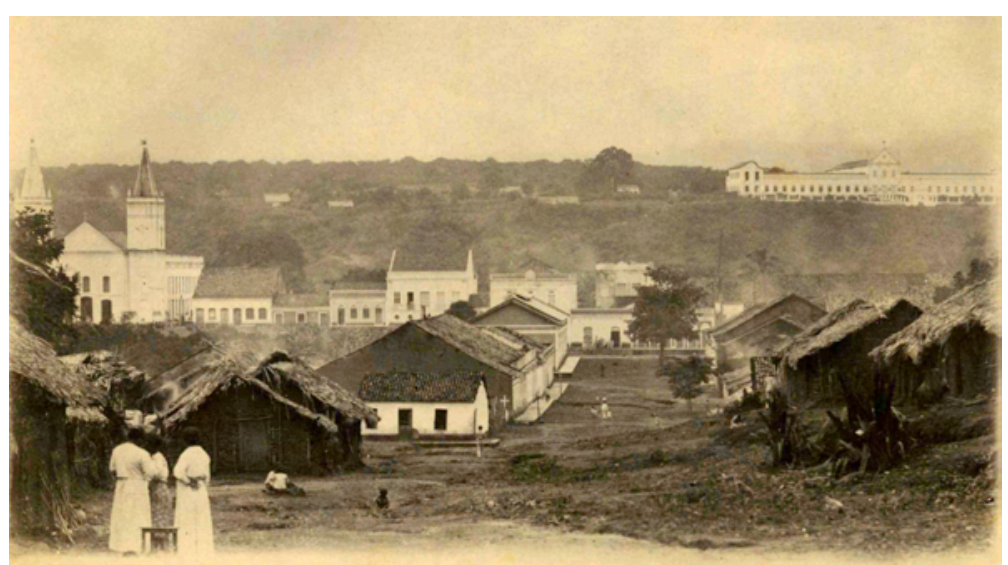

Figura 161 - Rua do Fogo, ao fundo, lado direto, casa de câmara e cadeia. Foto cedida pelo AHDC - CE.

Figura 162 - Rua Formosa. Foto cedida pelo AHDC - CE.

Figura 163 - Rua da Liberdade, à direira igreja matriz e seu adro. Foto cedida pelo AHDC - CE. 


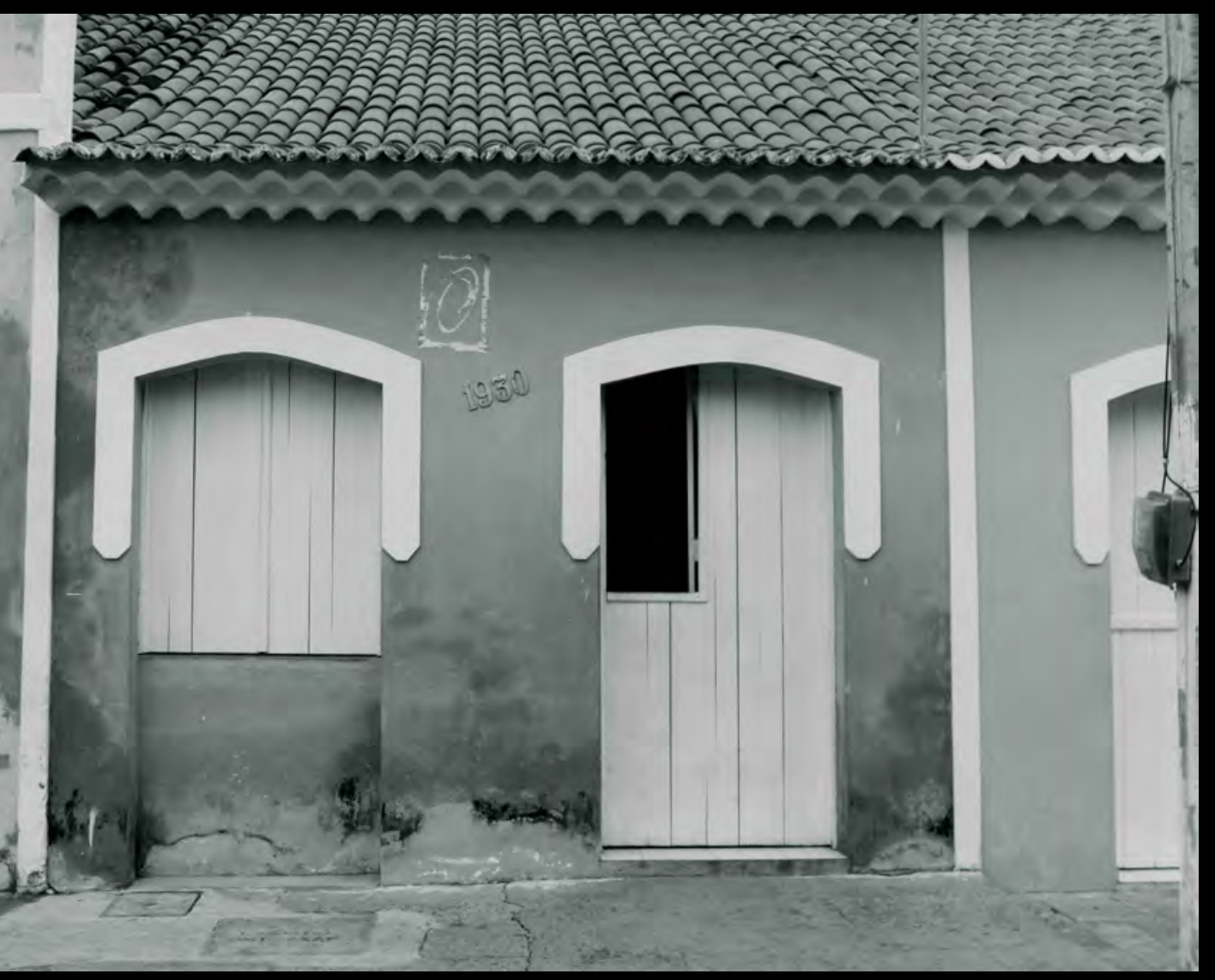

\section{CONSIDERAÇÕES FINAIS}




\section{CONSIDERAÇÕES FINAIS}

"Ora os filhos de Rubem e os filhos de Gade haviam chegado a ter muito gado, de fato, muitíssimo. E eles começaram a ver a terra de Jazer e a terra de Gileade, e eis que o lugar era lugar para gado.” [sem grifo no original]

Trecho do livro bíblico de Números 32:1

"Como os encontrei mais animais do que homens na sua maneira de viver, apliquei-me, primeiramente, a formar pouco a pouco uma vida racional e civil (...) Introduzi entre eles alguns elementos de governo, criando oficiais para a Igreja e para o civil, que eu autorizava da melhor maneira que fosse possível e que eu prendia a mim por meio de pequenos presentes e pelo respeito à obediência que eu exigia, a fim de que me apoiassem no que fosse necessário."

Frei Martinho de Nantes, em sua primeira relação. 
Capistrano de Abreu, em Capítulos de história colonial ${ }^{1}$, primeira edição de 1907, teceu reflexões sobre o povoamento do interior do Nordeste açucareiro. Em detrimento dos primeiros colonizadores "arranharem" a praia como caranguejos, a solução encontrada para a posse do sertão nordestino, segundo Abreu, foi o gado vacum, pois dispensava a proximidade da praia, adaptava-se às regiões áridas e pedia pouca gente para o manejo das técnicas de criação $^{2}$. Além do mais, a arremetida dos animais para o interior foi determinada pela necessidade de sustentar o litoral, como outras regiões da colônia, com carne e couro. ${ }^{3}$

A expansão da pecuária nordestina ocorreu paulatinamente para o sertão. Os animais rumavam para o interior seguindo as margens dos principais cursos fluviais, eixo condutor de penetração e conquista do território da caatinga. Afastando-se desses rios, criaram caminhos feitos tanto de enchada, como foice e machado ${ }^{4}$, irrigando aqui, ali e além, desmistificando o desconhecido e dilatado. A pecuária e as rotas desenvolvidas pelo gado favoreceram a embrionária urbanização do sertão nordestino.

Urbanização esta fortalecida por cartas régias e outros documentos oficiais em forma de lei. Uma das provisões do rei D. Pedro II, no final do século XVII, autorizou a exploração de uma estrada para se conhecer a calidade, e préstimo das terras, e como podem ser de utilidade para a Fazenda de Sua Magestade e dos mais de hum, e outro Estado ${ }^{5}$. Essa rota uniu os portos de São Luiz e Salvador, cuja comunicação por mar esteve impedida pela existência de barreiras marítimas naturais, era mais fácil ir de São Luiz ao Reino do que de Salvador à urbe do Maranhão. O monarca citado emitiu uma carta régia, em 1701, estabelecendo a criação de gado em no mínimo dez léguas para o interior. O motivo: o boi criado com a lavoura de cana-de-açúcar passou a destruir as plantações ${ }^{6}$.

A posse da terra para a criação de gado ascendia, principalmente por potentados que atuaram em conjunto, associados: Casa da Torre, Casa da Ponte, família Rocha Pita e Domingos Afonso Mafrense foram alguns dos sesmeiros detentores de grandes latifúndios no sertão. Os Rochas Pitas eram senhores de fazendas de gado localizadas no sertão da capitania

\footnotetext{
${ }^{1}$ ABREU, Capistrano de. Capítulos de história colonial, 1500 - 1800. 7 ed. rev. São Paulo, Publifolha, 2000. $278 \mathrm{p}$.

${ }^{2}$ ABREU, Capistrano de. Capítulos de história colonial, 1500 - 1800...Opus cit., p. 151.

3 ANDRADE, Manuel Correia de. O processo de ocupação do espaço regional do Nordeste. 2 ed. Recife, SUDENE, 1979.

${ }^{4}$ SOBRINHO, Barbosa Lima. "Capistrano de Abreu e o povoamento do sertão pernambucano". In Revista do Instituto Arqueológico, Histórico e Geográfico de Pernambuco. Vol 50. Recife, 1978.

${ }^{5}$ PROJETO RESGATE. AHU_ACL_N_MARANHÃO, D.957.

${ }^{6}$ HOLLANDA, Sérgio Buarque de. História da civilização brasileira. vol II. Tomo I. São Paulo, Difusão Européia do Livro, 1960. P. 221.
} 
de Pernambuco: no termo da vila de Flores, comarca do sertão, tinha o acervo inventariado a fazenda Três Irmãos, com casas, currais, quatorze escravos, duzentas cabeças de gado (...) a fazenda das Pedras com casa, cercado, currais, sete escravos, trezentas fazendas de gado (....). ${ }^{7}$ André João Antonil apontou a dimensão das terras, no sertão da Bahia, senhoreadas à Casa da Torre e à família Guedes de Brito:

Sendo o sertão da Bahia tão dilatado, como temos referido, quase todo pertence a duas das principais famílias da mesma cidade, que são a da Torre, e a do defunto mestre de campo Antônio Guedes de Brito. Porque a Casa da Torre tem duzentas e sessenta léguas pelo rio São Francisco, acima à mão direita, indo para o sul, e indo do dito rio para o norte chega a oitenta léguas. E os herdeiros do mestre de campo Antônio Guedes possuem desde o morro dos Chapéus até a nascença do rio das Velhas, cento e sessenta léguas. E nestas terras, parte dos donos delas tem currais próprios, e parte são dos que arrendam o sitio delas. ${ }^{8}$

O resultado de um território dominado por poucos e com muito poderio fundiário, como vimos no segundo capítulo, são focos de povoação distantes muitas léguas uns dos outros. Pior, os fazendeiros sobreditos pouco contribuíram a um dos desígnios básicos dos colonizadores: fundar arraiais para o beneficio da Metrópole. Antes das terras serem suas, pertenciam majoritariamente à jurisdição eclesiástica da Ordem de Cristo ${ }^{9}$. Assim constatou o frei carmelita, Nicolau de São José, em missão ambulante pelo sertão sanfranciscano:

(...) E preguntandolhe eu porq' não fazião Igreja e substentavão Padres q' lhes desse missão responderão me q' Leonor Pereira Marinho (Casa da Torre) hera senhora da mayor parte do sertão e q' não queria q' se fizesse Igrejas, e o mesmo dizia Antonio Guedes de Brito q' he senhor de mais de trezentas legoas emtre o sertão e o Rio de São Francisco e q' não sabião q' rezão ouvesse para q' so achey como tambem Domingos Affonso Sertão se lhes desse todas as terras q' Sua Magestade tem nos seus governos de Pernambuco e Bahia, as quais forão perdidas (...) e se tem senhoreado de mais terras do que aquellas q' derão em Sismarias e q' não havia oje mais terras descubertas e povoadas hera por culpa dos dittos senhores porq' asim

\footnotetext{
${ }^{7}$ PINHO, Wanderley. História de um engenho do Recôncavo, 1552 - 1944. Rio de Janeiro, Livraria Editora, 1946. p. 231.

${ }^{8}$ ANTONIL, André João. Cultura e opulência do Brasil. 3 ed. Belo Horizonte, Itatiaia/Edusp, 1982. (Coleção Reconquista do Brasil). p. 96.

${ }^{9}$ LIMA, Ruy Cirne. Pequena história territorial do Brasil: sesmarias e terras devolutas. Fac - símile da 4 ed. São Paulo, Secretaria do Estado da Cultura, 1990. p. 35.
} 
como alguém descobre alguõ sitio e o quer povoar por lhes ter custado a vida e despendio da sua fazenda em despossar o gentio e aldeallo e pollo no grêmio da Igreja, dizem os dittos senhores das terras q' lhe andem pagar renda ou quando não q' despejem porq' querem meter os seus gados nelle, e desta sorte se tinhão feitos senhores de mais terras do q' aquelles q' se tinhão dado em Sismaria $(. . .)^{10}$

Ao mesmo tempo em que se apropriava da terra, o colono expulsou ou combateu o nativo contrário aos seus objetivos fundiários e econômicos. Esse choque acarretou no saque de fazendas e no abatimento do gado dos currais pelo indígena insurreto. Os monarcas lusos, em observância ao pacto feito com a Santa Sé, conhecido como padroado real, ordenaram que enviassem missionários ao sertão, afim de domesticar, catequizar e congregar o nativo à Igreja. Primeiramente, os religiosos jesuítas, capuchinhos e franciscanos se instalaram na ribeira do rio São Francisco e às margens dos caminhos criados. Na década de sessenta do século XVII, padres inacianos do Colégio de Salvador foram encaminhados para os sertões da capitania da Bahia de Todos os Santos, ali criaram reduções ou aldeamentos missioneiros célula máter de futuras freguesias e vilas. A catequização do gentio foi, antes de tudo, uma estratégia geopolítica da empresa colonial portuguesa, visando assegurar os seus domínios ultramarinos americanos.

Sendo um projeto da Coroa e da Igreja, a fundação de um aldeamento missioneiro também poderia partir por iniciativa particular, através de um fazendeiro (ou grupo desse) receoso de perder o seus currais. Isso aconteceu, por exemplo, às margens do rio São Francisco quando o capuchinho francês, Martinho de Nantes, reduzia os índios Cariris daquelas paragens ${ }^{11}$. Na Paraíba, os moradores do Piancó recorreram ao capitão - mor da capitania para que transladassem os índios da nação Corema para o riacho do Aguiar, devido aos distúrbios e damnos q' cauzavão aos supplicantes matando lhes os seus gados, e destruindo suas rossas $(. . .)^{12}$. Em resposta ao pedido, o ouvidor geral da Paraíba recomendou

\footnotetext{
${ }^{10}$ PROJETO RESGATE. AHU_ACL_CU_016,Cx. 1, D. 4. Segundo explanado no segundo, terceiro e quartos capítulos a fundação de uma igreja envolvia a doação de uma fatia de terra ao santo de devoção. No terreno sacralizado erigiam uma capela que poderia aspirar ou não à condição de freguesia. Conseqüentemente, moradores se assentavam nas proximidades da igreja, o que significava menos terra para os fazendeiros ou doadores do chão.

${ }^{11}$ MARTINHO DE NANTES, padre O.F.M. Cap. Relação de uma missão no Rio São Francisco: relação sucinta e sincera da missão do padre Martinho de Nantes, pregador capuchinho, missionário apostólico no Brasil entre os índios chamados cariris. Tradução e comentário de Barbosa Lima Sobrinho. São Paulo, Ed. Nacional, 1979. 123 p.

${ }^{12}$ PROJETO RESGATE. AHU_ACL_CU_014, Cx. 8, D. 707.
} 
aos trabalhos de catequese frei Félix Maria, capuchinho italiano ${ }^{13}$. O mesmo fato ocorreu nos confins do Ceará através da fazendeira Joanna Paula Vieira Mimosa ${ }^{14}$. Nesses casos, o outro, o gentio, foi visto como ameaça, a aculturação pretendeu o controle fundiário e econômico dos criadores de gado, (...) que eles próprios haviam chamado mais para a segurança de seu gado que pelo zelo da conversão dos índios (... $)^{15}$.

A criação de um aldeamento missioneiro, por vezes, gerou conflitos entre curraleiros e religiosos. Grosso modo, dois foram os motivos das brigas entre os citados atores: uso dos neófitos como mão - de - obra escrava e expulsão do índios de suas terras para o estabelecimento de currais. Segundo Martinho de Nantes:

Nossos missionários se viram obrigados a se opor à invasão violenta das terras dos índios pelos portugueses, uma vez que os rebanhos devoraram as plantações dos índios e os obrigavam a separar-se em diversos lugares para poder viver, o que acabava impedindo a presença das missões.

Fui visto como um inimigo e não como um missionário, visto que me opunha ao bem do Estado e às ordens, que o rei havia dado, para povoar as terras do rio para a subsistência das cidades da Bahia e Pernambuco. Foi assim que Dias (da Casa da Torre) me apontou. Dizia, também, que eu tinha grande crédito junto aos índios e que se podia temer que me valesse deles $(\ldots)^{16}$

Os acontecimentos entre os missionários franceses e fazendeiros ocorreram entre meados e final dos Seiscentos. Somente em 1700, a Coroa portuguesa reconheceu a necessidade de chão para os índios, ordenou, através de alvará de 23 de novembro, a doação de uma légua em quadra para os nativos do sertão, desde que estivessem convertidos e devidamente reduzidos ${ }^{17}$. O documento oficial previa o desenvolvimento de novas comunidades indígenas: aumentando-se o número de casais as autoridades eclesiásticas e governamentais deveriam ser acionadas, edificariam um novo aldeamento, uma outra légua em quadra seria "presenteada" aos Tapuias.

\footnotetext{
${ }^{13}$ PROJETO RESGATE. AHU_ACL_CU_014, Cx. 8, D. 707.

${ }^{14}$ SOUZA, Eusébio de. "Um pouco de história (Chronica de Ipu)". In Revista do Instituto do Ceará. Anno XXIX. Fortaleza, 1915. p. 156.

${ }^{15}$ MARTINHO DE NANTES, padre O.F.M. Cap. Relação de uma missão no Rio São Francisco...Opus cit., p. 40.

${ }_{16}$ MARTINHO DE NANTES, padre O.F.M. Cap. Relação de uma missão no Rio São Francisco...Opus cit., p. 40 e 61.

17 “Informação Geral da Capitania de Pernambuco, 1749”. In Annaes da Bibliotheca Nacional do Rio de Janeiro. Vol. XXVIII. Ano 1906. Rio de Janeiro, Officinas de Artes Graphicas da Bibliotheca Nacional, 1908. p. 384.
} 
Fazendas de gado e missões religiosas salpicaram o sertão nordestino em pontos estratégicos. Nos domínios das herdades foram construídas ermidas, com o tempo se tornaram curadas ou visitadas por um padre, a população da região, ansiava subir outro patamar, tornarse freguesia. Pleiteava-se autonomia eclesiástica e, como escreveu Murillo Marx, usufruir da formalidade civil com todo o direito e a segurança que pudesse propiciar ${ }^{18}$. Vemos no final dos Seiscentos o surgimento das primeiras paróquias do hinterland nordestino: Nossa Senhora da Montanha do Ararobá foi criada nas bases na redução oratoriana do Ararobá; Nossa Senhora do Cabrobó, Nossa Senhora da Vitória, Santo Antônio da Jacobina Velha e São Francisco da Barra do Rio Grande ergueram-se em terras doadas pelos criadores de gado aos seus santo de devoção.

Como analisado no terceiro capítulo, a rede eclesiástica de freguesias acelerou o povoamento da região estudada, por se tratar de um fenômeno urbano ${ }^{19}$. O rei, como patrono da Igreja em seus domínios ultramarinos, deveria patrocinar a construção de novas paróquias. Coroa e a Mitra tiraram bons proveitos com a instituição de freguesias. Ambos lucraram através dos dízimos a Deus: (...) porque sobre o rendimento de todos os dízimos ser da fazenda de V. Mag. ${ }^{\text {de }}$ tem Sempre a aplicassão de se gastarem com a Igreja, e outros actos muy pios ${ }^{20}$.

Os aglomerados dotados de igreja matriz não eram implantados em qualquer sítio, elegiam pontos específicos do território: lugares povoados, presença de rios ou riachos para o abastecimento dos fregueses durante as estiagens, existência de caminhos que facilitassem a comunicação e terrenos planos e férteis foram os condicionantes sociais e físicos, considerados pelos povoadores e autoridades religiosas na concepção de uma nova freguesia. Quando se fracionou a paróquia da vila do Pombal (PB), em 1784, originando a de Nossa Senhora dos Remédios do Jardim do Rio do Peixe (futura vila de Sousa - PB), o bispo da capitania de Pernambuco observou que se acha povoada de moradores por todo o seu âmbito e extensão em grande numero ${ }^{21}$. O padre Miguel de Carvalho e os moradores do sertão do Piauí selecionaram o meyo do Certão ${ }^{22}$ nas proximidades de um caminho sabido para edificar a igreja matriz de Nossa Senhora da Vitória. "Chave do sertão" foi o atributo dado à freguesia

\footnotetext{
${ }^{18}$ MARX, Murillo. Cidades no Brasil, terra de quem? São Paulo, Edusp, 1991. p. 19.

${ }^{19}$ LE GOFF, Jacques. O apogeu da cidade medieval. São Paulo, Martins Fontes, 1992. p. 43.

${ }^{20}$ ENNES, Ernesto. A guerra nos Palmares. Rio de Janeiro, Cia. Editora Nacional, 1938. p. 350.

21 "TERMO de criação e divisão do Curato de Nossa Senhora dos Remédios do Jardim do Rio do Peixe. 1784/03/07”. Apud SARMENTO, Christiane F. Povoações, freguesias e vilas na Paraíba colonial: Pombal e Sousa, 1697 - 1800. Dissertação de mestrado. Natal, UFRN, 2007. p. 88.

${ }^{22}$ ENNES, Ernesto. A guerra nos Palmares...Opus cit., p. 371.
} 
de Nossa Senhora da Montanha do Ararobá, pelo padre oratoriano João Duarte do Sacramento $^{23}$, instalada no caminho das boiadas que partiam do Recife às minas gerais.

Com a chegada do século XVIII um novo cenário urbano delimita-se no sertão nordestino. A pecuária extensiva se consolida no mercado interno colonial. Carne e couro, antes monopolizado pelos pólos - Recife, São Luiz e Salvador -, foram comercializados na capitania das Minas Gerais para o seu abastecimento. ${ }^{24}$ Em Recife e Salvador os produtos derivados do boi partiam, via marítima, para o Rio de Janeiro e Reino. Antonil citou o montante de $169.000 \$ 000$ réis ${ }^{25}$ de importação em meios de sola e couro em cabelo, desde os portos de Pernambuco e Bahia para Lisboa. Ao longo Setecentos, e segundo Nestor Goulart Reis Filho, a Coroa chama para si as responsabilidades de urbanização dos seus domínios americanos, vigiando mais atentamente a vida colonial brasileira. ${ }^{26}$

No reinado de $\mathrm{D}$. João $\mathrm{V}$, alguns núcleos urbanos (freguesias na maioria) se beneficiaram pela sua importância de centros fornecedores de gado. E, por estarem num degrau mais elevado do sistema urbano, a Metrópole concedeu os foros de vila. As paróquias situadas na estrada real do gado - Nossa Senhora da Vitória e Santo Antônio da Jacobina passam a ser denominadas vilas do Mocha e Jacobina, respectivamente. No trecho viário, paralelo ao rio São Francisco, na capitania da Bahia, a povoação de Santo Antônio do Urubu recebeu, em 1745, a nomeação de Paratinga. A vila cearense de Icó, elevada em 1736, se localizou no entroncamento de dois caminhos de gado. Ao sul do sertão baiano surge a vila de Rio de Contas que, ao nosso ver, foi criada para evitar o contrabando do ouro extraído nas minas gerais, idem para Paratinga. Emergiu, portanto, uma rede civil de vilas e povoações no semi-árido nordestino com funções hierárquicas bem definidas.

Os bispados de Pernambuco e Maranhão, em associação com o arcebispado da Bahia, Junta das Missões e órgãos superiores das ordens religiosas, não deixaram de fundar aldeamentos missioneiros. Nasceram as missões do Cariri cearense: Nova, Velha e Miranda. Ainda na capitania do Ceará, o poder oficial patrocinou a fundação das reduções da Palma, Telha e Jucá. O grande aldeamento jesuítico da Ibiapaba se consolidou no início do século XVIII sob a direção do padre Ascenso Gago. Ali milhares de índios foram "encurralados" para o bem da Santa Sé e de Portugal.

\footnotetext{
${ }^{23}$ PROJETO RESGATE. AHU_ACL_CU_PERNAMBUCO, Cx. 10, D. 242.

${ }^{24}$ PRADO Jr., Caio. História econômica do Brasil. $48^{\mathrm{a}}$ reimp.da 1 ed. São Paulo, Brasiliense, 2008. p. 68.

${ }^{25}$ ANTONIL, André João. Cultura e opulência do Brasil...Opus cit., p. 98.

${ }^{26}$ REIS FILHO, Nestor Goulart. Contribuição ao estudo da evolução urbana do Brasil (1500/1720). 2 ed. São Paulo, Pini, 2000. p. 71.
} 
Dilata-se, sobretudo, a rede eclesiástica de paróquias. Os dois sistemas urbanos, civil e religioso, dependentes entre si, adaptaram-se à nova realidade política, econômica e social da época, visto ser fruto da união entre Estado e Igreja. Se compararmos a ação da Igreja com a das autoridades oficiais, perceberemos que religião acelerou o povoamento de áreas periféricas à colonização. Por exemplo, entre os anos de 1706 - 1750, cerca de trinta aglomerados sertanejos foram instituídos como freguesias, enquanto que somente seis povoações receberam o pelourinho.

Apesar dos estímulos, os relatos das autoridades coloniais e clericais não foram favoráveis ao estado temporal, espiritual e físico das capitanias e vilas fundadas, ao longo do século XVIII, no sertão nordestino. Segundo os oficiais da câmara da cidade da Paraíba, o interior paraibano carece muito e com mais efficacia do pasto espiritual (... $)^{27}$. No Ceará os capitães mores vexaram os missionários com grande violência porq' os obrigão (os neófitos) a que lhe trabalhem para elles sem estipêndio $(. . .)^{28}$. Notória a grande mizéria em que se acha aquella Villa pella falta de rendimentos do Conselho $(. . .)^{29}$, estado da vila do Mocha em 1735. Ainda no Piauí, a vila de Marvão foi considerada pelo ouvidor Moraes Durão a pior de toda a Capitania, porque se acha no sítio mais seco e fúnebre da mesma $(\ldots)^{30}$. O termo da vila da Jacobina foi reduto de muitos criminosos, malfeitores e ladrões ${ }^{31}$, idem para o Ceará:

(...) E como nesta Capitania ha muitos Portugueses, mullattos, e mamelucos q' andão vagabundos sem occupação nem domicilio vivendo como siganos a que ali chamão Peralvilhos os quaes são de grande encargo e prejuízo, não so aos Índios mas ainda aos mesmos brancos, por q' vivem a se sustentão a custa alheia, com embustes, violências e roubos, será precizo q' se ordene ao Ouvidor q' por edditaes, eo Governador por bandos os notefiquem para que todos dentro de três meses tomem occupação e domicilio certo e q' não o fasendo sejão prezos e mandados para Pernambuco $(. . .)^{32}$

Muitas cartas régias de criação de vilas, emitidas a partir da época joanina, foram precedidas de preocupações urbanísticas ${ }^{33}$. Em Icó (CE), o documento oficial recomendou a

\footnotetext{
${ }^{27}$ PROJETO RESGATE. AHU_ACL_CU_014,CX. 13, D. 1070.

${ }^{28}$ PROJETO RESGATE. AHU_ACL_CU_CEARÁ, Cx. 1, D. 67.

${ }^{29}$ PROJETO RESGATE. AHU_ACL_CU_016, Cx. 2, D. 115.

${ }^{30}$ PROJETO RESGATE. AHU_ACL_CU_016, Cx. 12, D. 684.

${ }^{31}$ Apud MELLO, Ceres Rodrigues. "O sertão nordestino e suas permanências (Séc. XVI - XIX)". In Revista do Instituto Histórico e Geográfico Brasileiro. Vol. 148. № 356 (Jul/Set). Rio de Janeiro, IHGB, 1987. p. 353.

${ }^{32}$ PROJETO RESGATE. AHU_ACL_CU_CEARÁ, Cx. 1, D. 67.

${ }^{33}$ SANTOS, Paulo F. Formação de cidades no Brasil colonial. Rio de Janeiro, Editora da UFRJ, 2001. p. 50.
} 
eleição de um sítio saudável e com provimento de água ${ }^{34}$. Após a escolha, o núcleo seria formulado a partir de sua praça, com ruas definidas em linha recta com bastante largura, deixando sítio para se edificarem as casas nas mesmas direituras e igualdade (... $)^{35}$. Em Iço, e noutros municípios erguidos ao longo do século do século XVIII, a praça torna o elemento balizador na formatação dos aglomerados. Este vazio urbano reuniu as sedes dos poderes temporal e espiritual, além de ser ponto de atração e irradiação das futuras estruturas urbanas e arquitetônicas.

No quarto capítulo abordamos que a praça dos núcleos sertanejos foram concebidas por duas vertentes: oficial, especificada por cartas régias ou outro tipo de documento reinol, e religiosa - resultante do chão sacralizado para a igreja matriz no ato da fundação da freguesia. Para o segundo caso, elencamos alguns aglomerados que tiveram suas praças derivadas de doações pias: Mocha, Ipú, Caboclo, entre outros. Através da análise da praça e sua morfologia, podemos compreender o significado de uma povoação no sistema urbano onde está inserida e o grau de seu desenvolvimento intraurbano. ${ }^{36}$

Caminhos atuaram como "espinhas dorsais" 37 na formação urbana de arraiais do sertão nordestino. Alongando-se pelo terreno, os núcleos obtiveram uma forma longilínea, elaborando uma paisagem horizontal reforçada pela predominância de casas térreas. O alargamento no espaço intraurbano ocorreu justamente no largo da matriz ou ermida, demarcando simbolicamente o lugar sacro da povoação. Esse tipo de "núcleo - rua" se alastrou por toda a parte do Brasil colonial, desde o litoral até os rincões do interior. $\mathrm{O}$ cotidiano da população se figurou na rua. Uma conexão tênue entre o mundo rural do protourbano. Tais aglomerados cumpriram o papel de passagem, do quê? De comerciantes do couro, de gado, de mascastes; eram pousos, descansos almejados diante da longa travessia pela caatinga ensolarada.

Vale mencionar que, alguns desses núcleos, posicionados no complexo sistema urbano de vilas e paróquias, se evidenciaram no mercado do gado, por locarem em seu perímetro urbano feiras de gado, de produtos europeus ou de gêneros primeira necessidade. Citamos os exemplos de Feira (MA), hoje Itapicurú - Mirim, Condeúba (BA), Feira de Santana (BA) e Areia (PB) [figura 164]. A existência de estradas nas proximidades desses

\footnotetext{
${ }^{34}$ SANTOS, Paulo F. Formação de cidades no Brasil colonial...Opus cit., p. 51.

${ }^{35}$ SANTOS, Paulo F. Formação de cidades no Brasil colonial...Opus cit., p. 51.

${ }^{36}$ CORREA, Antonio Bonet. El urbanismo en España e hipanoamerica. Madrid, Ed. Cátedra, 1991. p. 175.

37 AZEVEDO, Aroldo de. Vilas e cidades do Brasil colonial. Ensaio de geografia urbana retrospectiva. Boletim $n^{\circ}$ 208. Geografia no 11. São Paulo, FFLCH, 1956. p. 71.
} 
arraiais, ou eles mesmos serem o caminho, facilitou as transações comerciais entre o litoral e o interior.

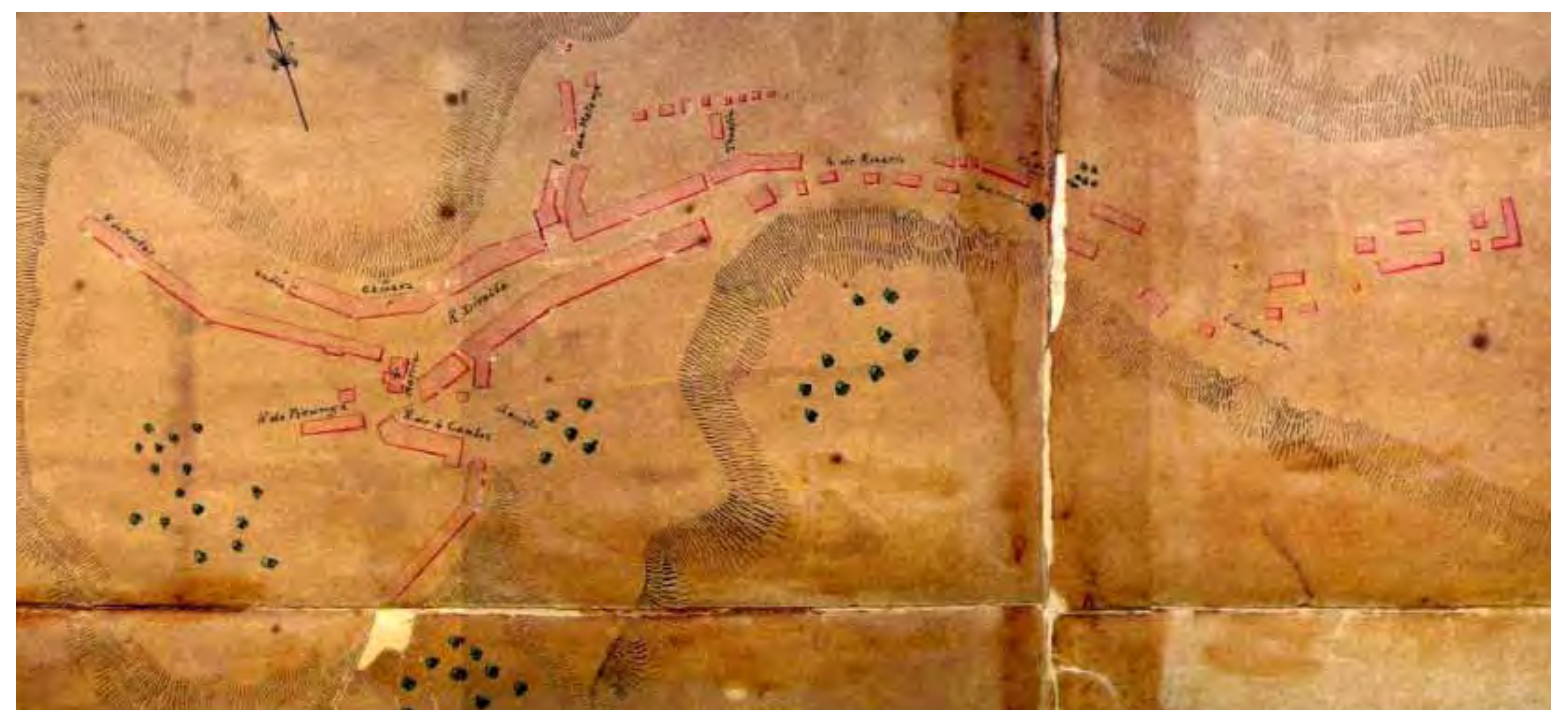

Figura 164 - Vila de Areia, em 1847. Original do AHEx - RJ. Extraído de MORAES, Carla Gisele M. S. Martins. Areia - Paraíba: morfologia e desenvolvimento urbano (séculos XVIII, XIX e XX). Dissertação de mestrado. Recife, UFPE/MDU, 2008. p. 47.

Com o marquês de Pombal, a centralização das funções governamentais e a reorganização econômica, política e religiosa deram novos rumos à colônia americana. Uma das primeiras medidas tomadas nessa fase foi a completa expulsão dos jesuítas do território brasileiro. A política reformista pombalina emitiu as leis de 06 e 07 de junho de 1755 e o Diretório dos Índios de 1758 conferindo, em tese, a liberdade dos índio e o respectivo mecanismo civilizatório. Separa-se a atividade temporal da espiritual nas vilas de maioria indígena. Ao pároco cabia somente as práticas religiosas e, ao diretor, o ensino da civilidade através do comércio, agricultura e nomeação do gentio habilitado a cargos públicos.

Averigua-se, ainda no governo de Dom José I, o crescimento do número de povoações que recebem o predicamento de vila, muitas delas tiveram como embrião urbano um aldeamento missioneiro: Viçosa (CE), Portalegre (RN), Cimbres (PE), Soure (BA), Pombal (BA), Crato (CE), Monte - Mor o Novo da América (CE), Tomar do Gerú (SE), entre outras. As autoridades coloniais segregaram no sistema as vilas de brancos daquelas de índios. Os governadores, ouvidores e demais autoridades continuaram a reunir o Tapuia para a sua domesticação, ou melhor, civilização, porém, não em aldeamentos, mas no lugar de índios. 
A missão civilizatória dos núcleos pombalinos esteve presente no discurso oficial, associada a imagem de comodidade e felicidade pública, polícia e cultura ${ }^{38}$. Os termos usuais aplicados à civilização foram "fixar", "recolher", "congregar" e "reunir" o homem. Por isso, as muitas cartas régias, homologadas nesse período, atingiram, além do indígena, outras camadas da sociedade colonial:

Sendo-me presentes em muitas e muito repetidas queixas os crimes e atrozes insultos que nos certões d'essa Capitania tem commetido os vadios e facinorosos que nelles vivem separados da sociedade civil e comercio humano, sou servido ordenar que todos os homens que nos ditos certões se acharem vagabundos, ou em sítios volantes, sejão logo obrigados a escolherem lugares acommodados para viverem juntos em povoações civis, que pelo menos tenhão cincoenta fogos para cima (...) [sem grifo no original $]^{39}$

No panorama intraurbano, as prerrogativas de planejamento a priori se intensificam com Pombal. O método de criar aglomerados, segundo a estética ilustrada - regulares, harmônicos e formosos - se pautou como teoria nas cartas régias e autos de ereção. Imperativo seria a formulação de um cenário composto pelo casario dos núcleos, ou seja, com a mesma figura pela parte exterior. Tais conceitos foram, portanto, os princípios essenciais do urbanismo da época moderna ${ }^{40}$.

Nos casos analisados no quinto e sexto capítulos percebemos que, entre a teoria e a prática, houve contradições, algumas pequenas outras mais evidentes. Em Oeiras, primeira cidade sertaneja, os agentes coloniais adaptaram o tecido urbano pré-existente com os novos lotes doados pós - fundação, resultando um traçado híbrido. Monte - Mor o Novo da América foi demarcada pelo engenheiro Custódio Francisco de Azevedo, todavia algumas discrepâncias entre os conceitos do seu Auto de Erecção e a realidade urbana existiram, contudo, sem agredir em demasia a linearidade do conjunto. Na vila Real do Crato as recomendações da carta régia, ao que parece, não foram efetuadas, cabendo ao ouvidor José da Costa Dias Barros reurbanizar, remodelar a forma da vila, dando a linearidade pretendida.

\footnotetext{
${ }^{38}$ BUENO, Beatriz P. Siqueira. Desenho e desígnio: o Brasil dos engenheiros militares (1500 - 1822). Tese de doutorado. São Paulo, FAU USP, 2001. p. 629.

39 "CREAÇÃO da Villa de Sobral”. In Revista do Instituto do Ceará. Anno V. Fortaleza, 1891. p. 114.

40 “DICIONÁRIO da arte barroca em Portugal”. Paulo Pereira (coord.). Lisboa, Editorial Proença, 1989. p. 508.
} 
Secas prolongadas e a concorrência da carne produzida nas charqueadas do sul favoreceram a estagnação econômica da pecuária do sertão no final do século XVIII. Os reflexos desses fatores no território foram vistos em muitas partes do Nordeste. Theodoro Sampaio, em sua viagem de inspeção ao rio São Francisco, testemunhou em Penedo (AL) o aumento de sua população devido a gente imigrada dos sertões assolados pela secca. Viamse nas ruas muito povo faminto e sem trabalho (...) homens que foram robustos, bellos typos de uma adaptação admirável, como se foram esqueletos vestidos de couro ${ }^{41}$.

Em 1801, o governador do Maranhão, D. Diogo de Sousa, proibiu a retirada das boiadas das fazendas do fisco para sua venda na Bahia. Consequentemente, a falta de carne fez o povo esfomeado concorriam me a porto a pedir socorro ${ }^{42}$. No Ceará, epicentro das estiagens, as repercussões da crise pastoril foram intensas. Renato Braga informou que nas primeiras secas, conhecidas como a dos três setes, o gado reduziu a um oitavo. O comércio das charqueadas da vila do Aracati ficou seriamente prejudicado porque não havia gado para o abate $^{43}$. A crise atingiu o sertão maranhense dos Pastos Bons, pois no ano de 1813, não exportaram seus bois para outras capitanias. ${ }^{44}$

O gado diminuiu. Em muitos casos, ficou restrito à alimentação familiar. Entretanto, certos núcleos sertanejos persistiram na pecuária como economia motriz de seus rendimentos. A vila piauiense de Valença, em 1808, exportou 3.200 cabeças de gado ${ }^{45}$. A vizinha Paranguá, segundo Francisco Xavier Machado, apresentou como gêneros mais comercializados o boi, a vaca, cavalos, couros em cabelo e curtidos ${ }^{46}$. Em Barra, vila criada em 1752 às margens do rio São Francisco, Theodoro Sampaio notou: a criação de gado é a sua melhor indústria ${ }^{47}$. Luis Vilhena descreveu que da vila da Jacobina, em 1802, vinham grandes boiadas, todavia, a carne produzida nos açougues era de má qualidade ${ }^{48}$. Ele ainda assegurou que no sertão da Paraíba não faltão fazendas de gado muito boas, do que tudo se

\footnotetext{
${ }^{41}$ SAMPAIO, Theodoro. O Rio São Francisco trechos de um diário de viagem e a Chapada da Diamantina. São Paulo, Escolas Profissionaes Salesianas, 1905. p. 11.

${ }^{42}$ PROJETO RESGATE. AHU_ACL_CU_016, Cx. 24, D. 1250.

${ }^{43}$ BRAGA, Renato. "Um capítulo esquecido da economia pastoril do Nordeste". In Revista do Instituto do Ceará. Tomo 61. Fortaleza, 1947. p. 156 - 157.

${ }^{44}$ RIBEIRO, Francisco de Paula, major.”Descripção do território de Pastos Bons, nos sertões do Maranhão: propriedades dos seus terrenos, suas producções, caráter dos seus habitantes colonos, e estado actual dos seus estabelecimentos.". in Revista do Instituto Histórico e Geográfico Brasileiro. Tomo XII. Rio de Janeiro, IHGB, 1849. p. 47.

${ }^{45}$ MACHADO, Francisco Xavier. "Memória relativa às Capitanias do Piahuy e Maranhão". In Revista do Instituto Histórico e Geográfico Brasileiro. Tomo XVII. Rio de Janeiro, IHGB, 1854. p. 62.

${ }^{46}$ MACHADO, Francisco Xavier. Memória relativa às Capitanias do Piahuy...Opus cit., p. 62.

${ }^{47}$ SAMPAIO, Theodoro. O Rio São Francisco trechos de um diário de...Opus cit., p. 47.

${ }^{48}$ VILHENA, Luiz dos Santos. Rcopilação de noticias soteropolitanas e brasílicas. Vol 1. Salvador, 1802. p. 341. Manuscrito disponível em http://www.bndigital.bn.br. Acesso em 01.11.2011.
} 
mantêm hum considerável commercio, tanto para o Reino, para onde sahem em direitura sete ou oito navios em cada hum anno, como para a Praça de Pernambuco (...) alem de outros portos da Costa ${ }^{49}$.

Durante a baixa da pecuária alguns sertanejos trocaram o comércio da carne e do couro pelo algodão ou rapadura, o último estabelecido, principalmente, na região do Cariri cearense. Segundo Manuel Correia de Andrade, a cultura algodoeira abriu novas perspectivas, com a ampliação das oportunidades de trabalho, renda e intercâmbio internacional $^{50}$. O principal centro algodoeiro do Nordeste foi a província do Maranhão, onde o termo da vila de Caxias se destacou como região produtora, melhor, como afirmou o major Francisco de Paula Ribeiro: a mais commerciavel de toda a capitania ${ }^{51}$.

Acerca da rede urbana, novas vilas e freguesias foram instituídas ao longo dessa fase de estagnação econômica e no alvorecer da independência. Entre os anos de 1777 - 1808 foram fundadas nove vilas; já entre 1808 - 1822 onze novos municípios surgiram no território do semi-árido. Se compararmos esses índices com os da era pombalina, onde 16 freguesias receberam o status de vila, podemos considerar um pequeno déficit da urbanização do interior nordestino.

Nos Seiscentos, o gado foi tangido para o sertão porque ameaçou as plantações de cana - de - açúcar. As reses encurtaram as distâncias entre o litoral e o sertão, apesar de ser um território isolado e dilatado, conforme caracterizaram as autoridades da época. Os versos de Olavo Bilac, "O caçados de esmeraldas", atribuídos à marcha de Fernão Dias, podem ser aplicados à atividade dos vaqueiros e das boiadas:

"Cada passada tua era um caminho aberto,

Cada pouso mudado, uma nova conquista,

Teu pé, como o de um deus, fecundava o deserto!"52

Os currais de reses se alastraram pela caatinga. À sombra desses, povoações foram erguidas. Depois de devassado e descoberto um lugar "infestado" de gentio, a Coroa e a Santa Sé, ligados por acordos entre si, investiram na conversão do nativo para "o bem" da

\footnotetext{
${ }^{49}$ VILHENA, Luís dos Santos. Recopilação de noticias referentes às Capitanias de Pernambuco e Goiás, e do pensamento político aplicados nas colônias portuguesas. Salvador, 1802. p. 26 - 27. Manuscrito disponível em http://bn.br. Acesso em 01. 11. 2011.

50 ANDRADE, Manuel Correia de. O processo de ocupação do espaço regional do Nordeste. 2 ed. Recife, SUDENE, 1979.

${ }^{51}$ RIBEIRO, Francisco de Paula, major.”Descripção do território de Pastos Bons, nos sertões do Maranhão... Opus cit., p. 55.

${ }^{52}$ Apud ARINOS, Afonso. História econômica do Brasil. Salvador, UFBA, 1958. p. 52.
} 
Igreja e dos seus vassalos. Implantaram os currais de almas, congregando, fixando e reunindo os índios dispersos pelos campos. Nos Setecentos novos impulsos foram dados a esses estabelecimentos indígenas, então não mais chamados de aldeamentos, mas vilas ou lugares de índios, demonstração de uma embrionária laicização do espaço urbano. O termo catequese foi mudado para civilização. A nomenclatura indígena para as povoações foi abolida, batizaram os núcleos urbanos de índios com os nomes das povoações mais notáveis do Reino. Também recolheram para os "currais institucionalizados" os vadios e facinorosos, visando sua adequação à cultura colonial. Os neófitos não adaptados ao sistema de viver imposto, fugiram, refugiando-se nos confins.

A realidade colonial do sertão nordestino passou por essa relação dialética e de dependência recíproca, resumidamente aqui apresentada. Não se trata de um fenômeno simples, mas de um complexo sistema comercial, fundiário, civilizatório e urbano, onde os envolvidos estiveram locados no Reino, nos principais centros litorâneos, nas vilas e paróquias sertanejas, nas fazendas de gado e nos pequenos núcleos de índios. De fato, a urbanização do sertão, entre os séculos XVII e XIX, abarcou variadas escalas e distintos atores, dinamizando suas trocas sociais. Convivendo lado a lado, os currais de reses e de almas sertanejos atravessaram o semi-árido, chegaram ao mar, aportaram no Reino, fazendo conhecido o sertão. 
REFERÊNCIAS BIBLIOGRÁFICAS 


\section{Referências bibliográficas}

\section{Fontes primárias manuscritas}

CARTA de José Vidigal ao provincial da Companhia de Jesus sobre os aldeamentos indígenas na Capitania do Maranhão . Destacava o povoamento, a multiplicação das fazendas de criação, a circulação dos metais preciosos, o papel importante desempenhado pelos missionários nos referidos aldeamentos e os problemas que tiveram em enfrentar. IEB/USP - COL. ML, 43.1

CERTIDÃO passada pelo coronel Miguel Corrêa Gomes, escrivão da Fazenda Real, com relação à repartição das léguas de terra que seriam doadas a cada aldeia de índios sob a jurisdição do desembargador Cristovão Soares Reimão, na Capitania do Rio Grande. IEB/USP - COL. ML, 72.3.

MAPPA da divisão civil, judiciária e eclesiástica da província do Piauí, com declaração aproximada da população livre e escrava, designadas por nacionalidade, e do genero de indústria que por mais se distingue a população dos Municípios. Secretária da Presidência da Província do Piauí, 1856. Disponível em http://www.bn.br. Acesso em 19/02/2010.

MAPA da Província do Brazil da Companhia de Jesus. IEB, Coleção Alberto lamego.

MAPA das Capitanias pertencentes a este Governo, Capitães mores e Sargentos mores dellas e Rol das Freguezias. IEB/USP - COL. ML, 50.13.

PETIÇÃO de 10 de março de 1730, dos moradores do rio de São Francisco, reclamando que, afora o título estabelecido a partir de 1727 para o transporte das boiadas, estavam sendo obrigados a pagar taxa nas diferentes passagens daquele rio e que a cobrança era feita com violência. IEB/USP - COL. ML, 50.34.

RELAÇÃO dos escravos das fazendas da inspeção de Nossa Senhora do Nazareth e todos quantos nelles se achão e também os das rossas da referida com suas idades pouco mais ou menos. Rio de Janeiro: FBN, 2010. Disponível em http://www.bn.br. Acesso em 04/03/2010. 
RELAÇÃO nominal dos capitães e numérica dos membros de diferentes companhias sob o título: Rezumo das cidades, villa do destricto do Governo de Pernambuco q' comprehende legoas da costa desde Camucy, em q' se divide do Governo do Maranham athé a Barra do Ryo de S. Francisco em q' se divide do Governo da Bahia; e legoas pella terra dentro athé o Ryo Carunhanha pouco mais, ou menos, em q' se divide do Governo das Minas (...). IEB/USP - COL. ML, 50.10.

ROTEIRO do caminho para Pojuca, passando por Urubá, Capitania de Pernambuco, 1738. IEB/USP - COL.ML, 72.60.

VILHENA, Luiz dos Santos. Recopilação de noticias soteropolitanas e brasílicas. Vol 1. Salvador, 1802. p. 84 - 85. Manuscrito disponível em http://www.bndigital.bn.br. Acesso em 01.11.2011.

Recopilação de noticias referentes às Capitanias de Pernambuco e Goiás, e do pensamento político aplicados nas colônias portuguesas. Salvador, 1802. p. 10. Manuscrito disponível em http://bn.br. Acesso em 01. 11. 2011.

\section{Fontes primárias cartográficas}

CARTA Topográfica da Capitania das Alagoas que a pedido do Ilustrissimo Senhor Coronel Francisco Manuel Martins Ramos commandante dos distritos das Villas de Penedo, e Poxim trasladou, Jozé da Silva Pinto, na Villa de Maceyó. Anno de MDCCCXX. Rio de Janeiro, Fundação Biblioteca Nacional.

CARTA geografica da Capitania do Piauhi, e parte das adjacentes, levantada em 1761 por João Antônio Galuci. Disponível em http://www.bn.br. Acesso em 03/02/2010.

ALEMÃO, Freire. Plano aproximado da Villa do Ipu, 30 de outubro de 1860. No verso notícias sobre as casas e desenhos azulejos. Rio de Janeiro, Fundação da Biblioteca Nacional. Sessão de manuscritos: I - 28,11,28.

MAPA da Comarca da Bahia de Todos os Santos sua divisão he do Rio Jiquiriça athé o Rio Real pela parte Norte. [17...]. Disponível em http://www.bn.br. Acesso em 20/06/2010. 
MAPA da Comarca da Bahia de Todos os Santos seguindo a continuação della parao poente. [17...]. Disponível em http://www.bn.br. Acesso em 20/06/2010.

MAPA geográfico da Capitania do Seará dellineado no anno de 1800 por Marianno Gregório do Amaral. Rio de Janeiro, Fundação Biblioteca Nacional.

MAPA do interior da Capitania do Maranham entre parte daquellas que ella se divide formado para mostrar os pontos que a limitão com a de Goiaz, segundo a Divizãp feita em 9 de Julho de 1816, por Avizo Régio de 11 de Agosto de 1813. Disponível em http://www.bn.br. Acesso em 15/03/2010.

MAPPA Topográfico das Capitanias do Maranhão e Piauhy feitas por Matias José da Silva Pereira. Disponível em http://www.bn.br. Acesso em 10/02/2010.

MAPPA geográfico da Capitania do Piauhy, e parte das do Maranhão, e do Gram Pará. Disponível em http://www.bn.br. Acesso em 22/10/2010.

MAPPA Topográfico da Capitania do Rio Grande do Norte, tirado por ordem do Governador da mesma Capitania José Francisco de Paula Albuquerque. Anno de 1811. Disponível em http://www.bn.br. Acesso em 25/04/2010.

PLANTA da Villa de Piancó da Parahyba pelo Eng. Francisco Pereira da Silva, em 1848. Rio de Janejeiro, AHEx.

PLANTA da Villa de Pombal da Parahyba pelo Eng. Francisco Pereira da Silva, em 1848. Rio de Janeiro, AHEx.

PLANTA da Villa de Souza da Parahyba pelo Eng. Francisco Pereira da Silva, em 1847. Rio de Janeiro, AHEx.

PLANTA da Villa de Jurumanha. Rio de Janeiro, AHEx.

PLANTA da Aldeia de São Gonçalo dos Índios, mandada levantar pelo Ilmo. Snr. Gov. Carlos Cezar Burlamaqui, na Capitania de S. Joze do Piauhi, por Joze Pedro Cezar de Menezes. Vista da parte do Sul. 1809. Rio de Janeiro, AHEx. 


\section{Fontes primárias impressas}

“Acento das cazas propias, e de aluguer q' ocupa os moradores da Cidade de Oeyras capitannia de Sa'Iozé do Piahuy', Suas Famílias, Pessoas de hum, e outro sexo, mossos, Escravos, Seus Subúrbios, e Rebaldes, cazas , Rossas delles q' o Ilmo. Sr. Ioao Pereyra Caldas Goverdador da ditta Capitania mandou fazer, e averiguar por Domingos Barreyra de Macedo Capp. ${ }^{\text {am }}$ mor da mesma Cid. ${ }^{\mathrm{e}}$, e da Governaça della, que foy Escrivão o Luis Ant. ${ }^{\circ}$ Ribr. ${ }^{\circ}$ da mesma Governaça”. Ver FALCI, Miridan Britto. "A cidade de Oeiras do Piauí”. in Revista do Instituto Histórico de Oeiras. Oeiras, Secretaria de Cultura, 2000. p. 174 - 206.

AGUIAR, Durval de. Descrições práticas da Província da Bahia: com declaração de todas as distâncias intermediárias das cidades, vilas e povoações. 2 ed. Rio de Janeiro, Livraria Editora Cátedra, 1979. 320 p.

ANNAES da Biblioteca Nacional do Rio de Janeiro. "Informações gerais da capitania de Pernambuco, 1749”. Vol. XXVIII. Rio de Janeiro, 1906. 535 p.

ANNAES da Biblioteca Nacional do Rio de Janeiro. "Idéias da população da capitania de Pernambuco, e das suas anexas, extensão das suas costas, rios, e povoações notáveis, agricultura, número de engenhos, contractos, e rendimentos reais, augmento que estes tem tido, desde o ano de 1774 em que tomou posse do governo das mesmas capitanias o governador e capitão general Jozé Cezar de Menezes”. Vol. XL. Rio de Janeiro, 1918. 375 p.

ANNAES da Bibliotheca Nacional do Rio de Janeiro. Vol XXXVI. Ano 1914. Rio de Janeiro, Officinas Graphicas da Biblioteca Nacional, 1916. 689 p.

ANNAES da Biblioteca Nacional do Rio de Janeiro. "Livro grosso do Maranhão". Vol. 66. Rio de Janeiro, 1948. 296 p.

ANAIS da Biblioteca Nacional do Rio de Janeiro. "Os manuscritos do botânico Freire Alemão". Vol. 81. Rio de Janeiro, 1961. 372 p.

"Apontamentos sobre as freguezias de Arneiroz e de Saboeiro". In Revista do Instituto do Ceará. Ano XVI. Fortaleza, 1902. p. 72 - 80.

“Actas da Câmara do Crato (de 11 de maio de 1817, até 27 de janeiro de 1823)". In Revista do Instituto Histórico e Geográfico Brasileiro, 1872. 
“ALVARÁ de 08 de maio de 1758”. In Revista do Instituto do Ceará. p. 183 - 186.

ANTONIL, André João. Cultura e opulência do Brasil. 3 ed. Belo Horizonte, Itatiaia/Edusp,1982. (Coleção Reconquista do Brasil).

“Auto da creação da Villa de S. Bernardo do Governador". In Revista do Instituto do Ceará. Anno XX. Fortaleza, 1906.

"Auto de Creação e Levantamento da povoação de S. Vicente Ferrer das Lavras da Mangabeira em villa,...”. in Revista do Instituto do Ceará. Anno IV. Fortaleza, 1890.

AVE - LALLEMANT, Robert. Viagens pelas províncias da Bahia, Pernambuco, Alagoas e Sergipe. São Paulo, Ed. da Universidade de São Paulo, 1980.

BERFORD, Sebastião Gomes da Silva. Roteiro e Mappa da viagem da cidade de S. Luiz do Maranhao até a corte do Rio de Janeiro, feita por ordem do Governador, e Capitao General daquella Capitania, pelo Coronel Sebastião Gomes da Silva Berford, Fidalgo da Casa real, com os officios relativos a mesma viagem. Rio de Janeiro, Impressão Régia, 1810.

BRIGIDO, João. "Carta ao Dr. P. Theberge”. In Revista do Instituto do Ceará. Ano II. Fortaleza, 1888.

BLUTEAU, Raphael, S. J. Vocabulário português, e latino...Coimbra, Real Collegio das Artes da Companhia de Jesus, 1712 - 1719. Disponível em http://www.brasiliana.usp.br. Acesso em 24. 11. 2011

CALDAS, Jozé Antônio. Notícia Geral de toda esta capitania da Bahia desde o seu descobrimento até o prezente anno de 1759. Ed. fac similar. Salvador, Tip. Beneditina, 1951.

"Câmara de Aquirás: ordens régias, alvarás, provisões, regimentos, etc. (1700 - 1801). In Revista do Instituto do Ceará. Tomo LXXXII. Fortaleza, 1964.

“Carta régia de 12 de Maio de 1798 ao capitão-general do Pará acerca da emancipação e civilisação dos índios, e resposta do mesmo acerca da sua execução". In Revista do Instituto Histórico e Geographico Brazileiro. Tomo XX. Rio de Janeiro, 1857. p. 439.

CÓDIGO do Direito Canônico. São Paulo, Loyola, 1983. 
CONSTITUIÇÕES Primeyras do arcebispado da Bahia feitas, e ordenadas pelo Ilustríssimo, e reverendíssimo senhor D. Sebastião Monteiro de Vide, 5. Arcebispado do dito Arcebispado, e do Conselho de Sua Magestade: propostas, e aceitas em o Synodo Diocesano, que o dito senho celebrou em 12 de junho de 1707. Introdução e revisão cônego prebendado Idelfonso Xavier Ferreira. São Paulo, Typ. 2 de dezembro, 1853. 510 p.

“Creação da Villa do Crato, 14 de junho de 1764". In FEITOSA, Carlos. As gentes dos Inhamuns na criação da Real Vila do Crato. Crato. p. 14 - 26.

“Creação da Villa de Sobral”. In Revista do Instituto do Ceará. Anno V. Fortaleza, 1891.

D’ABBEVILLE, Claude. História da missão dos padres capuchinhos na ilha do Maranhão e terras circunvizinhas. Belo Horizonte, Itatiaia, 1975. 297 p.

“Descripção da cidade do Crato em 1882 pelo Dr. Gustavo Horácio”. In Revista do Instituto do Ceará. Ano XX. Fortaleza, 1906.

"Descripção Geographica Abreviada da Capitania do Ceará, pelo Coronel dos Engenheiros Antônio Jozé da Silva Paulet”. In Revista do Instituto do Ceará. Anno XII. Fortaleza, 1898.

DESCRIPÇÃO do território de Pastos Bons, nos sertões do Maranhão. Propriedades dos seus terrenos, suas producções, caracter dos seus habitantes colonos, e estados actual dos seus estabelecimentos: pelo major Francisco de Paula Ribeiro. 1819.

"Directorio, que se deve observar nas Povoaçoens dos Indios do Pará, e Maranhaõ em quanto sua Magestade naõ mandar o contrario”. In “O diretório dos índios: um projeto de civilização no Brasil do século XVIII. Brasília, Editora da UnB, 1997.

"Estatuto da freguezia de Nossa Senhora do Rosário das Russas concordados em 29 de Setembro de 1761”. In Revista do Instituto do Ceará. Ano XV. Fortaleza, 1901.

"Extractos dos assentos do antigo senado de Icó, desde 1738 até 1835. Colligidos nos archivos de Icó, Aracaty, Fortaleza, etc. pelo Dr. Theberge”. In Revista do Instituto Histórico e Geográfico Brasileiro, 1872. 
FALLA, que derigio a assembléia legislativa do Piahuy no ato da sua instalaçam, o Presidente da Província no dia 04 de maio de 1835. Oeiras do Piahuy, Typ. de Silveira e Companhia, 1835. Disponível em http://www.crl.edu. Acesso em 26. 07. 2010.

FALLA, que derigio a assembléia legislativa do Piahuy no ato da sua instalaçam, o Presidente da Província no dia 04 de maio de 1837. Oeiras do Piahuy, Typ. de Silveira e Companhia, 1837.Disponível em http://www.crl.edu. Acesso em 27. 07. 2010.

FALLA, que derigio a assembléia legislativa do Piahuy no ato da sua instalaçam, o Presidente da Província no dia 04 de maio de 1843. Oeiras do Piahuy, Typ. de Silveira e Companhia, 1843. Disponível em http://www.crl.edu. Acesso em 10. 11. 2011.

FALLA, que derigio a assembléia legislativa do Piahuy no ato da sua instalaçam, o Presidente da Província no dia 07 de julho de 1844. Oeiras do Piahuy, Typ. de Silveira e Companhia, 1844. Disponível em http://www.crl.edu. Acesso em 26. 07. 2010.

FALLA, que derigio a assembléia legislativa do Piahuy no ato da sua instalaçam, o Presidente da Província no dia 04 de maio de 1845. Oeiras do Piahuy, Typ. de Silveira e Companhia, 1845. Disponível em http://www.crl.edu. Acesso em 10. 11. 2011.

GARDNER, George. Viagem ao Interior do Brasil. São Paulo: Edusp, 1975.

HALFELD, Henrique Gulherme Fernando. Atlas e relatório concernente a exploração do rio São Francisco desde a cachoeira da Pirapora até o oceano Atlântico. Levantado por ordem do governo de S.M.I. o Senhor D. Pedro II. Em 1852, 1853 e 1854. Rio de Janeiro, 1860.

KIDDER, Daniel P. Reminiscências de viagens e permanências nas províncias do Norte do Brasil. São Paulo, Edusp, 1980. p. 157. 279 p.

KOSTER, Henry. Viagens ao Nordeste do Brasil. Tradução e notas: Luis Câmara Cascudo. Rio de Janeiro, Ed. Nacional, 1942.

LEY, porque V. Magestade ha por bem restituir aos índios do Grão Pará, e Maranhão a liberdade das suas pessoas, e bens, e commercio - na forma que nella se declara. Lisboa, 1755.

"Lei de 10 de setembro de 1611 de proteção aos índios do Brasil". In Revista do Instituto do Ceará. Tomo VII. Fortaleza, Editora do Instituto do Ceará, 1963. p. 325 - 328. 
MACHADO, Francisco Xavier. "Memória Relativa às Capitanias do Piahuy e Maranhão por Francisco Xavier Machado". In Revista do Instituto Histórico e Geographico do Brazil. Tomo XVII. Rio de Janeiro, Typographia Universal de Laemmert, 1854.

MAPA geral de todas as Misoens ou Aldeias de gentio manso que estao situadas neste Capitania da Bahia, e nas mais q comprehende o seo governo com os nomes delas, Vilas e sao termo, Freguezias a e pertecem, quali ${ }^{\text {de }}$ dos Misionr ${ }^{o s} q$ as administrao, Orago das Igrejas $q$ nelas existem, Parochias a q se elevarão as q estavam na administrasam dos Jesuiras, Diocezes, Capitanias, e Comarcas a q pertecem, extensam do n. de cazais, Almas, e qualid das nasoens de cada huma delas. Bahia, dezembro 20 de 1758.

MARTINHO DE NANTES, padre O.F.M. Cap. Relação de uma missão no rio São Francisco: relação sucinta e sincera da missão do padre Martinho de Nantes, pregador capuchinho, missionário apostólico no Brasil entre os índios chamados cariris. Tradução e comentário de Barbosa Lima Sobrinho. São Paulo, Editora Nacional, 1979. 123 p.

MELLO, Francisco Ignácio Marcondes Homem de Mello. "Excursões pelo Ceará, S. Pedro do Sul, e São Paulo". In Revista do Instituto Histórico e Geográfico Brasileiro. Tomo XXXV. Segunda parte. Rio de Janeiro, B.L. Garnier, 1872. p. 80 - 155.

MENEZES, Luiz Barba Alardo de. "Memória sobre a Capitania do Ceará". in Revista do Instituto Histórico e Geographico e Etnographico do Brasil. Tomo XXXIV. Rio de Janeiro, IHGB, 1871.

PARENTE, Fillipe Alberto Patroni Martins Maciel. As viagens de Patroni pelas províncias brasileiras: de Ceará, Rio de S. Francisco, e Rio de Janeiro: nos anos de 1829, e 1830. 2 ed. Lisboa, 1851.

"Ordem para a criação das Villas e Vigaria dos índios". Arquivo da matriz da cidade de Viçosa, livro de registro nº2. In Revista do Instituto do Ceará. Fortaleza, 1929 - 1930. p. 0107 . 
ORDENAÇÕES Filipinas - Livro IV, Título XLIII: Das sesmarias. Disponível em http://www.uc.pt/ihti/proj/filipinas/ordenacoes.htm. Acesso em 14/10/2011.

"Registro dos Autos de erecção da real villa de Monte Mor - o - Novo da América, na Capitania do Ceará Grande”. In Revista do Instituto do Ceará. Fortaleza, 1891.

RELATORIO do Presidente da Província do Piahuy no dia 01 de Agosto de 1845. Oeiras do Piahuy, Typ. de Silveira e Companhia, 1845. p. 25. Disponível em http://www.crl.edu. Acesso em 26. 07. 2010.

ROTEIRO e mappa da viagem da cidade de São Luiz do Maranhão até a corte do Rio de Janeiro, feita por ordem do Governador, e Capitão General daquela Capitania, pelo Coronel Sebastião Gomes da Silva Berford, Fidalgo da Casa Real, com os officios relativos a mesma viagem. Rio de Janeiro, Impressão Régia, 1810.

"ROTEIRO do Maranhão a Goiaz pela Capitania do Piahui". In Revista do Instituto Histórico e Geográfico Brasileiro. Tomo LXII. Vol. 99. Rio de Janeiro, Imprensa Nacional, 1900. p. $60-161$.

SAMPAIO, Theodoro. O Rio São Francisco: trechos de um diário de viagem e a Chapada da Diamantina. São Paulo, Escolas Profissionaes Salesianas, 1905. 195 p.

SPIX, J. B. \& MARTIUS, C.F.P. Viagem pelo Brasil. Trad. De Lucia Furquim Lahmeyer e notas de Brasílio de Magalhães. Rio de Janeiro, Imprensa Nacional, 1938.

VIAGENS de Patroni pelas províncias brasileiras: de Ceará, Rio de S. Francisco, e Rio de Janeiro: nos anos de 1829 e 1830. Segunda edição. Lisboa, 1851.

WIED-NEUWIED, Maximiliano. Viagem ao Brasil. São Paulo, Edusp 1989. 536 p.

“1 Regimento que levou Thomé de Souza, Governador do Brazil”. In Revista do Instituto Histórico Geográfico Brasileiro. Tomo LXI. Rio de Janeiro, Imprensa Nacional, 1898. p. 48 $-49$. 
Fontes primárias manuscritas do Projeto Resgate Barão de Rio Branco:

\section{Maranhão:}

AHU_ACL_N_Maranhao,

D. 957; AHU_ACL_N_Maranhão,

D. 1335;

AHU_ACL_N_Maranhão,

D. 1352; AHU_ACL_N_Maranhão,

D. 1603;

AHU_ACL_N_Maranhão,

D. 2099; AHU_ACL_N_Maranhão,

D. 2794;

AHU_ACL_N_Maranhão,

D. 2980; AHU_ACL_N_Maranhão,

D. 3071;

AHU_ACL_N_Maranhão,

D. 3493; AHU_ACL_N_Maranhã,

D. 3671;

AHU_ACL_N_Maranhão,

D. 3692; AHU_ACL_N_Maranhã0,

D. 3768 ;

AHU_ACL_N_Maranhão,

D. 3778; AHU_ACL_N_Maranhão,

D. 3848;

AHU_ACL_N_Maranhão, D. 3494; AHU_N_CU_Maranhão, Cx. 38, D. 3767;

\section{Piauí:}

AHU_ACL_CU_016, Cx.1, D. 1; AHU_ACL_CU_016, Cx.1, D. 15; AHU_ACL_CU_016, Cx.1, D. 19; AHU_ACL_CU_016, Cx.1, D. 64; AHU_ACL_CU_016, Cx.1, D. 66; AHU_ACL_CU_016, Cx.1, D. 68; AHU_ACL_CU_016, Cx.2, D. 85; AHU_ACL_CU_016, Cx.2, D. 97; AHU_ACL_CU_016, Cx.2, D. 100; AHU_ACL_CU_016, Cx.2, D. 111; AHU_ACL_CU_016, Cx.2, D. 126; AHU_ACL_CU_016, Cx.2, D. 143; AHU_ACL_CU_016, Cx.3, D. 157; AHU_ACL_CU_016, Cx.3, D. 187; AHU_ACL_CU_016, Cx.3, D. 227; AHU_ACL_CU_016, Cx.4, D. 231; AHU_ACL_CU_016, $\quad$ Cx.4, D. 238; AHU_ACL_CU_016, Cx.4, D. 284; AHU_ACL_CU_016, Cx.4, D. 298; AHU_ACL_CU_016, Cx.5, D. 324; AHU_ACL_CU_016, Cx.5, D. 359; AHU_ACL_CU_016, Cx.6, D. 378; AHU_ACL_CU_016, Cx.6, D. 381; AHU_ACL_CU_016, Cx.7, D. 407; AHU_ACL_CU_016, Cx.7, D. 437; AHU_ACL_CU_016, Cx.8, D. 445; AHU_ACL_CU_016, Cx.8, D. 450; AHU_ACL_CU_016, Cx.8, D. 462; AHU_ACL_CU_016, Cx.8, D. 464; AHU_ACL_CU_016, Cx.9, D. 563; AHU_ACL_CU_016, Cx.9, D. 572; AHU_ACL_CU_016, Cx.9, D. 572; AHU_ACL_CU_016, Cx.10, D. 589; AHU_ACL_CU_016, Cx.11, D. 603; AHU_ACL_CU_016, Cx.11, D. 643; AHU_ACL_CU_016, Cx.11, D. 649; AHU_ACL_CU_016, Cx.11, D. 656; AHU_ACL_CU_016, Cx.12, D. 710; AHU_ACL_CU_016, Cx.13, D. 764; AHU_ACL_CU_016, Cx.18, D. 904; 
AHU_ACL_CU_016, Cx.21, D. 1092; AHU_ACL_CU_016, Cx.24, D. 1250; AHU_ACL_CU_016, Cx.2, D. 75; $\quad$ AHU_ACL_CU_016, Cx.8, D. 462; AHU_ACL_CU_016, Cx.11, D. 633; AHU_ACL_CU_016, Cx.11, D. 649; AHU_ACL_CU_016, $\quad$ Cx.16, D. 905; AHU_ACL_CU_016, Cx.9, D. 547; AHU_ACL_CU_016, Cx.1, D. 35; AHU_ACL_CU_016, Cx.14, D. 816; AHU_ACL_CU_016, Cx.11, D. 642; AHU_ACL_CU_016, Cx.11， D. 663; AHU_ACL_CU_016, Cx.12, D. 730; AHU_ACL_CU_016, Cx.1, D. 4; AHU_ACL_CU_016, Cx. 3, D. 210; AHU_ACL_CU_016, Cx. 1, D. 57; AHU_ACL_CU_016, Cx. 12, D. 711; AHU_ACL_CU_016, Cx. 12, D. 684; AHU_ACL_CU_016, Cx. 11, D. 647; AHU_ACL_CU_016, Cx. 2, D. 115; AHU_ACL_CU_016, Cx. 2, D. 96; AHU_ACL_CU_016, Cx. 15, D. 826; AHU_ACL_CU_016, Cx. 6, D. 381; AHU_ACL_CU_016, Cx. 6, D. 395; AHU_ACL_CU_016, Cx. 9, D. 547; AHU_ACL_CU_018, Cx. 8, D. 504; AHU_ACL_CU_016, Cx. 12, D. 690; AHU_ACL_CU_016, Cx. 9, D. 524; AHU_ACL_CU_016, Cx. 12, D. 714; AHU_ACL_CU_016, Cx. 26, D. 1363; AHU_ACL_CU_016, Cx. 17, D. 849; AHU_ACL_CU_016, Cx. 31， D. 1622; AHU_ACL_CU_016, Cx. 31, D. 1654;

\section{Ceará:}

AHU_ACL_N_Ceará, $\quad$ Cx.1, $\quad$ D. $\quad 40 ; \quad$ AHU_ACL_N_Ceará, $\quad$ Cx.1, $\quad$ D. $\quad 65$; AHU_ACL_N_Ceará, $\quad$ Cx.1, D. 67; AHU_ACL_N_Ceará, Cx.2, D. 126; AHU_ACL_N_Ceará, Cx.2, D. 140; AHU_ACL_N_Ceará, Cx.3, D. 182; AHU_ACL_N_Ceará, $\quad$ Cx.4, $\quad$ D. 271; AHU_ACL_N_Ceará, Cx.5, D. 326; AHU_ACL_N_Ceará, Cx.6, D. 416; AHU_ACL_N_Ceará, Cx.6, D. 418; AHU_ACL_N_Ceará, Cx.7, D. 464; AHU_ACL_N_Ceará, Cx.8, D. 518; AHU_ACL_N_Ceará, Cx.9, D. 592; AHU_ACL_N_Ceará, Cx.9, D. 593; AHU_ACL_N_Ceará, Cx.13， D. 745; AHU_ACL_N_Ceará, Cx.14， D. 806; AHU_ACL_N_Ceará, Cx.16, D. 905; AHU_ACL_N_Ceará, Cx.17, D. 944; AHU_ACL_N_Ceará, Cx. 6, D. 380; AHU_ACL_N_Ceará, Cx. 6, D. 376; AHU_ACL_N_Ceará, Cx. 6, D. 381; AHU_ACL_CU_Ceará, Cx. 17， D. 994; AHU_ACL_CU_Ceará, Cx. 4, D. 237; AHU_ACL_CU_Ceará, Cx. 7, D. 464; AHU_ACL_CU_Ceará, Cx. 9, D. 591; AHU_ACL_CU_Ceará, Cx. 4, D. 271; AHU_ACL_CU_Ceará, Cx. 12, D. 674; AHU_ACL_CU_Ceará, Cx. 9, D. 592; AHU_ACL_CU_Ceará, Cx. 9, D. 564; 


\section{Rio Grande do Norte:}

AHU_ACL_CU_018, Cx.1, D. 42; AHU_ACL_CU_018, Cx.1, D. 51; AHU_ACL_CU_018, Cx.1, D. 68; AHU_ACL_CU_018, Cx.1, D. 73; AHU_ACL_CU_018, Cx.2, D. 97; AHU_ACL_CU_018, Cx.2, D. 99; AHU_ACL_CU_018, $\quad$ Cx.2, D. 140; AHU_ACL_CU_018, Cx.2, D. 141; AHU_ACL_CU_018, $\quad$ Cx.2, D. 161; AHU_ACL_CU_018, Cx.3, D. 183; AHU_ACL_CU_018, Cx.5, D. 308; AHU_ACL_CU_018, Cx.7, D. 446; AHU_ACL_CU_018, $\quad$ Cx.8, D. 450; AHU_ACL_CU_018, Cx. 2, D. 116; AHU_ACL_CU_018,Cx. 8, D. 507;

\section{Paraíba:}

AHU_ACL_CU_014, $\quad$ Cx.4, $\quad$ D. 310; $\quad$ AHU_ACL_CU_014, $\quad$ Cx.5, D. 349; AHU_ACL_CU_014, Cx.5, D. 426; AHU_ACL_CU_014, Cx.6, D. 522; AHU_ACL_CU_014, Cx.8, D. 700; AHU_ACL_CU_014, Cx.8, D. 707; AHU_ACL_CU_014, Cx.9, D. 728; AHU_ACL_CU_014, Cx.10, D. 800; AHU_ACL_CU_014, Cx.12, D. 1011; AHU_ACL_CU_014, Cx.14, D. 1204; AHU_ACL_CU_014, Cx.16, D. 1321; AHU_ACL_CU_014, Cx.26, D. 1988; AHU_ACL_CU_014, Cx.30, D. 2173; AHU_ACL_CU_014, Cx.30, D. 2200; AHU_ACL_CU_014, Cx.31， D. 2270; AHU_ACL_CU_014, Cx.33, D. 2423; AHU_ACL_CU_014, Cx.35, D. 2510; AHU_ACL_CU_014, Cx.38, D. 2711; AHU_ACL_CU_014, Cx.41, D. 2853; AHU_ACL_CU_014, Cx.9, D. 727; AHU_ACL_CU_014,Cx. 10, D. 798;

\section{Pernambuco:}

AHU_ACL_CU_Pernamb., Cx. 95, D. 7493; AHU_ACL_CU_Pernamb., Cx. 10, D. 242 


\section{Fontes secundárias}

ABREU, Capistrano de. Capítulos de história colonial: 1500 - 1800. 7 ed. São Paulo, Publifolha, 2000. 280p.

. Caminhos antigos e povoamento do Brasil. São Paulo, Ed. Itatiaia, 1956. 306 p.

ALENCAR, José de. O sertanejo. São Paulo, Ática, 2004. 247 p.

ALMEIDA, Rita Heloísa. O diretório dos índios: um projeto de civilização no Brasil do sécul XVIII. Brasília, Editora UnB, 1997. 430 p.

. "A carta régia de 12 de maio de 1798 e outros documentos sobre índios no códice 807”. In Revista do Instituto Histórico e Geográfico Brasileiro. no 416 (jul/set). Rio de Janeiro, IHGB, 2002.

ALMEIDA, Furtado de. História da Igreja em Portugal. Vol II. Lisboa, Livraria Civilização - Editora, 1968.

ANDRADE, Francisco de Paula Dias de. Subsídios para o estudo da influência da legislação na ordenação e na arquitetura das cidades brasileiras. São Paulo, Politécnica USP, 1966. $376 \mathrm{p}$.

ANDRADE, Manuel Correia de. A terra e o homem no Nordeste. 3 ed. São Paulo, Brasiliense, 1973. $251 \mathrm{p}$.

O processo de ocupação do espaço regional do Nordeste. 2 ed. Recife, SUDENE, 1979.

ARAÚJO, pe. Antônio Gomes de. A cidade de frei Carlos de Ferrara. Crato, FFCRATO, 1971.

ARAÚJO, Renata Malcher. As cidades da Amazônia no século XVIII: Belém, Macapá e Mazagão. Porto, FAUP Publicações, 1998. 356 p.

. “A razão na selva: Pombal e a reforma urbana da Amazônia”. In Revista Camões. no 15/16. Lisboa, Instituto Camões, 2003. p. 157. 
ARAÚJO, Renata Malcher. "Engenharia miltar e urbanismo”. In MOREIRA, Rafael (dir.). História das fortificações portuguesas no mundo. Lisboa, Alfa, 1989. Vol II. p. 269.

ARGAN, Giulio Carlo. História da arte como história da cidade. 5 ed. tradução Píer Luigi Cabra. São Paulo, Martins Fontes, 2005. 280 p.

ARINOS, Afonso. Síntese da história econômica do Brasil. Salvador, UFBA, 1958. p. 47 -56.

ASSUNÇÃO, Paulo de. Negócios Jesuíticos: o cotidiano da administração dos bens divinos. 1 ed. São Paulo, Edusp, 2009.

AYMONINO, Carlo. O significado das cidades. Lisboa, Editorial Proença, 1984. 243 p.

AZEVEDO, Aroldo de. Vilas e cidades do Brasil colonial. Boletim n. 208 (Geografia n. 11). São Paulo, FFCLH - USP, 1956. 96 p.

. Aldeias e aldeamentos de índios. Boletim Paulista de Geografia n. 33 (outubro). São Paulo, 1959. 69 p.

AZZI, Riolando. “A instituição eclesiástica durante a primeira época colonial”. In História da Igreja no Brasil: ensaio de interpretação a partir do povo: primeira época, Período Colonial. 5 ed. Petrópolis, Editora Vozes, 2008.

BANDEIRA, Luiz Alberto Moniz. O feudo: a Casa da Torre de Garcia d'Ávila - da conquista dos sertões à independência do Brasil. Rio de Janeiro, Civilização Brasileira, 2000. $602 \mathrm{p}$.

BARBALHO, Nelson. Cronologia pernambucana: subsídios para a história do agreste e do sertão. Recife: CEHM/FIAM, 1983. 17 v.

BARBOSA, Bartira Ferraz. Paranambuco: herança e poder indígena Nordeste séculos XVIXVII. Recife, Ed. Universitária UFPE, 2007. 220 p.

Índios e missões: a colonização do médio São Francisco pernambucano nos séculos XVII e XVIII. Dissertação de mestrado. Recife, UFPE, 1991.

BARRETO, Paulo Thedin. "Casas de Câmara e Cadeia". In Revista do IPHAN. Rio de Janeiro, 1947. 
BARRETO, Paulo Thedim. “O Piauí e a sua arquitetura.” In Arquitetura Civil I. Vol 2. Rio de Janeiro, 1938. pp. $191-219$.

BAYÓN, Damián. Pensar con los ojos: ensayos de arte latinoamericano. México, Fondo de Cultura Económica, 1993. 400 p.

BELlOTTO, Heloísa L. O governo do Morgado de Mateus: primórdios da restauração da capitania de São Paulo (1765 - 1775). Tese de doutoramento, FFLCH-USP, 1976.

• "Política indigenista no Brasil colonial (1570 - 1757)." In Revista do IEB. no 29. São Paulo, 1988. pp. 49 - 60.

BEOZZO, José Oscar. Leis e regimentos das missões: política indigenista no Brasil. São Paulo, Ed. Loyola, 1983. 224 p.

BOAVENTURA, Deusa Maria Rodrigues. Urbanização em Goiás no século XVIII. Tese de doutoramento. São Paulo, FAU - USP, 2007. 279 p.

BORDIEU, Pierre. A economia das trocas simbólicas. 6 ed. São Paulo, Perspectiva, 2005.

BOSCHI, Caio. “As missões no Brasil.” In BETHENCOURT, Francisco; CHAUDHURI, Kirti. História da Expansão portuguesa. Lisboa, Circulo de Leitores, 1993. pp. 388 - 402.

- "Colonialismo, poder e urbanismo no Brasil Setecentista". In Anais do I Colóquio de Estudos Históricos Brasil-Portugal. Belo Horizonte, PUC, 1994.

BOSCHI, Caio César. Os leigos e o poder: irmandades leigas e política colonizadora em Minas Gerais. São Paulo, Ática, 1986.

BOSI, Alfredo. Dialética da colonização. 4 ed. São Paulo, Companhia das Letras, 2008. $420 \mathrm{p}$.

BOXER, C. R. Igreja e expansão ibérica. Lisboa, Edições 80, 1981.

BRAGA, Renato. "Um capitulo esquecido da economia pastoril do Nordeste". In Revista do Instituto do Ceará. Tomo 61. Fortaleza, 1947. pp. 149 - 162. 
BRITTO, Miridan Knox. O Piauí na primeira metade do século XIX. Teresina, Projeto Petrônio Portela, 1992. p. 16.

BUENO, Beatriz Piccolotto Siqueira. Desenho e desígnio: o Brasil dos engenheiros militares (1500 - 1822). Tese de doutoramento. São Paulo, FAU - USP, 2001.

. "Decifrando mapas: sobre o conceito de "território"e suas vinculações com a cartografia”. In Anais do Museu Paulista. Vol. 12 (jan - dez). São Paulo, 2004. pp. 193 - 234.

- "Dilatação dos confins: caminhos, vilas e cidades na formação da capitania de São Paulo (1532 - 1822)”. In Anais do Museu Paulista. Vol 17 (jul - dez). São Paulo, 2009. pp. $251-294$.

. "A iconografia dos engenheiros militares no século XVIII: instrumento de conhecimento e controlo de território”. In Universo Urbanístico português (1415 - 1822). Lisboa, Comissão Nacional para as comemorações dos Descobrimentos portugueses, 1998. p. $89-118$.

. "A cidade como negócio: mercado imobiliário em São Paulo no século XIX”. In FRIDMAN, Fania; ABREU, Mauricio. Cidades latino-americanas: um debate sobre a formação de núcleos urbanos. Rio de Janeiro, Casa da Palavra, 2010. p. 160.

CABRAL, Maria do Socorro Coelho. Os caminhos do gado. São Luís, Siorge, 1992. 265 p.

CALVINO, Ítalo. As cidades invisíveis. São Paulo, Cia. das Letras, 1990. 150 p.

CANIGGIA, Gianfranco; MAFFEI, Gian Luigi. Composizione architettonica e tipologia edilizia: lettura dell'edilizia di base. Vol 1. 9 ed. Venezia, Marsílio Editori, 1995. pp. 122 203.

CÂMARA, Epaminondas. Municípios e freguesias da Paraíba: notas acerca da divisão administrativa, jurídica e eclesiástica. Campina Grande, Edições Caravelas, 1997.

CAMPOS, Hélcio Ribeiro. Transformações urbanas recentes em Tiradentes - MG: anos 80 e 90 do século XX. Dissertação de mestrado. São Paulo, FFLCH, 2006. 
CARVALHO JR. Dagoberto Ferreira. Passeio a Oeiras. 6 ed. Teresina, Fundação Cultural do Piauí, 2010. 202 p.

CASTELO BRANCO, José Moreira Brandão. "Igrejas e freguesias no Rio Grande do Norte". In RIHGB. Volume 215 (abr - jun). Rio de Janeiro, 1953. pp. 3 - 10.

CASTRO, Josué de. Geografia da fome. 6 ed. Rio de Janeiro, Civilização Brasileira, 2006. $318 \mathrm{p}$.

CASTRO, José Liberal de. "Urbanização pombalina no Ceará: a paisagem da vila de Montemor - o - Novo d'América". In Revista do Instituto do Ceará. Ano CXIII. Fortaleza, 1999. p. 43.

CAUQUELIN, Anne. A invenção da paisagem. São Paulo, Martins Fontes, 2007. 196 p.

CHICÓ, Mário. A cidade ideal do Renascimento e as cidades portuguesas da Índia. S.1.p., s.c.p., s.d. (microfilme).

CORREA, Antonio Bonet. "La ciudad y el arte en Iberoamerica". In America siglos XVIII $X X$. III Simpósio sobre el V centenário del Descubrimiento de América. Madrid, Turner, 1989.

El urbanismo en España e Hispanoamérica. Madrid, Ediciones Cátedra S.A., 1991.

COSTA, Lucio. “A arquitetura jesuítica no Brasil.” In Revista do Serviço do Patrimônio Histórico e Artístico Nacional. vol. 5. Rio de Janeiro, 1941. pp. 11 - 98.

CRUZ, Glenda Pereira. "Rural e urbano espaços da expansão medieval: origem da organização espacial Ibero-Americana?’. In Universo Urbanístico Português (1415 - 1822). Lisboa, Comissão Nacional para as Comemorações dos Descobrimentos Portugueses, 1998. pp. $157-203$.

CUNHA, Euclides da. Os sertões. 3 ed. São Paulo, Martin Claret, 2009. 637 p.

CARVALHO Jr., Dagoberto Ferreira de. Passeio a Oeiras. 6 ed. Teresina, Fundação Cultural do Piauí, 2010. 202 p. 
D’ALENCASTRE, José Martins Pereira. “Memória Choronologica, Histórica e Corographica da Província do Piauí”. in Revista do Instituto Histórico e Geographico Brazileiro. Tomo XX. Rio de Janeiro, 1857. p. $48-61$.

DAMASCENO, Darcy; CUNHA, Waldir da. "Os manuscritos do botânico Freire Alemão". In Anais da Biblioteca Nacional do Rio de Janeiro. Vol 81. Ano 1961. Rio de Janeiro, Fundação da Biblioteca Nacional, 1964. p. 25 - 26.

DANTAS, Beatriz G.; SAMPAIO, José Augusto; CARVALHO, Maria Rosário G. de. "Os povos indígenas no Nordeste brasileiro: um esboço histórico". In História dos índios no Brasil. São Paulo, Companhia das Letras, 1992. p. 431 - 456.

DEFFONTAINES, Pierre. Como se constituiu no Brasil a rede das cidades. Boletim Geográfico. Rio de Janeiro, IBGE, 1944. 34 p.

DELSON, Roberta Marx. Novas vilas para o Brasil colônia: planejamento espacial e social no século XVIII. Brasília, Ed. Alva-Ciord, 1997. 124 p.

DERNTL, Maria Fernanda. Método e arte: criação urbana e organização territorial na capitania de São Paulo (1765 - 1811). Tese de doutoramento. São Paulo, FAU - USP, 2010. $225 \mathrm{p}$.

“DICIONÁRIO da arte barroca em Portugal”. Paulo Pereira (coord.). Lisboa, Editorial Proença, 1989.

DINIZ, Nathália Maria Montenegro. Velhas fazendas da Ribeira do Seridó. Dissertação de mestrado. São Paulo, FAU USP, 2008. 205 p.

DOMINGUES, Ângela. "O Brasil no relato dos viajantes ingleses do século XVIII: produção de discursos sobre o Novo Mundo." In Revista Brasileira de História. V. 28. № 55. São Paulo, 2008.

DOURADO, José Ribamar; BOCLIN, Roberto Guimarães. A indústria do Maranhão: um novo ciclo. Brasília, IEL, 2008.

DUARTE JR. Romeu. “Ceará no século XVIII: Icó, Aracati e Sobral”. In Revista Oceanos. n. 41. Lisboa, CNCDP, 2000. pp. $104-118$. 
ENNES, Ernesto. As guerras nos Palmares. Rio de Janeiro, Cia. Editora Nacional, 1938. pp. $349-389$.

FALCI, Miridan Britto. "A cidade de Oeiras do Piaû́”. in Revista do Instituto Histórico de Oeiras. Oeiras, Secretaria de Cultura, 2000. pp. 165 - 205.

FAORO, Raimundo. Os donos do poder: formação do patronato político brasileiro. Rio de Janeiro, Ed.Globo, 1958. 913 p.

FARIAS FILHO, Waldemar Arraes de. Crato: evolução urbana e arquitetura 1740 - 1960. Fortaleza, Expressão Gráfica e Editora, 2007. 272 p.

FEITOSA, Carlos. As gentes dos Inhamuns na criação da Real Vila do Crato. Crato.

FERRARA, Lucrecia D’Alessio. Comunicação, espaço, cultura. São Paulo, Annablume, 2008. 216 p.

FERRAZ, Álvaro. Floresta memórias duma cidade sertaneja no seu cinquentenário. Recife, Secretária de Educação e Cultura, 1957.

FERREIRA, Murilo Cunha (coord.). Cidades do Piauí testemunhas da ocupação do interior do Brasil durante o século XVIII: conjunto histórico e paisagístico de Oeiras - dossiê de tombamento. Teresina, IPHAN/ Regional do Piauí, 2010.

FIGUEIREDO FILHO, José. História do Cariri. Vol. III/IV. Crato, FFCrato, 1968.

FONSECA, Cláudia Damasceno. "Funções, hierarquias e privilégios urbanos: a concessão dos títulos de vila e cidade na Capitania de Minas Gerais". In Varia História. n. 29. Belo Horizonte, Depto. História da Fafich, 2003. pp. 39 - 51.

. "Do arraial à cidade: a trajectória de Mariana no contexto do urbanismo colonial português.” In Universo Urbanístico Português (1415 - 1822). Lisboa, Comissão Nacional para as Comemorações dos Descobrimentos Portugueses, 1998. pp. 269 - 482.

FLEXOR, Maria Helena Ochi. “Cidades e vilas pombalinas no Brasil do século XVIII.” In Universo Urbanístico Português (1415 - 1822). Lisboa, Comissão Nacional para as Comemorações dos Descobrimentos Portugueses, 1998. pp. 257 - 266. 
FLEXOR, Maria Helena Ochi. "Núcleos urbanos planeados do século XVIII e a estratégia de civilização dos índios do Brasil”. In Cultura portuguesa na Terra de Santa Cruz. Maria Beatriz Nizza da Silva (coord.). Lisboa, Ed. Estampa, 1995. pp. 79 - 88.

. "Núcleos urbanos criados por Pombal no Brasil do século XVIII". In Anais do IV

Seminário de História da Cidade e do Urbanismo. Denese B. Pinheiro (Org.). Rio de Janeiro, UFRJ/PROURB, 1996. Vol 01. p. 603.

FRIDMAN, Fania. "Breve história do debate sobre a cidade colonial brasileira". in Cidades latino-americanas: um debate sobre a formação de núcleos urbanos. Fania Fridman e Mauricio de Abreu (org.). Rio de Janeiro, Casa da Palavra, 2010. pp. 11 - 36.

."Freguesias do Rio de Janeiro ao final do século XVIII". In Anais do II Encontro Internacional de História Colonial. Disponível em http://www.cerescaico.ufrn.br/mneme/anais. Acesso em 23.09.2010.

- Donos do Rio em nome do rei: uma história fundiária da cidade do Rio de Janeiro. 2 ed. Rio de Janeiro, Editora Garamond, 1999. 302 p.

FONTANA, Riccardo. As obras dos engenheiros militares Galluzzi e Sambuceti e do arquiteto Landi no Brasil colonial do século XVIII. Brasília, Senado Federal, Conselho Editorial, 2009. 104 p.

FREYRE, Gilberto. Casa grande e senzala: formação da família brasileira sob o regime da economia patriarcal. 48 ed. São Paulo, Global, 2003.

GALLIZA, Diana Soares de. “As economias açucareira e criatória (pecuária) no Nordeste brasileiro à época colonial: estudo comparado". In Revista do Instituto Histórico e Geográfico Paraibano. Ano LXXVII. Vol. 24. João Pessoa, 1986. pp. 141 - 150.

GANDAVO, Pero Magalhães de. Tratado da terra do Brasil; História da província de Santa Cruz. São Paulo, Edusp, 1980. 207 p.

GASPAR, Jorge. As feiras de gado na beira litoral. Lisboa, Chorographica, 1970.

GATTI, Agatha Francesconi. O trâmite da fé: a atuação da Junta das Missões de Pernambuco (1681 - 1759). Dissertação de mestrado. São Paulo, FFCLH - USP, 2010. 
GIORDANO, Cláudio (coord.). Escritos instrumentais sobre os índios. São Paulo, EDUC/Loyola/Giordano, 1992. p. 122-190

GIRÃO, Raimundo. Bandeirismo baiano e povoamento do Ceará. Fortaleza, Ed. Instituto do Ceará, 1949. 20 p.

GIRÃO, Valdelice Carneiro. As oficinas ou charqueadas no Ceará. Fortaleza, 1995. . “As charqueadas”. In Revista do Instituto do Ceará. Tomo CX. Fortaleza, 1996.

GOMES, Luís Miguel Martins. "Geometria no traçado de praças, teoria versus prática, no tempo de Pombal". In TEIXEIRA, Manuel C. A praça na cidade portuguesa. Lisboa, Livros Horizontes, 2001.

GOITIA, Fernando Chueca. Breve historia del urbanismo. Madrid, Alianza Editorial S.A, 1968.

GOULART, José Alípio. “A formação da zona pecuária nordestina”. In Revista do Instituto Histórico e Geográfico Brasileiro. Vol. 29 (abril - junho). Rio de Janeiro, Imprensa Nacional, 1963. pp. $16-26$.

. O ciclo do couro no Nordeste. Rio de Janeiro, Ministério da Agricultura, 1966.

. Brasil do boi e do couro. 2 vol. ( o couro). Rio de Janeiro, Edições GRD, 1966. $120 \mathrm{p}$.

GROPIUS, Walter. "El corazón de la ciudad por una vida más humana de la comunidad". In Congreso Internacional de Arquitectura Moderna. 2 ed. Bacelona, 1961.

GUERRA, Flávio. Evolução histórica de Pernambuco. Vol 1. Recife, Cia. Editora de Pernambuco, 1970. 264 p.

GUTIÉRREZ, Ramón. "Povoados e reduções indígenas na região de Cuzco: persistências e inovações". In Cidades latino-americanas: um debate sobre a formação de núcleos urbanos. Fania Fridman e Mauricio de Abreu (org.). Rio de Janeiro, Casa da Palavra, 2010. pp. 37 61. 
GUTIÉRREZ, Ramón. "Reflexione para una Metodologia de Análisis Del Barroco Americano”. In Simposio Internazionale sul Barocco Latino Americano, Atti Del Simposio. Roma, Instituto Ítalo Latino Americano, 1982. pp. 367 - 385.

HARDOY, Jorge E. "La forma de las ciudades coloniales en la America española". SOLANO, Francisco (coord.). Estudios sobre la ciudad iberoamericana. Madrid, Consejo Superior de Investigaciones Científicas - Instituto Gonzalo Fernandez de Oviedo, 1983. p. $315-344$.

HAUBERT, Maxime. Índios e jesuítas no tempo das missões. São Paulo, Companhia das Letras, $1990.313 \mathrm{p}$.

HEIDEGGER, Martin. "Construir, habitar, pensar." In Vortäge und Ausfätze. Conferencia pronunciada por ocasião da Segunda Reunião de Darmastad. Pfullingen, 1954.

. A origem da obra de arte. Lisboa, Edições 70, 2004. 73 p.

HOLANDA, Sérgio Buarque. Caminhos e fronteiras. 3 ed. São Paulo, Companhia das Letras, 1994. $301 \mathrm{p}$.

Raízes do Brasil. 6 ed. Rio de Janeiro, José Olympio, 1957. 583 p.

. Visões do Paraíso. São Paulo, Companhia das Letras, 2010. p. 48.

História da civilização brasileira. vol II. Tomo I. São Paulo, Difusão Européia do Livro, 1960.

HORNAERT, Eduardo. História da Igreja no Brasil: ensaio de interpretação a partir do povo. Primeira época, período colonial. 5 ed. Petrópolis, Editora Vozes, 2008. 442 p.

"INVENTÁRIO do Patrimônio Cultural do Estado de Pernambuco: sertão pernambucano do São Francisco”. Recife, Fundação do Patrimônio Histórico e Artístico de Pernambuco FUNDARPE, 1985. p. 215 - 216

KERN, Arno Alvarez. Missões: uma utopia política. Porto Alegra, Mercado Aberto, 1972. $275 \mathrm{p}$. 
KNOX, Miridan Brito. O Piauí na primeira metade do século XIX. Teresin, Projeto Petrônio Portella, 1992. 129 p.

KOSSOY, Boris. Fotografia \& história. 2 ed. São Paulo, Ateliê Editorial, 2001. 173 p. Os tempos da fotografia: o efêmero e o perpétuo. Cotia - SP, Ateliê Editorial, 2007.

KOSSOY, Boris. Realidades e ficções na trama fotográfica. Cotia - SP, Ateliê Editorial, 2002.

LACOMBE, J.A. "Ordens religiosas, irmandades e confrarias". In RIHGB. Vol. 288 (jul set). Rio de Janeiro, 1971. pp. $69-80$.

LAMAS, José M.R. Garcia. Morfologia e desenho da cidade. Lisboa, Fundação Calouste Gulbenkian, 1992. 564 p.

LE GOFF, Jacques. O apogeu da cidade medieval. São Paulo, Martins Fontes, 1992. 235 p. . "Memória". in Enciclopédia Einaudi. vol. 1 (Memória - História). Lisboa, Imprensa Nacional - Casa da Moeda, 1984. pp.11 - 47.

LEITE, Serafim. História da Companhia de Jesus no Brasil. Tomos II, III e V. Rio de Janeiro, Civilização Brasileira, 1938.

Luiz Figueira: sua vida heróica e a sua obra literária. Lisboa, Agencia Geral das Colônias, 1940.

. “João de Barros, lisboeta, apóstolo dos Quiriris e Acareses". In Congresso do Mundo Português. Vol. IX. Lisboa, Comissão Executiva do Centenário, 1940. P. 473 - 481.

LEPETIT, Bernard. Por uma nova história urbana. Heliana Angotti Salgueiro (org.). São Paulo, Edusp, 2001. 323 p.

LIMA, Ebion de. “As missões oratorianas no Brasil”. In RIHGB. Vol. 300 (jan - abr). Rio de Janeiro, 1983. pp. $69-92$. 
LIMA, Ruy Cirne. Pequena história territorial do Brasil: sesmarias e terras devolutas. 2 ed. Porto Alegre, Sulina, 1954. 110 p.

LOPES, Fátima Martins. Em nome da liberdade: as vilas de índios do Rio Grande do Norte sob o diretório pombalino do século XVIII. Tese de doutorado. Recife, UFPE, 2005. 700 p.

MAGALHÃES, Basílio de. Expansão geográfica do Brasil colonial. 3 ed. Rio de Janeiro, Epasa, 1944.

MAIA, Ligio José de Oliveira. Serras de Ibiapaba: de aldeia à vila de Índios - vassalagem e identidade no Ceará colonial (século XVIII). Tese de doutoramento. Niterói, UFF, 2010. 409 p.

MALHEIROS, Agostinho Perdigão. A escravidão no Brasil: ensaio histórico e jurídico. Petrópolis, Editora Vozes, 1944.

MARIANI, Anna. Pinturas e platibandas. 2 ed. São Paulo, Instituto Moreira Salles, 2010. $239 \mathrm{p}$.

MARTINS, Renata Maria de Almeida. Tintas da terra, tintas do reino: arquitetura e arte nas Missões Jesuíticas do Grão-Pará (1653 - 1759).Tese de doutoramento. São Paulo, FAUUSP, 2009. 483 p.

MARTINS, Vicente. "O hospício dos jesuítas de Ibiapaba”. In Revista do Instituto do Ceará. vol XLIII. Fortaleza, 1930. p. 158.

MARX, Murillo. “Olhando por cima e de frente". In Revista da USP. Junho - Agosto. São Paulo (30), 1996. pp. $170-181$.

. "Das tulhas, pelos trilhos, aos trapiches". In Cidades latino-americanas: um debate sobre a formação de núcleos urbanos. Fania Fridman e Mauricio de Abreu (org.). Rio de Janeiro, Casa da Palavra, 2010. pp. 167 - 179.

. Cidade brasileira. São Paulo, Melhoramentos, 1980. 151 p.

. Cidades no Brasil, em que termos? São Paulo, Studio Nobel, 1999. 143 p.

. Cidade no Brasil: terra de quem? São Paulo, Edusp / Nobel, 1991. 143 p. 
MARX, Murillo. Seis conventos, seis cidades. Tese de doutoramento. São Paulo, FAU-USP, 1984. $213 \mathrm{p}$.

. Nosso chão: do sagrado ao profano. São Paulo, Edusp, 1989. 219 p.

. "Olhando por cima e de frente". In Revista da USP. n³0. Junho / Agosto. São

Paulo, 1996. pp. $170-181$.

MEDEIROS, Maria do Céu. Os oratorianos de Pernambuco: uma congregação “a serviço”do estado português. Dissertação de mestrado. Recife, CFCH - UFPE, 1981.

MELLO, Ceres Rodrigues. "O sertão nordestino e suas permanências (séc. XVI - XIX)". In Revista do Instituto Histórico e Geográfico Brasileiro. v. 148. n. 356 (julho - setembro). Rio de Janeiro, 1987. pp. $283-365$.

MELLO, Magno; LEITÃO, Henrique. “A pintura barroca e a cultura matemática dos jesuítas: o Tractado de Prospectiva de Inácio Vieira, S. J. (1715). In Revista de História da Arte. ํo 01. Lisboa, Instituto de História da Arte - Faculdade de Ciências Sociais e Humanas (UNL), 2005. p. $95-141$.

MELO NETO, João Cabral de. 4 ed. Rio de Janeiro, Editora Fronteira, 2002. 163 p.

MELlO NETO, José Antônio Gonsalves de. Três roteiros de penetração do território pernambucano (1733 e 1802). Recife, UFPE, 1966. 41 p.

MENESES, Ulpiano T. Bezerra de. "Fontes visuais, cultura visual, história visual. Balanço provisório, propostas cautelares." In Revista Brasileira de História. Vol. 23. n. 45. São Paulo, 2003. pp. $11-36$.

MORAES, Carla Gisele Macedo Santos Martins. Areia - Paraíba: morfologia e desenvolvimento urbano (séculos XVIII, XIX e XX). Dissertação de mestrado. Recife, MDU UFPE, 2008. 223 p.

MORAES, Fernanda Borges de. A rede urbana das Minas coloniais: na urdidura do tempo e do espaço. Tese de doutoramento. São Paulo, FAU - USP, 2005. 
MOREIRA, Rafael. "A arte da ruação e a cidade Luso-brasileira”. in Cadernos de pesquisa LAP. n. 37 (jan-jun). São Paulo, FAU - USP, 2003. pp. 5 - 31.

. História das fortificações portuguesas no mundo. Lisboa, Alfa, 1989. Vol II. p. 269.

MOREIRA, Vicente Deocleciano. "Caminhos históricos da feira de Feira de Santana: origens e secularidade”. In Sitientibus. n 10. Jul/dez. Feira de Santana, 1992.

MOTT, Luiz R. B. Piauí colonial: população, economia, sociedade. Teresina, Projeto Petrônio Portella, 1985. 144 p.

MOTA, Aroldo. “Município de Tauá: origem”. In Revista do Instituto do Ceará. Ano CXV. Fortaleza, 2001.

NICÉAS, Alcides. Aboio: um ritual agreste. Recife, Fundaj - Centro de Estudos Folclóricos, 1979. (Folclore, $\mathrm{n}^{\circ}$ 93).

NETO, Clovis Ramiro Jucá. A urbanização do Ceará setecentista: as vilas Nossa Senhora da Expectação do Icó e de Santa Cruz do Aracati. Tese de doutoramento. Salvador, UFBA, 2007. $531 \mathrm{p}$.

NEVES, André Lemoine. A transferência da cidade portuguesa para o Brasil (1532 - 1640). Tese de doutoramento. Recife, MDU - UFPE, 2009. 357 p.

NOVAIS, Fernando A. Portugal e Brasil na crise do antigo sistema colonial (1777 - 1808). 6 ed. São Paulo, Hucitec, 1995. 420 p.

NUNES, Odilon. Pesquisa para a história do Piauí. vol. 1. 2 ed. São Cristóvão - RJ, Ed. Artenova, 1975.

OLIVEIRA, José do Carmo. Bicentenário da paróquia de Nossa Senhora das Mercês de Jaicós - Piauí (1805 - 2005). Jaicós, 2005. Artigo disponível em http://www.jaicos.com. Acesso em 14/07/2009.

OLIVEIRA, Miguel de, padre. História eclesiástica de Portugal. Lisboa, União, 1940. 
OLIVEIRA, Perdigão. “A villa de Quixeramombim”. In Revista do Instituto do Ceará. Anno IV. Fortaleza, 1890.

PANERAI, Phillippe. Elementos de analisis urbano. Madrid: Instituto de Estudios de Administración local, 1983. 280p.

PARAÍSO, Maria Hilda Baqueiro. Os capuchinhos e os índios do sul da Bahia: uma análise preliminar de sua atuação. São Paulo, Museu Paulista, 1986. p. 151.

PEIXOTO, Tatiana da Cunha. Os mandarins do sertão: os criadores de gado do São Francisco (1650 - 1750). Dissertação de mestrado. Belo Horizonte, UFMG, 2006. 130 p.

PERRONE-MOISÉS, Beatriz. "Índios livres e índios escravos: os princípios da legislação indigenista do período colonial (séculos XVI a XVIII). In História dos índios no Brasil. São Paulo, Companhia das Letras, 1992. p. 115 - 132.

PIDAL, Ramón Menéndez. El siglo del Quijote: 1580 - 1680. Vol II. Madrid, Espasa, 1996.

PINHO, Wanderley. História de um engenho do Recôncavo, 1552 - 1944. Rio de Janeiro, Livraria Editora, 1946.

PIRENNE, Henri. As cidades da idade média. 4 ed. São Paulo, Coleção Saber, 1977. 177 p.

POMPA, Maria Cristina. Religião como tradução: missionários, Tupi e Tapuias no Brasil colonial. Tese de doutoramento. Campinas, IFCH - UNICAMP, 2001. 461 p.

POMPEU, Thomaz. "A população do Ceará”. in Revista do Instituto do Ceará. Ano III. Fortaleza, 1889.

POPPINO, Rollie E. Feira de Santana. Trad. Arquimedes Pereira Guimarães. Salvador, Ed. Itapuã, 1968.

PORTAS, Nuno. "Algumas (hipó)teses sobre o urbanismo português no Brasil". In TEIXEIRA, Manuel (org.). A construção da cidade brasileira. Lisboa, Livros Horizonte, 2004.

PRADO Jr., Caio. Formação do Brasil contemporâneo: colônia. São Paulo, Brasiliense, 1999. $390 \mathrm{p}$. 
PRADO Jr., Caio. História econômica do Brasil. São Paulo, Brasiliense, 2008. 364 p.

PRIMEIRO, P. Fr. Fidelis M. de. Capuchinhos em Terra de Santa Cruz nos séculos XVII, XVIII e XIX. São Paulo, Livraria Martins, 1942. 392 p.

PUNTONI, Pedro. A guerra dos Bárbaros: povos indígenas e a colonização do sertão do Nordeste do Brasil, 1650 - 1720. São Paulo, Hucitec, 2002. 323 p.

QUEIROZ, Raquel de. O quinze. São Paulo, Cia. Editora Nacional, 1942. 217 p.

RAU, Virgínia. Estudos de história medieval. Lisboa, Editorial Proença, 1986. . Subsídios para o estudo das feiras medievais portuguesas. Lisboa, 1943. 180 p.

REGO, Junia Motta Antonaccio Napoleão do. Dos sertões aos mares: história do comércio e dos comerciantes de Parnaíba (1700-1950). Tese de doutoramento. Niterói, UFF, 2010.

REIS FILHO, Nestor Goulart. Quadro da arquitetura no Brasil. 2 ed. São Paulo, Editora Perspectiva, 1973. $211 \mathrm{p}$.

. "Notas sobre o urbanismo no Brasil. Primeira parte: período colonial." In Universo Urbanístico Português (1415 - 1822). Lisboa, Comissão Nacional para as Comemorações dos Descobrimentos Portugueses, 1998. pp. 485 - 505.

. Contribuição ao estudo da evolução urbana do Brasil: 1500 - 1720. São Paulo, Pioneira / Edusp, 1968. 235 p.

. "As principais cidades e vilas do Brasil - importância da vida urbana colonial". In Oceanos. n41 (Jan/Mar, 2000). Lisboa, Comissão Nacional para as comemorações dos Descobrimentos Portugueses, 2000.

. "Notas sobre a evolução dos estudos de história da urbanização e do urbanismo no Brasil". in Cadernos de pesquisa do LAP. n² 29. Jan/Jun. São Paulo, FAU USP, 1999.

RIBEIRO Jr., José. Colonização e monopólio no Nordeste brasileiro: a Companhia Geral de Pernambuco e Paraíba, 1759 - 1780. São Paulo, Hucitec, 2004. 
RODRIGUES, Isabel Vieira. "A política de Francisco Xavier de Mendonça Furtado no Norte do Brasil (1751 - 1759). In Revista Oceanos. n. 40 (out/dez). Lisboa, Comissão Nacional para as Comemorações dos Descobrimentos Portugueses, 1999.

RONCAYOLO, Marcel. "Cidade". In Enciclopédia Einaudi. Vol 8 (Região). Lisboa, Imprensa Nacional - Casa da Moeda, 1984. pp. 396 - 481.

ROSA, Guimarães. Grande sertão: veredas. Rio de Janeiro, Nova Fronteira, 2006. 553 p.

ROSSA, Walter. "O urbanismo regulado e as primeiras cidades coloniais portuguesas." In Universo Urbanístico Português (1415 - 1822). Lisboa, Comissão Nacional para as Comemorações dos Descobrimentos Portugueses, 1998.

. "A cidade portuguesa". In A urbe e o traço. Uma década de estudos sobre o urbanismo português. Coimbra, Ed. Livraria Almedina, 2002.

RUSSEL-WOOD, A.J.R. "Fronteiras no Brasil colonial”. In Oceanos. $\mathrm{n}^{\circ}$ 40, Outubro/Dezembro. Lisboa, Comissão Nacional para as Comemorações dos Descobrimentos de Portugueses, 1999. p. $10-20$.

SAIA, Luis. "O alpendre nas capelas brasileiras." In Revista do Serviço do Patrimônio Histórico e Artístico Nacional. vol. 5. Rio de Janeiro, MEC, 1944. p. 101 - 113.

SALEMA, Vasco da Costa. Pelourinhos do Brasil. Lisboa, Sociedade Acadêmica da Independência de Portugal, 1982.

SALVADOR, frei Vicente do. História do Brasil: 1500-1627. 7 ed. São Paulo, Edusp, 1982. $437 \mathrm{p}$.

SANTANA, Mario Pires. "De Nossa Senhora do Monserrath". In Paranaíba de A a Z: guia afetivo. José de Nicodemos Alves Ramos. (org.). Brasília, Multicultural Arte e Comunicação, 2008.

SANTOS, Eugénio dos. "Pombal e os oratorianos". In Revista Camões. n” 15/16. Lisboa, 2003. p. $75-86$. 
SANTOS, Fabiano Vilaça dos. "Uma vida dedicada ao real serviço: João Pereira Caldas, dos sertões do Rio Negro à nomeação para o Conselho Ultramarino (1753 - 1790)". In Varia História. vol 26. n 44. Jul/dez 2010. p. 505. Disponível em http://www.scielo.com. Acesso em 05. 07. 2011.

SANTOS FILHO, Lycurgo. Uma comunidade rural do Brasil antigo (aspectos da vida patriarcal no sertão da Bahia nos séculos XVIII e XIX). São Paulo, Companhia Editora Nacional, 1956. 447 p.

SANTOS, Paulo F. Formação de cidades no Brasil colonial. Coimbra, V Colóquio Internacional de Estudos Luso-Brasileiros, 1968. 125 p.

SANTOS, Milton. A natureza do espaço: técnica e tempo, razão e emoção. 4 ed. São Paulo, Edusp, 2009. 384 p.

SARMENTO, Christiane Finizola. Povoações, freguesias e vilas na Paraíba colonial: Pombal e Sousa, 1697 - 1800. Dissertação de mestrado. Natal, UFRN, 2007.

SEIXAS, Wilson. O velho arraial de Piranhas (Pombal): no centenário de sua elevação a cidade. 1 ed. João Pessoa, A Imprensa, 1962.

SETTE, Hilton. Pesqueira: aspectos de sua geografia urbana e de suas interrelações regionais. Recife, 1956.

SIMONSEN, Roberto C. História econômica do Brasil. 7 ed. São Paulo, Editora Nacional, 1977. $473 \mathrm{p}$.

SILVA, Jacionira Coelho. Arqueologia no médio São Francisco: indígenas, vaqueiros e missionários. Tese de doutoramento. Recife, CFCH -UFPE, 2003.

SILVA FILHO, Olavo Pereira da. Carnaúba, pedra e barro na Capitania de São José do Piahuy. Vol 1 (estabelecimentos rurais), vol 2 (arquitetura urbana), vol. 3 (Urbanismo). Belo Horizonte, Rona, 2007.

SOBRINHO, Barbosa Lima. "Capistrano de Abreu e o povoamento do sertão pernambucano". In Revista do Instituto Arqueológico, Histórico e Geográfico Pernambucano. Vol L. Recife, 1978. 9 - 48. 
SOUZA, Bernardino José de. O ciclo do carro de bois no Brasil. São Paulo, Editora Nacional, 1958. 557 p.

SOUZA, Eusébio de. "Um pouco de história (Chronica de Ipu)". In Revista do Instituto do Ceará. Anno XXIX. Fortaleza, 1915.

STUDART FILHO, Carlos. "Vias de comunicação do Ceará colonial.” In Revista do Instituto do Ceará. Tomo LI. Fortaleza, 1937. p. 15 - 47.

SUASSUNA, Ariano. Romance da pedra do reino e o príncipe do Sangue do Vai - e - volta. 7 ed. Rio de Janeiro, Livraria José Olympio, 2005. 754 p.

SUASSUNA, Luiz Eduardo Brandão. História do Rio Grande do Norte colonial: 1597 1822. Natal, Natal Editora, 1997. 176 p.

TEIXEIRA, Manuel C. "Os modelos urbanos portugueses da cidade brasileira". in TEIXEIRA, Manuel (org.). A construção da cidade brasileira. Lisboa, Livros Horizonte, 2004.

. “As praças urbanas portuguesas quinhentistas.” In TEIXEIRA, Manuel C. A praça na cidade portuguesa. Lisboa, Livros Horizontes, 2001. pp. 69 - 89.

TEIXEIRA, Rubenilson Brazão. "O espaço urbano regular como discurso: as vilas do Rio Grande do Norte na era de Pombal". In Vivência. Vol. 9. Natal, 2005. p. 189 - 206.

TINOCO, Jorge Eduardo Lucena. Conservação da Basílica da Penha: proposta de tombamento. Recife, CECI, 2006. p. 09. Disponível em www.ceci-br.org. Acesso em 14.05.2010.

VASCONCELLOS, Sylvio de. Vila Rica: formação e desenvolvimento, residência. Rio de Janeiro, INL, 1956. 318 p.

. "Formação urbana do arraial do Tejuco". In Revista do Patrimônio Histórico e Artístico Nacional. no 14. Rio de Janeiro, MEC, 1959. p. 121.

VASCONCELOS, Pedro de Almeida. "Complexidade racial: mitos e realidade em duas freguesias de Salvador em 1775”. In Cidades latino-americanas: um debate sobre a formação 
de núcleos urbanos. Fania Fridman e Mauricio de Abreu (org.). Rio de Janeiro, Casa da Palavra, 2010.

VIANA, Urbino. Bandeiras e sertanistas baianos. São Paulo, Companhia Editora Nacional, 1935.

ZEMELLA, Mafalda P. O abastecimento da capitania das Minas Gerais no século XVIII. 2 ed. São Paulo, Edusp, 1990. 247 p. 
ANEXOS 


\section{Anexos}

Estes anexos constam das velhas cartografias adquiridas em nossa Viagem científica pelo sertão nordestino ou através da Fundação Biblioteca Nacional, Arquivo Histórico do Exército Brasileiro, como, pelos sites da fundação supracitada, Biblioteca Nacional de Portugal e Arquivo Nacional da França. A análise dessas cartas foi fundamental para a produção dos mapas e plantas expostos ao longo dos capítulos.

01: MONTEIRO, Domingos. Mapa do interior da capitania do maranham : entre parte daquelas de que ella se divide, formado para mostrar os pontos que a limitão com a de Goiáiz. Ano de produção: 1819. Desenho a nanquim (95 x 60 cm). OD: cart. cart525801.tif. Disponível em http://www.bn.br. Acesso em 18.02.2010.

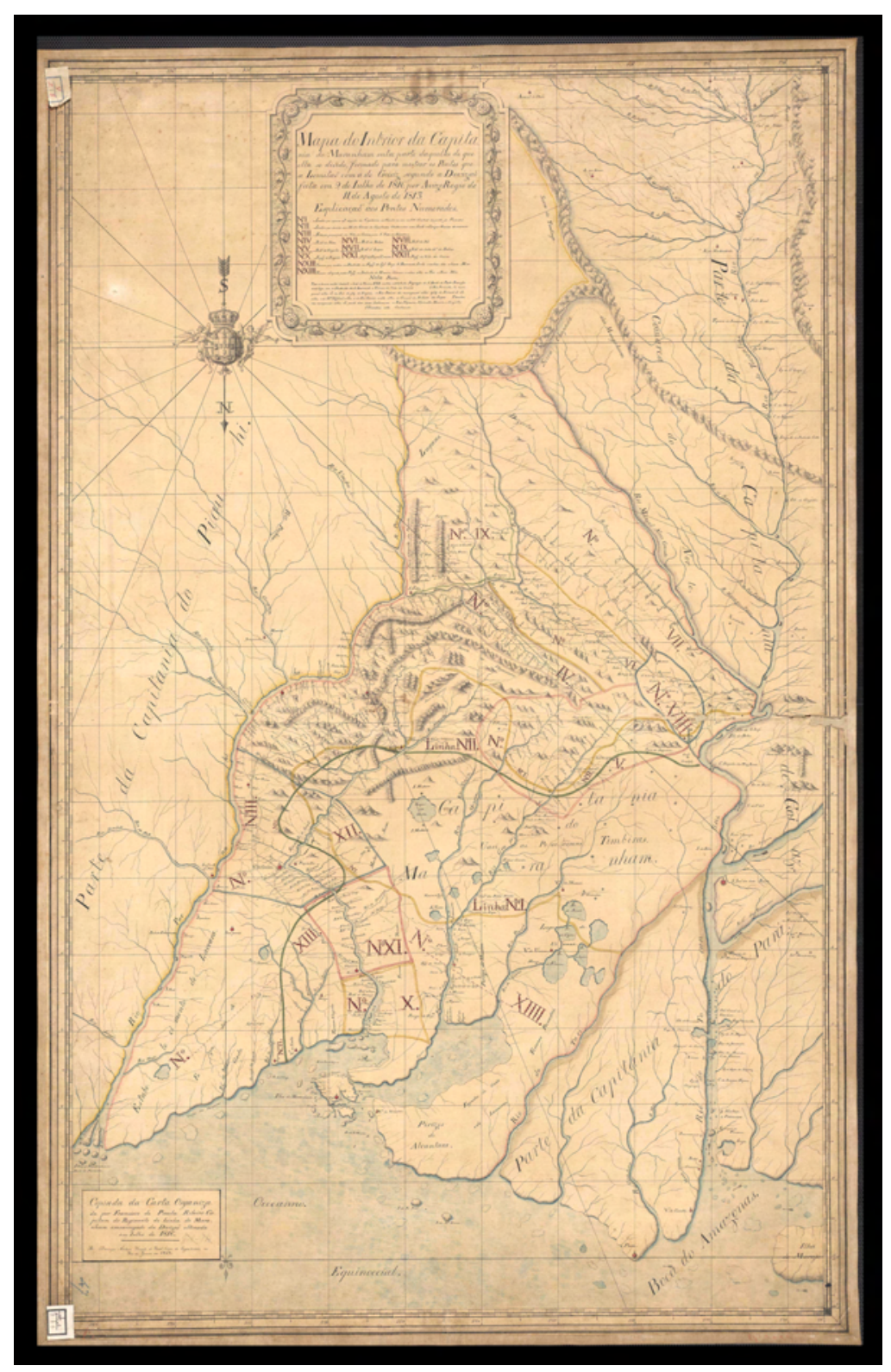


02: RIBEIRO, Francisco de Paula. Mappa geographico da capitania do Maranham: que pode servir de memória sobre a população, cultura, e couzas mais notáveis da mesma capitania. Ano de produção: 1819. Desenho em aquarela 95,5 x 60 cm. OD: cart. 529483.tif. Disponível em http://www.bn.br. Acesso em 18.02.2010.

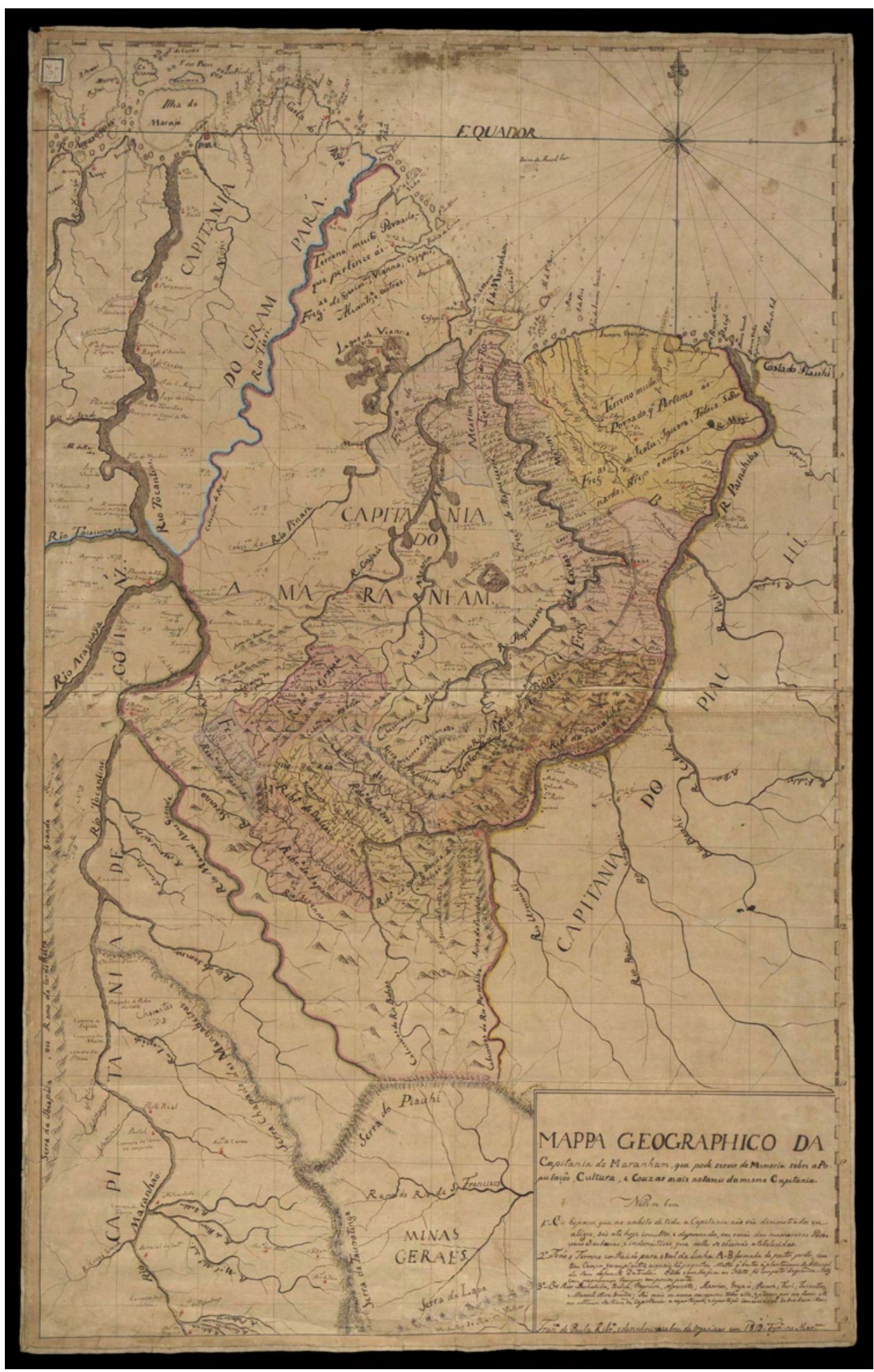


03: MAPPA das Cidades, Villas, Lugares, e Freguezias das Capitanias do Maranhão, e Piauhy com o numero em geral dos ábitantes das ditas Capitanias, e em particular, de cada huma das refridas Povoaçõens, e da distancia em que ficão da capital: vindo pela noticia dos mortos e nascidos, no conhecimento do augmento da populacao desde XIII de Fevereiro de MDCCLXXXIIII, athé XVII de Dezenbro de MDCCLXXXVII. Que foy o tempo que as governou Jozé Telles de Menezes. Ano de produção: 1787. Desenho a tinta nanquim (68 x 48 cm). OD: cart543219.tif. Disponível em http://www.bn.br. Acesso em 03.02.2010.

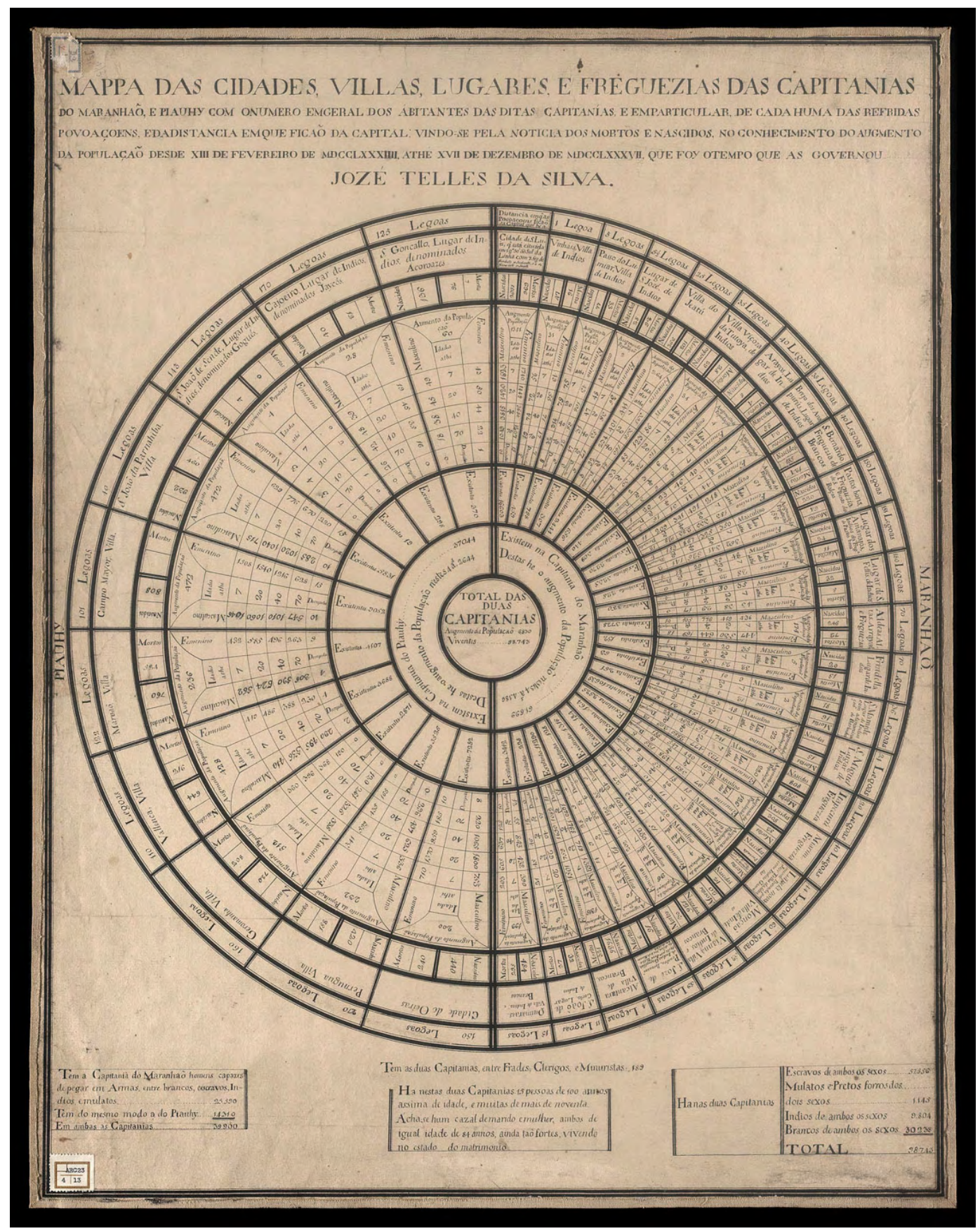


04: PAUlETE, Antonio José da Silva. Carta da Capitania do Ceará. Ano de produção: 1818. Desenho aquarelado (65 x 66 cm). OD: cart 529227.tif. Disponível em http://www.bn.br. Acesso em 22.02.2010.

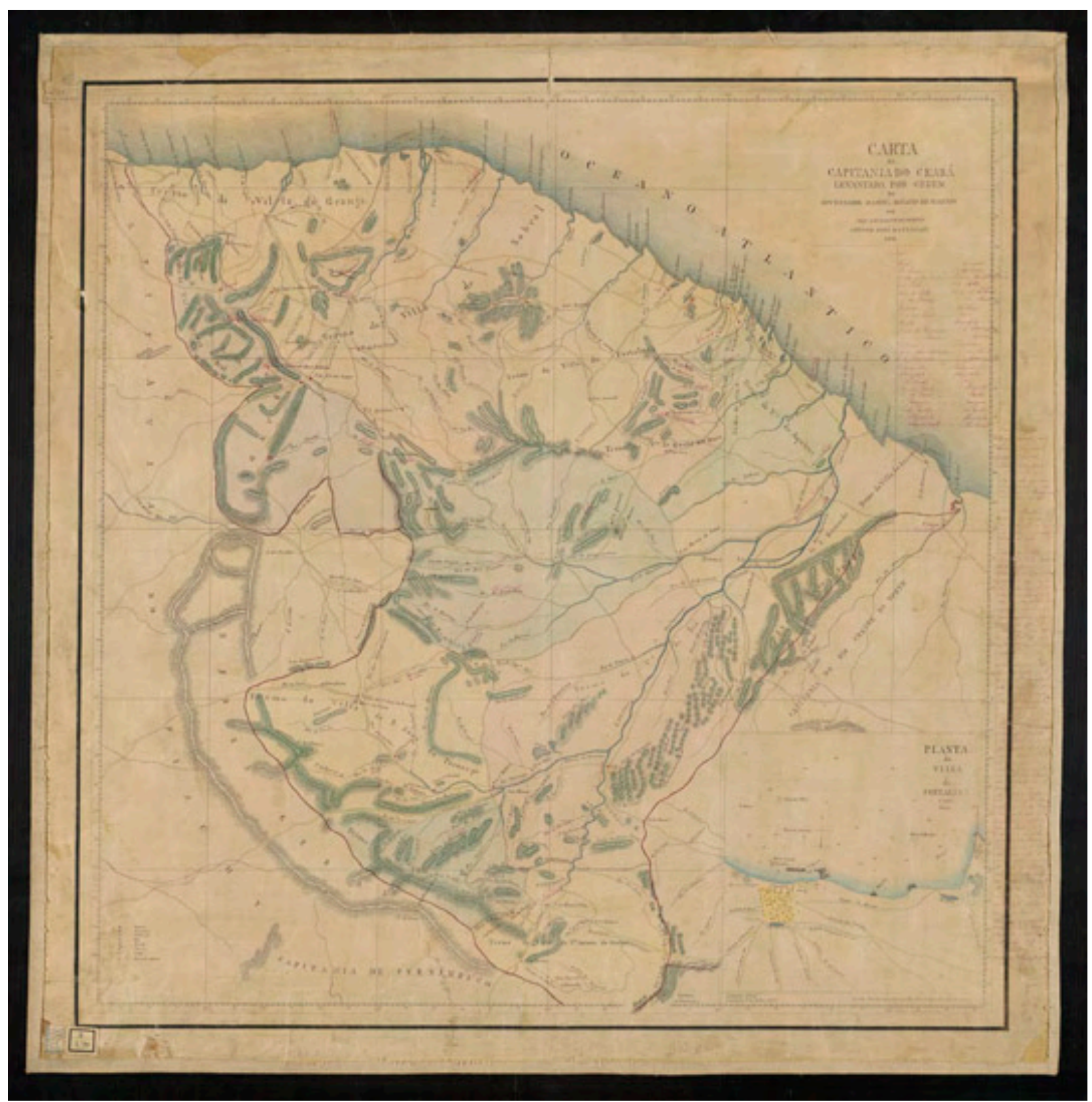


05: THÉBERGE, Pedro. Carta Chorographica da Província do Ceará: com a divisão Ecclesiástica, e indicação da Civil e Judiciária até hoje. Ano de produção: 1861. OD: cart 249878. Disponível em http://www.bn.br. Acesso em 22.02.2010.

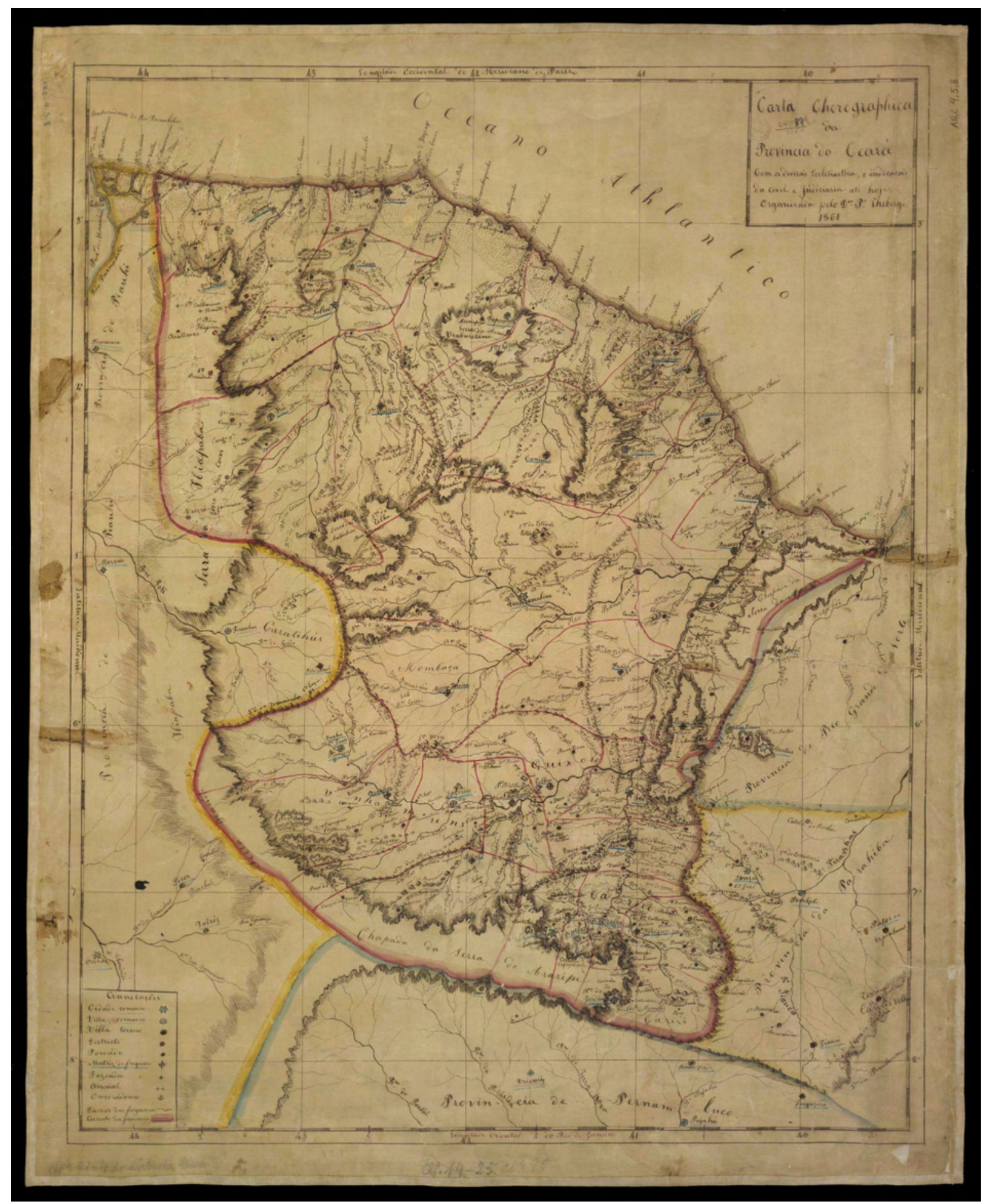


06: MONTENEGRO. Mappa Topographico da Capitania do Rio Grande do Norte: tirado por ordem do Gov. da mesma Capitania José Francisco de Paula Cavalcanti de Albuquerque. Ano de produção: 1811. Desenho a nanquim (50 x 47,7 cm). OD: cart 542340. Disponível em http://www.bn.br. Acesso em 16.04.2010.

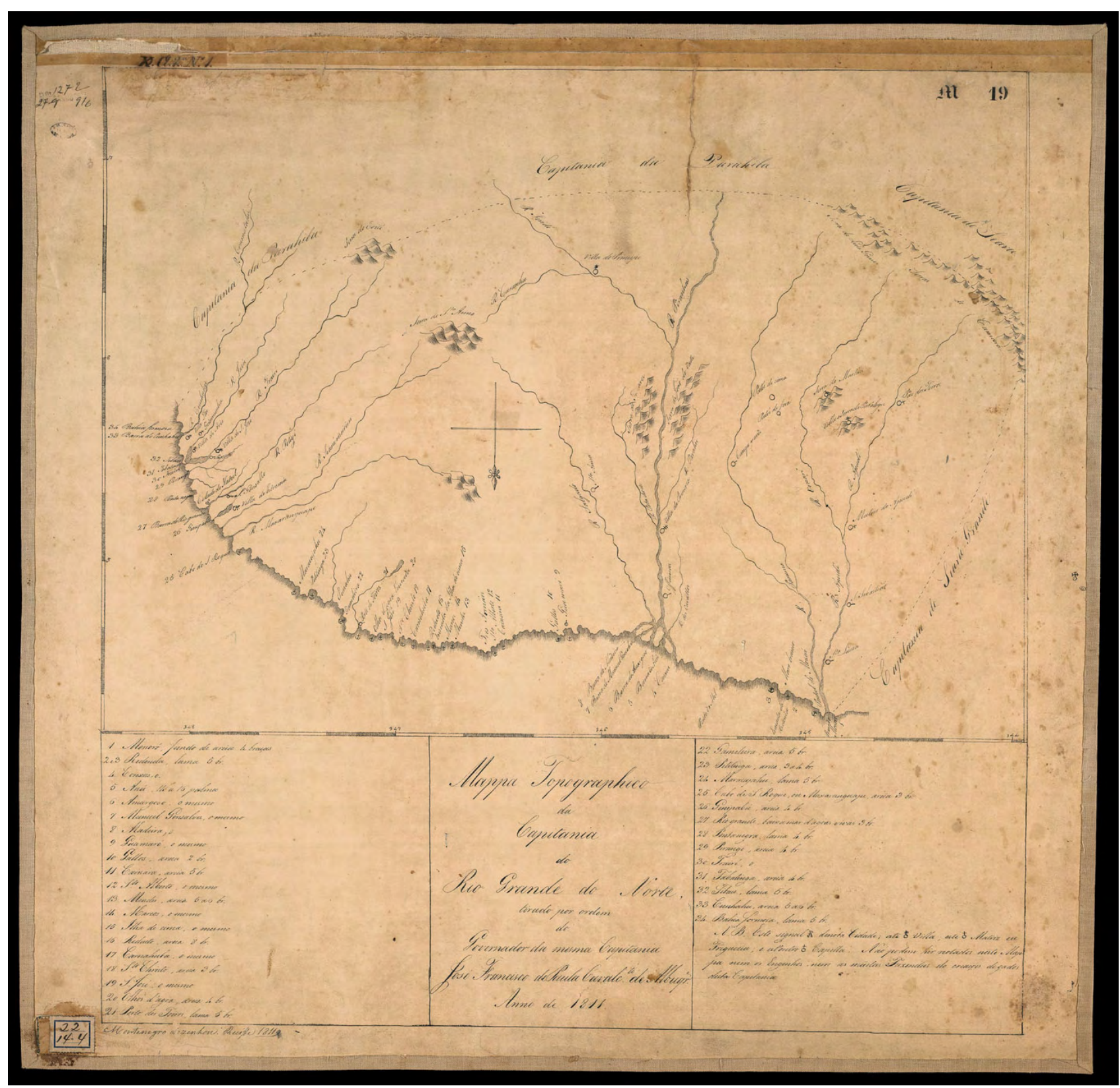


07: SILVA, Francisco Pereira da. Planta da Villa de Pombal. Ano de produção: 1848. Desenho a nanquim, colorido (41 x $31 \mathrm{~cm})$. AHEx - RJ. ID: 03.03.493.

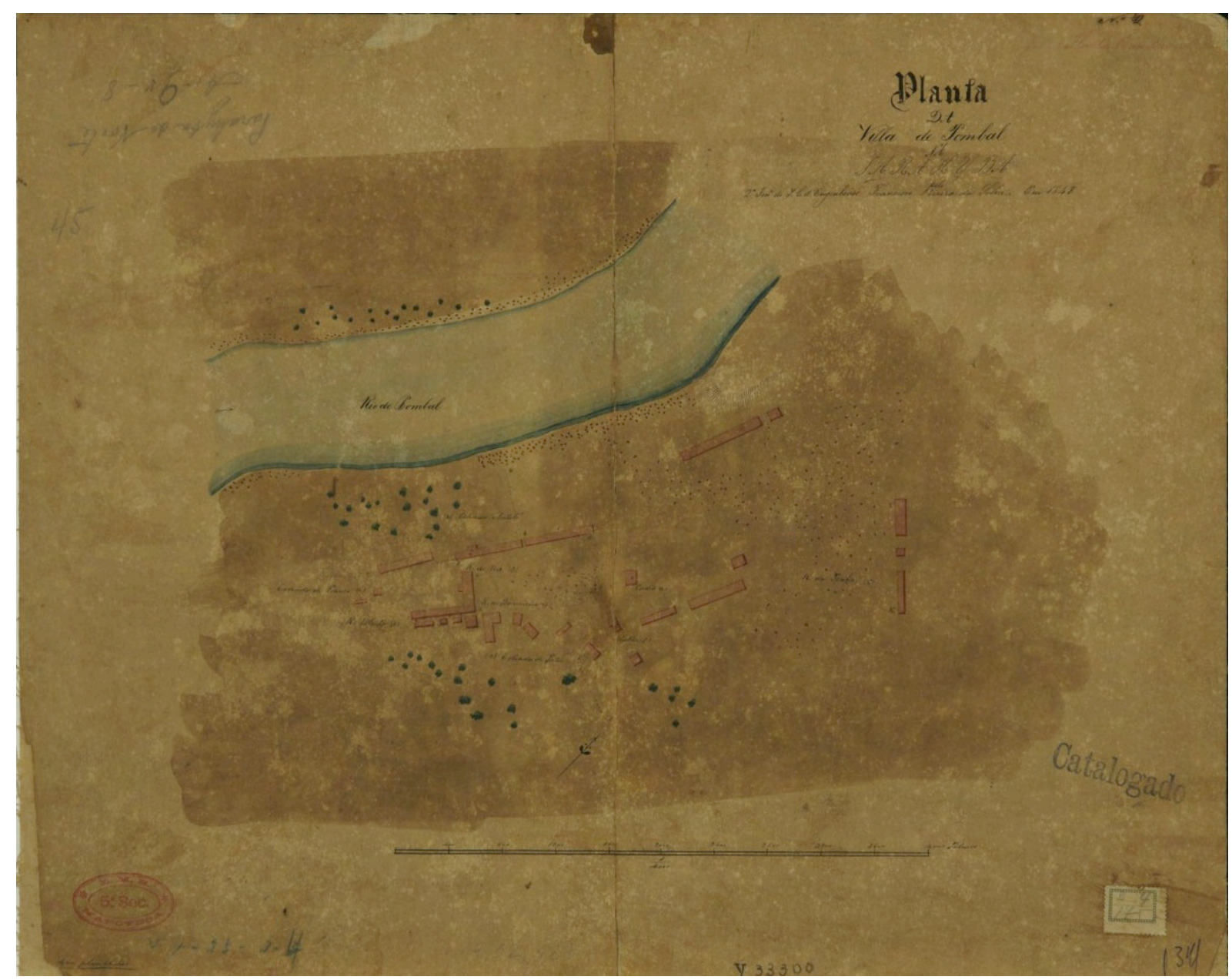


08: SILVA, Francisco Pereira da. Planta da Villa de Souza na Parahyba. Ano de produção: 1848. Desenho a nanquim, colorido (41 x $31 \mathrm{~cm}$ ). AHEx-RJ. ID: 03.02.265.

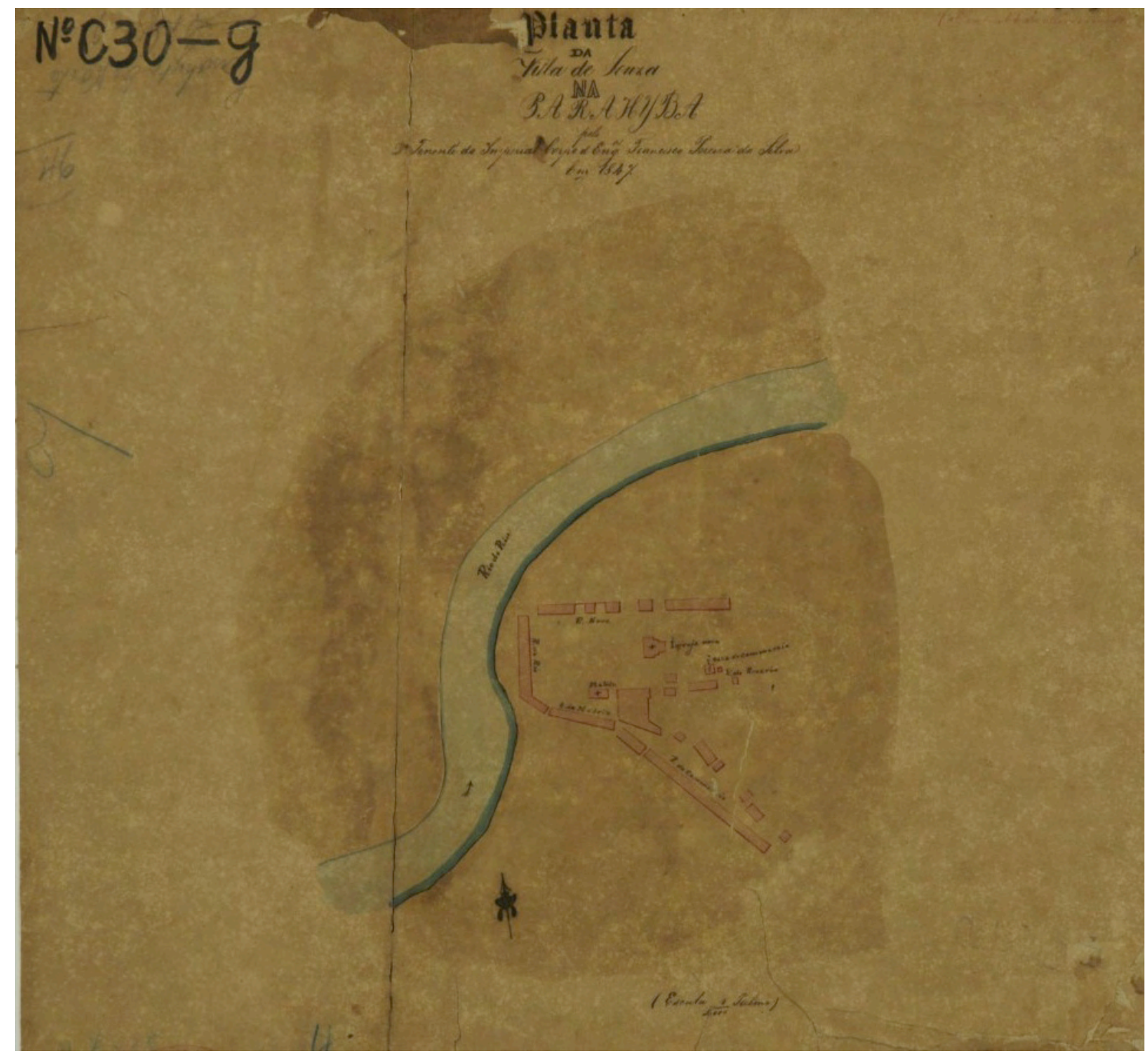


09: SILVA, Francisco Pereira da. Planta da Villa do Piancó na Parahyba. Ano de produção: 1848. Desenho a nanquim colorido (41 x $31 \mathrm{~cm})$. AHEx-RJ. ID: 03.03.493.

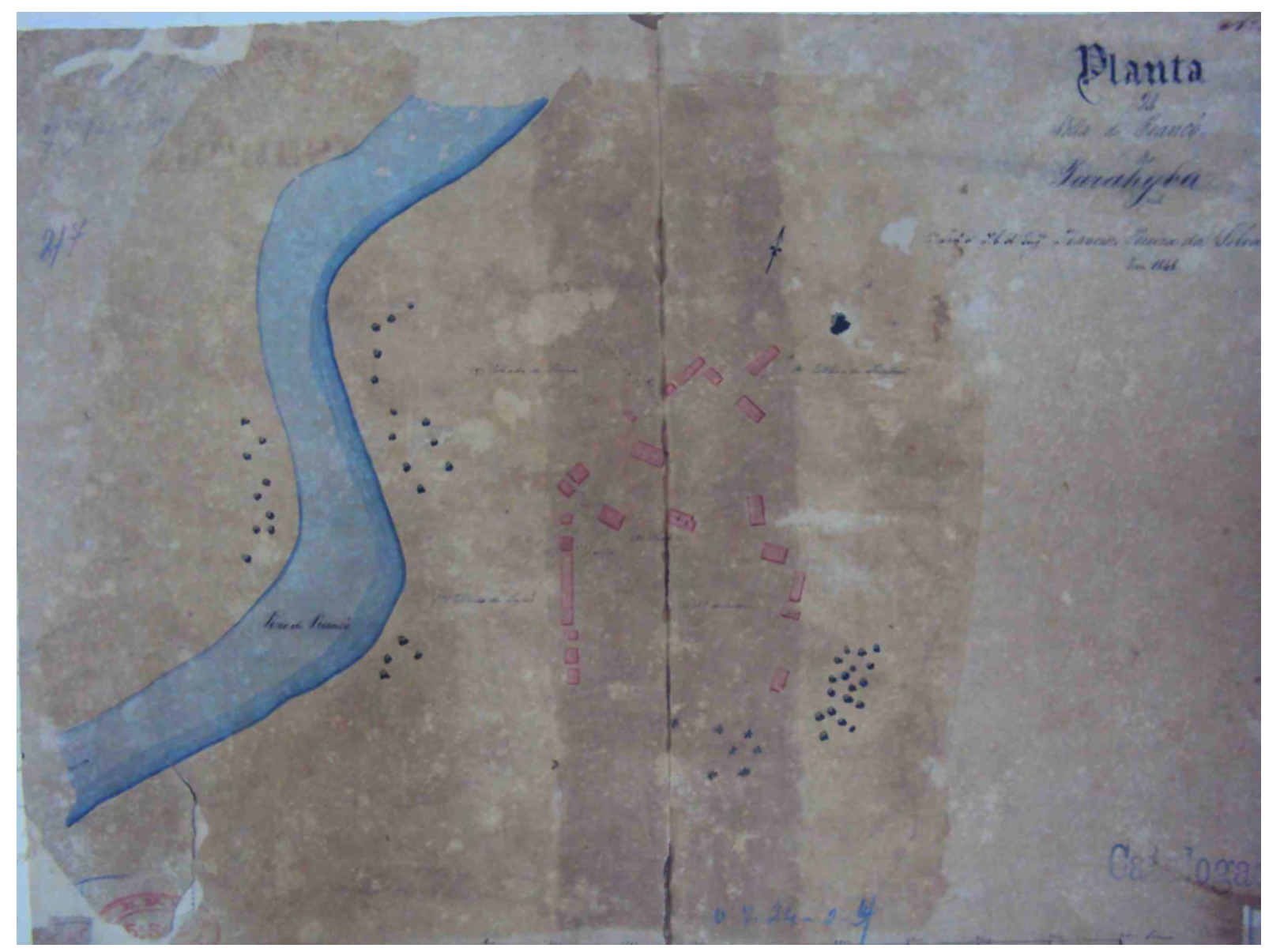


10: PINTO, Jozé da Silva. Carta Topográfica da Capitania das Alagoas que a pedido do Ilmo. Snr. Coronel Manuel Francisco Martins Ramos commandante dos Districtos das Villas de Penedo e Poxim. Ano de Produção: 1820. Desenho a nanquim, colorido. Rio de Janeiro, Fundação Biblioteca Nacional, out/2010.

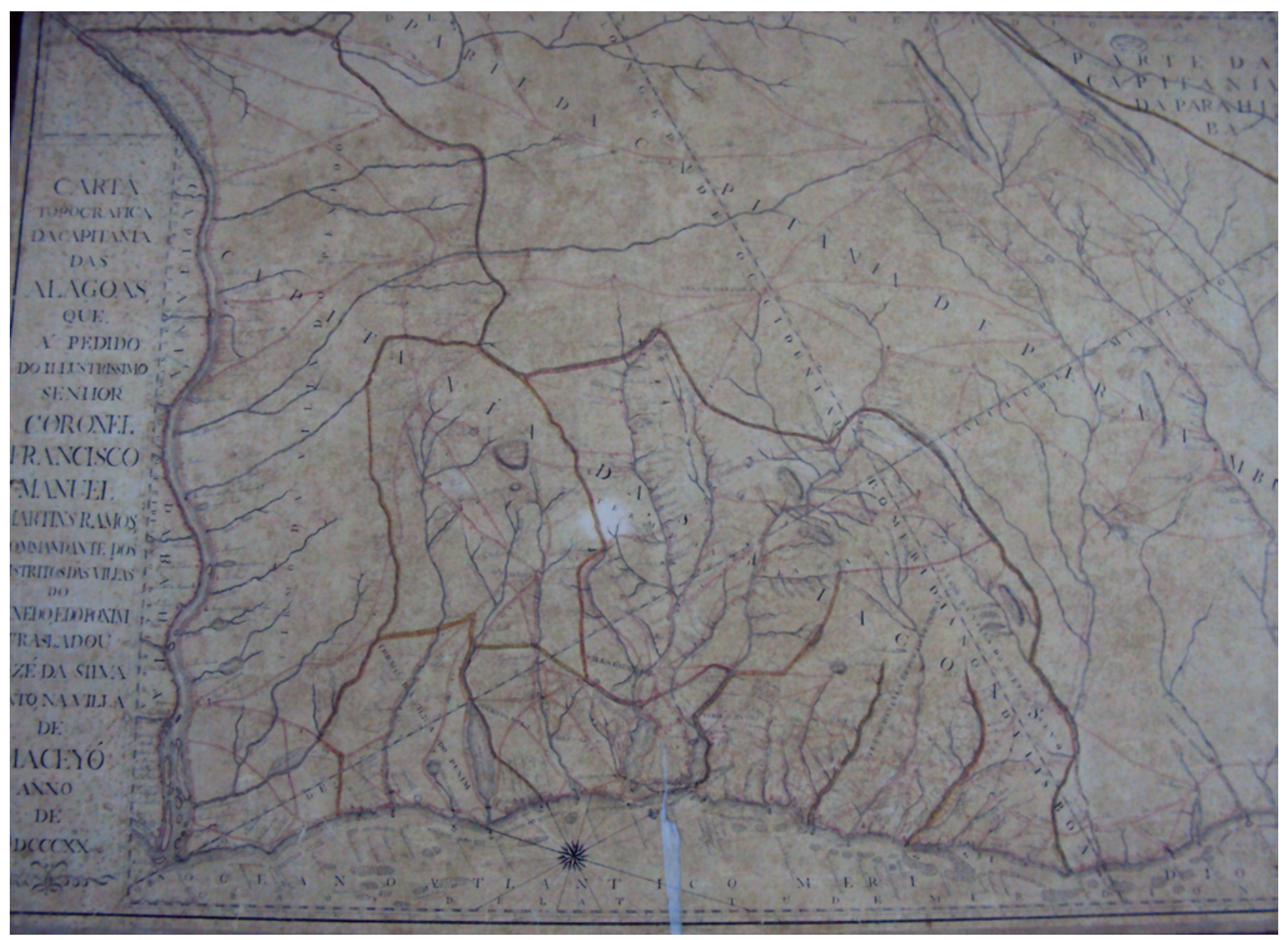


11: MAPA da Comarca da Bahia de Todos os Santos sua divisão desde o rio Jiquicirá athé o rio Real pela parte Norte. Ano de produção: indefinido [17...]. Desenho à tinta ferrogálica (44 x 54,5 cm). OD: cart 525818.tif. Disponível em http://www.bn.br. Acvesso em 02.06.2010.

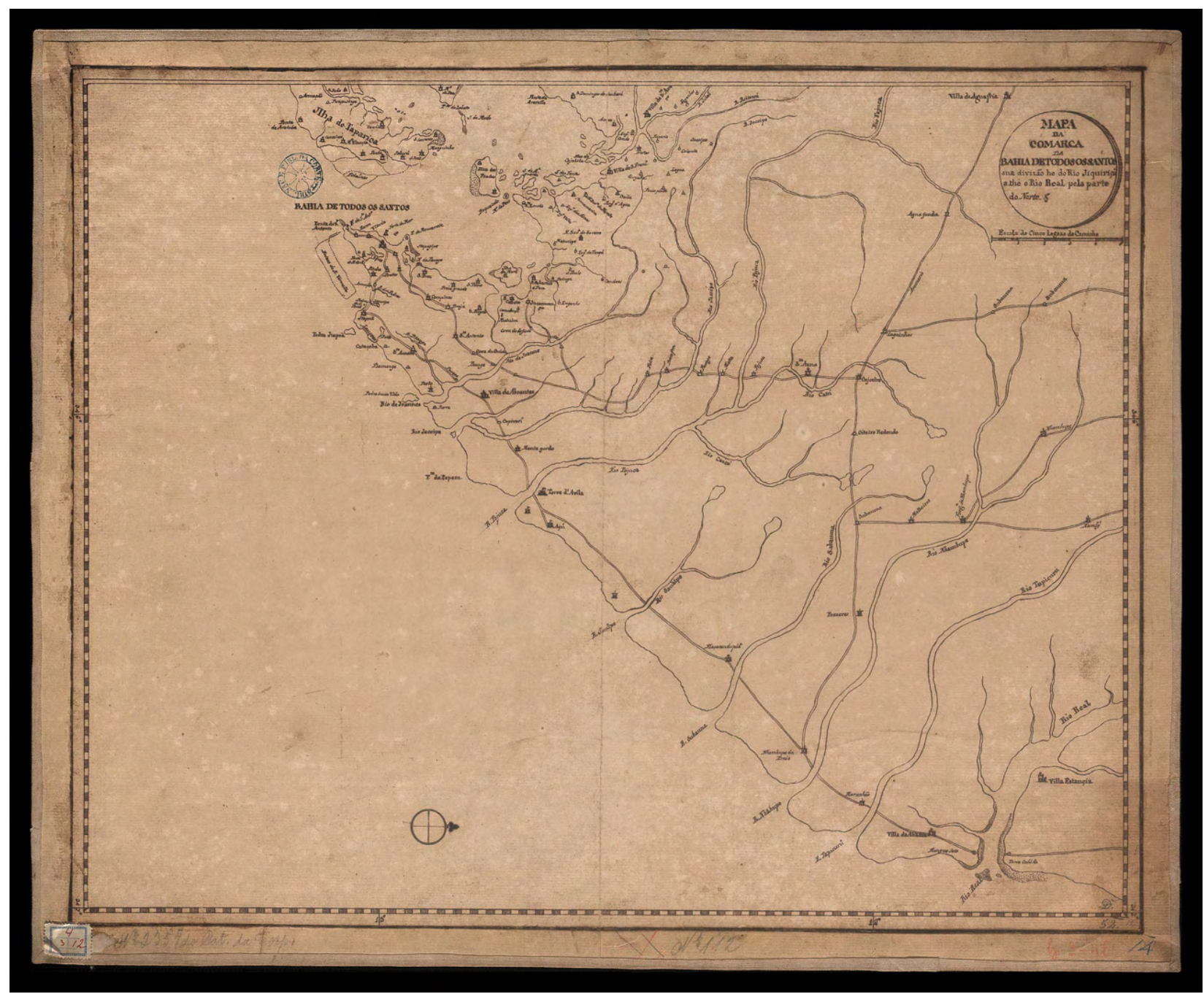


12: VILHENA, Luís. Planta da commarca do Ceará e sequito pelo Certão athé a cidade da Bahia de Todos os Santos. Escala em patipé de vinte e cinco léguas. 1801. Cartografia disponível em http://www.bn.br. Acesso em 30.10.2011.

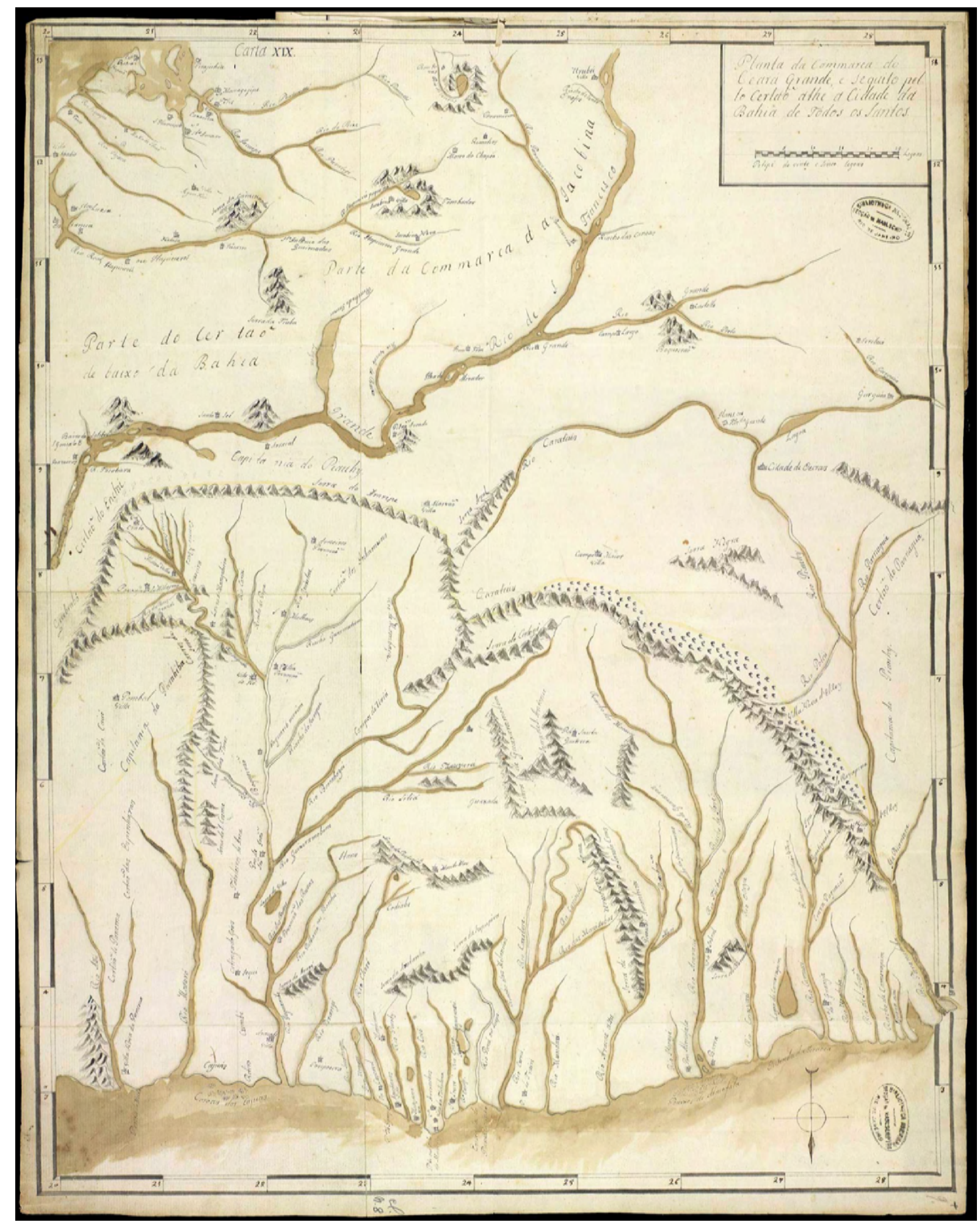


